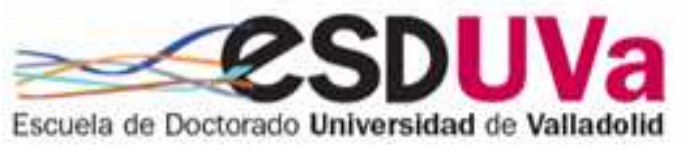

Universidad deValladolid

PROGRAMA DE DOCTORADO EN FILOSOFÍA

TESIS DOCTORAL

\title{
SECULARIZACIÓN Y REENCANTAMIENTO \\ DEL MUNDO SEGÚN CHARLES TAYLOR: \\ UNA VISIÓN SOBRE EL FUTURO DE LA \\ RELIGIÓN EN LA ESFERA PÚBLICA
}

\author{
Presentada por \\ FCO. JAVIER MARTÍNEZ PÉREZ \\ para optar al grado de \\ Doctor por la Universidad de Valladolid \\ Dirigida por \\ DR. SIXTO CASTRO RODRÍGUEZ
}


"Todos los hombres por naturaleza desean saber" ARISTÓTELES, Metafísica

"La filosofía es en realidad nostalgia, un impulso de estar en todas partes en casa" NOVALIS, Schriften 


\section{AGRADECIMIENTOS}

Hace algunos años me dijeron que en una Tesis doctoral se descubría, entre otras muchas cosas, los límites y dificultades de la propia personalidad. Que una tesis era un trabajo para superarse a sí mismo. Y al concluir la presente tesis doctoral, puedo afirmar que así es. Una tesis doctoral se asemeja a correr un gran maratón. En algunos momentos, uno va a buen ritmo, sintiendo que todo resulta fácil, que no hay cansancio, completamente focalizado en la meta, sin desviarse del objetivo...; en cambio, en otros, pareciera que todo pierde sentido, cada página leída, cada párrafo escrito se hace largo, tedioso y agotador. Entonces el norte parece perderse, los objetivos se diluyen, el paso se ralentiza y la meta tan soñada se aleja hasta casi desaparecer. Es en estos momentos cuando se necesita ese ánimo que yo, afortunadamente, he encontrado en muchas personas de mi entorno más querido; ellos han sido un apoyo, una ayuda, una orientación..., y a ellos van dirigidas estas palabras de agradecimiento.

En primer lugar, a D. Sixto Castro Rodríguez por haber aceptado la propuesta de dirigir esta tesis, de su acompañamiento, siempre decidido y animoso, y, sobre todo, la sugerencia inicial de haber planteado la tesis en torno a un autor que en principio era poco conocido para mí: el filósofo Charles Taylor. Sus sugerencias constantes, el haberme planteado este pensador tan relevante en la filosofía contemporánea ha abierto en mí tantos interrogantes, tantos planteamientos, tantas preguntas..., que nunca tendré palabras suficientes para agradecerle el enriquecimiento que ha supuesto el encuentro intelectual con uno de los grandes hermeneutas del mundo actual. Gracias, Sixto, por haberme exigido rigor intelectual, por haber abierto camino a tantos horizontes que han enriquecido sin medida mi propia vida intelectual y espiritual y, sobre todo, por haber mantenido juntos el buen ánimo para hacer síntesis en torno a un tema tan relevante para el mundo actual: el futuro de la religión en un mundo entristecido, desfundamentado y oscurecido. Gracias, Sixto, por tantos retos que han hecho de este estudio una aventura auténticamente apasionante.

Seguidamente quiero dar las gracias, de todo corazón a mis padres, Francisco y Flora, pues de ellos he aprendido lo que significa ser querido sin condiciones, en los buenos y en los malos momentos, en los triunfos y en los fracasos. Quiero agradecer a mi madre el haberme enseñado a caminar por la vida apreciando cada minuto que se nos regala. 
Agradezco enormemente las constantes palabras de ánimo de mi hermana Teresa y el apoyo incondicional de mi cuñado Manuel. De la misma manera, les doy las gracias a mis hermanos, Miguel Ángel y Juan Luis, que han estado ahí siempre presentes con su palabra cercana y su interés permanente.También me siento verdaderamente agradecido a la Diócesis de Valladolid, manifestada en el rostro de muchos amigos de tantos lugares diversos, especialmente en la figura del Cardenal de Valladolid, Excmo. y Rvdmo. D. Ricardo Blázquez Pérez, en quien siempre he encontrado ánimo y apoyo; y en el Excmo. D. Luis Javier Argüello, Obispo Auxiliar de la Diócesis de Valladolid, que desde el primer momento confió en mí inculcándome, con su fraternal palabra, la fuerza decisiva para seguir adelante.

Quiero dar las gracias a cuantos han caminado conmigo durante años y me han formado tanto en lo humano como en lo espiritual e intelectual, entre los que están mi amigo Fernando Bogónez y algunos profesores, amigos también, del Departamento de Ciencias, Matemáticas y Ciencias Sociales de la Facultad de Educación de la Universidad de Valladolid, que han sido para mí un gran soporte en todo momento, con sus palabras de aliento, llenas de amistad y cercanía. Me gustaría además ofrecer mi más cordial agradecimiento por el interés mostrado a dos grandes amigos, David Martínez Barbero y Francisco Sánchez Oreja, OCD.

Igualmente, quisiera agradecer a las personas integrantes del Departamento de Filosofía de la Universidad de Valladolid, y muy particularmente al grupo de investigación filosófica GIR del Departamento de Filosofía.

A todos vosotros, GRACIAS.

Fco. Javier MARTÍNEZ PÉREZ

Valladolid, junio 2021 


\section{ÍNDICE}

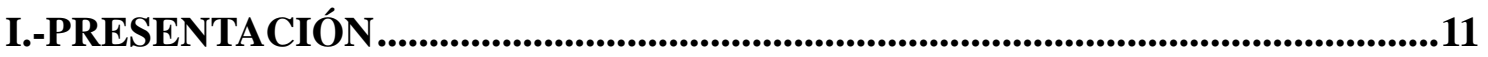

II.-INTRODUCCIÓN GENERAL ........................................................................ 17

II.1.-CHARLES TAYLOR. BIOGRAFÍA .......................................................... 18

II.2.-CHARLES TAYLOR Y SU "RELATO FILOSÓFICO”............................... 21

III.-FUNDAMENTOS FILOSÓFICOS PARA COMPRENDER LA

SECULARIZACIÓN SEGÚN CHARLES TAYLOR ................................................... 39

III.1.-EVOLUCIÓN DE LAS FUENTES MORALES DEL YO.......................... 40

III.1.1.-INTRODUCCIÓN. LA IDEA DEL YO COMO IDENTIDAD

PERSONAL Y COLECTIVA EN RELACIÓN A LA IDEA DEL BIEN MORAL

III.1.2.-LA IDENTIDAD DEL YO EN SU PROCESO DE

DESVINCULACIÓN DE LA RAZÓN TRASCENDENTE …………………...... 58

III.1.2.1. EL TIEMPO DE LOS ORÍGENES. EL YO COLECTIVO

INTEGRADO EN EL COSMOS Y EL SURGIMIENTO DE LAS

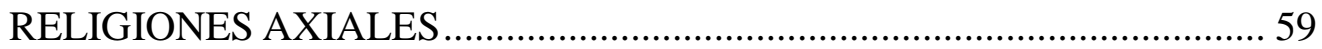

III.1.2.2. PLATÓN: EL YO COMO AUTODOMINIO Y CONTROL ........... 72

III.1.2.3. SAN AGUSTÍN DE HIPONA: EL YO COMO INTERIORIDAD 77

III.1.2.4. DESCARTES: LA CONCIENCIA DEL YO.................................. 83

III.1.2.5. LOCKE: EL YO PUNTUAL....................................................... 94

III.1.2.6. MONTAIGNE: EL YO PARTICULAR QUE SE AUTOEXPLORA

III.1.2.7. EL YO KANTIANO: EL SUJETO COMO SER RACIONAL DEL

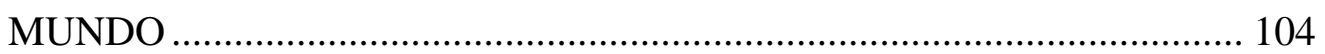

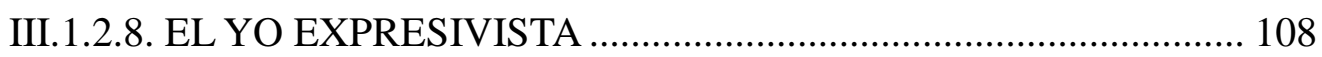

III.1.2.9. EL YO HEGELIANO COMO VEHÍCULO DEL GEIST ................111

III.2.-NARRACIÓN DE LOS CAMBIOS EN EL PENSAMIENTO ................118

III.2.1.-CAMBIOS QUE INICIAN EL CAMBIO. LA SUPERACIÓN

PROGRESIVA DE LOS TRES BALUARTES DE LA FE. 118

III.2.1.1. DE UN MUNDO ENCANTADO A "UNA MENTE QUE PIENSA" 118

III.2.1.2. DE UNA SOCIEDAD ENRAIZADA EN DIOS A UN INDIVIDUO DESVINCULADO SOCIAL Y TRANSCENDENTEMENTE ..................... 128

III.2.1.3. DE UN COSMOS ETERNO A UNA NATURALEZA .................. 142

III.2.2.-HACIA "LA GRAN DESINSERCIÓN". HISTORIA DE LAS IDEAS

QUE DES-ENCANTARON EL MUNDO ………………………………...... 144

III.2.2.1. EL RENACIMIENTO DEL SIGLO XV ..................................... 146

III.2.2.2. EL ENS CREATUM Y EL CAMBIO NOMINALISTA. HACIA UNA NUEVA POIESIS DE LA NATURALEZA ........................................ 154 
III.2.2.3. LA REFORMA PROTESTANTE. HACIA UNA NUEVA POIESIS DEL ESTADO. 166

III.2.2.4. EL SUJETO DESVINCULADO Y EL AUTOCONTROL RACIONAL 189

III.2.2.5. LA REVOLUCIÓN CIENTÍFICA Y SU CORRELATO METAFÍSICO KANTIANO 194

III.2.2.6. EL DEÍSMO Y "LA ÉPOCA DE LA FILOSOFÍA” 211

III.2.2.7. EL AVANCE IMPARABLE DE LA INCREENCIA.................... 260

III.2.2.7.1. El inconsciente filosófico. Schelling y Schopenhauer .......... 271

III.2.2.7.2. El inconsciente hereditario. Darwin ..................................... 280

III.2.2.7.3. El inconsciente psíquico. Freud .......................................... 286

III.2.2.8. LA DECONSTRUCCIÓN DEL ORDEN SIGNIFICANTE......... 293 IV.-UN PROYECTO PARA LA RECONSTRUCCIÓN DE LA IDENTIDAD

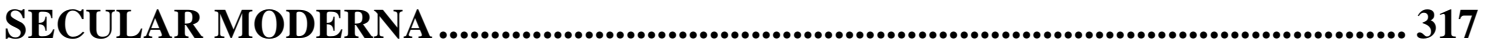

IV.1.-EL NUEVO ORDEN MORAL DE LA MODERNIDAD..................... 321 IV.2.-LA EDAD SECULAR Y LA SECULARIZACIÓN. ¿ESTAMOS EN

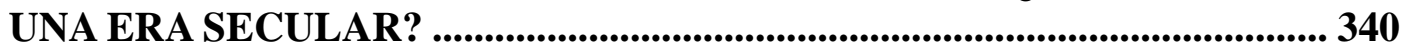

IV.3.-LA SECULARIZACIÓN COMO RUPTURA ENTRE LO INMANENTE Y LO TRASCENDENTE .......................................................356

IV.3.1.-DE LA RAZÓN RESPONSABLE AL NATURALISMO Y DEL ORDEN NATURAL PROVIDENTE AL MODERNISMO POSTROMÁNTICO 361

IV.3.2.-HACIA UNA REDEFINICIÓN DE LA SECULARIDAD EN CLAVE

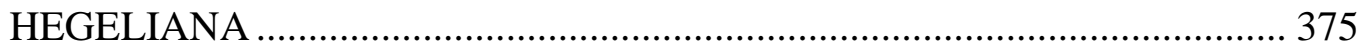

IV.4.-OTRAS NARRACIONES DE LA SECULARIZACIÓN........................ 385

IV.4.1.-NARRACIONES SOCIOLÓGICAS .............................................. 389

IV.4.2.-NARRACIONES FILOSÓFICO-POLÍTICAS ................................. 431

V.-CHARLES TAYLOR. REENCANTANDO EL MUNDO. EL FUTURO DE LA RELIGIÓN EN LA ESFERA PÚBLICA ...................................................................... 443

V.1.-UNA SITUACIÓN NUEVA. LA RELIGIÓN COMO PROBLEMA Y

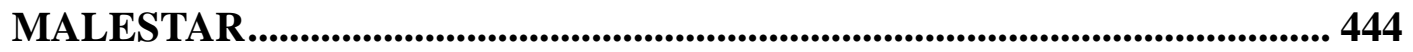

V.2.-ESTAMOS ABIERTOS A “ALGO MÁS”’................................................ 455

... PERO DESDE EL MARCO INMANENTE ................................................. 462

V.3.-EL FUTURO DE LA RELIGIÓN. PERSPECTIVAS. RETOS.

REFLEXIONES .......................................................................................................... 467

V.3.1.-LA ETAPA POST-DURKHEIMIANA COMO UNA BÚSQUEDA

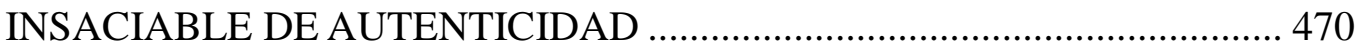

V.3.2.-LA RELIGIOSIDAD POPULAR, ¿UNA NUEVA ESPIRITUALIDAD

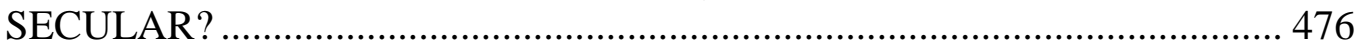

V.3.3.-EDAD SECULAR Y NATURALIZACIÓN DE LA ESPIRITUALIDAD 
V.3.4.-¿TIENE FUTURO LA RELIGIÓN? ¿UNA SEGUNDA ERA AXIAL?495 VI.-CONCLUSIÓN GENERAL 511 PROPUESTAS PARA UNA NUEVA TEORÍA SOBRE LA SECULARIZACIÓN. LA RELIGIÓN EN LA ESFERA PÚBLICA ............................................................ 512

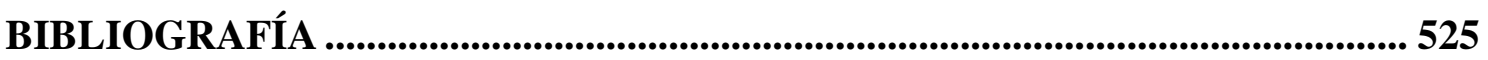
OBRAS DE CHARLES TAYLOR: FUENTES PRIMARIAS ........................ 526 OTRAS FUENTES BIBLIOGRÁFICAS........................................................5 528 


\section{I.-PRESENTACIÓN}

La lectura del corpus filosófico de Charles Taylor, uno de los grandes hermeneutas del mundo actual, ha supuesto adentrarnos en un ámbito en el que se entremezclan Historia, Filosofía y Moral. Creo que estos tres elementos laten en la obra del filósofo canadiense como tres elementos estrechamente vinculados a lo largo de toda la historia de la humanidad.

Quizás pudiéramos empezar afirmando que uno de los grandes retos de la obra de Charles Taylor ha sido dar una explicación coherente al fenómeno de la Modernidad. Su obra cumbre, Fuentes del Yo, pretende adentrarse en este fenómeno que ha cambiado el horizonte intelectual y ético del mundo tal y como se comprendía este hace cuatro siglos.

El proceso iniciado en Occidente en la Baja Edad Media ha dado lugar a un mundo en el que la cultura y la sociedad, del modo en que se entendían anteriormente, se han configurado de una forma totalmente distinta. El fenómeno así denominado de la Modernidad ha supuesto un giro copernicano con respecto a las fundamentaciones y visiones culturales, filosóficas y éticas tal y como se entendían hasta entonces. Todo cambió. Surgió un mundo nuevo configurado por referentes culturales y éticos, que suponían una ruptura con respecto a las cosmovisiones que fundamentaban el mundo hasta ese momento.

Charles Taylor es consciente de lo ardua que fue la tarea de rastrear los movimientos que permitieron el surgimiento de la Modernidad y definir filosófica y moralmente la nueva etapa que se abría. Pretende hacer un estudio más provechoso y menos sesgado en torno al surgimiento y consecuencias de la Modernidad. Frente a aquellos que plantean la Modernidad como una etapa superior que ha supuesto un enriquecimiento intelectual y moral, y frente a aquellos que por el contrario plantean una visión de la Modernidad como un declive y un retroceso, con la pérdida de muchos elementos que habían enriquecido el saber y la cultura hasta entonces, Charles Taylor pretende superar cualquier visión extremista o llena de prejuicios y adentrarse con la sabiduría del "erizo hermeneuta" para contribuir a reconstruir una narración maestra e innovadora del relato de la Modernidad. Para Taylor, aún está por entender la insólita combinación de grandeza y de peligro, de grandeur et misère que caracteriza la Edad Moderna. Hay que reconfigurar la narración de la Modernidad en toda su complejidad y riqueza. $^{1}$

Charles Taylor pretende articular un relato adecuado sobre la Modernidad intentando adentrarse en su génesis. La obra de Taylor, en su conjunto, tiene como uno

\footnotetext{
${ }^{1}$ Cfr. TAYLOR, Ch., Fuentes del yo, pág. 12.
} 
de sus objetivos fundamentales la articulación de una antropología filosófica desde la cual, partiendo de la metodología trascendental kantiana, llegar a una filosofía antropológica que define al ser humano como "ser-en-el-mundo", que hace filosofía, se autocomprende, se define en relación con los demás, es un animal de lenguaje, vive en una cultura y está abierto a la trascendencia. Todas sus obras intentan articular esta invariabilidad del ser humano a través del estudio de todas las condiciones de la variabilidad humana, definida por el tiempo y la historia o, en términos heidegerianos, por el ser y el tiempo. Cada obra de Taylor profundiza en una circunstancia histórica del ser humano y pretende introducirse más adentro en la comprensión de dicha variabilidad del ser en el tiempo. Taylor, a través de todas sus obras, pretende dar un sentido de unidad, de invariabilidad, a través de una cosmovisión que define su gran proyecto: articular una antropología filosófica de carácter fenomenológico que contribuya a realizar esa síntesis filosófica que es capaz de reconocer hegelianamente que en el fondo siempre ha habido una sola filosofía: el autorreconocimiento del Espíritu en todo lo que es. ${ }^{2}$

La presente investigación doctoral también pretende centrarse en el hecho religioso tal como es estudiado por Taylor en su proyecto filosófico, comprendiéndolo en toda su complejidad y variedad; un hecho que va modelando cada época y configurando las fuentes morales del yo, entendido como un ser dinámico en clave aristotélica y hegeliana. ${ }^{3}$

En su obra La Era Secular, compuesta de dos tomos, ${ }^{4}$ Charles Taylor afirma en el prefacio al primer tomo, que pretende relatar una historia, la de lo que en el Occidente moderno solemos llamar "secularización" y, al hacerlo, trato de esclarecer qué implica este proceso, a menudo invocado pero aún no del todo esclarecido, ${ }^{5}$ tratando de responder a la pregunta de por qué en nuestra sociedad occidental era virtualmente imposible no creer en Dios en el año 1500, mientras que en el 2000, eso no solo no es fácil para muchos de nosotros, sino incluso inevitable. ${ }^{6}$

Este es uno de los objetivos fundamentales de la presente investigación: acompañar la respuesta a esta pregunta siguiendo el guión planteado por Charles Taylor en sus obras, en las que se centra de manera clara en el estudio del significado de la secularización, las razones por las que hemos llegado hasta aquí y qué futuro le espera a la Religión en el mundo actual. Al propio tiempo, intentaremos ver cuál es su proyecto

\footnotetext{
${ }^{2}$ Cfr. TAYLOR, Ch., Hegel, Anthropos, Barcelona, 2010, págs. 445-465.

${ }^{3}$ Cfr. GRACIA CALANDÍN, J., "Legado filosófico en Charles Taylor", Asimov, No 46, (2009), págs. 171-187.

${ }^{4}$ TAYLOR, Ch., La Era Secular, tI, Gedisa, Barcelona, 2014; TAYLOR, Ch., La Era Secular, tII, Gedisa, Barcelona, 2015.

${ }^{5}$ Cfr. TAYLOR, Ch., La Era Secular, tI, pág. 17.

${ }^{6}$. Ibid., pág 55 .
} 
filosófico en un intento de adentrarse en esas fuentes morales que ubican la comprensión del hombre desde sí mismo en clave hegeliana.

Charles Taylor da tres sentidos a la palabra "secularización":

i.- "En términos de los espacios públicos, se afirma que a estos se los ha vaciado de Dios o de toda referencia a una realidad última."

ii.- "La secularidad consiste en el declive de la creencia y las prácticas religiosas, en el alejamiento de Dios por parte de la gente y en la no concurrencia a la Iglesia."

iii.- "Consiste en el paso de una sociedad en la que la fe en Dios era incuestionable y en verdad estaba lejos de ser problemática, a una sociedad en la que se considera que esa fe es una opción entre otras, y con frecuencia, no la más fácil de adoptar". 7

Taylor se propone estudiar el cambio experimentado en la Modernidad en este tercer sentido, esto es, el proceso que permite reconfigurar las fuentes morales del yo, de tal manera que de ser prácticamente imposible no creer en Dios, se pasa a considerar la creencia en Dios como una posibilidad más entre otras, cuando no una realidad problemática.

En otro contexto, pero apuntando hacia las mismas referencias, Charles Taylor afirma que su relato filosófico ha consistido fundamentalmente en analizar el origen de la aparición de fuentes alternativas a las fuentes morales existentes hasta entonces. Para nuestro hermeneuta, ver dónde se ubica ese origen no es tarea fácil ni puede darse por concluido su estudio. ${ }^{8}$ La multiplicidad de fuentes morales de la Modernidad está en la base de la inseguridad y en la incertidumbre en la que se mueve el hombre de hoy, y cuyas repercusiones en el futuro de la Religión es indudable, bien como problema bien como campo abierto al futuro. Creemos que esta es una de las claves del presente estudio y para el que necesitamos la sabiduría del maestro hermeneuta. Podríamos afirmar que el momento actual está caracterizado por una situación de permanente provisionalidad, con lo que no es fácil de analizar, ni ver hacia dónde se dirige el rumbo

\footnotetext{
${ }^{7}$ TAYLOR, Ch., La Era Secular, tI, págs. 21- 22.

8 "El hecho de que las direcciones sean múltiples contribuye a nuestra sensación de incertidumbre. Forma parte de la razón por la cual casi todos permanecemos en un estado provisional en el que virtualmente nadie puede hacer gala de una afianzada confianza en su postura... Cabría afirmar que todas las posiciones se problematizan por el hecho de que existen en un campo de alternativas. No obstante, mientras que lo que se cuestiona de la fe es su verdad, también se ponen en entredicho la dignidad y la naturaleza en cuanto a la verdad de su adecuación. El persistente interrogante del teísmo moderno es simplemente ¿existe realmente un Dios? La amenaza en los márgenes del humanismo moderno no teísta es ¿importa?”. Ibid., págs. 435-436.
} 
moral del hombre de hoy, porque caben casi todas las posibilidades y no es fácil vislumbrar cuáles pueden ser las más plausibles.

Taylor considera, en toda su profundidad, el gran interrogante que surge en el seno del teísmo a partir de la Modernidad y al que debe responder desde el tribunal de la razón ilustrada: “Existe realmente Dios?”. Una pregunta constantemente formulada desde el lado de las fuentes a-teístas y a la que inmediatamente se añade otra casi sin solución de continuidad: “¿Realmente importa?”.

Por eso, nos parece importante indagar, en línea con el planteamiento anterior, y a través del legado filosófico de Charles Taylor, la relación entre la secularización y fuentes morales, relacionando las causas político-sociales de la secularización con la noción moral que permitió que las fuentes morales alternativas tuvieran potencia y encaje en la Modernidad. Intentaremos analizar en toda su profundidad las relaciones entre el teísmo, la razón desvinculada y la bondad de la naturaleza; esto es, interrelacionar Religión, Filosofía y Moral, y a partir de ahí, plantear qué futuro le espera a la Religión en la esfera pública.

Nos parece, pues, muy importante intentar vislumbrar, como centinelas del pensamiento y la cultura actuales, el futuro de la religión en un mundo postsecularizado, su papel y el protagonismo que puede desempeñar en medio de tantas encrucijadas históricas, filosóficas y éticas.

El objetivo general de esta Tesis Doctoral es enmarcar el Fenómeno Religioso tal y como lo percibe Charles Taylor dentro de su Proyecto Filosófico, entendido como un gran estudio de la Modernidad. Desde esta preocupación fundamental que late en todas sus obras, Charles Taylor quiere proponer un análisis sobre lo que es el ser humano; esto es, un gran proyecto de Antropología Filosófica. Taylor pretende hacer una Filosofía centrada en el hombre ubicado y contextualizado en las distintas etapas de la historia, una filosofía sobre el hombre encarnado y situado, que hace, piensa, se relaciona, crea el lenguaje, expresa sus sentimientos, crea arte y manifiesta una apertura a la trascendencia. Para Charles Taylor, sin la Antropología difícilmente podremos comprender la Filosofía, dado que para él la Filosofía no es otra cosa que una reflexión del espíritu de los tiempos en el que el hombre se ha desenvuelto a lo largo de las distintas etapas de la historia. ${ }^{9}$

Por eso, en su opinión, en continuidad con el pensamiento hegeliano, cada filosofía tuvo necesariamente que aparecer en el momento en que lo hizo, y el objetivo de cada filósofo no fue otro que intentar comprender el espíritu de su tiempo en el pensamiento. Por lo tanto, nuestro propósito es hacer una lectura de los textos

\footnotetext{
${ }^{9}$ Cfr. TAYLOR, Ch., Hegel, pág. 445.
} 
filosóficos más importantes de los filósofos sugeridos por Taylor (y algunos no sugeridos y ver por qué no los promueve para su estudio) y, desde su hermenéutica, comprender la autocomprensión del hombre en cada coyuntura histórica.

A partir de todas estas realidades en las que se entremezcla el hecho religioso, intentaremos ver qué es el hombre y qué piensa de sí mismo, lo que supuso el gran giro copernicano de la Modernidad, para tratar de ubicar el hecho religioso en la realidad actual y las perspectivas de futuro que se abren tanto a nivel personal como comunitario.

El trabajo se estructura en tres fases diferentes:

Una primera fase conceptual-teórica de investigación exploratoria y analítica. En esta primera etapa nos acercaremos al tema objeto de la investigación a través del estudio analítico de la presente investigación doctoral, a partir de las fuentes primarias, es decir, las obras de Charles Taylor.

Esta fase incluye una Introducción general en la que realizaremos un breve acercamiento a su biografía y una breve presentación del relato filosófico de Charles Taylor, así como las corrientes en las que se inscribe su filosofía.

A partir de ahí, nos centraremos en los Fundamentos filosóficos que nos ayuden a comprender la secularización según Charles Taylor. Fundamentos que estudian la evolución de las fuentes morales del yo y la narración de los cambios que se van produciendo en el pensamiento: la superación progresiva de los tres baluartes de la fe y una breve historia de las ideas que desencantaron el mundo.

En una segunda fase, que denominaremos de investigación analítico-comparativa, nos centraremos en el objetivo fundamental de la Tesis Doctoral, y que lleva por título: "Hacia la reconstrucción de la narración de la secularidad moderna según Charles Taylor". Esta segunda fase será el estudio central de la tesis. Estudio que se pregunta sobre si estamos realmente en una edad secular y si la secularidad es la gran invención de Occidente. Pretendemos analizar la secularización tal y como la entiende nuestro autor, esto es, como la ruptura entre el marco inmanente y el trascendente. Al propio tiempo, nos adentraremos en la nueva narrativa de la secularización que Taylor pretende realizar con vistas a redefinir la secularidad en la cultura posmoderna en la que nos encontramos.

En la tercera fase, trataremos de realizar una síntesis general en dos grandes bloques que pretenden recoger la síntesis tayloriana en torno a la edad secular y que llevan por título: Reencantando el mundo. El futuro de la Religión en la Esfera pública.

Por último, finalizaremos con una Conclusión General. 
Intentaremos hacer un estudio científico y lo más fundamentado posible, estructurando enfoques y sacando conclusiones generales sobre el papel de la religión en el mundo actual a partir el horizonte filosófico de Charles Taylor. Un estudio que pretende acrecentar la propuesta filosófica de Taylor de un "reencantamiento filosófico del mundo" en torno a la moralidad y a las propuestas de la razón trascendente. 


\section{II.-INTRODUCCIÓN GENERAL}




\section{II.1.-CHARLES TAYLOR. BIOGRAFÍA}

Charles Taylor nació en Montreal en 1931. Creció en un medio urbano caracterizado por el encuentro y el conflicto entre dos lenguas y culturas: por un lado, la cultura inglesa, la de su padre, y por el otro, la cultura francesa, la de su madre. ${ }^{10}$ Esto nos sugiere una situación socio-cultural conflictiva y que sin duda alguna influirá en su futuro personal y en los compromisos que le llevarán a tomar decisiones en el ámbito socio-político.

La provincia de Quebec está dividida en población similar entre anglófonos y francófonos. Es una provincia que contrasta mucho con su provincia vecina, Toronto. Mientras Toronto tiene más reminiscencias de carácter americano, su vecina Quebec tiene una forma de vida que se enmarca más en la tradición europea. En este sentido, Taylor es un representante de esa dualidad que se desarrolla en Canadá entre ambas tradiciones. Charles Taylor es católico, vive en un barrio francófono, es francófono y sin embargo va a estudiar a la Universidad McGill, universidad que se convertirá al final en su universidad de referencia. En esa universidad se gradúa en Historia en el año 1952. Prosigue su formación como Rhodes Scholar de la Universidad de Oxford, primero como becado en el Balliol College donde se graduará como Bachelor of Arts en Filosofía, Política y Economía en 1955 y donde conseguirá su doctorado en Filosofía en 1961, bajo la supervisión de Isaiah Berlin y Elizabeth Anscombe ${ }^{11}$. Su tesis, publicada en 1964 y titulada The Explanation of Behavior, sustenta una crítica a la psicología conductista. Sucedió a John Plamenatz como profesor de Teoría Social y Política en la Universidad de Oxford.

Durante un largo periodo, antes y después de Oxford, ejerció como Profesor de Ciencia Política y Filosofía en la Universidad McGill, ${ }^{12}$ institución en la que posteriormente será nombrado Profesor Emérito. ${ }^{13}$ Tras su paso por McGill, ocupó el cargo de Profesor de Leyes y Filosofía en la Universidad Northwestern en Evanston, Illinois. En 1986, Taylor fue elegido Miembro Extranjero Honorífico de la Academia Estadounidense de las Artes y las Ciencias.

Partidario ardiente de la identidad propia del Quebec francófono, su compromiso con la política lo llevó a postular en varias ocasiones a la Cámara de los Comunes de

\footnotetext{
${ }^{10}$ TAYLOR, Ch., Hegel, Anthropos, Barcelona, 2010, pág. IX.

${ }^{11}$ En Oxford entrará en contacto con la filosofía analítica; no obstante, pronto se desencantará de ella y entroncará con la Fenomenología y con lo que nosotros conocemos como la Filosofía Continental.

${ }^{12}$ En los datos que aparecen en la página web de McGill University se presenta el siguiente curriculum al que hemos hecho referencia más arriba: "BA (History) McGill University, 1952; BA (Oxford) (Politics, Philosophy and Economics), 1955 MA (Oxford), D Phil (Oxford), 1961”.

${ }^{13}$ En la McGill University, según la página web de dicha Universidad, el campo de investigación de Charles Taylor es "Philosophy of Action, Philosophy of Social Science, Political Theory, Greek Political Thought, Moral Philosophy, the Culture of Western Modernity, Philosophy of Language, Theories of Meaning, Language and Politics, German Idealism". En el Equipo de Profesores Eméritos de dicha universidad aparecen profesores de la categoría de Mario Bunge, Storss McCall, Calvin Normore y Charles Taylor.
} 
Canadá como candidato del Nuevo Partido Democrático de Quebec. ${ }^{14}$ A pesar de su apellido inglés, es un quebequense orgulloso de serlo. Sus ideas sobre el multiculturalismo han tenido enorme influencia en estos tiempos en que varios países del mundo se enfrentan al problema de la integración de sus minorías. En el 2007, el gobierno canadiense le encargó, junto a Gérard Bouchard, la coordinación de la "Comisión Bouchard-Taylor", para plantear formas de convivencia en torno a las diferencias culturales en la provincia de Quebec. Charles Taylor posee el título de Companion de la Orden de Canadá. En 2000 fue nombrado Gran Oficial de la Orden Nacional de Quebec. ${ }^{15}$

En 1998-1999 pronunció las Gifford Lectures con el título Living in a Secular Age. En 2007 publica la gran obra titulada A Secular Age, uno de los escritos sobre la secularización que ha suscitado mayor reconocimiento por su profundidad $\mathrm{y}$ complejidad de análisis. Comentando dicha obra, Taylor la define como un relato, tal y como lo entiende el propio Paul Ricoeur. ${ }^{16}$

El profesor Taylor recibió el premio Templeton, en 2007, por avanzar hacia la investigación o los descubrimientos acerca de las realidades espirituales. Fue el primer canadiense en ganar el premio Templeton. En 2008 fue galardonado con el premio Kyoto en la categoría de las artes y la filosofía. En 2015 Habermas y Taylor reciben el

\footnotetext{
${ }^{14}$ En Quebec está por una parte el Partido Democrático de Quebec que intenta reclamar la independencia, porque no se consideran canadienses, sino que se sienten una provincia y una nación totalmente diferente por esa población francófona, y por otro lado, está el Partido Liberal de Quebec, que intenta mantener de alguna forma esa idiosincrasia propia de la provincia, pero que al final lo que quiere es que Quebec esté totalmente integrada en Canadá. En el Nuevo Partido Democrático de Quebec, Taylor va a participar activamente. En esta búsqueda de lo que significa la identidad "canadiense", los angloparlantes se sienten como algo muy parecido a los norteamericanos. Sin embargo, para los quebequenses ellos no sentían ese problema de identidad que les distinguiera de los norteamericanos, ya que ellos se sentían ante todo franceses y europeos, por lo que reivindican dicha identidad. De ahí que el mundo cultural y político en el que se desenvuelve Taylor se plantea el tema del multiculturalismo no como un debate teórico sino como un tema realmente práctico que debe ser afrontado en toda su profundidad filosófica para luego, desde ahí, volver a la práctica. Hay que tener en cuenta que el fracaso político de Taylor le hace volver posteriormente a su mundo universitario, a su mundo de intentar fundamentar teóricamente su gran proyecto de profundizar en lo que ha sido la Modernidad para plantear el debate sobre el yo, sobre la identidad y sobre la comunidad política.

${ }^{15}$ Para más aspectos relacionados con su biografía, sobre todo sus motivaciones para el estudio de la historia y la filosofía, Cfr. TAYLOR, Ch.; BERNSTEIN, R. y GAMPER, D., Diálogos, Gedisa, Barcelona, 2017.

${ }^{16}$ En una de sus últimas entrevistas para el periódico El País, afirma en relación con la publicación de su gran obra La Edad Secular:"Bueno, lo que se cuenta es siempre una narración, un relato, como dice Paul Ricoeur. Yo creo que la vida humana no se comprende sin un relato. Al analizar la situación de la espiritualidad y de la religión compruebo que hay muchas personas que buscan algo, sea una concepción atea o religiosa. Hay también muchas personas que lamentan la erosión de la cristiandad y se resisten a su desaparición. El desafío es entender a las dos partes, creyentes y no creyentes y que convivan".

Disponible en: https://elpais.com/internacional/2015/08/06/actualidad/1438877393 088926.html. (20-III-2017).

Ricoeur define la palabra relato como: “... Si el acontecimiento es un fragmento del relato, sigue la suerte del relato, y no existe acontecimiento de base que pueda escapar a la narrativización. Y, sin embargo, no podemos prescindir de la noción de 'mismo acontecimiento' al no poder comparar dos relatos que tratan, como se dice, del mismo tema". RICOEUR, P., La Memoria, la historia, el olvido, Trotta, Madrid, 2010, pág. 321.
} 
premio Kluge, considerado como el Premio Nobel de la Filosofía. El premio fundado por el empresario germano-estadounidense John Werner Kluge ha recaído en estos dos brillantes filósofos, sobre todo por su participación en el debate político a nivel público. Así lo ha indicado el director de la biblioteca del Congreso estadounidense James Billington, en Washington D.C., donde se ha anunciado el premio. ${ }^{17}$

En 2016 es el primer ganador del Premio Berggruen por sus ideas sobre el autoconocimiento y el crecimiento de la especie humana. ${ }^{18}$

En 2019 recibe el premio Ratzinger junto con el jesuita Paul Béré. Dijo de él el Papa Francisco en la entrega del galardón que "en el curso de su larga vida de investigación, enseñanza y acción, el profesor Taylor ha abarcado muchos campos, pero en particular ha dedicado el esfuerzo de su mente y de su corazón a comprender el fenómeno de la secularización en nuestro tiempo que plantea, efectivamente, un gran desafío para la Iglesia Católica, todavía más, para todos los cristianos y podemos decir para todos los creyentes en Dios". 19

Tras su jubilación, el profesor Charles Taylor no ha dejado de viajar, escribir y dar charlas por todo el mundo, desarrollando una importante actividad intelectual. Taylor es un realista que pretende fundamentar el acceso a una epistemología del mundo exterior a nosotros y que se sitúa frente al posmodernismo predominante en el mundo filosófico. En este sentido, los filósofos que más huella han dejado en él son Aristóteles y Heidegger. Concluimos afirmando que su obra se caracteriza por tender puentes entre corrientes a menudo enfrentadas: Ilustración y comunitarismo, fe y razón, filosofía y acción política, filosofía analítica y filosofía continental. ${ }^{20}$

\footnotetext{
17،"Habermas es conocido por sus trabajos en filosofía y Ética del Derecho. Taylor por su parte se ha ocupado de la multiculturalidad criticando la tesis del "choque de las culturas" La Fundación Kluge financia a intelectuales de las humanidades y las ciencias sociales, como por ejemplo los filósofos Paul Ricouer y Leszek Kolakowski”.

Disponible en: http://www.abc.es/cultura/20150813/abci-habermas-taylor-obtienen-premio201508122044.html (20-III-2017).

${ }^{18}$ En dicho artículo se destaca que el jurado estuvo compuesto por múltiples personalidades entre las que destacan el Nobel de Economía Amartya Sen, el médico Antonio Damasio y la matemática Alison Miller. Nicolas Berggruen destacó que la obra de Taylor ha contribuido a transformar el pensamiento sobre el mundo y sobre aspectos básicos de la vida humana. El presidente de la entidad, Cail Calhoun, resaltó el carácter intelectual y a la vez humilde de la filosofía de Taylor, así como su calidad humana y su capacidad para la enseñanza y el compromiso público. Disponible en: https://elpais.com/cultura/2016/10/05/actualidad/1475657119_206840.html (20-III-2017).

${ }^{19}$ Oficina de Prensa de la Santa Sede. Boletín Diario de 9 de noviembre de 2019.

${ }^{20}$ Taylor, según el parecer de muchos autores, no se centra en la Modernidad exclusivamente, sino que va más allá, afirmando que hay múltiples Modernidades. Según Taylor, a partir de la Ilustración, hay una eclosión de múltiples formas de entender el yo o, lo que es lo mismo, una eclosión de modernidades múltiples. Lo que pretende a lo largo de su proyecto filosófico es adentrarse en dicho estudio, y analizar cómo van surgiendo las distintas modernidades hasta llegar a lo que él denomina "edad secular". Siguiéndole rastrearemos en el surgimiento de dichos tipos de modernidad hasta llegar al momento "postsecular" actual. En este sentido, Taylor hablará de la situación actual caracterizada por un "malestar de la cultura" que a veces se vive de manera angustiosa, debido a lo que él denomina aspectos fundamentales
} 


\section{II.2.-CHARLES TAYLOR Y SU "RELATO FILOSÓFICO”}

En las palabras preliminares de Charles Taylor al libro recopilatorio de algunos de sus más relevantes artículos, titulado La libertad de los Modernos, es el propio Taylor quien nos indica cómo fueron sus inicios en el estudio de la Filosofía, dada su formación histórica. ${ }^{21}$ En estos comienzos filosóficos, en la década de los 50 y bajo la influencia del pospositivismo, Taylor comienza su andadura apasionada en el mundo de la filosofía.

Según el propio Taylor indica, la lectura del libro de la Fenomenología de la Percepción, de Merleau-Ponty, le señaló la dirección que quería seguir, esto es, una crítica al Positivismo tanto en el ámbito de la filosofía como en el de las ciencias humanas. Dicha crítica le abrirá el camino hacia la definición de una nueva antropología, basándose en una "teoría vigorosa que le permita circunscribir los límites del ser", frente a otras teorías no realistas (Hume) o antirrealistas (Rorty). ${ }^{22}$

Y a partir de Merleau-Ponty, Taylor accede al estudio de Heidegger, y de la mano de ambos, llega a conocer y adentrarse en la lectura de Wittgenstein, autores todos ellos que le llevarán a considerar las limitaciones de la tradición epistemológica y a identificar su aporía central: en la base de todo, reside el espíritu como sede de las representaciones mentales, como huellas del mundo exterior en la mente (las ideas de Descartes, de Locke o las impresiones de Hume). Todo se resume en imágenes que retienen cautivo al hombre. Imágenes que, según Charles Taylor, no están fundadas, ya que ni se las reconoce como tales. Por el contrario, Taylor se identifica con la corriente metacrítica de Kant, en su Crítica de la Razón Pura, de Hegel, en su Fenomenología del Espíritu y retomada posteriormente por Heidegger y Merleau-Ponty.

Las relaciones cartesianas cuerpo-mente se simplifican con el mecanicismo, asentando el vacío mental y afirmando las explicaciones físicas. Frente a ello, Merleau-

\footnotetext{
de la cultura "secular" actual, caracterizados por la razón instrumental, el individualismo radical y la disolución del vínculo social. En este sentido nos parece interesante la entrevista de Radio Uned, en la que participan Sonia Rodríguez García y Jesús García Álvarez, dirigida por Antonio García Santesmases. Disponible en: https://www.youtube.com/watch?v=eOLasljncGc (20-III-2017).

${ }^{21}$ Cfr. TAYLOR, Ch., La libertad de los modernos, Amorrortu Editores, Madrid, 2005, pág. 9. "Desde sus estudios en Oxford se verá fuertemente influenciado por la corriente analítica del Círculo de Viena, pero esta corriente no satisfará su curiosidad intelectual, lo que le llevará a estrechar lazos con la Filosofía Continental y, especialmente, con la fenomenología de Merleau-Ponty. Fenomenología y Filosofía del Lenguaje son dos corrientes que Taylor entremezcla en sus análisis, conjugando lo que para él es el método fundamental de la filosofía: la investigación trascendental. En los trabajos de Kant, Hegel, Merleau-Ponty, Heidegger y Wittgenstein, Taylor encuentra una familia de argumentos que parten de algunas facetas supuestamente innegables de nuestra experiencia con el fin de concluir que "esta experiencia debe tener ciertas características o ser de un cierto tipo, pues de otro modo estas facetas no podrían ser innegables." RODRÍGUEZ GARCÍA, S., "Antropología filosófica y filosofía antropológica en la obra de Charles Taylor", Actas I Congreso Internacional de la Red española de Filosofía, Vol. II, (2015), págs. 85-86.

${ }^{22}$ Cfr. TAYLOR, Ch., La libertad de los modernos, págs. 9-10.
} 
Ponty se dedicará a explorar lo que él llamaba el cuerpo viviente y el cuerpo vivido y a redescubrir lo carnal, la carne merleaupontiniana, el espíritu humano encarnado tanto individual como socialmente, ${ }^{23}$ frente al sujeto descomprometido, como pura mirada o pura voluntad, que se observa desde afuera. ${ }^{24}$ Atiendo al objeto a través de mi experiencia, "frente al giro al yo como yo". ${ }^{25}$

Taylor sigue el método de la investigación trascendental ${ }^{26}$ en la búsqueda de aquellas condiciones de posibilidad de la naturaleza humana. ${ }^{27}$ Este método de investigación trascendental, que adopta Taylor, intenta pasar de una tesis más débil a otras más fuertes, desde la experiencia como siendo de algo, a la aplicabilidad de las categorías. Las tesis más débiles pueden parecer al principio las más simples; sin embargo, a partir de ellas, se intentará llegar a conclusiones más fundamentadas y ricas, más detalladas, tratando de complementar y enriquecer las condiciones límite que se habían planteado en el primer esbozo de descripción. "Las conclusiones de los argumentos trascendentales son apodícticas y además están abiertas a un debate inacabable". 28

Puede parecer muy sencillo de aceptar los primeros estadios, pero podemos disentir más en las siguientes etapas, como es evidente, a medida que el discurso se hace más complejo y se matizan las descripciones y las condiciones límite que se van captando. ${ }^{29}$ Taylor parte de la idea kantiana de que en la experiencia hay un orden objetivo de cosas y un orden subjetivo, ${ }^{30}$ ya que, de lo contrario, la experiencia no sería

\footnotetext{
23 "El Espíritu humano encarnado es también el ser humano entre los humanos, cuando la relación con el otro, a través del lenguaje, penetra en la intimidad más profunda de cada uno". TAYLOR, Ch., Argumentos filosóficos. Ensayos sobre el conocimiento, el lenguaje y la modernidad, Paidós, Barcelona, 1997, pág. 12. Charles Taylor trata así de superar la tradición epistemológica que siempre partía del individuo "atrincherado en su fuero íntimo y amo de su pensamiento" (Id., pág. 12) y concederá una gran importancia al lenguaje (relación carne-lenguaje-sociedad).

${ }^{24}$ Cfr. LARA, F., "Introducción" a TAYLOR, Ch., La libertad de los modernos, pág. 15.

${ }^{25}$ Cfr. TAYLOR, Ch., Fuentes del yo, págs. 227, 245.

${ }^{26}$ “La argumentación trascendental es una cadena de afirmaciones apodícticas de indispensabilidad ( $a$ chain of apodictic indispensability claims) que conciernen a la experiencia y que, en último término, se ocupan de nuestra propia actividad, de modo que la tesis fuerte siempre estará vinculada a la naturaleza del sujeto humano". RODRÍGUEZ GARCÍA, S., "Antropología filosófica y filosofía antropológica en la obra de Charles Taylor", pág. 86.

27 "Así partimos con un esbozo de caracterización que puede ser visto como una formulación de una condición límite: por ejemplo, que la experiencia debe ser de algo. Entonces continuamos mostrando que esto supone que la experiencia debe tener coherencia y entonces tratamos de mostrar que esta coherencia debe consistir en la aplicabilidad de las categorías". TAYLOR, Ch., Argumentos filosóficos, pág. 56.

${ }^{28}$ Ibid., pág. 57.

29 "Empiezan con la afirmación de que algún rasgo de nuestra experiencia es indudable y que está más allá de cualquier objeción, para luego avanzar hacia una conclusión más fuerte, relativa a la naturaleza del sujeto o a la posición del sujeto en el mundo. Realizan este paso por medio de un argumento regresivo, con el propósito de que la conclusión sea más fuerte si el hecho indudable acerca de la experiencia es posible (y al verlo, debe ser posible)". Ibid., pág. 43.

30 "De esta elaborada teoría de la experiencia, podemos deducir que el criterio de verdad y falsedad en Kant es un criterio basado en una síntesis entre los conceptos y los datos de la experiencia, sean estos puros o empíricos; o dicho en otras palabras: para que pueda existir un criterio de verdad los 'data' de la experiencia deben ser interpretados, deben adquirir significación". OCTAVI PIULTAS, R., "La filosofía
} 
establecida como "experiencia de algo", se le privaría de ese carácter objetivo, sería una experiencia sin un objeto, lo cual la haría imposible. ${ }^{31}$

Para Kant, las representaciones mediacionales no pueden ser meros bits empíricos, vacíos, huecos... Es necesaria la presencia relacional del objeto que hace de la experiencia una experiencia en el mundo como ámbito "intencional y necesario", que ubique un trasfondo vital de referencias, y opina que la naturaleza no puede ser un mero compendio de fenómenos, por lo que se precisa una facultad radical del conocer desde una unidad, que es la que permite que la llamemos objeto de toda experiencia posible. Por eso podemos conocer dicha unidad a priori que evite que la naturaleza sea una mera pluralidad de representaciones del psiquismo. ${ }^{32}$ Las representaciones, así entendidas, no serían meramente individuales, sino que habría un ámbito de relaciones unitarias que convierten la experiencia en un "ser-experiencia-de-un-objeto": "es necesario que nuestras experiencias tengan una unidad con el fin de que todas nuestras experiencias nos pertenezcan como sujetos". Es decir, que el cogito cartesiano no puede ser un ámbito mediacional de representaciones empíricas, vacías, individuales, sino que debe ser capaz de entender todas las experiencias como referidas al propio yo, a lo que Taylor define como "potencial de reconocimiento de propiedad", en clave kantiana. ${ }^{33}$

A partir de estos argumentos trascendentales kantianos, Taylor se considera continuador de la moderna Fenomenología planteada por Wittgenstein, Heidegger y Merleau-Ponty en la concepción del sujeto como agente encarnado, vinculado al mundo. ${ }^{34}$

Partiendo de la primera argumentación trascendental kantiana, Taylor se basará en los planteamientos que posteriormente realizará Merleau-Ponty a partir de la tesis del agente encarnado, de la naturaleza de la percepción y de ser conscientes del mundo. Es decir, que sin mundo no hay experiencia, es el trasfondo para todo lo demás: la experiencia básica es percibir el mundo. Nuestra percepción solo puede ser la de un agente con autoconciencia para vincularse trascendentalmente al mundo de la experiencia, dado que las representaciones son de algo, de un contenido de experiencia con el mundo. Es decir, que nuestra percepción, en un sentido fuerte, es nuestra apertura a un mundo como un ámbito de orientación que nos hace entender el hilo de nuestra

\footnotetext{
trascendental de Kant y la cuestión del escepticismo" Thémata, No 45, (2012), pág. 340.

31 "Para Kant, la experiencia ha de tener un objeto, esto es, ha de ser de algo; ya que ha de ser coherente; y para ser coherente ha de estar formada por el entendimiento a través de categorías". TAYLOR, Ch., Argumentos filosóficos, pág. 51.

${ }^{32}$ Cfr. KANT, I., Crítica de la Razón Pura, A114; A104.

${ }^{33}$ Cfr. TAYLOR, Ch., Argumentos filosóficos, pág. 44.

34 "Se trata de una afirmación acerca de la naturaleza de nuestra experiencia, de nuestro pensamiento y de todas aquellas funciones que son nuestras como sujetos y no de una afirmación sobre las condiciones empíricamente necesarias de tales funciones. Decir que somos esencialmente agentes encarnados es lo mismo que afirmar que es esencial para nuestra experiencia y nuestro pensamiento que lo sean de seres encarnados". Ibid., pág. 45.
} 
experiencia como sentido trascendental, una orientación que evita cualquier comprensión desmoronada o borrosa de lo que se percibe.

Percibimos el mundo a través de nuestras capacidades para actuar en él, es decir, como agentes encarnados. $\mathrm{O}$, dicho con otras palabras, estamos capacitados para estructurar el mundo a través de la capacidad para estar y actuar en equilibrio. Y esto solo puede ser experimentado por un ser encarnado. Es así como Merleau-Ponty habla del sujeto humano como "être-au-monde", como perceptor de experiencia, como agente vinculado al mundo, como agente que actúa en y sobre el mundo, abierto al mundo, entrelazado con el mundo. No podemos ser conscientes de un mundo sin una idea de nosotros mismos como sujetos encarnados, ya que esta idea es constitutiva de nuestra conciencia. ${ }^{35}$ Sería un mundo mediacional, representacional, dualista, mecanicista, vacío, empirista, con bits de información individual a partir de los cuales sacar conclusiones establecidas racionalmente. ${ }^{36}$

La alternativa realista retoma aspectos de la epistemología de autores como Wittgenstein y Heidegger. Heidegger en Ser y Tiempo trata de diferenciar entre "describir prefenomenológicamente" el mundo desde un punto de vista óntico (la descripción queda retenida en el ente, en lo que hay en el mundo y describe el aspecto de los entes: casas, árboles, montañas...) y "describir fenomenológicamente" el mundo, que significaría mostrar el ser del ente que está-ahí dentro del mundo. ${ }^{37}$

Para Heidegger el Dasein solo se entiende como "ser-en-el-mundo" y no existe una comprensión del mundo que no sea en referencia a ese modo de ser, de estar en el mundo. De ahí que al Dasein le es esencialmente propia su comprensión del ser "comprensión del estar-en-el-mundo, como un ente que siempre está vuelto". ${ }^{38}$ Por lo tanto, a su modo de ver, el agente desvinculado no pone significado en un segundo momento a un conocimiento previo neutral y atomizado, proyectando actitudes sobre las cosas, sino que desde el primer momento el Dasein está proyectado "en su apertura al mundo", "vuelto hacia" y el ser de su comprensión no es otro que "su comprensión del estar-en-el-mundo". Es, desde el comienzo, un agente que comprende el mundo desde su estar en el mundo. Desde el comienzo existe ese "trasfondo" kantiano que supera cualquier desvinculación y descontextualización neutra previa. Heidegger, al

\footnotetext{
${ }^{35}$ La conciencia para Taylor es "la condición de nuestro captar las cosas que me capacita, inter alia, a formular preguntas. (...) No puedo formular duda coherente alguna acerca de si soy consciente en el sentido de consciente, despierto y captando algo. Los argumentos trascendentales articulan pretensiones de indispensabilidad relativas a la experiencia como tal". TAYLOR, Ch., Argumentos filosóficos, pág. 55; cfr. Ibid., pág. 50.

${ }^{36}$ Cfr. TAYLOR, Ch. y DREYFUS, H., Recuperar el realismo, pág. 50.

${ }^{37}$ Cfr. HEIDEGGER, M., Ser y Tiempo, Trotta, Madrid, 2003, pág. 85. "Ni la descripción óntica del ente intramundano ni la interpretación ontológica del ser de este ente aciertan, como tales, en el fenómeno del 'mundo'. Ambos modos de acceso al 'ser objetivo' suponen ya el 'mundo', y esto, de diversas maneras". Ibid., pág. 86.

${ }^{38}$ Cfr., Ibid., pág. 107.
} 
afirmar que las cosas "están a la mano", está indicando que no hay un "después de significado" a un antes neutral y meramente representacional. ${ }^{39}$ En este mismo sentido, el profesor Cincunegui afirma, comentando a Taylor, que el trasfondo es el equivalente a la precomprensión heideggeriana entendida como capacidad para "sacar a relucir" de la condición de implícito; de ahí que el trasfondo no pueda explicitarse totalmente. ${ }^{40}$

Para Heidegger, la comprensión desvinculada del mundo no es la comprensión primera y básica, sino que es una comprensión que supone una modificación reorientadora frente al compromiso paradigmático del agente como un agente encarnado. ${ }^{41}$ En este sentido, Taylor afirma la importancia de distinguir, para evitar equívocos, entre la concepción desvinculada y neutra propia del ámbito científico y racionalista, y la concepción del yo vinculado que supera la visión puntual y que es espacio de cuestiones constitutivas en términos de significación a partir de un "trasfondo" inicial y primero que desvela "el ser a la vista". ${ }^{2}$

Así pues, las cosas pueden aparecer como portadoras de significado para nuestra acción según la fuerza de ofrecimientos que son capaces de desplegar; es decir, las cosas aparecen como inteligibles según la carga de significado que nos ofrezcan: unas veces de atracción o repulsión, otras inquietantes o apaciguantes; otras posibilitadoras o bloqueantes... Pero también pueden aparecer como neutras, sin significado, tal y como plantea la inteligibilidad propia del conocimiento científico. ${ }^{43}$

Taylor considera que esta ontologización de la mente desvinculada ha tenido un gran éxito en la clave epistemológica mecanicista que ha dado un gran prestigio a las explicaciones mecanicistas en el mundo actual, sobre todo en la ciencia natural, sabiendo además que ambos paradigmas epistemológicos van a apoyarse indistintamente el uno en el otro cuando sea necesario.

\footnotetext{
39 "En Ser y Tiempo, Heidegger sostiene que las cosas se descubren primero como parte de un mundo, es decir, como los correlatos de un compromiso relativo y dentro de la totalidad de tales compromisos (...) Pensar en esta naturaleza como algo que proyectamos sobre las cosas, que previamente serían percibidas de modo neutro sería cometer un error fundamental”. TAYLOR, Ch., Argumentos filosóficos, pág.,106.

${ }^{40}$ CINCUNEGUI, J. M., Charles Taylor y la identidad Moderna, pág. 85.

41 "Para que la actitud desvinculada frente a las cosas resulte inteligible ha de estar integrada en una actitud constante de encuadre hacia el mundo que es antitética a la primera, por lo que no puede afirmarse que sea primera y fundamental". TAYLOR, Ch. y DREYFUS, H., Recuperar el realismo, pág. 71.

${ }^{42}$ Cfr. TAYLOR, Ch., Fuentes del yo, págs. 79, 83 y 197. "(El conjunto de todo) aquello en lo que el Dasein se comprende previamente en la modalidad del remitirse, es justo aquello con vistas a lo cual el ente es previamente dejado comparecer. El en-qué del comprender que se autorremite, entendido como aquello-con-vistas-a-lo-cual se deja comparecer a los entes que tienen el modo de ser de la condición respectiva, es el fenómeno del mundo (la cursiva es nuestra). Y la estructura de aquello a lo que el Dasein se remite es lo que constituye la mundaneidad del mundo". HEIDEGGER, M., Ser y Tiempo, págs.107108.

${ }^{43}$ Cfr. TAYLOR, Ch., Hegel, pág. 7.
} 
Y lo que está claro es que el modelo fundacional racionalista es el que está en la base de nuestro pensamiento cuando se trata de explicar cualquier argumento o dar fundamentación a lo que pensamos. ${ }^{44}$

A su entender, serán Heidegger y Wittgenstein los que empezarán a plantear argumentaciones en favor de un agente vinculado, encarnado y finito, y contribuirán de manera decisiva a liberarnos del racionalismo envolvente que todo lo explica, así como a apreciar la importancia del trasfondo al que hemos hecho ya referencia anteriormente.

Cuando Taylor habla de "agente vinculado", está haciendo referencia a que el yo solo puede comprender el alcance de su experiencia si se sitúa como "autoconsciente", haciéndola inteligible, $\mathrm{y}$, al mismo tiempo, dicha conciencia, como agente, la refiere a la experiencia con la que está vinculado. La forma de actuar es una experiencia inteligible, accesible al yo que le permite hacerla inteligible y, por otro lado, el yo no puede autocomprenderse sin referirse a sí mismo como agente encarnado, ubicado en el mundo. Todo nos remite a un contexto de inteligibilidad: tanto del yo que aprehende el mundo, como del mundo que se hace inteligible desde el yo ontológicamente encarnado. Es decir, que el contexto, entendido como trasfondo, es el que confiere inteligibilidad a la experiencia para ser comprendida. Sin dicho contexto, la experiencia no puede ser comprendida y captada adecuadamente. Un trasfondo del que no soy simplemente inconsciente ni tampoco explícitamente consciente. ${ }^{45}$

Es decir, que el trasfondo, en clave tayloriana, es aquello de lo que soy implícitamente consciente, soy capaz de hacerlo relucir, ya que soy capaz de articularlo implícitamente al estar familiarizado con él, por la idea que tenía de él. El trasfondo es, en clave heideggeriana, un tipo de precomprensión que me hace comprender, hacer inteligible la realidad. Wittgenstein emplea una noción parecida sobre la definición ostensiva a la que haremos referencia posteriormente. ${ }^{46}$

Admite Taylor que, una vez superados dichos equívocos, y siguiendo a Heidegger y Merleau-Ponty, existe un orden de inteligibilidad, es decir, una secuencia según la cual el modo de inteligibilidad vinculado precede al desvinculado. Esto quiere decir que primero el mundo se nos muestra como ofrecimiento de significados, como portador de sentido para nosotros en una amplia variedad de experiencias atractivas o repulsivas, placenteras o dolorosas, frustrantes o motivadoras, y solo en un segundo momento

\footnotetext{
${ }^{44}$ Cfr. TAYLOR, Ch., La Era Secular, tII, pág. 387.

${ }^{45}$ Cfr. TAYLOR, Ch., Fuentes del yo, pág. 694.

${ }^{46}$ Taylor intenta socavar las argumentaciones de los defensores de la imagen desvinculada tratando de poner el foco en "los grandes desconstructores de la imagen desvinculada" y viendo cómo las filosofías del retrato desvinculado emplean "estrategias argumentativas" al hablar de que también el agente desvinculado tiene un "trasfondo" sobre el que argumenta filosóficamente. En cierto sentido comprometen argumentativamente a los defensores del agente vinculado a partir de la necesidad de "hacer explícita" dicha precomprensión, sin la cual no se puede hacer nada, llegando a afirmar que sin dicha explicitación todo puede convertirse en un parloteo que no lleva nada fructuoso.
} 
ontogénico, tendría lugar la comprensión desvinculada y objetivadora. Primero se da la "vinculación configuradora con el mundo" de manera precomprensiva, y luego viene la actitud objetivadora que racionaliza y objetiva. ${ }^{47}$

Piensa Taylor que el atomismo de significado lockeano rompe la relación semántica entre el significante y la realidad de significado. La palabra no remite al mundo de lo real, sino a la idea mental que lo representa. La palabra remite a una representación mental, no al mundo real. La realidad lockeana es la mente que representa el mundo. Locke reifica la mente en grado extraordinario y considera que el hombre solo puede trabajar con los materiales de esa sala de recepciones de la mente. ${ }^{48}$ Por eso, el significante lingüístico remite a una "idea representacional del mundo" no al mundo mismo. Y como las ideas se realizan individualmente en la mente del que las representa, el lenguaje es distinto en cada individuo, pues para cada individuo las palabras significan realidades distintas, con lo cual se plantea la posibilidad de un lenguaje privado, ya que las palabras adquieren alcances semánticos distintos, con referentes mentales propios para cada individuo. En este sentido, Locke, en el Ensayo sobre el entendimiento humano, afirma, al hablar del lenguaje y las ideas que representan, que el hombre tiene una disposición natural para formar sonidos articulados y que los sonidos son "signos de ideas". 49

Taylor sostiene que, para los que intentan superar esta concepción agustiniana tradicional, es posible establecer el significado de las palabras, no a través de la idea mental (o significado) que representa el término o vocablo lingüístico que lo refiere, sino señalando directamente (y superando cualquier mediación mental) el objeto real al que se refiere el término lingüístico. Lo mismo que Kant intentó superar la visión epistemológica del atomismo de inputs a través de su teoría del trasfondo, ${ }^{50}$ así

\footnotetext{
${ }^{47}$ Cfr. TAYLOR, Ch., DREYFUS, H., Recuperar el realismo, págs. 72 y 73. Pienso que aquí se ofrece una clave de comprensión de lo que tiene que ser la filosofía, no tanto como disciplina académica, cuanto una configuración experiencial que nos abre al mundo y que tiene su sentido primero y básico como una filosofía experiencial, vital, interrogadora del sentido, estructuradora de preguntas y captadora del mundo como ofrecimiento de significados. El mundo y la experiencia nos configuran. Hacer filosofía desde lo que aparece ante nosotros como "experiencia fenomenológica del mundo", un amor a la sabiduría que nos predispone para entendernos como seres en el mundo. En un segundo momento, vendrá la categorización filosófica desde un punto de vista académico. Taylor afirma, siguiendo a Heidegger y Merleau Ponty que "los ofrecimientos del mundo" no forman parte de la categorización lingüística "desvinculada" que ofrece la ciencia.

${ }^{48}$ Cfr. TAYLOR, Ch., Fuentes del yo, pág. 232. "Locke, al no tener en cuenta este aspecto y encontrar en la experiencia conceptos puros del entendimiento, derivó también de ella esos conceptos, pero procedió con tal inconsecuencia, que quiso obtener con ellos conocimientos que sobrepasan ampliamente todos los límites de la experiencia”. KANT, I., Crítica de la Razón Pura, B-127.

49 "Este uso ventajoso de los sonidos se obtuvo solamente por la diferencia de las ideas de las que ellos eran signos, convirtiéndose así esos nombres en generales, los cuales se han hecho para establecer las ideas generales, quedando como particulares aquellos en que las ideas para las que se usan son particulares". LOCKE, J., Ensayo sobre el entendimiento humano, Gredos, Madrid, 2015, pág. 69.

50 "Esos juicios (sintéticos a priori) no pueden nunca ir más allá de los objetos de los sentidos y únicamente poseen validez si se aplican a objetos de experiencia posible”. KANT, I., Crítica de la Razón Pura, B-73.
} 
Wittgenstein intentará superar ese atomismo de significados que establece una relación semántica entre la palabra y el objeto a través de un trasfondo de comprensión, sin el cual es imposible entender el significado real de las palabras. Para San Agustín de Hipona, según Wittgenstein, las palabras del lenguaje nombran objetos, y la palabra está por el objeto. ${ }^{51}$ Wittgenstein afirma que San Agustín tiene una imagen primitiva de cómo funciona el lenguaje ya que se trata tan solo de un sistema de comunicación; sin embargo, no hay que olvidar que no todo lo que llamamos lenguaje es este sistema. Y esto debe decirse en muchos casos en que surge la cuestión. ${ }^{52}$

Wittgenstein asegura que este planteamiento agustiniano del lenguaje constituye un uso primitivo del mismo, "una enseñanza ostensiva de palabras" entendida como una conexión asociativa entre la palabra y la cosa. Sin embargo, para Wittgenstein, el aprendizaje del lenguaje no solo tiene una dimensión ostensiva (aprendizaje del uso), sino también una dimensión de uso de las palabras (modo de uso). Luego, decir que el lenguaje designa algo es un rótulo sobre el objeto. ${ }^{53}$

Es decir, el lenguaje no es solo bits de significados, sino que hay un trasfondo sobre el que comprender las palabras, ya que sin dicho trasfondo no se puede comprender adecuadamente su significado. ${ }^{54}$ Nombrar, dice Wittgenstein, es preparar para el uso de la palabra. Según Wittgenstein, nuestras palabras esconden una historia vital que nos remite a un trasfondo de significado sin el cual las palabras difícilmente alcanzarían su verdadero significado. Las palabras expresan una vida que se hace historia e imaginar un lenguaje significa imaginar una forma de vida. ${ }^{55}$ Por otra parte, para Wittgenstein, las palabras necesitan de un trasfondo para ser utilizadas adecuadamente, para ser comprendidas y para poder interrogar sobre ellas. Únicamente

\footnotetext{
${ }^{51}$ Wittgenstein cita a San Agustín de Hipona en el Libro de las Confesiones $(1,8)$ en el que resume la idea agustiniana de lenguaje: "Así, oyendo repetidamente las palabras colocadas en sus lugares apropiados en diferentes oraciones, colegía paulatinamente de qué cosas eran signos y, una vez adiestrada la lengua en esos signos, expresaba ya con ellos mis deseos". WITTGENSTEIN, L., Investigaciones filosóficas, Gredos, Madrid, 2019, P-1.

${ }^{51}$ Ibid., P-32.

52 “¿Es esta la finalidad de la palabra? Sí, puede ser la finalidad. Puedo imaginarme tal empleo de las palabras (de series de sonidos). (Pronunciar una palabra es como tocar una tecla en el piano de la imaginación) pero en el lenguaje de 2 no es la finalidad de las palabras evocar imágenes. (Pudiera ciertamente descubrirse que es provechoso para la verdadera finalidad)". Ibid., P-8.

${ }^{53}$ Cfr. Ibid., P-15.

${ }^{54}$ Según nuestro punto de vista, esto es realmente relevante, ya que con la secularización muchas palabras del lenguaje religioso ni se entienden, ni se comprenden, porque se ha perdido la conexión con el mundo espiritual que expresa, con ese trasfondo de sentido, sin el cual la palabra queda desprovista de significado o se encuentra desubicada. Además, indirectamente, se está sugiriendo que existe la necesidad imperiosa de encontrar nuevas palabras para volver a poner en conexión con el trasfondo de vida trascendente. Muchas palabras han podido perder esa capacidad... Otras (ya existentes o nuevas), por el contrario, pueden incorporarse a un nuevo acerbo lexicológico que recuperan significados que han sido perdidos por el camino a través de palabras huecas.

55 "Nuestro lenguaje puede verse como una vieja ciudad: una maraña de callejas y plazas, de viejas y nuevas casas, y de casas con anexos de diversos períodos; y esto rodeado de un conjunto de barrios nuevos con calles rectas y regulares y con casas uniformes". WITTGENSTEIN, L., Investigaciones filosóficas, P-18.
} 
pregunta con sentido quien ya ha aprendido a usar el lenguaje en un determinado contexto de conocimiento. ${ }^{56}$

Taylor considera también el significado contracultural que adquieren los ataques tanto de Heidegger como de Wittgenstein a las formas culturales hegemónicas de nuestra época. ${ }^{57}$ Un significado contracultural que confirma lo que Charles Taylor denomina la dimensión monológica del agente desvinculado. Una dimensión que se explicita en que el atomismo de inputs y de procesamiento tiene lugar en los individuos, un individualismo que viene reforzado por la visión mecanicista del mundo. Frente a esta visión individualista y monológica, el punto de vista encarnado y vinculado refuerza nuestra visión compartida del mundo a partir del trasfondo que nos hace partícipes de un mundo relacional en el que participamos todos como individuos. ${ }^{58}$

Así, en esta visión contracultural de carácter dialógico y encarnado, Heidegger concede gran importancia a la multitud (das Man) y realiza un ataque al subjetivismo y al humanismo como planteamientos que refuerzan el individualismo monológico ${ }^{59}$. Heidegger, según Taylor, al usar el término "Lichtung" (claro del bosque) y sus diferentes usos de ser, trata de conectar con una realidad que es experimentada y revelada, ${ }^{60}$ que se puede manifestar y que aparece ante nosotros en toda su profundidad y que conecta, de alguna manera, con la Idea platónica. Las cosas son dignas de andar tras de ellas. ${ }^{61}$

El sentido se revela en un mundo que aparece ante nosotros idealmente, en toda su capacidad fenomenológica y que permite ser experimentado de manera también colectiva. ${ }^{62}$ Dicha visión platónica fue superada por "una explicación que veía la

\footnotetext{
${ }^{56}$ Cfr., Ibid., P-29.

57 "Esto se trasluce, por ejemplo, en el hecho de que ambos son críticos de la moderna civilización tecnológica: Heidegger explícitamente en algunos de sus escritos más conocidos, como el ensayo sobre la tecnología; Wittgenstein, al tomar distancia del chauvinismo de la moderna cultura de la razón instrumental". TAYLOR, Ch., Argumentos filosóficos, pág., 109.

58 Cfr. CABANCHIK, S., "La noción de sentido en el Tractatus Lógico-philosophicus de L. Wittgenstein”, Revista de Filosofía y Teoría Política, No 26-27, (1986), págs. 219-223.

${ }^{59}$ Cfr. TAYLOR, Ch., La ética de la autenticidad, pág. 68.

${ }^{60}$ Cfr. LOZANO, V., "Heidegger y la cuestión del ser", Espíritu, Vol. LIII, (2004), pág. 201. "Manifestarse solo es posible sobre la base del mostrarse de algo. Pero este mostrarse composibilitante del manifestarse no es el manifestarse mismo. Manifestarse es anunciar-se por medio de algo que se muestra... Eso en lo que algo 'se manifiesta' quiere decir aquello en lo que algo se anuncia, es decir, no se muestra. Y cuando se dice que 'no es ella misma manifestación', la palabra manifestación tiene el sentido de mostrarse”. HEIDEGGER, M., Ser y Tiempo, pág. 50.

${ }^{61}$ Cfr. TAYLOR, Ch., Argumentos Filosóficos, pág. 158.

62 “Como significación de la expresión 'fenómeno' debe retenerse, pues, la siguiente: lo-que-se-muestraen-sí-mismo, lo patente. Los 'fenómenos ', son entonces la totalidad de lo que yace a la luz del día o que puede ser sacado a la luz, lo que alguna vez los griegos identificaron, pura y simplemente con los entes. (...) Se da incluso la posibilidad de que el ente pueda mostrarse desde sí mismo de diversas maneras, cada vez según la forma de acceso a él. Se da incluso la posibilidad de que el ente se muestre como lo que él no es en sí mismo. (...) En este mostrarse, el ente 'parece'... semejante mostrarse lo llamamos parecer. Lo nombrado en las dos significaciones de fenómeno (fenómeno: lo que se muestra, y fenómeno: apariencia) tiene, por su estructura misma, interna coherencia”. HEIDEGGER, M., Ser y tiempo, pág. 49. De ahí que los defensores de la imagen desvinculada critiquen la Fenomenología.
} 
desocultación dependiente de una capacidad del sujeto de reflejar las cosas en el espejo de la representación interna". ${ }^{63} \mathrm{Y}$ así, surgen dos visiones: por una parte, la visión racionalista y empirista que nos aleja del "ser en el mundo" y que puede conducirnos a planteamientos meramente objetivistas y científicos, desvinculados y neutrales del mundo; $\mathrm{y}$, por otra, la visión que propugna una formulación de significados para nosotros pero no centrados en lo humano (sin capacidad de autoexpresión).

La propuesta contracultural de Wittgenstein, en su obra Investigaciones filosóficas, apunta en otra dirección. Según la interpretación de Charles Taylor, el término referente de Wittgenstein sería "Lebensform", con el que intenta superar cualquier visión desvinculada del mundo y nos acerca a un naturalismo liberador para dominar las distorsiones en las que nos hemos enraizado culturalmente. ${ }^{64}$

Taylor, a pesar de sus dudas al respecto, se atreve a hablar de un humanismo wittgensteiniano y de un antihumanismo heideggeriano. Al propio tiempo que se manifiesta en línea con ambas filosofías en sus trazados de "trasfondo y revelación fenomenológica", aparentemente antitéticas, Taylor plantea con contundencia un humanismo que supere cualquier hegemonía de la razón instrumental porque nos adentra en una antropología incorrecta. ${ }^{65}$

Además de seguir el método trascendental, Taylor intenta comprender la idea de expresión en relación con el lenguaje; expresión como algo que se encarna, que se hace manifiesto tomando cuerpo, carne puesta al alcance de la mirada de todos, que se ve y se desvela, y piensa que, pese al influjo del positivismo cientificista, la expresión es ineludible para el pensamiento contemporáneo, enfrentado al enigma del lenguaje. ${ }^{66}$

Taylor va más allá de la mera concepción designativa del lenguaje para adentrarse en los parámetros de la dimensión constitutiva de la expresión lingüística: el lenguaje constituye, hace emerger la realidad. En ese sentido, Taylor habla de la palabra correcta, de "le mot juste" para hacer referencia a que el uso adecuado de una palabra no solo designa el concepto al que hace referencia desvelándolo, articulándolo, sino que de alguna manera hace surgir dicho concepto, lo produce, de tal forma que esta sería la dimensión correcta del uso lingüístico. ${ }^{67}$

La expresión lingüística matiza y completa el mundo, añadiendo nuevos significados, creando nuevos horizontes, al mismo tiempo que la realidad se convierte por el lenguaje en portadora potencial de nuevas propiedades. Así, lenguaje y realidad se complementan en una simbiosis creadora de misterio. ${ }^{68}$ El lenguaje desvela y

\footnotetext{
${ }^{63}$ TAYLOR, Ch., Argumentos filosóficos, pág. 111.

${ }^{64}$ Cfr. TAYLOR, Ch. y DREYFUS, H., Recuperar el realismo, pág. 59.

${ }^{65}$ Cfr. TAYLOR, Ch., Fuentes del yo, pág. 694.

${ }^{66}$ Cfr. LARA, Ph., "Introducción”, en TAYLOR, La libertad, pág. 17.

${ }^{67}$ Cfr. TAYLOR, Ch., Argumentos filosóficos, pág. 147.

68 "Poseer lenguaje nos hace capaces de relacionar de nuevas formas las cosas, como loci de características y a tener nuevas emociones, objetivos y relaciones, así como a responder de cuestiones de
} 
completa la realidad y la realidad aparece ante el lenguaje como posibilitadora de nuevas propiedades que emergen de su propia naturaleza. Sin el lenguaje, el mundo estaría empobrecido de significados. Taylor cita a Heidegger en su célebre definición del lenguaje como "la casa del ser". 69

Taylor defiende que, frente a la tradicional teoría estructuradora e instrumental de Hobbes, Locke y Condillac — que concibe la vida humana sin referencia alguna al lenguaje, o entiende que primero está la imagen y luego la asociación lingüística ${ }^{70}$-, está la teoría constitutiva de Herder, según la cual el lenguaje hace posible "nuevos propósitos, nuevos niveles de conducta, nuevos significados y, por consiguiente, no es explicable dentro de un marco de vida humana concebido sin lenguaje". ${ }^{71}$

En nuestra tradición cultural, frecuentemente pensamos que el lenguaje es fundamentalmente representativo-designativo-instrumental-objetivo y que su función constitutivo-expresiva es algo secundario. ${ }^{72}$ Por el contrario, Taylor retoma el valor fundamental del lenguaje como construcción "constitutiva-constituyente" del mundo, concediendo un interés primordial a la expresión. Y en este sentido, su relato filosófico, pretende contribuir a recrear el concepto del hombre, su autocomprensión constitutiva

valor fuerte. Podríamos decir: el lenguaje transforma nuestro mundo, usando esta palabra en un sentido claramente derivado de Heidegger". Ibid., pág. 151.

${ }^{69}$ TAYLOR, Ch., Animal de lenguaje, Rialp, Madrid, 2017, pág. 39.

${ }^{70}$ Cfr., TAYLOR, Ch., Argumentos filosóficos, pág. 145. Dicha teoría es la expresión más concreta de la filosofía del lenguaje a partir de la epistemología constitucional moderna. El conocimiento son las "representaciones mentales" que se ajustan lo más certeramente posible a la realidad y para ello se necesita un "método responsable y coherente" que no permita la más mínima sombra de duda cartesiana. Es la palabra que "adquiere significado" al establecer una correspondencia con las cosas representadas por medio de las ideas. La concepción estructuradora relaciona la expresión lingüística con algún contenido preexistente. El contenido precede a los medios externos de expresión. Las palabras son consideradas, según esta concepción, como discriminadoras de matices de nuestras ideas, "controlan" el pensamiento y las ideas preexistentes. El lenguaje sería como el "afinamiento" del concepto, de la idea, sabiendo que las ideas preceden a su "nombre". Una vez que se "nombra" se empieza a discriminar, a matizar, a afinar el concepto, la idea. "Por una parte la concepción instrumental-designativa hace una separación entre pensamiento y lenguaje transformando a este último en un mero instrumento que solo permite nombrar las cosas del mundo o designar lo previamente pensando. Por otra parte, la concepción expresivo-constitutiva no admite dicha separación porque considera que el lenguaje es "pensamiento/discurso" que aparece como una articulación creativa que constituye nuestro mundo y a nosotros mismos como seres-en-el-mundo". CÁRCAMO LANDERO, S., "Lenguaje de contrastes sutiles: el sentido hermenéutico de las ciencias humanas según Charles Taylor”, Alpha, No 41, (2015), pág. 270.

${ }^{71}$ Cfr. TAYLOR, Ch., Argumentos filosóficos, pág 145. "Taylor desarrolla una reflexión que nos permite comprender que en nuestra tradición occidental nos han educado para pensar que el lenguaje solo es un vehículo o instrumento del pensamiento; que resulta muy peligroso, pues distorsiona la realidad y, en consecuencia, debemos elegir de manera escrupulosa y lo más 'objetivamente' posible las palabras que usamos para designar las cosas "tal y como son”. CÁRCAMO LANDERO, S., "Lenguaje de contrastes sutiles”, pág. 271.

72 "But some of the basic ideas of that Hobbes-Locke tradition sill survive in transposed form. With truthconditional theories of meaning, for instance, we still have the basic notion that meaning is to be understood in terms of the things language is used to talk about. The crucial unit is now the sentence and not the word, and relations like "making true" and "satisfying" replace the earlier emphasis on designation (or "signifying" in seventeenth-century parlance) but meaning is still being explicated by some notion of representation: the meaning of a Word is to be explained by the way it can be used to depict the world". TAYLOR, Ch., Philosophical Papers 1, Cambridge University Press, 1985, pág. 9. 
de carácter lingüístico. Por eso es tan importante para nuestro autor el hombre "como animal de lenguaje". Para Taylor, como para Herder, hay que emplear la corrección para dar cuenta de aquello que justifica el uso de las palabras adecuadas y poder ser identificado el objeto. Taylor usa la expresión "corrección irreductible" para hacer referencia a la articulación del concepto y a la clarificación del mismo. Es decir, que el uso de "le mot juste" significa que se articula correctamente la palabra adecuada y al mismo tiempo clarifica en toda su dimensión semántica el alcance conceptual de la misma. "Aprender a usar el signo es aprender a aplicarlo apropiadamente para la satisfacción de algún propósito o tarea no-lingüísticamente-definidos". ${ }^{73}$ Por lo tanto, la relación es unidireccional en el sentido de que va del éxito de la tarea conseguida por la palabra, de la acción a la palabra, no al revés. El éxito de la consecución del objetivo "no está definido en términos de la exactitud de la señal". Por lo tanto, el adjetivo de tres palabras (tarea) — no-lingüísticamente-definida - viene a expresar lo que define la acción, estableciendo el mundo una relación unidireccional con el lenguaje. Es el mundo el que define la palabra, no la palabra la que define el mundo. ${ }^{74}$

Luego el relato filosófico de Taylor, en continuidad con Herder, pretende contribuir a acrecentar el mundo psíquico en el que se ha desenvuelto el espíritu humano y a matizar e incrementar la riqueza de sentimientos y de expresiones que articulan los nuevos conceptos y matices que los explicitan. La filosofía es comprendida, en este sentido, como el gran relato que ayuda a comprender el sentido del hombre y a acrecentar un "sentido más rico del mundo", 75 y realizar una valoración en el sentido fuerte y analizar cómo debería ser tratada la realidad. Es decir, a través del lenguaje, el mundo es capaz de expresar toda la realidad en su intensidad y profundidad ontológica. Sin el lenguaje "la realidad no estaría ahî". 76

Lo mismo que para Kant, sin la sensibilidad de la intuición a priori, y sin el entendimiento de los conceptos a priori, no existiría la posibilidad y la necesidad de la experiencia. $^{77}$

En este sentido el relato filosófico de Taylor pretende contribuir a redescribir el mundo para descubrir todos sus matices, ${ }^{78}$ y crear puentes entre la Filosofía Analítica

\footnotetext{
${ }^{73}$ TAYLOR, Ch., Argumentos filosóficos, pág. 121.

${ }^{74}$ Cfr. TAYLOR, Ch., Animal de lenguaje, pág. 71.

${ }^{75}$ Cfr. TAYLOR, Ch., Argumentos filosóficos, pág. 149.

76 "Siguiendo a Herder, Taylor argumenta que el lenguaje es un vehículo de nuestra autoconciencia; hablar es la expresión de esta capacidad y su realización. Cuando hablamos, damos expresión a esta conciencia reflexiva, un poco como lo haría un pintor o un poeta a través de su creación artística. Nuestra conciencia reflexiva se forma o deviene a través del lenguaje" BICH, M., "De la epistemología a la antropología filosófica de Charles Taylor”, Persona y Sociedad, Vol. XXX, No 2, (2016), pág. 26.

${ }^{77}$ KANT, I., Crítica de la Razón Pura, A-128.

${ }^{78}$ Cfr. TAYLOR, Ch., La libertad de los modernos, pág. 18. "Redescribir", según Charles Taylor, sitúa a la filosofía en la conjunción de dos concepciones, tanto la interpretación como la descripción. La filosofía no es solo conocimiento, descubrimiento, sino ante todo clarificación, ontología descriptiva, en clave kantiana. Según Taylor, la filosofía contribuye a la reconstitución del mundo y redescripción del mismo
} 
anglosajona, que al ir a los problemas filosóficos puede olvidar la tradición histórica, y la Filosofía Continental, muy atenta a la historicidad de la filosofía en sus obras. Podemos decir que Charles Taylor es un espíritu libre que se adentra en la filosofía con el deseo de analizar la "permanencia" de las cuestiones filosóficas más allá de cualquier visión analítica o continental. Por eso, el relato filosófico de Taylor, debido a su orientación antipositivista, a sus planteamientos de la superación de la epistemología y a su estudio de la expresión, termina enmarcándose dentro de las corrientes filosóficas de la Fenomenología y la Hermenéutica, siendo Gadamer, Heidegger, Wittgenstein y Merleau-Ponty las fuentes filosóficas de su pensamiento.

Taylor cree que un estudio del mundo desde la perspectiva positivista, neutra, desde ninguna parte, no es posible para el ámbito de las ciencias sociales. Lo que le interesa es la "idea de que toda ciencia debe dilucidar sus propias condiciones y pensar lo que hace efectivamente esclarecedoras sus explicaciones, así como la noción de que esas condiciones varían según los dominios científicos". 79

Taylor intentará superar la visión cientificista de las visiones naturalistas del mundo para anclar al hombre como intérprete de sí mismo, capaz de narrar la historia y comprenderla en una suerte de "síntesis mágica entre narración y acontecimiento", en el sentido del "relato" de Ricoeur. El hombre no puede ser comprendido solo desde el embrujo de las ciencias naturales, sino también como intérprete de sí mismo ${ }^{80}$ y capaz de autocomprenderse a través de la experiencia histórica. ${ }^{81}$ Por eso, para Taylor, al igual que para Kant, sin la autoconciencia omnicomprensiva a priori, no existiría la posibilidad de la experiencia humana.

Charles Taylor piensa que la Hermenéutica tiene este carácter omnicomprensivo que parte del propio sentido del yo tal como se entiende a sí mismo participando de una cultura determinada.

No obstante, la precomprensión no debe ser entendida como etnocéntrica. Taylor, siguiendo a Gadamer, asegura que la comprensión puede cambiar. Y aquí entra en valor un aspecto importante de la hermenéutica de Charles Taylor: la importancia del encuentro con otras culturas. "La comparación o, mejor, el encuentro intercultural, es para Taylor, el paradigma del conocimiento del hombre". ${ }^{82}$ Opina que en este diálogo

\footnotetext{
no solo descripción.

${ }^{79}$ LARA, Ph., "Introducción”, pág. 19, en TAYLOR Ch., La libertad de los modernos.

${ }^{80}$ Cfr. LAZO BRIONES, P.-LEYVA, G., "Introducción” pág. X, en TAYLOR, Ch., Hegel.

81 "En este sentido es en el que afirma en Las Fuentes del yo que el bien es una dimensión inevitable de toda vida humana y presupuesto de toda su investigación. Es por lo tanto una concepción hermenéutica de la modernidad. Hermenéutica y también genealógica porque el retrato de las auto-interpretaciones que constituyen la identidad moderna solo es posible comprenderlas a la luz de la génesis, esto es, el origen y las transformaciones de dichas interpretaciones". GRACIA CALANDÍN, J., "Modernidad hermenéutica en Charles Taylor", Quaderns de filosofia i ciencia, No. 40, (2010), págs. 109-110.

${ }^{82}$ LARA, Ph., "Introducción", pág. 21, en TAYLOR, Ch., La libertad de los modernos; cfr. TAYLOR,
} 
intercultural el hombre es capaz de enriquecer su propia comprensión, modificándola y dándole un nuevo alcance deliberativo y constructivo. ${ }^{83} \mathrm{Se}$ es capaz de adquirir un nuevo enfoque de los límites de la inteligibilidad propia y así verlos en un nuevo horizonte de sentido para la motivación y doblegar los contornos más fijos de nuestra cultura. ${ }^{84}$

El diálogo intercultural nos lleva a un conocimiento del hombre entendido desde una hermenéutica esencialmente comparativa. Charles Taylor dirá que "la comprensión del otro es siempre en cierto sentido comparativa, hacemos inteligible al otro a través de nuestra propia comprensión de lo humano". ${ }^{85}$ Taylor es consciente de que la comparación y el contraste intercultural permite dejar ser al otro, superando el "home understanding” y accediendo así al valor del otro, superando visiones etnocéntricas y rompiendo límites empobrecedores que nos abren a la auténtica comprensión del otro (o de otras épocas) y llegando a establecer una hermenéutica que ve la propia comprensión como una posibilidad más entre otras. Su relato, por lo tanto, es omnicomprensivo e intercultural, y trata de superar la visión etnocéntrica, neutra, cientifista y universalista, al propio tiempo que pretende evitar una visión relativista de las propias concepciones. ${ }^{86}$

Taylor quiere acercarse a "un lenguaje de contrastes transparentes", entendido como una articulación lingüística que nos permite entender lo humano en toda su dimensión y profundidad ontológica, esto es, capaz de expresar las constantes de lo humano, al propio tiempo que coadyuva a hacer transparentes las propias comprensiones como posibilidades enriquecedoras para el diálogo mutuo. ${ }^{87}$ Charles Taylor quiere llegar a esa antropología común, a esa hermenéutica de lo humano que nos engrandece a partir del contraste y la comparación.

Ch., Argumentos filosóficos, págs. 202-203.

${ }^{83}$ Cfr. TAYLOR, Ch., El multiculturalismo y la política del reconocimiento, pág. 42.

${ }^{84}$ Cfr. TAYLOR, Ch., Argumentos filosóficos, pág. 203. Nos parece algo muy enriquecedor para propiciar una hermenéutica que supera los propios límites y abre al hombre a una nueva situación que enriquece el horizonte ontológico de la propia comprensión humana y es capaz de entrar en diálogo con nuevas motivaciones éticas. Se difuminan los determinismos culturales y se posibilitan enriquecimientos mutuos para un futuro compartido. Pero siempre desde un discurso racional que nos abre a la comprensión del otro debilitando los propios contornos de inteligibilidad propia. Charles Taylor es consciente de las dificultades que ello conlleva y de que no es fácil articular un nuevo discurso racional de comprensión propia abierto desde los propios límites de inteligibilidad. No es fácil relativizar o debilitar los contornos de valor racional de nuestra propia motivación cuando se está plenamente convencido de la precomprensión que motiva el propio actuar.

${ }^{85}$ Creemos que es fundamental la comprensión del otro a través de nuestra propia pre-comprensión, que nunca queda al margen o en tierra de nadie o desde ninguna parte, alejándose del modelo neutro de las ciencias naturales, y siendo consciente de la influencia de dicha precomprensión que funciona consciente (valoraciones y motivaciones fuertes) e inconscientemente (ser capaz de debilitar los límites de la propia inteligibilidad racional).

${ }^{86}$ Cfr. TAYLOR, Ch., Fuentes del yo, págs. 20,47.

87 "Taylor pretende escapar a las pretensiones de las explicaciones de la modernidad como la culminación de un proceso de racionalización que podría ser explicado en términos universalistas. Por el contrario, aboga por una 'tesis sustancialista de la modernidad' que la define en contraste con el pasado tradicional. Solo en alusión a este es posible no perder el sentido de nosotros mismos". GRACIA CALANDÍN, J., "Modernidad hermenéutica en Charles Taylor", pág. 111. 
Taylor también es consciente de que la nueva comprensión alcanzada a través del ejercicio de las virtudes deliberativas también tendrá límites, nuevos contornos sobre los que iniciar de nuevo la aventura del enriquecimiento mutuo. Los nuevos límites de inteligibilidad racional tienen que servir para hacer un proceso indefinido de encuentros que nos lleve "a situar en contraste el nuevo límite, y 'dejar ser a los otros' mucho más efectivamente". 88

Es una invitación a seguir haciendo hermenéutica para seguir avanzando de manera constante e ininterrumpida en la propia comprensión innovada para seguir haciéndola sugerente, capaz de crear reconocimiento propio y mutuo y abrir el horizonte a un permanente ejercicio de intersubjetividad y reencuentro. Es una implicación por entender y comprendernos mejor y comprender a los otros de una manera cada vez más real y auténtica. El contraste deliberativo nos lleva a una transparencia cada vez mayor de la propia comprensión y de la de los otros. Taylor, siguiendo a Gadamer en la imagen de una conversación con visiones enfrentadas, plantea el esfuerzo por llegar a una opinión común, una comprensión y propósito común, a un lenguaje común, a un entendimiento humano común "que nos permitiría a nosotros y a ellos ser sin distorsión y englobarlos de manera no deformada" 89 y comprendernos desde el multiculturalismo y desde las distintas etapas históricas. ${ }^{90}$ Hay una verdad que se esconde en el fondo del otro al que solo se puede acceder desde la comprensión de ese trasfondo. Mi propio horizonte de sentido se profundiza al percatarme de esas verdades que se encuentran escondidas en nuestro propio horizonte cultural, accediendo así a una ampliación de mi lenguaje y de mi comprensión del mundo.

Siguiendo a Hegel, Taylor considera que se trata de analizar el estudio del hombre a partir de la historia en su potencialidad reveladora, accediendo así a una comprensión de la racionalidad como expresión del espíritu humano, que lleva a su constante realización, a una autocomprensión más ajustada de la propia realidad, evitando retrocesos y analizando las aspiraciones más permanentes e inevitables. El objetivo fundamental es comprender al hombre en su verdad total, intentando acceder a la "organización de todo el saber del mundo", 91 en la búsqueda insaciable e inagotable del movimiento del espíritu humano como saber y realización de lo absoluto. ${ }^{92}$ Taylor habla así de una dirección entendida como ganancia que se ha ido manifestando hasta llegar a

\footnotetext{
${ }^{88}$ TAYLOR, Ch., Argumentos filosóficos, pág. 204.

${ }^{89}$ Cfr. Id., pág. 204.

90 "El segundo presupuesto del enfoque cultural de la modernidad es el pluralismo cultural. Aspecto que hoy en día parece bastante evidente y que vemos que reaparece en los debates sobre el 'multiculturalismo'; pero que para el enfoque hermenéutico supone un cambio de actitud radical consistente en ver nuestra propia cultura como una entre otras. Lo cual combate la simplificación acomodada de la explicación acultural". GRACIA CALANDÍN, "Modernidad hermenéutica”, pág. 110.

${ }^{91}$ Cfr. DUQUE, F., Historia de la Filosofía Moderna. La era de la crítica, Akal, Madrid, 1998.

92 "Son un tipo de cambios que quienes los han sufrido tienden irresistiblemente a definirlos como desarrollo, evolución, avance o adelantos de lo auténticamente humano" TAYLOR, Ch., Argumentos filosóficos, pág. 216.
} 
la racionalidad moderna, una racionalidad caracterizada por su universalismo, por la mayoría de edad de la inteligencia ${ }^{93}$ y por su baja tolerancia al sufrimiento. ${ }^{94}$

Taylor, sirviéndose del concepto hegeliano de "historia", 95 afirma que todas las culturas y todas las épocas, más allá de sus semejanzas y diferencias, más allá del concepto controvertido de igualdad, han contribuido al desarrollo humano; de modo que no sería muy correcto hablar entonces de una cultura en términos de lo que ellos no tienen, con respecto a lo que nosotros tenemos. A lo largo de la historia hay procesos de ganancia y progreso, y procesos de pérdidas y ocasos. La interpretación de la historia incluye ambos elementos, que se entremezclan en una historia común que avanza y retrocede. ${ }^{96}$ En esta dialéctica hegeliana hay siempre continuidad como superación que lleva a conseguir síntesis más logradas que motivan avances históricos a través de oposiciones y tensiones, a la vez que síntesis que se superan a través de un mantenimiento mejorado de lo anterior.

La comparación de culturas, según Taylor, debe llevar a comprender al otro desde nuestra propia idiosincrasia axiológica; una potencialidad racional que no anula la comprensión del otro, sino que le deja ser desde el reconocimiento y la riqueza complementaria. Taylor considera que somos dos donde antes había uno y su negación. Los bienes y los valores no se excluyen y se niegan por su aparente falta de comprensión y sintonía con lo diferente, sino que la comparación cultural trata de ver la manera de comprender lo diferente para dejarlo ser desde su propia potencialidad reveladora. ${ }^{97}$ En este sentido, Taylor trata de superar cualquier interpretación naturalista

\footnotetext{
93 "La cópula es a la vez la universalidad, el 'fondo' en el que coinciden los extremos (el sujeto y el predicado) y la negatividad de ambos. El 'parar mientes' en cada uno de los extremos y en su fundamento o 'medio', por separado, es propio del 'yo' en cuanto entendimiento". DUQUE, F., Historia de la Filosofía Moderna, pág. 469.

${ }_{94}$ "La razón tiene la certeza de ser la verdad de todo y de ser toda la verdad. Pero ahora ha de hacer (¡no de 'sufrir'!) la experiencia de sí misma, ha de ponerse a prueba y convertir su formal objetualidad en plena objetividad” Ibid., pág. 471.

${ }^{95}$ Según Charles Taylor, Hegel hace uso del concepto aristotélico de potencia: "Lo que es se revela en la historia... Esta potencialidad reveladora es la misma para todos los seres humanos... y se revela en estadios fijos, donde cada uno es precondición del siguiente". TAYLOR, Ch., Argumentos filosóficos, págs. 214-215.

${ }^{96}$ Se desarrolla el concepto hegeliano de "dialéctica hermenéutica" en clave tayloriana: "La encarnación del Concepto en el mundo, en su transcurrir por oposición, crítica y renovación en los fenómenos culturales, o si se quiere, atendiendo a la voz Aufhebung, por superación del momento anterior el tiempo que rescata lo mejor de él en una conservación..." LAZO BRIONES-LEYVA "Introducción", pág. XV, en TAYLOR, Ch., Hegel.

${ }^{97}$ Cfr. TAYLOR, Ch., La ética de la autenticidad, pág. 104. Taylor sugiere acerca del peligro emergente de una visión "incrustada" de la historia según la cual el concepto hegeliano de evolución y progreso podría estar en declive, aunque pudiera mantenerse la idea de potencialidad reveladora. Es decir, que si partimos de la idea de que las potencialidades hacen surgir elementos culturales diferentes, se podría llegar al enfrentamiento y al choque intercultural en el que sería muy difícil valorar las "ganancias del contraste comparativo", concluyendo más en la dimensión de pérdidas que en la de enriquecimiento por "desvelamiento racional mutuo". Este temor, dice Charles Taylor, no debería llevarnos a asumir visiones relativizadoras y localistas, entendido estas últimas como la renuncia a la relevancia universal de nuestros bienes. Antes bien, estos temores deben impulsar con más ahínco a un futuro más esperanzado para la humanidad en la que los "proyectos comparativistas" sean vistos como una fuente de anhelos nuevos para
} 
y mecanicista del ser humano, ${ }^{98}$ así como del humanismo exclusivo, ${ }^{99}$ que tiene su origen en el sujeto desvinculado y en la tradición epistemológica moderna cartesiana.

El yo cartesiano es ante todo un yo-espíritu, con capacidad representacional, con conciencia monológica, que le hace capaz de estar al margen del cuerpo y de los otros; y que puede entrar en contacto con lo exterior a través de las ideas representacionales que están en el interior. ${ }^{100}$ Se trata, pues, del dualismo cuerpo-mente, exterior-interior. ${ }^{101} \mathrm{El}$ relato filosófico de Taylor pretende superar el estudio del hombre desde esta epistemología de la mediación cartesiana y dualista que acaba en el cientificismo naturalista. ${ }^{102}$ Frente al mecanicismo reinante, se trata de recuperar la creatividad de la experiencia vivida, que subyace en la conciencia que tenemos del mundo. Frente a las pretensiones imperiales del mecanicismo omnímodo y de la tecnología omnipresente, Taylor pretende aportar su propia reflexión para recuperar la experiencia que permita hacerla más vívida y abra alternativas que estaban hasta entonces muy ocultas. Frente al constante olvido del ser, Taylor, siguiendo a Heidegger, pretende construir una analítica existencial que nos abra al significado del ser que ha quedado oscurecido y tapado en la cosmovisión moderna. Un significado del ser asociado a los bienes constitutivos que es preciso recuperar como valoración moral fuerte. ${ }^{103}$

El proyecto filosófico de Taylor es un trabajo de "erizo" que le llevará a esa búsqueda insaciable de ese elemento nuclear que constituye una evaluación fuerte del ser humano en el trasiego por ir descubriendo lo fundamental del mismo y que converge

miradas compartidas en horizontes que enriquezcan la enorme gama de potencialidades humanas.

98 "Taylor subrayará el rol constitutivo que le corresponde a la actividad de interpretación y autointerpretación en la actividad humana... De este modo, los deseos, preferencias e intenciones subjetivos y su evaluación... pueden ser comprendidos, según Taylor, como diversas formas de la autocomprensión personal, como interpretaciones que los sujetos tienen de sí mismos". LAZO BRIONES-LEIVA, "Introducción”, pág. X, en TAYLOR, Hegel.

${ }^{99}$ Cfr. TAYLOR, La ética de la autenticidad, pág. 50. Cfr. TAYLOR, El multiculturalismo y la política del reconocimiento, pág. 103. Cfr. TAYLOR, Ch., Argumentos filosóficos, pág. 225.

100 "El antecedente fundamental de la denominada 'ontologización' (de la perspectiva desvinculada), es la afirmación gradual, en la modernidad, de un enfoque atomista para comprender el modo en que el hombre conoce, la respectiva convicción de que la acción apropiada de la inteligencia humana radica en la experiencia del procedimiento racional, más que en la razón, en sentido sustantivo (esto es, como un medio de acceso a la realidad del mundo)". MEDINA, C., "La fenomenología del lenguaje y el concepto de la razón práctica en el pensamiento de Charles Taylor", Cinta Moebio, 50, (2014), pág. 54.

${ }^{101}$ "He thought of mental contents as neutral, self-contained units of information which, when suitable processed, could yield objective knowledge of the world. Knowledge thus seemed to have its basis in discrete, separably identifiable "mental items or representations, which are self-contained in the sense that they are only contingently connected to the world disclosed to an engaged point of view". ABBEY, R., “Taylor and the Hermeneutic Tradition" CUP, 2004, pág. 33.

${ }^{102}$ Charles Taylor habla del "Mito de lo Dado", afirmando que nuestro conocimiento consiste en la mera recepción pasiva de datos no interpretados; es decir, que el "cogito ergo sum" cartesiano primeramente se limita a recibir a través de un marco intermedio mediacional las percepciones del mundo exterior y así aprehendemos el mundo. Luego vendrá el razonamiento y la argumentación inferencial hasta asegurarnos de que nuestro conocimiento es científico y está contrastado como "verdad segura y cierta". Receptividad y razón argumentativa llevan al verdadero conocimiento científico y alejan al hombre de cualquier inseguridad epistémica.

${ }^{103}$ TAYLOR, Ch., Fuentes del yo, Paidós, Barcelona, 2006, págs. 624-625. 
en un único centro. Es la visión totalizadora, de alcance universal, que pretende llegar a la raíz de las cosas, ${ }^{104}$ tratando de poner orden en las cosas y descubrir la transparencia en medio de la confusión de cosas.

Taylor pretende "dar sentido y existencia a su objeto", es decir, definir claramente, como evaluación fuerte, una reflexión filosófica sobre el ser humano, y más en concreto, sobre la condición del hombre moderno, el ser humano tal y como ha llegado hasta la Modernidad y lo que define a la Modernidad. Emprende una "empresa a la vez filosófica e histórica". Como afirma el mismo Taylor en el prólogo a su gran obra Fuentes del yo, pretende narrar una historia de la identidad moderna, ${ }^{105}$ y continuar con la idea de que en realidad solo ha existido una filosofía a lo largo de la historia, tratando de objetivar una comprensión universal del mundo y contribuir a la teoría del hombre como ser y tiempo heideggerianos.

Se trata de rastrear no solo a los sujetos históricos que en el espíritu humano desde dentro han motivado los cambios históricos, sino también las fuerzas y hechos que movieron desde fuera. Agentes que se orientan en el mundo (sujetos históricos) y acontecimientos que mueven desde fuera (historia de los sujetos), ${ }^{106}$ en una síntesis difícil de expresar y de rastrear. ${ }^{107}$

\footnotetext{
104 “"El zorro conoce muchas cosas, pero el erizo conoce una sola gran cosa'. Con esta cita de Archulocus al comienzo de su artículo 'The Hedgebog and The Fox': An Essay on Tolstoy's View of History, Isaiah Berlin compara a los relación entre sí e incluso contradictorias (...) Habiendo, pues, construido diferentes corrales, Berlin encierra en erizos humanos de este mundo - aquellos 'que todo lo refieren a un único aspecto central, a un principio ordenador único y universal' - con los zorros humanos, aquellos que persiguen muchas metas, frecuentemente sin ellos a algunas personalidades intelectuales y artísticas: zorro como Herodoto, Aristóteles, Montaigne, Erasmo, Moliére, Goethe, Puschkin, Balzac, Shakespeare y Joyce significa llevar una vida más rica, más variada y abierta. Son los erizos como Dante, Platón, Hegel, Nietzsche, Dostojewski y Marx quienes viven una existencia invariable, incompleta o fanática". SIMON, P., "El 'zorro' contra el 'erizo'. Una consideración histórica de la disputa de Berlin contra Carr". Cuadernos de Historia Contemporánea, No 16, (1994), págs. 152-153.

105 "El conjunto de comprensiones de lo que significa ser un agente humano: los sentidos de interioridad, de libertad, de individualidad y de estar encarnado en la naturaleza que encuentran cabida en el Occidente moderno. (...) Este retrato de nuestra identidad tiene como objetivo servir como punto de partida para una renovada comprensión de la modernidad". TAYLOR, Ch., Fuentes del yo, Paidós, Barcelona, 2006, págs. 11-12.

${ }^{106}$ Cfr. GRACIA CALANDÍN, J., "Legado filosófico en Charles Taylor”, pág. 175.

${ }^{107}$ Cfr. CÁRCAMO LANDERO, S., "Lenguaje de contrastes sutiles. El sentido hermenéutico de las ciencias humanas según Charles Taylor", Alfa 41, (2015). Cfr. GRACIA CALANDÍN, J., "Modernidad hermenéutica en Ch. Taylor", Quaderns de Filosofia i Ciencia, 40, (2010), págs. 109-110.
} 


\section{III.-FUNDAMENTOS FILOSÓFICOS PARA COMPRENDER LA SECULARIZACIÓN SEGÚN CHARLES TAYLOR}




\section{III.1.-EVOLUCIÓN DE LAS FUENTES MORALES DEL YO}

\section{III.1.1.-INTRODUCCIÓN. LA IDEA DEL YO COMO IDENTIDAD PERSONAL Y COLECTIVA EN RELACIÓN A LA IDEA DEL BIEN MORAL}

Charles Taylor pretende ante todo aclarar el significado de qué es ser persona, un yo en la identidad moderna, un significado que va indisociablemente unido a la idea de bien. Es imposible rastrear la idea del yo sin interrelacionarlo con su sentido moral. Por eso la Filosofía es la historia del yo, de cómo se ha comprendido moralmente el sujeto humano como ser-en-sí-mismo en relación a los bienes morales.

La Filosofía moral contemporánea, según Charles Taylor, se ha centrado más en lo que es correcto hacer en vez de en lo que es bueno ser, en el concepto de obligación (entendida como corrección) en vez de en lo que es "la naturaleza de la vida buena". 108 Nuestras reacciones morales son, por una parte, "casi como los instintos" y, por otra parte, implican una pretensión, implícita o explícita, un deseo de la voluntad, como voz interior o como búsqueda irrefrenable de la condición humana. Por eso Taylor habla abiertamente de "una ontología dada de lo humano", que implica un asentimiento del propio yo para dar un consentimiento, superando así las visiones naturalistas modernas que pretenden minimizar cualquier explicación ontológica de la moral. ${ }^{109}$ Nuestro autor cree que no es adecuado conformarse con una visión moral meramente naturalista e instintiva, y que olvida una ontología que da un enmarque racional explicativo a la implicación del yo en nuestra identidad moral. Sin la participación del yo en la toma de decisiones morales, quedaríamos reducidos a puro instinto naturalista primitivista en el que el yo queda minimizado a partir de una epistemología racionalista y empirista, y en el que se da finalmente una explicación sociobiológica del ser humano. ${ }^{110}$

La argumentación ontológica y trascendental implica afirmar que nuestras reacciones morales no son solo sentimientos viscerales basados en instintos de naturaleza primitiva, sino que implican también un reconocimiento de pretensiones implícitas respecto a dichos objetos, lo cual nos lleva a asegurar que esas pretensiones definen al sujeto como un ser de valoraciones que va más allá de la sola razón práctica y que las argumentaciones ontológicas son necesarias para definir la identidad moral del

\footnotetext{
108 "Intuiciones morales que son particularmente profundas, intensas y universales. De hecho, son tan profundas que estamos tentados a pensar que están enraizadas en el instinto, en contraste con otras reacciones morales que parecen, en gran medida, la consecuencia de una forma concreta de crianza y educación." TAYLOR, Ch., Fuentes del yo. La construcción de la identidad moderna. Paidós. Barcelona, 2006, pág. 21.

${ }^{109}$ Cfr. TAYLOR, Ch., La ética de la autenticidad, págs. 49 y ss; cfr. BLOOM, A., El cierre de la mente moderna, Plaza\&Janés, Barcelona, 1989, pág. 235. Charles Taylor intenta explicar el descrédito de las explicaciones ontológicas de la moral en la identidad del yo moderno basándose en justificaciones dadas en torno a supuestos seres inferiores, o en el respeto instintivo de la vida en ciertas cosmovisiones primitivistas, o en planteamientos epistemológicos racionalistas y empiristas basados en el éxito de la ciencia natural moderna.

${ }^{110}$ Cfr. TAYLOR, Ch., Fuentes del yo, págs. 122 y ss.
} 
ser humano. La comprensión que tengo de mí mismo necesariamente tiene una profundidad temporal e incorpora la narrativa. ${ }^{111}$

Todo ello nos lleva a la necesidad de explicar la identidad moral del ser humano desde argumentaciones ontológicas que atribuyen predicados a los seres humanos (ya sean como criaturas de Dios, como emanaciones de lo divino o como agentes racionales), tratando así de establecer analogías entre dichos predicados y una explicación científica del mundo, tal y como por ejemplo se realiza en la ontología platónica, en la que se destaca la unidad a partir de la teoría de las Ideas entre la moral del trato justo y la teoría científica subyacente del universo. ${ }^{112}$

Para Taylor, es fundamental establecer argumentaciones ontológicas que explican las pretensiones de nuestros instintos morales en base a una relación con el mundo, definido a partir de dichas argumentaciones. ${ }^{113}$ La concepción naturalista, por el contrario, pretende desacreditar cualquier tipo de valoración fuerte a través de un universo neutral y subjetivo. ${ }^{114}$ Charles Taylor trata de poner las bases de una ontología moral con argumentaciones de sentido sobre la imagen que asumimos y las valoraciones morales que nos identifican. ${ }^{115}$ No se trata de meras respuestas instintivas, sino que el mundo y el yo vienen configurados en una unidad de sentido sobre la cual el mundo despierta la identidad del yo, y el yo es capaz de vislumbrar un mundo que estructura y reconoce respuestas de sentido que configuran la identidad moral del hombre. ${ }^{116}$

La imagen que asumimos es, bajo el punto de vista de Taylor, el referente fundamental de sentido espiritual, que deviene en la configuración moral del propio yo $\mathrm{y}$, al mismo tiempo, estructura nuestra visión de acceso al mundo. Una imagen que a veces no está suficientemente articulada argumentalmente, pero que se da por hecho tanto a nivel personal como social. Una cosa es "lo que se cree oficialmente" y otra cosa es "lo que se necesita entender" como base fundamental de referencia de sentido. Frecuentemente, según Charles Taylor, se desacredita cualquier planteamiento ontológico como cuentos irrelevantes sin validez alguna, en base a epistemologías naturalistas, sociobiológicas y racionalistas de carácter reduccionista y, por otra parte, no deja de referirse a qué objetos son dignos de valor y cuáles son las reacciones más apropiadas. $^{117}$

\footnotetext{
${ }^{111}$ Cfr. Ibid., pág. 83.

112 Cfr. Ibid., pág. 25.

113 "Ningún argumento puede mover a alguien desde una postura neutral hacia el mundo, se haya adoptado esta por exigencias de la ciencia o sea consecuencia de una patología, hasta la razón de la ontología moral”. Ibid., pág. 26.

${ }^{114}$ Cfr. TAYLOR, Ch., La ética de la autenticidad, pág. 98; cfr. TAYLOR, Ch., Argumentos filosóficos, pág. 64.

${ }^{115}$ Cfr. TAYLOR, Ch., Fuentes del yo, págs. 112,115,149.

${ }^{116}$ Cfr. TAYLOR, Ch., Argumentos filosóficos, pág. 128.

${ }^{117}$ Cfr. TAYLOR, Ch., Fuentes del yo, pág. 121.
} 
Hay, por una parte, un saber oficial que se plantea como validez científica y sociobiológica, ${ }^{118}$ y, por otra, una necesidad de sentido que frecuentemente entran en controversia. Y lo que, según Taylor, suele hacerse para superar la contradicción es que dicho saber oficial reduccionista asume el papel de ontología moral, es decir, comienza por ofrecer la base para la discriminación sobre los objetos idóneos o las respuestas válidas. ${ }^{119}$ Se empieza discriminando cualquier argumentación ontológica y como alternativa se plantea una visión oficial de validez científica, que a su vez adquiere dimensión ontológica. Se parte de una teoría científica que destaca la irrelevancia de cualquier ontología moral y se termina afirmando el naturalismo desvinculado que solo reconoce el orden de la explicación científica. ${ }^{120}$ Charles Taylor afirma que los planteamientos ontológico-espirituales "reales" de dichos juicios morales contradicen las afirmaciones oficiales de la explicación sociobiológica y naturalista. ${ }^{121}$

Taylor asume la pretensión de recuperar la ontología moral, para identificarnos como seres metafísicos y adentrarnos en el sentido de las cosas, ${ }^{122}$ al propio tiempo que autentificar nuestro sentido de responsabilidad. ${ }^{123}$ Es decir que, para él, sin la asunción de la ontología moral, difícilmente podemos hablar de respuestas morales y de identidad moral del yo. La identidad moral del yo solo es explicable sobre la base del reconocimiento de las pretensiones que están en la base de nuestro comportamiento moral. El relato de Taylor pretende superar una visión meramente naturalista e instintiva de las respuestas morales, para dar una explicación fundamentada de lo que constituye la identidad moral de la persona humana.

Charles Taylor comienza afirmando que el mundo moral de los modernos es significativamente diferente al de civilizaciones anteriores. Para él, el hombre moderno, en su visión reduccionista de su identidad moral, tiende a considerar la moral referida casi de manera exclusiva al respeto a los demás y a las obligaciones que tenemos respecto de los otros. ${ }^{124}$ Taylor intenta ampliar este sentido restringido de la moral hacia

\footnotetext{
${ }^{118}$ Cfr. Ibid., pág. 124. Los asuntos humanos para el naturalismo sociobiológico aparecen descritos en términos externos, en continuidad con las ciencias de la naturaleza extrahumana, no en términos culturalmente vinculados. Frente a esto, Charles Taylor propone un lenguaje de descripción densa como lo hace Clifford Geertz. Taylor recurrirá de nuevo a dicho autor al hablar de "lo interior" y "lo exterior" a partir de los términos batin/lair.

${ }^{119}$ Cfr. TAYLOR, Ch., La ética de la autenticidad, págs. 129-130. "Sobre los trasfondos morales de la razón instrumental"; cfr. TAYLOR, Ch., Fuentes del yo, pág. 28.

${ }^{120}$ Cfr. TAYLOR, Ch., Fuentes del yo, pág. 569.

${ }^{121}$ Charles Taylor continúa afirmando que la discriminación hacia la irrelevancia de los argumentos ontológicos en la sociedad moderna se deben al pluralismo social y a los planteamientos epistemológicos y a las perspectivas espirituales derivadas de dicha epistemología. Dichos planteamientos epistemológicos están estudiados detalladamente en el apartado anterior titulado la superación de la tradición epistemológica.

${ }^{122}$ Cfr. TAYLOR, Ch., Argumentos filosóficos, pág. 230.

${ }^{123}$ Cfr. TAYLOR, Ch., Ética de la autenticidad, pág. 108.

${ }^{124}$ Cfr. TAYLOR, Ch., Fuentes del yo, págs. 122-123; cfr. TAYLOR, Ch., Argumentos filosóficos, pág. 179. Taylor clarifica el alcance del talante naturalista moderno y la epistemología que de dicha actitud se desprende: lo que hay que hacer frente a lo que hay que ser, la obligación frente a la naturaleza de la vida
} 
aspectos que tienen que ver con la dignidad de la vida humana y aquellos aspectos que hacen que la vida merezca la pena ser vivida. Es a lo que Charles Taylor se refiere cuando habla de la necesidad de fuertes valoraciones frente a aspectos triviales o cuestiones secundarias o reduccionistas. Taylor sostiene que la afirmación de los bienes constitutivos como fuente de valoración moral incluye tres ejes: el respeto y las obligaciones hacia los demás, los elementos que constituyen una vida plena $\mathrm{y}$, finalmente, las características por las que nos pensamos a nosotros mismos como sujetos merecedores del respeto de los demás.

Charles Taylor critica las visiones simplistas de la filosofía naturalista que intentan analizarlo todo desde la inevitabilidad propia de las reacciones naturales. Critica que para la filosofía naturalista no sea obvia la inevitabilidad de la dignidad humana, así como lo son las reacciones viscerales en nuestro propio comportamiento. Para Taylor, el interrogante absoluto no solo es posible que se plantee, sino que inevitablemente se plantea. ${ }^{125}$

Taylor defiende que hay algo que está meridianamente claro en el horizonte moral del mundo moderno: la pérdida de horizontes o de marcos de referencia tradicionales, manifestándose dicha pérdida como apatía hacia los mismos, o como problematicidad a la hora de ser abordados. El espacio de la fama, la ética del guerrero y el honor, la ética platónica de la vanagloria, han perdido cualquier referencia de sentido. La noción platónica del orden del ser ha dejado de ser comprensible y verosímil. Las religiones reveladas están siendo puestas de manera permanente en tela de juicio. Todo ello ha devenido en un desencanto weberiano, entendido como disipación del sentido del cosmos, como un orden de significados, y la aparición del atomismo naturalista y neutro. ${ }^{126}$ Se deja de mirar al cosmos o a los dioses como órdenes de significación, para ir interiorizando el horizonte de sentido moral en un yo que todo lo busca y lo discierne a partir de la razón.

\footnotetext{
buena, lo que debemos hacer frente a lo que hay que ser. Se excluye tanto lo que es bueno hacer como lo que puede ser bueno. No hay lugar para la noción del bien. Se trata de una filosofía de acción obligatoria. Explicar lo que genera las obligaciones válidas para nosotros, los criterios que nos permiten derivar aquello a lo que estamos obligados. La filosofía moral moderna basa sus principios en el utilitarismo (qué es lo que produce más felicidad a un mayor número de personas), en Kant (elegir una vez que hayas considerado las prescripciones ajenas como si fueran propias, qué criterios debo adoptar para distinguir qué acciones son obligatorias) y en Rawls/Habermas (normas en las que se pondrían de acuerdo todos los interesados si es que fuera posible deliberar conjuntamente). Habermas debe algo a Kant, a esas normas aceptadas por todos, pero ofrece un procedimiento "dialógico" en vez de la búsqueda en solitario kantiana. Frente a esto Charles Taylor aboga por la articulación de las "distinciones cualitativas" para saber identificar las fuentes morales que nos fundamentan y el sentido de nuestras acciones, explicando de manera completa y sustancial la orientación moral de nuestras acciones.

${ }^{125}$ Cfr. TAYLOR, Ch., Fuentes del yo, pág. 78.

${ }^{126}$ Cfr. TAYLOR, Ch., Argumentos filosóficos, pág. 106.
} 
No hay un marco referencial asumido por todos como una "formulación definitiva" que sea capaz de explicar el estatuto fenomenológico de un hecho dado. ${ }^{127}$ Siempre hay algo provisional en la adhesión y podemos vernos como si en cierto sentido siempre estuviéramos buscando algo. ${ }^{128}$

Taylor habla a este respecto de MacIntyre como iniciador de búsquedas en torno a la pregunta sobre cuál es o podría ser ese bien final, o ese marco de referencia global. Una búsqueda que adquiere contextos de narración para autocomprenderse y comprender el mundo. ${ }^{129}$ Se trata de una búsqueda como agentes racionales en clave de autoconocimiento y autoconciencia hegeliana. Buscar desde las experiencias con las que hemos entrado en contacto y que han supuesto una mayor autocomprensión del propio yo en la búsqueda de la propia identidad personal. Experiencias autorreveladoras del propio yo, entendido en clave de una mayor conciencia y conocimiento para entendernos a nosotros mismos. La búsqueda para MacIntyre es "esa percepción de mi vida como si estuviera encaminada en la dirección hacia lo que aún no soy", ${ }^{130}$ o lo que Taylor afirma "lo que soy ha de entenderse como lo que he llegado a ser". ${ }^{131}$

En este mismo sentido que MacIntyre, nuestro autor canadiense dice que encontramos el sentido de la vida al articularla, al narrarla. Encontrar significado a la vida es ser capaz de encontrar las palabras que definen el propio yo en su autoconciencia y en su autocomprensión. Es lo que Charles Taylor denomina "nuestro poder de expresión". De ahí la importancia de la Filosofía del Lenguaje para nuestro autor. La Filosofía del Lenguaje es la Filosofía que revela el sentido a través de la expresión que narra la propia autoconciencia. ${ }^{132}$ En el ámbito de los significados metabiológicos, la expresión, para Taylor, abre a dominios nuevos e insospechados.

Con el advenimiento de la Modernidad, opina Charles Taylor que las nuevas expresiones despliegan formas nuevas de estar en el mundo. Nos encontramos en el dominio de la innovación cultural. Es la fuerza particular y constituyente que tienen algunas expresiones. ${ }^{133} \mathrm{El}$ lenguaje expresa los desplazamientos de las fuentes morales a

\footnotetext{
${ }^{127}$ Cfr. TAYLOR, Ch., La Era Secular, tI, pág. 212.

${ }^{128}$ Cfr. TAYLOR, Ch., Fuentes del yo, págs. 11,39.

129 "Por lo tanto, los agentes reflexivos se entienden cada vez más a sí mismos y a otros en términos de cierto tipo de narración, una historia en la cual ellos como agentes se dirigen a sí mismos hacia un bien final o fracasan en ese intento, un bien final cuya naturaleza aprehenden inicialmente en y a través de sus actividades en tanto agentes racionales". MACINTYRE, A., Ética en los conflictos de la Modernidad. Rialp, Madrid, 2017, pág. 105.

Cfr. RICOEUR, P., La memoria, la historia, el olvido, págs. 366 y ss.

${ }^{130}$ TAYLOR, Ch., Fuentes del yo, pág. 81.

${ }^{131}$ Cfr. MACINTYRE, A., Etica de los Conflictos de la Modernidad, págs. 59-63

Cfr. TAYLOR, Ch., Fuentes del yo, pág. 80.

132 "Descubrir aquí, depende de la invención y está entretejido con ella. Encontrar un sentido para la vida depende del enmarque que demos a las expresiones significativas adecuadas. (...) las vidas tienen o carecen de significado cuando tienen o dejan de tener sentido; pero significado también se aplica al lenguaje o a otras formas de expresión”. Ibid., págs. 38-39.

${ }^{133}$ Cfr. TAYLOR, Ch., Animal de lenguaje, pág. 252.
} 
través del significado hecho narración. Por lo cual, según nuestro autor, existe el riesgo de "problematicidad" en el intento de establecer marcos de referencia, al propio tiempo de que existe el peligro de temor al sin sentido, a perder contornos espirituales, a una especie de vértigo de la nada, a una vida en constante fractura del no saber qué y para qué. ${ }^{134}$ Son los "conflictos inherentes de la cultura moderna" de los que habla Taylor. ${ }^{135}$

Frente a esta sensación de vacío y de no saber qué y hacia dónde, Charles Taylor utiliza una serie de términos que describen su relato filosófico: marcos referenciales, fuerte valoración, naturalismo, utilitarismo, conciencia moral moderna, discriminaciones cualitativas, lo incomparablemente mejor. Taylor habla también de la "ambivalencia modernista", entendida, por una parte, como la tensión entre la afirmación de la vida corriente y, por otra parte, como la necesidad de encontrar algunas de nuestras distinciones morales más importantes a pesar de la incapacidad moderna para articularlas. ${ }^{136}$ Anhelamos el héroe, pero preferimos vivir como antihéroes, afirmamos los ideales de los bienes mejores y más elevados y, al mismo tiempo, intentamos vivir desde las experiencias más concretas de la vida corriente. Esta es la confusión y reducción naturalista. Taylor se pregunta: ¿sé lo que digo? ¿Comprendo verdaderamente aquello de lo que hablo? ${ }^{137}$

Charles Taylor entiende que ir más allá de dichos límites y saltarse cualquier tipo de discriminación cualitativa lleva a no tomarse en serio la condición humana, lo que él denomina "lo intacto de la personalidad humana"; personalidad humana que viene definida por la cuestión de la identidad y por la pregunta: ¿Quién soy yo ${ }^{138}$ Es decir, si no sé dónde me encuentro y cómo me ubico en el mundo, difícilmente podré tomar postura, articular una narración, expresar el mundo en el que me encuentro desde lo que yo soy lo que considero digno de ser considerado como bueno, como admirable y como valioso. ${ }^{139}$ Sin esta valoración fuerte de la propia identidad moral, no será fácil que haya una orientación moral en términos de la pregunta: ¿Quién soy yo?

\footnotetext{
${ }^{134}$ Cfr. TAYLOR, Ch., Argumentos filosóficos, pág. 112.

${ }^{135}$ Cfr. TAYLOR, Ch., Fuentes del yo, pág. 150.

${ }^{136}$ Cfr. TAYLOR, Ch., La ética de la autenticidad, pág. 53.

${ }^{137}$ Cfr. TAYLOR, Ch., Fuentes del yo, pág. 66.

138 "Saber quién soy es como conocer dónde me encuentro. Mi identidad se define por los compromisos e identificaciones que proporcionan el marco u horizonte dentro del cual yo intento determinar, caso a caso, lo que es bueno, valioso, lo que se debe hacer, lo que apruebo o a lo que me opongo. En otras palabras, es el horizonte dentro del cual puedo adoptar una postura". TAYLOR, Ch., Fuentes del yo, pág. 52.

${ }^{139} \mathrm{Y}$ frente a esta autoconciencia expresiva de lo que soy y lo que considero narrativamente como valioso desde el propio autoconocimiento, lo opuesto sería una desorientación, una crisis de identidad, una incertidumbre respecto al lugar en que me encuentro, una vulnerabilidad frente a la ausencia de marco $u$ horizonte dentro del cual las cosas adquieren una significación estable y capacidad para percibir como buenas y significativas ciertas posibilidades vitales. Charles Taylor dice que la identidad autoconsciente da seguridad y orientación, saber quiénes somos, para identificar el espacio moral en el que nos movemos y ser capaces de distinciones cualitativas en torno al bien o al mal, a lo que merece la pena hacer o no, hacia lo que tiene significado e importancia o no. Es decir, que para Taylor no se puede responder por uno mismo si uno no sabe dónde se encuentra y a qué quiere responder.
} 
En opinión de Taylor, el riesgo y la problematicidad de la condición moral del hombre moderno es que se alejan de las nociones de carácter universal y cualitativo en relación al orden moral. Para el hombre de la época de la Reforma eso no tendría sentido. Había claramente definido un marco moral básico expresado en términos universales que orientaba la acción individual. Para el hombre moderno, esa unidad inquebrantable, en torno a los términos universales de discriminación cualitativa, se ha visto superada por otro tipo de discriminaciones de identificación personal, que hace que no haya una vinculación exclusiva a lo universal. Hay una identidad más profunda y multilateral, dirá Taylor, y, por lo tanto, más compleja, en la que los referentes universales tienen que ser matizados desde identificaciones individuales, en la que el héroe en su idealismo tiene que ser integrado armoniosamente con el antihéroe de lo particular y lo individual. ${ }^{140}$

Este es el gran cambio de la Modernidad: la identidad moral del sujeto humano debe responder por sí mismo, debe ser autoconsciente y autorresponsable. ${ }^{141}$

Taylor se sirve de la importancia dada en la Modernidad a la autodefinición responsable para reivindicar el establecimiento de valoraciones fuertes, para superar la sensación de vacío de algo que debe definirse sin saber cómo. Marcos referenciales que ofrezcan orientación moral y horizontes de sentido, a partir de los cuales, el hombre pueda ubicarse existencialmente para saber dónde está y qué significan las cosas. Dentro de dichos marcos referenciales, de dichas valoraciones fuertes y distinciones cualitativas, se define nuestra identidad moral, que nos permite definir lo que es realmente importante para nosotros y lo que no lo es. Las fuentes morales nos identifican ontológicamente y nos permiten realizar valoraciones cualitativas.

Por lo tanto, para Taylor, las descripciones mecanicistas, utilitaristas y naturalistas, que ponen al margen los marcos referenciales, no tienen sentido si queremos establecer una ontología moral que fundamente el sentido moral del yo. $\mathrm{Si}$ partimos del supuesto naturalista que afirma que la ontología moral o las valoraciones fuertes son un simple añadido a algo que no nos identifica como lo que somos, o meros inventos que no responden a nuestros interrogantes, entonces las distinciones cualitativas son despreciadas sobre la base de una consideración moral humana, basada en simples deseos, gustos, aversiones y antipatías, con una orientación básica de carácter naturalista.

\footnotetext{
${ }^{140} \mathrm{Y}$ aquí nos surge una pregunta: ¿Se puede, desde esta multilateralidad, expresar y narrar el sentido de lo auténticamente humano? ¿Se puede conjugar una armonía entre el ideal del héroe y la particularidad individualista del antihéroe? ¿Es posible articular una narración de estas antítesis?

${ }^{141}$ Cfr. TAYLOR, Ch., Argumentos filosóficos, pág. 49; cfr. TAYLOR, Ch., La edad secular, tII, págs. $281,415$.
} 
Las valoraciones fuertes serían consideradas como un invento al margen de nuestra naturaleza, definida por reacciones, deseos, gustos, aversiones...; y cualquier distinción cualitativa sería una adopción, que solo podría ser aceptada si es capaz de incorporarse en esa "naturaleza de orientación básica". ${ }^{142}$

Charles Taylor asegura que lo importante no es solo las valoraciones cualitativas en las que nos ubicamos moralmente, sino "dónde estamos situados en relación a dichas fuentes morales", evitando el "liberalismo de la neutralidad". ${ }^{143}$ Nuestra identidad moral no puede configurarse sin marcos referenciales que nos pongan en contacto con la idea del bien. Y al definir nuestra identidad moral se va acrecentando la autocomprensión de lo que vamos siendo en relación a nuestra ubicación, en relación a esa idea de lo cualitativamente mejor. La identidad moral y la idea de bien nos posicionan en la aspiración de contactar con la idea de bien, que no puede realizarse de otra manera que no sea a través de la identidad moral siendo asumida y definida como ideal de autorrealización. La cuestión fundamental es dónde me ubico en relación al bien y si estoy en contacto con él. Se trata de ver si la vida vale la pena, si es significativa, plena y sustancial, o vacía y vana, si posee unidad, o está desconectada de un centro vital configurador de la propia identidad.

\footnotetext{
${ }^{142}$ Cfr. TAYLOR, Ch., Fuentes del yo, pág. 41. Taylor habla de la profunda crisis que supone comprendernos a nosotros mismos desde la visión naturalista que relega las cuestiones sobre los marcos referenciales, como cuestiones adoptadas o como algo artificioso. Tal pretensión Charles Taylor la denomina como "una persona dominada por una tremenda crisis de identidad", sin saber cómo orientarse y cómo responder a las preguntas sobre quién soy o qué es lo importante y significativo para uno. Esta crisis de identidad potenciada por la visión naturalista dice Taylor que se expresa como una "imagen distorsionada y disociada" del propio yo, llegando a hablar de "trastorno" y de "ir más allá de los límites de la superficialidad". Taylor distingue entre la "visión patológica naturalista" y el "marco referencial del utilitarismo" que por el contrario sí que tiene un marco referencial caracterizado por la racionalidad y la benevolencia en esa búsqueda de la felicidad según las claves de la racionalidad. Para Taylor, las respuestas de una posible aceptación de la visión naturalista de una explicación fenomenológica de la identidad se queda corta, porque las distinciones cualitativas de valoraciones fuertes como explicación ontológica de la moral van más allá de la explicación fenomenológica tratando de llegar a las condiciones trascendentales de la vida humana y superando cualquier visión de definir la identidad moral sobre la base del hacer, de captar las posibilidades humanas desde lo que en realidad hacemos cuando hacemos algo. Taylor pone gran énfasis en oponerse a las tesis naturalistas por quedarse muy limitadas en la "visión de horizontes de sentido con valoraciones fuertes", sin los cuales, la identidad moral del hombre quedaría seriamente y patológicamente en entredicho.

${ }^{143}$ TAYLOR, Ch., La ética de la autenticidad, pág. 53. Taylor utiliza dos metáforas que creo son reseñables para acercarnos a la interrelación entre la identidad moral y el bien: "el contacto" con el bien y "dónde nos situamos" en relación al bien. La imagen del contacto nos hace caer en la cuenta de que el bien no es algo abstracto, sino asumido existencialmente, que tiene que ver con algo que se encarna y con lo que uno puede contactar a través de la propia vida que se deja moldear por la divinidad, o por, el honor, o por el autodominio racional, o por la afirmación de la vida corriente, o por formas expresivas de carácter artístico. Y en relación con la imagen de la "situación" en relación al bien, esta metáfora nos ayuda a entender el bien como una toma de postura, que nos sitúa y nos ubica en un lugar que nos permite reconocernos como identidades moldeadas por el bien, y que nos hace estar satisfechos donde estamos: la razón a través de una vida en orden, la familia a través de espacios de felicidad e intimidad doméstica... y en el lado opuesto por "insatisfacción" de lo que se vive: dominio de pasiones, sentido de impotencia, vacío existencial, sentido de conformidad mezquina.
} 
En relación con la aspiración moderna al significado, hay una evidente concordancia con otras aspiraciones fraguadas históricamente y que tienen que ver con el deseo de ser mejor, o de una búsqueda de la inmortalidad; aspiraciones que se han manifestado bajo distintas formas, como la fama, valores...; o bien relacionándose con algo externo superior, como la vida eterna, o ideales a través de una historia más elevada. Para Taylor, es imposible deshacerse de los marcos referenciales y de las discriminaciones cualitativas. ${ }^{144}$

Así pues, si la relación entre el bien y la identidad personal viene caracterizada por una ubicación en relación a dicho bien, está claro que lo fundamental no es solo dónde estamos sino hacia dónde vamos. En consecuencia, Charles Taylor afirma que la cuestión fundamental jamás se agota en lo que somos, porque la dinámica del hacia dónde vamos nos hace caer en la cuenta de que siempre estamos cambiando. La metáfora de la ubicación espacial, en relación al bien, define una identidad en la que lo más relevante no es tanto el más o menos, en relación a dicho bien, cuanto la dinámica de cambio en la que estamos inmersos en relación a dicho bien. O lo que es lo mismo, la cuestión de la identidad moral no es tanto una cuestión de más o menos cuanto de sí o no, es decir, si nos encontramos en un proceso de ir acercándonos cada vez más al bien. Para Charles Taylor, pues, lo realmente importante es la dirección de nuestras vidas, hacia dónde se encaminan nuestros pasos en relación al bien. Y esto hace de nosotros seres que cambian, que van deviniendo, que están en un proceso constante hacia el bien como foco orientador de la propia identidad personal o si estoy en contacto con él.

Charles Taylor nos remite a uno de sus grandes referentes filosóficos, Heidegger, que entiende al ser en relación al tiempo, un ser que se va realizando en el tiempo y en la historia, que es capaz de narrar de sí mismo, un ser-en-el-mundo, encarnado en el tiempo, que se hace historia personal, y una historia que va siendo asumida por la autoconciencia de lo que vamos siendo. El ser es lo que está siendo en el tiempo, es temporeidad. ${ }^{145}$ El ser es lo que está realizándose en el cambio hacia donde se va encaminando. Y cualquier significado que atribuyamos a la parte debe tener sentido en el conjunto, y contribuir a definir el significado de este. ${ }^{146}$

La identidad como autocomprensión hacia donde nos vamos encaminando no olvida la autoconciencia de dónde estoy y de mi lugar en referencia al bien. Desde lo que soy (ahí estaba A) entonces me encamino (hago B) hacia lo que proyecto llegar a ser. Y en esta dialéctica entre lo que soy y lo que proyecto llegar a ser (que nos recuerda a Hegel), lo que soy estaba siendo (ahí estaba A) porque deviene en un proyecto que está empezando a ser (hago B). Se trata de una dinámica procesual entre el ser y el hacer

\footnotetext{
${ }^{144}$ Cfr. TAYLOR, Ch., Fuentes del yo, pág. 51.

${ }^{145}$ Cfr. HEIDEGGER, M., Ser y tiempo, pág. 40.

${ }^{146}$ Cfr. TAYLOR, Ch., Animal de lenguaje, pág. 290.
} 
que va recreando la propia historia en una dinámica narrativa. Una narración que no es simplemente estructurar el presente, sino que, como dirá Charles Taylor, la narración forma parte de este proyecto que está deviniendo, porque lo que soy ha de entenderse como lo que he llegado a ser. ${ }^{147}$

Para nuestro autor, la narración se convierte en la clave para entendernos como lo que estamos siendo y llegando a ser. "No podemos estar siendo", si no, no nos entendemos desde esta dinámica histórico-narrativa que nos ubica en una identidad hacia la que nos encaminamos desde lo que ya somos.

En definitiva, Taylor pretende poner las bases de un proyecto de construcción de la propia identidad moral, desde la narración de lo que la vista ha alcanzado a mirar, para proyectar la mirada sobre lo que somos capaces de ser. El futuro es lo que somos capaces de narrar sobre la autoconciencia de lo que hemos sido y en la capacidad de proyectarnos hacia el pasado. Sabemos lo que somos a través de lo que hemos llegado a ser. Y eso requiere una actitud narrativa en la vida que aporta autopercepción y conciencia.

Para lograr su proyecto, Charles Taylor indaga en la definición de la identidad del yo como autoconciencia, la conciencia de sí mismo, la percepción de sí mismo, lo que se aparece esencialmente a sí mismo. Y se refiere a Locke, porque su concepción filosófica tendrá una gran repercusión en la concepción moderna de lo que significa la identidad. Un yo que viene definido en términos neutros, sin marcos de referencia, neutro, puntual, desvinculado, sujeto de control racional, que olvida que el ser se construye fundamentalmente como autopreocupación y cuya comprensión de sí mismo queda reducido a la neutralidad, a un punto desvinculado de cualquier inquietud constitutiva, un yo reducido a la autoconciencia. Este es el yo moderno, puntual, que parece carecer de cualquier valoración constitutiva moralmente.

Charles Taylor reivindica, frente al yo "puntual" lockeano, un yo como espacio de cuestiones e inquietudes constitutivas. Frente a la imagen del punto para expresar el yo reducido a la mera autoconciencia, Charles Taylor aboga por la imagen del "espacio" para identificar a un yo abierto a los interrogantes y a las inquietudes en relación con el bien, por el cual uno se orienta y se sitúa en relación a él. Frente a un yo reducido a un punto, Taylor propugna un yo expansivo, espaciado y abierto como un ser de inquietudes y convicciones, con una capacidad narrativa que le proyecta hacia lo que está encaminándose, que está llamado a configurarse al completo, como una unidad en torno a un centro vital orientador y configurador de identidad y personeidad. No puedo saber lo que soy si no soy capaz de narrar cómo he llegado a ser lo que soy, de escribir una biografía en torno a una unidad significativa, con un presente que manifiesta huellas

${ }^{147}$ Cfr. TAYLOR, Ch., Fuentes del yo, pág. 80. 
del pasado y que se en-camina y proyecta hacia el futuro, es decir, que sobre la base de lo que soy proyecto mi futuro.

Asimismo, según Taylor, somos seres que poseen los requisitos de profundidad y complejidad, en el sentido de que tienen una identidad, o luchan por conseguirla. ${ }^{148}$ Taylor trata de criticar las restricciones que suponen: a) el yo freudiano, que lucha por ocupar su espacio de libertad frente al ello y al superyó, buscando el mayor margen posible de beneficios; y b) el yo psicológico o sociológico, caracterizado como imagen de uno mismo, que apenas guarda conexión con la autocomprensión moral y autodefinidora, y cuya imagen está inducida socialmente y viene caracterizada como "la humana-demasiado-humana debilidad del ego". ${ }^{149}$

Frente a dichas versiones problemáticas del yo, Charles Taylor considera un yo que conecta identidad y bien, y que afirma imperiosamente la necesidad de marcos de referencia que sostienen la propia identidad para una orientación al bien, afirmando la identidad moral que está asociada a valoraciones fuertes desde un punto de vista cualitativo. El yo no puede ser aprehendido científicamente porque no es un objeto y no puede ser reducido a un mero ideal de autoelección que elimina las condiciones de significado. ${ }^{150}$ De ahí la importancia del "relato" de autocomprensión, en la que el fragmento es una parte del evento y contribuye a retomar la vida "en su conjunto". ${ }^{151}$

Por otra parte, Charles Taylor llega a afirmar que no es posible articular total y absolutamente lo que somos. Una narrativa abre campos a nuevas explicaciones de sentido, pero nunca se termina de completar el alcance de lo que somos. La narración de nuestra identidad abre caminos a nuevos interrogantes y a valoraciones nuevas, a nuevas referencias de ontología moral que nunca se dan por concluidas. Por eso, Taylor da tanta importancia al lenguaje y a los lenguajes que exploran la identidad del yo como parte del objeto de estudio. El lenguaje siempre existe como comunidad lingüística en la que el yo solo puede concebirse y entenderse en referencia al entorno y a los otros con los que interacciona. Adquiero identidad personal en el contacto con el lenguaje y con los otros. Taylor dice que la manera de introducirnos en la "personeidad" solo es posible a través del lenguaje. ${ }^{152}$ Los significados se identifican dentro de la comunidad lingüística

\footnotetext{
${ }^{148}$ Cfr. TAYLOR, Ch., Argumentos filosóficos, pág. 241.

149 ¿El estudio científico del objeto es aplicable al yo, tal y como lo hace la psicología y las ciencias sociales? Un estudio científico en el que el objeto de estudio es considerado objetivamente (no por significaciones de valoración fuerte), "considerado independientemente de cualquier consideración subjetiva", con el objetivo de establecer una "descripción explícita, sin referencia a su entorno".

${ }^{150}$ Cfr. TAYLOR, Ch., La ética de la autenticidad, pág. 75.

151 "Lo que soy como un yo, mi identidad, está esencialmente definida por la manera en que las cosas son significativas para mí. (...) y el asunto de mi identidad se elabora solo mediante un lenguaje de interpretación que he aceptado como válida articulación de esas cuestiones... Solo somos yos en la medida en que nos movemos en un cierto espacio de interrogantes, mientras buscamos y encontramos una orientación al bien" TAYLOR, Ch., Fuentes del yo, págs. 61-62.

${ }^{152} \mathrm{Y}$ antes que el lenguaje, Winnicott habla de objetos y fenómenos transicionales que son "otra forma de lenguaje" que ayuda a forjar la "personeidad" en contacto con lo que le rodea. "El niño se hace la ilusión
} 
en la que estoy inserto y el sentido de las palabras clave para mí serán los significados que dichas palabras tengan para nosotros en una conversación de carácter dialógico o en algo similar a un círculo hermenéutico. ${ }^{153}$

Si las palabras no significan nada para nosotros, difícilmente significarán algo para el niño. Y solo a partir de significados comunes y compartidos podré matizar conceptos y significados con alcance propio. Taylor habla de que sin ese lenguaje compartido básico que crea personeidad, difícilmente el niño podría salir de su anonimato y oscuridad confusa. ${ }^{154}$

Luego la identidad moral para Charles Taylor viene definida por dos ámbitos configuradores: desde las preguntas de significado que voy articulando en torno a la pregunta “ ¿quién soy yo?”, narrando lo que es importante para mí y lo que tiene sentido (toma de posición en las cuestiones morales y espirituales a través de las valoraciones fuertes y las discriminaciones de sentido) y, al mismo tiempo, desde el lugar de donde hablo y a quién hablo (la urdimbre de la interlocución en referencia a una comunidad definidora). ${ }^{155}$

Saber lo que se quiere decir no puede realizarse sin sentirnos pertenecientes a una comunidad lingüística. Nuestra propia originalidad lingüística entra necesariamente en conexión con una urdimbre de significados compartidos a través de una comunión lingüística. Adquirir un lenguaje original, propio, que nos hace conscientes del alcance significativo de nuestras palabras, significa que hay un camino hacia la autenticidad que

de que existe una realidad externa que corresponde a su capacidad de crear. De este modo, el seno materno es creado por el niño tantas veces como tiene necesidad. 'La madre pone el seno real allí donde el niño está listo para crear y al momento justo.' Desde un punto de vista psicológico, en esta relación no hay ningún tipo de intercambio. El niño se alimenta de un seno que es parte de él mismo, y la madre alimenta a un niño que es parte de ella. Lo mismo que el lenguaje 'personea' al individuo, así también en etapas anteriores los objetos y fenómenos transicionales van haciendo que el niño se vaya identificando con su propio yo". GALLEGO, F., "La religiosidad en los primeros años de la Infancia. Perspectivas Teóricas", Consonancias, 9, No 34, (2010), pág. 12.

${ }^{153}$ Cfr. TAYLOR, Ch., Animal de lenguaje, págs. 253,290.

154، 'Soy un yo solo en relación con ciertos interlocutores; en cierta manera, en relación a esos compañeros de conversación que fueron esenciales para que lograra mi propia autodefinición (...) El yo solo existe dentro de lo que denomino la 'urdimbre de la interlocución'”. TAYLOR, Ch., Fuentes del yo, pág. 64.

${ }^{155}$ Cfr. TAYLOR, Ch., La ética de la autenticidad, pág. 70. Charles Taylor afirma que la cultura moderna ha potenciado más el individualismo que la urdimbre de interlocución y analiza cómo las más importantes tradiciones espirituales y filosóficas han potenciado el desapego de determinadas urdimbres comunitarias: el libro de los profetas y salmos, Platón y la opinión ateniense, el ideal de los héroes... No obstante, Taylor continúa afirmando que los espacios para la originalidad y el individualismo solo serán posibles, si no se quiere caer en la confusión y la ambigüedad, si se rompe con la comunidad lingüística que pone en relación con los demás. Mi visión del mundo no puede desvincularse de la genealogía subyacente a dicha urdimbre lingüística. La propia originalidad debe ser contrastada con el pensamiento y por ende con el lenguaje de los otros, que es testigo de una herencia que nos vincula. La propia originalidad se expresará en un lenguaje que lleva consigo las experiencias comunes de una historia y una valoración del ser humano de los que no podemos desvincularnos. No podríamos expresarnos desconectándonos de dicha comunidad lingüística a la que subyace una genealogía moral y una visión que heredamos. Uno de los retos de la razón moderna es que podemos tener necesidad de relaciones para realizarnos, pero no para definirnos. 
pasa por configurar lo que realmente me importa y es decisivo para mí y que encuentra fuerza motivacional en la comunidad. ${ }^{156}$

Según Charles Taylor, la fuerza que en la Modernidad adquiere el individualismo, ha llevado consigo ciertas visiones de la identidad personal y del lenguaje que la han negado casi por completo. Son las teorías modernas del lenguaje de Hobbes, Locke y Condillac, que lo presentan como un instrumento que puede ser inventado por cada individuo, pudiendo alcanzar así un carácter privado. Ya hemos comentado la crítica de Wittgenstein sobre la posibilidad de un lenguaje privado, así como lo que Charles Taylor denomina "la imagen habitual del yo moderno". ${ }^{157}$

En la condición moderna se da a ese salto hacia afuera de la condición trascendental de la interlocución, resaltando, de manera casi exclusiva, la postura independiente y olvidándonos de la urdimbre interlocutoria en la que estamos inmersos ontológicamente. Taylor, siguiendo a Heidegger, Gadamer y Ricoeur, intenta resaltar "la condición trascendental de la interlocución" para superar la confusión del yo moderno. El relato tayloriano pretende resaltar la importancia de la comunidad linguística, comunidad que nos pone en relación con el pequeño grupo al que nos adherimos (justos, salvados, sabios, verdaderos creyentes). Pequeño grupo que tiene que ver con el círculo hermenéutico que, según Taylor, se puede generalizar, para entender cómo actuamos con la serie de significados interdependientes que son centrales para nuestra autocomprensión humana. ${ }^{158}$ Taylor habla también de la comunión cargada de emoción, así como de la "experiencia y expresión" capaces de articular la propia autodefinición moral. $^{159}$

La crítica tayloriana a la modernidad considera la importancia de realizar una categorización de los bienes, definiéndolos por un "contraste cualitativo", concediendo a uno de ellos una importancia superior con relación a los otros. Es este bien fundamental el que compromete la identidad de la persona y el que proporciona las pautas para juzgar la orientación de su vida. Todos los demás bienes son considerados en su adecuada proporción y como referente de valoración personal y social. No obstante, lo que Taylor denomina "único bien supremo" adquiere una relevancia especial, como el que mejor define la identidad de la persona, dado que es el bien lo que motiva las actuaciones más nobles de la persona. Para Taylor, en este proceso de definición y autonombramiento, comprendemos la situación desesperada y trágica de no tener biografía moral, de quedarse sin identidad. ${ }^{160}$

\footnotetext{
${ }^{156}$ Cfr. TAYLOR, Ch., Animal de lenguaje, pág. 255.

${ }^{157}$ Cfr. TAYLOR, Ch., Fuentes del yo, pág. 91.

${ }^{158}$ Cfr. TAYLOR, Ch., Animal de lenguaje, pág. 290.

${ }^{159}$ Cfr. Ibid., pág. 306.

${ }^{160}$ Cfr. Id., pág. 306.
} 
Es ese bien el que me identifica y hacia el que oriento mi vida, es ese bien especial de tal relevancia para mi vida, que desviarse de él o no encarrilar la propia vida en función de él, crea una sensación de amenaza e inseguridad que golpea los propios fundamentos de mi ser persona. Y en sentido contrario, tener encaminada la propia vida en dirección a dicho bien es lo que crea una sensación de felicitad e integridad que confiere un sentido de plenitud a la propia vida.

Taylor habla de una "discontinuidad cualitativa" entre ese bien superior que compromete fundamentalmente la vida y los demás bienes que son reconocidos como tales y respecto a los cuales puedo tener un sentido de mayor o menor reconocimiento. Es más imperiosa la fuerza que fundamenta la orientación hacia dicho bien superior, que el reconocimiento de una vida con valores. Son estos bienes de orden superior a los que Taylor se refiere como "hiperbienes" dado que son más relevantes que los otros, dan un fundamento de identidad moral a la persona y permiten juzgar y decidir sobre ellos. ${ }^{161}$

En la cultura moderna, los hiperbienes vienen identificados por la noción de justicia o benevolencia universal, según la cual todos deben ser tratados con la misma dignidad y respeto, independientemente de su raza, lengua, sexo, cultura o religión. Una cultura que da por superada cualquier concepción jerárquica de la sociedad y que vincula dichos hiperbienes con la ciencia. Son estos hiperbienes de nuestra cultura moderna los que han ido desfundamentando otros referentes morales, en torno a los cuales se establecieron hiperbienes anteriores, basados en el platonismo y en las revelaciones judeo-cristianas; lo mismo que estas últimas, desfundamentaron hiperbienes que fueron establecidos sobre la base de la ética homérica del honor o formas de idolatrías religiosas.

Taylor propugna un "naturalismo depurado" que vaya más allá de las valoraciones morales como proyecciones subjetivas sobre un mundo neutro. Si el naturalismo nos ha hecho caer en la cuenta de que nuestras valoraciones tienen mucho que ver con la experiencia de cómo nos situamos en el mundo, Taylor plantea un reto a un naturalismo más depurado que pudiera entender nuestras valoraciones como parte de las percepciones del mundo y de nuestra existencia social, que son inseparables de nuestro modo de vivir y que no pueden estar al margen de ciertas distinciones cualitativas.

\footnotetext{
${ }^{161}$ Cfr. TAYLOR, Ch., Fuentes del yo, pág. 104. Las dos visiones clásicas sobre los hiperbienes están representadas por Platón y Aristóteles. El primero representa lo que Taylor considera la "postura de la intransigencia revisionista", que pretende negar por completo cualquier bien que se interponga en el camino del hiperbién. Todo está enfocado hacia el hiperbién y se niegan por completo otros bienes menores. Por el contrario, Aristóteles representa la teoría inclusiva, es decir, la postura de afirmar todos los bienes, aunque reconoce también que hay bienes de rango superior como los que tienen que ver con la vida racional (theoria y phronesis) y que tendrían una consideración de prioridad, pero sobre la base común de una afirmación general de todos los bienes juntos y en proporciones adecuadas. Aristóteles habla del "bien completo", todos los bienes en la proporción adecuada. No hay unificación. Cada bien es bueno porque está en esa totalidad, no porque lo sea en sí.
} 
Luego el malestar epistemológico en torno a los hiperbienes, fruto de nuestra cultura moderna racional-naturalista, se superaría, según Taylor, con la aceptación de que las palabras morales no son solo proyecciones subjetivas en torno a un mundo neutro, sino aceptando que nuestra experiencia del mundo se incardina y tiene lugar a partir de distinciones cualitativas. Charles Taylor habla así de que la objetividad de nuestras valoraciones y distinciones cualitativas está imbricada en nuestras formas de vida, en una comprensión encarnada, en ese habitus que activa las reglas. ${ }^{162}$

Frente a un naturalismo basto, que pretende demostrar la invalidez de cualquier distinción moral o hiperbienes al ir, de alguna manera, en contra de las bases de nuestras valoraciones y reacciones subjetivas, Charles Taylor no solo propugna un naturalismo depurado con el que poder entrar en diálogo, sino que pretende recurrir a lo que él denomina la "fenomenología moral". Una fenomenología que considera que la orientación al bien no es algo opcional, y frente a lo cual uno puede "abstenerse" o "abstraerse". Se trata de afirmar la condición de ser yos con una identidad moral que permite realizar valoraciones fuertes y no meras reacciones subjetivas ante el mundo o proyecciones ante un mundo neutro. Es decir, la existencia humana, la identidad moral del yo se fundamenta en la consideración de que somos seres humanos con una forma de vida dada, con una cierta forma de vida en orientación hacia el bien, con una conciencia. $^{163}$

Taylor afirma que, intentando superar cualquier visión naturalista de corte bajo, no podemos explicar el mundo de otra manera sin esta fenomenología moral, que nos lleva a definir los asuntos humanos en términos del significado que las cosas tienen para nosotros. Es lo que él mismo denomina como una ontología moral, que es capaz de "dar la mejor explicación" a lo que las cosas significan para nosotros, superando así cualquier inquietud epistemológica promovida por el naturalismo y el precedente platónico en torno a los hiperbienes. ${ }^{164}$

\footnotetext{
${ }^{162}$ Cfr. TAYLOR, Ch., Argumentos filosóficos, pág. 238.

${ }^{163}$ Cfr. TAYLOR, Ch., Fuentes del yo, pág. 108.

${ }^{164}$ Es muy interesante la reflexión de Taylor en torno al escepticismo moderno hacia los hiperbienes por lo que supone, en primer lugar, de falta de acuerdo y la carencia de unanimidad en torno a los mismos. En un segundo lugar, por el hecho de lo que implican como un referente de cambio, superación o elevación moral, o incluso a veces de rechazo a bienes anteriores. De ahí que como reacción el naturalismo moderno haya intentado fundamentar lo común, lo no regenerado, lo primitivo, la conciencia común, l'homme moyen sensuel concediendo así una gran importancia a la afirmación de la vida corriente, frente a formas de vida superiores o consideradas más altas, como el ascetismo, la contemplación, el heroísmo idealista... De ahí las reacciones que frecuentemente se han desencadenado en contra de la religión como promotora de dichas formas más altas, frente a la reivindicación de lo primitivo y el deseo naturalista de la satisfacción. Y de ahí también la referencia de Taylor a Nietzsche como el que pretende deshacerse de cualquier referente moral para volver a la autoafirmación, sin otro referente que la voluntad de poder. "La expresión nietzscheana 'voluntad de poder' quiere decir: la voluntad, tal como se la comprende comúnmente, es propia y exclusivamente voluntad de poder... La expresión voluntad de poder no significa que la voluntad, en concordancia con la opinión habitual, sea un tipo de apetencia, el cual, sin embargo, tendría como meta el poder, en lugar de la felicidad o el placer... Tomado estrictamente en el
} 
Charles Taylor reflexiona también sobre las dos visiones que engendran sospechas sobre los hiperbienes. ${ }^{165}$ La primera es la consideración de los hiperbienes desautorizados desde el razonamiento práctico al margen de convicciones morales. ${ }^{166}$ Taylor, en esta reflexión sobre la ontología moral y los prejuicios naturalistas sobre la incomodidad epistemológica moderna frente a los hiperbienes, trata de analizar lo que suponen los argumentos de transición según el modelo del razonamiento práctico, de tanta raigambre en la tradición epistemológica. Se trata de una postura epistemológica que supone no la dinámica "correcto" (A) frente a "incorrecto" (B), sino la transición de A a B a partir de la dinámica superior comparativamente. Argumentar las contradicciones existentes en A, como ganancia y superación de errores a través del paso a $\mathrm{B}$ es una transición no solo correcta, sino necesaria. Y hay que demostrar dichas transiciones tanto de A a B, como de $\mathrm{B}$ a A, demostrando la ganancia argumentativa en ambas direcciones. Así, para el razonamiento práctico, la argumentación de transiciones se convierte en un razonamiento comparativo de una superioridad que se impone por la fuerza de la ganancia, es decir, que hay bienes superiores que implican capacidad de reducción de error, al propio tiempo que un avance epistémico. Taylor afirma que esto es todo un desafío, pues la crítica demoledora nietzscheana a la moral se realiza en base a la transición que produjo el hiperbién referencial a la moral de esclavos explorando genealogías de razonamiento práctico. El hiperbién, dirá Taylor, no puede definirse por la genealogía de transiciones, sino por su génesis. Se esconde un peligro en el razonamiento práctico de los argumentos de transición enraizado en nuestra tradición epistemológica. Taylor invita más bien a buscar las referencias valorativas que nos mueven moralmente. Se trata de analizar la génesis, no la transición del hiperbién. Para nuestro autor el argumento comparativo de razonamiento práctico esconde un gran peligro.

La segunda sospecha moderna contra los hiperbienes es la que despiertan, desde nuestra concepción naturalista y científica, concepciones que aparecen como desvinculadas de nuestras concepciones modernas y de la vida ordinaria, tales como el Bien platónico, o visiones teístas de la revelación divina, o nociones románticas de la Naturaleza como fuente primordial. Dichas visiones problemáticas no son consideradas en sí mismas como tales. Su sospecha surge de la visión moderna de que, para aceptar

sentido del concepto nietzscheano de voluntad, el poder no puede ser nunca antepuesto a la voluntad como una meta, como si el poder fuera algo que pudiera ponerse de antemano fuera de la voluntad. Puesto que la voluntad es resolución a sí mismo, en cuanto dominar más allá de sí, puesto que la voluntad es querer más allá de sí, la voluntad es el poderío que se da poder a sí como poder". HEIDEGGER, M., Nietzsche, Ariel, Madrid, 2014, pág. 49. De ahí que frecuentemente la Modernidad ha considerado que el hiperbién y los representantes de dicha moral superior (sacerdocio y aristocracia) hayan potenciado una moral de superiores e inferiores, potenciando así formas de exclusión y dominación bajo aspectos de marginación.

${ }^{165}$ Cfr. TAYLOR, Ch., Fuentes del yo, pág. 109.

${ }^{166}$ TAYLOR, Ch., Argumentos filosóficos, págs. 61-62, 219. 
algo complejo, tiene que tener la característica de que "nos muevan". ${ }^{167}$ No se percibe el bien como algo que nos importa y nos configura moralmente, o al cual le reconocemos su autoridad, o al que damos adhesión por la fuerza de la empatía social, sino como algo cuya fuerza empodera y encaja en un proyecto de libertad autodeterminada que nos mueve a ello. ${ }^{168}$ Charles Taylor afirma que este es un modelo falsificador, pues nos desubica de las fuentes morales, de la fenomenología moral y de la ontología de las referencias morales. El bien moral y la identificación personal no deben consistir en el que nos muevan, cuanto la consciencia de ser movidos por un bien superior. Es valioso el bien que nos mueve, no la reacción natural subjetiva que nos mueve. Nos debe mover lo que se percibe como infinitamente valioso, no el hecho de ser movidos por algo independientemente de su valor. Sostiene Taylor que cualquier movimiento axiológico debe ir en esa dirección moral, dado que, de lo contrario, no sería computado como hiperbién. Si lo que me mueve es un bien mayor en la reducción-de-error, estaríamos encaminados hacia un movimiento superior con capacidad de identificación moral. Si lo que me mueve queda en el ámbito subjetivo del relativismo moral, puede que estemos falsificando y desconfigurando las fuentes del enriquecimiento valorativo. ${ }^{169}$ Taylor habla de la consciencia en el asentimiento de las transiciones. Una consciencia que se expresa corporalmente a través de reacciones somáticas, y que supone para el yo lo que Taylor denomina una "ocasión particular" que enfatiza la confianza y el sentido, así como la autoafirmación de las ganancias. En clave hegeliana, es lo que significaría un incremento de autoconciencia en el que "la subjetividad necesita estar relacionada con algo más para poder ser". ${ }^{170}$

Los hiperbienes y las valoraciones fuertes también tienen que ver con la configuración de la relación trascendente/inmanente. Para Taylor, el gran invento de la modernidad occidental es la de buscar un orden inmanente a la Naturaleza, que puede ser explicado desde la ciencia postgalileana, dejando abierta la posibilidad de la búsqueda de una significación de sentido trascendente a través de un Creador. Para él, esta noción de lo "inmanente" implicaba de alguna manera negar, aislar o problematizar cualquier relación entre las cosas de la Naturaleza y un Dios trascendente o la fuerza de los espíritus o fuerzas mágicas. Se trata, según su opinión, de una distinción fundamental para comprender los cambios que han tenido lugar en Occidente desde la llegada de la Modernidad, y ver si las personas reconocen algo que esté más allá de sus vidas o de la Naturaleza. ${ }^{171}$ Taylor pretende realizar el estudio de la Modernidad a partir de la antinomia inmanente/trascendente, porque para él, dicha antinomia es lo que interesa realmente al estudio de la secularidad, a pesar de la vaguedad o ambigüedad del

\footnotetext{
${ }^{167}$ TAYLOR, Ch., La ética de la autenticidad, pág. 82 y ss.

${ }^{168}$ Cfr. TAYLOR, Ch., El multiculturalismo y la política del reconocimiento, págs. 49-51; cfr. TAYLOR, Ch., La ética de la autenticidad, pág. 130.

${ }^{169}$ Cfr. TAYLOR, Ch., Fuentes del yo, pág. 115.

170 TAYLOR, Ch., Hegel, pág. 35.

${ }^{171}$ Cfr. TAYLOR, Ch., Fuentes del yo, pág. 123.
} 
concepto trascendente, y a pesar de que la distinción inmanente/trascendente haya sido construida a lo largo del proceso de la modernidad. Por lo que, en su opinión, es fundamental reconstruir la narración de la secularidad moderna.

Por otra parte, y en relación a lo anterior, Taylor habla de un concepto clave: la "desinserción". ${ }^{172}$ Un concepto que está en íntima relación con otros dos términos. El primer término es "plenitud" y tiene que ver con la bienaventuranza humana y su relación con la Religión. El segundo término es "inserción" y tiene que ver con la Religión y su relación con la bienaventuranza humana. Se trata de dos conceptos que interrelacionan Religión y bienaventuranza humana en sentidos ambivalentes y diversos. $^{173}$

Considera Taylor que el advenimiento de Modernidad secularizadora supuso una uniformidad en principios y objetivos propia del orden racional, frente a lo que él denomina "complementariedades ambivalentes" del mundo encantado asociado a las religiones. Este concepto de ambivalencia, que se vivía con tanta naturalidad en las sociedades antiguas, se expresaba en la coexistencia pacífica entre vida mundana y rigorismo monástico, entre orden cotidiano y ruptura temporal del mismo. Para el mundo encantado y para la Religión, la ambivalencia puede coexistir y no se impone ningún orden racional uniformador. Es la ingenuidad que permite orden y ruptura temporal, vida mundana y ciertos elementos de rigor espiritual (tiempos superiores, vida monástica...). La relación entre Religión y bienaventuranza humana se expresaba ingenuamente desde la ambivalencia y la coexistencia. ${ }^{174}$

Con la llegada de la Modernidad, se impone una uniformidad racional que elimina aspectos que eran vividos encantadamente, y se expulsan los espíritus que impiden la racionalización del orden. Se pasa progresivamente de lo que Taylor denomina un equilibrio inestable de la era postaxial entre la devoción individual y los rituales sociales, a una novedad Moderna en la que se impone el desencantamiento, la moral virtuosa racional y la religión individual. ${ }^{175}$ Esto es una novedad para nuestro autor canadiense, ya que hasta entonces las religiones habían identificado las fuentes morales del yo desde la trascendencia que encantaba el mundo y lo espiritualizaba. Ahora la novedad consiste en una ruptura del equilibrio para pasar a un orden moral racional y uniformador. ${ }^{176}$

Es lo que Taylor denomina "la gran desinserción", que de alguna manera estaba implícita en la revolución axial y que ahora llega a su expresión máxima con la llegada

\footnotetext{
${ }^{172}$ Cfr. TAYLOR, Ch., La Era Secular, tI, pág. 237.

${ }^{173}$ Cfr. TAYLOR, Ch., Argumentos filosóficos, págs. 175-197.

${ }^{174}$ Cfr. TAYLOR, Ch., La Era Secular, tI, págs. 46-47.

${ }^{175}$ Cfr. TAYLOR, Ch., La ética de la autenticidad, págs. 61-62.

${ }^{176}$ Cfr. TAYLOR, Ch., MACLURE, J., Laicidad y libertad de conciencia, Alianza Editorial, Madrid, 2011, pág. 23; cfr. TAYLOR, Ch., Hegel, pág. 61.
} 
de la Modernidad secularizadora. Pero veamos qué autores estudia Taylor que nos ayuden a comprender esta desinserción axial y en qué medida, a partir de ella, se configurarán procesos secularizadores. ${ }^{177}$

\section{III.1.2.-LA IDENTIDAD DEL YO EN SU PROCESO DE DESVINCULACIÓN DE LA RAZÓN TRASCENDENTE}

Como hemos estado viendo, Charles Taylor afirma incansablemente que nuestro sentido del yo está íntimamente relacionado con el sentido de nuestras fuentes morales. Para Taylor "el ser un yo" está inseparablemente unido a "estar ubicado en un espacio moral" que confiere identidad y permite distinciones cualitativas. El bien es lo incomparablemente superior en una distinción cualitativa. ${ }^{178}$

Nuestro autor canadiense afirma que lo realmente importante es caer en la cuenta de los universales humanos y ser capaces de distinguirlos de las constelaciones históricas en las que lo humano ha ido configurándose. ${ }^{179} \mathrm{~A}$ su modo de ver, lo relevante es lo que los seres humanos de todos los tiempos han ido compartiendo como "el mín" y "lo mío"; esto es, la identidad en relación al sentido del bien. Pero esto, según la interpretación de Taylor, significa afirmar la gran variedad de sentidos radicalmente distintos de lo que es el bien, asociados a una gran pluralidad de concepciones del yo. ${ }^{180}$

Vamos a seguir a Taylor en su estudio de las distintas configuraciones morales del yo, y cómo la razón trascendente, que ha identificado al yo en muy diversos y distintos momentos históricos, ha ido evolucionando hasta llegar a la razón instrumental de carácter naturalista y moralmente neutra.

\footnotetext{
${ }^{177}$ Me parece importante citar aquí el estudio de Rémi BRAGUE, La sabiduría del Mundo. Historia de la experiencia humana del universo, Ediciones Encuentro, Madrid, 2008. Un libro que puede servirnos como pórtico para lo que se va a decir a continuación en relación a la ruptura que experimenta el hombre con el advenimiento de la Modernidad. De estar "mirando el cielo" para descubrir el "orden cósmico" y así ser sabio con la Modernidad, el hombre deja de "mirar a fuera" para descubrirse a sí mismo como "una cosa que piensa" y que descubre a partir de su razón el orden tanto exterior como interior. La sabiduría deja de estar en el orden del universo y pasa a ser descubierta como una imagen racional. Para el hombre de la antigüedad "el hombre 'no hace' nada en el mundo, porque su presencia no añade nada a ninguna parte de este, y su ausencia tampoco le quita nada, puede aparecer como el sujeto al que el mundo se manifiesta en su totalidad." (pág. 47). El preceptor del hombre no será el cosmos, sino la razón que indaga. Se pasa del "cosmos ético" al "mundo perdido" entendido este como "un mundo inteligible" (Kant) y un "mundo humanizado" (Vico y Marx). Para Kant, "el mundo físico no es lo suficientemente sólido como para proporcionar una base que permita el acceso a Dios, pues no podemos saber si el mundo real es el mejor de todos los mundos posibles sin conocer estos últimos, lo que exigiría una exploración sucesiva e interminable. En cambio, el mundo moral está dado de un golpe como el único posible. El verdadero mundo es el reino de los fines. Esto está implícito en la conclusión de la Crítica de la razón práctica" (pág. 320).

${ }^{178}$ TAYLOR, Ch., Fuentes del yo, pág. 138.

${ }^{179}$ Cfr. Ibid., pág. 162.

${ }^{180}$ Cfr. Ibid., pág. 155.
} 


\section{III.1.2.1. EL TIEMPO DE LOS ORÍGENES. EL YO COLECTIVO INTEGRADO EN EL COSMOS Y EL SURGIMIENTO DE LAS RELIGIONES AXIALES}

Taylor, al referirse al tiempo en su diversidad de concepciones, habla del "tiempo de los orígenes" citando a Mircea Elíade. Un tiempo en el que tuvo lugar la fundamentación del orden de las cosas. ${ }^{181}$ Analizamos brevemente la conciencia del yo de este tiempo primigenio, originario, que nos remite a la fundación del cosmos y que, según nuestro autor, el orden de las cosas estaba referido a tiempos inmemoriales, a algún momento fundacional que tenía la categoría del tiempo de los orígenes. ${ }^{182}$

Comenzamos por estudiar las religiones antiguas para ver cómo contribuyeron a fundamentar el orden del cosmos en sus referencias al tiempo primigenio y qué supuso todo esto en el enraizamiento moral de la humanidad en su sentido trascendente. Para ello, nos serviremos de algunos autores que Taylor sugiere para adentrarse en el mundo de las religiones antiguas y el tipo de yo que se configura a partir de ellas. ${ }^{183}$

Piensa Taylor que las religiones antiguas, las que se desarrollaron en la época preaxial según K. Jaspers, definen la vida social de los seres humanos. Taylor afirma que se puede hablar de una "capacidad religiosa humana común", expresada en cada sociedad según sus propias características, para entrar en relación con el mundo de los espíritus. ${ }^{184}$ El hombre entra en relación en estas sociedades antiguas con espíritus, fuerzas o poderes que son reconocidos como algo superior, relación que adquiere motivaciones y características distintas según el tipo de sociedades. Según Taylor, no se trata de teorías o creencias, sino de una gran variedad y diferencia de capacidades y experiencias que definen las distintas formas de vivir la religión en la antigüedad. ${ }^{185}$

\footnotetext{
181 "En términos del tiempo secular, este origen se ubica en un pasado remoto, es un 'tiempo fuera de la mente' (...) Es lo que ocurrió al comienzo, pero también es el Gran Ejemplo, al que podemos acercarnos o del que podemos alejarnos a medida que atravesamos la historia”. TAYLOR, Ch., La Era Secular, tI, pág. 104.

${ }^{182}$ Cfr. TAYLOR, Ch., La Era Secular, tII, pág. 648.

${ }^{183}$ Cfr. MORRIS, B., Introducción al estudio antropológico de la Religión, Paidós, Barcelona, 2009.

${ }^{184}$ Cfr. TAYLOR, Ch., La Era Secular, tI, págs. 244 y ss.; cfr. OTTO, R. Lo santo, lo racional y lo irracional en la idea de Dios, Alianza Editorial, Madrid, 1980, págs.1-231. Por el contrario, en su estudio sobre el origen de la religión, PUECH advierte sobre la abusiva generalización de la tesis sobre el homo religiosus. Cfr. PUECH, H. C., Historia de las Religiones Antiguas I, Siglo XXI Editores, Madrid, 1979, págs. 32-33.

${ }^{185}$ Cfr. TAYLOR, Ch., La Era Secular, tI, pág. 237. Sobre la etimología de la palabra "religión" Cfr. FERNÁNDEZ LÓPEZ, F., "Etimología de la palabra latina religio" Disponible en: hispanoteca.eu/Foro/ARCHIVO-Foro/Religión-religare-relegere.htm (14-IV-2018). Parece ser que el significado más antiguo de la palabra religio en latín lo encontramos en unos versos de Aulus Gellius (130-180 d. de C.) en su obra Noctes Atticae (Noches en Atenas): Liber IV, IX, 1-2 en las que cita un verso de Nigidius Figulus: 1.Nigidius Figulus, homo, ut ego arbitror, iuxta M. Varronem doctissimus, in undecimo commentariorum grammaticorum versum ex antiquo carmine refert memoria hercle dignum: religentem esse oportet, religiosus ne fuas, cuius autem id carmen sit, non scribit. 2.Atque in eodem loco Nigidius: "Hoc" inquit inclina mentum semper huiusce modi verborum, ut "vinosus", "mulierosus", "religiosus", significat copiam quandam inmodicam rei, super qua dicitur. Quo circa "religiosus" is appellabatur, qui nimia et
} 
Siguiendo a Taylor en su estudio sobre la edad secular, las religiones preaxiales y axiales, insertan al agente en una vida religiosa socialmente establecida, contrariamente a lo que sucederá posteriormente con el equilibrio inestable de la era postaxial y de las etapas posteriores del Cristianismo. ${ }^{186}$

Para R. Bella, la religión en la antigüedad es descrita bajo la perspectiva mítica y ritual de la existencia humana, de tal manera que, a través de sus mitos y ritos, las religiones primitivas identifican al ser humano con sus ancestros y actualizan ritualmente el tiempo de los antepasados, el tiempo de los orígenes y lo hace presente en un ahora que actualiza las raíces históricas en las que se ubica la existencia y el sentido

superstitiosa religione esse alligaverat, eaqueres vitio assignabatur. Gelius cita un verso de Nigidus Figulus para explicar el sentido que tiene para él la palabra "religioso". Nigidus dice que el sufijo "osus" significa abundancia (copiam) en relación a la cosa a que se refiere (super qua dicitur). En ese sentido se denomina (apellabatur) "religioso" (religiosus) a alguien que está atado (alligaverat) a una religión supersticiosa (superstitiosa religione), lo cual es considerado (assignabatur) como una falta (res vitio). Por el contrario, se destaca la diferencia en el verso primero entre "religentem" y "religiosus": religentem ese oportet, religiosus ne fuas, teniendo la palabra religentem el sentido de "religioso" y la palabra religiosus el sentido de "supersticioso". Deberías ser "religioso" (religentem) para que no llegues a ser "supersticioso" (religiosus). En otras palabras, hay que ser temeroso de los dioses, no miedoso que lleva a la superstición. En la obra de Plauto titulada Curculio se habla de la invitación a una cena: "vocat me ad coenam". Y se comenta que el aceptarla es una cuestión de "religión", pues el aceptar dicha invitación es un deber de conciencia (religiofuit) cuando se ha hecho una invitación. Negar dicha invitación iría contra el sentido de conciencia que implica responder a una invitación (denegare nolui). En la obra de Cicerón, titulada De Natura Deorum II, 72, habla del culto a los dioses y las personas religiosas: "Los que retomaban cuidadosamente y de algún modo 'reunían escrupulosamente (relegerent)' todas las cosas que se refieren al culto de los dioses, estas personas han sido llamadas 'religiosas' de relegendo, como elegantes de eligendo, diligentes de diligendo e intellegentes de intellegendo. En todos estos términos subyace el mismo sentido de legere que en religioso." (Sobre la naturaleza de los dioses II, 72). "Nam qui totos diesprecabantur et immolabant, ut sibi sui liberi superstites essent, superstitiosi sunt appellati, quod nomen patuit postea latius; qui autem Omnia quae ad cultum deorum pertinerent diligenter retractarent et tamquam relegerent, [i] sunt dicti religiosi ex relegendo, [tamquam] elegantes ex eligendo, [tamquam] [ex] diligendo diligentes, ex intellegendo intellegentes; his enim in verbis omnibus in est vis legendi eadem quae in religioso. Ita factum est in superstitioso et religioso alterum vitii nomen alterum laudis. Ac mihivideor satis et essedeos et quales essent ostendisse". En el uso que Cicerón hace de la palabra "relegendo" (relegere) significa la observancia cuidadosa y atenta del culto y de los ritos externos. Una observancia que tiene como objetivo principal el mantenimiento del Imperio. En este sentido para Cicerón la religión cohesiona el Estado y las relaciones sociales, tal y como hemos analizado anteriormente en las religiones primitivas. Otro autor al que no podemos dejar de hacer referencia es Lucio Cecilio Lactancio, en su obra Divinae Institutiones 4, 28: "Estamos ligados y unidos (religati) a Dios con este vínculo de la piedad, del que la misma religión ha tomado su nombre y no, como interpreta Cicerón, de relegendo." "Hac enim conditione gignimur, ut generanti nos deoiusta at debita obsequia praebeamus, hunc solum noverimus, hunc sequamur. Hoc vinculo pietatis obstricti deo et religatisumus, unde ipsa religionomen ceperit, non, ut Cicero interpretatus est, a relegendo" El sentido que Lactancio da a la palabra religión (religare) entronca con el sentido de la verdadera religión que es una sabiduría divina que relaciona y re-liga al hombre con Dios. Lactancio pretende diferenciar el sentido de la religión auténtica frente a la superstición y a los engaños. La auténtica piedad vincula al hombre con Dios en una relación auténtica con la trascendencia. Relación que también hace sentirse al hombre como criatura que depende de Dios. El vínculo de la "vera religio", para Lactancio, religa al hombre con Dios y "supera" la religión ciceroniana que tiene que ver más con el paganismo y los cultos exteriores. Lactancio rechaza el sentido ciceroniano de la religión en su aspecto más exterior y cultual y lo refiere a un sentido más íntimo, confiriendo a la religión la verdad de una relación con Dios como "vinculum pietatis" que invita a una experiencia de Dios como "criatura-ligada-alcreador" Y finalmente nos referiremos a San Agustín, en su obra Retractaciones I, 12, 9, en la que partiendo del sentido ofrecido por Lactancio (religantes) matiza y enriquece el alcance de la etimología de la palabra, refiriéndola a "reeligere" o lo que es lo mismo "ser consciente del vínculo" o "volver a elegir".

${ }^{186}$ Cfr. TAYLOR, Ch., La Era Secular, tI, págs. 237 y ss. 
último de la vida. ${ }^{187}$ Se trata de una participación colectiva en el "Ser Mítico", sin otra mediación que la euforia ritual que nos pone en comunión con él directamente y donde desaparece cualquier distancia con el mundo de lo sagrado. ${ }^{188}$ Como afirma R. Brague, "el mundo está constituido como totalidad porque aparece ante un sujeto frente al cual la realidad se construye como independiente de él". ${ }^{189}$ Es el orden precósmico que le viene impuesto al sujeto. El mundo crece frente al hombre que se siente empequeñecido. Para Taylor, el yo es incapaz de imaginarse a sí mismo fuera de esa matriz cósmica. ${ }^{190}$

Son sociedades en las que el yo individual casi desaparece ante la comunidad que homogeneiza intelectual y moralmente. Todo el mundo se encuentra identificado con la comunidad cuyos ritos religiosos son representaciones colectivas. ${ }^{191} \mathrm{G}$. Liendhardt afirma, por ejemplo, que la sociedad no se entiende a sí misma sin el sentido trascendente que implica la relación con los niños y el ganado. ${ }^{192} \mathrm{El}$ sentido del yo está prácticamente desprovisto o cuestionado, o, como dirá Gauchet, "el afuera como fuente y lo inmutable como regla" es lo que define esta etapa. ${ }^{193}$ Balandier abunda en esta misma idea al afirmar que con las religiones primeras se da lo que él denomina una “desposesión radical" del hombre en lo que determina su existencia y una permanencia intangible del orden que los une. ${ }^{194} \mathrm{El}$ hombre fundamenta su identidad moral y su

\footnotetext{
187 "Por un lado, los mitos se refieren a un tiempo primigenio y simbólico asociado con la formación de alguna de las características de la realidad de una sociedad, como el mito de la creación del mundo, la cosmovisión del sol, la existencia de la luna, la presencia de los animales sagrados y del hombre mismo. Por otro lado, estos mitos toman lugar en la realidad inmediata de las personas, es decir, cada vez que se reproducen, generalmente de manera oral o escrita, toman lugar en el tiempo y el espacio de la interacción, volviéndose parte de la misma realidad". CAMARENA ADAME, M.E. y TUNAL SANTIAGO, G., "La religión como una dimensión de la cultura", Nómadas, № 22, (2009), pág. 6.

188 "Just as the primitive symbol system is myth par excellence, so primitive religious action is ritual par excellence. In the ritual the participants become identified with the mythical beings they represent. The mythical beings are not addressed or propitiated or beseeched. The distance between man and mythical being, which was at best slight, disappears altogether in the moment of ritual when everyone becomes now. There are no priests and no congregation, no mediating representative roles and no spectators. All present are involved in the ritual action itself and have become one with the myth". BELLA, R., "Religious evolution", American Sociological Review, Vol. 29, No 3, (1964), pág. 363.

${ }^{189}$ BRAGUE, R., La sabiduría del mundo, Encuentro, Madrid, 2008, pág. 31.

${ }^{190}$ Cfr. TAYLOR, Ch., La Era Secular, tI, pág. 241.

191 "Todo es común a todos. Los movimientos están estereotipados. Todo el mundo ejecuta los mismos en idénticas circunstancias, y esta conformidad en la conducta no hace sino traducir otra al nivel del pensamiento. Arrastrados todos por un mismo torbellino, el tipo individual casi se confunde con el genérico. A la par que uniforme, todo es simple". DURKHEIM, E., Las formas elementales de la Vida Religiosa, Schapire, Buenos Aires, 1968, pág. 5.

192 "Así pues si un hombre enumerara sus niños o su ganado se separaría moralmente, con sus propias y específicas "posesiones", de todo el grupo en el que al fin y al cabo debería estar integrado. Este aspecto de la actitud de los dinkas hacia el ganado, tiene cierta importancia para entender la dedicación del ganado a la divinidad, y a otros Poderes, pues en esta sus derechos superiores a 'poseer' el ganado se reconocen claramente". LIENDHART, G., Divinidad y experiencia. La religión de los dinkas, Akal, Madrid, 1985, pág. 31.

${ }^{193}$ Cfr. GAUCHET, M., El desencantamiento del mundo, Trotta, Madrid, 2005, pág. 42.

194 "Las sociedades consideradas por los antropólogos son aquellas en las que la tradición y su relación con lo sagrado son más manifiestas. Es además según esta doble característica que han sido definidas hace mucho tiempo: sociedades mantenidas por los mandatos de la tradición, poco productoras de
} 
existencia en una desposesión de sí, que le une a otros seres que no son de nuestra naturaleza: ancestros, dioses o héroes. La desposesión se determina por lo que es recibido, es decir, que hay un proceso de desasimiento que lleva al hombre a mirar a un mundo que no le pertenece, en cuanto tal, y del que depende para buscar su yo. Frazer afirma esto mismo cuando habla del paso de la magia a la religión como un tipo de desposesión del poder del yo para afirmar el poder divino. ${ }^{195}$

Hay un pasado fundador que es actualizado ritualmente y que nos remite al tiempo de los orígenes fundamentando nuestra búsqueda moral. Se puede afirmar que hay una actitud constante y sistemática durante milenios, que sobrepasa latitudes y culturas y establece lazos comunes en torno a esta búsqueda racional de un más allá que nos pone en contacto con seres de otra naturaleza.

Gauchet habla de una "inferioridad" del ser humano en relación a unos poderes extremadamente superiores y distintos a él. Cuanto más grandes son los dioses, mayor es su poder. ${ }^{196}$ En este sentido, considera que la revolución neolítica, con lo que supuso de superación técnica del hombre sobre sí mismo, no evitó la superación de esta experiencia de trascendencia. El hombre sigue respetando las referencias míticas en medio de "la domesticación de las plantas", tal y como refiere Gauchet. El hombre sigue utilizando el lenguaje de la desposesión mítica, siendo los héroes y los dioses los que determinan el devenir de estas sociedades agrarias y remitiendo a los dioses el futuro de la nueva humanidad. El hombre se sigue sintiendo en condiciones de inferioridad, vulnerabilidad e inmovilidad, es decir, la mayor productividad y el disponer de más tiempo no suponen ningún cambio cultural en el lenguaje de la desposesión; los tiempos de los orígenes siguen movilizando los sentimientos morales que imponen la

desorden, y por estos motivos capaces de oponer una fuerte resistencia a las improntas históricas. Así, no tendrán un futuro salido de su seno, repetirán el orden antiguo, se reproducirán sin variaciones de importancia”. BALANDIER, G., El desorden, la teoría del caos y las ciencias sociales. Elogio de la fecundidad del movimiento. Gedisa. Barcelona, 1993, pág. 35.

195 "Así, cortando a la ventura sus antiguas amarras y dejándose llevar por el proceloso mar de la duda y la incertidumbre, sacudida rudamente la feliz confianza de antes en sí mismo y en sus fuerzas, nuestro primitivo filósofo debió quedar tristemente perplejo y conmovido hasta que descansó, como en un puerto tranquilo después de un tempestuoso viaje, en un sistema nuevo de práctica y fe que creyó le ofrecía una solución a las dudas azarosas, y un substituto, por precario que fuese, de aquel imperio, sobre la naturaleza del cual había abdicado bien a su pesar. Si el universo caminaba sin su ayuda ni la de sus compañeros, de seguro que ello se debía a otros seres semejantes a él, pero más poderosos, los que invisibles dirigían su curso y producían toda la serie de acontecimientos diversos que hasta entonces creyó dependientes de su propia magia" (la cursiva es nuestra). FRAZER, J., La rama dorada. Magia y religión, Fondo de Cultura Económica, México, pág. 84.

${ }^{196}$ Cfr. GAUCHET, M., El desencantamiento del mundo, Trotta, Madrid, 2005, pág. 45. Cfr. ELIADE, M., Lo sagrado y lo profano, Labor/Punto Omega, Barcelona, 1983, págs. 1-185. Mircea Eliade habla del misterium tremens et fascinans. Un misterio que tiene una ambivalencia en cuanto a que nos atrae y al mismo tiempo nos inspira temor y pavor. Es ese elemento de misterium tremens el que hace que el hombre se sienta en "inferioridad" frente a poderes superiores que le "desposeen" y le hacen aceptar algo frente a lo cual no pueden si no "recibir lo que le es dado" sin otra capacidad que la de aceptar y asumir dicha realidad. Gauchet enfatiza este sentimiento de pavor con la palabra "inferioridad". 
vulnerabilidad y el desasimiento del propio yo. ${ }^{197}$ Se impone por las referencias míticas de lo originario y lo inmutable cualquier intento de superación de la desposesión y de la vulnerabilidad. Es lo que Gauchet denomina "monopolio del principio del orden colectivo", en el sentido de que todas las reglas que nos mantienen unidos vienen de fuera, de algo anterior y más elevado que nosotros. ${ }^{198}$

Por otra parte, la religión antigua en sus expresiones rituales también configura socialmente a las personas. Y es este sentimiento de estar juntos, como el toro está junto una vez sacrificado, el que al partir la carne acrecienta ritualmente la identidad colectiva, formando parte todos de la unidad del toro a través de sus partes, como la sociedad tiene también sus partes (clases, parentesco, edad, sexo...) y forma un todo. El sacrificio incrementa los lazos de pertenencia y los vínculos dentro de la colectividad, dentro de la cual está la divinidad, con la que también se participa del sacrificio al entregar a los dioses su parte de la res. Es una comida que expresa un sacrificio de comunión entre los hombres (lazos sociales) y entre los hombres y la divinidad (no se puede entender la colectividad sin su vinculación con la Divinidad). En torno al sacrificio todos se sienten "medio-hermanos". Y es en el rito donde se tiene lugar la unión de lo sagrado y lo profano. Es la ritualidad de la que habla Taylor y que rompe la homogeneidad del tiempo y del espacio. En el rito podemos acercarnos al tiempo superior de los acontecimientos originales. Según esta concepción del tiempo, las modalidades superiores del tiempo (eternidad platónica, eternidad de Dios y el tiempo de los orígenes) estaban entrelazadas con el tiempo secular e interferían con el orden simple y coherente del tiempo y el lugar seculares. ${ }^{199}$

\footnotetext{
${ }^{197}$ Cfr. DÍAZ, C., Manual de Historia de las Religiones, Desclee de Brouwer, Bilbao, 2004, págs. 18-23.

${ }^{198}$ Cfr. GAUCHET, M., El desencantamiento del mundo, Trotta, Madrid, 2005, pág. 41; cfr. DUMONT, L., Ensayos sobre el Individualismo. Una perspectiva antropológica sobre la ideología moderna, Alianza Editorial, Madrid, 1983, págs. 41 y ss. Louis Dumont se pregunta cómo fue posible el cambio de una sociedad holística a una sociedad que potencia el individualismo. Y habla del paso de un individuo fuera del mundo (un-individuo-en-relación-a-Dios del Cristianismo) a un individuo-en-el-mundo (Modernidad). Dumont también habla del paso (a great gap) de la "polis autosuficiente" de Platón y Aristóteles, al individuo que se basta a sí mismo con la emergencia de las escuelas helenísticas (epicúreos, cínicos y estoicos). Dumont se refiere finalmente a la emergencia del mundo helenístico y sus escuelas filosóficas como un mundo en el que "se relega lo social" debido a que la "sabiduría" consiste en un alejamiento del mundo. El nuevo sabio se opone al hombre que vive desde el mundo y ahí es donde se intenta la "desvinculación de los social" y su relegación a un segundo plano. Es lo que aparece en Diógenes, en Crisipo o en los "renunciantes de la India". Esto es lo que según Dumont será aprovechado por los apologetas cristianos para introducir la vida del cristianismo como una vida en la que se potencia la "extramundanidad", tan en boga entre los sabios de la época, como ideal a alcanzar. Así, el Cristianismo sería presentado por los apologetas cristianos de los primeros siglos como la posibilidad de una nueva "sabiduría-en-Cristo" que implica el apartamiento del mundo y la búsqueda de una felicidad individual. En este sentido, el Cristianismo se posicionaría en línea con la sabiduría de las Escuelas helenistas que potencian este alejamiento de lo social intramundano para alcanzar la sabiduría individual extramundana con la que el cristianismo conectaría al relacionarla con Cristo.

${ }^{199}$ Cfr. TAYLOR, Ch., La Era Secular, tI, págs. 161-163, 311 y ss.
} 
En las religiones antiguas la religión era fundamentalmente un fenómeno social. ${ }^{200}$ Era la sociedad como tal la que se relacionaba con Dios. El individuo estaba inmerso en una fuente identificadora social que le hacía implicarse e involucrarse en el mundo de los espíritus. Identificación personal y social significaban lo mismo. Se es individuo en una sociedad y la sociedad como tal acompañaba la identificación moral de los individuos a través de una visión trascendente del mundo. Los ritos refuerzan los vínculos sociales. ${ }^{201}$

La religion configura no solo la Sociedad, sino también la forma de organización política, como dirá Francis Oakley, otro de los autores citados por Taylor. Tras las prácticas de coronación de reyes, se esconde la concepción del estado como la encarnación de la totalidad del cosmos. En este sentido, la institución del Reinado monárquico es una de sus tipologías institucionales que expresan la religiosidad y el orden cósmico que a lo largo de varios milenios se ha establecido como la estructura religioso-política más común de la humanidad. Una configuración política que ha sustentado la religiosidad cósmica que escondía los fundamentos de la razón del mundo. De tal forma que la coronación ritual del rey era una "reactualización" del gran momento cosmogónico de la creación. El rey se eleva y vuelve a crear el mundo como el gran protagonista del orden racional y del Estado monárquico, como reinstaurador que actualiza el orden cósmico inherente a todo lo creado. ${ }^{202}$ Así, por ejemplo, el Rey es el representante de Dios en la tierra, con la consiguiente responsabilidad de expresar, a través de los ritos y sacrificios, el orden racional cósmico presente en la Naturaleza e impulsar actualizadamente, como un trasunto de dicho orden, la paz social y la configuración de una sociedad política que potencia las mencionadas identidades morales. ${ }^{203}$ Para Mircea Eliade la sacralidad de la naturaleza se manifiesta en las

\footnotetext{
200 "La religión acompaña al hombre y a la sociedad como un elemento básico de la composición del individuo y de su propia identidad, de manera que las formas en que se presenta y organiza la religión al interior de la masa social, es lo que le da el carácter de una estructura y de una entidad que va a formar parte del devenir humano. Tan importante es la referencia de la religión para la sociedad, que de ella depende gran parte del accionar moral que se haga presente". CAMARENA, A. y TUNAL, S., "La religión como una dimensión de la cultura”, pág. 8. Cfr. TAYLOR, Ch., La Era Secular, tI, pág. 238.

${ }^{201}$ Cfr. TAYLOR, Ch., La Era Secular, tII, pág. 741. "At the primitive level religious organization as a separate social structure does not exist. Church and society are one. Religious roles tend to be fused with other roles, and differentiations along lines of age, sex and kin group are important... As for the social implications of primitive religion, Durkheim's analysis seems still to be largely acceptable. The ritual life does reinforce the solidarity of the society and serves to induct the young into the norms of tribal behavior". BELLA, R., "Religious evolution”, pág. 364.

202 "It was the cosmic nature of that religiosity that determined the cosmic character of kingship. It was the source from which the latter drew its ideological sustenance. And with its fate the fate of kingship was destined to be inextricably entangled". OAKLEY, F., Kingship, pág. 14. Cfr. GAUCHET, M., El desencantamiento del mundo, págs. 38-39. La religion ha contribuido, por otra parte, a establecer una "sociedad que no permite la aparición del Estado" dado que el Estado lo constituye una autoridad cuyo sentido es mantener el orden mítico de los antepasados, sin otra capacidad que mantener la ley eterna y el tiempo primero que es actualizado ritualmente.

${ }^{203}$ Es relevante el matiz que aporta Remi Brague en torno a la idea del orden del cosmos. Hay una sabiduría precósmica según la cual "el orden no preexiste a la sabiduría; no se ofrece, en el cosmos físico, como un modelo a imitar. Si el mundo es lo que es por el orden que conlleva, la sabiduría no se deriva del
} 
estructuras del mundo. Los dioses van mucho más allá de la sacralidad que lo impregna todo. $^{204}$

La expresión de Oakley, "cartografía de la mente", clarifica y contribuye a expresar la ubicación moral de cada etapa de la historia. Para Oakley, existió una etapa primitiva que estableció los fundamentos del mundo sobre el orden racional del cosmos y las Ideas platónicas y que, según el autor de Kingship, llegan hasta nuestros días en lo que él denomina la cuna desencantada de la modernidad occidentalizadora, no solo bajo las formas institucionales monárquicas renovadas, sino bajo algunos elementos ideológicos que las constituyeron. Oakley habla del mundo "primitivo-arcaicopremoderno" caracterizado por el poder del símbolo y la analogía, así como el sentimiento de formar parte de una naturaleza llena de dioses y magia. ${ }^{205}$ Oakley sostiene que fue fatídico para la historia de Occidente la idea judía de la creación exnihilo, que sacó a Dios del cosmos y lo colocó por encima de él. Taylor considera que Dios se convierte en la Fuente de exigencia para que rompamos la forma en que funcionaba el mundo, o lo que afirma Brague, que "la sabiduría del mundo no nos limite". ${ }^{206}$ Para Taylor, el cambio fue doble: lo trascendente puede ahora estar mucho más allá o fuera del cosmos o si se sigue siendo cósmico, pierde su carácter ambivalente original y exhibe un orden de bondad pura, como sucede con el Paraíso, garante de la regla justa, o el orden de las Ideas en Platón. ${ }^{207}$ Con la creación ex-nihilo, Dios no repara la fisura original, mientras que en la ritualidad preaxial el orden sagrado se reconfigura y la sabiduría primigenia acepta lo inexorable y es capaz de celebrar con jubilo lo que no se puede cambiar, al contrario del relato del Génesis. ${ }^{208}$ Es lo que Taylor afirma cuando habla de la ambivalencia de lo preaxial, caracterizada por ser un mundo que consagra los rituales de guerra o relacionan la violencia con lo sagrado, confiriendo una especie de profundidad numinosa a la matanza, a las emociones y a lo sexual. $^{209}$ Taylor reflexiona sobre la pervivencia de la violencia numinosa en muchos elementos de las religiones postaxiales, como la guerra santa, el chivo expiatorio, las

\footnotetext{
mundo, sino que, más bien, lo produce como tal”. REMI, B., La sabiduría del mundo, pág. 35.

204 "Para el hombre religioso la naturaleza nunca es exclusivamente natural. Y esto tiene su explicación. Porque el cosmos es una creación divina, esto es, salido de las manos de Dios. El mundo queda impregnado de sacralidad. No se trata únicamente de una sacralidad comunicada por los dioses, por ejemplo, la de un lugar u objeto consagrado por una presencia divina. Los dioses han ido mucho más allá”. ELIADE, M., Lo sagrado y lo profano, Paidós, Barcelona, 2014, pág. 87.

205 “The peoples of 'premodern' societies appear instinctively to have been moved by the explanatory power of symbol and analogy... The mainspring of the acts, thoughts, and feelings of early man was the conviction that the divine was immanent in nature and nature intimately connected with society... Nature was alive; it was to the peoples of the Classical world 'full of gods' or 'full of Jupiter'; it expressed, both in its benign cyclical rhythms and in its intimidating and catastrophic upheavals, the movements and in dwelling of the divine". OAKLEY, F., Kingship, pág. 15.

${ }^{206}$ Cfr. TAYLOR, Ch., La Era Secular, tI, pág. 245.

${ }^{207}$ Cfr. Ibid., pág. 246.

${ }^{208}$ Cfr. Ibid., pág. 247.

${ }^{209}$ Cfr. TAYLOR, Ch., La Era Secular, tII, pág. 493, 561.
} 
cruzadas... y otros usos religiosos de la violencia, aunque este tipo de respaldo numinoso va desapareciendo cada vez más. ${ }^{210}$

En otro orden de cosas, la religion primera o arcaica no se ha limitado a enriquecer un pensamiento primigenio que necesitaba ser complementado $\mathrm{y}$ completado, sino que es la religión la que ha contribuido a que el espíritu reflexivo de la razón humana se desplegara en toda su hondura espiritual. Ha sido la religión preaxial y axial la que ha impulsado de manera fundamental la identidad racional del ser humano, elevándolo hacia las profundidades de una racionalidad filosófica y científica. Es decir, que de alguna manera la religión está en la base de la identidad humana que se ha desplegado racionalmente. La religión no ha entrado en conflicto con la razón humana, sino que ha contribuido a que la identidad espiritual del ser humano se elevara hacia el sentido de lo universal, tal y como refiere Durkheim. ${ }^{211}$ Taylor afirmará que en el contexto pre-axial, el lenguaje religioso, las capacidades o los modos de experiencia provienen de la sociedad en la que se nace, de alguna manera rige para todos y ese vocabulario preexistente capacita para fomentar el espíritu reflexivo de la razón humana. ${ }^{212}$

En este sentido, la religión ha configurado el sistema racional del hombre, de tal manera que la identidad racional se configura espiritualmente y la identidad espiritual del hombre se expresa desde la razón. Hay un fondo de misterio y de encanto mágico que se esconde en la identidad espiritual del ser humano, que se configura racionalmente y que, a la vez, a partir de la razón, lleva a la elevación del espíritu humano hacia metas de trascendencia. Levi-Strauss enfatiza esta dimensión de la religión como posibilitadora de la configuración del yo al "antropomorfizar" la naturaleza. $^{213}$

Durkheim afirma que las religiones han estado en la base de la comprensión humana del tiempo, con lo que esto implica en relación a la configuración de la identidad moral del yo. La conciencia del fluir del tiempo y la diferenciación de

\footnotetext{
${ }^{210}$ Cfr. Ibid., págs. 604-611.

${ }^{211}$ Cfr. DURKHEIM, E., Las formas elementales de la Vida Religiosa, págs. 440-441.

${ }^{212}$ Cfr. TAYLOR, Ch., La Era Secular, tI, pág. 238.

${ }^{213}$ Cfr. LEVI-STRAUSS, El pensamiento salvaje, Fondo de Cultura Económica, México, 1964. En la religión el hombre humaniza las leyes naturales, es decir, tal como afirma Comte, el hombre se comprende a sí mismo desde la naturaleza y para ello interioriza el mundo o humaniza la naturaleza que es lo mismo. La religión no es otra cosa que "antropomorfizar" la naturaleza, entender la naturaleza y el cosmos desde su propio yo, es decir, es la asimilación de la naturaleza, para dominarla y comprenderla, desde las propias leyes antropomórficas, desde lo que constituye el dominio del propio yo. La religión contribuye a "dominar" la naturaleza, comprendiéndola desde los propios actos humanos o refiriéndola al campo antropomórfico desde el que el hombre se comprende a sí mismo y del que no puede separarse. En la religión el hombre es el espejo de la naturaleza (la naturaleza adquiere "forma" humana). Y en la magia la naturaleza es el espejo del hombre (el hombre adquiere "forma" de naturaleza). En la religión el hombre comprende la naturaleza desde su propio yo que busca y relaciona (fuerza natural humanizada) y en la magia el hombre se comprende a sí mismo desde la naturaleza que le "conforma naturalmente" (hombres transformados en fuerzas naturales).
} 
tiempos, así como la comprensión del tiempo de los orígenes, han sido fundamentales en la fundamentación moral del ser humano. Tiempos de los orígenes, tiempos superiores, tiempos míticos, tiempos filosóficos. Es así como la religión ha contribuido a forjar la identidad del yo que es tiempo, que se desarrolla en el tiempo y que es consciente del fluir del tiempo y la diferenciación del mismo. La religión ha contribuido a forjar la identidad espiritual y racional del ser humano, a partir de esa conciencia del tiempo; en el caso de las religiones primitivas, a partir de un tiempo de los orígenes, y en el caso del Cristianismo, a partir de los tiempos superiores.

Por otro lado, y continuando con la reflexión anterior, Durkheim habla de una diferenciación espacial y temporal que está íntimamente asociada al concepto de identidad del yo. ${ }^{214}$ La relación de los conceptos de espacio y tiempo, entendidos como categorías sociales, tiene una importancia fundamental. El hombre antiguo no tiene conciencia solo de su tiempo individual como diferenciación y conciencia de ruptura en la sucesión de los distintos eventos que van sucediéndose temporalmente. Tiene conciencia de que unos sucesos se diferencian de otros y que el tiempo en que "suceden" y "se suceden" es algo que está interrelacionado, y lo que es pasado vuelve a suceder en un presente que se actualiza con características propias. El pasado se vuelve a hacer presente de manera distinta, diferenciada. Se trata no solo de mi tiempo tal y como es experimentado individualmente, sino también del tiempo como es vivenciado por todos los hombres. Hay una conciencia del tiempo individual experimentado socialmente. La dimensión social del tiempo en las sociedades antiguas moldea de alguna manera la experiencia individual del mismo. Mi tiempo es el tiempo de la sociedad. Durkheim habla de que no es mi tiempo el que está organizado así, sino el tiempo de la humanidad. Por eso las religiones organizan como una necesidad este tiempo colectivo que supera la propia conciencia individual del mismo.

Las sociedades antiguas necesitan configurarse religiosamente a partir de la urgencia vivida como tiempo colectivo. La conciencia de la diferenciación temporal es algo que moldea no solo la existencia individual, sino la de toda la humanidad. El pasado se hace presente individual y colectivamente. $Y$ en ambos planos se entremezcla todo. Individualmente soy consciente de un pasado que se repite diferenciadamente en un presente nuevo y distinto, pero del que no me puedo separar. Y socialmente el tiempo es vivenciado como un tiempo de los orígenes colectivos, de tal manera que lo que surgió en los orígenes sigue estando presente en el momento del recuerdo que

\footnotetext{
${ }^{214}$ Cfr. DURKHEIM, E., Las formas elementales de la Vida Religiosa, págs. 16-18. "Las raíces de toda religión parten de una experiencia individual, como fase de sensibilización previa a la de ritualización y por ello los elementos materiales observables podrán poseer una menor homogeneidad, (...) lo que equivale a una amplia gama de sentimientos religiosos independientes entre sí, pero con un punto en común que sería el código representacional de esas emociones". CERRILLO MARTÍN DE CÁCERES, E., "Arqueología de las Religiones primitivas y arqueología de las religiones organizadas. Una reflexión", Zephirus, Vol. 43, (1990), pág. 191.
} 
rememora, vivenciando el estado primero en el que surge el clan o la tribu. La sociedad configura el tiempo del yo y no logra separarlo ritualmente del tiempo colectivo. Ambos se identifican de forma que el tiempo ritualizado colectivamente es el que determina las experiencias fundantes de la sociedad, que son las que contribuyen a configurar la identidad del yo. El tiempo social se ritualiza colectivamente a través de las religiones, de modo que no se puede entender la configuración social sin el hecho religioso. ${ }^{215}$ Taylor habla, en este sentido, del tiempo de los orígenes como un "tiempo fuera de la mente", que no está simplemente en el pasado, porque podemos vivenciarlo ritualmente, pero este ritual también puede tener un efecto de renovación y consagración y de esta forma puede acercarse más al origen. El Gran Tiempo está así detrás de nosotros, pero en un sentido también sobre nosotros. ${ }^{216}$

Y lo mismo en el ámbito espacial. El espacio para el hombre antiguo es captado en su conciencia a través de la diferenciación cualitativa del mismo. ${ }^{217}$ No todos los espacios son ubicados en la conciencia individual y social de manera idéntica. Y así como todos los hombres adquieren una diferenciación espacial común — porque así son establecidos afectivamente desde las mismas categorías por todos los hombres-, así podemos hablar también de espacios que colectivamente son identificados de la misma manera. De ahí que lo mismo que el tiempo no es mi tiempo, los espacios no son mis espacios, sino que también los espacios adquieren una dimensión social. La subdivisión social en clanes establece los espacios que adquieren esta dimensión social unitaria. Así, la división social es una división espacial. El espacio expresa la vida social, lo mismo que el tiempo. El espacio integra colectivamente a los distintos clanes y les da conciencia social. Y dependiendo del espacio en el que se está ubicado se adquiere una identidad distinta como clan. El espacio configura identidad social. ${ }^{218}$ Todos los individuos están configurados por el espacio, porque todos los individuos, desde nuestra constitución orgánica, somos afectados de la misma forma. Igual que el tiempo nos afecta a todos de la misma manera, así la organización social ha seguido el modelo de la organización espacial. Los espacios geográficos habitados por nuestros ancestros han configurado la convivencia social de grupos nuevos que se iban ubicando en los mismos espacios o dando identificación social a los nuevos grupos en virtud de los espacios que ubicaban. Incluso Durkheim va más allá de los conceptos de izquierda y derecha como

\footnotetext{
${ }^{215}$ Cfr. DURKHEIM, E., Las formas elementales de la Vida Religiosa, pág. 453.

${ }^{216}$ Cfr. TAYLOR, Ch., La Era Secular, tI, págs. 103-104.

217 "El cosmos, visto como mundo completo y saturado de poder, se distingue como algo que está más allá de la comprensión humana y puede someter la vida (Rosendahl, como fuerza y amplitud). En ese sentido, ese campo de fuerzas es visto como un mundo capaz de elevar al ser humano más allá de sí mismo, y por lo tanto como un mundo sagrado en donde viven seres divinos". LE BOURLEGAT, C.A. y DE CASTILHO, M. A., "Lo sagrado en el contexto de la territorialidad", Polis, No 8, (2004), págs. 2-3.

218 "De otro modo, para explicar este acuerdo, habría que admitir que todos los individuos, en virtud de su constitución orgánico-psíquica, son afectados del mismo modo por las diferentes partes del espacio: lo que es tanto más improbable cuanto que, por sí mismas, las diferentes zonas son efectivamente indiferentes”. DURKHEIM, E., Las formas elementales de la Vida Religiosa, pág. 10.
} 
espacios geográficos y los refiere más bien a conceptos identitarios que expresaban configuración moral, esto es, conceptos que guardan relación con las representaciones religiosas de carácter colectivo. ${ }^{219}$ Para Taylor, es la visión del mundo encantado en el que la significación está fuera, independientemente de nosotros. El objeto, el lugar, el agente pueden comunicarnos esta significación, imponérnosla y llevarnos a su campo de fuerzas por así decirlo. Taylor habla de ese mundo en el que "caemos en su campo de fuerzas", un sentido de magia que encanta y que nos llega desde fuera, en la ritualidad temporal o en el espacio en el que nos ubicamos. ${ }^{220}$

Completando la idea de tiempo y las religiones, Jaspers habla de un tiempo eje que configura la identidad humana. Un tiempo que alcance todas las civilizaciones y culturas y que determina un antes (preaxial) y un después (postaxial). Para Jaspers hay pues un período axial definido como eje de la historia universal. ${ }^{221}$ Este eje que define de alguna manera la historia de la humanidad es el último milenio antes de Cristo y en el que se concentran muchos hechos extraordinarios. ${ }^{222}$ Un tiempo axial en el que el hombre toma conciencia de sí, del mundo y de su propia contingencia humana. ${ }^{223}$ Es lo que Jaspers denomina la época en la que se define el concepto de "lo universal" en relación con las religiones, el concepto de la consciencia de uno mismo y los límites de la naturaleza humana. Jaspers opina que hay dos tipos de pueblos que se pueden definir desde la gran crisis axial, "los pueblos históricos y los pueblos primitivos". Los primeros son los que tienen su fundamento en el tiempo axial con la consiguiente configuración espiritual y moral que se deriva de dicho tiempo eje, y los segundos los que quedan al margen de dicha crisis. Es el tiempo eje hacia el que todo converge y del que todo parte. Son las tres fases de la historia universal y en el que la segunda fase constituye el tiempo eje. ${ }^{224}$

\footnotetext{
${ }^{219}$ Cfr. Ibid., pág. 16.

${ }^{220}$ Cfr. TAYLOR, Ch., La Era Secular, tI, pág. 68.

${ }^{221}$ Cfr. GIL GIMENO, J., "Religiones universales y creatividad”, Imagonautas, No 10, (2017), pág. 66.

222 "En China viven Confucio y Lao-tsé, aparecen todas las direcciones de la filosofía china... En la India surgen los Upanischadas, vive Buda, se desarrollan, como en China, todas las posibles tendencias filosóficas, desde el escepticismo al materialismo, la sofística y el nihilismo. En el Irán enseña Zaratustra la excitante doctrina que presenta al mundo como el combate entre el bien y el mal. En Palestina aparecen los profetas, desde Elías, siguiendo por Isaías y Jeremías, hasta el Deuteroisaías. En Grecia encontramos a Homero, los filósofos —Parménides, Heráclito, Platón-, los trágicos, Tucídides, Arquímedes". JASPERS, K., Origen y meta de la historia, Alianza Editorial, Madrid, 1980, pág. 20.

${ }^{223}$ Cfr. EISENSTADT, Sh., "La era axial: la emergencia de las visiones trascendentales y el ascenso de los clérigos", Sociología Histórica, Vol. 7, (2017), págs. 385-406. "La novedad de esta época estriba en que en los tres mundos el hombre se eleva a la conciencia de la totalidad del Ser, de sí mismo y de sus límites. Siente la terribilidad del mundo y la propia impotencia. Se formula preguntas radicales. Aspira desde el abismo a la liberación y salvación, y mientras cobra conciencia de sus límites se propone a sí mismo las finalidades más altas. Y, en fin, llega a experimentar lo incondicionado, tanto en la profundidad del propio ser como en la claridad de la trascendencia”. JASPERS, K., Origen y meta de la historia, pág. 20."Para Hegel, la diversidad de las filosofías no tiene otro sentido que la de señalar las etapas necesarias del desarrollo de la razón que llega a la conciencia de sí misma”. GONZÁLEZ GARCÍA, M., Filosofía y Cultura, Madrid, Siglo XXI Editores, 1992, pág. 2.

224 "La primera fase solo es accesible en la yuxtaposición de una infinita variedad de hombres, como una
} 
Jaspers afirma que, una vez establecido el tiempo axial, "todos los pueblos pasan a ser históricos", ya que el arrastre de dicha crisis espiritual es irrefrenable y ningún pueblo quiere quedar al margen de la historia que se inicia. Jaspers habla de "una iniciación de la humanidad". Una iniciación que implica interpretación y apropiación. Es lo que él denomina como "secreto manifiesto", es decir, hay un deseo vehemente de ser comunicado y transmitido, pero al mismo tiempo solo el que está preparado para asumirlo puede acercarse a la nueva experiencia espiritual de alcance universal. Es algo que lo va envolviendo todo, pero a la vez implica percepción y consciencia por ser asumido. $^{225}$

A partir de este tiempo axial Occidente se estructura espiritualmente, según $\mathrm{K}$. Jaspers, en torno a algunas características que serán determinantes: ${ }^{226}$

1. La libertad política según el concepto de la polis griega. Es en la polis griega donde se prepara el camino, por las características políticas que enmarcan la vida en las ciudades, hacia la sabiduría y el pensamiento. Pensamiento filosófico que es pesar y sopesar, y que hace posible el acceso a una sabiduría que configura la identidad moral desde la libertad.

2. La racionalidad que emprende un camino imparable hacia el pensamiento lógico y la ciencia empírica, que llevan a una comprensión definitiva de lo particular en constante tensión hacia la búsqueda de la totalidad.

3. La interioridad consciente de la mismidad personal, que cobra una gran relevancia a partir de los profetas judaicos, los filósofos griegos y los hombres de Estado romanos. Una búsqueda irrefrenable de la identidad moral del yo, que ha hecho experimentar al hombre occidental los límites de la libertad en la nada.

4. Una comprensión del mundo en su realidad y, desde él, haciendo síntesis de la misma a partir de la Idea que supera la división entre la naturaleza en estado bruto y el misticismo de la conciencia que eleva hacia la eternidad. ${ }^{227}$

multiplicidad de fenómenos naturales. En ella debe haber existido una comunidad de propiedades y modos de pensar que procedía de la esencia común de las dotes humanas, no esencialmente de la historia. (...). La segunda fase se articula, por centrarse en la crisis que fue el tiempo-eje de la historia. Hacia él van y de él parten todos los movimientos. La tercera fase todavía es, esencialmente, futuro. Al contemplarla se retrocede a aquellos rasgos del pasado, que son como una anticipación o preparación: a las grandes unificaciones históricas (los Imperios), a los grandes hombres universales de la Antigüedad y de la Edad Moderna...”. JASPERS, K., Origen y meta de la historia, pág. 103.

${ }^{225}$ Jaspers establece tres etapas en la historia de occidente: 3000 años hasta el tiempo axial, mil años basados en la gran crisis axial desde el 500 a. de C. hasta el 500 d. de C. y, finalmente, el resto de la historia de occidente con la división en Este y Oeste, desde la mitad del primer milenio después de Jesucristo hasta la actualidad en la que destaca un intervalo de quinientos años hasta que en el Oeste desde el siglo X con los pueblos germano-románicos se inicia una historia de mil años hasta la actualidad. Cfr. JASPERS, K., Origen y meta de la historia, págs. 86-87.

${ }^{226}$ Cfr. Ibid., págs. 92-94. 
5. Configuración de lo general que no se establece en representaciones del mundo monolíticas, sino que son el germen para las distinciones y donde se obtiene una valoración polidimensional del mundo, expresada como inquietud, incapacidad e imposibilidad de lograr una síntesis perfecta e inacabada.

6. Frente al ansia de libertad infinita, Occidente es capaz de integrar con pretensiones de exclusividad la verdad religiosa, una tensión que se va a expresar en una elevación del espíritu y en un deseo infatigable de buscar e indagar, de hacer introspección en una experiencia que se amplía y se enriquece constantemente.

7. Es propio del Occidente "una decisión que lleva las cosas al vértice último, llega a la más completa claridad, se plantea resueltamente el 'esto o aquello'; de aquí que llegue a la plena conciencia de los principios y establezca los frentes de combate más íntimos". 228

8. En la civilización occidental se ha desarrollado un combate imparable en la búsqueda de la propia interioridad espiritual a través del sentido que se descubre en la comunicación entre los hombres y el horizonte de la verdadera razón. ${ }^{229}$

Concluimos con este misterio que se esconde en el fondo del corazón humano y que no pretende establecer respuestas concluyentes: ¿Qué es lo que ha ido surgiendo y desvaneciéndose de múltiples formas y maneras, para que desde las huellas de la cultura occidental se haya configurado el mundo? ¿Qué es lo que se puede rastrear desde los comienzos y que ha ido permitiendo que del yo evanescente y debilitado en el cosmos vaya surgiendo progresivamente un yo configurador del cosmos? ¿Qué es lo que esconde la verdad del hombre como verdad de un yo racional que no ha podido

\footnotetext{
${ }^{227}$ Los filósofos escépticos, minoritarios, que dudaban de la "viabilidad y efectividad" de la magia fueron los instauradores del hombre-dios de la religión. Fueron los filósofos-religiosos los que contribuyeron a establecer una religión de la razón y del orden cósmico: "Así, sin embargo, aunque podemos justamente rechazar las pretensiones extravagantes de los magos y condenar las supercherías con que engañaron a la humanidad, la institución original de esta clase de hombres, tomándola en su conjunto, ha producido un bien incalculable para los humanos. Ellos fueron los predecesores directos, no solo de nuestros médicos y cirujanos, sino de nuestros investigadores y descubridores en cada una de las ramas de la ciencia natural". FRAZER, J., La rama dorada. Magia y religión, pág. 89. "Estas teorías constituyen la religión, cuya técnica (ceremonias, ritos, culto) llamo magia. Como esta práctica y esta teoría son indisolubles convirtiéndose en metafísica la teoría sin la práctica, y en ciencia la práctica fundada en otra teoría, emplearé siempre el adjetivo mágico-religioso". VAN GENNEP, A., Ritos de Paso, Alianza Editorial, Madrid, 2013, pág. 29. Cfr. WINCH, P., "Para comprender a una sociedad primitiva", Alteridades, Vol. 1, No 1, (1991), págs. 82 y ss.

${ }_{228}^{28}$ JASPERS, K., Origen y meta de la historia, pág. 96.

229 "Pero lo que ha sido menos destacado es que la religión no se ha limitado a enriquecer a un espíritu humano ya confirmado anteriormente con un cierto número de ideas; es ella la que ha contribuido a que ese mismo espíritu se forjara. Los hombres no deben tan solo a la religión, en gran parte, la materia de sus conocimientos, sino también la forma en base a la que estos son elaborados". DURKHEIM, E., Las formas elementales de la Vida Religiosa, pág. 8.
} 
entenderse a sí mismo sin la razón trascendente? ${ }^{230}$ Para Taylor, una vez analizado este primer aspecto introductorio y general hay que investigar los fundamentos filosóficos.

\section{III.1.2.2. PLATÓN: EL YO COMO AUTODOMINIO Y CONTROL}

Taylor entiende que Platón es un referente fundamental en esta evolución filosófica de la mente del mundo y sus referencias a él son constantes. Una mente que en cierto sentido pone el fundamento de la civilización occidental ontologizando la Idea configuradora del cosmos. ${ }^{231}$ Para nuestro autor, difícilmente se puede comprender lo que somos sin la ontología platónica. Taylor vuelve una vez y otra a él para hacernos caer en la cuenta de las rupturas que se han ido realizando en la historia del pensamiento, pero, al mismo tiempo, como raíces que permanecen y que siguen configurando nuestro pensamiento actual. Para Taylor, Platón tiene mucho que ver en el encantamiento del mundo a partir de su mundo de las Ideas. Hay muchos textos platónicos que nos ponen en conexión con el cosmos y con pensamientos que la sociedad de hoy comparte, aunque no los refiera evidentemente a Platón: cosmología, razón, orden, Ideas, Bien, dominio de sí... Son, pues, textos e ideas que tienen que ver con la Religión hoy, pues de alguna manera siguen enraizando el pensamiento moral o la apertura a lo trascendente.

En Platón, las fuentes morales del yo se encuentran en el pensamiento. Es en el pensamiento donde se encuentra el acceso a una condición moral superior. En La República, después de hablar de los tres principios del alma - la razón, la cólera y la concupiscencia-, afirma, a propósito de los verdaderos filósofos, que son los que aman la verdad. ${ }^{232} \mathrm{Y}$ es esta hegemonía de la razón, como contemplación reflexiva y autodominio, la que ha fundamentado la filosofía moral en Occidente frente a la ética de la gloria o de la acción. ${ }^{233}$

A través del conocimiento, se llega al ser, y después de distinguir entre la opinión, la ignorancia y el conocimiento, Platón afirma que los que se quedan en la opinión no han llegado al verdadero conocimiento de la esencia de las cosas, puesto que aquellos

\footnotetext{
${ }^{230}$ Para Taylor es importante reseñar el empuje a la desinserción que implican las formulaciones axiales. Una ruptura en tres dimensiones: el orden social, el cosmos y el bien del hombre. El vínculo estrecho con el cosmos a través de la vida religiosa colectiva comienza a ser problemático. Cfr. TAYLOR, Ch., La Era Secular, tI, págs. 239,244.

${ }^{231}$ Cfr. TAYLOR, Ch., Fuentes del yo, pág. 168.

232 "Entonces, ¿a quiénes llamas 'verdaderamente filósofos'? A quienes aman el espectáculo de la verdad. Bien, pero ¿qué quieres decir con eso? (...) Y el mismo discurso acerca de lo Justo y lo Injusto, de lo Bueno y de lo Malo y de todas las Ideas: cada una en sí misma es una, pero, al presentarse por doquier en comunión con las acciones, con los cuerpos y unas con otras, cada una aparece como múltiple". PLATÓN, La República, Gredos, Madrid, 2018, 475e-476b.

${ }^{233}$ Cfr. TAYLOR, Ch., Fuentes del yo, pág. 170.
} 
"contemplan colores bonitos", mientras que los filósofos verdaderos "se acercan en todo a la esencia de las cosas", están enamorados de la ciencia y de las "esencias eternas". 234

Para Platón, lo que el pensamiento y la razón dan al hombre es el dominio de uno mismo. ${ }^{235}$ Ser dueño de uno mismo es conocer la verdadera sabiduría, conocer la esencia de las cosas, dedicarse a la contemplación y ejercer el autodominio y el dominio sobre las "regiones bajas" para llenarse realmente del "ser". ${ }^{236}$ Somos buenos cuando nos regimos por la razón, la sabiduría y la virtud. Cuando en el alma rige el principio de la razón, se impone el orden (kosmos), la concordia y la armonía, se experimenta la unidad consigo mismo, la serenidad y la tranquilidad como dominio de sí, experimentando el autocontrol como expresión de estar "centrados en uno mismo". 237 Como concluye Platón en La República: "El sabio realizará la ciudad ideal en sí mismo" a través de la autocontemplación y el autodominio. Por el contrario, los que se dejan llevar por los deseos, viven en el caos, el conflicto interno y la autodestrucción, son personas agitadas, inquietas y llevadas por sus afanes, viviendo en la turbación de los deseos y apetitos que jamás se satisfacen, siempre quieren más, y viven en la insaciabilidad. El vicio y el deseo esclavizan al hombre, frente a la libertad del autocontrol y la razón. Se trata de una liberación elevadora del espíritu, una ascensión. $^{238}$

Este es el concepto de ser racional en Platón, el que ejerce el autodominio y el pensamiento. Hay que adoptar una postura desapasionada en la vida, calmada, serena, ser dueño de sí mismo. Esta racionalidad ha tenido una influencia enorme en nuestra cultura occidental y Taylor no puede por menos de tenerlo como referente constante en su estudio al hablar de la ruptura que supone la Modernidad respecto a las etapas anteriores, configuradas desde el platonismo y el Cristianismo. Ser racional es ser verdaderamente dueño de sí mismos y capaces de ejercer la contemplación de las verdades eternas presentes en el orden (kosmos). Según el pensamiento de Platón, frente

\footnotetext{
234 ¿Qué diremos, en cambio, de los que contemplan las cosas en sí y que se comportan siempre del mismo modo, sino que conocen, y que no opinan? (...) Entonces ha de llamarse 'filósofos' a los que dan la bienvenida a cada una de las cosas que son en sí y no 'amantes de la opinión'? Completamente de acuerdo". PLATÓN, La República, 479e-480a.

235 "Por lo tanto, aquellos que carecen de experiencia de la sabiduría y de la excelencia y que pasan toda su vida en festines y cosas de esa índole son transportados hacia abajo y luego nuevamente hacia el medio, y deambulan toda su vida hacia uno y otro lado; jamás han ido más allá de esto, ni se han elevado para mirar hacia lo verdaderamente alto".Ibid., 586a.

236 "Nadie puede rechazar este proyecto de liberación; ningún hombre escapado ya de la propia caverna de su animalidad, en un nivel de evolución histórica, puede negarse a la ascensión". LLEDO, E., La memoria del Logos, Debolsillo, Barcelona, 2018, pág. 35.

${ }^{237}$ Cfr. TAYLOR, Ch., Fuentes del yo, pág. 172.

238 “ ¿Y no son censurados el lujo y la molicie por la flojedad y relajamiento de esa misma parte, cuando hacen surgir la cobardía? Sin duda. Y la adulación y el servilismo”. PLATÓN, La República, 590b.
} 
al control y dominio racional, el exceso de libertad conduce a la servidumbre, al caos, al desorden. $^{239}$

Históricamente se han realizado cuestionamientos a la hegemonía de la razón platónica. El Cristianismo incorporó gran parte de la filosofía platónica, pero "desde un sí pero no". La teología cristiana iba más allá de la razón platónica al incorporar la necesidad de una conversión de la voluntad. La razón por sí misma no conduce al bien tal y como lo entiende el Cristianismo. En la Edad Moderna, desde el Romanticismo, Nietzsche y la Escuela de Frankfurt, se ha insistido en que la hegemonía de la razón puede sofocarnos, desecarnos, reprimirnos, llevarnos a una "autodominación esclavizante". 240

Por otra parte, también otros mapas morales de la antigüedad cuestionaron el dominio de la razón. La moral guerrera valora la pasión, el anhelo por la fama y la gloria, el coraje, el ímpetu de energía, el valor y el ardor apasionado. La posesión enloquecida lanza al guerrero hacia el límite de sus energías para conseguir la gloria de la inmortalidad. De ahí que para Platón la pintura y la poesía no representen ese orden racional contemplativo, sino que son "puras ilusiones". 241

Es en este sentido en el que Taylor señala la oposición platónica a la ética homérica, el alma racional platónica frente a la psyche homérica. Platón contrapone la unidad del entendimiento autocontrolado a la fragmentación de la psicología homérica, caracterizada por "la fuerza vital", por un ímpetu de fuerza infuso en él por un dios. ${ }^{242}$ Las fuentes morales se sitúan en muy diferentes contextos. Taylor interrelaciona los diferentes mapas morales que se van configurando en torno a la fragmentación de la psyche homérica o en torno a la unidad racional platónica. La fragmentación e infusión divina del hombre homérico frente a la unidad racional platónica. En el héroe homérico, dichas fuentes más elevadas se ubican en estados especiales, la inspiración acrecentada por las grandes hazañas, las descripciones detalladas de las experiencias heroicas de luchas y glorias que superan cualquier imaginación y que suponen una ruptura con el sentir corriente. Por el contrario, las fuentes morales platónicas se enraízan en el sentimiento reflexivo del autocontrol, evitando cualquier fragmentación de estados especiales y profundizando en la unidad de todas las potencias en nuestra hegemonía racional, centrándonos en nosotros mismos. Las experiencias de gloria homérica serían más bien un lapsus para la razón y suponen rupturas en el autodominio racional. Los

\footnotetext{
239 "La razón no es solo un principio organizador de la vida humana y posible armonizador de sus contradicciones, sino también un medio universal donde confluyen las tendencias superiores del individuo y por cuyo predominio hay que luchar”. LLEDO, E., La memoria del Logos, pág. 95.

${ }^{240}$ Cfr. TAYLOR, Ch., Fuentes del yo, pág. 169.

241 "Y es a esta dolencia de la naturaleza que se dirige la pintura sombreada, a la que no le falta nada para el embrujamiento, la prestidigitación y todos los demás artificios de esa índole. Es cierto". PLATÓN, La República, 602d.

${ }^{242}$ Cfr. TAYLOR, Ch., Fuentes del yo, pág. 171.
} 
estados especiales representarían multiplicidad de lugares y experiencias de error, que nos alejarían de la mente como unidad. Frente a la psyche homérica como principio vital que proyecta una multiplicidad de experiencias, "el alma debe ser una si hemos de alcanzar lo más alto en la autocontrolada comprensión de la razón que ocasiona la armonía y la concordancia de toda la persona". ${ }^{243}$ Son geografías morales completamente diferentes. De la exaltación de lo externo (acción gloriosa), se pasa a la exaltación de lo interno (la razón). Por eso, desde el siglo VI a. de C., se producirá esa superación del antropomorfismo de la religión griega (se hace a los dioses a semejanza de los hombres y se considera por ejemplo a Zeus como padre de dioses y hombres) y un cierto agnosticismo, para ir progresivamente, a través de poetas y filósofos, a superar la figura humana de la divinidad y a asentarla en su propia esencialidad divina. La gran revolución platónica consistirá en fundamentar una nueva teología helenística sobre la base del Dios desconocido e inefable. ${ }^{244}$

Platón considera que la vida del justo está por encima de la gloria y el poder. La persona justa carece de interés por el poder. El justo se deja guiar por "el hombre interior", para dominar al "hombre entero" y "domesticar", para no dejar crecer "las bestias salvajes". ${ }^{245}$ Todo lo contrario de lo que vemos en el héroe homérico, que se deja llevar por la gloria humana y la fama. Es un héroe valiente, valeroso, temible y, por otra parte, capaz de amar y sentir culpa y vergüenza y de ser comprensivo. El fin último de las hazañas de los héroes es conseguir la máxima de las glorias posibles y alcanzar la fama por los siglos de los siglos. Aquiles canta su hazaña dirigiéndose agradecido a los dioses y a todos los presentes. ${ }^{246}$

En Platón, lo realmente importante es configurar el yo desde el control racional, captando las esencias y educando la mirada contemplativa "hacia la parte más brillante del ser", hacia el Bien, "corrigiendo la orientación" cuando sea necesario. La razón es ver y comprender. Ver según la comprensión correcta que capta el orden natural rigiéndose por la razón. Estar regido por la razón es estar regido por la visión de dicho orden natural. Se trata de una ontología conectada a lo trascendente, a la Idea conformadora del mundo. No existe ruptura entre el marco inmanente y el trascendente, antes bien, la trascendencia configura la inmanencia; esto es, la Idea con-forma el mundo de lo inmanente, un mundo de sombras y esclavitud.

\footnotetext{
${ }^{243}$ Ibid., pág. 173.

${ }^{244}$ Cfr. ISAR HERNÁNDEZ, M.C., "Evolución de la relación hombre Dios desde Platón hasta el siglo II d. C" Anuario de Estudios Filosóficos, Vol. 16, (1993), pág. 208.

${ }^{245}$ Cfr. PLATÓN, La República, 581 a-e.

246 "El divino Aquiles, ligero de pies, tan pronto como hubo despojado el cadáver, se puso en medio de los aqueos y pronunció estas aladas palabras: ¡Oh amigos, capitanes y príncipes de los argivos! Ya que los dioses nos concedieron vencer a ese guerrero que causó mucho más daño que todos los otros juntos, sin dejar las armas cerquemos la ciudad para conocer cuál es el propósito de los troyanos: si abandonarán la ciudadela por haber sucumbido Héctor, o se atreverán a quedarse todavía a pesar de que este ya no existe". HOMERO, Obras Completas de Homero. La Iliada, Rapsodia XXII, Montaner y Simón Editores, Barcelona, 1927, pág. 251.
} 
Lo importante como seres racionales no es tanto algo que sucede en nosotros, cuanto el "modo de conectarnos con el mundo" en el que nos hallamos. ${ }^{247}$ Es volver la mirada del alma desde las tinieblas a la luminosidad del verdadero ser. ${ }^{248}$ Para Platón, el tema clave es hacia dónde se dirige el alma. Lo importante no es lo que sucede dentro del alma, sino "hacia dónde mira" dentro del paisaje metafísico. El ojo corporal ve la realidad adecuadamente iluminada por el sol. El ojo del alma ve la realidad, el ser iluminado por la idea del bien (sol metafísico). ${ }^{249}$ Se trata, pues, de una concepción sustantiva de la razón. Una razón que está en conexión con el orden de las cosas en el cosmos. Este orden se relaciona con el orden correcto del alma como el todo se relaciona con la parte. "La verdadera razón es que solo en el plano del orden en su conjunto puede uno ver que todo está ordenado para el bien". 250

La visión del bien se sitúa en el centro de la doctrina de los recursos morales de Platón. Una idea que engloba todos los bienes, los demás bienes. A la luz del Bien podemos ver que nuestro bien, el orden correcto en nuestras almas posee ese valor categórico, referido ineludiblemente a dicho Bien, y disfruta de él como parte de la totalidad del orden. ${ }^{251}$ Toda una visión en la que lo trascendente como Razón Eterna configuradora del mundo establece los fundamentos del cosmos. De aquí se parte y desde aquí se irán experimentando todos los cambios posteriores. De un mundo de espíritus como Idea o como Espíritu de Honor, a un mundo impermeabilizado y secularizado. De un cosmos que se sobrepone como Razón a la voluntad del hombre, a un mundo como voluntad subjetiva que determina el sentido del mundo. ${ }^{252}$

Así pues, se puede afirmar que, según Taylor, en Platón la razón capta su plenitud en la visión del orden mayor, que es la visión del Bien. A través de la contemplación del orden natural por medio de la razón se llega a la visión del Bien como lo que globaliza ese orden natural. Todo está encaminado hacia el Bien, una vez captado el orden natural, forzando a elevar el ojo del alma para mirar hacia lo que proporciona luz a todas las cosas: el Bien. ${ }^{253}$

\footnotetext{
247 "La razón está conectada con el orden de las cosas en el cosmos". TAYLOR, Ch., Fuentes del yo, pág. 176; Cfr. TAYLOR, Ch., Argumentos filosóficos, págs. 72,111.

248 "En la visión platónica del mundo la razón es una especie de ojo que para ver (conocer) requiere reenfocarse, dirigirse hacia la contemplación de las ideas. Pero para lograrlo la razón debe controlar las pasiones y los deseos que intentan atraparla en la particularidad y la contingencia de las cosas sensibles. La visión del orden cósmico e inmutable despierta el amor por la idea del Bien”. FORERO REYES, Y.M., Epifanías de la identidad. La comprensión multiculturalista de Charles Taylor, Anábasis, Bogotá, 2008, pág. 126.

${ }^{249}$ Cfr. PLATÓN, La República, 532a.

${ }^{250}$ TAYLOR, Ch., Fuentes del yo, pág. 176.

${ }^{251}$ Cfr. Id., pág. 176.

${ }^{252}$ Cfr. TAYLOR, Ch., La Era Secular, tI, pág. 220.

${ }^{253}$ Cfr. PLATÓN, La República, 540 a-b.
} 
Las fuentes morales a las que accedemos por la razón no están en nosotros, están fuera de nosotros, en el orden natural y más allá del orden natural, en el Bien ${ }^{254}$. Lo importante para Platón, tal como lo interpreta Taylor, no solo es el predominio de la razón sobre los sentidos, sino a qué atiende y ama la razón como un todo: "el eterno orden del ser". El orden racional platónico es encontrado, no es algo interiorizado como hecho, tal y como vemos en Descartes, por ejemplo. En Platón, amar ese descubrimiento del orden eterno a través de la razón es el Bien. ${ }^{255}$ Ese es el yo platónico, el dejarse guiar por la razón hacia la plena contemplación del Bien, contemplación que lleva inexorablemente a la virtud, dado que la observación de la inteligencia del cosmos nos permite aplicarla a nuestro entendimiento. ${ }^{256} \mathrm{El}$ amor al Bien es la fundamentación del yo que llega a la percepción del mismo. ${ }^{257}$ Por eso, la filosofía es lo que mejor podrá llevar a vivir una vida virtuosa. ${ }^{258} \mathrm{Se}$ trata de una ontología que potencia la configuración del mundo a partir de la "Religión de la Idea Configuradora", un mundo conectado a la Idea del Bien y a la Razón Eterna. Es una Religión Filosófica y dualista que "con-forma" el Todo y que se constituyó en el modelo filosófico predominante en el mundo antiguo.

\section{III.1.2.3. SAN AGUSTÍN DE HIPONA: EL YO COMO INTERIORIDAD}

Bajo el punto de vista de Taylor, era natural imaginar para los platónicos cristianos, como San Agustín, a Dios ocupando el lugar de la idea del Bien de Platón, aunque San Agustín adopta su propia visión desde el Cristianismo. ${ }^{259}$ San Agustín da un paso más en la comprensión del yo como autodominio racional, pero en continuidad con

\footnotetext{
254 "El Bien no es ninguna realidad determinada que exista con independencia de la inteligencia, pero al mismo tiempo no es un producto de esta, siendo por ello una idea imposible. Antes bien, resulta que la buena inteligencia es un producto del Bien, que es el foco que hace visible los inteligibles. Advertir el Bien exige pues que no se lo piense como una realidad determinada al margen del inteligir ni como un producto de la inteligencia". ROJAS JIMÉNEZ, A., "El Bien y la intelección según Platón", Thémata, No 50, (2014), pág. 58.

${ }^{255}$ Cfr. TAYLOR, Ch., Fuentes del yo, pág. 177. "Es la más indudable de todas las realidades. En segundo lugar, que se trata de una Idea o esencia - el 'Bien mismo', a diferencia de las concretas y cambiantes existencias que participan en diversos grados de su naturaleza-; y que por tanto tiene propiedades comunes a todas las Ideas, de las que las más fundamentales son la eternidad y la inmutabilidad. En tercer lugar, que constituye el polo opuesto a 'este' mundo; para aprehenderla, la facultad del conocimiento junto con toda el alma, debe apartar la vista de todo lo que está a devenir, hasta ser capaz de soportar la contemplación de lo que es y de su parte más resplandeciente; que es, afirmamos, el Bien. (...) En quinto lugar, que la Forma del Bien es el objeto universal del deseo, lo que atrae a todas las almas hacia sí; y que el principal bien del hombre, incluso en esta vida, no es sino la contemplación de este Bien absoluto o esencial". LOVEJOY, A., La Gran Cadena del Ser, Icaria Editorial, Barcelona, 1983, págs. 52-53.

${ }^{256}$ Cfr. PLATÓN, Timeo 47b, Gredos, Madrid, 2018, pág. 317. Cfr. PLATÓN, Timeo 90, b-d; Leyes 716 c-d en donde se invita al alma a "imitar" el orden divino, de tal manera que el que contempla sea semejante al objeto de contemplación.

257 "En la comprensión de la capacidad del logos de dar razón de sí, de autojustificar las propias determinaciones, es decir, de 'fundar' la propia búsqueda de la verdad y de ese modo sustraerla no solo al relativismo de Protágoras, sino también a la ciega necesidad de los atomistas". VANZAGO, L., Breve historia del alma, Fondo de Cultura Económica, México, 2011, pág. 38.

${ }^{258}$ Cfr. TAYLOR, Ch., Fuentes del yo, pág. 177,179.

${ }^{259}$ Cfr. Ibid., pág. 140.
} 
las Ideas y las oposiciones platónicas comprendidas desde un punto de vista cristiano. Para San Agustín, las Ideas platónicas son los Pensamientos de Dios. ${ }^{260}$ Para Platón, todo es creado como "conformado" (participación en las Ideas). Para San Agustín, la realidad es también expresión externa de los pensamientos (Ideas) de Dios, todo es también participación o semejanza de la Mente de Dios que crea todo "ex-nihilo". Según Taylor, en San Agustín, la doctrina de la creación "ex-nihilo" se empareja con la noción platónica de la participación.

La comprensión agustiniana del universo es platónica, como expresión externa del orden racional. Todo lo que existe tiene un orden y captar ese orden eterno del Ser es percibir el Bien. Tanto para San Agustín como para Platón, el orden cósmico es percibido por la razón, y en ambos la virtud significa contemplar y amar dicho orden. ${ }^{261}$

Esa es la fuente moral de la que ambos participan. La oposición platónica corpóreo-incorpóreo se transforma en San Agustín en la oposición carne-espíritu. Lo fundamental para ambos está en la dirección en la que ama el alma, superar las apetencias sensibles para captar el orden eterno del ser. Pero para Taylor la diferencia en relación con Platón es la ruptura del equilibrio entre el amor y la atención en la dirección del alma. Según Taylor, para San Agustín lo fundamental será el amor, con la consiguiente pérdida de protagonismo de la atención.

Taylor afirma que las oposiciones platónicas (alma-cuerpo; inmaterial-corporal; eterno-temporal) se orientan en San Agustín hacia la "oposición central y esencial", en términos de lo "interior-exterior". ${ }^{262}$ Es decir, que enfocar y redireccionar la mirada del ojo del alma hacia el orden eterno del Ser y amar ese orden natural viene definido por una clave: "descubrirnos a nosotros mismos como seres interiores", que Taylor entiende en relación con la imagen del ojo del alma, que no es tanto la fuerza de la mirada, como la idea de "volver y reubicar la mirada". Se trata de no derramarse, de entrar dentro de uno mismo "porque en el hombre interior reside la verdad, elevándose sobre el alma dotada de razón y ubicarse allí donde la luz de la razón se enciende". 263

\footnotetext{
${ }^{260}$ Cfr. Ibid., págs. 186-187. San Agustín, siguiendo a Plotino, que hace una relectura de Platón, afirma que todo procede de la mente de Dios y que no ha podido crearse nada que no hubiera sido previsto por el pensamiento divino. Y si todo lo divino es eterno e inmutable, los pensamientos divinos corresponderían con las ideas platónicas. Así San Agustín llegará a firmar que cada cosa ha sido "creada" con la idea de Dios en ella, todo parte de la "mente del creador". Dios crea a partir de la nada y no puede concebir algo que sea anterior a Él y menos que lo tomara como modelo. Todo ha sido creado a partir de la idea de Dios.

${ }^{261}$ Cfr. PLATÓN, La República, 517 b.c.

262،“El hombre exterior es lo corporal, lo que tenemos en común con las bestias, incluyendo los sentidos y el almacenaje en la memoria de imágenes de las cosas externas. El interior es el alma. Es esta oposición interior-exterior, ojos/sentidos corporales-potencia intelectiva la que hace consciente al hombre de que solo desde esa dimensión superior de la interioridad intelectiva el hombre puede tener acceso a Dios. El sendero que lleva a Dios está dentro". TAYLOR, Ch., Fuentes del yo, pág. 185.

${ }^{263}$ Cfr. HIPONA, A. de, Sobre la verdadera religión, XXXIX.72.
} 
Para San Agustín, ese hombre interior es el único que es capaz de descubrir a Dios. ${ }^{264}$ Sin el acceso a esa interioridad del alma, Dios no se hace accesible. Por eso, lo primero es descubrirnos por dentro, habitados por una interioridad, volvernos hacia nosotros mismos. Y a partir de ahí, podemos descubrir a Dios. ${ }^{265}$

Según Taylor, para San Agustín el acceso a Dios no está principalmente en la contemplación del orden eterno del ser, en la contemplación intelectiva del orden natural que participa del Pensamiento de Dios, en el orden de las cosas externas que participan de Dios (Idea), como en Platón, sino fundamentalmente en lo que subyace a la capacidad cognitiva misma o en "lo que potencia el ojo que ve". Dios no está solo ahí fuera para ser contemplado platónicamente, sino también y fundamentalmente dentro, como el que potencia la capacidad cognitiva para acceder al conocimiento de las cosas, en el interior de nosotros mismos, ${ }^{266}$ como una luz interior que "potencia y enfoca la mirada". ${ }^{267} \mathrm{~A}$ través del conocimiento de la luz racional que conoce, se puede acceder a la Luz incognoscible. ${ }^{268}$ No solo encontrar a Dios en las cosas externas, sino en el proceso que permite conocer las cosas externas. El primer aspecto es para todos y es público. El segundo es particular, y por eso San Agustín invita a volver la mirada hacia el yo, a adoptar una postura reflexiva. Lo exterior está para todos. Lo interior implica "una ocupación individual", una "mirada propia", un "cuidado de uno mismo". ${ }^{269}$ Lo realmente relevante es lo que subyace a nuestra capacidad cognitiva: Dios. De ahí que

\footnotetext{
${ }^{264}$ TAYLOR, Ch., Argumentos filosóficos, pág. 296.

${ }^{265}$ ¡Ay, ay de mí, por, qué grados fui descendiendo hasta las profundidades del abismo, lleno de fatiga y devorado por la falta de verdad! Y todo, Dios mío - a quien me confieso por haber tenido misericordia de mí cuando aún no te confesaba—, todo por buscarte no con la inteligencia — con la que quisiste que yo aventajase a los brutos-, sino con los sentidos de la carne, porque tú estabas dentro de mí, más interior que lo más íntimo mío y más elevado que lo más sumo mío". HIPONA, A. de, Confesiones, Libro III, cap. VI, No 11.

266 "Al revelarse Dios en la intimidad de la consciencia, la trascendencia teórica de Platón entra al ámbito de la experiencia subjetiva. Frente al modelo antiguo, San Agustín establece la absoluta realidad de la experiencia interior. La experiencia interior es la experiencia del alma misma que conoce y tiene certeza de sí misma como sujeto, y así es experiencia de Dios". BURLANDO, G., "El Espíritu, surco del yo en San Agustín", Mirabilia 25, No 2, (2017), pág. 90.

${ }^{267}$ San Agustín de Hipona habla de tres miradas: la mirada corporal, la mirada de la mente y la mirada de la fe. Hay una luz exterior que entra por el ojo y otra luz por la que el ojo es capaz de percibir las cosas exteriores que es la luz del alma. "Mientras lees esta carta, recuerdas que has visto el sol con los ojos de tu cuerpo, puedes volver a verlo al instante, si el tiempo lo permite y te encuentras en lugar despejado para poderlo ver. En cambio, para ver esas cosas que, según dije, se perciben con la mente, por ejemplo, que vives, que quieres ver a Dios, que lo preguntas, que sabes que vives, quieres y preguntas, pero que no sabes cómo se le ha de ver, no empleas los ojos corporales ni buscas o sientes distancias locales para tender la mirada, para que llegue a los objetos que quieres ver. Así ves tu vida, tu voluntad, tu búsqueda, tu ciencia, tu ignorancia, pues tampoco se ha de desdeñar esta vista con que ves que no sabes". HIPONA, A. de, Cartas, Carta 147.3.

268 "San Agustín retira el enfoque centrado sobre los objetos que conoce la razón, el campo de las Ideas, y lo dirige a la actividad de procurar conocer lo que cada uno de nosotros lleva dentro de sí; y nos hace conscientes de ello en una perspectiva de primera persona. (...) Se encuentra en la intimidad de mi autopresencia. De hecho, está más cerca de mí que yo mismo, aunque esté infinitamente por encima de mí; él es interior intimo meo et superior summo meo. Puedo pensar a Dios como el principio más fundamental que ordena dentro de mí. Como el alma anima el cuerpo, así Dios al alma. La vivifica". TAYLOR, Ch., Fuentes del yo, pág. 195.

${ }^{269}$ Cfr. TAYLOR, Ch., Fuentes del yo, pág. 186.
} 
sea necesaria la mirada interior, pues Dios es el que potencia el ojo que ve. El camino hacia lo interior me lleva hacia lo más alto. ${ }^{270}$

Según interpreta Taylor, la postura reflexiva agustiniana adopta un carácter radical. San Agustín nos invita más a centrarnos en el agente experimentador, que en las cosas experimentadas. Sería una postura opuesta a la visión científica del mundo como un ámbito de consideración neutra que se centra en las cosas en sí mismas. San Agustín da un vuelco para centrarse en el mundo tal y como es experimentado por mí, una postura vinculada que es consciente de que el mundo es experimentado por mí y adquiere una significación propia por la manera como es para mí.

San Agustín se interesa tanto por la luz interior, por esa reflexividad radical que hace presente al "yo ante mí mismo", que este lenguaje de la interioridad marcará toda la tradición epistemológica occidental desde Descartes hasta la cultura moderna. El "yo pienso cartesiano" está de alguna manera fuera de las cosas que experimentamos. San Agustín marca el inicio de la interioridad como postura intermedia entre el orden exterior platónico y el yo pienso cartesiano que da identidad a un ser que es solo ser porque piensa, al margen de las cosas exteriores. La interioridad agustiniana es un "yo ante mí mismo" que nos permite acceder al Dios que está en las cosas exteriores. Es un vuelco hacia el yo en la dimensión de la primera persona, que no lo desvincula de la experiencia exterior, del acceso hacia Dios presente en las cosas creadas. Se trata de un yo interior que da luz a la comprensión de Dios presente en el mundo creado. Sin la verdad de este yo interior no se puede acceder a Dios presente en la creación exterior. $^{271}$

El lenguaje de la interioridad agustiniana es una experiencia de pensar en primera persona, adoptar el punto de vista de la primera persona. San Agustín piensa que se trata de una certeza "para mí." Se trataría de un precogito cartesiano. A un interlocutor le diría "si tú no existieras sería imposible engañarte" y a sí mismo se dice "estoy seguro de mi existencia". ${ }^{272}$ El conocedor y lo conocido son lo mismo. Es la certeza de la autopresencia. Taylor afirma que San Agustín es el gran inventor del “cogito” ya que es

\footnotetext{
${ }^{270}$ Cfr. Ibid., pág. 194.

${ }^{271}$ Cfr. Ibid., págs. 187,189.

272 "Sin embargo, el ejercicio mismo de la duda es contradictorio en cuanto que no puede prescindir de la certeza de haber comprendido la duda misma: 'Todo el que comprende que duda, comprende algo verdadero y está cierto de esa realidad por él comprendida; luego, está cierto de la verdad. (...) Quien duda, pues, de algún modo, no puede dudar de la verdad' (La verdadera religión, 39, 73). (...) En todo caso, dice San Agustín, para rebatir el escepticismo, que niega la existencia de la verdad objetiva y universal, es suficiente con la certeza que el sujeto tiene de sí mismo: ‘(..) Y si te engañas ¿qué? Si me engaño, existo; pues quien no existe no puede engañarse; y por esto, si me engaño, existo. Entonces, puesto que si me engaño existo, ¿cómo me puedo engañar sobre la existencia, siendo tan cierto que si me engaño existo?' (La Ciudad de Dios, 11, 26), palabras agustinianas de indudable influjo en el célebre cogito cartesiano" LAZCANO, R., "El amor a la verdad según San Agustín de Hipona”, Revista Española de Filosofía Medieval, No 17, (2010), pág. 13.
} 
el primero que afirma la primera persona como fundamento para la búsqueda de la verdad. $^{273}$

Y es aquí en esta autoconciencia de que el conocedor y lo conocido son lo mismo donde se alcanza una conciencia de profunda intimidad para captar que Dios está por encima de mí. Es ahí donde el alma encuentra a Dios en la raíz de la memoria. Es entonces en esa "intimidad de autopresencia" de estar delante de Dios cuando el alma "recuerda a Dios". ${ }^{274}$

Si el camino para conocer a Dios en las cosas creadas le lleva a San Agustín a ser consciente de que Alguien marca el camino de la interioridad para el conocimiento de Dios en las cosas exteriores, San Agustín adoptará en un segundo momento una postura reflexiva sobre esa luz interior como autopresencia, como un camino en primera persona que le llevará a ser consciente de sí mismo, como un cogito para la búsqueda de la verdad. No solo es válido para el acceso a Dios en lo exterior, sino para el acceso al conocimiento de mí mismo en el que yo soy el mismo que se conoce.

En esta idea de la autopresencia, Taylor encuentra que el hombre tiene conciencia de que lo superior incluye a lo inferior, y que lo superior juzga a lo inferior. ${ }^{275}$ La razón es lo superior y lo que juzga a lo inferior. Nada hay superior en el hombre a la razón. Todos percibimos las cosas del mundo por los sentidos. Y también todos somos conscientes de que hay realidades a las que solo podemos tener acceso por la razón, verdades de sabiduría que somos conscientes de que están ahí, de que se descubren a través de la mente. En la actividad racional en la experiencia de pensar y razonar me hago consciente de que depende de algo que lo sobrepasa. Y según Taylor, esto no solo abarca la realidad exterior objeto de conocimiento, sino también los propios parámetros a los que la razón se acoge. La actividad racional que es de cada uno se fundamenta así en algo, y presupone algo que es superior a mí. El camino de la metafísica de la interioridad me lleva hacia algo más alto, hacia lo más alto. Dios no solo se encuentra en el mundo, sino también, y más esencialmente, en los fundamentos de la persona, en la intimidad como autopresencia divina. Dios, como verdad, nos ofrece los criterios del

\footnotetext{
${ }^{273}$ Cfr. TAYLOR, Ch., Hegel, pág. 6.

274 "El camino interior lleva hacia arriba. Cuando llegamos a Dios, la imagen del lugar se hace múltiple y multifacética. En un importante sentido, la verdad no está en mí. Veo la verdad en Dios. Al darse el encuentro, tiene lugar una inversión. Adentrarme en la memoria me conduce más allá... Mientras que para Platón lo de 'dentro' era solamente un camino que llevaba a un 'antes', para San Agustín es la senda que conduce a lo 'alto' y tan indispensable como el camino fue allá”. TAYLOR, Ch., Fuentes del yo, pág. 194.

275 "Por los ojos del cuerpo cada uno posee todo lo que con agrado contempla. Y ¿quién hay que, al no poder conservar ambas cosas, en la alternativa de perder una de ellas, no prefiera perder las riquezas antes que la vista? Y puesto en idénticas condiciones, si le preguntamos qué desea perder, los ojos o el alma, ¿quién no ve con la mente que antes prefiere perder los ojos que el alma? Sin los ojos corporales sigue siendo humana; los ojos sin el alma son ojos de bestia. ¿Y quién no prefiere ser hombre ciego en la carne antes que ser cuadrúpedo dotado de vista?" HIPONA, A. de, De Trinitate, XIV, 14,19.
} 
juicio correcto, pero no nos los ofrece mediante el espectáculo de un mundo organizado por las Ideas, sino más básicamente a través de la "luz incorpórea". 276

La verdad que está detrás de lo que aparece delante de nosotros. La verdad aparece en la mente como criterio fundamental, no para ser juzgada, sino para aceptar y alegrarse de encontrarse con ella. Esa verdad última que existe es Dios. Dios es algo superior a la razón. Aunque accedemos a Dios a través de ella. Es como un ascenso por grados. Dejar las cosas bellas para vislumbrar lo Bello. Dejar las cosas buenas para encontrar lo Bueno. Es Dios mismo quien ha puesto en el corazón del hombre la noción del bien mismo y de la belleza misma. San Agustín afirma que Dios es el Bien, el Bien de todo bien. A Dios, según San Agustín, le amamos por sí mismo, por ser el Bien mismo, y a todas las demás cosas en cuanto que participan de dicho Bien. Podemos juzgar del bien (moral) de las cosas, porque en nosotros está "impresa" (una palabra realmente relevante en San Agustín) la noción del bien mismo.

Taylor también presta atención a la doctrina agustiniana de la voluntad. Para Platón el deseo del Bien está en función del conocimiento de él. Para San Agustín la voluntad no depende simplemente del conocimiento. Hay un poder de consentir, un poder que en cada caso es esencialmente mío. Luego la perfección moral requiere no solo conocimiento del bien, sino adhesión total y compromiso de la voluntad. Y así, en relación con dicha voluntad personal e intransferible, partiendo de la teología agustiniana, se van forjando las ideas de "fuerza de voluntad" y "buena o mala voluntad". Para San Agustín hay una cierta "perversidad" en la voluntad debido a la falta de una intuición del bien, que lleva al hombre a actuar por debajo y a veces en contra de nuestra voluntad. Y según Agustín, esta "perversidad" de la voluntad tiene que ver con la "reflexividad humana" que nos lleva a centrarnos en nosotros mismos y a tener una relación de dominio de las cosas. Por lo tanto, el mal no solo tiene que ver con la falta de visión del bien sino también, con lo que Taylor llama "la dimensión del sentido que el alma tiene de sí misma", en relación con la tendencia a la "reflexividad humana". 277

Pero, asegura Taylor que hay algo más que completar. La reflexividad no es solo tendencia a la posesión y dominio de las cosas que nos descentra, sino una posibilidad para abrirnos a la autopresencia que hace vislumbrar la luz de Dios. El mal se da cuando la voluntad reflexiva se cierra en sí misma. No obstante, hay una reflexividad que posibilita la apertura a la salvación de un Dios que se ofrece en esa misma interioridad reflexiva. Es en esa intimidad de nuestra presencia ante nosotros mismos donde se decide la apertura a Dios, o la reflexividad insana que lleva a poseer y dominar y a

\footnotetext{
${ }^{276}$ Cfr. TAYLOR, Ch., Hegel, 453; cfr. TAYLOR, Ch., Fuentes del yo, pág. 192.

${ }^{277}$ Cfr. HIPONA, A. de, El combate cristiano, XIII.
} 
centrarnos en un yo obsesivo con la fascinación por las propias obsesiones y lo sensible. El alma así puede adoptar un doble camino de apertura autocomprensiva que vislumbra la salvación gratuita de Dios, o una reflexividad insana que nos autoempodera en experiencias de empequeñecimiento esclavizante. ${ }^{278}$

\section{III.1.2.4. DESCARTES: LA CONCIENCIA DEL YO}

En Platón, las fuentes de energía moral están fuera. Tener acceso a lo superior es estar vuelto hacia el orden cósmico y captar dicho orden natural a través de la razón. San Agustín transforma la mirada y realiza una metafísica de la interioridad. San Agustín mantiene el orden cósmico, pero a través del camino interior, del Señor interior en el que lo conocido interiormente y el agente conocedor se identifican. Esta interioridad de autopresencia está habitada. Y Dios plenifica la mirada para llegar a Él. El camino interior es para acceder a Dios. Las fuentes morales también están fuera, están en Dios, aunque el camino es interior. Según Taylor, a pesar de que Descartes es profundamente agustiniano, sin embargo, se diferencia de él en que sitúa las fuentes morales "dentro de nosotros mismos". 279

Descartes rechaza la teoría de las Ideas y del orden eterno de las cosas y del logos óntico. El universo no está lleno de significados trascendentales. La razón cartesiana no se pone en sintonía con el logos óntico, sino con el yo que piensa y conoce la realidad como representación de las cosas. ${ }^{280}$ Es un universo regido mecanicistamente y que permite acceder a él a través del método experimental galileano. Las esencias dejan de tener sentido alguno, para adentrarse en las cosas tal como son desde un punto de vista científico. El orden de las ideas deja de ser algo que encontramos (autorrevelación), para convertirse en algo que construimos. La separación entre la res extensa y la res cogitans hace que también haya una independencia completa desde el punto de vista epistemológico. La teología se encarga del estudio de las esencias y realidades espirituales, y la ciencia se encarga del estudio de las cosas, tal y como son en su entidad científica, a las que se accede por vía experimental. El conocimiento representacional de la mente se tiene que corresponder con la realidad, sin que haya la más mínima sombra de duda, poniéndose en aviso sobre ese "genio maligno" engañador que lleva a consideraciones que no se corresponden con la realidad. ${ }^{281}$ En el Discurso del Método asegurará la veracidad de nuestros conocimientos en contra de ese "mal genio" que equivoca o lleva al engaño. Conocimientos claros y distintos sobre los que no haya ninguna duda de su certeza y veracidad. ${ }^{282}$ Todo pues debe sujetarse al proceso

\footnotetext{
278 TAYLOR, Ch., Fuentes del yo, pág. 198.

${ }^{279}$ Cfr. Ibid., pág. 203.

${ }^{280}$ Cfr. Ibid., pág. 204.

${ }^{281}$ Cfr. DESCARTES, R., Meditaciones metafísicas, Gredos, Madrid, 2018, pág. 17.

${ }^{282}$ Cfr. DESCARTES, R., Discurso del Método, Gredos, Madrid, 2018, pág. 114.
} 
del pensar. Pensar desde el significado etimológico de la palabra cogitare, como recoger y ordenar.

Frente al dualismo platónico que ve en el alma racional la capacidad de enfocar la mirada hacia el orden eterno y captar las ideas inmutables presentes en las cosas que me rodean como partícipes de las Ideas que les proporcionan el ser, el dualismo cartesiano supone una ruptura total entre el mundo material y el mundo espiritual, entre interior y exterior, entre la mente y el mundo como loci aislados. ${ }^{283}$ Descartes objetiva científicamente el mundo, incluyendo nuestros cuerpos, mirándolo todo como un observador externo. ${ }^{284}$ Solo conocemos la realidad porque la entendemos mentalmente, no por la imaginación ni por los sentidos, ni por verla o tocarla, tal y como afirma en la Segunda meditación Metafísica sobre el trozo de cera. Y solo entendemos la realidad cuando la percibimos desprovista de cualquier esencia espiritual, desencantada de cualquier significación trascendental y ubicada de forma neutra en un mundo científico, a cuyo conocimiento se accede por vía experimental. Se rechaza la ontología tradicional platónica, dado que conocer es "mirar el mundo" de manera desvinculada, desprovistos de cualquier subjetivismo ontológico. Se rechaza totalmente la presencia de lo eterno en lo temporal. Pero, tal y como afirma Taylor, Descartes necesita del cuerpo para descubrir la esencia espiritual racional. ${ }^{285}$ Mientras que el alma platónica pretende liberarse de la experiencia corporal de los sentidos elevándose a través de la razón hacia el mundo de lo suprasensible y captando el orden eterno, Descartes, por el contrario, necesita del cuerpo para abrirse a la comprensión de lo inmaterial, necesita objetivar el mundo y la experiencia corporal. El alma necesita del cuerpo "para dar el salto que la librará de él". Se parte del cuerpo para "la liberación intramundana" del alma como camino para el descubrimiento del yo, noción que queda demostrada, mientras que todo lo de afuera, incluso Dios, está en duda. ${ }^{286}$ Con Descartes "se empieza a romper la mente del mundo conectada con la Idea" configuradora del cosmos. La unidad de lo trascendente y lo inmanente queda superada por un dualismo desconfigurador de "esencias espirituales", algo que marcará el devenir de la Modernidad y la Religión en el futuro.

Si para Platón ser racional es estar en sintonía con el orden cósmico y eterno que hay que amar, para Descartes no existe ese orden cósmico, por lo que percibir la

\footnotetext{
${ }^{283}$ Cfr. TAYLOR, Ch., La Era Secular, tII, pág. 382.

284 "Conocí por ello que yo era una sustancia cuya esencia y naturaleza toda es pensar, (la cursiva es nuestra) y que no necesita, para ser, de lugar alguno, ni depende de cosa algún material; de suerte que este yo, es decir, el alma por la cual yo soy lo que soy, es enteramente distinta del cuerpo y hasta más fácil de conocer que este, y, aunque el cuerpo no fuese el alma no dejaría de ser cuanto es. (...) Y habiendo notado que en la proposición 'yo pienso, luego soy' no hay nada que me asegure que digo verdad, sino que veo muy claramente que para pensar es preciso ser, juzgué que podía admitir esta regla general: que las cosas que concebimos muy clara y distintamente son todas verdaderas". DESCARTES, R., Discurso del Método, pág. 124.

${ }^{285}$ Cfr. TAYLOR, Ch., Fuentes del yo, pág. 207.

${ }^{286}$ Cfr. TAYLOR, Ch., Hegel, pág. 6.
} 
racionalidad es ser capaz de construir órdenes que satisfagan los parámetros exigidos por el conocimiento o la certeza. El orden no viene dado, como en Platón, hay que construirlo a través de una racionalidad científica que busca la evidencia y la claridad. Taylor considera que en Descartes el autodominio consiste, no como en Platón en el que la razón vislumbra el bien cósmico y se adapta al mismo, elevándose hacia lo suprasensible, sino en "construir órdenes" percibidos por nuestra capacidad de razonar a través del dominio científico y experimental. ${ }^{287}$ Con Descartes se inicia una "primera desconexión" del yo con lo trascendente, no ruptura, sino un vuelco en la configuración moral que enfoca la mirada hacia otra realidad distinta al orden cósmico, esto es, "el yo que piensa" y que por lo tanto es. Soy porque pienso y pienso porque soy lo que pienso.

En opinión de Taylor, la visión moral de Descartes se enmarca en la tradición estoica de la "autarkeia" y la "proairesis" como opción moral basada en la voluntad. ${ }^{288}$ Es la razón la que domina los deseos y la que determinándose a través del entendimiento la que puede representar mentalmente lo bueno y lo malo, y lo que va a terminar decidiendo la voluntad según dicho entendimiento: basta juzgar bien para obrar bien. Con Descartes se inician caminos secularizadores de la razón que es capaz de "determinar el orden y la voluntad": el juicio del entendimiento asegura el bien obrar. Se avanza inexorablemente hacia el voluntarismo kantiano como fuente del deber moral.

Existen claras diferencias entre la moral estoica y cartesiana del dominio de la razón y la opción moral frente a la moral platónica del Bien cósmico que es descubierto racionalmente y que atrae la voluntad humana a esa elevación hacia lo sobrenatural en el mundo de las Ideas. Y, por otra parte, la visión agustiniana del doble camino de la reflexividad humana que plantean los dos amores: en la ambigüedad de la voluntad está su grandeza al ser una posibilidad para la apertura a Dios y a una mayor intuición del Bien, transformando la voluntad a base de más intuición y una reflexividad de empequeñecimiento esclavizante.

El dualismo cartesiano, con esa separación ontológica entre materia y espíritu, lleva al desencanto del mundo o a lo que Taylor denomina neutralización del cosmos: se desmitifica el cosmos como encarnación de un orden significativo que expresa el Bien; $\mathrm{y}$ todo adquiere un significado neutro, funcional, como ámbito de control instrumental. ${ }^{289}$ Para Taylor, visto todo esto desde la deconstrucción, se trata de una

\footnotetext{
${ }^{287}$ TAYLOR, Ch., Argumentos filosóficos, pág. 97.

288 "Pues no determinándose nuestra voluntad a seguir o a evitar cosa alguna, sino porque nuestro entendimiento se la representa como buena o mala, basta juzgar bien para obrar bien, y juzgar lo mejor que se pueda, para obrar también lo mejor que se pueda”. DESCARTES, R., Discurso del Método, pág. 120.

289 "Podríamos aprovecharlas del mismo modo en todos los usos a que sean propias, y de esa suerte hacernos como dueños y poseedores de la naturaleza”. Ibid., pág. 142.
} 
ceguera autoimpuesta de la máxima envergadura. Una teoría que postula la primacía de lo individual, lo neutral y lo intramental. ${ }^{290}$

Taylor sostiene que la hegemonía de la razón cartesiana no viene determinada por el descubrimiento de un orden ontológico fundamentado en la Idea del Bien, sino por el dominio que permite realizar en el mundo un control funcional y mecanicista del mismo que nos convierte en dueños y señores de la naturaleza. La razón cartesiana permite dominar la naturaleza olvidando el sentido trascendental del cosmos platónico. En este dominio de la razón en un mundo neutro e instrumental, las pasiones para Descartes también pueden ser controladas por la razón cuando las sujeta a su normal función instrumental. No se trata, como Platón, de despojarse de las pasiones, sino de sujetarlas al dominio racional. ${ }^{291}$ Las pasiones no son un problema en sí, ni su virulencia ni su fuerza arrolladora, siempre y cuando están bajo el control de la razón. Se trata de un control instrumental para realizar eso que nos proponemos, al mismo tiempo que la indiferencia por el resultado. Es lo que Taylor denomina un "compromiso despreocupado". Descartes, en el Discurso del Método, habla de tres máximas en su vida. En la tercera afirma que hay que "obrar lo mejor que se puede ajustando todo al poder de nuestros pensamientos". La voluntad está dominada por "las representaciones mentales" ya que estas deciden el valor del deseo y la posibilidad de su realización. Ese "obrar lo mejor que se pueda" expresa el compromiso despreocupado por los resultados. El éxito puede parecer a veces imposible de alcanzar. Lo que importa es el dominio de la razón. ${ }^{292}$

Las fuentes morales ya no están fuera de nosotros, en un cosmos como encarnación significativa del Bien. Las fuentes morales con Descartes pasan a estar dentro del hombre, en ese control funcional de la mente, que se expresa en la conciencia de la propia dignidad humana, para adoptar una postura instrumental del mundo, de las pasiones y del cuerpo. Es decir, para Charles Taylor, la ética del control racional, que tanta importancia tendrá en la modernidad, se inicia con Descartes a partir del giro dado a las fuentes morales del yo. Ahora, las fuentes morales se enraízan en el sentido de la dignidad y la autoestima del hombre a partir del dominio de la razón instrumental sobre un mundo desencantado.

\footnotetext{
${ }^{290}$ Cfr. TAYLOR, Ch., La Era Secular, tII, pág. 414.

${ }^{291}$ Cfr. PLATÓN, La República, págs. 571-572. Platón afirma que "el vicio esclaviza al hombre a la bestia que hay en él" y de "la superioridad de los placeres intelectuales". Y que la tradición ha censurado todo aquello que lleve al hombre a vivir como las bestias o todo aquello que le conduce a vivir "en la oscuridad de las tinieblas".

292 "Mi tercera máxima fue procurar siempre vencerme a mí mismo antes que a la fortuna, y alterar mis deseos antes que el orden del mundo, y generalmente acostumbrarme a creer que nada hay que esté enteramente en nuestro poder sino nuestros propios pensamientos; o de suerte que después de haber obrado lo mejor que hemos podido, en lo tocante a las cosas exteriores, todo lo que falla en el éxito es para nosotros absolutamente imposible”. DESCARTES, R., Discurso del Método, pág. 119.
} 
Las fuentes morales las podemos encontrar en el "orden natural de las cosas" que encontramos en el mundo (Platón: sintonía con el orden eterno de la Realidad) o bien en la construcción de un orden intramental de ideas, de acuerdo con las disposiciones de las cosas que encontramos en el mundo (Descartes). Según Descartes, pues, se trata de construir "órdenes de representaciones mentales" que reproducen el orden del mundo (según la evidencia y las reglas de la certeza a través de ideas claras y distintas). La razón práctica cartesiana "construye mentalmente" el mundo de acuerdo a la disposición natural de las cosas, tal y como se presentan ante nosotros, para acrecentar el dominio racional. Para Taylor, en la tradición cartesiano-empirista, el agente no es visto como el "ser adherido" al mundo, sino como el "ser afectado" por el mundo. La unidad era un substrato incognoscible o construida, pero no experimentada. ${ }^{293}$

Frente a la razón sustantiva platónica que descubre el orden eterno del cosmos, la razón moderna cartesiana ontologiza el método y se centra en las propiedades del acto de pensar. La racionalidad ahora es un proceso interno del pensamiento subjetivo, en lugar de un descubrimiento del orden de las cosas. Sin duda alguna, la razón cartesiana hunde sus raíces en la interioridad agustiniana como reorientación hacia el ser humano que se piensa y se descubre como sujeto. ${ }^{294}$

Descartes imprime su propio giro a la tradición agustiniana. ${ }^{295}$ En San Agustín, afirma Taylor, a través del yo imperfecto (en su interioridad) se llega al Dios perfecto. Partiendo de San Agustín, de esa metafísica de la interioridad, se realiza un giro en Descartes. Descartes abandona la interioridad agustiniana entendida como "necesidad ontológica" para descubrir al Dios mismo que me habita y la convierte en un camino para el descubrimiento del propio yo que "me permite una plenitud de autopresencia de mí mismo". Y a partir de esta conciencia cierta de mi propia realidad, infiero un aval y una causa trascendente. Dios no está en la raíz de mi interioridad como lo que me permite "ver más allá", sino que en la inferencia de mi propia autoconsciencia descubro una fuente ineludible de trascendencia. Dios no está en la raíz de mi propio yo, sino en la inferencia que realizo a partir de mi interioridad, de mí mismo, de mi propia

\footnotetext{
${ }^{293}$ Cfr. TAYLOR, Ch., Hegel, pág. 234.

294 "Descartes, con el giro que imprimió al pensamiento occidental, puso en pie la metafísica de la subjetividad, y con ella el paradigma de la conciencia con el principio del cogito como seña de identidad. Ello fue revolucionario, a pesar de que él insistiera en que su obra no era más que la 'filosofía antigua' de siempre". PÉREZ TAPIAS, J.A., Ser humano. Cuestión de dignidad en todas las culturas, Trotta, Madrid, 2019, pág. 158.

295 "Para San Agustín la senda interior era solo un paso en el camino que llevaría a lo alto. (...) Siguiendo la senda agustiniana, el pensador llega a sentir cada vez más su falta de autosuficiencia, a cada vez más que Dios actúa en él. Contrastando con ello, para Descartes la importancia del vuelco reflexivo reside precisamente en alcanzar una certeza muy autosuficiente. (...) Aquí la tesis no es que yo adquiero el conocimiento al volverme a Dios con fe. Es más bien la certeza de que la percepción clara y distinta es incondicional y autogeneradora. Lo que ha sucedido es que la existencia de Dios se ha convertido en una etapa de mi progreso hacia la ciencia, mediante el ordenamiento metódico de la intuición evidente. La existencia de Dios es un teorema de mi sistema de ciencia perfecta. El centro de gravedad ha dado un vuelco decisivo". TAYLOR, Ch., Fuentes del yo, págs. 220-221.
} 
autoconciencia. Lo primero es el descubrimiento de mi yo como certeza absoluta, y desde lo que encuentro en mí mismo, la razón me lanza para que se busque como inferencia un aval trascendente. Es aquí donde la ruta hacia el deísmo queda abierta definitivamente. A través del orden mental del mundo establecido como interioridad autopresente, se realiza un control procedimental científico del mundo en el que se vislumbra el aval de la trascendencia, no como raíz, sino como inferencia racional. Surge la imagen del sujeto desvinculado y del control racional de tanta influencia en la identidad del hombre moderno.

El yo cartesiano aparece como separado del mundo y de las cosas, y su esencia consiste en pensar. No puedo conocer si no sé que me conozco, si no sé que soy, si no sé quién soy. Y no puedo conocer-me si-no-me-pienso. Por eso "conocerse es tener la absoluta garantía de que soy-en-mí por la distinción respecto a lo otro, algo que me obliga a originar-me, a constituir-me como certeza". ${ }^{296}$ Es el yo que late, que emerge, que aparece, y cuya conciencia de pensar fundamentará la ontología del ser-que-existe. Aparece "la primera persona" desde la que se conquista el mundo. Para Taylor, con Descartes, ser y pensamiento se identifican, es la autoconciencia como pensamiento la que descubre la inmediatez del ser. La identidad es inmediata. ${ }^{297}$

Con Descartes se intenta "superar la visión ingenua del mundo" como un mundo ordenado, se empieza a poner en duda los "ídolos de la tribu y del foro", para no dar por sentada cualquier afirmación basada en un principio analógico. La completa autoposesión implica que nos alejemos de las significaciones de sentido cósmico y nos retiremos del mundo para concentrarnos en el yo y sus procesos de observación y pensamiento. ${ }^{298}$ Se pasa del conocimiento basado en la comparación de las medidas y del orden de la naturaleza, ${ }^{299}$ a una nueva episteme basada en el orden del pensamiento. ${ }^{300} \mathrm{El}$ pensamiento se torna universal, abstraído de todo contenido. Es el pensamiento subjetivo del yo que no alcanza al ser, con lo que termina en una oposición entre pensamiento y ser, debido a que no hay representación, solo inmediatez. El cogito

\footnotetext{
${ }^{296}$ DOMÍNGUEZ HERRERO, C., El nacimiento de la Yoidad, Gráficas Lope, Salamanca, 2011, pág. 40.

${ }^{297}$ Cfr. TAYLOR, Ch., Hegel, pág. 454.

${ }^{298}$ Cfr. Ibid., págs. 6-7.

${ }^{299}$ Cfr. BENTANO, F., Aristóteles, Editorial Labor, Barcelona, 1983, págs. 33-57

300 "El papel de la comparación no es ya el revelar el ordenamiento del mundo; se la hace de acuerdo con el orden del pensamiento y yendo naturalmente de lo simple a lo complejo. Con esto se modifica en sus disposiciones fundamentales toda la episteme de la cultura occidental. Y en particular el dominio empírico en el que el hombre del siglo XVI veía aún anudarse los parentescos, las semejanzas y las afinidades y en el que se entrecruzaban sin fin el lenguaje y las cosas — todo este inmenso campo va a tomar una nueva configuración”. FOUCAULT, M., Las palabras y las cosas, pág. 61. "La actividad del espíritu — tal es el cuarto punto- no consistirá ya en relacionar las cosas entre sí, a partir de la búsqueda de todo aquello que puede revelarse en ellas como un parentesco, una pertenencia y una naturaleza secretamente compartida, sino por el contrario en discernir: es decir, en establecer las identidades y después la necesidad del paso a todos los grados que se alejan” (la cursiva es nuestra)”. Ibid. pág. 62.
} 
se convierte en no-pensamiento, en materia, iniciando así el camino hacia el naturalismo. $^{301}$

La episteme clásica que se va a ir imponiendo es un conocimiento basado en la relación de la mathesis con el orden y la medida; un análisis que, según Foucault, se expresará como "método universal" a través del orden matemático y la experimentación, que adoptará el sistema de signos como instrumento fundamental de análisis. ${ }^{302}$ La similitud y la analogía del siglo XVI pasan ahora a ser puestas en orden a través del sistema de signos: por un lado, una teoría general de los signos y, por otro lado, el análisis empírico de las semejanzas y diferencias.

La teoría general de los signos significará que, así como en la naturaleza se descubrían signos de relación y semejanza puestos por Dios para establecer el conocimiento (la teoría de las signaciones), ahora los signos se establecen en el interior del conocimiento, en la mente, para establecer las relaciones representacionales mentales entre mente y naturaleza. De descubrir las huellas de semejanza y analogía presentes en la naturaleza, se pasa a establecer una teoría de los signos como representación mental del mundo de la naturaleza, y a partir de la mente, en su capacidad representacional, se comprobará la certidumbre o falsedad del conocimiento. ${ }^{303}$ Los signos no están transmitidos relacional y analógicamente por la naturaleza, sino que se descifran en el interior de la mente. Es la mente la que establece la capacidad simbólica para descubrir y conocer la realidad representacionalmente. Se establece una relación de significado entre signo mental y realidad, una relación que se irá desvelando desde la probabilidad a la certeza más absoluta. ${ }^{304}$ De ahí que Taylor considere que Descartes sea el padre del mecanicismo: la materia se transposiciona al mundo de lo exterior, del movimiento y la extensión. ${ }^{305}$

Se pasa de la forma que está realizándose en el cosmos en Platón, a la forma que está realizándose pero que requiere nuestra participación en el Neoestoicismo, a la forma que es impuesta desde fuera por la fuerza de la voluntad racional en Descartes. Se trata de una evolución clara en relación con la noción de "forma" y cómo se va estableciendo la forma en relación con el mundo y con el hombre. Con Descartes, que beberá de las fuentes neoestoicas de Lipsio, Du Vair y Charron y Laflèche, esta forma

\footnotetext{
${ }^{301}$ Cfr. TAYLOR, Ch., Hegel, pág. 455.

${ }^{302}$ Cfr. TAYLOR, Ch., Argumentos filosóficos, págs. 128,160, 223.

303 "Su tarea era revelar un lenguaje previo repartido por Dios en el mundo; en este sentido, y por una implicación esencial, adivinaba y adivinaba lo divino. A partir de ahora, el signo empezará a significar dentro del interior del conocimiento: de él tomará su certidumbre o su probabilidad. Y si Dios usa todavía signos para hablarnos a través de la naturaleza, se sirve de nuestros conocimientos y de los enlaces que se establecen entre las impresiones a fin de instaurar en nuestro espíritu una relación de significación" FOUCAULT, M., Las palabras y las cosas, pág. 66.

${ }^{304}$ Cfr. BERKELEY, G., Principios del Conocimiento humano, Gredos, Madrid, 2018, pág. 86.

${ }^{305}$ Cfr Cfr. TAYLOR, Ch., Argumentos filosóficos, págs. 21-24.
} 
pasa a estar plenamente establecida a partir de la voluntad racional del hombre. ${ }^{306} \mathrm{Se}$ pasa de una ética cuyo orden está establecido en el cosmos, a una ética del orden impuesto por la voluntad humana. La forma pasa del orden natural al ámbito de la mente. Todo lo extramental es puro mecanicismo y la actitud que se adopta es la instrumental y la de reconstrucción. Todo se puede controlar por la voluntad: el cuerpo y todo lo que aparece en la mente, aunque no sea pura mente, como son las pasiones; y así, las pasiones no son el mundo de las ilusiones estoicas que desaparecen, sino respuestas impresas en la naturaleza por el Creador, para que adoptemos frente a ellas una actitud de voluntad y autocontrol racional. Es la reificación de la primera persona del singular, desvinculada y autónoma. ${ }^{307}$

Descartes afirma que los antiguos apenas hablaron de las pasiones y cuando lo hicieron lo articularon de manera defectuosa. ${ }^{308} \mathrm{Y}$ así, después de haber estudiado con detenimiento cuáles son las "funciones del cuerpo" pasa a reflexionar sobre las "funciones del alma", limitadas a los pensamientos, dentro de los cuales están las voluntades y las pasiones, entendiendo por pasiones todas las clases de percepciones o conocimientos que se hallan en nosotros, porque a menudo no es nuestra alma la que los hace tal como son y porque siempre los recibe de las cosas que son representadas por ellos. ${ }^{309}$ Dos conceptos que entrarán a configurar también el pensamiento de la Modernidad y que deberán ser integrados, a pesar de su problematicidad, en el mundo de la Religión y en el futuro que esta deberá desempeñar en la era postsecular. Razón y mente, cuerpo y alma, voluntad y pasiones serán conceptos que marcarán el discurrir de la filosofía en la Modernidad y a los que la Religión deberá dar respuesta como interrogantes de sentido en la vida del hombre.

Para Descartes las pasiones son "emociones del alma", 310 causadas por ella misma desde la percepción y en las que la vaga unión entre alma y cuerpo las motiva, mantiene e incluso amplifica. Luego no son un ejercicio de la voluntad, sino que son percepciones que motivan, mantienen e implican una emoción interior dentro del alma, causada por ella misma. ${ }^{311}$ Las pasiones deben ser conocidas y sometidas al poder de la razón.

\footnotetext{
${ }^{306}$ Cfr. TAYLOR, Ch., Fuentes del yo, pág. 213.

307 TAYLOR, Ch., Argumentos filosóficos, pág. 225.

${ }^{308}$ Cfr. DESCARTES, R., Las pasiones del alma, art. 1, Gredos, Madrid, 2018, pág. 155.

${ }^{309}$ Cfr. Ibd., art. 17, pág. 163.

${ }^{310}$ Cfr. Ibd., art. 27, pág. 166. Descartes matiza el concepto de pasiones del alma explicando detalladamente las palabras percepción, sentimiento y emoción del alma: percepciones en el sentido de que la unión del alma y el cuerpo hace confusas al no existir la acción explícita de la voluntad humana, sentimientos como percepciones del alma que no pueden ser conocidas de otro modo y emociones del alma en el sentido de los pensamientos que llegan al alma y que la agitan y la sacuden fuertemente. Las pasiones del alma se refieren explícitamente a sí misma, no se refieren a objetos exteriores, ni a nuestro propio cuerpo, sino que "son motivadas, mantenidas y amplificadas" no por la voluntad, sino que "son causadas por ella misma" como "emociones del alma".

${ }^{311}$ Cfr. Ibd., art. 45, pág. 173. Para Descartes las funciones del alma son los pensamientos que se manifiestan como "voluntad" y esas son las acciones del pensamiento y los pensamientos que se manifiestan como "percepciones y conocimientos que se hallan en nosotros" y esas son las pasiones
} 
Descartes conserva la "desconexión" propia del pensamiento estoico y neoestoico y la configura como constancia, determinación y autocontrol racional. Se empieza a "psicologizar" el alma y la razón a través de un mundo neutro e instrumental. ${ }^{312}$ Hay un desplazamiento respecto de las fuentes morales de la antigüedad. Mientras que la forma actuaba en el cosmos, como en Platón, el hombre era capaz de encontrar en el orden cósmico su propia armonía y la motivación para una vida ordenada que se configura con la razón eterna presente en el universo. Esa es la inclinación de nuestra naturaleza respecto al cosmos. En Aristóteles y en los estoicos hay una cierta variación respecto a la actuación de las formas, y así el hombre sabio es el que sigue su naturaleza. De las formas platónicas que actúan en el cosmos, se pasa a la configuración moral estoica que establece las fuentes morales en la propia naturaleza humana, la sabiduría que se descubre cuando se siguen los dictados de la propia naturaleza humana. Con Descartes se ponen sustratos diferentes. El universo pasa a ser visto como una naturaleza con su propio funcionamiento mecánico y eso es lo que debe inspirar la propia propuesta moral. Las fuentes de la moralidad no están determinadas exclusivamente por el reloj cósmico, sino que con Descartes el reloj del "yo que piensa" entra en la dinámica del "saber del mundo". ${ }^{313}$ El cosmos ya no ofrece configuración de orden moral, sino que "a través de la lucha, impone un orden que en realidad es el previsto, pero que solo puede alcanzarse a través de este triunfo de la voluntad". ${ }^{314}$ Se impone así el dominio de la mente y la razón que logra el orden de la voluntad. Y esto es lo que para Descartes lleva al hombre a conseguir la auténtica estima personal. ${ }^{315}$ Se trata del poder de la voluntad

porque el alma no los hace, sino que "los recibe de las cosas que son representadas por ellos". Es decir, que mientras que "los pensamientos que actúan en el alma" se manifiestan como voluntad, "los pensamientos que recibe el alma" son las pasiones, no siendo una acción propiamente del alma, sino algo que "recibe" de fuera por la representación mental de las cosas en sí misma. Por lo tanto, para Descartes, el tipo de pensamiento que se denomina pasión es una "percepción" que se adentra en el alma por la "representación que hace en sí misma de las cosas exteriores". Por lo cual podemos afirmar que en las pasiones "el pensamiento no actúa, sino que solo recibe" a través de la percepción de las cosas que se manifiesta como "representación interior". En la voluntad el pensamiento actúa interiormente mientras que en la pasión el pensamiento "percibe representacionalmente" a partir de las cosas exteriores.

${ }^{312}$ Cfr. TAYLOR, Ch., La Era Secular, tI, pág. 185.

313 "Dos relojes pueden concordar perfectamente, y sin embargo puede ser que una disposición totalmente diferente de las ruedas en su interior produzca el mismo resultado: también, por lo tanto, el conjunto de los fenómenos que se presentan puede haber sido producido por dios por modo muy diferente. En la concordancia de los hechos bajo las necesidades del pensamiento tenemos la garantía de la corrección de las hipótesis explicativas acerca de la génesis y de la conexión interna del universo, y esta corrección nos garantiza la posibilidad de que aquel conjunto de fenómenos haya podido surgir asín". DILTHEY, W., Hombre y mundo en los siglos XVI y XVII, pág. 368. "Las ideas claras tienen una dimensión formal (la evidencia, como distinta de la suposición), cuya causa soy yo mismo, y una dimensión objetiva, cuya causa es la realidad de la que la objetividad es representación... No es superfluo volver a recordar que esta conducción de la idea a una causa es sentada por las necesidades de la afirmación, que es quien detenta el "contacto" con el ser, quien llega, en principio, hasta él. La aplicación a la idea del principio de causalidad tiene por objetivo, en una primera etapa la afirmación... La realidad extramental tiene que ser alcanzada por la afirmación". POLO, L., Evidencia y realidad en Descartes, Eunsa, Navarra, 1996, págs. 67-69.

314 TAYLOR, Ch., La Era Secular, tI, pág. 215.

315 "Solo observo en nosotros una cosa que puede autorizar con razón a estimarnos: el uso de nuestro libre arbitrio y el dominio que tenemos sobre nuestras voluntades; pues solo por las acciones que dependen de este libre arbitrio podemos ser alabados o censurados con razón; y nos hace en cierto modo semejantes a 
racional que "nos hace dueños de nosotros mismos" pero sin perder la referencia de que hay un Alguien superior, ${ }^{316}$ que es el que nos confiere tal poder y tales derechos. Esta es la máxima dignidad del hombre como ser racional, poder ejercer esa voluntad racional, ese poder de ejercitar el libre albedrío y el dominio sobre nuestras voluntades a través de la razón. ${ }^{317}$

De esta concepción racional del ser humano como dueño de su propia dignidad, surge la idea ética de la generosidad, la generosité de los héroes de Corneille a los que se refiere Taylor y que de alguna manera expresa este rango de superioridad y de honor que es propio del ser humano. Una superioridad que para Descartes adoptará el sentido de generosidad, ${ }^{318}$ entendida como la sabiduría que el ser humano adquiere como expresión de su voluntad libre como ser racional y que asegura su propia dignidad y satisfacción. Es adquirir el autoconocimiento y la autoconciencia prekantiana del propio valor intrínseco que conlleva la dignidad humana entendida como ser racional, ${ }^{319}$ algo de lo que no se puede dudar, algo que identifica el ser con el pensar auto-transparente, ${ }^{320}$ una intuición que, tal y como aparece descrita en las Reglas, nos lleve a un grado absoluto de evidencia del que no se pueda dudar por la sola luz de la razón y como “concepción no dudosa del espíritu", ${ }^{321}$ adentrándose por el camino de autoconocimiento y la propia experiencia. ${ }^{322}$

Dios haciéndonos dueños de nosotros mismos, con tal de que no perdamos por cobardía los derechos que nos da”. DESCARTES, R., Las pasiones del alma, pág. 218.

316 "Descartes no fundamentó de manera inmediata su célebre demostración de la existencia de Dios en esta última certeza, sino en la idea de lo infinito siempre presupuesta en la conciencia del yo. Con todo, aquella, es decir, la certeza que va ligada al yo, constituye el punto de partida de su argumentación. Sin embargo, desarrollar un argumento a favor de la existencia de Dios con principio en el carácter trascendental a priori de lo infinito - como condición de toda aprehensión de contenidos finitos- no resultaba posible sino mediante la vía de la identificación de lo infinitum con lo perfectum". PANNENBERG, W., Una historia de la filosofía desde la idea de Dios, pág. 155.

317 "El sujeto pensante edifica libremente a partir de sí y desde su propia riqueza el nuevo sistema cultural. El hombre encuentra solo en sí mismo el centro inconmovible de toda realidad y verdad: desde el yo conquistamos el mundo”. Ibid., pág. 152.

${ }^{318}$ Descartes entiende la generosidad como "libre disposición de sus voluntades... y que siente en sí mismo una firme y constante resolución a haber buen uso de dicha disposición, es decir, a no carecer nunca de voluntad para emprender y ejecutar todas aquellas cosas que juzgue mejores; lo cual representa seguir perfectamente la virtud”. DESCARTES, R., Las pasiones del alma, pág. 526.

${ }^{319}$ Cfr. TAYLOR, Ch., Fuentes del yo, pág. 219. "Pero advertí luego que, queriendo yo pensar, de esa suerte, que todo es falso, era necesario que yo, que lo pensaba, fuese alguna cosa; y observando que esta verdad: 'yo pienso, luego soy', era tan firme y segura que las más extravagantes suposiciones de los escépticos no son capaces de conmoverla, juzgué que podía recibirla, sin escrúpulo, como el primer principio de la filosofía que andaba buscando". DESCARTES, R., El Discurso del Método, págs. 123124.

${ }^{320}$ Cfr., TAYLOR, Ch., Hegel, pág. 70.

321 “Así, cada cual puede intuir con el espíritu, que existe, que piensa, que el triángulo está determinado por tres líneas solamente; la esfera, por una sola superficie y otras cosas semejantes, que son mucho más numerosas de lo que creen muchos, porque desdeñan parar mientes en cosas tan fáciles". DESCARTES, R., Reglas para la dirección del espíritu, pág. 9.

${ }^{322}$ (Eudoxio): "Pues no puedo creer que haya existido alguna vez alguien tan estúpido que haya tenido que aprender qué es la existencia antes de que pudiera concluir y afirmar que él es. Y lo mismo ocurre en el caso de la duda y el pensamiento. Añado incluso que es imposible que alguien aprenda estas cosas por 
Taylor defiende que la nueva metafísica cartesiana contribuirá al desencantamiento del mundo, lo mismo que lo hará, desde otra perspectiva, la Reforma. A partir de ahora, la verdad no está en la razón eterna del Cosmos, sino que se puede alcanzar a través de la razón natural, pues somos cosas pensantes. ${ }^{323}$ Los deseos dejan de tener significados de trascendencia superior para ser dominados por la razón, ya que son solo "solicitaciones" en medio de un mundo mecánico. ${ }^{324} \mathrm{Y}$ además los deseos pueden ser dominados por el poder de la razón y así determinar la mejor forma de usar de ellos para provecho propio. ${ }^{325}$

Para nuestro autor, el "halo" de prestigio que a veces ha envuelto al deseo como expresión de referencias superiores se ha ido disipando poco a poco en todas las éticas, tanto las tradicionales como las de orden natural y de orden racional. El halo terminará siendo, si alguna vez lo tuvo, en la ética de la gloria o en sus dimensiones distorsionadas, una completa ilusión. El control racional e instrumental impulsará las auténticas actitudes a desarrollar, para superar los mundos sentimentales y acercarnos así a una naturaleza auténticamente desencantada. Los deseos dejan de ser loci de significaciones elevadas, desapareciendo así su significación ontológica. Los sentimientos perturban la mente racional del ser humano, por lo que hay que asegurar su identidad impermeabilizada frente a cualquier "halo" de sentimiento. El cosmos encantado pasa a ser un universo mecanicista, regido por las leyes naturales, y controlado racionalmente. ${ }^{326}$ La ruta del deísmo ha quedado abierta. ${ }^{327}$

otro medio que por sí mismo, ni que se convenza de ellas de otro modo que por su propia experiencia y por la conciencia o testimonio interno que cada cual experimenta en sí mismo cuando las considera". DESCARTES, R., Investigación de la verdad por la luz natural, pág. 93.

${ }^{323}$ (Poliandro): "En efecto, si no pensara, no podría saber ni que dudo ni que existo. Sin embargo, soy y sé que soy, y lo sé porque dudo, esto es, porque pienso. Es más, quizá podría ocurrir que, si por un momento dejara de pensar, también dejaría de ser; por consiguiente, lo único que no puedo separar de mí, lo único que sé con certeza que soy, y que ahora puedo afirmar sin temor a equivocarme, es que yo soy una cosa pensante". Ibid., pág. 91.

324 "En cuanto al deseo, hay que señalar que la propiedad que le he atribuido, es decir, dar al cuerpo más movilidad, solo vale para cuando cree que el objeto deseado es tal que desde ese mismo momento puede hacer algo para conseguirlo; pues si, por el contrario, se imagina que por el momento es imposible hacer nada que sea útil para ello, toda la agitación del deseo permanece en el cerebro, sin pasar a los nervios, y, enteramente dedicado a afianzar en él la idea del objeto deseado, deja languideciente el resto del cuerpo". DESCARTES, R., Las pasiones del alma, pág. 203.

325 "Es la segunda que debe hallarse continua y firmemente resuelto a llevar a cabo todo cuanto le aconseje la razón, sin que lo desvíen de ello sus pasiones o apetitos... Es la tercera que debe saber que, mientras se esfuerce cuanto le sea posible en seguir esa conducta conforme a la razón, como los bienes que no posee están todos ellos fuera de su alcance, de esa forma se acostumbra a no desearlos". (la cursiva es nuestra) DESCARTES, R., Correspondencia con Isabel de Bohemia, Carta 4 de agosto de 1645, Gredos, Madrid, 2011, pág. 346.

326 "Esta objetivación de lo ente tiene lugar en una representación cuya meta es colocar a todo lo ente ante sí de tal modo que el hombre que calcula pueda estar seguro de lo ente, o lo que es lo mismo, pueda tener certeza de él. La ciencia se convierte en investigación única y exclusivamente cuando la verdad se ha transformado en certeza de la representación. Lo ente se determina por vez primera como objetividad de la representación y la verdad como certeza de la misma en la metafísica de Descartes". HEIDEGGER, M., Caminos de Bosque, Alianza Editorial, Madrid, 2010, pág. 72.

${ }^{327}$ Cfr. TAYLOR, Ch., Fuentes del yo, pág. 221. 


\section{III.1.2.5. LOCKE: EL YO PUNTUAL}

A través del yo desvinculado de Descartes, se llegará al yo puntual de Locke. Un yo puntual caracterizado por la objetivación. Se trata de despojar y desconfigurar de cualquier significado a la realidad. Esa realidad platónica que reproduce significativamente el mundo de las Ideas, a través del orden eterno, queda desprovista de cualquier sentido normativo para configurar las fuentes morales del yo. ${ }^{328}$

El mecanicismo cartesiano y objetivista neutraliza los significados cósmicos como valores de construcción moral del yo e instala una moral antiteleológica propia de la ciencia. Moral que emana, en sus orígenes, de una fuente propiamente teológica en continuidad con el giro nominalista de Guillermo de Ockham. Este nominalismo plantea un universo mecanicista único, compatible con la soberanía de Dios, frente a la teoría de los universales platónicos que interferiría en la libre designación de Dios para configurar moralmente al hombre frente a un cosmos significativo. ${ }^{329}$ Dios tiene libertad eterna y absoluta autonomía para determinar el bien. ${ }^{330}$

Descartes enlaza el mecanicismo con una cierta teología desvinculando el cosmos de cualquier teleología de significados. Una teología que plantea un "designio divino" en la soberanía de Dios sobre todo lo creado, pero al mismo tiempo percibe la ciencia nueva como lo que hará de nosotros "conocedores de los fundamentos físicos del mundo". 331

\footnotetext{
${ }^{328}$ Cfr. Ibid., pág. 224.

329 "Libertad infinita de Dios, desvinculada de su esencia, y fe del hombre que no tiene la capacidad de conocer a Dios racionalmente: he aquí dos postulados típicamente modernos, en los que vienen a coincidir Ockham, Lutero, Descartes y Kant. El nominalismo es también el origen histórico del voluntarismo moderno, según el cual, al ser negada la posibilidad de penetrar racionalmente en la esencia de las cosas (como Kant afirma continuamente en la primera Crítica), la acción moral queda privada de fundamento y guía racional (cosa igualmente afirmada por Kant en la segunda Crítica)". PRIETO LÓPEZ, L., "El espíritu de la Filosofía Moderna en sus rasgos esenciales", Thémata. No 43, (2010), pág. 346.

${ }^{330} \mathrm{El}$ individuo es lo único concreto que existe frente a los universales platónico-aristotélico-tomistas. Ockham es el representante del conceptualismo según el cual los universales solo existen en la mente. Carece pues de sentido el principio de individuación de una esencia en un individuo particular, así como la distinción materia-forma o el proceso epistemológico de conocimiento del orden eterno del cosmos, como también las ideas ejemplares que limitan la soberanía divina y, finalmente, las pruebas de la existencia de Dios que se basan en lo universal como esencia común de la que participan los entes. "De otro modo se toma este nombre 'singular' por todo aquello que es uno y no varios. Y tomando así 'singular' ningún universal es singular, pues cualquier universal es por naturaleza signo de varios y por naturaleza se predica de varios. De aquí que al llamar universal algo que no es uno en número —que es la acepción que muchos atribuyen al universal - digo que nada es universal a menos que quizás abuses de este vocablo, al decir que pueblo es un universal, pues no es uno sino muchos; pero aquello sería pueril. Hay que decir entonces que cualquier universal es una cosa singular, y por eso no es universal sino por la significación, porque es signo de varios. (...) Quiere decir que el universal es una intención singular del alma misma, que por naturaleza se predica de varios, no por sí, sino por aquellos varios, se declara universal; pero porque es una forma, existente realmente en el intelecto, se llama singular". OCKHAM, G. de, Suma de Lógica, Norma, Bogotá, 1994, págs. 64-65.

${ }^{331}$ Cfr. TAYLOR, Ch., Fuentes del yo, pág. 226.
} 
Taylor afirma que "la desvinculación se acrecienta cuanto más se vuelve hacia el propio sujeto". Así, para Descartes, en vez de atender al objeto a través de la experiencia, nos apartamos de la dimensión intencional de la experiencia, de lo que hace que esa experiencia sea de algo. Se deja de relacionar la experiencia con un objeto, con algo, y lo relaciono con una causa externa. Se parte de una reflexividad radical de la propia experiencia en primera persona (en continuidad con la interioridad agustiniana) para, a partir de dicha experiencia, sustraernos, desconexionarnos, y reconstruir la experiencia objetivándola, de modo que no nos engañen los sentidos, afirmando así ideas mentales claras y distintas. Se parte de la experiencia en primera persona, pero hay que "ajustarla"; un ajuste que implica desvinculación-objetivación, por una parte, y, por otra parte, dominio-control de la propia experiencia a través de una ontologización del método: procedimiento correcto para ordenar la mente a través de ideas claras y distintas que impidan el "genio maligno". Es decir, según Taylor, los dolores y cualidades secundarias observadas son ideas en la mente causadas por varias propiedades del órgano $\mathrm{u}$ objeto. Una vez desvinculadas y apartadas de nuestra experiencia, hay que invocar algún supuesto interpretativo y así proporcionar una explicación que ocupe el lugar de la experiencia a la que hemos renunciado. ${ }^{332}$

Frente a la mirada teleológica de un cosmos como encarnación del logos óntico, Locke va más allá de Descartes y se sitúa en un punto de vista científico caracterizado por la revolución newtoniana. Locke se desvincula de cualquier doctrina de las ideas innatas, tanto en su variedad platónica en la identificación del yo con el orden eterno del cosmos, como en la versión cartesiana que afirma la tendencia innata para desplegar el pensamiento hacia la verdad.

Lo que pretende es poner en entredicho todo lo que se nos ha transmitido como sabiduría o como algo profundamente consolidado como saber. A veces se trata tan solo de "persuasiones afirmadas con total seguridad" frente a las cuales faltan fundamentos de verdad y certeza a través de un método adecuado. ${ }^{333}$ A partir de ahí, Locke pretende demoler y reconstruir, pero de una manera distinta a como lo había planteado la tradición platónica o aristotélico-tomista. Lo radical en Locke es el alcance de la desvinculación que propone, que va más allá de las propiedades secundarias o las sensaciones corporales cartesianas. Afecta a todo nuestro proceso mental.

Se trata de asegurar el ideal de la independencia frente a cualquier tradición, y el de la autorresponsabilidad frente a cualquier autoridad. Locke revindica la noción de la

\footnotetext{
${ }^{332}$ Cfr. Ibid., pág. 228; cfr. TAYLOR, Ch., Hegel, págs. 6-7.

333 "Si en esta investigación de la naturaleza del entendimiento llego a descubrir también hasta dónde alcanzan sus facultades, a qué cosas están proporcionadas, hoy dónde nos fallan, supongo que será útil persuadir a la mente humana de que tenga más precaución al tratar cosas que exceden de su comprensión, y a que permanezca en una tranquila ignorancia de aquellas cosas que, después de haber sido examinadas, advertimos que se hallan más allá del alcance de nuestras capacidades". LOCKE, J., Ensayo sobre el Entendimiento humano, Gredos, Madrid, 2015, pág. 8.
} 
razón libre, dado que el pensamiento no es genuino si no lo desarrolla uno mismo. ${ }^{334}$ Todo se somete a escrutinio. La única meta es la verdad. Y no hay que dar nada por sentado a pesar de que otros hayan indagado sobre lo mismo o hayan "dejado huella" en su búsqueda. Lo que ha podido parecer "ciencia" se puede convertir, cuando se indaga desde el único objeto de la búsqueda de la verdad, en "mera obstinación". 335 Se trata de un proceso de conexiones entre la desvinculación y la objetivación y el autocontrol, entre el autocontrol y el procedimiento correcto que define la racionalidad y, por último, entre la racionalidad y el conocimiento. Es la afirmación de la reflexividad radical para evitar el control de nuestros apetitos y receptores, ajustando la experiencia y con ello privándola de su poder a través del ideal de la objetivación y la desvinculación. ${ }^{336}$

La razón filosófica va adquiriendo nuevas configuraciones. De la razón sustantiva platónica se evoluciona a la razón instrumental que definirá el devenir de la Modernidad y el futuro de la Religión. Para Descartes y Locke, se trata de una razón procedimental: llegar a conocer lo que son las cosas en realidad a través de la razón. Pero en ellos, la racionalidad es "una propiedad del proceso del pensar", no el contenido sustantivo del pensamiento. Se pasa de ser contempladores del orden cósmico a "constructores de una imagen" siguiendo los cánones del pensamiento racional. ${ }^{337}$

En relación a las fuentes morales del yo, se elimina cualquier referencia platónicoaristotélica de las teorías innatas como descubrimiento de la sintonía del yo con el orden eterno del cosmos que prodiga la connaturalidad con la idea del Bien. Locke profundiza, por el contrario, en una doctrina antiteleológica para adoptar unas fuentes morales del yo de tipo hedonista: las cosas son buenas o malas en relación al placer o al dolor que provocan tanto en el cuerpo como en la mente. Y llega a afirmar que ni la idea de la propia identidad ni la idea de Dios son innatas. Las ideas del pensamiento son producidas por la experiencia de los sentidos. ${ }^{338}$

\footnotetext{
${ }^{334}$ Cfr. Ibid., pág. 234.

335 "Concedo fácilmente que existe gran número de opiniones que son recibidas y adaptadas como primeros e incuestionables principios por hombres de países, educación y temperamento diferentes, aunque muchas, debido a su absurdidad y también a su oposición, es imposible que sean verdaderas". Ibid. pág. 21. Cfr. TAYLOR, Ch., Argumentos filosóficos, pág. 66.

${ }^{336}$ Cfr. TAYLOR, Ch., Fuentes del yo, pág. 228.

${ }^{337}$ Cfr. Ibid., pág. 235. "La filosofía, el saber supremo, no se ocupa de las cosas cambiantes, ni siquiera de las leyes generales y constantes de la concomitancia y la sucesión, que son las adecuadas para estas cosas y sus cambios, ni siquiera de las verdades matemáticas, sino del reino trascendente de los puros noúmenos de los que el mundo natural no es más que una sombra débil y distorsionada, solo puede dejarse de lado si estamos dispuestos a considerar omisible toda la serie de pronunciamientos más características y temerarios de Platón”. LOVEJOY, A., La gran cadena del ser, pág. 49.

338 "Estas ideas simples, el material de todo nuestro conocimiento, son proporcionadas a la mente por esos dos caminos ya mencionados: el de la sensación y el de la reflexión. Cuando el entendimiento posee estas ideas simples tiene el poder de repetirlas, compararlas y verlas en una variedad casi infinita, y así puede formar nuevas ideas complejas". LOCKE, J., Ensayo sobre el Entendimiento humano, pág. 28. Cfr. TAYLOR, Ch., Fuentes del yo, pág. 230; cfr. TAYLOR, Ch., Argumentos filosóficos, pág. 95.
} 
Locke, en su teoría moral, concede una gran importancia al malestar. Una vez que una cosa ha sido elegida como fuente de felicidad surge el deseo y ese deseo provoca malestar. Se inician procesos de psicologización de la mente, que es la que determina el alcance del deseo y la que finalmente "siente" su ausencia como bien o como mal. ${ }^{339}$

Locke afirma que sin este malestar que provoca el deseo y la actividad humana no habría una determinación de la voluntad. Según Taylor, se trata de un "argumento cuasimecánico", por el cual sólo el malestar está presente, dado que es imposible que lo ausente opere donde no está. Sin este malestar únicamente hay veleidad, por lo que se llega a un grado sumo de desvinculación. La acción voluntaria viene motivada por el malestar, por la ausencia de algo, no por la búsqueda consciente de un bien que lanza el ánimo voluntario. Es lo que Taylor denomina como un estado interior que carece en sí mismo de un objeto intrínseco. Locke habla de la asociación que cada uno de nosotros hace entre malestar interior y ciertos bienes como nuestro deleite. Se trata, pues, de una conexión entre hedonismo y desvinculación. El malestar del deseo provoca la voluntad en la búsqueda del placer. ${ }^{340}$

Para Locke, el amor a la verdad implica, asimismo, que todo sea contrastado con el peso de la evidencia y el amor a la verdad, una verdad que se expresa a través de la iluminación de la mente o por medio de la argumentación que nos pone ante la "irresistible evidencia misma", de la cual no hay sombra de duda debido al contraste de la demostración y la argumentación científica.

Un amor a la verdad que hará que la mente busque los cánones de la evidencia racional y en esa búsqueda entren las verdades morales del mayor de los bienes. Según este autor, una vez que una cosa ha sido elegida, el deseo la asume como parte de la felicidad, y ese deseo "provoca malestar" para intentar lograr dicho bien moral. Luego aquello que no nos provoca malestar ni crea deseo, no nos afecta. Por tanto, la mente, que controla la voluntad, ${ }^{341}$ es capaz de estar eligiendo constantemente y "creando" representaciones mentales de nuevos bienes morales que producen deseo, el deseo hace surgir el malestar.

Locke considera que somos capaces de reconstruirnos siempre de un modo más racional y ventajoso, superando "la indolencia y el hedonismo de la felicidad presente" para romper con ciertos hábitos que nos hacen caer en la veleidad, en el anonimato de la

\footnotetext{
${ }^{339}$ Cfr. TAYLOR, Ch., Fuentes del yo, pág. 237.

${ }^{340}$ Cfr. Id., pág. 237.

341 "Y si se pregunta qué es lo que mueve al deseo, respondo: la felicidad, y solo esto (...) Sin embargo, todo bien, incluso el que se considera y reconoce que es tal bien, no despierta necesariamente el deseo de cada hombre, sino solo una parte del bien, aquella que cada hombre considera necesaria para su felicidad. Es fácil notar que, aunque todos los hombres desean la felicidad, sin embargo, sus voluntades los conducen contrariamente a ella, y, como consecuencia, a lo que es malo". LOCKE, J., Ensayo sobre el Entendimiento humano, pág. 49.
} 
moda asumida como opinión o en la falta de compromiso moral con nosotros mismos. Taylor afirma que la desvinculación radical abre la perspectiva de la autorreconstrucción. Desvinculación hedonista autorresponsable en su propia mejora moral. Todo depende de una teoría objetivadora de la mente. ${ }^{342}$ Es la metafísica de la Modernidad, desde Descartes a Leibniz, que, en opinión de Taylor, todo lo hace depender de un orden suprasensible del ser que sostiene el mundo empírico. ${ }^{343}$

Se trata de un yo que asume así la ley impuesta por el derecho natural divino. Derecho natural que determina la conexión entre la búsqueda de la felicidad que crea el deseo en el yo a través de la búsqueda del bien, y una ley impresa en la naturaleza humana por el "poder de un legislador". Hay pues una voluntad desvinculada del yo en la búsqueda de la felicidad que entra en conformidad con el poder de una ley natural divina que hace que experimentemos placer o dolor en el cumplimiento o violación de dicha ley impresa en nuestra común naturaleza humana, que es lo que a su vez se percibe como recompensa o castigo. Llegamos al bien o al mal moral a través de la propia voluntad humana y del "poder de un legislador", siendo ya ese placer que acompaña al bien o ese dolor que acompaña al mal la recompensa o castigo que recibimos. $^{344}$

En Locke encontramos una mezcla de voluntarismo teológico, mecanicismo, iusnaturalismo y hedonismo, y estima que hay tres tipos de leyes: divina, civil y filosófica. Leyes que han sido establecidas por el Todopoderoso, por la sociedad o por el sentido del yo en su búsqueda racional de la felicidad. Se trata de un yo desvinculado que viene determinado por el control racional (mente que se impone al yo que desea) y por el hábito no como conexión con un orden vinculado a un trasfondo de la naturaleza, sino como lo que se ajusta instrumentalmente a lo que aporta más placer o felicidad en el "deseo que crea malestar".

Es lo que Locke denomina el "yo puntual", un yo sin extensión desde el punto de vista geométrico. Un yo que no es configurado por ningún tipo de axiología moral cósmica o religiosa, sino que se va reconfigurando y reconstruyendo desde sí mismo en la búsqueda desvinculada de la propia felicidad a través del malestar que va experimentando y en conexión con las leyes propias del Creador, impresas en la naturaleza, por las que vamos experimentando castigo o recompensa (leyes divinas), crímenes o inocencia (leyes civiles), o virtud o vicio (leyes filosóficas).

Un yo puntual que se expresa en su identidad personal como un ser con conciencia. ${ }^{345}$ Una identidad de conciencia personal que es consciente, por el

\footnotetext{
${ }^{342}$ Cfr. TAYLOR, Ch., Fuentes del yo, pág. 233.

${ }^{343}$ Cfr. TAYLOR, Ch., Hegel, pág. 459.

${ }^{344}$ Cfr. TAYLOR, Ch., La Era Secular, tI, pág. 237.

345 "Es imposible que nadie perciba sin percibir que él mismo percibe. Cuando vemos, oímos, etc.,
} 
pensamiento, de que es consciente de sí mismo, una identidad racional que le permite ser consciente del pasado desde el presente y un yo presente que piensa en el pasado. El yo puntual es esta conciencia puramente independiente que entraña autocontrol y autorreconstrucción: un yo que viene determinado por esta íntima conexión entre su propia autoconciencia e identidad y su autocomprensión moral, que se va reconstruyendo como búsqueda de la felicidad y en vistas a una futura retribución por parte del Todopoderoso. ${ }^{346}$

Este es el yo que tanta importancia ha tenido en la Modernidad y por el que, con razón, hace que Locke sea considerado como el gran maestro de la Ilustración. Es un yo que reivindica el gran ideal de la libertad y la dignidad personal que respalda la desvinculación y la razón procedimental. Un yo puntual que será la base para el "ego freudiano", casi vacío de pulsión instintiva, con una fuerza mucho menor que el yo puntual lockeano y cuya función será "maniobrar" entre el ello, el superyó y la realidad externa. El yo puntual será el punto y seguido antes de llegar al yo freudiano entendido como un sujeto desvinculado que ejerce el control instrumental. ${ }^{347}$

Taylor hace una reflexión crucial en relación con la introspección y la evolución de los yos: el yo platónico no daba importancia a la introspección, y el yo estoico no pensaba que fuera relevante. El primero solo planteaba la captación del orden cósmico, y el segundo pensaba que lo importante era la prioridad de las metas humanas en relación con la razón y la naturaleza humana autosuficiente. En contraste, el yo moderno desvinculado requiere una postura reflexiva. Un yo que vuelve hacia el interior de sí-mismo, consciente de los procesos mentales que configuran la representación del mundo que asegura la verdad y la ciencia.

Platón y los estoicos nos invitan a conformarnos moralmente a partir de un orden objetivo expresado en el orden cósmico o en lo que vale la pena vivir desde la razón y la naturaleza humana. La desvinculación moderna invita a separarnos de nosotros mismos desde la auto-objetivación, siendo conscientes de la actividad de pensar o de los

sabemos que hacemos eso. Por esto cada uno es para sí mismo lo que él llama 'yo' (la cursiva es nuestra). Pero se ha de inquirir si es la misma e idéntica sustancia”. LOCKE, J., Ensayo sobre el Entendimiento humano, pág. 62. "De acuerdo con Locke, el término "persona", que en este caso se encuentra en lugar de "identidad", se refiere a la apropiación de acciones y sus méritos por parte de los agentes inteligentes capaces de felicidad, miseria y sujeción a la ley. (...) De este modo, sostiene Taylor, el propio Locke reconoce la conexión constitutiva entre la noción de identidad y nuestra autocomprensión moral". CINCUNEGUI, J.M., "El yo en el espacio moral”, Eikasia, No 58, (2014), pág. 287, nota 38.

${ }^{346}$ Cfr. TAYLOR, Ch., Fuentes del yo, pág. 239. "El yo es aquella cosa consciente, pensante - sea cualquiera la sustancia de que esté formado: espiritual o material, simple o compuesta, esto no importa-, que es sensible al placer y al dolor, capaz de felicidad o miseria (...) La identidad personal consiste, no en la identidad de sustancia, sino en la identidad de conciencia (...) Debemos tener en cuenta qué es a lo que se aplica la palabra 'yo', que en este caso significa solamente hombre. Como se presume que el mismo hombre es la misma persona, se supone que 'yo' representa también la misma persona”. LOCKE, J., Ensayo sobre el Entendimiento humano, pág. 64.

${ }^{347}$ Cfr. TAYLOR, Ch., Fuentes del yo, pág. 243. 
procesos de habituación para que me desvincule de ellos y los objetive. Desaparece la "necesidad" radical de la realidad en su esencia para "encontrarse" con la objetividad empírica a partir de un yo puntual. ${ }^{348}$

Taylor reflexiona sobre una de las grandes paradojas de la Modernidad. Partiendo de este yo objetivo, puntual, desvinculado, en el que parece que se eliminan todos los vestigios de la subjetividad, se llega a la perspectiva de la importancia central de la postura del yo como un "mí mismo". Taylor dirá que la objetividad radical es solo inteligible y asequible a través de la subjetividad radical tal y como han afirmado Heidegger y Merleau-Ponty. La desvinculación requiere la posición de la primera persona, algo muy interesante sobre lo que habrá que volver y profundizar. Desde el yo desvinculado y reducido a la "máxima ligereza existencial posible" se llega a la afirmación del yo en primera persona, a la subjetividad más radical mezclada de naturalismo. ${ }^{349}$ Es la desvinculación radical que abre la perspectiva de la autorreconstrucción. ${ }^{350}$

\section{III.1.2.6. MONTAIGNE: EL YO PARTICULAR QUE SE AUTOEXPLORA}

El giro "in interiore homine” de San Agustín fue muy influyente en Occidente tanto en la espiritualidad cristiana como en otras formas secularizadas que se desarrollaron a lo largo de la Edad Media y el Renacimiento. Nos volcamos hacia dentro, no solo para buscar a Dios, sino también para descubrir el impacto de nuestro misterio, o la búsqueda de sentido, o una justificación para nuestras vidas. Junto a la desvinculación del yo, está la autoexploración como necesidad ontológica para establecer nuestra identidad. Y aquí es donde aparece una figura clave: Michel de Montaigne. Para él, la única búsqueda que debemos emprender es descubrir dentro de nosotros la única naturaleza humana universal. ${ }^{351}$ Por esta razón es un personaje importante para Taylor.

Para los clásicos, la naturaleza era la razón que da fundamento inquebrantable a nuestro yo más allá de los deseos del alma insensata, o de la fortuna del mundo exterior. Sin embargo, Montaigne, humanista francés del siglo XVI que busca y autoexplora su identidad, se da cuenta del desasosiego que experimenta cuando intenta "ordenar sus pensamientos". El objeto de sus ensayos es "solo darse a conocer a sí mismo". ${ }^{352}$ Y la

\footnotetext{
${ }^{348}$ Cfr. TAYLOR, Ch., Hegel, pág. 457.

349 Cfr. TAYLOR, Ch., Argumentos filosóficos, pág. 20. Taylor sugiere que lo que está detrás de la "superación de la epistemología y el abandono del fundacionalismo" es la "naturalización de la epistemología", privándola de toda condición a priori y considerarla como una ciencia más entre otras que contribuye a crear "imagen del mundo" en relación con otras disciplinas.

${ }^{350}$ Cfr. TAYLOR, Ch., Fuentes del yo, pág. 238.

${ }^{351}$ Cfr. Ibid., pág. 248.

352 "Quien pretenda buscar aquí ciencia, no se encuentra para ello en el mejor camino, pues en manera alguna a hago yo profesión científica. Contiénense en estos ensayos mis fantasías, y con ellas no trato de
} 
forma en que los va relatando es serena y al mismo tiempo desordenada, al azar, con el único empeño de expresar su estado natural y ordinario. ${ }^{353}$ Montaigne busca todo aquello que le pueda dar consistencia y fundamento en la vida, expresando serenamente los mejores razonamientos de sentido sobre la vida. ${ }^{354}$

Montaigne representa otro paso más en la desconexión ontológica del ser humano. Un paso caracterizado por lo siguiente: no se trata de buscar lo universal, lo ejemplar, la naturaleza humana tal cual es, sino de perfilar y describirse a sí mismo, dibujando los contornos de un ser, él mismo, y a partir de él mismo, comprender la condición humana. Una condición humana caracterizada por la inconsistencia; esto es, "nada queremos libremente, absolutamente, constantemente". ${ }^{355}$ Todo está caracterizado por la volubilidad de pensamientos, ideas y sensaciones que marcan la vida del hombre según su propia circunstancia. De ahí que sea preciso adentrarse en lo más escondido del alma, para allí, en el secreto del corazón, reconocerse a sí mismo en los resortes que motivan el actuar humano.

El conocerse a sí mismo es el secreto para adentrarse en los misterios que surcan la condición humana, y para ello hace falta reconocer la propia miseria, debilidad e imperfección. ${ }^{356}$ La gran honra del ser humano es ejercer el bien, pues es lo que permanece frente a la utilidad y a la temporalidad de la vida humana. ${ }^{357}$ Una vida humana que no es más que una sombra, una oscura apariencia y una idea caracterizada por la incertidumbre y la debilidad. ${ }^{358}$ Un cierto escepticismo en el que el hombre difícilmente se comprende en lo que es, adquiriendo una vaga idea de sí mismo, como una apariencia o una frágil imagen de algo que siempre aparece borroso o indeterminado. Es lo que Taylor denomina la particular manera de vivir fluyendo de

explicar las cosas, sino solo de darme a conocer a mí mismo". MONTAIGNE, M. de, Ensayos, Tomo II, cap X, Editorial Garnier Hermanos, París, 1912, pág. 348.

353 "Al transcribir mis ideas no sigo otro camino que el de azar. A medida que mis ensueños o desvaríos aparecen a mi espíritu voy amontonándolos: unas veces se me presentan apiñados, otras arrastrándose penosamente y uno a uno". Ibid., pág. 349.

354 "Expongo libremente mi opinión sobre todas las cosas, hasta sobre las que sobrepasan mi capacidad y son ajenas a mi competencia; así que los juicios que emito dan la medida de mi entendimiento, en manera alguna la de las cosas mismas" (...) "En los libros solo busco un entretenimiento agradable, y si alguna vez estudio, me aplico a la ciencia que trata del conocimiento de mí mismo, la cual me enseña el bien vivir y el bien morir" (la cursiva es nuestra). Ibid., pág. 350.

355 "Creo que la cualidad dominante en los hombres es la inconstancia; la cualidad contraria rara vez se ve en ellos; quien los juzgare al por menor, menudamente se acercará más a la verdad”. Ibid., pág. 282.

356 "Mi espíritu se conforma con librarse del desorden o perturbación, pero reconoce y confiesa de buen grado su debilidad. Cree interpretar acertadamente las apariencias que su concepción le muestra, las cuales son imperfectas y débiles”. MONTAIGNE, M. de, Ensayos, pág. 351.

357 “Amamos la vida, el existir, y el existir consiste en movimiento y acción, por los cuales cada uno reside en algún modo en su obra. Quien ejecuta el bien ejerce una acción honrada y hermosa; quien lo recibe la ejerce solo útil. Y como lo útil es mucho menos amable que lo honrado, puesto que lo segundo tiene un carácter de estabilidad y permanencia que procura al que lo hizo una gratitud constante, lo útil se pierde y escapa fácilmente, y su recuerdo no permanece en la memoria tan fresco ni tan dulce". Ibid., págs. 320-321.

${ }^{358}$ Cfr. MONTAigne, M. de, Ensayos, Cátedra, Madrid, 1987, pág. 340. 
Montaigne. Un vivir en el que el autoconocimiento lleva a la autoaceptación, a aceptar los límites de lo que somos capaces de entender y asumir desde dentro, desde mí mismo.

Taylor insiste en la importancia de aceptar los "contornos" de la propia naturaleza humana, vivir según la condición natural que se expresa en el propio yo a través de sus limitaciones y su "ignorancia en relación al conocimiento" dada la condición cambiante del mundo. ${ }^{359}$ Se trata de dejar que la naturaleza fluya evitando el control racional o la superación artificial de la misma por presuntas aspiraciones sobrehumanas. Autocomprenderse desde el autoconocimiento es conocer los propios límites, los de cada uno. La naturaleza fluye en cada uno a la manera de cada uno; de ahí la incapacidad de Montaigne para hacer síntesis entre lo fragmentario y lo irremplazable. ${ }^{360}$ Una síntesis que debe llevar a afirmar la serenidad y la inevitabilidad de la muerte, asumiéndola con familiaridad. ${ }^{361}$

Buscamos el autoconocimiento, pero un autoconocimiento que no es solo un saber que permite acceso a la sintonía con la razón eterna del cosmos platónico. Cada uno debe descubrir su propia manera de acceder al autoconocimiento. No vamos a la búsqueda de la naturaleza universal como orden cósmico que expresa las Ideas Eternas, sino a la búsqueda del propio yo, del propio ser. Taylor considera a Montaigne como uno de los más insignes representantes de la introspección del yo entendida como autoexploración en las profundidades interiores. ${ }^{362}$

Montaigne inaugura un conocimiento intensamente individual, una reflexión que persigue el propio autoconocimiento al lograr ver, a través de los autoengaños, las pasiones y orgullos que se han ido acrecentando en nosotros. Lo que importa es la primera persona. La ciencia y la tercera persona sirven de poca ayuda. La diferencia entre Montaigne y Descartes es clara. Mientras que para Descartes todo se basa en el racionalismo que asegura el autoconocimiento como regla general a través del método que asegure la verdad y la certeza libre de toda duda, Montaigne, por el contrario, persigue el objetivo de centrarse en el individuo como realidad única e irrepetible, y procede con la crítica de las autointerpretaciones en primera persona, analizando las propias exigencias, deseos y razonamientos interiores. ${ }^{363}$

\footnotetext{
${ }^{359}$ Cfr. LLINAS BEGÓN, J.L., "Sobre el concepto de Filosofía y Experiencia en Montaigne, y su repercusión sobre el concepto de Filosofía y experiencia en Montaigne", Cuadernos Salmantinos de Filosofía, No 40, (2013), págs.78-79.

${ }^{360}$ Cfr. TAYLOR, Ch., Fuentes del yo, pág. 250; cfr. PALACIOS CRUZ, V., "Una crítica de la Modernidad desde la reconciliación con la finitud", Valenciana, Vol. 6, No 11, (2013), pág. 20.

${ }^{361}$ Cfr. TAYLOR, Ch., La Era Secular, tI, pág. 118.

${ }^{362}$ Cfr. TAYLOR, Ch., La Era Secular, tII, pág. 382.

${ }^{363}$ Cfr. TAYLOR, Ch., Fuentes del yo, pág. 252.
} 
Descartes busca al pensador individual que construya, en sí y por sí mismo, un orden del pensamiento que asegure la verdad más allá de la sombra de cualquier duda en la primera persona del singular. Pero ha de atenerse a criterios universales; ha de razonar por sí mismo, "pero como todos". Montaigne, sin embargo, busca la originalidad de la propia búsqueda. Se busca por sí mismo y desde sí mismo con la peculiaridad del propio yo. $^{364}$

Ambos vuelven al interior, pero cada uno a su manera: Descartes asegurando la verdad universal y Montaigne orientándose a la búsqueda de la propia creatividad personal. Para Descartes todo se encamina hacia una ciencia con un conocimiento claro y distinto en términos universales que aseguren el control instrumental. Montaigne, en cambio, quiere liberarse del peso de la razón universal para que de alguna manera aflore la originalidad del propio yo. La meta de Montaigne no es la de encontrar un orden intelectual para analizar las cosas en general, sino más bien el encontrar los modos de expresión que permitan que no pase desapercibido lo particular. Descartes busca el orden racional del alma universal, mientras que Montaigne busca la originalidad que el alma individual puede realizar en dicha búsqueda.

Para Taylor, Descartes exige una desvinculación radical de la experiencia habitual para ordenar la mente y el mundo a través de un orden racional del alma. Montaigne quiere, por el contrario, que nos vinculemos más profundamente a través de nuestra peculiaridad. En Descartes el orden racional es búsqueda de la verdad universal en un mundo desvinculado. En Montaigne se trata de una búsqueda de la verdad canalizada a partir de la propia originalidad a través de un mundo vinculado con la propia creatividad personal. En Descartes, la verdad universal se realiza como vuelta hacia adentro, pero en el que se garantiza el proceso racional para todos. En Montaigne, la verdad universal se realiza como vuelta hacia adentro, pero en el que solo la originalidad de la propia búsqueda expresa la verdad de todos. La verdad universal se realiza como búsqueda original del propio yo. Cada persona realiza su propia búsqueda y expresa su propia verdad. La verdad universal cartesiana pasa a ser una búsqueda individual de la propia verdad que es descubierta como originalidad desde el propio yo. En este sentido, Montaigne representa un paso más en la "desconexión ontológica” potenciando la mirada hacia la interioridad propia y original de cada uno como verdad que expresa "lo

\footnotetext{
364 "Montaigne comprende esta manera de existir común y natural del Sócrates de Jenofonte en términos de "saber vivir" y, a partir de él, define su particular modo de concebir el cuidado de sí. En un sentido amplio, alguien que cuida de sí mismo sabe vivir, y esto significa vivir conforme a la naturaleza. Podríamos entrever en esta afirmación la búsqueda de un tipo de estado natural de armonía, tan característico del romanticismo, o la reivindicación de una vida sin ninguna comodidad o posesión, como bien lo hacían los cínicos, pero lo cierto es que vivir conforme a la naturaleza se resume en vivir agradablemente y sin preocupaciones, de acuerdo con las cualidades y los limitantes propios". PIRACOCA FAJARDO, C., "El saber vivir de Montaigne: entre la preocupación por el mundo y la realización de la autárkeia”, Cuadrantephi, No 26-27, (2013), págs. 6-7.
} 
que somos", en una suerte de individualismo del autodescubrimiento y que abre las puertas a la búsqueda de las fuentes de la autenticidad. ${ }^{365}$

\section{III.1.2.7. EL YO KANTIANO: EL SUJETO COMO SER RACIONAL DEL MUNDO}

Para Taylor, a comienzos del siglo XVIII, el yo moderno ya está en proceso de constitución, al menos entre las élites sociales y espirituales. Un yo caracterizado por formas de autocontrol y formas de autoexploración que constituirán el fundamento del individualismo moderno. ${ }^{366}$ Frente a la teoría clásica del logos óntico que ubicaba las fuentes morales "fuera", en el orden cósmico, con el advenimiento de la Modernidad, las fuentes morales se ubican en la mente del sujeto pensante. Pensamiento y sentimiento se encierran en la mente, se limitan, se confinan, se localizan en la mente. Y a ello seguirá la desvinculación del mundo, el desencanto weberiano. Del cosmos se pasa al mundo de la reflexividad radical de la mente, un yo que avanza con paso seguro hacia la impermeabilización y que se configura desde la independencia responsable, la particularidad reconocida y el individualismo del compromiso personal. Es la ciudad del hombre moderno en la que lo verdaderamente importante es que uno pueda ejercer la autonomía y la libertad absoluta en sus compromisos más trascendentes. ${ }^{367}$

Con la Modernidad se produce el gran vuelco ontológico. En la teoría del logos óntico platónico-aristotélica el conocimiento y la valoración solo se dan cuando se establece una sintonía con el orden eterno del cosmos. Un conocimiento y una valoración que están situadas ónticamente, es decir, que son capaces de ponernos en conexión con el mundo de la Idea que conforma el cosmos. El conocimiento platónicoaristotélico es lo que "está en medio" según Taylor; es decir, el conocimiento es lo que separa el sujeto del objeto. Las formas actúan en la configuración del orden cósmico y en la configuración de mi inteligencia que la hacen capaz de "conocer" (pensamiento) y "sintonizar" (valoración) con dicho orden. ${ }^{368}$

Con la desvinculación desencantadora del mundo, las teorías del logos óntico dejan de tener sentido. Ahora las valoraciones y las fuentes morales se establecen en la mente y no en el orden significativo de la realidad. Las fuentes de valoración moral están en las mentes y no en el objeto exterior. El sujeto y el objeto están separados a partir del dualismo cartesiano. Son realidades que podrían existir por sí mismas, "autosubsistentes". Para la teoría platónica no puede existir el mundo de las cosas particulares sin las Ideas platónicas y por lo tanto sin el pensamiento. Para la teoría aristotélica las Formas son las que conforman los particulares, así como las

\footnotetext{
${ }^{365}$ Cfr. TAYLOR, Ch., Fuentes del yo, pág. 255.

${ }^{366}$ Cfr. Ibid., pág. 257.

${ }^{367}$ Cfr. TAYLOR, Ch., La libertad de los modernos, pág. 248.

${ }^{368}$ Cfr. TAYLOR, Ch., Fuentes del yo, pág. 263.
} 
inteligencias, siendo el conocimiento la misma actividad (energeia) que relaciona el nous con el objeto. ${ }^{369}$

Con el advenimiento de la Modernidad, es posible establecer una ruptura o independencia entre el sujeto y el objeto. Ahora las Ideas están en la mente y no es posible verlas en otro lugar. Las Ideas (las nuevas ideas hechas concepto mental) solo están en la mente. Para Platón las Ideas son una realidad óntica, la base de la realidad, mientras que para Descartes son contenidos de la mente. Surge así el subjetivismo. Situamos dentro del sujeto lo que antes existía como si estuviera entre el agente/conocedor y el mundo, anudándolos y haciéndolos inseparables. ${ }^{370}$

Taylor habla de las oposiciones sujeto/objeto y físico/psíquico como aspectos de la nueva localización moral moderna. ${ }^{371}$ Se trata de categorías excluyentes. Es el dualismo moderno postcartesiano. Descartes tiene que demostrar con "reglas de evidencia" la existencia de las cosas para que ningún "mal génie" le engañe. ${ }^{372}$ Y el Idealismo Kantiano tendrá que demostrar desde una metafísica científica la existencia de las cosas, llegando a la conclusión de que "la cosa en sí" no existe sino como "representación" a priori. Kant pretende llevar a la categoría de ciencia la metafísica del yo cartesiano, o lo que es lo mismo, la demostración del mundo a partir del yo, no admitiendo nada fuera de nosotros si no por fe. ${ }^{373}$

\footnotetext{
${ }^{369}$ Cfr. THIEBAUT, C., Cabe Aristóteles, Visor, Madrid, 1988, pág.81.

${ }^{370}$ Cfr. TAYLOR, Ch., Fuentes del yo, pág. 261.

${ }^{371}$ Cfr., Ibid., págs. 264-265.
}

Taylor pone un ejemplo clarificador: la melancolía y la bilis negra. Para la concepción platónica del logos óntico la bilis produce sentimientos melancólicos porque estos manifiestan su estatus óntico-lógico. La bilis negra es melancolía. Para la concepción racionalista de las ideas cartesianas se plantea una nueva localización: los sentimientos melancólicos están en la mente. En la concepción poscartesiana pensamos en una relación causal psicofísica: demasiada bilis produce melancolía. La melancolía ahora está en mi bilis, en la cosa sin ninguna analogía con visiones precedentes (como las Formas aristotélicas que están en las cosas informándolas porque no existen independientemente en un mundo inmaterial como las Ideas Platónicas. La forma no está encarnada en la cosa en el sentido de que su existencia dependa de la cosa. La Forma continúa independientemente de la cosa "informada". Así para la mentalidad moderna la naturaleza se localiza en la cosa. La bilis es una realidad física y es la causa de la melancolía. Para las antiguas teorías de los humores es el sentimiento (la melancolía) el que se encarna en una cosa, siendo así la cosa (bilis) expresión del sentimiento. La cosa adquiere una significación y va más allá de sí misma. Para la mentalidad moderna el sentimiento (la melancolía) es la causa de una cosa (la bilis). Con la mentalidad moderna desaparece la magia de ciertos objetos, sustancias o actos de habla. El mundo se desencanta. El objeto no expresa ningún poder, ni el poder se "manifiesta en" un objeto, dado que no hay "una significación" de valoración total. La naturaleza de un objeto, de una sustancia solo expresa el conjunto de fuerzas causales que le identifican como tal. La naturaleza de la cosa, el conjunto de causas y fuerzas que la constituyen como tal, se realiza en la cosa misma. Una naturaleza manifiesta un conjunto de similitudes de las causas que constituyen su identidad propia, dando lugar a "una clase de cosa" que es identificada ontológicamente independiente de las "otras clases de cosas"

${ }^{372}$ Cfr. FICHTE, J., Lecciones de Filosofía Práctica, Sígueme, Salamanca, 2017, pág. 61. Para Fichte solo el mundo espiritual y de los conceptos es el auténtico mundo.

373 "Si no comenzamos por la experiencia o no procedemos conforme a las leyes de conexión empírica de los fenómenos, en vano haremos alarde de adivinar o de investigar la existencia de una cosa". KANT, I., Crítica de la Razón Pura, B 274. 
Para la mentalidad moderna postcartesiana se trata de superar la visión de uno mismo como una mente, para pasar a ser un organismo biológico natural en el que se expresan los sentimientos propios y cuyas percepciones psicológicas son inherentes a dicha naturaleza. El ser humano es una naturaleza en la que se realizan una serie de similitudes causales que le determinan como tal en oposición a otra naturaleza de cosas. La idea moderna de la psique como realidad que expresa las características biológicas propias de la naturaleza humana determinó un cambio de mentalidad, no solo por la desvinculación desencantada del mundo, sino por los profundos cambios en la perspectiva espiritual. ${ }^{374}$

Kant habla del Idealismo como la teoría que afirma que la realidad fuera de nosotros o es indemostrable o es falsa. Y define dos tipos de Idealismos, el Idealismo cartesiano problemático y el Idealismo dogmático de Berkeley. Este último afirma que todo lo que existe son ideas pensadas o espíritus o fantasías, dado que el espacio es algo imposible en sí mismo con todas las cosas a él ligadas. El mundo es solo ideas pensadas. Este Idealismo es refutado en la Estética Trascendental kantiana. El idealismo problemático solo afirma que "no podemos demostrar" una existencia fuera de la nuestra. Por eso Kant se afanará en demostrar que nuestra "experiencia interna" solo es posible si suponemos la experiencia externa. ${ }^{375} \mathrm{Y}$ a ello se dedicará en la parte de la Analítica Trascendental correspondiente a la Lógica trascendental. ${ }^{376}$ Kant denomina su filosofía trascendental, porque se centra no en conocer cosas, sino en conocerse autorreferencialmente en los objetos, que denominará "fenómenos". 377 Todo el conocimiento tiene que partir de la experiencia y debe ser acerca de algo. No son bits mecánicos y empíricos de sensaciones particulares. Kant descubrirá que hay intencionalidad y necesidad. Los bits de información con un objeto no pueden ser tomados aisladamente, hay una vinculación de la sensibilidad a través de las formas a priori del espacio y el tiempo que nos hace conscientes de los fenómenos. Es la unidad proporcionada por la estética trascendental de la sensibilidad empírica a priori. ${ }^{378}$ Kant rompe con la incoherencia de las impresiones sensoriales de carácter individual e inicia el socavamiento del empirismo a través de su Estética y Lógica trascendentales. Se trata de un yo que piensa el mundo, pero que al mismo tiempo necesita del mundo, porque él es también un objeto empírico que se conoce en la medida que conoce. Frente a la ontologización del método cartesiano y la "idea invisible" humeana entendida como bit empírico de carácter individual, en Kant todo aparece transido de una inteligibilidad de la mente. Sin la mente, no existe la imagen del mundo (como representación), y sin el

\footnotetext{
374 "Desde la perspectiva de ese nuevo sentido del yo, el mundo de la magia parecía implicar una suerte de esclavitud, de aprisionamiento del yo en misteriosas fuerzas externas, incluso un rapto o pérdida del yo". TAYLOR, Ch., Fuentes del yo, pág. 266.

375 KANT, I., Crítica de la Razón Pura, A 1.

${ }^{376}$ Cfr. Ibid. B 275 y ss.

${ }^{377}$ Cfr. Ibid., B 25-A 12.

${ }^{378}$ Cfr. TAYLOR, Ch., Argumentos filosóficos, págs. 105 y ss.
} 
mundo, el yo no es inteligible, no puede conocer ni conocerse. El mundo existe en cuanto objeto de la experiencia del yo, y el yo es también objeto de la experiencia de la mente, es un yo empírico en relación con el mundo. ${ }^{379}$

Taylor asegura que los argumentos de la deducción trascendental pueden ser entendidos como la invalidación del atomismo empirista del input individual como "idea inteligible" que hace posible el puzle de conexión de todos los trozos. Kant habla de la necesaria relación de la "sensibilidad y el entendimiento a priori" (transcendentalidad) con un objeto de conocimiento (fenómeno). ${ }^{380} \mathrm{El}$ conocimiento está en una relación "de trasfondo" con un objeto. Si la sensibilidad y la percepción no pertenecieran o estuvieran en relación con un objeto, con una cosa, con algo, sería un ciego juego de representaciones, serían algo parecido a un sueño. ${ }^{381}$

La conciencia de mi existencia está ligada a la conciencia inmediata de la existencia de cosas reales fuera de mí. Luego soy consciente de mi yo porque soy consciente de que existen cosas fuera de mí y no puedo conocerme sin conocer que existen cosas fuera de mí, es decir, sin la experiencia. Necesito de la experiencia y de las cosas fuera de mí para conocerme y conocer. ${ }^{382}$ Por consiguiente, el yo trascendental kantiano es un "objeto empírico" que solo puede conocerse a sí mismo como fenómeno, no como cosa en sí, un espíritu subjetivo vuelto sobre sí que se reconoce como "objeto cognoscente", quien, por tanto, como observador no es lo observado, según afirma Taylor. ${ }^{383}$ Por argumento trascendental, mostró que el sujeto de la experiencia tenía que ser una unidad, la del "yo pienso", un yo que tenía que acompañar potencialmente todas "mis" representaciones; y que las conexiones necesarias que Hume quería negar en el mundo de los fenómenos debían necesariamente habitarlo, pues de ellas obtiene su "indispensable estructura". Una estructura que enmarca el conocer en la condición necesaria del espacio y el tiempo. Fuera de estas condiciones no es posible la experiencia. Serán "puras ideas", mero pensar sin condiciones de sensibilidad ni esquemas base. Ahí incluye Kant a Dios, el alma y el mundo, sin condiciones de posibilidad ni esquemas de base, en el fondo consuelo de nuestros sueños o entretenimientos para la fantasía.

Así, el mundo kantiano de la experiencia se distingue de la realidad última. Toma su forma en parte del sujeto, de la forma de nuestras mentes, y estas estructuras pueden ser exploradas por argumento trascendental; pero, por el hecho de que esa forma fue en

\footnotetext{
${ }^{379}$ Cfr. TAYLOR, Ch., Hegel, págs. 77,82-83,86,95,97.

${ }^{380}$ Cfr. TAYLOR, Ch., Argumentos filosóficos, págs. 130,31.

${ }^{381}$ Cfr. KANT, I., Crítica de la Razón Pura, A 111.

382 "Este yo trascendental es quien hace posible la experiencia, puesto que constituye toda condición lógica, a priori, de la experiencia. En tal sentido la experiencia es una construcción del sujeto, hay objetos porque hay sujeto, más allá de la experiencia la cosa en sí resulta incognoscible". CORONA FERNÁNDEZ, J., La irrupción de la subjetividad moderna, Pliego Filosofía, México, 2007, pág. 109.

${ }^{383}$ Cfr., TAYLOR, Ch., Hegel, pág. 27.
} 
parte dada a nosotros, no podemos concluir nada acerca de la forma de las cosas tal y como son en sí mismas. Las cosas son porque nosotros somos afectados como sujetos finitos, nuestra intuición recibe su contenido de fuera de nosotros; pero la naturaleza de esta realidad última, la forma de las cosas tal y como son en sí mismas es "un libro cerrado para nosotros" y lo es de modo insuperable. ${ }^{384}$

Desde este intento por ir superando esa sensación de pérdida del yo, podemos entender la nueva noción moderna de "dependencia individual", en el sentido de que se trata de una búsqueda insaciable de la independencia y de la individualidad como medios para buscar "dentro" lo que antes estaba "fuera"; la significación del mundo no se encuentra en un orden mayor establecido en el orden natural, sino en buscar las metas de sentido en el propio yo.

Kant reivindica la voluntad racional como reacción a la objetificación de la naturaleza humana. De la teología del creador, se pasa a la nueva legislación universal de la naturaleza, con lo que el hombre tiene vía libre para acceder a ser legislador de su naturaleza moral. ${ }^{385}$ Para Taylor, Kant está al borde del deísmo, es alguien que definía muy nítidamente la fuente interior de la ley moral y equiparaba la moralidad a la autonomía, en una suerte de vocación moral suprasensible. ${ }^{386}$

\section{III.1.2.8. EL YO EXPRESIVISTA}

La libertad de Kant de autodeterminación estaba llamada a ser completada. Debe ser total y superar las limitaciones de la libertad espiritual, interna. El sujeto radicalmente libre, autodeterminado, vuelto en exclusividad hacia su yo individual, debía superar la oposición de la naturaleza y la autoridad externa. Era posible intentar relacionar expresión integral y libertad radical. ${ }^{387}$ Es la Filosofía de la naturaleza como fuente moral y que fue central en la gran conmoción que produce, en el pensamiento, la sensibilidad; lo denominamos Romanticismo. ${ }^{388}$ La idea de la verdad se halla en nosotros y, en particular, en los sentimientos. Es la voz de la naturaleza en nuestro interior.

Taylor cree que lo realmente relevante aquí es que el acceso al orden natural y benevolente es primordialmente interior. ${ }^{389}$ Tener una postura moral correcta hacia el orden natural es tener acceso a la voz interior propia. Es distinto a la postura del "designio externo benevolente" y a la "voz interior". Aquí se trata de tener acceso al

\footnotetext{
${ }^{384}$ Cfr., Id., pág. 27. Cfr. VILlACAÑAS, J.L., "Estudio Introductorio" en KANT, Crítica de la Razón Pura, pág. IX.

${ }^{385}$ Cfr. VILLACAÑAS, J.L., "Estudio Introductorio” en KANT, I., Crítica de la Razón Pura, pág. CII.

${ }^{386}$ Cfr. TAYLOR, Ch., La Era Secular, tII, pág. 32.

${ }^{387}$ Cfr. TAYLOR, Ch., Hegel, pág. 29.

${ }^{388}$ Cfr. TAYLOR, Ch., Fuentes del yo, pág. 503.

${ }^{389}$ Cfr. Ibid., pág. 505.
} 
orden exterior a través de la voz interior. Se trata de superar esa visión fría y externa del mundo como algo providencial. Se produce un enfrentamiento entre la captación externa y fría del orden providente, y la voz que resuena en el interior. Sin esta sintonía interna con el orden providente, no es posible captar nada. La voz interior, según Taylor, se puede perder con la postura desvinculada de la razón calculadora, una visión externa, desvinculada, racional de dicho orden que no llega a ponerse en sintonía con la voz interior. Sin esa voz interior no es posible "estar en contacto" con dicho orden providencial. No podemos ser simplemente contempladores/observadores externos de dicho orden deísta.

Se trata, según Taylor, de abrirse a la voz interior, a una suerte de "gracia divina secularizada", que recupera el contacto y supera la desvinculación racional. Hay que abrirse a ese "elan de la naturaleza interior" que pone en contacto ambas naturalezas. De ahí que sea posible recuperar la relación de la naturaleza como fuente, con ciertas teologías cristianas de la gracia de Dios. Aquí tenemos a filósofos como Rousseau, y a ciertos románticos alemanes como Schiller. La voz interior que pone en contacto con el orden natural también pone en contacto con ciertas tradiciones filosóficas de carácter teísta y deísta. Sin embargo, la voz interior también puede ser entendida como lógica exclusiva y definitiva de una teoría de la naturaleza. Y así es posible llegar a una teoría de la naturaleza como voz interior que interpreta a Dios como luchando en la naturaleza y que halla su voz en nuestro interior. Se trata de un deslizamiento que Taylor denomina panteísta y que puede verse en Schelling.

Y se puede llegar aún más lejos, llegando a adoptar posturas que dejan fuera visiones cristianas como en Goethe o llegar a explicaciones cercanas al naturalismo: el significado de las cosas es el que emerge de la naturaleza física y nuestro ser material. Pero este anclaje naturalista está todavía muy lejos. Se trata, aquí, todavía, de otorgar al sentimiento un lugar central y positivo en la vida moral. El bien que hay que amar es la naturaleza que habla a través de uno. ${ }^{390}$ Lo que aquí nos interesa resaltar es que, a diferencia de otras épocas, en las que existía algún objeto transcendental en relación al Bien (Platón, Aristóteles, Cristianismo), en este momento no se requiere dicho objeto transcendental, se trata solo de "una cierta manera de experimentar" nuestras vidas y deseos. Sintonizar con la naturaleza es tan solo experimentar esos sentimientos naturales que se conectan en el interior del ser humano, es responder al torrente de la vida que fluye en la naturaleza. No hay una fuente de motivación moral. Se trata tan solo de dejar brotar los sentimientos que surgen dentro para definir la vida buena. Se trata de un sentimentalismo que se identifica con lo bueno. No hace falta más. Los sentimientos son en sí la definición más original que tenemos del bien, no hace falta derivarlo de ningún objeto transcendente (Platón), o de ninguna motivación para la acción (Aristóteles). Se

\footnotetext{
${ }^{390}$ Cfr. Ibid., pág. 508.
} 
trata de un sentimiento moral que recuerda, por una parte, a Rousseau y Herder, y, por otra parte, también al materialismo ilustrado. Un sentimiento moral que es difícil de definir o de fijar los límites. Taylor se hace la siguiente pregunta: $¿ Y$ acaso tiene algún sentido fijarlos? ? $^{391}$

Realizarme, realizar mi naturaleza significa acoger la voz interior e integrarla en la fuente de la vida. Se trata de expresarme y definirme, y articularme como lo que soy y me confiere identidad. Ha habido un largo camino hasta llegar aquí. Aristóteles hablaba de que la naturaleza de una cosa tiende a su forma completa según su potencial. Herder invitaba a un crecimiento que permitiera realizar esa energía interior. Ahora la naturaleza "está dentro". Esta idea ayuda a matizar el alcance de las oposiciones dentro/fuera, mente/cuerpo que tanta importancia tendrá en la comprensión del alcance de la secularización. Ya no se articula una forma o una energeia, sino un ser capaz de articularse a sí mismo. Este es el yo expresivo en el que tanto influirá Leibniz con su concepto de mónada. Taylor afirma que la mónada es un proto-yo. ${ }^{392}$ Cada uno tiene que descubrir su voz interior, su propio camino a transitar. Cada uno tiene que vivir de acuerdo a su originalidad. Lo que surge con el yo expresivo, a finales del siglo XVIII, es que cada ser humano es original e irrepetible: "Es la individuación radical." No se debería confiar en ninguna otra fuente moral de identificación que no sea nuestra propia originalidad, nosotros mismos, "mi yo". Es la revolución de la individuación que denomina Taylor, el individualismo expresivo generalizado que se extenderá a lo largo del siglo XIX. ${ }^{393}$

Esta es una de las piedras fundamentales de la cultura moderna, según Taylor. Atrás han quedado el viejo orden del logos óntico o el orden providencial de designios engranados del siglo XVIII. A finales del siglo se impone el giro expresivista por las influencias materialistas de la Ilustración radical y los nuevos descubrimientos científicos de la teoría de la evolución. El orden engranado estaba muy vinculado a la armonía de designios premorales propia de la Ilustración humanista. Y del orden engranado se pasó a la idea romántica de designio o vida que transcurre a través de la naturaleza. El Romanticismo, de hecho, surgió del orden deísta de naturalezas armonizadas según un orden providente ("cada cosa es de provecho para la otra"). El orden romántico no se organiza a partir de la razón desvinculada, antes bien, es un orden que es un enigma, y solo se puede comprender participando de dicho misterio. Del orden como armonía entre naturalezas, al que se puede acceder racionalmente, se pasa a un orden romántico, en el que un torrente de vida y amor confunde al entendimiento, como afirmará Taylor. ${ }^{394}$ Luego esta confusión romántica necesitará ser

\footnotetext{
${ }^{391}$ Cfr. Ibid., pág. 510.

${ }^{392}$ Cfr. Ibid., pág. 512.

${ }^{393}$ Cfr. TAYLOR, Ch., La Era Secular, tII, págs. 277,281.

${ }^{394}$ Cfr. TAYLOR, Ch., Fuentes del yo, págs. 519-520.
} 
aclarada con la expresión de la propia originalidad. Estas son las dos reacciones al naturalismo ilustrado. La autonomía moral de Kant y el expresivismo, que percibe la naturaleza como fuente, son dos reacciones ante lo que parece una ausencia de una dimensión moral apropiada, en el deísmo y el naturalismo. Ambas parecen opuestas, pero tienen mucho en común. Kantianos y utilitaristas parecen participar de la misma ideología liberal según Taylor. Y entre los románticos son muy diversas las visiones de Rousseau, Hobbes, Locke o Bentham. A Taylor le interesa no solo la oposición en lo que representan, sino la aspiración a la unidad. La oposición es lo que nos bloquea. Por eso el yo hegeliano supondrá ese punto de inflexión al que nos referiremos a continuación.

Se trata, desde el Romanticismo, de superar las divisiones entre razón y sensibilidad. Somos parte de la corriente de la vida y formamos parte de un orden más extenso. Por otra parte, la autonomía moral radical y la asunción de la razón instrumental son una especie de separación y declaración de nuestra autosuficiencia que no termina de completar el sentido del yo. Para Taylor, esta batalla de fuentes morales que comienza en el siglo XVIII sigue en pie hoy en día, pese a haberse desconfigurado las doctrinas románticas del torrente de la vida o el humanismo ilustrado en su forma deísta. Pero dicha tensión sobrevive tanto en el naturalismo o en el giro expresivista o en la autonomía moral, que destaca ante todo la libertad que decide o la voluntad libre. ${ }^{395}$

Concluimos afirmando, con Taylor, la relación entre Herder y Hegel, en la que el primero desapareció de escena y el segundo se convirtió en el punto canónico de referencia de ciertas ideas, como por ejemplo, la comprensión expresivista del ser humano. Pasamos a considerar a Hegel en esa conexión que, según Taylor, establece con el expresivismo. ${ }^{396}$

\section{III.1.2.9. EL YO HEGELIANO COMO VEHÍCULO DEL GEIST}

Desde el punto de vista de Taylor, la síntesis Hegeliana intenta combinar la más completa autonomía moral del sujeto, con la más alta unidad expresiva del hombre; llegar a realizar un intento por comprender al hombre en su totalidad, en la que se supere cualquier dicotomía en la aspiración por la autocomprensión más completa y realizada de sí mismo. Compartió la esperanza de que esta síntesis solo podría ser realizada si uno podía ganar una visión de la realidad espiritual que subyace a la naturaleza con la cual el hombre pudiera relacionarse y configurarse como vehículo de una realidad más grande. En este sentido, es un autor fundamental para Taylor, no solo por las referencias constantes a su pensamiento, sino sobre todo por haber escrito un

\footnotetext{
${ }^{395}$ Cfr. TAYLOR, Ch., Hegel, págs. 31-43; cfr. TAYLOR, Ch., La Era Secular, tII, pág. 508.

${ }^{396}$ Cfr. TAYLOR, Ch., Argumentos filosóficos, pág. 115.
} 
texto que lleva por título Hegel, y que significa un hito fundamental en la trayectoria intelectual y filosófica de Taylor. ${ }^{397}$ Se trata de una síntesis que en buena medida supone una invitación a redefinir la secularidad bajo nuevos parámetros a partir del intento por comprender lo universal como objetivo último de la filosofía. Se trata de una ontología abierta al nosotros y al Espíritu, entendido como saber puro y absoluto. El yo hegeliano asume todo el proceso de autorrevelación de sí mismo hasta llegar a la autoconciencia del yo en el Espíritu Universal. Se trata de una síntesis al final del camino, entre afirmaciones, negatividades y negación de la negación, como elevación hacia un bien superior que lo enriquece todo.

Si Kant reacciona con su Crítica a la objetificación de la naturaleza humana reivindicando las posibilidades de la razón, Hegel pretende dar un salto y buscará llegar a la síntesis de lo aparentemente irreconciliable de identidad y no identidad, de lo racional y lo afectivo, de sujeto y objeto, del yo y lo otro, de lo finito y lo infinito. Todo se resuelve en el Saber Absoluto, en el Geist Sujeto Cósmico que se vehiculiza en el espíritu finito. $^{398}$

Hegel estudia el proceso de desvelamiento de la conciencia del yo como la historia de autorrevelación de la conciencia humana ${ }^{399}$ llegando a realizar él mismo su propia propuesta de un yo que niega la negatividad y asume una síntesis universal. Estas etapas conllevan un "incremento en la autocerteza" y suponen una superación progresiva de las inadecuaciones en vistas al logro de una síntesis más elevada como autoconciencia que se va "auto-des-velando" en el Saber Absoluto, en el Concepto, en el yo como vehículo del Geist. ${ }^{400}$

\footnotetext{
${ }^{397}$ Cfr. TAYLOR, Ch., Hegel, pág. 43.

${ }^{398}$ Cfr. Ibid., pág. 42.

399 "El Absoluto debe concebirse más bien como la unidad móvil y viviente de un sujeto que permanece idéntico a sí justamente 'en' cada una de sus múltiples manifestaciones, cada una de sus 'objetivaciones'. Ese sujeto (...) se trata más bien del Espíritu, que debe ser concebido como movimiento, proceso, perfilado históricamente, y que encuentra una representación en cada una de sus determinaciones, es decir, en cada configuración históricamente dada de la relación misma entre sujeto y objeto, una forma única de esta estructura general que determina al Absoluto como totalidad en devenir". VANZAGO, L., Breve Historia del Alma, pág. 129.

${ }^{400}$ Cfr. TAYLOR, Ch., Hegel, págs. 129-147. 1.- La realidad externa que no refleja al Geist debido a que la exterioridad y el Geist (como conciencia Universal y como conciencia finita) son dos mundos independientes. Cfr. El tiempo de los orígenes y "el yo colectivo integrado en el cosmos". 2.- Una segunda etapa en la que somos felices en una "relación de dependencia" con lo otro, aunque no somos conscientes de ello porque la conciencia está "en un estado bruto". Cfr. Platón y "el yo como autodominio y control". 3.- Un tercer momento en el que el hombre alcance una percepción de sí mismo a través de un incremento de autoconciencia, aunque limitado a la autoidentificación "yo es igual a yo" (todavía existe bipolaridad entre sujeto y objeto por lo que desde la autoidentificación es imposible la elevación de la conciencia a su dimensión ontológica). Cfr. San Agustín de Hipona y "el yo como interioridad". 4.- Otra etapa superior sería la etapa de la incorporación del yo a su otro (su encarnación), entendiéndose a sí mismo "desde-su-otro-en-sí-mismo", produciéndose en esa expresión encarnada un "retorno-a-sí-mísmo Cfr. Descartes y "la conciencia del yo". 5.- Otra etapa en la que la autoconciencia del yo "retorna-a-símismo" pero desde el objeto de deseo (hay un predicamento ontológico en el objeto) que permite que asumir la propia corporalidad como un "retorno-a-sí-mismo" desde el deseo que le permite a su vez "estar
} 
El Geist, el Espíritu Absoluto, el Sujeto Infinito se "supera a sí mismo" desde la necesidad de ir más allá de su propia inmediatez. La oposición primera entre lo que el Geist es de manera "inmediata" y lo que está llamado a ser como necesidad expresiva y encarnada o "mediada", es lo que explica en última instancia su propia contradicción interna. La inmediatez del todo lleva inscrita en su propia realidad la mediación. El Geist está definido, pues, por lo que es (inmediatez), esencia que se define como "contradicción" que lleva a la mediación. Y si todo es mediado porque no puede existir desde la inmediatez, entonces la contradicción interna explica "la necesidad racional de la mediación". ${ }^{401}$ La contradicción define pues a la realidad y a la identidad, ya que es lo que define el movimiento y la esencia de lo que el Geist es. ${ }^{402}$

Una autoconciencia que se expresa como "certeza de sí mismo". ${ }^{403}$ De tal manera que sin la circularidad dialógica entre Autoconciencia y Realidad Efectiva difícilmente el hombre crecería en su dimensión ontológica para recrear su propio yo, porque "somos-seres-en-el-mundo" y, desde la realidad histórica en la que vive, se siente interpelado constantemente a realizar, como movimiento interior de contradicción ontológica, un cuestionamiento entre lo que comprende como fundamentación de lo que es y las realizaciones históricas en las que se ubica como "expresión” y "exterioridad". Un mundo que es entendido como totalidad cuando alcanza la autoconciencia, como el Todo de la Cosa. La realidad está hecha para el yo y el yo para la realidad hasta llegar a la autoconciencia generadora del saber puro.

Taylor retoma el alcance de la conciencia primaria o percepción sensible. Según dicho tipo de percepción, para Hegel, no hay mediación de conceptos, con lo que el

en casa". El deseo tal y como lo explica Taylor, siguiendo a Hegel, refleja "no solo la necesidad fáctica por un objeto, sino también la búsqueda fundamental de integridad". El deseo provoca incremento de autoconciencia a partir de la realidad objetual. Cfr. Kant y "el sujeto como ser relacional del mundo y el yo expresivista como individuación radical". 6.- Y finalmente la etapa que nos interesa resaltar sería la etapa en la que el hombre se explica a sí mismo en la naturaleza y en las cosas, una vez que las transforma según sus propios proyectos. Se ha logrado avanzar hacia la elevación de la propia conciencia como un espíritu universal. Las cosas proyectan el yo autoconsciente y este yo "determina" el sentido de las cosas, concediéndoles un sentido y un proyecto. Es el yo como vehículo de un Concepto Superior, el Geist. Cfr. Hegel y "el yo como vehículo del Geist". "Cuando los hombres alcanzan la intuición de que la racionalidad, es decir, el principio de su propio pensamiento, determina toda la realidad, y en consecuencia ellos se sienten 'como en casa' en el mundo. O como Hegel lo dice en una frase lapidaria, 'la razón es la certeza de la conciencia de que es toda la realidad'”. TAYLOR, Ch., Hegel, pág. 140.

${ }^{401}$ Cfr. TAYLOR, Ch., Hegel y la sociedad moderna, pág. 69.

402 "Hegel piensa en la contradicción como la fuente del movimiento porque cualquier cosa que esté en contradicción debe superarse en algo más, siendo este paso ontológico, entre los niveles del ser que continúan existiendo de igual manera, o histórico, entre las diferentes etapas de la civilización humana... Si la contradicción es la fuente de tránsito de un nivel a otro, lo es porque es fatal para la existencia continuada, o al menos así lo pensaría uno desde el principio de sentido común que nada contradictorio puede existir". TAYLOR, Ch., Hegel, pág. 91.

403 "El hombre aspira a una encarnación externa que lo exprese, y ve frustrado este propósito cuando las realidades de las que depende reflejan algo ajeno a él. La certeza de sí mismo es la confianza de que todo aquello de lo que dependo no me es ajeno, que nosotros estamos como 'en casa' en ello. Solo se puede pensar en ello como la definición de nuestra integridad en el sentido más amplio. (...) Esto es lo que los hombres luchan por conseguir”. Ibid., pág. 119. 
acceso al objeto es inmediato, se percibe al yo "en inmediatez con el aquí y ahora" del mundo. Se trata de una percepción ontológica según la cual "somos-en-el-mundo". Este yo para Hegel es un yo en relación inmediata con el mundo, que se restringe a sí mismo por la exterioridad del mundo. Es la certeza sensible. Una certeza que se irá transformando poco a poco en percepción que es capaz de captar las múltiples propiedades del objeto. Es el sentido común que es capaz de vislumbrar la unidad de la cosa, aunque de forma primitiva, ya que la concibe o como dada en el objeto o como producto de su propia conciencia. ${ }^{404}$

Lo particular, según Hegel, no puede ser un conocimiento no mediado. Lo particular no puede explicarse de manera inmediata. Hay que hacer uso de descripciones, de palabras, de términos descriptivos. Lo particular es inalcanzable a la inmediatez de la conciencia sensible. Serán precisos los conceptos, las definiciones. "Lo inmediato es negado, pero es retenido en forma mediada". ${ }^{405}$ La conciencia irá avanzando, como contradicción, a través de la conciencia en lo otro, a través de lo otro, en una reflexividad por medio de la cual se manifiesta el yo "en lo otro de uno". La autoconciencia se va constituyendo y expresando a través de lo otro, como una reflexividad del yo en las cosas, como unidad de saber puro entre el este (yo) y el esto (objeto).

Con el advenimiento de la revolución cartesiana y la autoconciencia expresada como razón científica, cambia el enfoque de estudio: se pasa de centrarse en lo inanimado, las esencias, el fundamento ontológico de las cosas, a centrarse en el orden de la naturaleza y en la búsqueda de lo que Taylor denomina, siguiendo a Hegel, "una forma autosustentable". La ciencia busca leyes que expresan la regularidad del orden natural, pero se queda en ese conocimiento superficial de la razón que observa y que analiza. ${ }^{406}$ Con el surgimiento del entendimiento, la conciencia de la ciencia empírica será capaz de captar la unidad del objeto en su multiplicidad o junto con ella, y es capaz de adentrarse en el conocimiento de leyes constantes. Hegel afirma que "para el entendimiento, solamente ahí, se abre en adelante, por encima del mundo sensible, como mundo que aparece fenoménicamente, un mundo suprasensible, como mundo verdadero, un más allá que permanece por encima de este más acá que desaparece; un en-sí que es la primera aparición de la razón". 407

\footnotetext{
${ }^{404}$ Cfr. RÜHLE, V., "Estudio Introductorio”, en HEGEL, G., La Fenomenología del Espíritu, pág. LXXI, Gredos, Madrid, 2014.

${ }^{405}$ Cfr. TAYLOR, Ch., Hegel, pág. 126.

406 "La razón observante no puede realmente sobrellevar el entretejido de lo dado y lo que el hombre hace de sí mismo, pero trata de separar estos dos aspectos el uno del otro. Trata al hombre como una cosa, por lo que Hegel considera apropiado conducir la discusión de esta sección hacia la cabeza, en un examen de la frenología, la cual estuvo en boga durante un tiempo a finales del siglo XVIII. En la frenología, las cualidades típicamente humanas del hombre son relacionadas con la materia inerte, con los surcos y los relieves de su cráneo". Ibid., pág. 141.

${ }^{407}$ HEGEL, F., Fenomenología del Espíritu, pág. 101.
} 
Se trata de un yo que va siendo consciente de la inconsistencia de esta distinción entre el reino de las leyes y el mundo de la vida, siendo necesario un paso más a través del paso al autoconocimiento de la conciencia y así poner pie en "el reino natal de la verdad".

Para Hegel, se trata de un momento especialmente crítico y reduccionista, porque se pierde de vista el "espíritu encarnado" como identidad que establece la contradicción ontológica inherente a sí mismo. El hombre es un agente racional y expresa esta dignidad ontológica a través de la razón. Pero reducir la autoconciencia a "la razón que observa", 408 es limitar las categorías de lo dado a mera causalidad que descubre un orden de engranaje causal y no un orden establecido ónticamente. Bajo la razón que observa científicamente y analiza, se diluye la comprensión del hombre como "agente" y cree encontrar "la necesidad racional de la naturaleza". 409

Taylor opina que Hegel nos ayuda a descubrir el alcance de esta razón instrumental y en qué medida ha contribuido en la Modernidad a las fundamentaciones morales del yo que se arraigan en un mero orden entretejido de causalidades naturales. Se considera al hombre en su "radical dignidad racional". Para Hegel se trata de un reduccionismo del orden moral de la Modernidad que hay que superar. Hegel quiere ir más allá porque en el fondo se inspira en la vieja ontoteología y en la gran cadena del Ser, en su proceso de autorrevelación de la conciencia y en la pluralidad de distintas manifestaciones del Espíritu. ${ }^{410}$

El yo hegeliano pretende superar la negatividad ontológica del yo cartesiano y de la razón científica, que se vuelve a sí mismo "desde su otro en sí mismo". Con la

\footnotetext{
408 “(En la razón) autoconciencia y ser son la misma esencia; la misma, no como una comparación, sino en y para sí... Ahora bien, esta categoría o unidad simple de la autoconciencia y del ser, empero, tiene en sí la diferencia; pues su esencia es justamente la de ser inmediatamente igual a sí misma en el ser-otro o en la diferencia absoluta. Por eso, la diferencia es; pero de un modo perfectamente transparente, y como una diferencia que, al mismo tiempo, no lo es". HEGEL, F., Fenomenología del Espíritu, pág. 162. "A esta conciencia (la razón que observa), para la que el ser tiene el significado de ser suyo, la vemos, ciertamente, adentrarse de nuevo en el íntimo querer decir y en el percibir, pero no como se entra en la certeza de algo que solo es otro, sino con la certeza de ser ella misma esto otro (la cursiva es nuestra). Anteriormente, tan solo le acontecía que percibía y experimentaba algo en la cosa; ahora, es ella misma la que plantea las observaciones y la experiencia. El íntimo querer decir y el percibir, que antes se cancelaban para nosotros, ahora son cancelados y asumidos por la conciencia para ella misma; la razón se propone saber la verdad; encontrar como concepto lo que para el íntimo querer decir y el percibir es una cosa, es decir, tener en la coseidad solamente la conciencia de sí misma. De ahí que la razón tenga ahora un interés universal por el mundo, pues ella es la certeza de tener presencia en él, o de que lo presente es racional. Busca su otro en tanto que sabe que no posee en ello otra cosa que a sí misma; no busca nada más que su propia infinitud". Ibid., pág. 165.

409 "La oposición de las formas de subjetividad y objetividad es por cierto una de las finitudes; pero el contenido, tal como se halla acogido en la sensación, la intuición o también en el elemento más abstracto de la representación y del pensamiento contiene las finitudes en su plenitud, las cuales, con la exclusión de aquella sola y única manera de la finitud que es la forma de lo subjetivo y lo objetivo, no han sido todavía de ningún modo expulsadas ni mucho menos han caído por sí mismas". HEGEL, G., La Lógica, Vol. I, CPSI, Lavergne, 2020, pág. 96.

${ }^{410}$ Cfr. TAYLOR, Ch., Argumentos filosóficos, pág. 163.
} 
negatividad de la negatividad del yo hegeliano, se afirma el sentido del mundo y de las cosas desde el yo que piensa, no limitándolo a una "representación conceptual" o imagen que sujeta al yo, sino como una conciencia que asume el mundo y lo engloba elevándose como Espíritu Universal. La razón no es la que ordena el mundo como imagen mental, sino que se entiende a sí misma como una certeza de que incluye toda la realidad como Espíritu. La negatividad del yo se afirma en el Espíritu Universal como una conciencia de la razón de que es toda la realidad. La razón, afirmando desde su negatividad, se ha elevado a la Infinitud del Espíritu Universal que comprende la Realidad Toda: la universalidad del ser entendida como objetividad y la representación mental del yo entendida como subjetividad. En la conciencia del yo elevada a Espíritu, se realiza la síntesis del yo ideal hegeliano. ${ }^{411}$

La estructura del objeto revelada paulatinamente a través de la razón científica y observadora resultará ser la estructura misma del sujeto. "Lo que el entendimiento mira en el fondo de la cosa no es más que él mismo". ${ }^{412}$ Se trata de un yo que intenta combinar las dos corrientes de pensamiento de la Modernidad, el pensamiento y la sensibilidad. Un yo que se reconoce como sujeto y como objeto de un análisis científico objetivador y un yo que integra a su vez todas las dimensiones de la sensibilidad autoexpresiva y comunitaria. Hegel asume este optimismo que supera los extremos, y sostiene que el hombre no es solo cuerpo y espíritu, razón y naturaleza, sino unidad expresiva que integra ambos. Para Taylor, la actitud analítica y disecante de la razón desvinculada y de la ciencia objetivante supuso una ruptura dualista empobrecedora. Hegel pretende superar las dos versiones de la Ilustración en su variante de radical objetivación del pensamiento (Descartes), pero también contra la objetivación de la naturaleza humana en el nombre de la libertad moral (Kant). Taylor considera que Kant pretende superar la libertad benefactora que otorgaba el sentimiento benevolente como expresión moral del orden natural. Era necesario, según Kant, superar la dispersión de deseos e inclinaciones y adentrarse en una libertad radical afirmada en su exclusividad racional. Kant, en su segunda Crítica, pretende dar por superada la motivación del placer o la felicidad. Es necesario un imperativo categórico que nos ata como voluntades racionales y por ninguna otra razón. ${ }^{413}$

Hegel es consciente de que Kant no termina de resolver el problema al realizar en su segunda Crítica una separación entre naturaleza y razón. No supo, según Hegel y

\footnotetext{
411 "Es el sí mismo de la conciencia efectivamente real, a la que él se enfrente, o que, más bien, viene a ponerse enfrente como mundo objetual efectivo que, sin embargo, ha perdido para el sí-mismo todo significado de algo extraño, del mismo modo que el sí-mismo ha perdido todo significado de un ser-parasí separado de ese mundo, dependiente o independiente de él. Sustancia y esencial universal permanente, igual a sí misma: él, el espíritu, es el fundamento y punto de partido, no quebrantado ni disuelto, de la actividad de todos, así como su fin y meta en cuanto lo en-si pensado de toda autoconciencia". HEGEL, F., Fenomenología del Espíritu”, pág. 286.

${ }^{412}$ VALLS PLANA, R., Del yo al nosotros, Estela, Barcelona, 1971, pág. 59.

${ }^{413}$ TAYLOR, Ch., Fuentes del yo, págs. 128-132.
} 
Taylor, sintetizar nuestra radical dependencia de la naturaleza y los sentimientos que libremente surgen en nosotros con su propuesta de una ley moral racional en sí misma y basada en la razón pura. Hegel intentará realizar una versión integradora entre la libertad radical de Kant y la teoría expresiva de la naturaleza humana. ${ }^{414}$

Taylor piensa que la libertad radical kantiana se hacía a costa de apartarse de la naturaleza y de una visión de sí mismo entre razón y libertad. El ideal hegeliano era aglutinar ambos ideales de libertad radical y de naturaleza expresiva. Lo mismo que otras propuestas que realizan Schiller, Fichte, Schelling, Schlegel, Hölderlin, Novalis, Schleiermacher y otros..., Hegel, según Taylor, es el gran propulsor de la superación de tantas oposiciones: libertad radical y expresión integral; pensamiento, razón y moralidad y deseo y sensibilidad; entre libertad autoconsciente y la vida en la comunidad; entre conciencia propia y comunión con la naturaleza, entre subjetividad finita y vida infinita. $^{415}$ ¿Cómo expresar esta autoconciencia definidora y desvinculada que afirme al mismo tiempo su relación con la naturaleza? Si ha de salvarse la autonomía radical, ¿hay que llevar más adelante la idea del microcosmos hasta la idea de que la conciencia humana racional no solo refleja el orden de la naturaleza, sino que lo completa? ¿El espíritu cósmico que se expresa en la naturaleza está esforzándose por completarse en un autoconocimiento racional y consciente, y la sede de esta autoconciencia es el espíritu del hombre? ¿Es el espíritu humano consciente el vehículo de dicho espíritu cósmico ${ }^{416}$ El expresivismo no alcanza su plena realización, sino en una expresión de autoconciencia racional. Así, también el orden natural no alcanza a completar su expresión última, sino en la conciencia racional del hombre como espíritu finito. Es el sentido hegeliano del hombre que alcanza la máxima expresión de su autoconciencia no solo como fragmento individual del universo (expresión de sí mismo), sino también como vehículo del Geist, en el que se realiza la tan ansiada integración de lo finito y lo infinito en una autoconciencia que integra razón y sensibilidad, pensamiento y naturaleza. Es el sujeto encarnado como síntesis entre autonomía racional y unidad expresiva. $^{417}$

En Hegel, el agente racional, el yo, el hombre, no pierde nada de su libertad al llegar a aceptar su vocación como vehículo de la necesidad cósmica, del Geist. ${ }^{418}$ Es posible una unidad más compleja y rica que resuelva todas las opciones. El hombre es el vehículo de dicha realización. ${ }^{419}$ Es posible el ascenso hacia un orden moral más elevado de carácter impersonal y racional. ${ }^{420}$ Por ello, según Taylor, en Hegel lo que se

\footnotetext{
${ }^{414}$ Cfr. TAYLOR, Ch., Hegel, pág. 28.

${ }^{415}$ Cfr. TAYLOR, Ch., Hegel y la sociedad moderna, pág. 27.

${ }^{416}$ Cfr. Ibid., pág. 31.

${ }^{417}$ Cfr. Ibid., pág. 38.

${ }^{418}$ Cfr. TAYLOR, Ch., Hegel, pág. 102.

${ }^{419}$ Cfr. TAYLOR, Ch., La Era Secular, tII, pág. 39.

${ }^{420}$ Cfr. TAYLOR, Ch., Hegel, pág. 423.
} 
transformó fue su apreciación del Cristianismo ortodoxo, que comenzó a ver, a través de los ojos de la filosofía especulativa, como la religión absoluta, más que como una aberración positiva, derivada de la enseñanza moral de Jesús.

\section{III.2.-NARRACIÓN DE LOS CAMBIOS EN EL PENSAMIENTO}

\section{III.2.1.-CAMBIOS QUE INICIAN EL CAMBIO. LA SUPERACIÓN PROGRESIVA DE LOS TRES BALUARTES DE LA FE}

\section{III.2.1.1. DE UN MUNDO ENCANTADO A “UNA MENTE QUE PIENSA”}

El gran paso que se realiza con la Modernidad es el paso de mundo de espíritus, demonios y fuerzas morales trascendentes ubicadas en el exterior, fuera de nosotros ${ }^{421}$, a un mundo en el que las fuentes morales se ubican "dentro", en la mente. Se deja de contemplar el orden eterno expresado en un cosmos espiritualizado y se pasa a un nuevo locus en el que el orden y la razón se ubican en la mente del hombre, esto es, en los pensamientos, los sentimientos y el sentido espiritual. Esta mente es el espacio espiritual, la urdimbre de la interioridad, la conciencia introspectiva. ${ }^{422}$

A Taylor lo que le interesa resaltar, bajo esta perspectiva, no es tanto el dualismo cartesiano o el materialismo monista o el utilitarismo, sino que sobre todo quiere hacernos conscientes de lo que significa este primer momento en relación al cambio fundamental que se experimenta: con el cambio de perspectiva desde el "exterior encantado" al "interior que piensa y siente", es la mente la que concibe por primera vez lo que Taylor resume como "el problema mente-cuerpo", que antes era impensable. Lo resume con una expresión que nos parece relevante: el que no experimentemos (ya) la existencia de Dios y de los espíritus, no significa que experimentemos su no existencia. ${ }^{423}$ El cambio, en relación con nuestra percepción del mundo, es un cambio desde un mundo en el que estos espíritus simplemente estaban allí y ejercían influencia sobre nosotros, a un mundo en el que estos espíritus ya no están o que prácticamente se

\footnotetext{
${ }^{421}$ Todo el estudio introductorio explica con amplitud y desde distintas visiones lo que aquí nuestro autor canadiense quiere manifestar con la expresión "mundo encantado"; seguramente que no está de acuerdo con todas las visiones allí contempladas, pero seguro que en todas hay elementos que enriquecen la expresión "encantamiento del mundo".

${ }^{422}$ Queremos resaltar la diferencia entre interioridad (como espacio espiritual) y conciencia. No todo lo que se esconde en nuestro yo, en esa urdimbre de la interioridad pasa a la conciencia. Taylor sugiere que hay muchas cosas que están escondidas y de las que no somos conscientes, no pasan de "la mente" como interioridad a la conciencia, bien sean porque pertenecen a estados "inconscientes" (no pasan a la conciencia) o bien sea porque están "reprimidos" y no les permitimos que afloren a la conciencia. La interioridad como ese espacio espiritual es lo que Taylor denomina "reflexividad radical". El "hacernos conscientes de nuestra conciencia" es lo que Taylor quiere decir cuando habla de esta "conciencia introspectiva".

${ }^{423}$ Cfr. TAYLOR, Ch., La Era Secular, tI, pág. 50.
} 
han vuelto inconcebibles. Lo que experimentamos ingenuamente es el hecho de que no ejerzan tanta influencia sobre nosotros. ${ }^{424}$

Se puede afirmar que con el advenimiento de la Modernidad no se niega la existencia de Dios, pero por primera vez se somete a la duda, a explicaciones mediadoras o a argumentos novedosos. Esta línea de reflexión es la que le interesa a Taylor porque es lo que nos lleva a dar respuesta a la secularidad tal y como se plantea en el tercer sentido. Es así como Taylor pretende llegar al corazón de la secularidad y las motivaciones que fueron fundamentando la aparición de fuentes morales alternativas.

Todo empieza con la noción de la mente. La mente no es un espacio racional que sintoniza con la Razón Eterna del Universo. La mente es una realidad "solo humana" y se entiende como un "espacio interior", como "antena perceptora" de sensaciones, experiencias, creencias, ideas sobre el mundo o sobre nosotros mismos y también de respuestas de sentido y ubicación moral en el mundo. ${ }^{425}$

La mente en este momento supone una ruptura con el anterior mundo encantado, pero no se sitúa en el mismo ámbito que lo que representa en las filosofías materialistas, idealistas o dualistas. La mente, en este primer momento, se afianza como la mirada interior que capta la significación del mundo "desde dentro", el sentido de las cosas se alcanza desde la "conciencia percibe"; de que el mundo y la naturaleza entran en diálogo con nuestra mente y es la mente la que capta el orden y la lógica de las cosas, y es capaz de vislumbrar un sentido más profundo. El orden del mundo necesita pasar el filtro de la mente, que ordena y encuentra sentido en la naturaleza y en el mundo, una mente que es consciente de que dentro hay sentimientos, deseos, aversiones. ${ }^{426}$

Este primer cambio que surge con la "aparición de la mente" es previo a la filosofía dualista cartesiana o a la filosofía idealista o materialista o utilitarista. Estas filosofías analizarán la mente bajo otras perspectivas. Ahora tiene lugar la afirmación genérica de lo que supone la aparición de esta mente primera, más básica y elemental, que supone una ruptura con el mundo encantado y que inicia el proceso hacia el desencantamiento del mundo weberiano y hacia la aparición del humanismo exclusivo. Por ser el momento primero, merece la pena enfatizar lo que supone su aparición, porque sin esta ruptura que inicia la aparición de la mente, no se hubieran iniciado los procesos hacia la mente dualista, monista, utilitarista o materialista. ${ }^{427}$

\footnotetext{
${ }^{424}$ Cfr., Ibid., pág. 63.

425 Ibid., pág. 52.

${ }^{426}$ Cfr. Ibid., págs. 67-70.

${ }^{427}$ Las perspectivas materialistas que fundamentan las fuentes morales en las funciones que las cosas tienen para nosotros o en las respuestas biológicas que activa la naturaleza humana. Taylor afirma que este tipo de perspectivas también se sitúan "dentro" pero desde otro planteamiento totalmente distinto: las respuestas están "dentro" por cómo hemos sido "programados" (materialismo) o como respondemos al
} 
Considera Taylor que la aparición de esta "mente primera" supone la ruptura con el mundo encantado, mundo que encuentra las fuentes de identificación moral, no en la mente humana, sino en ese mundo de espíritus tanto benignos como malignos, agentes espirituales, ${ }^{428}$ culto a los santos y su acción curativa en torno a las reliquias y demás loci de poder espiritual que despertaban el respeto y la veneración. Para el mundo encantado, la significación de las cosas está fuera, en los objetos y agentes, independientemente de nosotros. Las cosas y los agentes pueden ser loci de poder espiritual, el mundo está encantado y, por lo tanto, puede haber realidades y personas que transmitan poder. La realidad transmite significación moral porque hay espíritus que se esconden tras ciertos objetos, realidades y personas que despiertan la veneración y el encanto que se esconde en el misterio espiritual. ${ }^{429}$ La significación moral se encuentra en el espíritu que habita en ciertos objetos y personas, y que, por lo tanto, está fuera. ${ }^{430}$

Por el contrario, con la aparición de la mente desaparece la significación de las cosas exteriores, de las Ideas que envuelven el mundo natural y de la Razón Eterna configuradora del cosmos, y la "mente humana" es la que descubre el mundo de significado de las cosas, sentimientos, percepciones. El significado moral del mundo se descubre por la mente que ordena y siente y experimenta. Sin esa percepción de la mente nada se da "ya" por supuesto. El mundo no está ahí con su significación. Ahora la significación se descubre por la mente. Somos nosotros los que con nuestra mente sentimos alegría o tristeza, experimentamos, percibimos, nos dejamos influir por lo que acontece.

Todo aquello que no es ser humano o experiencia humana está fuera de la mente, aunque nos puede influir de dos maneras:

i.- Dejándonos influir por esas realidades y cambiar la perspectiva ante la que nos situamos moralmente. Es decir, que cuando soy consciente de que experimento realidades y deseos que están fuera de mí y con los que puedo entrar en diálogo, puedo experimentarme como un yo que se deja influir y no ser un yo/mente impermeabilizado, sino un yo que permite espacios abiertos a otras realidades que no pasan por el autocontrol de la mente y que pueden abrirme al misterio.

\footnotetext{
descubrir la función de las cosas para nosotros (utilitarismo).

${ }^{428}$ Nos parece importante reseñar la apreciación de Taylor en torno a la "mente divina" que en este mundo encantado tiene una percepción benevolente o malevolente sobre el ser humano. Por el contrario, con el advenimiento de la Modernidad las únicas mentes del cosmos son las mentes humanas. El hecho de que la mente divina desaparezca del imaginario de la Modernidad como una mente que actúa sobre el mundo nos parece también relevante con esta ruptura que se inicia en torno a la aparición de la mente y la posterior ruptura dualista mente-cuerpo.

${ }^{429}$ Cfr. TAYLOR, Ch., La Era secular, tII, pág. 49.

${ }^{430}$ Cfr. TAYLOR, Ch., La Era secular, tI, págs. 75-78.
} 
ii.- O bien no limitándonos a ser una mente que solo se deja influir por las reacciones que experimentamos en nuestro cuerpo, sino permitir motivaciones diversas como fuentes morales que abren nuestro campo de juego con el mundo. No todo es reacción biológica (neurofisiología) o materialismo que solo descubre las funciones de las cosas, sino que nuestro cuerpo/mente pueden verse motivados e influenciados por fuerzas que van más allá de lo que se ve o se puede encontrar en el mundo natural en el que vivimos. ${ }^{431}$

Nos consideramos como "una mente" que opera con el mundo y busca significaciones, o unos organismos biológicos que ocultan mentes. Es la mente la que deduce las significaciones y fundamenta las respuestas que surgen del propio organismo biológico (filosofías dualistas, materialistas y biologicistas-mecanicistas). No es el mundo el que nos afecta según su propia naturaleza, encantándonos o apoderándose de nosotros como en el mundo encantado, sino que es nuestra propia mente la que confiere significación al mundo cuando este incide sobre ella. La significación no está fuera, independientemente de nosotros, sino que es la mente en cada uno de nosotros la que determina y reacciona ante el mundo, descubriendo significaciones de muy diversas maneras, bien sea de forma dualista, utilitarista o biologicista. ${ }^{432}$

En clave utilitarista y biologicista, podríamos decir que las significaciones están fuera, como cuando nos dejamos influenciar por el estado de ánimo de los otros, o cuando, por ejemplo, la altura moral de otras personas incide en nuestro compromiso moral hacia los demás. Ciertamente que en este caso las fuentes morales están fuera, pero no en el sentido del "fuera" del mundo encantado. En ambos casos están fuera, pero todo se decide desde dentro, no hay significaciones del mundo cósmico que están ahí independientemente de nosotros. Ahora esas significaciones están fuera, en los otros, pero son descubiertas por mí, desde dentro de mi propia identidad moral, y soy yo quien decido que estando fuera, estén dentro, porque así lo establezco desde mi propia identidad y voluntad moral. Todo está dentro de las mentes individuales, lo de fuera y por supuesto lo que yo determino desde dentro. Es lo que Taylor define como "teorías atomistas" de la mente y que desembocarán en el atomismo filosófico empirista y en el utilitarismo individualista de carácter metodológico que arraigará en el subjetivismo y en el individualismo autosuficiente. ${ }^{433}$

La mente que interactúa con el mundo y los acontecimientos y experiencias y deseos y percepciones, no nos sitúa en un marco de encantamiento, pero ofrece un "encanto que enamora", ya que el sujeto es consciente de poder determinar significaciones. En ese sentido la mente ofrece una analogía al "encantamiento del

\footnotetext{
${ }^{431}$ Cfr. Ibid., pág. 67.

${ }^{432}$ Cfr. TAYLOR, Ch., Fuentes del yo, págs. 162-163.

${ }^{433}$ Cfr. TAYLOR, Ch., Argumentos filosóficos, págs. 177-178,183; cfr. TAYLOR, Ch., Fuentes del yo, págs. 265-268; cfr. TAYLOR, Ch., La Libertad de los modernos, págs. 229 y ss.
} 
mundo", porque ayuda a comprender de manera endógena lo que en el mundo encantado se realizada exógenamente. El mundo moderno, con la aparición de la mente y el surgimiento del yo, hace que las significatividades cambien de loci y el poder encantador del mundo se sitúe en la mente que encanta de significatividad la experiencia, los acontecimientos y los deseos. Se sitúa desde dentro un poder que otorga significatividad a algo que anteriormente solo estaba fuera. La significatividad sigue estando en las cosas, pero no en sí mismas, sino desde el poder del yo que les otorga. Es una significatividad exógena (a través de la mente) no endógena en las cosas mismas. ${ }^{434}$

En el mundo encantado las cosas transmiten un poder que maravilla el mundo y produce efectos mágicos, no solo en el hombre, sino también en otras realidades. Este poder puede transformar el alma humana, la puede llenar de trascendencia y poder espiritual, pero al mismo tiempo también puede verificar las cosas, salvando de naufragios o cambiando desastres. Las cosas tienen un poder causal debido a la significatividad que llevan dentro. Esto es algo que podemos comprobar no solo en la religión arcaica llena de magia, sino también en las religiones preaxiales y axiales. También podemos comprobarlo en la teoría de las correspondencias del Alto Renacimiento, donde aparece la realidad de las cosas que llena de poder y significatividad el mundo tal y como Copérnico, por ejemplo, afirma sobre la creación del mundo por "el mejor y más regular artífice de todos", con lo que esto significa de estar lleno de significatividad trascendente. ${ }^{435}$

Taylor entiende que con la Modernidad las relaciones causales entre las cosas del mundo no vienen determinadas por objetos cargados de significados que posibilitan la magia y causan positividad o negatividad, sino que es la mente la única que garantiza los significados del mundo. El mundo físico está fuera de la mente y las relaciones causales se establecen entre objetos, no entre significados que preceden al mundo natural. En el mundo premoderno existen relaciones causales establecidos por los significados que establecen los loci de lo sagrado con influencia y poder causal.

Con el advenimiento de la ciencia galileana y la primera Modernidad las significaciones están exclusivamente en la mente, están circunscritas a un espacio mental que define el sentido de las cosas por los sentimientos, las ideas, las experiencias y las percepciones. En el mundo de espíritus premoderno hay una suerte de espacio mágico de encantamiento, fuera, que incluye el yo del individuo que se siente bajo dicha

\footnotetext{
${ }^{434}$ Cfr. TAYLOR, El multiculturalismo y la política del reconocimiento, pág. 48; cfr. TAYLOR, Ch., La Era Secular, tI, pág. 69; cfr. TAYLOR, Ch., La Ética de la autenticidad, pág. 62.

435 "Pues ¿quién, adhiriéndose a lo que ve constituido en óptimo orden, dirigido por la providencia divina, mediante la asidua contemplación y cierto hábito hacia estas cosas, no es llamado hacia lo mejor y admira al artífice de todo, en el que está la felicidad y el bien completo? Pues, no en vano, aquel salmista divino se confesaría: delectado por el trabajo de dios y arrebatado por la obra de sus manos; si no es porque, por medio de estas cosas como por una especie de vehículo, fuéramos llevados a la contemplación del sumo bien”. COPÉRNICO, N., Sobre las revoluciones, Editora Nacional, Madrid, 1982, págs. 97-98.
} 
influencia de poder divino y mágico. Con la aparición de la mente hay una especie de "espacio intermedio" que no está fuera (mundo encantado) ni dentro (racionalidad absolutizadora del mundo), sino en un espacio intermedio que se ubica entre el fuera encantado y el dentro del yo impermeabilizado; un espacio que Taylor define como un "yo poroso" que asume elementos de encantamiento premoderno y elementos de una racionalidad que empieza a desvincularse y a impermeabilizarse de influencias exteriores, que inicia el camino hacia la desaparición de elementos trascendentes (distinto al de la negación). ${ }^{436}$

Esta imagen de lo poroso que define este espacio intermedio entre lo abierto (encantamiento) y lo impermeabilizado (racionalidad moderna) es muy clarificadora para definir este primer momento de la Modernidad. ${ }^{437}$ Una porosidad que permite que se introduzcan elementos de la etapa premoderna en una realidad nueva en la que se entrecruzan lo anterior que no ha terminado de finalizar, con algo nuevo que acaba de empezar. Este espacio intermedio suprime fronteras definidas y, ante lo nuevo que acaba de comenzar, no se cierran las puertas a lo que sigue latente de la etapa anterior, como la porosidad que permite la entrada elementos de etapas anteriores en una situación que acaba de comenzar y que tampoco está definida del todo. Taylor pone el ejemplo de la posesión, que no termina de identificarse como algo que está completamente determinado por algo interno, y al mismo tiempo se siguen dando explicaciones en torno a "influencias exteriores". 438

Desde el punto de vista de Taylor hay, pues, una interacción que influye y entra en diálogo en este espacio intermedio entre lo interior y lo exterior. Cualquier sensación interior no solo es captada desde dentro, con la mente, sino que al mismo tiempo hay espacios para conjugar los sentimientos con explicaciones exteriores que influyen y coadyuvan a que esta situación interna pueda ser entendida desde otras dimensiones. El mundo encantado sigue proporcionando marcos de explicación creíbles para una situación en la que la mente lo explica todo o tiende a buscar significaciones desde dentro. Y, por otra parte, a la inversa, desde dentro se pueden captar poderes externos y sobrecogedores que debilitan nuestra condición y que influyen en nuestra condición psicológica, configurándola o acentuando elementos propios, de tal manera que su acción de poder no es solo exterior, sino que actúa y se proyecta en los sentimientos y el

\footnotetext{
${ }^{436} \mathrm{Cfr}$. TAYLOR, Ch., Imaginarios sociales modernos, págs. 214 y ss.

${ }^{437}$ Taylor cita el estudio de Stanley Tambiah titulado Magic, Science, Religion and the Scope of Rationality, Cambridge, CUP, 1990. En la Introducción, Tambiah habla de algunos elementos que confluyeron en los siglos XVI y XVII y que determinaron la evolución religiosa y filosófica de Occidente, entre ellos la ética protestante y el espíritu del capitalismo y la revolución científica y la Reforma Protestante. Cfr. págs. 12 a 15 y lo que expresa en el capítulo 5 titulado "Multiple ordering of realities", págs. 84 y ss.

438 "Lo interior ya no es solo interior; también es exterior. Es decir, las emociones que yacen en las profundidades de la vida humana existen en un espacio que nos transporta más allá de nosotros mismos, que es permeable a cierto poder externo, un poder con apariencia de persona". TAYLOR, Ch., La Era Secular, tI, pág. 72. Cfr. TAYLOR, Ch., Hegel, págs. 12 y ss.
} 
alcance de la experiencia personal. Siguiendo a Taylor, consideramos que esta reflexión es muy enriquecedora y permite ampliar horizontes de comprensión del mundo, de nuestro mundo, en el que conviven porosamente poderes exteriores que encantan el alma con explicaciones racionales que desde dentro nos hacen conscientes del poder del deseo y de los sentimientos propios y de los otros.

En este sentido, llama la atención el que Taylor apenas cite a Tomás de Aquino como uno de los grandes referentes que inician el cambio. A partir de la Quinta Vía de Tomás de Aquino, en la que se considera la existencia de Dios a partir de la necesidad de un "ser inteligente que dirige todas las cosas a su fin", algunos han querido ver también un momento fundamental en la transformación del alma de Occidente. Si el Aquinate habla de una inteligencia que configura el mundo y el hombre está creado a imagen y semejanza de esta Inteligencia ordenadora del mundo, de alguna manera se está promoviendo desde dentro del mundo medieval el gran cambio antropológico que sobrevendrá con la Modernidad. Si se enfatiza desde el pensamiento tomista que la semejanza divina en el hombre no debe ser entendida solo como "poder estático" sobre las demás criaturas, sino como "fuerza dinámica que actúa en el mundo", entonces podríamos pensar que desde el propio Tomás de Aquino se están poniendo las bases para una visión de un universo mecánico y espiritual. ${ }^{439}$ Además, el realismo tomista también incluye la consideración de las cosas, no como un hecho inerte, sino como una especie de acción interna por la cual se mantiene su forma adecuada. ${ }^{440}$

Por otra parte, esta etapa de la configuración moral del mundo ha sido enriquecedora para el pensamiento filosófico y ayudó a establecer, sobre la base de etapas anteriores, el alumbramiento de un nuevo orden que supuso un enriquecimiento desde la mente, acudiendo a las fuentes interiores de la moralidad, sin olvidar la visión trascendente y porosa del ser humano. Sin duda alguna esta porosidad de la primera Modernidad supuso un avance en la configuración moral del ser humano, enriquecida racionalmente e integrando elementos de valoración trascendente. ${ }^{441}$

\footnotetext{
${ }^{439}$ Cfr. CAPRA, F., El punto crucial, Troquel, Buenos Aires, 1992, pág. 27; cfr. CASTELLANOS, R., "Magia, religión y ciencia", Cap. VI, pág. 18. Disponible en Biblioteca Jurídica Virtual del Instituto de Investigaciones Jurídicas de la UNAM, www. juridicas.unam.mx. (14-IV-2019).

${ }^{440}$ Cfr. TAYLOR, Ch., La Era Secular, tII, págs. 722.

${ }^{441}$ Hay un elemento que merece ser comentado al respecto y que completa la reflexión previa. Y es lo que, según Taylor, supuso el advenimiento de la Modernidad en relación con la vulnerabilidad humana. Taylor afirma que la sensación de vulnerabilidad desapareció con el desencantamiento del mundo. La vulnerabilidad del hombre en un mundo premoderno y encantado es vivida como sobrecogimiento ante poderes que se le imponían "desde fuera". Con la llegada de la Primera Modernidad y el hombre poroso se empiezan a poner las bases para fuentes morales que refuerzan el yo y configuran la identidad humana "desde dentro", sin olvidar las influencias positivas de fuerzas exteriores que enriquecen la experiencia humana. La vulnerabilidad vivida como incapacidad o sentimiento de debilidad no solo es superada con los poderes divinos exteriores propios de la época de encantamiento, sino que ahora se ponen las bases para un enriquecimiento moral de la identidad del yo desde la mente y el espacio de la interioridad. Las fuerzas cósmicas no son desechadas del horizonte de la experiencia moral del hombre, sino que con la aparición de la mente siguen siendo necesarias para comprender la gran empresa del hombre que se va
} 
Con el paso del tiempo, este yo poroso, casi identificado con el encantamiento del mundo o en proceso de transición hacia el desencantamiento, se irá impermeabilizando y se irá haciendo inmune a cualquier referencia a poderes exteriores, quedando establecido en la inmanencia más absoluta o en un humanismo sin referencias trascendentes, un humanismo exclusivo. En esta primera Modernidad ilustrada se trata tan solo de "plantear la posibilidad que tengo de desconectar" con las fuerzas de significatividad exteriores, puedo impermeabilizar el yo, de tal manera que permita que no me afecten. ${ }^{442}$

Por otra parte, Taylor refiere que este humanismo exclusivo, que terminará estableciéndose como referencia de valoración moral, crea en el hombre un estado de nostalgia del mundo encantado, como si el hombre experimentara un desasimiento y una situación de desposesión que, al mismo tiempo que le ha establecido en sus referencias éticas fundamentadas racionalmente, también le llevara a una situación de desvalimiento y vulnerabilidad que le lanzara a la búsqueda de algo perdido, de algo que necesita y que no termina de encontrar, o porque ha desconectado precipitadamente, o porque esa desconexión crea en él un estado de incomodidad espiritual.

configurando desde su propio yo. La mente no desacredita las fuerzas de poderes divinos exteriores, sino que son integradas en la nueva identidad del yo que surge con la mente que crea espacios de interioridad. El surgimiento de la mente que percibe, desea, experimenta y siente integra elementos para la creencia en fuerzas exteriores que contribuyen también a su manera a crear espacios de significación. El nuevo imaginario filosófico sigue incorporando "desde la mente interior" espacios de significación cósmica que enriquecen la experiencia de identificación moral del yo. Y así la vulnerabilidad no solo es contemplada como experiencia vivida "desde dentro", sino que también necesita de significaciones cósmicas que interactúan con un mundo de deseos y percepciones que no alcanza a ser explicado solo desde dentro. Se necesitan no solo experiencias de interioridad que nos hacen conscientes de lo que somos, sino que hay realidades "simbólicas" que evocan poderes exteriores y que necesitamos para "recuperar la significatividad de lo que vivimos". El hombre moderno necesita dar explicaciones "desde la mente" racional a lo que vive, pero al mismo tiempo "surgen" en su interior deseos de una explicación que vaya más allá de la pura "mente" para recuperar significatividad a partir de fuerzas cósmicas o poderes que también entran en confluencia con la mente. Necesitamos seguir conectados con poderes exteriores, aunque en nosotros hayan echado raíces explicaciones interiores que conectan con la mente del yo. El primer yo moderno no encuentra plena justificación en la explicación "desde dentro" que desconecta del "exterior cósmico", sino que necesita encontrar significación en poderes que siguen conectándonos con el Orden Exterior. Algo semejante a lo que ocurre en la actualidad. Por ejemplo, el día 31 de julio de 2018 hubo un accidente de avión en Durango, Méjico. Todas las personas, 135, salieron ilesas, 94 de ellas, heridas. Al escuchar las noticias se hablaba del "milagro" de Durango. Se siguen utilizando expresiones propias del mundo encantado no solo como algo folklórico sino como "necesidad" de recurrir a fuentes morales exteriores para explicar todo aquello que produce extrañamiento o que sale de nuestra lógica intramundana y científica. Según nuestro punto de vista Taylor a veces utiliza con cierta ambigüedad el término "yo poroso". En unos momentos, lo refiere a el mundo encantado como un yo abierto a influencias de poderes exteriores y, en otras ocasiones, lo refiere a esa situación intermedia entre el mundo encantado y el yo impermeabilizado de la Modernidad. Aunque entendemos su referencia al mundo encantado del yo poroso, sin embargo, nos parece más correcto el uso que del término yo poroso hace cuando lo refiere a este primer momento de la Modernidad como situación intermedia entre el mundo premoderno o encantado y la Modernidad plenamente establecida.

${ }^{442}$ TAYLOR, Ch., La Era Secular, tI, pág. 74. 
Taylor ve un segundo aspecto de este yo impermeabilizado que va rompiendo con cualquier "temor exterior", ${ }^{443}$ y que le ha encaminado por la senda del autocontrol y la autodirección más absoluta. El temor inherente al encantamiento del mundo por fuerzas que sobrecogen, es superado a base de autocontrol, de sentimientos de autorreferencia. Va surgiendo progresivamente un yo impermeabilizado que establece un humanismo inmune a cualquier sentido de significado trascendente. $\mathrm{Y}$ ese sentimiento de "nostalgia trascendente" es superado a base de incrementar autorreferencias humanistas del propio yo. $^{444}$

Asimismo, el yo impermeabilizado se ha ido construyendo también por influencia de la ciencia como experiencia de empoderamiento del yo que autocontrola y autodirige. ${ }^{445}$ En el mundo encantado los objetos de poder exteriores, sea la propia Fuerza Divina, sean objetos llenos de poder mágico y religioso, tienen poder para encantar de salud la vida del hombre cuando aparecen las enfermedades o el pecado (que frecuentemente son expresiones del mismo mal). La enfermedad es vista en este mundo premoderno como expresión de debilitamiento del hombre interior. Se pensaba que un hombre bien constituido moralmente o después de la confesión sacramental podía recuperar la salud, no solo del alma, sino del cuerpo también. Los objetos que transmiten poder exterior, sean objetos, sean sacramentos, "actúan por sí mismos", no se pone en duda su acción, son expresión de un Dios que actúa objetivamente, independientemente de nuestro deseo espiritual o de nuestra adhesión a la fe. La acción de la reliquia o del sacramento que actúa "ex opere operato" transmite poder en sí misma, independientemente del deseo espiritual del que lo recibe. La reforma luterana se posicionará abiertamente en contra de este mundo encantado religiosamente potenciando espacios de interioridad moral y racional. ${ }^{446}$

También hoy en día quedan huellas de este encantamiento del mundo, pero expresado desde la racionalidad científica. Con la misma fe con la que en el mundo premoderno se frotaban las manos en la reliquia y se esperaba la curación, así también

\footnotetext{
${ }^{443}$ Cfr. Id., pág. 74. En relación con el temor a poderes sobrenaturales, no queremos olvidar la definición de Mircea Eliade de "mysterium" como algo tremens et fascinans. Algo que nos inspira temor, pero al mismo tiempo nos sobrecoge, nos fascina, nos atrae, y en este sentido crea nostalgia. Es una nostalgia de algo que configuraba la propia identidad moral y que sin ella ahora se experimenta como "pérdida". La nostalgia se relaciona con la pérdida de algo que enriquecía las fuentes morales del yo. Cuando esa experiencia se desfundamenta, se desontologiza, se debilita, entonces surge desde las mismas fuentes de identificación moral del yo, desde dentro, un sentimiento de vulnerabilidad que busca algo que se ha perdido, algo que se necesita para la propia construcción del yo.

Y por otra parte, en relación con el sentimiento de temor, no queremos olvidar las referencias taylorianas al cuadro del Bosco, El Jardín de las Delicias que expresa ese mundo encantado en el que se entremezclan sentimientos de miedo, de pavor, de esperanza, de oposición ética entre lo que nos identifica con el Bien y las fuerzas del mal que se adentran en los sentimientos y deseos del corazón humano. Un mundo que es difícilmente expresable pictóricamente sin recurrir a la metáfora y a las fuentes bíblicas.

${ }^{444}$ Cfr. TAYLOR, Ch., Hegel, pág. 319.

${ }^{445}$ Cfr. TAYLOR, Ch., Argumentos filosóficos, págs. 26-28

${ }^{446}$ Cfr. TAYLOR, Ch., La Era secular, tI, págs. 133 y ss.

Cfr. TAYLOR, Ch., Fuentes del yo, pags. 39-41
} 
hoy expresamos la veneración por la ciencia y el alcance de totalidad que a veces pretende imprimir a la fundamentación del mundo. En un mundo en el que se sobredimensiona el papel de la ciencia, a veces se quiere dar una explicación del todo y de la totalidad del mundo desde la ciencia, como la única verdad incuestionable, y cuesta fundamentar otros referentes que no tengan que ver con la sola razón científica. $^{447}$

Y por otra parte también, según Taylor, quedan restos de un mundo encantado cuando en un mundo tecnocientífico, ante el problema del mal o la enfermedad, seguimos pensando como si viviéramos en un mundo encantado o nos cuesta desentendernos del encantamiento como nostalgia o explicación que va más allá de la mente y que tiene que ver con poderes exteriores. A veces da la impresión de que necesitamos de algo más para explicar el problema del Todo, del Sentido, como si la tecnociencia no nos bastara y anheláramos otras creencias que nos retrotraen a mundos premodernos. Para Taylor, se desata la búsqueda por necesidad, surgiendo, así, los buscadores herederos de la revolución expresiva. ${ }^{448}$

Taylor también se refiere a las excepciones a la regla general. En el mundo encantado siempre existía la posibilidad de una cosa y la contraria: las cosechas abundantes o el hambre, la paz y la guerra, ser rescatados del mar o el naufragio. Lo que no respondía al "orden" establecido positivamente era también asumido como "actos de Dios" que tienen que ver con nuestros actos. ${ }^{449}$ Con la aparición de la Modernidad todo es regido por la ley natural, para la que no existen excepciones. Es un orden científico, racional, en el que no caben excepcionalidades a la ley natural. Todo responde a nuestro esfuerzo, pensamiento o fuerza carismática. Es la mente, desde dentro, la que lo controla todo, lo explica todo, lo experimenta todo y es consciente de que eso es todo lo que se desea y anhela, resultando así una visión en la que todo es explicable por acciones efectivas (programadas, anheladas), sin poder enmarcarlas en un único conjunto de leyes. ${ }^{450}$

\footnotetext{
${ }^{447}$ TAYLOR, Ch., La Era Secular, tII, pág. 387. Cfr. TAYLOR, Ch., Argumentos filosóficos, págs. 64-65. "Ninguna ciencia tiene o puede tener esa ambición y, por esta razón, está lejos de satisfacer plenamente esa necesidad humana fundamental, aunque la ciencia pueda ofrecer muchas herramientas útiles para lograr los objetivos que figuran en una determinada elección inspirada por ciertos valores. Por supuesto, esta función de orientación no la desempeñan en exclusiva las religiones en el sentido literal del término, sino que también puede ser realizada por las ideologías, o simplemente por ciertas cosmovisiones secularizadas que una persona puede abrazar con particular seriedad y compromiso existencial". AGAZZI, E., "Conocimiento científico y fe cristiana", págs. 27-28.

${ }^{448}$ Cfr. TAYLOR, Ch., La Era secular, tII, pág. 332.

449 "Asimismo por nuestra pobreza se muestra todavía mejor aquella inmensidad de bienes que en Dios reside; y principalmente esta miserable caída, en que por la transgresión del hombre caímos, nos obliga a levantar los ojos arriba, no solo para que, ayunos y hambrientos, pidamos de allí lo que nos haga falta, sino también para que, despertados por el miedo aprendamos humildad". CALVINO, J., Institución de la Religión Cristiana, Felire, Barcelona, 1999, pág. 3.

${ }^{450}$ Cfr. TAYLOR, Ch., La Era Secular, tII, pág. 411.
} 
Taylor afirma que, en el mundo encantado, la ausencia de fe es muy difícil de entender. Dios es el Espíritu que está por encima de los santos y los espíritus y es el que garantiza que el Bien triunfará. ${ }^{451}$ Lo que nos interesa resaltar aquí no es tanto el hecho de la fe cristiana, que envolvía el universo moral de Occidente, cuanto el hecho de que en un mundo así la perspectiva de rechazar a Dios era altamente improbable por el hecho de que Dios garantizaba la experiencia de plenitud humana. Posicionarse al margen de Él era entrar en un mundo de vacío y de desposesión. Solo quedaba elegir entre Dios o su Antagonista, pero esta opción era muy improbable y reducida. En el mundo encantado era inimaginable posicionarse al margen de Dios. Con el advenimiento de la primera Modernidad se da el primer paso hacia el yo impermeabilizado, eliminando el primer obstáculo que estamos comentando, hacia un humanismo exclusivo y en el que las fuentes morales trascendentes empiezan a perder relevancia o a imaginarse que un mundo así es "posible". ${ }^{452}$ Este primer momento es analizado como una posibilidad, no como una realidad hacia el yo desencantado e impermeabilizado. ${ }^{453}$ En momentos posteriores, se irán dando pasos en los que la posibilidad se va a transformar en realidad para la mayoría de las personas. ${ }^{454}$

\section{III.2.1.2. DE UNA SOCIEDAD ENRAIZADA EN DIOS A UN INDIVIDUO DESVINCULADO SOCIAL Y TRANSCENDENTEMENTE}

Durkheim asevera que los primeros sistemas de representación que el hombre se ha hecho de sí mismo y del mundo son de origen religioso. Representaciones religiosas que, a su vez, son representaciones colectivas. La religión es una cosa eminentemente social. ${ }^{455}$ Las sociedades primitivas no se entendían sino como sociedades amalgamadas en torno a un tótem y al mundo de los espíritus. De tal manera que, según Taylor, el aldeano que rechaza la transcendencia o practica la idolatría es una amenaza para la cohesión social. De ahí que fuera tan difícil ponerse al margen o que fuera tan complicado el que surgieran personas que no tuvieran fuentes morales trascendentes. ${ }^{456}$ Todo ello explica, por otra parte, el hecho de que la cohesión social fuera tan sólida.

El sentido social estaba ligado a los espíritus de poder trascendente, por lo cual eran ellos los protectores del bien social. De ahí que los ritos y las devociones fueran algo colectivo, en los que la sociedad se sentía protegida, y al mismo tiempo experimentaba como sociedad la fuerza de este poder divino que encantaba el mundo. Los ritos tenían una dimensión fundamentalmente comunitaria, ya que pretendían fundamentar y proteger el bien común de la sociedad. No practicarlos era desentenderse

\footnotetext{
${ }^{451}$ Cfr. TAYLOR, Ch., Argumentos filosóficos, págs. 199-220.

${ }^{452}$ Cfr. TAYLOR, Ch., El multiculturalismo y la política del reconocimiento, pág. 51.

${ }^{453}$ Cfr. TAYLOR, Ch., La ética de la autenticidad, págs. 54-59.

${ }^{454}$ Cfr. TAYLOR, Ch., Imaginarios sociales modernos, págs. 214-215.

${ }^{455}$ Cfr. DURKHEIM, E., Las formas elementales de la vida religiosa, págs. 14-15.

${ }^{456}$ Cfr. TAYLOR, Ch., La Era Secular, tI, pág. 80.
} 
de esta responsabilidad colectiva, era despreocuparse del sentido de plenitud experimentado colectivamente. Quizás por esto entendamos mejor la responsabilidad común ante los herejes (Inquisición) que dispersaban o desconfiguraban el sentido social y religioso de la vida o la dificultad de que alguien se posicionara de esa manera, pues el sentido de pertenencia social casi lo hacía imposible.

La sociedad no sentía la ruptura entre el sentido colectivo y religioso. Ser sociedad era sentirse vinculado a los ritos que la protegían y, al mismo tiempo, lo religioso era un pilar fundamental de su constitución como sociedad. Ser sociedad e iglesia era prácticamente lo mismo. No existía ruptura o división. Se vivía socialmente perteneciendo a la iglesia y se vivía el sentido eclesial como sociedad. Era lo mismo. De ahí que el sentido social estuviera estructurado eclesialmente o teológicamente. El reino, la ciudad, las aldeas, las parroquias..., toda la configuración social y política se vivía desde este sentido que les conducía a Dios. Y todos eran responsables de todo: de la ortodoxia, de la herejía, de los ritos y tiempos sagrados. Según Taylor, posicionarse al margen de la ortodoxia significaba no contribuir a la unidad social y política del Reino, y de ahí que los herejes merecieran la pena del castigo, pues podían "despertar la ira de Dios" y se desprotegía la sociedad del Bien que aseguraba la trascendencia. ${ }^{457}$

Para Delumeau es claro que, la Iglesia (y por ende la sociedad) y la sociedad (y por tanto la Iglesia), debían defenderse y hacer frente a toda clase de enemigos que desconfiguraban la unidad política del Reino y de la Iglesia. En esta atmósfera obsesiva por el miedo y la propia autodefensa frente al enemigo, la Inquisición era un brazo ejecutor de la Iglesia y de la sociedad, que actuaban conjuntamente. Según Delumeau, en esta sociedad encantada y de espíritus, el primer elemento al que debía enfrentarse la sociedad y la Iglesia era los chivos expiatorios: herejes, brujas, turcos..., como expresión del maligno; y el segundo elemento, igualmente importante, era hacer consciente a toda la sociedad, no solo de los adversarios exteriores, sino también de la presencia del malo en el propio corazón humano, que invita a dejarse arrastrar por todo tipo de pasiones y que debilita el alma humana en el camino hacia la santidad. Todo ello contribuía a crear una atmósfera obsesiva y de miedo que atemorizaba las mentes y los corazones. El miedo estaba omnipresente, acrecentado por la idea de que cada individuo enfrentará su propio juicio inmediatamente después de su muerte. ${ }^{458}$

Taylor es de la misma opinión respecto a la idea de que los herejes y no creyentes eran una amenaza para la convivencia social que se mantuvo hasta bien entrada la Ilustración, y cita a Locke como ejemplo de filósofo que defiende que los juramentos de lealtad debían ser nulos para los ateos, ya que no temen el castigo después de la

\footnotetext{
${ }^{457}$ Cfr. DELUMEAU, J., El miedo en Occidente, Taurus, Madrid, 1978.

${ }^{458}$ Cfr. TAYLOR, Ch., La Era Secular, tI, pág. 119. "No basta temer esto o aquello. Se requiere el temor absoluto y total para cobrar conciencia de lo negativo y devenir así hombre". VALLS PLANA, R., Del yo al nosotros, pág. 135.
} 
muerte. ${ }^{459}$ Según Locke, a los no creyentes no debería concedérseles los plenos derechos de ciudadanía. ${ }^{460}$

Lucien Febvre ilustra claramente "lo inimaginable" que sería no ubicarse personal y socialmente en aquella época sin las fuentes morales trascendentes. Cualquier persona tenía aspiraciones morales trascendentes que conllevaban la afirmación ineludible de Dios. Y al mismo tiempo la sociedad no se entendía sin estas referencias socialmente establecidas. Dios cohesiona la sociedad y no se puede entender la sociedad sin Dios. Es más, es esta sociedad, fundamentada en los orígenes trascendentes, la que confirma colectivamente la existencia de Dios. Dios existe porque existimos como sociedad. La colectividad era, de alguna manera, una prueba que llevaba a la convicción de que Dios existe. Según Lucien Febvre, en el siglo XVI "solo la religión iluminaba el universo y el hombre que pretendiera no pensar como los demás, el hombre de palabras atrevidas, de crítica fácil, recibía las aclamaciones: ‘impío', 'blasfemo' y para terminar 'ateo’”. 461 Taylor afirma que estamos unidos en una sociedad y por lo tanto Dios existe. ${ }^{462}$

En este sentido, podemos decir con Taylor que la religiosidad medieval tiene muchos elementos en común con lo que hemos visto de las civilizaciones de las religiones naturales y arcaicas. ${ }^{463}$ Sin embargo, hay dos elementos que conviene destacar en este proceso de desvinculación social que estamos estudiando: por un lado, el deseo de bienaventuranza humana que ineludiblemente busca todo ser humano y, por otro lado, la invitación del Cristianismo a promover un sentido de autotrascendencia y un compromiso de transformación total de la persona. Integrar los requerimientos de la bienaventuranza humana con la invitación a superarla desde un sentido más profundo de conversión y búsqueda de valores superiores, conlleva frecuentemente tensiones. ${ }^{464}$ Son las tensiones entre la vida buena y la buena vida, entre negarse a uno mismo y afirmarse en el propio deseo de felicidad humana. Veamos cómo se van integrando ambos

\footnotetext{
459 "En la Europa de principios de los tiempos modernos, el miedo, camuflado o manifiesto, está presente en todas partes. Así ocurre en toda civilización mal armada técnicamente para responder a las múltiples agresiones de un entorno amenazador". DELUMEAU, J., El miedo en Occidente, pág. 34. Este miedo que se supone a los creyentes que participan de la fe en la resurrección y temerosos de la vida eterna es lo que se les supone carentes a los no creyentes o herejes. Y es ese miedo el que garantiza de alguna manera la rectitud de intención en esta vida, la bondad, el amor misericordioso... todas ellas actitudes que encaminan la vida terrena hacia el reino futuro. Sin esta fe en la vida eterna difícilmente se puede garantizar en esta vida el "santo temor de Dios" con lo cual los no creyentes o herejes difícilmente pueden hacer juramento sincero en esta vida ya que no tienen ese santo temor a la muerte y en esta vida a vivir de acuerdo con los valores que conducen a la vida eterna.

${ }^{460}$ No obstante, parece recomendable hacer una lectura de Escritos sobre la Tolerancia, de Locke, en la que incide en la libertad de cada persona para orientarse de acuerdo a sus convicciones personales y a asegurar el camino propio de la salvación, incidiendo en la separación entre el poder del magistrado y la conciencia propia del creyente. También es aconsejable la lectura del Tratado de la Tolerancia, de Voltaire, para comprobar el alcance de estas expresiones y matizar conceptos.

${ }^{461}$ FEBVRE, L, El problema de la incredulidad en el siglo XVI, Akal, Madrid, 1993, pág. 92.

${ }^{462}$ Cfr. TAYLOR, Ch., La Era Secular, tI, pág. 80.

${ }^{463}$ Cfr. TAYLOR, Ch., Hegel, págs. 170-175.

${ }^{464}$ Cfr. TAYLOR, Ch., Argumentos filosóficos, págs. 210-211; cfr. TAYLOR, Ch., La ética de la autenticidad, págs. 52 y ss.
} 
elementos en las dificultades inherentes a ambos planteamientos y su influencia en el proceso secularizador.

I.- La vida buena y la buena vida. Según Taylor, en el primitivo Cristianismo surgen las vocaciones eremíticas y monásticas como respuesta a superar la vida que nos instala en las demandas del pecado original y a superarlas elevando el espíritu hacia una vida de entrega total a Dios en la castidad. ${ }^{465}$ La tensión entre el celibato "celestial" y la vida que prolonga en el tiempo las consecuencias del pecado original con la procreación, no es fácil de integrar y superar. ${ }^{466}$ La idea de que el cuerpo era malo y estaba asociado a la debilidad por la que entró la muerte en el mundo, llenó de sospechas cualquier cosa que se relacionara con el cuerpo y la sexualidad. Por todo ello, la sexualidad era vista como el tiempo del pecado y de la historia herida por las consecuencias de la debilidad humana, y el celibato como el tiempo de la eternidad de Dios.

Frente a la vida del mundo está la vida del tiempo nuevo: "El tiempo se ha cumplido, el Reino de Dios está cerca; convertíos y creed en la Buena Nueva" (Mc. 1,15). "Ha llegado el tiempo de Dios frente al tiempo del hombre". Como dice San Pablo: "Atrás ha quedado el hombre viejo" (2 Cor. 5,17), el tiempo viejo, el tiempo de la condición humana, invitando a pasar al tiempo de la eternidad que "se empieza a realizar" en medio del mundo. Algunos textos evangélicos como Mateo 19, 12: "Hay eunucos que a sí mismos se hicieron eunucos por el Reino de los Cielos. El que pueda entender, que entienda"; y Lucas 18, 29 "Dejar casa, mujer, hermanos, padres e hijos por el Reino de los Cielos", invitan a superar la mentalidad del "mundo" y pasar a vivir según una mentalidad nueva, yendo más allá de la bienaventuranza humana e invitando a una experiencia de hacerse célibes, con un compromiso único por el Reino, así como a dejar cualquier tipo de "lazo familiar" para vivir en una entrega totalizadora.

Los textos paulinos, Rom. 15, 18-19, Gal. 1, 22 y I Cor. 15, 8, hablan de la criatura nueva que aparece perfectamente expresada en Gal. 6, 15: "En Cristo Jesús ni la circuncisión vale nada ni la incircuncisión, sino una nueva creación". La bienaventuranza humana queda "pospuesta" o "entendida" o "iluminada" por los sentimientos propios de una vida en Cristo Jesús. Según Taylor, la fe cristiana apuntaba

\footnotetext{
${ }^{465}$ Cfr. TAYLOR, Ch., Argumentos filosóficos, pág. 347, y las referencias al orden metafísico inherente a la gran cadena del ser en la jerarquización social y eclesial; cfr. TAYLOR, Ch., La Era Secular, tI, pág. 83.

${ }^{466}$ Hay autores que afirman que el primer cristianismo en su expresión cultural se impone hegemónicamente bajo la forma de un cristianismo monástico que dominaría todas las manifestaciones culturales hasta la Reforma del siglo XVI con un cristianismo bíblico y laico. Cfr. el capítulo titulado "El retiro monástico y el ideal ascético" del libro de Febvre.
} 
a la autotrascendencia, un viraje de la vida hacia algo que estaba más allá de la bienaventuranza humana corriente. ${ }^{467}$

En esta misma línea, Peter Brown, en su obra titulada El cuerpo y la sociedad, cita a Clemente de Alejandría, que propone un ideal de vida cristiana basado en la apatheia como estado de serenidad de propósitos. ${ }^{468}$ En parecidos términos se expresarán otros Padres de la Iglesia, que inciden en esta libertad para superar necesidades e impulsos indomables. ${ }^{469}$

Esta tensión, en opinión de Taylor, se expresó de diversas maneras a lo largo de la historia de la Iglesia: la importancia que cobraron las vocaciones célibes en los primeros siglos en la Iglesia oriental, la tentación de imponer el celibato a todos o el planteamiento de la Reforma que rechaza de plano las vocaciones célibes.

Pero con el tiempo, en la cristiandad latina occidental romana y ortodoxa, se verán ambas vocaciones como complementarias, donde el clero reza por la vida laica matrimonial y donde se superan tensiones identitarias o de supuesta superioridad de una vocación sobre la otra. Con el tiempo, a la tensión se superpone un equilibrio basado en una complementariedad de funciones.

Naturalmente, según Taylor, esto no elimina las continuas formas de tensión. Inadecuaciones que se han ido resolviendo de distintas maneras intentando equilibrar la conversión evangélica con la ética del honor, el estatus social, el amor propio, la vida guerrera. $^{470}$

Las tensiones entre bienaventuranza humana y exigencias evangélicas se han ido manifestando en cada momento histórico bajo distintas formas de equilibrio y complementariedad. ${ }^{471}$ En el mundo de espíritus y premoderno, una de las formas de superar la tensión entre la bienaventuranza humana y las exigencias de conversión evangélica se resolvía con lo que Taylor denomina el mundo de "al revés" o inversión del orden natural de las cosas: los niños se ponían la mitra, los tontos eran nombrados reyes y había un espectáculo general de burla como en los carnavales. $\quad$ La significación de estos rituales de inversión es doble: por una parte, destacan el carácter enigmático de la vida de la que se hace una parodia temporal, y por otra parte, potencian

\footnotetext{
${ }^{467}$ Cfr. TAYLOR, Ch., La Era Secular tI, pág. 83.

${ }^{468}$ BROWN, P., El cuerpo y la sociedad. Los cristianos y la renuncia sexual, Muchnik Editores, Barcelona, 1993, pág. 183.

${ }^{469}$ CHOZA, J., Historia de los sentimientos, Thémata, Sevilla, 2011, págs. 75-134.

${ }^{470}$ Cfr. TAYLOR, Ch., La Era Secular, tI, págs. 84 y ss.; cfr. TAYLOR, La ética de la autenticidad, págs. 62 y ss. Por otra parte, Taylor afirma, siguiendo a Erasmo, que el Cristianismo contribuirá en cierta manera a dar un alcance distinto a la magia y a iniciar pasos hacia una primera secularización de la misma, a través de procesos de purificación de la devoción popular y a través de una adecuada comprensión de los sacramentos. Cfr. ROTTERDAM, E. de, Elogio de la locura, Austral, 2008, Madrid, págs. 52, 114-115,126

${ }^{471}$ Cfr. TAYLOR, Ch., Argumentos filosóficos, págs. 176,180,195,218,245,261,266,320-321.
} 
el sentido del humor como algo que nos acerca a lo importante, que a veces no se logra comunicar en lo ordinario de la vida. ${ }^{472}$ En el fondo dichos ritos de inversión pretendían confirmar los valores morales existentes y expresar, a través de estas rupturas temporales del orden, que se desea vivir desde ellos el sentido más profundo de la vida. ${ }^{473}$ En realidad se trataba de auténticas "válvulas de escape" en una sociedad tan estructurada y tensionada, que necesitaba de momentos de distensión para que el sistema se mantuviera. ${ }^{474}$

La teoría de la válvula de escape está indicando, en cierto sentido, que el orden establecido era un orden demasiado tenso y que no permitía armonizar de manera equilibrada la bienaventuranza divina con el deseo y la búsqueda de la propia satisfacción. En cierto sentido, con el ritual del mundo al revés, se está volviendo al tiempo de los orígenes, en el que la energía del desorden, que estaba en el origen del caos primitivo, sucede al orden y al esfuerzo de organizar la vida de acuerdo a determinados parámetros. Y ese orden, cada cierto tiempo, exige "recuperar la energía de los orígenes" para así dar un impulso nuevo al orden que se va imponiendo de nuevo. ${ }^{475}$ Burke habla de la vuelta al estado de la naturaleza o salvaje, para poder revitalizar el estado del orden y ser conscientes de lo que supone vivir en ese estado, recuperando de cuando en cuando la energía de los orígenes. Se trata de "un escape controlado del vapor", de un ritual del desorden que pretende recuperar el orden con impulso renovado. No se está señalando ningún impulso de ruptura, sino tan solo un ritual que potencia aún más el orden establecido. ${ }^{476}$ De igual manera piensa Taylor cuando afirma que no se trataba de impulsar ningún orden antitético de las cosas para impulsar un reemplazo del orden imperante. La parodia se enmarcaba en la idea de que son los mejores, los superiores, la virtud, el carisma eclesiástico, los que deberían regir el mundo. ${ }^{477}$

Bakhtin habla de la risa y de la dualidad en la percepción del mundo: los dos mundos, uno oficial y un segundo mundo o una segunda vida. El carnaval representa ritualmente este segundo mundo que forma parte de la cosmovisión del hombre

\footnotetext{
${ }^{472}$ Cfr. PRAT I CARÓS, J., "El carnaval y sus rituales: algunas lecturas antropológicas", Temas de Antropología Aragonesa, No 4, (1993), págs. 285-289.

${ }^{473}$ Cfr. TAYLOR, Ch., La ética de la autenticidad, pág. 198. Hoy los "tiempos de vivencia de gran intensidad" se expresan de otras formas, aunque "no se enmarcan en una comprensión profundamente compartida", ni en antagonismos de estructuras.

474 "El carnaval era una fiesta, un juego que tenía — por lo tanto — un fin en sí mismo, sin necesidad de explicarlo o justificarlo. Era un tiempo de éxtasis y liberación. (...) Los tres temas más importantes en los carnavales —en su sentido real e imaginario - eran la comida, el sexo y la violencia. El primero de ellos, la comida, era el más evidente: era esta la que ponía la carne, la salsa al carnaval... La carne significaba también la carnalidad". BURKE, P., La cultura popular en la Europa Moderna, Alianza Editorial, Madrid, 1996, págs. 257-284.

${ }^{475}$ Cfr. Ibid., pág. 273.

${ }^{476}$ Cfr. Ibid., pág. 288.

${ }^{477}$ Cfr. TAYLOR, Ch., La Era Secular, tI, pág. 86.
} 
medieval, ${ }^{478}$ un realismo grotesco de espontaneidad y vida. ${ }^{479}$ Según Turner, el carnaval resalta este aspecto inclusivo e igualitario del sentido de la vida. El orden estructura y fundamenta la diferencia, por lo que es necesario volver a expresar ese sentido igualitario y comunitario de la vida que el orden olvida o margina. Por eso, cada cierto tiempo, se vuelve a expresar ritualmente ese tiempo de los orígenes en el que lo social y comunitario nos hermanaba en una cosmovisión que nos hace iguales, ${ }^{480}$ a través del contrapoder temporal de los débiles y la interacción humana de yuxtaposiciones y alternancias. $^{481}$

En las sociedades premodernas existen los ritos de paso, en los que la comunidad asume un papel protagonista, encarnando los valores, la cultura de la tradición depositaria de la sabiduría. ${ }^{482}$ Se trata de la liminalidad o el umbral en el que los 478 "El carnaval es la segunda vida del pueblo, basada en el principio de la risa. Es su vida festiva. La
fiesta es el rasgo fundamental de todas las formas de ritos espectáculos de la Edad Media. Todas esas
formas presentaban un lazo exterior con las fiestas religiosas. Incluso carnaval, que no coincidía con
ningún hecho de la vida sacra, con ninguna fiesta santa, se desarrollaba durante los últimos días que
precedían a la gran cuaresma". BAJTIN, M., La cultura popular en la Edad Media y el Renacimiento,
Alianza Editorial, Madrid, 2003, pág. 14 .
479 Cfr. Ibid., pág. 21 .
480 "Parece como si existieran aquí dos 'modelos' principales de interacción humana, yuxtapuestos y
alternativos. El primero es el que presenta a la sociedad como un sistema estructurado, diferenciado, y a
menudo jerárquico, de posiciones político-jurídico-económicas con múltiples criterios de evaluación, que
separan a los hombres en términos de 'más' o 'menos'. El segundo, que surge de forma reconocible
durante el período liminal, es el de la sociedad en cuanto comitatus, comunidad, o incluso comunión, sin
estructurar o rudimentariamente estructurada, y relativamente indiferenciada, de individuos iguales que se
someten a la autoridad genérica de los ancianos que controlan el ritual". TURNER, V., El proceso ritual,
pág. 100. Taylor también resalta en este sentido el alcance de la palabra "comunitas" para referirla no solo
a los elementos codificados en los que nos relacionamos a nivel institucional y que determinan roles y
justifican el orden en el que nos movemos, sino a ese otro aspecto de ruptura en el que nos relacionamos
como sociedad a otros niveles más intuitivos que justifican la inversión y la trasgresión. Creemos que este
segundo aspecto es relevante tenerlo en cuenta para la reflexión que estamos haciendo.

${ }^{481}$ Cfr. TAYLOR, Ch., La Era Secular, tI, págs. 112 y ss.

Los subordinados pasan a ocupar una posición preeminente... A la autoridad política suprema se la describe "como un esclavo", lo que recuerda ese aspecto de la coronación del Papa en la cristiandad occidental en el que se le exhorta a ser el servus servorum Dei. Es lo que Taylor define como el contrapoder de los débiles, como una estructura que debe necesariamente complementar el poder instituido. También Taylor habla de que otro ejemplo del juego estructura-antiestructura sería la tensión entre la bienaventuranza corriente y las vocaciones superiores.

${ }^{482}$ Cfr. TAYLOR, Ch., Hegel, págs. 48,69,74-75 y ss; cfr. TAYLOR, Ch., Imaginarios sociales modernos, págs. 213 y ss; cfr. TAYLOR, Ch., La Era Secular, tI, págs. 127 y ss. Taylor considera la importancia de la "antiestructura" para manifestar elementos que difícilmente puede ser comunicados desde el orden institucional y que pertenecen a una clase de sabiduría que comunica con planos espirituales y que necesitan del anticódigo para transmitirse. La rigidez del orden imposibilita la comunicación de valores que están escondidos en lo hondo de la tradición, en una sabiduría del mundo que nos hermana en un sentido universal de la vida y que difícilmente puede comunicarse por el orden establecido. Hay una sabiduría de los débiles, de los subyugados, del pueblo que va más allá del orden institucional y jurídico y que solo cuando el pueblo asume su protagonismo liminal o del umbral puede acompañar los ritmos que nos enraízan en el misterio de la vida. Según Taylor, hay una necesidad de la antiestructura y del anticódigo. Si con el advenimiento de la Modernidad se impone la rigidez de un solo concepto moral y falta este contrapeso de lo espiritual o de lo mágico difícilmente se puede avanzar en la comprensión de los ritmos de la vida cayendo en lo que Taylor denomina "negación, debilitamiento y atrofia en la estructuración social que coopera en el advenimiento de una cierta "autodestrucción". También hoy en día, según Taylor, se precisa de contrapesos a la rigidez del orden cotidiano y buscamos rupturas como las vacaciones para "hacer un corte y recargar las baterías". También hay elementos "carnavalescos" como 
neófitos viven en una suerte de antiestructura, "una tabula rasa, una pizarra en blanco, en la que se inscribe la sabiduría y el conocimiento del grupo, en aquellos aspectos que son propios del nuevo status". ${ }^{483}$ Se trata de los ritos liminares que marcan el paso de una etapa a otra. ${ }^{484}$

los días festivos, los partidos de fútbol..., donde la comunitas aparece en toda su fuerza y se rompen esquemas establecidos para sentir la fuerza del sentido colectivo y hasta cierta transgresión... También la comunitas aparece en momentos especiales y con expresiones laicas de duelo en medio de la calle, lejos de los espacios religiosos, donde se levantan altares improvisados y con velas la gente expresa su duelo, sus lloros y penas, como en los atentados de París o de Barcelona. Cfr. TAYLOR, Ch., La Era Secular, tI, págs. 93 y ss. Para Taylor la pérdida de este sentido de estructura y antiestructura, de código y anticódigo con la llegada de la Modernidad es una de las causas de la aparición de la secularización del tipo 1. Quizás la complementariedad de ambos códigos se realizaba en un mundo encantado y espiritual o de fuerzas superiores. Cuando ese mundo colapsa caen con él las estructuras antitéticas y de alguna manera todo contribuye al advenimiento de un vacío secular en el que no tiene mucho sentido las antiestructuras o no se las considera asumidas como tal ni por la sociedad ni por los poderes establecidos. Son expresiones que pueden ser restos de épocas anteriores, pero que ya no tienen la conciencia espiritual de un cosmos encantado y por lo tanto todo queda desconfigurado en el camino hacia el vacío secularizador en el que todo pierde el fundamento o el sentido y se hacen cosas sin mucha conciencia de por qué, o al mismo tiempo, no tienen la fuerza encantadora que subyace a un mundo espiritual. Se impone un código, el propio de la Modernidad y no se necesita crear anticódigos ni antiestructuras. En el mundo encantado teníamos un código que se imponía de manera totalizadora y sin límites. Surgía la naturalidad de las antiestructuras. Con el eclipse de las antiestructuras, ahora se impone el código de la Modernidad que sin necesidad de antiestructuras cierra cualquier "porosidad" que permita entrar la trascendencia para finalmente imponerse un yo humanista autorreferencial. Este nuevo código de la modernidad no tiene límites a su nivel de imposición, con lo que las antiestructuras caen por sí mismas. Ya no es necesario poner límites al código establecido como era el caso de la estructura encantada. Incluso Taylor da una gran relevancia a la desaparición de la antiestructura como posibilidad que permitió la aparición de regímenes totalitarios en nuestra época. Esa "tolerancia cero" fue el humus que permitió la desaparición de cualquier alternativa de poder al ya establecido. No obstante, según Taylor, también la Modernidad ha intentado superar la tentación del olvido de la antiestructura, proponiendo ideales y modelos en lo que se realiza la diversidad, la valoración múltiple, la oposición y la división de poderes...Taylor considera la Revolución Francesa como el momento fundamental en el que se puso fin a cualquier alternativa antiestructural y se plantea la posibilidad de establecer un código sin límite moral alguno. Se trataba de consolidar el código revolucionario con tanta pasión de cambio que todo estaba permitido con tal de ir en contra de cualquier vestigio del antiguo régimen. En este momento, se trataba de llenarse del nuevo espíritu revolucionario con lo que cualquier "anticódigo" resultaba contraproducente e inadecuado a la nueva situación. Para Mathiez, todos los revolucionarios se fundamentaron en la filosofía del siglo XVIII. "Todos se preocuparon sobremanera de lo que llamamos actualmente la cuestión social. Todos construyeron más o menos su ciudad futura, todos creyeron en la omnipotencia de las instituciones para lograr la felicidad de los hombres. Más que nadie, Montesquieu es consciente de la grandeza de la organización social, de la que hace derivar incluso la propia moral. Cree que basta con cambiar a propósito las leyes para mejorar la sociedad e incluso regenerarla". MATHIEZ, A., Los orígenes de los cultos revolucionarios 1789-1792, CIS, Madrid, 2012, pág. 18. "Cada uno de nosotros pone en común su persona y todo su poder bajo la suprema dirección de la voluntad general, y nosotros recibimos además a cada miembro como parte indivisible del todo. Este acto produce inmediatamente, en vez de la persona particular de cada contratante, un cuerpo moral y colectivo, compuesto de tantos miembros como votos tiene la asamblea, el cual recibe de este mismo acto su unidad, su yo común, su vida y su voluntad". ROUSSEAU, J.J., El pacto social, Austral, Madrid, 2007, pág. 46.

${ }_{483}$ Cfr. TURNER, V., El proceso ritual, pág. 107.

484 "Los ritos del umbral no son, por consiguiente, ritos de "alianza" propiamente hablando, sino ritos de preparación para la alianza, precedidos a su vez por ritos de preparación al margen. Propongo en consecuencia llamar ritos preliminares a los ritos de separación del mundo anterior, ritos liminares a los ritos ejecutados durante el estadio de margen y ritos postliminares a los ritos de agregación al mundo nuevo". VAN GENNEP, A., Los ritos de paso, pág. 37. 
Con el advenimiento de la Modernidad, se impone el código único, ${ }^{485} \sin$ una estructura antagónica de contrapeso. No obstante, como afirma Taylor, también hay distintos principios de oposición que, de alguna manera, realizan dicho papel de contrapeso: la división de poderes como principio básico de oposición, ${ }^{486} \mathrm{o}$ la distinción público/privada en la que el ámbito de la estructura correspondería al ámbito privado. ${ }^{487}$ En la Modernidad la vida del ciudadano se irá enriqueciendo en toda una gran variedad de matices a través de la participación en un proyecto de vida socio-política y a una vida centrada en el autoenriquecimiento y los placeres privados. ${ }^{488}$ Con lo que se va desplazando el lugar de la vida buena desde una esfera especial de actividades

${ }^{485}$ Cfr. TAYLOR, Ch., La Era Secular tI, pág. 75 y ss. Taylor insiste en este código único y omnicomprensivo de la Modernidad, a pesar de que como han insistido algunos autores como Benjamin Constant, Alexis de Tocqueville e Isaiah Berlin nos gusta guardar fidelidad a más de un principio a pesar de que entre algunos de ellos haya conflicto. Son los regímenes liberales con una orientación de carácter pluralista. Cfr. TAYLOR, Ch., La ética de la autenticidad, págs. 90 y ss."Nos representamos al hombre como una voluntad valerosa y desnuda rodeada por un mundo empírico fácil de abarcar. Hemos sustituido la dura idea de verdad con una idea fácil de sinceridad. Hemos aceptado la teoría liberal tal como está, porque hemos querido alentar a la gente a pensar en sí misma como libre, al precio de perder el trasfondo". MURDOCH, I., "Contra la aridez. Esbozo polémico" Revista Internacional de Filosofía, No. 60, (2013), pág. 15.

${ }^{486}$ Cfr. MONTESQUIEU, C. de, El espíritu de las leyes, Libro XI, cap. VI, Librería Valeriano Suárez, Madrid, 1906, pág. 227. Esta es la forma que adopta la antiestructura. En este código común asumido democráticamente desde un punto de vista político, los tres poderes asumen unos respecto de otros, cierto carácter de antiestructura y de código al mismo tiempo.

${ }^{487}$ Cfr. TAYLOR, Ch., La Era Secular, tI., págs. 117 y ss; cfr. TAYLOR, Ch., La ética de la autenticidad, pág. 65. La antiestructura en la actualidad adopta esta forma de "salirse" de lo público introduciéndose en esferas que son asumidas por el código como pertenecientes a lo privado y que se manifiestan en la vida doméstica y en las esferas públicas que se sostienen fuera de este: en la música, arte, literatura, vida religiosa, en la solidaridad frente a... Es lo que Taylor denomina "antiestructura de lo individual" que se desarrolla en el ámbito de lo público y que evita ese empobrecimiento flagrante que conlleva el empoderamiento de lo individual. Un salirse que según Taylor tiene el peligro del empobrecimiento propio del aislamiento y limitar el compromiso con el código a la acción puramente voluntaria. Otra manifestación de la antiestructura en nuestro mundo se manifiesta, según Taylor, en las corrientes de protesta contra el código único de la tecnología, la ciencia, la globalización burocratizada, la razón instrumental controladora de todo, el saqueo a la naturaleza o la eutanasia. Aquí la negación del código adquiere referencias utópicas hacia alternativas que eleven el sentido moral hacia propuestas de integración ecológica o en opciones humanistas que vayan más allá de la razón utilitarista y tecnológica. Taylor habla de que el objetivo de la antiestructura revolucionaria es reemplazar el orden actual, socavar las antiestructuras previas y así dejar el campo abonado para diseñar un nuevo código de libertad, fraternidad e igualdad universales, sin necesidad de limitaciones morales. Taylor habla de la "antiestructura destinada a terminar con toda antiestructura". Una antiestructura que niega toda antiestructura es una Modernidad que entra en situaciones complicadas en su orientación moral, dado que es difícilmente comprensible una situación del hombre en la historia en la que no haya ese juego de análisis-antítesis y síntesis. La evolución como sentido de acrecentamiento moral queda gravemente comprometida bajo el acrecentamiento de la antítesis como referencia única. Un no-código como dice Taylor que se establezca con el ánimo de permanencia sin elementos de una antítesis superadora pone en declive el sentido profundo de esperanza que oriente la historia y las bases morales del hombre hacia niveles elevados de utopía. Las bases para el desencantamiento se van acrecentando. Taylor también considera el "socialismo científico" como ejemplo de una antiestructura que elimina el anticódigo para construir una utopía con la desaparición del estado. "Solo ahora había apuntado la aurora, el reino de la razón; en adelante la superstición, la injusticia, el privilegio y la opresión serían desplazados por la verdad eterna, por la eterna justicia, por la igualdad basada en la naturaleza y por los derechos inalienables del hombre". MARX-ENGELS, Obras Escogidas. Tomo II. Del Socialismo Utópico al Socialismo Científico, Ediciones en Lenguas Extranjeras, Moscú, 1962, pág. 119.

${ }^{488}$ Cfr. TAYLOR, Ch., Argumentos filosóficos, pág. 192. 
superiores (orden rígido que exige válvulas de escape) hasta llegar a situarlo en el seno de la vida misma (no se necesita ningún escape, el orden, la vida buena viene configurada por la vida misma). Una vida plena ahora se definirá en términos de producción y trabajo, por un lado, y matrimonio y vida familiar, por otro. Además, las actividades superiores, antes altamente valoradas, ahora son fuertemente criticadas. ${ }^{489}$

II.- El tiempo de Dios y el tiempo del hombre. Todos estos ritos de inversión, desde el punto de vista de Taylor, hay que analizarlos también en relación con el tiempo y la relación entre el tiempo y la bienaventuranza humana. Con la Modernidad, se tiende a ver nuestras vidas exclusivamente dentro del flujo horizontal del tiempo secular. Junto al desencantamiento y el eclipse de la antiestructura, el tiempo moderno es un tiempo secular definido a partir de una comprensión del mundo desencantado y sujeto a las leyes de la ciencia. La ciencia mecanicista del siglo XVII ofrecía una noción completamente diferente de la realidad estable que subyace al cambio. Eso ya no era la eternidad, lo estable no es algo que esté más allá del tiempo, sino tan solo la ley de los cambios a lo largo del tiempo. No tiene sentido la ritualidad de inversión en un tiempo definido por la eternidad de Dios. ${ }^{490}$ La bienaventuranza divina no define el tiempo del hombre, sino que es el hombre el que define su propia felicidad en un tiempo exclusivamente secular, uniforme, unívoco, que tratamos de medir y controlar para lograr que las cosas se hagan. Taylor hace referencia a la "jaula de hierro" de la Modernidad, de Weber, que obtura todos los tiempos superiores e incluso los vuelve difíciles de concebir. El tiempo de Dios y las rupturas de inversión no encajan con la Modernidad definida por el humanismo exclusivo y la afirmación de la vida corriente. $^{491}$

El tiempo premoderno, al contrario del tiempo secular y horizontal de la Modernidad, es un tiempo en el que hay rupturas kairóticas, es decir, lapsos de tiempo de manifestaciones de especial trascendencia o donde suceden cosas importantes. El tiempo premoderno, por su relación con procesos de liminalidad, es un tiempo donde hay lapsos, rupturas que expresan los misterios que esconde la vida en sus ritmos, y nos despierta para captar el fluir del tiempo de una manera distinta al tiempo ordinario. De ahí la importancia de los procesos de inversión y de antiestructura. En la Premodernidad lo fundamental venía establecido por los tiempos superiores, por los nudos kairóticos entendidos como tiempos de Dios, y a partir de ahí se organizaban el resto de los ritmos ordinarios de la vida. Los nudos kairóticos serían las manifestaciones del tiempo de Dios, definido por su eternidad, frente al tiempo ordinario de la Modernidad, referido al

\footnotetext{
${ }^{489}$ Cfr. TAYLOR, Ch., Fuentes del yo, pág. 291.

${ }^{490}$ Cfr. TAYLOR, Ch., La Era Secular, tI, págs. 106-107.

${ }^{491}$ Cfr. TAYLOR, Ch., Fuentes del yo, págs. 33,289-340.
} 
transcurrir histórico de la vida de las personas en su temporalidad y su secularidad, como refiere Taylor. ${ }^{492}$

La idea medieval de la simultaneidad, como anuncio y prefiguración en una omnipresencia divina sin causalidad y que interrelaciona presente pasado y futuro, es superada por una simultaneidad en la que se entrecruzan acontecimientos separados temporalmente por un tiempo entendido desde el reloj y los calendarios. La percepción natural de todo el orden de la naturaleza, primero como orden providencial deísta y posteriormente como negación naturalista de dicho orden, impulsará progresivamente a la consideración del tiempo como un fluir natural, vacío y secular. La negación de las actividades superiores conllevará la negación del tiempo de la eternidad. Todo queda confinado a un tiempo profano. ${ }^{493}$

El tiempo premoderno es el que hereda el Medievo de la filosofía platónica y aristotélica. El tiempo eterno es el tiempo de las Ideas, donde todo es inmutable y donde no existe la "variabilidad temporal imperfecta" de la encarnación de la Forma. El mundo de lo eterno y de las formas es fijo, permanente e invariable. Lo que ocurre en el tiempo es menos real que lo que ocurre en el mundo de las Ideas, porque es la perfección suma; luego el tiempo de la eternidad es el tiempo de lo perfecto, de lo inmutable y de lo auténticamente real. La Divinidad solo "es", no puede entenderse como un "fue" o un "será". ${ }^{494}$ Por otra parte, Platón plantea la idea del tiempo como una huida en el sentido de una superación progresiva de una circularidad repetitiva, para ir comprendiendo el tiempo en una linealidad que asegure el compromiso del hombre por elevarse hacia la eternidad. ${ }^{495}$ El tiempo es huir del mundo para elevarse hacia la eternidad, donde no exista el tiempo que va asociado a los males y a este mundo natural, tal y como plantea Platón. ${ }^{496}$ De ahí que, para Platón, en relación a su Idea del tiempo eterno, la vida mejor es la que está regida por la razón, por la virtud y por el orden, que

\footnotetext{
${ }^{492}$ Cfr. TAYLOR, Ch., La Era Secular, tI, págs. 99,103,137,330.

${ }^{493}$ Cfr. TAYLOR, Ch., Fuentes del yo, pág. 449.

494 "Estas son todas partes del tiempo y el 'era' y el 'será' son formas devenidas del tiempo que de manera incorrecta aplicamos irreflexivamente al ser eterno. Pues decimos que era, es y será, pero según el razonamiento verdadero solo le corresponde el 'es', y el 'era' y el 'será' conviene que sean predicados de la generación que procede en el tiempo, pues ambos representan movimientos, pero lo que es siempre idéntico e inmutable no ha de envejecer ni volverse más joven en el tiempo". PLATÓn, Timeo, 37e-38.

495 "Los males no habitan entre los dioses, pero están necesariamente ligados a la naturaleza mortal y a este mundo de aquí. Por esa razón es menester huir de él (la cursiva es nuestra) hacia allá con la mayor celeridad y la huida consiste en hacerse uno tan semejante a la divinidad como sea posible, semejanza que se alcanza por medio de la inteligencia con la justicia y la piedad". PLATÓN, Teeteto, 176a-b.

496 "Entonces, al formular las Ideas, y la Idea del Bien, y el enlace de todas las cosas eternas en ella misma y en la eternidad, tendríamos algo que se le aproxima mucho: una esfera que gira sobre sí misma y con regularidad, y conforme a los números. Esto será el tiempo: el movimiento de la esfera es el tiempo. Una vez ahí, el movimiento de la esfera puede ser comunicado poco a poco, cada vez más y más abajo. Tendremos así todos los cambios; tendremos así el mundo del devenir que habrá sido dado, en efecto, por el solo hecho de que el mundo de la eternidad lo está". BERGSON, H., Historia de la idea del tiempo. Paidós, Barcelona, 2018, pág. 130.
} 
gobiernan los deseos y su tendencia al exceso, a la insaciabilidad y al conflicto (las actividades "superiores"). ${ }^{497}$

En Aristóteles, la idea del tiempo va asociada al cambio y al movimiento. El tiempo es lo que tiene que ver con lo mutable, "la medida del movimiento según el antes y el después". ${ }^{498}$ Luego solo los seres en movimiento están en la "temporalidad", porque el tiempo está indisociablemente unido al movimiento. Y a partir del cambio y el movimiento, la vida buena es definida en términos de equilibrio entre el "demasiado" y el "muy poco" y así lograr el bienestar del "todo". "Un bienestar asociado al ejercicio de la razón que contempla el bien, reflexiona sobre la excelencia moral y delibera acerca del bien común y de la aplicación de las leyes. ${ }^{500}$

Con la llegada del Cristianismo y la encarnación de Dios "en el tiempo", todo se desconfigura. El tiempo histórico pasa a ser considerado totalmente real, porque Dios actúa en el tiempo y el tiempo es un tiempo de salvación. La concepción cristiana del tiempo evoluciona y se impone la idea agustiniana del mismo. ${ }^{501}$ Un tiempo que, siguiendo la senda aristotélica, se mantiene asociado a la idea de movimiento, pero un tiempo que asocia dicha idea de movimiento a la "percepción" que se tiene de él. El movimiento es captado por un alma, por una interioridad, con lo cual la idea del movimiento va asociada a una "experiencia de interioridad" que capta dicho tiempo. El tiempo lo mide el alma como una percepción subjetiva y llega a dudar de que pueda conseguir comprenderlo o ser capaz de explicarlo.

Un tiempo que asume el presente como el instante de la eternidad, lo que hace que el tiempo sea tiempo, pues la eternidad es la ausencia de tiempo, con lo que el presente es el instante que asume el tiempo en su realidad y que engloba el instante que deja de existir, y existe como pasado y acoge en esa huida el futuro como presente. Por tanto, el tiempo es esa conjunción en el presente de un instante que deja de serlo y pasa a ser pasado, y de un instante que acoge la esperanza de algo que todavía no es. Para Agustín, el tiempo es lo que deja de ser presente para ser pasado, pues si fuera permanentemente

\footnotetext{
${ }^{497}$ Cfr. TAYLOR, Ch., Fuentes del yo, pág. 43.

${ }^{498}$ ARISTÓTELES, Física, 219 b1. “Además, si de un tiempo finito se sustrae un (intervalo) finito, lo que reste será también, necesariamente, finito y tendrá un comienzo. Ahora bien, si el tiempo de desplazamiento tiene un comienzo, habrá un comienzo del movimiento, de modo que también lo habrá de la distancia que se ha recorrido. Y lo mismo (ocurrirá) en los demás casos". ARISTÓTELES, Acerca del cielo, Gredos, Madrid, 1996, pág. 60.

${ }_{499}$ Cfr. TAYLOR, Ch., Fuentes del yo, pág. 180.

${ }^{500}$ Cfr. Ibid., pág. 290.

501 "Lo que sí digo sin vacilación es que sé que si nada pasase no habría tiempo pasado; y si nada sucediese, no habría tiempo futuro; y si nada existiese, no habría tiempo presente. Pero aquellos dos tiempos, pretérito y futuro, ¿cómo pueden ser, si el pretérito ya no es él y el futuro todavía no es? Y en cuanto al presente, si fuese siempre presente y no pasase a ser pretérito, ya no sería tiempo, sino eternidad. Si, pues, el presente, para ser tiempo es necesario que pase a ser pretérito, ¿cómo decimos que existe este, cuya causa o razón de ser está en dejar de ser, de tal modo que no podemos decir con verdad que existe el tiempo sino en cuanto tiende a no ser?". HIPONA, A. de, Confesiones. Libro XI, Cap. XIV, 17.
} 
presente no existiría el tiempo, de modo que el tiempo es lo que va dejando de ser, para ser lo que es, un permanente presente que deja de serlo para ser pasado y que acoge dentro de sí la semilla de algo que todavía no es. ${ }^{502}$ La consistencia del tiempo es una simultaneidad en torno a un presente que está dejando de existir. Es el nunc stans que fluye constantemente, el eterno presente. ${ }^{503}$

Taylor afirmará que, para San Agustín, hay que elevarse a la eternidad para participar del "instante de Dios". Todo en Dios es instante de eternidad, mientras que el tiempo ordinario es "dispersión y pérdida de unidad". Frente a la pérdida de la unidad en la cotidianidad del tiempo, para San Agustín todo se renueva en esa eternidad divina que todo lo envuelve. ${ }^{504}$

Este sentido de lucha para ir más allá del tiempo ordinario que dispersa, a veces nos incapacita para captar en profundidad el "instante de Dios" y en esa incapacidad, dice Taylor, se puede abajar la mirada y, en vez de elevarse, se cae irremediablemente en la debilidad. ${ }^{505}$ El tiempo ordinario es una lucha por recuperar la eternidad, según San Agustín, y el sentido de unidad en un tiempo que divide "la simultaneidad trascendente" y hace que nos quedemos en un presente que puede llevar a divinizar las cosas en vez de elevarse sobre ellas para recuperar la unidad trascendente. De ahí que el cuidado de uno mismo y la vida por los caminos de la interioridad sean la propuesta de felicidad cristiana según el tiempo de Dios agustiniano. El cuidado del yo significa el cuidado del alma propia restando importancia a las cosas externas como la riqueza, el éxito, el placer y el poder. ${ }^{506}$

Así pues, Taylor llega a la conclusión de que en la Edad Media tenemos tres tiempos: el tiempo de la eternidad inmóvil platónica, el tiempo de la eternidad de Dios

\footnotetext{
${ }^{502}$ Cfr. TAYLOR, Ch., La Era Secular, tI, pág. 102. Taylor habla aquí de que en este sentido San Agustín es un predecesor de los "tres ekstaseis" de Heidegger. Para Heidegger la temporalidad es el "fuera de sî" en sí mismo. Y en este sentido nos recuerda el presente que deja de ser constantemente para ser lo que es. "Futuro, haber-sido, presente, muestran los caracteres fenoménicos del 'hacia-sí', del 'de-vuelta-a' y del 'hacer-comparecer-algo'. Los fenómenos del 'hacia...', del 'a...', del 'en medio de...' manifiestan la temporeidad como lo ekstatikon por excelencia. Temporeidad es el originario 'fuera-de-sí', en y por sí mismo. Por eso, a los fenómenos de futuro, haber-sido y presente ya caracterizados los llamamos éxtasis de la temporeidad. La temporeidad no es primero un ente que, luego, sale de sí, sino que su esencia es la temporización en la unidad de los éxtasis”. HEIDEGGER, M., Ser y Tiempo, pág. 344. En este sentido hay otro texto de San Agustín que nos recuerda de alguna manera los éxtasis heideggerianos. "¿En qué espacio de tiempo, pues, medimos el tiempo que pasa? ¿Acaso en el futuro de donde viene? Pero lo que aún no es, no lo podemos medir. ¿Tal vez en el presente, por donde pasa? Pero tampoco podemos medir el espacio que es nulo. ¿Será, por ventura, en el pasado, adonde camina? Pero lo que ya no es no podemos medirlo". HIPONA, A. de, Confesiones. Libro XI, Cap. XXI, 27.

${ }^{503}$ Para San Agustín, en Dios todo es presente, en Dios todas las etapas de la historia están presentes ante Él en una simultaneidad ampliada. Dios es un ahora que contiene el presente, el pasado y el futuro. En Dios todo es un presente eterno. La eternidad de Dios abarca todos los tiempos porque es siempre presente. Dios dirige el tiempo, Dios dirige la historia y todo va encaminado hacia un fin. Será una idea que recogerá Hegel en las lecciones sobre la filosofía de la historia.

${ }_{504}$ Cfr. TAYLOR, Ch., La Era Secular, tI, pág. 103.

${ }^{505}$ Cfr. Id., pág. 103.

${ }^{506}$ Cfr. TAYLOR, Ch., Fuentes del yo, pág. 187.
} 
agustiniana y el tiempo de los orígenes de tradición popular. ${ }^{507}$ Tiempos que enmarcaban un mundo encantado y una sociedad enraizada en Dios. Todas estas referencias temporales a la eternidad mítica en sus tres dimensiones se vacían en la Modernidad en un solo tiempo horizontal, vacío y homogéneo. Un tiempo secular, uniforme, unívoco, que tratamos de controlar y medir, y organizar. Un tiempo antropológico en el que el hombre se vuelve hacia las cosas del mundo y en el que se siente protagonista de su acción controladora y dominadora a través de la ciencia y la técnica. El tiempo ordinario ha dejado de estar en relación con tiempos superiores. El tiempo es el tiempo que es indiferente a cualquier contenido. Se pasa, en opinión de Taylor, del lugar medieval al espacio moderno. El lugar viene definido por lo que está en él, por lo que lo contiene, mientras que el espacio es indiferente a cualquier contenido, es solo un recipiente. Lo mismo sucede con la idea del tiempo moderna. La idea de que el tiempo es indiferente a su contenido marca la idea de su homogeneidad y vaciamiento. Si ya no hay relación a tiempos superiores, entonces lo que sucede dentro de él no importa realmente. ${ }^{508}$ Según Taylor, este tiempo vacío es un tiempo en el que hay más probabilidad de desorden. El tiempo es indiferente a los eventos que se suceden en él. No hay rupturas en relación a tiempos superiores y "todo sucede como si nada". El tiempo de la eternidad es entendido no tanto en sus referencias transcendentes cuanto en la permanencia de las leyes. ${ }^{509}$

Afirma nuestro autor que la modernidad implica el olvido de ese cosmos poroso y la introducción en un mundo en el que los tiempos superiores son olvidados o muy difíciles de concebir o, aunque puedan ser admitidos, no explicitan en su integridad un convencimiento que arraigue en las fuentes morales del yo. ${ }^{510} \mathrm{Se}$ ha pasado de una sociedad enraizada en Dios a un individuo atomizado social y culturalmente y enraizado en una ética "que solo yo puedo enunciar y descubrir". 511

En este nuevo contexto de la Modernidad, a finales del siglo XVIII, terminará por imponerse el ideal de la vida corriente, caracterizado por un nuevo modelo de civismo, por el cual, la vida burguesa del comercio y la adquisición ganan un lugar positivo sin precedentes. Por otra parte, la imagen de la razón desvinculada se vincula a una concepción de la dignidad humana caracterizada por la autonomía responsable y la

\footnotetext{
${ }^{507}$ Hay un tiempo de los orígenes o el "Gran Tiempo". Según Mircea Eliade es "el tiempo mítico primordial hecho presente", el tiempo ontológico, el tiempo creador y santificado de los Dioses, el "in illo tempore", es la creación divina que funda el tiempo "ab origine", el eterno presente mítico que se actualiza ritualmente. El tiempo cósmico aparece con la creación que da lugar al tiempo. La creación tiene lugar en el principio, in principio, en el comienzo del tiempo.

${ }^{508}$ Cfr. TAYLOR, Ch., Imaginarios sociales modernos, pág. 214.

${ }^{509}$ Cfr. TAYLOR, Ch., Argumentos filosóficos, pág. 94.

${ }^{510}$ Cfr. TAYLOR, Ch., La ética de la autenticidad, págs. 121 y ss. "Sobre todo ya no requiere apoyarse en la aprobación de los poderes religiosos y considera como un obstáculo toda influencia perceptible sobre la vida económica de las normas eclesiásticas o estatales". WEBER, M., La ética protestante y el espíritu del capitalismo, Fondo de Cultura Económica, México, 2014, pág. 10.

511 TAYLOR, Ch., La ética de la autenticidad, pág. 65.
} 
liberación de las exigencias de cualquier autoridad. ${ }^{512}$ Tanto el deísmo lockeano como el deísmo de Shaftesbury impondrán sus planteamientos. En el primer caso, a través del sujeto desvinculado, responsable de sí mismo y con clarividencia racional y controlador. En el caso de Shaftesbury, ahondando en los sentimientos que anidan en nosotros. Se conduce irremediablemente a un mundo desencantado en el que la Ilustración radical irá imponiendo sus criterios morales a partir de la idea de que ciertos bienes vitales pueden ser alcanzados si están relacionados con una fuente no teísta. El cambio vital será, en sí mismo, reinterpretado, como afirma Taylor, naturalmente. ${ }^{513}$

\section{III.2.1.3. DE UN COSMOS ETERNO A UNA NATURALEZA}

Para nuestro hermeneuta canadiense, el cosmos significaba que el orden que lo envolvía todo era poroso y llegaba a la vida del hombre. El orden cósmico tenía así una significación humana, daba sentido y ordenaba la vida del hombre. Pero el desencantamiento disolvió el cosmos. ${ }^{514}$

La razón eterna platónica era descubierta para dar orden y razón a nuestras vidas. ${ }^{515}$ El tiempo de los orígenes era el tiempo fundador que establece un orden creador y actualizaba ritualmente dicho orden.

Para Aristóteles, el universo era finito, esférico y el cielo era único, perfecto, con múltiples traslaciones y con un movimiento regular de los astros. ${ }^{516}$ Además, el mundo terrestre está en contacto con el mundo de los astros, en constante movimiento, ${ }^{517} \mathrm{y}$ ejerce una influencia en el mundo sublunar. Todo el cosmos tiene su fin último en Dios como realidad inmóvil, algo semejante a la Razón eterna platónica, la Idea. ${ }^{518} \mathrm{Y}$ desde

\footnotetext{
${ }^{512}$ Cfr. TAYLOR, Ch., Fuentes del yo, pág. 335.

${ }^{513}$ Cfr. Ibid., págs. 362,390,433-438.

${ }^{514}$ Cfr. TAYLOR, La Era Secular, tI, pág. 351.

515 "Dicen los sabios, Calicles que, al cielo, a la tierra, a los dioses y a los hombres los gobiernan la convivencia, la amistad, el buen orden, la moderación y la justicia, y por esta razón, amigo, llaman a este conjunto 'cosmos' (orden) y no desorden y desenfreno. Me parece que no fijas la atención en estas cosas, aunque eres sabio". PLATÓN, Gorgias, 508a.

516 "Así en un sentido se llama naturaleza a la materia primera que subyace en cada cosa que tenga en sí misma un principio del movimiento y del cambio. Pero, en otro sentido, es la forma o la especie según la definición. (...) Así, en este otro sentido, la naturaleza de lo que tiene en sí misma el principio del movimiento sería la forma o la especie, la cual solo conceptualmente es separable de la cosa. En cuanto a lo que está compuesto de materia y forma, por ejemplo, un hombre, eso no es naturaleza, sino 'por naturaleza"” ARISTÓTELES, Física, 193a-b. Cfr. DUPRÉ, L., Passage to Modernity, Yale University Press, 1993, pág. 21.

517 "Ahora bien, este (mundo) está necesariamente en contacto inmediato con las traslaciones superiores, de modo que toda su potencia está gobernada desde allí: en efecto, aquello de donde (procede) el principio del movimiento para todas las cosas hay que considerarlo como la causa primera". ARISTÓTELES, Meteorológicos, Gredos, Madrid, 1996, pág. 247-48.

518 "Hay ciertamente algo que mueve sin estar en movimiento y que es eterno, entidad y acto". ARISTÓTELES, Metafísica, Libro XII, (1072a20-25). "Hay cierta entidad eterna e inmóvil, y separada de las cosas sensibles. Tal entidad no tiene en absoluto magnitud, sino que carece de partes y es indivisible, es impasible e inalterable, pues los demás movimientos son posteriores al local”. Ibid., (1073a35-5).
} 
esta mente ordenadora del mundo se concluye que la mente del hombre es la dimensión más divina del mismo y la vida según la mente será la expresión más alta de su felicidad, ${ }^{519}$ precisamente porque es la que le pone en contacto con esa dimensión última del cosmos que es Dios. ${ }^{520}$ Por lo tanto, para el hombre premoderno, según Taylor, ese orden racional configurado en el cosmos es el que tiene que expresar la vida social e individual de los hombres. El cosmos expresa una realidad jerárquica, con realidades superiores, lunares y sublunares. Todo es referido a una Idea, a un Motor Inmóvil, a un Creador o a un orden que se estableció desde el comienzo, a unas formas esenciales comprendidas según una estructura, que puede ser comprendida teleológicamente según alguna idea moral de Bien o de Ser. ${ }^{521}$

Todo esto se desvanece con el advenimiento de la razón científica de la Modernidad. Y se pasa del cosmos "formalizado aristotélicamente" o "idealizado platónicamente", a un universo que tiene su propio orden con unas leyes inherentes a su propia naturaleza. Desaparecen las jerarquías establecidas ontológicamente y la eternidad como motor que determina el orden personal y social. Ya no hay tiempos superiores y es el tiempo secular el que transcurre de manera homogénea y sin ninguna otra determinación que el ineludible paso del tiempo del reloj, en un fluir vacío e indiferente del tiempo. ${ }^{522}$

Con la aparición de la ciencia y la revolución científica galileana y newtoniana, se desconfiguran las miradas ontológicas del cosmos y todo puede establecerse según unas leyes naturales que determinan el funcionamiento del universo. Todo ello influye, según Taylor, en la necesidad de reubicar intelectualmente la fe en el ámbito de la razón científica y del marco inmanente, con los consiguientes debates entre creacionismo y evolucionismo. El problema ha radicado, según Taylor, allí donde el Cristianismo se ha quedado encerrado en la idea del cosmos y ha intentado explicar el mundo creacionalmente, evitando establecer un diálogo entre fe y ciencia, entre razón y religión.

Así como Galileo desubicó a la Iglesia intentando reclamar una mejor explicación de los textos bíblicos para establecer una relación entre la verdad de la Biblia y la

\footnotetext{
519 "Así pues, si Dios se encuentra siempre tan bien como nosotros a veces, es algo admirable. Y si más aún, aún más admirable. Y se encuentra así. Y en él hay vida, pues la actividad del entendimiento es vida y él se identifica con tal actividad". Ibid., (1072b25-30).

520 "Si la felicidad es una actividad de acuerdo con la virtud, es razonable (que sea una actividad) de acuerdo con la virtud más excelsa, y esta será una actividad de la parte mejor del hombre. Ya sea, pues, el intelecto ya otra cosa lo que, por naturaleza, parece mandar y dirigir y poseer el conocimiento de los objetos nobles y divinos, siendo esto mismo divino o la parte más divina que hay en nosotros, su actividad de acuerdo con la virtud propia será la felicidad perfecta”. ARISTÓTELES, Ética Nicomáquea, (1177a10-15).

${ }^{521}$ Cfr. TAYLOR, Ch., Argumentos filosóficos, pág. 71.

${ }^{522}$ Cfr. TAYLOR, Ch., La Era Secular, tI, pág. 106; cfr. TAYLOR, Ch., Hegel, pág. 13; cfr. TAYLOR, Ch., Argumentos filosóficos, pág. 176.
} 
verdad de la ciencia, que no podían estar en contradicción, así también la verdad científica darwiniana lanza un reto fundamental a la explicación del "cosmos bíblico" para que entre en diálogo con la verdad científica que se va abriendo camino y que tampoco debería entrar en contradicción con la verdad de la fe. Taylor no está satisfecho en que los hallazgos de la ciencia se utilicen para refutar la religión. ${ }^{523}$

Taylor invita a repensar la Biblia dentro del marco del "universo científico" que se abre con la Modernidad. Algo que se remonta, desde su punto de vista, a la mejor tradición de pensamiento religioso. Pascal es un referente a tener en cuenta cuando invita a comprender la razón que se abre al conocimiento de las cosas, que al mismo tiempo, no olvida la importancia de comprender el Todo. La ciencia nos ubica en el conocimiento de una parte, pero la comprensión del Todo sigue siendo ese referente que llena al hombre de misterio y trascendencia. Pascal invita al hombre a repensarse a sí mismo y considerar su pequeñez en relación al cosmos y a sus posibilidades cognitivas. Hay un misterio que se esconde en todo y al que es muy difícil sustraerse en esa explicación última por el Todo. La razón científica permite al hombre seguir entendiendo el mundo y es una expresión fiel de la espiritualidad inherente a la condición humana en su apertura a la naturaleza, pero nunca deja de sorprendernos y llenarnos de interrogantes ante "panoramas infinitos" que surgen de las partes que se interrelacionan en el Todo. ${ }^{524}$

Taylor concluye afirmando que "la verdadera relevancia de la concepción del universo es más sutil e indirecta. Reside en la forma en que ha alternado los términos del debate y reconfigurando las posibilidades tanto de la fe como de la ausencia de fe, abriendo nuevos loci de misterio y ofreciendo nuevas formas de negar la trascendencia" $" 525$.

\section{III.2.2.-HACIA “LA GRAN DESINSERCIÓN”. HISTORIA DE LAS IDEAS QUE DES-ENCANTARON EL MUNDO}

"La mayoría de las historias acerca de la humanidad comienzan con la palabra evolución y con una exposición bastante prolija de la misma (...). Realmente, es mucho más lógico empezar diciendo: 'En el principio, un poder inimaginable dio lugar a un proceso inimaginable'. (...) Un

\footnotetext{
${ }^{523}$ Cfr. TAYLOR, Ch., La Era Secular, tI, pág. 24; cfr. BENEDICTO XVI, "Discurso del Santo Padre en la Universidad de Ratisbona" (12-IX-2006); CHESTERTON, G.K., El hombre eterno, Cristiandad, Madrid, 2004; JORDANA, R., "El origen del hombre: estado actual de la investigación paleoantropológica" Scripta Theologica 20, (1988), págs. 65-99; JUAN PABLO II, "Mensaje del Santo Padre a los miembros de la Academia Pontificia de las Ciencias" (22-X-1996); PIO XII, Humani generis, Amicizia Cristiana, Roma, 2008.

524 “Si el hombre comenzara estudiándose primero, advertiría su incapacidad de ir más allá (la cursiva es nuestra). ¿Cómo podría una parte conocer el todo? Pero quizás aspira a conocer por lo menos las partes con las cuales tiene proporción. Pero las partes del mundo tienen todas relación y encadenamiento unas con las otras, que creo imposible conocer las unas sin las otras y sin el todo". PASCAL, B., Pensamientos, Sección II, Disponible en Ediciones Aleph.com, (19-IV-2017). pág. 101.

${ }^{525}$ TAYLOR, Ch., La Era Secular, tI, pág. 109.
} 
suceso no es más o menos comprensible en función del tiempo que tarda en producirse. Para un hombre que no cree en los milagros, un milagro lento será tan increíble como uno rápido. (...) Lo que importa en último término es conocer la causa del proceso. Por eso, todo el que realmente entienda este asunto se dará cuenta de que detrás ha habido y habrá siempre una cuestión religiosa o, al menos, filosófica o metafísica”. ${ }^{26}$

Para Taylor, la identidad moderna surgió porque los cambios ocurridos en las autocomprensiones, vinculadas a un amplio ámbito de prácticas —religiosas, políticas, económicas, familiares, intelectuales, artísticas - convergieron y se reforzaron entre sí para producirla. Es lo que nuestro autor denomina la relación recíproca causaldiacrónica. ${ }^{527}$

El siglo XVI es el siglo que "disciplina" la sociedad, que inicia el orden que configura la vida personal y social bajo otros parámetros distintos a los del orden cósmico. Los humanistas del Renacimiento inician este "giro copernicano" que lleva a un interés por la naturaleza como tal y no como expresión de la Idea o de la Forma, o como Imagen de un Dios Creador. El mundo cósmico va desapareciendo progresivamente a través de la aparición de un mundo natural que se va configurando sobre la ciencia, el realismo en el arte y la vuelta a la ética aristotélica y estoica. Una desconfiguración del mundo premoderno que ya se había iniciado en el Renacimiento del siglo XII y en el interés por la ciencia, el arte y la ética de los siglos XIII y XIV, que se manifiesta con claridad en el Renacimiento del siglo XV y que se establecerá definitivamente con la ciencia galileano-newtoniana del siglo XVII. ${ }^{528}$

Para Taylor, lo realmente relevante no es que el hombre se interese por la naturaleza, sino que poco a poco el interés por la naturaleza se irá convirtiendo en algo exclusivo. Se trata de un primer paso que se va a convertir con el tiempo en algo exclusivo. La naturaleza ocupará el único espacio de preocupación. Del humanismo que conjuga la presencia de Dios con la naturaleza, se pasará a un humanismo exclusivo en el que Dios desaparecerá casi totalmente de las fuentes morales del ser humano. Del horizonte cósmico ontológico en el que Dios, la Idea o la Razón eterna eran las referencias morales del ser humano, se pasará a una visión en la que la naturaleza, en sí misma o por sí misma o el hombre, serán las fuentes morales que constituyan la identidad del ser humano. La naturaleza y el ser humano se considerarán el único camino correcto, el exclusivo. ${ }^{529}$

\footnotetext{
${ }^{526}$ CHESTERTON, G.K., El hombre eterno, I, 1.

${ }^{527}$ Cfr. TAYLOR, Ch., Fuentes del yo, pág. 284.

${ }^{528}$ Cfr. TAYLOR, Ch., La Era Secular, tI, pág. 151.

${ }^{529}$ Cfr. TAYLOR, Ch., La Era Secular, tI, págs. 46,57,79,112,144,164,211,351,371,383.
} 


\section{III.2.2.1. EL RENACIMIENTO DEL SIGLO XV}

La historia de esta "ruptura" con el mundo premoderno se inicia con el Renacimiento. Es un giro antropológico que reorienta la imagen del mundo. ${ }^{530} \mathrm{El}$ Humanismo Renacentista también contribuye significativamente a dimensionar al hombre como agente transformador y conocedor del mundo entendido como una naturaleza que tiene sus propias leyes impresas por el Creador, y a las cuales se puede acceder para comprender e interactuar. ${ }^{531}$ Algunos autores hablan de varios tipos de Renacimiento desde varias procedencias. Algunos ubican los orígenes del Renacimiento como continuidad de la Edad Media, mientras que otros prefieren hablar de ruptura e inicio de una etapa totalmente novedosa. ${ }^{532}$ En este sentido, Taylor opina que el nuevo interés por la naturaleza no significa el abandono de la idea de Dios. Antes bien, en la nueva síntesis aristotélico-tomista las cosas tienen su propia forma natural que se esfuerza en encarnarse según su propio tipo de perfección. Con Santo Tomás se produjo una "autonomización de la naturaleza" que no rompe con la gracia. El orden de la naturaleza evidencia la bondad de Dios, aunque, según Taylor, la autonomización fue el primer paso hacia la negación de toda supranaturaleza. ${ }^{533}$

Parar Taylor, es importante la influencia de Nicolás de Cusa y su visión de un cosmos como loci de significado en clave platónica. ${ }^{534}$ Ya no se trata de acceder a las esencias de los entes, sino que se pretende comprender dinámicamente el funcionamiento de la naturaleza y a través de ella acceder al Autor. Dos autores

\footnotetext{
530 "Es en los siglos XV y XVI cuando se manifiesta el primer germen de lo que será un giro decisivo en la imagen del mundo y del hombre y en el modo de pensar sobre ellos. Este germen no es universal. Aparece en algunas ciudades de Italia y de los Países Bajos. Allí empezará a forjarse la figura moderna del mundo cuyo desarrollo verán los siglos siguientes". VILLORO, L., El pensamiento moderno. Filosofía del Renacimiento. FCE, México, 1992, pág. 9.

${ }^{531}$ En el Renacimiento esta apertura al conocimiento científico y experimental no está reñida con una visión mística de la vida y de la naturaleza: "Es conveniente, sin embargo, que no intentemos separar lo místico de lo científico cuando ambos estén presentes en la obra de un autor. Hacerlo sería deformar el ambiente intelectual de ese periodo. Por supuesto, no es difícil destacar las leyes matemáticas que rigen los movimientos planetarios formuladas por Kepler o la descripción matemática del movimiento expuesta por Galileo: fueron hitos fundamentales en el desarrollo de la ciencia moderna. (...) Ambos autores arribaron a conclusiones que estaban influidas profundamente por su creencia en la perfección de los cielos. En nuestros días llamaríamos científicos a los primeros ejemplos, mas no a los segundos. Pero imponer nuestra distinción al siglo XVII sería incurrir en un anacronismo". DEBUS, A., El hombre y la naturaleza en el Renacimiento, Fondo de Cultura Económica, México, 1985, pág. 19.

532 "La crítica moderna ha desbaratado la concepción, de Burckhardt y de Symonds, de un Renacimiento de corte italiano, alumbrador de resplandores que ponían fin al tenebrismo medieval, encontrando en la Edad Media muchos supuestos renacentistas y hallando en pleno Renacimiento muchos rasgos medievales, como los mencionados para el siglo XV por Huizinga en El otoño de la Edad Media. (...) En definitiva, hubo renacimientos diferentes y los diversos pueblos europeos hicieron sus aportaciones particulares a la civilización común. Pero no puede negarse la excelencia predominante del Renacimiento italiano, donde se produjo la más notable actualización de la cultura antigua, tal vez porque "questa provincia pare nata per risuscitare le cose morte", como escribirá Maquiavelo en El arte de la guerra." GONZÁLEZ SEARA, L., La metamorfosis de la ideología, Editorial Ramón Areces, Madrid, 2011, pág. 23.

${ }_{533}^{3}$ Cfr. TAYLOR, Ch., La Era Secular, tI, pág. 152.

${ }^{534}$ Cfr. Ibid., págs. 164.186.
} 
florentinos posteriores a Nicolás de Cusa, Marsilio Ficino y Pico della Mirandola marcarán, cada uno a su manera, el nuevo paradigma filosófico y cultural del siglo XV. Al igual que Taylor, Fazio insiste en la importancia del giro antropocéntrico realizado en su platonismo, un giro que no implica negación de lo trascendente, al contrario del aristotelismo de la Escuela de Padua. ${ }^{535}$ A este respecto, Kristeller sostiene que el aristotelismo paduano, representando por Pomponazzi, inicia el camino hacia un naturalismo autónomo que entra en colisión con algunas verdades religiosas. ${ }^{536} \mathrm{Se}$ inician, así, visiones contrapuestas en torno a la inmortalidad del alma, una visión platónica más armónica y serena y una visión aristotélica más conflictiva.

Marsilio Ficino, desde sus reflexiones neoplatónicas, determinará el pensamiento de toda una época. Con él, de alguna manera, se pasa del conocimiento estático y metafísico a un conocimiento científico de la naturaleza, consciente de sus capacidades para descubrir las leyes impresas por el creador. El hombre es consciente de su fuerza, "casi similar", a la naturaleza divina, e imita las obras de Dios a través de la razón y la procreación. ${ }^{537}$

Además, este hombre, con esta capacidad cuasi ilimitada como razón y centro del universo, como "microcosmos", puede acceder desde su libertad a desempeñar el protagonismo que le corresponde. Y si es microcosmos, también de alguna manera, en toda su realidad, puede expresar ese macrocosmos a través de su realidad. El hombre ya no está estáticamente contemplando el orden y la razón eterna del macrocosmos, sino que adopta una actitud activa $\mathrm{y}$, consciente de su realidad central, accede al conocimiento de ese macrocosmos desde su realidad de microcosmos racional. La mente humana es la esencia de la creación divina, una esencia oscura que se vuelve luz, a través del deseo divino con el que se identifica y que le concede esa capacidad para conocer todas las cosas creadas. ${ }^{538}$

\footnotetext{
${ }^{535}$ Cfr. TAYLOR, Ch., Fuentes del yo, pag 348.

Cfr. FAZIO, M., Historia de las ideas contemporáneas. Una lectura del proceso de secularización, Rialp, Madrid, 2017, pág. 28.

${ }^{536}$ Se puede hablar de una tradición aristotélica en el Renacimiento y en un Platonismo renacentista. Ambas corrientes pugnan por establecerse dentro de la vuelta a la tradición clásica en el Renacimiento. "Al afirmar que todo el conocimiento humano descansa en los objetos sensoriales, Pomponazzi va más allá de la posición sostenida por Aristóteles; pero podemos decir aún que su argumento fundamental contra la inmortalidad refleja la posición aristotélica, interpretada de un modo empírico o naturalista, que se opone a la posición platónica básica representada por Ficino. Resulta muy iluminadora esta confrontación entre el aristotelismo de Pomponazzi y el platonismo de Ficino, expresada en su discusión sobre la inmortalidad". KRISTELLER, P.O., El pensamiento renacentista y sus fuentes, Fondo de Cultura, México, 1982, pág. 260.

537 Cfr. TOLCACHIER, J., El Humanismo como expresión de lo sagrado, Parques de Estudio y Reflexión, Paravachasca, 2012, pág. 25.

538 "Ciertamente, en estos tres mundos se consideran también tres caos. Al principio Dios crea la sustancia de esa mente que llamamos esencia. Esta, en el primer momento de su creación, es informe y oscura, pero, porque nació de Dios, por un cierto deseo innato, a Dios su principio se vuelve. Vuelta hacia Dios, es iluminada por su rayo. Y es por el resplandor de aquel rayo que su deseo se enciende. Y encendido, se une entera a Dios, y al unirse es formada, pues Dios que todo lo puede, imprime en la mente que a él se
} 
Autores como Granada sostienen que en Ficino se realiza un ensalzamiento del ser humano, porque en él se expresa sintéticamente la unión ontológica entre la dimensión trascendental e inmortal del alma humana que le eleva hacia lo divino, y la dimensión inmanente que por el cuerpo le vincula hacia la existencia natural en el mundo. ${ }^{539} \mathrm{El}$ ser humano descubre posibilidades inherentes a su propia alma que le pone en conexión con el mundo y Dios. En este sentido, para Taylor, Ficino es uno de los antepasados del expresivismo, a través de esa noción de fuerza espiritual que aúna la naturaleza. ${ }^{540}$

En línea similar, Taylor afirma que Ficino asienta las bases para una colaboración del hombre con la obra creadora de Dios. ${ }^{541}$ Una colaboración que se realizaría desde el papel nuevo asignado al artista como alguien que completa, desde su propia actitud humanista, la forma ya impresa en el mundo y contribuye a completar el modelaje de la Forma a través de la creación artística, entendiendo así al artista como el que contempla la belleza de la Idea en el universo y es capaz de "seguir modelando la Forma" a través de su creación humanista. Se trata de un arte asociado a la Forma del cosmos y un artista que debe contemplarla para seguir "dando forma" a la Idea en el arte. Y en el campo de la literatura, se expresará en los poemas del amor platónico. ${ }^{542}$

Podemos afirmar que Ficino se inserta en esa corriente de optimismo antropológico en el que también insiste Petrarca al resaltar la "dignidad del hombre", y que en la Oratio, de Pico della Mirandola, adquiere su expresión más establecida filosóficamente. ${ }^{543}$ Pico della Mirandola, en su obra Sobre la Dignidad del Hombre, siguiendo a otro gran humanista italiano -Manetti-, destaca, frente a la visión medieval de un hombre caído y necesitado de la gracia divina, la dignidad del hombre como "intérprete de la naturaleza" a través de la luz que la razón proyecta sobre todo lo

une la naturaleza de todas las cosas que deben ser creadas. En aquella entonces se pintan de un modo espiritual, por así decir, todas las cosas que percibimos en los cuerpos”. FICINO, M., De Amore, Tecnos, 2001, cap. III, n. 11.

539 "La inserción en el cuerpo y en el mundo no es, pues, negativa y puede ser armonizada con la dimensión trascendente. El hombre, que es fundamentalmente el alma, muestra en sí mismo el doble apetito natural (hacia lo inteligible y hacia el cuerpo) que el alma cósmica: por eso puede el hombre ser con justicia un microcosmos, la cópula del mundo y tener el carácter divino del alma. Hombre, mundo y Dios se encuentran así estrechamente articulados en Ficino en una representación fundamentalmente optimista y positiva del sujeto humano, en la cual los iconos negativos del pecado original palidecen ante la glorificación optimista del hombre procedente de la tradición platónica y hermética griega y del humanismo florentino". GRANADA, M.A., Cosmología, Religión y política en el Renacimiento. Anthropos, Barcelona, 1988, pág. 161.

${ }^{540}$ Cfr. TAYLOR, Ch., Fuentes del yo, pág. 601.

${ }^{541}$ Cfr. TAYLOR, La Era Secular, tI, pág. 188. No obstante Taylor afirmará que Ficino, junto con Bruno, Dee y Fluud, serán representantes de una poiesis no mecanicista que no logrará imponerse a las posiciones galileana-baconianas, pero que expresará en cierta medida cómo dichas posiciones no son inseparables del paso a la mecanización del mundo y cómo al mismo tiempo fueron capaces de conjugar una agenda de progreso con una fuerte creencia en la Idea configuradora del cosmos y el alma en la naturaleza.

${ }^{542}$ Cfr. TAYLOR, Ch., Fuentes del yo, pág. 568.

543 Cfr. PETRARCA, BRUNI, VALLA, PICO DELlA MIRANDOLA, ALBERTI, Manifiestos del Humanismo, Ediciones Península, Barcelona, 2000. 
creado. Todas las cosas están determinadas según su ousia, su esencia determinada, su naturaleza. El hombre, en cambio, puede ser lo que desee, no hay nada que le determine a ser lo que no desea ser, o a seguir irremediablemente el camino del instinto, como los animales; en su dignidad está la libertad que le abre a todo un mundo de posibilidades en la construcción de su propio yo y el lugar que desee en la historia. Se trata de un ente que puede ser como se proyecta y es capaz de trascender lo natural (frente a lo que es como es), ${ }^{544}$ libre y afanado por autoconstruirse, libre y determinado a "ser lo que quiera", según el libre arbitrio. ${ }^{545}$ Defiende Taylor, con Della Mirandola, que el orden del ser aún se mantiene geográfico y jerárquico. El hombre tiene potestad para degradarse o elevarse. Los fines más altos, su sentido moral sigue hundiendo sus raíces en un orden del bien realizado cósmicamente. ${ }^{546}$

Dando un paso más, Taylor considera a Leonardo da Vinci como la expresión más lograda del hombre renacentista, abierto al humanismo y que sintetiza en su vida los dos tipos de creación: la razón científica y la imaginación artística. ${ }^{547}$ El hombre empieza a asumir su protagonismo en el conocimiento de la naturaleza que tiene sus propias leyes y puede comprenderlas a través del conocimiento científico, y a su vez, ese protagonismo le convierte en artista, en creador a partir de ciertos elementos tomados de la naturaleza y sujeto a ciertas reglas y técnicas. Leonardo da Vinci es pintor y teórico de la pintura, al mismo tiempo que filósofo de la ciencia e ingeniero. Representa ese

\footnotetext{
${ }^{544}$ Cfr. VILLORO, L., El pensamiento moderno. Filosofía del Renacimiento, pág. 33.

545 “Tomó por consiguiente al hombre así construido, obra de naturaleza indefinida, y habiéndolo puesto en el centro del mundo, le habló de esta manera: Oh, Adán, no te he dado ni un lugar determinado, ni un aspecto propio, ni una prerrogativa peculiar con el fin de que poseas el lugar, el aspecto y la prerrogativa que conscientemente elijas y que de acuerdo con tu intención obtengas y conserves. La naturaleza definida de los otros seres está constreñida por las precisas leyes por mí prescritas. Tú, en cambio, no constreñido por estrechez alguna te la determinarás según el arbitrio a cuyo poder te he consignado. Te he puesto en el centro del mundo para que más cómodamente observes cuanto en él existe". DELLA MIRANDOLA, P., Discurso sobre la Dignidad del Hombre. Disponible en www.editorialpi.com, (24-IV2019). Medellín, 2006, pág. 5. La esencia de la dignidad humana está, según Pico della Mirandola, en la capacidad del hombre de ser aquello que elige, tener libre albedrío, no estar determinado por nada más que por la propia capacidad de elegir y optar. La dignidad del hombre reside en su libertad. Pero no una libertad para hacer lo que quiera sino para aspirar a las cumbres más altas. La clave según Pico para ascender a la cumbre de la dignidad humana está en el ocio contemplativo (es la otra perspectiva de la libertad). Libertad que lleva al hombre al conocimiento de sí mismo a través de la contemplación de su propia verdad. Una libertad anclada en la filosofía, porque lleva al encuentro en definitiva con la propia verdad y con el propio yo. Se trata de llegar, en ascenso progresivo, a la verdad última del hombre que es su comprensión en Dios. Sin este peldaño último de la escalera difícilmente puede el hombre ser libre pues la libertad está en Dios y en reconocernos hechura suya. Sin este saber como reconocimiento de nuestra propia realidad no podemos ser libres. La afirmación de Dios da sentido a la libertad del hombre. No podemos entendernos sino desde Dios que es quien nos hace libres. Por eso sin esa libertad y sin el anclaje que le da raíz y sentido no podemos entendernos.

${ }^{546}$ Cfr. TAYLOR, Ch., Fuentes del yo, pág. 276.

547 "La naturaleza no contradice las leyes, por el contrario, es ordenada, regular, en espera del hombre científico, quien la estudiará y descubrirá esos principios-leyes que la rigen; el artista, también científico, la pintará o creará obras estéticas. Espera la aparición de las ciencias y las artes: las ciencias, especialmente las matemáticas, al servicio de la invención, la práctica, la acción, la técnica, el arte; la filosofía como la ciencia ideal, última". MONTES DE OCA NAVAS, E., "Leonardo da Vinci, un gran artista del Renacimiento", La Colmena, No 67/68, (2010), pág. 21.
} 
uomo universale que es capaz de acceder al conocimiento de la totalidad de lo que existe y que, al mismo tiempo, vive en armonía total entre su cuerpo y su espíritu. ${ }^{548} \mathrm{El}$ hombre del renacimiento, representado por Ficino y Leonardo, no solo asume su protagonismo en la elaboración de ciencia nueva y en la creación artística, ${ }^{549}$ sino que también hace su propia reflexión moral. ${ }^{550}$ Es el nuevo agente activo, constructivo, hacedor, que no se limita a las actividades que favorecen una aprehensión contemplativa del mundo (ciencia y arte), sino que también comienza a tener un lugar más importante en la ética, bajo la forma de una nueva concepción del progreso ético, de cómo alcanzar la buena vida. ${ }^{551}$

En esta situación nueva, el hombre experimenta un nuevo nacimiento (Renacimiento), adquiere una conciencia moral que le lleva a sentirse agente en la construcción de un nuevo paradigma existencial. Un nuevo paradigma que se expresa en el ideal del hombre universal que puede acceder a un conocimiento de las leyes de la naturaleza a través de la ciencia experimental y consciente de su imaginación y capacidad creativa que le convierte en artista capaz de acceder a una nueva representación del mundo. Taylor asegura que el hombre es consciente, en este momento, de sus poderes poiéticos que contribuirán al prestigio de las artes plásticas y visuales. La aspiración renacentista a imitar la naturaleza en el arte, también prepara el camino hacia el surgimiento de la Edad Moderna. ${ }^{552} \mathrm{El}$ artista se ve a sí mismo frente a la naturaleza, con capacidad para contemplar el objeto, estableciendo una nueva relación sujeto-objeto desde un punto de vista y una situación personalizada. Taylor

\footnotetext{
${ }^{548}$ Un hombre lo tenemos en la representación del hombre de Vitruvio de Leonardo da Vinci. El hombre aparece como centro de todas las cosas, hace posible la cuadratura del círculo y aparece en el círculo como expresión de su sentido trascendente y en el cuadrado que le envuelve en su naturaleza humana. El hombre es lo que conecta el cielo y la tierra, el espíritu y la materia. El alma humana es el vínculo entre lo material y lo divino.

${ }^{549}$ Una creación artística que le llevará al estudio por ejemplo de la anatomía humana sin desdeñar de la preocupación espiritual del ser humano. Por ejemplo, en la representación de Adán y Eva en Durero, artista moderno, aparece un interés por captar no solo la intención religiosa del hombre creado a imagen y semejanza de Dios, sino también el deseo de estudiar la anatomía del ser humano y expresar el interés por el individuo. Mientras que por ejemplo en cualquier otra obra pictórica de la época medieval lo importante no es el estudio anatómico, sino el mensaje teológico, siendo la obra artística solo un medio simbólico para expresar dicho contenido.

550 "En las luchas del Renacimiento y la Reforma por la liberación del espíritu, la Reforma volvió a la libertad de espíritu de la conciencia en su libre vida natural; Maquiavelo dominó la idea romana de dominio; Grocio, Descartes, Espinoza restauraron sobre la base del estoicismo, la autonomía de la razón moral y científica. Pero en esta época de los siglos XV y XVI, tan cargada de tensiones, energías nuevas y fuerzas en desarrollo, todo es al mismo tiempo nuevo. Las naciones jóvenes han logrado su unidad. (...) Con el Renacimiento renacen los epicúreos, los estoicos, los panteístas embriagados de naturaleza, los escépticos, los ateos. Y por primera vez aparecen en los jóvenes pueblos romano-germánicos, a la luz del día y con la visera levantada, todos estos matices del temple vital y de la fe. Lorenzo Valla, Erasmo, Maquiavelo, Montaigne, Justo Lipsio, Giordano Bruno, representan actitudes del hombre ante la vida". DILTHEY, W., Hombre y mundo en los siglos XVI y SVII, Obras II., FCE, México, 2013, págs. 26-27.

${ }^{551}$ Cfr. TAYLOR, Ch., La Era Secular, tI, pág. 165.

${ }^{552}$ Cfr. TAYLOR, Ch., Fuentes del yo, pág. 277.
} 
afirma que liberar al objeto conlleva una liberación del sujeto en forma de una mayor autoconciencia. $^{553}$

Para Taylor, una vertiente fundamental de esta historia comienza con la noción renacentista de civilidad, antecesora de nuestra civilización. Se pasa de la cortesía del Alto Renacimiento, a la civilidad que se tenía en la misma época. Es lo que caracteriza la excelencia, el refinamiento y los logros de un cierto tipo de vida frente a la barbarie del hombre salvaje. Siguiendo a los antiguos, particularmente a Aristóteles, la ciudad es considerada el mejor y más supremo lugar de la vida humana. La vida en la ciudad va asociada al gobierno que ordena y establece códigos jurídicos y leyes que organizan "civilizadamente" la convivencia política. Un gobierno que asegura la paz y evita los conflictos y reyertas, a través de nuevas formas de disciplina económica, militar, religiosa..., que constituirán, según Taylor, los rasgos llamativos de la sociedad europea en los siglos posteriores. ${ }^{554}$

Todo esto es lo que va configurando la aparición de un nuevo humanismo, que es lo que propicia la transición a un Estado Moderno, y que iniciará un proceso hacia una de las corrientes principales de la cultura democrática moderna, relacionado con la importancia que adquiere la política como "autorregulación participativa como un bien en sí mismo". 555

Quizás sea la obra de Maquiavelo, El Príncipe, la expresión de teoría política que se va a ir imponiendo con la aparición del primer estado moderno representado por Florencia. Una teoría política que expresa una clara manifestación de la secularización en sentido fuerte. ${ }^{556}$ Un Príncipe que debe adoptar características propias ante el surgimiento de un mundo nuevo. El Renacimiento y el Humanismo son conscientes de que se entra en una nueva era donde el mundo medieval ha quedado atrás, por lo que era necesario adaptar la comprensión del poder político a los nuevos tiempos. Maquiavelo fue consciente de esta nueva coyuntura histórica, de ahí que pretenda ayudar al Príncipe a conseguir el poder y a mantenerse en él. Y no solo desde un punto de vista teórico, sino desde la referencia a personajes históricos concretos tanto de la antigüedad clásica como del presente.

Para Taylor, uno de los temas principales de la obra política de Maquiavelo es la relación entre "ejército de ciudadanos y libertad", motivando la autorregulación y el compromiso de todos por defender el bien más preciado: la libertad en la que se conjuga

\footnotetext{
${ }^{553}$ Cfr. Ibid., pág. 278.

${ }^{554}$ Cfr. TAYLOR, Ch., La Era Secular, tI, págs. 175, 343.

${ }^{555}$ Cfr. TAYLOR, Ch., Argumentos filosóficos, pág. 191; cfr. TAYLOR, Ch., La ética de la autenticidad, pág. 109.

${ }_{556}$ Cfr. FAZIO, M., Historia de las ideas contemporáneas, pág. 30.
} 
lo social y lo individual. ${ }^{557}$ La solidaridad republicana fundamenta y acrecienta la libertad porque motiva moralmente la disciplina autoimpuesta y reguladora.

El camino del Príncipe maquiavélico tendrá mucho que ver con algunas teorías de la Modernidad en torno a los bienes morales y cómo se conjugan todos los elementos para una "buena vida". Taylor habla, en este sentido, de luchas entre formas superiores o inferiores de la libertad. ${ }^{558}$ El camino que plantea el príncipe de Maquiavelo tiene una fuerte carga de ambigüedad moral, abierta a cualquier justificación malévola: "No alejarse del bien, si es posible, pero sabiendo entrar en el mal si es necesario". ${ }^{559} \mathrm{Se}$ rompe con la moral tradicional, no importa hacer el mal si es necesario para mantenerse en el poder. Es el relativismo moral hecho teoría política e historia, y que se expresará en la Modernidad bajo múltiples formas en torno a la cultura de la autenticidad. ${ }^{560}$ No se niega a Dios ni a la fortuna, siguen estando ahí, pero empiezan a ser compatibles Dios, la fortuna y la libertad. ${ }^{561}$

Maquiavelo está reivindicando que un mundo nuevo ha surgido. El mundo premoderno estaba gobernado casi de manera exclusiva por la fortuna y por Dios, los hombres apenas se sentían protagonistas de su destino. Con el humanismo renacentista se es consciente de algo nuevo: el libre albedrío y la participación ciudadana son expresión fundamental de la común dignidad humana. Es el inicio del humanismo cívico y que ha tomado como modelo la antigua polis o la república, y en el que se insertarán no solo pensadores, como Maquiavelo, sino también Montesquieu, Rousseau, Tocqueville y, en nuestros días, Arendt. ${ }^{562}$ Se está iniciando una de las corrientes centrales de la moderna cultura democrática basada en la autorregulación, el control racional y las relaciones de beneficio mutuo sobre la base del valor incuestionable de la libertad. ${ }^{563}$

\footnotetext{
${ }^{557}$ Cfr. TAYLOR, Ch., Argumentos filosóficos, pág. 254.

${ }^{558}$ TAYLOR, Ch., La ética de la autenticidad, pág. 109.

${ }_{559}^{55}$ MAQUIAVELO, El Príncipe, Cátedra, Madrid, 1985, pág. 140.

${ }^{560} \mathrm{Da}$ la impresión que todo está orientado a la gloria y a la riqueza y al poder. No importan los medios ni los principios. Se reivindica la libertad para actuar según las circunstancias. Se podría decir que es un humanismo que rompe con cualquier atadura moral o religiosa como principio absoluto. La astucia, el arrojo, la valentía, la libertad. En algunos aspectos recuerda La Vida es Sueño, de Calderón de la Barca: la lucha por el poder, la astucia, las alianzas. En algunos aspectos a Segismundo y en otros aspectos a su padre. Tras todos estos planteamientos no está solo el individuo, el príncipe que ostenta el poder, sino el Estado, un nuevo estado renacentista basado en intereses, en la economía, en nuevas alianzas y estrategias, expresión de un nuevo mundo. Para nada aparecen referencias al derecho divino.

561 "Ya sé que muchos han creído y creen que las cosas del mundo están hasta tal punto gobernadas por la fortuna y por Dios, que los hombres con su inteligencia no pueden modificarlas ni siquiera remediarlas; y por eso se podría creer que no vale la pena esforzarse... No obstante, puesto que nuestro libre albedrío no se ha extinguido, creo que quizás es verdad que la fortuna... nos deja gobernar la otra mitad, o casi, a nosotros". MAQUIAVELO, El Príncipe, pág. 170.

${ }^{562}$ Cfr. TAYLOR, Ch., Argumentos filosóficos, pág. 191.

${ }^{563}$ Cfr. Ibid., págs. 191-192; cfr. TAYLOR, Ch., Imaginarios Sociales modernos, pág. 204; cfr. TAYLOR, Ch., Ética de la autenticidad, 56.
} 
Taylor considera que, en estos cuatro siglos (de 1400 a 1800), Europa va a experimentar el inicio y el arraigo del nuevo ideal de vida civilizador. Un estilo de vida que va a ir imponiéndose poco a poco a pesar de las dificultades, retrocesos y estallidos de violencia o barbarie. Los gobiernos van imponiendo como agenda este ideal civilizador que se irá expresando de distintas formas: desarrollo de las artes, la ciencia y la tecnología y sobre todo el establecimiento de fuentes morales nuevas que se manifiestan como autocontrol racional, buen gusto, modales, buena educación y cortesía.

La civilidad, en este contexto, es todo aquello que se opone a lo salvaje y a la naturaleza. Según Taylor, surge un etnocentrismo que se va acrecentando a partir del surgimiento de una cultura más elevada y superior, frente a todo lo que representa lo salvaje, lo natural o las culturas que están asociadas a la naturaleza, a lo que está por civilizar, por cultivar, por elaborar. Una civilidad que significa el surgimiento de gobiernos que buscan la paz, promueven proyectos culturales y humanistas, elaboran leyes que potencian el orden y la convivencia; pero al mismo tiempo, una civilidad que implica un hacerse a uno mismo, un autocontrol, un remodelarnos por dentro, un reconfigurarnos interiormente de acuerdo a unos valores que potencian el humanismo y las fuentes morales que elevan el espíritu. ${ }^{564}$

Todo esto implica disciplina, orden, autocontrol, esfuerzo por "domesticar" las fuerzas interiores que conducen a la violencia y la necesidad de ir configurando estados y gobiernos que potencien este sentido de civilidad, potenciando valores que acrecienten el humanismo y la civilización a través de la filosofía, la ciencia y el arte. Se trata de un humanismo civilizador que no entra en contradicción con la religión, sino que expande la razón como expresión de orden y autodominio. ${ }^{565}$

Taylor afirma, en este sentido, que con el humanismo renacentista surge una "actitud afanosa", por parte de las élites, por implicar al pueblo en este sentido civilizador y de "reconfiguración interior". En el siglo XVI, después de las Reformas, se intenta transformar a los estratos más bajos de la sociedad para que abandonen actitudes poco conformes con el sentido civilizador e inicien procesos hacia vidas más ordenadas y configuradas moralmente. Se trataba de hacerles caer en la cuenta de que era

\footnotetext{
${ }^{564}$ Cfr. TAYLOR, Ch., Argumentos filosóficos, págs. 336-338.

565 "El siglo XVI había tratado de extender en Europa la razón, de confinar la religión en su esfera específica, de crear un campo de acción para la ciencia y el pensamiento libre. (...) Los esfuerzos de Lorenzo Valla o de Pomponazzi, por escandalosos que resultaran en su tiempo, no permitían un desafío serio de la ciencia a la fe. Como máximo se podía llegar a la doctrina averroísta de la doble verdad o a un ateísmo filosófico camuflado. La ciencia no triunfó en la vida renacentista, a pesar de los descubrimientos y conquistas y Lutero pudo calificar tranquilamente de ramera a la razón, sin sufrir por ello grave quebranto". GONZÁLEZ SEARA, L., págs. 56-57.
} 
necesario dejar la vida de laxitud, violencia y desorden, para ingresar como sociedad en una cultura humanista y "civilizada". 566

Las motivaciones eran muy diversas. En sentido negativo, se trataba de evitar todo tipo de desórdenes asociados a la pobreza, a la violencia y a la falta de configuración social. Pero en un sentido más positivo, pronto las élites se dieron cuenta de que esto implicaba una reforma profunda en el arte de gobernar y en el aumento del poder de los Estados. El Príncipe de Maquiavelo da prueba fehaciente de ello.

Era necesario configurar Estados fuertes con gobiernos que potenciaran el desarrollo económico y el poder militar, y evitaran las invasiones. Un desarrollo económico que garantiza beneficios fiscales y evita la escasez y la pobreza. La intervención de los gobiernos en el desarrollo económico evitaba la inflación, la subida de precios y la movilidad de masas de indigentes a las ciudades. Y con el aumento de la productividad y la prosperidad de la población se aseguraba el poder militar. El aumento de la disciplina y el poder militar repercutía en el desarrollo económico, y la prosperidad potenciaba el surgimiento de ejércitos poderosos. El sentido disciplinario y civilizador que se pretende expandir entre la población repercute en el desarrollo de Estados fuertes, bien armados militarmente y con un fuerte nivel de productividad económica. Estados que precisan un nuevo arte de gobernar en el que sea posible conjugar ciudadanía y libertad.

En definitiva, al iniciarse el siglo XVI, ya se halla bien delimitada, en sus trazos fundamentales, la silueta del nuevo mundo que comienza a surgir. Se habla con enorme insistencia sobre lo "nuevo", sobre la luz emergida de las tinieblas, sobre un mundo que se ha ampliado, sobre un universo que ha mudado el rostro. ${ }^{567}$

\section{III.2.2.2. EL ENS CREATUM Y EL CAMBIO NOMINALISTA. HACIA UNA NUEVA POIESIS DE LA NATURALEZA}

Otro tema clave en el desarrollo de Taylor es el que remite a la polémica nominalista. Una polémica que está en la base del posterior desarrollo del mecanicismo. Analicémoslo con detenimiento.

I.- El nuevo interés por la naturaleza. Santo Tomás no opuso naturaleza y gracia. La gracia perfecciona la naturaleza, no la destruye. ${ }^{568}$ Por lo tanto, según Santo Tomás, no puede haber oposición entre las verdades de la fe y la verdad que ha impreso en la naturaleza humana. La fe completa o profundiza la verdad natural, no está en oposición a la naturaleza. Razón y fe están llamadas a complementarse. Para Tomás de Aquino,

\footnotetext{
${ }^{566}$ Cfr. TAYLOR, Ch., La Era Secular, tI, págs. 175 y ss.

${ }^{567}$ Cfr. GARIN, E., La revolución cultural del Renacimiento, Crítica, Barcelona, 1984, pág. 67.

568 "Gratia non tollit naturam sed perficit”, DE AQUINO, T., Summa Theologiae, I, q.1, a.8, ad 2.
} 
por lo tanto, no es la naturaleza la que "necesita" de la gracia debido al pecado original, sino que la naturaleza tan solo es perfeccionada por la gracia. Las cosas que nos rodean tienen su propia naturaleza, las formas que se afanan por encarnar $\mathrm{y}$, por lo tanto, su propio tipo de perfección. ${ }^{569}$ Taylor asegura que, para Tomás de Aquino, las pruebas de la existencia de Dios transitan por la realidad de la naturaleza y de los objetos, al contrario de San Agustín, que evidencia su existencia a partir del sujeto y de la autopresencia del yo. ${ }^{570}$

Taylor también sitúa en la tradición aristotélico-tomista la primacía de la sensación en nuestro conocimiento del mundo. ${ }^{571}$

En la religiosidad medieval, según Taylor, hay dos maneras de entender la naturaleza. Una, entendida como "loci de grandes actos divinos", las grandes "gesta Dei" a lo largo de la historia de la salvación, como si se olvidara del gran prodigio de la creación; y la otra manera es la que se centra en la naturaleza como cosmos ordenado o universitas mundi, olvidándose en cierta manera del poder de Dios que actúa. En un caso, la naturaleza es solo el "lugar" de la salvación de Dios, el marco en el que tienen lugar los "actos de habla de Dios". Y en el otro, la naturaleza es "el orden impreso por Dios en lo creado", lo que hace posible esos actos de habla salvíficos. Para los que asumen este segundo camino de espiritualidad, la naturaleza sigue siendo expresión del orden creador divino, pero ahora poniendo el foco en la naturaleza, afirmando el orden y las leyes naturales tal y como fueron impresas por el creador. ${ }^{572}$ En esta línea se posiciona Tomás de Aquino.

Para Taylor, en este momento, afirmar la consistencia de las leyes naturales, no surge de fuentes morales ajenas a las referencias divinas. Antes bien, la afirmación de la naturaleza tiene la referencia a ese marco creador divino que le imprimió su huella, de tal manera que afirmar la naturaleza es consecuencia de la afirmación del Creador. ${ }^{573}$ Reivindicar la importancia de la naturaleza es reivindicar el dedo creador divino. Y si se afirma la naturaleza, es para afirmar al Creador. La importancia del Creador lleva a afirmar la relevancia de la creatura, la creación del mundo natural y la creación del hombre como centro de ese mundo. Todo es manifestación del "dedo de Dios". 574

\footnotetext{
${ }^{569}$ Cfr. TAYLOR, Ch., La Era Secular, tI, pág. 152.

${ }^{570}$ Cfr., TAYLOR, Ch., Fuentes del yo, pág. 201. En este sentido, los primeros humanistas del Renacimiento no pensaban en un camino que negara cualquier supranaturaleza. No suponían que el afirmar un camino llevara a la anulación del otro. Lo que Taylor resalta es que, poco a poco, esta afirmación de la naturaleza llevará a su afirmación exclusiva como un humanismo moral autorreferente. Cfr. TAYLOR, Ch., Hegel, págs. 3-5, 7, 9-12 y ss; cfr. TAYLOR, Ch., Argumentos filosóficos, pág. 288.

${ }^{571}$ Cfr., TAYLOR, Ch., Fuentes del yo, pág. 232.

572 Cfr. TAYLOR, Ch., La Era Secular, tI, pág. 154.

${ }^{573}$ Cfr. TAYLOR, Ch., Fuentes del yo, pág. 160.

${ }^{574}$ Cfr. DUPRÉ, L., Religion and Modern Culture, University of Notre Dame Press, 2008, Indiana, pág. 7. Estos cambios iniciales en la espiritualidad de la naturaleza se manifestarán de diversas maneras. En el cambio de perspectiva que asume el arte. Lo simbólico va a ir perdiendo relevancia en favor del realismo,
} 
El nuevo interés por la naturaleza no implica el abandono de motivaciones religiosas. Se trata de poner el foco en la naturaleza y en el hombre, pero dentro de un modo cuyas fuentes morales siguen estando impregnadas de religiosidad. ${ }^{575}$ Nuestro hermeneuta está en contra de la teoría del "camino directo" como explicación de que se iniciaba algo que irremediablemente conduciría a la negación de las bases morales trascendentes. Taylor prefiere hablar, por el contrario, de la teoría del "zigzag". No es cierto que la autonomización tomista de la naturaleza condujera directamente y sin solución de continuidad al humanismo exclusivo, aunque ciertamente tuvo que ver en ello. Taylor piensa, en este sentido, que la influencia de la espiritualidad de Francisco de Asís, como la posterior fundamentación filosófica de Ockham y Scotto, tendrán mucha relación. ${ }^{576}$

II.- El Nominalismo. Para Taylor, en la medida en que el orden de las cosas encarne un logos, también las ideas y valoraciones se verán localizadas en el mundo y no solo en los sujetos. Su lugar privilegiado es el cosmos o quizá, más allá, el reino de las ideas, en el cual participan tanto el mundo como el alma. En este sentido, para Platón, percibir el mundo como encarnación de las Ideas es percibir el conocimiento como algo que se logra en sintonía con la mirada del alma. En la formulación de Aristóteles, el conocimiento se presenta cuando la acción de las Formas que configuran lo real, coincide con su acción en la configuración de mi inteligencia (nous). El conocimiento verdadero se presenta cuando conectamos debidamente con la significación que las cosas poseen ónticamente de antemano. ${ }^{577}$ Este es el realismo de las esencias que determina a un Agente Divino, que conforma el mundo según una Forma (esencia) que se haya impreso en las cosas y frente al cual Dios deja que fluya por sí mismo una vez creado, resaltando así la autonomía de la naturaleza. Una esencia que unifica en un ente materia y forma, potencia y acto, siendo la forma el elemento determinante de la esencia, dado que es lo que "determina" a la materia a ser así, lo que actúa para realizar lo que antes era solo "potencia abstracta" y generando así la planta, la piedra o el organismo vivo. ${ }^{578}$

del individualismo y de motivaciones extrarreligiosas. También se manifiesta en la relevancia que van a ir asumiendo las órdenes mendicantes en detrimento de la vida monástica tradicional. La nueva espiritualidad se manifiesta como incardinación en el mundo, iniciando la superación de la visión monástica de huida del mundo. En tercer lugar, está el cambio que experimenta la devoción popular en relación a Cristo: crece la devoción por el Cristo humanado, sufriente, hermano entre nosotros, cercano a la gente y se va olvidando el Pantócrator del Juicio Final. Finalmente aparece la espiritualidad franciscana de la naturaleza en la que se bendice a Dios por el agua, por el sol, por la luz, por las criaturas..., así como el acento que se pone en lo particular, en el principio de individuación, la haecceitas de Scoto, en el conocimiento de la "forma individual", tal y como refiere Taylor.

${ }^{575}$ Cfr. TAYLOR, Ch., La Era Secular, tI, págs. 158-159.

${ }^{576}$ Cfr. Ibid., págs. 156,365.

${ }^{577}$ Cfr. TAYLOR, Ch., Fuentes del yo, págs. 229,259.

${ }^{578}$ Podríamos afirmar que el gran hallazgo de Tomás de Aquino fue el de unificar la doctrina platónica de la participación y la doctrina aristotélica de potencia y acto en una síntesis según la cual el acto es a la potencia como lo participado al participante. Es la presencia de la potencia lo que explicaría la limitación 
Frente a este realismo de las esencias que configuran el ser de las cosas creadas por Dios, los nominalistas resaltan el dinamismo de un Agente Divino que sigue implicándose en las cosas, relacionándose con ellas de manera autónoma y libre, y actuando soberanamente sobre ellas cuando lo determine su voluntad creadora. ${ }^{579}$ Ockham se quedará con la singularidad de la sustancia aristotélica, pero perderá su esencialidad, abriendo así el camino al empirismo. Y afirma que universales serán solo las palabras y los conceptos porque se predican de muchos. ${ }^{580}$

Según Taylor, se ha producido un viraje radical. Nosotros, los agentes dependientes, tenemos que relacionarnos con el mundo no como algo que "está ahî", descubriendo la esencia o el patrón divino creador y asegurando su autonomía natural, pues lo importante es la esencia impresa. El cambio reside en que la naturaleza comienza a considerarse no como algo que está determinado por una esencia, sino por algo que responde a los fines de un Creador, que puede actuar libremente, y con su voluntad seguir configurando las cosas creadas. El mundo es la criatura de Dios y un todo ordenado, pero el orden deja de ser normativo para moldearnos a nosotros mismos; se trata de un vasto campo de partes que se influyen mutuamente. ${ }^{581}$

En Ockham lo que importa es, pues, la verdad empírica, no el ser. No existen universales, dado que no puede existir una realidad común en dos entes de la misma especie, porque, por ejemplo, con la aniquilación de un hombre, no queda determinada la esencia de los demás, con lo que lo único que existe es lo singular. Los universales son termini conceptus que se refieren a cosas individuales. Afirmar lo universal sería

(lo participado) de las realidades finitas; puesto que, como capacidad definida y concreta, la potencia determina el acto que recibe y lo circunscribe según su propio modo y medida. Cfr. ALVIRA, T.; CLAVELL, L. y MELENDO, T., Metafísica, Eunsa, Pamplona, 2001, págs. 279-280.

${ }^{579}$ Así como para Santo Tomás, esencia y existencia solo se identifican en Dios y en todos los demás seres se distinguen, para Ockham la esencia y la existencia de una cosa es lo mismo, pues no puede darse una esencia de una cosa sin que esta adquiera una naturaleza; luego podemos decir que la naturaleza de una cosa es su esencia.

${ }^{580}$ Cfr. SANGUINETI, J.J., "Individuo y naturaleza en Guillermo de Ockham”, Scripta Theologica, No 17, (1985), pág. 845. El realismo de Santo Tomás y Aristóteles incluye no solo la universalidad que en sentido estricto se da solo en el entendimiento, sino que además el concepto expresa "universalidad" en el sentido de incluye dentro de sí la "esencia universalizada de la cosa" más allá de la individuación material determinada. Las cosas particulares son también universales en potencia dado que el entendimiento, que es el reflejo del espíritu universal, es capaz de universalizar lo que "en potencia" hay de universal en las cosas. Con lo que el entendimiento pone acto universal a la potencia universal de la cosa, referida a la universalidad del entendimiento cuyo "acto" lo universaliza en el concepto el cual es la "esencia" de la cosa exterior ya que el concepto "capta" la potencia universal de la cosa y la universaliza en acto. Para Tomás y Aristóteles, la ciencia, que opera con conceptos, versa directamente sobre las cosas exteriores a través del entendimiento. Ockham niega esto último. Para él, las cosas no tienen en potencia lo universal. De ahí que los conceptos, que son universales, no pueden captar la esencia de las cosas conocidas, sino que son reemplazadas en el entendimiento por el concepto. Por eso para Ockham la ciencia trata con conceptos, no con la realidad de las cosas, pues no existe una esencia universal en potencia en las cosas. Los conceptos ocupan el lugar de las cosas, son "signos" de las cosas, pero no las cosas, dado que los conceptos no pueden captar la esencia universal de la cosa, y que no existe lo universal en lo particular, ni en potencia.

${ }^{581}$ Cfr. TAYLOR, Ch., La Era Secular, pág. 163; cfr. TAYLOR, Ch., Fuentes del yo, pág. 126. 
una insensatez. Si digo: "Juan es hombre", identifico solo a un hombre como singular, en su característica de hombre animal racional, pero no configuro mentalmente a Juan "personificándolo" en todo su género, porque Juan no es a la vez uno y muchos; luego Juan no es igual a hombre, sino que en él, como individuo singular, no se excluye ni se incluye ni la singularidad ni la pluralidad como universales, sino que Juan es un singular animal-racional que "verifica" lo universal en cuanto singularidad y pluralidad. ${ }^{582}$ Para Ockham, pues, el individuo singular es la esencia. Al radicalizar el sentido aristotélico de la naturaleza en lo singular, Ockham identifica la naturaleza con la singularidad, convirtiendo a la Filosofía del Lenguaje en el fundamento de su sistema nominalista.

Este es el cambio impreso por Ockham a partir del conocimiento intuitivo, a partir de la experiencia y la realidad de los singulares, abandonando los conceptos aristotélicos de causalidad y sustancia, y abriendo el camino a una ciencia nueva, intuitiva y experimental. ${ }^{583}$ Según Taylor, se está iniciando el proceso hacia la mecanización del cuadro del mundo. ${ }^{584}$ Ya no se trata de un orden normativo en el que Dios se revela en signos y símbolos, en esencias o patrones. Se trata de un mundo que tenemos que habitar como agentes de razón instrumental, haciendo funcionar el sistema de manera efectiva, para llevar a cabo los fines de Dios, porque es a través de estos fines autónomos cómo Dios se revela al mundo: Dios es el creador y el preservador. ${ }^{585} \mathrm{El}$ agente que conoce no debe fijarse tanto en "los fines intrínsecos" a las cosas (realismo de las esencias), los transcendentales (patrones normativos) la esencia divina presente en las cosas, la causa final, cuanto en los fines extrínsecos a ellas, "los fines autónomos" que Dios imprime en las cosas. Así pues, si los fines que siguen las cosas son extrínsecos a ellas mismas, no están en ellas, sino en los fines autónomos impresos en ellas por Dios para funcionar de determinada manera; el agente cognoscente debe descubrir esos fines a través de la razón instrumental y el conocimiento intuitivo. ${ }^{586}$ Hay

\footnotetext{
582 "Nunca el término de una proposición, al menos si se toma significativamente, supone por algo, si no se predica de él con verdad". OCKHAM, G., Summa Logicae, I, c. 63. "La solución es que en la frase 'Petrus est homo', 'homo' indica la naturaleza particular de Pedro, que es el mismo Pedro. Y así Ockham ha identificado la naturaleza con la persona: he aquí el paso trascendental". SANGUINETI, J.J., "Individuo y naturaleza en Guillermo de Ockham", pág. 853.

${ }^{583}$ Para Ockham los universales dejan de ser una realidad que determinan la naturaleza en cuanto presentes en los entes confiriéndoles su esencia (realismo de las esencias) para pasar a ser un concepto. Un concepto que remite al mundo de los singulares, que "actualiza" la realidad y que como concepto está presente en acto en el alma humana cuando la realidad no está delante. "La tesis presentada por Ockham es esencialmente semántica: une de manera implícita el ámbito especulativo que hoy estaría en manos de la psicología cognitiva, la teoría del signo (semiótica) y la teoría de la referencia. El universal no es una realidad sino un concepto. El concepto, a su vez, no es un simple contenido 'objetivo' sino un acto que remite a una pluralidad de objetos singulares. Y este acto, finalmente, es un accidente real del espíritu, una cualidad del alma, un acto cognitivo que no tiene existencia 'objetiva' sino solamente un esse in anima por cuanto su existencia radica en ser una cualidad inherente en un sujeto". LARRE, O., "La justificación de la libertad...", pág. 154.

${ }^{584}$ Cfr. TAYLOR, Ch., Fuentes del yo, pág. 426.

${ }^{585}$ Cfr. Ibid., pág. 301.

${ }^{586}$ El hombre asume su protagonismo en la realización de su libertad. Es la característica de la libertad humana como la dignidad de Pico, al contrario de Scotto y Tomás que refieren dicha libertad al Bien trascendente. Podríamos decir que Ockham sitúa "enfrente" estas dos libertades: la divina y la humana.
} 
fines extrínsecos en el sentido de que no hay esencia impresa como patrón normativo en un ente. Todo funciona como un mecanismo en el que todas las partes pueden confluir para lograr determinados resultados. La naturaleza no está predeterminada intrínsecamente, sino que se puede experimentar y provocar determinados fines, y se puede comprobar el alcance y funcionamiento de la naturaleza. Así lo ha hecho Dios y su omnipotencia no conoce límites, pudiendo conocerse a través de la Biblia o a través de todo lo creado. ${ }^{587}$ Para el nominalismo, en opinión de Taylor, no existe más criterio de identidad de una naturaleza que el de la similitud de las causas que operan en un número de entidades, y cada clase de cosa así identificada es ontológicamente independiente de todas las demás; puede depender de ellas causalmente, pero su naturaleza no está definida por su lugar en el todo. ${ }^{588}$

Taylor afirma que por este camino se llega a la externalización del conocimiento del mundo a través del conocimiento científico, que es capaz de descubrir el entramado de la naturaleza y los fines impresos en ella por el Creador. El conocimiento científico se abre a lo ilimitado al no estar constreñido en las esencias presentes en los entes. No hay contradicción en el conocimiento científico y los fines que Dios ha impreso en la naturaleza. Es a través de estos fines impresos por Dios en la naturaleza, y que podemos descubrir, cómo Dios está presente en ella y no a través de las esencias que confieren entidad a los entes. Se impone no el realismo de las esencias, sino el realismo de los singulares y de la experiencia. Se abandona la concepción de un cosmos como loci de los signos de Dios para adoptar la comprensión de una naturaleza en la que Dios ha impreso unos fines que pueden conocerse a "partir de la experiencia y lo singular adoptando la razón instrumental". En el cosmos desencantado de signos se descubre una naturaleza como "máquina silenciosa" que avanza según sus propios fines, los fines impresos por el Creador. ${ }^{589}$ Esto ha sido también destacado por Uña, quien destaca que,

Una situación que permite por primera vez ponerse en frente, aunque al final el conflicto se resuelve desde la omnipotencia divina que permite la conservación y la libertad humana queda referida a Dios. Pero el planteamiento es totalmente moderno, al separar Ockham la libertad humana de la naturaleza, dado que esta no está referida a ningún moral extrínseco de carácter trascendente. La determinación de la naturaleza es distinta de la autodeterminación de la voluntad. La contingencia de lo creado es referida a la contingencia de la voluntad con lo que no hay ningún principio que determine la voluntad, sino la propia espontaneidad del querer, así como la indeterminación radical de la voluntad. El hombre es imagen del Todopoderoso, y por lo tanto, autosuficiente y causa de sí, con lo que todo queda supeditado a la omnipotencia divina que refiere al hombre su propia autonomía y espontaneidad libre. El intelecto del hombre está construido sobre la libertad autónoma y esta sobre la omnipotencia divina. Cfr. LARRE, O., "La justificación de la libertad", pág. 163.

${ }^{587}$ Cfr. TAYLOR, Ch., Fuentes del yo, pág. 126.

${ }^{588}$ Cfr. Ibid., pág. 264.

${ }^{589}$ Dios no está limitado en su potentia divina a una teleología intrínseca, sino que puede seguir influyendo en la naturaleza a través de las causas externas, los fines extrínsecos que actúan en la realidad de las cosas. La realidad tiene su propio funcionamiento autónomo, externo, su existencia, también impresa por Dios en su creación. Dios puede seguir interviniendo infinitamente en la realidad. Todo esto lleva a la consideración de que no hay distinción entre esencia y existencia. La naturaleza de un ente es su existencia, como la existencia no puede expresarse fuera de la esencia de un ente. Naturaleza y existencia se identifican completamente. La nueva ontología se expresa como física de la experiencia y la naturaleza física manifiesta la esencia ontológica de un objeto. No existe solo la ontología de las esencias sino la 
con Ockham, se inicia el "rebajamiento del universal" y la individuación absoluta del ser, de tal forma que con él se da comienzo a una nueva concepción del saber, del conocimiento y de la ciencia, una metafísica de lo individual en la que lo singular queda reducido a "su mera singularidad" al margen de las Ideas o Formas. ${ }^{590}$ Blumemberg considera que la teología nominalista "dio la alarma" de que una nueva relación del hombre con el mundo era posible. ${ }^{591}$ Para Taylor, es el mecanicismo que surge desde el interior de la teología nominalista. ${ }^{592}$

Para Ockham, Dios, en su omnipotencia, no puede dejar de ser libre para seguir determinando lo que es bueno para el ser humano. Dios dispone de su libre poder y voluntad para relacionarse con los seres creados. Frente a las éticas tradicionales, que ponían el énfasis en el autodominio, en la búsqueda de la armonía del alma y en dejar "emerger" lo que la naturaleza ya llevaba dentro, el nuevo modelo ético que sustenta las nuevas fuentes de moralidad intenta superar la inclinación de la naturaleza, ya que pone límites a la soberanía de Dios. Dios ha de conservar la plena libertad para establecer el bien y el mal por decreto. Se impone así lo que Taylor denomina "la imagen de Dios", cuya soberanía se define en términos de la eterna libertad de su designio. ${ }^{593}$ Nos convertimos así en constructores de nuestro propio carácter. Las nuevas fuentes de la moralidad ponen el énfasis en un patrón que está fuera y por el que hay que luchar para adaptarse a través del término moderno de "voluntad". 594

III.- Nicolás de Cusa y la subjetividad espiritual del yo. Siguiendo la filosofía de Nicolás de Cusa y la gnoseología de Ockham podemos rastrear en sus escritos la capacidad subjetiva del hombre para llegar al conocimiento de las cosas creadas, de tal forma que se puede establecer ya, a partir de ahora, un paralelismo entre la acción creadora de Dios y la actividad "creativa" del hombre para acceder al conocimiento de las cosas. Dios crea y el hombre a través de la subjetividad de su espíritu es capaz de "activar" gnoseológicamente las causas de las cosas creadas, accediendo a través de su actividad intelectual a las cosas mismas. ${ }^{595}$ Este es un aspecto de la Modernidad que

singularidad de la existencia del objeto ubicado espacial y temporalmente. La metafísica queda reducida a la mínima expresión para que de los universales se pase a la realidad singular como realidad física, en su materia cuantificada y forma geométrica, provocando así la mecanización del mundo.

${ }^{590}$ Cfr. UÑA JUÁREZ, A., "Guillermo de Ockham rechaza las Ideas. El giro filosófico de la modernidad y Platón”, Anales del Seminario de Historia de la Filosofía, Vol. 8, (1990), págs. 26-27.

591 "La teología nominalista dio la alarma de una relación del hombre con el mundo donde la implicación humana hubiera podido ser formulada mediante el postulado de que el ser humano tenía que comportarse como si Dios estuviese muerto. Esto llevaría a la realización de un inventario ilimitado del mundo que podría ser caracterizado como el impulsor de la era de la ciencia". BLUMENBERG, H., La legitimación de la Edad Moderna, Pretextos, Valencia, 2008, pág. 348.

${ }^{592}$ Cfr. TAYLOR, Ch., Fuentes del yo, pág. 426.

${ }^{593}$ Cfr. Ibid., pág. 226.

${ }^{594}$ Cfr. Ibid., págs. 126,273.

595 "En cuarto lugar ten presente la afirmación de Hermes Trimegisto de que el hombre es un segundo Dios. Efectivamente, lo mismo que Dios es creador de los entes reales y de las formas naturales, de igual modo el hombre lo es de los entes racionales y de las formas artificiales, las cuales no son otra cosa que semejanzas de su intelecto, como las criaturas de Dios son semejanzas del intelecto divino. En 
valora la subjetividad espiritual del yo en el proceso gnoseológico y que se inicia ya desde el Cusano. ${ }^{596}$ Frente a la gnoseología clásica que basaba el conocimiento en la "recepción" y captación de una verdad dada o contenida en el universo anterior al proceso humano del conocimiento, ahora la gnoseología del Cusano entiende esta correspondencia entre la actividad del espíritu subjetivo humano y la causa divina del universo. ${ }^{597}$

Nicolás de Cusa es el precursor de la Modernidad en el sentido de promover la unidad de lo real como expresión del Dios Infinito, ${ }^{598}$ una "contracción de Dios" que llevará a la consideración de un solo universo físico, con la consiguiente desaparición de la "Forma Absoluta" del Timeo platónico, la eliminación de la materia absoluta aristotélica o la anulación del movimiento eterno y perfecto del cosmos. ${ }^{599}$ A Dios se le

consecuencia, el hombre posee un intelecto, que en el crear es semejanza del intelecto divino. Por eso, crea semejanzas de las semejanzas del intelecto divino, como en efecto las figuras artificiales extrínsecas son semejanzas de la forma natural intrínseca". (la cursiva es nuestra). CUSA, N. de, El Berilo. 6 y 7 , en GONZÁLEZ, A.L., "La doctrina de Nicolás de Cusa sobre la mente", Studia Philologica Valentina, Vol. 10, No 7, (2007), pág. 3.

596 "No es yo un moderno, o el 'portero de la modernidad', como diversos autores quieren considerarlo; por supuesto todavía menos es un declinar del Medievo; coincido con el mesurado juicio que subraya que Nicolás de Cusa 'representa un productivo 'interludio de las épocas', que reflexiona cuidadosamente sobre la tradición y que al mismo tiempo la prosigue determinando una irrupción, que se realiza desde raíces profundas en lo antiguo pensado críticamente hasta el fondo y asimilado aprobatoriamente, hacia nuevos campos y modos de proceder de un pensamiento que se hace cada vez más consciente de sí mismo como nuevo y distinto"'. GONZÁLEZ, A.L., "La doctrina de Nicolás de Cusa sobre la mente", pág. 2.

${ }^{597}$ Cfr. TAYLOR, Ch., La Era Secular, tI, págs. 164,186. "A partir de este momento (con Nicolás de Cusa y Guillermo de Ockham) dicha concordancia se funda en el parentesco del espíritu del hombre - parentesco que atañe precisamente a su carácter productivo - con la causa divina del universo y, por consiguiente, con la causa de esas mismas cosas a las que se dirige el conocimiento humano". PANNENBERG, W., Una historia de la filosofía desde la idea de Dios, pág. 126.

598 "En cambio, la antropología cusana del De coniecturis alberga la idea del hombre como microcosmos: un cierto anticipo de la moderna idea de subjetividad, de acuerdo con la cual el hombre se aísla e incluso enfrenta a la naturaleza; o una percepción de la interioridad humana desgajada de su entorno real, y por ello problemática y abocada a la soledad. Pero, en cambio, si el hombre culmina y dota de sentido a la naturaleza, que es su hábitat, entonces solo por la mediación del hombre la naturaleza remite adecuadamente a Dios". GARCÍA GONZÁLEZ, J.A., "La naturaleza según Nicolás de Cusa", Espíritu LVI, (2007), pág. 12. El Cusano es considerado uno de los precursores de la subjetividad de la Modernidad, uno de los que inicia el giro antropológico en la consideración del alma humana. Se pasa de considerarla "una sustancia espiritual" a una "fuerza para comprender". "De la definición de alma como sustancia espiritual y fuente de facultades espirituales se pasa a esta primacía del entendimiento operante" MANCHETA, J., "Introducción", en Nicolás de Cusa. Un ignorante discurre acerca de la mente, Biblos, Buenos Aires, 2005, pág. 19. Cfr. FOLGER, R., "Hacia la subjetividad moderna", Ibero, (2016), págs. 161-177.

599 "Les estoy presentando a Cusa como precursor de la modernidad; por su visión de la unidad de lo real: el ser infinito y su expresión en las realidades finitas. ¿Cómo no ver también en la contractio cusana concomitancias con el hegeliano extrañamiento de la idea en la naturaleza? La naturaleza mecánicamente entendida, como Newton había propuesto, le parece a Hegel irracional, la alienación de la idea lógica. Pero mucho antes, Nicolás de Cusa nos quería mostrar algo así: que la aceptación de la nueva ciencia empírica deriva en la ruptura del cosmos griego; que la consiguiente inserción del hombre en el caos de los espacios siderales infinitos le hace perder su puesto propio y su orientación. ¿Qué remedio arbitra para ello el cusano? Precisamente este: remitir la naturaleza a Dios. Porque en esta versión premoderna, la naturaleza ya no tiene unidad propia, no es un cosmos heterogéneamente organizado y jerarquizado, autónomo y con una naturaleza en propio; su integridad e inteligibilidad remiten solo y directamente a Dios. Lo creado implica a Dios. En la naturaleza todo es contracto, plural, reino de finitud y oposiciones; inexplicable sin el telón de fondo de Dios". GARCÍA GONZÁLEZ, J.A., "La naturaleza según Nicolás de 
puede buscar y encontrar "por medio de lo que se ha descubierto en la vista, siendo Dios todo lo que hay en lo que existe, de la misma manera que la luz discernidora lo es en los sentidos y la luz intelectual lo es para las razones y que El mismo es lo que la criatura posee lo que es". ${ }^{600}$ En este sentido, para el Cusano, no somos nosotros quienes conocemos, sino que es más bien Dios el que conoce a través de nosotros. Es Dios en el hombre el que produce una "intensificación del conocimiento" que le hace capaz de descubrir su huella en la naturaleza. Para Blumemberg, dicha intensificación se expresa como "insaciabilidad del espíritu" que encuentra su correlato en la inagotabilidad de la naturaleza, una interrelación que acrecienta la búsqueda del espíritu en la misma medida que descubre la inalcanzable riqueza escondida en el propio objeto de análisis". ${ }^{601}$ Una insaciabilidad del conocimiento que se manifiesta, según el Cusano, como un deseo vehemente, como un "abrazo amoroso" entre el entendimiento y la verdad. ${ }^{602}$

Hay una "intención cognoscitiva”, un deseo de la razón de encontrar satisfacción en la búsqueda de la verdad que esconden las cosas, de tal forma que se alcance un "juicio apropiado" a dicha intención. Un apetito que se expresa como impulsividad por alcanzar la paz a través del conocimiento adquirido por el peso de la propia naturaleza, como algo que consigue alcanzar su propio objeto cognoscitivo, siendo casi imposible que la razón no consiga alcanzar dicho objeto y que no lo exprese por medio del discurso adecuado, del lenguaje en el que la palabra expresa la verdad del conocimiento adquirido.

Para Nicolás de Cusa, alcanzar "el abrazo amoroso", conseguir la adecuación del objeto a la verdad del conocimiento, lleva implícito que no se necesita recurrir a la comparación, pues "los que investigan mediante la comparación con algo presupuesto como cierto, juzgan, proporcionalmente, lo incierto". 603

Nicolás de Cusa habla de esta vehemencia investigadora de la razón por alcanzar el fin cognoscitivo que le lleva a elevarse sobre cualquier dificultad, y a pesar de eso, se encuentra con la "docta ignorancia", ${ }^{604}$ con la afirmación ineludible de que no se sabe

Cusa", pág. 11.

${ }^{600}$ CUSA, N. de, La búsqueda de Dios, Cuadernos de Anuario Filosófico, Navarra, 2011, pág. 59.

${ }^{601}$ Cfr. BLUMENBERG, H., La legitimación de la Edad Moderna, pág. 357.

602 "Por lo cual decimos que el entendimiento sano y libre conoce la verdad aprehendida (que, de modo insaciable, mediante el discurso, desea alcanzar dondequiera), como por un abrazo amoroso, sin dudar que sea absolutamente verdadero aquello de lo que ninguna sana puede disentir". CUSA, N. de, La docta ignorancia, Libro I, Cap. I, Ediciones Orbis, Barcelona, 1981, pág. 23.

${ }^{603}$ Cfr. CUSA, N. de, La docta ignorancia, Libro I, Cap. I, pág. 23.

604 "Toda investigación consiste en la proporción comparativa"; la actividad de conocer es ir de lo conocido a lo desconocido mediante la comparación y la proporción. De este modo, se establece un límite que distingue lo que se puede conocer de lo que no: todo aquello que no puede ser comparado, no puede ser conocido. En el reconocimiento de ese límite y en la necesidad de trascenderlo - o de no caer en el escepticismo puesto que nuestro deseo natural de conocer 'no es en vano' - es en donde se abre lugar el programa de la docta ignorancia: saber incompresiblemente (la cursiva es nuestra). El saber incomprensible es la respuesta cusana a la necesidad de que el hombre pueda, al menos de algún modo, conocer inclusive aquello que no se encuentra al alcance de la razón”. LEVINAS, M.L. y SZAPIRO, A., 
nada o que la inteligencia y la sabiduría no logran alcanzar su objetivo; por lo cual necesitamos "saber que somos ignorantes", que a pesar de nuestros deseos cognoscitivos, no se alcanza la meta o que somos como "búhos que intentan ver el sol". 605

Necesitamos saber que somos ignorantes, porque nunca alcanzaremos la verdad en cuanto tal, pues lo que realmente es, para Cusa, se relaciona con la verdad como una necesidad, y con el entendimiento como una posibilidad. Es decir, que la "impulsividad" por conseguir el conocimiento de lo que es, realmente se expresa como una necesidad por querer conseguir alcanzar dicho conocimiento verdadero, por alcanzar la adaptación de lo que es a la verdad; mientras que en relación con el entendimiento, lo que es siempre es una posibilidad, pues el entendimiento nunca logrará comprender la verdad con exactitud, la total identificación entre el entendimiento y la verdad, ya que la verdad siempre esconderá aspectos a los que el entendimiento nunca llegará. La docta ignorancia es la expresión de dicha posibilidad. La verdad siempre esconde elementos de posibilidad al entendimiento. El entendimiento siempre estará asumiendo su imposibilidad, ${ }^{606}$ en un deseo de "cazar la sabiduría". 607

En Nicolás de Cusa, ese deseo insaciable de cognoscibilidad que caracteriza al ser humano, se expresa como deseo de conocer de modo mejor y más completo, aunque, según él, nos encontramos irremediablemente con la incapacidad de conocer al máximo, dado que si la esencia de Dios no puede ser conocida en su totalidad, tampoco puede ser conocida la esencia de todas las cosas en toda su cognoscibilidad, convirtiéndose así Dios, según Blumemberg, en cierto sentido, en la causa y origen de la ciencia. ${ }^{608}$

Hay una motivación que el espíritu humano encuentra para hacer ciencia y que va más allá del descubrimiento de las ideas esenciales en las cosas del mundo. ${ }^{609} \mathrm{El}$

"El carácter histórico de la concepción cusana de verdad", Revista Latinoamericana de Filosofía, Vol. 37, No 1, (2011), pág. 73.

605 “Así, pues, el entendimiento, que no es la verdad, no comprende la verdad con exactitud, sin que tampoco pueda comprenderla, aunque se dirija hacia la verdad mediante un esfuerzo progresivo infinito (...) Es evidente, pues, que nosotros no sabemos acerca de lo verdadero, sino que lo que exactamente es en cuanto tal, es algo incomprensible y que se relaciona con la verdad como necesidad absoluta, y con nuestro entendimiento como posibilidad”. CUSA, N. de, La docta ignorancia, Libro I, Cap. III, pág. 27.

${ }^{606}$ Cfr. CUSA, N. de, La docta ignorancia, Libro I, Cap. II, pág. 25. Todo el esfuerzo de Nicolás de Cusa le llevará a manifestar "constantemente la raíz de la docta ignorancia con la exactitud inaprensible de la verdad".

607 "Un instinto grabado en nuestra naturaleza nos hace apetecer no solo la ciencia, sino la sabiduría o ciencia sabrosa. Luego a quien quiera filosofar le describiré lo que llamo caza de la sabiduría, así como los territorios y en ellos ciertos lugares, y le conduciré a los campos que considero sobreabundantes como ningún otro en las presas que buscan”. CUSA, N. de, La caza de la sabiduría, Sígueme, Salamanca, 2014, Prólogo, pág. 27.

${ }^{608}$ Cfr. BLUMENBERG, H., La legitimación de la Edad Moderna, pág. 358.

609 "Cuanto más hondamente se conozca el espíritu en el mundo que él ha desarrollado a partir de sí mismo tanto más rica será la fructificación que él experimenta en sí mismo; pues su meta es la razón infinita, la única en la que él se ve en su propio ser, como la única medida de la razón a la que nosotros nos adecuaremos tanto más cuanto más profundamente nos ensimismemos en nuestro propio espíritu, 
conocimiento de las cosas creadas, por su propio espíritu, debe llevar al hombre a experimentar tal satisfacción en sí mismo, que sea el principio motivador para "ensimismarnos en nuestro propio espíritu", que nos lleve desde nuestro propio centro, desde nuestro propio yo, a entrar en conexión con la razón infinita, con el espíritu infinito. Y de ahí la motivación para seguir aprendiendo y experimentado. Llegar al máximo de la sabiduría partiendo del conocimiento y la ciencia de las cosas creadas por su propio espíritu. Una ciencia que nos lleva a la sabiduría de la razón eterna, motivo por el que el saber se está retroalimentando constantemente. Un saber basado, por una parte, en la "inexactitud" de todo lo dado con la consiguiente inagotable actitud teorética ante el mundo y, por otra parte, en la "infinitud" entendida como indeterminación que siempre abre nuevos campos para la investigación. ${ }^{610}$

Lo realmente relevante en el Cusano es que, a pesar del "abrazo amoroso" entre el entendimiento y la verdad, entre la naturaleza humana y el despliegue del espíritu racional en su búsqueda insaciable de la inconmensurabilidad de la naturaleza, sin embargo, todo sigue estando bajo la huella de Dios como Providencia Infinita. Según Blumemberg, el platonismo del Cusano le impide cerrar la grieta abierta entre Dios y el individuo, entre la humanidad y el hombre individual y a pesar de la infinidad de determinaciones individuales, la individualidad sigue fundamentando lo realmente relevante bajo el umbral de la Providencia divina. ${ }^{611}$

Nicolás de Cusa abre la puerta a la consideración del universo infinito. Ello nos advierte de cómo la ciencia medieval fue abriéndose camino lentamente hacia la ciencia moderna, sin la cual difícilmente habría conseguido los resultados que se derivaron en los siglos posteriores. La teoría de Burckhardt sobre un Renacimiento independiente, arreligioso y opuesto a la Edad Media, está superada. No obstante, tal y como afirma Koyré, Nicolás de Cusa no usa la palabra infinito para el mundo, porque solo Dios representa lo infinito. Al mundo lo refiere con la palabra interminatum: es interminado e indeterminado, por lo que no se puede conseguir un conocimiento preciso y total, sino parcial y relativo, abriendo así el camino a la teoría de la "docta ignorancia". Para Koiré, el universo de Nicolás de Cusa no termina de fundamentar una adecuada relación entre la unidad de Dios y la determinación de individualidades en su multiplicidad de cualidades y determinaciones del ser, y que en Hegel encontrará su propio camino hacia la síntesis de la Razón Pura. En el Cusano, cada cosa expresa en su individualidad una "peculiar" relación con la unidad de la Providencia divina, produciéndose una “contracción”. Será necesario esperar al surgimiento de la ciencia moderna, con Newton

cuyo único centro, dispensador de vida, es aquel espíritu infinito. Y este es también el motivo de por qué nuestra naturaleza ansía ardientemente perfeccionar su saber". CUSA, N. de, De Coniecturis, I,3 en BLUMENBERG, H., La legitimación de la Edad Moderna, pág. 359.

${ }^{610}$ Cfr. BLUMENBERG, H., La legitimación de la Edad Moderna, pág. 513.

${ }^{611}$ Cfr. Ibid., pág. 518. 
y Galileo, que permita superar el "sensualismo" de lo particular y pasar a la matematización de la naturaleza. ${ }^{612}$

Para Taylor están surgiendo las nuevas fuentes morales que permiten emerger la mecanización del mundo. La nueva explicación del mundo como un universo infinito se expresará en la aparición de nuevas fuentes morales en las que se pierde la sensación de estar en el centro y en el que todo se relativiza, y el hombre está vagando sin límite, sin centro, sin lugar determinado. ${ }^{613}$ Para Taylor, con Nicolás de Cusa en el siglo XV vemos emerger una nueva idea de lo que estamos haciendo cuando hacemos ciencia. Un constructivismo que permitirá el surgimiento posterior de la ciencia. Es la concepción del agente humano como alguien activo, constructivo, hacedor, que no se limita a las actividades que favorecen una aprehensión contemplativa del mundo; a saber: la ciencia y el arte. También comienza a tener un lugar más importante en la ética, bajo la forma de una nueva concepción del progreso ético, de cómo alcanzar la buena vida. ${ }^{614}$ Desarrollo que posibilitará, según el pensamiento de Taylor, el surgimiento de la ciencia baconiana, gracias a nuestra actitud constructiva ante el mundo y una ciencia más de la razón instrumental que de la razón contemplativa, una ciencia experimental que busca cómo funcionan las cosas. ${ }^{615}$ Todo ello contribuirá a la reubicación de las fuentes morales en ámbitos hasta entonces desconocidos. Ya no se trata de una ciencia que contempla la Idea en el cosmos, sino una ciencia que analiza relaciones de causalidad eficiente y que desencadena en último término una ciencia del control. ${ }^{616}$ Taylor considera que, con la ciencia baconiana (Francis Bacon), se trataba no solo de crear objetos de contemplación, sino de mitigar la condición de la humanidad, ponerse al servicio de la humanidad, convirtiéndonos en los administradores de Dios en la creación. ${ }^{617}$

De descubrir algo dado, de buscar el orden en el cosmos, pasamos a construir un orden dentro del universo, en unas claves hasta ahora desconocidas: ya sea porque imitamos a Dios y descubrimos en la actividad interna de Dios nuestro propio espíritu investigador, o ya sea que surge en el interior del hombre una "incomodidad" al percatarse del poder invasor de Dios que, como dice Taylor, no termina de conferir al

\footnotetext{
${ }^{612}$ Cfr. Ibid., pág. 13.

${ }^{613}$ Cfr. TAYLOR, Ch., Fuentes del yo, págs. 341 y ss. “¿Por qué no aceptar, más racionalmente, que la nuestra es una entre muchas posibilidades de cultura? De allí basta un paso para sostener que nuestra civilización cristiana es una de las civilizaciones posibles y no el centro de la historia humana. Giordano Bruno da este paso. Llega a pensar que todas las religiones son válidas como caminos a Dios y todas tienen semejantes derechos a considerarse ordenadas por Él”. VILLORO, L., El pensamiento moderno. Filosofía del Renacimiento, págs. 19-20. Cfr. BRUNO, G., Del Infinito: el universo y los mundos, Alianza Editorial, Madrid, 1993; cfr. DEL GIUDICE, G., Giordano Bruno: El Profeta del Universo Infinito. Electronic Edition, 2014.

${ }^{614}$ Cfr. TAYLOR, La Era Secular, tI, pág. 164.

${ }^{615}$ Cfr. TAYLOR, Fuentes del yo, pág. 292.

${ }^{616}$ Cfr. TAYLOR, La Era Secular, tI, pág. 132.

${ }^{617}$ Cfr. TAYLOR, Fuentes del yo, págs. 129, 226,315-317.
} 
hombre el lugar que le corresponde en el cosmos ordenado. Taylor afirma que se avanza irremediablemente hacia el concepto de "autoafirmación" del hombre. O como dice Villorio, todo es posible en un universo infinito, donde no hay órdenes y todo es relativo y lo que importa son las relaciones y la función. ${ }^{618}$

Se pasa del mundo medieval finito y donde cada cosa ocupa su lugar en los órdenes del ser y en el que cada ente ocupa su lugar natural, a un universo infinito en el que todo queda por definir y todo está abierto porque "se ha perdido el centro". Recordemos que las concepciones infinitistas del universo, sostenidas por los atomistas Lucrecio y Epicuro, Demócrito y Diógenes, no triunfaron frente a las corrientes filosóficas fundamentales de la filosofía griega, con lo que en la tradición medieval apenas se cita a dichos filósofos. ${ }^{619}$

\section{III.2.2.3. LA REFORMA PROTESTANTE. HACIA UNA NUEVA POIESIS DEL ESTADO}

I.- El siglo XVII y la agenda reformista. En una sociedad configurada religiosamente, las reformas, tanto protestante como católica, inciden en el sentido de conversión y disciplina interior que potencian el autocontrol y las fuentes morales que elevan el espíritu. Taylor pone como ejemplos del siglo XVI la Ginebra de Calvino, por parte protestante, y la Milán de Carlos Borromeo, por parte católica. Se trata de reformas en las que la conversión religiosa propiciaba un fuerte compromiso social y en las que la disciplina cívica, fuertemente arraigada socialmente, elevaba también el espíritu religioso. ${ }^{620}$

La Reforma protestante plantea un fuerte rechazo a la jerarquía de vocaciones. Todo el pueblo está invitado a vivir su fe con exigencia y a un nivel máximo. Y esto exigía evitar cualquier clase de recurrencia mágica o la superación de ciertas tradiciones, como la adoración del santísimo o bailar alrededor del palo en mayo, al propio tiempo que universalizar ciertas normas que comprometieran a toda la comunidad. Uno de los puntos comunes a todos los reformadores fue el rechazo a la mediación. El compromiso personal debía ser total o, por el contrario, carecía de valor. $^{621}$

\footnotetext{
618 "Lo que interesa conocer no es ya el lugar natural que corresponde a cada cuerpo, sino las relaciones que tienen con otros, las funciones, en que se encuentra el movimiento de un cuerpo respecto a los movimientos de los otros. Y hemos dado, me parece, con la palabra clave: función. Si en la Edad Media una noción central era el lugar, el sitio natural de cada cosa y de cada persona, en la nueva imagen del mundo, una palabra importante empieza a ser la función, las relaciones que rigen entre las cosas y los hombres". VILLORO, L., El pensamiento moderno. Filosofía del Renacimiento, págs. 18-19.

${ }^{619}$ Cfr. KOYRÉ, A., Del mundo cerrado al universo infinito, Siglo Editores XXI, 1999, Madrid, pág. 8.

${ }^{620}$ Cfr. TAYLOR, Ch., La Era Secular, tI, pág. 171.

${ }^{621}$ Cfr. TAYLOR, Ch., Fuentes del yo, pág. 295.
} 
Taylor sugiere que se entremezclan tanto las motivaciones religiosas como las estrictamente laicas de civilidad humanista, a través de gobiernos fuertes. Nuestro autor habla así de dos reformas en paralelo: la reforma religiosa y la reforma laica, que a veces interfieren la una en la otra, se autoimplican y se automotivan, pero sin entrar en conflicto. $^{622}$

Taylor considera que la motivación para el orden y la civilidad no tiene un sentido exclusivo y unívoco en la reforma religiosa. Cuando el modelo de vida religiosa estaba en la vida monacal, era muy difícil de comprender e implicar a la sociedad en un compromiso por el orden, la paz y el autocontrol. Cuando la vida religiosa rompe los marcos jerárquicos de distintos niveles de compromiso cristiano y se extiende a toda la población, es más fácil comprender ese esfuerzo disciplinario a nivel colectivo.

No obstante, Taylor hace caer en la cuenta que la motivación no puede ser exclusivamente religiosa. La reforma protestante, siguiendo una posición hiperagustinista, habla de que solo una pequeña minoría se salvaría, ${ }^{623}$ que solo una élite cristiana está llamada a asumir el compromiso de controlar colectivamente a la gran mayoría. Esa minoría va interiorizando la idea de que Dios les castigará colectivamente por las faltas de los hermanos descarriados, con lo cual, al final la salvación o es de todos o de nadie. La minoría más consciente de su salvación se compromete en la salvación de todos para asegurarse la suya propia. Así pues, está claro que la agenda reformista y de compromiso civilizador tenía que tener otras motivaciones, aparte de las estrictamente religiosas. No era posible llegar a todos solo desde las motivaciones religiosas, aunque indirectamente todo se implicaba y se interrelacionaba. Siguiendo a Taylor, podemos afirmar que ambas agendas estaban íntimamente relacionadas. La agenda de conversión religiosa comprometía profundamente a las élites religiosas en su compromiso por implicar a los otros en la reforma de vida cristiana, ya que en ello se garantizaba su propia salvación. Al propio tiempo, la agenda de reforma social y de civilidad daba una dimensión social a la vida devota y facilitaba una mayor conexión con el talante de los reformadores que motivaban dicha agenda disciplinaria.

Se llega a la conclusión de que una sociedad reformada religiosamente sobre "la sola fe y la sola gracia" luteranas llevaría ineludiblemente a mejores gobiernos, a un compromiso personal y laboral mejor asumido, a una vida más transparente y comprometida socialmente, a la mejora de la vida familiar y social, a la eliminación de la pobreza y de todo tipo de supersticiones. ${ }^{624}$ Es la fe de confianza, como don gratuito, la que motiva la transformación del mundo. No son las obras las que justifican, sino la

\footnotetext{
${ }^{622}$ Cfr. TAYLOR, Ch., La Era Secular, tI, pág. 172.

${ }^{623}$ Cfr. CALVINO, J., "La elección eterna con la que Dios ha predestinado a unos para la salvación y a otros para la perdición", Institución de la Religión cristiana, Libro III, Cap. XXI, Felire, Barcelona, 1999, págs. 723 y ss.

${ }^{624}$ Cfr. TAYLOR, Ch., Fuentes del yo, págs. 294-296.
} 
fe. Tal y como refiere el profesor Ramírez, "obramos bien porque estamos justificados". ${ }^{625}$ Según Taylor, se da una afinidad entre este sentido espiritual y la teología scottista-ockhamista que enfatizaba el poder absoluto de Dios. ${ }^{626}$

Taylor estudia el compromiso religioso calvinista con la agenda social reformadora en los puritanos del siglo XVI y XVII en Inglaterra y EE.UU. A partir de la conversión religiosa, se podía esperar un cambio de vida y el consiguiente orden social y político. Frente a la indolencia monacal y el libertinaje de un pueblo laxo y violento de la sociedad medieval, surge un "santo" consciente de su vocación personal y de su compromiso en la agenda social. Tal y como afirma Cely, de la sumisión y obediencia al orden divino del mundo medieval, el puritano piensa que el orden depende de él, más que él dependa del orden, motivando así actitudes de esfuerzo y responsabilidad en la construcción del Reino de Dios. ${ }^{627}$ Un celo puritano que, tal y como Walzer afirma, libera de la pasividad medieval y eleva espiritualmente hacia el compromiso social de carácter político y militar en el contexto del Renacimiento. El calvinismo hizo surgir un sentido nuevo y renovado de método y propósito, una superación del mundo inalterable de la tradición y del lugar social familiar para conformar un humanismo nuevo en el que la actividad se personaliza y el hombre siente renacer dentro de sí toda la fuerza en nuevas posibilidades creativas de carácter moral. ${ }^{628}$

Este es el contexto puritano que tanta influencia tuvo en la imposición de una agenda de orden en la aparición de Estados fuertes. Estos son los santos que deben gobernar a un pueblo disoluto y laxo en costumbres. Tal y como Walzer afirma, los puritanos sienten como tarea primordial la destrucción del orden tradicional a través de una política de innovación y cambio de la sociedad; son los nuevos arquitectos de un nuevo orden moral que está por construir. ${ }^{629}$ Se trata de que la nueva agenda social de orden y rectitud de costumbres vaya calando poco a poco en la mentalidad del pueblo, para que de forma personal y libre todos se vayan adhiriendo al Cristianismo. Una sociedad, cuyo ejemplo de los más devotos, cunda entre los más rezagados para que todos se adhieran a una atmósfera imbuida de Cristianismo e impulso espiritual. Solo los elegidos son los que pueden realizar las buenas obras, porque de alguna manera son signos de la elección y expresión de la gracia que le acompaña. Por ejemplo, Max Weber afirma que frente al ascetismo personal del monacato medieval que "aleja del

\footnotetext{
${ }^{625}$ Cfr. RAMÍREZ, Z., "Martín Lutero y la Reforma del Cristianismo Occidental”, RAM, No 5, (2014), pág. 78. Sobre este trasfondo de que obramos bien, porque estamos justificados por la sola gracia, Lutero pretende individualizar la experiencia religiosa e interiorizarla como una experiencia de salvación. Y así, esta comprensión personal de la vida cristiana llevaría a una vida de compromiso social y de mejora de las condiciones de vida.

${ }^{626}$ Cfr. TAYLOR, Ch., La Era Secular, tI, pág. 172.

${ }^{627}$ Cfr. CELY Q., M., “La ética económica de los puritanos”, RS 21, Vol.14, No 1 (2012), pág. 11.

${ }^{628}$ Cfr. TAYLOR, Ch., Fuentes del yo, pág. 257,302,310. WALZER, M., La revolución de los santos, Katz Editores. Barcelona, 2005, pág. 27.

${ }^{629}$ Cfr. WALZER, M., La revolución de los santos, pág. 17.
} 
mundo", el nuevo ascetismo del santo puritano va a realizar su ideal ascético dentro de la vida profesional profana. ${ }^{630}$ Taylor afirma, en este sentido, que el puritano es el pilar del nuevo orden social, ya que se trata de rehacer la cultura del pueblo. ${ }^{631}$

La revolución puritana, en opinión de Taylor, unificaba los dos elementos partiendo de la raíz cristiana. La conversión como identificación con el proyecto cristiano ayudaba a solucionar los graves problemas sociales de la época. Según nuestro hermeneuta canadiense, la recuperación espiritual y la redención del orden civil iban de la mano. ${ }^{632}$ Desde una devoción cada vez más profunda, se inspiraba el sentido de una reforma social que intensificaba el desarrollo político y económico de los estados y a su vez desde un sentido de civilidad más interiorizado y organizado socialmente se propiciaba una mayor vivencia espiritual y más extendida. Se trata de una simbiosis entre ambas agendas de reforma. Para los reformadores se trataba, como asevera Taylor, de una santificación de la vida mundana en toda su extensión. ${ }^{633}$

El siglo XVI ha sido definido como un siglo de "expansión y conflicto"; y al mismo tiempo como un siglo de transición entre el "feudalismo" y el "capitalismo", con la consiguiente influencia cada vez más importante y decisiva de la burguesía, frente a la tradicional nobleza del honor, la posesión de la tierra y el poder militar. Es el inicio del paso de la sociedad estamental a la sociedad de clases, ${ }^{634}$ de una sociedad rural a una urbana y de una sociedad caracterizada por el "status" (oración, guerra, trabajo) a una sociedad de los medios de producción. ${ }^{635}$

El análisis de Taylor se desarrolla atendiendo a cuatro grandes programas de mejora: ${ }^{636}$

1.- Las leyes de pobres. ${ }^{637}$ En la Edad Media, la pobreza era una ocasión para la santificación, una especie de "pacto bíblico-teológico asumido entre ricos y pobres". La

\footnotetext{
${ }^{630}$ Cfr. WEBER, M., Ética protestante y espíritu del capitalismo, págs. 143-144.

${ }^{631}$ Cfr. TAYLOR, Ch., La Era Secular, tI, págs. 182-183,194.

${ }^{632}$ Cfr. Ibid., pág. 176.

${ }^{633}$ Cfr. TAYLOR, Ch., Fuentes del yo, pág. 302.

634 "Aparece así un nuevo tipo de hombre cuyo poder no está sujeto a las regulaciones y rangos de la sociedad antigua, sino que depende de la función que, de hecho, cumple en la sociedad. Alfred van Martin resume así la situación en Florencia: 'Es la formación de una capa social completamente nueva, de una nueva aristocracia del talento y de la energía activa (que sustituye a la anterior de nacimiento y de rango) Y que asocia al arte económico el político, pero siendo siempre el momento económico (el burgués) el que, predominando, determina el estilo de aquella vida"'. VILLORO, L., El pensamiento moderno. Filosofía del Renacimiento, pág. 21.

${ }^{635}$ Cfr. MACKENN, R., La Europa del siglo XVI. Ediciones Akal, 1996, Madrid. Según Mackenn la revolución de Lutero consistió más en atacar la división entre el clero y los laicos que entre la nobleza y el pueblo (cfr. pág. 54), el núcleo principal de poder político en el siglo XVI era la corte y lo caballeresco (cfr. pág. 58), sigue aminorándose el poder militar autónomo de los nobles (cfr. pág. 60) y afirma que 'el más grande evento jamás acaecido' en la historia de la humanidad fue el descubrimiento de las Indias Occidentales y Orientales (cfr. págs. 64 y ss.) y el incremento de la población el hecho más importante del siglo XVI (cfr. págs. 78 y ss.)

${ }^{636}$ Cfr. TAYLOR, Ch., La Era Secular, tI, págs. 178 y ss.
} 
súplica de Lázaro al rico Epulón era una invitación a ayudar a los pobres como medio de salvación e imitación de Jesucristo. Este sistema se volvió ineficaz ante el alarmante aumento del número de pobres. En el siglo XVI, con el aumento de la población y la consiguiente movilidad social de las zonas rurales a las ciudades, tanto por necesidad como por atracción, se hicieron necesarias las leyes de pobres que ayudaran a las personas que lo necesitaban, ${ }^{638}$ a rescatar a niños de la mendicidad y ayudar a los enfermos mentales en su indigencia, ${ }^{639}$ o evitar la enfermedad venérea. ${ }^{640}$

En el siglo XVI, el libro que fundamentó filosófica y teológicamente la ayuda a los pobres y marginados fue el libro de Luis Vives El Tratado del Socorro de los Pobres. Algunos autores lo consideran el primer libro que fundamenta la asistencia social en Europa y pone las bases para una legislación en favor de los más desfavorecidos. Vives habla de que con el aumento de población surgen el vagabundeo, la pobreza y la miseria; situaciones que motivan la aparición de leyes de propiedad y el dinero como gran acuerdo público. ${ }^{641}$

Al pobre ya no se le miraba como la "imagen de Cristo" y la pobreza como un camino hacia la santificación personal (Francisco de Asís y la hermana pobreza), sino como alguien a quien rescatar, tanto si se trataba de una situación de indigencia personal (laxitud moral y psicológica) o una situación asociada a las calamidades y hambrunas.

Con las leyes de pobres, se adopta hacia la pobreza y los pobres un punto de vista instrumental-racional, tal y como afirma Taylor. ${ }^{642}$ En los asilos, se les pone a trabajar para lograr su sustento y en la medida de lo posible su rehabilitación. La concepción puritana era de extrema dureza y crueldad hacia ellos. Criticaban con crueldad la vagancia, el ocio, el vagabundeo, la vida descuidada, el vivir al día sin esfuerzo y responsabilidad, dado que desde ahí "no había salvación posible". ${ }^{643}$ En los países católicos, la nueva orientación hacia los pobres fue impulsada en París y Milán.

\footnotetext{
${ }^{637}$ Cfr. TAYLOR, Ch., Fuentes del yo, págs. 312,332.

${ }^{638}$ Cfr. MACKENN, R., La Europa del siglo XVI, pág. 81.

639 "Los móviles éticos y religiosos fueron perdiendo peso y en todos los tratados el trabajo productivo se erige en el eje de las soluciones y en el medio de integrar la asistencia social y la lucha contra la relajación social. El incremento de la pobreza no daba lugar a actitudes compasivas; había que insertar al pobre en un marco de clara funcionalidad económica, como medio de regulación del mercado de trabajo. La asistencia se transformaba en una cuestión de policía que perseguía el doble objetivo de lograr el bienestar general y aumentar la potencia de la nación”. LÓPEZ CASTELLANO, F., "La literatura de la pobreza: Malthus y la falacia de la beneficencia”, en www.aehe.es, pág. 3.

${ }^{640}$ Cfr. FOUCAULT, M., Historia de la locura en la época clásica, 1998, Colombia, pág. 9.

${ }^{641}$ Cfr. VIVES, J.L., Tratado del Socorro de los pobres, Libro I, Valencia, Imprenta de Benito Monfort, 1781, pág. 12.

${ }^{642}$ Cfr. TAYLOR, Ch., Imaginarios sociales modernos, pág. 179.

${ }^{643}$ Cfr. WALZER, M., La revolución de los santos, pág. 232.
} 
Según Taylor, se va imponiendo la búsqueda del bienestar humano y el alivio del sufrimiento, que procede tanto de fuentes cristianas como del impulso negativo del utilitarismo que se aleja progresivamente de órdenes cósmicos de significado. ${ }^{644}$

2.- Los gobiernos y las autoridades eclesiásticas impulsan una nueva visión de la cultura popular: carnavales, fiestas del desgobierno o desfiles con ollas y sartenes. Según Taylor, lo que antes se consideraba normal, ahora se considera perturbador y problemático. $^{645}$

En este sentido, Burke considera que a lo largo de todo el siglo XVI se produce lo que él denomina "la reforma de la cultura popular". Una reforma que para él tiene dos vertientes: por una parte, la llevada a cabo por parte de las clases dirigentes y el clero, que intentaban reformar y civilizar al resto de la población, y, por otra parte, la llevada a cabo por los propios agricultores y artesanos como una labor de "autorreforma y autocontrol y autoperfeccionamiento". ${ }^{646}$

Es importante hacer notar esta doble vertiente; los gobernantes con un nuevo arte de gobernar y civilizar, y el propio pueblo, consciente de que había que entrar en una nueva dinámica de autocontrol civilizador. El gobierno fue capaz de imprimir su propia dinámica dirigente, pero el pueblo asumió su propia responsabilidad en el nuevo cambio de valores disciplinarios y de perfeccionamiento moral. Podríamos decir que hay un movimiento reformista desde arriba y otro promovido por los propios interesados desde abajo. La Reforma Protestante contribuye a potenciar una reforma cultural que conlleva una potenciación de la producción y la vida familiar, convirtiéndose en una fuente primordial hacia el giro de la era moderna. ${ }^{647}$

Todo ello trajo dos consecuencias: una negativa, en el sentido de que se eliminaron muchos elementos de la cultura popular por considerarlos "inadecuados" en el nuevo contexto sociocultural y civilizador; y una positiva, en el sentido de que la reforma tanto gubernamental como eclesial impulsó este movimiento de perfeccionamiento moral entre las clases populares y fue asumido como tal por ellas.

Los reformadores protestantes se opusieron con la misma radicalidad contra la religiosidad popular católica en todas sus manifestaciones externas y sacramentales, como contra la cultura tradicional secular. Veían en muchas de sus expresiones vestigios supersticiosos de culturas precristianas y paganas, por lo que luchaban contra ellas, en muchos casos, por no tener fundamentación teológica, o por fomentar comportamientos morales inadecuados. Está claro que había dos éticas en conflicto: la ética de la

\footnotetext{
${ }^{644}$ Cfr. TAYLOR, Ch., Fuentes del yo, tI, pág. 33.

${ }^{645}$ Cfr. TAYLOR, Ch., La Era Secular, tI, pág. 180.

${ }^{646}$ Cfr. BURKE, P., La cultura popular en la Europa Moderna, Alianza Editorial, Madrid, 1996, págs. 295-331.

${ }^{647}$ Cfr. TAYLOR, Ch., Imaginarios sociales modernos, pág. 126.
} 
prudencia, la disciplina, la razón y el autocontrol, fomentada por los "piadosos"; y la ética de la espontaneidad y de un cierto desorden, fomentada desde la cultura tradicional. ${ }^{648}$

Por parte católica, desde el Concilio de Trento, se intenta evitar cualquier tipo de superstición o magia asociada a la cultura tradicional o a ciertos aspectos de la vida sacramental o de devoción popular, sobre todo con la reforma de las fiestas y ciertas creencias de la plebe. ${ }^{649}$

En relación con esto, Burke también habla de la cultura de lo piadoso asociado a la gran divulgación y estudio que se hace de la Biblia, principalmente en la parte protestante, dada la falta de instrucción bíblica entre los agricultores y artesanos. Quizás el libro mejor conocido era el libro de los Salmos por la gran identificación que existía entre muchos protestantes con el pueblo de Israel, especialmente los calvinistas. También con la divulgación de Catecismos de Lutero, Calvino y el Catecismo que resultó del Concilio de Trento, también llamado Catecismo Tridentino, de San Pío V o Romano. Por parte católica, los objetivos de la Contrarreforma eran luchar contra los protestantes y contra la superstición e inmoralidad. ${ }^{650}$

3.- Surgen también intentos de crear estructuras estatales, frecuentemente de carácter absolutista o dirigista, de imponer por decreto un proyecto reformista de bienestar económico, educativo y espiritual para todos sus súbditos. ${ }^{651}$

Se trataba de ir expandiendo, desde el propio Estado, este ideal civilizador que llegara a todas las capas sociales. Un ideal que iba asociado a la idea del progreso social y económico y que implicaba la reforma escolar, un aumento de la productividad y sobre todo ir proyectando sobre la sociedad una visión del mundo más racional, científica y técnica que fundamentara una nueva orientación moral y vital. Y la sociedad solo podía ser disciplinada si se autodisciplinaba y autocontrolaba el individuo. De ahí la importancia de la educación y el desarrollo de los bienes de producción que asegurara una calidad de vida con la que afrontar los nuevos retos vitales y morales. Con individuos que entienden este nuevo ideal cultural y civilizador se podrían afrontar los nuevos retos económicos y políticos sobre los que asentar las reformas y proyectar un nuevo estilo de vida. Con el paso del tiempo, afirma Taylor, se pondrá un énfasis cada vez mayor en los aspectos materiales del progreso, con la idea de que ello proporcionaría innumerables beneficios para los individuos y la sociedad.

\footnotetext{
${ }^{648}$ Cfr. TAYLOR, Ch., La Era Secular, tI, pág. 181; cfr. TAYLOR, Ch., Fuentes del yo, pág. 265.

${ }^{649}$ SCHMITT, J.C., "El Cuerpo en Cristiandad", Anales de Historia Antigua, Medieval y Moderna, No 31, (1998), pág. 58.

${ }^{650}$ Cfr. BURKE, P., págs. 326 y ss.

${ }^{651}$ Cfr. TAYLOR, Ch., La Era Secular, tI, pág. 183.
} 
Se trata de ir formulando la razón del estado moderno siguiendo los principios del Príncipe de Maquiavelo, ${ }^{652}$ un estado fuerte y un estado civilizador. Un estado, según Meinecke, que se mueve entre el crathos y el ethos, es decir, entre el ideal de poder y el ideal ético, entre la idea de establecerse a sí mismo como un Estado fuerte, capaz de legislar y organizar según la razón moderna y de estado, y al mismo tiempo la idea de la solidaridad, de la ética, teniendo en cuenta que ese afán civilizador llegue a las mayores capas posibles de la sociedad. ${ }^{653} \mathrm{Y}$ para ello, como afirma Taylor, se necesita que compartamos el amor a las leyes que Montesquieu definió como "virtud". 654

Con la aparición del Estado Moderno y la razón de Estado, se van a asentar las bases racionales del buen gobierno, una vez superada la idea medieval de que la autoridad tiene un origen divino. No obstante, esta razón de estado va a estar más allá de las justificaciones en un sentido religioso o secular. Lo que interesa en este momento es ir viendo cómo "la razón de Estado de tipo sustantivo" es algo que se irá estableciendo, independientemente de los posicionamientos religiosos o secularizados que la justifiquen. ${ }^{655}$

4.- En cuarto lugar, Taylor reflexiona sobre las estructuras de gobiernos locales y estatales que fueron impregnando de racionalidad y disciplina la vida social y política de los nuevos Estados que iban surgiendo. Taylor pone el ejemplo de Prusia y los Países Bajos y la aparición de un funcionariado que centralizara los servicios del Estado con orden y rigor, y a través de la competencia de hombres que antepusieran el trabajo a cualquier clase de ocio y vagabundeo. ${ }^{656}$

Estas estructuras fueron posibles por la dedicación y la disciplina, lo que permitió, en muchos casos, un aumento de la recaudación económica, y una mayor disciplina militar en relación con la política de defensa. Según Taylor, estas virtudes de laboriosidad y compromiso personal tienen mucho que ver con la filosofía neoestoica de

\footnotetext{
${ }^{652}$ Cfr. TAYLOR, Ch., Imaginarios Sociales Modernos, pág. 97.

${ }^{653}$ Cfr. MEINECKE, F., La idea de la razón de Estado en la Edad Moderna, I.E.P. Madrid, 1959, pág. 7.

${ }^{654}$ Cfr. TAYLOR, Ch., Argumentos filosóficos, pág. 193.

655 "Las relaciones entre religión y política van definiendo los avatares de la razón de Estado desde posiciones laicas y secularizadas, como las de Maquiavelo o Furió Ceriol, hasta las que señalan la primacía de lo religioso en la consideración del orbe político, como ocurre con Ribadeneyra o Botero. La tensión entre religión y política — entre el ethos y el cratos, que decía Meinecke-, buscaba su salida de seguridad en la apelación a razones de orden superior, ya fuesen los intereses del Estado, ya fuesen los intereses de la fe. Que los tratadistas cristianos situaran como razones formales superiores los intereses de la fe no desvirtuaba en nada la esencia de la razón de Estado". GONZÁLEZ SEARA, L., La metamorfosis de la Ideología, págs. 79-80.

${ }^{656}$ Cfr. TAYLOR, Ch., La Era Secular, tI, pág. 183. "Después de rememorar las virtudes guerreras de los ingleses medievales, Thomas Scott se volvió, abruptamente, hacia las virtudes más contemporáneas de los calvinistas holandeses. Enfatizó su industriosidad: hacía muy poco que la palabra había adquirido un todo casi religioso que sugería aplicación celosa y esmerada. La imagen del holandés industrioso, cuyas loas cantaron muchos ministros exiliados, fue reemplazando gradualmente a la del señor patriarcal y la del sólido campesino terrateniente. Los puritanos descubrieron una utopía de hombres sin ocio." WALZER, M., La revolución de los santos, pág. 226.
} 
ciertas élites culturales y políticas, así como con la influencia de la espiritualidad puritana. ${ }^{657}$ Taylor considera en este sentido las satisfacciones de la autoestima, así como el papel de la generosité, virtud suprema de la ética del honor del siglo XVII, ahora transformada en la base motivacional para la ética del control racional. ${ }^{658}$

Taylor estudia el proceso civilizatorio siguiendo a Norbert Elias en su estudio ya clásico al respecto. Un proceso que, tal y como señala Elias, no sigue unas pautas racionales como si todo estuviera planificado o determinado según un plan prestablecido racionalmente, aunque dicho proceso pueda afirmarse que sigue un orden $\mathrm{y}$ unas pautas determinadas. Elias afirma, en este sentido, y a dicha idea se adhiere Taylor, que no hay un plan predeterminado para ir imponiendo una agenda civilizatoria que estructure las relaciones sociales a partir de un proyecto racional. Es más bien otra idea la que va estableciendo los cambios que se van imponiendo. ${ }^{659}$ Según Taylor, siguiendo a Walzer, uno de los motivos impulsadores de la Reforma fue el horror por el desorden, tanto social como personal. ${ }^{660}$

Este proceso civilizatorio tiene que ver más con las relaciones humanas de amistad que con planes civilizatorios establecidos a través de la razón y la voluntad. Taylor considera al respecto dos razones que configuran los procesos en la importancia que van adquiriendo las formas de politesse y cortesía: en primer lugar, las cortes europeas van imponiendo reglas más estrictas debido a que quieren asegurar la diferenciación de clases para contrarrestar el surgimiento de la burguesía; y en segundo lugar, la configuración social cada vez más interactiva, que exige un trato cada vez más correcto y establecido culturalmente. Sin duda alguna, las razones atribuidas por Taylor, tienen más que ver con los afectos y las amistades, que con la voluntad y la razón. Son las amistades o enemistades, los movimientos de interdependencia de unos hacia otros, los que van configurando el nuevo proceso civilizador.

En relación al primer aspecto, el que trata de marcar diferencias respecto a las clases sociales emergentes, es algo que tiene que ver con las enemistades o afectos que se establecen respecto a otras personas de otras clases sociales. Se trata del sentido de pertenencia que intenta marcar diferencias respecto a otra clase social a la que se pretende evitar incorporar al propio círculo de amistades, debido a que no "cumple" con los requisitos que se marcan desde la propia pertenencia a la misma. Es un sentido de

\footnotetext{
${ }^{657}$ Cfr. TAYLOR, Ch., La Era Secular, tI, pág. 177.

${ }^{658}$ Cfr. TAYLOR, Ch., Fuentes del yo, págs. 215-216.

659 "Los planes y las acciones, los movimientos emocionales o racionales de los hombres aislados se entrecruzan de modo continuo en relaciones de amistad o enemistad. De esta interdependencia de los seres humanos se deriva un orden de un tipo muy concreto, un orden que es más fuerte y más coactivo que la voluntad y la razón de los individuos aislados que lo constituyen. Este orden de interdependencia es el que determina la marcha del cambio histórico, es el que se encuentra en el fundamento del proceso civilizatorio". ELIAS, N., El proceso de la civilización, pág. 536.

${ }^{660}$ Cfr. TAYLOR, Ch., Fuentes del yo, pág. 312.
} 
interdependencia humana que establece rupturas respecto a otras clases sociales emergentes y frente a las cuales se establece una hostilidad que marca las diferencias a través de la rigidez en los modales y para los cuales difícilmente se puede acceder, bien por costumbre, bien por formación, bien por las propias posibilidades humanas que una clase tiene respecto a otra.

En relación al segundo aspecto, y que Elias refiere como procesos de evolución social en los que las sociedades establecen ritmos nuevos de interacción humana, es algo que viene determinado por la condición humana que desarrolla sus propios elementos de interdependencia afectiva y relacional, y que tiene que ver más con las relaciones de amistad o enemistad, que con los esfuerzos de la voluntad humana por establecer una etiquette fundamentada racionalmente.

En este sentido, Taylor reflexiona sobre la forma en que la actitud desconectada, disciplinada, restringe la intimidad y nos hace tomar distancia de nuestras poderosas emociones y de nuestras funciones corporales. ${ }^{661} \mathrm{Se}$ puede decir que el hombre va asumiendo una mentalidad más "incorpórea" que nuestros antepasados, estamos más desconectados. Y en esta nueva visión del hombre moderno, la figura de Descartes marca un punto de inflexión, en el sentido de que el hombre se va configurando poco a poco en un "desinteresado observador externo del mundo", desapasionado, como agente de disciplina y orden.

Es decir, que nos movemos en un mundo mecánico, en el que todo se objetiva de tal forma que la experiencia corporal se va reduciendo a favor de un racionalismo, en el que la persona controla el mundo desapasionadamente, sin emociones ni expresiones corporales, y en el que la intimidad se va restringiendo hasta ir encaminándonos hacia un yo puntual lockeano. El mundo de las emociones se va controlando para "desapasionar la mirada" y objetivar el mundo. Taylor afirma al respecto que la ética de Descartes, al igual que la epistemología, apela a la desvinculación del mundo y del cuerpo, y a la asunción de una postura instrumental respecto a ambas. ${ }^{662}$

El yo moderno se va configurando desde unas fuentes morales en las que lo corpóreo, los sentimientos, las pasiones y la intimidad pierden relevancia y va surgiendo un agente disciplinado, desapasionado y en el que el sentido de la civilidad imprime una visión del mundo que controla, sofoca y limita la aparición de sentimientos y los encauza disciplinadamente a través del control racional. ${ }^{663}$ Taylor afirmará que el rechazo hacia la intimidad corporal, la violencia o el deseo sexual en bruto se encauza a través del sentimiento de la "delicadeza" como "virtud social correcta". Se restringe enormemente el grado de intimidad permitida para que no surjan sentimientos que

${ }^{661}$ Cfr. TAYLOR, Ch., La Era Secular, tI, pág. 226.

${ }^{662}$ Cfr. TAYLOR, Ch., Fuentes del yo, pág. 218.

${ }^{663}$ Cfr. TAYLOR, Ch., La ética de la autenticidad, págs. 61-65. 
descontrolen este yo impermeabilizado y disciplinado y se establecen los círculos en los que dicha intimidad es aceptada social y culturalmente. Para Taylor, la influencia calvinista en torno a la moderación de los afectos y a no regodearnos en el placer ha influido de manera decisiva en la cultura moderna a través del matrimonio como compañerismo y el amor sexual. ${ }^{664}$

Al igual que Taylor, Norbert Elias estudia con detallada profundidad cómo las sociedades feudales van dando paso a los Estados absolutos y cómo las relaciones sociales se van haciendo más complejas y diferenciadas, potenciando los organismos de control organizado y al mismo tiempo las actitudes de autocontrol personal. ${ }^{665}$

II.- El orden disciplinario y la afirmación de la vida ordinaria. Taylor afirma que el mundo ha experimentado una evolución de tal nivel que, así como para el hombre del siglo XVI era casi imposible no creer en Dios, ahora, con el advenimiento de la Modernidad, la posibilidad de la increencia es la respuesta más natural y plausible para una gran mayoría.

En un primer momento, para Taylor se trata de pasar de un mundo sacralizado y de espíritus a un mundo en el que se diferencia lo natural y lo sobrenatural, lo inmanente y lo trascendente. Una separación que se vio necesaria para "asegurar" una religiosidad más profunda y densamente vivida, pero que irremediablemente introduciría procesos secularizadores. En el siglo XVII, la Reforma y la Contrarreforma invitarán a procesos personalizadores de la fe, a una interiorización de la vivencia religiosa y a un compromiso personal en la vida de fe. Un compromiso que, en un primer momento, se expresa como "furor por el orden" y que se enraíza profundamente en la fe, pero que con el tiempo irá perdiendo dicho fundamento iniciándose procesos secularizadores de carácter irreversible.

Por otra parte, el compromiso personal en la vida de fe lleva a muchos cristianos a vivir la vida ordinaria desde la fe, llegando a igualar los compromisos personales y reduciendo las distancias entre unas vocaciones y otras, a diferencia de "las dos velocidades" propias de las etapas anteriores. ${ }^{666}$ Todo este movimiento, dentro de la Iglesia católica, se puede ver claramente en la evolución que se experimenta desde la vida monástica a la vida mendicante del siglo XIII, para pasar finalmente a la fundación de órdenes como los Jesuitas. Se trataba, en opinión de Taylor, de superar el orgullo

\footnotetext{
${ }^{664}$ Cfr. TAYLOR, Ch., Fuentes del yo, págs. 309-310.

665 "Cuanto más densa es la red de interdependencias en que está imbricado el individuo con el aumento en la división de funciones, cuanto más extensos son los ámbitos humanos sobre los que se extiende esa red y que se constituyen en una unidad funcional o institucional con dicha red, tanto más amenazado socialmente está quien cede a sus emociones y pasiones espontáneas, mayor ventaja social tiene quien consigue dominar sus afectos y tanto más intensamente se educa a los individuos desde pequeños para que reflexionen sobre los resultados de sus acciones o de las acciones ajenas al final de una larga serie sucesiva de pasos". ELIAS, N., El proceso de la civilización, pág. 541.

${ }^{666}$ Cfr. TAYLOR, Ch., Fuentes del yo, pág. 257.
} 
espiritual y aceptar con humildad la naturaleza que Dios nos ha dado para alabar a Dios. No se nos pide ningún altruismo de abnegación. ${ }^{667}$

La afirmación de la vida ordinaria, como ámbito para vivir la fe, se expresa también desde el compromiso por alabar a Dios desde la propia existencia, en el trabajo y en la vida de familia, ${ }^{668}$ unificando la vida cotidiana con la vida sagrada. Al igual que Taylor, Trevor-Roper afirma que los inicios del capitalismo moderno estuvieron inspirados en ese "ascetismo disciplinario" de carácter moral que motiva la autoexigencia y el autocontrol y en el que la religión jugaba un papel fundamental. ${ }^{669}$

Para nuestro hermeneuta canadiense, con la Reforma se tiene la conciencia de que se puede alabar a Dios en la vida ordinaria. ${ }^{670 ~ " D i o s ~ g u s t a ~ d e ~ l o s ~ a d v e r b i o s " ~ d i r a ́ ~ J o s e p h ~}$ Hall. Lo realmente relevante es el modo en el que vivimos la vida corriente. En la Reforma la cuestión es vivir devotamente para Dios, en la transposición lockeana la cuestión es vivir racionalmente. ${ }^{671}$ Lo cotidiano deja de ser profano y se convierte en un ámbito en el que se integra lo más auténtico de la vida cristiana. La oración está estrechamente vinculada con la vida común y ordinaria. El tiempo sagrado se confunde con el tiempo ordinario. El tiempo ordinario tiene una dimensión sagrada y el tiempo sagrado se realiza en lo ordinario de la vida común. Ambos tiempos se entremezclan en experiencias espirituales comunes. El tiempo sagrado continúa en el tiempo ordinario y el tiempo ordinario adquiere una dimensión espiritual de vida de fe. ${ }^{672}$ Como consecuencia de todo ello, la "jerarquía espiritual" desaparece y la distinción de tiempo profano y tiempo sagrado también. Personas y tiempo rompen cualquier diferenciación, unificándose así los ritmos personales de vida cristiana y los tiempos de vivencia espiritual. Todas las personas están llamadas a los mismos objetivos de vida cristiana y todos los tiempos son tiempos de salvación.

Louis Dupré relaciona este nuevo "realismo espiritual" con la expresión en las bellas artes, especialmente la pintura de Giotto. Un realismo que se interesa por los detalles, las personas particulares enmarcadas en los más concretos momentos cotidianos y espirituales. Se ensalza el tiempo cotidiano, el tiempo concreto, casi son

\footnotetext{
${ }^{667}$ Cfr. Ibid., pág. 332.

${ }^{668}$ Cfr. TAYLOR, Ch., Argumentos filosóficos, pág. 196.

${ }^{669}$ Cfr. TREVOR-ROPER, H., La crisis del siglo XVII. Religión, Reforma y Cambio social, pág. 19. Trevor-Roper afirma que fueron los protestantes los que de alguna manera imprimieron el dinamismo económico e intelectual a Europa en dicho siglo, a partir de 1620, configurando así la Ilustración que incluye todo el período desde 1660 a 1800, estableciéndose dicho dinamismo en los nuevos países que asumen el liderazgo como Holanda, Inglaterra y Francia. De ahí que Trevor-Roper llegue a denominar al protestantismo como la religión del progreso. Y tanto Karl Marx como Max Weber piensan que el protestantismo es la religión del capitalismo, cada uno con sus matices, siendo sus posiciones las que se mantienen como las más reconocidas todavía en la actualidad. Frente a los aventureros capitalistas judíos de la etapa medieval.

${ }^{670}$ Cfr. TAYLOR, Ch., Fuentes del yo, pág. 47.

${ }^{671}$ Cfr. Ibid., pág. 332.

${ }^{672}$ Cfr. TAYLOR, Ch., Imaginarios Sociales Modernos, pág. 126.
} 
personas con las que nos podríamos encontrar en nuestra realidad cotidiana. Todo lo cual conlleva una preocupación por la ternura, el realismo, el naturalismo, la preocupación por el cuerpo, los sentimientos y las actitudes humanas. Lejos quedan las representaciones icónicas en las que Cristo es ubicado en el tiempo superior, expresiones arquetípicas de lo divino. Ahora se ensalza la humanidad de Cristo y la experiencia humana en la que se enmarca el encuentro con lo trascendente. ${ }^{673}$

Taylor considera que esta afirmación de la encarnación de Cristo, o de la vida cotidiana no debe ser entendida en clave secularizadora, sino como una expresión de una "espiritualidad encarnacional", una mejor comprensión del significado de la Encarnación del Hijo de Dios. Dios "toma carne" y es también "verdaderamente hombre". Quizás sea un paso necesario en una comprensión más correcta del significado teológico de Jesucristo en su totalidad, como "verdaderamente Dios y verdaderamente hombre", el "Hijo Engendrado por el Padre" y que "se encarnó por obra del Espíritu Santo, nació de Santa María Virgen". Es un paso en una comprensión más correcta del "misterio de Cristo" en su totalidad.

Inmanencia y trascendencia van de la mano, como en el misterio de Cristo, en el que está integrado hipostáticamente su naturaleza humana y su naturaleza divina en una sola persona. Taylor afirma que se corre el riesgo de la inmanencia por la inmanencia, encaminándose hacia un olvido o un retraimiento de la trascendencia. Se corre el riesgo de la tensión, de la ruptura a favor de lo inmanente, como algo que va "implícito" en la afirmación de la armonía entre ambos aspectos de la realidad. No obstante, en este momento no se afirma una realidad en detrimento de la otra. Por ejemplo, en el caso de la escultura barroca, se caracteriza por mantener el equilibrio entre lo inmanente y lo trascendente a través del realismo, el movimiento, la captación del momento concreto y el "talante psicológico" que invita a entablar un diálogo con la escultura que "transmite sentimientos humanos" a partir de la plasmación de situaciones concretas. Por otra parte, en el caso de la pintura barroca, afirma Taylor, en este riesgo que pretende asegurar el equilibrio, también existe la posibilidad de ensalzar la realidad superior, como ocurre en el manierismo, deformándose la expresión que se aleja un tanto de la realidad humana. ${ }^{674}$

\footnotetext{
673 "The problem arose in the wake of what was perhaps the most attractive development of medieval Christianity: Francis of Assisi and his thirteenth-century followers extended the effect of the Incarnation to the entire created world. Even the image of Jesus changed. He was not merely God's eternal Word among us, but a concrete human being. Francis concluded that Christ's human nature itself deserved to be honored and adored. The religious humanism he had initiated blossomed into an artistic movement in which, contrary to the Greek primacy of the universal, the highest spiritual meaning resided in the individual. It was the time of the great innovators in painting, Cimabue, Duccio, and Giotto, and in poetry, Dante, Petrarch, and Boccaccio". DUPRE, L., Religion and the Rise of Modern Culture, pág. 7.

674 "Y así más de un vector en la cristiandad occidental contribuyó al corte entre la inmanencia y la trascendencia; no solo el furor por el orden que estaba implícito en buena parte de la piedad más intensa y cuya tendencia al desencantamiento es clara, sino también en la necesidad de que Dios estuviera más
} 
Llama la atención que, por un deseo de mayor devoción y renovación espiritual, se va preparando el camino para un abandono de las fuentes morales trascendentes hacia un mundo exclusivamente inmanente. Estamos en los inicios, pero la ironía está en que la fe que propicia el orden disciplinado y la devoción en la vida ordinaria van a ser el inicio de un camino que llevará hacia la afirmación exclusiva del mundo inmanente. Se inicia el cambio hacia un mundo completamente distinto en el que, con la desaparición de los espíritus y el encantamiento del cosmos, se abre camino a una espiritualidad encarnada, en la que el equilibrio entre lo inmanente y lo trascendente se irá rompiendo hacia posibilidades totalmente imprevisibles. Estamos en un momento de equilibrio que augura cambios impredecibles. ${ }^{675}$ Las circunstancias históricas y la nueva ciencia renacentista irán preparando el camino hacia nuevas comprensiones del mundo. Las fuentes morales empiezan a encaminarse hacia ámbitos hasta ahora insospechados. ${ }^{676}$

III.- Hacia una nueva poiesis del Estado. La Reforma va configurando la existencia de un gobernante que promueve una nueva praxis, una nueva forma de hacer política a partir de la aparición de un Estado que se configura como "ingeniero de la moral". Taylor se centra en Lipsio, una figura que él considera clave para establecer el relato que está configurando. ${ }^{677}$ Lipsio fue considerado a finales del siglo XVI y principios del XVII como uno de los principales humanistas del momento y un referente intelectual para todos ellos.

Lipsio promueve un "estoicismo semicristianizado", tanto en el lado calvinista como en el lado protestante y católico. En la nueva configuración de los Estados surge una nueva forma de hacer política que va más allá de las diferencias y promueve la paz y la reconciliación. En definitiva, se pretende crear un nuevo orden político. Buscaban un guía filosófico que les condujera en este camino y, de alguna manera, Lipsio se convirtió en su mejor promotor e ideal. Lipsio representa un estoicismo secularizado que promueve, frente al Cristianismo de la gracia y la acción de Dios, el poder racional

plenamente presente en la vida cotidiana y todos sus contextos, lo que llevó a las personas a investir a estos contextos de una nueva significación y solidez". TAYLOR, Ch., La Era Secular, tI, págs. 232-233.

${ }^{675}$ El fresco de la Capilla Sixtina de Miguel Ángel titulado "La Creación de Adán” quizás exprese como nada este realismo que expresa el equilibrio y al mismo tiempo la demarcación diferenciadora de ámbitos distintos en una relación adecuada de equilibrio: "los dos dedos que casi se juntan". Espacios distintos, realidades distintas, en un equilibrio en el que los dos dedos de las manos se acercan irremediablemente porque no pueden entenderse de otra manera: Dios para el hombre y el hombre hacia Dios. La realidad y la imagen que no se pueden separar pero que son a la vez distintas.

${ }^{676}$ Cfr. TAYLOR, Ch., Fuentes del yo, pág. 265.

${ }^{677}$ Cfr. MIKUNDA FRANCO, E., "J. Lipsio: Neoestoicismo, iusnaturalismo y derechos humanos", Anuario de Filosofía del Derecho, Vol. VII, (1990), págs. 356-357. Siguiendo a Mikunda Franco, Lipsio es un autor que ha sido a veces marginado o porque no se le ha estudiado en el contexto adecuado y no se han sacado conclusiones adecuadas en relación con lo que plantea, o porque no se le ha interpretado dentro de los cánones oficialmente asumidos como tales. Taylor contribuye a rescatar su importancia y en sintonía con el investigador alemán Oestreich contribuye a darle la importancia y relevancia que se merece, sacándole del ostracismo en el que a veces ha estado. Entre sus rescatadores del olvido están Dilthey y Oestreich. 
y el autocontrol y, frente al Cristianismo del ágape y el amor al prójimo, la apatheia y la desconexión benevolente, más allá de cualquier sentimiento compasivo.

Este neoestoicismo secularizado o esta secularización del Cristianismo, según dónde pongamos el acento, será un paso más en el camino hacia el humanismo exclusivo. No se pronunciará sobre la necesidad de la gracia, pero tampoco estamos en el humanismo exclusivo, Dios sigue fundamentando la ratio en la que se enraíza la vida. ${ }^{678}$ Seguirá las huellas erasmistas de su predecesor y compatriota y ahondará los caminos hacia el surgimiento de un estado nuevo configurador de la vida social y moral. El neoestoicismo que aparece en Europa en los siglos XVI y XVII no solo será un movimiento filosófico, sino que tendrá su referente en la nueva teoría política que pretende proyectar una ética que dé fundamento a los nuevos Estados emergentes en sus luchas de religión y en la disciplina militar. ${ }^{679}$ Se trata de un humanismo tardío que se va alejando de la teología dogmática católica, para ir acercándose progresivamente a una filosofía de valores más neutrales o que guardan relación con las tesis bíblicas, pero no necesariamente expresados en los mismos términos. Se recurre a una fundamentación más genérica, que evite cualquier controversia entre las distintas confesiones, para evitar así los enfrentamientos civiles y de religión de los que Europa había sido testigo.

Van surgiendo pensadores, entre ellos Lipsio, que contribuyen a potenciar una versión de la fe menos obsesionada con la ortodoxia tradicional y más en relación con el nuevo orden filosófico y político que se va configurando, al propio tiempo que propician una sana relación entre todas las Iglesias.

Lo que realmente interesa resaltar aquí es analizar en qué medida el neoestoicismo conduce al deísmo a través del abandono de ciertos elementos cruciales del Cristianismo, tal y como se ha señalado anteriormente. Cuando se abandona la teología de la gracia para centrarse en el autocontrol racional y el ágape para centrarse en la apatheia estoica como desconexión benevolente, entonces, dice Taylor, nos encaminamos irremediablemente hacia un deísmo que cultiva la razón y la constancia como el culto razonable a Dios. El camino recto de la constancia nos posiciona en la misma dirección que el seguir a Dios. ${ }^{680}$

\footnotetext{
${ }^{678}$ Cfr. TAYLOR, Ch., La Era Secular, tI, pág. 189.

679 “Ante esta situación se convertirá en el primer líder del estoicismo político de su tiempo, presentando en sus obras 'Constantia' y 'Política', — ambas íntimamente concatenadas - una ideología coherente, basada en fuentes romanas clásicas, de un modelo de Estado absolutista, pero 'moderado', que refleja la estructuración de la burocracia estatal y del ejército, la teoría legitimadora del poder soberano estatal y del príncipe, y las relaciones entre el Estado y la Iglesia”. MIKUNDA FRANCO, E., "J. Lipsio: neoestoicismo, iusnaturalismo y derechos humanos", pág. 363.

${ }^{680}$ TAYLOR, Ch., La Era Secular, tI, pág. 189.
} 
En este autocontrol racional, Lipsio, en su obra La Constancia, advierte sobre la necesidad de apaciguarse interiormente y buscar en el propio yo las causas de los males que aquejan la conciencia y el alma. La razón y el autocontrol adoptan en Lipsio el nombre de "constancia" como firmeza, como relevancia personal, como disciplina autocontroladora que asume riesgos y emprende el valor de luchar frente a toda clase de peligros que debilitan la propia conciencia racional, ${ }^{681}$ invitando a la templanza personal. Una constancia que es definida como "vigor y firmeza de ánimo" que encuentra su fundamentación en el juicio y el recto entendimiento. ${ }^{62}$ Según Taylor, Lipsio propugna una moralización de El Príncipe de Maquiavelo, con estrictos principios morales y una búsqueda irrefrenable del bienestar público. ${ }^{683}$ Frente al príncipe despiadado de Maquiavelo, que actúa al margen de cualquier moral cristiana y al que le está permitido toda clase de artimañas con tal de conseguir y mantenerse en el poder, el príncipe de Lipsio tiene que mantener una actitud moralizante y actuar conforme a un estoicismo ético que impregne de moralidad todo el aparato burocrático del Estado, incluidos los soldados. ${ }^{684}$

Y este príncipe es el que, al modo de ver de Taylor, con su ética personal y ejemplo moral, pondría las bases para una reconstrucción profunda de la sociedad a través de la disciplina y el autocontrol de la población. Mediante la ejemplaridad de vida del príncipe, se llevaría a cabo un proceso de interiorización de los valores que conduciría a toda la sociedad a realizar una agenda de reforma y autocontrol disciplinario. ${ }^{685}$ Nadie podría negarse a seguir el ejemplo del príncipe. ${ }^{686}$

Taylor sugiere que son dos los elementos que contribuyen a realizar esta agenda de civilidad: por una parte, la ética calvinista del rigor disciplinario y, por otra parte, la actuación del Estado a través de una tarea ejemplificadora por parte del Príncipe. Ambos

\footnotetext{
681 “QQué importa que vayas a lugares muy pacíficos? ¿La guerra la llevas contigo aunque vayas a lugares quietos? Los alborotos están alrededor de ti, o por mejor decir, en ti mismo, porque este ánimo discorde combate siempre, y combatirá contigo, apeteciendo, huyendo, esperando, y desesperando". LIPSIO, J., Sobre la constancia, Libro I, capítulo II, Sevilla, 1616, págs. 9-10 (adaptación propia del texto original).

${ }^{682}$ Cfr. LIPSIO, J., Sobre la constancia, Libro I, Cap. III, pág. 11.

${ }^{683}$ Cfr. TAYLOR, Ch., La Era Secular, tI, págs. 193-194.

684 "Dos cosas hay que hacen al príncipe legítimo y de todo punto cumplido: la prudencia y la virtud. La una ha de parecer y lucir en las acciones, y la otra, en la vida (...) Porque entonces el Rey se elige entre los más idóneos y capaces por la excelencia de su virtud o acciones que lo sean. Yo digo con el poeta ser rey verdadero, no quien tiene el dominio, sino el que bien obra". LIPSIO, J., La política, Los seis libros de las Políticas o doctrina civil de Justo Lipsio, Libro II, Cap. VII, Madrid, Imprenta Real, 1604, pág. 31 (adaptación propia del texto original).

${ }^{685}$ Cfr. MIKUNDA FRANCO, E., "J. Lipsio: neoestoicismo, iusnaturalismo y derechos humanos", pág. 366. Según nuestro autor canadiense, Lipsio propugna una vía ecléctica entre los monarcómacos y los absolutistas, a través de un príncipe absoluto, pero con participación del pueblo en el censo y la vinculación del monarca a Dios, a las leyes y a la filosofía estoica de la virtud y la prudencia. Lipsio representa así un eslabón entre Bodino y Hobbes.

686 "Como los reyes quieran las cosas virtuosas, no habrá quien no las quiera. Queréis los disolutos y malos, descomponeos. Porque los príncipes no solo conciben los vicios, pero los derraman por la ciudad, haciendo más estrago y daño por el ejemplo, que por la maldad que cometen”. LIPSIO, J., La política, Libro II, Cap. IX, pág. 34.
} 
aspectos coadyuvaron, en igual medida, a que se introdujera esta agenda de civilidad en una vida racionalizada, disciplinada y profesionalizada. Calvinismo y Neoestocismo, uno desde abajo a través de un voluntariado comprometido y emprendedor, y el otro desde arriba a través de burocracias estatales entrenadas en un sentido profundo de la disciplina y el orden. Para Taylor se trata de la ética protestante del trabajo de la que habla Weber, pero también de una autoridad política perfectamente entrenada para establecer una agenda de reformas profundas de la sociedad que empezaban por la ejemplaridad moral del príncipe virtuoso y prudente. Se pretendía ordenar la sociedad a través de fuertes dosis de racionalidad, tanto a nivel privado en el desempeño de las actividades profesionales propias de su condición, como a nivel público desde la implicación en un funcionariado que conllevara un ordenamiento moral de la sociedad desde una agenda comprometida y solidaria de reformas por el bien común. Y no era difícil que el Neoestoicismo estableciera vínculos con el calvinismo y también con el protestantismo y el catolicismo. ${ }^{687}$

Se trataba de inculcar en la sociedad un sentido de civilidad y vida ordenada, y para ello, era necesario evitar cualquier tipo de violencia y desorden tanto en la vida personal como en la social. Es decir, se pretendía que la violencia quedara reducida al crimen individual o a la legítima violencia del estado en guerra. Se ponía el listón muy alto a pesar de ser conscientes de que había habido otras edades de oro en la historia de la humanidad. Por parte del calvinismo se ponía como ejemplo el pueblo de Israel en el Antiguo Testamento o los inicios del Cristianismo. Por parte del Neoestocismo se miraba al Imperio Romano con sus grandes ideales de civilidad en torno al derecho y la política, a los historiadores como Tácito y al Estoicismo de Séneca. Los ideales de la cultura romana en su derecho y la filosofía estoica recuperan su auge. El Derecho Romano inspira la acción política de un Estado que promueve reformas sociales y el Estoicismo filosófico motiva el autocontrol ejercido desde la voluntad y las virtudes estoicas. ${ }^{688}$

Pero para Taylor, lo realmente relevante está en analizar qué es lo que motivó esta agenda civilizadora para todos, creando una sociedad en la que todos se sintieran implicados en una voluntad personal de reforma y autocontrol y al mismo tiempo motivando el surgimiento de estados que ayudaran en dicha agenda de disciplina y racionalidad. ${ }^{689} \mathrm{Se}$ trataba de un proyecto de ingeniería social en la que se entremezclaba, por una parte, la idea de que la persona era moldeable, con un profundo sentido positivo de la condición humana y, al mismo tiempo, en la creencia de que los Estados podrían implicarse en dicha agenda de reforma personal y autocontrol racional,

\footnotetext{
${ }^{687}$ Cfr. TAYLOR, Ch., La Era Secular, tI, pág. 194.

${ }^{688}$ Cfr. Ibid., pág. 196.

${ }^{689}$ Cfr. TAYLOR, Ch., Imaginarios Sociales Modernos, págs. 87 y ss.
} 
a través de la ejemplaridad de los gobernantes y a través de una burocracia estatal que ayudara con reformas y cambios legislativos.

Taylor refiere un aspecto que nos parece relevante no olvidar, y es la fe de los calvinistas en la capacidad del ser humano por regenerarse y modelarse según una agenda civilizadora establecida a través de proyectos legislativos que llevaran a cabo una profunda transformación de la naturaleza humana. ${ }^{690}$ Ante este ideal que se va imponiendo, y los esfuerzos por llevarlo a cabo, Taylor se pregunta qué impedimentos podían interponerse ante una agenda civilizadora que implicara a todos o a casi toda la sociedad. Nuestro autor canadiense cita la mentalidad tradicional medieval, que podría influir en una visión distinta de las cosas y desmotivar, de alguna manera, en una agenda de reforma de tan alto alcance. La Edad Media europea se expresaba en las formulaciones de San Agustín y las dos ciudades, una ciudad terrena y una ciudad de Dios, que viven entremezcladas y que manifiesta la dificultad por introducir a la ciudad terrena en los planes de orden y de santidad. Este vivir juntos debe llevar a "soportarse", de tal manera que no parece que haya otra posibilidad de cambio en la ciudad terrena que desea vivir según sus gustos e inclinaciones. ${ }^{691}$ Era necesario superar la mentalidad medieval de pasividad y paciencia en el soportarse e iniciar una agenda que posibilitara el orden y el control racional en la sociedad. Se trataba de creer en la capacidad de reforma del ser humano, en su naturaleza moldeable y en su capacidad para cambiar y recrearse en procesos de autocontrol disciplinario, para así introducir agendas de reforma social que motivaran el cambio individual y lo encauzaran vital y socialmente. San Agustín no creía que el Estado pudiera influir en la reforma de la ciudad terrenal, con lo cual solo la ciudad de Dios, representada por la Iglesia, podía aspirar a eso. En estos momentos, con la Reforma, la ciudad de Dios, apoyada por la nueva teoría política del Estado indulgente y benevolente que motiva esta agenda de reformas legislativas, puede implicarse en un cambio disciplinario y de orden "de todos". 692

Los reformadores siguen pensando en San Agustín como su gran guía espiritual y que los salvados serán pocos. Por eso, esta élite intelectual y espiritual, tanto desde el gobierno como desde la espiritualidad calvinista, puede orientar esta labor de reforma "para todos". Los elegidos están convencidos de que son la élite que puede gobernar y disciplinar toda la sociedad. Esta es la gran propuesta de la Reforma: se diluyen los

\footnotetext{
${ }^{690}$ Cfr. TAYLOR, Ch., La Era Secular, tI, pág. 198. "Los puritanos sentían dentro de sí mismos —santos sin lugar a dudas y a menudo hombres enjundiosos - la fuerza y la energía necesarias para controlar la maldad humana, trascendiendo, incluso, el mundo del pecado y distinguiéndose de sus miembros menos afortunados". WALTER, M., La revolución de los santos, pág. 225.

691 "Así que, a mi modo de ver, no es despreciable la razón por la que pasan penalidades malos y buenos juntamente, cuando a Dios le parece bien castigar incluso con penas temporales la corrompida conducta de los hombres. Sufren juntos no porque juntamente lleven una vida depravada, sino porque juntos aman la vida presente. No con la misma intensidad, pero sí juntos. Y los buenos deberían menospreciarla para que los otros, enmendados con la reprensión, alcanzasen la vida eterna”. HIPONA, A. de, La ciudad de Dios, Libro I, Cap. IX, 3.

${ }^{692}$ Cfr. TAYLOR, Ch., La Era Secular, tI, pág. 200.
} 
límites agustinianos tan estrictos numéricamente en torno al número de los salvados, con lo que a nadie se le quita la posibilidad de estar entre ellos.

Lo que realmente nos interesa es seguir "la idea que subyace a estos cambios". La sociedad de estamentos y de estructuración interna y jerarquizada va dejando paso a una articulación totalmente distinta de la vida y de su relación con los bienes morales. El marco de concepción cambia totalmente. En el marco anterior, la pobreza tenía un alcance teológico en el que la frase de Jesús: "a los pobres siempre les tendréis entre vosotros", expresaba un sentido de ayuda a los pobres, pero también una ocasión de salvación para aquellos que se solidarizaban con ellos. No se trataba tanto de un Estado que establecía una agenda de reforma social, sino de una sociedad teológica en la que se daba por hecho que la pobreza siempre estaría ahí y no se podría evitar.

Con la aparición de la Modernidad se empieza a comprender que la complementariedad entre el orden y el caos, la ciudad de Dios y la ciudad secular ya no es necesaria. Se trata de una nueva concepción del mundo y del tiempo que surge en el ámbito cristiano y que se irá deslizando poco a poco hacia referencias seculares, como hemos visto en Justo Lipsio y el Neoestocismo cristianizado. Poco a poco se irá llegando al tiempo homogéneo y secular, a un orden personal de autocontrol y a un orden social caracterizado por una nueva forma de teoría política. Las viejas teorías de la complementariedad se van superando en el establecimiento de un orden civilizador, expresado personal y socialmente. No es necesario el orden que se establece por su opuesto necesario del caos y el mundo patas arriba. ${ }^{693}$

Las referencias que ponen límites a las posibilidades humanas o a desequilibrios que difícilmente pueden ser superados, se van reorientando para ir tras un ideal que cree profundamente "en la capacidad humana para realizar sus propias metas y establecer fuentes morales que nos identifiquen en nuestra autonomía personal y social". Hacia dichas metas se encaminan los primeros pasos de Justo Lipsio y su agenda neoestoica. En el siglo XVI, se producirá la domesticación de las élites, y en el siglo XVIII, se habrá extendido ya a todas las capas sociales. Se impondrá definitivamente el nuevo marco de comprensión e identificación social. No hay límites para establecer racionalmente la propia autoidentificación de control moral.

Y la pregunta lógica y consecuente que surge en este contexto: ¿qué es lo que motiva en las élites este deseo irrefrenable por transformar la sociedad e instaurar un orden establecido para todos?

\footnotetext{
693 "Se vuelve más fácil perder el sentido de que en principio hay un límite a la maleabilidad de las personas, al triunfo de lo superior sobre lo inferior. La naturaleza salvaje puede resistir la civilidad, pero no existe tal cosa como una pérdida irreparable, como un desequilibrio fatal, como la destrucción de algo esencial al todo. Se llega tan lejos como se puede". TAYLOR, Ch., La Era Secular, tI, págs. 203-204.
} 
Taylor pone en escena a un discípulo de Lipsio llamado Grocio y su propuesta sobre la Ley Natural. Ciertamente en la metafísica tradicional se hablaba de este orden que imponen las Formas en el mundo y que interactúan desde dentro por dar forma a este orden que puede contemplarse como razón eterna en el cosmos. ${ }^{694}$ En la nueva cosmovisión que se pretende instaurar, el orden ya no opera por sí mismo a través de las formas, sino que Dios ha establecido un orden natural que opera de hecho en la naturaleza. No son las formas las que se afanan por expresarse y dar razón del orden cósmico, sino que es la naturaleza la que tiene su propia expresión tal y como fue establecida por el Creador. Y esto se expresa no solo en el orden natural, sino también en el orden social. En el ámbito social no se trata de algo que está funcionando dentro de la propia configuración social estableciendo órdenes jerárquicos en el orden del ser, sino de descubrir el orden social como correlato del orden natural que posibilita relaciones de engranaje y entendimiento a través de la razón.

Esto es lo que se configura bajo la idea de la Ley Natural por parte de Grocio. Los fines de la naturaleza humana, según la definición aristotélico-tomista, son distintos a los que se conciben desde la ley natural. Para Grocio, la ley natural "conviene" a la condición propia del hombre como ser social y ser racional. ${ }^{695}$ Una ley natural que dicta la "recta razón" y que invita a seguir los dictados de la naturaleza racional y en última instancia al Dios, autor de la naturaleza. ${ }^{696}$

Se trata de establecer leyes según la razón humana que iluminan por su propia naturaleza la mente para un comportamiento moral adecuado, evitando así la fealdad de comportamientos que no se conducen por la razón. Es la razón la que en su luz natural ilumina el camino de comportamiento moral. Una razón que, a su vez, pone en relación con Dios como "autor de la naturaleza". De tal manera que seguir los dictados de la razón es seguir los "mandatos de Dios".

No obstante, para Grocio, esta ley es obligatoria siguiendo la razón, "aunque concediésemos, lo que no se puede hacer sin gran delito, que no hay Dios, o que no se cuida de las cosas humanas", ${ }^{697}$ mientras que Pufendorf y Locke, como dirá Taylor, "consideran que es obligatoria en tanto mandato de Dios". ${ }^{698}$ Grocio, de alguna manera, sugiere (aunque reconozca que "puede ser un gran delito su sola sugerencia"), que el

\footnotetext{
${ }^{694}$ Cfr. DILTHEY, W., Hombre y mundo en los siglos XVI y SVII, págs. 14-15.

695 "Lo que se dice, pues, no a Carneades solamente, sino a otros también: la utilidad es madre no lejana de lo justo y equitativo, hablando con exactitud, no es verdadero; porque la madre del derecho natural es la misma naturaleza humana, la cual, aunque de nada necesitáramos, nos inclinaría a desear la sociedad mutua; y la madre del derecho civil es la misma obligación nacida del consentimiento, la cual, como tome su fuerza del derecho natural, puede también llamarse a la naturaleza como la bisabuela de este derecho. Pero la utilidad se añade al derecho natural". GROCIO, H., Del Derecho de la Guerra y de la Paz, Tomo I, Madrid, Editorial Reus, 1925, pág. 15.

${ }^{696}$ Cfr. Ibid., pág. 52.

${ }^{697}$ Cfr. Ibid., pág. 13; cfr. TAYLOR, Ch., Fuentes del yo, págs. 323,349.

${ }^{698}$ Cfr. TAYLOR, Ch., La Era Secular, tI, pág. 206.
} 
seguir los dictados de la razón es ley obligatoria para el comportamiento humano. Da tanta importancia a la identificación entre ley natural y Dios que incluso podría plantearse el seguimiento de la ley natural sin tener en cuenta a Dios "como posibilidad", "aunque se planteara dicha concesión de pensamiento". 699

Frente a este derecho natural, Grocio habla de otra clase de derecho determinado por la "voluntad" y que puede ser humano o divino. Según dirá Grocio, como "apenas se encuentra un derecho fuera del natural... este derecho civil o de gentes... es una invención del tiempo o la costumbre". ${ }^{700}$ Para Grocio, el derecho voluntario divino prácticamente se identifica con el derecho natural, en el sentido de que en el derecho natural "Dios quiere una cosa porque es justa", mientras que en el derecho voluntario divino "una cosa es justa porque Dios lo quiere". ${ }^{701}$ Es decir, que en el derecho natural vemos por qué una cosa es justa y descubrimos que es Dios quien lo quiere así, mientras que en el derecho de voluntad divino Dios manifiesta "la justicia porque así Él lo quiere", es el mismo Dios que quiere la justicia en sus propios términos y voluntad. Se puede afirmar que "casi llega" a identificarse el derecho natural con el derecho voluntario civil (se le añade la fuerza de la costumbre y la tradición) y con el derecho voluntario divino (porque Dios lo quiere). Por lo tanto, para Grocio el derecho natural, de alguna manera, incluye tanto el derecho voluntario civil o de gentes y el derecho voluntario divino. En un caso, es una matización de costumbres y tradiciones respecto al derecho natural y, en el otro, una expresión concreta de Dios "porque así lo quiere" manifestar Él. En conclusión, podemos afirmar que, según la Ley Natural, no se necesita la revelación porque por la "naturaleza de los productos de Dios" podemos saber lo que Él quiere. Las reglas están inscritas en lo que Dios ha creado, dejando el Creador la impronta de lo que Él quiere.

En este sentido Taylor sugiere que, a la sociedad, se le concede una existencia anterior al gobierno, pues esta sociedad surge en torno al derecho natural que es anterior al civil. Taylor afirma que la nueva actitud reconstructiva de la sociedad tuvo en el Neoestocismo y en la ley natural las actitudes que se impusieron con mayor naturalidad. $^{702}$

No obstante, nuestro autor canadiense no se olvida de que también estuvo la respuesta del Estado Absoluto como otra respuesta que también tiene lugar en este

\footnotetext{
699 "Aun el mismo derecho natural de que hemos tratado, ya el social, ya el que se llama así más ampliamente, aunque nace de los principios internos del hombre, con todo puede en justicia atribuirse a Dios, porque él quiso que existieran en nosotros tales principios: en el cual sentido Crisippo y los Estoicos defendían que el origen del derecho no se había de buscar más que en el mismo Júpiter, de cuyo nombre de Júpiter (Jovis) puede afirmarse probablemente que derivaron los latinos la palabra ius (derecho)". GROCIO, H., Del Derecho de la Guerra y de la Paz, pág. 14.

${ }^{700}$ Cfr. Ibid., págs. 59-60.

${ }^{701}$ Ibid., pág. 61.

${ }^{702}$ Cfr. TAYLOR, Ch., La Era Secular, tI, págs. 389,442.
} 
momento histórico. Según Taylor, fue una respuesta perdedora, anacrónica, porque no representaba la "transición necesaria", dado que no tenía el encanto de las "ideas premodernas", puesto que mantenía la complementariedad jerárquica, con lo que era menos "innovadora", a pesar de que también propugnaba la idea de orden como la respuesta neoestoica y naturalista. Bossuet es el que representa la respuesta absolutista, aunque sin olvidar su actitud abierta también a ciertos elementos de la Modernidad. ${ }^{703}$

En Bossuet el orden jerárquico y el gobierno absoluto no son una expresión del orden inherente a la naturaleza del cosmos. Se trata más bien de una respuesta más al problema del orden y la civilidad que se buscan desde una visión moderna. Aparentemente, la respuesta es premoderna, pero el mundo que se reconoce es un mundo ubicado en la modernidad y en la realidad de agentes que no son expresión de un mundo "dado" desde la naturaleza del cosmos, sino desde un mundo construido desde la racionalidad. La jerarquía y el gobierno absoluto ya no responden a un "locus" de orden natural, sino a una concepción centrada en un orden a construir, asignando a cada uno su propio lugar. Se pretende asignar desde el poder absoluto de la cúspide la capacidad de poder trasladar a la sociedad dicho orden de civilidad. De alguna manera, las teorías de Grocio y Pufendorf, según Taylor, transigían con esta posibilidad de autoridad absoluta. Además, dichas teorías del poder absoluto encajaban con el ideal de la Providencia divina, según la cual al obedecer a la autoridad regia se estaba obedeciendo a la voluntad de Dios. ${ }^{704}$

Según Taylor, esta concepción está a medio camino entre el orden medieval y el orden moderno dominado por el Derecho Natural. Se trataba de conjugar la autoridad divina de los reyes con la apertura al Derecho Natural establecido racionalmente. Surge un mundo nuevo, pero en el que la tradición anterior busca su propio encaje dentro de la civilidad y el orden que se busca racionalmente. El estado absoluto entra en contacto con la Iglesia católica tridentina y con el Antiguo Régimen. Es lo que Taylor denomina con la expresión "concepción barroca” de la política y la existencia. ${ }^{705}$

Por el contrario, la concepción neoestoica de la Ley Natural y posteriormente lockeana desarrollan una concepción de la vida y la política totalmente distinta. Es una

\footnotetext{
${ }^{703}$ Cfr. Ibid., pág. 208. "La serie de estas dos cosas, quiero decir la de la religión y la de los imperios, es la que debéis grabar en vuestra memoria; y como la religión y el gobierno político son los dos ejes sobre los que ruedan las cosas humanas, ver lo que 'a ellas concierne' encerrado todo en un compendio, y descubrir por este medio todo su orden y sucesión, es comprender en su pensamiento tolo lo que hay de más grande entre los hombres, y tener, por decirlo así, en la mano el hilo de todos los acontecimientos del universo". BOSSUET, J-B., Discurso sobre la Historia Universal, C. G. de Impresores y Libreros, Madrid, 1842, págs. 4-5.

${ }^{704}$ Cfr. TAYLOR, Ch., Argumentos filosóficos, pág. 279.

${ }^{705}$ Cfr. TAYLOR, Ch., Imaginarios sociales modernos, pág. 201. Este derecho natural será no solo el que sirva para configurar el poder absoluto a través del contrato de sometimiento frente al cual Rousseau planteará el contrato social, sino que además se invocará para defender la independencia en la revolución social y política de Norteamérica frente a "los derechos de los ingleses".
} 
teoría voluntarista, que establece leyes y objetos de reconstrucción sobre esta base racional de la existencia en la que los individuos son iguales, establecen criterios de una nueva política de beneficio mutuo y ponen las bases de una política económica basada en el crecimiento y el desarrollo de los recursos naturales y en el asentamiento de la propiedad privada. ${ }^{706}$ Para Taylor, frente a las teorías clásicas del contrato, Grocio y Locke parten del individuo. Estar dentro de un orden político al que se debe lealtad presupone que uno ha otorgado a ello su consentimiento. ${ }^{707}$ Las teorías del contrato previas a Grocio, Locke y Pufendorf están en el estoicismo, en el consentimiento conciliar y F. Suárez. ${ }^{708}$

Este es el objetivo nuevo que surge sobre la conciencia racional del ser humano, un nuevo horizonte vital basado en el orden natural de las cosas, en el que la providencia divina va actuando a través del Espíritu que ordena todo hacia nuevas metas de racionalidad, civilidad y orden. Un objetivo que irá plasmando el sentido hegeliano de la historia en clave constructivista y partiendo de la teleología aristotélica. ${ }^{709}$ En el fondo, la idea de Grocio es una ética de libertad. ${ }^{710}$ Es el bien social que se va abriendo camino a partir de nuevas visiones de la historia y del hombre. Es la nueva concepción del tiempo basado en la linealidad frente a los tiempos superiores y de rupturas. Todo se vuelve homogéneo y, por ende, "vacío", "hueco", en el que otros referentes se van desdibujando y en el que los nuevos horizontes morales se empiezan a construir desde el yo histórico y racional del ser humano. ${ }^{711}$ Un horizonte moral en el que la gran

\footnotetext{
706 "Esta noción ha nacido del sentimiento de insuficiencia de las ideas eclesiásticas para la configuración de lo real, y si unas veces luchaba contra las ideas religiosas y otras trataba de aliarse con ellas, siempre se afanó por penetrar lo real, por analizarlo y construirlo, por construir sus leyes, logrando así el dominio sobre la naturaleza y procurando dar satisfacción a las enormes necesidades de la nueva sociedad tan fecundamente laboriosa mediante un orden nuevo. El principio de esta gran filosofía más potente que cualquier filosofía anterior y con respecto a la cual las diversas doctrinas metafísicas habrían de ser consideradas como productos accesorios ha surgido de la conciencia de la inmanencia del carácter intelectual de lo real. Así como la naturaleza se halla regulada armónicamente mediante grandes leyes, así como los cuerpos celestes no tropiezan jamás en sus trayectorias ordenadas, existe también en la sociedad humana una legalidad que sin ninguna intervención artificial procura la armonía de la misma. Esta teoría es la del sistema natural en la sociedad". DILTHEY, W., Hombre y mundo en los siglos XVI y XVII, pág. 253.

${ }^{707}$ Cfr. TAYLOR, Ch., Fuentes del yo, pág. 127.

${ }^{708}$ Cfr. Ibid., pág. 267.

709 "La naturaleza no 'servía' ya al hombre. Por teleológica que pudiera ser, por mucho que el hombre y la sociedad pudieran alzarse como 'objetivos' suyos, este objetivo no es ya subjetivo, sino objetivo. Teleología de la naturaleza, significa que la naturaleza conduce necesariamente al hombre, pero no que existe necesariamente para beneficio del hombre. De aquí pudo surgir una y otra vez la idea —aunque a menudo de forma primitiva - de que la cosa en sí podía transformarse en para nosotros. La humanidad no está más 'completa' que la naturaleza. Mediante el conocimiento de la naturaleza y su uso, el hombre puede realizar todo lo que hasta el momento le contenía, en tanto que finalidad y solo objetivamente, en el "ser para sí’”. HELLER, A., El hombre del Renacimiento, págs. 387-388.

${ }^{710}$ Cfr. TAYLOR, Ch., La Era Secular, tI, pág. 447.

${ }^{711}$ Taylor cita a Benedict Anderson en su estudio sobre el surgimiento de los estados Modernos. Estados modernos que surgen en el siglo XVIII en relación con los nacionalismos emergentes y que él contextualiza culturalmente, filosóficamente, en relación con las cosmovisiones religiosas y los reinos dinásticos que les precedieron. Benedict Anderson en su obra Comunidades Imaginadas habla de la nueva aprehensión del tiempo que surge con la Modernidad. Un tiempo que ya no nos remite a los orígenes
} 
cadena del ser se ve superada por el orden natural, cuyas formas siguen "actuando en la naturaleza", en una realidad de las naturalezas en las que todas sus partes, uncidas de manera mecánica, contribuyen al funcionamiento mecanicista del mundo a través de su propio entramado. $^{712}$

\section{III.2.2.4. EL SUJETO DESVINCULADO Y EL AUTOCONTROL RACIONAL}

El siglo XVII es un siglo decisivo para la desontologización del mundo. El orden de las Ideas deja de ser algo que encontramos en el cosmos para pasar a ser algo que "construimos" científicamente. El camino interior agustiniano, en el que el yo siente su impotencia ontológica para comprenderse a sí mismo desde su propia interioridad, enfatizando así la necesidad de lo trascendente para ubicarse moralmente y comprenderse como "necesitado de Dios", es superado en Descartes para abrirse a nuevas fuentes morales en las que el yo, sin perder las referencias trascendentes, se afirma en su camino interior como yo que piensa y desde el que adquiere una nueva autocomprensión, como yo autónomo. Los pasos intermedios de Ockham, Scoto, Lipsio y Grocio parecen también relevantes en el análisis que se está realizando.

Con Descartes "se cambia la mirada" desde el camino interior agustiniano, que pone el fundamento y la raíz de todo en Dios, a la mirada interior que afirma la "plenitud de la autopresencia" como consciencia de orden mental que es capaz de inferir el orden del mundo como inferencia racional. Se pasa de fundamentar el orden del mundo a través de la mirada interior que descubre a Dios como raíz y fundamento de todo, al descubrimiento intelectual de un orden que parte de la "autoafirmación del yo que piensa" y que infiere posteriormente el aval de la trascendencia. Dios es el que garantiza la verdad de nuestros medios cognoscitivos. Alguien ha impreso, en nuestro yo que piensa, la capacidad de descubrir al que ha organizado "la máquina del mundo".

míticos del mundo, a los tiempos de los orígenes o al tiempo creador divino. Las nuevas aprehensiones del tiempo configuran una nueva cosmovisión cultural que tiene que ver con el surgimiento de los Estados Modernos y las ideologías nacionalistas. El cristianismo asumió una mirada atemporal del mundo de tal forma que el presente medieval o premoderno se expresaba desde las fuentes morales del cristianismo. El cristianismo lo englobaba todo. La cosmovisión cristiana se realizaba universalmente y se expresaba en lo concreto de cada comunidad. La visión del Cristianismo tenía "alcance universal" para expresarse en cada realidad concreta. La concepción medieval de la historia no establecía rupturas o visiones del tiempo fracturadas en pasado o presente o futuro, sino que todo es un presente eterno que envuelve los ropajes de la historia en un halo de eternidad. El presente es el tiempo futuro en el que todo puede ocurrir a partir del pasado mítico del cristianismo ("el día del Señor llegará como un ladrón en la noche"). Afirma Anderson que la idea de la simultaneidad, del "mientras tanto" medieval desaparece con el advenimiento de la Modernidad. Y pone el ejemplo de la nación como la realidad sociológica que expresa este "vaciamiento ontológico" del tiempo que se transforma en un tiempo vacío y homogéneo. "La idea de un organismo sociológico que se mueve periódicamente a través del tiempo homogéneo, vacío, es un ejemplo preciso de la idea de la nación, que se concibe también como una comunidad sólida que avanza sostenidamente de un lado a otro de la historia". ANDERSON, B., Comunidades Imaginadas, FEC, Madrid, 1992, pág. 48.

${ }^{712}$ Cfr. TAYLOR, Ch., La ética de la autenticidad, págs. 129-131; cfr. TAYLOR, Ch., La Era Secular, tI, págs. 276,300 . 
Para Taylor, la interioridad agustiniana está detrás del giro cartesiano, y el universo mecanicista fue en origen una demanda de la teología. Es decir, en Descartes, Locke y Kant, la dignidad que como agentes racionales poseemos, se ubica en una perspectiva teísta: las formidables facultades humanas de la razón y voluntad forman parte del plan de Dios y constituyen la imagen de Dios en nosotros. Pero en la medida en que las fuentes anidan dentro de nosotros mismos, afirma Taylor, ahí está la base para una moral independiente, no teísta. ${ }^{713}$

En el comienzo de la Edad Moderna, se comienza a reclamar la reafirmación del espíritu humano que lleva a una seguridad autofundamentadora. La libertad que conlleva esta fundamentación autorreveladora es la que conduce a una consciencia que no acepta sin más las condiciones en las que se fundamenta el camino de la razón y esa seguridad autoconsciente, sino que abre espacios para la búsqueda insaciable del conocimiento cierto y seguro, y evidente. El desarrollo de la facultad de la razón desvinculada y autorresponsable ha tendido a dar crédito a una visión del sujeto como un yo no situado, incluso puntual. Se objetivan las facetas de nuestro ser en la ontología del sujeto, como si fuéramos agentes separables de todo lo que nos es meramente dado: un yo que piensa en un alma desencarnada (Descartes), una capacidad puntual para reificar (Locke) o, finalmente, la reducción a un puro ser racional (Kant). ${ }^{714}$

Algunos autores como Blumemberg, Koselleck y Jauss afirman que Descartes es, en cierto sentido, un vínculo entre el mundo medieval y el mundo Moderno, dado que la autogarantía del cogito lleva a un cierto desprendimiento de la escatología, pasando así a la utopía. ${ }^{715}$ Descartes confirma con su pensamiento el fin de la inseguridad del conocimiento y la crisis de verdad, pero al mismo tiempo abre y posibilita los nuevos caminos que permiten andar con seguridad en esta vida dando comienzo a la Modernidad.

Según Blumemberg, todo esto nos remite a Ockham como uno de los antecedentes de la Modernidad. "Al separar la pasividad de la percepción sensorial, en la que el hombre está a merced del influjo que se ejerza sobre él, y la actividad del juicio, que es donde se expone al riesgo del error, los nominalistas ponían ya el fino y sólido cimiento de la autoafirmación". ${ }^{716}$ Para Ockham y el Nominalismo existe la "posibilidad" de una ruptura en la relación entre objeto real e impacto cognitivo, de tal forma que se produciría la posibilidad de que más que objetos reales se trataran unas "causalidades secundarias" adaptadas al acto cognoscitivo, produciéndose así un cierto "rodeo" sobre la propia realidad creada, una "reducción epistemológica" que permitiría el acto cognoscitivo no desde el objeto mismo o de la posibilidad de su existencia, sino de una

\footnotetext{
${ }^{713}$ Cfr. TAYLOR, Ch., Fuentes del yo, pág. 432.

${ }^{714}$ Cfr. Ibid., pág. 694.

${ }^{715}$ Cfr. BLUMEMBERG, La legitimación de la Edad Moderna, pág. 41.

${ }^{716}$ Ibid., pág. 194.
} 
"causalidad secundaria" que estaría en la base del acto cognoscitivo (Dios puede causar la cognición intuitiva de lo no existente). ${ }^{717}$

Lo que permite el acceso a la ciencia y a la realidad para Ockham es la intención, la proposición, la suposición, no las cosas mismas. ${ }^{718}$

Según Taylor, la revolución nominalista contra el realismo aristotélico estuvo motivada por el pensamiento de que la propuesta de una ética fundada en la supuesta inclinación de la naturaleza significaba poner límites al poder de Dios. Dios ha de conservar la plena libertad para establecer el bien y el mal por decreto. ${ }^{719}$

El poder omnipotente del Creador permitiría así la "inmediatez" cognoscitiva más allá de la realidad de los objetos, así como la superación de las mediaciones del mundo objetual, con lo cual se resalta el poder divino en toda la realidad creada y en todos los seres del mundo. Sería, de alguna manera, admitir la actuación de ese "genio maligno" que nos puede engañar, aunque ese engaño haya sido introducido por ese poder divino que no permitiría el acceso al mundo de lo objetual. Según Blumemberg, el nominalismo no permite diferenciar entre las representaciones causadas de forma primaria y las de tipo secundario, con lo que se mantiene ese absolutismo teológico de carácter omnipotente que evita el acceso al conocimiento de lo real sin genio maligno. ${ }^{720}$

Es curioso afirmar que la novedad cartesiana no parte de una oposición violenta al pensamiento nominalista, sino que enfrenta con valentía sus flancos más débiles teñidos de "absolutismo teológico" e incapacidad para asegurar la necesidad de una comprensión del mundo cierta y verdadera. Descartes asume el reto nominalista e imprime "decisión" para superar el arrastre teológico que impedía asumir la totalidad de un conocimiento "cierto" de lo real. Por otra parte, Taylor afirma que lo que Descartes conserva del Neoestoicismo es la norma de la desconexión, en el sentido de que la razón es la que nos dice lo que es mejor y cómo hay que actuar para conseguirlo. ${ }^{721}$

Descartes representa el primer paso "desvinculador" racionalizando el mundo para controlarlo y sacar consecuencias. Una desvinculación que, en opinión de Taylor, pretende detraer la dimensión intencional de la experiencia, lo que hace que la

\footnotetext{
${ }_{717}^{717}$ Cfr. Ibid., pág. 189.

718 "Hemos de afirmar con los filósofos que en la substancia particular nada es substancial sino la forma particular y la materia particular o algo compuesto por ellas. Y por tanto no hay que imaginar que en Sócrates exista una humanidad o una naturaleza humana distinta de Sócrates de algún modo, a la cual se añada una diferencia individual que contraiga esa naturaleza”. OCKHAM, G., Summa Logicae, I, c. 16.

${ }^{719}$ Cfr. TAYLOR, Ch., Fuentes del yo, pág. 226.

${ }^{720}$ Cfr. BLUMENBERG, H., La legitimidad de la Edad Moderna, pág. 190.

${ }^{721}$ Cfr. TAYLOR, Ch., La Era Secular, tI, pág. 169. “Todo lo que podemos llegar a vislumbrar en él es una idea de cómo se supone que deben funcionar las cosas, y eso es entonces algo que debemos poner en práctica, como vemos en el caso paradigmático de las pasiones”. Ibid., pág. 170.
} 
experiencia sea "de" algo. La desvinculación cartesiana significa, bajo esta perspectiva, atribuir a la experiencia un carácter no intencional, como las sensaciones internas y al igual que estas, en vez de relacionarlas con un objeto, las relaciono con una causa externa. ${ }^{722}$ Allí donde el alma platónica descubre su naturaleza eterna al ser absorbida en lo suprasensible, el alma cartesiana descubre y afirma su naturaleza inmaterial objetivando lo corporal. El alma cartesiana no se libera obviando la experiencia, sino objetivando la experiencia encarnada. ${ }^{723}$

Locke dará un paso más a través de lo que Taylor denomina el yo puntual. Un yo que se desvincula de las ideas innatas y de cualquier visión teleológica y ontológica del yo. No hay ideas innatas que predispongan hacia la Verdad ni en el sentido clásico del alma interior que contempla el orden del cosmos y se sitúa en sintonía con él, ni en el sentido moderno cartesiano de que se puede probar la existencia de Dios, pues es una idea clara y distinta y "pues no es posible imaginar que su idea (la idea de este ser soberanamente perfecto e infinito) no me representa nada real". ${ }^{724}$

Locke, por el contrario, niega la existencia de las ideas innatas y da un paso más hacia ese yo puntual. ${ }^{725} \mathrm{Al}$ desestimar el innatismo cartesiano en su afirmación de la existencia de Dios, ${ }^{726}$ Locke abre el cauce a una visión antiteleológica de la naturaleza humana, dando paso así hacia el mecanicismo empirista y el control racional del mundo. ${ }^{727}$ Locke atomiza la mente y su teoría de las ideas le lleva a reificarla hasta el grado sumo. ${ }^{728}$ Es la reificación de la primera persona en singular. Todo debe ser deconstruido para posteriormente reensamblar la idea del mundo de una manera totalmente objetiva. Hay que demoler cualquier clase de error basado en la impresión, en la costumbre o en la simple tradición de errores. Hay que reconstruir todo sobre la base de la "experiencia sensorial" y sobre nosotros mismos, que somos algo que existe realmente.

El yo puntual lockeano está desprovisto de cualquier teleología o disposición innata con la verdad o la búsqueda de la sintonía con el orden, el bien o la virtud. ${ }^{729}$ Locke supera y deja atrás la visión clásica y tradicional de la moral, como la voluntad que busca el bien, para pasar a unas fuentes morales que se basan "en el deseo que nos

\footnotetext{
${ }^{722}$ Cfr. TAYLOR, Ch., Fuentes del yo, pág. 227.

${ }^{723}$ Cfr. Ibid., pág. 207.

${ }^{724}$ DESCARTES, R., Meditaciones Metafísicas, Meditación Tercera, pág. 35.

725 "Quienes se tomen la molestia de reflexionar sobre las operaciones del entendimiento hallarán que este rápido asentimiento de la mente a ciertas verdades depende, no de una inscripción nativa, ni del uso de la razón, sino de una facultad de la mente completamente distinta, como veremos más adelante". LOCKE, J., Ensayo sobre el Entendimiento Humano, pág. 13.

${ }_{726}$ Cfr. DESCARTES, R., Meditaciones Metafísicas, pág. 34.

${ }^{727}$ Cfr. TAYLOR, Ch., Fuentes del yo, pág. 230.

${ }^{728}$ Cfr. Ibid., pág. 232.

729 "Lo que determina inmediatamente a la voluntad a cada acción voluntaria es la inquietud del deseo, ya sea negativa como la privación del dolor, o positiva, como el gozo en el placer". LOCKE, J., Ensayo sobre el entendimiento humano, pág. 49.
} 
inquieta para anhelar el bien". ${ }^{730}$ Se pasa del bien que motiva a la voluntad, al deseo que busca el bien. Del Bien como búsqueda insaciable de la voluntad humana se pasa a la inquietud de deseo como malestar (privación) o como gozo (posesión). La idea del bien se cambia por el deseo (una idea de la reflexión) que mueve la voluntad, sea por malestar o placer provocados por el Bien. Sin el deseo que inquieta y motiva reflexivamente (como acto intelectivo) no puede haber motivación moral. El malestar o el placer del deseo es lo que provoca inmediatamente a la voluntad según Locke. Para Taylor, Locke representa el voluntarismo teológico. La ley natural es normativa porque es el dictado de Dios. ${ }^{731}$

Locke pone así las bases de este "yo puntual" a través de este "absolutismo desvinculador" de base racional, que tiene su máxima expresión en la razón "controladora" de la fe y que establece un "determinismo voluntarista" de carácter reconstructivo. El yo real es, "sin extensión"; es el único que posee el poder de fijar las cosas como objetos. Es esta conciencia de la propia identidad y mismidad del yo que nos hace sentirnos como una conciencia, que nos percibe como seres totalmente únicos e independientes, capaces de voluntad autocontroladora y percepción con capacidad de "reconstrucción". ${ }^{732}$ Este es el yo lockeano de la autorresponsabilidad racional que representa la transición entre el nous aristotélico y la filosofía moral kantiana. ${ }^{733}$

Para Taylor, el mecanicismo nominalista afirma que la soberanía de Dios queda mejor salvaguardada ante una creación sin designios propios. Pero el sujeto desvinculado se asemeja a la deidad en este aspecto. La desvinculación opera objetivando el ámbito en cuestión, transformándolo en neutro. El sujeto desvinculado del mecanicismo empirista se arrogará algunos de los privilegios acordados para Dios en la teología de Ockham. ${ }^{734}$

\footnotetext{
${ }^{730}$ Id., pág. 49.

${ }^{731}$ Cfr. TAYLOR, Ch., Fuentes del yo, pág. 322.

732 "La experiencia nos convence, pues, de que tenemos un conocimiento intuitivo (la cursiva es nuestra) de nuestra propia existencia y una infalibilidad interna de lo que somos. En cada acto de sensación, de razonamiento o de pensamiento, somos conscientes de nuestro propio ser, y en este asunto llegamos al más alto grado de certeza que es posible imaginar". LOCKE, J., Ensayo sobre el entendimiento humano, pág. 94.

${ }^{733}$ Cfr. TAYLOR, Ch., Fuentes del yo, pág. 242. "La conglomerada mente cartesiana que Locke daba por supuesta se parecía al nous aristotélico solo lo suficiente para dar un sabor tradicional a la idea de la "impresión" y se separaba de él lo suficiente para hacer posible el escepticismo de Hume y el trascendentalismo kantiano. Locke estaba haciendo difíciles equilibrios entre el conocimiento-comoidentidad-con-el-objeto y el conocimiento-como-juicio-verdadero-sobre-el-objeto, y solo gracias a esta postura de transición fue posible la confusa idea de la "filosofía moral" en cuanto "ciencia del hombre" empírica”. RORTY, R., La filosofía y el espejo de la naturaleza, Cátedra, Madrid, 2017, pág. 138.

${ }^{734}$ Cfr. TAYLOR, Ch., Fuentes del yo, pág. 342.
} 


\section{III.2.2.5. LA REVOLUCIÓN CIENTÍFICA Y SU CORRELATO METAFÍSICO KANTIANO}

En el descubrimiento de la naturaleza, no como configuración ontológica de la Razón Eterna, sino como engranaje de causalidades inscritas así por el Orden Providencial divino, nos parece importante dedicar un capítulo a la aportación de la ciencia newtoniana para comprender el nuevo "sistema del mundo". ${ }^{735}$ Tal y como Taylor afirma, es Newton quien instaura el modelo científico triunfante en la Modernidad. ${ }^{736}$ Para Taylor, la revolución epistemológica, que estuvo en la base de la revolución científica del siglo XVII y al mismo tiempo fue propiciada por ella, se desarrolló a través de pensadores como Descartes y Locke y fue autentificada por la ciencia de Galileo y Newton. ${ }^{737}$

I.- La Modernidad como la época de la imagen del mundo. Con el advenimiento de la Modernidad y la ciencia moderna, el hombre deviene el centro de referencia del

\footnotetext{
${ }^{735} \mathrm{Al}$ hablar de Newton no podemos olvidar a Copérnico y Galileo. La revolución copernicana como la gran revolución según la cual y según los instrumentos de investigación de su época supuso el gran cambio del geocentrismo tradicional y ptolemaico al heliocentrismo. Es el gran cambio revolucionario del movimiento de los planetas. La tierra no es el centro del universo sino que todo gira en torno al sol. La gravedad hacia el sol define el movimiento de traslación de los planetas alrededor del sol en movimientos elípticos. Con Copérnico podemos afirmar que el cambio no plantea cambios "ontológicos" como explicación del todo. Sus explicaciones son matemáticas y no plantean cambios metafísicos en relación al puesto del hombre en relación con el mundo. Podemos decir que con Copérnico el cambio es absolutamente revolucionario desde el punto de vista científico y matemático, pero no desde el punto de vista ontológico. Se trataba de astrónomos matemáticos que no entraban en la explicación de lo que Evandro Agazzi ha denominado la constitución real del universo, limitada a los "filósofos astrónomos". Con Galileo y sus investigaciones podemos afirmar que se llega a una "explicación del mundo" que socava los fundamentos metafísicos en relación al puesto del hombre en relación al cosmos. Se pasa de la explicación copernicana de carácter "matemático" a la explicación galileana de una "verdadera" explicación del mundo, con el alcance ontológico que esto implica. De ahí todo lo que supuso su proceso inquisitorial en el que ahora no entramos. Baste decir que las investigaciones galileanas, a partir de ese gran instrumento que será el telescopio (alguien lo ha relacionado con el cambio que supuso la aparición del fuego en la historia de la humanidad), le va a llevar a afirmar "la verdad científica" sobre la que ya no hay "sombra de duda", hay certeza experimental con su método hipotético-deductivo y cuya veracidad llevará al inicio de un gran cambio en la "explicación real" del universo y a un "primer acercamiento científico" a su intento de explicación del Todo. Cfr. AGAZZI, E., "Conocimiento científico y fe cristiana", págs. 100-101. "Gran felicidad digna de ser envidiada. Porque si el saber es naturalmente deseado por todos y si tanto da ser como aparentar que se es, esas personas gozan de un grandísimo bien y pueden persuadirse a sí mismos de que lo entienden y saben todo, a expensas de aquellos que conocen que no saben lo que no saben". GALILEO, Diálogo sobre los dos máximos sistemas del mundo ptolemaico y copernicano, Alianza Editorial, Madrid, pág. 161. Y este es el deseo de los científicos del siglo XVII, aunque no exigían una comprensión experimental de todo sí son conscientes de que la ciencia se va configurando sobre nuevas bases y que la ciencia está iniciando un cambio revolucionario de tales dimensiones que el horizonte queda abierto para una comprensión lo más amplia posible de la naturaleza circundante. "Este desarrollo continuo del conocimiento, acumulado a partir de las investigaciones y observaciones realizadas en todo el mundo, unido a un continuo e igual avance de la comprensión de la naturaleza, constituía otro aspecto importante de la nueva ciencia, habiéndose constituido desde entonces en característica distintiva de la empresa científica en su conjunto". COHEN, B., La revolución newtoniana y la transformación de las ideas científicas, Al. Univ., Madrid, 1983, pág. 31.

${ }^{736}$ Cfr. TAYLOR, Ch., Fuentes del yo, pág. 230.

${ }^{737}$ Cfr. TAYLOR, Ch., Hegel, pág. 4; cfr. HUSSERL, E., La crisis de las ciencias europeas y la fenomenología trascendental, Prometeo Libros, Madrid, 2008, págs. 65-103.
} 
ente como tal. ${ }^{738}$ El ente del mundo adquiere entidad en el ente del hombre. "Representar no significa copiar el mundo, sino poner imagen al mundo a partir del propio yo entendido como sujeto". Imagen no significa una imagen del mundo, sino el mundo entendido como imagen. ${ }^{739}$ Taylor se expresa en parecidos términos al referirse a la imagen "mediacional" en la que el mundo es comprendido "a través de". 740

El hombre trae ante sí lo presente, lo presencializa y le confiere imagen en el sentido de que el yo es el que crea el mundo como representación de sí mismo. ${ }^{741}$ Frente al "intelegir" griego, tenemos el "representar" moderno. En el intelegir griego es el hombre el que es reconocido por el ente. ${ }^{742}$ En el mundo clásico era imposible que el hombre construyera una imagen del mundo porque era el mundo el que representaba la imagen del hombre o era el mundo el que posibilitaba que el hombre tuviera una imagen de sí mismo; ahora, con el advenimiento de la ciencia, "el conocimiento como investigación pide cuenta y razón al ente para que diga cómo y hasta qué punto puede ser puesto a disposición del representar". ${ }^{743}$ Solo vale, aquello que es capaz de ser representado por el sujeto: el mundo adquiere el rango de imagen, no como copia, sino como lo que es puesto delante, lo que es objetivado a partir del propio sub-iectum (lo que está por debajo para ser eyectado).

Con la aparición del sujeto moderno aparece la "imagen" del mundo como una imagen que "representa", que pone delante el mundo, con su asombrosa reducción de los movimientos de la materia a exactas fórmulas matemáticas en función de la masa que provocaba en aquellos un constante asombro y con el descubrimiento de que las unidades fundamentales de la mecánica podían definirse en unidades de masa, de espacio y de tiempo. Para Taylor, en este sentido, la posición galileana-baconiana, y por ende la newtoniana, basta para mostrar que la tendencia a la reconstrucción no era

\footnotetext{
${ }^{738}$ HEIDEGGER, M., La época de la imagen del mundo, Editorial Nascimento, Anales de la Universidad de Chile, 1958, pág. 37.

${ }^{739}$ Cfr. Ibid., pág. 39.

${ }^{740}$ Cfr. TAYLOR, Ch.-DREYFUS, H., Recuperar el realismo, págs. 21 y ss.

741 "Desterrado Dios de la existencia, toda la espiritualidad que quedaba en el mundo estaba encerrada en los sensorios de los dispersos seres humanos. El vasto reino exterior era simplemente una máquina matemática; era un sistema de masas que se mueven en el espacio y en el tiempo absolutos. No era necesario postular algo más. En función de estas tres entidades todos sus cambios múltiples parecían susceptibles de una formulación exacta y decisiva”. BURTT, E.A., Los Fundamentos metafísicos de la ciencia moderna, pág. 288. "El único lugar que se reservó a Dios era el simple hecho irreductible del orden inteligible de las cosas que, por lo que hace al cosmos como un todo no se le escapó a Hume el escéptico, y tocante al reino de las relaciones morales fue casi hipostasiado por Kant, el despiadado destructor de las pruebas teístas tanto tiempo propugnadas. La doctrina de Newton es una etapa de transición históricamente importante entre el providencialismo milagroso de la anterior filosofía religiosa y la tendencia ulterior de identificar a la Divinidad con el claro hecho del orden y armonía racionales". Ibid., pág. 327.

742 "Es el hombre el contemplado por el ente, lo colegido por lo que se abre a la presencia donde él. Ser contemplado por el ente, involucrado en lo abierto del ente, conservado en él, y así ser sostenido por él, llevado y traído por sus contraposiciones y marcado por su discordia; esta es la esencia del hombre en la gran época griega”. HEIDEGGER, M., La época de la imagen del mundo, pág. 41.

743 Ibid., pág. 35 .
} 
inseparable del paso a la mecanización, ni estaba necesariamente atada a una rebelión contra el poder absoluto de Dios. ${ }^{744}$ Dios está en la base de esta gran maquinaria cósmica. $^{745}$

II.- Newton y la gran máquina del universo. En el Escolio General de su gran obra Principia, Newton afirma que todo está bajo el dominio de "Uno", de un "ente inteligente y poderoso". ${ }^{746}$ Para la existencia del funcionamiento del cosmos y de los planetas en su conjunto con sus satélites, cometas y estrellas, Newton precisa de la existencia del Uno, de un Configurador Eterno del cosmos, que permita el funcionamiento perfecto de la Gran Máquina del Universo. Dios ha puesto en funcionamiento este engranaje del cosmos en el que todo funciona por voluntad del que "rige todas las cosas, no como alma del mundo, sino como dueño de los universos".747 Dios es un ente espiritual necesario para Newton, porque, así como para Platón la Idea es el correlato de la esencia de las cosas sensibles, así el Uno está en la base de todo lo creado necesariamente. Con Newton, la razón científica expresada en términos físicos y matemáticos justifica, como necesidad, la existencia de un Ser Espiritual, de un Uno sin el cual no existiría todo lo que existe.

En relación con la fuerza gravitatoria, sobre la que pivota su sistema de explicación del mundo, pretendía pasar, mediante otro tipo de análisis diferente de las propiedades matemáticas de las causas (o fuerzas) a las físicas, de modo que se ocupaba primordialmente de las verae causae, causas que, como él decía, eran a la vez verdaderas y suficientes para explicar los fenómenos. ${ }^{748}$ Este análisis consiste en descubrir esos principios matemáticos de la filosofía, y así pasar de los fenómenos de movimiento a la "investigación" de las fuerzas de la naturaleza, y luego "demostrar" los

\footnotetext{
${ }^{744}$ Cfr. TAYLOR, Ch., La Era Secular, tI, pág. 188.

${ }^{745}$ Cfr. TAYLOR, Ch., Argumentos filosóficos, págs. 74,77,85-86.

746 "Este elegantísimo sistema del Sol, los planetas y los cometas solo pueden originarse en el consejo y dominio de un ente inteligente y poderoso. Y si las estrellas fijas son centros de otros sistemas similares, creados por un sabio consejo análogo, los cuerpos celestes deberán estar todos sujetos al dominio de Uno, especialmente porque la luz de las estrellas fijas es de la misma naturaleza que la luz solar, y desde cada sistema pasa a todos los otros". NEWTON, I., Principios Matemáticos de la filosofía natural, Editora Nacional, Madrid, 1982, pág. 814.

${ }^{747}$ Id., pág. 814. "El Dios supremo es un ente eterno, infinito, absolutamente perfecto, pero un ente así perfecto y sin dominio no es el señor dios. (...). Es eteno e infinito, omnipotente y omnisciente, esto es, dura desde la eternidad hasta la eternidad y está presente desde lo infinito hasta lo infinito. Rige todo y conoce todo cuanto es o puede ser hecho. No es eternidad e infinitud, sino eterno e infinito; no es duración o espacio, pero dura y está presente. (...) Se reconoce que un dios supremo existe necesariamente, y por la misma necesidad existe siempre y en todas partes. (...) Una ciega necesidad metafísica, idéntica siempre y en todas partes, es incapaz de producir la variedad de las cosas". Ibid., págs. 815-816.

${ }^{748}$ Cfr., COHEN, B., La revolución newtoniana y la transformación de las ideas científicas, pág. 48. "Hasta aquí hemos explicado los fenómenos de los cielos y de nuestro mar por la fuerza gravitatoria, pero no hemos asignado aún causa a esa fuerza. Es seguro que debe proceder de una causa que penetra hasta los centros mismos del Sol y los planetas, sin sufrir la más mínima disminución de su fuerza". NEWTON, I., Principios Matemáticos de la filosofía natural, págs. 816-817.
} 
otros fenómenos a partir de esas fuerzas. ${ }^{749}$ Se parte del movimiento a la fuerza, para pasar posteriormente de la fuerza a otros movimientos. ${ }^{750}$ Se trata, pues, de una filosofía de la naturaleza con un nuevo planteamiento epistemológico, teniendo como referencia fundamental el movimiento en sí mismo y "deducir el resto de los fenómenos de la naturaleza, siguiendo el mismo tipo de razonamiento a partir de principios mecánicos". 751

El método newtoniano, su filosofía de la naturaleza, tiene un proceso metodológico con unas Reglas para filosofar. Todo es percepción y experimentación. Una filosofía del movimiento y de las fuerzas, una filosofía que tiene su propio método de rigor científico y al que se dedica con profundo empeño en los libros I y II de sus Principia y que serán la base para el libro III. Es una filosofía de la naturaleza de principios matemáticos, por lo que Newton dice que son principios "no tanto filosóficos como matemáticos", aunque "conciernen especialísimamente a la filosofía", ${ }^{752}$ y por eso realiza los Escolios en los que hace consideraciones generales de carácter filosófico, relativos a la densidad y resistencia de los cuerpos, ${ }^{753}$ los espacios vacíos de cuerpos y el movimiento de luz y sonidos. ${ }^{754} \mathrm{Y}$ a partir de ahí escribe el libro III, titulado " $E l$ Sistema del Mundo" con las Reglas para Filosofar. Para Taylor, si el mundo cósmico ya no está cargado de significados ontológicos, la naturaleza debe responder a un orden y este era una condición de la retención racional del mundo que llamamos ciencia, en el supuesto de que la racionalidad coincida con la visión de este orden. Y este es el sentido de la ciencia newtoniana, expresar científicamente la razón que subyace a este orden. Taylor se refiere al término "autorresponsabilidad" que utiliza Husserl y que está en el horizonte de la razón científica. ${ }^{755}$ Por eso los postkantianos pueden presentarlo como argumento trascendental desde el hecho de la ciencia. ${ }^{756}$

La primera regla que Newton considera es evitar lo superfluo, ya que la naturaleza nos proporciona "lo suficiente" para explicar los fenómenos. Newton habla de que la Naturaleza es simple y hay que buscar, pues, las causas "verdaderas y suficientes"

\footnotetext{
${ }^{749}$ Cfr. Ibid. pag 200.

${ }^{750}$ Cfr. TAYLOR, Ch., Hegel, pág. 458.

${ }^{751}$ NEWTON, I., Principios Matemáticos de la filosofía natural, pág. 200.

752 Ibid., pág. 655 .

753 "Newtonian selection is 'metaphysical not in the sense that he is doing metaphysics, but that the natural objects are not approached through antecendent critiques of conceptual frameworks or linguistic analysis. (...) Newton insisted to Oldenburg that only two legitimate objections could be leveled at the Principia: either that experiments were insufficient to solve the questions raised or that other experiments could be produced which would directly contradict the conclusions obtained". BUCKLEY, M., Motion and Motion's God, Princeton University Press, 1971, pág.164.

${ }^{754}$ NEWTON, I., Principios Matemáticos de la filosofía natural, págs. 655.

${ }^{755}$ Cfr. TAYLOR, Ch., Argumentos filosóficos, pág. 26. Cfr. TAYLOR, Ch., Fuentes del yo, pág. 234.

${ }^{756}$ Cfr. TAYLOR, Ch., Hegel, pág. 6.
} 
sabiendo que no hay ninguna certeza a priori, como decían Galileo, Kepler o Descartes, que "explicaban matemáticamente el mundo". 757

Newton afirma que el aspecto matemático (Libros I y II) necesita ser complementado con el aspecto físico-experimental, ${ }^{758}$ por lo que podemos concluir que a su modo de ver era más relevante el método empírico experimental que el matemático, y que solo le interesaban los razonamientos matemáticos si tenían su correlato en un problema físico. ${ }^{759} \mathrm{Y}$ para ello era fundamental la experimentación físico-empírica. ${ }^{760}$ La filosofía natural de carácter físico tiene una fundamentación matemática y la matemática está en Newton para resolver problemas físicos de carácter filosófico. ${ }^{761}$ También la existencia de Dios puede pertenecer a la filosofía experimental. Para Newton, la metafísica, que se basa en la experiencia o en los fenómenos, es una parte de la filosofía experimental. Una experiencia que incluye todas las sensaciones, incluyendo las sensaciones internas, de ahí que el cogito cartesiano pertenezca también a la filosofía experimental. También las pruebas de la existencia de Dios pertenecen, en este sentido, a la filosofía experimental. ${ }^{762}$ Completando la argumentación, para Taylor, la completa autoposesión racional requiere que nos liberemos de las proyecciones del sentido de las

757 "Para Newton las matemáticas deben modelarse continuamente sobre la experiencia. Y siempre que se permitió hacer largas deducciones valiéndose de principios destacó escrupulosamente el carácter puramente abstracto de los resultados hasta que no se los hubiese comprobado físicamente (experimentalmente)". BURTT, E.A., Los Fundamentos metafísicos de la ciencia moderna, Editorial Sudamericana, Buenos Aires, 1980, pág. 234.

758 "Newton fue así el heredero de dos movimientos fecundos e importantes en el precedente desarrollo de la ciencia: el movimiento empírico y experimental y el deductivo y matemático. Él fue el continuador de Bacon, Gilbert, Harvey y Boyle, y el sucesor de Copérnico, Kepler, Galileo y Descartes”. Id., pág. 234.

${ }^{759}$ No obstante, podemos hablar en Newton de la unión de la matemática y el experimento: "Así, para Newton, la experimentación cuidadosa debe estar al principio y al fin de todo importante paso científico, porque lo que buscamos comprender son siempre los hechos sensibles; pero la comprensión, en tanto es exacta, debe expresarse en lenguaje matemático. Por medio de los experimentos debemos, pues, descubrir los aspectos que pueden expresarse en ese lenguaje, y nuestras conclusiones deben comprobarse también por medio de los experimentos". Ibid., pág. 244. Para Newton la ciencia es la expresión matemática de la experimentación en el mundo de la naturaleza: "Para Newton, pues, la ciencia se compone de leyes que expresan solo el comportamiento matemático de la naturaleza - leyes que se deducen claramente de los fenómenos y se comprueban con exactitud en los fenómenos-, y todo lo demás hay que desterrarlo de la ciencia, que se presenta así como un cuerpo de verdades absolutamente ciertas sobre los hechos del mundo físico". Ibid., pág. 248.

760 “Como los antiguos (según cuenta Pappus) consideraban de la mayor importancia la mecánica para la investigación de las cosas naturales, y como los modernos - rechazando formas substanciales y cualidades ocultas - han intentado reducir los fenómenos de la naturaleza a las leyes matemáticas, he querido en este trabajo cultivar la matemática en tanto en cuanto se relaciona con la filosofía" (la cursiva es nuestra). NEWTON, I., Principios Matemáticos de la filosofía natural. Prefacio, pág. 199.

761 "Es justamente la habilidad de Newton para separar en los problemas los aspectos matemáticos de los físicos la que le permite lograr en los Principia tan espectaculares resultados. Precisamente lo que caracteriza al estilo newtoniano es la posibilidad de elaborar las consecuencias matemáticas de las suposiciones relativas a posibles condiciones físicas, sin tener que discutir la realidad física de tales condiciones en las primeras etapas de la investigación. Difícilmente se podría considerar una novedad del siglo XVII el ideal de crear una ciencia física exacta basada en las matemáticas". COHEN, B., La revolución newtoniana y la transformación de las ideas científicas, pág. 49.

${ }^{762}$ Cfr. SAPHIRO, A., "La Filosofía experimental de Newton", Estudios Filosóficos, No 35, (2007), pág. 125. 
cosas, que seamos capaces de retirarnos del mundo y concentrarnos puramente en nuestros propios procesos de observación y pensamiento sobre las cosas. ${ }^{763}$

Para Newton, pues, la matemática era solamente un método para la solución de problemas que planteaba la experiencia sensible. Tenía poco interés en los razonamientos matemáticos que no eran aplicables a los problemas físicos. ${ }^{764}$ A esto se refiere cuando habla de la divisibilidad de la materia en relación a aquello que puede observarse, a aquello que puede demostrarse matemáticamente y a aquello que exige la prueba de un solo experimento. ${ }^{765}$

Este es un aspecto clave en el desarrollo del pensamiento posterior, hasta tal punto que llevará a Heidegger a considerar que la física newtoniana se hace matemática o, como dice él, "la física moderna se llama matemática porque aplica, en un sentido preferente, una matemática muy determinada" ${ }^{766}$ La Física Moderna de la Naturaleza "es" Matemática. Ta mathémata, para los griegos, era aquello que ya se conoce de antemano, aquello que al ser observado "ya" es conocido como algo ya dado, como algo ya "determinado para ser conocido", o como "lo siempre ya conocido". Si la Física se configura como matemática es porque se entiende como "algo-ya-conocido", la física de la naturaleza será a partir de entonces "el conjunto de movimientos —en sí cerrado— de puntos de masa espacial temporalmente relacionados". ${ }^{767}$ Newton puede decir así de su método que deduce de los fenómenos los principios del movimiento, porque estos principios son afirmaciones exactas y completas de los fenómenos hasta donde toca a

\footnotetext{
${ }^{763}$ Cfr. TAYLOR, Ch., Hegel, pág. 6.

${ }^{764}$ Cfr. BURTT, E.A., Los Fundamentos metafísicos de la ciencia moderna, pág. 235.

765 "Con todo, si tuviésemos la prueba de un solo experimento siquiera en el sentido de que cualquier partícula indivisa sufría una división al romper un cuerpo duro y sólido, podríamos en virtud de esa regla concluir que tanto las partículas indivisas como las divididas pueden dividirse y separarse efectivamente hasta lo infinito" (la cursiva es nuestra). NEWTON, I., Principios Matemáticos de la filosofía natural. Reglas para filosofar, pág. 658. En este sentido también nos interesa destacar el escaso valor que Newton concede a las hipótesis. Para él es fundamental las deducciones que se obtienen por la comprobación empírica: "En Filosofía experimental debemos recoger proposiciones verdaderas o muy aproximadas inferidas por inducción general a partir de fenómenos, prescindiendo de cualesquiera hipótesis contrarias, hasta que se produzcan otros fenómenos capaces de hacer más precisas esas proposiciones o sujetas a excepciones. Hemos de seguir esta regla para que el argumento por inducción no pueda ser eludido por hipótesis". Ibid., pág. 659. Para Newton, el empirismo, ante cualquier hipótesis que pueda ser planteada en sentido contrario, es el único argumento a las excepciones que puedan surgir. El único criterio de validez es la experimentación empírica. La verdad metafísica que esconde dicha argumentación se basa en que la naturaleza no puede entrar en contradicción consigo misma. Una verdad contrastada empíricamente no puede contradecir cualquier excepción que pueda ser planteada, de tal forma que la verdad metafísica abre caminos a nuevas experimentaciones que confirmen las ya establecidas a partir de los fenómenos y la inducción. Newton parte siempre de que su obra no se basa en hipótesis sino en afirmaciones contrastadas experimentalmente y que si hay alguna sombra de duda sobre sus afirmaciones se debería volver sobre ella a base de más experimentación y "comprobaciones exactas". "Pues todo lo no deducido a partir de los fenómenos ha de llamarse una hipótesis, y las hipótesis metafísicas o físicas, ya sean de cualidades ocultas o mecánicas, carecen de lugar en la filosofía experimental. En esta filosofía las proposiciones particulares se infieren a partir de los fenómenos, para luego generalizarse mediante inducción" (la cursiva es nuestra). Ibid. pág. 817.

${ }^{766}$ HEIDEGGER, M., La época de la imagen del mundo, pág. 20.

${ }^{767}$ Ibid., pág. 22.
} 
sus movimientos. No hay cabida para las hipótesis en la filosofía natural. Se analizan los fenómenos para deducir sus leyes matemáticas, y la inducción hace generales a las que tienen una gran esfera de aplicación. ${ }^{768}$ Es lo que Taylor denomina el control sobre las cosas que creció con la ciencia y la tecnología modernas, ${ }^{769}$ o la ciega aceptación de un apodíctico modelo fundacionalista del razonamiento, ${ }^{770} \mathrm{o}$ el principio de inferencia que subyace a la racionalidad como un estándar universal. ${ }^{771}$ Taylor afirma que el retrato debe ser correcto y todo debe ser explicado mecanicísticamente. ${ }^{772}$

La naturaleza que es conocida matemáticamente con el advenimiento de la Modernidad, como algo que es visto de antemano, da accesibilidad a ser considerada en su posibilidad experimental. Es el cambio de visión de la naturaleza lo que permite la investigación experimental. No es el experimento el que cambia la visión de la naturaleza. Es más, no sería posible la investigación sin esta visión moderna de la naturaleza. Por eso no había investigación en la ciencia griega ni medieval. ${ }^{773}$ La ciencia aristotélica admitía el experimentum, pero no era capaz de captar la "accesibilidad" a la ley como investigación posible. Comprender la naturaleza en su consideración de mutabilidad constante hecha ley es el primer paso para el acceso al experimento que

${ }^{768}$ Cfr. BURTT, E.A., Los Fundamentos metafísicos de la ciencia moderna, pág. 246.

Cfr. KUHN, T.S., La estructura de las revoluciones científicas, Fondo de Cultura Económica, Mexico, 1971, págs., 68-79.

${ }^{769}$ Cfr. TAYLOR, Ch., Hegel, pág. 7.

${ }^{770}$ Cfr. TAYLOR, Ch., Argumentos filosóficos, págs. 69-73.

${ }^{771}$ Cfr. Ibid., pág. 213.

${ }^{772}$ Cfr. Ibid., pág. 100.

${ }^{773}$ El experimento griego no captaba la "ley" de la naturaleza y por lo tanto faltaba lo decisivo del experimento moderno. Y por otra parte, para la escolástica medieval lo fundamental eran las autoridades que configuraban la verdad de la ciencia revelada escondida en las Escrituras. Por otra parte, el escolástico medieval Bacon no puede ser el precursor de la ciencia moderna pues, aunque reclame el experimento, para él el experimento tiene el carácter de la empireia aristotélica como observación de las cosas mismas, los procesos regulares de funcionamiento y las mutaciones que pueden experimentar bajo ciertas condiciones. La condición experimental está todavía alejada de los fundamentos de la ley impresa en la naturaleza. El conocimiento se basa en la palabra revelada que ayuda a comprender el sentido del mundo y de la naturaleza. "Pero para Roger Bacon la materia no es una simple potencia universal que en su potencialidad universal puede recibir cualquier forma, como decían Aristóteles y sus seguidores, sino que, en la escala que va de lo más general a lo más especial hasta llegar al individuo, hay distintos grados de materia, como hay distintos grados de sustancia. (...) Pues bien, lo mismo que todos estos grados de sustancia tienen distinta forma, igualmente poseen una materia distinta. Y un tipo de materia se distingue de otra materia mediante diferencias específicas. Bacon termina diciendo que hay tantos grados de materia como de cosas. De ello saca una conclusión que a la vez es un consejo para sus seguidores para que se dediquen a la Ciencia experimental: 'Mira las cosas mismas, experiméntalas, mira cómo las cosas actúan sobre ti, y cómo tú puedes actuar sobre ellas'. En cuanto a la gran controversia medieval sobre los universales, Bacon sacará una conclusión análoga que incita a la dedicación a la ciencia experimental. Con su forma de entender los universales y el estímulo hacia la ciencia experimental que supone su concepción, Roger Bacon se anticipa a la concepción de los universales de Guillermo de Ockham". BONNIN AGUILÓ, F., "Roger Bacon y la ciencia experimental", Indagación, (1999), pág. 31. "Puesto que la naturaleza se entiende en dos sentidos, como forma y como materia, tenemos que estudiarla de la misma manera que si investigásemos qué es lo chato en una nariz (...) Pero, con respecto a este doble sentido, pueden plantearse otra dificultad: ya que hay dos naturalezas, ¿cuál ha de ser estudiada por el físico? ¿O tendrá que estudiar más bien lo que resulta de ambas? Pero, si tiene que estudiar lo que resulta de ambas, entonces también cada una de ellas. En tal caso, ¿habrá una misma ciencia para ambas naturalezas, o bien una ciencia para la una y otra para la otra?”. Cfr. ARISTÓTELES, Física, 194a10-15. 
"capta" la ley natural y la recrea en la investigación. El experimento no es una recreación arbitraria de elementos, sino que necesariamente debe expresar la ley de la naturaleza. ${ }^{774}$ Por otra parte, según Husserl, con Galileo, en virtud de la matemática pura y del arte práctica de la medida, se puede crear, para todo lo extenso similar en el mundo de los cuerpos, una previsión inductiva de tipo enteramente nuevo, un camino infinito de verificaciones, una ciencia de la naturaleza cuya esencia es ser en infinitas hipótesis y en infinitas verificaciones, llegando cada vez más a su verdadero ser verdadero. ${ }^{775}$

Taylor se refiere al término heideggeriano "precomprensión" para analizar el incremento del conocimiento que va asociado a la ciencia galileana y que permite explicitar esta precomprensión y así ampliar nuestra captación de las conexiones subyacentes a nuestra capacidad de relacionarnos con el mundo tal como lo hacemos. Para nuestro hermeneuta canadiense es virtualmente imposible extender este conocimiento sin tener nuevas recetas disponibles, y una ampliación de nuestra capacidad práctica es, por tanto, un criterio fiable del incremento del conocimiento. ${ }^{776}$

En la racionalidad moderna, tanto empiristas como racionalistas se encuentran fascinados por la ecuación que hace corresponder la verdad con evidencia y evidencia con certeza. De ahí que tanto la verdad cartesiana como la verdad newtoniana se fundamentan en la búsqueda de la verdad que es evidente y cierta, sin sombra de duda, bien sea por vía racional o empírica. ${ }^{777}$ Por lo tanto, se podría afirmar que Newton es, en muchos sentidos, el genuino fundador de la racionalidad moderna. ¿Por qué? Porque sus deficientes doctrinas acerca de la certeza y la evidencia permitieron que la verdad dejase de estar encadenada a ellas. No hay evidencia empírica, ni de otro tipo, que nos permita estar seguros de los principios que constituyen y dinamizan el universo. "La búsqueda de verdades apodícticas es una misión imposible, lo cual no impide la existencia ni el hallazgo de verdades a secas". Verdades que son tanto más objetivas, tanto más reales, cuanto más desnudas están de adornos psicológicos y epistémicos. La física de Newton es verdadera (hasta donde lo sea), no porque inspire confianza de un modo intrínseco al que la estudia, ni porque tenga una particular limpidez desde el punto de vista lógico,

\footnotetext{
774 “(El experimento) comienza con la suposición de una ley. (...) Por eso decía Newton: hypotheses non fingo, los supuestos no se han colegido arbitrariamente. Ellos se han explicitado del esquema de la naturaleza y están incluidos en él. El experimento es aquel procedimiento que está sostenido y guiado en su trazo y ejecución por la ley que le ha sido puesta por base, y que persigue aducir hechos que verifiquen la ley o le nieguen su verificación. Cuanto más exactamente ha sido proyectado el esquema de la naturaleza, tanto más exacta se hace la posibilidad del experimento". HEIDEGGER, M., La época de la imagen del mundo, pág. 26.

${ }_{775}$ Cfr. HUSSERL, E., La crisis de las ciencias europeas y la fenomenología trascendental, pág. 75.

${ }^{776}$ Cfr. TAYLOR, Ch., Argumentos filosóficos, pág. 76.

${ }^{777}$ Cfr. TAYLOR, Ch., Argumentos filosóficos, pág. 74. Cfr. TAYLOR, Ch., La ética de la autenticidad, págs. 129-131. Taylor pone en duda el hecho de que esta ciencia posgalileana se haya mostrado superior "en tanto que conocimiento". El interrogante para el debate queda ahí. Desde la Modernidad "preferimos" ese resultado. Pero $¿$ es esa toda la verdad?
} 
sino porque a través de ella llegamos a conocer las cosas que hay en el mundo. La instancia que garantiza la solvencia de sus fórmulas no está en el sujeto ni en el mundo de la representación: está afuera, a la intemperie, allí donde no hay otro aval que la pura conformidad de pensamiento y ser. La naturaleza es sencilla y todo se limita a conocer las causas naturales como causas de las cosas. Taylor afirma, en este sentido, que con Newton y Galileo se acrecienta la imagen del mundo como un lugar de correlaciones neutrales y contingentes, y donde se puede establecer el mapeo de las regularidades de las cosas por el razonamiento matemático. ${ }^{778}$ Taylor habla de la perspectiva desvinculada tanto de dualistas (la mente no se encuentra esencialmente encarnada) como de empiristas o mecanicistas (el pensar es un evento que tiene lugar en un cuerpo mecanicistamente entendido). El mecanicismo puede sostener, al igual que el dualismo, la perspectiva desvinculada, porque la creencia que le subyace es que necesitamos seguir esta perspectiva para hacer justicia a un universo mecanicista. ${ }^{779}$

Para Taylor, sin duda, había valores, virtudes, excelencias en lo que impulsaba la teoría científica: las del sujeto independiente, desvinculado, reflexivamente al mando de sus propios procesos de pensamiento o responsable de sí mismo. La imagen completa atravesada de valores, que se abre a lo objetivo sin prejuicios, se presenta ahora como existente desde el principio e impulsora de la totalidad del proceso de descubrimiento. $^{780}$

Pronto se irá dando el paso metafísico, hoy muy familiar, que consiste en pasar de la afirmación de que "los cuerpos son masas" al supuesto de que los cuerpos no son nada más que masas", y de que todos los fenómenos restantes pueden explicarse por factores exteriores a los cuerpos mismos, ${ }^{781}$ lo objetiva y lo hace suyo al mismo tiempo. ${ }^{782}$ Para Taylor, en un principio se ofrece un punto de vista neutral, pero su neutralidad resultará falsa. Naturaliza una determinada visión de las cosas. Y se avanzará irremediablemente hacia el camino de la increencia y el naturalismo ontológico. Se irá asumiendo que las realidades que estudia están construidas exclusivamente de materia, por lo que se supone que debemos concluir que todo es materia. Frente a las ilusiones anteriores se asumirá el materialismo como la posición de personas adultas y valientes. ${ }^{783}$

III.- Kant y la metafísica en el seguro camino de la ciencia. Kant, para preservar el alto estándar de rigor que ha establecido, tiene que redimensionar la metafísica y

\footnotetext{
778 TAYLOR, Ch., Hegel, pág. 7.

${ }^{779}$ Cfr. TAYLOR, Ch., Argumentos filosóficos, pág. 798.

${ }^{780}$ Cfr. TAYLOR, Ch., La Era Secular, tII, pág. 414.

${ }^{781}$ Cfr. BURTT, E.A., Los Fundamentos metafísicos de la ciencia moderna, pág. 268.

782 “A partir de Newton el espíritu moderno concibe esencialmente la naturaleza como un reino de masas que, bajo la influencia de fuerzas definidas y seguras, se mueven de acuerdo con las leyes matemáticas del tiempo y del espacio". Ibid., pág. 263.

${ }^{783}$ Cfr. TAYLOR, Ch., La Era Secular, tII, pág. 438.
} 
transformarla en un saber propedéutico al estilo de la lógica, intentando así, salvar a la ciencia natural de las dudas escépticas planteadas por críticos como Hume. Kant optará por ubicar a la metafísica en el ámbito "del seguro camino de la ciencia". ${ }^{784}$

En un primer acercamiento al concepto de naturaleza, Kant habla de "naturaleza" como un concepto que incluye dos sentidos distintos: "la doctrina de los cuerpos y la doctrina del alma; la primera, considera la naturaleza extensa, y la segunda, la naturaleza pensante". ${ }^{785}$ Un concepto que inicialmente está lleno de reminiscencias cartesianas. Sin embargo, a medida que avanza la presentación de dicho concepto, Kant refiere su significación en una doble vertiente: la doctrina histórica de la naturaleza, que considera los principios inductivos que se extraen a partir de la experiencia, hechos ordenados según principios empíricos (no racionales), y la ciencia de la naturaleza propiamente dicha cuyo sistema de conocimientos está basado en un principio racional: no se infiere a partir de la experiencia sino que se extrae de la razón misma. Y es la ciencia de la naturaleza la única que puede ofrecer una certidumbre apodíctica, esto es, una ciencia racional definida por un conocimiento que sea un encadenamiento de principios y consecuencias y que esté determinado por "una necesidad justificada apodícticamente". Apodíctico en el sentido de "necesidad": una cosa sólo puede ser así y va a ser siempre así. ${ }^{786}$

Para Kant, la Ciencia de la naturaleza propiamente dicha estudia la ley inscrita en la naturaleza y definida como "principio a priori" que determina la necesidad de principios y consecuencias o lo que expresa las determinaciones de la cosa: "la necesidad" de las leyes es lo que explica el concepto de naturaleza. Por eso, la Química es un arte sistemático, ya que no puede explicitar "principios a priori", pues está configurada desde la contingencia y no por la certidumbre apodíctica. Kant distingue, en este sentido, entre lo que la razón puede conseguir por sí misma (y que configura el carácter de ciencia de la naturaleza en su certidumbre apodíctica y apriorística- ciencia propiamente dicha) y lo que está determinado por la necesidad de recurrir a los principios de la experiencia (un arte sistemático determinado por la contingenciaciencia de la naturaleza impropia).

\footnotetext{
${ }^{784}$ Cfr. ARANA, J., Los sótanos del universo, Biblioteca Nueva, Madrid, 2012, pág. 37. "Kant tomó la ciencia de Newton por algo parecido a la verdad absoluta no solo antes de que Hume le despertara de su sueño dogmático, sino también después. En otro caso no hubiera tenido sentido escribir la Crítica de la razón pura y los Principios metafísicos de la ciencia natural, libros que sirven menos para descubrir ciertas verdades absolutas que para reconocer como tales las que habían descubierto los nuevos filósofos naturales". Ibid., pág. 22.

${ }^{785}$ KANT, I., Principios metafísicos de la ciencia de la naturaleza, Alianza Editorial, Madrid, 1989, pág. 28.

786 "Como la palabra naturaleza lleva ya consigo el concepto de ley y este, por su lado, el de necesidad de todas las determinaciones de una cosa, que pertenecen a su existencia, se ve fácilmente por qué razón la ciencia de la naturaleza tendría que derivar la legitimidad de esta denominación, únicamente de su parte pura, la cual contiene, a propósito, los principios a priori de todas las otras explicaciones de la naturaleza, y, además, por qué ella no es propiamente ciencia más que en virtud de esta parte”. Ibid., pág. 29.
} 
Es la Metafísica de la Naturaleza la que está en la base de la Ciencia de la Naturaleza. ${ }^{787}$ La Metafísica de la Naturaleza reconoce la necesidad que determina la existencia de una cosa y la Ciencia de la Naturaleza construye conceptos sobre la existencia de esa cosa a partir de la intuición a priori. El conocimiento racional de los simples conceptos, o sea, la Metafísica de la Naturaleza, accede a la necesidad de una ley que determina la cosa, y luego será la Ciencia de la Naturaleza, entendida como Matemática, la que accede a la construcción de conceptos por medio de la presentación del objeto en una intuición a priori. La ciencia de la Naturaleza construye conceptos a partir de la intuición a priori del objeto, mientras que la Metafísica "solo identifica" la necesidad (=ley) de existencia de la cosa. ${ }^{788}$

Kant aboga por una interrelación entre la metafísica de la naturaleza y la ciencia de la naturaleza porque la ciencia de la naturaleza que hace uso de conceptos matemáticos ha recurrido también a principios metafísicos, "aun cuando protesten solemnemente contra toda pretensión de la metafísica sobre su ciencia". ${ }^{789}$ Y aunque a veces los físicos matemáticos desprecian la metafísica por ser una quimera, sin embargo Kant reivindica el papel de la metafísica de la naturaleza. ${ }^{790}$ Para Kant, los físicos matemáticos no pueden prescindir de los principios metafísicos, ya que el objeto de su estudio, la materia, es susceptible de una intuición a priori a la experiencia externa, tal y como se demuestra en los conceptos de movimiento, espacio, lleno, inercia; por lo que son los propios físicos matemáticos los que reconocen que su experiencia no alcanza en dichos conceptos la certidumbre apodíctica que pretenden dar a sus leyes de la naturaleza, prefiriendo perder el alcance de certidumbre apodíctica, a buscar en dichas leyes sus fuentes a priori. En este sentido, Taylor afirma que en la Modernidad se realizan diversas síntesis, no siempre fáciles de compaginar, esto es, "la noción de subjetividad que se autodefine correlativa a la nueva objetividad". ${ }^{791}$ Por eso, para Taylor, Kant pretende ir desde la experiencia al sujeto de la experiencia, superando a los ilustrados radicales que "amalgamaban" objetividad y subjetividad, o a Hume para quien el sujeto es un mero objeto más como paquete de percepciones. ${ }^{792}$

Consecuentemente, Kant ofrece una solución para evitar que las leyes de la naturaleza establecidas por los físicos matemáticos no alcancen ese grado de certidumbre apodíctica al desechar ese ámbito de fuentes a priori. Y es que, en la ciencia de la naturaleza de carácter general, lo que se denomina physica generalis, se suelen

\footnotetext{
${ }^{787}$ Cfr. KANT, I., Crítica de la Razón Pura, Gredos, Madrid, 2018, B 3- B 4.

${ }^{788}$ Cfr. Id., B 3.

${ }^{789}$ KANT, I., Principios metafísicos de la ciencia de la naturaleza, pág. 33.

790 "No procede de la experiencia, sino que contiene las puras acciones del pensar, y, por consiguiente, conceptos y principios a priori, los cuales son los primeros en reunir lo diverso de las representaciones empíricas en una conexión según leyes, para que dicha diversidad pueda devenir conocimiento empírico, es decir, experiencia”. Ibid., pág. 34.

${ }^{791}$ TAYLOR, Ch., Hegel, pág. 9.

792 Cfr. Ibid., pág. 27.
} 
entremezclar principios metafísicos y físicos. ${ }^{793}$ Es decir, que dadas las dificultades de la física matemática para acceder a las fuentes a priori con la consiguiente "incompletud de certidumbre apodíctica”, Kant plantea que la Física de la naturaleza, en su parte pura (no empírica), ponga en relación los principios metafísicos en su carácter de intuición a priori junto con "la construcción de conceptos" que permitan una "teoría matemática de la naturaleza misma". De esta manera, Kant avanza la posibilidad y sugerencia de que en el solo sistema de la ciencia de la naturaleza se posibilite el acceso al concepto mismo de naturaleza junto con la "construcción de conceptos", de tal modo que el conocimiento de la razón, a través de la construcción de los conceptos, sea matemático. ${ }^{794}$

Kant pretende separar las ciencias y no mezclar principios heterogéneos. Pero por otra parte, es consciente de que a partir de la metafísica se puede alcanzar lo que él denomina la "absoluta completitud" de las ciencias; es decir, que sin el "acceso metafísico" a través de la intuición a priori, muchas leyes de la ciencia quedan "sin completar", ante la imposibilidad de alcanzar la "certidumbre apodíctica". ${ }^{795}$ Según Kant, pues, la metafísica ofrece un número de conocimientos "completo", dado que trabaja con un puro conocimiento racional, a partir de simples conceptos que se comparan con "todas las leyes necesarias del pensamiento," esto es, conceptos sobre la necesidad de existencia de las cosas que no admiten construcción de conceptos, mientras que la Ciencia de la naturaleza nunca agota la completitud de construcción de conceptos, dado que las intuiciones a priori (puras o empíricas) pueden llevarse hasta el infinito. ${ }^{796}$ Es decir, que solo a partir de la Metafísica de la naturaleza puede lograrse la "absoluta completitud" de las ciencias. ${ }^{797}$ Considera Kant que la forma de nuestras mentes puede ser explorada y, como algo dado trascendentalmente, también se puede acceder a las cosas como algo dado. Siendo "afectados" como sujetos finitos, nuestra intuición recibe su contenido fuera de nosotros, de ahí que no podamos concluir nada acerca de las cosas en sí mismas.

Kant reivindica la necesidad de una metafísica de la ciencia que posibilite la completitud absoluta de la ciencia de la naturaleza, dado que sin "principios a priori" difícilmente se puede alcanzar el "conocimiento de los objetos" a través de la experiencia. Por todo lo anterior, se puede afirmar que muchos de los conceptos físicos, como los de espacio y tiempo, son explicados con mayor precisión y profundidad desde la metafísica kantiana que desde la propia física experimental newtoniana. En el fondo

\footnotetext{
793 "Presentar en un sistema las construcciones metafísicas y con ellas, al mismo tiempo, los principios de la construcción de estos conceptos metafísicos, y por los principios de posibilidad de una teoría matemática de la naturaleza, misma”. KANT, I., Principios Metafísicos, págs. 34-35.

${ }_{794}^{794}$ Cfr. Ibid., pág. 30.

${ }^{795}$ Cfr. Ibid., pág. 35.

${ }^{796}$ Cfr. Ibid., pág. 47.

${ }^{797}$ Cfr. Ibid., pág. 43.
} 
se trata de una construcción arquitectónica de la ciencia. La obra Principios Metafísicos de la ciencia de la naturaleza se plantea antes de la Crítica de la Razón Pura, pero se escribe despúes. No puede haber unos principios metafísicos de la naturaleza si antes no está determinada la estructura de la subjetividad del sujeto que conoce. Kant plantea en primer lugar y como base base de su propuesta, estos principios puros a priori, esto es, cómo está conformado el sujeto trascendental y eso es lo que conduce a una metafísica como base de construcción de la ciencia. En segundo lugar, a partir de esa metafísica se podrán extraer leyes generales que provienen de esos principios puros a priori podemos hablar de una ciencia propiamente dicha. $\mathrm{Y}$ en un tercer momento esas leyes generales sirven para interrelacionar los fenómenos y establecer relaciones de causa y efecto entre los distintos fenómenos de la naturaleza y se pueden configurar en leyes de la naturaleza. Es aquí cuando se puede hablar de una ciencia de la naturaleza propiamente dicha. Se establece una jerarquía y desde ahí un establecimiento de las distintas ciencias de las que hemos hablando antes. No vale lo mismo para Kant una ciencia de la naturaleza que una doctrina histórica de la naturaleza y dentro de la ciencia vale más una ciencia propiamente dicha basada en principios a priori que una ciencia impropia que se basa nada más en la aplicación de ciertos principios racionales basados en la experiencia. Dicha construcción arquitectónica esta atravesada por ese sujeto trascendental que parte del apriorismo de la racionalidad universal.

Taylor opina, en este sentido, que Kant no era lo suficientemente moderno, ya que todavía no había recorrido la larga ruta del desencanto que llevaría al desprendimiento de cualquier metafísica o filosofía antigua. ${ }^{798}$ Según Taylor, para Kant "la realidad, tal como es en sí misma, o sea, inalterada por alguna estructura que le impongamos, está para siempre más allá de nuestro conocimiento". ${ }^{799}$ Se impone, pues, una metafísica de la naturaleza, dado que siempre será una terra incognita para el hombre. Para poder conocer objetivamente la realidad, necesitamos tener intuiciones de los objetos que no sean empíricas, sino a priori. Y esto, tan solo es posible a partir de las formas a priori de la sensibilidad, y es aquí donde surge la fuente de la geometría y la aritmética. Para Kant, la naturaleza es un libro escrito en caracteres matemáticos debido a que Dios habría empleado estos caracteres, no para crear una realidad independiente y substante, sino una para que esta confluyera ineludiblemente a la receptividad de la mente a partir de las impresiones sensibles. El mundo que nos rodea es matemático, simplemente porque es la única clase de mundo que somos capaces de intuir, tal y como afirma Arana. ${ }^{800}$ Es decir, para Kant sólo puede haber ciencia propiamente dicha si las matemáticas están incluidas. Es lo que permite construir conceptos utilizando la intuición a priori del espacio. Las matemáticas construyen leyes generales que se van a referir a la experiencia pero que lo puede hacer de manera a priori. Ponen en conexión

\footnotetext{
${ }^{798}$ Cfr. TAYLOR, Ch., Fuentes del yo, pág. 141.

799 TAYLOR, Ch., Hegel, pág. 67.

${ }^{800}$ Cfr. ARANA, J., Los sótanos del universo, pág. 123.
} 
lo que aparece empíricamente y lo que está ya establecido a partir de la intuición a priori en el sujeto trascendental. Cuando Kant dice que para que haya ciencia propiamente dicha se necesitan las matemáticas, se está orientando claramente hacia el lado de la Física en la que hay toda una formalización matemática de esas relaciones, algo que no existe en la Psicología. ${ }^{801}$ Se puede concluir que con Kant, la ciencia físico-matemática moderna se eleva a paradigma del conocimiento y del saber en general, y esto señala de modo explícito la transición a la modernidad que precisamente por eso se caracteriza por su modo específico de concebir la racionalidad. ${ }^{802}$

Kant es el gran deconstructor del empirismo entendido como "atomismo de inputs" o impresiones individuales. Para Kant los inputs o sensaciones deben ser "acerca de algo", o lo que es lo mismo, tiene que haber una conciencia única que combine en una representación fenomenológica la diversidad. ${ }^{803}$ La relación de la sensibilidad y del entendimiento con el objeto no puede ser una relación individual, sino como fenómeno y en relación con los demás objetos. Es localizar el objeto en el mundo, en contraposición a lo que está dentro de mí. Para Taylor, la "deducción trascendental", junto con los argumentos trascendentales, supone ubicar el objeto en el "trasfondo" y así superar las visiones reificadas que emergen de la ontologización de la epistemología fundamentalista moderna que convierte la idea/imagen en invisible, ${ }^{804}$ o lo que Taylor denomina como "cosificación del mobiliario de la mente" a través de una oclusión del trasfondo. ${ }^{805} \mathrm{El}$ empirismo solo "se encuentra con la cosa", "se las está viendo con una realidad no derivada de la necesidad (trascendental)". ${ }^{806}$

La experiencia kantiana tiene que ser "de" algo, porque de lo contrario no tendríamos "conciencia de conocer", pues el conocer es de algo: no podemos conocer "nada". Se necesita la "experiencia de algo". ${ }^{807}$ Y, así, se pasa de la experiencia "de" algo, a la experiencia "del" sujeto, del que es consciente de algo. Para Kant, el conocimiento, pues, implica la experiencia del sujeto y de la cosa conocida, en una síntesis de necesidad y de posibilidad a través del apriorismo y la universalidad; al contrario del empirismo, que se limitaba al reconocimiento del yo como un objeto más de conocimiento y como "un paquete de percepciones", sin principio de unidad visible,

\footnotetext{
${ }^{801}$ La Psicología para Kant no se puede matematizar y por lo tanto no puede ser ciencia. Los estados internos no tienen un carácter individual como los cuerpos que existen en el espacio. Nuestros estados psicológicos y del alma no tienen la misma existencia sustancial que los objetos en el espacio. Al no ser sustancias no pueden ser definidas como unidades discritas que puedan ser contadas y matizadas. No puede ser una ciencia propiamente dicha. Y tampoco alcanza el carácter de ciencia impropia como en el caso de la Química (arte, técnica que puede ser matizada: las sustancias que estudia pueden ser concebidas como individuos en el espacio y pueden ser matematizadas. La Psicología y las Ciencias de la Vida no pueden ser consideradas ni como ciencias propiamente dichas ni como ciencias impropias.

${ }^{802}$ Cfr. AGAZZI, E., La ciencia y el alma de Occidente, pág. 64.

${ }^{803}$ Cfr. KANT, I., Crítica de la Razón Pura, A-104; cfr. TAYLOR, Ch., Argumentos filosóficos, pág. 104.

${ }^{804}$ Cfr. TAYLOR, Ch., Argumentos filosóficos, pág. 105.

${ }^{805}$ Cfr. TAYLOR, Ch., Argumentos filosóficos, pág. 128.

${ }^{806}$ Cfr. TAYLOR, Ch., Hegel, pág. 457.

${ }^{807}$ Cfr. TAYLOR, Ch., Argumentos filosóficos, pág. 43.
} 
y limitando la experiencia a bits de información sin conexión. Hume, "quedándose simplemente en la proposición sintética que liga el efecto a su causa (principium causalitatis), creyó mostrar que semejante proposición era totalmente imposible, a priori". 808

El conocimiento tiene que ser alguna "unidad de representación" en la que se vinculen la diversidad de la experiencia con el yo capaz de realizar una síntesis trascendental. Las categorías de la experiencia deben ser comprendidas desde la unidad de aprehensión del entendimiento que hace posible la "coherencia" de la experiencia diversa; lo mismo que las categorías del entendimiento se expresan como "condiciones de necesidad aplicables" a la experiencia.

El yo kantiano no es el "bulto de percepciones empíricas humeano", sino que va más allá de los fenómenos en su capacidad de introspección. Hay un sujeto que unifica la experiencia en el yo que "aprehende el mundo conceptualmente", y una experiencia que está referida en su diversidad a un yo que la unifica "necesariamente" desde un punto de vista fenoménico. ${ }^{809}$ La unidad representacional del yo convierte la experiencia en una condición necesaria del objeto "que-está-presente-para-el entendimiento":

"La misma representación de que todos estos fenómenos y de que, consiguientemente, todos los objetos de los que podemos ocuparnos se hallan en mí (es decir, constituyen determinaciones de mi yo idéntico) expresa la necesidad de una completa unidad de tales determinaciones en el interior y única apercepción”. ${ }^{810}$

Sin la unidad de apercepción de todos los fenómenos (objetos de la sensibilidad a priori), no puede realizarse la síntesis entre la sensibilidad y el entendimiento como posibilidad de universalidad y necesidad. $\mathrm{O}$, dicho de otra manera, según Taylor, es necesario que toda la experiencia "conocida" tenga cierta unidad para que "tenga sentido" desde la comprensión del yo como sujeto. ${ }^{811}$ Existe, pues, una "homogeneidad", como dice Kant, entre la unidad sintética pura del entendimiento, y la diversidad de representaciones de la unidad sintética a priori de la intuición. Homogeneidad que se expresa como capacidad de "subsumir" los fenómenos bajo el esquema de los conceptos del entendimiento. ${ }^{812}$

El yo pienso cartesiano debe ser capaz de integrar como necesidad y posibilidad todas las intuiciones de la sensibilidad a priori en una unidad de apercepción, o lo que es

${ }^{808}$ KANT, I., Crítica de la Razón Pura, B 20; cfr. TAYLOR, Ch., Hegel, pág. 26.

${ }^{809}$ Cfr. TAYLOR, Ch., Hegel, pág. 26.

${ }^{810}$ KANT, I., Crítica de la Razón Pura, A 129.

${ }^{811}$ Cfr. TAYLOR, Ch., Argumentos filosóficos, pág. 31, 49-50; cfr. TAYLOR, Ch., Hegel, pág. 9.

${ }^{812}$ Cfr. KANT, I., Crítica de la Razón Pura, pág. A-139. Cfr. GARCÍA MORENTE, M., La Filosofía de Kant, Ediciones Cristiandad, Madrid, 2018, pág. 134. Solo pueden ser conocidos científicamente los objetos perceptibles (fenómenos). Los objetos no perceptibles (virtudes ocultas, entes de razón, seres metafísicos...) no pueden ser nunca conocidos científicamente. Kant está superando totalmente la metafísica medieval aristotélica. 
lo mismo, "reconocer en la conciencia que la experiencia es mía", me pertenece como sujeto. Sin este "reconocimiento de propiedad" no existiría experiencia y, por lo tanto, no habría tampoco conocimiento, pues el conocimiento es conocimiento de la experiencia. ${ }^{813}$ No existiría el entendimiento como conciencia trascendental y, por lo tanto, no existiría tampoco la posibilidad de captación de la experiencia en su múltiple variedad fenoménica. Se trataría de experiencia de "percepciones" y conciencia de "hábitos y costumbres", pero no sentido de "sometimiento a las condiciones de indispensable unidad de apercepción". ${ }^{814}$ En este sentido, Taylor considera que la aportación kantiana es una afirmación del yo frente a la afirmación de la ciencia moderna newtoniana que considera el mundo como un reloj y en el que el hombre estaba destinado a "ponerse en sintonía" y captar cada vez más las leyes del universo. ${ }^{815}$

Las cosas son en la medida en que son para nosotros y afectadas por nosotros, a través de nuestra sensibilidad a priori (no como cosas en sí mismas) y subsumidas en su diversidad por nuestra aprehensión de la conciencia. La intuición recibe su contenido de fuera de nosotros, pero la naturaleza de esta realidad última es un "libro cerrado para nosotros" y lo es de modo insuperable, dice Taylor. ${ }^{816}$ La objetividad, en este sentido, no la da el conocimiento empírico y sensible, sino que "todos nuestros conocimientos residen en la experiencia posible tomada en su conjunto, y la verdad trascendental, que precede a toda verdad empírica y la hace posible, consisten en la relación general con esa experiencia". ${ }^{817}$ No existe, pues, sucesión empírica humeana basada en la simple introspección de la causalidad, sino que la experiencia consiste en la aplicación de la categoría del entendimiento causal a la experiencia del mundo que vivimos. ${ }^{818}$

Con Kant la relación entre el objeto y la representación cambia de lugar. ¿Es la Crítica de la Razón pura una fundamentación de la metafísica sobre la teoría científica del conocimiento y de las ciencias (Riehl), o un intento de respuesta a la gran pregunta sobre el hombre a partir del examen de la forma del conocimiento humano (Heidegger) $?^{819}$ Para Heidegger, el problema que plantea Kant en la Crítica es la finitud del conocimiento humano $\mathrm{y}$, por ende, la finitud del ser humano. Se trata de tomar conciencia de la finitud misma, "dándose cuenta" de que el entendimiento "no crea" objetos, sino que los presencializa y los representa. ${ }^{820} \mathrm{El}$ ser de estos objetos no es del entendimiento, sino que este solo puede ser consciente de su presencia y de su

${ }^{813}$ Cfr. TAYLOR, Ch., Hegel, pág. 67,77.

${ }^{814}$ Cfr. KANT, I., Crítica de la Razón Pura, A-110.

${ }^{815}$ Cfr. TAYLOR, Ch., Hegel, pág. 11.

${ }^{816}$ Cfr. Ibid., pág. 27.

${ }^{817}$ KANT, I., Crítica de la Razón Pura, B-185.

${ }^{818}$ Cfr. TAYLOR, Ch., Argumentos filosóficos, pág. 44.

${ }^{819}$ Cfr. CASSIRER, E., "Kant y el problema de la metafísica", Humanitas, No 8, (1957), págs. 107-108.

820 "Yo como inteligencia y sujeto pensante, me conozco a mí mismo como objeto pensado en la medida en que me soy dado a mí mismo como algo aparte de lo dado en la intuición, si bien, al igual que ocurre con otros Fenómenos, no como yo soy frente al entendimiento, sino como me manifiesto". KANT, Crítica de la Razón Pura, B-155. 
capacidad de representación. Frente a Dios, que lleva el ser y configura el ser, el entendimiento humano recibe o le es dado el objeto. Esto es lo propio de la intuición finita frente a la "intuición originaria". Por la intuición nos es dado el objeto y por el entendimiento "lo aprehendemos" a través de su "pura espontaneidad". ${ }^{821}$ Todo conocimiento está transido de finitud y, por tanto, el ser es pura finitud. ${ }^{822}$

No obstante, y siguiendo la lectura de Heidegger, podemos afirmar que esta "finitud" del conocimiento humano "va más allá", cuando Kant considera los principios de la razón que no están determinados por la intuición. Si el "entendimiento" está referido a la intuición sensible y precisa de ella, "la razón" no está condicionada por lo sensible, sino que "pregunta más allá". La razón trascendental, en su dialéctica, no está determinada por un objeto empírico ni por ninguna realidad cosificada, va más allá de la cosidad y entramos en el terreno de la trascendencia y lo incondicionado, en los conceptos de razón. ${ }^{823}$ Para Heidegger, "finito" puede ser llamado el entendimiento cuando no puede comprender nunca los objetos absolutos, pero es "infinito" en tanto corresponde a su verdadera y esencial tarea la "absoluta totalidad en la síntesis de las condiciones". 824

La razón, según Kant, nos coloca, pues, ante el imperativo de lo indeterminado, posicionándose así al lado de Platón. ${ }^{825}$ La razón kantiana, a semejanza de la platónica, pretende elevarse sobre los imperativos del entendimiento en su relación con la estética trascendental, y así proponer un conocimiento de las ideas que posibilitan lo incondicionado, manteniendo el enlace del entendimiento con la intuición empírica. En el entendimiento de los conceptos puros a priori, en su determinación como conciencia, el yo se determina a través de la pura espontaneidad del concepto a elevarse hacia el mundo de lo inteligible, que supera cualquier dependencia "cerrada" de lo empírico, y permite la "apertura" a la inmediatez de lo inteligible e indeterminado. Por consiguiente, para Kant, todo se resuelve entre la experiencia del fenómeno y la idea, entre ser y deber ser, al contrario que en Heidegger, que lo resuelve todo entre ser y tiempo, una experiencia que configura el ser en el tiempo, no una experiencia del ser como en Kant, que se resuelve en una razón trascendente capaz de comprender lo inteligible del ser. ${ }^{826}$

Concluimos afirmando que en el nuevo sistema del mundo que aparece con la Modernidad, el mundo deviene "en una imagen" representada por el hombre y realizada a su imagen y semejanza. Una imagen que, en los inicios de la Modernidad, todavía no ha recorrido el largo camino hacia el desencantamiento y la desconexión naturalista. Se

\footnotetext{
${ }^{821}$ KANT, I., Crítica de la Razón Pura, B-150.

${ }^{822}$ Cfr. CASSIRER, E., "Kant y el problema de la metafísica", pág. 112.

${ }^{823}$ Cfr. KANT, I., Crítica de la Razón Pura, A-380.

${ }^{824}$ CASSIRER, E., "Kant y el problema de la metafísica", pág. 116.

${ }^{825}$ Cfr. KANT, I., Crítica de la Razón Pura, B-371.

${ }^{826}$ Cfr. CASSIRER, E., "Kant y el problema de la metafísica", pág. 120.
} 
podría decir que, con el advenimiento de la ciencia newtoniana y la metafísica kantiana, el hombre ocupa el centro del escenario del mundo y crea el mundo como representación de sí mismo, tal y como dice Heidegger. Por eso, para Taylor, la Aufklärung alemana desarrolló su propio clima intelectual tan proclive al deísmo, que considera a Dios como un super-sujeto, y al hombre como alguien destinado a secundar el orden de la naturaleza desde su propio conocimiento de las leyes del mundo. ${ }^{827}$

Newton sostiene que la naturaleza "comunica todos sus secretos" y se puede experimentar y crear una ciencia de la naturaleza en sus movimientos y fuerzas mecánicas, donde la matemática está al servicio de la física experimental. Para Kant, el mundo de las cosas, de la naturaleza, de la experiencia, es un mundo abierto al encuentro con el sujeto cognoscente, con el que "interfiere", puesto que, sin la lógica trascendental de la categoría conceptual, no se puede decir "nada relevante", dado que la experiencia no aportaría conocimiento, solo sería pura desconexión de percepciones. Entonces se puede concluir que tanto Newton, desde su comprensión del mundo como un reloj, como Kant, desde la afirmación del hombre como subjetividad que se autodefine, realizan la síntesis perfecta encaminada a la afirmación del deísmo como la doctrina espiritual más adecuada a este clima intelectual, en el que se intenta realizar una síntesis amalgamadora entre el yo que se autodefine y la consideración del mundo como lugar de correlaciones contingentes. Pero, aunque no siempre fuera posible realizar dicho intento, lo que está claro, según Taylor, es que tanto desde el lado de la objetivación científica (Newton), como del lado del subjetivismo autodefinidor (Kant), ambos se apoyan en la defensa del devenir secularizador hacia el atomismo como expresión de un mundo entendido como relaciones causales eficientes entre sus partes constitutivas. ${ }^{828}$

\section{III.2.2.6. EL DEÍSMO Y "LA ÉPOCA DE LA FILOSOFÍA”}

A partir de las bases de la racionalidad moderna establecidas por Descartes y Locke, por Newton y Kant, no es de extrañar que nos encontremos con que el siglo XVIII ubica las fuentes de la moralidad en otro locus. Un locus no definido por el logos óntico de la razón ordenadora del cosmos, sino en un mundo establecido por un orden racional que ha sido impuesto por el Creador y que tiene que ser "descubierto" por la razón como la base que fundamenta la dignidad del ser humano.

El mundo ya no encarna el logos óntico, con lo que las fuentes de valoración moral ya no están "determinadas" por dicho orden cósmico, sino que "la razón ha vuelto la mirada" hacia un nuevo locus configurador de sentido: la razón. La razón ya no mira al orden cósmico para configurar el orden moral a partir del orden que actúa en las ideas

${ }^{827}$ Cfr. TAYLOR, Ch., Hegel, pág. 11.

${ }^{828}$ Cfr. Ibid., pág. 9. 
configuradoras de lo real, sino en la razón que es capaz de conocer el mundo de los objetos como un mundo que tiene su propio encadenamiento lógico, establecido así por la Mente del Creador. Se pasa de una localización paradigmática que está organizada en el cosmos (las cosas poseen una significación óntica predeterminada de antemano) y la realidad, a una fundamentación de un nuevo paradigma axiológico. ${ }^{829}$

Para el objeto de nuestro estudio, este momento es decisivo y de alguna manera inicia el proceso, la piedra filosofal que posibilita la diversidad de enraizamientos morales posteriores. En lenguaje filosófico weberiano sería el inicio del "desencantamiento". Por eso, este momento filosófico, correspondería, en términos arquitectónicos, a la imagen de la construcción de un edificio nuevo. Quedan cimientos, elementos de construcción, espacios que nunca permanecerán olvidados. Se reconstruye un nuevo edificio sobre el viejo solar del pensamiento humano, pero con un estilo distinto. No es fácil poner cimientos, crear nuevas configuraciones de estilo, ideas, nuevos materiales. En este sentido son relevantes dos ideas: la idea del "encadenamiento" y la idea de la "angularidad" del nuevo edificio que se va a erigir.

Es el inicio del proceso. El "atrevimiento" de volver la mirada hacia el interior es lo que posibilita todo un recorrido nuevo. La mirada se dirige hacia otros horizontes, con lo cual los resultados de la visión se van encaminando en otra dirección, No obstante, el mundo sigue siendo el mismo, los materiales de construcción que han quedado en el proceso de derrumbamiento permanecen como ruinas, aunque el fin sigue siendo idéntico: buscar el suelo nutricio y adecuado para enraizar la configuración moral que sostendrá el edificio interior del ser humano. Un edificio que antes se edificaba sobre un suelo cósmico y que ahora ocupa el suelo del propio sujeto humano, aunque con la misma finalidad: albergar la construcción moral del ser humano.

Desde estas nuevas bases morales cartesianas y lockeanas se va estableciendo una visión del Cristianismo totalmente distinta. Es el paso al deísmo. A partir del teísmo premoderno y de los autores que han configurado las bases para el cambio, se empiezan a enraizar unas fuentes morales que ubican el yo sobre bases filosóficas distintas.

Si el yo, en su incremento de autoconciencia racional, ontologiza su propio fundamento moral en sus potencialidades de "dominio" del mundo, es evidente que el mundo de la gracia queda de alguna manera marginado. La gracia y el misterio quedan desubicados en un mundo en el que todo parece depender del hombre y su capacidad

\footnotetext{
829 “Ahora podemos pensar que las ideas están en este ser independiente, porque tiene sentido verlas ahí y no en otro lugar... El giro desde las ideas platónicas a las 'ideas' cartesianas es quizá la ilustración más elocuente del cambio que vengo describiendo. Para el primero, las Ideas son ónticas, la base de la realidad; para el segundo son contenidos de la mente..., implica una nueva localización por la que situamos 'dentro' del sujeto lo que antes, a nuestro juicio, existía como si estuviera entre el agente/conocedor y el mundo, anudándolos y haciéndolos inseparables". TAYLOR, Ch., Fuentes del yo, pág. 261. Cfr. TAYLOR, Ch., Argumentos Filosóficos, pág. 225.
} 
racional. No se niegan las aspiraciones morales superiores, pero el hombre ocupa un lugar desde el que pretende afianzarse como garante para la explicación moral (y por ende racional) del mundo y de su propio yo.

En este cambio de orientación de la mirada, el yo cartesiano que piensa y el yo humeano que percibe sensaciones en la introspección empírica, se convierte en Kant en un sujeto que solo puede entenderse desde la "unidad sintética" de la variedad de la experiencia fenoménica y la aprehensión del entendimiento. Es un yo que unifica el cogito cartesiano y el empirismo humeano. En el yo kantiano las cosas no son en sí mismas, sino que van más allá, a partir de la transcendentalidad de un yo que capta fenómenos y es capaz de percibir la experiencia como "necesidad de las cosas" para este sujeto que las aprehende.

Hay un cambio absolutamente radical. La mirada ya no solo cambia hacia el yo que piensa, sino que se ontologiza el yo como única mirada posible para entender el mundo. La experiencia es experiencia del yo y solo se conoce la experiencia, y la experiencia es del yo cognoscente. En Kant hay un estudio arqueológico del yo que conoce, porque solo se tiene acceso al mundo a través del yo que contiene "a priori" los conceptos que "suministran el fundamento objetivo de la posibilidad de la experiencia" y a la vez a "una originaria referencia a la experiencia posible en la que se presentan todos los objetos del conocimiento". 830

Para Taylor, el deísmo no es solo una cobertura para el naturalismo, sino que además inicia procesos hacia la casi desaparición por completo del misterio en la Religión. Todo parece estar controlado racionalmente. La benevolencia divina, a pesar de que hay aspectos que se nos escapan, puede ser escrutada racionalmente. Es el avance imparable hacia la transparencia racional, en cuyo recorrido aparecen dos autores: J. Toland y su obra fundamental Christianity not Mysterious, y M. Tindal con su obra Christianity as old as Creation.

\section{I.- J. Toland y M. Tindal. Hacia un Cristianismo racional, sin lágrimas. ${ }^{831}$}

Tindal afirma que "la razón debe llevarnos al conocimiento de Dios y al descubrimiento de esa ley universal que fundamenta la constitución del mundo y la mirada racional del hombre. ${ }^{832}$ Una ley inscrita en el universo que "debe ser" la misma que la ley de la revelación y de los preceptos divinos. Es la misma ley la que rige la maquinaria de la naturaleza y a la que se puede acceder por la razón, y la que es expresada a través de la

\footnotetext{
${ }^{830}$ KANT, I., Crítica de la Razón Pura, A-94.

${ }^{831}$ Cfr. TAYLOR, Ch., Fuentes del yo, pág. 336.

832 "Your Design I must own, is highly commendable; but in order to succeed, you are to prove two things: First, that the Supreme Governor of Mankind has given his subjects an Universal Law, which they when they come to the use of Reason, are capable of knowing. Secondly, that the Divine Precepts must be the same, whether internally or externally revealed". TINDAL, M., Christianity as old as Creation, Volume I, London, 1730, pág. 9.
} 
revelación divina. No puede haber ruptura, pues se trata de la misma ley comunicada en un caso a través de la Razón que conecta desde el hombre con el mundo y en otro caso a través de la Revelación transmitida por Dios a través de los preceptos divinos. Todos aquellos preceptos divinos que no estén en relación con la Razón natural deberían ser desechados, ya que no puede haber contradicción entre los principios de la misma ley. Al mismo tiempo, todos los hallazgos de la razón humana en el conocimiento de la ley universal que no estén en armonía con los preceptos divinos, difícilmente serían asumibles o debería volverse sobre ellos para analizar el alcance de dicha investigación racional. Razón y Revelación son dos ámbitos de la misma huella divina. Una huella inscrita en la naturaleza y otra huella revelada por designio divino. Para Taylor, con Tindal se avanza irremediablemente hacia un ocultamiento de la gracia y un Cristianismo sin lágrimas, racional. Dios se hace más abarcable para la razón. ${ }^{833}$

Para Tindal, lo propio de Dios es su amor bondadoso y eterno hacia todos nosotros como criaturas suyas, mientras que, por el contrario, la tendencia natural del hombre es la búsqueda de su propio bien. Solo en la medida en que adquirimos "conciencia" a través de la Razón, de su amor hacia nosotros, es cuando las criaturas somos capaces de responder proporcionalmente a su Amor. El Amor de Dios queda ensalzado porque, sin necesitarnos, Él busca el amor a todas sus criaturas. ${ }^{834}$

Según Taylor, Tindal no cree que se nos invite a responder a su amor, ya que Dios "no necesita" de nuestro amor, aunque su Amor despliega en nosotros la conciencia de una debida respuesta proporcional al suyo, pero sin que eso sea buscado por Dios, ya que Él se encuentra, como Tindal refiere, infinitamente feliz en Él mismo. Se está avanzando, pues, irremediablemente hacia un deísmo en el que el bien que Dios quiere se identifica cada vez más con el bien natural y la búsqueda de la propia felicidad. No es que la referencia a Dios esté ausente, aunque la felicidad humana aparece descrita en términos casi exclusivamente criaturísticos. ${ }^{835}$

Se inicia, así, un cierto desapego del yo que concibe, por una parte, la necesidad de una proporcionalidad como respuesta al amor de Dios, pero, por otra parte, un alejamiento de Dios de su criatura, al no necesitar Dios del amor creatural. Para Taylor, se trata de un deísmo en el que el bien humano que Dios promueve se ha reducido tanto, que prácticamente se identifica con la búsqueda de la felicidad natural y el bien recíproco. $^{836}$

\footnotetext{
${ }^{833}$ Cfr. TAYLOR, Ch., Fuentes del yo, págs. 336-338.

834 "That all his actions, in relation to his creatures, flow from a pure and desinterested love; whereas the spring of all the actions of the creatures is their own good: we love God because he first love us; and consequentely our love to him will be in proportion to our sense of his goodness to us". TINDAL, M., Christianity as old as Creation, pág.16.

${ }_{835}$ TAYLOR, Ch., Fuentes del yo, págs. 338,366.

${ }^{836}$ Cfr. Ibid., pág. 371.
} 
Taylor opina que la labor de los Reformadores supone un empuje hacia este Deísmo tindaliano. ${ }^{837} \mathrm{Si}$ Dios no necesita de nuestro amor como necesidad y como respuesta justificada a su amor primero, tampoco es necesaria la ofrenda arrogante de un amor que se entrega al amor de Dios como totalidad de vida. Dios no lo necesita y, por lo tanto, tampoco son necesarias vocaciones de especial consagración a un Dios. Dios puede prescindir de nuestro amor, aunque entiende que la respuesta del hombre a su amor desinteresado sea un amor "proporcionalmente desinteresado". Taylor afirma, en este sentido, que la Reforma Protestante proponía liberar a los cristianos del peso del ascetismo gratuito y presuntuoso. ${ }^{838} \mathrm{Y}$ así, en esta línea, la labor reformadora, que se sustenta en el conocimiento de las Escrituras, pretendía liberar al creyente de la "autoridad esclavizante" que usurpaba el protagonismo del cristiano ordinario y "mistificaba" su vida a través de los sacramentos, entendidos como "misterios de vida cristiana", en los que dependían de una "autoridad" que alejaba a los cristianos de su propia autonomía de vida.

Por lo tanto, Tindal, en su propuesta deísta, llega a afirmar que Dios propone una suerte de bienaventuranza humana de acuerdo con el uso proporcionado y equilibrado de la razón, los sentidos y los sentimientos. La bondad de Dios se identifica con nuestra propia felicidad. ${ }^{839}$ Tindal propone un Deísmo en el que la razón regulariza de manera equilibrada el ejercicio del cuerpo y los sentidos, llegando a compatibilizar la bienaventuranza humana, ejercida de manera racional y equilibrada, con los designios de Dios. Dios lo que espera es que el hombre actúe de manera racional, potenciando una vida equilibrada y de acuerdo a la naturaleza propia; esto es, como criatura creada a imagen del Creador. ${ }^{840} \mathrm{El}$ hombre es consciente, según Tindal, de las "imperfecciones que siente" así como de las "perfecciones que ve en el Creador". Y de este sentimiento interior y de esta visión natural surge la verdadera religión, que no es otra que la que consiste en una disposición de la mente para hacer todo el bien posible y así estar en amistad agradecida con Dios. ${ }^{841}$

El deísmo de Tindal se distingue en este sentido del de Whichcote, que plantea un deísmo más minoritario, entendido en un sentido opuesto como deificación del hombre o como elevación de la naturaleza humana hacia una participación en lo divino. Es el representante más clarividente de los platonistas de Cambridge. ${ }^{842}$

\footnotetext{
${ }^{837}$ Cfr. Ibid., pág. 372.

${ }^{838}$ TAYLOR, Ch., La Era Secular, tI, pág. 366.

${ }^{839}$ Cfr. TAYLOR, Ch., Fuentes del yo, pág. 366. "And in a Word, whoever so regulates his natural appetites as will conduce most to the exercise of Reason, the health of his body and the pleasure of his senses, taken and considered together (since here in his happiness consists) may be certain he can never offend his Maker; who, as he governs all things according to his natures, can't but expect his rational creatures should act according to their natures”. TINDAL, M., Christianity as old as Creation, pág. 17.

${ }^{840}$ Cfr. TAYLOR, Ch., La Era Secular, tI, págs. 352-353.

841 TINDAL, M., Christianity as old as Creation, pág. 21.

842 "The Gospel is a Vital Principle, not of natural life, but Divine. As it satisfies the Reason of our minds
} 
Para Whichcote, la verdadera religión es un "estado mental", un equilibrio racional que pone en contacto con todo lo creado y descubre el orden del mundo a través de la razón y la disposición divina del cosmos. La religión natural es el equilibrio saludable entre todas las facultades de la razón, una disposición del alma que pone en contacto la razón con la verdad, de tal forma que dicha saludabilidad de la mente es la que predispone para el encuentro entre el alma y la verdad, una vez que esta viene al encuentro con el alma. ${ }^{843}$

Taylor afirma que los Platónicos de Cambridge, por ejemplo, Henry More, Ralph Cudworth, Benjamin Whichcote y John Smith, se opusieron con brío a una religión de ley externa, propugnando otra que percibía a los humanos en intrínseca armonía con Dios. El ser humano se aproxima a Dios con temor, como legislador inescrutable y cuyos juicios están inexorablemente fuera del alcance de la comprensión humana. ${ }^{844}$ Así lo expresa John Smith cuando dice que Dios dejó su huella en el mundo sensible, pero que el hombre necesita un intérprete interior que le haga comprender los inescrutables designios de Dios. ${ }^{845}$

Los Platónicos de Cambridge, en su deísmo, tienen sus raíces en el platonismo del Renacimiento, tal y como Ficino y Pico della Mirandola lo desarrollan en el siglo XIV. Un platonismo muy influido por Plotino, para quien los bienes verdaderos como propios del alma cuando actúa según su naturaleza y en objetos definidos, son entidades sustanciales, mientras que los no verdaderos no son más que afecciones pasivas. ${ }^{846}$

Se va experimentando un estrechamiento teológico y espiritual que se expresará bajo la idea de un Dios Providente y Creador, que desdibuja el lugar que desempeña la gracia en la vida cristiana, así como el misterio de Cristo en su acción salvadora por la humanidad o en la necesidad de una vida devota y religiosa. Un cambio que se inicia, tal

by removal of fears and doubts, by the life of faith, affiance and trust in God- and as it reforms our spirits and lives as conveying and communicating principles of goodness and righteousness by which we are made partakers of the divine nature". WHICHCOTE, B., The Cambridge Platonists. The Venerable nature and transcendent benefit of Christian religión, Clarendon Press, Oxford, 1901, págs. 31-32.

843 "But truth if it does appear if it be represented and fairly proposed it will find entertainment in a man'smind; if a man's mind be not by contrary in disposition made in an incapacity. Truth is the soul'shealth and strength, natural and true perfection. As increated wisdom speaks to God so truth speaks the same language to man's soul. Truth is so near to the soul; the very image and form of it". WHICHCOTE, B, The Cambridge Platonists. Evidence of divine truth, Oxford, Clarendon Press, 1901, pág. 3.

${ }^{844}$ Cfr. TAYLOR, Ch., Fuentes del yo, pág. 343.

845 "And though the whole fabrique of this visible univers be whispering out the notions of a diety and always inculcates this lesson to the contemplators of it, (...) yet we cannot understand it without an interpreter within... yet it must be something within that must instruct us in these mysteries and we shall then best understand them when we compare that copie which we find of them withing ourselves, with that we see without us". SMITH, J., The Cambridge Platonists. Existence and nature of God, pág. 163. Cfr. TAYLOR, Ch., Fuentes del yo, págs. 344-345. Este "something within" es la "naturaleza interior" de la que habla Taylor como una nueva modalidad de la interioridad agustiniana.

${ }^{846}$ Cfr. TAYLOR, Ch., Fuentes del yo, pág. 199; cfr. PLOTINO, Eneada III, Sobre el Amor. Ed. Gredos, Madrid, 2015, pág. 305. 
y como hemos visto, con los Platónicos de Cambridge especialmente en Tindal, Whichcote y Smith, que inciden en el potenciamiento de la razón, para encaminarnos hacia una religión natural en la que se viene a identificar la religión con la práctica de las mejores expresiones de la racionalidad humana. ${ }^{847}$

Otro autor que aparece en el estudio filosófico de Taylor es Toland, en su obra emblemática Christianity not mysterious, subtitulado: "No hay nada en el evangelio contrario a la razón". Toland analiza hasta sus últimas consecuencias lo que esto significa, con lo que "el misterio insondable de Dios", de alguna manera, queda marginado. Si todo es asumible por la razón y el único plan de Dios es que el hombre comprenda la insondable riqueza del corazón humano en la que Dios ha dejado su huella imborrable, entonces "no hay nada más allá" de la razón y el corazón humano. Todo es comprensible a través de la naturaleza humana, que esconde los secretos de Dios para el hombre. No hay otros misterios ocultos que puedan esconderse o que Dios nos tenga reservados. ${ }^{848}$

Evidentemente, si todo es razón inscrita en la naturaleza humana y Dios ha diseñado todo para que el hombre descubra por sí mismo "los misterios escondidos de Dios”, entonces no se necesita más que ejercitar la razón y sondear los misterios inherentes a la naturaleza humana. En consecuencia, se puede afirmar que el misterio escondido en Cristo y el sentido revelador de Dios en la historia quedan marginados frente a este antropocentrismo racionalista. Y así, la Iglesia queda reducida a una asociación de hombres comprometidos en la reforma de costumbres y en la búsqueda de las fuentes morales escondidas en el corazón humano. Todo se va estrechando, empequeñeciendo. ${ }^{849}$ Dios va dejando de ser el "misterio tremendo y fascinante" para

\footnotetext{
${ }^{847}$ Cfr. TAYLOR, Ch., La Era Secular, tI, pág. 353. Taylor hace también relación a los hugonotes holandeses y al Abate Saint-Pierre. Para el Abate Saint Pierre religión y política que busca la paz son prácticamente lo mismo. Un proyecto de paz europea para los estados cristianos tal y como se afirma en el propio Tratado. Se trata de la paz como la realización de la razón y el compromiso moral por una religión que se compromete con el orden providencial de Dios que busca dicho orden en la búsqueda de la paz. "Si en las épocas antigua y medieval, la idea de guerra estaba vinculada a conceptos positivos como el honor, en la época moderna comienza a cambiar dicha percepción (...). El abate de Saint-Pierre ha contribuido, sin duda, a promover, por medio de Rousseau y Kant entre otros, no solo el valor de la paz estable a nivel supranacional, sino a buscar el modo de institucionalizar dicha situación de paz". BELLO, E., "La construcción de la paz: el proyecto del abbé de Saint-Pierre" Res Publica, No 24, 2010, pág. 134.

${ }^{848}$ Cfr. TAYLOR, Ch., Fuentes del yo, pág. 336. "We hold that reason is the only foundation of all certitude; and that nothing revealed whether as to its manner or existence is more exempted from its disquisitions than the ordinary phenomena of nature. Wherefore, we likewise maintain according to the title of this discourse that there is nothing in the gospel contrary to the reason nor above it; and that no Christian doctrine can be properly called a mystery". TOLAND, J., Christianity not Mysterious, Sam Buckley Edition, Londres, 1696, pág. 6; cfr. Ibid., pág. 46. Cfr. CHAMPION, J., Republican Learning. J. Toland and the crisis of Christian culture 1696-1722, Manchester University Press, 2003.

${ }^{849}$ Cfr. BUCKLEY, M., At the origins of modern atheism, New Haven, Yale University Press, 1987, págs. 37-67.
} 
convertirse en una "huella escondida" en el fondo de la naturaleza humana. Lo interior está constituido, cada vez más, por la reflexividad radical. ${ }^{850}$

Todo esto va a significar la importancia que adquiere la moral, que ocupa prácticamente todo el campo de la religión. La religión es moral y la moral racional adquiere un significado cuasi religioso. Poco a poco se va abandonando la idea de la gracia que acompaña la vida del hombre y el sentido profundo de la debilidad humana que necesita ser acompañada por Dios para realizar "su designio salvífico", para pasar a una moral racional que disciplina la vida del hombre y encauza las fuerzas negativas que rompen la coherencia psíquica. La voluntad humana se va imponiendo al sentido gratuito de la gracia.

Frente al cansancio de las luchas interminables de la reforma sobre la gracia, el libre albedrío o la predestinación, los Platónicos de Cambridge inician el camino hacia una "simplificación" de la religión cristiana como una religión natural, que en el fondo encauzaba la vida hacia un sentido de equilibrio psíquico y mental, que se entremezclaba con el bien común y la búsqueda de la felicidad; todo ello entendido como un orden providencial diseñado por el Creador en el corazón humano.

Por otra parte, del cansancio de las polémicas de la Reforma y la súplica de los Platónicos de Cambridge a una simplicidad de vida cristiana, se llega poco a poco, a una propuesta de vida cristiana en la que el núcleo de vida era una cuestión de conducta moral basada en el orden y la disciplina. La religión va camino de centrarse en un moralismo voluntarista y disciplinario basado en las fuerzas de la razón humana para encaminar las fuerzas morales que anidan en el corazón del hombre.

A medida que se pasa de los Platónicos de Cambridge a Locke y Tillotson, la experiencia espiritual se va tornando cada vez más una experiencia que entronca con la psicología humana. El pecado va dejando de ser una realidad de la que somos rescatados por la gracia y la transformación del ser y pasa a considerarse más como un "comportamiento incorrecto" al que enfrentarse por la fuerza de la voluntad humana. La religión cae en el riesgo de convertirse en moralismo. ${ }^{851}$

II.- J. Locke y el voluntarismo teológico en clave puritana y hedonista. Para Locke, el hombre tiene acceso al conocimiento de Dios como un conocimiento "evidente", ya que es imposible que un ser pensante como el ser humano no haya sido creado por un Espíritu igualmente pensante e inmutable desde toda la eternidad. Solo un Espíritu podría haber creado a seres espirituales o pensantes como nosotros. ${ }^{852}$

\footnotetext{
${ }^{850}$ Cfr. TAYLOR, Ch., La Era Secular, tI, pág. 62; cfr. TAYLOR, Ch., Fuentes del yo, págs. 455-456.

${ }^{851}$ Cfr. TAYLOR, Ch., La Era Secular, tI, pág. 358.

852 “Así pues, de la consideración de nosotros mismos, y de lo que hallamos infaliblemente en nuestra
} 
Locke, como hemos afirmado anteriormente, representa la Ilustración primera o suave, que retiene la perspectiva trascendente en la afirmación de la vida corriente a través de la filosofía de la libertad y la razón desvinculada. Es la posición deísta de la primera Ilustración.

Locke piensa que la moral debe fundamentarse en la ley natural más que en los mandamientos divinos, ya que no puede haber contradicción en lo que Dios dejó inscrito en la naturaleza humana expresada a través de su racionalidad y los dictados de la ley divina revelada. ${ }^{853}$ No es cierto pues, interpretar a Locke como referente de un escepticismo religioso tal y como se manifiesta en la Modernidad actual. Sobre la base del conocimiento humano debe sustentarse la "firmeza de la revelación divina". La revelación divina debe encajar en las dimensiones propias del conocimiento humano y Dios no puede "revelar" algo que no pueda ser acogido por la razón humana, o que la razón humana asuma un estrechamiento empequeñecedor respecto a la revelación divina. Para Locke, hay una relación absolutamente entrelazada entre conocimiento humano y revelación divina, puesto que toda la certeza humana respecto a su capacidad de conocimiento se basa en que Dios es el que ha revelado tal proposición y Dios no puede contradecir sobre la base y fundamento del conocimiento humano. ${ }^{854}$ En vez de seguir el telos de la naturaleza, nos convertimos en constructores de nuestro carácter. ${ }^{855}$

propia constitución, nuestra razón nos conduce al conocimiento de esta verdad cierta y evidente: que existe un Ser eterno, omnipotente y omnisciente, llámesele como quiera, sea que se le llame Dios o de otro modo, pues eso no hace al caso. No hay nada más evidente. Y de esta idea debidamente considerada, deduciremos fácilmente todos aquellos atributos que debemos reconocer en este Ser eterno". LOCKE, J., Ensayo sobre el entendimiento humano, pág. 95.

853 “Todo lo que Dios ha revelado es ciertamente verdadero, y ninguna duda puede surgir. Este es el objeto propio de la fe, pero, si algo es o no revelación divina, la razón es la que lo debe juzgar”. Ibid. pág. 102.

854 "Locke reconcilia las dos, pues piensa que en efecto estamos capacitados para leer con toda facilidad los designios de Dios partiendo de la verdadera naturaleza de su creación”. TAYLOR, Ch., Fuentes del yo, pág. 328. Para Locke hay dos tipos de racionalidad: la racionalidad moral y la racionalidad intelectual. La primera como seguimiento de las fuentes morales de la racionalidad y la segunda como ejercicio de la propia razón. Ambos tipos de racionalidad están en relación con una vida de acuerdo con la ley divina que también nos hace racionales moralmente. "Al acatar esas dos órdenes de la razón instrumental —aceptar la ley de Dios y adquirir el conocimiento que es útil y reflexionar sobre él一, participamos en los planes de Dios. La racionalidad instrumental, correctamente conducida, es la esencia de nuestro servicio a Dios". Ibid., pág. 333. Nos encontramos en el descubrimiento de la razón instrumental frente a la razón sustantiva de los teólogos anteriores a la Reforma que afirman que a partir de la razón se puede descubrir el orden del bien en el camino hacia la visión beatífica. Con Locke se incide en el descubrimiento de la razón instrumental a partir de la razón moral. Es la moralidad inherente a la racionalidad humana la que permite descubrir la racionalidad intelectual que desemboca en la razón instrumental. De ahí que para Locke sea tan importante descubrir la racionalidad moral ya que sobre la base del descubrimiento moral de la razón natural inscrita en la naturaleza es necesario potenciar posteriormente la racionalidad intelectual que nos permita tener la seguridad y la certeza de que lo que conocemos es cierto y nadie nos engaña, porque está en juego la racionalidad moral que sustenta el ejercicio de la racionalidad intelectual. Es Dios y el orden inscrito en la naturaleza el que nos lanza al ejercicio de la racionalidad intelectual, de ahí el Ensayo sobre el Entendimiento humano. No vale cualquier conocimiento, ya que está en juego la base de nuestras fuentes morales.

${ }^{855}$ Cfr. TAYLOR, Ch., Fuentes del yo, pág. 273. 
Taylor reflexiona sobre el voluntarismo teológico de Locke en clave puritana, y afirma que es capaz de conciliar a través de dicho voluntarismo los mandamientos de Dios y la razón humana ${ }^{856}$. Se tiene una seguridad absoluta en que Dios no puede engañarse ni engañar en los dictados de su revelación, pues Dios nos ha hecho receptores de sus designios a través del conocimiento humano y la racionalidad capaz de desentrañar dichas verdades a través de su interconexión con el pensamiento humano.

Este voluntarismo teológico de carácter hedonista es lo que determina la moral lockeana. Atrás quedan motivaciones de la gracia divina o seguimiento absoluto de la moral cristiana. Todo pasa por el asentimiento de la razón y por la voluntad humana que sigue los dictados del placer o el dolor, al mismo tiempo que la recompensa o castigo divinos. Seguir los planes de Dios provoca placer y felicidad. Es la propia naturaleza humana la que está "ordenada" a seguir la ley natural inscrita en el corazón del hombre, la que provoca placer, $y$, en esa misma medida, ha sido "establecida" para que pueda ser seguida en función del placer moral que provoca. Y, por otra parte, seguir los planes de Dios es causa de recompensa y premio eterno de un Dios Juez tal y como se revela en los mandamientos divinos. Dios nos ha hecho para que sigamos los preceptos establecidos según una ley natural inscrita en la naturaleza humana y según la cual nadie debe dañar a otro en su vida, salud, libertad o posesiones. ${ }^{857}$ Es la religión del hedonismo y del Juicio divino en función del asentimiento o desacato de la voluntad divina. Taylor habla del hedonismo calculador de Locke frente al cual reaccionará Shaftesbury. ${ }^{858}$

Nos espera una recompensa si cumplimos su ley inscrita en la naturaleza humana, ya que somos sus servidores como Hacedor de todo lo creado. Somos su propiedad y a Él le debemos pleitesía y obediencia absoluta, y dependemos de Él en un designio absoluto del Creador sobre la creatura. Y también conocemos la ley divina de su revelación. En ambos casos, corresponde a la racionalidad del ser humano comprender que una ley, tanto revelada como natural, debe ser cumplida, y dependiendo de su cumplimiento u olvido, nos esperará la felicidad y la inmortalidad propia de los justos, o el castigo a los pecadores. ${ }^{859}$

\footnotetext{
${ }^{856}$ Cfr. Ibid., pág. 322.

857 "El estado natural tiene una ley natural por la que se gobierna, y esa ley obliga a todos. La razón, que coincide con esa ley, enseña a cuantos seres humanos quieren consultarla que, siendo iguales e independientes, nadie debe dañar a otro en su vida, salud, libertad o posesiones; porque, siendo los hombres todos la obra de un Hacedor omnipotente e infinitamente sabio, siendo todos ellos servidores de un único Señor soberano, llegados a este mundo por orden suya y para servicio suyo, son propiedad de ese Hacedor y Señor que los hizo para que existan mientras le plazca a Él y no a otro". LOCKE, J., Segundo Tratado sobre el Gobierno, Gredos, Madrid, 2015, pág. 120.

${ }^{858}$ Cfr. TAYLOR, Ch., La Era Secular, tII, pág. 36.

${ }^{859}$ Cfr. LOCKE, J., La Racionalidad del Cristianismo, Paulinas, Madrid, 1977, pág. 61; cfr. TAYLOR, Ch., Fuentes del yo, págs. 321-329.
} 
No obstante, para Locke, aunque el hombre puede conocer a Dios a través de la razón y a través de la revelación, sin embargo, la revelación para Locke profundiza y da un alcance mayor a la comprensión racional de los planes de Dios. El hombre puede acceder a su comprensión a través de la creación y la razón natural; sin embargo, la revelación completa y hace posible una comprensión de los planes de Dios, que, utilizando solamente la razón, difícilmente estarían al alcance de la comprensión racional del hombre.

La revelación de Dios se realiza desde lo más profundamente humano de la vida de Jesús, no a través de una revelación del poder trascendente de Dios, sino una revelación a través de lo que el hombre puede comprender de acuerdo a su naturaleza, no forzando la voluntad y el conocimiento humano a través de poderes sobrenaturales, sino adaptándose al "humano comprender" y a las situaciones más normales de la vida humana. Dios no abusa del "poder" que evidencian los milagros, sino que quiere que demos nuestra adhesión a Dios desde la capacidad propia del conocimiento humano, desde la libertad personal que esto implica y no forzando a creer, sino motivando para la apertura al Amor de Dios, evitando cualquier confusión entre lo natural y lo sobrenatural. Constantemente, el hombre descubre los propósitos divinos por medios que funcionan según su naturaleza, desde la humana comprensión y desde la libertad y voluntad propias. ${ }^{860}$

Dios acompaña al hombre a través de la ley natural inscrita en la naturaleza humana por medio de la razón. La providencia y misericordia de Dios tuvo en cuenta la posibilidad de la corrupción humana, miseria, miedos, susceptibilidades, temores..., a pesar de la ley racional establecida en el orden divino; y le envió un Mediador, "llegado el tiempo oportuno", para su rescate salvador. Y así, toda la humanidad tiene acceso a una salvación ofrecida por Dios y a la que probablemente no accederían por la sola razón humana, debido a la aptitud inherente al ser humano "para caer en toda clase de corrupción y miserias". 861

Según Locke, la "ley divina viene en ayuda de la ley natural" en una suerte de amalgama liberadora, como si la ley divina posibilitara caminos de "salvación" para la gente común, mientras que otra minoría podría acceder a dicho encuentro con Dios a través de la razón y la ley natural. Dicha amalgama creó cierta incomodidad en muchas mentes religiosas de la época que ven en Locke una inestabilidad intelectual difícil de asumir. ¿Qué debe fundamentar la ley moral, el orden natural establecido por el creador

\footnotetext{
${ }^{860}$ Cfr. LOCKE, J., La Racionalidad del Cristianismo, pág. 154.

861 "Dios, por la infinitud de su misericordia, ha tratado al hombre como un Padre compasivo y tierno. Le dio la razón y con ella una ley que no podía ser de otra manera que la razón dictara, a menos que pensáramos que un ser racional tuviera una ley irracional. Pero considerando la debilidad del hombre, propenso a incurrir en la corrupción y la miseria le prometió un Libertador a quien envió a su tiempo". Ibid., pág. 248.
} 
o la virtud religiosa establecida por la ley divina revelada? ¿Qué voluntarismo moral debe fundamentar el comportamiento del hombre, el establecido por la ley divina o el placer o dolor (hedonismo) que provoca el seguimiento o rechazo del bien moral? Locke, dando un paso más en relación a la ley natural inscrita en la naturaleza humana por el Hacedor, piensa que el fin del hombre, siguiendo con la afirmación protestante de la vida ordinaria, es conservar o preservar su propia vida que evite el destruirse a sí mismo o corromperse, evitando el "relativismo moral". 862

Desde este imperativo moral de preservar la vida como ley natural establecida en el orden moral de la naturaleza, Locke establece dos dimensiones morales que caracterizan al ser humano:

1.- El hombre es constructor de su propio dinamismo moral. Preservar la vida y cuidar del mundo significa activar los resortes morales del propio yo y ser consciente de la racionalidad que configura la propia vida personal. ${ }^{863}$

2.- El hombre debe cuidar y proteger la vida de los demás para que juntos construyan la vida desde los mejores resortes morales que le lleve a compartir la vida y defenderla unos con otros, trabajando para el bien común y el compromiso con los demás. ${ }^{864}$ Taylor asegura que Locke es el primero y de forma más influyente, que expresó esa concepción básica de la Modernidad del orden moral como servicio mutuo. ${ }^{865}$

Esta integración lockeana del cuidado de uno mismo, sin descuidar aquellos compromisos hacia los otros, es lo que abre el camino hacia el capitalismo burgués que intenta amalgamar el propio interés personal con la atención hacia los otros. ${ }^{866} \mathrm{El}$ dinamismo moral lockeano que busca el propio individualismo y los intereses privados no está reñido con la búsqueda del bien común. ${ }^{867}$ Es más, el bien común favorece el desarrollo de los intereses privados, con lo que la interacción de ambos intereses es la

\footnotetext{
862 "Cada uno de nosotros está obligado a su propia conservación y a no abandonar voluntariamente el puesto que ocupa... Y para que sea observada la ley de la naturaleza, que busca la paz y la conservación de todo el género humano, ha sido puesta en manos de todos los hombres, dentro de ese estado, la ejecución de la ley natural”. LOCKE, J., Segundo Tratado sobre el Gobierno, pág. 121.

863 "Pero, aunque ese estado natural sea un estado de libertad, no lo es de licencia; aunque el hombre tenga en semejante estado una libertad sin límites para disponer de su propia persona y de sus propiedades, esa libertad no le confiere derecho de destruirse a sí mismo, ni siquiera a alguna de las criaturas que posee, sino cuando se trata de consagrarla con ello a un uso más noble que el requerido por su simple conservación”. Ibid., pág. 120.

864 "De la misma manera que cada uno de nosotros está obligado a su propia conservación y a no abandonar voluntariamente el puesto que ocupa, lo está, así mismo, cuando no está en juego su propia conservación, a mirar por la de los demás seres humanos y a no quitarles la vida, a no dañar esta". Ibid., pág. 121; cfr. págs. 124,126.

${ }^{865}$ Cfr. TAYLOR, Ch., La Era Secular, tII, pág. 237.

${ }^{866}$ Cfr. TAYLOR, Ch., Argumentos filosóficos, pág. 194.

${ }^{867}$ Cfr. TAYLOR, Ch., La ética de la autenticidad, págs. 61-62; cfr. TAYLOR, Ch., Imaginarios sociales modernos, pág. 204.
} 
mejor manera para propiciar el individualismo propio. Se consigue más a nivel individual a través de la interacción con el bien común que la sola búsqueda egoísta del interés individual. Es posible la interacción entre el bien individual y el bien común, la búsqueda del bien individual a través del bien común y la búsqueda del bien común a través del bien individual. Locke abre el camino hacia la Primera Ilustración posibilitando la aparición de los dinamismos que encaminan la economía hacia el Capitalismo emergente. En este sentido, tal y como afirma Taylor, Locke es la figura clave que posibilita el cambio desde la afirmación de la vida corriente en clave teológica hacia la formulación meramente naturalista burguesa. ${ }^{868}$

Frente a los ideales de una sociedad jerárquica y de clase y valores guerreros, Locke inicia el cambio decisivo hacia una "ética basada en la vida corriente" que se afirma a partir del orden racional y la búsqueda de los valores que constituye la preservación de la vida comenzando por la propia y asegurando esta sobre la base del interés común. En este sentido, Locke supuso un cambio fundamental para iniciar la transición de las fuentes morales del yo hacia una cosmovisión totalmente distinta del yo y del mundo. ${ }^{869}$

Según la opinión de Taylor, Locke es consciente de las dificultades de seguir la ley natural. ${ }^{870} \mathrm{Se}$ observa en los niños que desean siempre su propio interés y quieren que todo esté en función de su propio egoísmo, como si estuviera innata en la naturaleza humana la búsqueda de la egolatría y el poder que busca estar por encima de los demás. ${ }^{871}$ La ley natural necesita, como se ha sugerido anteriormente, del complemento de la revelación divina, pues por nosotros mismos, según los dictados de la razón natural, no somos capaces de vislumbrar los planes de Dios en su totalidad. Dios quiere "clarificar" el camino a través de la revelación divina, para orientar la senda hacia las fuentes morales del yo que no encuentran su plena realización en la razón natural. Y además el castigo o la recompensa motivarán nuestro comportamiento en un sentido $\mathrm{u}$ otro.

No somos capaces de lograr todo por nuestras propias fuerzas. Dios, con su revelación, nos ayuda y completa aquello que dejó inscrito en la naturaleza humana y a lo que tenemos acceso a través de la razón natural. Sin el castigo o la recompensa, la fuerza de la ley divina quedaría desprovista de la motivación necesaria. Pero además de

\footnotetext{
${ }^{868}$ Cfr. TAYLOR, Ch., Fuentes del yo, pág. 328.

${ }^{869}$ Cfr. Ibid., págs. 289-340.

${ }^{870}$ Cfr. Ibid., pág. 329.

871 "We see children (as soon almost as they are born, I am sure long before they can speak) cry, grow peevish, sullen, and out of humour, for nothing but to have their wills. They would have their desires submitted to by others. Another thing, wherein they show their love of dominion, is their desire to have things to be theirs; they would have property and possession, pleasing themselves with the power which that seems to give, and the right they thereby have to dispose of them as they please". LOCKE, J., Some Thoughts Concerning Education, Posthumous Works, Familiar Letters, 1690, 104.1 y 105.2.
} 
la posibilidad de castigo o recompensa y del disfrute o dolor que se experimenta por una elección u otra, y que conecta con la razón natural, Dios, ante todo, es Misericordioso. Dios siempre da una oportunidad y la confianza en Dios a través del arrepentimiento se expresa siempre en una palabra salvadora.

A este respecto, los ateos, para Locke, no comprenden el sentido definitivo de la vida que se encuentra en el reconocimiento de Dios como fundamento de la vida. Sin este asentimiento, el ateísmo, en su opinión, es un peligro para la vida social, ya que se pone al margen del compromiso ético por los demás o menosprecia la vida civil entendida desde el bien común. Desde todo lo argumentado anteriormente por Locke, es comprensible su falta de tolerancia hacia los ateos por lo que significa de falta de ejercicio racional en el descubrimiento del orden racional inherente a todo lo creado y que lleva la huella del Dios Hacedor del Mundo y, consiguientemente, por el compromiso ético que dicho descubrimiento implica en relación a la búsqueda del bien común. $^{872}$

En relación con la ética hedonista, que busca el placer en la realización del bien y experimenta el dolor cuando no se realiza, se trata de algo inscrito por Dios en la naturaleza humana y, por lo tanto, un camino positivo que lleva la huella del Hacedor. Es un amor de sí natural, que tiene en Locke una significación teológica, pero que prepara el camino para la primera Ilustración que habla de la positiva inocencia inherente al amor de sí. Serán otros los que recorran este camino, pero Locke, al abrir la puerta a esta positividad del amor a sí, está preparando el camino hacia la negación de su relación con la trascendencia en un momento posterior de la primera Modernidad.

Con Locke, se llega a Dios a través del orden natural regido por una ley inscrita por Dios y que la razón permite descubrir. Según Taylor, en Locke el ejercicio de la racionalidad es la forma de participar en el plan de Dios. ${ }^{873}$ Lo que la Reforma plantea como "vida devota" a partir de la vida cotidiana, ahora con Locke se traspone y se da un paso más a partir de la configuración racional del mundo: se puede descubrir a Dios a través de la "vida racional" inscrita de la naturaleza del mundo y del hombre. Un orden que nos invita a elevarnos sobre la corrupción y el engaño pasional y al mismo tiempo

\footnotetext{
872 "Por último, los que niegan la existencia de Dios, no deben tolerarse, porque las promesas, los contratos, juramentos y la buena fe, que son los principales vínculos de la sociedad civil, no pueden inducir a un ateísta a cumplir su palabra; y que, si se destierra del mundo la creencia de una divinidad, no puede menos de darse entrada franca inmediatamente al desorden y general confusión. Por otra parte, los que profesan el ateísmo no tienen derecho ninguno a la tolerancia sobre el capítulo de la religión, supuesto que su sistema las destruye todas". LOCKE, J., Carta sobre la tolerancia, pág. 420. "Pero hay otro mal más oculto y peligroso que este, quiero decir, la prerrogativa que ciertas gentes se arrogan contra toda especie de derecho, y con exclusión de todas las demás sectas, y que encubren bajo bellas apariencias y bajo la capa de grandes palabras engañosas". Ibid. pág. 419.
}

${ }^{873}$ Cfr. TAYLOR, Ch., Fuentes del yo, pág. 332. 
nos lleva hacia la promoción de la propia vida que entra en conexión con el bien común. $^{874}$

Con la religión "razonable" de Locke y su Cristianismo racional-deísta se avanza de manera irremediable en clave secularizadora y potenciando el desencantamiento del mundo. Destacamos tres elementos:

1.- El misterio retrocede. Todo es visto en clave de una racionalidad moral que conduce a una racionalidad instrumental. ${ }^{875}$ Afirmar el orden inherente a todo lo creado lleva a descubrir una ley natural inscrita por el Hacedor. Es esa ley natural la que enraíza moralmente al ser humano, ya que le capacita racionalmente para descubrir a Dios. De ahí la relevancia que adquiere la racionalidad intelectual: hay que poner de manera correcta las bases que fundamenten el conocimiento humano, ya que está en juego el acceso a dicha racionalidad moral. La razón moral eleva a la racionalidad intelectual. De ahí que los espacios para el encantamiento del mundo queden estrechados por ambas racionalidades. El misterio queda asumido por la fe, que acepta la revelación divina como una iniciativa que intenta superar la indigencia humana en su acceso a la racionalidad.

2.- La inteligibilidad racional de los designios de Dios. Dios ha inscrito su huella en la naturaleza y la razón permite el acceso a dicha comprensión racional de la voluntad divina. El misterio se identifica con la razón indagadora. ${ }^{876}$ La razón ha sido puesta por Dios para que busque el orden racional inherente al mundo. El misterio es orden y el orden se identifica con la mente racional que accede a dicha comprensión. De ahí que el misterio se estrecha por la racionalidad moral y la moralidad motiva el acceso a la razón instrumental. No se puede comprender el orden moral sin descubrir el orden de las ideas y la certeza del conocimiento. ${ }^{877}$

3.- El orden de la gracia tiende a desaparecer. ${ }^{878}$ No se necesita el empuje divino para comprender sus planes. Los planes están inscritos en la naturaleza, y Dios ha

\footnotetext{
${ }^{874}$ Cfr. TAYLOR, Ch., Argumentos filosóficos, pág. 248; cfr. TAYLOR, Ch., Imaginarios sociales modernos, págs. 203-204; cfr. TAYLOR, Ch., La ética de la autenticidad, pág. 69. "La razón procedimental desvinculada nos eleva de la destrucción a la beneficencia porque rompe los herrajes de la ilusión, la ciega costumbre y la superstición y al hacerlo nos alza desde el egoísmo salvaje y desordenado a la búsqueda productiva de la felicidad, la cual también beneficia a los demás". TAYLOR, Ch., Fuentes del yo, pág. 332.

${ }^{875}$ Cfr. TAYLOR, Ch., Argumentos filosóficos, pág. 27.

${ }^{876}$ Cfr. TAYLOR, Ch., Hegel, págs. 101-102.

${ }^{877}$ Cfr. TAYLOR, Ch., La Era Secular, tI, págs. 358,363.

${ }^{878}$ En relación con la teología de la gracia y su relación con la naturaleza, hay dos visiones tradicionales que planteaban objetivos distintos:

1.- La visión tomista según la cual la gracia no destruye la naturaleza, sino que la completa. AQUINO, Tomás de, Suma Teológica, Cap. I, artículo 8, BAC, Madrid, 2001, pág. 96. “Como quiera que la gracia no suprime la naturaleza, sino que la perfecciona, es necesario que la razón natural esté al servicio de la fe, de la misma forma que la tendencia natural de la voluntad se somete a la caridad". AQUINO, Tomás de, Suma Teológica, Cap. I, art. 8. Es decir que según Tomás de Aquino, hay un plan escondido en Dios
} 
dejado una ruta de acceso a Él a través de la razón moral y la razón instrumental. La gracia es la razón inscrita en la naturaleza humana capaz de indagar el misterio del Hacedor. Si el misterio está inscrito en el "libro de la naturaleza", no se necesita de una gracia que empuje al hombre a descubrir a Dios. La gracia divina se identifica con la racionalidad que descubre la ley natural.

Para Taylor, en Locke, por sus influencias hiperagustinistas, la gracia todavía está presente a través de las inspiraciones del Espíritu Santo. No obstante, desaparece el papel de la gracia en su ímpetu motivacional para que seamos buenos.

Vendrán otros autores, como Hutcheson, que completarán el recorrido hacia el deísmo. Un deísmo en el que el papel de la gracia como ayuda en el sentimiento de debilidad y fracaso también desaparecerá. ${ }^{879}$

III.- Hutcheson y el positivismo ético y benevolente. Frente a las tesis calvinistas que hablan de la corrupción de la naturaleza humana, así como la incapacidad natural para realizar obras buenas en línea con el pesimismo moral de Locke, Mandeville y Hobbes, otro autor, Hutcheson plantea un positivismo ético según el cual es posible una acción buena y benevolente por parte del hombre, es decir, es posible un principio intrínseco de moralidad. El hombre es capaz de realizar acciones generosas; el egoísmo no es lo que rige la naturaleza humana. Hutcheson afirma que hay una bondad natural inherente al ser humano, frente a las teorías egoístas de Pufendorf y legalistas de Locke. El deísmo de los sentimientos morales de Hutcheson es distinto completamente al deísmo lockeano anteriormente reseñado.

que nos lleva más allá de las virtudes naturales hacia las virtudes teologales y que nos eleva a la santidad invitándonos a llevar "una vida escondida con Cristo en Dios". En esta línea se encuentra la filosofía de Erasmo de Rotterdam.

2.- La visión agustiniana según la cual la naturaleza está herida por el pecado original y necesita de la rehabilitación salvadora de Dios, se necesita de la gracia para cualquier intento de acceso al bien. Sin la gracia es imposible el encuentro con Dios e incluso para el descubrimiento de la bondad natural. En esta línea se encuentra la teología de Lutero. Así lo afirma San Agustín. "Pues el Señor no solo nos ha mostrado el mal que hemos de evitar y el bien que hemos de practicar, cosa que solo está al alcance de la letra de la ley, sino también nos ayuda a evitar el mal y a obrar el bien, y esto nadie lo consigue sin el espíritu de la gracia, faltando el cual la ley solo sirve para nuestra culpable condenación. Por lo cual dice el Apóstol: La letra mata, pero el espíritu vivifica. Quien, pues, legítimamente se sirve de la ley, por ella viene en conocimiento del mal y del bien y, desconfiando de sus fuerzas, acude a la gracia, para que con su ayuda evite lo malo y haga lo bueno”. HIPONA, A. de, De la corrección y la gracia, Cap. I, n. 2.

El primer período de la Modernidad estuvo caracterizado por las teorías hiperagustinianas en torno a la teología de los movimientos de la Reforma (luteranos, jansenistas, calvinistas, puritanos...). Posteriormente, con el deísmo de la Ilustración, se van superando dichas visiones hiperagustinistas, que al final terminan por suprimir el papel de la gracia del tipo 2 (agustiniano), y allanar el camino hacia el naturalismo. Y en dicho camino también el deísmo, a pesar de haber recurrido a los teólogos de tradición erasmista, también termina por eliminar el papel de la gracia del tipo 1 (tomista). En Locke todavía no se llega al final del deísmo, sino que hay elementos de hiperagustinismo en la referencia de la corrupción y debilidad humana, pero al mismo tiempo en Locke se va reduciendo progresivamente el papel de la gracia del tipo 1 . Se trata de un deísmo suavizado.

${ }^{879}$ Cfr. TAYLOR, Ch., Fuentes del yo, pág. 338. 
Hutcheson parte del principio hedonista lockeano según el cual la eficacia de la verdad nos pone en conexión con la felicidad y el placer. ${ }^{880}$ Dicho placer, para Hutcheson, no depende directamente de nuestra voluntad, al contrario que para Locke. El placer o el dolor son proporcionados, según Hutcheson, al margen de nuestra voluntad. Los objetos se nos presentan como tales al margen de nuestra voluntad, ocasionándonos un sentimiento u otro, sin que nuestra voluntad intervenga en ningún momento.

En continuidad con Descartes, para Hutcheson es la idea presente en la mente la que invita a la contemplación de dicho placer o dolor, y no la percepción sensorial. El placer o dolor es "una idea" que se contempla y no una percepción sensorial. Hutcheson distingue entre "sentidos" como unas determinaciones a ser agradados por esas ideas contempladas, "sentido interno" como capacidad inherente al ser humano que nos permite percibir la bondad, el orden, la belleza y la armonía y "sentido moral" como determinación a ser agradados por la contemplación de los afectos, acciones o caracteres de los agentes racionales denominados "virtuosos". Según Taylor, para Hutcheson, el sentido moral libera ideas, y estas ideas no se cuestionan. ${ }^{881}$

El Autor de la Naturaleza nos ha dotado de una capacidad natural para sentirnos atraídos por la acción virtuosa, haciendo "de la virtud una acción deliciosa para excitarnos a perseguirla y nos ha dado fuertes sentimientos que son las fuentes de cada acción virtuosa". ${ }^{882}$ Se trata de una teoría que sigue la psicología lockeana y que se aparta de las ideas innatas cartesianas. En nuestra naturaleza se desarrollan así los sentimientos morales y van creciendo con la misma naturalidad con que crecemos en edad y estatura. Es como una semilla plantada en nuestra naturaleza y que se desarrolla en toda su integridad según la naturaleza que le es propia.

Hutcheson prefiere hablar de "sentido moral" en lugar de ideas innatas. La psicología lockeana le ha derivado por un camino distinto. El sentido interno nos capacita para "captar" la belleza y armonía de las cosas. Hutcheson entiende que hay un sentido de la belleza que es distinto a nuestro deseo de ella. El deseo de la belleza podrá ser contrapesado por recompensas o amenazas, pero no nuestro sentido de la misma, que es anterior a todo.

Para Hutcheson, la belleza original o absoluta no está en los objetos, sino que se necesita "una mente" que la perciba como tal. Es la expresión racional de la belleza moral y del sentido interno capaz de captarla. Una captación que es mental y un sentido

\footnotetext{
880 "La importancia de cualquier verdad no es más que su relevancia o eficacia para hacer a los hombres felices y proporcionarles el mayor y más duradero placer y la sabiduría significa solamente una capacidad de perseguir este fin con los mejores medios". HUTCHESON, F., Una investigación sobre el origen de nuestra idea de belleza, Tecnos, Madrid, 1992, pág. 3.

${ }^{881}$ Cfr. TAYLOR, Ch., Fuentes del yo, pág. 357.

${ }^{882}$ HUTCHESON, F., Una investigación sobre el origen de nuestra idea de belleza., pág. 6.
} 
interno que va asociado a la mente. "Si no hubiera una mente con un sentido de la belleza para contemplar los objetos no veo cómo podrían llamarse bellos" ${ }^{883}$ El sentido moral brota de la razón humana que configura el sentimiento capaz de identificarse como tal. El sentimiento moral es la expresión racional del ser humano para configurarse a partir de sus fuentes morales. ${ }^{884}$

Sin embargo, para Hutcheson, la belleza es una cualidad inherente a los objetos que va más allá de la sensación que capta la belleza, ya que las sensaciones pueden ser modificaciones de la mente que los percibe. Por eso, aunque es necesaria una mente que capta la belleza, sin embargo, la belleza va más allá de las sensaciones o tiene que superar esa dimensión sensorial que capta. Una cosa es la captación de la belleza a través de una mente que la percibe, y otra, la belleza misma presente en los objetos y que es previa a la captación mental de la misma, aunque para captarla es necesario "el sentido de una mente". ${ }^{885}$ "El sentido interno es una capacidad pasiva de recibir ideas de belleza a partir de todos los objetos en los que hay uniformidad en la variedad" ${ }^{886}$ Es decir, el sentido moral viene configurado no solo por la sensibilidad para captar la belleza natural inscrita en el corazón humano, sino también por la racionalidad que compatibiliza y empatiza con dicho sentimiento. Sentimiento moral y espíritu racional se expresan de manera coordinada. Es el sentimiento espiritual de una mente configuradora.

Hutcheson sigue a Locke y construye el concepto así llamado de "sentido moral". ${ }^{887}$ El Diseño del Creador, la perfección de la naturaleza humana, permite que el

\footnotetext{
${ }^{883}$ Ibid., pág. 21.

${ }^{884}$ Cfr. TAYLOR, Ch., La Era Secular, tI, págs. 354,368.

${ }^{885}$ Cfr. HUTCHESON, F., Una investigación sobre el origen de nuestra idea de belleza, pág. 23.

${ }^{886}$ Ibid., pág. 72; cfr. Ibid., págs. 53-55 sobre el sentido interno. "Las figuras que suscitan en nosotros las ideas de belleza parecen ser aquellas en las que hay uniformidad en la variedad. Hay muchas concepciones de objetos que son agradables bajo otras perspectivas como la sublimidad, la novedad, la santidad y otras de las que trataremos después. Pero lo que llamamos bello en los objetos para decirlo en términos matemáticos parece ser una razón compuesta de uniformidad y variedad”. Ibid., pág. 24.

Es decir que para Hutcheson, dentro de la uniformidad la variedad aumenta la belleza. Habrá que profundizar en el concepto de variedad dentro de la uniformidad para darnos cuenta de lo que implica el aumento de la belleza dentro de lo que supone el equilibrio y la armonía de lo uniforme. La uniformidad que encontramos en los movimientos celestes, en el crecimiento de plantas o la constitución biológica de las diferentes partes de los animales y proporcionalidad de sus miembros..., o la belleza de la obra de arte que está basada en la uniformidad y la unidad de proporción.

"De aquí se sigue que, aunque toda regularidad, combinación y semejanza en el universo constituyen presunciones de finalidad, sin embargo, la irregularidad no es presunción de lo contrario, a menos que supongamos que el agente está determinado por un sentido de la belleza a actuar siempre de modo regular y a deleitarse en la semejanza y que no puede tener otro motivo inconsistente de acción, siendo la última de las condiciones claramente absurda”. Ibid., pág. 59.

887 "Our moral Senses hews this to be the highest Perfection of our Nature; what we may see to be the End or Design of such a Structure, and consequently what is required of us by the Author of our Nature: and therefore, if anyone like these Descriptions better, he may call Virtue, with many of the Ancients, 'Vita secundum naturam'; or 'acting according to what we may see from the Constitution of our Nature, we were intended for by our Creator"'. HUTCHESON, F., An Essay on the Nature and Conduct of the Passions, Liberty Fund, Indianapolis, 2002, pág. 8.
} 
sentido moral haga emerger de nuestra propia naturaleza ideas morales que no se cuestionan, lo que se necesita de nosotros para descubrir el plan del creador inscrito en ese diseño. Es lo que se ha denominado virtud o vida según la naturaleza o actuar de acuerdo a lo que está inscrito en la naturaleza por el Creador. Se trata de dejarse llevar pasivamente por ese sentido moral inscrito en la naturaleza y que, cuando se vive de acuerdo a él, emerge en la mente, como ideas que motivan el comportamiento moral virtuoso o la vida según la propia naturaleza. ${ }^{888}$

Se trata, pues, de dejar que "el sentido moral inscrito en la naturaleza" humana llegue a nuestra mente como ideas. Ideas que, según Hutcheson, siguiendo a Locke, provienen de sensaciones y reflexiones; esto es, sensaciones externas y percepciones internas, a través de las cuales emerge la vida según la naturaleza. La naturaleza en sus sensaciones y percepciones llegan a la mente y se transforman en ideas que motivan "naturalmente" el comportamiento moral del hombre. El sentido moral emerge de la naturaleza humana que libera ideas que motivan el comportamiento "natural" del hombre. ${ }^{889}$

En este sentido, Hutcheson define "sentido" como la determinación de la mente para recibir ideas independientemente de nuestra voluntad y así tener percepciones de dolor y placer. ${ }^{890} \mathrm{Y}$ establece cinco tipos de "sentidos": los sentidos externos; las percepciones agradables o sentido interno para los "placeres de la imaginación”; el

${ }^{888}$ Cfr.TAYLOR, Ch., Fuentes del yo, pág. 366.

${ }^{889}$ Hutcheson cita en su prefacio al obispo anglicano Butler y sus Fifteen Sermons Preached at the Rolls Chapel, donde también se habla del sentido moral inherente a la propia naturaleza humana. En el Sermón primero, Butler habla de que se puede seguir la naturaleza y hacer obras en el espíritu de la benevolencia y al mismo tiempo también siguiente la naturaleza obras de depravación y maldad. Pero Butler continúa diciendo que hay un principio superior en el hombre de reflexión o conciencia. "Which distinguished between the internal principles of his heart as well as his external actions: which passes judgement upon himself and them; pronounces determinately some actions to be in themselves just, right, good; others to be in themselves evil, wrong, unjust. Which without being consulted, without being advised with, magisterially exerts itself, and approves or condemns Him the doer of them accordingly...It is by this faculty, natural to men, that he is moral". BUTLER, S., Fifteen Sermons preached at the Rolls Chapel, Sermon II, Printed by W. Botham, Londres, 1726, pág. 35.

Taylor considera a Boyle y Clarke como figuras importantes que se ocuparon de producir pruebas sólidas de la existencia y bondad de Dios, en plena efervescencia de una religion más simple, doctrinalmente menos elaborada y más accessible a la razón. Cfr. TAYLOR, Ch., La Era Secular, tI, pág. 357.

"That sudden and immediate sense of pleasure arising from the view or observation of some sort of actions, separate from all expectations of any Benefit to ourselves from them, seems intended by the Great Author of the Nature to invite mankind to the practice of virtuous actions to turn and fix the attention of the mind upon them in order to discover more completely their tendency and the natural benefits and advantages that may reasonable be expected from them by the practitioners". CLARKE, J., Foundation of Morality, Printed by Thomas Gent, York 1730, page 97.

"I will argue in what follows that Hutcheson's theory of morality shares far more common ground with Clarke's morality than is generally acknowledged. In fact, Hutcheson's own view of his innovations in moral theory suggest that he understood moral sense theory more as an elaboration and partial correction to Clarkean fitness theory than as an outright rejection of it". SHERIDAN, P., "The Metaphysical Morality of Francis Hutcheson: A Consideration of Hutcheson's Critique of Moral Fitness Theory" Sophia, (2007), pág. 263.

${ }^{890}$ Cfr. HUTCHESON, F., An Essay on the Nature and Conduct of the Passions, Liberty Fund, Indianapolis, 2002, pág. 17. 
sentido social que nos sensibiliza hacia la felicidad de los otros, también llamado "sentido común"; el sentido moral que nos capacita para la sensibilidad para captar la virtud o el vicio; y el sentido del honor que se expresa en aprobación o condena por parte de los otros en relación con nuestro propio comportamiento moral. Cinco sentidos que provocan "deseo" en el placer que causan, y aversión cuando no se encaminan en la realización del mismo. ${ }^{891} \mathrm{Y}$ así es como Dios nos ha hecho, de tal manera que, a través de los sentidos internos, el sentido común, el sentido moral y el sentido del honor, sintamos bondad y benevolencia hacia los demás.

Para Hutcheson, en la historia de la Filosofía moral hay dos posibilidades que motivan el comportamiento moral del hombre:

1.- La tradición epicúrea, que es promovida por Cicerón y Hobbes, según la cual es el amor propio y la búsqueda de la propia felicidad la que motiva el comportamiento moral del hombre. ${ }^{892}$ Es el elogio del sabio que busca la propia libertad y felicidad en el bien, y el bien que es promovido por la felicidad que provoca en la propia realización de dicho bien anhelado a través de la filosofía. El único motivo de elección es la felicidad privada.

2.- La otra opinión es que no solo tenemos amor propio, sino también afecto hacia los otros, en distintos modos y grados, que nos motiva hacia la búsqueda de su felicidad como fin último, olvidándose de la felicidad propia. ${ }^{893}$

Y concluye Hutcheson afirmando que las dos opiniones tienen consistencia racional, son inteligibles, pero solo la segunda "parece" ser más acorde con la naturaleza humana, mientras que la primera "no parece" representarla. Según Hutcheson, en cualquier acción moral hay un presupuesto racional que lo motiva, un fin que determina el deseo. ${ }^{894}$ Para Taylor, lo realmente relevante es que Hutcheson no alcanza a darse cuenta de cómo esto abre la puerta al relativismo, ni de lo problemático

\footnotetext{
${ }^{891}$ Cfr. Ibid., págs 18-19.

892 "That all the Desires of the human Mind, nay of all thinking Natures, are reducible to Self-Love, or Desire of private Happiness: That from this Desire all Actions of any Agent do flow". Ibid. pág. 134."Verdaderamente, iqué grave, qué magnífica, qué constante se nos presenta la figura del sabio! Cuando la razón le ha enseñado que lo moral es el único bien, por necesidad es siempre dichoso y sin duda ninguna posee todos aquellos títulos de los que suelen burlarse los ignorantes. (...) Y si es verdad que solo es feliz el hombre bueno y que todos los hombres buenos son felices, ¿qué cosa hay más digna de ser cultivada que la filosofía y qué cosa más divina que la virtud?". CICERÓN, Del Supremo bien y del supremo mal, págs. 120-121.

${ }^{893}$ HUTCHESON, F., An Essay on the Nature and Conduct of the Passions, pág. 136.

${ }^{894}$ Ibid., págs. 138-139. Nos parece importante resaltar el enfrentamiento de Hutcheson con los racionalistas al hablar de si hay un "deseo" que motiva la acción moral. La tesis de Bishop ayuda a aclararlo: "Hutcheson assumes throughout that if he can prove that exciting reasons presuppose affections (...) then he has proved that reason cannot provide the motive for virtuous acts. (...) He assumes that if he can show that moral concepts are not reducible to the non-moral concepts usually associated with the faculty of reason, then he has shown that justifying reasons, and hence moral approval, presupposes the moral sense.” BISHOP, J.D., The moral philosophy of Hutcheson, University of Edinburgh, 1979, pág. 192.
} 
que ello hace su juicio acerca de la bondad moral de la deidad. ${ }^{895}$ No es que Hutcheson defendiera un camino explícito hacia el subjetivismo relativista y al naturalismo, sino que "sin darse cuenta" lo posibilita. La bondad de Dios es previa a los sentidos de los que nos dota. Todo está configurado para que nuestro comportamiento moral esté orientado hacia la bondad natural y a la benevolencia. De ahí que es más conforme con la naturaleza humana un comportamiento moral basado en la benevolencia que acciones morales que se fundamenten en la propia búsqueda de la felicidad individual. Esto último no parece tan acorde con la naturaleza humana establecida por el Diseñador del mundo. Y así, las cosas funcionan de manera más acorde para el funcionamiento de la totalidad del engranaje establecido por esta Deidad. ${ }^{896}$

Y lo mismo ocurre en relación con la felicidad humana. El servicio a los demás es lo que lleva a la propia felicidad. No hay contradicción entre amor propio y compromiso con los demás. ${ }^{897}$ Nos servimos mejor a nosotros mismos desde el afecto a los demás. Estamos programados para armonizar los intereses propios desde el servicio a los demás. La búsqueda de los afectos sociales y comunitarios está en íntima relación con el amor propio, de tal forma que la moral del egoísmo solo puede ser compatibilizada con el bien común.

Para Taylor, Hutcheson coincide en parte con la moral egoísta de los teóricos extrínsecos (Pufendorf y Cumberland), pero no se limita a ella. Ambas visiones participan de la idea de la armonía de intereses. La diferencia está en que los teóricos extrínsecos no aciertan en el reconocimiento de las fuentes morales que fundamentan la benevolencia humana. Mientras que Hutcheson confirma la disposición natural humana para el bien y la benevolencia como algo que no está reñido con la búsqueda del bien personal, los teóricos extrínsecos no parten de estas fuentes morales de la natural benevolencia humana, sino que encuentran dificultades para configurar el bien social cuando este entra en contradicción con la moral del propio interés personal. Hutcheson, por el contrario, habla de una "satisfacción de la mente" como recurso para afirmar la conexión entre el bien común y el interés personal. Sin esta satisfacción moral es muy difícil realizar dicha conexión. Ambas están intrínsecamente relacionadas. Hutcheson habla de una incapacidad de ruptura entre ambas conexiones, dado que se rompería esa "satisfacción moral". No se trata de un conflicto de intereses, sino de una

\footnotetext{
${ }^{895}$ TAYLOR, Ch., Fuentes del yo, pág. 358.

${ }^{896}$ Cfr. Ibid., págs. 389-390,393,414; cfr. TAYLOR, Ch., La Era Secular, tI, pág. 357. En este ambiente de una religión más simple y más accesible a la razón emerge una actitud de desdén hacia la fe, que según Taylor, tiene más que ver con una actitud burlona o un clima general de escepticismo que con una falta de fe.

897 "When any Event may affect both the agent and others, if the agent have both self-love and public affections, he acts according to that affection which is strongest, when there is any opposition of interests; if there be no opposition, he follows both. If he discovers this truth, that 'his constant pursuit of public good is the most probable way of promoting his own happiness', then his pursuit is truly reasonable and constant; thus, both affections are at once gratified, and he is consistent with himself". HUTCHESON, F., An Essay on the Nature and Conduct of the Passions, pág. 143.
} 
fundamentación moral en la que no se puede entender un bien sin el otro, mientras que para los teóricos extrínsecos es posible realizar dicha ruptura cuando el bien personal entra en contradicción con el bien común. Las fuentes morales son distintas. En el caso de Hutcheson no se puede buscar el bien personal sin el compromiso moral por un mundo mejor, mientras que para los teóricos extrínsecos, cuando la moral egoísta no se puede alcanzar armónicamente a través del bien social, entonces prima el bien personal, es posible la preeminencia de un bien sobre el otro. Hutcheson no problematiza el vínculo porque hay una fuente moral que lo garantiza. Los teóricos extrínsecos anteponen el bien personal cuando la conexión no es posible. Se da por supuesta la ruptura. En Hutcheson, la ruptura no se puede dar porque "la satisfacción de la mente" no entiende un bien sin el otro. ${ }^{898}$ Las fuentes morales en Hutcheson evitan "an alternate prevalence of seemingly contrary desires". 899

Hutcheson habla de una exciting reason (razón motivadora) para servir al bien común, ya que el bien común es lo que mejor garantiza (effectual means) la obtención de ambos fines. No es el bien privado, es que se antepone al bien común si surge un conflicto de intereses (teóricos extrínsecos), sino que hay una razón primera que motiva al bien común, ya que desde el bien común se garantiza mejor ambos fines.

No obstante, Hutcheson habla de que son las fuentes morales (a moral sense) las que motivan que se anteponga el bien público al bien personal, no una razón o una verdad. En este sentido, Hutcheson distingue entre justifying reason y exciting reason. La razón puede justificar una acción moral del tipo que sea, pero solo hay una razón que motiva las fuentes morales para un determinado comportamiento moral y esa es la razón que motiva el sentido moral. La verdad moral que antepone el bien común que "posibilita" la armonía de ambos fines es el sentido moral. ${ }^{900}$ Reconocer el "sentido moral" que anida en nosotros como expresión de la benevolencia de la naturaleza humana, es abrirnos al Diseñador de todo lo creado que quiso configurar todo de esta manera. Reconocer este carácter benevolente del ser humano nos hace mejores. No se trata de dar razones o de fundar una verdad, sino de recurrir al sentido moral que anida en la naturaleza humana y que nos hace comprender lo que somos y al Diseñador que configuró todo este engranaje. ${ }^{901}$

\footnotetext{
${ }^{898}$ Cfr. TAYLOR, Ch., Fuentes del yo, págs. 389-390,393,414.

${ }^{899}$ Cfr. HUTCHESON, F., An Essay on the Nature, pág. 144; cfr. TAYLOR, Ch., Fuentes del yo, págs. 355-357, 359-360.

900 "When we say one is obliged to an Action, we either mean, 1. That the Action is necessary to obtain Happiness to the Agent, or to avoid Misery: Or 2. That every Spectator, or he himself upon Reflection, must approve his Action, and disapprove his omitting it, if he considers fully all its Circumstances". HUTCHESON, F., An Essay on the Nature, pág. 146.

${ }^{901}$ Cfr. TAYLOR, Ch., Fuentes del yo, págs. 355-357; cfr. TAYLOR, Ch., El multiculturalismo y la política del reconocimiento, págs. 57-58.
} 
Taylor opina que Hutcheson está más en línea con los Platónicos erasmistas de Cambridge, que con el psicologismo lockeano, más próximo a la interiorización del bien como un sentimiento natural de Shaftesbury que al deísmo lockeano. No obstante, reconoce que está en línea con todos ellos hacia el utilitarismo. ${ }^{902}$

IV.- Leibniz y el deísmo providencial. En el camino hacia el humanismo exclusivo del que estamos hablando tiene un papel fundamental este deísmo de finales del XVII y todo el siglo XVIII. Es, por lo tanto, una etapa intermedia, tal y como refiere Taylor, y es lo que nuestro autor refiere como "deísmo providencial". El mundo diseñado por Dios asume un "cambio antropocéntrico" en relación a la primacía que adquiere el orden impersonal y el avance hacia una religión natural. ${ }^{903}$ Ambos presupuestos tendrán una expresión fundamental en la filosofía de Leibniz.

\footnotetext{
${ }^{902}$ Cfr. TAYLOR, Ch., Fuentes del yo, pág. 361.

${ }^{903}$ El así llamado "cambio antropocéntrico" significa para Taylor: 1.- No existe un propósito añadido al plan diseñado por Dios. Dios solo espera de nosotros que asumamos el plan diseñado por Él como seres racionales (Cfr. Tindal, Christianity as old as the Creation; cfr. Abate Saint-Pierre y su concepto de "bienfaisance"). En este sentido, para Tindal, Dios no necesita "actos heroicos" que justifiquen una supuesta arrogancia espiritual frente al resto de vocaciones. Se abre así el camino a los reformadores, que asumen el compromiso fundamental de todos los cristianos frente a opciones jerárquicas de diferenciación espiritual. 2.- El eclipse de la gracia y su justificación filosófica en Locke a partir de su libro La racionalidad del Cristianismo . 3.- El sentido del misterio se va desvaneciendo y todo se va configurando en relación a un "diseño" establecido por Dios en la naturaleza donde el misterio va desapareciendo y donde el misterio casi queda reducido a la fe cristiana y al misterio del mal en el corazón del hombre. Si podemos acceder al conocimiento de las leyes de la naturaleza se puede acceder al conocimiento del Diseñador que solo "nos pide" que confiemos en la razón humana para acceder al conocimiento de dicho "orden natural", identificándose así Providencia divina y diseño ordenado de la naturaleza. En este sentido también se abrió el camino a los reformadores que "evitan" los sacramentos del misterio y abren el camino a la cristificación de la vida ordinaria. 4.- La idea de la vida más allá de la muerte va también a sufrir su propia evolución desde los platónicos de Cambridge, pasando por Tillotson hasta llegar a Locke. Una idea que es reformulada por los platónicos de Cambridge en base a lo que ellos denominan "teosis" y que significa que es posible una "divinización" progresiva del ser humano que comienza ya aquí, aunque cumplirá su realización en el más allá. Una idea que va a sufrir su propia evolución en Tillotson y Locke que incidirán cada vez más en la superación del pecado como una "incapacidad ontológica de la que necesitamos ser rescatados" para pasar a una identificación casi absoluta del cristianismo con la moral en el sentido de que es necesaria la voluntad humana para asumir un comportamiento en el que el hombre va siendo cada vez más protagonista de su propio devenir. Es la razón moral la que va llevando a la consideración de que el cristianismo es cada vez más "un refuerzo moral de la voluntad" para cambiar lo que el hombre en su libertad y responsabilidad puede ir asumiendo por sí mismo: es posible el cambio de vida moral a partir del esfuerzo humano. En eso incidirá mucho la predicación del ArzobispoTillotson. Y también, en el ámbito de la teología católica, los Ejercicios Ignacianos se ubican en esta importancia dada a la posibilidad humana de cambio moral a través de la disciplina voluntaria y el método. También se ubicaría aquí, aunque unos años antes, San Francisco de Sales y sus obras Introducción a la vida devota y Tratado del Amor de Dios. Frente a este "optimismo antropológico" por asumir el propio protagonismo moral se encuentra la vía opuesta hiperagustinista que desconfía de las posibilidades humanas para elevarse espiritualmente dada la "incapacidad ontológica" que experimenta el hombre como consecuencia de las heridas del pecado. Dicha visión hiperagustinista pone el acento en el "engaño" de este optimismo voluntarista para elevar el vuelo y ubicarse en unas fuentes morales que nos abran el camino para el encuentro con Dios. Según la visión hiperagustinista necesitamos entregarnos a la misericordia divina para iniciar el camino de "regreso", no se puede fomentar el voluntarismo moral para enfrentar la propia condición humana transida de debilidad e incapacidad. Esta es la corriente representada por el Jansenismo.
} 
Este "cambio antropológico" va a suponer, en cierto sentido, una reubicación del propio yo a partir de la confianza ilimitada en las propias posibilidades de la razón, donde la ayuda de la gracia y el sentido del misterio se van desvaneciendo. Se trata de un paso más en el proceso desencantador del mundo.

Esta situación encamina el mundo hacia una "religión natural", hacia un deísmo desencantador del mundo, en el que el misterio del poder organizador de Dios se va desconfigurando, y además Dios pasa a ser más el que "dirige" nuestras acciones en un mundo desencantado. Es decir, el surgimiento del deísmo providencial es el reconocimiento de un paso fundamental en el proceso desencantador del mundo, que, al propio tiempo que afirma a Dios como "origen" de nuestra fundamentación ontológica para reconocer al Creador, sin embargo "capacita" al hombre para asumir su propio protagonismo en el reconocimiento del orden inherente al mundo y posibilita el reconocimiento de este Dios benevolente que quiere que "reconozcamos" dicho orden y vivamos de acuerdo a él.

El deísmo del siglo XVIII es, en cierta manera, un paso intermedio hacia la Ilustración radical, laica e increyente. Se ha hablado de la falta de coraje del deísmo para afirmar la increencia, basado en las apariencias o en la hipocresía. No obstante, sería una afirmación un tanto superficial pensar que el deísmo no tenía consistencia intelectual o que simplemente "ocultaba" la increencia por falta de arranque para afirmar el ateísmo. Taylor prefiere hablar del deísmo como período intermedio o "proceso" que encamina hacia la Ilustración radical. ${ }^{904}$

Con el deísmo se afirma la postura trascendente de un horizonte moral en el que Dios está como telón de fondo, empujando la benevolencia del mundo e impregnando la racionalidad que descubre el orden en todo lo creado. Una creación en la que el Diseñador ha impreso su imagen en todo. No obstante, la idea tan fundamental en el judeocristianismo de un Dios que ama y que busca una relación personal con el hombre queda difuminada con el Deísmo. La felicidad está más en el descubrimiento de las fuentes morales que han sido impresas en la racionalidad inscrita en la naturaleza humana, que en el descubrimiento de lo que nos es dado a través de la revelación cristiana. Todo está diseñado como un engranaje en el que el hombre es una criatura del Diseñador, una criatura que descubre su lugar en el mundo como centro de la racionalidad cósmica y que tiene un sentido moral capaz de anteponer el bien de los demás como premisa para la búsqueda armónica del bien personal y del bien social. Al mismo tiempo, afirma la vida eterna, no tanto como una promesa que plenifica el corazón, cuanto un alcance de posibilidad que garantiza y permite el comienzo de la felicidad en este mundo.

${ }^{904}$ Cfr. TAYLOR, Ch., Fuentes del yo, págs. 363-365. 
La felicidad no es referida hacia un asentimiento moral con una propuesta de amor divino, sino hacia el descubrimiento de un engranaje racional que plenifica la realidad total y que ha sido inscrita en la naturaleza del hombre y del mundo. La benevolencia de Dios busca que el hombre descubra la benevolencia de todo lo creado para su propio disfrute. Se afirma a Dios, pero como una pieza más del engranaje general, no tanto como base y fundamento de un amor personal. Eso es lo que hemos descubierto en Locke y Hutcheson. ${ }^{905}$ La felicidad así es una propuesta intramundana, no teológica y, "en esa búsqueda de la felicidad", se descubre como horizonte de sentido la creación benevolente de Dios, que ha dejado su huella en la naturaleza humana para que descubra esa invitación a servir al otro como parte integrante de la felicidad humana. Son los sentimientos morales expresados como propuesta de liberación personal los que llevan al encuentro con Dios y con los demás. "Liberar el sentimiento" es descubrir la huella de lo trascendente e impregnar de humanismo el mundo. Todo comienza como una indagación en el sentido moral inherente a toda interioridad humana y, a partir de ahí, se descubre un horizonte de trascendencia impulsora de referencias solidarias y autodescubrimientos.

El horizonte de sentido deísta, al contrario del que se había vislumbrado en la tradición religiosa occidental, es un horizonte en el que el hombre parte de sí mismo, de su sentido moral, y a partir de ahí, descubre a Dios como el creador de unos sentimientos morales que "potencian" las dimensiones de lo personal y lo social, del bien individual y del bien común. Es el ser humano el que recupera el protagonismo y descubre en su sentido moral a Dios. Se parte de la propia afirmación personal y de ahí se llega a la afirmación de la trascendencia. No al revés. En ese sentido, hay una ruptura deísta. Una ruptura que implica que no se parte de Dios como una propuesta que afirma al hombre, sino que el deísmo afirma al hombre y desde ahí se abre al sentido trascendente. Taylor afirma que para el deísmo "los humanos están ahí para Dios y no viceversa". ${ }^{906}$ Se afirma a Dios desde el hombre, no al hombre desde Dios. El cambio de perspectiva es radical, aunque la afirmación trascendente sigue vigente. Pero la autoafirmación antropológica lo disloca todo. Nos ubicamos en otras fuentes morales a

\footnotetext{
905 Cfr. Ibid., pág. 362.

${ }^{906}$ Cfr. Ibid., pág. 367. Se mantiene la referencia a Dios en la búsqueda del bien personal y del bien común, pero de manera "subordinada" a la felicidad tal y como se entiende, según Taylor, en términos "criaturísticos". Se antepone la criatura al Creador, aunque se siga afirmando el Creador. La felicidad se considera en términos de placer o ausencia de dolor tal y como hemos visto en Locke, de tal forma que las referencias al Creador son subsiguientes a esa búsqueda propia de la felicidad y del bien común. Primero se afirma dicho enfoque criaturístico y luego se afirma el Hacedor de dicho orden impreso en la naturaleza. Dios es el que confirma con su orden el impulso primero de la criatura hacia su propia felicidad. Es el hombre el que se afirma en su búsqueda de la felicidad, un impulso de bondad que le persigue y que compagina con la benevolencia divina que refrenda dicho impulso. Tanto la bondad humana como la bondad divina están "determinadas" hacia la felicidad universal. Se trata así pues del impulso hacia una felicidad no teocéntrica. Lo que realmente importa es la felicidad humana y es la pretensión última de Dios. El hombre está ahí para Dios y no viceversa. En este aspecto, el deísmo supone una ruptura con la tradición religiosa y por otra parte está firmemente enraizado en ella.
} 
pesar de que se siga afirmando el sentido trascendente de la vida. Para la tradición religiosa no todo se reduce a una propuesta moral de carácter racional. Hay lo que Taylor denomina "una dimensión extra" que desaparece con el deísmo. Esta "dimensión extra" significa que en la tradición religiosa "hay una participación en el poder afirmador de Dios", es decir, tanto en el Judaísmo como en el Cristianismo, dicha afirmación significa que no todo depende de la voluntad moral del sujeto, sino que hay una afirmación "inicial" del poder de Dios, que se expresa como Torah o como Amor de Dios, y que reconoce que, sin este "poder divino", el sujeto humano se encuentra desvalido e incapaz de volver hacia sí y recuperar el optimismo ontológico.

Con el deísmo este "poder afirmador divino" se desvanece y la mirada se vuelve hacia el hombre como sujeto moral que "afirma" el poder divino. Se cambia la mirada. Las fuentes morales adquieren otra dimensión. Es el hombre el que determina "el alcance" del poder divino, no es Dios el que "reafirma" la dimensión moral del hombre.

Es en este sentido en el que Taylor habla cuando afirma que el Deísmo, con una ruptura total de la tradición religiosa, se aproxima más al modelo filosófico pagano. ${ }^{907}$ Taylor habla del camino recorrido contra las posiciones hiperagustinianas desde los Platónicos de Cambridge hasta Whichcote, pasando por Tindal. Todos ellos inciden en que Dios no "necesita" de nuestra pleitesía para encontrar satisfacción frente a la maldad humana. Se va allanando el camino hacia la solución de Whichcote, según la cual, el hombre es el fundamento sobre el que Dios encuentra su camino para afirmarse. Se mira al hombre para afirmar a Dios, con lo cual se superan las visiones negativistas de la naturaleza humana del hiperagustinismo, para afirmar que la naturaleza humana puede llegar a elevarse espiritualmente, en una suerte de "deificación" tal y como hemos referido anteriormente. La naturaleza humana lleva inscrita la afirmación del poder divino tal y como ha sido inscrito en ella por el Diseñador. De ahí que no sea necesaria la gracia como "necesidad" a una situación de total desvalimiento. La naturaleza humana lleva inscrita las huellas de un poder divino que la eleva "desde sí misma" a la afirmación de un poder superior. ${ }^{908}$

Se trata de un deísmo que encuentra apoyos también en el Cristianismo erasmista que sugiere que Dios lo ha diseñado todo para que "no necesitemos de Él", ni que vivamos para Él, ni que pensemos que Él es nuestra fuerza. ${ }^{909}$ Dios quiere que pensemos exclusivamente en nuestro bienestar y su benevolencia consiste en que busquemos nuestra felicidad y la felicidad de los demás. Dios solo exige de nosotros que realicemos el plan diseñado por Él para que seamos felices a partir de lo inscrito en la naturaleza humana. No se nos pide más que afirmar dicho plan y ser consecuentes

\footnotetext{
${ }^{907}$ Cfr. Ibid., pág. 368,370.

${ }^{908}$ Cfr. TAYLOR, Ch., La Era Secular, tII, págs. 109,148,185.

${ }^{909}$ Cfr. TAYLOR, Ch., La Era Secular, tI, págs. 84-85,114,124-125.
} 
con Él. El hombre afirma así a Dios desde la propia configuración del orden natural y Dios afirma al hombre al inscribir dicho orden para que el hombre, siguiéndolo, sea feliz. No le pide otro tipo de contraprestaciones. ${ }^{910}$

Surge una pedagogía de la evolución del espíritu humano, según la cual, la razón natural viene a suplantar a la historia y a la revelación. La verdadera religión es la religión natural. Hay una pedagogía divina, por la que la revelación histórica es superada a partir del momento en el que la elevación del espíritu humano le lleva al hombre a comprender el alcance del orden natural impreso providencialmente por el Creador. Comprender dicho orden es la etapa superior de dicha evolución y le lleva a dar por superada cualquier tipo de revelación histórica de la divinidad. Son dos etapas de infancia (Judaísmo) y juventud (Cristianismo). Ahora, en la madurez de la racionalidad humana, se abre una nueva etapa, la etapa de la religión natural y de la razón, como expresiones máximas del espíritu humano, expresiones que invalidan las revelaciones históricas, ya que se abre ante la humanidad un nuevo futuro lleno de esperanza por las posibilidades de la razón humana, que son capaces de expresar ese orden natural impreso por el Creador. Es la llegada de la religión de la razón tal y como se plasma en la tesis hegeliana de la religión manifiesta, según la cual, el sí mismo se recupera por y para la autoconciencia. ${ }^{911}$ Es la evolución de la providencia eterna que, como afirma Lessing, ha organizado el curso de la historia hacia el tiempo de la perfección, según el cual, el hombre no toma prestados los motivos de sus actos, sino que en su entendimiento se sienta cada vez más seguro de un futuro mejor y de los premios intrínsecos del bien. ${ }^{912}$

Se va evolucionando hacia un momento en el que el Deísmo, por una parte, se enraíza en la tradición religiosa que confirma al Dios Creador, pero, por otra parte, se va suplantando dicho Dios revelado, para ser afirmado como un Dios "descubierto" por la razón humana. No se niega a Dios, pero el amor que se le debe como Dios Amor que toma la iniciativa y se revela es suplantado por un Dios que es descubierto por la razón humana y que no "necesita" otra respuesta que vivir de acuerdo al orden encontrado. Dios y Orden Providencial se identifican. Se descubre el orden natural y, a través de dicho orden, se llega al Creador. Las fuentes morales se van suplantando de un orden trascendente a un orden natural que sigue afirmando a Dios, "no tanto por Dios mismo

\footnotetext{
${ }^{910}$ Cfr. TAYLOR, Ch., Fuentes del yo, págs. 341-363.

${ }^{911}$ Cfr. HEGEL, G., Fenomenología del Espíritu, pág. 475. Hegel habla de tres religiones en su evolución: la religión natural, la religión-arte y la religión manifiesta. Para Hegel hay un proceso en el que en la primera tipología el espíritu se rebaja de tono al sí-mismo como forma de la sustancia (natural), en la segunda tipología se eleva la sustancia a la forma de sujeto en sí o para nosotros (arte) y finalmente el sí mismo recupera la esencia absoluta "por y para la autoconciencia misma (manifiesta)". "Y lo que puede ser dicho sobre la relación de dios con el hombre debe ser dicho sobre el entero desarrollo de la relación humana con Dios, en la que el hombre llega a reconocer su identidad con lo divino". TAYLOR, Ch., Hegel, pág. 430.

${ }_{912}$ Cfr. TAYLOR, Ch., Fuentes del yo, pág. 375; cfr. TAYLOR, Ch., La Era Secular, tII, pág. 109; cfr. LESSING, G.E., La educación de la humanidad, págs. 85-86.
} 
sino por su benevolencia en crear dicho orden", y "solo pedir" vivir de acuerdo a dicho orden. Se pasa del Dios del orden al orden de Dios. Es el orden deísta de la gran cadena del ser de Alexander Pope, un orden muy distinto al de la tradición antigua y teológica. En la teoría de la emanación platónica, la Idea toma forma en la encarnación del cosmos. Todo remite a la Idea. En el orden de Pope no se remite a una Idea configuradora, sino a una interconexión causal de todo lo creado, en el que las cosas, tal y como afirma Taylor, "se alimentan mutuamente" y así cada entidad, al servirse a sí misma, sirve a todo el orden. ${ }^{913}$ Mientras que la conexión del orden platónico es "organicista", todo se sostiene en el Todo, todo se remite al Orden Último de la Idea configuradora, en Pope y en el deísmo, dicho orden es un nuevo orden de "naturalezas engranadas" en el que se erosiona la idea precedente y configuradora, y se va estableciendo la ciencia mecanicista. ${ }^{914}$ Se trata de un orden que, según Taylor, significa vivir de acuerdo con el designio de las cosas; esto es, lo que el designio marca para cada tipo de cosa, son los propósitos que hacen que cada una de las cosas engrane con todas las demás. ${ }^{915}$

Para profundizar en el estudio de dicho orden providencial, nos detenemos en Leibniz, un pensador que, como asevera Taylor, quiso embarcarse en el mecanicismo, aunque conservando y reconstruyendo la visión teológica del sujeto. ${ }^{916}$

Se ha distinguido a Leibniz, el filósofo de los individuos, de la singularidad de cada cual, frente a Descartes, el filósofo del sujeto pensante. ${ }^{917}$ Para Leibniz el mundo está formado por "sustancias individuales", las mónadas, que se interrelacionan entre sí y configuran un orden de armonía cósmico. Una armonía que se basa en la esencia propia de cada sustancia que se interrelaciona con las demás, porque todas constituyen la común esencia del mundo, y cada una de ellas "expresa todo el universo". ${ }^{918} \mathrm{El}$ alcance que Leibniz le concede a las sustancias individuales, por una parte, es algo "sobrenatural", ya que cada sustancia individual expresa la totalidad del cosmos o el

\footnotetext{
913 TAYLOR, Ch., Fuentes del yo, pág. 377.

914 “Tal vez nos parecería mejor que todo fuese armonía en el mundo físico y todo virtud en el moral; que jamás se viesen el aire ni el mar agitados por los vientos, así como tampoco el alma por las pasiones. Pero todo subsiste por este combate de los elementos y nuestras pasiones son los elementos de la vida. Desde el principio del mundo fue observado este orden general y también lo ha sido en el hombre". POPE, A., Ensayo sobre el hombre, Imprenta Nacional, Madrid, 1821, pág. 13.

${ }^{915}$ Cfr. TAYLOR, Ch., Fuentes del yo, págs. 384-385.

${ }^{916}$ Cfr. Ibid., pág. 230.

917 “Cada sustancia es como un mundo aparte, independiente de todo excepto de Dios. Así pues, todos nuestros fenómenos, es decir, todo lo que nos puede llegar a suceder solo es consecuencia de nuestro ser. Esos fenómenos observan cierto orden conforme a nuestra naturaleza o, por así decirlo, con el mundo que existe en nosotros. Eso hace que podamos llevar a cabo observaciones útiles para regular nuestra conducta, que se justifican por el éxito de los fenómenos futuros”. LEIBNIZ, G., Discurso de Metafísica, Gredos, Madrid, 2018, pág. 95.

918 "Se podría decir en cierta forma y con buen sentido, aunque sea alejarse del uso, que una sustancia particular no actúa jamás sobre otra sustancia particular, ni tampoco la padece, si se considera que lo que sucede a cada una es únicamente consecuencia de su idea o noción completa, puesto que esa idea encierra ya todos los predicados o acontecimientos y expresa todo el universo". Ibid., pág. 96.
} 
orden general del universo, y, por otra parte, es algo "natural", ya que el funcionamiento general del universo ha sido impreso a partir del orden general del todo. ${ }^{919}$ Es decir, por una parte, hay un elemento sobrenatural en el orden cósmico a partir del cual cada sustancia expresa el todo, pero, por otra parte, cada sustancia tiene su propia esencia en el "determinismo" de su propia esencia natural, lo que viene a ser la esencia de su propia naturaleza. Con todo ello, se afirma la presencia de Dios a partir de la esencia propia de las sustancias individuales. ${ }^{920}$ Se trata de sustancias que, por una parte, remiten al orden cósmico, al estar en relación con el todo que se interrelaciona; y, por otra parte, remiten al orden natural propio de cada una, ya que cada sustancia tiene en su "esencia" la cualidad que le permite entrar en contacto con todas las demás desde el orden impreso por el Creador en el todo. El todo se realiza en la sustancia individual y no puede entenderse sin ese carácter "sobrenatural" y, por otra parte, cada sustancia expresa su propia esencia natural sin que tenga que "justificar" su esencia debido al orden propio de su naturaleza. Este es el deísmo leibniziano de las naturalezas y las sustancias individuales en relación con el todo que expresan. ${ }^{921}$ Se trata, como resalta Taylor, de un deísmo de "esfuerzo subjetivo y de propósito". 922

Leibniz da un paso más configurando la relación causa-efecto. Por el efecto se puede uno referir a la causa motivadora de dicho efecto, de tal manera que la forma más adecuada de conocer el efecto es por el conocimiento de la causa. ${ }^{923}$ No nos podemos

\footnotetext{
919 "Y en cuanto toda persona o sustancia es como un pequeño mundo que expresa el mundo más grande, se puede decir incluso que tal acción extraordinaria de dios sobre esta sustancia no deja de ser milagrosa, por más que esté comprendida en el orden general del universo, en tanto se halla expresada por la esencia o noción individual de esa sustancia. Por lo cual, si comprendemos en nuestra naturaleza todo lo que ella expresa, nada le es sobrenatural, pues se extiende a todo, ya que un efecto expresa siempre su causa y Dios es la verdadera causa de las sustancias". Ibid., pág. 97.

${ }^{920}$ Leibniz intenta superar las dificultades de la filosofía de Ockham planteando la necesidad en lugar de la contingencia, aunque ambas formulaciones se mantienen como "modales". "En efecto, el ser ya no se concebirá como contingente sino como necesario. Recuérdese que en la filosofía leibniziana Dios es el ser necesario y que este mundo es el mejor de los posibles. Ambas formulaciones son modales". SELLES, J.F., "La sombra de Ockham es alargada", pág. 244.

921 "Luego de haber dicho que 'lo existente es lo que tiene ser o posibilidad, y algo más' sigue diciendo 'digo por tanto que lo existente es el ser que es compatible con la mayoría de las cosas, o el ser más posible, de modo que todas las cosas coexistentes son igualmente posibles'. De esto se desprenden extrañas consecuencias si Leibniz se propuso formular en estricto sentido una definición de la 'existencia'. Pues si tal era su intención, queda excluido el acto de la Creación: las relaciones de las esencias son parte de las verdades eternas, y la construcción de un mundo que contenga el mayor número posible de esencias coexistentes es un problema de lógica pura. De allí se concluiría que este mundo existe por definición, sin necesidad de ningún Decreto Divino: además es parte de Dios, por cuanto las esencias existen en la mente divina”. RUSSELL, B., Exposición crítica de la filosofía de Leibniz, Siglo Veintiuno, Buenos Aires, pág. 11.

${ }^{922}$ Cfr. TAYLOR, Ch., Argumentos Filosóficos, pág. 161.

923 "No es razonable introducir una inteligencia soberana ordenadora de las cosas, y después, en lugar de emplear su sabiduría, no servirse sino de las propiedades de la materia para explicar los fenómenos". LEIBNIZ, G., Discurso de Metafísica, págs. 102-103.

Y continúa diciendo que es como si en vez de analizar el alcance de una conquista en base al estudio estratégico del conquistador nos quedáramos analizando las características de los corpúsculos de la pólvora utilizada para invadir la plaza conquistada. "De este modo no poseemos en nuestra alma las ideas de todas las cosas sino en virtud de la acción continua de Dios sobre nosotros, es decir, puesto que todo efecto expresa su causa y de este modo la esencia de nuestra alma es una determinada expresión,
} 
quedar en la mera consideración de las sustancias individuales y no referirnos al Hacedor de las mismas dentro del engranaje del cosmos. Por las características de las sustancias podemos llegar a la causa final que motivó el engranaje del cosmos, para que todas las sustancias se interrelacionen en un todo configurador de la armonía del universo. Leibniz hace uso las causalidades aristotélicas: agente, material, formal y final, y diferencia entre el "propósito" del artesano al confeccionar una máquina y "los medios" de que se ha servido dicho artesano para construir cada pieza. ${ }^{924}$ En este sentido, para Taylor, el deísmo leibniziano, que proviene de Shaftsbury, aunque no rechaza la razón desvinculada lockeana, sin embargo, se participa en el plan de Dios, en su propósito, mediante una revinculación. Nos volvemos hacia adentro para restaurar la verdadera forma del afecto natural. ${ }^{925}$

En Leibniz, Dios es el único objeto externo que toca nuestra alma y excita inmediatamente nuestra percepción. ${ }^{926}$ Es decir, las ideas que tenemos en el alma son la acción directa de Dios sobre nosotros, que "motiva" nuestro conocimiento del mundo. Conocemos el mundo a través de Dios y es Dios el que hace suscitar y mantener en nosotros las ideas que tenemos de las cosas y objetos del mundo. Es Dios el que "determina" el conocimiento del mundo en el hombre. No comprenderíamos las sustancias del mundo si no fuera por la determinación divina a que las comprendiéramos así. Dios participa activamente en nuestro conocimiento del mundo a través de los sentidos, tal y como han sido establecidos por la mente divina creadora y por las leyes impresas en la naturaleza. "Dios es el sol y la luz de las almas... Dios es la luz del alma y, conforme a su modo de hablar, intellectus agens animae rationalis". ${ }^{927}$

Es Dios el que confiere las ideas y las conserva en nosotros, y por eso mismo también es Dios el que nos "orienta" hacia un determinado comportamiento basado en la idea del bien. Dios produce continuamente nuestro ser y, desde la libertad, "prevé todo desde la eternidad" y configura nuestra libertad hacia el bien, "aunque no de modo necesario". 928

El orden deísta de Leibniz expresa la idea de un orden configurado por lo que él denomina "mónadas" y su relación con el mejor de los mundos posibles, en una

imitación o imagen de la esencia, pensamiento y voluntad divina y de todas las ideas que en ellos están comprendidas. Se puede pues decir que solo Dios es nuestro objeto inmediato fuera de nosotros y que vemos todas las cosas por medio de él”. Ibid., pág. 113.

924 “Dios es artesano suficientemente hábil para producir una máquina aún mil veces más ingeniosa que la de nuestro cuerpo, no recurriendo más que a algunos líquidos bastante simples expresamente formados de modo que solo se requieran las leyes ordinarias de la naturaleza para desarrollarlos como es preciso con el fin de producir un efecto tan admirable, pero es verdad también que esto no sucedería si Dios no fuera el autor de la naturaleza". Ibid., pág. 108. Cfr. TAYLOR, Ch., Fuentes del yo, pág. 380.

${ }^{925}$ Cfr. TAYLOR, Ch., Fuentes del yo, pág. 363.

${ }^{926}$ Cfr. LEIBNIZ, G., Discurso de Metafísica, pág. 113.

${ }^{927}$ Ibid., pág. 114.

${ }^{928}$ Cfr. Ibid., pág. 115. 
armonía preestablecida, o en lo que Taylor denominará "un orden providencial". ${ }^{929}$ Ante el vacío que surge con la desaparición del logos óntico, se irá configurando una nueva metafísica más conforme con el éxito de la ciencia mecanicista. Una metafísica compatible con la concepción moderna, según la cual, la naturaleza de una cosa se crea por las fuerzas que operan dentro de ella. El orden deísta leibniziano es un universo de mónadas distintas por su diferenciación interna. ${ }^{930}$ Todo el universo está lleno de mónadas distintas, cada una experimentando sus propios procesos de cambio a través de un "principio interno" y motivando así una huella específica que Leibniz denomina "detalle de lo que cambia" y que expresa la especificidad y las diferencias de este universo lleno de mónadas. ${ }^{931}$ Taylor resalta ese orden en el que las cosas se inclinan sin necesidad. ${ }^{932}$

Almas y cuerpos están unidos, al contrario del dualismo cartesiano. ${ }^{933}$ Es el nuevo orden de las naturalezas engranadas. ${ }^{934}$

Esta es la ciudad de Dios llena de armonía, orden y equilibrio; una ciudad en la que todo coopera con todo a partir de la Sustancia Primera Increada que ha puesto todo en movimiento y en dependencia hacia Ella. Todo tiende hacia Dios como Primera Sustancia y su ciudad está llena de armonía, porque así ha sido "preestablecida” por Él. Dios creó así el mejor mundo posible. ${ }^{935}$

Cada mónada cambia, pues es unidad y, al mismo tiempo, multitud y diversidad, pero dentro de la configuración como "sustancia simple", no compuesta. En su interior se inician procesos de cambio "por grados" y "algo cambia y algo queda", ${ }^{936}$ con lo que

${ }^{929}$ Cfr. TAYLOR, Ch., Fuentes del yo, pág. 380. "Ya Abelardo se adelantó a la idea del "mejor de los mundos posibles" cuando afirma que "para Dios es intrínsecamente imposible hacer o dejar de hacer (o deshacer) cualquier cosa distinta de las cosas que de hecho hace en un momento o bien que omite hacer; así como hacer cualquier cosa de otra manera distinta o en otro momento distinto de cómo y cuándo realmente la hizo". LOVEJOY, A., La Gran Cadena del Ser, pág. 91. Lovejoy alude en su estudio a la tradicional tensión medieval entre "el mejor de los mundos posibles" de Abelardo y la posibilidad de que Dios pudiera haber hecho otras cosas o cosas mejores de Pedro Lombardo. Una tensión que intentará ser equilibrada y analizada detenidamente por Tomás de Aquino.

930 "La mónada de que hablamos aquí no es sino una sustancia simple que integra los compuestos; siempre, es decir, sin partes". LEIBNIZ, Discurso de Metafísica, pág. 173. Es algo "parecido" al átomo de Demócrito. No son todas iguales, como los átomos, sino que cada una de ellas es distinta, "pues jamás hay en la naturaleza dos seres que sean completamente iguales uno al otro y en el que no sea posible encontrar una diferencia interna o fundada en una denominación intrínseca".

${ }_{931}$ Cfr. Ibid., No 12, pág. 174.

${ }^{932}$ Cfr. TAYLOR, Ch., Hegel y la sociedad moderna, pág. 289.

933 "Esos principios me han permitido explicar naturalmente la unión o, más bien, la conformidad del alma y del cuerpo orgánico. El alma sigue sus propias leyes, y los cuerpos también las suyas, y se encuentran en virtud de la armonía preestablecida entre todas las sustancias, puesto que todas ellas son representaciones de un mismo universo". Ibid., No 78 y 79, pág. 186.

${ }_{934}$ Cfr. TAYLOR, Ch., Fuentes del yo, pág. 380.

935 "Esta ciudad de Dios, esta monarquía verdaderamente universal es un mundo moral en el mundo natural, y lo más elevado y divino que hay de las obras de Dios. En eso consiste la verdaderamente la gloria de Dios puesto que no tendría ninguna si su grandeza y su bondad no fueran conocidas y admiradas por los espíritus". LEIBNIZ, Discurso de Metafísica, No 86, pág. 187.

${ }_{936}$ Ibid., No 12, pág. 174. 
dentro de la unidad hay "un estado pasajero que envuelve y representa una multitud en la unidad o en la sustancia simple que es la llamada percepción". ${ }^{937}$ Para Leibniz, este proceso interno de cambio, en lo que tiene que ver como estado pasajero en el que se integra unidad y multitud, es la percepción. Y "la acción del principio interno que realiza el cambio o paso de una percepción a otra puede llamarse apetición". ${ }^{938}$ En este sentido, Leibniz distingue entre alma y mónada. Una cosa es la mónada que, como sustancia simple experimenta percepciones y apetitos, y otra cosa es el alma que además de ser sustancia simple "su percepción es más distinta y está acompañada de memoria". 939

Según argumenta Leibniz, la mónada increada es Dios como "una sustancia necesaria en la cual el detalle de los cambios está solo eminentemente, como en su fuente". ${ }^{940}$ Dios como mónada increada es una sustancia única y universal. ${ }^{941}$ Es decir, todo participa de Dios, todo está "limitado" (con límites y referido a...) a Dios, que es la única mónada independiente y consistente en sí misma. En la mente de Dios las mónadas siempre han existido, produciéndose en su entendimiento un conflicto entre las mónadas y pasar de la "potencia mental divina" al mundo real y creado. Las sustancias simples son creadas y solo pueden concluir por aniquilación. Por lo tanto, cada porción de materia es ese microcosmos que "tiende al infinito", entendiendo el mundo como "un mundo de criaturas, de seres vivientes, de animales, de entelequias, de almas, hasta en la menor parte de la materia". ${ }^{442}$ Todo se va "subdividiendo" hasta el infinito, siendo todo llenado, por pequeño que sea, por mónadas, por infinidad de mónadas interrelacionadas entre sí. Todo es creado y todo es subdividido hasta el infinito. Cuerpo y alma se van subdividiendo en tantos cuerpos y almas hasta el infinito. En cada cuerpo hay un alma, y en cada alma, un cuerpo... y así hasta el infinito.

Para Taylor, la mónada leibniziana es una expresión especulativa profunda de la noción de un yo, ya que es una unidad real de la simplicidad con la diferencia, como el yo. Es activa y no solo un sujeto de representación. ${ }^{943}$

Y si este es el orden deísta leibniziano caracterizado por la armonía preestablecida, hay una ley de la razón suficiente que lo constituye todo. Todo lo que existe tiene una razón suficiente para que exista. Es muy relevante su argumento de la existencia divina. Todo puede existir si tiene una razón suficiente, si es posible que

\footnotetext{
${ }_{937}^{937}$ Ibid., No 14, pág. 174.

${ }^{938}$ Ibid., No 15, pág. 174.

${ }^{939}$ Ibid., No 19, pág. 175.

${ }^{940}$ Ibid., pág. 178; “No hay más que un Dios y este Dios es suficiente”. Ibid., pág. 179.

941 "Y necesaria y no tiene nada fuera de sí que sea independiente de ella y como es una consecuencia simple del ser posible, debe ser incapaz de límites y debe contener tanta realidad como sea posible". Ibid., No 40, pág. 179.

${ }^{942}$ Ibid., No 66, pág. 184.

${ }^{943}$ Cfr. TAYLOR, Ch., Hegel, pág. 458.
} 
exista. Dios es la única Sustancia en la que lo que es posible "determina" intrínsecamente su realidad. En la mente de Dios existen las mónadas o ideas que pugnan por existir. ${ }^{944}$ Es decir, que mientras la posibilidad en el resto de las mónadas o ideas hace posible o no su existencia, puede haber o no razón suficiente para existir, en el caso de Dios la mera posibilidad o la posibilidad de una razón hace que sea intrínsecamente necesaria su existencia. La esencia de la Idea como posibilidad está indisociablemente unida a su existencia. ${ }^{945}$ Es el orden moderno que, según Taylor, está caracterizado, no por el orden jerarquizado de la naturaleza, sino por los designios de Dios. Y descubrir qué dispuso Dios para nosotros y cómo quiere que vivamos es fundamental para el nuevo orden metafísico que se va configurando. ${ }^{946}$ Es el mejor de los mundos posibles que, como afirma Taylor, es, en un sentido importante, contingente. $^{947}$

El mundo de Leibniz es el mundo del orden mecanicista y del esfuerzo y propósito subjetivo, en el que incluso se descubre una cierta efervescencia de los espíritus. Pero, al mismo tiempo, es el mundo de la razón, en el cual, según D’Alembert, se produce un incremento de la filosofía y donde todo se analiza, se discute y se remueve, un mundo que rompe diques y allana caminos nuevos para cuestiones nuevas. Se pone luz en la ciencia del mundo y del conocimiento. ${ }^{948}$ Todo comienza de nuevo. Es la luz de la razón que se abre camino sobre recovecos hasta entonces insospechados. Todo aparece con nuevo refulgor y se presentan nuevas perspectivas para una comprensión renovadamente apasionada y certera. Es la marea, utilizando la imagen de D'Alembert, que deposita nuevos descubrimientos y arrastra hacia sí nuevas incertidumbres para ser reposadas en el fondo de una nueva ciencia que emergerá en la superficie del conocimiento científico, revelando luz sobre aquello que estaba escondido.

\footnotetext{
944 "Si hay una realidad en las esencias o posibilidades, o en las verdades eternas, es preciso que esta realidad esté fundada en algo existente y actual; y por consiguiente en la existencia del Ser necesario, en quien la esencia envuelve la existencia o al que le basta con ser posible para ser actual". LEIBNIZ, Discurso de Metafísica, No 44, pág. 179.

945 “Así solo Dios (o el Ser necesario) tiene el privilegio de que es preciso que exista, si es posible. Y como nada puede impedir la posibilidad de lo que no encierra ningún límite, ninguna negación y por consiguiente ninguna contradicción, solo basta con esto para conocer la existencia de Dios a priori”. Ibid., No 45 , pág. 179.

${ }^{946}$ Cfr. TAYLOR, Ch., Fuentes del yo, pág. 383.

${ }^{947}$ Cfr. TAYLOR, Ch., Hegel, pág. 240.

${ }^{948}$ Cfr. TAYLOR, Ch., Argumentos filosóficos, pág. 161. "Al Comienzo de su Ensayo sobre los elementos de la filosofía presenta D’Alembert un cuadro del estado general del espíritu humano a mediados del siglo XVIII. (...) En cuanto observemos atentamente — prosigue D'Alembert- el siglo en que vivimos... nuestra época gusta de llamarse la época de la filosofía. (...) Pero el descubrimiento y el uso de un nuevo método de filosofar despierta, sin embargo, a través del entusiasmo que acompaña a todos los grandes descubrimientos, un incremento general de las ideas... Todo ha sido discutido, analizado, removido, desde los principios de las ciencias hasta los fundamentos de la religión revelada, desde los problemas de la metafísica hasta los del gusto, desde la música hasta la moral, desde las cuestiones teológicas hasta las de la economía y el comercio, desde la política hasta el derecho de gentes y el civil”, CASSIRER, E., Filosofía de la Ilustración, Fondo de Cultura Económica, México, 1972, pág. 17.
} 


\section{V.- Rousseau. El Dios cósmico y la configuración moral del subjetivismo moderno.}

El giro desde un modo de acceso exclusivamente racional hasta el que otorga también un lugar al sentimiento, es el giro que hemos observado desde Locke, a través de Shaftesbury, hasta llegar a la teoría de los sentimientos morales de Hutcheson. Este es el deísmo del orden providencial. Nuestra manera de conectar con el designio de la naturaleza reside también en nosotros, en los sentimientos naturales que configuran nuestro propio yo: la compasión y la benevolencia. ${ }^{949}$ En el camino hacia el subjetivismo moderno, este movimiento deísta afirma que lo que es correcto es lo que encaja en mi designio, en el cual mis sentimientos son parte integral. Nuestros sentimientos morales son parte integral del orden providencial, según Hutcheson. Es la interiorización de los sentimientos morales de Hutcheson frente al modelo del yo puntual y la razón instrumental lockeana. La naturaleza es experimentar el impulso interior correcto. La naturaleza, como norma, es una tendencia interna y está dispuesta a convertirse en la voz interior con Rousseau, y a ser transportada por los románticos hacia una interioridad más profunda y más rica. ${ }^{950}$ El giro deísta abrió el camino para un papel sin precedentes del "sentimiento" y que desempeñará un papel fundamental en la cultura de la Modernidad, según Taylor.

Frente a la visión superficial del deísmo del siglo XVIII en relación con la voluntad, ${ }^{951}$ Rousseau potencia el papel de la voluntad humana y reactiva las dimensiones agustinianas del bien y del mal, inscritas en el corazón humano. ${ }^{952}$ En el hombre existen estos dos amores y baten dentro de él en un conflicto ineludible para la voluntad.

\footnotetext{
${ }^{949}$ Cfr. TAYLOR, Ch., Fuentes del yo, pág. 388.

${ }^{950}$ Cfr. Ibid., pág. 391.

951 "Se consideró que no tenía interés discutir sobre su esencia y el máximo interés, por el contrario, ver operar a esta buena operaria, conocer su método y sus realizaciones. Observa los hechos que registran los sentidos; como los hechos se le presentan en un conjunto que parece a primera vista inextricable, los extrae de esa confusión: sin interpretarlos, sin aventurar acerca de ellos ninguna hipótesis, intenta captarlos en estado de pureza, luego retenerlos como tales. El análisis es su método favorito. En lugar de principios a priori como hacían los hombres de otros tiempos, que se contentaban con palabras y daban vueltas sin darse cuenta de ello, se apega a lo real; mediante el análisis distingue sus elementos, luego los colecciona con paciencia. Tal es su primera labor. La segunda consiste en compararlos, en descubrir los lazos que los unen, en derivar de ellos leyes". HAZARD, P., El pensamiento europeo del siglo XVIII, Alianza Editorial, Madrid, 1991, pág. 35. Cfr. GUSDORF, G., Les príncipes de la pensé au Siêcle des Lumiêres, Payot, París, 1971. Dieu, la nature, l’homme au Siècle des Lumières, Payot, París, 1972. Naissance de la conscience romantique au Siècle des Lumires, Payot, París, 1976. Cfr. GAY, P., The Enlightenment: An Introduction. The Raise of Modern Pagannism, Londres, Widenfeld-Nicolson, 196770.

952 "Buscaba qué amar amando el amar y odiaba la seguridad y la senda sin peligros, porque tenía dentro de mí hambre del interior alimento, de ti mismo, ¡oh Dios mío!, aunque esta hambre no la sentía yo tal; antes estaba sin apetito alguno de los manjares incorruptibles, no porque estuviera lleno de ellos, sino porque, cuanto más vacío, tanto más hastiado me sentía.”. HIPONA, A. de, Confesiones, Libro III, Cap.I, 1 .
} 
Para Taylor, podemos encontrar en Rousseau ecos de la reacción jansenista a Descartes, así como de Pascal en su defensa de la nueva ciencia. ${ }^{953}$ Un jansenismo que no termina de creerse que la confianza cartesiana en la razón pudiera llevar al hombre en la determinación hacia el bien por el mero empeño intelectual. Siembran sus dudas sobre la "incapacidad ontológica" del hombre debido a la culpa original y la necesidad de la gracia, debido a las tres heridas mortales que el pecado original infringió en el hombre: la flaqueza de la memoria, la ignorancia del entendimiento y la inclinación de la voluntad al mal. ${ }^{954}$

Para Pierre Nicole, como para Antoine Arnauld, no hay ninguna seguridad en las propias capacidades morales e intelectuales del hombre, porque lo que hay que hacer es eliminar cualquier clase de soberbia y enseñoramiento intelectual. Taylor sostiene que para la teología jansenista, lo que define al hombre es su debilidad y su incapacidad para afrontar el autoconocimiento y la autoexploración por sí mismo. ${ }^{955}$

A partir de las influencias y los ecos de Pascal y el Jansenismo, Rousseau retoma esta tradición para trasladarla al deísmo y establecer sus campos propios de reflexión sobre la naturaleza y la bondad natural del hombre. Se pasa de los dos amores agustinianos a establecer un campo de reflexión deísta en torno al Dios cósmico. Se olvida la doctrina del pecado original y se retoma la dimensión de la voz de la naturaleza. El hombre sale de las manos de Dios y las manos del hombre son las que lo estropean todo. La naturaleza es buena, el hombre es naturalmente bueno, pero cuando el hombre se separa de este orden natural "se encuentra irremediablemente" con lo malo y lo torcido. ${ }^{956}$ Este es el inicio que motiva a Rousseau y la Ilustración francesa a dar el paso al Dios cósmico de la razón natural. ${ }^{957}$

\footnotetext{
${ }^{953}$ Cfr. TAYLOR, Ch., Fuentes del yo, pág. 486.

${ }^{954}$ Cfr. ARNAULD, A., Arte de pensar o lógica admirable. Al lector. Imprenta Antonio Muñoz, Madrid, 1759.

${ }^{955}$ Cfr. TAYLOR, Ch., Fuentes del yo, págs. 222.487. "Dimanando pues la soberbia de la idea que el hombre tiene de su propia fuerza y excelencia, parece que el mejor medio de humillarlo es convencerlo de su flaqueza. Es menester picar o reventar esta hinchazón, para que arroje fuera el viento que la causa. Es menester desengañarlo de la ilusión por la cual se representa grande a sí mismo, mostrándole su pequeñez y sus enfermedades, no a fin de reducirlo por este medio al abatimiento y desesperación, sino a fin de inclinarlo a buscar en Dios el firmamento, el apoyo, la grandeza y la fuerza que no puede hallar en su ser y en todo lo que él le agrega". NICOLE, P., Ensayos de Moral, Tomo I, Madrid, Imprenta Real, 1800, pág. 5. "La necesidad de la verdadera satisfacción: esta necesidad que raramente deja de atormentarnos, la encaminó a un objeto a cuya presencia desaparecen todos los demás, y suelto su corazón de ilusiones, y libre de todos los demás gustos variados y pasajeros, se entregó a las dulzuras de la piedad religiosa; y bien convencida que es falso todo lo que se aleja y dista de la religión, concibió el proyecto de romper con el mundo, que solo deja a los sentidos el cansancio del tedio y de la deformidad". ARNAULD, A., Recreaciones del hombre sensible, Tomo II, Imprenta Leonardo Núñez, Madrid, 1831, pág. 6.

956 "Todo es perfecto cuando sale de las manos de Dios, pero todo degenera en las manos del hombre. Obliga a una tierra a que dé lo que debe producir otra, a que un árbol dé un fruto distinto; mezcla y confunde los climas, los elementos y las estaciones, mutila su perro, su caballo y su esclavo; lo turba y desfigura todo; ama la deformidad, lo monstruoso; no quiere nada tal como ha salido de la naturaleza, ni al mismo hombre, a quien doma a su capricho, como a los árboles de su huerto". ROUSSEAU, J.J., El Emilio. Disponible en Textos.info, No 2897, (14-IV-2017). Menorca, pág. 6.
} 
A partir del arrinconamiento de la doctrina del pecado original, Rousseau va a establecer su propio campo de reflexión deísta. Nos remontamos unos siglos antes, al Renacimiento, en primer lugar, y luego, a la Reforma. El Renacimiento plantea un humanismo que no confronta con la religión, sino que, a través de ella, amplía el horizonte y plantea nuevas formas espirituales y un nuevo paradigma de alcance universal en la relación entre el hombre y el mundo. La Reforma Protestante también confirma dicho compromiso con el mundo, al propio tiempo que le añade una visión distinta de la fe, caracterizada por el individualismo y por el compromiso en el orden social secular, tal y como señalamos también en su momento. ${ }^{958}$

El Humanismo renacentista, sin atacar el dogma del pecado original, lo afloja y lo debilita, para hacer compatible la apertura del hombre al espíritu universal y así dar un sentido atemporal a la Revelación. La Reforma, por el contrario, va en contra de este universalismo y afirma con contundencia la fe y la gracia como únicos elementos que elevan el espíritu humano, llegando a situarse así en una dirección totalmente hiperagustiniana. Para la Reforma nada puede ser más opuesto al plan de Dios que exaltar un humanismo autorrealizador que no confíe absolutamente en la "sola gratia”. ${ }^{959}$ Taylor destaca, en este sentido, que el camino preferido por Agustín para

Y en este mismo sentido, algo deviene en los orígenes, que todo se estropea y el hombre tiene que realizar un "contrato" social para organizar la convivencia. Por una parte, el hombre nace libre, pero "se encuentra encadenado". Rousseau invita a reflexionar sobre qué pudo pasar. "Supongo a los hombres, llegados a un punto en el que los obstáculos que dañan a su conservación en el estado de naturaleza se imponen, mediante su resistencia, a las fuerzas que cada individuo puede emplear para mantenerse en ese estado. A partir de ese momento ese estado primitivo no puede subsistir y el género humano perecería si no cambiase de manera de ser". ROUSSEAU, J.J., El Contrato Social. Disponible en Textos.info, No 2898, (14-IV-2017), Menorca, pág. 14.

${ }^{957}$ En relación con Rousseau y la Ilustración hacemos una breve referencia a lo que se ha dado en llamar Ilustración y que engloba distintas sensibilidades, momentos, países, y que requeriría un estudio pormenorizado de cada momento. Lo que sí está claro es que todo comienza con Inglaterra en lo que se dio en llamar "The Enlightenment" a fines del siglo XVII. Luego vendría la Ilustración francesa en el siglo XVIII en lo que se denominó "Le Siècle des Lumières". que junto con la Ilustración alemana (Aufklärung) tienen sus propios matices y cosmovisiones.

958 "Pero si de esta forma el Humanismo y la Reforma se encuentran en un plano común, permanece separado en sus raíces últimas; la fe reformada se mantiene separada, por su origen y por su fin, de los ideales religiosos del Humanismo. El núcleo de esta oposición se puede señalar con una sola palabra: la actitud, radicalmente distinta, del Humanismo y de la Reforma ante el problema del pecado original". CASSIRER, E., Filosofía de la Ilustración, pág. 161.

${ }^{959}$ Frente al universalismo del Renacimiento que "afloja” la teología del pecado original por el yo que se universaliza, se agranda y se asienta, la Reforma afirma el yo que tiene certeza en la salvación desde la "confianza en la gracia" que recobra seguridad en las promesas divinas. El yo luterano es el que obtiene garantías de la fe que redime y salva y justifica. Se está justificado desde el primer momento en que se tiene esa seguridad de que se está en la gracia que salva y libera totalmente. El yo es el que se asienta en esa seguridad salvífica. Se trata de una fe en la que el yo recupera el protagonismo que "reconoce" la salvación y la experimenta universalizándola. Frente a la teología católica que está centrada en Dios y es por ello fundamentalmente especulativa y teórica, la teología protestante es, según Maritain, esencialmente práctica, porque está centrada en el hombre y en su autoconciencia "necesitada" de gracia y salvación. Por eso junto a la "seguridad del yo que experimenta la salvación" está al mismo tiempo el reconocimiento de la necesidad de ser salvado debido a la corrupción inherente al ser humano, de ahí que sea Dios y no nuestras obras el que justifica. Dios justifica y el yo del hombre es el que reconoce y tiene la certeza de la salvación de Dios. “¿Qué es el dogma luterano de la certidumbre de salvación, sino la transmisión al individuo humano y a su estado subjetivo de esta absoluta seguridad en las promesas 
probar la existencia de Dios es a través del conocimiento de la propia imperfección. Pascal será el primero en su época en explorar meticulosamente esta inquietud. ${ }^{960}$

Pascal se sitúa en la mejor tradición agustiniana de afirmación del dogma y la debilidad ontológica del hombre debido al pecado original. En su obra, Pensamientos, plantea el pecado original a través de Jansenio y en relación con San Agustín, "pero de una manera distinta" y con argumentos físico-matemáticos, y utilizando la lógica moderna cartesiana. Hay que llevar la razón y la lógica hasta los últimos misterios de la fe, intentando comprenderlos y situarlos racionalmente, con ideas claras y distintas. ${ }^{961}$ Según Taylor, lo que hace Pascal es reformular la inflexible crítica agustiniana. ${ }^{962}$

En este sentido Pascal sitúa su estudio del pecado original en clave agustiniana, pero abierto a un "pensar sin límites". Lo mismo que en la naturaleza física, la ciencia dispone de explicaciones matemáticas que permiten conocer el alcance real de los fenómenos que se estudian, así también, en la religión, se puede utilizar argumentos racionales que hagan creíble lo que se cree. Y para Pascal, es evidente que el hombre aparece como una naturaleza dividida, rota, que sufre todo tipo de contradicciones, un constante vaivén entre el deseo de superación y el permanente decaer. ${ }^{963}$ Según Taylor, para Pascal nuestro yo, lejos de ser autotransparente, es un misterio para nosotros mismos. La gracia es la que puede poner orden en medio de tantos conflictos internos. $^{964}$

El hombre se encuentra en una contradicción que le deja siempre a medio camino de comprender lo que es, pues viene de la nada y no logra alcanzar lo infinito, encontrándose en una desesperanza por ser algo y no nada, y no ser todo, pues no alcanzamos a ver más allá. Lo que tenemos de ser, nos priva del conocimiento de los primeros principios que nacen de la nada, y lo poco que tenemos de ser, nos oculta la visión de lo infinito. Ardemos en deseos de encontrar unos fundamentos sólidos, una última base firme para edificar sobre ella una torre que se eleve hasta el infinito, pero todos nuestros cimientos se resquebrajan y la tierra se abre hasta los abismos. ${ }^{965}$ Nuestro verdadero estado es desesperante. Se trata de un estado caracterizado por su debilidad,

divinas que anteriormente era el privilegio de la Iglesia y su misión?", MARITAIN, J., Tres Reformadores, Epesa, Madrid, 1948, pág. 37. "La Reforma ha dejado sin freno al yo humano en el orden espiritual y religioso, como el Renacimiento ha dejado sin freno al yo humano en el orden de las actividades naturales y sensibles". Ibid., pág. 35 .

${ }_{960}$ Cfr. TAYLOR, Ch., Fuentes del yo, pág. 352.

${ }_{961}^{961}$ Crr. Ibid., pág. 487.

${ }^{962}$ Cfr. Ibid., pág. 293.

${ }^{963}$ Cfr. PASCAL, B., Pensamientos, pág. 87; cfr. CASSIRER, E., Filosofía de la Ilustración, pág. 165.

${ }^{964}$ Cfr. TAYLOR, Ch., Fuentes del yo, pág. 487.

965 Cfr. PASCAL, B., Pensamientos, págs. 88-89. 
como "la caña más débil de la naturaleza". ${ }^{966}$ Taylor afirma que Pascal fue el primero en explorar esta imperfección innata como seres incompletos. ${ }^{967}$

Por otra parte, según Pascal, la razón no alcanza por sí misma cualquier certeza, pudiéndose solo alcanzar la verdad a través del complemento de la fe. Ambas se necesitan la una a la otra. Nos recuerda el axioma agustiniano, según el cual, la fe "busca" el entendimiento racional y la razón "necesita" de la fe para alcanzar la certeza que, por sí misma, es incapaz de lograr. ${ }^{968}$ En esta misma línea de pensamiento agustiniano, Pascal afirma que la razón "sabe retirarse" cuando hay que retirarse, y que la razón no significa "razonar siempre", lo mismo que la fe no significa "creer todo y siempre de la misma manera". ${ }^{969}$ Es muy razonable pensar que hay cosas que van más allá de la razón y la rebasan, ${ }^{970}$ y que el corazón también tiene sus razones que la razón no las conoce. ${ }^{971}$

Luego una vez que, según Pascal, acudimos a la razón y vemos la realidad de contradicción del hombre, no podemos dejar de acudir a la certeza que nos ofrece la fe, pues la sola razón nos deja a mitad de camino. Necesitamos de la fe y completar el argumento racional. Y es ahí donde recobra su pleno sentido el argumento de la Caída. Sin el argumento racional, el misterio del primer pecado aparecía envuelto en la nebulosa de la irracionalidad. Ahora, a partir de la razón, el misterio recobra renovada lucidez para "comprender" algo que no termina de entenderse desde la razón. Sin la

966 "El hombre es solo una caña, la más débil de la naturaleza; pero es una caña que piensa. No hace falta que el universo entero se arme para aplastarlo; un vapor, una gota de agua bastan para matarle. Pero, aunque el universo le aplastase, el hombre seguiría siendo superior a lo que le mata, porque sabe que muere y la ventaja que el universo tiene sobre él, el universo no la conoce. Toda nuestra dignidad consiste, por lo tanto, en el pensamiento. Desde ahí es desde donde debemos elevarnos y no desde el espacio, desde el tiempo, que no sabríamos llenar. Esforcémonos, pues, en pensar mucho: he ahí el principio de la moral". Ibid., pág. 92. Y a continuación, en el capítulo XV Bis, pone por título "La naturaleza está corrompida". Un texto que dejó vacío, en el que no puso ningún pensamiento, quizás porque quería dejar al lector la posibilidad que completara, desde sus pensamientos anteriores, sus propias reflexiones en torno a la corrupción de la naturaleza. "La naturaleza está corrompida. Sin J.C. el hombre tiene que estar en el vicio y en la miseria. Con J.C. el hombre está exento del vicio y de la miseria". Ibid., pág. 147.

${ }_{967}$ Cfr. TAYLOR, Ch., Fuentes del yo, pág. 352.

968 "Todo hombre quiere entender; nadie hay que no lo quiera; no todos quieren creer (la razón no es suficiente para acceder a la verdad, es necesario creer). Me dice un hombre: 'Entienda yo para que pueda creer'. Le respondo: 'Cree para que puedas entender'. Y ya que ha nacido entre nosotros una controversia tal, por así decirlo, cuando uno me dijo: 'Entienda yo para que pueda creer', y yo le respondí: 'Mejor cree para que puedas entender', vayamos con esta controversia al juez y ninguno de los dos presuma que la sentencia caerá de su parte, no sea nuestro juez un poeta, sino un profeta (se refiere al profeta Isaías $(7,9)$ : 'Si no tenéis fe, no podréis entender')". HIPONA, A. de, Sermón, 43,4.

969 “La razón no se sometería jamás si no juzgase que hay ocasiones en las que debe someterse. Es, pues, justo que se someta cuando juzga que debe someterse". PASCAL, B., Pensamientos, pág.79.

970 "No hay nada tan conforme a la razón como esa negación de la razón. Dos excesos: excluir la razón; no admitir más que la razón... El último paso de la razón consiste en reconocer que hay infinidad de cosas que la rebasan. Es más bien débil si no llega a comprenderlo. Pues si las cosas naturales la rebasan, ¿qué se dirá de las sobrenaturales”. Ibid., pág. 81.

971 "El corazón tiene sus razones que la razón no conoce; lo sabemos por mil cosas. El corazón es el que siente a Dios y no la razón. He aquí en lo que consiste la fe. Dios sensible al corazón, no a la razón". Ibid., pág. 154. 
razón, la fe quedaba en la nebulosa. Ahora, con la razón que no alcanza a "comprender", la fe recobra fuerza y empeño de certeza. ${ }^{972}$

Para Pascal, el misterio del hombre siempre invita a ir más allá, un misterio que llama a escuchar a Dios, porque cuando creemos descubrir al hombre nos encontramos con algo más grande y más alto a lo que no podemos acceder por la sola razón. En la afirmación de la verdad del hombre no podemos evitar al camino de lo trascendente, ya que el hombre siempre se trasciende a sí, es una realidad que siempre va más allá. Considera que el hombre siempre supera infinitamente al hombre, y en ese misterio puede reconocer aquello que ignora. Es ahí donde se escucha el misterio insondable de Dios. $^{973}$

Antes de volver con Rousseau, veamos qué plantea Voltaire a Pascal, intentando poner en diálogo a ambos autores a través de las anotaciones que Voltaire realiza en torno al pensamiento de Pascal y analizar así cómo se va configurando el giro hacia el deísmo. Voltaire denomina a Pascal el "misántropo sublime" y se niega a asumir los planteamientos de Pascal, encerrándose en su propio mundo de lo inmanente y negándose a profundizar en el auténtico nudo gordiano de la cuestión que se plantea aquí. Voltaire se quedará en la superficie de la condición humana, reduciendo la verdad de Pascal sobre el hombre a la razón y a la mera existencia humana. Para Voltaire, la realidad se basta a sí misma para trascender, a partir de ella, a la afirmación de un ser trascendente. No es necesaria la fe teísta, se basta el deísmo como afirmación del orden natural configurador del mundo. ${ }^{974}$

Voltaire afirma que hay que distinguir entre lo dado, lo fenoménico, la experiencia, lo que puede ser captado por la observación y, por otra parte, lo inquirido, lo encontrado, la ley, la ciencia newtoniana. Pascal ya lo había intentado en el siglo anterior. Ahora Voltaire trata de reconstruir esa nueva metafísica sobre la base de la física newtoniana, el compás del análisis matemático y la antorcha que ilumina la experiencia. Pero frente a la fe de Pascal, Voltaire da un paso más en la afirmación del orden deísta, que no precisa de otra realidad que la razón que se basta a sí misma para acceder al orden trascendente. Voltaire se mueve en el ámbito de la experiencia y la razón para dar el paso al deísmo y así se le considera el deísta por antonomasia. No existen ideas innatas cartesianas, tenemos una idea de Dios a través del orden creado y no necesitamos de un Dios que escuche plegarias y sea confidente del hombre. Es tan solo el Dios configurado del orden creado y se le puede conocer por la obra creada.

\footnotetext{
972 "La fe sin la razón era una 'hipótesis' ahora con la razón es una clave que nos descifra nuestra naturaleza más auténtica y profunda. La naturaleza humana se hace comprensible mediante la incomprensibilidad que descubrimos en su base. Así se subvierten todos los criterios respecto a la forma lógica, 'racional' del saber. ... con Pascal lo conocido y dado, la existencia en que nos hallamos directamente inmersos, se funda en algo desconocido". CASSIRER, Filosofía de la Ilustración, pág. 166. ${ }^{973}$ Cfr. PASCAL, B., Pensamientos, pág. 58.

974 Cfr. TAYLOR, Ch., Fuentes del yo, págs. 346,443,454.
} 
En relación a la Teología del pecado original, Voltaire cita a Pascal, según el cual, el hombre es más "inconcebible sin ese misterio que lo que ese misterio es inconcebible para el hombre". ${ }^{975}$ Para Voltaire, por el contrario, el hombre no es ningún enigma, ocupa su propio lugar en la naturaleza, siendo superior a los animales e inferior a otros seres. Es como todo lo que vemos, una mezcla de mal y de bien, de placer y dolor. Está dotado de pasiones para actuar y de razón para gobernar sus acciones, aunque lleno de contradicciones, pues en él se dan los ingredientes necesarios para ser lo que debe ser. ${ }^{976}$

Voltaire afirma la contundencia de la razón humana, frente a Pascal, para resolver cualquier enigma que esconda la naturaleza humana y que el hombre es "lo que debe ser", en el que se realiza una mezcla contradictoria entre el mal y el bien, entre la pasión y la razón. Frente a la "incapacidad de la razón" para comprender al hombre en su misterio y contradicciones de Pascal, Voltaire reafirma el compromiso de la razón para comprender al hombre en su "totalidad", en su complejidad, en sus ambivalencias y no se extraña de las mismas para recurrir a la fe, sino que le sirven para reafirmar lo que el hombre "debe ser". El deber ser no se configura desde la contradicción que afirma la fe, sino que es una invitación a reafirmar el camino de la razón frente a la fe que no añade nada a lo que ya está inscrito en la obra de la creación por el relojero del mundo.

Las contradicciones no invitan, según Voltaire, a iniciar un camino de perfección en el hombre a partir de la fe, sino que son un acicate aún mayor para incrementar la razón que ilumina las contradicciones inherentes al ser humano, ya que eso es el hombre y lo que debe ser. La contradicción reafirma el sentido del hombre en su capacidad racional, no una invitación a adentrarnos en el "abismo" de la fe. ${ }^{977}$ Las rupturas internas que para Pascal se expresan como contradicciones ontológicas y que remiten al pecado original, para Voltaire no son sino expresiones de la realidad humana tal como es, y de la que no se puede esperar otra cosa, porque es así "como debe ser", son expresiones de la riqueza humana y no nos encaminan hacia caminos de fe, sino que son una invitación a asumir la realidad humana tal como es, y no hay otra explicación superior, porque es así "como debe ser". ${ }^{978}$

\footnotetext{
${ }^{975}$ VOLTAIRE, Cartas Filosóficas, Sobre los pensamientos del Sr. Pascal, Gredos, Madrid, 2018, pág. 111.

${ }^{976}$ Cfr. Ibid., pág. 112.

977 "Sumisión. Hay que saber dudar donde es preciso, afirmar donde es preciso, sometiéndose donde es preciso. El que no lo hace así no comprende la fuerza de la razón. Hay quien peca contra esos tres principios, bien asegurando todo como demostrativo, por no estar ducho en demostración; bien dudando de todo, por no saber en lo que hay que someterse; bien sometiéndose a todo, por no saber dónde hay que juzgar. Pirroniano, geómetra, cristiano: duda, certidumbre, sumisión”. PASCAL, B., Pensamientos, pág. 79. Se trata de una sumisión de la razón, que no negación, porque la razón filosófica que se erige como verdad ontológica sobre el yo y que determina el alcance de la verdad metafísica según Descartes, en Pascal dicha razón cartesiana que pretende así olvidarse de los beneficios de la fe acaba siendo una filosofía escéptica, dado que "no alcanza" la certeza y de alguna manera "necesita" de la fe.

978،Lejos, pues, de que la idea del mejor de los mundos posibles consuele, es desesperante para los filósofos que la abrazan. La cuestión del bien y del mal sigue siendo un caos inextricable para los que
} 
Esta duplicidad inherente al ser humano, su versatilidad, expresa un mundo lleno de posibilidades, que lejos de abrirnos al camino de la fe, como único camino de salida para Pascal, en Voltaire nos reafirma en la fuerza y las capacidades que habitan el ser humano. Unas capacidades que crean un amor propio que despliega la seguridad en lo que uno es y debe ser. ${ }^{979}$ Pascal hace una apuesta decidida por Dios, una apuesta que lleva a la ganancia, frente a la pérdida que supone el no tomar partido. ${ }^{980}$ Frente a este argumento contundente de fe y de razón, Voltaire habla de un cierto infantilismo de argumentación en Pascal y afirma que no incluye al que duda, ya que en este caso ni afirma la apuesta decidida por Dios ni la niega al no tomar partido. El que duda, dice Voltaire, está "ni por, ni contra". Y no comprende por qué va a creer en su propuesta si en el fondo "no puede hacer nada por sí mismo". ${ }^{981}$ Voltaire se pregunta qué es la fe, que no es creer algo que parece evidente, ya que afirmar que existe un Ser necesario y eterno no es fe, es razón. La fe, para Voltaire, consiste en creer, no lo que parece cierto, sino lo que parece falso a nuestro entendimiento. Pensamos que, si Pascal afirmaba la fe por la inconsistencia de la razón, Voltaire afirma la razón porque la fe solo puede entenderse como adhesión a algo que parece falso al entendimiento. ${ }^{982}$

El escepticismo de Pascal respecto a la razón y la consiguiente necesidad de recurrir al "abismo de la fe", ${ }^{983}$ se manifiesta en Voltaire como escepticismo respecto a la fe, ya que esta solo puede ser comprendida como algo que aparece como falso al entendimiento, con la necesaria afirmación de la razón y la esperanza de que todo transcurra desde la sabiduría que se va desvelando para el bien del hombre, reconociendo lo inevitable de la naturaleza humana en sus flaquezas e impulsos. ${ }^{984}$

buscan de buena fe; es un juego de espíritu para los que disputan; son prisioneros que juegan con sus cadenas. Pongamos al fin de casi todos los capítulos de metafísica las dos letras que los jueces romanos cuando no entendían una causa: N.L., Non liquet, no está claro". VOLTAIRE, Cartas Filosóficas. Diccionario Filosófico, págs. 205-206.

979 "Este amor propio es el instrumento de nuestra conservación; se parece al instrumento de la conservación de la especie: nos es necesario, nos es querido, nos agrada, pero hay que disimularlo". Ibid., pág. 180.

980 VOLTAIRE, Cartas Filosóficas. Sobre los pensamientos del Sr. Pascal, pág. 113.

${ }^{981}$ Cfr. Ibid., pág. 114. En este sentido además Voltaire reivindica el sentido común como expresión fiel de la dimensión racional del hombre que debe recuperar el sentido que el "sensus communis" tenía para los romanos. "No solo sentido común, sino también humanidad, sensibilidad". Ibid., pág. 285.

${ }^{982}$ Cfr. Ibid., pág. 238. Una creencia en Dios que no evita el amor a las criaturas, sino más bien “... hay que amar, y muy tiernamente, a las criaturas... y hay que amarlos hasta tal punto que Dios nos los hace amar pese a nosotros mismos". VOLTAIRE, Cartas Filosóficas, Sobre los pensamientos del Sr. Pascal, pág. 116.

983 "El pecado original es locura ante los hombres, pero se le tiene por tal. No debéis por lo tanto reprocharme el defecto de la razón en esta doctrina ya que la doy como falta de razón. Pero esta locura es más sabia que toda la sabiduría de los hombres, sapientius est hominibus. Pues, sin esto, ¿qué se diría que es el hombre? Todo su estado depende de ese punto imperceptible. ¿Y cómo se hubiera apercibido de él por su razón puesto que es una cosa contra la razón y que su razón, lejos de descubrirla por sus medios, se aleja de ella cuando le es presentada? PASCAL, Pensamientos, pág. 248.

${ }^{984}$ Cfr. CASSIRER, E., Filosofía de la Ilustración, pág. 170. 
En uno de sus Cuentos, Voltaire haciendo un paralelismo con Jonás y Nínive, recrea una historia con el ángel Ituriel, Babuc y la ciudad de Persépolis. Después de analizar la condición humana y ser invitado a dar un veredicto final, Babuc decide que ese informe fuera encargar a un orfebre una estatua, y que, aunque no todo esté bien en ella, no merece la pena romperla, ya que es preferible dejarla que siga como va, al igual que el mundo. ${ }^{985}$ Es el reconocimiento de Voltaire de que todo está "perfectamente" en su sitio, a pesar de que el globo terráqueo es el manicomio del universo y de que nuestra mirada es la mirada de un tuerto. ${ }^{986}$

Y lo mismo ocurre en Cándido o el Optimismo en el que se recomienda, frente al misterio del mal, adentrarse cada uno en el ejercicio de sus propios talentos. Cada cual tiene que comprometerse en realizar sus mejores proyectos para el bien común. ${ }^{987}$ Todo está encaminado hacia un mundo positivo y favorecedor, en el que poder comprometernos saludablemente. Es posible encontrar la felicidad, porque todo se orienta hacia nuestro propio bien, y merece la pena ir en su búsqueda, sabiendo que es posible encontrarla "aunque no del todo".

Cambiando la perspectiva y dejando ya de lado el diálogo entre Pascal y Voltaire, aunque ahondando en lo mismo, Kant afirma que todo comienza con el bien en la historia de la humanidad, pero pronto se estableció este comienzo como un "sueño", ya que aparece el mal, y la caída en el mal conduce irremediablemente a la ruina del hombre. Para Taylor, Kant habla de la maldad radical de la naturaleza humana profundamente influenciado por el pensamiento de San Agustín. ${ }^{988}$

Sin embargo, frente a esta afirmación fundamental, Kant considera que, con el advenimiento de la Modernidad, el hombre va adquiriendo la audacia de atreverse a servirse del propio entendimiento, abriéndose camino otra percepción, según la cual, la naturaleza es el espejo del orden establecido por el Creador, en el que el hombre es bueno por naturaleza y todo progresa hacia el bien moral del hombre. Si el hombre por naturaleza nace sano, según el cuerpo, no hay ninguna causa para no aceptarlo igualmente como sano y bueno por naturaleza, según el alma. ${ }^{989}$

\footnotetext{
${ }^{985}$ Cfr. VOLTAIRE, Opúsculos.Cuentos, Gredos, Madrid, 2018, pág. 126

${ }^{986}$ Cfr. VOLTAIRE, Cuentos, Memnón, o la Sabiduría humana, pág.195.

987 "Y Pangloss decía algunas veces a Cándido: 'Todos los acontecimientos están encadenados en el mejor de los mundos posibles; porque, en última instancia, si no hubierais sido expulsado de un hermoso castillo a puntapiés en el trasero por amor a la señorita Cuynegunda, si no hubierais caído en manos de la Inquisición, si no hubierais recorrido América a pie, si no hubierais propinado... no comeríais aquí cidros confitados ni pistachos"”. VOLTAIRE, Cuentos. Cándido o el Optimismo, pág. 285.

${ }^{988}$ Cfr. TAYLOR, Ch., Fuentes del yo, pág. 499. Las fuentes del bien son interiores según San Agustín, Rousseau y Kant. Kant ofrece una base firme pero sumamente nueva para la subjetivación o la interiorización de las fuentes morales del yo que inaugura Rousseau. La ley moral es lo que surge desde dentro, pero tampoco se define por el impulso de la naturaleza en mí, solo por la naturaleza del razonamiento. Cfr. Ibid., págs. 497-498.

${ }^{989}$ Cfr. KANT, I., La religión dentro de los límites de la razón, pág. 30. "Ilustración significa el abandono
} 
Se va desconfigurando la idea del "mal intrínseco" inherente al hombre y se va racionalizando la idea de que todo está organizado para el bien y estamos viviendo en el mejor de los mundos posibles, porque así ha sido querido por el Creador Omnipotente. Para Kant, Rousseau supuso el empuje definitivo a una teodicea totalmente configurada desde el Dios Organizador y Bueno que ha creado todo para el bien y la felicidad del hombre. ${ }^{990}$ Se cambia la perspectiva. Frente al hombre caído y ontológicamente roto por el pecado original, se incide en un Dios bondadoso que todo lo ha dispuesto para la felicidad del hombre. ${ }^{991}$ Por otra parte, y ahondando en la misma idea, según Taylor, en Kant lo que asume el lugar de la benevolencia universal rousseauniana es el considerar a todos los seres racionales como fines en sí mismos. ${ }^{992}$ Todo en la naturaleza conforma ciegamente con las leyes. Solo las criaturas racionales, con las leyes humanas que ellas mismas formulan, son fines en sí mismas. Esto es incomparablemente superior.

Para Taylor, frente a la perversión de la voluntad del ser humano, anclado en su propia ruptura ontológica en el pecado original, Rousseau plantea una bondad natural del ser humano, y considera a la sociedad la fuente de todos los males que rodearán al hombre, como los vicios y la voluntad exacerbada de poder y dominio. Sufrimos esta pérdida porque hemos dejado de depender de nosotros mismos y de nuestro impulso interior, para depender de otros y de lo que ellos piensan de nosotros, esperan de nosotros, admiran o desprecian en nosotros. Una espesa red de opinión que se teje entre nosotros y la sociedad nos separa de la naturaleza y no nos permite recuperar el contacto con ella. ${ }^{993}$

por parte del hombre de una minoría de edad cuyo responsable es él mismo. Esta minoría de edad significa la incapacidad para servirse de su entendimiento sin verse guiado por algún otro. Uno mismo es el culpable de dicha minoría de edad cuando su causa no reside en la falta de entendimiento, sino en la falta de resolución y valor para servirse del suyo propio sin la guía del de algún otro. Sapere aude! ¡Ten valor para servirte de tu propio entendimiento! Tal es el lema de la Ilustración". KANT, I., Contestación a la pregunta ¿Qué es la Ilustración? Tomo III, Gredos, Madrid, 2018, pág. 319. "Su existencia tiene en sí el más alto fin; el hombre es el fin final de la creación, pues sin él la cadena de los fines, sometidos unos a otros, no estaría completamente fundada. Solo en el hombre, pero como sujeto de la moralidad, encuéntrase la legislación incondicionada en lo que se refiere a los fines". KANT, I., Crítica del Juicio, Gredos, Madrid, 2018, pág. 265. "Solo entonces la interpretación es estrictamente auténtica, al convertirse Dios dentro de nosotros en el intérprete mismo, pues no comprendemos a nadie que no nos hable a través de nuestro entendimiento y nuestra propia razón, de modo que la divinidad de una enseñanza recibida no puede ser reconocida sino mediante conceptos de nuestra razón, en tanto que dichos conceptos sean moralmente puros y por eso mismo falibles". KANT, I., El conflicto de las facultades en tres partes, Gredos, Madrid, 2018, pág. 419. Cfr. TAYLOR, Ch., Argumentos filosóficos, pág. 343.

${ }^{990}$ Cfr. TAYLOR, Ch., Fuentes del yo, pág. 488. Según Taylor, no hay perversidad original en el corazón humano. Nos lo hemos buscado nosotros. Todo degenera en las manos del hombre, por eso se pierde el contacto con esa voz interior de la conciencia que habla en lenguaje de la naturaleza. Rousseau reivindica la conciencia. Rousseau reivindica el elan de la naturaleza y la voz de la naturaleza como la conciencia.

${ }^{991}$ Cfr. Id., pág. 488.

${ }^{992}$ Cfr. Ibid., pág. 500. Según Taylor, para Rousseau la imagen de la voluntad agustiniana es abandonada para afirmar que todo está bien al salir de las manos de Dios. Cfr. KANT, I., Fundamentación de la Metafísica de las costumbres, Espasa, Madrid, 2019, págs. 102-104.

${ }^{993}$ Cfr. TAYLOR, Ch., Fuentes del yo, págs. 488 y ss. "La sociedad no solamente ha hecho al hombre más débil privándole del derecho que tenía en sus propias fuerzas, sino procurando hacerlas insuficientes; de aquí que sus necesidades sean multiplicadas en razón directa a su debilidad”. ROUSSEAU, J.J., Emilio o 
Rousseau afirma que la educación consiste en permitir que el hombre desarrolle su estado natural, motivarle para saber vivir y promover la vida en él observando la naturaleza. ${ }^{994}$ Rousseau reconoce distintos tipos de ignorancia, aunque una es digna de todo tipo de elogio: la ignorancia razonable, modesta, que nace de un vivo amor a la virtud, una dulce y preciosa ignorancia, el tesoro de un alma pura y contenta de sí, que cifra toda la ventura en recogerse en sí misma, en darse testimonio de su inocencia. ${ }^{995}$ Rousseau reconoce las influencias perversas de una sociedad en la que se encuentra arraigada la injusticia y la falta de compromiso con los otros. ${ }^{996}$ Por eso reivindica el arte de aprender a vivir según el orden natural, porque lo que realmente importa es el estudio de la condición humana. ${ }^{997}$

Y en este sentido, para Rousseau, es más racional partir de la religión como una realidad ética, que como una realidad metafísica. Kant será el gran continuador del punto de vista que abre el gran Rousseau. En todo caso la "metafísica" rousseauniana, si es que podemos emplear en él este término, se enmarca en su apuesta decidida por un concepto de Dios dentro del entramado de la experiencia existencial del hombre, cercano a su vida y no solo como en Leibniz como el ordenador-organizador del mejor de los mundos posibles. ${ }^{998}$ Taylor opina que Rousseau representa el sentimiento de la existencia como contacto moral auténtico con nosotros mismos. ${ }^{999}$

El deísmo de Rousseau no es tanto un deísmo filosófico, que aleja a Dios de la experiencia del hombre y le introduce en el mundo de la razón como un "estratega del mundo natural". Antes bien, es un deísmo "accesible" que pone en relación a la razón con la experiencia humana. ${ }^{1000}$ Para Rousseau, ubicar a Dios en la razón no significa "alejarle" de la experiencia humana. Precisamente porque la razón es esencial a la

la Educación, Gredos, Madrid, 2018, pág. 66.

994 "Hombre, encierra tu existencia dentro de ti, y no serás desgraciado. Quédate en el sitio que te marcó la naturaleza en la cadena de los seres, y nada te podrá forzar a que salgas de él... Tu poderío y tu libertad alcanzan hasta donde rayan tus fuerzas naturales, pero no más allá”. Ibid., pág. 65.

${ }_{995}$ Cfr. ROUSSEAU, J.J., Discurso sobre las ciencias y las artes, Gredos, Madrid, 2014, pág. 68.

996 "El primero a quien, tras haber cercado un terreno, se le ocurrió decir: 'Esto es mío', y encontró personas lo bastante simples para creerle, fue el verdadero fundador de la sociedad civil. Cuántos crímenes, guerras, asesinatos, cuántas miserias y horrores habría ahorrado al género humano el que, arrancando las estacas o cegando el foso, hubiera gritado a sus semejantes: Guardaos de escuchar a ese impostor; estáis perdidos si olvidáis que los frutos son de todos y la tierra no es de nadie". ROUSSEAU, J.J., De la desigualdad entre los hombres, Gredos, Madrid, 2014, pág. 171.

${ }^{997}$ Cfr. ROUSSEAU, J.J., Emilio o la Educación, pág. 15.

${ }^{998}$ Mientras que en el deísmo filosófico Dios es el organizador de un mundo mecanicista y con un orden físico que frecuentemente acaba en el ateísmo o en el agnosticismo, en Rousseau se trata de un deísmo más tradicional, de distinto orden, en el que no solo Dios establece el orden físico, sino también el orden moral, "religioso", con lo que se pone un muro que impide el acceso al agnosticismo. "Dios ha establecido una ordenación moral del mundo que coincide con el Evangelio. Y este Dios es un Dios bondadoso porque da tranquilidad al hombre, ya que restaurará la justicia en el otro mundo si el hombre es moralmente correcto conforme a la ordenación moral del mundo". FERRANDO LÓPEZ, A., El elemento religioso en J.J. Rousseau, pág. 138.

${ }_{999}$ Cfr. TAYLOR, Ch., Argumentos filosóficos, pág. 296.

${ }^{1000}$ Cfr. TAYLOR, Ch., El multiculturalismo y la política del reconocimiento, págs. 49-50. 
experiencia humana, Dios también, desde la razón deísta, se hace accesible y cercano al mundo existencial del hombre. Algunos autores en este sentido hablan del deísmo de Rousseau más en términos de "religioso" que en clave "filosófica", dado que su religión natural introduce la experiencia religiosa como una experiencia viva y cercana a la existencia humana. ${ }^{1001} \mathrm{El}$ deísmo es la única forma posible de religión civil que expresa las convicciones irrenunciables a las que se ha llegado. ${ }^{1002}$ Un deísmo que se expresa, según Taylor, como fondo existencial para una ética de la autenticidad. ${ }^{1003}$

Otros autores han hablado de un deísmo sentimental en Rousseau más que filosófico o racional. Un deísmo que accede a la "universalidad" de la experiencia religiosa y del que pueda sentirse partícipe el pueblo llano que no entiende de matices filosóficos o ideas complicadas. Pero no se trata de un sentimiento más, sino equilibrado por la razón. ${ }^{1004}$ Afirmamos con el profesor Antonio Pintor-Ramos que el deísmo arranca de la teología natural o quizás la teología natural desemboca en el deísmo, debido a la merma de las fuerzas probatorias de la existencia de Dios ante el embate implacable del nuevo estatuto epistemológico. ${ }^{1005}$

${ }^{1001}$ Cfr. TAYLOR, Ch., Argumentos filosóficos, pág. 288. "Con Rousseau nos encontramos ante el caso, quizá excepcional en Francia, de una religión natural que, sin embargo, sigue siendo religiosa". Cfr. GOUHIER, Les meditations, pág. 47 en nota 136 de PINTOR-RAMOS, A., El deísmo religioso de Rousseau, Kadmos, Salamanca, 1982, pág. 215.

1002 "Si Rousseau no renuncia al deísmo como conjunto de convicciones inalienables e innegociables, ello se debe a que le resultan imprescindibles para su imagen del mundo y su ideal de humanización. Si se limita fundamentalmente a los contenidos teóricos del deísmo es porque estos son la consecuencia lógica de algunos valores típicos de la modernidad que Rousseau considera ya patrimonio común adquirido e irrenunciable para todos los tiempos, a pesar de su desconfianza de los valores vigentes. El resultado final es una sorprendente figura del deísmo, la búsqueda de un deísmo animado por una fuerte vida religiosa que aquí no conozca ningún otro ejemplo similar". PINTOR-RAMOS, A., El deísmo religioso de Rousseau, pág. 221. Además, podemos decir que en cierto sentido Rousseau representa un cierto pensamiento religioso anti-intelectualista, dado que está más interesado en la experiencia y en las verdades prácticas que en la mera razón deísta. Es un deísmo "religioso" más que filosófico tal y como se ha afirmado anteriormente. "Las verdades prácticas son las únicas que le interesan, lo cual quiere decir que no desea la verdad por sí misma (más bien se asustaría de ella y temerá encontrarla fría), sino en relación al bien del hombre y a lo que da precio a la vida humana. La verdad que él amó es más moral que metafísica". MARITAIN, J., Tres Reformadores, pág. 191. Cfr. también PINTOR-RAMOS, A., "Rousseau: en el crepúsculo de la teología natural", Cuadernos Salmantinos de Filosofía, No 33, (2006), págs. 181-230.

${ }^{1003}$ Cfr. TAYLOR, Ch., Argumentos filosóficos, págs. 301-302. "Conciencia, conciencia. Instinto divino, inmortal y celeste voz; guía segura de un ser ignorante y limitado, pero inteligente y libre; juez infalible del bien y del mal, que hace al hombre semejante a Dios; tú eres quien hace de la excelencia de la naturaleza y la moralidad de sus acciones; sin ti no siento nada en mí que me eleve por encima de los animales, salvo el triste privilegio de perderme de error en error con la ayuda de un entendimiento sin regla y una razón sin principio”. ROUSSEAU, J.J., Emilio o la educación, Libro IV, pág. 323.

1004 “Un sentimiento atemperado por la razón, lo que hemos llamado un 'sentimiento razonable'. En Rousseau no se critica la razón, sino la razón sin freno... La opción por el sentimiento razonable se opone tanto al sentimiento individualista como a la razón crítica, ya que ambas desembocan en la desunión y el fraccionamiento. La opción de Rousseau es una opción por el conservadurismo moral, lo que quiere decir, por la estabilidad y la cohesión social". FERRANDO LÓPEZ, A., El elemento religioso en J.J. Rousseau, pág. 138.

${ }^{1005}$ Cfr. PINTOR-RAMOS, A., "Rousseau: en el crepúsculo de la teología natural”, pág. 191."El deísmo puede entenderse en algún sentido como la consecuencia de la teología natural y quizá no fuese disparatado decir que es la "apologética" de la teología natural cuando esta ya había culminado su fase 


\section{VI.- Conclusión.}

1.- El deísmo de Locke, de Hutcheson y de Leibniz es el deísmo del orden providencial y de la armonía preestablecida. Según Cassirer, el centro de gravedad se ha desplazado y los distintos campos del saber se emancipan cada vez más de la tutela de la metafísica tradicional. No es Dios el que configura el concepto de cada parcela del saber, sino que es cada campo particular del saber el que, partiendo de su forma específica, configura y determina el concepto de Dios a partir de su propia determinación. No se renuncia, según Cassirer, a la relación entre el concepto de Dios y la verdad propia de cada ámbito del saber, pero la dirección cambia. Lo que hasta ahora justificaba, a partir de ahora necesita justificación. ${ }^{1006}$ En esta misma línea, Taylor afirma que Leibniz, como Spinoza y Locke, no pueden aún alcanzar la visión especulativa del concepto, desarrollando la realidad a partir de sí mismo por una necesidad interna. ${ }^{1007}$

Desde fines del siglo XVII y a lo largo de todo el XVIII, se produce un cambio ontológico. Si en la naturaleza todo es orden y el Creador todo lo ha dispuesto para que captemos este orden y vivamos de acuerdo con él a través de las posibilidades de la razón, es la propia naturaleza la que nos encamina en la búsqueda de las fuentes morales. La manera de actuar y de ser bueno es vivir de acuerdo con la naturaleza en donde está inscrito el orden providencial y donde se puede descubrir al Hacedor de dicho orden. ${ }^{1008}$ En este orden moderno existe un triángulo: el espíritu finito, el espíritu infinito y el mundo de las cosas que se encuentran en unión última, en donde el espíritu y la materia son uno. Pero el espíritu finito no se da cuenta, por sí mismo, de esta unión, y necesita del espíritu infinito. Descartes liga la mente, a través de la certeza de la percepción, a Dios. El pensamiento y la extensión se encuentran en el "Absoluto" para Spinoza. Las mónadas de Leibniz son armonizadas por Dios. ${ }^{1009}$ Para Taylor, con Rousseau se avanza en el camino secularizador, ya que los motivos para las acciones se exploran dentro de uno mismo, en un yo sin contradicción y división que desembocará en el subjetivismo. Todas las filosofías de la autoexploración y de la libertad autodeterminante parten de él, aunque no dé el paso a una ruptura con el designio providencial de la naturaleza. Eso sí, su ensanchamiento de las fuentes de la moralidad, permitirán accesos hacia autonomías más hondas y autónomas, más radicales. Según

creadora. El rápido deterioro que, a su vez, sufrirá el deísmo se debe, no tanto a la omnipresente 'ontoteología', sino a la necesidad de compensar la debilidad de los argumentos racionales con otros argumentos, traídos ya no de la metafísica, sino de la vida religiosa. Por tanto, alguna forma de deísmo es paso hacia el agnosticismo o incluso el ateísmo; otros deísmos marcan un tránsito entre la teología natural y una todavía nonata filosofía de la religión; incluso hay algún deísmo que pretende una renovación religiosa mediante la purificación de las religiones de las corrupciones históricas, en última instancia siempre relacionadas con la tentación de poder". Ibid., pág. 187.

${ }^{1006}$ Cfr. Ibid., pág. 182.

${ }^{1007}$ Cfr. TAYLOR, Ch., Hegel, pág. 459.

${ }^{1008}$ Cfr. TAYLOR, Ch., Fuentes del yo, pág. 373.

${ }^{1009}$ Cfr. TAYLOR, Ch., Hegel, pág. 459. 
Taylor, Kant, partiendo de la voz interior rousseauniana, dará un paso más y ofrecerá una base nueva para la subjetivación e interiorización de las fuentes morales. La ley moral es lo que surge desde dentro y ya no puede definirse por ningún otro orden externo. $^{1010}$

\section{2.- Si consideramos a Platón como la principal fuente histórica de la corriente} ultramundana de la filosofía, ${ }^{1011}$ y como el referente filosófico del mundo de lo Absoluto y de la ultramundaneidad, ${ }^{1012}$ entonces seremos conscientes de su influencia

${ }^{1010}$ Cfr. TAYLOR, Ch., Fuentes del yo, págs. 494-495,497.

${ }^{1011}$ Siguiendo a Lovejoy, podemos establecer que las fuentes morales de la tradición filosófica occidental se dividen entre la "ultramundaneidad" y la "estamundaneidad". "No hay duda alguna que Platón representa el origen de la corriente 'ultramundanista' según la cual 'lo genuinamente real' como lo verdaderamente bueno tiene características esenciales radicalmente antitéticas de todo lo que se encuentra en la vida natural del hombre, en el curso ordinario de la experiencia humana, por normal, inteligente o afortunada que sea. El mundo que conocemos aquí y ahora (...) parece carecer de sustancia para el entendimiento ultramundano; los objetos de los sentidos e incluso los conocimientos científicos empíricos son inestables, contingentes y constantemente se descomponen en las meras relaciones de otras cosas que, en cuanto se examinan, resultan ser asimismo relativas y elusivas" LOVEJOY, A., La gran cadena del Ser, págs. 34-35. Es esta "ultramundaneidad" basada en los Diálogos de Platón la que ha caracterizado la tradición occidental como una concepción del mundo como una "pálida copia de las Ideas" y que se ha establecido como referente fundamental de nuestra visión filosófica del mundo y la historia, considerando el bien del hombre como una realidad que tiene su configuración definitiva en el mundo más allá de este mundo.

1012 "La teoría de las ideas es la aceptación de realidades absolutas, eternas, inmutables, universales e independientes del mundo de los fenómenos; por ejemplo, la belleza absoluta, la justicia absoluta, la bondad absoluta, de las cuales derivan su entidad todas aquellas cosas que llamamos bellas, justas o buenas". GRUBE, G.M.A., El pensamiento de Platón, Gredos, Madrid, 1987, pág. 16. El mundo de las ideas platónicas no es un mundo al margen del mundo de las sensaciones y de la realidad objetiva. No se puede entender un mundo sin el otro. Lovejoy afirma que "sería temerario" y forzaríamos el pensamiento platónico si consideráramos que su filosofía no tuviera en cuenta el mundo de las cosas cambiantes y de las leyes matemáticas para centrarse solo en el mundo de los "puros noúmenos". Para Platón, el mundo sensible no era una mera imagen ilusoria. Y el otro mundo, el mundo de las ideas era más una "réplica" atemporal de este mundo que una "negación" del mismo. Para Lovejoy, la Idea platónica del Bien ha ejercido a través del Neoplatonismo y la metafísica medieval su gran influencia en el Absoluto, el Uno, en la Idea de Dios, en lo absolutamente opuesto e inefable. No obstante, tal y como afirma Lovejoy comentando a Ritter, la Idea del Bien no tiene que "radicalizar" el mundo de las Ideas conduciéndolo a una creación fantasiosa del pensamiento, sino que más bien habría que relacionar la Idea del Bien como el "deseo del bien" inherente en todo lo creado. Concluyendo, Lovejoy afirma intentando hacer síntesis de tantas lecturas realizadas de Platón e intentando superar visiones incluso contradictorias del propio Platón o dudando de que sea el mismo Platón el autor de todos los textos atribuidos a él, dice: "si había que encontrar alguna razón para la existencia del mundo sensible, necesariamente tenía que encontrarse, para Platón, en el Mundo Intelectual y en la misma naturaleza del único Ser Autosuficiente. Lo no-tan-bueno, por no decir lo malo, debía entenderse como derivado de la Idea del Bien, como algo incluido en la esencia de la Perfección. El Dios idéntico-a-sí-mismo, que era el Fin de todo deseo, debía ser también el Origen de las criaturas que lo desean". LOVEJOY, A., La gran cadena del ser, pág. 58. Y al mismo tiempo "Platón encuentra en su Absoluto ultramundano, en la Idea del Bien mismo, la razón de que el Absoluto no exista solo mediante una audaz inversión lógica, la noción de Perfección Autosuficiente se convertía — sin perder ninguna de sus implicaciones originales - en la noción de Fecundidad Autotrascendente. El Uno incorpóreo e intemporal se convertía en la razón lógica, así como en la fuente dinámica, de la existencia de un universo temporal, material y extremadamente múltiple y abigarrado (...) de una Inmutabilidad que precisa y se expresa a sí misma en el Cambio; de un Absoluto que, sin embargo, nunca fue un verdadero absoluto, puesto que estaba vinculado, al menos por implicación y causación, a seres cuya naturaleza no era su naturaleza y cuya existencia y perpetua transitoriedad eran antitéticas de su permanencia inmutable" Ibid., págs. 62-63. Por lo cual, si partimos de estas "contradicciones platónicas" entre Los Diálogos y el Mito de la Caverna de la República, de alguna manera este último queda invalidado, ya que, según lo afirmado anteriormente, la dualidad de tendencias metafísicas es lo 
en los neoplatónicos, en la filosofía medieval, ${ }^{1013}$ en el Renacimiento, en la Ilustración, en el Romanticismo y hasta en la actualidad. ${ }^{1014}$

Con la Modernidad, las actividades se clasifican no en función de un orden jerárquico de tipo racional, sino en función de la relación que dichas actividades son capaces de establecer con el orden impreso en la naturaleza y la capacidad del hombre por expresar esa naturaleza racional inscrita en la naturaleza. Se trata de que vivamos no de acuerdo con el orden racional cósmico expresado en la naturaleza racional del hombre, sino en vivir de acuerdo con el orden inscrito en la naturaleza. No es necesario un orden cósmico que estructura la vida racional y moral del hombre. El orden está en la naturaleza y solo se pide que el hombre descubra dicho orden y viva de acuerdo al mismo. ${ }^{1015}$ Es el paso del teísmo al deísmo. ${ }^{1016}$ El teísmo suponía el reconocimiento del

que caracteriza las Ideas Platónicas. Una Idea de las Ideas que nos remite a la Perfección Absoluta que "necesita" o sería deficiente sin el mundo sensible, un Uno y un Absoluto que "precisa" del Suplemento de la Naturaleza para expresar su perfección. Una Idea del Bien o una Idea de las Ideas, según la cual, la Perfección Absoluta es Fecundidad Total, con lo cual, la Idea del Bien "precisa" de la Fecundidad Absoluta o, lo que es lo mismo, se trata de Dos-Dioses-en-Uno y nos lleva a la conclusión metafísica de que Dios sin la Naturaleza no sería "Absolutamente Bueno" no expresaría en su Totalidad la Idea del Bien. Y por lo tanto, el Mundo Sensible, si emana del Mundo Intelectual, está estrechamente "vinculado" a éste último, no pudiéndose comprender el Uno sin el Otro. Si Dios sin la Naturaleza no sería Divino, también se sigue, como conclusión metafísica, que Dios no sería el Totalmente Bueno y lo que es lo mismo no sería el Totalmente Absoluto.

${ }^{1013}$ En el paso de la filosofía medieval a la renacentista, Dante y su obra La Divina Comedia, expresa ese orden jerárquico como esa naturaleza engranada, como esa gran cadena del ser en ese orden único de seres en el que todo se expande en la bondad infinita de Dios y la dimensión "humana" del universo. "Te fijas solamente en pasajeras cosas terrenales, que oscurecen las luces de tu mente. Los infinitos goces celestiales irradian hacia amor sus resplandores, como un rayo de sol sobre cristales; y se dilatan, cuantos más ardores la caridad de todos y uno enciende, y la eterna virtud fecunda amores; y cuanto más el número se extiende de los electos, más lo bueno se ama, como un espejo en otro, luz trasciende". ALIGHIERI, D., La Divina Comedia, XV, Centro Cultural Latium, Buenos Aires, 1922, págs. 291-292.

1014 “Ahora ha llegado a ser natural concebir (la naturaleza) como existente y operante en su propia y autónoma independencia, en la medida en que la relación entre el hombre y la naturaleza resulta de algún modo clara, considerar el conocimiento y propósitos humanos producidos en parte por ella, y el destino del hombre como totalmente dependiente de ella". BURTT, E.A., Los fundamentos metafísicos de la ciencia moderna, pág. 21.

${ }^{1015}$ Cfr. TAYLOR, La Era Secular, tII, págs. 109,132,142,406,470,474726.

${ }^{1016}$ En el proceso intermedio de la etapa medieval nos parece importante resaltar las características de la astronomía precopernicana según la cual el hombre, contrariamente a lo que se nos ha hecho entender en el geocentrismo, no solo no ocupaba el centro del universo, sino como afirmaba Montaigne se encuentra inmerso en una enfermedad que no le hace reconocer el lugar en el que realmente se encuentra ubicado. "La más frágil y calamitosa de todas las criaturas es el hombre, y a la vez la más orgullosa: el hombre se siente y se ve colocado aquí abajo, entre el fango y la escoria del mundo, amarrado y clavado a la peor parte del universo, en la última estancia de la vivienda, el más alejado de la bóveda celeste, en compañía de los animales de la peor condición de todas, por debajo de los que vuelan en el aire o nadan en las aguas, y sin embargo se sitúa imaginariamente por encima del círculo de la luna, suponiendo el cielo bajo sus plantas". MONTAIGNE, Ensayos, págs. 388-389. "La cosmología geocéntrica servía para la humillación del hombre y no para su exaltación y que el copernicanismo fue combatido en parte, debido a que asignaba una posición demasiado digna y elevada a su morada (...) Así, pues, aunque este sótano oscuro y escuálido del universo fuera (con solo una excepción) el lugar menos respetable donde podían establecerse los seres, también era el lugar donde se desarrollaba todo lo dramático y emocionante". LOVEJOY, A., La Gran cadena del Ser, pág. 130. A pesar del giro copernicano "el sistema solar y el universo se mantenían idénticos; este mundo aunque no geocéntrico, seguía estando centrado, seguía siendo de forma esférica, seguía inexpugnablemente vallado por la esfera exterior, 'se ipsam et Omnia continens'; con lo que todo el sistema moral y religioso permanecía inmutable y el único cambio de esta 
orden cósmico establecido de manera jerarquizada por Dios. El deísmo supera la jerarquía de tipo cósmico y establece el orden natural como una invitación del Creador a vivir de acuerdo con él. Se pasa del cosmos teológico a la naturaleza deísta. Mientras que las Ideas jerarquizaban el funcionamiento cósmico y establecían la naturaleza racional del hombre como expresión máxima de dicho orden, con el deísmo se supera dicha visión del cosmos jerarquizado y se pasa a la consideración de la naturaleza como expresión viva de la huella del orden divino expresado en la creación y a expresar dicho orden con la racionalidad y el orden propio de dicha providencia divina.

Y de esta visión de la naturaleza del orden divino expresado como providencia, se pasará a una visión de la moral como una "ética de la vida corriente", que tanta importancia adquirirá en la Modernidad. ${ }^{1017}$ A Taylor, lo que le interesa resaltar es la transición que hizo zozobrar las jerarquías de la ética ciudadana y del honor, al desplazar el lugar de la vida buena desde una esfera especial de actividades superiores, hasta llegar a situarlo en el seno de la "vida" misma. ${ }^{1018}$ Desaparece el orden jerárquico de actividades y "todas" las actividades se contextualizan en el ámbito de la vida ordinaria y "todas" deben expresar el orden impreso en la naturaleza, no expresión de un cosmos jerarquizado. El orden metafísico desaparece para configurar un orden de causalidad natural en el que todo está coordinado según un "engranaje". La ética de razón jerárquica se configura ahora como "un vivir de acuerdo con la naturaleza", con lo que existe una continuidad, pero en clave secularizada.

Hay un cambio de lugar ontológico. Se pasa del "qué" actividades expresan mejor el orden jerárquico del cosmos, al "cómo" se viven y el significado que expresan en relación con el orden providencial de la naturaleza. En este sentido, la frase de Taylor "Dios gusta de los adverbios", ${ }^{1019}$ resume perfectamente el nuevo orden de la Modernidad. No importa ya tanto el "qué", como el "cómo" de lo que lo somos y sentimos. Este cambio es fundamental: pasar de "qué" actividades expresan mejor la naturaleza jerárquica del cosmos, al "cómo" se viven esas actividades y el alcance de interioridad que experimenta el yo en la vivencia de las mismas. "Se trata de poner el mundo en su lugar". Taylor afirma que el paso espiritual esencial que aquí se produce es el de instrumentalizar las cosas para preservar el orden de Dios y "no absorbernos en ellas". ${ }^{1020}$ Se pasa, de manera coordinada y lógica, de una razón ontológica a una razón instrumental. Si en la razón ontológica las esencias determinaban el orden cósmico, en la razón instrumental la naturaleza lleva inscrito el orden de causalidades engranadas, y

clase que conllevaba el abandono del sistema geocéntrico era (...) el rechazo de la idea aristotélica de que la posición central es una posición peculiarmente degradada y de toda la antítesis entre el mundo sublunar propio del devenir y los inmortales inmutables cielos”. Ibid., pág. 131. Será Kepler el auténtico autor del heliocentrismo señalando todas sus consecuencias y no Copérnico como tradicionalmente se ha afirmado.

${ }^{1017}$ Cfr. TAYLOR, Ch., La ética de la autenticidad, págs. 50-51.

${ }^{1018}$ Cfr. TAYLOR, Ch., Fuentes del yo, pág. 291.

1019 Cfr. Ibid., pág. 289.

${ }^{1020}$ Cfr. TAYLOR, Ch., Fuentes del yo, pág. 317. 
todo está determinado por un orden providente que es capaz de descubrirse por dicha razón. ${ }^{1021}$

La razón instrumental nos lleva a descubrir el orden del engranaje inscrito en la naturaleza, por lo tanto, también nuestras acciones deben "incardinarse" en un orden, en el que todos necesitamos de todos, de tal manera que la mejor manera de alcanzar nuestros objetivos es ubicarlos en el contexto del bien general. Y al mismo tiempo que dicha razón instrumental nos permite descubrir la interrelación de las propias actividades dentro del contexto general de intereses compartidos, es dicha razón la que también nos permite descubrir el todo como algo que expresa un orden providencial global. La razón instrumental nos permite descubrir no solo el orden total como orden providencial inscrito por el Hacedor de todo, sino que también nos ayuda a descubrir el engranaje en el que cada parte realiza y busca su propio bien dentro de un contexto en el que todo depende de todo, y la mejor manera de descubrir el propio beneficio es ubicarlo en el contexto del beneficio general. ${ }^{1022}$

\section{III.2.2.7. EL AVANCE IMPARABLE DE LA INCREENCIA}

Para Taylor, en el siglo XIX se produce un avance imparable de la increencia. La gran pregunta que late en el fondo de esta reflexión es cómo acabó siendo posible la reubicación moral de la felicidad humana en un locus inmanente, intramundano, sin referencia e inspiración moral en lo trascendente. Este acrecentamiento de la increencia en el siglo XIX tiene, en opinión de Taylor, un alcance novedoso respecto al giro antropológico que se había iniciado en el siglo XVIII. Las perspectivas no creyentes se van generalizando. En este avance imparable de la increencia en el siglo XIX, tiene mucho que ver el desplazamiento progresivo que se realiza en el imaginario social en torno a la forma de imaginar el mundo: se pasa de la consideración del mundo como un cosmos, hacia una visión del mundo como "universo". Esto significa que atrás quedó la visión del orden cósmico como un "principio de plenitud" que despliega todas sus posibilidades de ser a partir de un número finito de formas. Se trata de un orden racional cósmico de carácter finito: podemos comprender "todas sus formas" a pesar de lo "inconmensurable" de su grandeza. Todo lo que contemplamos es una "encarnación" del mundo de las Ideas, y todo se explica desde este orden introducido por la Idea

\footnotetext{
1021 "Preguntemos entonces cómo ocurrió que los hombres comenzaron a pensar el universo en términos de átomos de materia en el espacio y el tiempo en vez de usar categorías escolásticas (...) qué ocurrió entre 1500 y 1700 para que pudiera cumplirse esta revolución; y, luego, qué implicaciones metafísicas últimas llegaron a la filosofía general, al realizarse la transformación (...) Cuando comenzamos a dividir nuestro problema en cuestiones específicas como estas nos damos cuenta que estamos proponiendo un tipo de investigación histórica que se ha descuidado bastante, es decir, un análisis de la filosofía de los comienzos de la ciencia moderna, y en particular de la metafísica de Sir Isaac Newton". BURTT, E.A., Los fundamentos metafísicos de la ciencia moderna, pág. 27.

${ }^{1022}$ TAYLOR, Ch., La Ética de la autenticidad, pág. 62.
} 
configuradora. Se trata de un mundo "encantado", porque todo nos remite a un mundo superior y trascendente, a un mundo lleno de "espíritus".

Todo este mundo queda "desvanecido" en ese progresivo desencantamiento del mundo cuando este ya no es visto como un cosmos encantado, sino como un universo natural. La imagen del mundo cambió, tal y como afirma Heidegger. El mundo deja de ser un signo de la Razón Cósmica, y pasa a ser considerado como un universo natural, con su propio estatuto ontológico, y que puede ser escudriñado en sus posibilidades científicas. La ciencia newtoniana contribuyó a este cambio de la imagen del mundo tal y como hemos analizado en el siglo XVIII. Podríamos decir que el mundo se independiza de su carácter de "signo", ${ }^{1023}$ y pasa a ser considerado de manera autónoma. En esa autonomía, el mundo pierde el estatus de cosmos y pasa a ser considerado como universo. Un universo que rompe límites y que acrecienta una visión del mundo como algo inmenso e insondable, tal y como hemos visto con la física y matemática newtoniana. La idea del universo está ahora establecida sobre sólidos fundamentos, como la inmensidad del tiempo y el espacio, o el funcionamiento mecánico del mundo en su engranaje natural; un universo ilimitado, inmenso, "en evolución", sin plan fijo predeterminado y en el que todo queda abierto para un acceso a través de la ciencia. La cosmología bíblica se arrincona y, con la ayuda de la ciencia, se abren camino las teorías de la evolución. ${ }^{1024}$

No se trata solo de un cambio de una teoría por otra, sino que lo que realmente nos interesa analizar es ver cómo cambió nuestra imagen del mundo en clave heideggeriana o "cómo se llegó a esa nueva visión de las cosas". Evidentemente, la ciencia contribuyó con sus investigaciones al cambio del imaginario social. Lo que Taylor quiere decir es que hay un "trasfondo" más profundo que debe ser analizado y en el que no puede darse nada por supuesto. Nuestro autor quiere evitar "el relato de secularización más simple", para ayudar a adentrarnos en la "explicación más rica”. El recurso al relato de que la ciencia conlleva a una inexorable secularización sería empequeñecer el alcance de lo que ocurre y limitar una explicación que va mucho más allá de un simple relato incompleto e insatisfactorio. No podemos limitarnos a una explicación limitadora y simplista, que contiene sus dosis de verdad, pero que puede llevarnos a olvidar que hay una explicación más convincente y globalizadora. Sin este "contexto más amplio", del que habla Taylor, difícilmente podremos entender incluso la historia de la ciencia moderna que sustenta los cambios que estamos analizando. ${ }^{1025}$

\footnotetext{
${ }^{1023}$ El cosmos platónico acrecentado desde la teología patrística y medieval en sus referencias bíblicas es un mundo que surge de la voz de Dios y de la mano de Dios y que puede ser comprendido, a pesar de su carácter desconcertante y magnificente, como un todo en sus límites determinados por el Creador. Es un cosmos finito y determinado por la imagen del Creador, una imagen que encanta todo de Espíritu y que limita el alcance de comprensión del mismo.

${ }_{1024}$ Cfr. TAYLOR, Ch., La Era Secular, tI, págs. 368,404.

${ }^{1025}$ Cfr. TAYLOR, Ch., La Era Secular, tII, págs. 107 y ss.
} 
Para comprender la nueva imagen del mundo en la que nos adentramos, hay que tener en cuenta que el mundo "limitado" de la creación bíblica y de la ciencia premoderna es abandonado por la idea de un mundo infinito de innumerables mundos, tal y como ya adelantó Giordano Bruno en el siglo XVI. ${ }^{1026}$ Esta infinitud del cosmos "exterior" también abre caminos a la inmensidad microscópica del microcosmos, de la naturaleza a la que se puede acceder hasta el conocimiento de lo infinitesimal. Todo aparece como un mundo desconocido y en el que apenas nos hemos adentrado. Este es el cambio del cosmos al universo. Un universo con un espacio y un tiempo inabarcables y que Newton pretende explicar en clave físico-matemática, y Kant en clave filosófica, de la forma en la que lo hemos visto en nuestro estudio del siglo XVIII. La razón científica que explica el mundo en su constitución físico-matemática de Newton necesita de la razón práctica que se ubica en el yo subjetivo de Kant, para el que lo correcto es cuestión de intención interna. ${ }^{1027}$

El espacio y el tiempo no son solo fenómenos físicos explicables matemáticamente, sino conceptos universales entendidos como una representación/intuición a priori no empírica, y "condiciones de posibilidad" de los fenómenos espaciales y temporales. Es el vuelco hacia uno mismo entendido como reflexividad radical del que habla Taylor. ${ }^{1028}$ Existe un yo infinito que se elige a sí mismo y que determina toda la realidad como puro ser racional. ${ }^{1029}$ La física es también metafísica.

Con la Modernidad se pasa, pues, de un cosmos pequeño y reducido en su carácter de "signo", a un "universo infinito" con un espacio inabarcable y un tiempo ilimitado. Se trata del "oscuro abismo del tiempo", un tiempo que va fraguándose poco a poco, en

\footnotetext{
1026 "La consideración acerca de la creatio ex nihilo ha de ceder su lugar a la especulación sobre un universo que proclama la presencia en él de la divina infinitud. Bruno se aplicará con denodado esfuerzo a explicar la distinción entre la infinitud del que se predica que es Absoluto, que es siempre "totalmente Infinito" y la infinitud que se dice del universo que jamás es "totalmente infinito": pues este último es infinito en su conjunto, pero no lo es en cada una de sus partes, impidiendo de este modo la identidad de Dios-mundo". SOTO BRUNA, M.J., "La Metafísica del Infinito en Giordano Bruno", Anuario Filosófico, No 47, (1997), pág. 8.

${ }^{1027}$ Cfr. TAYLOR, Ch., Fuentes del yo, pág. 174. Para Kant el espacio no puede depender de la experiencia con el mundo de los fenómenos y los objetos, sino que la experiencia externa de relación con el mundo de los objetos externos depende de "una representación pensada". Cfr. KANT, I., Crítica de la Razón Pura, B 39. El espacio se representa como "magnitud dada infinita" tal y como refiere Kant; es decir, todos los conceptos del espacio parten de una concepción del espacio como "concepto universal" (intuición a priori) y solo desde dicha universalidad y unicidad el espacio puede subsumir los distintos conceptos de espacio en su multiplicidad, con lo que los conceptos de espacio (al ser limitado) tienen que ver con dicha magnitud dada infinita o, lo que es lo mismo, con una intuición a priori no empírica. El tiempo como forma a priori es lo que permite que los objetos "estén en el tiempo" "ser captados en el tiempo" a través de nuestra intuición sensible, no que el tiempo "esté indisociablemente unido a las cosas como propiedad absoluta". Es la intuición a priori la que permite captar "el tiempo de las cosas" o que las cosas puedan ser intuidas en el tiempo, confiriendo al tiempo ese carácter de realidad empírica. Cfr. KANT, I., Crítica de la Razón Pura, A 36.

${ }^{1028}$ Cfr. TAYLOR, Ch., Fuentes del yo, pág. 245.

${ }^{1029}$ Cfr. Ibid., pág. 611.
} 
una génesis que nos remite al proceso de nuestro "llegar a ser". Un tiempo como un abismo del que surgen formas y expresiones del ser en una "interminable cadena", hasta llegar a la forma más consciente y racional de lo que es el ser humano. Todo evoluciona a partir de un oscuro origen en el que de formas simples se va evolucionando hacia realidades cada vez más complejas, en una oscura y permanente reconfiguración que se orienta hacia la racionalidad del mundo moderno. ${ }^{1030}$

En este sentido, Diderot habla de "la gran cadena que une todas las cosas". ${ }^{1031}$ Una gran cadena que se remonta a Platón, Plotino, Leibniz, Buffon, Maupertius y otros. El mecanismo del Universo, para Diderot, está inscrito en el universo al que se accede a través del entendimiento, utilizando la observación y la experiencia. Diderot reivindica una lengua de la ciencia para acceder al conocimiento del mundo; un conocimiento que le lleve más allá de los resultados exiguos que frecuentemente ha alcanzado. Diderot propone ese carácter sintético de la nueva ciencia en el que se haga síntesis entre la araña racionalista y la hormiga empírica, a través de la imagen de la abeja como la representación del "verdadero trabajo de la filosofía", en la que se integren sintéticamente tanto el de la ciencia experimental como el conocimiento racional. Ya Bacon reivindicaba dicha síntesis. ${ }^{1032}$

${ }^{1030}$ Cfr. TAYLOR, Ch., La Era Secular, tII, pág. 129. GALFIONE, M.V., "Historia natural y temporalización: consideraciones sobre la Historia Natural de Buffon", História, Ciencias, SaúdeManguuinhos, Vol. 20, No 3, (2013), págs. 813-829. En dicho artículo se cita a G.L. BUFFON en dos textos relevantes para nuestro estudio. 1.- "Parece como si todo lo que puede ser, existiese efectivamente, como si la mano del creador no se hubiera abierto solo para dar el ser a un cierto número determinado de especies, sino como si él hubiese tirado todo a la vez, un mundo lleno de seres que en parte se relacionan entre sí y en parte no, una masa infinita de combinaciones armónicas y contradictorias, y un curso interminable de destrucción y renovación" (1749c, pág. 11). GALFIONE, M.V., "Historia natural y temporalización", pág. 820. Para Buffon, no se puede explicar el todo a partir de "solo una parte", sino que hay que estudiar, parte a parte, en sus características fundamentales, para llegar a la explicación del todo. Hay que estudiar, según Buffon, "cada cosa particular". 2.- "Estas fuerzas... son relativas al interior de la materia y no tienen relación con las cualidades externas de los cuerpos pero actúan sobre las partículas más íntimas y les penetran en todos los puntos; estas fuerzas, como ya hemos demostrado, no podrán jamás llegar a nuestros sentidos, porque su acción tiene lugar en el interior de los cuerpos y nuestros sentidos no pueden representarse sino aquello que es exterior, ellas no son ese tipo de cosas que nosotros podemos percibir" (1749b, pág. 45). GALFIONE, M.V., "Historia natural y temporalización", pág. 823.Buffon habla de un "molde interior" y de una "causación interior", no determinada por los sentidos, sino por las propias fuerzas "ad intra" de la naturaleza.

${ }_{1031}$ Cfr. DIDEROT, Sobre la Interpretación de la naturaleza, Anthropos, Barcelona, 1992, pág. 15.

1032 "Todo se reduce a volver de los sentidos a la reflexión y de la reflexión a los sentidos: entrar en sí mismo y volver a salir sin cesar. Es el trabajo de la abeja. Habrá explorado mucho terreno en vano, si no vuelve a la colmena cargada de cera. Habrá hecho montones de cera inútiles si con ella no sabe formar panales". Ibid., pág. 21. "Las ciencias han sido tratadas o por los empíricos o por los dogmáticos. Los empíricos, semejantes a las hormigas, solo deben recoger y gastar; los racionalistas, semejantes a las arañas, forman telas que sacan de sí mismos; el procedimiento de la abeja ocupa el término medio entre los dos; la abeja recoge sus materiales en las flores de los jardines y los campos, pero los transforma y los destila por una virtud que le es propia. Esta es la imagen del verdadero trabajo de la filosofía, que no se fía exclusivamente de las fuerzas de la humana inteligencia y ni siquiera hace de ella su principal apoyo; que no se contenta tampoco con depositar en la memoria, sin cambiarlos, los materiales recogidos en la historia natural y en las artes mecánicas, sino que los lleva hasta la inteligencia modificados y transformados. Por esto todo debe esperarse de una alianza íntima y sagrada de esas dos facultades experimental y racional, alianza que aún no se ha verificado". BACON, Novum Organum, I, 95, págs. 89- 
Para Taylor, Diderot es uno de los representantes de lo que significa ser un pensador autónomo, un filósofo. ${ }^{1033}$

El nuevo conocimiento científico tiene que basarse en esa síntesis de reflexión y experiencia, de entrar en sí mismo y volver a salir. El saber empírico tiene que llevar a la reflexión, y la reflexión es la palanca para volver a salir. Se trata del instinto empírico que constantemente mira, prueba, toca, escucha (física experimental), y de la razón "empujada a permanecer en sí misma". ${ }^{1034}$ Una síntesis que Diderot quiere expresar con la imagen de la totalidad, de la "cadena general" en la que todo está inmerso y todo se va diversificando. ${ }^{1035}$ En este sentido, para Taylor, el pensamiento de Diderot es sensible a la tensión constitutiva del naturalismo, al propio tiempo que, curiosamente, contiene temas protorrománticos. ${ }^{1036}$

Esta idea de Diderot y Buffon, en la que todo evoluciona y todo se va diversificando y a la que la filosofía experimental debe acceder a través de la síntesis entre entendimiento (saber racional) y experiencia (saber empírico), es una idea que se despliega a principios del XVIII y se completa esencialmente a mediados del XIX con Darwin en su libro El Origen de las especies (1859). Todo es un proceso evolutivo difícil de sondear, no solo por el vasto despliegue de fuerzas evolutivas, sino también por "el oscuro abismo del tiempo" en el que todo sucede y se desarrolla. ${ }^{1037}$

Todo se va desplazando hacia una nueva visión del cosmos. Del viejo cosmos lleno de significados y de un orden según las Ideas y sus correspondencias en el mundo de lo real, se pasa a un universo infinito en el que todo puede ser explicado literalmente como una realidad física en constante evolución y diseñada por un Ente Divino que dejó previsto su plan en la Naturaleza.

Ello lleva a la eliminación del misterio en las cosas, ya que todo sigue su curso natural y su funcionamiento puede ser explicado por las leyes naturales, tal y como explicó Newton. "El misterio queda referido al origen", al momento del acto creador divino en el que el Diseñador trazó su plan y que puede ser desvelado a partir de la física y la matemática moderna. No existe ningún misterio intracósmico. El misterio queda referido a la intención primera o al "diseño desde el principio".

\footnotetext{
90.

${ }^{1033}$ Cfr. TAYLOR, Ch., Fuentes del yo, pág. 443.

${ }^{1034}$ DIDEROT, Sobre la Interpretación de la naturaleza, pág. 21.

1035 “No podríamos creer que no hubo más que un primer animal prototipo de todos los animales en el cual la naturaleza solo ha alargado, acortado, transformado, multiplicado, desgastado ciertos órganos? Pues es evidente que la naturaleza no ha podido conservar tanto parecido en las partes y presentar tanta variedad en las formas, sin haber hecho a menudo patente en un ser organizado lo que ha ocultado en otro. Es una mujer a la que le gusta disfrazarse, y cuyos diversos disfraces, exhibiendo ora una parte, ora otra, conceden a aquellos que la siguen asiduamente cierta esperanza de conocer toda su persona algún día". Ibid., págs. 26-27.

${ }^{1036}$ Cfr. TAYLOR, Ch., Fuentes del yo, pág. 470.

${ }^{1037}$ Cfr. TAYLOR, Ch., La Era Secular, tII, págs. 54-55.
} 
Como expresión de este mundo desencantado, que avanza inexorablemente hacia la secularización, está la comprensión que se tiene de lo sublime. Tal y como aparece a finales del siglo XVIII, en textos de Burke y Kant, lo sublime se identifica con la percepción de sí mismo que tiene el yo impermeabilizado y encerrado en su propia sorpresa y latido. Lo sublime también empieza a configurarse como la contemplación de lo inabarcable, que provoca espanto y despierta fuentes morales hasta ahora insospechadas, como son la vocación moral kantiana o la contemplación de la infinitud cósmica. $^{1038}$

En este contexto en el que se va estableciendo la identidad impermeabilizada y ensimismada, lo sublime es un "eco" de la apertura a un sentido trascendente que se va definiendo como algo "inabarcable", como algo que nos supera y que nos despierta a realidades y valores que van más allá del propio ensimismamiento existencial. Lo sublime empieza a despertar sentimientos ante los que la identidad ensimismada no puede sino comenzar a abrirse a realidades que van más allá de su propia impermeabilización ontológica, y que permiten que el yo no se sienta tan seguro de sí mismo, y se adentre en el misterio que provoca la infinitud trascendente o lo "suprasensible".

La naturaleza ha tenido para el hombre primitivo ese sentido trascendente que le sobrecogía y le elevaba sobre sí mismo hacia mundos de espíritus y de misterio. Una naturaleza en la que el hombre ha vislumbrado, por un lado, el aspecto de lo salvaje, lo abrupto y el deseo animal y, por otro lado, esa visión preagrícola y más suave en la que la naturaleza "produce sus frutos", sin intervención directa del hombre. Una naturaleza en la que el hombre va configurando su espacio en relación con ella, hasta llegar al Renacimiento, en el que el hombre busca su propio espacio natural a través del jardín como expresión de una fuerza de la naturaleza que se pone al servicio del hombre en su afán contemplativo y lúdico.

Una vez que la naturaleza deja de ser vista como un locus de sentido trascendente en el orden jerárquico de las Ideas, y solo tiene un "referente trascendente" en el Diseño del comienzo a partir de un gran Organizador que ha dejado impreso su orden cósmico, la naturaleza comienza a ser vista, en sus implicaciones para el hombre, como algo independiente que provoca sentimientos sublimes en su interior. No es la naturaleza la que define las fuentes morales del hombre, sino el hombre el que "determina" el alcance moral de la naturaleza. Con el advenimiento de la Modernidad podemos decir que la Naturaleza no determina el orden moral del hombre, sino que es el hombre el que contempla la dimensión moral que esta puede ofrecerle. El sentido de lo sublimo y de la profundidad se encuentra, no ya en la eternidad cósmica, sino en la inmensidad del espacio y en el abismo del tiempo.

${ }^{1038}$ Cfr. Ibid., pág. 70. 
Es decir, que ante el advenimiento del antropocentrismo deísta y de la racionalidad escondida en una identidad impermeabilizada, el hombre "necesita" de la experiencia sublime y de lo bello que ayude a dicha identidad antropocéntrica a "romper límites" hacia un encuentro con la naturaleza salvaje, como "deseo de supervivencia moral" en un estado que podríamos calificar de "emergencia ontológica". Es la naturaleza salvaje la que lleva al hombre a poder vivir como lo que es sin ser ya lo que era y "avanzando hacia lo que quiera ser".

Todo esto nos lleva, según Taylor, como consecuencia de este giro antropocéntrico, a pensarnos a nosotros mismos emergiendo de la profundidad de los tiempos en una naturaleza profunda y, por tanto, despertándonos a "la sorpresa de lo desconocido". ${ }^{1039}$ Fruto de este centramiento en la naturaleza humana, el hombre se ubica progresivamente en un rescate de la naturaleza originaria, dentro de la cual se ve a sí mismo como formando parte de ella. Este giro antropocéntrico lleva a una contemplación de sí mismo como formando parte de esa naturaleza primigenia. En el siglo XIX, surge esta conciencia de que fruto de este "ensimismamiento antropocéntrico" el hombre no puede olvidar "la voz de la naturaleza más profunda", no puede ahogarse en este encerramiento asociado a la impermeabilidad trascendente. La impermeabilidad no puede llevar al "ahogamiento" de la voz de la naturaleza. Y esto es lo que representa el Romanticismo asociado a Rousseau y otros autores que a continuación analizaremos.

Se ha pasado de una razón dada en el cosmos platónico a una razón descubierta a partir de la mente cartesiana, de una Idea encarnada en un cosmos jerarquizado a una idea realizada en la mente del hombre que descubre el mundo. Y a partir de la mente cartesiana se produce el giro copernicano que establece el antropocentrismo impermeabilizador. Un antropocentrismo que descubre la interioridad humana como una interioridad abierta y en conexión con la naturaleza. Del Cosmos que encarna la Idea a la idea que descubre la mente. De la Idea a la idea que crea espacios de racionalidad e interioridad, para volver de nuevo a la interioridad que descubre la naturaleza, pero una naturaleza que no encarna la Idea, sino que pone en conexión el yo impermeabilizado con un nuevo estatuto natural basado en su propia autonomía ontológica: un yo impermeabilizado que "descubre" una naturaleza sin espíritus, una naturaleza que evoca lo sublime como expresión desencantada de lo otro, de lo distinto, de lo diferente. Nos pertenecemos a nosotros mismos. El mundo sublime de la naturaleza desencantada es nuestro hogar, un hogar de una identidad personal impermeabilizada.

Hay una naturaleza, con un tiempo infinito y un espacio insondable, que reclama la percepción de una naturaleza personal como una identidad, que invita al propio éxtasis de extrañamiento y al análisis de una génesis que nos sobrecoge. El espacio de la

${ }^{1039}$ Cfr. TAYLOR, Ch., La Era Secular, tI, págs. 355 y ss. 
naturaleza infinita se familiariza con una interioridad llena de misterio y capacidad para sondear las profundidades del propio yo. La mente cartesiana que crea el yo que piensa se sobrecoge ante un mundo que le pone en sintonía con su propio yo. La corriente de unidad entre el yo que se sobrecoge ante lo sublime de la naturaleza le hace consciente de su propia pequeñez, pero al mismo tiempo de su grandeza al captar la grandeza sublime del universo. Como diría Pascal, el hombre es grande porque es capaz de comprenderse como ser pensante, al darse cuenta de lo que es, de ser solo un "junco" pensante, que, siendo pequeño, solo un junco, no hay nada más sublime, pues no hay ninguna otra realidad que sea capaz de "comprender el mundo". Por el espacio, el hombre es solo un punto en el universo, sin embargo, con su mente, es capaz abarcarlo. Para Pascal, el hombre está lleno de contradicciones y su grandeza consiste en saberse miserable, un saber que le permite sobrecogerse ante sí mismo y ser capaz de comprender que hay razones en el corazón que la razón no conoce. Por eso el corazón es el que siente a Dios y no la razón; y en esto consiste la fe. ${ }^{1040}$

Para Kant, también la naturaleza reclama la percepción de un sujeto personal entendido como una mente infinita, como espacio del yo racional que, según Taylor, permite que la mente domine a un mundo desencantado de la materia. Por todo lo cual, el sentido moral del hombre exige que el agente tenga su dignidad como ser racional. ${ }^{1041}$ En este sentido, para Kant, todo el mundo exterior o de los objetos, "posibilita" el que el sujeto no esté encerrado sobre sí mismo, sino que sea "permeable" al mundo exterior, a la naturaleza. Son los objetos, y la naturaleza dentro de ellos, los que establecen relación de impresionabilidad con el sujeto, posibilitando la apertura del sujeto a los objetos exteriores y a la naturaleza en general. Los conceptos están dispuestos para la diversidad experiencial y la experiencia es la que hace posible el conocimiento. ${ }^{1042}$

Taylor sostiene que la importancia moral del sentimiento surge desde otro ángulo si se contempla el creciente sentimiento hacia la naturaleza que se desarrolla en el siglo XVIII. Se recupera otra visión de la naturaleza. Se extiende la moda de residir en el campo, en el encanto que sobrecoge un paseo por la campiña o en la popularidad que va adquiriendo lo rústico. Se recupera por otra parte ese "lado salvaje e indómito" que

\footnotetext{
${ }^{1040}$ PASCAL, B, Pensamientos, Gredos, Madrid, 2018, pág. 52. Cfr. Ibid. pág. 154.

${ }^{1041}$ TAYLOR, Ch., Fuentes del yo, pág. 214.

1042 "Dos cosas colman el ánimo con una admiración y una veneración siempre renovadas y crecientes, cuanto más frecuente y continuadamente reflexionamos sobre ellas: el cielo estrellado sobre mí y la ley moral dentro de mí. Ambas cosas no debo buscarlas ni limitarme a conjeturarlas, como si estuvieran ocultas entre tinieblas, o tan en lontananza que se hallaran fuera de mi horizonte; yo las veo ante mí y las relaciono inmediatamente con la conciencia de mi existir". KANT, I., Crítica de la Razón Práctica, A 289. "La primera comienza por el sitio que ocupo dentro del mundo exterior de los sentidos y amplía la conexión en que me hallo con una inconmensurable vastedad de mundos, metamundos y sistemas de sistemas, en los ilimitados tiempos de su movimiento periódico, de su comienzo y perdurabilidad. La segunda parte de mi propio yo invisible, de mi personalidad y me escenifica en un mundo que posee auténtica infinitud, pero que solo es perceptible por el entendimiento, y con el cual (mas también a través de él con todos aquellos mundos visibles) me reconozco, no como allí en una conexión simplemente azarosa, sino con una vinculación universal y necesaria”. Id., A 289.
} 
esconde la naturaleza, como algo que despierta posibilidades creativas en el hombre para llevar una vida civilizada y una fuerza para vivir mejor donde estamos. ${ }^{1043}$

Pero para Taylor, lo realmente relevante en Rousseau es la negación de la autotransparencia y la forma que tiene de integrarlo en una nueva versión del deísmo. ${ }^{1044} \mathrm{Si}$ para la teoría ortodoxa la fuente del amor supremo divino se manifiesta en la gracia, para Rousseau, sin embargo, se ha convertido en la voz de la naturaleza. Según Taylor, para Rousseau, la razón calculadora y más Ilustración no nos lleva a ser mejores. Antes bien, puede ser fuente de corrupción. ${ }^{1045}$ La estrecha alianza de razón y naturaleza puede llevar a la confusión. ${ }^{1046}$ En Rousseau, la razón ilustrada por sí sola puede llevar al ahogamiento de la conciencia. Por eso, según Taylor, para Rousseau la conciencia habla el lenguaje de la naturaleza. La voz de la naturaleza se convierte en nuestro guía interior, porque la conciencia capta dicha voz. Taylor piensa que el sustituto de la gracia es el impulso interno de la naturaleza. ${ }^{1047}$ Se trata de la naturaleza interior rousseauniana. La naturaleza, siguiendo la teoría de Rousseau, según Taylor, se asemeja a un inmenso teclado en el que interpretamos nuestros más intensos sentimientos. ${ }^{1048}$ La naturaleza se convierte en fuente moral.

En el contexto de la identidad impermeabilizada de carácter deísta, la vuelta a la naturaleza es una posibilidad para descubrir enraizamientos morales que permiten al hombre sentirse como él es y participar de algo que le "eleva espiritualmente" sobre su propio yo. Son esas cumbres inhóspitas rousseaunianas que inspiran "inmensidad" y nos elevan sobre el abismo del tiempo y de la vida, y nos pone en contacto con un sentido que nos trasciende. Es este alcance ético el que se descubre en la naturaleza que nos emociona y nos encumbra. "Lo sublime", como valor moral, se expresa en la contemplación de la naturaleza en toda su sobrecogedora "expresividad". ${ }^{1049}$

La naturaleza esconde algo que en su contemplación nos ayuda a desvelarnos a nosotros mismos. La naturaleza nos pone en contacto con algo que se esconde de nosotros mismos y nos ayuda a vivir "fuera de ella", como si un deseo irrefrenable nos condujera al contacto con ella para poder vivir fuera de ella. "Sin ella no podríamos vivir fuera de ella". Es la naturaleza que provoca extrañeza y nos permite reconocernos desde nosotros mismos, a la vez formando parte de ella. Lo que somos en nuestro yo no puede separarse de lo que sentimos en relación con una corriente que nos une a la naturaleza exterior. "Lo que hay en mí entra en vibración con lo que hay fuera de mí en una suerte de armonía trascendental". Lo que vibra en mi interior "entra en conexión"

\footnotetext{
${ }^{1043}$ Cfr. TAYLOR, Ch., Fuentes del yo, págs. 408 y ss; cfr. TAYLOR, Ch., La Era Secular, tII, pág. 73.

1044 Ibid. pág. 487.

1045 Cfr. TAYLOR, Ch., La Era Secular, tI, págs. 321-323.

${ }^{1046}$ Cfr. TAYLOR, Ch., Fuentes del yo, págs. 490 y ss.

1047 Cfr. Ibid., pág. 561.

1048 Cfr. Ibid., pág. 409.

${ }^{1049}$ Cfr. TAYLOR, Ch., La Era Secular, tII, págs. 65,76,83,104,485.
} 
con la vibración cósmica de la naturaleza, de tal suerte, que no puedo ser yo sin esta conexión cósmica con todo lo creado. ${ }^{1050}$ Con Rousseau, según Taylor, "el subjetivismo moral moderno" llega a su etapa más avanzada, a partir de distintas variantes del deísmo: en su visión de la razón autodefinidora y desvinculada, en la autonomía en Kant y en la naturaleza como fuente ${ }^{1051}$ Es el deísmo de finales del siglo XVIII que, potenciado por la visión de la naturaleza como fuente, va preparando el camino hacia el expresivismo. Taylor opina que se trata del siguiente paso hacia el individualismo radical. No es posible conocer la voz de la naturaleza sin conocer antes nuestra definición de ella y, a partir de ahí, realizar nuestra más honda naturaleza. El sentimiento normal es la forma de acceso al designio de las cosas, lo que le convierte en fuente moral. Es la individuación expresiva como uno de los pilares de la cultura moderna. Se trata de la originalidad como vocación tanto a nivel personal como colectivo. ${ }^{1052}$ Cada uno de nosotros tiene su propia forma de tomar conciencia de nuestra humanidad y descubrir su propia originalidad vital. ${ }^{1053}$

Taylor plantea, a partir de este momento, otros tres elementos que van a conducir a un imaginario cósmico muy variado en el que caben sensibilidades y percepciones muy distintas, desde el materialismo más ortodoxo, hasta visiones cristianas, pasando por concepciones intermedias en las que caben muchos matices. La Modernidad conduce hacia lo que Taylor denomina "una zona neutra", donde se deambula por distintos ámbitos morales, en una especie de "tierra de nadie", en la que son posibles todas las opciones y todo se nos muestra disponible para ser transitado, sin terminar de aterrizar en nada ni quedar saciado por nada. ${ }^{1054}$ Este humanismo exclusivo estará caracterizado por configuraciones morales que hasta ahora eran casi imposibles de considerar y que en esta tierra de nadie pueden considerarse como una alternativa más entre las muchas posibles. No hay nada cerrado y todo es posible y, además, el tránsito de unas configuraciones morales a otras es algo viable, así como la influencia de unas configuraciones morales en otras. ${ }^{1055}$

Desde el punto de vista de Taylor, se va abriendo camino, como una posibilidad moral más, la idea de un sujeto opaco para sí mismo, locus de procesos inconscientes y en parte impersonales, que debe tratar de encontrarse en la inconmensurable época de una oscura génesis y nacido de lo prehumano, dentro y fuera. ${ }^{1056}$ Se trata de un yo neutro, impermeabilizado, con raíces profundamente naturalistas y en el que debemos ahondar si queremos entender la perspectiva en la que estamos basándonos para

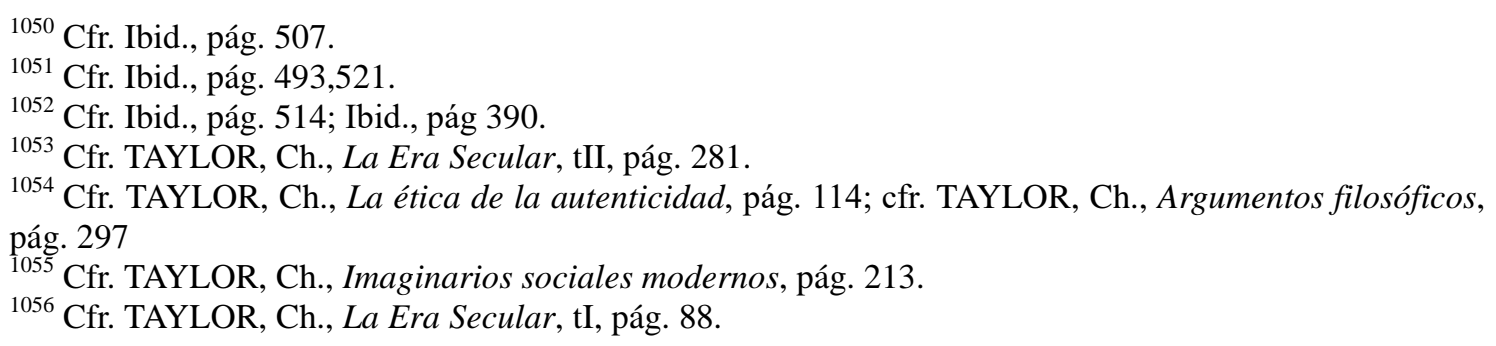


comprender el alcance de la secularización. Creemos que el siglo XIX es fundamental para entender "el malestar de la religión" en el mundo de hoy.

Para nuestro autor, el siglo XIX supone el afianzamiento de la oposición inevitable entre ciencia y religión, y la afirmación implícita de que la religión es en cierta manera un pensamiento primitivo, sentimental, menos maduro. Por otra parte, el universo inmenso en el que parece desaparecer la idea de un Dios personal o un propósito benigno se va configurando como imaginario cósmico. La profundidad del universo, en Taylor, parece requerir una explicación en términos de ley causal impersonal y natural. Según él, en el siglo XIX se va extendiendo la idea de un universo vacío, que se despoja de todo significado humano y en el que la razón desvinculada, el yo impermeabilizado y el orden impersonal avanzarán irremediablemente hacia una edad secular. $^{1057}$

En conclusión, para Taylor, en el siglo XIX crece, en varias dimensiones, un nuevo sentido acerca de la naturaleza que habitamos como algo inmenso: no solo en el espacio, sino en el tiempo, y luego sobrepasándolos, en la dimensión de su microconstitución. La nueva perspectiva del tiempo y la nueva dirección en la biología se combinaron en la teoría de la evolución de las especies darwiniana y continuaron con las teorías de Freud medio siglo después. ${ }^{1058}$ Todo ello permitirá la expansión de la idea de que, tanto nuestro pensamiento como nuestra voluntad, están en íntima relación con las funciones fisiológicas de nuestro cerebro, abriendo así un campo totalmente novedoso en relación con una perspectiva que podríamos considerar psico-fisiológica.

En este sentido, Gauchet habla de tres inconscientes: el inconsciente filosófico procedente en buena parte del Romanticismo alemán (Schopenhauer, Hartmann y Nietzsche), el inconsciente hereditario (Darwinismo social y Psicología de masas) y el inconsciente neurológico o cerebral (Freud). El "yo impermeabilizado" ahora se repliega sobre sí mismo, no solo en su autoconciencia hegeliana, sino hacia los repliegues neurológicos de la inconsciencia. Una palabra que aparece antes de Freud pero que alcanza en Freud un despliegue científico que explora todas las dimensiones del yo, como veremos posteriormente. ${ }^{1059}$

\footnotetext{
${ }^{1057}$ Cfr. TAYLOR, Ch., La Era secular, tII, págs. 85-87.

${ }^{1058}$ Cfr. TAYLOR, Ch., Fuentes del yo, pág. 551. Gauchet afirma que ya antes de Freud se ponía en duda la identificación entre psiquismo y consciencia debido ya a las investigaciones de los neurofisiólogos. "Se le quita a la visión clásica del dominio consciente y de la actividad voluntarista el soporte fisiológico que postulaba de una manera más o menos confusa; se descubre que es incompatible con las representaciones mínimas del funcionamiento del aparato nervioso, que los datos evidentes obligan a aceptar". GAUCHET, M., El inconsciente cerebral, Ediciones Nueva visión, Buenos Aires, pág. 28.

${ }^{1059}$ Cfr. TAYLOR, Ch., La Era secular, tII, pág. 88.
} 


\section{III.2.2.7.1. El inconsciente filosófico. Schelling y Schopenhauer}

Con el advenimiento de la Modernidad, en lugar de ver el mundo como un orden providencial, se va considerando como un dominio neutro que hay que entender para poder dominarlo a partir de las relaciones causales. ${ }^{1060} \mathrm{El}$ orden impersonal y la razón desvinculada se imponen a través de la actitud científica. La naturaleza es inmensa en el tiempo, en el espacio y en su microconstitución. Por otra parte, la nueva constitución de la biología conduce a las teorías darwinianas y freudianas. ${ }^{1061}$

Para Taylor el pensamiento schopenhaueriano anticipó las doctrinas freudianas de la determinación inconsciente del pensar y del sentir. ${ }^{1062}$ De ahí la importancia de adentrarnos en el inconsciente filosófico schopenhaueriano y en la articulación de las profundidades a través de lo que Taylor denomina una ciencia natural de la mente. ${ }^{1063}$

En este sentido, tanto Descartes como Locke no pueden plantear el término "inconsciente" debido a que para ellos el cogito es todo lo que significa pensamiento y de lo que somos conscientes. Por eso, para ellos, no se puede hablar de un "pensar inconsciente". Descartes y Locke marcaron el camino del cogito y del yo puntual. Sin embargo, Leibniz habla de percepciones insensibles o pequeñas percepciones, caracterizadas por su cantidad y por su carácter difuminado y oscuro.

Se trata de imágenes, cualidades de los sentidos que nos ponen en conexión con el cosmos y no se alcanza muy bien a determinar qué conexiones se establecen entre los propios sentimientos y el universo. ${ }^{1064}$

Por otra parte, Kant habla de "una función anímica ciega", pero indispensable, sin la cual no tendríamos conocimiento alguno, y de la cual, sin embargo, raras veces somos conscientes. ${ }^{1065} \mathrm{Y}$ continúa afirmando que "una regla lógica exige que reduzcamos lo más posible esa aparente diversidad descubriendo, por comparación, la identidad oculta y que examinemos si la imaginación, asociada a la conciencia, no equivaldría al recuerdo, al ingenio, al discernimiento o acaso incluso al entendimiento y a la razón. Aunque la lógica no pueda comprobar si existe una facultad básica, esta idea constituye al menos el problema de una representación sistemática de la diversidad de facultades". 1066

En el pensamiento de Kant, el ser humano se halla inmerso, pues, en una realidad que solo puede aproximarse a conocer mediante verdades aparentes o, lo que él

\footnotetext{
${ }^{1060}$ Cfr. TAYLOR, Ch., Fuentes del yo, pág. 441.

1061 Cfr. Ibid., pág. 551.

1062 Cfr. Ibid., pág. 606.

1063 Cfr. Ibid., pág. 607.

${ }^{1064}$ Cfr. LEIBNIZ, G., Nuevos Ensayos sobre el entendimiento humano, pág. 148.

1065 Cfr. KANT, I., Crítica de la Razón Pura, A78-B103.

1066 KANT, I., Crítica de la Razón Pura, A 549-B677.
} 
denomina, mediante una lógica ilusoria, tal y como el propio Kant afirma: "Se comprueba que el uso trascendental de la razón no posee validez objetiva y que, consiguientemente, no pertenece a la lógica de la verdad, es decir, a la analítica, sino que, como lógica de la ilusión, requiere una parte especial del edificio escolástico bajo el nombre de dialéctica trascendental". ${ }^{1067}$ Kant va a sostener que la razón es capaz de postular ciertos conceptos que rebasan el mundo de los fenómenos, reconociendo la imposibilidad de la mente humana de alcanzar conclusiones propias a tales cuestiones. Por eso, los argumentos dialécticos se expresan en paralogismos, antinomias, y no pasan de ser demostraciones negativas, contradictorias, o que se contradicen. Con lo cual, para Kant, el ser humano está facultado a ordenar el mundo, las cosas que lo rodean, de un modo incompleto, y que la realidad lo lleva a buscar respuestas a preguntas que finalmente puede, mediante la razón, avanzar en sus pretensiones de respuesta, no de modo constitutivo, sino solo de un modo regulativo. ${ }^{1068}$

Por otra parte, Taylor afirma que, a partir de La crítica de la razón práctica, se puede hablar de una "motivación interna" del deber que es la corona de la vida moral. ${ }^{1069}$ El imperativo moral que nos obliga incondicionalmente y se desarrolla en la libertad moral. Pero, al mismo tiempo, dicha libertad, según Taylor refiere, está condicionada por "deseos e inclinaciones" debido a que depende de la naturaleza. Con lo que existe una lucha moral constante que Kant, según Taylor, no logra resolver. ${ }^{1070}$ Kant se refiere, pues, al mundo de lo inconsciente que condiciona el imperativo categórico.

Dando un paso más en relación al concepto de lo inconsciente nos encontramos con un autor al que Taylor estudia: Schelling. Un autor que desde la filosofía trascendental habla de lo objetivo y lo subjetivo, de la naturaleza y el yo o inteligencia. Y afirma que en el saber se realiza la síntesis entre lo objetivo y lo subjetivo en tanto que conozco, pues en el conocer hay un "yo" que representa lo representable, siendo así el saber el lugar donde lo objetivo y lo subjetivo se encuentran.

El empoderamiento del yo y esa impermeabilización del mismo le permite acceder a la naturaleza para recrearla a través de la obra de arte, de tal manera que la obra de arte, realizada en el ejercicio de la libertad, le permite crear naturaleza, la obra de arte deviene en naturaleza. Schelling considera la obra de arte en relación con la naturaleza, dado que la naturaleza, para los románticos, como Hegel y Schelling, se sitúa como a medio camino, ya que, por un lado, la naturaleza expresa el orden cósmico que encarna ideas, y, por otro lado, ven el cosmos como algo incompleto hasta que no encuentre su expresión en un "medio humanamente sostenido como la religión, el arte o la

\footnotetext{
${ }^{1067}$ KANT, I., Crítica de la Razón Pura, A 131-B170.

1068 Cfr. MOLINA URETA, J., "Filosofía del inconsciente”, Liberabit, No 13, (2007), pág. 59.

${ }^{1069}$ Cfr. TAYLOR, Hegel, pág. 27.

${ }^{1070}$ Ibid., pág. 28.
} 
filosofía". ${ }^{1071}$ Para Taylor, todo esto tiene que ver con las facultades de autodefinición expresiva, especialmente la imaginación artística: en el joven Schelling, el acceso al orden de la naturaleza sufre un giro subjetivista y nuestro acceso a él potencia dichas facultades de la imaginación. ${ }^{1072}$

En este sentido, Taylor asegura que el artista no imita la naturaleza como natura naturata, sino que está más bien formando naturaleza como natura naturans. ${ }^{1073} \mathrm{El}$ producto (la obra de arte), tiene que ser producido desde la libertad autoconsciente y, al mismo tiempo, tiene en común con el producto natural (la naturaleza), que es producido inconscientemente. En la libertad de la obra de arte, y como arte consciente, se realiza lo inverso a la inconsciencia objetiva presente en la naturaleza (producto natural orgánico). ${ }^{1074} \mathrm{La}$ actividad inconsciente que se realiza en la obra de arte se expresa como consciente a partir de la "autoconsciencia" inherente al ser humano. Y a la inversa, la consciencia de la obra de arte, en el ejercicio de la libertad humana, se expresará en la inconsciencia, en lo que tiene en común con la naturaleza. Es decir, que en la obra de arte se conjugan admirablemente la consciencia de la libertad humana con la inconsciencia de la naturaleza orgánica. La consciencia del yo se expresa en la producción y la inconsciencia en el producto. ${ }^{1075}$

A partir de ahora, el designio o la idea o el orden natural solo se define plenamente a partir de su encarnación, no como encarnación de ideas o designios divinos. La idea se interpreta a partir de su forma de expresión artística. El hombre se convierte, en cierto sentido, en mayordomo de la naturaleza, en el único ser capaz de entender esto y expresarlo, como resume Taylor. ${ }^{1076}$ Producir la epifanía, para Schelling, es mostrar qué es lo que se encarna en la realidad, qué orden subyace al mundo que nos

1071 TAYLOR, Ch., Argumentos filosóficos, pág. 162. "La intuición postulada debe conjuntar lo que existe dividido en el fenómeno de la libertad y en la intuición del producto natural, es decir, la identidad de lo consciente e inconsciente en el yo y la consciencia de esa identidad. El producto de esta intuición limitará al producto natural, por una parte, y al producto de la libertad, por otra, teniendo que reunir los caracteres de ambos”. SCHELLING, F., Sistema del Idealismo Trascendental, Gredos, Madrid, 2018, pág. 127.

1072 Cfr. TAYLOR, Ch., Fuentes del yo, pág. 568.

${ }^{1073}$ Cfr. Ibid., pág. 626.

${ }^{1074}$ Cfr. TAYLOR, Ch., Hegel, pág. 36. Para Schelling la naturaleza es el producto inconsciente de la subjetividad.

${ }^{1075}$ Cfr. SCHELling, F., Sistema del Idealismo Trascendental, pág. 127. "El espíritu cósmico que se desarrolla en la naturaleza está empujado a completarse a sí mismo en el auto-conocimiento consciente, y el lugar de la autoconciencia es la mente del hombre". TAYLOR, Ch., Hegel, pág. 38. "Desde la perspectiva de la filosofía trascendental no se resuelve en un hallar la correspondencia entre el yo-soy y el hay-cosas-fuera-de-mi. Establece Schelling que el objetivar es hacer consciente aquello de lo que no se tenía consciencia (podría ser un "caer en la cuenta"), es decir, incorporar en mi subjetividad aquello que establezco objetivamente ¿Cómo opera el paso de lo no consciente a mi consciencia? Schelling responde, mediante un acto libre que pertenece al ámbito de la intuición, ya que lo que objetivamos, algo que sucede en una acción libre, justamente se da en el ejercicio de una libertad que no está sujeta al proceso mismo del objetivar; según Schelling, el hecho de que esa acción libre es independiente, se constituye en fenómeno intuitivo, no derivado o demostrado". MOLINA URETA, J., Filosofía del inconsciente, págs. 59-60.

${ }^{1076}$ Cfr. TAYLOR, Ch., Fuentes del yo, pág. 504. 
rodea. Nuestro acceso subjetivo al orden de la naturaleza potencia nuestras capacidades de autodefinición expresiva, la imaginación artística. La obra artística es una epifanía del ser. ${ }^{1077}$

En este sentido, para Taylor, con Schelling se introduce el subjetivismo en la visión de la naturaleza. Una ruta de acceso al orden inherente de la naturaleza es el impulso interior o las insinuaciones del espíritu dentro de nosotros. ${ }^{1078}$ Para Schelling, la naturaleza es el producto inconsciente de la subjetividad. ${ }^{1079}$ La naturaleza está relacionada con la noción de resonancia en el sujeto. ${ }^{1080}$

Para Taylor, en Schelling, como en Hegel, el espíritu de la naturaleza gana conciencia en el hombre. Hay un vínculo entre el espíritu de la naturaleza y el alma humana. La realidad espiritual que emana del orden del mundo también está dentro de nosotros. Todo crece y se configura a sí mismo desde dentro. ${ }^{1081}$ Para Schelling, a partir de la autoconsciencia, tiene lugar el impulso creativo de la imaginación. En este sentido, el saber trascendental, para Schelling, reconoce que las cosas externas son "un prejuicio natural": por una parte, está la necesidad de "elevarse para buscar sus fundamentos" y, por otra parte, la necesidad de "separar para demostrar" la conexión entre "yo soy" y "hay cosas fuera de mí". Para el saber trascendental de Schelling no es el saber mismo el que desaparece tras el objeto, como en el saber común, sino que es el objeto como tal el que desaparece tras el acto del saber. Lo que realmente le interesa al saber trascendental es el saber del saber en tanto que es subjetivamente puro. Este saber del saber introduce así al hombre en un yo cada vez más "encerrado" en su propia identidad que sabe (autoconsciencia), y que no solo abandona el objeto para centrarse en el saber mismo, sino que va más allá, hacia la comprensión del saber sobre el saber. Un saber que adquiere tonos de "autoconsciencia inconsciente", al contrario de lo que ocurría en la obra de arte en la que se daba una "inconsciencia consciente". En el saber trascendental domina el saber sobre el saber, se eleva al concepto del concepto, a un continuo autobjetivarse de lo subjetivo. ${ }^{1082}$

La pregunta por un "más allá" de nuestro primer saber no tiene sentido y no se pregunta por ella. En Schelling, lo importante es este primer saber, al que denomina autoconsciencia. Más allá de este saber no se pregunta el filósofo trascendental. Un primer saber que se centra en "lo subjetivo del saber", en el saber sobre el saber, en la autoconsciencia. Un saber para nosotros, la autoconsciencia. Una autoconsciencia que no nos refiere a "algo explicable", desde lo que no podemos saber nada. ${ }^{1083}$ Schelling

${ }^{1077}$ Cfr. Ibid., págs. 568,646.

${ }^{1078}$ Cfr. Ibid., pág. 582.

${ }^{1079}$ Cfr. TAYLOR, Ch., Hegel, pág. 36.

${ }^{1080}$ Cfr. TAYLOR, Ch., Fuentes del yo, pág. 414.

${ }^{1081}$ Cfr. Ibid., pág. 626.

${ }^{1082}$ Cfr. SCHELLING, F., Sistema del Idealismo Trascendental, pág. 13.

1083 "Precisamente porque mediante la autoconsciencia se realiza ante todo la síntesis total de nuestro 
considera que la autoconsciencia no nos remite a un saber ontológico sobre el ser, sino a un saber que no puede ir más allá del propio saber, "limitándose" al saber. Se trata de una clase de saber, "el último" que existe para nosotros.

El yo de Schelling es un yo autoconsciente, que sabe que sabe, solo en la medida que sabe sobre sí mismo o, lo que es lo mismo, el saber sobre el saber le lleva al saber sobre sí mismo. Preguntarse por un saber fuera de dicho saber no interesa, ya que el yo está impermeabilizado en su propio saber y todo lo que esté fuera de dicho saber autoconsciente no es relevante, ya que solo quiere fundamentar su saber en el saber en sí mismo que se hace autoconsciente. Se trata de una autoconsciencia que se cierra a cualquier fundamentación que pueda estar fuera, dado que el fundamento, si existe, y que necesariamente tiene que residir fuera del saber, no le lleva a indagar en ello, puesto que lo único que le interesa es la autoconsciencia en el saber en sí mismo.

De lo afirmado anteriormente, se puede

\begin{abstract}
“comprender qué y por qué la filosofía como tal no puede ser nunca universalmente válida. El arte es lo único en lo que está dada la objetividad absoluta. Se podría decir: retira del arte la objetividad y entonces deja de ser lo que es y se convierte en filosofía. Dale a la filosofía la objetividad, y entonces deja de ser filosofía para convertirse en arte. La filosofía alcanza ciertamente lo supremo, pero eleva a este punto solo un fragmento del hombre, por así decirlo. El arte eleva al hombre entero tal y como es al conocimiento de lo supremo, y sobre esto reposa la diferencia eterna y el milagro del arte". 1084
\end{abstract}

En conclusión, Schelling, para afirmar la subjetividad que capta el orden de la naturaleza y pone en sintonía con él, ya sea una deidad o un espíritu cósmico, configura la afirmación del yo autoconsciente, sin el cual la subjetividad no podría ser asumida como tal y sin el cual no podría realizarse la capacidad imaginativa de la libertad creadora. "El punto de partida y el fundamento originario del sistema del idealismo trascendental era la intuición intelectual, la autoconsciencia, lo sabido que se sabe, la identidad entre lo subjetivo y lo objetivo. La obra de arte nos ofrece eso mismo, pero nos lo ofrece separando primero lo subjetivo y haciéndolo luego objetivo. Así el sistema acaba con lo que había comenzado: la identidad entre lo subjetivo y lo objetivo". 1085

En esta misma línea, según Taylor, para quienes han retenido el sentido del impulso interno de la naturaleza, su significado ha comenzado a cambiar. Y eso sucede en parte debido a los avances de la ciencia, y en parte también debido a que el orden providencial deviene cada vez más pulcro, transparente y accesible a nuestra experiencia. Se deja de percibir ese gran torrente de vida y fuerza de la naturaleza de la

saber, no nos afecta como filósofos trascendentales; pues la autoconsciencia no es una clase de ser, sino una clase de saber, y en verdad el supremo y último que existe en general para nosotros”. Ibid., pág. 23.

${ }^{1084}$ Ibid., pág. 141.

1085 GABÁS, R., "Estudio Introductorio", pág. LV, en SCHELLING, F., Sistema del Idealismo Trascendental, Gredos, Madrid, 2018. 
que formamos parte como orden providencial del ser y algo abarcable, y se pasa a considerar como algo inmenso, ajeno y amoral. Este giro encuentra su expresión en la filosofía de Schopenhauer. ${ }^{1086}$

En su obra magna El mundo como Voluntad y Representación, Schopenhauer reivindica el papel de la representación mental y de la voluntad como ejes fundamentales de su filosofía. ${ }^{1087}$ Frente al sujeto como "portador del mundo" y al papel de la razón que explica el mundo y las cosas desde la representación intuitiva de la espacialidad, la temporalidad y la causalidad, hay otro ámbito, el de la voluntad, que "escapa" al control de la razón, y que no tiene que ver con los principios de la racionalidad.

Es el sujeto el que establece el mundo como representación, de tal manera que sin él no existiría. Tanto el mundo como el sujeto son inseparables, aunque se limitan hasta donde llega cada uno de ellos. ${ }^{1088}$ Para Schopenhauer, hay formas esenciales y universales de todo objeto (espacio, tiempo y causalidad) y que pueden ser captadas independientemente por el sujeto, al margen del objeto, ya que son "formas a priori". Luego, no todo el mundo fenoménico depende del objeto, sino que hay realidades de esencialidad y universalidad que pueden ser captadas a priori por el sujeto. Según Taylor, en Schopenhauer se realiza una estrecha alianza de deseo y razón, de libertad y naturaleza que encanta a nuestra experiencia vital. ${ }^{1089}$

Para Schopenhauer, el mundo es representación y solo existe en relación al ser que es capaz de representación. El sujeto "porta el mundo" porque sin el sujeto no hay representación del mundo, e indirectamente, no hay mundo, pues el mundo solo es representación y existe en relación al ser que lo representa o lo lleva representacionalmente. Según el pensamiento de Schopenhauer, hay una representación abstracta de conceptos (el ámbito de la razón), y una representación intuitiva (intuición

\footnotetext{
${ }^{1086}$ Cfr. TAYLOR, Ch., Fuentes del yo, pág. 569.

1087 "En mi sistema, en cambio, la materia y el intelecto son correlatos inseparables, existen solamente el uno para el otro, por lo tanto, de forma relativa: la materia es la representación del intelecto; el intelecto es aquello en cuya sola representación existe la materia. Ambos unidos constituyen el mundo como representación, el cual es precisamente el fenómeno de Kant, por lo tanto, algo secundario. Lo primario es lo que se manifiesta, la cosa en sí misma, y como tal llegaremos después a conocer la voluntad. Esta no es en sí ni representante ni representada, sino completamente distinta de su forma fenoménica". SCHOPENHAUER, A., El mundo como voluntad y representación, tII, Trotta, Madrid, 2013, pág. 45.

1088 "Son, por tanto, inseparables, incluso para el pensamiento, pues cada una de ellas tiene significado y existencia solo por y para la otra, y con ella existe y desaparece. Ellas se limitan mutuamente: donde comienza el objeto termina el sujeto. El carácter común de este límite se muestra precisamente en que las formas esenciales y, por ende, universales, de todo objeto, que son tiempo, espacio y causalidad, pueden ser halladas y totalmente conocidas partiendo del sujeto, aun sin conocimiento del objeto mismo, es decir, empleando el lenguaje de Kant: se encuentran a priori en nuestra conciencia”. Ibid., pág. 30.

${ }^{1089}$ Cfr. TAYLOR, Ch., Fuentes del yo, pág. 602.
} 
inmediata de formas a priori de las leyes de la espacialidad, temporalidad y causalidad) al margen del objeto. ${ }^{1090}$

Para Schopenhauer, es la intuición, entendida como "entendimiento puro, inmediato, necesario y seguro", la que determina a la experiencia, ya que esta solo puede ser entendida desde dicha intuición inmediata. ${ }^{1091}$ Hay una representación intuitiva del mundo que configura la experiencia, la determina y la piensa. ${ }^{1092} \mathrm{La}$ intuición conoce inteligiblemente la experiencia: no es la experiencia la que determina la intuición, sino que es la intuición, entendida como entendimiento inmediato, la que comprende el alcance de la experiencia. Existe una determinación intelectual de la experiencia a partir de la intuición pura e inmediata. Es la intuición la que capta la experiencia temporal, espacial y causal, no es la experiencia la que determina la intuición. ${ }^{1093}$

En Schopenhauer hay un cierto escepticismo en relación a la ciencia de su tiempo, que creía encontrar las respuestas a los orígenes de las leyes naturales, cuando no podemos olvidarnos de que "el mundo es inteligible al entendimiento". ${ }^{1094}$ No todo el mundo de los objetos puede ser descrito con "completa objetividad científica", ya que hay una "idealidad trascendental" en la comprensión del mundo que va asociada al sujeto: el mundo es representación transcendental y en ese sentido depende del sujeto y el sujeto "porta" el mundo, lo determina y lo trasciende.

Schopenhauer piensa que, frente a los filósofos inauténticos que "parten de un libro con un sistema ya existente", los filósofos auténticos "expresan perplejidad a partir del propio espectáculo del mundo". Y en esta perplejidad, los filósofos auténticos comprenden que la esencia del mundo está no en la veritas aeterna, sino en los fenómenos, como algo que aparece ante el sujeto y para el sujeto, y no cosa en sí. ${ }^{1095} \mathrm{El}$

\footnotetext{
1090 "Esta intuición no sea un fantasma surgido de la repetición de la experiencia, sino algo tan independiente de esta que, por el contrario, es más bien la experiencia la que debe ser pensada como dependiente de la intuición”. SCHOPENHAUER, A., El mundo como voluntad y representación, pág. 31. ${ }^{1091}$ Cfr. Ibid., pág. 36.

1092 "Toda intuición no es meramente sensorial, sino intelectual, esto es, puro conocimiento por el entendimiento de la causa a partir del efecto; en consecuencia, presupone la ley de causalidad, de cuyo conocimiento depende toda intuición, y, por lo tanto, toda experiencia en su primera y entera posibilidad, y no a la inversa, que el conocimiento de la ley de causalidad dependa de la experiencia”. Ibid., pág. 37.

1093 "Toda la realidad y sus componentes, que se nos manifiesta de modo fenoménico, pueden ser descritos por nosotros, explicados de acuerdo a su aparición y en relación a cómo aparecen, explicados igualmente por las leyes de que disponemos para el estudio de los fenómenos (...); sin embargo, no llegamos a explicar la razón que supone su aparición. Podemos, por ejemplo, describir y llegar a determinar explicaciones causales del magnetismo, lo que no podemos explicar es lo que es magnetismo". MOLINA URETA, J., Filosofía del inconsciente, pág. 60.

1094 “Todo el mundo de los objetos es ni más ni menos que representación, y precisamente por ello, está condicionado absoluta y eternamente por el sujeto; esto es: tiene idealidad trascendental. El mundo es, como tal, incluso en su significación más interna, inteligible al sano entendimiento, y habla a este en un lenguaje completamente claro". SCHOPENHAUER, A., El mundo como voluntad y representación, págs. 39-40.

1095 “La esencia íntima del mundo, la cosa en sí, no podrá nunca encontrarse con la guía de este principio
} 
fundamento del mundo, el principio de razón, no está en verdades eternas, inmutables, fuera y por encima del mundo, expresado de manera incondicional, sino que el mundo es el mundo de los fenómenos y dicho principio de razón tiene una validez relativa y referida únicamente al fenómeno como ley de la razón del conocimiento. ${ }^{1096}$

Schopenhauer no parte del objeto, como el materialismo, que pone la materia como absolutamente existente al margen de su relación con el sujeto; ni del sujeto, como Fichte, que justifica todo en el sujeto como un "yo" principio del mundo, sino que parte de la representación como primer hecho de la conciencia, ${ }^{1097}$ acercándonos al concepto de razón suficiente. ${ }^{1098}$ En el principio de razón suficiente, todas las representaciones están entrelazadas, interrelacionadas de forma regular y a priori, porque todos los objetos que existen representacionalmente en el sujeto están así, determinados por dicho "enlace" que podríamos definir como ontológico.

Pero el mundo no es solo representación del objeto por parte del sujeto, sino también voluntad entendida como "objetidad", en el sentido de que voluntad y corporalidad son una misma cosa. ${ }^{1099} \mathrm{El}$ cuerpo puede ser visto como un objeto más de representación, pero, al mismo tiempo, como lo inmediatamente conocido, como "lo que es en sí”. El cuerpo que, en el volumen I, libro primero de su obra, El mundo como voluntad y representación, y en el tratado De la Cuádruple raíz del principio de la razón suficiente, es visto como el objeto inmediato, ahora en el libro segundo, se percibe como "la objetidad de la voluntad". ${ }^{1100}$ Luego el cuerpo y la voluntad son uno y

(veritas aeterna), sino que todo aquello a lo que él conduce es siempre a su vez dependiente y relativo, siempre solo fenómeno (algo que aparece ante el sujeto y para el sujeto) y no cosa en sí; que, además, el principio de razón no concierne de ningún modo al sujeto, sino que es solo la forma de los objetos, los cuales no son, precisamente por eso, cosas en sí y que, con el objeto, existe inmediatamente el sujeto y, con este, aquel. Por tanto, ni el objeto puede agregarse al sujeto, ni este a aquel como la consecuencia a su fundamento". Ibid., pág. 59.

${ }^{1096}$ Cfr., Id. pág. 59.

1097 “Así el tiempo no es más que la razón del ser en él mismo, es decir, sucesión; el espacio no es otra cosa que el principio de razón en él mismo, es decir, situación; la materia no es sino causalidad; el concepto no es nada más que la relación con la razón del conocimiento" (la cursiva es nuestra). SCHOPENHAUER, A., El mundo como voluntad y representación, págs. 60-61.

1098 "Nuestra conciencia cognoscitiva, manifestándose como sensibilidad exterior o interior (receptividad), entendimiento y razón, se escinde en sujeto y objeto, y fuera de esto no contiene nada. Ser objeto para el sujeto, y ser nuestra representación, es lo mismo. Todas nuestras representaciones son objetos del sujeto, y todos los objetos del sujeto son nuestras representaciones. Ahora bien, sucede que todas nuestras representaciones están relacionadas unas con otras en un enlace regular y determinable a priori en lo que se refiere a la forma, en virtud del cual nada de existente por sí e independiente, y tampoco nada de singular ni de separado, puede hacerse objeto para nosotros". SCHOPENHAUER, A., De la Cuádruple Raíz del Principio de Razón suficiente, Gredos, Madrid, 1998, pág. 56.

${ }^{1099}$ Cfr. TAYLOR, Ch., Hegel, pág. 491.

1100 “Al sujeto del conocimiento, que por su identidad con el cuerpo aparece como individuo, ese cuerpo le es dado de dos formas completamente distintas: una vez como representación en la intuición del entendimiento, como objeto entre objetos y sometido a las leyes de estos; pero a la vez, de una forma totalmente diferente, a saber, como lo inmediatamente conocido para cada cual y designado por la palabra voluntad. Todo verdadero acto de su voluntad es también inmediata e indefectiblemente un movimiento de su cuerpo: no puede querer realmente el acto sin percibir al mismo tiempo su aparición como movimiento del cuerpo". SCHOPENHAUER, A., El mundo como voluntad y representación, pág. 133. 
lo mismo, es decir, que no siguen la ley de la causalidad, sino que son "dos maneras completamente distintas de lo mismo", es decir, la voluntad como lo enteramente inmediato y el cuerpo como lo intuido para el entendimiento. ${ }^{1101}$ Para Schopenhauer, la intuición inmediata de la voluntad y la "objetidad" de la misma a través de la corporalidad expresada en acto son una sola cosa. ${ }^{1102}$ No hay causalidad, sino que es la misma cosa, una y lo mismo: la voluntad como conocimiento a priori del cuerpo, intuición inmediata, y el cuerpo como conocimiento a posteriori de la voluntad, pero entendidas como una y lo mismo; esto es, algo que se produce a la vez, como una sola cosa, aunque en la reflexión in abstracto se puedan diferenciar, querer y hacer. ${ }^{1103}$ Para Schopenhauer, la voluntad se "corporaliza" en una experiencia empírica, tiene un carácter experiencial, que se manifiesta en un lugar, en un tiempo y en circunstancias determinadas. ${ }^{1104}$ Es el mundo como voluntad y representación schopenhaueriano, ${ }^{1105}$ siendo la voluntad la cosa en sí, y la representación todo lo fenoménico. ${ }^{1106}$

Es decir que, frente al carácter fenoménico del objeto representacional, la voluntad es una fuerza ciega, instintiva, ¿inconsciente?, cosa en sí, en expresión kantiana, que no depende de la representación del sujeto. Se trata de una representación que es objeto y que, por lo tanto, no pierde su carácter de "cosa en sí", es decir, lo que puede definirse como "objetidad" en sí, no como "representación de un objeto". Si la representación del mundo hace que el objeto sea solo representación ideal, en el caso de la voluntad se trata de "objetidad", al ser la única "cosa en sî́ que puede ser

\footnotetext{
${ }^{1101}$ Id., pág. 133.

1102 "La base óntica de la expresión es la voluntad y esta ya no es considerada como la fuente del ser y de la bondad, sino como la fuente interminable de esfuerzo desordenado y de sufrimiento". TAYLOR, Ch., Argumentos filosóficos, pág. 163.

1103 "Conozco mi voluntad no en su totalidad, no como unidad, no perfectamente en su esencia, sino que la conozco solo en sus actos particulares, por tanto, en el tiempo, que es la forma del fenómeno de mi cuerpo, como de cualquier otro objeto. Por eso es el cuerpo condición del conocimiento de mi voluntad. En consecuencia, no puede representarme propiamente esta voluntad sin mi cuerpo". SCHOPENHAUER, A., El mundo como voluntad y representación, pág. 135.

1104 "Si cada acción de mi cuerpo es el fenómeno de un acto de voluntad en el que, con unos motivos dados, mi misma voluntad en general y en su totalidad, por mi carácter, se expresa de nuevo, entonces también la condición y el presupuesto indispensables de esa acción ha de ser un fenómeno de la voluntad, (la cursiva es nuestra) pues su aparecer no puede depender de algo que no fuera inmediata y exclusivamente por ella, de algo que por tanto sería para ella”. Ibid., pág. 141.

1105 "El carácter de cada hombre en particular, en tanto es completamente individual y no está comprendido en la especie, puede ser considerado como una idea especial, correspondiente a una objetivación característica de la voluntad. Este acto sería entonces su carácter inteligible, y su carácter empírico el fenómeno del mismo. El carácter empírico está fundamentalmente determinado por el inteligible, que es voluntad, voluntad sin razón, o sea, no subordinada como cosa en sí al principio de razón (la forma del fenómeno)”. MOLINA URETA, J., Filosofía del inconsciente, pág. 60.

1106 "Fenómeno significa representación, y nada más: toda representación, sea del tipo que sea, todo objeto, es fenómeno. Cosa en sí lo es únicamente la voluntad; como tal, ella no es en modo alguno representación, sino algo toto genere distinto: es aquello de lo cual toda representación, todo objeto, es fenómeno, visibilidad, objetidad. Ella es lo más interno, el núcleo de todo ser particular e igualmente de la totalidad; aparece en cada fuerza ciega de la naturaleza, y también en el actuar reflexivo del hombre". SCHOPENHAUER, A., El mundo como voluntad y representación, pág. 144.
} 
caracterizada en su "objetidad", que puede afirmar su carácter de "objeto en sî", no por representación, sino por su objetidad misma.

En este sentido, según Taylor, la visión de Schopenhauer ofrece una perspectiva pesimista de la libertad humana, debido a que la naturaleza instintiva del hombre es distinta e incombinable con la libertad racional y, al mismo tiempo, inconquistable. ${ }^{1107}$ Para nuestro hermeneuta canadiense, es esa difícil sintonía entre razón y voluntad lo que en el fondo hace que nos sintamos desafinados y depravados, y a atribuir a esta falta de sintonía la verdadera naturaleza de las cosas. Este es el camino más plausible y liberador, la sensación de la propia inadecuación. ${ }^{108}$ Es el pesimismo schopenhaueriano que expresa esa incapacidad para aunar razón y deseo, y frente a la cual, solo cabe la liberación a través del "escape del yo y la voluntad". Un escape que motiva la transfiguración de lo real a través del arte, que no solo es reposo para un yo torturado en su camino hacia la liberación plena, sino el fin y propósito de las cosas. La transfiguración schopehaueriana es lo que hace que todo sea grande, que recobre sentido el mundo. A través de la fuerza creativa de la imaginación, la voluntad es transformada en belleza, y la realidad es transfigurada. ${ }^{1109}$

En este sentido, según Taylor, para Schopenhauer la naturaleza es ese gran depósito de fuerza amoral, con el que no debemos perder el contacto. Es lo que Taylor denomina como la hondura interior del ser humano que permite fundamentar un renovado sentido de nuestro vínculo con el todo de la naturaleza, pero como gran depósito del desenfrenado poder en que se sustenta nuestra vida mental. A este respecto, Taylor considera que Schopenhauer anticipó las doctrinas freudianas de la determinación inconsciente del pensar y el sentir. La voluntad schopenhaueriana es el antepasado directo del ello freudiano. Pero, en lugar de adoptar la postura comprometida en un intento de renovar el contacto, Freud adopta una postura cartesiana hacia ese mundo interior. ${ }^{110}$

\section{III.2.2.7.2. El inconsciente hereditario. Darwin}

Según Taylor, el siglo XVIII presencia los albores del sentido real del tiempo geológico, o sea, no solo de la inmensa escala del tiempo en el que ha evolucionado el universo, sino también de los cambios cataclísmicos que han llenado esos eones. Dicho cambio respondía en parte al descubrimiento que conduciría a la formulación y aceptación general de la teoría de Darwin. ${ }^{111}$ Una teoría que es entendida como una

\footnotetext{
${ }^{1107}$ Cfr. TAYLOR, Ch., Hegel, pág. 491.

${ }^{1108}$ Cfr. TAYLOR, Ch., Fuentes del yo, pág. 602.

${ }^{1109}$ Cfr. Ibid., págs. 603-604.

${ }^{1110}$ Cfr. Ibid., págs. 605-606,621.

${ }^{1111}$ Cfr. Ibid., pág. 478.
} 
evolución, en la que la ontogénesis reproduce la filogénesis; esto es, nos remite a un cambio en la evolución de las especies.

Para Taylor, Darwin demuestra que era posible un designio sin Diseñador. ${ }^{112}$ Taylor considera que Darwin abre una gran grieta en el deísmo, según el cual, era imposible dudar de la existencia de un ser superior a la materia y creador de la misma. A partir de Darwin se pasa del solo Diseñador del principio (Deísmo) a un diseño sin Diseñador, aunque con las puertas abiertas a ser admitido como "afirmación que no contradice" la afirmación evolucionista.

Cuando en el siglo XVIII aparece el factor tiempo en el estudio de los seres vivos, se empieza a admitir la posibilidad de una evolución o transformación de los organismos y especies. ${ }^{1113}$ Una vez que se introduce el tiempo en el estudio de los seres vivos, se introduce una categoría que abre una posibilidad nueva: hay una génesis, una historia en la evolución del ser humano; así, la teoría del fijismo se ve superado por una nueva teoría: el evolucionismo. Se tenía la certidumbre científica de que había habido especies que habían desaparecido y que otras habían "evolucionado". Los estudios de Georges Cuvier y Jean-Baptiste Lamarcke así lo acreditaban. Con la aparición del libro de Charles Darwin, La evolución de las especies, todo adquiría un color distinto y la controversia entre fijismo y transformismo empezaba a darse con especial virulencia. ${ }^{114}$ Taylor considera que la lucha entre ciencia y teología no había hecho más que comenzar.

Con el avance de los estudios de la geología y la biología, se abría el camino a una explicación de los fenómenos de la vida en clave mecanicista. ${ }^{1115}$ Según Darwin, los animales no tienen capacidad para adaptarse al medio ambiente, sino que se produce una "lucha por la vida" en competencia con los demás seres vivos, donde cada uno vive merced a una lucha en algún período de sus vidas. ${ }^{116}$ La teoría de la selección natural de las especies de Darwin asegura la supervivencia del más apto y, por una especie de "anomalía" asociada a las variaciones útiles o a ligeras diferencias de estructura o constitución, hará que la balanza en la lucha por la existencia se incline por un lado o por el otro. Es el propio ritmo de la naturaleza el que va asegurando una multiplicidad de variaciones, rechazando las que son malas, y conservando y sumando las que son buenas; trabajando silenciosa e insensiblemente "cuando quiera y donde quiera que se

\footnotetext{
1112 Cfr. Ibid., pág. 551.

1113 Cfr. JOSA I LLORCA, J., Introducción, en El origen de las especies, Austral, Madrid, 2017, pág. 15.

1114 "La aceptación de la evolución tuvo un gran impacto positivo en diversas ciencias biológicas a un nivel que podemos llamar "descriptivo", pero al mismo tiempo estimuló la mentalidad de los científicos para encontrar una explicación de este hecho, es decir, para proponer los factores o "mecanismos" que han producido la extinción de determinadas especies, su transformación en otras nuevas y su adaptación al medio ambiente". AGAZZI, E., "Conocimiento científico y fe cristiana", pág. 107.

${ }_{1115}$ Cfr. TAYLOR, Ch., Fuentes del yo, pág. 551.

${ }^{1116}$ Cfr. DARWIN, Ch., El origen de las especies, pág. 126.
} 
ofrece la oportunidad", como afirma Darwin, y que determina una orientación u otra: por una parte, el perfeccionamiento silencioso de cada ser orgánico en relación con sus condiciones orgánicas e inorgánicas de vida, ${ }^{1117} \mathrm{y}$, por otra parte, la lucha por la vida en aquellos individuos caracterizados por las variaciones útiles que aseguren mayores probabilidades de conservación. ${ }^{118}$

Por lo tanto, las condiciones de vida se van modificando lentamente, de tal manera que hay un continuo cambio en el que unas formas de vida se van extinguiendo de manera irremediable, y formas nuevas van apareciendo con mayor vigor y fortaleza a partir de las ya existentes. Para Darwin, la "selección natural o la supervivencia de los más adecuados" no implica necesariamente desarrollo progresivo, sino que ilumina las complejas relaciones de la vida. ${ }^{1119}$ Luego una cosa es la selección natural y otra cosa es el "desarrollo progresivo" de formas más simples a más complejas, que no interfiere en la persistencia de formas de vida "inferiores". Pero lo realmente relevante es que para Darwin se produce un proceso irremediable y de evolución en una "cadena" en la que se unen los más elementales organismos con los más evolucionados y complejos. ${ }^{1120}$

Entramos aquí en un debate realmente importante, pues si lo que se produce es un proceso de evolución gradual, estaríamos en unas diferencias de grado, no de cualidad, en el proceso de evolución, desde los primates al ser humano, con lo que el ser humano se diferenciaría de los primates "solo en grado", no en diferencia ontológica. ${ }^{121}$ Esto, lógicamente, crearía conflictos, pero matizado como sería, por el propio Darwin, en la recapitulación y conclusión general, todo adquiere un sentido distinto, y no sería tan simple y sencilla la explicación científica de la "simple evolución" de animales inferiores a animales superiores como una "mera diferenciación biológica de grado" y no de cualidad.

Afirmar que los elementos metafísicos que definen al ser humano, como la inteligencia y la voluntad, tendrían que ver solo con un elemento de "perfeccionamiento biológico y de grado" en la escala de evolución a partir de animales más primitivos, y no a la presencia en el hombre de un principio ontológico como el alma o el espíritu, sería reducir el alcance de lo que estamos intentando explicar y mezclar campos de estudio distintos que se complementan y que para nada pretenden entrar en conflicto, como el propio Darwin sugiere en su obra. A este respecto nos parece relevante el

\footnotetext{
${ }^{1117}$ Cfr. Ibid., pág. 144.

${ }^{1118}$ Cfr. Ibid., pág. 195.

${ }^{1119}$ Cfr. Ibid., pág. 189.

1120 "El resultado final es que todo ser tiende a perfeccionarse más y más, en relación con las condiciones. Este perfeccionamiento conduce inevitablemente al progreso gradual (la cursiva es nuestra) de la organización del mayor número de seres vivientes en todo el mundo". Ibid., pág. 187.

${ }^{1121}$ Lo que Holbach había afirmado en su Sistema de la Naturaleza en relación a que "la naturaleza no tiene formas fijas" y que todo evoluciona es confirmado con la ciencia darwiniana.
} 
análisis de Agazzi al respecto sobre el valor del Todo en su relación con las teorías científicas y su capacidad de valoración ontológica. ${ }^{1122}$

Para Agazzi, si en el siglo XVIII se produjo una "temporalización en la cadena del ser", en el siglo XIX podemos decir que se produce una "historicidad de la naturaleza", en el sentido de que se podría hablar de una creatio continua, esto es, una creación en la que Dios no es solo el "relojero" newtoniano que pone en funcionamiento el mundo y luego "deja" que funcione a partir del respeto a las leyes inscritas por él en la naturaleza. La visión darwiniana abriría esta historicidad de la naturaleza a la posibilidad de un diseño sin Diseñador, pero en el que cabe la posibilidad del mismo, porque "no contradice" el evolucionismo, o este no pretende entrar en conflicto con dicho Organizador. Según Agazzi, la afirmación darwiniana de un mundo sin Diseñador, pero que admite su posibilidad, sería congruente con el hecho de que la naturaleza tuviera su autonomía y estatuto propio en la evolución, entendida como una selección natural, y en el que todo está interrelacionado en una gran cadena que une formas más simples y formas más complejas. Además, sería congruente en cierto sentido con el "azar", ya que se podría explicar racionalmente a partir de la providencia divina, y sería más fácilmente compaginable con la libertad en la naturaleza y con la vida histórica del hombre. En opinión de Agazzi, el azar se estaba produciendo en el marco de un mundo estructurado de un modo muy determinista, de manera que la evolución podía considerarse como el resultado combinado de azar y orden natural. ${ }^{1123}$

La síntesis entre azar y mundo estructurado enriquece la visión de la física mecanicista newtoniana y abre a nuevas posibilidades más congruentes con la ciencia y la razón humana. Por primera vez pueden ser congruentes el azar y el orden, la selección natural (en el que aparentemente todo es azar y en el que los cambios se producen por casualidad y una acción mecánica de factores ambientales sin plan ni diseño ni orden) y el orden inscrito en la naturaleza, que es afirmado de manera contundente por Darwin.

En este sentido, pensamos que Taylor comparte en buena medida las tesis de Agazzi al afirmar que el cientifismo no puede erigirse como única razón concluyente sobre las verdades que necesitamos para creer. Según nuestro hermeneuta, nada asegura la superioridad epistemológica de la ciencia sobre aquellas cuestiones acerca de las que formulamos una creencia. En este momento, el conflicto entre la ciencia y la religión se

\footnotetext{
1122 "En consecuencia, sería un error introducir la categoría de las teorías científicas como factores explicativos de Dios o del espíritu, ya que estos no pueden ser expresados a través de los predicados de las ciencias empíricas, alcanzados a través de los procedimientos de referencia de estas ciencias". AGAZZI, E., "Conocimiento científico y fe cristiana", pág.113.

${ }^{1123}$ Cfr. Ibid., pág. 110.
} 
resuelve en base a una supuesta superioridad moral de la ciencia: "uno no debería creer aquello para lo cual no cuenta con suficiente evidencia". ${ }^{1124}$

El propio Darwin es consciente de las graves objeciones que puede tener su estudio científico, ya que se rompe con una larga tradición en la que han primado la recurrencia a "medios superiores-aunque-análogos a la razón humana". ${ }^{1125}$ Es decir, no cree que haya contradicción al afirmar la analogía entre la ciencia y los medios superiores, entendidos como explicaciones trascendentes al origen del mundo. En cierto sentido se está admitiendo que no todo puede ser explicado a través de muchos estados graduales, o lo que es lo mismo, que la mera gradación evolutiva no puede ser totalmente confirmada por la ciencia, con lo que hay "casos de especial dificultad opuestos a la teoría de la selección natural". ${ }^{1126}$

Darwin afirma que no todo es espontáneo o al azar. ${ }^{1127}$ La variabilidad se expresa en leyes muy complejas. ${ }^{1128} \mathrm{Y}$ dicha variabilidad no se produce solo en el estado doméstico, sino en el natural. ${ }^{1129}$ Además, si cada especie primero existió como variedad, Darwin reconoce la dificultad de trazar una clara línea divisoria entre especies, que se supone que han sido producidas, generalmente, por actos especiales de la creación, y las variedades que se sabe que lo han sido por leyes secundarias, una terminología claramente teológica y escolástica. ${ }^{1130}$

Darwin concluye que, si cada especie primero existió como una variedad, la teoría de que cada especie fue creada independientemente es algo inteligible. Es decir, admite la posibilidad de una creación independiente, de una posibilidad de un Creador si se admite el hecho irrefutable científicamente de que cada especie primero existió como

\footnotetext{
${ }^{1124}$ Cfr. TAYLOR, Ch., Fuentes del yo, pág. 552.

${ }^{1125}$ DARWIN, Ch., El origen de las especies, pág. 599.

${ }^{1126}$ Ibid., pág. 600. Sobre la distribución geográfica, la falta de formaciones geológicas que acrediten la existencia de "formas intermedias" de enlace entre unas variedades y otras... En este sentido, Darwin es muy escéptico respecto a las "pruebas museísticas". "El conjunto de ejemplares de todos los museos es absolutamente nada comparado con las innumerables generaciones de innumerables especies que es seguro que han existido". Ibid., pág. 604. Además, afirma, muchas especies desaparecen directamente sin dejar "descendientes modificados".

${ }^{1127}$ Cfr. TAYLOR, Ch., Hegel, pág. 305. Taylor habla de la "contingencia" de la naturaleza, con lo que es preferible evitar el recurso a las fórmulas. Hay saltos y posibilidades de evolución que difícilmente pueden ser establecidas objetivamente.

1128 "La variabilidad está regida por muchas leyes complejas: por correlación de crecimiento, compensación, aumento del uso y desuso de los órganos y acción definida de las condiciones ambientes (...) Podemos admitir con seguridad que las modificaciones han sido grandes y que pueden heredarse durante largos períodos”. DARWIN, Ch., El origen de las especies, pág. 607.

1129 "En la supervivencia de los individuos y razas favorecidas durante la incesante lucha por la existencia vemos una forma poderosa y constante de selección. La lucha por la existencia resulta inevitablemente de la elevada razón geométrica de propagación, que es común a todos los seres orgánicos”. Ibid., pág. 608.

${ }^{1130}$ Cfr. Ibid., pág. 610.
} 
una variedad, ${ }^{1131}$ es decir, que no ve incompatible la selección natural de las especies con la existencia de un Creador. ${ }^{1132}$

Para Darwin, "la selección natural está siempre pronta a adaptar los descendientes de cada especie que varíen un poco a algún puesto desocupado o mal ocupado en la naturaleza". ${ }^{1133}$ Todo aparece diseñado con unas leyes naturales en las que todo ocupa su lugar, su orden, y todo está determinado para que el azar y la novedad se ubiquen en el orden establecido y adecuado. Hay un azar en el orden, un cambio en el diseño y un cambio en lo determinado. Darwin deja abiertas muchas posibilidades en relación al papel del Diseñador del cosmos. ${ }^{1134}$

Para Taylor, con Darwin aparecen nuevos mundos insospechados, acompañados por la profunda convicción de búsqueda autorresponsable, que se despliega en horizontes nuevos de comprensión de nuestros orígenes. ${ }^{1135}$ Pero una cosa es comprender el origen y otra cosa el ser: no hay que confundir el ser con la génesis del hombre. Tal y como afirma el profesor Alfredo Marcos, el estudio naturalista de las bases físicas y biológicas del ser humano no equivale a la completa naturalización del mismo. ${ }^{1136}$ Es indudable que Darwin ha contribuido a configurar nuevos imaginarios

\footnotetext{
1131 "Por consiguiente, durante un largo proceso de modificación, las pequeñas diferencias características de las variedades de una misma especie tienden a aumentar hasta convertirse en las diferencias mayores características de las especies de un mismo género. Las variedades nuevas o perfeccionadas, inevitablemente suplantarán y exterminarán a las variedades más viejas, menos perfeccionadas e intermedias, y así las especies se convertirán, en gran parte, en cosas definidas y precisas”. Id., pág. 610. 1132 "Según la opinión ordinaria de que cada especie ha sido creada independientemente (...) Si las especies son tan solo variedades bien señaladas, cuyos caracteres se han vuelto muy permanentes, podremos comprender este hecho, pues desde que se separaron del antepasado común han variado ya en ciertos caracteres, por lo que han llegado a ser específicamente distintas unas de otras; por lo cual estos mismos caracteres tienen que ser todavía mucho más propensos a variar que los caracteres genéricos que han sido heredados sin modificación durante un período inmenso". Ibid., pág. 614.

La explicación de Darwin de la selección natural tiene una base científica que puede causar un impacto en aquellos que no tienen la apertura de mente para reconocer que no hay contradicción entre su teoría y los planteamientos científicos que surgen del estudio detallado de la naturaleza y la evolución de las especies en una selección natural y en una larga lucha por la supervivencia y el "perfeccionamiento" en la variedad. Darwin cita a un teólogo reconocido que le ha escrito: "Gradualmente ha ido viendo que es una concepción igualmente noble de la Divinidad creer que Ella ha creado un corto número de formas primitivas capaces de transformarse por sí mismas en otras formas necesarias, como creer que ha necesitado un acto nuevo de creación para llenar los huecos producidos por la acción de sus leyes". Ibid., pág. 622.

${ }_{1133}^{13}$ Ibid., pág. 612.

1134 "Autores eminentísimos parecen estar completamente satisfechos de la hipótesis de que cada especie ha sido creada independientemente. A mi juicio se avienen mejor con lo que conocemos de las leyes fijadas por el Creador a la materia el que la producción y extinción de los habitantes pasados y presentes de la Tierra hayan sido debidas a causas secundarias, como las que determinan el nacimiento y muerte del individuo. Cuando considero todos los seres, no como creaciones especiales, sino como los descendientes directos de un corto número de seres que vivieron mucho antes de que se depositase la primera capa del sistema cámbrico, me parece que se ennoblecen” (la cursiva es nuestra). Ibid., págs. 630-631.

1135 TAYLOR, Ch., Argumentos filosóficos, pág. 26.

1136 "El paso que nos falta no está en la biología de Darwin, sino en la filosofía de Nietzsche. Por eso decía al comienzo que las consecuencias filosóficas del darwinismo son más bien pobres. Se vuelven, eso sí, potentes y apasionantes si al darwinismo le sumamos el nihilismo. Pero no existe una conexión necesaria entre ambos". MARCOS, A., "Naturaleza humana y derechos animales", Hombres y animales:
} 
sociales a partir de contextos a los que no podemos dejar de referirnos a partir de entonces. ${ }^{1137}$ Taylor considera que las concepciones orgánicas y desarrollistas de la biología de Darwin han influido considerablemente en la visión mecanicista del orden moderno. ${ }^{1138}$ Se va imponiendo la idea del orden impersonal de regularidades en el que existen todas las cosas particulares y que engloba todo el espacio y el tiempo, frente al Dios Creador cristiano de carácter personal. ${ }^{1139}$

\section{III.2.2.7.3. El inconsciente psíquico. Freud}

La mirada moderna sobre el yo, desde el punto de vista psicológico, tiene en Freud (1856-1939) al referente más importante. Toda su psicología, basada en el psicoanálisis, pretende fundamentar psicológicamente esa mirada interior sobre el mundo que comienza por el propio yo. Sus trabajos sobre la mente humana pondrán de manifiesto no solo lo propio de la identidad humana, sino también lo que tiene en común con toda otra vida y otros seres. ${ }^{1140}$

Si todo tiene que pasar por "el yo que sospecha de todo", también el estudio del propio yo tiene que pasar por los filtros de una psicología que hace del propio yo la base fundamental de todo. No solo es el yo el que fundamenta cualquier comprensión del mundo, sino que también el propio yo es puesto en cuestión y bajo sospecha. Un yo que nace psicológicamente sobre la base de un autoanálisis y que precisa de una nueva fundamentación. Nada se da por supuesto y todo es susceptible de ser comprendido de una u otra manera. Taylor afirma que Freud, en vez de propugnar una actitud renovada hacia el contacto con la naturaleza, propugna una postura cartesiana hacia el propio mundo interior, fomentando la libertad y la dignidad del sujeto desvinculado, en una actitud de autodominio hacia las profundidades interiores. ${ }^{1141}$ Una naturaleza profunda que puede ser recuperada e interpretada, y que puede ser en parte salvaje y amoral. ${ }^{1142}$

Para Freud, incluso el sentimiento religioso debe ser rastreado en el psiquismo humano como una experiencia mnémica que sigue estando presente desde el sentimiento primitivo yoico. Un sentimiento que permanece como "unas ruinas" de una ciudad psíquica que puede ser explorado en una biografía siempre por descubrir. ${ }^{114}$

¿Qué hemos aprendido de Darwin? Curso de verano de la Universidad de Málaga Ronda, Málaga, (2010), pág. 6.

${ }^{1137}$ Cfr. TAYLOR, Ch., Imaginarios sociales modernos, págs. 214 y ss.

${ }^{1138}$ Cfr. TAYLOR, Ch., Hegel, pág. 473.

${ }^{1139}$ Cfr. TAYLOR, Ch., La Era Secular, tII, pág. 108.

1140 Cfr. Ibid., pág. 87. Cfr. TAYLOR, Ch., La Era Secular, tI, págs. 24,31,57,444,466.

${ }^{1141}$ Cfr. TAYLOR, Ch., Fuentes del yo, pág. 606.

1142 Cfr. TAYLOR, Ch., La Era Secular, tII, pág. 86.

${ }^{1143}$ Este sentimiento religioso para Freud es una realidad ilusoria que persiste en la biografía psíquica del individuo como una "ruina ilusoria" sobre la que es difícil descubrir ninguna otra realidad psíquica que fundamente el yo objetivo del individuo. "En cuanto a las necesidades religiosas, considero irrefutable su derivación del desamparo infantil y de la nostalgia por el padre que aquel suscita, tanto más cuanto que 
Para Freud, este "sentimiento oceánico" no solo se refiere a la imagen ilusoria del padre, que es difícilmente congruente con la naturaleza racional del hombre, sino que además solo tiene sentido como un sentimiento ubicado en los fundamentos del yo infantil. ${ }^{1144}$

Dentro de la gran variedad de posibilidades que analiza en relación con la búsqueda del principio del placer y la evitación del principio del dolor, Freud ubica la religión en un ámbito especialmente problemático y que merece ser analizado porque "queda al margen" o evita la búsqueda de la felicidad o la descontextualiza. ${ }^{1145}$ Taylor considera que el gran proyecto de Freud es una declaración de la inocencia de la naturaleza frente a las calumnias amontonadas sobre ella por la religión y la moral. ${ }^{1146}$

Tradicionalmente la filosofía ha adoptado, según Freud, dos posiciones distintas en relación al inconsciente: o lo han referido al mundo de "lo místico, inaprehensible e indemostrable, cuya relación con lo anímico permanecía en la oscuridad", ${ }^{1147}$ o han identificado lo psíquico con lo consciente, con lo que lo inconsciente no puede ser psíquico.

Freud afirma que los filósofos no han sospechado de la afinidad entre el mundo consciente y el inconsciente ni de las diferencias que existen entre ambos, y anima a la filosofía a adentrarse en el mundo de lo inconsciente, partiendo de lo consciente, y así "descubrir lo inconsciente y seguir sus desarrollos, cosa imposible de conseguir, por lo menos hasta ahora, partiendo del proceso físico". ${ }^{1148}$ Es lo que Taylor denomina el adentramiento en el control racional absoluto sobre las propias emociones y, de este modo, alcanzar la objetivación desvinculada a través del escrutinio científico del propio yo en todas sus dimensiones. ${ }^{1149}$

Para M. Gauchet, el psicoanálisis freudiano es una resultante indirecta de la teoría de la evolución y de los avances en relación con la neurofisiología. ${ }^{1150} \mathrm{Si}$ se parte de la

este sentimiento no se mantiene simplemente desde la infancia, sino que es reanimado sin cesar por la angustia ante la omnipotencia del destino. Me sería imposible indicar ninguna necesidad infantil tan poderosa como la del amparo paterno". FREUD, S., El malestar en la cultura. Disponible en Biblioteca libre Omegalfa, pág. 12.

1144 "El hombre común no puede representarse esta Providencia sino bajo la forma de un padre grandiosamente exaltado, pues solo un padre semejante sería capaz de comprender las necesidades de la criatura humana, conmoverse ante sus ruegos, ser aplacado por las manifestaciones de su arrepentimiento". Ibid., pág. 13.

1145 "A este precio imponiendo por la fuerza al hombre la fijación a un infantilismo psíquico y haciéndolo participar en un delirio colectivo, la religión logra evitar a muchos seres la caída en la neurosis individual. Pero no alcanza nada más. Como ya sabemos, hay muchos caminos que pueden llevar a la felicidad, en la medida en que es accesible al hombre, mas ninguno que permita alcanzarla con seguridad”. Ibid., pág. 26. ${ }^{1146}$ Cfr. TAYLOR, Ch., Fuentes del yo, pág. 638.

${ }^{1147}$ FREUD, S., Esquema del Psicoanálisis, Alianza Editorial, Madrid, 2016, pág. 233.

${ }^{1148}$ Ibid., pág. 234.

${ }^{1149}$ Cfr. TAYLOR, Ch., Fuentes del yo, pág. 77.

1150 “Si se sostiene que el corazón de la operación freudiana consiste en la introducción de la historia en el interior del sujeto individual —el sujeto deviene el producto de su propio devenir, al mismo tiempo bajo el aspecto universal de su estructura y bajo el aspecto singular de sus motivaciones-, entonces es 
introducción del término "inconsciente" por parte de los neurofisiólogos para describir el funcionamiento del espíritu humano (antes de Freud) y se relaciona dicho estudio con las investigaciones de la teoría de la evolución, resulta que las teorías freudianas retoman el término de lo inconsciente y lo refieren a la historia del sujeto individual. Si no se puede describir al sujeto sin su propia historia (universal e individual), tampoco se puede olvidar el alcance de lo que significa el inconsciente dentro de dicha historia. Para M. Gauchet, si la teoría freudiana representó una fractura en la idea del hombre, es también porque es la heredera y la prolongación en el registro de la interioridad de otras dos grandes rupturas en el orden de la objetividad realizadas en el siglo XIX: la teoría de la evolución de las especies y las investigaciones suscitadas en el sistema nervioso. Ambas no terminan de expresar la totalidad de las inspiraciones. ${ }^{1151}$ Taylor considera lo mismo al afirmar que en la explicación mecanicista de los fenómenos de la vida se combinan las nuevas perspectivas del tiempo, la biología, la teoría de la evolución y el impacto de las teorías de Freud. ${ }^{1152}$

Gauchet ha relacionado de manera original y clarividente el psicoanálisis freudiano (en el ámbito de la interioridad) con la evolución de las especies y las investigaciones neurofisiológicas (en el ámbito de la objetividad). Las nuevas investigaciones sobre el sistema nervioso (que se habían iniciado antes de la teoría psicoanalítica) y la nueva ciencia biológica de la evolución de las especies, ${ }^{1153}$ prepararon el camino hacia esa nueva comprensión del alma humana a partir del psicoanálisis. Es lo que Taylor denomina como el camino hacia la ciencia natural de la mente. ${ }^{1154}$ Gauchet afirma que con la nueva ciencia de la mente no se trata solamente de la constatación fundamentada por la fisiología de que una gran parte de la vida mental se desarrolla fuera de la conciencia, desconfigurando su carácter de fuente. Se trata de colocar a la conciencia fuera de juego con respecto a un funcionamiento más amplio y profundo a la vez que ella refracta parcialmente sin conducirlo. ${ }^{1155}$

La vida psíquica, para Freud, tiene relación con el sistema nervioso y con los actos de conciencia que se nos dan de forma inmediata. ${ }^{1156}$ Para Freud, la naturaleza de

\footnotetext{
fundado pensar que se trata aquí de una segunda recaída o de una resultante indirecta de la teoría de la evolución a la que el paralelo ontogénesis/filogénesis sirvió de esquema generador". GAUCHET, M., El inconsciente cerebral, pág. 29.

${ }^{1151}$ Ibid., pág. 30.

1152 Cfr. TAYLOR, Ch., Fuentes del yo, pág. 551.

1153 "De esta historia individual, de su naturaleza, de sus etapas de sus modalidades, la teoría darwiniana no dice nada sustancial o casi nada. Establece en profundidad de alguna manera la posibilidad de pensarla”. GAUCHET, M., El inconsciente cerebral, pág. 29.

${ }^{1154}$ Cfr. TAYLOR, Ch., Fuentes del yo, pág. 607.

1155 "La conciencia es un acompañamiento, un plus. No es una fuente (...) No se trata solamente de la constatación fundamentada por la fisiología de que una gran parte de la vida mental se desarrolla fuera de la conciencia. Se trata de colocar a la conciencia fuera de juego con respecto a un funcionamiento más amplio y profundo a la vez que ella refracta parcialmente sin conducirlo”. GAUCHET, M., El inconsciente cerebral, pág. 49.

${ }^{1156}$ Cfr. FREUD, S., Esquema del Psicoanálisis, pág. 134.
} 
lo psíquico tiene que ver con diversas "provincias" o instancias: el ello, el yo y el superyó. "El ello tiene por contenido todo lo heredado, lo innato, lo constitucionalmente establecido..., los instintos originados en la organización somática". ${ }^{1157}$ El yo, como "una organización especial que (...) oficia como mediadora entre el ello y el mundo exterior". ${ }^{1158} \mathrm{Y}$, finalmente, "como sedimento del largo período infantil durante el cual el ser humano en formación vive en dependencia de sus padres, fórmase en el yo una instancia especial que perpetúa esa influencia parental y a la que se ha dado el nombre de superyó". 1159

El mundo psíquico freudiano establece con total claridad los límites entre el pasado y el presente. El ello y el superyó recogen las influencias del pasado: el ello a partir de la herencia y el superyó a partir de las influencias recibidas. El yo es determinado por las vivencias actuales y accidentales. $\mathrm{Y}$ al mismo tiempo los tres elementos del psiquismo freudiano se interrelacionan en una suerte de entramados en los que hay relaciones determinantes y configuradoras, con lo que a veces es difícil de establecer los límites entre el yo-ello (en relación, por ejemplo, con el instinto del eros), ${ }^{1160}$ y el yo-superyó (en relación, por ejemplo, con el instinto de destrucción). ${ }^{1161}$

Freud, partiendo de la ciencia neurofisiológica, establece la ciencia psicoanalítica en relación con la ciencia biológica de la evolución de las especies. ${ }^{1162}$ El psicoanálisis se establece, para Freud, como una nueva ciencia natural que toma como base el inconsciente, frente a la psicología de la consciencia. Se trata de establecer un nuevo diseño científico sobre la base del inconsciente. Según él, es posible alcanzar lo que se considera una "comprensión" del respectivo sector de los fenómenos naturales. ${ }^{1163}$

Para Freud, el mundo del psiquismo tiene que ver con los "fenómenos naturales", por lo que es necesario establecer hipótesis, conceptos nuevos y asumir en el estudio del yo las conquistas de la ciencia y establecer nuevos conceptos, modificarlos, corregirlos o precisarlos. ${ }^{1164}$ Se trata de una ciencia nueva que acepta y adapta conceptos de "otras" ciencias naturales. Sin duda alguna, Freud está pensando en la biología darwinista y en

\footnotetext{
${ }^{1157}$ Ibid., pág. 135.

${ }^{1158}$ Id., pág. 135.

${ }^{1159}$ Ibid., pág. 137

${ }^{1160}$ Cfr. FREUD, S., Psicología de Masas, Alianza Editorial, Madrid, 2015, págs. 32-35 en sus referencias a la libido y la sugestión.

${ }^{1161}$ Cfr. FREUD, S., Esquema del Psicoanálisis, págs. 212-215. "El superyó continúa desempeñando ante el yo el papel de un mundo exterior, por más que se haya convertido en parte integrante del mundo interior". Ibid., pág. 214. "El superyó asume una especie de posición intermedia entre el ello y el mundo exterior, reúne en sí las influencias del presente y del pasado. En el establecimiento del superyó vemos, en cierta manera, un ejemplo de cómo el presente se convierte en el pasado”. Ibid., pág. 215.

1162 "Pues mientras que la psicología de la consciencia jamás logró trascender esas series fenoménicas incompletas, evidentemente subordinadas a otros sectores, la nueva concepción de que lo psíquico sería en sí inconsciente permitió convertir la psicología en una ciencia natural como cualquier otra". Ibid., pág. 150.

${ }_{1163}^{15 f r ., ~ I d ., ~ p a ́ g . ~} 150$.

${ }^{1164}$ Cfr. Ibid., pág. 151.
} 
la neurofisiología de las que hemos hablado anteriormente. Apoyadas, y en relación con ellas, Freud pretende partir de hipótesis y conceptos nuevos que se irán precisando en función de la experimentación, de tal manera que surja una comprensión nueva del psiquismo.

La novedad de esta nueva ciencia del psicoanálisis se basa en las experimentaciones y observaciones por medio del aparato psíquico, coincidiendo en este caso el medio utilizado con el objeto mismo de estudio: el aparato psíquico. Y a partir de sus inconsistencias, inferir y traducirlo a material consciente, estableciendo la nueva ciencia psicoanalítica, que es definida como "material consciente" a partir de los datos que ofrece "lo psíquico inconsciente".

Para Freud, existe el aparato psíquico consistente en el material consciente que lo refiere a "la consciencia de los filósofos y del habla cotidiana", y el mundo del inconsciente. Freud habla de tres estados: el inconsciente, el preconsciente y el consciente. Lo inconsciente puede tornarse preconsciente por unos instantes y lo inconsciente puede volverse consciente a base de esfuerzo humano. Con el tiempo, Freud abandona esta terminología y se referirá al ello, al superyó y al yo.

Para Freud, el interior del yo comprende, ante todo, los procesos preconscientes asociados a lo cogitativo y lo intelectivo. Los procesos inconscientes son los que están asociados al ello. Y ambos, el yo y el ello, están íntimamente relacionados, como lo inconsciente y lo preconsciente. Un inconsciente que domina el mundo psíquico del ser humano y que "emerge" en estados de preconsciencia más o menos prolongados, de manera voluntaria o involuntaria.

Es de destacar la importancia que Freud concede a lo inconsciente, al ello. En la "historia del individuo", afirma Freud, originalmente, todo era ello; el yo se desarrolló a partir del ello, por la incesante influencia del mundo exterior. Durante esta lenta evolución, ciertos contenidos del ello pasaron al estado preconsciente y se incorporaron al yo; otros permanecieron intactos en el ello, formando su núcleo, difícilmente accesible. ${ }^{1165}$ En este sentido, para Taylor, la voluntad schopenhaueriana es el antepasado directo del ello freudiano. ${ }^{1166}$

Para Freud, el mundo inconsciente emerge en la preconsciencia a partir de una cierta simbiosis entre ambos estados, pasando de lo inconsciente a lo preconsciente y de lo preconsciente a lo inconsciente, siendo el estado inconsciente el "estado originario" del individuo, el que determina el mundo psíquico. El ello inconsciente expresa el mundo de lo "libremente móvil" con una energía desplegada a través de "magnitudes de

\footnotetext{
${ }^{1165}$ FREUD, S., Esquema del Psicoanálisis, pág. 157; cfr. págs. 202-203 en donde se afirma que el núcleo de nuestra esencia psíquica lo constituye el ello.

${ }^{1166}$ Cfr. TAYLOR, Ch., Fuentes del yo, pág. 606.
} 
excitación". ${ }^{1167}$ El yo, por el contrario, partiendo de la percepción (pre)consciente, somete diferentes capas del ello, con lo que, en la síntesis realizada a través del contacto con el mundo real, a través del yo se puede captar todo ese mundo del inconsciente como algo a lo que remite por su primitivo origen. Según Taylor, con Freud surge una cultura en la que, cuando se trata de configurar la historia del individuo, los lenguajes éticos y espirituales son cada vez más extraños. ${ }^{1168}$

La función del yo freudiano es "ponerse en medio" entre el mundo del instinto del ello y el deseo irrefrenable de satisfacción a través de la actividad intelectiva; sitúa al ello en una "síntesis preconsciente" y le hace prever las consecuencias que puede conllevar el mundo de los deseos del ello, así como tantear e invitar a una cierta precaución que refrene o posponga o ponga límites desde la racionalidad y el contacto con el mundo real. El yo pone seguridad y límites de racionalidad allí donde el ello solo ve deseos y exigencias del instinto. El yo pone autoconservación allí donde el ello solo persigue su propio deseo de realización sin prever las consecuencias de su tentativa de satisfacción. El yo examina la realidad allí donde el ello no prevé los peligros. El yo enfrenta, para Freud, un doble mundo de peligros: los que provienen del mundo exterior (estímulos exorbitantes) y los del mundo instintual del ello (el mundo interior elloico). En este sentido, para Taylor, el yo freudiano es más libre y está más capacitado para ejercer el control cuando tiene más margen de maniobra en relación a las demandas del superyó y a las exigencias del ello. Es el ego idealmente libre que ejerce un lúcido cálculo y control de beneficios. ${ }^{1169}$ Bajo el punto de vista de Taylor, el yo freudiano tiene una fuerza incomparablemente menor que la del yo puntual lockeano. Se trata de un mecanismo puramente dirigido a maniobrar a través de los accidentados obstáculos impuestos por el ello, el superyó y la realidad exterior. ${ }^{1170}$ En el fondo, para Taylor, se llega así a antropologías, como el psicoanálisis, que presuponen grandes rigideces en la formación del carácter humano, caracterizadas en muchos casos por lo propedéutico. ${ }^{1171}$

Por otra parte, para Freud, los dioses son creaciones de estas "necesidades psíquicas" vividas con profunda intensidad dentro del yo del niño, "basadas en renovaciones (reavivaciones) y reproducciones (reinstauraciones) de las tempranas representaciones infantiles del padre y de la madre. Esto es a lo que la teoría psicoanalítica llamará más tarde "representaciones objetales", concepto este esencial dentro de dicha teoría. Freud había afirmado explícitamente que el elemento del complejo de Edipo que brindaba la imagen de Dios era la imagen infantil del padre. ${ }^{1172}$ Dios se convierte, para la teoría psicoanalítica, en un proceso de elaboración

\footnotetext{
${ }^{1167}$ Cfr. FREUD, S., Esquema del Psicoanálisis, pág. 163.

${ }^{1168}$ Cfr. TAYLOR, Ch., La Era Secular, tII, pág. 509.

${ }^{1169}$ Cfr. TAYLOR, Ch., Fuentes del yo, pág. 60.

${ }^{1170}$ Cfr. Ibid., pág. 243.

${ }^{1171}$ Cfr. TAYLOR, Ch., La Era Secular, tII, pág. 527.

${ }^{1172}$ Cfr. RIZZUTTO, A.M., El nacimiento del Dios vivo. Un estudio psicoanalítico. Trotta. Madrid, 2006,
} 
psicológica y antropológica en la que el padre proporciona el material fundamental para dicha representación. ${ }^{173}$ En Freud, Dios es una ilusión promovida por la fuerza de los deseos que permiten al niño y al adulto superar la indigencia y los miedos. ${ }^{1174}$

No es difícil concluir que desde todo lo afirmado anteriormente se van configurando fuentes morales que interfieren progresivamente con la epistemología de la fe cristiana. Para Taylor, lo realmente importante no es que la ciencia apoyara las teorías de la evolución de las especies y desde la argumentación científica se caminara inexorablemente hacia el ateísmo. Taylor considera que el giro más importante se produce en la consideración de las fuentes morales: una idea del sujeto opaco para sí mismo como locus de procesos inconscientes y, en parte, impersonales. ${ }^{1175}$

A partir de los tres inconscientes que hemos analizado, se va a transmitir una sensación colectiva de que las fuentes morales que definen la propia identidad del yo van siendo cada vez más compatibles con el materialismo y con la increencia, de tal manera que la expansión de la no creencia va a ser una característica cada vez más reseñable en el imaginario cósmico de la modernidad. Taylor afirmará incluso que nos encaminamos hacia el cuestionamiento de la misma idea de la autonomía racional, debido a la notabilidad de las ansias irracionales y destructivas, con lo que se socava la idea de una naturaleza en nosotros que desea. ${ }^{1176}$

pág. 32. Rizzutto cita en dicha página un texto de Freud de su obra Un recuerdo infantil de Leonardo da Vinci (1910). "El psicoanálisis nos ha descubierto una íntima conexión entre el complejo del padre y la creencia en Dios, y nos ha mostrado que el Dios personal no es, psicológicamente, sino una superación (exaltación) del padre... En el complejo paterno-materno reconocemos, pues, la razón de la necesidad religiosa. El Dios omnipotente y justo y la bondadosa Naturaleza se nos muestran como magnas sublimaciones del padre y de la madre, o mejor aún, como renovaciones y reproducciones de las tempranas representaciones infantiles de ambos". La idea de Freud de las hordas primitivas la toma directamente de los estudios de Darwin sobre la evolución de las especies y lo refiere a ese tiempo primero, casi mitológico, en el que hicieron su primera aparición los hombres, entendiendo por ello las consiguientes superaciones de las condiciones zoológicas (y evolutivas) y la consiguiente diferenciación de los animales.

1173 "El padre es, por consiguiente, la representación objetal que brinda el material para la formación de la representación de Dios y del demonio... Dos padres diferentes contribuyen a este proceso: uno, el más remoto es el padre primigenio de la horda primitiva, cuya influencia permanece activa en todo nuevo niño que viene al mundo dotado con ella por sus ancestros. El otro es la representación objetal del padre real del niño en el ámbito de la experiencia vital”. Ibid., pág. 36.

1174 “La génesis psíquica de las ideas religiosas... son ilusiones, realizaciones de los deseos más antiguos, intensos y apremiantes de la Humanidad. El secreto de su fuerza está en la fuerza de estos deseos. Sabemos que la penosa sensación de impotencia experimentada en la niñez fue lo que despertó la necesidad de protección, la necesidad de una protección amorosa, satisfecha en tal época por el padre, y que el descubrimiento de la persistencia de tal indefensión a través de toda la vida llevó luego al hombre a forjar la existencia de un padre inmortal mucho más poderoso". FREUD, S., El porvenir de una ilusión, Alianza Editorial, Madrid, 2015, págs. 192-193.

${ }_{1175}$ Cfr. TAYLOR, Ch., La Era Secular, tII, pág. 88.

${ }^{1176}$ Cfr. TAYLOR, Ch., Hegel, pág. 493. 


\section{III.2.2.8. LA DECONSTRUCCIÓN DEL ORDEN SIGNIFICANTE}

La expansión de la increencia adopta en el siglo XIX el rostro de dos alternativas que se entrecruzan en una compleja relación entre las fuentes morales teístas y las secularizadas, al menos en la cultura anglosajona tal y como Taylor afirma. En Inglaterra y Estados Unidos, en la primera mitad del siglo XIX, todo fluye hacia la ortodoxia y el deísmo, mientras que, en la segunda parte, parece que se va asentando la idea de la increencia, el ateísmo y el agnosticismo. El teísmo pasa a ser una opción entre otras muchas y las fuentes morales son ontológicamente diversas. En relación con el Cristianismo empieza a ser más plausible la epistemología del Cristianismo que la epistemología de la fe cristiana, tal y como afirma Taylor. ${ }^{1177}$ Por otra parte, el ateísmo y agnosticismo se convierten ahora en una opción. ${ }^{1178}$ Lo que ocurre, según Taylor, es que una perspectiva moral dio paso a otra. Triunfó otro modelo de lo que se consideraba superior a partir de elementos que lo favorecen: imágenes de poder, de autocontrol, de agencia libre de ataduras. ${ }^{1179}$

I.- Taylor considera que se va expandiendo de manera progresiva el ideal de la ética de la creencia planteado por el filósofo y matemático ingles W. K. Clifford, con un ideal que pudiera ser resumido en este lema: "uno no debería creer aquello para lo cual no cuenta con suficiente evidencia". ${ }^{1180}$ Sin duda alguna se trata de un lema que rezuma escepticismo. Si la fe es según Hebreos "la certeza de lo que se espera, la convicción de lo que no se ve" (Heb. 11,1), el principio de Clifford invita al menos a la duda, dado que buscar en la fe "suficiente evidencia" es ciertamente un ideal difícil de alcanzar.

Para Taylor este lema de la ética de la creencia invita a considerar dos ideales. El primero es el de la libertad racional autorresponsable: no se puede creer cualquier cosa. Y el segundo ideal implica una especie de heroísmo de la increencia, según el cual, se experimenta una honda satisfacción espiritual al saber que uno ha confrontado la verdad de las cosas. ${ }^{1181}$ En la conjunción de ambos ideales se llega a la conclusión de que uno puede creer y no creer. De alguna manera se va abriendo camino al agnosticismo, al asumir el riesgo de no poder encontrar evidencia fehaciente en la búsqueda de la verdad

\footnotetext{
${ }^{1177}$ El hermeneuta canadiense intenta diferenciar entre las argumentaciones morales que subyacen a la filosofía del cristianismo y que de alguna manera fraguaron la aparición de la Ilustración y la investigación científica, y las argumentaciones morales de la premodernidad que estaban imbuidas de fuentes morales que identificaban el yo del hombre en relación a una "fe" que desvinculaba del empoderamiento de la razón y de la libertad humana entendida como voluntad que indaga y decide. Con la Modernidad se impone esa epistemología que tiene que ver con la reforma y los caminos de la voluntad que abren horizontes a la búsqueda racional y a la libertad que decide y asume el propio futuro. También tiene que ver con los caminos del agnosticismo y la ética de la creencia que asume el "riesgo" de creer y no solo "asentir desde la fe". Se va así asentando, según Taylor, un cristianismo de base filosófica frente a una fe cristiana de base teológica.

${ }^{1178}$ Cfr. TAYLOR, Ch., Fuentes del yo, págs. 548-549.

1179 Cfr. TAYLOR, Ch., La Era Secular, tII, pág. 420.

${ }^{1180}$ Cfr. TAYLOR, Ch., Fuentes del yo, pág. 552.

${ }^{1181}$ Cfr. Id., pág. 552.
} 
y de la creencia. No vale cualquier método para buscar dicha razón suficiente que comprometa la verdad de la vida. Es necesario afirmar el método científico y adentrarse en lo que Taylor denomina la hombría moral, para arrostrar la verdad desnuda. ${ }^{1182}$

Por otra parte, según Taylor, la ética de la creencia suponía asumir la demanda de la benevolencia. El vuelco de la religión a la ciencia implicaba no solo un ejercicio de la libertad responsable y una mayor pureza de espíritu, sino que además significaba asumir una opción decidida en favor del progreso y el bienestar humano. ${ }^{1183}$

Para Clifford, la ética de la creencia supone asumir el deber moral de investigar las razones que dan fuerza a las convicciones. La existencia de una creencia no suficientemente fundada a través de una investigación honda y profunda incapacita a una persona para cumplir con su obligación. ${ }^{1184}$ Las convicciones, las creencias y la fe deben sostenerse racionalmente y ser capaces de motivar de manera comprometida y responsable el comportamiento moral. Una creencia que no tiene su correlato en el comportamiento de quien la sostiene no es una verdadera creencia. Quien realmente cree en algo que le insta a una determinada acción la ha contemplado y deseado ya en su corazón. ${ }^{1185}$ Las convicciones mueven a la acción. Tener convicción, fe razonada y decidida, implica un deseo profundo de realizar aquello en lo que se cree. La acción está escondida ya en el corazón de la creencia. Una creencia que no mueve al compromiso moral que sustenta dicha creencia no puede ser tenida como tal.

Hay un imaginario social, una concepción general del curso de las cosas que es la que guía nuestras vidas. Para la ética de la creencia, nos movemos en un "universo cósmico" de creencias que nos han sido transmitidas y que son la joya de la familia que la siguiente generación hereda como un precioso depósito; tesoro que será entregado a la siguiente, tal y como afirma Clifford, no intacto, sino ampliado y purificado, con indicios evidentes de su propia utilización. ${ }^{1186}$ Es inevitable asumir el riesgo de poner en tela de juicio aquello en lo que se cree y evitar así un falso esplendor o un deslumbrante espejismo. Hay, pues, un compromiso ineludible con la Humanidad. Para Taylor, los victorianos asumieron la imperiosa demanda moral de no creer en base a este profundo sentido en favor de la benevolencia humana y como expresión de los dos ideales anteriormente expresados: la libertad racional autorresponsable y el heroísmo de la increencia. $^{1187}$

La ética de la creencia es, de alguna manera, asumir esa sensación de poder, como el mayor y mejor de los deseos, cuando la creencia en la que se funda es verdadera y ha

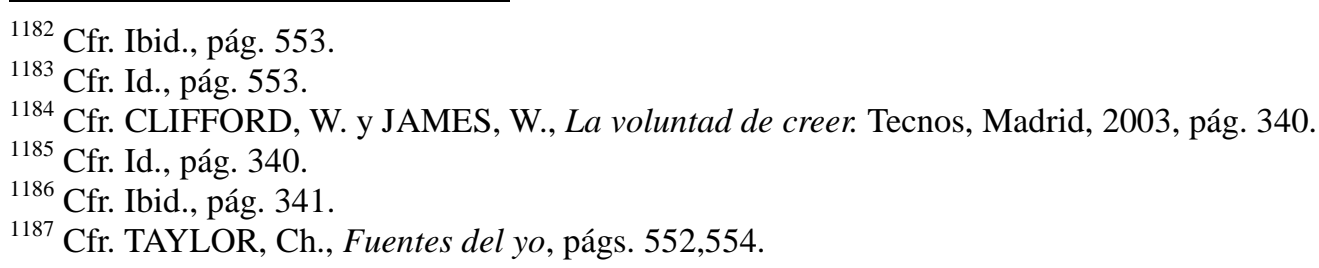


sido alcanzada limpia y honestamente a través de la investigación. Solo entonces podemos sentir que la creencia es propia de todos, que es el mejor legado para transmitir a la humanidad. ${ }^{1188}$ La investigación nos hace sentirnos partícipes de la moldeabilidad de nuestro propio yo y de las consecuencias que debemos asumir en relación a nuestra conciencia autorresponsable. Sentir ese poder personal de la convicción invita a asumir el riesgo de la duda para incrementar las convicciones y participar de ese sentido de humanidad en el que nos hacemos partícipes sintiéndonos parte por lo que corresponde a nuestro compromiso moral personal. Pero no, como afirma Clifford, porque yo haya aprendido secretos gracias a los cuales estoy más seguro, sino porque nosotros, los seres humanos, conseguimos el control sobre una parcela mayor del mundo. ${ }^{1189} \mathrm{Y}$ para ello hace falta convertir en certeza la sombra de la duda que pueda poseernos y así, a través de la certidumbre, entrar a formar parte de ese "nosotros" en el que nos implicamos por nuestro propio sentido de verdad.

Para Taylor, lo realmente relevante que se produce con la ética de la creencia es la transformación crucial que sufre el estatus concedido a la inclinación a la creencia. Hay un desplazamiento radical de la interpretación de nuestras motivaciones en nosotros: ya no hay "ímpetus" hacia la verdad, sino que se trata de construir nuestra situación ética en su conjunto. El deseo de creer aparece ahora como una tentación infantil. Es el lamento y la nostalgia que acompaña a la ética de la increencia, la idea de que se hace de mala gana, como afirma Taylor. Es, por otra parte también, la nostalgia de la pérdida de un mundo más bello. ${ }^{190}$

Todo ello invita a un replanteamiento de las fuentes de la moralidad. Lo mismo que la evolución humana ha experimentado sus cambios (sin admitir una diferencia discontinua entre humanos y animales), también la moralidad puede ser bosquejada a partir de un sentido procesual gradual en relación al acrecentamiento ético del hombre. ${ }^{1191}$ Este es el origen de una ética humana, basada en el egocentrismo propio de "la lucha por la supervivencia" y no en el altruismo o en el sentido de la responsabilidad personal y comunitaria. Es aquí donde empiezan a surgir las filosofías del agnosticismo y referentes filosóficos como el ensayo de Huxley, Evolución y Ética. Para Taylor, la increencia, en estos momentos, libera las fuentes morales del yo para la autoafirmación humana. ${ }^{1192}$

\footnotetext{
${ }^{1188}$ Cfr. CLIFFORD, W. y JAMES, W., La voluntad de creer, pág. 343.

${ }^{1189}$ Cfr. Id., pág. 343.

${ }^{1190}$ Cfr. TAYLOR, Ch., La Era Secular, tII, pág. 421.

1191 "Pero es importante añadir que una ética genuinamente biológica, que tenga en cuenta la evolución cultural humana y el programa genético humano, tendría mucha más consistencia interna que los sistemas éticos que no tienen en cuenta estos factores. Un sistema así, biológicamente informado, no sería producto de la evolución, pero sería inherente a ella”. MAYR, E., “¿Puede la evolución explicar la ética?", Ars Medica, Vol. 2, (2008), pág. 223.

${ }^{1192}$ Cfr. TAYLOR, Ch., Fuentes del yo, pág. 768.
} 
Para la ética natural, el interrogante fundamental es ¿cómo conciliar el principio de la selección natural que conlleva a individuos básicamente egoístas, con la existencia de conductas altruistas? Darwin habla del "altruismo inclusivo" (del padre y la madre en defensa de la prole), del "altruismo recíproco" (por intereses propios) y del "altruismo social" que supone la adaptación de los intereses propios a los del grupo por un sentido de bienestar de la tribu y por los beneficios que supone la fuerza del grupo. ${ }^{1193}$

Este escepticismo, respecto a la afirmación ética del ser humano, en planteamientos de normas dictadas por Dios o en base a la razón humana (que también era un referente trascendente), conduce a la afirmación de la ética natural, tal y como fue replanteada por el diseño darwiniano de la evolución humana. Todo queda reconfigurado y las fuentes morales empiezan a reubicarse. Lo realmente relevante es cómo va surgiendo el agnosticismo a partir de la ética de la creencia y a partir de la ética natural.

II.- El agnosticismo es un término acuñado por T. Huxley en el contexto del desarrollo de las ciencias biológicas darwinianas y en la termodinámica. El propio Darwin hace referencia a él para confirmar que no hay ninguna razón para colocar al hombre en un orden distinto al animal. ${ }^{1194}$ Es una filosofía del conocimiento que da por sentado el factum de la ciencia y donde no cabe la duda ni el escepticismo. ${ }^{1195}$ Taylor asegura que si uno no podía creer, entonces la sinceridad le exigiría que lo dijese. Así, los agnósticos mostraban su filiación respecto al Cristianismo evangélico del que muchos procedían. ${ }^{1196}$

El profesor Velarde Lombraña explica con gran claridad el alcance del término "agnóstico" al explicar sus antecedentes y al analizar la diferencia entre el alcance de la experiencia en Hume y en Huxley. Mientras que Hume establece un "corte" entre los humanos y los animales basado en la diferencia entre las impresiones de sensación y las

\footnotetext{
${ }^{1193}$ Cfr. DARWIN, Ch., El origen del hombre, Sempere Editores, Valencia, 1909, págs. 119-143. "La especie humana es el ejemplo por excelencia de animal social. (...) Para que una familia extensa o una pequeña tropa evolucionen hasta convertirse en una sociedad mayor y más abierta, el altruismo que antes se reservaba para los parientes próximos debe extenderse a los no parientes”. MAYR, E., ¿¿Puede la evolución explicar la ética?”, pág. 228.

1194 "Nuestro eminente anatomista y filósofo, el profesor Huxley, en un profundo estudio de este asunto ha sentado la afirmación de que, en todas las partes de su organización, el hombre difiere menos de los monos superiores, que estos de los miembros inferiores de su mismo grupo. Por consiguiente, "no hay ninguna razón para colocar al hombre en un orden distinto.", DARWIN, Ch., El origen del hombre, pág. 149.

1195 "Huxley establece asimismo el agnosticismo por referencia a la ciencia. (...) Su propósito no es negar o cuestionar determinadas capacidades mentales, sino determinar qué es conocimiento (auténtico); y, en este sentido, restringirlo al ámbito religioso (el llamado 'agnosticismo teológico' o 'agnostoteísmo') es injustificable. El agnosticismo sistemológico es, pues, en gran medida, deudor del criticismo kantiano, como así lo reconocen los propios agnósticos: Huxley, L. Stephen, Tyndall y Clifford". VELARDE LOMBRAÑA, J., "Raíces del Agnosticismo en el pensamiento inglés del siglo XIX", Pensamiento, Vol. 62, No 232, (2006), págs. 91-92.

${ }^{1196}$ Cfr. TAYLOR, Ch., Fuentes del yo, pág. 553.
} 
impresiones de relación (escepticismo empirista), Huxley habla de una "continuidad" entre el hombre y el animal (agnosticismo). ${ }^{1197}$

Para el agnosticismo de Huxley, pues, existe esa continuidad animal según la cual los fenómenos más complejos de la conciencia humana aparecen de manera gradual y sin cortes. Pero además una continuidad que podría denominarse materialista, donde los cambios sobrevienen por acrecentamiento en la complejidad de moléculas cerebrales. Se trata de una "continuidad determinista" que determina que somos sencillamente autómatas con capacidad de libertad, capaces de conjugar ambos elementos en un sentido que asombra al propio ser humano, pero que, al propio tiempo, le hace sentirse parte de una continuidad irrefrenable.

Para Hume, por el contrario, hay una discontinuidad basada en lo que se ha dicho sobre las impresiones de sensación y de relación. Para él hay una gran relación entre impresiones e ideas: "Las unas parecen ser en cierto modo el reflejo de las otras, así que todas las percepciones de la mente humana son dobles y aparecen a la vez como impresiones e ideas". ${ }^{1198}$ Y así como las ideas complejas son imagen de una idea simple, se puede concluir que todas las ideas complejas son imágenes, a su vez, de una impresión simple que fue la que inició el proceso de "representación", fundamento que lleva a Hume a negar las ideas innatas.

Cuando una impresión está en la "mente" como idea o representación, cuando aparece de nuevo, "aparece como una idea" bajo dos modos diferentes. ${ }^{1199}$ Estas impresiones de sensación y de relación significarían, para Hume, la base de ese "corte" que garantizaría la discontinuidad entre el hombre y los animales. ${ }^{1200}$ No obstante, en Hume se da lo que ha dado en llamarse una "naturalización de la naturaleza humana",

1197 "De acuerdo con esta doctrina de la continuidad, los humanos son animales directamente ligados (sin corte alguno) a los demás animales por las cadenas de la evolución. No hay ninguna 'barrera cerebral entre el hombre y los simios'. De manera que tanto los 'principios de asociación' ('principios de la mente' o 'de la naturaleza humana') —en los que Hume funda el razonamiento humano-, como la síntesis del sujeto trascendental —en la que Kant funda el conocimiento todo_-, no son actividades espontáneas, puramente intelectivas (o mentales) y exclusivamente humanas, sino que son continuación y evoluciónde las operaciones (síntesis) físicas (corpóreas) y de las relaciones físicas (sensibles) de los sujetos con otros sujetos y objetos. (...) Situados ahí, no hay límites (no hay zonas inaccesibles) a nuestro conocimiento, porque 'el orden de la Naturaleza es asequible por nuestras facultades hasta tal extremo que es prácticamente ilimitado. Y tampoco hay escepticismo (al estilo de Hume), porque el ámbito del conocimiento se va ensanchando, internamente con los desarrollos de las ciencias"'. VELARDE LOMBRAÑA, J., "Razón ilustrada y agnosticismo", $\Delta \alpha \iota^{\prime} \mu \omega v$, Suplemento 4, (2011), págs. 289-290.

${ }^{1198}$ HUME, D., Tratado de la Naturaleza humana, Gredos, Madrid, 2019, pág. 14.

1199 "Cuando en su nueva aparición conserva un grado considerable de su primera vivacidad y es así algo intermedio entre una impresión y una idea y cuando pierde enteramente esa vivacidad y es una idea por completo. La facultad por la que reproducimos nuestras impresiones del primer modo es llamada memoria, y aquella que las reproduce del segundo, imaginación”. HUME, D., Tratado de la Naturaleza humana, pág. 19.

1200 “(La relación) designa a veces la cualidad por la cual dos ideas se hallan enlazadas entre sí en la imaginación y por la que una de ellas despierta naturalmente a la otra, (...) y otras, la circunstancia particular según la que, aun en la unión arbitraria de dos ideas en la fantasía, consideramos apropiado compararlas". Ibid., pág. 23. 
frente a las concepciones "no naturalistas" de la naturaleza humana que ponen "fuera" del mundo natural lo esencial del ser humano (razón, trascendencia, sociedad, cultura, libertad, historia...). Hume afirma que esta ciencia del hombre, basada en la experiencia y en el método inductivo, y abandonando "aburridos y lánguidos métodos" de investigaciones filosóficas, debe tomar irremediablemente una decisión, la de fundamentarse en la experiencia y la observación. ${ }^{1201}$ Es así como Hume, según Taylor, intenta explorar los caminos del naturalismo y el relativismo. ${ }^{1202}$

La naturalización de la naturaleza humana se expresa, en Hume, como una ética natural en la que una reducción metodológica de lo normativo acaba por establecerse como una reducción ontológica definitiva de la razón y la libertad humanas. ${ }^{1203}$ Como afirma Taylor, Hume pretende evitar nuestra falsa confianza en alcanzar precipitadas extrapolaciones centrando la atención en su origen, en nuestras ideas. Y es "ahí" donde nos damos cuenta de que el yo no es más que un haz de impresiones. ${ }^{1204}$

Completando esta idea, y bajo otra perspectiva, para Hume se produce una sumisión de la razón a las pasiones humanas: "la razón es, y solo debe ser, la esclava de las pasiones, y no puede pretender ningún otro oficio más que servirlas y obedecerlas". ${ }^{1205}$ Pero teniendo en cuenta que para Hume, la pasión es "una existencia original $\mathrm{o}$, si se quiere, la modificación de una existencia, y no contiene ninguna cualidad representativa que la haga copia de otra existencia o modificación"1206 y que además, "cuando la pasión ni se halla fundada en falsos supuestos, ni escoge medios insuficientes para su fin, el entendimiento no puede ni justificarla ni condenarla", ${ }^{1207}$ se puede concluir que, salvo en esos dos supuestos, la pasión no puede considerarse irracional y debe ser considerada como una existencia original promovida por sí misma y hacia sus propios fines.

Por otra parte, esta naturalización de la naturaleza humana se expresará en Hume a través de planteamientos tan radicales que le llevará a hablar también de "la razón de los animales". Tanto los seres humanos como los otros animales comparten los mismos

\footnotetext{
1201 "Y del mismo modo que la ciencia del hombre es el único fundamento sólido para la fundamentación de las otras ciencias, la única fundamentación sólida que podemos dar a esta ciencia misma debe basarse en la experiencia y en la observación" "... y en lugar de tomar de vez en cuando un castillo o una aldea en la frontera, marchar directamente hacia la capital o centro de estas ciencias, hacia la naturaleza humana misma (la cursiva es nuestra); una vez dueños de ella, podemos esperar en todas partes una fácil victoria". Ibid., pág. 7. Esta ciencia del hombre humeana partirá de los principios de la filosofía natural newtoniana y tendrá como centro y fundamento el estudio de una ética natural. Cfr. Libro 2, Sobre las Pasiones (págs. 243-394) y Libro 3, De la Moral (págs. 395-538).

${ }^{1202}$ Cfr. TAYLOR, Ch., Fuentes del yo, pág. 358.

${ }^{1203}$ Cfr. TAYLOR, Hegel, págs. 4,9,26; cfr. TAYLOR, Ch., La ética de la Autenticidad, págs. 91-92; cfr. MARCOS, A., "Naturaleza humana y derechos animales", pág. 5.

${ }^{1204}$ Cfr. TAYLOR, Ch., Argumentos filosóficos, pág. 24.

${ }^{1205}$ HUME, D., Tratado de la naturaleza humana, pág. 361.

${ }^{1206}$ Ibid., pág. 361.

${ }^{1207}$ Ibid., pág. 362.
} 
principios naturales: "ninguna verdad me parece más evidente que la de que los seres brutos se hallan dotados de pensamiento y razón lo mismo que los hombres", ${ }^{1208}$ aunque afirmará la "diferencia de grado" por el desarrollo de las capacidades en el ser humano. $^{1209}$

El naturalismo de Hume hace dos precisiones finales que parece relevante tener en cuenta: por una parte, considerar la sutiliza y la perspicacia que los sistemas filosóficos han aportado al pensamiento humano, ${ }^{1210} \mathrm{y}$, por otra parte, considerar la razón bajo múltiples perspectivas y poder analizar así la experiencia humana como una experiencia del espíritu racional y desarrollo de la conciencia. ${ }^{1211}$

En resumen, y a partir de las reflexiones sobre la naturaleza animal y la naturaleza humana, queda suficientemente matizado que para Hume hay una "ruptura de continuidad" entre ambas naturalezas sobre la base de las percepciones de sensación y reflexión. Huxley, por el contrario, destaca la continuidad entre el hombre y el animal, sin darse ningún tipo de ruptura o discontinuidad. Taylor opina, en este sentido, que los planteamientos de Huxley suponen una llamada al cientifismo y a superar los atavismos de la tradición y la autoridad. ${ }^{1212}$

Según Taylor, Hume se propuso encontrar el yo lockeano puntual, cuya única propiedad constitutiva es la autoconciencia, aunque no lo encontró. ${ }^{1213}$ Para Taylor, Hume intenta explorar alternativas a la pérdida de la cosmovisión providencialista, pero,

\footnotetext{
${ }^{1208}$ Ibid., pág. 163. "Nadie puede negar que existan profundas diferencias cuantitativas entre el pensamiento humano y el de los antropoides, pero con todo y eso no debemos sobreestimar tales diferencias. La complejidad de las actividades humanas "normales", en comparación con la de los otros animales, no permite una base exacta para su medida; en uno y en otros casi todo el comportamiento es cuestión de hábitos. Si el animal civilizado puede hacer más cosas que el animal salvaje, se debe a las mayores oportunidades (agentes internos y externos) que ha tenido de aprender a hacerlas. (...) Aquí entra en juego el lenguaje, un aspecto importantísimo que pone límites y mayor distancia en la relación del ser humano con los demás animales, obviamente lo pone en ventaja respecto de los otros". GARCÍA ÁLVAREZ, P. y SESENTO GARCÍA, L., "David Hume, de la razón y pasiones en los animales", Revista Caribeña de las Ciencias Sociales, (2012), pág. 3.

1209 "Las bestias jamás perciben ciertamente una relación real entre los objetos; por consiguiente, infieren el uno del otro por experiencia. Por lo tanto, tan solo mediante la costumbre actúa sobre ellos la experiencia. Todo esto era suficientemente evidente con respecto al hombre". HUME, D., Tratado de la naturaleza humana, pág. 165.

1210 "El defecto común de los sistemas que los filósofos han empleado para explicar las acciones de la mente es suponer una sutilidad y refinamiento tales del pensamiento, que no solo exceden la capacidad de los animales, sino también la de los niños y la de la gente corriente de nuestra propia especie, quienes son, sin embargo, susceptibles de las mismas emociones y afecciones que las personas del más refinado genio y entendimiento". Ibid., pág. 164.

1211 "Si consideramos la cuestión como es debido, la razón no es más que un instinto maravilloso e ininteligible de nuestras almas que nos lleva a lo largo de cierto curso de ideas y las dota de ciertas cualidades particulares según sus situaciones y relaciones especiales. Este instinto, es cierto, surge de la observación y experiencia pasadas; pero ¿puede alguien dar razón última de por qué la experiencia y observación pasadas producen un efecto tal y aún más de por qué la naturaleza lo produce por sí sola”. Ibid., pág. 165.

${ }^{1212}$ Cfr. TAYLOR, Ch., Fuentes del yo, pág. 553.

${ }^{1213}$ Cfr. Ibid., pág. 82.
} 
al mismo tiempo, guarda distancias con la búsqueda desvinculada de eficacia de los Aüfklarer radicales. Es posible suprimir casi por completo el asunto de la significación y objetivar el ámbito natural con una visión de máxima eficacia utilitarista, pero sin caer en el radicalismo de los Aüfklarer. Hume se opone a la metafísica tradicional porque menosprecia la naturaleza humana, pero, a la vez, allí donde la meta era la naturaleza humana como ámbito neutro que permite el control, él se encamina hacia la meta de la "autoaceptación". ${ }^{1214}$ Hume intenta abrir el camino de la autoexploración con miras a la autoaceptación. Su meta es mostrar la casa en la que como humanos estamos llamados a habitar. Se trata de saber en qué dirección residimos. De ahí su intento por distanciarnos de las preocupaciones por el orden moral y asumirnos como somos. ${ }^{1215}$ Por eso, su estudio de las impresiones en clave de autoexploración, trata de explorar neolucrecianamente la forma de la vida humana. No importa si el universo proporciona significación moral. Lo importante es reconocer la significación moral que se esconde en la forma de vida humana y aceptarla aprendiendo a vivir en ella. ${ }^{1216}$ Consecuentemente, Hume se adentra en su investigación de la naturaleza humana que autoexplora y que está en la base de las futuras explicaciones espirituales del naturalismo. No obstante, según Taylor, para Hume esto no significaba negar la existencia de Dios, era completamente outré entonces ser increyente total. ${ }^{1217}$ Hume no asume la postura de la desvinculación totalmente a pesar de negar la visión providencial del mundo y asumir las ideas lockeanas totalmente. ${ }^{1218}$

III.- El estudio científico de la evolución de las especies en su génesis histórica y biológica, así como los planteamientos naturalistas en torno a la naturaleza humana de Hume, implicaban asumir las consecuencias filosóficas de este proceso. Darwin remite a los orígenes de las especies, pero no entraba en las consideraciones filosóficas que suponía el nihilismo o la asunción de la continuidad. Se puede afirmar que Nietzsche fue el primer filósofo que asumió las consecuencias del evolucionismo en su intento por comprender, al igual que el origen de las especies, el origen del ser, hacer una "reconstrucción genealógica" de la inteligencia y la moral. Si los humildes orígenes del ser humano nos hablan de una lucha por la supervivencia y adaptación a la vida, entonces también habrá que hacer una reconstrucción-deconstrucción del origen del bien y la moral, del origen del ser y la inteligencia. Para Taylor, esto significa, según Nietzsche, la voluntad de poder y la autoafirmación total para decir sí a lo que se es. ${ }^{1219}$

Nietzsche invita a poner en tela de juicio el valor mismo de esos valores que han configurado las cosmovisiones del mundo a lo largo de la historia de occidente. En estos

\footnotetext{
${ }^{1214}$ Cfr. Ibid., pág. 470.

${ }^{1215}$ Cfr. Ibid., pág. 471

${ }^{1216}$ Cfr. Id., pág. 471.

${ }^{1217}$ Cfr. Ibid., pág. 425.

${ }^{1218}$ Cfr. Ibid., pág. 470.

${ }^{1219}$ Cfr. Ibid., pág. 111.
} 
tres tratados de la Genealogía de la Moral, Nietzsche hace no solo un estudio del origen de la moral y la repercusión que ha tenido hasta nuestros días, sino sobre todo una interpretación. No se contenta con teorizar, sino que hace hermenéutica, y una hermenéutica radical, profunda, atenta, desenmascaradora. No tenemos que olvidar sus orígenes como filólogo. Intenta no solo ayudarnos a entender la verdad o falsedad de determinadas posturas, sino que sobre todo pretende liberarnos de lo que él denomina autoengaños o ilusiones. Se trata de ir al fondo de la cuestión y así hacer una hermenéutica de la "sospecha" que permita descubrir esos engaños que, según él, han ido configurando las fuentes morales de Occidente.

Si Nietzsche pretende hacer una ciencia histórica real de la moral para ser conscientes de que "la moral ha podido ser el peligro de los peligros", su método es el de la genealogía que se remonta a los orígenes documentables. ${ }^{1220} \mathrm{Su}$ método genealógico pretende "mostrar no solo cómo ser originan y se desarrollan los valores, sino, sobre todo, hacia dónde conducen, qué significan sus implicaciones y consecuencias para la vida". ${ }^{121}$ En este sentido, Taylor piensa que las genealogías nietzscheanas son devastadoras, porque a partir de él un hiperbién solo podrá defenderse a partir de una cierta lectura de su génesis. ${ }^{1222}$

Ese esfuerzo genealógico nietzscheano consiste, según Foucault, en "recoger allí la esencia exacta de la cosa, su más pura posibilidad, su identidad cuidadosamente replegada sobre sí misma, su forma móvil y anterior a todo aquello que es externo, accidental y sucesivo. Buscar tal origen es intentar encontrar 'lo que estaba ya dado', 'lo aquello mismo' de una imagen exactamente adecuada a sí; es tener por adventicias todas las peripecias que han podido tener lugar, todas las trampas y todos los disfraces; es intentar levantar las máscaras, para desvelar finalmente una primera identidad". ${ }^{1223} \mathrm{Y}$ aquí está, según Taylor, el origen del escepticismo moral en nuestra cultura, entendido como incredulidad moral o como un desafío a sus pretensiones. ${ }^{1224}$

Nietzsche quiere llegar, a la "primera identidad", a lo que es la cosa en sí sin ningún tipo de aditamento. Y así, para él, lo importante es abandonar la fe en la metafísica y ahondar en la verdad de la historia, de la genealogía que nos remonta a "las cosas que están sin esencia" o "que su esencia fue construida pieza a pieza a partir de

\footnotetext{
1220 "Es palmario que para un genealogista de la moral tiene que ser cien veces más importante que el brillo de las mejores hipótesis, el color gris y apagado de lo documentable, lo realmente comprobable, lo que realmente ha existido, en suma, ;toda la larga y difícilmente descifrable escritura jeroglífica del pasado de la moral humana”. NIETZSCHE, F., La genealogía de la moral, Gredos, Madrid, 2018, pág. 19.

${ }^{122 i}$ Cfr. SÁNCHEZ MECA, D., En torno al Superhombre. Nietzsche y la crisis de la modernidad. Anthropos, Madrid, 1989, pág. 127.

${ }^{1222}$ Cfr. TAYLOR, Ch., Fuentes del yo, pág. 114.

${ }^{1223}$ FOUCAULT, M., Microfisica del poder. Nietzsche, la genealogía, la historia, Ediciones La Piqueta, Madrid, 1992, págs. 9-10.

${ }^{1224}$ Cfr. TAYLOR, Ch., Argumentos filosóficos, pág. 59.
} 
figuras que le eran extrañas". ${ }^{1225}$ Foucault señala que esas piezas "extrañas" son identificadas como la razón, la verdad, la libertad... Y concluye afirmando que Nietzsche quiere ir más allá del "disparate" al que nos ha llevado una razón que es puro azar, de una verdad que es "mera pasión de sabios" o de una libertad que se fundamenta en la verdad de las clases dirigentes. ${ }^{1226}$ Taylor refiere la famosa cita de Nietzsche en Así habló Zaratustra: "cambiar cada así fue por así será", para reconciliarse consigo mismo. ${ }^{1227}$

La ciencia histórica del comienzo de las cosas de Nietzsche se ríe de las solemnidades metafísicas, de comienzos que nos remiten a "lo precioso y a lo esencial", de un desear creer lo que en realidad procede de algo distinto. Nietzsche busca en la ciencia histórica que indaga en la genealogía, algo más allá de principios metafísicos, algo más allá de explicaciones predeterminadas sobre la base de un comienzo del Dios creador, o de un principio de la esencia perfecta de las cosas. ${ }^{1228}$

Para Nietzsche se trata de ir en busca de una "transvaloración de todos los valores", de filosofar con el martillo, para empezar a sacar la imagen del hombre en su origen, superando cualquier supuesta metafísica y sonsacar a los ídolos, puesto que hay más ídolos que realidades, y así, desde el silencio, empezar a hablar. ${ }^{1229}$

El sueño dogmático que comenzó con Platón, "el error más nefasto, el error más pertinaz y nocivo que se cometió jamás fue el de un artífice de sistemas: me refiero a la invención del espíritu puro y del bien en sí hecha por Platón”, ${ }^{1230}$ y que, continuando con el "platonismo popular", el Cristianismo, no ha dejado de robar la vida y vivir en una continua pesadilla. De ahí que haya que mantenerse constantemente en vela para ir a las fuentes de la vida robada y descubrir la fuerza de lo primigenio. ${ }^{1231}$ Se trata, según afirma Taylor, de ir tras la búsqueda de la libertad de autodependencia radical, en la autoafirmación a través del rechazo de todos los valores, permaneciendo solo la voluntad de poder. ${ }^{1232}$

\footnotetext{
${ }^{1225}$ Cfr. FOUCAULT, M., Microfísica del poder. Nietzsche, la genealogía, la historia, pág. 10.

${ }^{1226}$ Cfr. Id., pág. 10. Cfr. NIETZSCHE, F., La genealogía de la moral, págs. 25 y ss., en lo que Nietzsche define como "el problema silencioso", la superioridad del carácter noble y de los veraces, frente al "mendaz hombre vulgar".

${ }^{1227}$ Cfr. TAYLOR, Ch., Hegel, Gredos, pág. 69.

1228 "Y a eso que habéis llamado mundo, eso debe ser creado primero por vosotros ;debe llegar a ser vuestra misma razón, vuestra imagen, vuestra voluntad! ¡Y en verdad, para vuestra bienaventuranza, hombres del conocimiento... Dios es una suposición más... Dios es un pensamiento que tuerce todo lo recto y voltea todo lo que está de pie ¿Cómo? ¿Se habrá abolido el tiempo y todo lo transcurrido sería solo mentira? ¡Malvadas y enemigas del hombre: así llamo yo a todas esas doctrinas de lo Uno y lo Pleno y lo Inmóvil y lo Saciado y lo eterno!" NIETZSCHE, F., Así habló Zaratustra, Gredos, Madrid, 2018, pág. 108.

${ }_{1229}$ Cfr. NIETZSCHE, F., El crepúsculo de los ídolos, Gredos, Madrid, 2018, págs. 151-152.

${ }^{1230}$ NIETZSCHE, F., Más allá del bien y del mal, Gredos, Madrid, 2018, pág. 384.

${ }^{1231}$ Cfr. TAYLOR, Ch., Fuentes del yo, pág. 299.

${ }^{1232}$ Cfr. TAYLOR, Ch., Hegel, pág. 491.
} 
Nietzsche invita siempre a ir más allá del origen (entendido como origen de la superioridad metafísica) y a buscar las raíces de la historia. El origen siempre termina refiriéndonos a una "teogonía poética" y al lugar de la verdad metafísica. Sin embargo, el comienzo de la historia, consiste en mil sucesos perdidos hasta ahora, en la exterioridad del accidente, en el sentimiento despierto de soberanía, ${ }^{1233}$ en lo que hace resurgir lo incógnito, ${ }^{1234}$ en la fuente de los comienzos, ${ }^{1235} \mathrm{y}$ en las figuras y repliegues que se esconden en el cuerpo. ${ }^{1236}$

La historia no obedece a un destino superior ni a un proceso de linealidad como sucesión racional de acontecimientos establecidos más o menos mecánicamente, sino a un espíritu de la historia o una historia del espíritu que se va abriendo camino desde el mero azar, en el que se imponen las ciegas anomalías del destino como una lucha del azar, y en el que las posibilidades siempre quedan abiertas, para que el espíritu humano se imponga en lo que es y está llamado a ser, no desde orígenes impuestos, sino desde la realidad de los principios siempre inacabada. Una historia que tiene que pasar del saber de las culturas (farmacología), a la ciencia de los orígenes (medicina), que ubique al hombre en espacios vitales que le hagan evolucionar, crecer y luchar, ${ }^{1237}$ y donde, como afirma Taylor, se produzca el estallido del humanismo de la libertad y la afirmación de uno mismo. ${ }^{1238}$

Para Nietzsche, debido a que "estamos cansados del hombre", es necesario hacer una genealogía para rastrear los caminos de la procedencia y evitar la mayor de las sospechas de interpretar la debilidad misma como libertad, ${ }^{1239} \mathrm{o}$ como afirmará Taylor, donde los viejos horizontes desaparezcan. ${ }^{1240}$

\footnotetext{
1233 "Es bajo, no en el sentido de modesto o de discreto como el paso de la paloma, sino irrisorio, irónico, propicio a deshacer todas las fatuidades: 'Se buscaba hacer despertar el sentimiento de la soberanía del hombre, mostrando su nacimiento divino: esto se convirtió ahora en un camino prohibido; pues a la puerta del hombre está el mono' (Aurora S49)". FOUCAULT, M., Microfísica del poder. Nietzsche, la genealogía, la historia, pág. 10.

1234 "El genealogista parte a la búsqueda del comienzo — de los comienzos innombrables que dejan esa sospecha de color, esta marca casi borrada que no sabría engañar a un ojo un poco histórico. El análisis de la procedencia permite disociar al yo, y hacer pulular en los lugares y plazas de su síntesis vacía, mil sucesos perdidos hasta ahora". Ibid., pág. 12.

1235 "Buscar los caminos de la procedencia y la fuente (...) es descubrir que en la raíz de lo que conocemos y lo que somos no está en absoluto la verdad y el ser, sino la exterioridad del accidente". Ibid., pág. 13.

1236 "Es decir, que en la procedencia histórica no está la verdad metafísica, sino todas aquellas fisuras y repliegues que se esconden en el cuerpo, en todos sus retrocesos y avances, y que permiten descubrir aquello que estaba en los comienzos y que no ha sido posible expresar en la historia, por eso se trata de "mostrar el cuerpo impregnado de historia y a la historia como destructor del cuerpo". Ibid., pág. 15.

${ }^{1237}$ Cfr. NIETZSCHE, F., El caminante y su sombra, Gredos, Madrid, 2018, pág. 242.

${ }^{1238}$ Cfr. TAYLOR, Ch., La Era Secular, tII, págs. 13,165.

1239 "Que todo sigue yendo para abajo, para abajo, hacia lo más tenue, más bondadoso, más prudente, más cómodo, más mediano, más indiferente, más chino, más cristiano: el hombre, no cabe duda, se está haciendo cada vez mejor" y que el sujeto (el alma en clave popular) "es quizás el mejor artículo de fe que ha habido hasta ahora en el mundo... aquel sublime autoengaño consistente en interpretar la debilidad misma como libertad, su ser lo que son como mérito". NIETZSCHE, F., La genealogía de la moral, pág.
} 
Y si la historia ha sido la destructora del cuerpo, de la energía primera, de la procedencia de los comienzos, la historia de la humanidad, para Nietzsche, ha sido la lucha de Roma contra Judea y de Judea contra Roma, ${ }^{1241}$ una lucha encarnizada cuyo cuerpo (la procedencia y la fuente) se ha hecho girones a través de las etapas de la historia en sus repliegues y fisuras, y en la que los filósofos han sido "enfermos urdidores de telas de araña", ${ }^{1242}$ creando un mundo verdadero que terminó por convertirse en fábula. ${ }^{1243} \mathrm{El}$ origen nos conecta con la verdad metafísica, ${ }^{1244}$ en la que a partir de Grecia "es preciso que hayamos tenido alguna vez nuestra casa en un mundo más alto ¡en vez de 'en uno mucho más bajo', que es lo que habría sido verdad! ¡Tenemos que haber sido divinos, puesto que poseemos la razón!”. ${ }^{245}$ Mientras que la genealogía nos remonta a la fuente del "cuerpo" que ha sido negado por la fuerza de las tesis filosóficas que han hecho historia y que han hablado de un mundo aparente, del verdadero ser de las cosas y de otra vida, mientras que el cuerpo nos habla de este mundo, de un mundo real, de un mundo verdadero que acaba en fábula y de un mundo aparente que es el verdadero. ${ }^{1246}$ De ahí la pregunta de Nietzsche: “Bebemos el mar hasta la última gota? ¿Quién nos dio la esponja para borrar todo el horizonte?”. ${ }^{247}$

La crítica genealógica nietzscheana pretende así "des-velar" la racionalidad inherente a la metafísica del origen para así descubrir la "irracionalidad" de los comienzos; una irracionalidad que a todas luces aparece como inverosímil porque la racionalidad metafísica la ha teñido de "no-natural". La memoria ha hecho que el discurso racional y metafísico sea establecido como el momento institucional, la verdad del origen frente a lo cual todo lo demás es considerado como irracional. ${ }^{1248}$

Es el propio sistema el que desde la veracidad "supuestamente" hizo surgir la razón metafísica de los orígenes, el que va a abrirse camino para descubrir desde el espíritu inherente al propio devenir histórico, según Nietzsche, la propia incoherencia de

\footnotetext{
41.

${ }^{1240}$ Cfr. TAYLOR, Ch., La Era Secular, tII, pág. 431.

${ }^{1241}$ Cfr. Ibid., págs. 46-47.

1242 NIETZSCHE, F., El crepúsculo de los ídolos, pág. 169.

1243 Cfr. Ibid., págs. 172-173.

1244 “Aunque se haya que confesar que el error más nefasto, el error más pertinaz y nocivo que se cometió jamás fue el de un artífice de sistemas: me refiero a la invención del espíritu puro y del bien en sí hecha por Platón". NIETZSCHE, F., Más allá del bien y del mal, pág. 384. "Malvadas y enemigas del hombre: así llamo yo a todas esas doctrinas de lo Uno y lo Pleno y lo Inmóvil y lo Sacadio y lo Eterno". NIETZSCHE, F., Así habló Zaratustra, pág. 108.

1245 NIETZSCHE, F., El crepúsculo de los ídolos, pág. 170.

1246 Cfr. Ibid., págs. 170-171.

1247 NIETZSCHE, F., La ciencia jovial, pág. 140.

1248 "La crítica genealógica no hace más que consumar la caída a la que este mundo trascendente él mismo se había condenado desde el principio. Pues allí donde los significados y valores se autoerigen en algo fijo y autónomo frente a la vida, ha surgido la mentira y el deseo de refutarla. En realidad, esa tendencia hacia la autosupresión, ínsita en la historia del espíritu, se muestra en la presión ejercida sobre él por uno de los principios fundamentales del sistema mismo de la razón: la verdacidad". SÁNCHEZ MECA, D., En torno al Superhombre. Nietzsche y la crisis de la modernidad, pág. 127.
} 
"falta de veracidad", tanto en sus principios semánticos, como en el método le que permitió desarrollarse como tal. Nietzsche cuestiona la verdad que "supuestamente" estuvo en el origen, omitiendo, olvidándose de esa otra verdad primera que ha sido negada, anulada y racionalizada. Se trata de desvelar esa supuesta veracidad establecida en el origen como verdad metafísica que niega la veracidad inherente de los comienzos en su irracionalidad vital. ${ }^{1249}$

Lo mismo que hay una lucha en la supervivencia de las especies, hay, según Nietzsche, una lucha por ir estableciendo la verdad del espíritu, una verdad que se va abriendo camino por el espíritu que habita en la historia y que no permite que se vayan asimilando intuiciones o verdades que no le son propias o que se han des-encaminado o des-virtuado. Y lo mismo que hay una evolución de las especies y se impone un tipo de hombre que "establece la anomalía" y logra permanecer a partir de unas funciones favorables, hay, según este mismo autor, otra "anomalía" inherente al propio devenir histórico, en su evolución moral, que ha fundamentado el desarrollo del espíritu humano: son los guerreros idealizados, los grandes depredadores antes de la "rebelión moral de los esclavos". ${ }^{1250}$

La racionalización conceptual, para Nietzsche, se olvida de la naturaleza y asume su idea representacional como original en sí frente al mundo de la apariencia que representan las cosas empíricas, ya que son un torpe e imperfecto trasunto de la idea representacional, con lo cual tenemos el mundo verdadero y el mundo de la apariencia. Pasamos de designar la realidad con el concepto a designar el concepto como la realidad. Y la realidad se convierte en una apariencia, porque el concepto en sí es la realidad. Todo se ordena con la lógica de la razón y se pone imagen linguística a la realidad, con lo que se olvidan los matices, se generaliza, se conceptualiza y se identifica la realidad con la representación mental encarnada en la imagen lingüística "acústica". El mundo es la lógica del concepto racional reducido a imagen acústica, una razón que ordena conceptualmente el mundo, lo limita, lo reduce, le quita matices, lo generaliza y lo diferencia en mundo real y mundo aparente, siendo el mundo real la representación conceptual; una representación mental que ordena el mundo, lo interpreta. Todo depende del sujeto que conoce, interpretando y ordenando representacionalmente. Es la mente que mueve los goznes del mundo y ve los ojos del

\footnotetext{
1249 "Nietzsche dirige sus ataques, básicamente, a la destrucción del ideal de vida que tiene su horizonte en la idea de un valor supremo como norma o verdad absolutas, y que encuentra en la noción de ser el fundamento último de todo lo bueno, lo verdadero, lo bello. Puesto que la voluntad de verdad no es otra cosa que búsqueda del fundamento y como tal se autoexplica, Nietzsche tomo como frente fundamental de su crítica esta búsqueda del fundamento, en la que confluyen tanto el contenido como el método del sistema a destruir". Ibid., pág. 128.

1250 "Entre los innumerables tipos de juicios y razonamientos que se producen, los más útiles para conservar y hacer triunfar a un determinado tipo humano - es decir, los que ofrecen a los individuos que los practican las posibilidades más favorables en su confrontación con los demás- son los que prevalecen, sin que esto diga nada en favor o en contra de su verdad en sî’. Ibid., pág. 188. Cfr. TAYLOR, Ch., La Era Secular, tII, pág. 573.
} 
universo, el intelecto entendido como "un recurso que retiene (a los seres humanos) un minuto en la existencia". ${ }^{1251}$ El lenguaje de la razón y el lenguaje de la imagen acústica es el arte de la ficción, donde se instala el engaño y la falacia, siendo necesario remontarse al tiempo de los orígenes que va más allá del origen. ${ }^{1252}$

Es precisamente este impulso sincero y puro hacia la verdad el que ha desentrañado las entrañas del mundo y ha desvirtuado el impulso hacia la vida. Es ese impulso sincero el que hace exclamar a Nietzsche: “¡Cómo ha sido posible! ¡De dónde procede en el mundo entero, en esta constelación, el impulso hacia la verdad!”. ${ }^{1253}$ Todo lo ha velado este impulso como una niebla que nos impide ver y es necesario poner de nuevo luz para des-velar y des-entrañar. Lo que uno no puede explicarse, según Nietzsche, es cómo ha sido posible que todo deba ser verdad y "que un mentiroso utilice palabras que hace aparecer lo irreal como real, querer la verdad en análogo sentido limitado, palabras como conchas vacías, meras reproducciones en sonidos articulados de un estímulo nervioso". 1254

Para Taylor, este lenguaje despiadado de las genealogías nietzscheanas es realmente extraño. Parece que están motivadas por los ideales de la libertad, el altruismo y el universalismo y, sin embargo, a lo que conducen esos ideales, en estas teorías de la acción obligatoria, es a la negación de todos esos bienes. ${ }^{1255}$ Según Taylor, el impulso hacia una visión original siempre se perderá en una confusión interior, al menos que se sitúe en relación con el lenguaje y la visión de los demás. Taylor lanza el gran cuestionamiento que late en el fondo de la genealogía moral nietzscheana: “Sé lo que digo? ¿Comprendo verdaderamente aquello de lo que hablo?"1256

Para Nietzsche, el hombre, entre el lenguaje de la razón y el lenguaje de las metáforas de las cosas se ha ido des-enraizando de su humus natural, de las esencialidades originarias ya que todo concepto se genera igualando lo no-igual, ${ }^{1257}$ con lo que el lenguaje no desvela, sino que equipara para generalizar ocultando, para "poner niebla generalizando", omitiendo las cualidades esenciales e individualizadas y haciendo una filosofía del lenguaje vacía, que expresa una qualitas occulta (generalizadora) con el nombre, en el que las verdades son ilusiones y todo suena a metáforas gastadas, cuyo valor ha quedado reducido al metal de la moneda, no al valor

\footnotetext{
${ }^{1251}$ Cfr. NIETZSCHE, F., Sobre verdad y mentira en sentido extramoral, Gredos, Madrid, 2018, pág. 349. 1252 "El engaño, la adulación, la mentira y el fraude, las habladurías, la hipocresía, el vivir de lustres heredados, el enmascaramiento, el convencionalismo encubridor, el teatro ante los demás y ante uno mismo, en una palabra, el revoloteo incesante en torno a la llama de la vanidad es hasta tal punto la regla y la ley, que casi no hay nada más inconcebible que el modo en el que haya podido introducirse entre los hombres un impulso sincero y puro hacia la verdad". Ibid., pág. 350.

${ }^{1253} \mathrm{Id}$.

1254 Ibid., pág. 351.

1255 Cfr. TAYLOR, Ch., Fuentes del yo, pág. 134.

${ }^{1256}$ Cfr. Ibid., pág. 66.

${ }^{1257}$ Cfr. NIETZSCHE, F., Sobre verdad y mentira, pág. 353.
} 
intrínseco a la moneda misma. Hay un olvido originario por esta inconsciencia, y en vez de volver a la vida, a las primeras impresiones como lo más firme a partir de la imagen (hija del impulso nervioso), se disuelve una imagen en un concepto, quedando todo reducido a un residuo de una metáfora, a una extrapolación artística de un estímulo nervioso, ${ }^{1258}$ a un cielo conceptual, a una construcción de telarañas. El único interés ha sido encontrar la verdad dentro de la jurisdicción de la razón, buscar la metamorfosis del mundo en los seres humanos luchando por una comprensión del mundo como una cosa de especie humana, consiguiendo un sentimiento de asimilación. ${ }^{1259}$

En este sentido, según Taylor, para Nietzsche y los neonietzscheanos, la afirmación de la moral y de los hiperbienes ha conducido a una represión de la naturaleza que ha llevado al incremento de la inconsciencia y a fomentar relaciones de represión entre nosotros. ${ }^{1260}$ Por eso, según Taylor, Nietzsche, dando un vuelco contra la Ilustración, afirmará que la benevolencia es el primer obstáculo para la autoafirmación. $^{1261}$

Por otra parte, para Nietzsche la relación entre sujeto y objeto se ha limitado a una relación estética, ${ }^{1262}$ a una traducción balbuciente, a un lenguaje completamente extraño, faltando una esfera intermedia que aglutine ambos elementos en una fuerza mediadora que invente el mundo en sus goznes originarios, en sus cimientos primeros y supere definitivamente la petrificación de la metáfora. ${ }^{1263}$ En este sentido, para Taylor, Nietzsche afirma la voluntad de poder del sujeto como una victoria sobre sí mismo, como una autosuperación por la cual uno es capaz de afirmar el mundo, aunque el mundo sigue siendo un ámbito de fuerzas ciegas, no espirituales, caóticas. Es el superhombre que es capaz de decir sí al mundo y a todo. Esta es la transfiguración del mundo según Nietzsche que no altera, según Taylor, ninguno de sus contenidos y sí el significado de todo. ${ }^{1264}$ Para Taylor, la facultad de la autoafirmación nietzscheana también es, en cierto sentido, una contribución a la configuración moral de las fuentes del yo en torno a la idea del bien: afirmar la voluntad de poder conduce la voluntad a una potencia superior, pero con una interpretación atea. ${ }^{1265}$

IV.- Por lo tanto, Taylor asegura que, desde la ética de la creencia y desde la revolución de Darwin con sus correlatos freudianos y nietzscheanos, se llega a una posición de afirmar la superioridad de la ciencia, no tanto por los hallazgos científicos

\footnotetext{
${ }^{1258}$ Cfr. Ibid., pág. 354.

${ }^{1259}$ Cfr. Ibid., pág. 355.

${ }^{1260}$ Cfr. TAYLOR, Ch., Fuentes del yo, pág. 149.

${ }^{1261}$ Cfr. Ibid., pág. 469.

${ }^{1262}$ Cfr. TAYLOR, Ch., La ética de la autenticidad, pág. 9: "Nietzsche busca una suerte de autocreación en el registro de la estética".

${ }^{1263}$ Cfr. TAYLOR, Ch., Argumentos filosóficos, págs. 37-40.

${ }^{1264}$ Cfr. TAYLOR, Ch., Fuentes del yo, pág. 615.

${ }^{1265}$ Cfr. Ibid., pág. 617.
} 
en sí mismos considerados, cuanto por la posición epistemológica que subyace, especialmente por motivos éticos. Si considero que la fe me posiciona en un relato inconsistente racionalmente y transido de infantilismo, es muy probable que se vaya realizando un tránsito hacia otras fuentes morales que aporten mayor seguridad y sintonía con el imaginario social predominante y que, por lo tanto, se produzcan abandonos. ${ }^{1266}$ En este sentido, para Taylor la crítica devastadora de Nietzsche sigue hablándole a mucha gente hoy. ${ }^{1267}$

Lo realmente relevante no es tanto que se asuman las conclusiones científicas como algo que está contrastado y responde a la verdad de la ciencia, sino el hecho de que se adopte la posición epistémica de la ciencia como lo realmente ético y lo que se exige como algo que debe ser aceptado, y a partir de dicha posición epistémico-ética de superioridad, asumir las consecuencias que de ello se dirimen. Es la ciencia la que tiene la última palabra y la que, como afirma Taylor, tiende a empujarnos en la dirección del atomismo y el instrumentalismo, y a imponernos sus exigencias una y otra vez, en la esfera pública o privada, en la economía y en el Estado. Nos vemos forzados a operar en cierta medida de acuerdo con las exigencias de la racionalidad moderna, se ajuste o no a nuestra perspectiva moral. ${ }^{1268}$ Se trata de superar cualquier visión basada en la superstición, impostura, error o confusión, como afirmaría Bacon. ${ }^{1269}$

La posición ético-epistémica de la ciencia moderna asume esa superioridad respecto a las posiciones de la religión, con lo que al converso a la no creencia, tal y como se expresa Taylor, le parece un relato mucho más convincente para su vida moralespiritual. Es una conclusión lógica en relación a la ética de la creencia de la que hemos hablando anteriormente: el relato de la no creencia se asume con mayor fundamentación ético-epistémica, dado que se posiciona desde un punto de vista superior y da por hecho que en dicho relato se sustentan las altas dosis de racionalidad que se exigen a cualquier relato. El relato de la religión se considera menos fundamentado racionalmente, menos comprensible, con lo que el relato de la no creencia parece más convincente. En el imaginario social se considera más ético y maduro asumir posiciones que tienen que ver más con la verdad científica, pues se considera algo más evidente y más en relación al sentido común. En grandes masas sociales se transita con facilidad hacia posiciones morales alejadas del sentido trascendente en un contexto impermeabilizado. ${ }^{1270}$ La única alternativa parece estar, según Taylor, en una suerte de exilio interior y de automarginación. ${ }^{1271}$

\footnotetext{
${ }^{1266}$ Cfr. TAYLOR, Ch., Hegel, págs. 4-7.

${ }^{1267}$ Cfr. TAYLOR, Ch., La Era Secular, tI, págs. 296,387,395; cfr. TAYLOR, Ch., Fuentes del yo, págs. 614-617.

${ }^{1268}$ Cfr. TAYLOR, Ch., La ética de la autenticidad, pág. 125.

1269 Cfr. BACON, F., Novum Organum, Libro I, CXXIV.

${ }^{1270}$ Cfr. TAYLOR, Ch., Hegel, pág. 476.

${ }^{1271}$ Cfr. TAYLOR, Ch., La ética de la autenticidad, pág. 124.
} 
Esta imagen arrasa con todas las propuestas anteriores de fundamentación moral y epistémica: la idea platónica de que el mundo es la realización de las Formas o teoría del logos óntico, la fundamentación deísta de propósitos de Dios en un universo mecanicista o las referencias a fondos espirituales en la interioridad humana (alma). Nos introducimos en un mundo materialista, desencantado, sin significado, impermeabilizado, invulnerable para el que se necesitan lenguajes más sutiles, como afirmará Taylor. Así como el imaginario anterior fue articulado por las ideas del cosmos, para el nuevo imaginario, según afirma Taylor, no existe nada análogo, salvo la ciencia, y esta no basta para articular el significado de las cosas. ${ }^{1272}$ Taylor se pregunta: ¿hay que explicar la vida humana (y ¿hasta qué punto ha de ser explicada?) en términos modelados por la ciencia natural? ¿Hay algún modo mejor para contestar a esta pregunta que ver qué explicaciones elimina de hecho? ${ }^{1273}$

No hay destino que comprometa el sentido moral del hombre. No hay ninguna opción personal que nos comprometa en un sentido de salvación trascendente o retribución divina. Todo es un mundo de ética natural en la que el hombre tiene que aprender a afrontar su destino y librarse del miedo al más allá y así alcanzar la ataraxia. Todo depende de nosotros y la motivación se descubre en nuestra propia interioridad inmanente, la que decide la vida y el horizonte de realización personal. Es la posición moral del razonamiento autorresponsable y autocontrolador. ${ }^{1274}$ Taylor afirma, en este sentido, que tanto el naturalismo como el temperamento crítico tienden conjuntamente a forzarnos a reconocer el modo apodíctico como el único juego posible en la ciudad y haciendo aparecer la argumentación ad hominem como irrelevante en el debate ético. ${ }^{1275}$

Solo queda esa dimensión de misterio envolvente en un mundo natural movido por fuerzas mecánicas, y constituido por la inmensidad del tiempo y el espacio, en el que el hombre emerge como una fuerza capaz de sentimiento, imaginación y pensamiento que le hace una realidad única en un universo neutro y en una profundidad microinfinitesimal. ${ }^{1276}$ Un misterio que la ciencia lo ve como un enigma, pero que es visto en el imaginario cósmico como un misterio que se esconde detrás de las honduras insondables del yo que sorprenden por su propia capacidad para sobrecogernos y entrar

\footnotetext{
${ }^{1272}$ Cfr. TAYLOR, Ch., La Era Secular, tII, pág. 79.

1273 Cfr. TAYLOR, Ch., Argumentos filosóficos, pág. 65.

${ }^{1274}$ Cfr. TAYLOR, Ch., La ética de la autenticidad, pág. 130.

${ }^{1275}$ Cfr. TAYLOR, Ch., Argumentos filosóficos, págs. 67,88-89,112,179-180.

${ }^{1276}$ Frente al mecanicismo filosófico del siglo XVIII que resucitaba el antiguo atomismo griego y asumía una metafísica de fondo, aceptada por Galileo y Newton, para el profesor Agazzi, sin embargo, "el mecanicismo decimonónico es distinto en parte, dado que no se limita a la aceptación de un cuadro metafísico a fin de cuentas muy general y genérico, sino que asume una bien precisa ciencia, o sea, la mecánica como clave de lectura de toda la realidad física, lo que significa, en sustancia que de todo fenómeno natural se presuponía que se podía explicar utilizando conceptos, leyes y principios de la mecánica, recurriendo en caso necesario a complejas modelizaciones y a cálculos matemáticos". AGAZZI, E., La ciencia y el alma de Occidente, Tecnos, Madrid, 2011, págs. 161-162.
} 
en contacto con el yo y el mundo a través de la conciencia, de manera creativa e iluminadora del orden que subyace a todo.

Incluso para algunos científicos, la explicación científico-natural del mundo no elimina el misterio, sino que lo acrecienta, ya que todo conduce a una actividad matemática casi incomprensible. Para Taylor, no es que la explicación natural del mundo elimine el misterio, sino que ayuda a acrecentar esas dimensiones que hacen sobrecoger al hombre por cómo todo conduce a un éter inquietantemente insustancial y que, en vez de aquietar, inquieta aún más, en una clase de sobrecogimiento cósmico. ${ }^{1277}$

V.- Para Taylor, pues, la no creencia se va extendiendo en el siglo XIX y sus formas son las que básicamente tienen continuidad hoy en día. Un siglo en el que se piensa por primera vez al hombre como centro que ocupa su lugar, como el rey que es capaz de establecer su metafísica del orden natural y del engranaje mecánico sobre la base de la analítica de la finitud. ${ }^{1278}$

Taylor considera a Foucault, Habermas y MacIntyre los filósofos que intentan hacer un retrato de nuestra identidad moral, intentando comprender las impresionantes transformaciones de nuestra cultura y sociedad en el decurso de los tres últimos siglos. ${ }^{1279}$ Para Foucault, antes del fin del siglo XVIII, el hombre no existía; en este sentido, el hombre es una criatura muy reciente. ${ }^{1280}$ Se puede afirmar que el siglo XIX es el siglo más importante a la hora de definir el gran cambio de paradigma. Es el siglo más importante por lo que significa de que se piense por primera vez al hombre o, lo que es lo mismo, que el hombre tome asiento y sea el rey y configure una metafísica desde él mismo, constituyéndose como único referente finito en un mundo finito. Y si no existía, podemos decir que lleva dos siglos de historia y que había estado escondido en los pilares del mundo, en una suerte de caverna platónica, y que ha salido a la luz del mundo para pensarse a sí mismo y constituir su propio fundamento. ${ }^{1281}$

Hasta el siglo XIX, se puede afirmar que no existía una ciencia del hombre, tal y como aparece en la filosofía de Schopenhauer, Freud y Nietzsche. Según Foucault, en la episteme clásica, las funciones de la naturaleza y de la naturaleza humana se oponían totalmente: la naturaleza hacía surgir, por el juego de una yuxtaposición real y desordenada, la diferencia en el continuo ordenado de los seres, en una comparación de elementos inactuales en la que el hombre representa la escala superior a partir de su propia constitución ontológica: ${ }^{1282}$ Pero lo curioso es que, al mismo tiempo, en la

\footnotetext{
1277 Cfr. TAYLOR, Ch., Fuentes del yo, pág. 477.

${ }^{1278}$ Cfr. TAYLOR, Ch., La Era Secular, tII, pág. 106; cfr. FOUCAULT, M., Las palabras y las cosas, págs. 299-309.

${ }^{1279}$ Cfr. TAYLOR, Ch., Fuentes del yo, pág. 11.

${ }^{1280}$ Cfr. FOUCAULT, Las palabras y las cosas, pág. 300.

${ }^{1281}$ Cfr. Id., pág. 300.

1282 Cfr. Ibid., pág. 301.
} 
episteme clásica, según Foucault, hay elementos de relación y continuidad entre la naturaleza y la naturaleza humana. La naturaleza determina la imagen del hombre y el hombre configura el orden de la naturaleza como cadena de representaciones a partir de su poder duplicativo. No se entienden la naturaleza humana sin la naturaleza cósmica. Su imagen no es la imagen de su yo aislado, sino la imagen del orden cósmico en el que el hombre ocupa la cúspide de la pirámide. El hombre nombra representacionalmente la naturaleza y la configura con su propio poder de duplicación; pero al mismo tiempo, no puede entenderse a sí mismo"por sí mismo, sino desde la naturaleza de la que forma parte en continuidad y sucesión ordenada. ${ }^{1283}$ La sucesión de cadena de seres está en relación a la naturaleza humana. Sin la representación humana no se encuentra sentido a la gran cadena del ser. No hay independencia en el mundo natural porque la naturaleza se configura "en relación al hombre" y no hay independencia del hombre en relación al mundo natural, porque la naturaleza humana forma parte de esa gran cadena del ser. El ser y la representación tienen un lugar común. O como dirá Hegel: "El ser del yo es una cosa". 1284

Existe un juego de la naturaleza en la que todo está enmarañado, y es precisamente la capacidad de representación humana la que aglutina el orden del ser, un orden en el que las diferencias estallan y las identidades se configuran en completa nitidez. Es decir, que al mismo tiempo que todo está ordenado, sin embargo, el enmarañamiento y el desorden y las diferencias hacen que el hombre no esté del todo formando parte de la naturaleza. Es una relación complicada porque el hombre se desenvuelve en la naturaleza, pero se diferencia de ella. Es una realidad espesa y un objeto difícil dentro de esta relación que, por una parte, existe, pero que, por otra parte, se problematiza o se separa al mismo tiempo. Es una relación en la tensión y la diferenciación, en la que el punto de encuentro entre ambas naturalezas, como dice Foucault, se dará por la relación entre representación y cadena del ser. Los seres son identificados, representados por el espíritu humano, y el espíritu humano forma parte de esta cadena de seres, pero una pertenencia problemática en el sentido de "diferencia ontológica".

Para Foucault, el discurso del siglo XVII se mueve también dentro de esta episteme clásica. En el "pienso luego soy" se sigue anudando la relación entre representación y ser. La representación identifica el ser humano y el ser representacional es un ser que existe dentro de la cadena de otros seres. Si existe el ser humano es porque

1283 "En efecto, por el poder que detenta de duplicarse (en la imaginación y el recuerdo, y la atención múltiple que compara), la cadena de las representaciones puede reencontrar, por debajo del desorden de la tierra, la capa sin ruptura de los seres; la memoria, en principio azarosa y entregada a los caprichos de las representaciones tal como estas se ofrecen, se fija poco a poco en un cuadro general de todo lo que existe; entonces, el hombre puede hacer entrar al mundo en la soberanía de un discurso que tiene el poder de representar su representación". Id., pág. 301.

${ }^{1284}$ HEGEL, F., Fenomenología del Espíritu, pág. 505; cfr. TAYLOR, Ch., Argumentos filosóficos, págs. 20-42; cfr. FOUCAULT, M., Las palabras y las cosas, pág. 301. 
es capaz de representar, y si representa es porque nombra en su poder representacional, formando parte de la gran cadena de ser. Se representa lo que es y es lo que existe como espíritu representacional. ${ }^{1285}$ Taylor habla de la superación del orden ontológico de la gran cadena del ser a partir de la teoría de la ley natural lockeana del siglo XVII. Se deja atrás el viejo cosmos de la Idea y la Forma que funciona en la realidad, para considerar el universo de las naturalezas creado de manera tal que, en la acción de satisfacer sus necesidades, sus actividades se entraman, se apoyan y se ayudan mutuamente. ${ }^{1286}$

Sin embargo, con el siglo XIX el hombre es el que configura en exclusividad el orden de la naturaleza, sin otra referencia que él mismo; por eso se puede afirmar que el hombre del siglo XIX se piensa a sí mismo a partir de una analítica de la finitud y de la ciencia biológica. ${ }^{1287}$ En la episteme clásica, el hombre se conocía desde la naturaleza que le identificaba. Y él, a su vez, representaba el mundo del que formaba parte. Ahora el hombre es objeto de estudio a partir de sí mismo y es sujeto que representa el mundo, pero a partir de sí mismo, no formando parte de ningún orden metafísico. El mundo es finito y él es una especie más entre otras especies. Charles Taylor considera que con el siglo XIX existe la sensación de que el ser ha quedado aislado de las corrientes superiores de significado. ${ }^{1288}$

Por eso, el orden se trastoca, porque el hombre no representa ningún orden del ser, sino que es el ser el que representa un mundo finito, sin ninguna ruptura o diferencia enmarañada. Todo evoluciona y el hombre es una parte más de esa evolución. De una gran cadena del ser se pasa a una gran evolución biológica de las especies en la que el hombre no está autorizado para formar un orden especial, consagrado a recibirle y en el que solo podría reclamar, como afirma Darwin, un suborden o una familia distinta. ${ }^{1289}$ Ahora el hombre forma parte de un mundo finito que es capaz de representar tal y como hemos visto en Schopenhauer. El hombre es el que representa el mundo y el mundo es lo que el hombre representa mentalmente. No hay ninguna otra referencia metafísica que el hombre mismo. El hombre se autodefine. ${ }^{1290}$ Por eso el siglo XIX es el siglo en el que el hombre se piensa a sí mismo por primera vez, aunque, en opinión de Taylor, se intente retener algún vestigio de trascendencia a través de una religión arnoldiana entendida como moral tocada por la emoción o una creencia en Dios como una fuerza

\footnotetext{
1285 "No puede objetarse a este paso ni que el ser en general no está contenido en el pensamiento ni que el ser particular tal como es designado por el "soy' no ha sido interrogado ni analizado por sí mismo". FOUCAULT, M., Las palabras y las cosas, pág. 303.

${ }^{1286}$ Cfr. TAYLOR, Ch., La Era Secular, tI, págs. 210,330.

${ }^{1287}$ Cfr. TAYLOR, Ch., Imaginarios sociales modernos, pág. 204.

${ }^{1288}$ Cfr. TAYLOR, Ch., La Era Secular, tII, pág. 107.

${ }^{1289}$ Cfr. DARWIN, Ch., El origen del hombre, pág. 152.

${ }^{1290}$ Cfr. TAYLOR, Ch., Hegel, pág. 5.
} 
impersonal. ${ }^{1291}$ No obstante, nada evita esa enorme sensación de escisión, vacío y pérdida. $^{1292}$

De la metafísica de la representación y del infinito, se pasa, en el siglo XIX, al análisis de la finitud. El hombre se convierte así en una especie más de la larga evolución biológica de seres (no en la gran cadena del ser en la que el hombre ocupa la cúspide de la pirámide), y en la que los demás seres le designan y requieren de él que ordene representacionalmente esta búsqueda genealógica en la que todos están conectados por vínculos biológicos. El hombre, en su capacidad representacional, ya no es el lugar en el que confluyen representación y ser, como en la episteme clásica, sino el lugar en el que se requiere de él que establezca los vínculos de una relación exterior de carácter biológico entre unos y otros. La ontología ha devenido en biología. El hombre es un cuerpo más entre otros muchos, un cuerpo con capacidad mental, y en su identidad biológica establece representacionalmente relaciones con otros seres con sus propias características biológicas. Según Foucault, la representación no confiere orden en el ser, sino orden en la biología que evoluciona en un mundo finito. La finitud no deja de referirse a sí misma. La metafísica del infinito se torna innecesaria. ${ }^{1293}$

En otros términos, Taylor habla del siglo XIX como el siglo en el que se produjo el "cisma moderno": un giro contra los valores de la Ilustración, denominada "contraIlustración externa", alimentada por las tradiciones que la Ilustración relegaba a la zona de la ilusión; y otra "contra-Ilustración inmanente" que comparte e intensifica este rechazo del pasado a través del sobrecogimiento ante el surgimiento de la conciencia y sensibilidad humana del seno de las profundidades del universo material. ${ }^{1294}$ Una contra-Ilustración inmanente en la que, según Taylor, Nietzsche se rebela contra la afirmación moderna de la vida misma basada en la bondad de la vida ordinaria, la producción y la familia y que entronca con el Cristianismo. ${ }^{1295}$ Nietzsche y Freud reivindican la superación de la benevolencia, la armonía y el orden, y proponen la destrucción, el caos, la fuerza vitalista e incluso esa moral del honor guerrero de talante

\footnotetext{
1291 "La representación dejó de tener valor, con respecto a los seres vivos, las necesidades y las palabras, como su lugar de origen y sede primera de su verdad. (...) En la representación, los seres no manifiestan ya su identidad, sino la relación exterior que establecen con el ser humano. Este, con su ser propio, con su poder de darse representaciones, surge en un hueco creado por los seres vivos, los objetos de cambio y las palabras cuando, al abandonar la representación que había sido hasta ahora su lugar natural, se retiran a la profundidad de las cosas y se vuelven sobre sí mismos de acuerdo con las leyes de la vida, de la producción y del lenguaje. En medio de todos ellos, encerrado por el círculo que forman, el hombre es designado — mejor dicho, requerido— por ellos, ya que es él el que habla." FOUCAULT, M., Las palabras y las cosas, págs. 304-305.

${ }^{1292}$ Cfr. TAYLOR, Ch., La Era Secular, tII, págs. 110-111.

${ }^{1293}$ Cfr. FOUCAULT, M., Las palabras y las cosas, pág. 308.

${ }^{1294}$ Cfr. TAYLOR, Ch., La Era Secular, tII, págs. 120,129.

${ }^{1295}$ Cfr. TAYLOR, Ch., La ética de la autenticidad, pág. 130; cfr. TAYLOR, Ch., Fuentes del yo, Cap. 13; cfr. TAYLOR, Ch., La Era Secular, tII, págs. 128-129,153-167.
} 
platónico y precristiano. Se trata de una afirmación de la vida que va más allá de la vida misma y ensalza la negación de la vida, la muerte y el sufrimiento. ${ }^{1296}$

El fin del siglo XIX (fin-de-siècle) se caracteriza por el pesimismo que embarga el ánimo social, una sensación de que falta algo. Taylor considera que la angustia por el sentido de la vida es típicamente moderna; angustia que posibilita que haya distintas opciones disponibles ante este estado de ánimo que aglutina a muy distintos estamentos sociales: una vuelta a la religión, una búsqueda del fundamento en filosofías de la afirmación de uno mismo en clave nietzscheana, un compromiso en la política y finalmente una exploración en el mundo del arte y la estética. ${ }^{1297}$ Todas estas salidas expresan tipos de lenguaje que marcan la expresividad humana para recuperarse desde dentro y al margen de cualquier compromiso óntico, sea de la Naturaleza, la Voluntad o Dios. $^{1298}$

La última salida, la que reivindica el arte y la estética, es quizás la que despierta mayor interés. Es el inmenso poder de lo bello para ampliar horizontes en tiempos de escasez, de falta de algo. Este es el legado de los escritores románticos que buscan en el trato con uno mismo sus ideas, más que en las autoridades o en las ideas de otros. ${ }^{1299} \mathrm{El}$ arte es para ser descubierto a partir de sus virtualidades evocadoras de la sensibilidad humana, conscientes de que allí donde la ciencia amplía sus horizontes, las fronteras del arte se reducen. El arte debe avanzar por los horizontes de la imaginación y la libertad de espíritu. La ciencia y la razón deben dejar espacios para la creatividad y la expansión espiritual. Para Taylor, el juego con la belleza schilleriana posibilita avanzar hacia una unidad superior en clave hegeliana, una reconciliación entre naturaleza, razón y libertad. $^{1300}$

El camino del arte permite solucionar muchos problemas y acceder a experiencias únicas. Muchos problemas de convivencia social y política pueden ser solucionados por

\footnotetext{
${ }^{1296}$ Se ha pasado del desencantamiento del mundo del siglo XVII, al giro antropocéntrico del siglo XVIII en el que Dios empieza a desvanecerse (deísmos) hasta llegar al siglo XIX en el que la no-creencia se expande en el oscuro abismo del tiempo. Es lo que Taylor denomina como la Nova, es decir, la proliferación de opciones nuevas en torno a la polémica entre la creencia y la no creencia en los siglos XIX y XX.

${ }^{1297}$ Cfr. TAYLOR, Ch., La Era Secular, tII, pág. 128.

${ }^{1298}$ Cfr. TAYLOR, Ch., Hegel, págs. 5-6; cfr. TAYLOR, Ch., Fuentes del yo, págs. 661-662. Para Taylor, dentro de estas filosofías neonietzscheanas, están dos autores a tener en cuenta: Foucault y Derrida. Ambos filósofos han asumido su desconfianza hacia la supuesta unidad de la transparencia del ser desvinculado o hacia las supuestas fuentes internas del yo expresivo o hacia la apertura hacia la epifanía. Y al mismo tiempo, ambas filosofías renuncian a toda noción del bien en su búsqueda de la fuerza y la libertad potencial del yo. En todo caso, tal y como afirma Taylor, se avanza hacia un socavamiento de las jerarquías, hacia un mundo de iguales en reconocimiento mutuo, aunque la deconstrucción impida afirmar algo, dado que lo único que nos define es el propio poder deconstructivo de sí mismo y ser pura libertad no obstaculizada.

${ }^{1299}$ Cfr. SCHILLER, F., Cartas sobre la Educación estética del hombre, Acantilado, Barcelona, 2018, pág. 7.

${ }_{1300}$ Cfr. TAYLOR, Ch., Fuentes del yo, pág. 585.
} 
la vía estética, porque el camino de la belleza conduce a la libertad. La belleza es un reclamo para liberar el espíritu y recrearlo en experiencias de nuevas posibilidades creadoras a nivel moral. No hay libertad que no surja de una motivación espiritual por la belleza moral. La belleza espiritual expande el espíritu hacia la belleza moral expresada como libertad.

Si la belleza nos relaciona con la razón y la libertad, además de lo estético en su dinamismo ético a través de lenguajes sutiles, hay otro aspecto que los autores románticos nos ayudaron a comprender en relación con la naturaleza: la naturaleza es una fuerza que se dirige a lo más profundo que hay en nosotros y que facilita la comprensión de lo que somos. La naturaleza humana se siente "tocada" por la fuerza de la naturaleza física. La naturaleza nos pone en relación con una fuerza que reside en lo más profundo de nosotros, se introduce en nuestros dominios espirituales y nos transmite toda su fuerza, como si nuestro espíritu y el espíritu de la naturaleza tuvieran extraños y misteriosos vínculos de comunión afectiva. Nuestro espíritu "se vuelve" hacia la naturaleza como si de una fuerza irrefrenable se tratase. ${ }^{1301}$

En este sentido, Taylor afirma que la única manera en que cabe explorar el orden en que nos hallamos, con objeto de definir las fuentes morales, es a través de la resonancia personal, la fuerza que late en nuestras profundidades. ${ }^{1302}$ Pero, por otra parte, Taylor no olvida las fuentes teístas y su gran esperanza la encuentra en la tradición judeo-cristiana y en su promesa central de una afirmación divina de lo humano, más plena que la que los humanos jamás podrían alcanzar por sí solos. ${ }^{1303}$

\footnotetext{
${ }^{1301}$ Cfr. TAYLOR, Ch., Hegel, págs. 476-495, 498-499; cfr. TAYLOR, Ch., El multiculturalismo y la política del reconocimiento, págs. 47-49.

${ }_{1302}$ Cfr. TAYLOR, Ch., Fuentes del yo, pág. 691.

${ }^{1303}$ Cfr. Ibid., pág. 703.
} 
IV.-UN PROYECTO PARA LA RECONSTRUCCIÓN DE LA IDENTIDAD SECULAR MODERNA 
Después de haberse centrado durante años en el estudio de los fundamentos morales e históricos de la Modernidad, Taylor se adentró en uno de los aspectos clave de dicha identidad: la secularidad o lo que él define como "una era secular". Una secularidad que se remonta ya a los estudios de Durkheim y Weber, y también, más recientemente, a los de Luckman y Berger, entre otros. Para Taylor, la secularidad tiene tres sentidos:

1.- Secularidad en relación a los espacios públicos. La secularidad ha vaciado estos espacios de referencias a Dios o a realidades últimas. Dios ha dejado de estar presente en gran parte de prácticas sociales y en todos los niveles de la sociedad. Las deliberaciones en las que participamos no nos remiten a Dios ni a ninguna creencia religiosa. ${ }^{1304}$

2.- Secularidad en relación a las creencias y prácticas religiosas. La secularidad ha llevado a un declive en dichas prácticas y a un alejamiento de las creencias y prácticas promovidas por la Iglesia. ${ }^{1305}$

3.- Secularidad en el sentido del paso de una sociedad en la que la fe en Dios era incuestionable, a una sociedad en la que esa fe es una opción entre otras.1306 La fe religiosa ha sido desplazada como fuente moral predominante y se ha desarrollado una nueva situación de pluralidad de fuentes. ${ }^{1307}$

Este último sentido de la secularidad es el que interesa a Taylor. Se trata de una secularidad en la que se entremezclan una gran variedad de elementos distintos y a la que Taylor tratará de dar una explicación congruente, no dando por concluido ningún análisis e intentando abrir horizontes que intenten profundizar en una situación ciertamente compleja y que no es fácil de comprender. ${ }^{1308}$

Taylor se propone analizar cómo se ha llegado hasta aquí en apenas cinco siglos y estudiar filosóficamente el paso de una sociedad en la que prácticamente era imposible no creer en Dios, a una sociedad en la que la fe es apenas una posibilidad más entre otras muchas. Su obra La Era Secular está llena de sugerencias, en la que se entrelazan, con gran sutileza y dramatismo, elementos históricos, filosóficos, morales y religiosos que han desencadenado en la sociedad actual, caracterizada por la secularidad.

\footnotetext{
${ }^{1304}$ Cfr. TAYLOR, Ch., La Era Secular, tI, pág. 17; TAYLOR, Ch., Imaginarios sociales modernos, págs. 214-215.

${ }^{1305}$ Cfr. TAYLOR, Ch., La Era Secular, tI, pág. 18; cfr. TAYLOR, Ch., Argumentos filosóficos, págs. 179,182 .

${ }^{1306}$ Cfr. TAYLOR, Ch., La Era Secular tI, pág. 22.

${ }^{1307}$ Cfr. TAYLOR, Ch., Fuentes del yo, pág. 462; cfr. TAYLOR, Ch., La Religión hoy, pág. 74.

${ }^{1308}$ Cfr. TAYLOR, Ch., Dilemmas and Connections, págs. 216,226,228,236,262,265,308.
} 
J. Casanova la ha definido como el mejor estudio analítico, fenomenológico y genealógico que poseemos de nuestra condición moderna secular. ${ }^{1309}$

Si a Charles Taylor se le considera como el que ha hecho una síntesis más lograda, compleja y comprensiva sobre la edad moderna en su condición secular, pretendemos que este estudio contribuya a clarificar sus objetivos y a hacer más relevante su actualidad. Cuando se han realizado tantos estudios sobre los cambios sociales y culturales en nuestras sociedades occidentales, sin duda alguna era una anomalía intelectual que un tema tan relevante como el de la secularidad no se hubiera abordado con esta hondura intelectual, superando los límites teológicos de su significación y analizando comprensivamente todos los elementos desde los que comprenderlo adecuadamente. ${ }^{1310}$

Son muchos los autores que han admitido la superación de las teorías secularizadoras y se han abierto a nuevos campos y horizontes de investigación. ${ }^{1311}$ En este sentido, el profesor Diego Bermejo, entre otros muchos, invita a repensar el concepto de secularización. Un concepto que reivindicó para sí la interpretación exclusiva y radical de erigirse en el paradigma interpretativo exclusivo de la Modernidad. ${ }^{1312}$ Para Bermejo, si la secularización puso en crisis la religión e incluso su pervivencia, el resurgimiento de las religiones ha puesto en crisis el concepto de la secularización. Por otra parte, no es aventurado afirmar que puede haber un diálogo entre la secularidad moderna y la religión a partir de una relación abierta y adecuada entre razón y fe, entre religión y democracia o entre ciencia y fe. ${ }^{1313}$

\footnotetext{
1309 "Charles Taylor's A Secular Age offers the best analytical, phenomenological, and genealogical account we have of our modern, secular condition. By 'best' I mean that it is simultaneously the most comprehensive, nuanced, and complex account I know. Analytically, it explains with distinct clarity the structural interlocking constellation of the cosmic, social, and moral orders that constitute the selfsufficient immanent frame within which we are constrained to live and experience our lives, secular as well as religious". CASANOVA, J., “A Secular Age: Dawn or twilight?", GEM 6125-10, (2009), pág. 265.

${ }^{2310}$ Cfr. TAYLOR, Ch., El poder de la Religión en la esfera pública, págs. 54-55.

1311 "My point is that the assumption that we live in a secularized world is false. The world today with some exceptions which I will come presently, is as furiously religious as it was, and in some places, more than ever. This means that a whole body of literature by historians and social scientists loosely lebeled 'secularization theory' is essentialy mistaken. (...) To be sure modernization has had some secularizing effects, more in some places than in others. But it has also provoked powerful movements of countersecularization. Also, secularization on the societal level is not necessarily linked to secularization on the level of individual consciousness". BERGER, P., The Desecularization of the World, Ethics and Public Policy Center and Eerdmans Publishing Co, Washington, 1999, pages 2-3.

1312 "Lo que la teoría de la secularización pone sobre la mesa es, en términos generales, falso y, en términos regionales, sinónimo de la deseuropeización del cristianismo, o quizá mejor, de la descristianización de Europa. Se habla desde hace años en el mundo académico del 'final de la teoría de la secularización' (Joas), 'fin de la secularización en Europa' y 'desecularización' (Kaufmann), o lo que también podríamos denominar la 'desoccidentalización de la secularización', entre otras expresiones, a las que viene a sumarse recientemente la de 'sociedad postsecular' (Habermas)". BERMEJO, D., "Repensar la secularización”, Pensamiento, Vol. 70, No 263, (2014), pág. 342.

${ }^{1313}$ Cfr. TAYLOR, Ch., La Era Secular, tII, págs. 425-438.
} 
Casanova, por otra parte, afirma que la función del secularismo, como filosofía de la historia, pretende convertir el proceso histórico de secularización del Cristianismo occidental en un proceso teleológico universal del desarrollo humano desde la creencia a la increencia, desde la religión primitiva irracional a la moderna conciencia secular, racional y postmetafísica. ${ }^{1314}$

La secularización radical y estándar pensaba que el proceso de secularización del Cristianismo occidental tenía alcance universal y era el principio de una dinámica que conduciría a la humanidad de la creencia a la increencia, de la metafísica a la postmetafísica, de lo irracional a lo racional. Sin embargo, en la actualidad, tal y como afirma Habermas, la mayoría de los sociólogos de la religión ponen en duda la intrínseca relación entre Modernidad y secularización.

Taylor sostiene que lo propio de la secularización europea, cuando se la compara con el resto del mundo, es el triunfo del secularismo como ideología, como cosmovisión generalizada, como conocimiento dado por supuesto, como algo no pensado. ${ }^{1315}$

Según el profesor Casanova, conviene distinguir tres términos para fundamentar adecuadamente el alcance de lo que pretendemos afirmar. El primer término es "secular", un concepto que tiene que ver con la capacidad del ser humano para codificar y experimentar una realidad diferenciada de lo religioso; el segundo término es "secularización", que expresa este proceso de pérdida de relevancia de lo religioso que se manifiesta en la transformación y diferenciación de las estructuras religiosas y seculares como parte de un desarrollo progresivo y teleológico de las sociedades modernas desde lo primitivo sagrado a lo moderno secular; y el tercer término es "secularismo", que expresa una ideología, una cosmovisión que se da por hecho, como doxa, como algo no pensado, porque es asumido como tal por su propia fuerza epistemológica. ${ }^{1316}$ Para Casanova, Taylor afronta con profundidad y detallado análisis un estudio fenomenológico de las condiciones seculares de la creencia, así como del contexto en el que se ubica la cosmovisión preontológica, con vistas a definir con exactitud el proceso de cambio de una sociedad cristiana a una sociedad postcristiana en la que la creencia es una opción entre otras muchas. ${ }^{1317}$

Según Taylor, la falta de fe se ha convertido, para muchos, en la principal opción por omisión. Una transformación que es definida por nuestro hermeneuta como "la gran invención de Occidente", esto es, el planteamiento novedoso de un orden inmanente a la

\footnotetext{
${ }^{1314}$ Cfr. CASANOVA, J., Five lectures in the Sociology of Religion, Renmin University, Beijing, 2010, pág. 110.

${ }^{1315}$ Cfr. TAYLOR, Ch., La Era Secular, tI, págs. 38-39; cfr. BERMEJO, D., "Repensar la secularización", pág. 345.

${ }^{1316}$ Cfr. CASANOVA, J., "The Secular and secularisms”, Social Research, Vol. 76, No 4 (2009), págs. 1049-1050.

${ }^{1317}$ Cfr. CASANOVA, J., “A Secular Age: ¿Dawn or twilight?”, págs. 265-266.
} 
naturaleza. ${ }^{1318}$ Se establece dicho orden como humanismo exclusivo, quedando abiertas dos posibilidades. La primera admite un Creador trascendente más allá de dicho orden inmanente, al fondo, como referente último, con una significación más o menos ambigua. La segunda pretende dejar asentada la idea de que la religión es una opción problemática y que por lo tanto debe ser aislada cualquier visión transcendente o cualquier forma de interrelación entre las cosas de la Naturaleza y lo sobrenatural. ${ }^{1319}$

Esta es la "invención de Occidente" explicada en clave secularizadora: la aparición de la inmanencia como puerta que deja abierta la posibilidad al descubrimiento de un orden intrínseco a la realidad propia, más allá de cualquier otra explicación trascendente o mágica. Esta invención racionalizadora da la confianza suprema a la mente como puerta abierta al descubrimiento de un orden racional dentro de la propia realidad de las cosas, como una pregunta que deja siempre abierta la posibilidad de la sospecha y la duda, o que abre a un horizonte siempre por descubrir. Esta será la clave: el descubrimiento de las posibilidades que se hallan escondidas en el interior de la inmanencia, de la naturaleza propia de las cosas tal y como aparecen ante nosotros, no como negación primera de la trascendencia, pero sí como camino abierto a un proceso encaminado hacia la posibilidad de un humanismo exclusivo. Este es el exclusivismo humanista al que Taylor se refiere como la secularización, entendida como algo que se da por hecho, como un impensado y a la vez como algo que se instaló sigilosamente. ${ }^{1320}$ Para Taylor, con la era de la autenticidad, la religión empezó a ser identificada como enemiga de la autonomía y de la libre búsqueda del propio yo. ${ }^{1321}$

La pregunta inicial del libro La Era Secular era la siguiente: ¿Por qué en nuestra sociedad occidental era virtualmente imposible no creer en Dios en el año 1500, por ejemplo, mientras que en el 2000 eso no solo no es fácil para muchos de nosotros, sino incluso inevitable? ${ }^{1322}$ Pregunta sobre la que está centrada la presente investigación doctoral guiados por la sabiduría hermenéutica de Taylor.

\section{IV.1.-EL NUEVO ORDEN MORAL DE LA MODERNIDAD}

El final del siglo XVIII fue testigo de la emergencia del humanismo exclusivo como alternativa viable al Cristianismo. Fue el principio de lo que Taylor denomina "efecto nova" con la aparición de esa diversidad de opciones de no creencia a lo largo del siglo XIX y que llega hasta hoy. ${ }^{1323}$ Van surgiendo los relatos de la secularización, de la era de la autenticidad y el marco inmanente como el contorno espiritual del

\footnotetext{
${ }^{1318}$ Cfr. TAYLOR, Ch., La Era Secular, tI, pág. 41.

${ }^{1319}$ Cfr. TAYLOR, Ch., Hegel, pág. 67.

${ }^{1320}$ Cfr. TAYLOR, Ch., La Era Secular, tI, pág. 46.

${ }^{1321}$ Cfr. TAYLOR, Ch., La Era Secular, tII, pág. 285.

1322 Cfr. TAYLOR, Ch., La Era Secular, tI, pág. 55.

${ }^{1323}$ Cfr. TAYLOR, Ch., La Era Secular, tII, pág. 197.
} 
presente. Para Taylor es muy importante ver en qué consiste este cambio en el que, si en el año 1500 era casi imposible no creer en Dios, hoy, creer en Dios se ha vuelto una realidad problemática para una gran mayoría de personas, llegándose incluso a manifestar un malestar en gran parte de los creyentes. ${ }^{1324}$

I.- Taylor habla de desencantamiento del mundo actual. Un desencantamiento de un mundo en el que Dios era una realidad connatural con la vida y el pensamiento del hombre, cambiando a un mundo impermeabilizado a realidades superiores y en el que todo debe pasar por el tribunal de la razón. Se pasa de un yo poroso, abierto a cualquier explicación espiritual o trascendente de la realidad, a un yo cerrado, en el que la fundamentación del mundo moral y la identidad del yo se expresa a través de la mente y de la autodefinición reguladora. Un yo impermeabilizado como expresión de la diferenciación cartesiana entre la Mente y el Mundo, entre lo interior y lo exterior como loci aislados. $^{1325}$

La identidad del yo se expresa tanto como racionalismo ilustrado, como expresividad romántica extasiada con la naturaleza. Surge un yo radicalizado en dos versiones distintas y casi contrapuestas: "yo ensimismado" en la contemplación del mundo como pura objetividad mecánica y neutra, y, por otra parte, como reacción a esta representación subjetiva del mundo como fenómeno, un "yo romántico" que invita a recuperar el propio mundo interior como búsqueda herderiana de "lo propio de cada uno" y a la ética de la autenticidad. El "yo impermeabilizado" como identidad que se autodefine a partir de la propia construcción del mundo y un "yo bondadoso por naturaleza" que resalta el éxtasis contemplativo del orden natural en su inmanencia expresiva. En ambos casos se ha avanzado hacia el desencantamiento y la desmagificación del mundo y se ha pasado al "encantamiento" del yo como profundidad de la psique. ${ }^{1326}$

Taylor comenta la gran obra de Norbert Elias como un estudio que permite ahondar en el "proceso civilizador" que significa el paso del mundo de los sentimientos y pasiones al mundo del psiquismo, la racionalización y la observación neutral del mundo. ${ }^{1327}$ Un mundo como contención de los instintos y una personalización del yo a través del psiquismo, la interioridad racional y el autodominio disciplinado. ${ }^{1328}$ Todo queda reducido a una sucesión encadenada de causalidades autónomas.

\footnotetext{
${ }^{1324}$ Cfr. Ibid., pág. 297.

1325 Cfr. Ibid., págs. 14-15,17,19,39,69,72,104,110,182,282,302,381,383,395,420,489,601,646.

${ }^{1326}$ Cfr. TAYLOR, Ch., Fuentes del yo, pág. 670; WEBER, M., El político y el científico, pág. 200.

1327 Cfr. TAYLOR, Ch., Fuentes del yo, pág. 676.

${ }^{1328}$ Cfr. ELIAS, N., El proceso de la civilización, pág. 485. Con la libertad vienen también los límites y controles que permiten desplegar la fuerza del yo y al mismo tiempo poner ciertos contornos disciplinarios. Esto es lo que estudia también Taylor a partir de la obra de Michel Foucault Vigilar y Castigar. El castigo deja de ser un teatro y se establece un proceso disciplinario de carácter administrativo y racional. Es lo que vemos en este texto de M. Foucault. "La ejecución pública se percibe ahora como un
} 
Con la libertad, vienen también los límites y controles que permiten desplegar la fuerza del yo y, al mismo tiempo, poner ciertos contornos disciplinarios, como afirma M. Foucault en su obra sobre la evolución del castigo disciplinario. Según Elias, se abandona la promiscuidad en las relaciones sociales para pasar a una visión más disciplinada de la intimidad. Las cosas se empiezan a entender "a largo plazo" y se supera la inmediatez de las emociones a través de la observación desapasionada que pasa por la objetivización tanto del yo como de las sociedades. ${ }^{1329}$

Los órdenes sociales de la Modernidad no expresan un sentido racional del cosmos ni un fundamento preexistente, sino que cada uno se incorpora a la sociedad como individuos, con una vocación natural de compromiso en la búsqueda del bien común; lo que Elias denomina "individuo en una situación social", bien a partir de nuestro compromiso individual (Locke, Bentham) o enfatizando la dimensión de búsqueda compartida (Rousseau, Hegel, Marx, Humboldt). ${ }^{1330}$ Para Taylor, muchos pretenden configurar dichos órdenes sociales a partir de un orden inmanente autosuficiente, en el que lo que nos convoca es una simpatía innata por todos los seres humanos y nuestro apego a una libertad racional que nos muestra cómo debemos comportarnos. Otros, sin embargo, afirma Taylor, prefieren vivir el marco inmanente como abierto a algo más. ${ }^{1331}$ Inmanencia y trascendencia no tienen por qué ser vistos como polos opuestos.

Taylor resume esta compleja situación con tres palabras que se entrelazan y refuerzan mutuamente: impermeabilidad, disciplina e individualidad, palabras que encuentran en torno a la Reforma un refuerzo de alcance inimaginable. Todo adquiere un compromiso de espiritualidad renovada en referencia a lo que Taylor denomina individualismo de la responsabilidad. ${ }^{1332}$ Se trata de asumir una decisión responsable, impulsada por una espiritualidad más cristocéntrica, más implicada y asumida por todos, de tal forma que termina por hacer casi incomprensibles las viejas visiones del logos óntico y del orden cristiano asociado al honor y al furor guerrero en un contexto social determinado. ${ }^{1333}$

foco en el que se reanima la violencia. El castigo tenderá, pues, a convertirse en la parte más oculta del proceso penal (...) es la certidumbre de ser castigado, y no ya el teatro abominable, lo que debe apartar del crimen; la mecánica ejemplar del castigo cambia sus engranajes". FOUCAULT, M., Vigilar y Castigar: el nacimiento de la prisión, Siglo Veintiuno, 1976, págs. 11-12.

1329 "Esta capacidad para entender a largo plazo las cosas de la naturaleza y de los seres humanos, solamente es accesible a los individuos en la medida en que la división creciente de funciones y el entramado cotidiano en cadenas humanas cada vez más largas, acaban acostumbrándoles a esta previsión a largo plazo, a una mayor contención de las emociones”. ELIAS, N., El proceso de la civilización, pág. 485.

${ }^{1330}$ Ibid., pág. 480; cfr. TAYLOR, Ch., Hegel, pág. 471.

${ }^{1331}$ Cfr. TAYLOR, Ch., La Era Secular, tII, pág. 302.

1332 Cfr. TAYLOR, Ch., La Era Secular, tI, págs. 142,185.

1333 "El furor guerrero era aquí un presupuesto necesario para el éxito y el prestigio del aristócrata. Todo esto cambia con la consolidación progresiva de los monopolios y con la centralización”. ELIAS, N., El 
Taylor considera que hay un proceso desde el primer individualismo "de largo alcance" (Elias) que surge de la introspección y pasa por el desarrollo personal, hasta llegar al ideal de la autenticidad. Desde el primer individualismo se evoluciona a un individualismo instrumental de la "jaula de hierro", según el cual la sociedad existe para el bien de los individuos que buscan vivir en autenticidad con lo que cada uno es y piensa. Una autenticidad que consiste en ser fieles a lo propio de cada uno, a nosotros mismos, pero a partir de una relación articulada con un todo más amplio. ${ }^{1334}$ Es el proceso de transición desde una visión de la naturaleza llena de fuerzas intencionales a partir de la razón sustantiva fundamentadora del Bien, a un mundo como proyecto para la razón instrumental que implica la acción constructiva del hombre a partir de la nueva ciencia. $^{1335}$

El establecimiento de dicho marco inmanente surge, según Taylor, como un logro de la cristiandad latina a finales de la Edad Media y principios de la Edad Moderna, que pretendía asegurar la autonomía de lo sobrenatural asegurando el poder soberano de Dios frente a las posturas "realistas" de Tomás de Aquino. Para Ockham, representante del Nominalismo, el universal es particular en cuanto que es algo que existe en la mente, pero es universal en cuanto es signo de muchos. Una rebelión nominalista que no acepta explicaciones sobre el bien y el mal que tengan que ver con inclinaciones de la naturaleza y así poder resaltar el poder absoluto de Dios. De igual manera, los Reformadores protestantes, intentarán asegurar y dar continuidad a esta separación entre el orden de la naturaleza y el orden de la gracia. Separación que llevará a desencantar el mundo y a dar autonomía a las realidades del mundo y de la sociedad. ${ }^{1336}$

Por otra parte, el auge e influjo de la ciencia postgalileana, influirá mucho, asimismo, en este empuje secularizador, que planteará una explicación del mundo que no necesita en un primer nivel de comprensión, de explicaciones metafísicas sobre la Idea platónica o la Idea de la Mente de Dios. Una ciencia que pretenderá, a partir de Bacon, explicar el mundo experimentalmente a través de observaciones detalladas y validadas de manera inductiva, superando cualquier idea preconcebida sobre el mismo. ${ }^{1337}$

Y aunque la ciencia no interfiriera en principio en admitir la idea de un Creador benévolo, sin embargo, sí que preparó, junto con las otras causas referidas anteriormente, un marco general que prepararía el camino para un humanismo exclusivo sin referentes trascendentes a partir de este individuo impermeabilizado y este mundo

\footnotetext{
proceso de la civilización, pág. 491.

${ }^{1334}$ Cfr. TAYLOR, Ch., Fuentes del yo, pág. 676; cfr. TAYLOR, Ch., La ética de la autenticidad, pág. 120.

${ }^{1335}$ Cfr. TAYLOR, Ch., La Era Secular, tII, pág. 308.

${ }^{1336}$ Cfr. TAYLOR, Ch., La Era Secular, tII, págs. 15,222,227,493.

${ }^{1337}$ Cfr. TAYLOR, Ch., La Era Secular, tI, págs. 163,188; cfr. TAYLOR, Ch., Argumentos filosóficos, págs. 74,77,85-86.
} 
desencantado referido solo a la razón instrumental y un nuevo contexto social en el que la interpretación de la sociedad era referida a leyes de pura objetivación y eficacia colectiva. ${ }^{1338}$ Taylor habla, en este sentido, de cómo la visión puritana del trabajo y la vida ordinaria contribuyeron de manera definitiva al desarrollo de la ciencia baconiana, y que unos y otros se veían en oposición a la visión tradicional y a la doctrina muerta que habían recibido. ${ }^{1339}$

Taylor analiza con detenimiento cómo la visión de la naturaleza se va reconfigurando hacia un orden inmanente de carácter exclusivo. Al principio este orden inmanente de la naturaleza se ve como autosuficiente, alojándose la posibilidad de entenderlo sin referencia a Dios, debido a que la propia Naturaleza diseña y configura dicho orden. Esta posibilidad del orden de la naturaleza como autosuficiente e inmanente, en un principio, no implica negar la existencia del Dios Creador y Artífice de la Naturaleza. Pero, siguiendo a Spinoza, se llega a plantear la posibilidad de identificar a la Naturaleza con Dios, posibilitando así una independencia de esta respecto a su Creador, con lo que el orden puede carecer de Ordenador y el plan de Planificador.

Taylor considera que se está configurando un relato filosófico, según el cual, un espectador imparcial muestra simpatía innata hacia todos los seres humanos a través de un proyecto de fraternidad universal y se deja guiar por una libertad racional que nos establece moralmente en la búsqueda de un comportamiento adecuado.

Todos, bien como individuos o como sociedades, se ven forzados a actuar de acuerdo a las exigencias de la razón instrumental moderna, se ajuste o no a nuestra perspectiva moral. ${ }^{1340}$ Este camino ofrece un recorrido inmanentista, pero no tiene por qué llegar a cerrarse completamente. Taylor afirma que el orden inmanente no tiene motivo para cerrarse al orden trascendente. Son miradas llamadas a complementarse, a enriquecerse mutuamente y a establecer caminos de cooperación y diálogo que ofrecen un futuro insospechado de nuevas perspectivas por explorar, siempre y cuando ambos órdenes permanezcan abiertos al encuentro y a la interacción. Descubrir el orden moral como "voz interior" no implica negar las fuentes trascendentes del bien y del mal. ${ }^{1341}$ Taylor asegura que se han borrado tantos bienes de nuestro relato oficial, se ha sepultado tanto su poder bajo capas de racionalismo filosófico, que corre el peligro de asfixiarse. $^{1342}$

\footnotetext{
${ }^{1338}$ Cfr. TAYLOR, Ch., La Era Secular, tI, págs. 46,57,79,112,144,164,211,351,371,383; cfr. TAYLOR, Ch., Dilemmas and Connections, págs. 172-173,177-178,181-184,186-187.

${ }^{1339}$ Cfr. TAYLOR, Ch., Fuentes del yo, pág. 314.

${ }^{1340}$ Cfr. TAYLOR, Ch., La Era Secular, tII, pág. 302; cfr. TAYLOR, Ch., La Era Secular, tI, pág. 456; cfr. TAYLOR, Ch., La ética de la autenticidad, pág. 124.

${ }^{1341}$ Cfr. TAYLOR, Ch., El multiculturalismo y la política del reconocimiento", págs. 47 y ss.

${ }^{1342}$ Cfr. TAYLOR, Ch., Fuentes del yo, pág. 702.
} 
II.- Lo que Taylor quiere analizar va más allá de un mero análisis de la teoría sociológica. Pretende realizar un estudio de esas imágenes que van configurando la realidad social, los elementos que van determinando las relaciones sociales y el entramado social que va siendo expresión de las fuentes morales. Todo ello es lo que constituye un "imaginario" que va envolviendo las propias motivaciones personales y sociales, ${ }^{1343}$ y que, según nuestro autor, es difícil de articular conceptualmente, ya que se trata de una comprensión inarticulada de nuestra situación y en la que se manifiestan los rasgos particulares de nuestro mundo tal como son. ${ }^{1344}$

No obstante, para Taylor, el imaginario social moderno primero comienza con las élites intelectuales y, a partir de ahí, se van configurando las nuevas motivaciones morales de la sociedad. Por eso hemos analizado con detenimiento a autores que han ido estableciendo esa nueva configuración del orden social moderno que parte de la ley natural: Grocio, Locke, Rousseau, Pufendorf y Hegel, entre otros. De tal manera que se puede afirmar que el orden moral de la Modernidad es muy distinto al de la era premoderna. $^{1345}$

\footnotetext{
${ }^{1343}$ Anderson usa el término "imagined" al hablar del concepto de nación como "imagined political community" en el mismo sentido que también lo utiliza Taylor: no tanto como teoría socio-política cuanto aquella realidad del "inconsciente colectivo" que entrelaza las relaciones de unos con otros, como un concepto imaginario que configura un sentido de comunión que va más allá de cualquier código legal establecido en una constitución. Anderson también, La idea tayloriana de imaginario social tiene este sentido, no como teoría histórica, ni como conceptos de teoría social ni como expresiones del poder político inherente a cada época, sino aquello que tiene que ver con lo que motiva el quehacer humano, con lo que se expresa en distintas realidades "sui generis" o en aquellos elementos filosóficos que desvelan las propias incoherencias o debilidades que motivan el quehacer humano. Cfr. ANDERSON, B., Introducción, en Comunidades Imaginadas, págs. 17-25.

${ }^{1344}$ Cfr. TAYLOR, Ch., Imaginarios sociales modernos, pág. 39.

${ }^{1345} \mathrm{El}$ orden moral premoderno estaba caracterizado por el tiempo de los orígenes que configuraba las leyes de los pueblos, así como un componente óntico que se expresaba en las normas que se establecían para configurar la convivencia social y política. Son los diferentes órdenes jerárquicos que se complementan en una escala descendente de dignidades. Las diferenciaciones jerárquicas expresan el orden óntico establecido en la naturaleza. Es el concepto platónico-aristotélico de la "forma" que está configurando el orden de la naturaleza. Separarse de ese orden natural y eterno implicaba ponerse, de alguna manera, en contra de sí mismo, porque todo estaba establecido para reproducir ese orden eterno configurado por la forma que rige el mundo. Para Platón el orden era expresión del orden natural que es a su vez analogía del orden del alma. Tal y como se refiere en el libro II de La República, el orden y el bien es causa de los dioses y estos no pueden configurar ninguna realidad que esté en relación con el mal o el desorden. Por eso los mitos tienen que expresar la relación del orden con los dioses. El orden del Estado debe reproducir ese orden mítico relacionado con la idea del bien que ha sido impresa por los dioses en todo lo creado: "Por consiguiente, dado que Dios es bueno, no podría ser causa de todo, como dice la mayoría de la gente; sería solo causante de unas pocas cosas que acontecen a los hombres, pero inocente de la mayor parte de ellas. En efecto, las cosas buenas que nos suceden son muchas menos que las malas, y si de las buenas no debe haber otra causa que el dios, de las malas debe buscarse otra causa". PLATÓN, La República, 379c. Y, por otra parte, este Estado debe ayudar a entender este orden mítico que lleva a la consecución de la virtud. El orden del Estado debe propugnar este fin último que tiene que ver con la virtud y la búsqueda de la Idea del Bien. En la Modernidad la forma ya no está configurando el orden eterno jerarquizando la naturaleza y las relaciones humanas. El orden moderno no es expresión de ningún orden mítico o razón eterna o fundamento óntico, sino que se trata de un acuerdo basado en la ley natural que garantice el bien común y la consecución de nuestros objetivos ordinarios en la vida como son la vida, el sostén propio y la familia. Al organizarnos en común garantizamos la defensa de nuestros propios intereses. Si nos organizamos es para la consecución de objetivos comunes que nos confraternizan en la
} 
Y así, poco a poco, las fuentes morales se van configurando de otra manera. Los derechos naturales son los que establecen los derechos y obligaciones que tenemos respecto de los demás. Y a partir de esos lazos morales fundamentales se promueven las relaciones políticas. La sociedad y las relaciones políticas que se establecen están precisamente para la defensa de esos derechos naturales que son los que configuran la nueva visión moral. La sociedad y su configuración política se estructuran para la defensa de estos derechos naturales que conforman moralmente la vida de las personas. Desaparecen los estatutos ontológicos y todo se dispone desde una mera diferenciación funcional que nos asegura la defensa de los intereses propios. El Estado configura un orden social basado en la ley natural que permite la búsqueda de los intereses propios amalgamados colectivamente en una búsqueda básicamente compartida por los derechos naturales.

Este orden social en el siglo XVII expresa los propósitos de Dios. Es un orden teísta sobre el que se organizan las relaciones sociales. En el siglo XVIII este orden teísta pasa a ser configurado filosóficamente por un Dios que asegura el orden cósmico. Es el paso del teísmo al deísmo. Vemos cómo se va evolucionando de la razón eterna (Platón) a la razón teológica (premodernidad y siglo XVII con el inicio de la modernidad) para pasar finalmente a la razón natural (modernidad del siglo XVIII).

Para Taylor, la razón teológica del siglo XVII, que entronca con la razón premoderna de los propósitos de Dios de reconstruir la sociedad sobre la base del moderno "individuo en el mundo", tuvo un efecto mucho más vasto y complejo. Contribuyó a situar primero la moral y luego el imaginario social en la senda del individualismo moderno. Podemos ver la emergencia de este individualismo en la nueva concepción del orden moral que trajo la teoría de la ley natural del siglo XVII. Dicha teoría mantiene serias deudas con el estoicismo, y es razonable considerar que sus creadores fueron los neoestoicos holandeses Justus Lipsius y Hugo Grocio. Pero en este caso se trataba de un estoicismo cristianizado, moderno, en el sentido de que atribuía un papel fundamental a la reforma voluntaria de la sociedad humana. Podríamos decir que

búsqueda común de los propios bienes individuales. Unos y otros buscamos bienes que nos ponen en común por la básica coincidencia de unos fines que se defienden mejor a partir del establecimiento de un Estado que los defiende y nos implica a todos en una convivencia común para la defensa de los propios intereses. Con Grocio y Locke se inicia el cambio hacia un nuevo orden. No se trata de configurarnos moralmente a partir del orden óntico establecido en la razón eterna del cosmos, sino a partir de lo que somos como seres racionales. No hay órdenes jerárquicos que reproducen un orden óntico, sino que la propia razón humana establece "diferenciaciones funcionales" que no están determinadas por un valor esencial, sino por la reflexión racional que nos fundamenta como seres con capacidad para promover un orden social y político como seres racionales que se dejan guiar por la ley natural. Las jerarquías diferenciadoras se ven superadas para establecer diferenciaciones no en base a la expresión de ningún orden óntico, sino como diferenciaciones funcionales que garantizan el orden, la seguridad y el beneficio mutuo. 
el desarraigo es tanto el resultado de la identidad resguardada (buffered identity), como del proyecto de reforma. ${ }^{1346}$

III.- En Taylor el orden moral de la Modernidad está basado en tres aspectos:

1.- El primero tiene que ver con la afirmación de la persona y los derechos inalienables de la misma, de tal manera que todo está orientado hacia la consecución de los mismos. ${ }^{1347}$ Se deja atrás la vieja concepción de que el hombre se considera agente moral en tanto y cuanto esté inserto en un todo social, enraizando su sentido moral en dicho sentido de pertenencia. Con el advenimiento de la Modernidad se afirman en primer lugar los derechos de la persona, y a partir de esta afirmación prepolítica, todo se encamina a la formación de una sociedad política que garantice por ley dichos derechos. Con la Modernidad, la identidad moral se basa en que cada uno debe definirse a sí mismo lo más amplia y profundamente posible. ${ }^{1348}$

Se supera la afirmación aristotélica, según la cual el sujeto humano solo puede ser comprendido moralmente formando parte de un todo social en el que se manifiesta una complementariedad jerárquica. ${ }^{1349} \mathrm{Si}$ la naturaleza del hombre es ser social, eso significa que su configuración moral está en relación directa a su pertenencia a la polis, a la casa y la ciudad como ámbitos privilegiados en los que se expresa su naturaleza social. Esta naturaleza social del hombre le vincula moralmente a la ciudad, a la participación en la vida social. Es un zoon politikon, en el sentido de que necesita de la sociedad para expresar su sentido del bien y del mal o, lo que es lo mismo, no puede expresarse moralmente sin participar de su conciencia social. Sentido social y naturaleza moral van indisociablemente unidos.

No obstante, Aristóteles también es consciente de que la propia naturaleza moral del hombre le refiere a su propia racionalidad, a su sentido individual como ser racional. No se puede participar moralmente de la vida en la polis sin esta conciencia previa de ser racional con una individualidad propia. El hombre es un animal viviente cuya esencia, cuyo ser está definido por su propia individualidad racional y a partir de la misma, y una vez afirmada dicha esencia individual, se afirma de manera indisociable a su configuración moral previa, el hecho de ser político, social o cívico. Ambas

\footnotetext{
${ }^{1346}$ Cfr. TAYLOR, Ch., La Era Secular, tI, págs. 168,203,212,363,389,442.

${ }^{1347}$ Cfr. TAYLOR, Ch., Fuentes del yo, pág. 680.

${ }^{1348}$ Cfr. TAYLOR, Ch., La ética de la autenticidad, pág. 69.

1349 "De todo esto es evidente que la ciudad es una de las cosas naturales, y que el hombre es por naturaleza un animal social... La razón por la cual el hombre es un ser social, más que cualquier abeja y que cualquier animal gregario, es evidente: la naturaleza, como decimos, no hace nada en vano, y el hombre es el único animal que tiene palabra". ARISTÓTELES, Política, I, 2, 1253a 9-11. "Quizá también es absurdo convertir al hombre feliz en un solitario, pues nadie elegiría poseer todos los bienes en soledad: el hombre es un ser político y nacido para vivir en compañía. Y en el hombre feliz, desde luego, se da esto porque posee los bienes naturales". ARISTÓTELES, Ética a Nicómaco IX, 9, 1169b15-20.
} 
realidades van irremediablemente unidas. Su esencia es político-social. La moralidad individual va interrelacionada con su carácter social, con su socialidad.

Con la Modernidad se va a afirmar de manera previa la esencia individual de la persona, sus derechos, la individualidad propia del ser humano, este concepto prepolítico, y luego se configurará socialmente una sociedad política que asegure sus derechos por ley. Para Taylor, en el Orden Moral Moderno, los individuos no son agentes que están esencialmente insertos en una sociedad que refleje el orden cósmico, sino más bien individuos desarraigados que se asocian entre sí. ${ }^{1350}$ Es la teoría de derechos y de ley legítima. Se rompe esa indisociabilidad moral del ser humano, en cuanto individualidad y socialidad, al mismo tiempo. Ahora se afirma la individualidad (al margen del carácter social moral del ser humano) como concepto prepolítico, y a partir de ahí se estructurará una sociedad política que asegura dichos derechos individuales. En la Modernidad todo emana de los individuos y la sociedad está para garantizar dichos derechos: el individuo es el que configura la sociedad para sus fines y derechos. ${ }^{1351}$ Taylor habla incluso de un individualismo metodológico, según el cual, es difícil integrar atomismo individual con perspectiva social debido a que se reduce la dimensión del significado y ya no hay eventos significativos, sino que todos son simples. No parece problemático, afirmará Taylor, incluir el atomismo en política como fue la norma en física, sobre la base de fundamentos naturalistas aceptados a priori. ${ }^{1352}$ No obstante, Taylor sostiene que la afirmación prepolítica de los individuos en la Modernidad avanzará por reescrituras posteriores en las cuales se irá avanzando hacia antropologías filosóficas que reafirman la naturaleza social del hombre. Taylor pone los ejemplos de Rousseau, Hegel y Marx, pero matiza una idea clave: se afirma el carácter social del ser humano, pero bajo la idea moderna de una sociedad de servicios comunes entre iguales y para la defensa de los intereses individuales. ${ }^{1353}$

2.- La Modernidad lleva a la consideración de la sociedad política como lo que permite asegurar el beneficio mutuo de los individuos, proporcionando a los mismos, seguridad y garantizando el intercambio y la prosperidad. La Modernidad considera la sociedad, no tanto como el ámbito de estructuración jerárquica que permite la realización personal y la búsqueda insaciable de la virtud, cuanto una creación que se

\footnotetext{
${ }^{1350}$ Cfr. TAYLOR, Ch., La Era Secular, tII, pág. 237.

${ }^{1351}$ Cfr. TAYLOR, Ch., Fuentes del yo, págs. 265-268.

${ }^{1352}$ Cfr. TAYLOR, Ch., La Era Secular, tII, págs. 294,300; cfr. TAYLOR, Ch., Argumentos filosóficos, págs. 184 y ss. Cfr. TAYLOR, Ch., La ética de la autenticidad, pág. 56.

${ }^{1353}$ Cfr. TAYLOR, Ch., La ética de la autenticidad, págs. 60-64. "En resumidas cuentas, a mi parecer, aquí se encuentra el fundamental legado aristotélico de Marx. Ambos comparten una visión teleológica de la naturaleza humana; eso sí, en Marx existe junto a otra dimensión descriptiva, analítica e histórica, que otorga al marxismo su carácter científico. Al igual que en el maestro griego, cuya teoría gira en torno a los fines (todo existe en la medida en que es fin), para Marx, es la adecuación a los fines del hombre lo que hace del comunismo afirmación, porque es la negación de la negación; es la negación del capitalismo, aniquilador de la verdadera esencia humana". SANZ ALONSO, S., "Indagando en los orígenes aristotélicos de Marx”, Nómadas, No 8, (2003), pág. 9.
} 
realiza para el beneficio mutuo y la satisfacción de las necesidades inmediatas. La sociedad no expresa ningún orden jerárquico, sino el beneficio mutuo que nos reporta para la satisfacción de nuestras propias necesidades. ${ }^{1354}$ Taylor considera que con la Modernidad desaparecen las estructuraciones jerárquicas que no aseguran la igualdad ni la libertad. ${ }^{1355}$

Taylor afirma que en las reescrituras posteriores —como, por ejemplo, la que realiza Rousseau-, se intentará no olvidar la virtud y se la identificará con la realización de la libertad individual y de la autosuficiencia, ${ }^{1356}$ aunque el énfasis siempre estará en la libertad que lleva a la satisfacción de las necesidades concretas de la vida. ${ }^{1357}$

3.- El concepto prepolítico son los derechos individuales y la libertad a la que la sociedad debe servir. Todo está en función de estos derechos y libertades. En el contrato social rousseauniano, se pierden los derechos individuales del estado de naturaleza para ganarlos en la seguridad del beneficio propio que garantiza el pacto social alcanzado. La naturaleza como tal solo vincula a la persona mientras necesita del vínculo familiar. Será necesaria la sociedad política surgida del pacto como vínculo que garantiza el mutuo beneficio y la libertad individual. Se pierde la libertad natural y se asegura la libertad individual. ${ }^{1358}$ El pacto garantiza el libre desarrollo de los derechos individuales y el despliegue de la libertad que asegura el mutuo beneficio y la satisfacción de todo tipo de necesidades de la vida. ${ }^{1359}$

Según Taylor, con la Modernidad surgen los yos impermeabilizados, disciplinados; un orden disciplinado para la búsqueda del beneficio mutuo y al mismo tiempo que asegure la libertad individual como proyecto fundamental de identidad humana. Desaparece cualquier tipo de estructuración jerárquica que busca la ética de la virtud en base a un yo moral entendido como pertenencia social y conciencia racional. Todo se impermeabiliza desde un orden social estructurado socialmente en base al

\footnotetext{
${ }^{1354}$ Cfr. TAYLOR, Ch., La ética de la autenticidad, págs. 80-85.

${ }^{1355}$ Cfr. TAYLOR, Ch., El multiculturalismo y la política del reconocimiento, pág. 17; cfr. TAYLOR, Ch., Argumentos filosóficos, pág. 297; cfr. TAYLOR, Ch., Hegel, pág. 21.

${ }^{1356}$ Cfr. TAYLOR, Ch., Argumentos filosóficos, pág. 192.

1357 "Encontrar una forma de asociación que defienda y proteja de toda fuerza común a la persona y a los bienes de cada asociado, y por virtud de la cual cada uno, uniéndose a todos, no obedezca sino a sí mismo y quede tan libre como antes. Tal es el problema fundamental, al cual da solución el Contrato social..." ROUSSEAU, J.J., El Contrato social, Austral, Madrid, 2007, págs. 45,47.

${ }^{1358}$ Cfr. TAYLOR, Ch., La ética de la autenticidad, pág. 63. Se habla de la libertad autodeterminada como un concepto que aglutina la libertad última del yo que es la que decida al margen de cualquier imposición exterior.

${ }^{1359}$ Cfr. TAYLOR, Ch., Fuentes del yo, págs. 405-409,561; cfr. TAYLOR, El multiculturalismo y la política del reconocimiento, pág. 19.
} 
beneficio mutuo y la búsqueda insaciable de la libertad individual. El nuevo orden social se va configurando a través de los intercambios de beneficios. ${ }^{1360}$

Se va avanzando progresivamente hacia la consideración de una sociedad civilizada en la que lo que importa es el beneficio mutuo. Todo está entrelazado con la idea de buscar el máximo beneficio. "Se superan los significados armonizados para pasar a considerar la causalidad eficiente". ${ }^{1361}$ Dios ha diseñado todo a través de causas que se van configurando unas a través de otras en una causalidad determinante y determinada. Todo está de alguna manera programado para conseguir la felicidad total. Hay una mano invisible que orienta todo hacia la consecución de la finalidad más lograda. ${ }^{1362}$ Todo está determinado hacia la consecución de la felicidad absoluta, hacia la armonía total. De alguna manera, la búsqueda anhelante de la propia felicidad lleva implícito un diseño que se encamina hacia la armonía general. Lo individual repercute en lo general a través de una mano invisible que ha diseñado el orden general como meta de todas las acciones individuales. No hay contradicción entre la búsqueda del bienestar individual y la consecución de metas colectivas de bienestar. ${ }^{1363}$

La idea de la causalidad eficiente es la que imprime el nuevo orden económico de la Modernidad. Un orden en el que todos estamos interrelacionados y donde todo está interactuando para que se consigan los máximos beneficios. El orden no está fuera marcado por la Forma y los diversos grados del ser que se acompasan jerárquicamente con esa Idea. El orden está impreso en la Naturaleza y todo interactúa con vistas a lograr el máximo beneficio a partir de la libertad y los derechos individuales. Todos necesitamos de todos y la libertad natural se reorganiza sobre la base de una nueva libertad política que surge de un contrato social.

\footnotetext{
${ }^{1360}$ Cfr. TAYLOR, La Era Secular, tI, pág. 284.

1361 TAYLOR, Ch., Fuentes del yo, pág. 358.

1362 Cfr. TAYLOR, Ch., Hegel, pág. 376. Para Hegel es la “astucia de la razón”.

${ }^{1363}$ Cfr. TAYLOR, Ch., La ética de la autenticidad, págs. 70 y ss. "Al preferir dedicarse a la actividad nacional que a la extranjera él solo persigue su propia seguridad; y al orientar esa actividad de manera de producir un valor máximo él busca solo su propio beneficio, pero en este caso como en otros una mano invisible lo conduce a promover un objetivo que no entraba en sus propósitos. El que sea así no es necesariamente malo para la sociedad. Al perseguir su propio interés frecuentemente fomentará el de la sociedad mucho más eficazmente que si de hecho intentase fomentarlo. Nunca he visto muchas cosas buenas hechas por los que pretenden actuar en bien del pueblo". SMITH, A., La riqueza de las Naciones, Alianza Editorial, Madrid, 1996, pág. 554. En otro libro titulado Teoría de los sentimientos morales, Adam Smith analiza los sentimientos morales y afirma que admiramos más aquello que nos distingue visiblemente de los demás como las cualidades de poder y rango que aquello que evocan sentimientos morales internos y menos visibles como la sabiduría u otro tipo de virtudes morales interiores. Sin duda no es el objeto de nuestro estudio entrar en el análisis de dicha obra, pero nos parece relevante el intento de Adam Smith por estructurar esa "mano invisible" que organiza las relaciones sociales a través del poder y la fama como lo que está moviendo el mundo más que otras cualidades de personas que aparentemente dicen que buscan el bien pero que luego no han hecho mucho por conseguirlo. En ocasiones este poder invisible que busca el propio beneficio como la fama o el amor a sí mismo repercuten indirectamente más en el ordenamiento moral del mundo que otras actitudes que pueden provocar más admiración como sentimiento moral.
} 
Hay un diseño divino que pone todo en relación en una concatenación causal y, tanto a nivel natural como social, todo está diseñado para lograr el máximo beneficio. ${ }^{1364}$ En el campo económico y social, todos estamos interrelacionados y el pacto social determina el funcionamiento económico para lograr el máximo de beneficios y la búsqueda de una mayor proyección de la libertad individual. Es la teoría de la ley natural de Locke, invitados todos a participar, sin distinción, de las mismas ventajas de la naturaleza en un estado de igualdad dentro del cual todo poder y toda jurisdicción son recíprocos. ${ }^{1365}$

Allí donde las doctrinas del compromiso personal estaban menos desarrolladas era necesario establecer medios para hacer frente al problema del atomismo social y a la erosión del sentido de autoridad como algo natural. Y así, a medio camino entre las visiones clásicas de la verticalidad (Idea y los grados del ser establecidos jerárquicamente) y la visión horizontal de la Modernidad (la agencia humana en la que todo interactúa para beneficio propio y la libertad individual), surge lo que Taylor denomina la "solución barroca", que pretende ser la última síntesis completa. Algunos autores definen este camino como una solución híbrida debido a la tensión que establece entre la afirmación jerárquica basada en la Idea que expresa distintos grados del ser y el establecimiento de una actitud constructiva que afirma la idea de la igualdad que nos compromete a todos por igual en la búsqueda de obligaciones recíprocas. Se trata de hacer una difícil síntesis entre el orden cósmico que es generado y un orden social que es reivindicado y descubierto desde la interacción que construye igualdad y mutuo beneficio. Es la etapa intermedia entre la solución cósmica y la solución moderna. ${ }^{1366}$

La solución barroca es la que viene representada por Bossuet y su defensa de la monarquía absoluta. En esta solución intermedia, la economía es el fin que domina en las relaciones sociales y el Estado es la estructura necesaria para que la economía prospere y todo esté organizado en función de la economía política. Se trata de un estado para fomentar la prosperidad económica y de una economía que determina la organización social y política del Estado. El Estado Absolutista solo se entiende como propuesta para un desarrollo económico que favorece el mutuo beneficio y el comienzo de una sociedad del bienestar. En este momento, el beneficio mutuo entiende como propuesta de Estado más apropiada la "solución barroca". Es una etapa intermedia entre el Antiguo Régimen y la Modernidad, y es una solución temporal para favorecer el resurgimiento económico como una propuesta innovadora y moderna. ${ }^{1367}$

\footnotetext{
${ }^{1364}$ Cfr. TAYLOR, Ch., Imaginarios sociales modernos, pág. 200.

${ }^{1365}$ Cfr. LOCKE, J., Segundo Tratado sobre el Gobierno, Cap. II, No 4, pág. 119.

${ }^{1366}$ Cfr. TAYLOR, Ch., La Era Secular, tI, págs. 285 y ss.

${ }^{1367}$ Cfr. TAYLOR, Ch., Fuentes del yo, pág. 270; cfr. TAYLOR, Ch., Argumentos filosóficos, págs. 279,291
} 
Para Taylor, la importancia que se concede a lo económico en la solución barroca tiene que ver fundamentalmente con dos razones. Por una parte, están las razones políticas. Unas razones que están relacionadas con el deseo de establecer una sociedad ordenada para el buen funcionamiento de la vida social y el desarrollo de la paz. Sin paz y sin orden social difícilmente se puede promover el orden y el desarrollo económico. El Estado político es el que tiene que garantizar y promover dicho orden social. El Estado tiene que encargarse de promover una vida auténticamente ordenada con vistas a sustentar las bases del benéfico económico mutuo. Todos están interesados en promover relaciones económicas que beneficien a todos y promuevan el bienestar, y eso pasa por establecer un Estado que sea garante del orden y promueva relaciones sociales basadas en el orden y en la sana convivencia. ${ }^{1368}$ Por otra parte, están las razones espirituales y filosóficas. Unas razones que tienen que ver con las propuestas de vida del calvinismo y que posteriormente serán también promovidas por el catolicismo.

Para Taylor, tan pronto como se abandona la idea de orden social como conjunto de Formas operativas en la realidad, y la sociedad es considerada como un engranaje de causalidades mecánicas impuestas por una agencia humana, necesitamos hacernos alguna imagen de la estructura de esta realidad inerte y de las conexiones causales que la determinan, del mismo modo que necesitamos modelos para nuestra acción colectiva sobre ella. ${ }^{1369}$ Taylor pone como ejemplo intermedio del paso de una idea a otra, la idea de Maquiavelo de las formas republicanas, en el que la forma de orden social que propugna es una forma normal, o lo que es lo mismo, una tensión entre estas dos formas que sobreviven. Posteriormente, con Adam Smith, se impondrá la forma normal con la mano invisible. ${ }^{1370}$

IV.- El nuevo imaginario social de la Modernidad a partir de la teoría grocianolockeana del orden moral: la esfera pública, la economía y el pueblo soberano. ${ }^{1371}$

A.- El advenimiento de la Modernidad propicia el surgimiento de la esfera pública. La esfera pública es ese gran espacio común en el que las personas encuentran la posibilidad de debate en torno a asuntos de interés común con la idea de poder conseguir un gran consenso acerca de ellos. Todo el mundo debe ser reconocido por su identidad única y, por ende, en su igualdad y en su posibilidad de hablar y escuchar. El orden de la dependencia de la opinión y del honor se hace compatible con la libertad. ${ }^{1372}$

\footnotetext{
${ }^{1368}$ Cfr. TAYLOR, Ch., La Era Secular, tI, pág. 284.

${ }^{1369}$ Cfr. TAYLOR, Ch., Imaginarios sociales modernos, pág. 96.

${ }^{1370}$ Cfr. TAYLOR, Ch., La Era secular, tI, pág. 321.

${ }^{1371}$ Cfr. Ibid., pág. 283.

${ }^{1372}$ Cfr. Ibid., págs. 252-255; cfr. TAYLOR, Ch., Argumentos filosóficos, pág. 312.
} 
Las personas se sienten protagonistas cuando se ubican en la esfera pública, dado que así se asegura su independencia con respecto a lo político y, al propio tiempo, se trata de alcanzar un cierto grado de legitimidad como fuerza para ser escuchados. ${ }^{1373}$

Uno de los autores que ha estudiado con más profundidad el surgimiento de la esfera pública en la Europa Occidental del siglo XVIII es Habermas. ${ }^{1374}$ Para él, es un locus que surge con la Modernidad y que permite activar mecanismos de actuación y consenso dentro del ámbito de lo público; supone una fuerza moral que debe ser escuchada por el Gobierno. Las personas se sienten protagonistas, se activan procesos de reflexión e interacción social con la idea de alcanzar un consenso o un equilibrio de fuerzas que expresa una legitimidad de orden moral. El poder, dentro de esta dinámica de la esfera pública, debe escuchar los consensos alcanzados, ya que supone una activación del protagonismo de una sociedad libre, en el libre ejercicio de su responsabilidad. La totalidad del "cuerpo público" constituye, según Habermas, un tribunal de más valor que todos los tribunales juntos. Todos perciben a este tribunal de la esfera pública como incorruptible, dado que busca constantemente aclararse y que contiene la entera sabiduría y justicia de un pueblo que decide siempre acerca de su destino y del destino de los hombres de Estado. ${ }^{1375}$

Lo realmente relevante no es que actúe como un elemento de control o de fuerza moral que emerge desde las bases sociales, sino la racionalidad que está impresa en la naturaleza propia de la esfera pública. No es un orden ontológico que controla y define las fuentes morales o una ley inscrita en la naturaleza social del ser humano, sino que se trata de una expresión de la razón humana. ${ }^{1376}$ Es la realización de la razón humana en relación al arte de la comunicación y aplicada a las nuevas configuraciones sociopolíticas, una vez superadas las estructuraciones sociales del Antiguo Régimen. La nueva configuración del Estado Moderno necesita del ejercicio de la razón realizado desde las mismas bases sociales que dieron paso al moderno aparato estatal, una cierta domesticación del poder desde lo que Habermas denomina el acrecentamiento de la capa burguesa que se ejercita en el arte del raciocinio público en comunicación con el "mundo elegante" frente a la esfera personal del monarca de la sociedad aristocrática. $^{1377}$

Frente al orden moral premoderno de carácter metafísico que concedía identidad al pueblo en relación a unas leyes determinadas que lo establecían como tal, el nuevo

\footnotetext{
${ }^{1373}$ Cfr. Ibid., págs. 301-302.

1374 Cfr. TAYLOR, Ch., La Era secular, tI, págs. 297,303,304; cfr. HABERMAS, J., TAYLOR, Ch., BUTLER, J., WEST, C., El poder de la religión en la esfera pública, págs. 39-67; cfr. TAYLOR, Ch., MACLURE, J., Laicidad y libertad de conciencia, págs. 53-58.

${ }^{1375}$ Cfr. HABERMAS, J., Historia y crítica de la opinión pública, E. Gustavo Gili, Barcelona, 1982, págs. 133-134.

${ }_{1376}$ Cfr. TAYLOR, Ch., La Era secular, tI, págs. 195,283,290,297,334.

1377 Cfr. HABERMAS, J., Historia y crítica de la opinión pública, pág. 67.
} 
orden moderno establece la identidad del pueblo al margen de ninguna consideración previa de carácter legal, siendo la libertad y la razón los fundamentos que configuran esta sociedad que está fuera y más allá del Estado. Se da protagonismo a la Sociedad frente al Estado. Ambos están llamados a configurar relaciones de intercambio mutuo. Un Estado para configurar un nuevo orden social, político y económico, y una Sociedad que actúa independientemente y como poder de ejercicio público que domestica los excesos del poder o influye desde fuera potenciando la racionalidad pública. ${ }^{1378}$

Taylor reflexiona sobre la secularidad radical de la esfera pública, una secularidad que establece su dinamismo propio en la consideración de la acción común como una acción participativa en sí misma. ${ }^{1379}$ Lo único que motiva la participación en la esfera pública es el sentido propio de la acción común que motiva engranajes de racionalidad y espacios de igualdad y libertad. ${ }^{1380}$ Es el ejercicio de la racionalidad y la secularidad radical lo que mueve el surgimiento y el engranaje de la esfera pública. La racionalidad del ser humano se ejercita como espacio de hombres libres e iguales $\mathrm{y}$, al propio tiempo, motiva las posibilidades de la acción conjunta como una acción que tiene sentido a partir de sí misma y que motiva la propia esfera de encuentro social.

B.- El pueblo soberano es el segundo eslabón de la cadena de cambios que el imaginario social de la Modernidad ha establecido. ${ }^{1381}$ Según Taylor, hay dos posibilidades que permiten "reconfigurar" el mundo y establecer nuevos arquetipos y paradigmas de novedad y ruptura. Por una parte, está el camino de la teoría que motiva nuevas prácticas sociales y reconfigura el mundo sobre bases morales nuevas. Es el camino de las primeras iglesias puritanas, por ejemplo. La teoría cambia el mundo y establece nuevos parámetros de configuración socio-política. Y el otro camino es la transformación del imaginario social existente que permita superar el tiempo de los orígenes y llegar a un tiempo nuevo asentado sobre bases morales distintas. Una cosa es el camino de la teoría que motiva la semilla del cambio y la ruptura hacia realidades y configuraciones morales nuevas, y otra cosa es partir de la práctica que reconoce legitimidades y a partir de ahí iniciar procesos hacia una nueva legitimidad enraizada en fuentes morales nuevas. ${ }^{1382}$ Veamos el camino recorrido por las tres revoluciones más importantes que conformaron el cambio a partir del pueblo soberano:

- En la revolución americana se reconocen las viejas legitimidades de los tiempos primeros e inmemoriales y, a partir de ahí, se inician procesos de cambio sobre un tiempo contemporáneo, enraizado en el hoy de la ruptura y

\footnotetext{
${ }^{1378}$ Cfr. TAYLOR, Ch., El multiculturalismo y la política del reconocimiento, págs. 70-78.

${ }^{1379}$ Cfr. TAYLOR, Ch., La Era Secular, tI, pág. 306; cfr. TAYLOR, Ch., Argumentos filosóficos, págs. 250,264-265,289-290,361-363,365-366,371-372.

${ }^{1380}$ Cfr. TAYLOR, Ch., Argumentos filosóficos, págs. 303-304.

${ }^{1381}$ Cfr. Ibid., págs. 313 y ss.; cfr. TAYLOR, Ch., La ética de la autenticidad, págs. 138-141; cfr. TAYLOR, Ch., Argumentos filosóficos, pág. 192.

${ }^{1382}$ Cfr. Ibid., pág. 205.
} 
puramente secular, y que se abre camino a través de las asambleas electas. ${ }^{1383}$ Taylor afirma que las fuerzas revolucionarias se basaron en la vieja y retrógrada idea de la legitimidad, según la cual, la soberanía popular no habría podido hacer el trabajo si hubiese entrado en escena demasiado pronto. La idea de invocar los derechos tradicionales de un pueblo definido por su constitución antigua tenía que alentar el primer paso, movilizar a los colonos al conflicto. La fuerza de las viejas instituciones representativas ayudó a interpretar el nuevo concepto en términos prácticos. ${ }^{1384}$

- En cuanto a la revolución rusa, sus actores establecen de antemano prácticas que ya indican el nuevo orden, de tal manera que las prácticas revolucionarias son expresión del nuevo orden que está en ciernes. ${ }^{1385}$ Lo contrario a lo que ocurre en la revolución francesa, en la que los actores no tienen definido de antemano las prácticas del nuevo orden, sino que el inicio del proceso es el que marca caminos de consenso para ir alcanzando acuerdos que vayan encaminados hacia la consecución de la nueva legitimidad. ${ }^{1386}$ En el caso ruso,

\footnotetext{
${ }^{1383}$ En el caso de la revolución americana no era fácil abrirse camino a una nueva legitimidad partiendo del reconocimiento de la legitimidad de los tiempos inmemoriales, de la ley emanadas del Parlamento y el Rey de Inglaterra. Era necesario establecer sobre la ley natural los nuevos fundamentos morales que abrieran horizontes de legitimidad basados en "otras verdades". La verdad del tiempo inmemorial se abre camino sobre el reconocimiento previo a otra verdad basada en el derecho natural y en verdades establecidas sobre bases y fundamentos de "verdad y racionalidad". La ruptura de una legitimidad moral tiene que tener una base moral que le permita establecer la nueva legitimidad y esa base moral tiene que ser "racional y evidente" y solo es posible a través de la ley natural impresa en la naturaleza humana. Es la voluntad de un pueblo que ya no necesita vincularse a los tiempos inmemoriales, sino que desde la ley natural se remite a sí mismo como voluntad creadora de legitimaciones nuevas. Es lo que Bernard Bailyn expresa con meridiana claridad en su libro sobre los orígenes ideológicos de la revolución americana: "Not that power was in itself -in some metaphysical sense - evil. It was natural in its origins, and necessary. It had legitimate foundations 'in compact and mutual consent' -in those covenants among men by which, as a result of restrictions voluntarily accepted by all for the good of all, society emerges from a state of nature and creates government to serve as trustee and custodian of the mass of surrendered individual powers. Power created legitimately by those voluntary compacts which the colonists knew from Lockean theory to be logical and from their own experience to be practical, power in its legitimate form inhered naturally in government and was the possession and interest of those who controlled government, just as liberty". BAILYN, B, The Ideological origins of the American Revolution, Belknap Press, Cambridge, 1967, pág. 92.

${ }^{1384}$ Cfr. TAYLOR, Ch., Imaginarios sociales modernos, págs. 136,205; cfr. TAYLOR, Ch., La Era Secular, tI, pág. 315; cfr. TAYLOR, Ch., La Era Secular, tII, págs. 241,296.

${ }^{1385}$ Cfr. TAYLOR, Ch., La Era Secular, tI, pág. 320. En el caso de la revolución rusa el imaginario social solo concebía el proceso revolucionario limitado al mir o aldea. Los campesinos no concebían el concepto de un gran proceso revolucionario que pudiera ser llevado a cabo desde la conciencia de "pueblo nacional", por lo que el esquema es distinto al de Francia. En este caso son los revolucionarios los que establecen de antemano los procesos a llevar a cabo dado que sin esta "percepción revolucionaria" por parte de una minoría difícilmente el pueblo ruso podría iniciar procesos que incluyeran al pueblo como nación. La aldea como agencia colectiva local era su imaginario social. "The village community was the centre of thissmall and isolated world. Indeed, the old peasant term for it (the mir) also carried the meaning in Russian of 'world', 'peace' and 'universe'. The mir was governed by an assembly of peasant elders which, alongside the land commune (obhchina), regulated virtually every aspect of village and agrarian life. Its powers of self-government had been considerably broadened by the Emancipation, when it took over most of the administrative, police and judicial functions of the landlords". FIGES, O., A People's Tragedy. A History of the Russian Revolution, CUP, Cambridge, 1996, pág. 98.

${ }^{1386}$ Cfr. TAYLOR, Ch., La Era Secular, tI, pág. 320. En el caso de la revolución francesa ese consenso se
} 
la ruptura inicia prácticas novedosas, la revolución implica que los agentes tienen claro los nuevos caminos hacia la legitimidad. En la revolución francesa, por el contrario, la ruptura solo es un camino hacia consensos que irán definiendo el horizonte de la nueva legitimidad.

- En relación con la revolución francesa, Taylor destaca la compleja noción rousseauniana de "representación por encarnación". No se trata de la representación premoderna, según la cual el rey representa al "cuerpo" del pueblo y el obispo al "cuerpo" de la Iglesia. Tampoco es la representación moderna en la que hay un grupo electoral que responde a sus electores y representa a aquellos que le han elegido. Se trata de una representación intermedia, un locus distinto, a medio camino entre los tiempos premodernos y la Modernidad. Se trata de una representación de una minoría que encarna la voluntad general y que asume su papel representacional que se enmarca en el ámbito de la teoría revolucionaria y que tiene la pretensión de erigirse en la palabra de todos. El pueblo, en este proceso revolucionario, tiene la obligación de expresarse a sí mismo como es, en su propia idiosincrasia revolucionaria y virtuosa, y a partir de una minoría representacional, expresar esa voluntad general. Hay dos voluntades que tienen que fundirse en una sola, la voluntad general y la voluntad de la minoría virtuosa que expresa dicha voluntad. Así pues, es fundamental que la voluntad general se exprese teatralmente, incluso de una manera cuasirreligiosa, para que la virtud de esa minoría exprese y capte el sentido de dicha voluntad general. Se trata de que la voluntad revolucionaria del pueblo se exprese directamente, con transparencia y unidad, de tal forma que esta transparencia sea captada en toda su integridad por esa minoría virtuosa que exprese el sentido más profundo de dicha voluntad general. ${ }^{1387}$

\footnotetext{
alcanza a través de la transparencia y de la voluntad general. Ambas están íntimamente relacionadas. Es la voluntad general el lugar de la máxima transparencia como dirá Taylor ya que la apertura a consensos y a los demás es el camino que abre horizontes hacia el fortalecimiento de la voluntad general que poco a poco se va aglutinando y fundamentando. La transparencia que propugna apertura al otro fortalece la transparencia y la transparencia es el camino para que las voluntades diversas se vayan encaminando hacia la voluntad general y se fundan en una. O lo que es lo mismo, en el caso francés se parte de una teoría que se va iniciando poco a poco a través de consensos y por la puesta en práctica de los procesos que se quieren ir realizando con vistas a que vayan "entendiendo" la teoría. Una teoría que no moviliza procesos de transformación y "comprensión" del camino hacia nuevas legitimidades difícilmente sirve para el proceso revolucionario. La teoría se expresa en nuevas prácticas de comprensión del mundo y abre caminos de legitimidades nuevas, pero es necesario ese momento de transición en el que todos estos procesos van llegando a más agentes para convertirse en un imaginario social. Sin esta comprensión que llega al imaginario social difícilmente la teoría puede ser comprendida, entendida y expresada como un camino de procesos hacia un cambio revolucionario y de legitimidades. Cfr. TAYLOR, Ch., Argumentos filosóficos, pág. 288, en relación a lo prepolítico en Rousseau: la sociedad en tanto constituida por la voluntad a través del contrato social y en su comprensión de la naturaleza como "voz interior".

${ }^{1387}$ Cfr. TAYLOR, La Era Secular, tI, págs. 328-329; cfr. TAYLOR, Ch., La Era Secular, tII, págs. $31,58,251,440$.
} 
Según Taylor, tanto en el caso norteamericano como en el francés, se produjo una reinterpretación retrospectiva, y por lo tanto, el nuevo imaginario estaba en deuda con el antiguo, al haber asumido este parte de la carga de dar nacimiento a las nuevas formas, ya fueran la constitución federal o la tradición revolucionaria. El nuevo imaginario lleva las marcas de su origen: la primacía de las formas representativas en el caso norteamericano, y una glorificación de la insurrección popular, incluso una cierta liturgia de la revuelta, en el caso francés. ${ }^{1388}$ Se trataba de unificar la tradición de la noble insurrección y el compromiso con las instituciones representativas.

Las dos grandes revoluciones del siglo XVIII entremezclan ambos imaginarios. Toman las referencias del imaginario social premoderno para, a partir de ellas, hacer surgir los nuevos imaginarios sociales de representación popular en los que el pueblo sea el soberano. La revolución norteamericana, partiendo del sentido premoderno de representación, permite justificar la nueva constitución federal enraizándola en referencias previas de legitimidad (premodernas) y así posibilitar las nuevas legitimidades. En el caso francés, dado que no existía un significado consensuado en un imaginario social, los revolucionarios diseñaron fiestas que expresaran y afianzaran la nueva sociedad, en su nuevo imaginario social, para lo cual se basaron primordialmente en las festividades anteriores (premodernas). Se trataba de dar expresión a un espíritu e inspirar la identificación con él en la nueva Constitución. ${ }^{1389}$

C.- La economía como realidad objetivada es la tercera forma de autoconcepción social que contribuye a reconfigurar el imaginario social de la Modernidad. Este nuevo concepto de la economía como realidad objetivada está en relación con la autoconcepción de la civilización instruida, en tanto fundada en una sociedad comercial y en la idea grociano-lockeana de orden. ${ }^{1390}$

Con la Modernidad ilustrada surge con fuerza la idea de Adam Smith de una sociedad del beneficio mutuo. ${ }^{1391}$ Una sociedad que abandona las concepciones platónicas de la armonía y el orden del ser y se configura a partir de propósitos que se entrelazan y nos involucran en intercambios para el beneficio mutuo. Este es el diseño de Dios que se realiza no a partir de significados armonizados, sino de causas entrelazadas a través de intercambio de servicios. Surge una nueva sociedad en la que los dos objetivos principales son la seguridad y la prosperidad económica, llegando a

\footnotetext{
1387 "Para la élite revolucionaria, asegura Ozouf, los símbolos utilizados en los festivales, más allá de cualquier otra táctica retórica, podían provocar sentimientos poderosísimos, capaces en últimas de generar cambios fundamentales en las ideas previamente concebidas y establecidas. Así, en la programación de los festivales revolucionarios se contempló siempre el uso de símbolos, imágenes y representaciones que avivaran las emociones y resultaran educativos". BEATRIZ SÁNCHEZ, S., "Los festivales de la Revolución Francesa. Símbolos y sentimientos en las fiestas revolucionarias, 1789-1799”, pág. 47.

${ }^{1388}$ Cfr. TAYLOR, Ch., Imaginarios sociales modernos, pág. 154.

1389 Cfr. TAYLOR, Ch., La Era Secular, tI, pág. 94.

${ }^{1390}$ Cfr. Ibid., pág. 283; cfr. TAYLOR, Ch., Imaginarios sociales modernos, págs. 88 y ss.

${ }^{1391}$ Cfr. TAYLOR, Ch., Imaginarios sociales modernos, págs. 282-283.
} 
considerarse este último como el fin dominante. Para Taylor, lo que nos puso en este camino no fue solo el nivel económico, sino también los aspectos políticos y espirituales, afirmando así su sintonía con Weber. ${ }^{1392}$

Los tres relatos de la esfera pública, la economía y el gobierno confluyen en la definición del Estado Moderno. Un estado que aparecía con Grocio y Locke en su espacio original como identidad política, y que en su configuración como Estado Moderno adquiere su significado como organización política para la acción colectiva dentro de un tiempo profano y como garantía de la voluntad común. ${ }^{1393}$ Por el contrario, "la época por venir", de Hegel, en su expresión última de la razón absoluta, concebía al Estado por lo que expresaba o encarnaba la Idea, no tanto por sus logros de organización colectiva en torno a la voluntad común. ${ }^{1394}$

Frente al Estado hegeliano, caracterizado como una síntesis superior del Geist, desde mediados del siglo XIX se impone una racionalización de estructuras burocráticas como mezcla moderna de romanticismo privado y utilitarismo público, y con vistas a la consecución del máximo bien privado posible. ${ }^{1395}$ Frente al individualismo que se acoge al Estado moderno como garantía de su propia supervivencia, Hegel habla del tiempo nuevo como un tiempo del Estado racional "en que la comunidad general del espíritu se ha fortalecido tanto y la singularidad, tal como debe ser, se ha hecho tanto más indiferente". ${ }^{1396}$ Según Taylor, para Hegel, el Estado es la manifestación de la voluntad sustancial, la comunidad en la que la plenitud de la voluntad racional se manifiesta en la vida pública. En el Estado se realiza la síntesis entre subjetividad individual y universalidad. ${ }^{1397}$ Planteando el optimismo hegeliano del Estado como el verdadero modo de realidad efectiva en el que se realiza la verdadera voluntad ética y en el que el espíritu vive en su veracidad, Taylor pretende plantear un cierto relato alternativo al desarrollo de la civilización occidental en sus dos últimos siglos ${ }^{1398}$ Frente a la consideración de la historia como realización de la razón y libertad, y de la naturaleza como expresión del orden natural y éxtasis de la sensibilidad, Taylor pretende contribuir a afianzar un relato que haga consciente de tantos bienes fundamentales que han caído en el olvido sirviéndose de la síntesis hegeliana. Según Taylor, la civilización occidental ha realizado un recorrido en el que, en realidad, la síntesis de Hegel ha sido antropologizada, transferida del Geist hacia el hombre. ${ }^{1399}$

\footnotetext{
${ }^{1392}$ Cfr. Ibid., pág. 287: vida ordenada y ocupación productiva (política) y espiritualidad reformada.

${ }^{1393}$ Cfr. TAYLOR, Ch., Imaginarios sociales modernos, pág. 216.

${ }_{1394}$ Cfr. HEGEL, F., Fenomenología del Espíritu, pág. 517; cfr. TAYLOR, Ch., Hegel, pág. 381.

1395 Cfr. TAYLOR, Ch., Hegel, pág. 474.

${ }^{1396}$ HEGEL, F., Fenomenología del Espíritu, pág. 49.

${ }^{1397}$ Cfr. TAYLOR, Ch., Hegel, pág. 381.

${ }^{1398}$ Cfr. HEGEL, F., Filosofía de la Religión, pág. 303.

${ }^{1399}$ Cfr. TAYLOR, Ch., Hegel, pág. 477. Según Taylor, Hegel introduce aquí una nota sobre las relaciones entre la Iglesia y el Estado. Si el Estado es la encarnación de la Idea, para Hegel la verdadera Religión debe respaldar al Estado. Y al mismo tiempo el Estado debe dar protección y ayuda a la Iglesia pues la
} 
Finalmente, Taylor llega a la conclusión de que Occidente ha establecido el marco inmanente con carácter casi de exclusividad y todo nos determina a vivir en órdenes impersonales, natural, social y éticamente. En nuestra época, el orden impersonal más prestigioso y bien fundado en la experiencia es el nacido de la ciencia natural que, entendido en sus propios términos narrativos, conduce al materialismo que adopta una perspectiva cerrada prácticamente. ${ }^{1400}$

\section{IV.2.-LA EDAD SECULAR Y LA SECULARIZACIÓN. ¿ESTAMOS EN UNA ERA SECULAR?}

I.- Para Peter Berger, la obra de Taylor, La Era Secular, es un estudio de ideas, un estudio filosófico en el que se analiza detalladamente el proceso experimentado por la civilización occidental, en el que para la gran mayoría es posible vivir la vida desde el marco inmanente. Pero hace una seria advertencia: el curso de los acontecimientos no es ante todo una historia de ideas, sino que la plausibilidad de las ideas se halla enormemente afectada por hechos que no tienen nada que ver con las ideas, sino con intereses políticos y económicos mucho más burdos. ${ }^{1401}$

Taylor afirma que, en realidad, la gran cuestión es la que concierne a la relación de la nueva cultura moral con su base económica y social. Las nuevas fuentes morales tienen que ver con un conjunto de causas económicas y filosóficas que contribuyeron a crear la sensación de vivir en un nuevo orden moral. Taylor sugiere más bien una relación de circularidad, según la cual, los filósofos articularon lo que ya estaba en marcha. ${ }^{1402}$ Para Taylor, algunas articulaciones filosóficas captan el espíritu de una cierta práctica irreflexiva, pero al mismo tiempo, es posible que las articulaciones alteren la práctica. El bien vital se convierte en algo diferente cuando no es inducido a percibir diferentemente el bien constitutivo. ${ }^{1403}$

De la interacción de acontecimientos históricos y filosóficos van surgiendo enraizamientos morales nuevos que son los que en definitiva marcan el ritmo cultural de la historia y de las cosmovisiones morales que entroncan con la identidad del yo en una circularidad que mueve el mundo. A Taylor le interesa esa amalgama de configuraciones

\footnotetext{
Religión es una forma de conocimiento de sí mismo del Espíritu. En realidad, para Hegel la Religión y el Fundamento del Estado son una misma cosa.

${ }^{1400}$ Cfr. TAYLOR, Ch., La Era Secular, tII, pág. 406.

${ }^{1401}$ Cfr. BERGER, P., Los numerosos altares de la modernidad, pág. 103. Berger no está de acuerdo tampoco con la descripción de nuestra era como era "secular". Afirma que el título es equívoco y que debería haber utilizado en su lugar el adjetivo "pluralista" ya que el mundo en su globalidad camina por otros derroteros, donde el pluralismo es la mejor definición, Quizás Berger no ha reparado suficientemente en que el análisis de Taylor se circunscribe a la Modernidad Occidental. No alude a otros espacios geográficos. Cfr. Ibid., pág. 142.

${ }^{1402}$ Cfr. TAYLOR, Ch., Fuentes del yo, págs. 420-421.

${ }^{1403}$ Cfr. Ibid., pág. 423.
} 
culturales que van estructurándose a lo largo de la civilización occidental y que van transformándose o escondiéndose o ampliándose, según los distintos momentos. ${ }^{1404}$

Taylor afirma que los procesos culturales de mentalidad y cosmovisión son difíciles de definir, ya que se entremezclan muchos elementos y a veces no es fácil ver ni el camino ni los manantiales en donde todo empieza. Habría que empezar por definir historia, cultura, pensador, filosofía...; temas todos ellos que superan el alcance de este estudio. ${ }^{1405}$

Para Taylor lo realmente valioso es ver la relación entre el pensador y su cultura. Por una parte, la cultura está en constante movimiento, la identificación vital con ciertos bienes constitutivos va transformándose constantemente y la filosofía trata de analizarlos de manera rigurosa y científica, al propio tiempo que dichos conceptos filosóficos contribuyen a motivar nuevos cambios posteriores en relación a los bienes vitales que van configurando la sociedad. ${ }^{1406}$

Taylor afirma que ontología e historia están en una relación circular en la que ninguna de las dos parece de absoluta prioridad y ninguna es totalmente dependiente de la otra. ${ }^{1407}$ De ahí la importancia, para Taylor, de recurrir a la historia, dado que las formulaciones del bien del presente se definen siempre en relación a las del pasado, tomando estas como éxitos o fracasos. En este sentido, por ejemplo, la autodefinición moderna nos induce a reexaminar ese pasado y la manera en que se ha asimilado o rechazado. $^{1408}$

Entre ontología e historia, no existe ni prioridad ni dependencia. Es difícil ver la prioridad y al mismo tiempo cuesta mucho determinar la dependencia causal de una sobre la otra. Entramos en una circularidad en la que cada parte tiene su autonomía, pero al mismo tiempo el flujo es constante de una parte a la otra. La filosofía contribuye a esclarecer algo que ya está empezando a ser un bien constitutivo de la vida moral de las personas y en ese extrañamiento primero es necesario el argumento filosófico. No se sabe bien qué es lo primero. Se trata de una corriente circular que fluye y en la que ambas partes interaccionan. Puede que a veces sea necesaria la explicitación filosófica, pero puede que no lo sea, dado que hay ciertos bienes vitales que nos atraen y determinan la configuración moral de las personas y del mundo, y no necesitamos explicitar el alcance significativo de los mismos, puesto que lo más importante es el

\footnotetext{
${ }^{1404}$ Cfr. TAYLOR, Ch., Hegel, pág. 60. Para Taylor, en clave hegeliana, la filosofía ocupa el lugar más alto, solo porque es la única expresión completa y adecuada de la mayor unidad, el medio en que el espíritu llega totalmente a sí mismo como autoconciencia y, por tanto, el desarrollo del pensamiento filosófico es esencial para la perfección de una síntesis superior que siempre queda por descubrir.

${ }^{1405}$ Cfr. TAYLOR, Ch., Fuentes del yo, págs. 433-439.

${ }^{1406}$ Cfr. Ibid., págs. 137-147.

${ }^{1407}$ Cfr. Ibid., pág. 156.

${ }^{1408}$ Cfr. Ibid., pág. 153.
} 
sentimiento, la intuición moral, las fuentes morales de significado, la situación metafísica que nos posiciona en el mundo. De ahí la importancia, para Taylor, de rastrear explicaciones metafísicas y religiosas anteriores para comprender lo que va surgiendo como novedad. Taylor afirma que el camino hacia la articulación ha de ser histórico, en el sentido de que las articulaciones modernas tienen que vérselas no solo con las doctrinas de los filósofos, sino también con actitudes y mentalidades que subyacen en el interior de las civilizaciones. ${ }^{1409}$

Las cosmovisiones morales son las que determinan la situación metafísica del yo en el mundo y solo posteriormente somos conscientes de que la filosofía en su conjunto contribuyó de manera relevante a fundamentar el sentido de los bienes vitales que iban configurando cada momento histórico. Llega un momento determinado en el que es necesario recurrir a formulaciones de sentido para alcanzar a comprender lo que se está viviendo, sea como un horizonte fracturado, sea como una continuidad vital en la que nos sentimos inmersos. ${ }^{1410}$

Los bienes vitales no pueden pasar desapercibidos, como si fueran autónomos, surgidos desde sí mismos. Siempre remiten a alguna articulación filosófica en la que encajan con mayor facilidad, aunque es posible que las articulaciones sean varias y diversas. Por lo tanto, los enraizamientos morales (otra acepción posible de la expresión "bienes vitales") remiten a una cierta articulación filosófica que puede reorientar o alterar el alcance de los mismos, concediéndole así una percepción distinta, una ubicación desde la cual interpretar dichos bienes. Está claro que los cambios que hemos ido analizando en el recorrido de los distintos siglos no podrían ser entendidos sin esas articulaciones filosóficas que ayudaron a comprenderlos y que al mismo tiempo contribuyeron a afianzarlos o a reorientarlos.

Taylor afirma que hay una ilusión que anida en la descripción determinante, ${ }^{1411}$ que hay una suerte de movimiento ascendente que evoluciona, como una corriente oculta que avanza y que no somos capaces de determinar del todo el alcance de dicho movimiento, como si hubiera un "impulso vital" que promoviera el cambio desde dentro, el proceso hacia algo distinto y que no termina de dejarse determinar por ninguna articulación. Según su opinión, es difícil ver qué es lo que hace que haya movimiento o qué motiva a determinados bienes vitales hacia el cambio hacia algo distinto. Taylor lo define como "continuidad-a-través-de-transformación en la

\footnotetext{
${ }^{1409}$ Cfr. Ibid., pág. 155.

1410 "Por eso no podemos considerar que los bienes vitales de una cultura son autosuficientes, como si careciesen de relación interna con varias articulaciones posibles de los bienes constitutivos. Por eso podemos decir que algunas articulaciones encajan, que captan el espíritu de una cierta práctica irreflexiva. Pero al mismo tiempo, también es posible que las articulaciones alteren la práctica. El bien vital se convierte en algo diferente cuando uno es inducido a percibir diferentemente el bien constitutivo". TAYLOR, Ch., Fuentes del yo, pág. 423.

${ }^{1411}$ Cfr. Id., pág. 423.
} 
tradición". ${ }^{1412}$ En otros términos, Taylor pretende superar la visión de la vida como fases predefinidas dentro de una tradición inmutable, y prefiere contarla como una historia de crecimiento hasta metas que suelen carecer de precedentes. ${ }^{1413}$ En este sentido, para él parece que cada civilización experimenta los cambios de una manera característicamente propia. ${ }^{1414}$

En este análisis de causaciones, Taylor concede una importancia relevante al deísmo. Es el deísmo el que configura el primer paso hacia la "Ilustración increyente" de figuras como Helvecio, Holbach y Condorcet. Y a partir de ahí se va configurando la cultura laica moderna. Por eso pretendemos, siguiendo a Taylor, analizar con detenimiento cómo se llega al deísmo, porque sin él difícilmente se hubieran producido otros cambios que nos han llevado a la Modernidad laica y a la secularización como humanismo exclusivo, como autodeterminación responsable.

II.- La secularización es un término que, para Taylor, es más fuente de preguntas que de explicaciones. ${ }^{1415}$ Es una palabra que para Taylor sugiere más que define. Una palabra que remite, sobre todo, a un cambio en la creencia y en el enraizamiento moral del mundo. Por otra parte, dicha palabra pretende no solo describir el problema sino analizar respuestas, por lo que nos adentramos en una situación realmente compleja.

Para Taylor, la secularización es percibida ante todo como cambio en la creencia. En el siglo XVII y buena parte del XVIII, difícilmente era asumible la comprensión del hombre sin las referencias trascendentes. El hombre no podía comprenderse a sí mismo sin dicho enraizamiento moral. ${ }^{1416}$ Cada época se ha definido a sí misma desde su propia configuración del mundo, o según afirma Emerson, "cada época debe escribir sus propios libros". 1417

En la edad de la creencia existían diversas fuentes morales y Dios se manifestaba en ellas de modos muy diferentes. Todas implicaban a Dios, pero cada una a su manera. Taylor habla sobre todo de dos fuentes: las fuentes de espiritualidad cristiana y las fuentes del deísmo como noción del orden y la providencia en los argumentos del designio. Todo remitía a Dios o a una articulación espiritual del mundo. ¿Qué es lo que motivó dicho cambio? ¿Por qué se fueron asentando enraizamientos morales que fueron "haciendo asumible" la increencia o el cambio en la creencia?

\footnotetext{
1412 TAYLOR, Ch., Argumentos filosóficos, pág. 39.

1413 Cfr. TAYLOR, Ch., Fuentes del yo, pág. 156.

1414 Cfr. Ibid., pág. 425.

1415 Cfr. Ibid., pág. 424.

${ }^{1416}$ Ciertamente existía una filosofía pagana en la filosofía antigua y que estuvo disponible en el Medievo y en el comienzo del período premoderno. Hubo ateos epicureístas como Chevalier de Meré, encontramos un cierto estoicismo en Shaftesbury y una cierta filosofía pagana cartesiana imbuida de espíritu cósmico en Spinoza.

${ }^{1417}$ EMERSON, W.E., “The American Scholar”, en Selected Essays, Viking Penguin, N. York, 1982, pág. 87.
} 
Los grandes cambios institucionales, como la industrialización, la tecnología o la movilidad hacia las grandes urbes, así como la propagación de la ciencia y la educación, no terminan de dar una explicación completa y convincente del cambio experimentado. ${ }^{1418}$

Taylor reflexiona sobre lo que él denomina su explanandum y que podríamos expresar en los siguientes términos: el cambio crucial es de tales dimensiones, que grandes mayorías sociales ya no piensan que la dimensión espiritual de sus vidas sea incomprensible si se parte de la idea de que Dios no existe. ${ }^{1419}$ Es decir, que para Taylor dicho cambio en la creencia, y que explica el alcance de la palabra "secularización", viene determinado por el hecho de que ha pasado a ser asumible algo que antes no lo era. En los bienes morales que configuraban al hombre premoderno se puede decir que difícilmente era asumible la comprensión de sí mismo sin dicha referencia trascendente. Dios entraba a formar parte necesariamente de la comprensión moral del hombre premoderno. Se daba lo que Taylor denomina la innegabilidad de Dios. ${ }^{1420}$ Con la secularización se produce un cambio fundante en la configuración moral del hombre. Se pasa de la edad de la creencia, en la que todas las fuentes morales asumibles por el hombre implican la creencia en Dios, a la edad secular, en la que el hombre empieza a asumir que para determinarnos moralmente no necesitamos de Dios. Se rompe el enlace con la ley tradicional que configura el alcance del fundamento de la acción común. La premodernidad estaba caracterizada por un ámbito que trasciende a las acciones comunes, donde la asociación estaba constituida a partir de referentes morales trascendentes. La Modernidad reubica dichas fuentes y el factor constituyente de la asociación no es otro que la misma acción común. Se rompe la conexión con la ley tradicional y los actos configuradores de los orígenes, ${ }^{1421}$ y se produce un confinamiento de todas las acciones en un tiempo profano. ${ }^{1422}$

Taylor sostienen que esta apertura de nuevas fuentes morales es una ganancia epistémica, es decir, que ha supuesto un enriquecimiento para el hombre el que se hayan abierto otras posibilidades de enraizamiento moral en los siglos XIX y XX. Estas nuevas fuentes morales alternativas representan reales e importantes potencialidades humanas. Sin embargo, a pesar de esta indudable ganancia, lo que Taylor quiere dejar muy claro es que todavía esta afirmación no nos autoriza a hablar de la verdadera

\footnotetext{
${ }^{1418}$ Taylor hace una reflexión aguda al afirmar cómo es posible que el hombre premoderno no se planteara la posibilidad de la increencia o que no se diera cuenta de dicha posibilidad. Como si le faltara unas gafas de visión "para-ver-de-lejos". Y en este sentido para algunos, afirma Taylor, la secularización es "la eliminación de anteojeras", la remoción de obstáculos asociados a la educación y la ciencia. Taylor participa, en cierto sentido, de dichos planteamientos, aunque le parecen respuestas provisionales.

${ }_{1419}$ Cfr. TAYLOR, Ch., Fuentes del yo, pág. 426.

${ }^{1420}$ Cfr. Ibid., pág. 427.

${ }^{1421}$ Cfr. TAYLOR, Ch., Argumentos filosóficos, pág. 349.

${ }^{1422}$ Crr. TAYLOR, Ch., Imaginarios sociales modernos, pág. 214.
} 
situación epistémica. Por lo que este es el gran giro que debemos comprender y al que tenemos que aproximarnos sin aventurarnos a dar respuestas simplistas y obvias. ${ }^{1423}$

La gran pregunta en la que Taylor nos introduce es: “¿Cómo han llegado a estar disponibles dichas fuentes morales alternativas asociadas a la secularización?"1424 ¿Qué es lo que ha causado dicho cambio de edad y ha permitido el inicio de procesos secularizadores posibilitando que sociedades enteras "no presupongan necesariamente a Dios”? Y retomando la pregunta inicial: ¿Cómo se ha llegado al deísmo, si es que el deísmo ha producido o posibilitado el paso de una edad a otra? ¿Cómo se ha llegado a identificar a Dios como un ser supremo vacío, sin contenido o iniciativa o voluntad? ${ }^{1425}$

Por otra parte, según Taylor, todas las cuestiones que rodean a la secularidad y a la historia narrativa de la no creencia se ven afectadas por una doble historicidad: por una parte, la no creencia se definió en relación a formas de creencia anteriores y, por otra parte, las formas de no creencia de aparición posterior se definen a sí mismas en relación con este primer y pionero humanismo de la libertad, la disciplina y el orden. ${ }^{1426}$

Estas fuentes alternativas comienzan a surgir en el siglo XVIII y se establecen filosóficamente de manera cuasidefinitiva en el siglo XIX. Para Taylor, las dos fuentes alternativas que surgen y que posibilitan el paso hacia una edad secular son las siguientes: la primera reside en las propias facultades del agente, inicialmente las del orden y el control; y la segunda reside en las honduras de la naturaleza, en el orden de las cosas y en lo que mana de mi propia naturaleza, deseos, sentimientos, afinidades. ${ }^{1427}$

La primera, tal y como hemos visto, va asociada al sujeto desvinculado del control racional y del yo puntual (Descartes, Locke y Kant en el siglo XVIII), que viene acompañado por un profundo sentido de dignidad personal, dignidad que deviene en su ontologización como fuente moral. Dicha dignidad tiene un fundamento teísta, es Dios el que ha establecido las facultades de la razón y la voluntad humana como expresión de su imagen en nosotros. Taylor invita a explorar la causación del cambio hacia el deísmo: las fuentes morales se ubican dentro de nosotros mismos. Es decir, que de esta relevancia otorgada a las propias posibilidades de la razón humana y del yo puntual que deviene en un profundo sentido de la dignidad humana que tiene su fundamento en Dios, se da un paso hacia una configuración moral no teísta, hacia una moral autónoma, autorreferencial, como dirán algunos autores modernos. Es posible profundizar en la mirada hacia la propia dignidad, pero entendida de manera distinta, autorreferencialmente, independientemente de una referencia teísta. Dicha

\footnotetext{
${ }^{1423}$ Cfr. Ibid., pág. 429.

1424 Ibid., pág. 431.

1425 Cfr. TAYLOR, Ch., Hegel, pág. 440.

${ }^{1426}$ Cfr. TAYLOR, Ch., La Era Secular, tI, pág. 425.

${ }^{1427}$ Cfr. TAYLOR, Ch., Fuentes del yo, págs. 431-432.
} 
autorreferencia tendrá un primer momento deísta, pero luego posibilitará una configuración puramente laica entendida como "secular". Estos serán los pasos intermedios que se irán produciendo a lo largo del siglo XIX, tal y como hemos analizado.

En relación a la segunda fuente moral, la que se establece a partir del descubrimiento de las profundidades de la naturaleza, que descubre el orden inherente a una enorme red de seres engranados (tal y como hemos visto en Darwin), tanto a nivel racional como a nivel de sentimientos. La idea de que el sentimiento y el pensamiento emergen de la naturaleza proporciona hondura y brío, e introduce una nueva noción de profundidad. ${ }^{1428} \mathrm{Y}$ cuando la idea del bien moral al que conduce la naturaleza es ahora un bien puramente neutral y autónomo a cuyo principio tenemos acceso dentro de nosotros como resonancia interior, se ha preparado el camino para otra ética independiente, la de la Naturaleza sin su creador. ${ }^{1429}$

Según Taylor, estas dos fuentes morales alternativas surgen, la primera, en el siglo XVIII, a partir de Descartes, Locke y Kant, y la segunda, en el siglo XIX, a partir de Darwin y la teoría de la evolución humana. Taylor considera que el Cristianismo ha tenido mucho que ver en el surgimiento de estas dos fuentes morales alternativas. En la primera, está la interioridad agustiniana como precedente del giro cartesiano y, en la segunda, está la teología como "origen" del universo mecanicista, tal y como hemos visto en Ockham y posteriormente en el siglo XVI.

Lo que surge, en todo caso, es una concepción que está a punto para la mutación y que desbordará la fe cristiana. ¿Qué significa estar a punto? A criterio de Taylor, se llega a un momento en el que "es casi irreversible retroceder el camino" o que todo se encamina hacia un cambio ontológico. Se está a punto porque se ha llegado a tal situación en la que "es posible iniciar un camino sin retorno", un cambio del que se desconocen sus consecuencias antropológicas. El estar a punto no significa que se produzca el cambio, es necesario algo más, se precisa de algún elemento novedoso y fundamental que posibilite la mutación, el proceso de cambio irrefrenable, el empuje definitivo. ${ }^{1430}$ Lo que interesa resaltar es que se llega a un momento en el que para afirmar algo que se establece como fundamento moral no se necesitan fuentes morales trascendentes. Y, lo que es más importante, se llega a afirmar que la verificación de lo trascendente puede ser un impedimento para la fundamentación moral del yo en su dignidad moral.

\footnotetext{
${ }^{1428}$ Cfr. Ibid., págs. 478,551.

${ }^{1429}$ Cfr. Ibid., pág. 432.

1430 "La mutación se hizo necesaria cuando - y en la medida en que a la gente le parecía que aquellas fuentes morales solo podían ser reconocidas correctamente- solo podían potenciarnos plenamente, en su forma no teísta. La dignidad del libre control racional solo parece genuina una vez liberada de la sumisión a Dios; la bondad de la naturaleza, y/o nuestra inserción sin reservas en ella, parecía requerir su independencia y la negación de toda vocación divina”. TAYLOR, Ch., Fuentes del yo, pág. 433.
} 
Son los horizontes fracturados de los que habla Taylor, en los que se produce una ruptura, una fractura de tales dimensiones, que se establecen dos fuentes morales que definen ontológicamente al hombre sin necesidad de referencias trascendentes o que concluyen en su negación para posibilitar la afirmación moral del yo. La dignidad del hombre racional solo parece genuina sin Dios, y la bondad de la naturaleza parece requerir su no dependencia de Dios. Por otra parte, según Taylor, a partir de las fronteras de la moralidad no teísta, se establecen relaciones complejas que conllevarán al surgimiento de la rivalidad y tensión entre ellas y al afianzamiento de nuevas formas de increencia más radicales. La Ilustración radical llevará al rechazo de Dios y la providencia, y a mantener una postura inflexible acerca de la razón desvinculada bajo dos formas: de la razón, desvinculada a una lectura instrumental de la naturaleza, y de la naturaleza expresiva a la naturaleza como fuente de moral interna. ${ }^{1431}$

Lo que requiere explicación es la mutación por la que se hacen disponibles las fuentes alternativas al teísmo. Y aquí, como defiende Taylor, hay que completar cualquier identificación de las causas socio-políticas de la secularización con alguna noción de qué fue lo que permitió que aquellas fuentes alternativas tuvieran tanta potencia o llegaran a ser bienes vitales predominantes o virtualmente innegables. Para Taylor, las dos direcciones modernas son inherentemente problemáticas, dado que surgen de la controversia y como reto al teísmo. De ahí la cuestión que plantea Taylor sobre "si esto justifica adecuadamente" la importancia que adquirieron los ideales a los que dieron lugar. ${ }^{1432}$

La rivalidad entre teístas, agnósticos y ateos no conduce a nada. Se pueden establecer relaciones entre las tres fronteras y darse cuenta de que hay influencia e intercambio mutuo entre ellas. Un contacto que ha posibilitado en muchas ocasiones que sea posible el diálogo y el encuentro por la propia interpretación que a veces ha tomado lo que Taylor denomina las nociones contemporáneas de la fe, nociones que se van transformando progresivamente en ideales que tienen que ver con la integridad de la expresión, la igualdad sexual y el feminismo, así como con la justicia económica con dimensiones de globalidad. Si, además, tal y como afirma Taylor, se va configurando una idea de que la salvación es universal, se concluye que hay todo un caldo de cultivo para el diálogo y la interrelación entre las tres fuentes de moralidad. El Papa Francisco habla del encuentro hecho cultura, una cultura que reivindica la vida como arte del encuentro a pesar de tantos desencuentros y confrontaciones. Para el Papa Francisco en la sociedad las diferencias conviven complementándose, enriqueciéndose e iluminándose recíprocamente. ${ }^{1433}$

\footnotetext{
${ }^{1431}$ Cfr. Ibid., pág. 438.

1432 Cfr. Ibid., pág. 433.

${ }^{1433}$ Cfr. PAPA FRANCISCO, Fratelli Tutti, BAC, Madrid, 2020, pág. 141.
} 
III.- En opinión de Taylor, queda claro que no podemos afirmar con contundencia, tal y como afirman el primer Berger y otros autores de las teorías de la secularización, que con el advenimiento de la Modernidad se haya producido un declive de la Religión en el imaginario social. El que haya disminuido la práctica religiosa no quiere decir que haya disminuido la creencia o que las sociedades occidentales, en su mayoría, hayan perdido las referencias trascendentes como expresión de su moralidad. Más bien hay, tal y como hemos afirmado anteriormente, el surgimiento de una pluralidad de fuentes morales, lo cual no significa que se hayan desconfigurado y desfundamentado totalmente las creencias que tradicionalmente definían a las sociedades occidentales. Se trata, pues, de un fenómeno de extrema complejidad y que nos invita a ser cautos a la hora de analizarlo con el detenimiento que se merece, para no establecer conclusiones precipitadas.

Además, no hay que olvidar, tal y como afirma Casanova, un autor referencial en el planteamiento desecularizador que, en muchos ámbitos, se ve un resurgir de la religión, bien dentro de la esfera pública o bien como ámbito reformulado para el diálogo dentro de una condición que efectivamente puede ser calificada de "secular". Una palabra que, por otra parte, debe ser definida adecuadamente y dentro de la que caben muchas acepciones y matices.

Para Taylor, y desde otra perspectiva, se ha llegado a una situación en la que en el ámbito de las modernidades laicas asociadas a la increencia se da una cierta incomodidad respecto a lo que hasta ahora se daba por sentado en relación a la irrelevancia de la creencia o a la seguridad ontológica respecto a sus convicciones. Y, por otra parte, en el ámbito de la modernidad creyente, surgen todo tipo de planteamientos y desconfiguración de certezas que hasta hace poco se pensaban plenamente establecidas. Desde esta circularidad dialógica, entre las distintas fuentes de moralidad, hay que reconocer que, por un lado, la increencia influye dentro del ámbito de las moralidades trascendentes y, por otro lado, las fuentes teístas se ven impelidas a responder a toda clase de retos planteados por el naturalismo ontológico. Hay una porosidad que permite la influencia desde ambos lados. Taylor afirmará esta necesidad de diálogo ya que se tiene la sensación de que la sociedad moderna fragmentada e instrumentalista ha menguado y empobrecido nuestras vidas $\mathrm{y}$, por lo tanto, la recuperación de ciertos bienes constitutivos o el diálogo entre las fuentes morales impulsa nuestras mejores facultades. ${ }^{1434}$

El reconocimiento del pluralismo religioso invita al replanteamiento y al estudio de las teorías clásicas de la secularización, como afirman muchos autores. Teorías que van dando paso a lo que se ha denominado como "edad postsecular" o lo que otros han

${ }^{1434}$ Cfr. TAYLOR, Ch., Fuentes del yo, pág. 664; cfr. TAYLOR, Ch., La Era Secular, tII, págs. 425, 446, $462,524,736$. 
denominado como "posmodernidad". ${ }^{1435}$ Se impone pues, un nuevo relato de la Modernidad y una redefinición de las narraciones clásicas de la secularidad.

La tesis fundamental de Taylor es que se ha llegado al establecimiento de un humanismo exclusivo con consecuencias antropológicas y por ende ontológicas, que se manifiesta en las dos fuentes de la modernidad laica a las que hemos hecho referencia anteriormente. Un humanismo que tiene pretensiones de exclusividad y que impermeabiliza cualquier porosidad que le haga susceptible a otro tipo de influencias. Pretende imponerse como autorreferencia excluyente y como significado único de fundamento moral. Es lo que Taylor denomina "secularismo" en el sentido de "no ser gobernados por ninguna agencia que pueda pasarnos por alto". ${ }^{1436}$

Taylor afirma que a este humanismo se llega a partir de un recorrido que no es fácil de explicar, que puede ser rastreado a partir de las fuentes filosóficas de las que se alimenta, pero que no es simplemente el recorrido natural en el que concluye la Modernidad laica. Hay más fuentes de moralidad y, al mismo tiempo, es curioso observar que dichas fuentes de moralidad laica hunden sus raíces en la espiritualidad cristiana. Taylor insiste, en clave hegeliana, que la Modernidad Ilustrada y secular no puede erigirse como exclusividad del significado moral del hombre ni puede darse por finalizado el movimiento del espíritu humano como un proceso continuo de incremento en el autorreconocimiento y la autoconciencia. ${ }^{1437}$ Taylor afirma, en este sentido, que no es cierto que la austeridad naturalista acerca de los bienes del espíritu nos capacite con mayor ahínco para fomentar el sentido de la benevolencia universal. ${ }^{1438}$

Por otra parte, es difícilmente asumible identificar a la modernidad occidental como el único fenómeno globalizador del mundo. La modernidad occidental tiene su propio recorrido, pero el mundo no es Occidente. Sin duda alguna que hay partes del planeta que han asumido sociológica y culturalmente la globalización occidental en

${ }^{1435}$ Cfr. BERMEJO, Diego, La identidad en sociedades plurales, Anthropos, Barcelona, 2011, 365 páginas; BERMEJO, D., Posmodernidad: pluralidad y transversalidad, Anthropos, Barcelona, 2016, 180 páginas; GAMPER, D., La fe en la ciudad secular, Trotta, Madrid, 2014, 214 págs.; LUHMANN, N., La religión de la sociedad, Trotta, Madrid, 2018, 314 pags; DE LA CUEVA MERINO, J., "Conflictiva secularización: sobre sociología, religión e historia", op.cit., 365-395; GIL GIMENO, J., "Secularizaciones múltiples", Sociología Histórica, No 7, 291-319, (2017); BERIAIN, J., "Modernidades múltiples y encuentro de civilizaciones"; GIL GIMENO, J., "Secularizaciones y manifestaciones religiosas. Las teorías de la secularización a través del Religion Monitor de la Fundación Bertelsmann", RIPS, 15, No 1, (2016), pags 9-28; RUBIO FERRERES, J. M., “¿Resurgimiento religioso versus secularización?" Gazeta de Antropología, No 14, (1998); CRUZ ESQUIVEL, “Declinación, retorno o reconfiguración de lo religioso? Balances de la sociología de la religión en los últimos 25 años”, Espacio Abierto. Cuaderno Venezolano de Sociología, Vol. 25, No 3, (2016), págs. 65-77.

${ }^{1436}$ TAYLOR, Ch., Imaginarios sociales modernos, pág. 217; cfr. TAYLOR, Ch., Fuentes del yo, pág. 671; cfr. TAYLOR, Ch., Dilemmas and Connections, págs. 271, 307, 309-311, 319, 325; cfr. TAYLOR, Ch., La Era Secular, tI, págs. 46, 57, 79, 112, 144, 164, 211, 351, 371, 383.

${ }^{1437}$ Cfr. TAYLOR, Ch., Hegel, pág. 474.

${ }^{1438}$ Cfr. TAYLOR, Ch., Fuentes del yo, pág. 670; cfr. TAYLOR, Ch., Argumentos filosóficos, págs. 64-65, 67, 88-89, 112, 179-180; cfr. TAYLOR, Ch., La Era Secular, tII, pág. 616. 
clave modernizadora, pero hay otras partes del mundo en las que la modernización ilustrada occidental se plantea en términos completamente distintos. ${ }^{1439}$

Si para Marx, Weber y Durkheim la modernidad era un programa cultural que llevaba inexorablemente al arrinconamiento de la religión y de las fuentes morales teístas, Eisenstadt prefiere hablar de modernidades múltiples. El recorrido del mundo, sobre todo a partir de la Segunda Guerra Mundial, confirma en este sentido lo errados que estaban esos planteamientos. Eisenstadt invita a realizar un estudio más detallado y no precipitado sobre la Modernidad y su repercusión en las fuentes de la moralidad creyente, al propio tiempo que invita a superar las visiones homogeneizadoras. ${ }^{1440}$ Taylor afirma, en este sentido, que las tres familias morales no permanecen iguales, constantemente toman prestado de uno u otro y se influyen entre sí. ${ }^{1441}$

Hay mucha variedad en los recorridos, el mundo es muy amplio y dentro de las sociedades occidentales, los resultados son muy diversos y las realidades múltiples. Para Eisenstadt la Modernidad occidental es la historia de una constitución y reconstitución continua de una multiplicidad de programas culturales. Modernidad y Occidentalización no son idénticas. Hay modernidades que también son auténticas y que no son occidentales, aunque reconoce que la modernidad occidental es la que marca la primacía histórica en el cambio ontológico que experimentan las fuentes de la moralidad. ${ }^{1442}$

Luego diferentes sociedades recorren diferentes modernidades. Y no todas viven la modernidad en la misma clave secularizadora que las sociedades occidentales. Cada religión, expresada como hecho cultural, ha enfrentado su propio proceso modernizador y por eso no se puede partir de un planteamiento previo de consenso según el cual todas las sociedades van a repetir el mismo proceso secularizador que las sociedades occidentales. ${ }^{1443}$ Se puede hablar de la índole poliédrica de todas las religiones en la

\footnotetext{
${ }^{1439}$ Cfr. TAYLOR, Ch., Las variedades de la religión hoy, págs. 47-48.

1440 “Todas estas (sociedades) desarrollaron dinámicas y modos de interpretación claramente modernos, para los que el proyecto occidental original constituyó el punto de referencia crucial (y a menudo ambivalente). Muchos de los movimientos que se desarrollaron en las sociedades no occidentales articularon sólidos temas antioccidentales, o incluso anti-modernos, pero todos fueron distintivamente modernos". EISENSTADT, S., "Las primeras múltiples modernidades: identidades colectivas, esferas públicas y orden político en las Américas", Nueva Época, № 218, (2013), pág. 129.

${ }^{1441}$ Cfr. TAYLOR, Ch., Fuentes del yo, pág. 671.

1442 Cfr. TAYLOR, Ch., La Era Secular, tII, págs. 628, 668; cfr. TAYLOR, Ch., Dilemmas and Connections, pág. 273. "Los desarrollos tal como se dieron en las sociedades en vías de modernización han refutado los supuestos homogeneizadores y hegemónicos de este programa occidental de modernidad" (...) "Resulta, en efecto, de importancia central en el análisis de las múltiples modernidades que, en estos marcos culturales e institucionales occidentales, derivados y en cierto sentido traídos de Europa, se desarrollaran no solo variaciones locales del modelo o modelos europeos, sino patrones ideológicos e institucionales radicalmente nuevos. En tanto que en ocasiones se asumía que los patrones europeos de desarrollo moderno se habían repetido en las sociedades de las Américas, es claro que Norteamérica, Canadá y América Latina se desarrollaron, desde el principio, de manera distintiva". EINSTADT, S., págs. 130-131. Cfr. COSTA, P., Introducción, en TAYLOR, Ch., Encanto y desencantamiento, Sal Terrae, Santander, 2015, pág. 12.

${ }^{1443}$ Los conceptos son clave a la hora de determinar el proceso recorrido y no siempre las palabras
} 
actualidad, así como del proceso experimentado en diálogo con la modernidad. Taylor considera que la secularización ha definido un terreno de juego muy accidentado. ${ }^{1444}$

Por otra parte, la globalización ejerce una gran influencia que establece relaciones de un lado y de otro. Lo mismo que podemos hablar de una influencia secularizadora en relación a las sociedades occidentales, también se puede hablar de una "influencia orientalizadora" en relación a las sociedades orientales que también hacen notar su influjo. Zygmunt Bauman afirma que la modernidad del siglo XXI (posmoderna) no es menos "moderna" que la que ingresó al siglo XX. Según Bauman, está igualmente caracterizada por la sobrecogedora, inextirpable e inextinguible sed de creación destructiva, por la limpieza del terreno en nombre de un diseño nuevo y mejorado; desmantelamiento, eliminación, discontinuidad, fusión, o achicamiento, todo en aras de una mayor capacidad de hacer más de lo mismo en el futuro. ${ }^{1445}$ Para Bauman, la modernidad está en continuo cambio, en un irrefrenable sentido de movimiento ascendente en clave hegeliana. Un movimiento que determina las configuraciones morales de la modernidad en una variedad múltiple y que invita a repensar el alcance de la secularidad. ${ }^{1446}$

IV.- Taylor afirma que la gran invención de Occidente fue la creación de un orden inmanente a la naturaleza, noción de lo inmanente que implicaba negar o al menos aislar y problematizar cualquier forma de interpenetración entre las cosas de la naturaleza, por un lado, y lo sobrenatural, por otro, ya sea que esto se refiriese a un Dios trascendente, a dioses o espíritus, a fuerzas mágicas o a lo que fuere. ${ }^{1447}$ Taylor habla de tres características de un mundo en el que la corriente era favorecedora para explicaciones trascendentes del mundo:

1.- El mundo natural en el que vivían las personas, que tenía su lugar en el cosmos que imaginaban, era el testimonio del designio y la acción divinos y en el que los grandes acontecimientos que tienen lugar en este orden natural eran considerados "actos de Dios". 1448

tradición, modernidad, secular y secularización son definidas a partir de las mismas categorías. Además, se parte de situaciones distintas en sociedades distintas, con lo que los procesos de la secularidad moderna no siempre son experimentados de la misma manera. "Hablar de Tradición y Modernidad como categorías universales al estudiar el proceso concreto y real de transformación de una sociedad, no muestra con suficiente claridad cómo explicar el proceso específico en sí mismo, dada la gran vaguedad y abstracción de los términos Tradición y Modernidad”. SOLÉ PUIG, C., "Acerca de la Modernización, la Modernidad y el riesgo", Reis, 080, (2007), pág. 115.

${ }^{1444}$ Cfr. TAYLOR, Ch., La Era Secular, tII, pág. 287.

1445 Cfr. BAUMAN, Z., Modernidad Líquida, Fondo de Cultura Económica, México, 2002, pág. 33.

${ }^{1446}$ Cfr. TAYLOR, Ch., Dilemmas and Connections, págs. 304-305.

${ }^{1447}$ Cfr. TAYLOR, Ch., La Era Secular, tI, pág. 41.

${ }^{1448}$ Cfr. Ibid., págs. 56, 72, 93, 107, 187. 
2.- Dios también estaba implicado en la existencia misma de la sociedad. Dios aparecía por doquier. El vínculo social aparecía en todos los niveles estaba entrelazado con lo sagrado. ${ }^{1449}$

3.- Las personas vivían en un mundo encantado, esto es, en un mundo de espíritus, de demonios, de magia y de objetos sagrados, de hechizos y de fuerzas morales. Se trata de un mundo en el que la significación existe ya fuera de nosotros, antes del contacto, y que puede apoderarse de nosotros, podemos caer en su campo de fuerzas, nos llega desde fuera. ${ }^{1450}$

Este era el mundo encantado que describe Taylor y al que también hará referencia Max Weber cuando habla del proceso de desencantamiento o desmagificación del mundo con el advenimiento de la Modernidad. ${ }^{1451}$ Un mundo que adquiere fundamento a través de disciplinas especializadas que superan sacralizaciones y reflexiones de sabios y filósofos. Es el mundo que ha superado el encantamiento de la antigüedad a través de una ciencia que es incapaz de responder a las cuestiones realmente relevantes sobre el sentido de la vida. ${ }^{1452}$ Se trata de llegar a lo que Weber se refiere como el control técnico de la vida, ${ }^{1453}$ superando la ceguera de la ética cristiana, ${ }^{1454}$ y las referencias ontológicas de la razón eterna platónica. ${ }^{1455}$ Frente al mundo encantado en el que, según Taylor, hay un campo de fuerzas y significados fuera de nosotros antes del contacto, en el mundo moderno, por el contrario, las significaciones están solo en la mente. Es el mundo del pensamiento cartesiano y el conocimiento de la experiencia kantiana. $^{1456}$

Para comprender el alcance del mundo encantado, Taylor analiza los tres tiempos superiores que han dejado de tener sentido para el tiempo secular de la Modernidad y a los que se han hecho referencia ya anteriormente: la eternidad platónica, el tiempo agustiniano y el tiempo de los orígenes. ${ }^{1457}$ En esta variedad de tiempos superiores,

\footnotetext{
${ }^{1449}$ Cfr. Ibid., págs. 80-87, 124, 148, 235, 371.

${ }^{1450}$ Cfr. Ibid., págs. 56, 68, 70 .

1451 "Ahora bien, cabe preguntarse si todo este proceso de desmagificación, (la cursiva es nuestra) prolongado durante milenios en la cultura occidental, si todo este 'progreso' en el que la ciencia se inserta como elemento integrante y fuerza propulsora, tiene algún sentido que trascienda de lo puramente práctico y técnico”. WEBER, M., El político y el científico, Alianza Editorial, Madrid, 1979, pág 200.

1452 “Cuál es el sentido que hoy tiene la ciencia como vocación? La respuesta más simple es la que Tolstoi ha dado con las siguientes palabras: 'La ciencia carece de sentido puesto que no tiene respuesta para las únicas cuestiones que nos importan, las de qué debemos hacer y cómo debemos vivir'”. Ibid., pág. 207; cfr. Ibid., pág. 201.

${ }_{1453}$ Cfr. TAYLOR, Ch., La ética de la autenticidad, págs. 125-126.

1454 "La ciencia 'sin supuestos previos', en el sentido de que rechaza toda vinculación religiosa, no reconoce en cuanto a ella ni el 'milagro' ni la 'revelación'. Si los aceptase traicionaría sus propios 'presupuestos', en tanto que el creyente acepta tanto el uno como la otra”. WEBER, M., El político y el científico, pág. 214.

1455 Cfr. Ibid., pág. 202.

1456 Cfr. Ibid., págs. 212-213.

${ }^{1457}$ Cfr. TAYLOR, Ch., La Era Secular, tI, págs. 103, 161, 311, 331.

"El tiempo, por tanto, nació con el universo, para que, generados simultáneamente, también desaparezca a
} 
cobra sentido la referencia de Taylor a la teoría medieval de los dos cuerpos del Rey, en el sentido de que la persona aureolada, con halo nunca moría, pasaba del tempus al aevum, como afirma Kantorowick. ${ }^{1458}$

Taylor afirma que con la Modernidad se difuminan estos tiempos superiores y tendemos a ver nuestras vidas en el flujo horizontal de un tiempo secular, el tiempo ordinario tal y como lo entendemos comúnmente. Al imponerse este tiempo secular, con la consiguiente superación o irrelevancia de estos otros tiempos superiores, se puede afirmar que nos encontramos en una "edad secular", entendiendo por "secular" como lo que tiene que ver con el saeculum, con el siglo, en el sentido del tiempo profano frente a los tiempos superiores. De esta manera podemos racionalizar el mundo, expulsar de él el misterio acomodando todo al tiempo secular. ${ }^{1459}$

Taylor asegura que este primer momento secularizador (de saeculum), es el momento inmediatamente posterior a la Reforma protestante y se manifestaba como el paso de la influencia y control de la Iglesia (y sus tiempos superiores) al dominio del Estado y de los laicos. Era el paso de una esfera a otra, pero manteniéndose las mismas referencias fundamentales de comprensión del mundo. Sin embargo, este primer momento va a dar lugar, con el comienzo del siglo XVII, a un segundo momento secularizador en el que ya apenas hay espacio en la vida social para lo que está más allá de lo secular. ${ }^{1460}$

V.- Para Taylor, lo "secular" contiene algunos elementos que surgen dentro de la espiritualidad cristiana y que ayudan a iluminar el alcance de la época en la que nos encontramos:

1.- Lo secular, en su sentido etimológico, remite a saeculum en relación al siglo, entendido como "tiempo profano", en contraposición al tiempo sagrado, al tiempo eterno, al tiempo superior. Luego lo secular se refiere en primer término a su oposición

la vez, si en alguna ocasión tiene lugar una eventual disolución suya, y fue hecho según el modelo de la naturaleza eterna para que este mundo tuviera la mayor similitud posible con el mundo ideal, pues el modelo posee el ser por toda la eternidad, mientras que este es y será todo el tiempo completamente generado". PLATÓN, Timeo, 38b-c.

"Pero de esos dos tiempos, pasado y futuro, ¿cómo pueden existir si el pasado ya no es y el futuro todavía no existe? En cuanto al presente, si siempre fuera presente y no se convirtiera en pasado, ya no sería tiempo sino eternidad". HIPONA, A. de, Confesiones, XI, 14, Madrid, Alianza, 1999.

1458 "Por tanto, el halo siempre indicaba en un sentido u otro, un cambio en la naturaleza del tiempo. Significaba que el individuo, persona o lugar aureolado participaba también de una categoría del tiempo diferente de la que determinaba la vida natural sobre la tierra tal y como la entendía la mentalidad medieval. Es cierto que el halo no trasladaba a su portador a la aeternitas Dei, que carece de continuidad, porque en ella todos los tiempos pasados y futuros están presentes. Sin embargo, el halo sí trasladaba a su portador, le trasladaba, escolásticamente hablando, del tempus al aevum, del tiempo a la sempiternidad; en todo caso a algún continuum del tiempo sin fin: la persona aureolada o mejor dicho la persona como halo, su ordo nunca 'moría". KANTOROWICZ, E, Los dos cuerpos del Rey. Un estudio de Teología política medieval, Akal, Madrid, 2012, pág. 111.

${ }^{1459}$ Cfr. TAYLOR, Ch., La Era Secular, tI, pág. 137.

${ }^{1460}$ Cfr. TAYLOR, Ch., Encanto y desencantamiento, Sal Terrae, Santander, 2015, págs 28-29. 
con sagrado/eterno. Es el tiempo ordinario, el tiempo histórico. ${ }^{1461}$ Según Taylor, en esta oposición saeculum/sacrum-aeternum de los tiempos premodernos, el tiempo ordinario, secular, de la sucesión temporal de acontecimientos históricos, está entrelazada con el tiempo superior, hay una conexión entre la sucesión secular del tiempo y los tiempos superiores. Ese era el encantamiento del mundo entendido en clave temporal.

Con el desencantamiento de la modernidad, se pierde la conexión entre ambos tiempos, y el tiempo secular no remite a ninguna eternidad. El tiempo ordinario se establece como el único tiempo en el que se desenvuelve la vida de los hombres. Nada remite a tiempos superiores, eternos, sagrados... La vida se sucede en la continuidad temporal de tiempos cronológicos establecidos como historia de los hombres. ${ }^{1462}$

2.- Hay otra oposición, tal y como refiere Taylor, entre "secular" y "espiritual". Lo secular son las actividades propias del siglo, las que se realizan en el marco del desenvolvimiento social propio, sin referencias a lo sagrado, y otras son las actividades espirituales que son las que se realizan en ámbitos que tienen que ver con lo sagrado y eclesial. Por una parte, están las actividades propias de la Iglesia entendidas como espirituales y, por otra parte, las actividades propias del Estado, entendido como brazo secular.

En esta diada, cada ámbito realiza las actividades que le son propias; unas entendidas de una manera y otras de otra, pero, al mismo tiempo, son partes de un mismo cuerpo: unas se realizan con un brazo y otras, con otro, formando parte del mismo tronco. En las sociedades premodernas, la gente se identifica con el régimen, representado por el cuerpo del rey, con dos identidades significativas o como expresión del orden jerárquico del cosmos. ${ }^{1463}$

En los tiempos premodernos de la Reforma, se realizará una primera desconexión con una secularización primera en la cual muchas actividades propias que realizaba la Iglesia pasarán a los laicos. Es un primer paso "secularizador" caracterizado porque los laicos, los que están en el tiempo del siglo, empiezan a realizar actividades que hasta entonces realizaban los que estaban en el tiempo superior, en el tiempo sagrado. Se transfieren actividades del tiempo superior al tiempo secular. ${ }^{1464}$ Este primer momento "secular/secularizador" no supone ningún dramatismo, no hay horizontes fracturados. Podríamos decir que el brazo secular va adquiriendo una importancia cada vez mayor. Pero seguimos estando dentro del mismo cuerpo, con brazos distintos. ${ }^{1465}$

\footnotetext{
${ }^{1461}$ Cfr. Ibid., pág. 27.

1462 Cfr. TAYLOR, Ch., La Era Secular, tI, págs.100-106.

${ }^{1463}$ Cfr. TAYLOR, Ch., Imaginarios sociales modernos, pág. 220.

${ }^{1464}$ Cfr. TAYLOR, Ch., Hegel, págs. 10, 460.

${ }^{1465}$ Cfr. TAYLOR, Ch., Encanto y desencantamiento, pág. 28.
} 
Con el advenimiento de la Modernidad Ilustrada se realiza la desconexión entre ambos brazos y lo que uno realiza es absolutamente independiente de lo que realiza el otro. Se hablará de separación Iglesia-Estado. Comienzan a constituirse cuerpos distintos (ya no vale la imagen del brazo), se produce una fractura en los horizontes con cosmovisiones y fuentes morales distintas y divergentes. $\mathrm{Y}$ con una consecuencia final realmente relevante: la vida social se comienza a configurar exclusivamente desde el tiempo secular, los tiempos superiores apenas tienen fuerza para configurar la vida social de las personas. ${ }^{1466}$

3.- En relación a lo anterior, y expresado con otra oposición "profano/espiritual", podríamos decir que el tiempo profano/secular, en oposición al tiempo superior, ocupa toda la vida social. Es el tiempo secular el que organiza la vida social. Los tiempos superiores pasan a ser cada vez más marginales. La vida social deja de estar configurada a partir de lo sagrado y pierde sentido la necesidad de una antiestructura. Se cede a la tentación de poner en vigor un código que no tolera límite alguno. ${ }^{1467}$

Lo secular ocupa todo el espacio y lo espiritual va dejando de tener significado. ${ }^{1468}$ Se irá procesando poco a poco, pero el cambio es completo, absoluto, fracturado. Se ha iniciado el cambio hacia una sociedad secular de tipo instrumental que, para Taylor, empobrece la vida de significados más profundos, haciendo que sea muy difícil discernirlos. ${ }^{1469} \mathrm{Al}$ principio se manifiesta como una clara división entre lo natural y lo sobrenatural, hasta dar el paso a un mundo donde llegará a ser posible vivir exclusivamente desde el mundo natural. Ahondando en esta última idea de fractura, hay que hacer notar que, desde el punto de vista de Taylor, este nuevo horizonte se irá realizando de forma progresiva. Inicialmente se sigue creyendo en lo trascendente, pero luego ese irá expresando en términos cada vez más secularizados, comenzando por el deísmo y llegando hasta el humanismo exclusivo o al naturalismo ontológico.

Lo realmente importante son los motivos que llevan al deísmo, dado que es el deísmo el que propicia la plataforma de salida hacia el humanismo exclusivo y radical. Sin el deísmo, para Taylor, difícilmente se podría haber llegado hasta donde se llegó. El bien vital se convierte en algo diferente cuando uno es inducido a percibir de manera diferente dicho bien. En este sentido, para el hermeneuta canadiense, la noción deísta del orden natural articuló novedosamente el trasfondo de la nueva cosmovisión que empieza a surgir en el siglo XVIII. Esta filosofía captó el sentido de dichos cambios e influyó de manera determinante en la forma que estos adoptaron. Posteriormente, el movimiento de los bienes vitales evolucionará desde las formulaciones deístas, llegando a convertirse en el proceso, en algo diferente, lo que, según Taylor, significará que

\footnotetext{
${ }^{1466}$ Cfr. TAYLOR, Ch., El multiculturalismo y la política del reconocimiento, págs. 23-25.

${ }^{1467}$ Cfr. TAYLOR, Ch., La Era Secular, tI, págs. 80-82.

${ }^{1468}$ Cfr. TAYLOR, Ch., Dilemmas and Connections, pág. 226.

${ }^{1469}$ Cfr. TAYLOR, Ch., Fuentes del yo, pág. 675.
} 
entrará en la órbita de cosmovisiones diferentes. Es el deísmo el que determinará la dirección y configuración de la diversidad de fuentes morales modernas. Será el primer paso hacia la Ilustración increyente de Helvecio, Bentham, Condorcet y Holbach. ${ }^{1470}$

Taylor concede relevancia a Grocio por ser uno de los promotores del nuevo orden socio-político, al margen de la vida buena (entendida filosóficamente) y al margen de una ética específicamente cristiana (entendida como santidad). ${ }^{1471} \mathrm{Se}$ comienza a configurar este nuevo orden social del beneficio mutuo y de protección compartida, desde un espíritu promovido desde los laicos y lo laico (entendido en su sentido secular en oposición a sagrado/espiritual) y, al margen de cualquier sentido virtuoso, desde la fe. Lo verdaderamente auténtico es la libertad autorresponsable y autodeterminada. ${ }^{142}$ Taylor afirma que el desarrollo del orden disciplinado e instrumentalmente racional del beneficio mutuo fue la matriz en el seno de la cual se pudo producir el desplazamiento de fuentes morales. ${ }^{1473}$

\section{IV.3.-LA SECULARIZACIÓN COMO RUPTURA ENTRE LO INMANENTE Y LO TRASCENDENTE}

Tal y como se ha analizado en los capítulos precedentes, "lo espiritual y lo mundano" siempre han estado en relación o no ha habido una distinción clara entre ellos. Lo superior, el mundo de las ideas, de los espíritus, del misterio, se relacionaba de manera muy intensa con el mundo de lo profano, de lo cotidiano, y difícilmente podían entenderse el uno sin el otro. La configuración de la vida social no se podía entender sin la vida superior, de los misterios y espíritus y en torno a estos surgían las sociedades.

Profundizando en esta idea, y bajo otra perspectiva, Marcel Gauchet afirma que, en continuidad con las religiones preaxiales y con el advenimiento de las religiones axiales, se produjo un reordenamiento de lo espiritual y lo mundano, un reensamblaje entre lo visible y lo invisible, un amalgamiento que se expresa como una fractura en el ser con consecuencias ontológicas. Se trata de una fractura que comienza por producir una transformación que desplaza el fundamento de la experiencia religiosa al interior de los hombres. ${ }^{1474}$ Se podría considerar este momento como "presecularizador", en el sentido que inicia cambios fundamentales en el mundo y que permite la promoción de la interioridad y reducción de la alteridad. ${ }^{1475}$

\footnotetext{
${ }^{1470}$ Cfr. Ibid., pág. 423.

${ }^{1471}$ Cfr. TAYLOR, Ch., La Era Secular, tI, págs. 206,257,276,300,447.

${ }^{1472}$ Cfr. TAYLOR, Ch., La ética de la autenticidad, págs. 130 y ss.

${ }^{1473}$ Cfr. TAYLOR, Ch., La Era Secular, tI, pág. 466.

1474 Cfr. GAUCHET, M., El desencantamiento del mundo, págs. 69 y ss.

1475 "Lo visible y lo invisible se ajustan, se ensamblan por todos los puntos como una sola e idéntica realidad. Aquí el acontecimiento es precisamente la reordenación de esta articulación de lo visible y de lo invisible, la conjunción que se torna disyunción; la complementariedad, diferencia; el ajuste, separación. El fundamental, el original nutriente del que irradia el sentido no es ya en lo dado, con el destino que nos
} 
Taylor afirma que, a partir del nuevo fundamento de la experiencia religiosa con la reforma protestante y la revolución del yo cartesiano, se produce un movimiento definitivo de alcance "secularizador" que se podría subdividir en tres momentos: se parte de la distinción, se llega a la independencia y todo concluye con la ruptura autoexcluyente. El primer paso se refiere a la distinción expresada como ámbitos distintos, distinción que se expresa en el deísmo. ${ }^{1476}$ En un segundo momento, se pasará de la distinción a la separación absoluta. Y en un tercer momento, tendrá lugar la negación de la trascendencia como irrelevante o mera invención humana. Taylor hace notar que esta ruptura de órdenes solo se da en la Cristiandad latina. Se trata de una ruptura de carácter ontológico, ${ }^{1477}$ semejante a la que se produjo, bajo otro paradigma, con el surgimiento de las religiones axiales, dado que va a desembocar en la afirmación del humanismo exclusivo, teniendo como paso intermedio la Ilustración radical. ${ }^{1478}$

toca, donde se libera, sino más acá; solo se encuentra mediante una travesía interior”. Ibid., pág. 70.

${ }^{1476}$ Cfr. TAYLOR, Ch., Encanto y desencantamiento, pág. 31. Antes de la ruptura de niveles, con el deísmo se establece una relación entre el orden inmanente y el orden trascendente de manera "distinta" al orden primero en el que no había separación o donde, posteriormente, cada orden tenía su propia hornacina, pero como un intercambio donde se iba readaptando el mobiliario a los mismos espacios dentro de la misma casa. Con el deísmo Dios es visto como el proveedor beneficiario de un orden natural que ha sido establecido por el Creador y que al mismo tiempo invita a crear una sociedad "expresión de dicho orden" a través del beneficio mutuo y por lo tanto como algo querido por Él. Y en el que al final habrá un castigo o un premio en el más allá. A la religión se la permite como configuradora de un orden natural y moral. Con el deísmo se racionaliza la religión como una institución más del orden estatal y se permite su funcionamiento en tanto y cuanto contribuye a la promoción del beneficio mutuo, iniciando así un proceso secularizador imparable, no solo porque se permite a la religión su funcionamiento bajo dicha perspectiva, sino que además inicia un declive imparable dentro de la configuración social.

1477 Cfr. TAYLOR, Ch., La Era Secular, tI, pág. 368.

${ }^{1478}$ Cfr. Ibid., pág. 371. Me parece relevante resaltar aquí otra distribución en relación a la evolución de la conciencia humana tal y como la plantea Bataille a partir de su lectura hegeliana de la Historia y de la Fenomenología del Espíritu. Cfr. BATAILLE, G., Teoría de la Religión, Taurus, Madrid, 1981, págs. 69107. Un primer momento denominado el orden militar, en el que se establece la unidad entre lo sagrado y lo profano y en el que el imperio es entendido como la cosa universal (cosa en clave hegeliana): "es el orden mismo de las cosas y es una cosa universal... ya no es una cosa, en tanto que lleva en sí misma más allá de sus caracteres intangibles una apertura a todo lo posible. Pero esta apertura es en ella un vacío" (Ibid., 71). Un segundo momento que denomina el dualismo y la moral, que sería la lectura de Bataille en relación al mundo de la filosofía clásica de Platón y Sócrates con el establecimiento de la moral y la relectura de lo sagrado y lo profano en clave moral como términos de bien y mal: "En la evolución dualista, lo divino se hace racional y moral y rechaza lo sagrado nefasto del lado profano. El mundo del espíritu (que tiene pocas relaciones con el primer mundo de los espíritus, en el que las formas distintas del objeto se añadían a la indistinción del orden íntimo) es el mundo inteligible de la idea, cuya unidad no puede descomponerse. La división en fasto y nefasto se encuentra también en el mundo de la materia, en el que la forma sensible es tan pronto aprehensible y tanto pronto no es aprehensible, permanece móvil, peligrosa e imperfectamente inteligible, no es más que azar, violencia, amenaza con destruir las formas estables y operatorias" (Ibid., pág. 76). Un tercer momento que lo titula la mediación y que tiene que ver con el cristianismo y el sacrificio de la divinidad: "Es la divinidad misma la que sufre. Como en la posición de un dios de venganza, el crimen es necesario para el retorno del orden íntimo. Si no hubiese ahí más que el hombre del orden de las cosas y la divinidad moral, no podría haber entre ellos comunicación profunda..." (Ibid., pág. 86). Y finalmente un cuarto momento denominado el desarrollo industrial y que es el momento de la Modernidad como "la posición de una entera ausencia de relaciones entre la intimidad divina y el orden real". (Ibid., pág. 91). Es este momento en el que se expresa la ruptura total de los dos marcos, el inmanente y el trascendente y la negación del trascendente: "Pronto se hace perceptible que, al convertirse él mismo en el hombre de la cosa autónoma, el hombre se aleja de sí mismo más todavía de lo que nunca había hecho. Esta escisión completa (la cursiva es nuestra) abandona 
La independencia de niveles se va a expresar, tal y como hemos dicho anteriormente, en un primer momento como deísmo. ${ }^{1479}$ Un deísmo que no es solo un paso intermedio, sino que su importancia es altamente relevante para Taylor, porque llegar a este momento es posibilitar todo lo demás. Sin este momento difícilmente se hubiera llegado a la radicalización humanista.

A partir del siglo XVII, se da algo fundamental y que no había ocurrido nunca hasta entonces. Gradualmente se va afirmando la idea, hasta que se asienta de forma definitiva, de que no hay ningún espacio dentro de la vida social para lo que está más allá de lo secular. Esto se expresa bajo la forma de que el único tiempo que configuraba la vida social y cultural es el tiempo profano; los espacios para los tiempos superiores quedaban reducidos de manera casi total. Ya no había espacios para lo que tuviera que ver con el sentido trascendente de la vida. Las rupturas propias de las etapas anteriores entre lo inmanente y lo trascendente se han resuelto como disolución de lo trascendente y no hay espacios para que la esfera de lo trascendente se manifieste en su ámbito propio. Todo queda definido a partir de lo secular. ${ }^{1480}$

De los malestares de la modernidad del siglo XVIII, se pasará a lo que Taylor denomina el oscuro abismo del tiempo y la expansión del universo de la no creencia en los siglos XIX y XX. ${ }^{1481}$

Se llega a una radicalización tal, que lo secular se convertirá progresiva y definitivamente en el ámbito que dominará toda la vida social, quedando lo trascendente limitado a espacios secularizados para el compromiso con la paz y la justicia, y como una posible contribución para el buen funcionamiento de las sociedades. Se ha impuesto de manera definitiva la vida social como un ámbito exclusivamente definido por el ámbito secular y en el que la sociedad se entiende de manera "postgrociana", como individuos que buscan su propio beneficio a través del beneficio de todos. Irá surgiendo así la sociedad del beneficio recíproco en la que todos estamos interesados en el beneficio de todos porque así se alcanza mejor el beneficio personal, desapareciendo irremediablemente cualquier ética de la virtud de la santidad o del amor cristiano. ${ }^{1482}$

decididamente su vida a un movimiento que él ya no dirige, pero cuyas consecuencias en último término le dan miedo" (Ibid., pág. 96).

1479 "Se ha llamado también religión natural aquello de Dios que el hombre puede conocer por la luz de $s u$ razón- deísmo. Pero eso no es religión de lo natural sino de la abstracción”. HEGEL, F., Fenomenología de la Religión, pág. 322.

${ }^{1480}$ Cfr. TAYLOR, Ch., La Era Secular, tI, págs. 383-388.Cfr. TAYLOR, Ch., La Era Secular, tII, págs. $13,197,213,256,353,381,423,436,445,474,489,592,594,733$. "Lo secular se contraponía a toda reivindicación propuesta en nombre de algo que trascendiera el mundo y sus intereses". TAYLOR, Ch., Encanto y desencantamiento, pág. 2.

${ }^{1481}$ Cfr. TAYLOR, Ch., La Era Secular, tI, págs. 13-129.

${ }^{1482}$ Cfr. TAYLOR, Ch., La ética de la autenticidad, págs. 77-78; cfr. TAYLOR, Ch., Hegel, pág. 472. 
Taylor considera que el deísmo hace posible de manera consecuente y natural el utilitarismo radical que se desvincula de cualquier orden providente de la ley natural (deísmo de Shaftesbury y de Rousseau). ${ }^{1483}$ Dejamos de ser por naturaleza parte de ese orden natural y se nos vincula a una causalidad eficiente en la que todo está definido por el hacer, por el utilitarismo, se nos hace así. No es el orden providencial de la naturaleza el que nos asocia a una bondad natural del ser humano (vinculación deísta), sino que es el hecho de que formamos parte de unas relaciones humanas que hacen que seamos de una manera $u$ otra en función del contexto en que nos movamos y por causas que pueden ser plenamente conocidas. Desaparece un orden providente y pasamos a ser una realidad más; orden en el que todo se puede explicar causalmente, una causalidad definida por la utilidad y los bienes vitales que motivan una moralidad totalmente laica. Nuestro carácter está definido, no por un orden natural providente, sino por unas relaciones causales que motivan nuestra moralidad y que están definidas por la utilidad eficiente de buscar la felicidad y evitar el dolor y la pena, esto es, por una neutralidad genética. La felicidad no viene establecida ni por un orden jerárquico de la razón (ideas platónicas y la cadena del ser) ni por un orden natural providente (deísmo). Se establece un naturalismo que tiende a considerar como irrelevante cualquier evaluación fuerte o argumentación ad hominem. ${ }^{1484}$

Esta desvinculación definitiva, hasta las últimas consecuencias, define la radicalidad de esta Ilustración moderna y explica el camino hacia la necesidad de una moralidad naturalista, sin ninguna referencia trascendente. Esta necesidad hace que el marco inmanente quede establecido como referencia que desvincule y desencante definitivamente el mundo y margine totalmente cualquier moralidad teísta o deísta. Se llega al momento, clave y fundamental, en el que el marco trascendente se considera como un impedimento para la realización moral del ser humano. ${ }^{1485}$ Por eso, este momento se establece con consecuencias antropológicas de carácter ontológico. Todo lo que no se considere desde el marco exclusivamente inmanente (humanismo exclusivo), se considerará que no define antropológicamente al hombre, que no tiene que ver con él y con su esencia autoconsciente. Consecuentemente, se establece de forma definitiva el marco inmanente como el marco único (o por lo menos así se intenta hacer ver).

Este momento del camino hacia el humanismo exclusivo y de abandono de cualquier orden providencial deísta se ve reforzado por tres características que según Taylor son determinantes para que así se establezca. ${ }^{1486}$

\footnotetext{
1483 Cfr. TAYLOR, Ch., Fuentes del yo, pág. 441.

${ }^{1484}$ Cfr. TAYLOR, Ch., Argumentos filosóficos, págs. 89 y ss; cfr. TAYLOR, Ch., Fuentes del yo, págs. 461-479, 485, 495-499, 520-525.

${ }^{1485}$ Cfr. TAYLOR, Ch., La Era Secular, tII, pág. 392-395.

${ }^{1486}$ Cfr. TAYLOR, Ch, Fuentes del yo, pág. 442.
} 
1.- El ideal de la razón autorresponsable. Cualquier otra autoridad que se considere no tiene que ver con la dignidad del ser humano que asocia su moralidad al marco totalmente inmanente, libre de cualquier tradición que vincule al ser humano a cualquier orden racional o natural de tipo trascendente. Todo ello conduce a la desvinculación radical. ${ }^{1487}$

2.- El utilitarismo eficiente que busca la felicidad en la vida corriente y en las satisfacciones propias de la psicología humana y de la vida familiar, afrontadas con la fuerza del que sabe que es un deseo inherente a nuestra propia vida, y que debe ser buscada, ante todo, sobre todo y en todo lo que tiene que ver con uno mismo, sin otra referencia que el yo que se autoconstruye moralmente a partir de sí mismo y de su propio carácter. ${ }^{1488}$ La psicología desplaza a cualquier orden ontológico que no tenga que ver con las propias fuentes morales del yo que busca y desea desde sí y para sí. La felicidad humana está en íntima relación con la utilidad, el sacar el mayor partido posible a lo que la vida humana da de sí, a lo que solo ella es capaz de proporcionar, sin otro tipo de realizaciones trascendentes. ${ }^{1489}$

3.- El ideal de benevolencia neutra y universal. ${ }^{1490}$ Cualquier otro tipo de orden natural benevolente es considerado como incongruente con la evidencia del sufrimiento humano. No se puede afirmar algo que contradice el común sentir de la vida ordinaria. Hay terremotos, maremotos, volcanes, riadas, muertes masivas de seres humanos que contradicen abiertamente que estemos en el mejor de los mundos posibles del doctor Pangloss en el Cándido de Voltaire. Desde la razón filosófica y psicológica no se sostiene un orden natural providente y benefactor para el ser humano. ${ }^{1491}$

Para Taylor, y lo queremos resaltar, "no es evidente" la narración de que con la razón autorresponsable, con el avance de la ciencia y la razón, las explicaciones teístas o deístas del mundo dejaran de tener fundamento. Sería tanto como olvidar los puntos dos y tres de su argumentación. O dar alcance de exclusividad a la razón autorresponsable como única explicación coherente de la secularización. Taylor quiere prevenir contra esta argumentación simplista y superficial.

\footnotetext{
${ }^{1487}$ Cfr. TAYLOR, Ch., Argumentos filosóficos, págs. 192, 193, 290-291; cfr. TAYLOR, Ch., Fuentes del yo, págs. 506, 539, 651, 669-692.

1488 Cfr. TAYLOR, Ch., Hegel, pág. 474.

${ }^{1489}$ Cfr. TAYLOR, Ch., Fuentes del yo, págs. 36, 46-47, 58, 119, 121, 123-124, 134, 342, 444-455, 461466; cfr. TAYLOR, Ch., La ética de la autenticidad, págs. 51,71.

${ }^{1490}$ Cfr. TAYLOR, Ch., Imaginarios sociales modernos, págs. 204-212; cfr. TAYLOR, Ch., Fuentes del yo, págs. 363, 366, 383-384; cfr. TAYLOR, Ch., La ética de la autenticidad, pág. 53.

${ }^{1491}$ Cfr. TAYLOR, Ch., El multiculturalismo y la política del reconocimiento, págs. 85,127-129.
} 


\section{IV.3.1.-DE LA RAZÓN RESPONSABLE AL NATURALISMO Y DEL ORDEN NATURAL PROVIDENTE AL MODERNISMO POSTROMÁNTICO}

Con la Modernidad, hay una variedad de fuentes de moralidad que se remiten unas a otras, se matizan, se contradicen y en ocasiones se necesitan para comprenderse a sí mismas. Por otra parte, Taylor añade complejidad a esta situación afirmando algo que nos parece importante destacar: todo parece provisional e incierto, incluso para aquellas personas que proceden de la moralidad teísta, asentándose en el miedo y la inseguridad. ${ }^{1492}$ Hasta ahora se podía ondear en las profundidades de una ontología que fundamentaba el surgimiento de fuentes morales, fueran platónicas, teístas, cartesianas o deístas. Había una ontología moral que fundamentaba un sentido y la imagen antropológica de sí mismo enraizada a partir de valoraciones fuertes. Con el surgimiento de una pluralidad de fuentes morales a partir de la Modernidad, vemos cómo todo se va diversificando, matizando, completando e incluso contradiciendo sobre la base de las ontologías precedentes.

Taylor sostiene que la primera fuente moral de la razón autorresponsable deísta, y posteriormente laica, nos lleva al utilitarismo y finalmente al naturalismo más excluyente con el relato subjetivista de los valores; y la segunda fuente de la modernidad laica, el orden natural providente y benefactor nos conduce a la consideración de la naturaleza como espacio para el reconocimiento de las profundidades morales del yo como orden inherente al ser humano y como reflejo de dicho orden en la naturaleza cósmica. ${ }^{1493}$ Esta segunda fuente conduciría, según Taylor, a una pluralidad de visiones alternativas que superan el ámbito de la autorrealización subjetivista y realizan una crítica al instrumentalismo utilitarista, pero que se quedan angostas y a veces insuficientemente articuladas. La crítica tayloriana es que todas estas visiones alternativas de la segunda moralidad se olvidan de explorar lo que él denomina la exploración del orden a través de la resonancia personal. ${ }^{1494}$ Vayamos por partes.

A.- La primera fuente de moralidad alternativa laica va del deísmo, al utilitarismo y finalmente, al naturalismo materialista. Frente a la razón cartesiana, la razón utilitarista pone definitivamente muros a cualquier sentido trascendente. Hay un largo recorrido hasta llegar aquí. Del yo que se descubre como yo que piensa, al yo que se define autorreferencialmente como única razón evidente. Si la razón es la identidad del

\footnotetext{
1492 "Es muy posible que algunos pierdan la fe al ser intimidados por el prestigio de la lectura naturalista de la razón científica. En ese caso, la biografía de dicho converso encajaría en la autoimagen: primero, repudia la religión porque 've' que es incompatible con (lo que piensa que es) la racionalidad científica a secas; luego adopta la mejor de las alternativas restantes, a saber, el utilitarismo o alguna otra forma de humanismo ilustrado. Esto parece haber ocurrido con bastante frecuencia en el siglo XIX y parte del XX. O quizá más cautelosamente, un tipo ideal de esta descripción se aproxima a encajar la realidad en dicho período". TAYLOR, Ch., Fuentes del yo, pág. 462.

${ }^{1493}$ Cfr. Ibid., pág. 685.

${ }^{1494}$ Cfr. Ibid., págs. 690-691.
} 
yo, cualquier razón que vaya contra la evidencia de la razón es descartable. Luego una razón que afirma un sentido de la vida que va contra la razón es irracional. Y es ahí donde se asienta el cambio ontológico que estamos analizando. Es más racional no creer que creer, pues es ya una hipótesis que no se necesita, como planteaba Laplace en su diálogo con Napoleón. La razón autorresponsable exige no necesitar de la hipótesis Dios. Se pasa así, de alguna manera, de la ética de la creencia a la ética de la razón. Si no se puede creer en Dios sin el ejercicio de la razón, ahora se pasa a no necesitar de Dios por el mismo ejercicio de la razón.

La tesis de Taylor está clara: la creencia en los veredictos de la razón no situada es una ilusión, el salto desde Descartes a Laplace entraña un vuelco en la manera en que se percibía la naturaleza y el lugar moral de la razón. ${ }^{1495}$ Este es el análisis que interesa destacar: el lugar moral de la razón. Se ha llegado a un momento en el que la razón exige un orden moral distinto, una configuración antropológica que no precisa de Dios para explicarse a sí mismo. Es la "razón tranquila", con su propio yo determinado en su propia autoconciencia, y que no precisa más para entenderse a sí mismo en su propia dignidad humana y ser íntegramente auténtico. Es lo que afirman los pensadores de la Ilustración radical que abrazaron el ateísmo y el materialismo, no solo como afirmación de la razón autorresponsable, sino como el modo de ser íntegramente verdadero según la demanda de la naturaleza. Se llega a lo que Taylor describe como la aceptación del modelo apodíctico que va más allá del utilitarismo, en una afirmación cuasidesesperada del subjetivismo más absoluto. ${ }^{1496}$

Entre estos pensadores está Holbach y su obra El Sistema de la Naturaleza. Para Holbach la dimensión moral del hombre está definida por su entidad natural, tal y como es por naturaleza. Lo único que define al hombre son sus modos de actuar caracterizados por ser meros efectos naturales y explicables por su pensamiento y voluntad. La esencia del hombre es su naturaleza física y esa es su dimensión moral. Somos una parte más de esa naturaleza universal que alcanza dimensiones de neutralidad benevolente. Schopenhauer también se referirá, en este mismo sentido, a la dimensión moral del hombre como pensamiento y voluntad, como razón y deseo. ${ }^{1497}$

La naturaleza no transmite ningún significado ontológico de carácter trascendente, es una realidad física de carácter universal, dentro de la cual el hombre forma parte, como otro elemento más entre otros muchos. La naturaleza como realidad física es la única realidad que debe regir la dimensión moral del hombre. No tiene sentido buscar fuera del mundo realidades que son solo imaginación y superstición. Atenta contra la dignidad de la razón adentrarse en profundidades que vayan más allá de la realidad

\footnotetext{
1495 Cfr. TAYLOR, Ch., Fuentes del yo, pág. 446.

${ }^{1496}$ Cfr. TAYLOR, Ch., Argumentos filosóficos, págs. 64,287,288,321.

${ }^{1497}$ Cfr. Ibid., pág. 446.
} 
física de la naturaleza y de las leyes naturales que rigen su funcionamiento. Esta es la felicidad del hombre, gravitar sobre su propio deseo de placer y bienestar, adentrarse en su propia naturaleza física como única fuente moral: un ser que piensa y que tiene voluntad como modos de actuar. Esta es su esencia, su psicología natural y su naturaleza física. ${ }^{1498}$ Para Holbach, los hombres deben abandonar los sistemas que se configuran en base a la imaginación engañosa. El hombre es naturaleza, forma parte de ella y no hay nada más allá. No hay un significado superior en ella. Todo es naturaleza y solo eso. $^{1499}$

La naturaleza circunscribe al hombre al ritmo inmanente que le envuelve, sin otro misterio que el sometimiento a sus leyes, inspirándose en la contemplación de los movimientos y energías que surgen de ella e inspirándose en sus leyes inmutables. La naturaleza es una fuerza universal de carácter físico y el hombre un ser físico que forma parte de ella. Y el hombre moral no es más que el hombre físico que considera su propia felicidad como reflexión e intuición hacia la que somos llevados por nuestra propia naturaleza. Este es el veredicto final de una "razón observadora", no distorsionada ni por religiones ni por espiritualismos y que impone el sometimiento en silencio a sus leyes. $^{1500}$

Todos los momentos históricos en los que el hombre se ha desenvuelto forman parte de la misma naturaleza primigenia que nos determina como Fuerza Universal. La Naturaleza ha dotado al hombre, como ser físico, de todas las posibilidades que se encuentran escondidas en sus profundidades, para ir desarrollándose y evolucionando de múltiples formas y maneras. El hombre es un ser físico que desarrolla su propia experiencia humana en el mundo, ya sea como hombre físico, moral, salvaje, civilizado, ilustrado, feliz, desgraciado. ${ }^{1501} \mathrm{Y}$ sin esta experiencia natural difícilmente el hombre puede encontrar el significado de lo que es; es más, todos los errores del hombre provienen por haberse "desconectado" de esta experiencia física con la Naturaleza. Es la Naturaleza la que evita el engaño de los dioses y al mismo tiempo la que, desprovista de significados, se limita a marcar la sucesión de leyes necesarias e inmutables. El hombre se ha engañado buscando seres imaginarios, cuando lo tenía todo en la Naturaleza, que marca sus propios ritmos y leyes, y donde el hombre se siente una realidad física más en la Naturaleza Universal que todo lo engloba y determina. Han sido estos engaños de seres imaginarios — que todo lo envuelven - los que han provocado que el hombre no haya seguido las leyes de la Naturaleza y el ritmo personal de su propia naturaleza. Y se

\footnotetext{
${ }^{1498}$ Cfr. TAYLOR, Ch., Hegel, págs. 4-9.

1499 "El hombre es obra de la Naturaleza: existe en ella, está sometido a sus leyes y no puede liberarse o salir de ella ni siquiera por el pensamiento... Para un ser formado por la Naturaleza y circunscrito a ella, no existe nada más allá del gran todo del que forma parte y a cuyas influencias está sujeto". HOLBACH, Sistema de la Naturaleza, Editora Nacional, Madrid, 1982, pág. 117.

${ }^{1500}$ Cfr. TAYLOR, Ch., Fuentes del yo, pág. 447.

${ }^{1501}$ Cfr. HOLBACH, Sistema de la Naturaleza, pág. 119.
} 
ha desviado por caminos de una moral que no tenía que ver con la naturaleza propia que le desvela los ritmos de su auténtico esclarecimiento moral. La moral es el conocimiento propio como realidad natural. $\mathrm{Y}$ así, en lugar de seguir el camino de la experiencia natural, de la reflexión y la razón, los hombres han sido engañados por sistemas de imaginación, autoridad, prejuicio y autoengaño. Para Taylor, el relato de Holbach pretende garantizar la objetividad del mundo a través de la posición desvinculada, en un universo neutral, atomista y mecanicista. ${ }^{1502}$

Holbach intenta ayudar al hombre a elevarse sobre sí mismo y consultar a la Naturaleza, la única fuente de sabiduría, que invita al hombre a seguir sus leyes y dejarse encumbrar por sus ritmos de experiencia. Para Holbach las esencias de los seres no son más que las diferentes propiedades de la materia y sus combinaciones posibles, que permiten contemplar la complejidad del mundo en sus diferentes órdenes y sistemas . ${ }^{1503}$ Eso es la Naturaleza. ${ }^{1504}$

Según Holbach, la distinción entre el hombre físico y el hombre moral es solo expresión del relato metafísico y la imaginación de muchos filósofos. El hombre es solo un ser físico, material y sometido a las leyes de la naturaleza, como los demás seres que viven en el mundo, y preguntarse por su origen es una pregunta que no interesa realmente. ${ }^{1505}$

Como puede comprobarse, con Holbach la naturaleza ha cambiado como fuente de moralidad. Ha perdido la referencia deísta de espejo de un orden providencial puesto

\footnotetext{
${ }^{1502}$ Cfr. TAYLOR, Ch., Argumentos filosóficos, pág. 112; cfr. TAYLOR, Ch., Hegel, págs. 4,9,20.

${ }^{1503}$ Holbach pretende superar la esencia aristotélica como "ousia" en su alcance de lo universal, de especie (caballo, perro, hombre...). La esencia en Holbach son las leyes naturales que definen el comportamiento de todos los seres entendidos como realidades físicas. Lo existente es lo sensible, lo material en sus propiedades físicas. Holbach identifica la esencia como la "sustancia aristotélica", lo individual, la materia. Todo un vuelco ontológico que determinará la consideración de la naturaleza como una realidad física y neutra respecto a significados ontológicos de sentido.

1504 "Llamo natural a lo que es conforme a lo que es conforme a la esencia de las cosas o a las leyes que la Naturaleza prescribe a todos los seres que contiene... Por esencia entiendo lo que constituye a un ser tal como es, la suma de sus propiedades o de sus cualidades de acuerdo con las cuales existe y actúa tal como lo hace". HOLBACH, Sistema de la Naturaleza, pág. 124.

1505 "Actúa en función de su energía particular y produce frutos, actos y obras igualmente necesarias. Percibirá que la ilusión que tiene a favor de sí mismo proviene del hecho de ser a la vez espectador y parte del universo. Reconocerá que la idea de excelencia que atribuye a su ser no tiene otro fundamento que el de su propio interés y la predilección que siente por sí. Además, las facultades intelectuales son solo maneras de ser y de actuar que se derivan de la facultad de sentir”. Ibid., pág. 173. Cfr. Ibid., págs. 180 y ss. Para Holbach, tanto la imaginación, como el juicio y la voluntad son facultades de nuestro cerebro. Incluso la sociabilidad y la moral son principios naturales que obedecen a modificaciones particulares del cerebro. Y por supuesto no hay ideas innatas. Cfr. Ibid., págs. 213 y ss. La vida eterna no es otra cosa que el deseo natural de supervivencia que anida en el hombre, lo cual no significa que exista una vida de ultratumba. Cfr. Ibid., pág. 275. "Este deseo depende, en los hombres, de la energía de sus almas o de la fuerza de su imaginación, siempre dispuesta para realizar lo que desean impetuosamente". Ibid., pág. 275. Y también, si el hombre no hubiera experimentado el mal y el dolor tampoco habría pensado nunca en ninguna divinidad: Cfr. Ibid., pág. 367 y ss. "Los hombres siempre han extraído sus primeras nociones sobre la divinidad en el sentido de la ignorancia, de inquietudes y calamidades". Ibid., pág. 370.
} 
para nosotros, como algo dado, a ser considerada sencillamente como una realidad física, y nosotros, como otra realidad física más. ${ }^{1506}$ Se niega cualquier fundamentación de significado moral porque impide el pleno desenvolvimiento de la felicidad humana. Para Taylor, frente a un deísmo que pretende fortalecer el valor de la felicidad humana y una visión optimista de la naturaleza humana, frente a visiones teístas de carácter hiperagustiniano, el utilitarismo radical se pone como abanderado de dichos valores, reforzando la posición de que es posible representarlos mejor sin ningún tipo de visión trascendente. Si el deísmo representaba un debilitamiento de la religión defendiendo bajo la bandera del orden providente valores de la vida cotidiana y de la felicidad honorable, ahora dicho debilitamiento se define como anulación de la trascendencia, porque no se precisa de ningún orden de fundamentación para defender lo mismo. La naturaleza es solo el lugar reverencial desde cuya hondura surge el pensamiento y el ser. ${ }^{1507}$ Taylor piensa que se trata de capacitarnos para captar toda la imagen como espectadores imparciales del mundo. ${ }^{1508}$

Otro autor de la Ilustración radical es Helvecio. Para él, el espíritu no significa ninguna esencia ni sentido racional en un orden natural providente, sino sencillamente una capacidad para ordenar ideas nuevas y descubrir relaciones entre objetos. ${ }^{1509}$ Todo se remite a conexiones estímulo-respuesta en relación con el racionalismo lockeano y empirista. ${ }^{1510}$ Para Taylor, el relato de Helvecio pretende, en el fondo, borrar cualquier distinción moral y hacer que todos los deseos humanos sean merecedores de la misma consideración. ${ }^{1511}$ Es la afirmación del hombre sensual común en su lógica antiplatónica y antiagustiniana. ${ }^{1512}$

Otro autor de la Ilustración radical que destaca Taylor es Bentham, para el que el principio de utilidad implica fundamentar la búsqueda de la felicidad a través de la ley y la razón, en contraposición a las opiniones de moralistas y religionistas. ${ }^{1513}$ Para Taylor,

\footnotetext{
${ }^{1506}$ Cfr. TAYLOR, Ch., Fuentes del yo, pág. 448. "Lo que se experimentaba como afirmación del yo en la visión de unos se sentía como exilio para los otros. El mundo objetivado es la prueba para unos de la auto-posesión del sujeto, para los otros es una negación de la vida del sujeto, de su comunión con la naturaleza y de su auto-expresión en su propio ser natural". TAYLOR, Ch., Hegel, pág. 20.

${ }^{1507}$ Cfr. TAYLOR, Ch., Fuentes del yo, pág. 476. Es la visión ilustrada radical de la naturaleza como el modelo para la acción humana, una visión que "dará paso" según Taylor, al expresivismo de Herder y Rousseau y que hay que poner en conexión para comprender "la voz de la naturaleza expresivista de tipo rousseauniano".

${ }^{1508}$ Cfr. Ibid., pág. 454.

1509 "Si el espíritu no es más que una amalgama de ideas nuevas, y si toda idea nueva no es más que una nueva relación descubierta entre ciertos objetos, el que quiera distinguirse por su espíritu ha de emplear necesariamente la mayor parte de su tiempo en la observación de las diversas relaciones existentes entre los objetos y gastar el mínimo posible en colocar hechos o ideas en su memoria. Por el contrario, el que quiera superar a los demás en extensión de memoria debe, sin perder tiempo en meditar y en comparar los objetos entre sí, emplear días enteros en almacenar sin parar nuevos objetos en su memoria". HELVECIO, Del Espíritu, Editora Nacional, Madrid, 1984, pág. 296.

${ }^{1510}$ Cfr. TAYLOR, Ch., Argumentos filosóficos, pág. 128.

${ }^{1511}$ Cfr. TAYLOR, Ch., Fuentes del yo, pág. 455.

${ }_{1512}$ Cfr. TAYLOR, Ch., La Era Secular, tII, pág. 541.

1513 "Cuando el moralista pasa más allá de los límites de la experiencia, cuando se deja guiar por otras
} 
en este nuevo contexto de modernidad ilustrada, poco sentido tiene el ascetismo, ya que contradice los principios del utilitarismo y de la razón ilustrada. ${ }^{1514}$ Desde la reivindicación deísta de la búsqueda de la felicidad, la ilustración radical rompe una barrera más, al reivindicar el valor de la sensualidad y la invitación sugerente de la naturaleza al disfrute, abandonando definitivamente el ascetismo teísta. ${ }^{1515}$ Según nuestro autor, se impone una moralidad del mecanicismo, atomismo, materialismo y utilitarismo radical. ${ }^{1516}$ En este sentido la Ilustración radical da un paso irreversible en la búsqueda de la felicidad, al reafirmar la búsqueda del placer sensual como algo significativo y buscando un modo de volver compatibles entre sí todos los deseos sensuales y ordinarios tanto en el interior de los seres humanos como entre ellos. ${ }^{1517}$

Para Taylor, el sensualismo fue lo que hizo radical al naturalismo ilustrado. Adoptar una postura con respecto al crudo deseo humano era una manera de pedir cuentas a los sistemas organizados del derecho, la política y particularmente de la religión. ${ }^{1518}$ Frente a los sistemas de la metafísica y de la religión, Diderot reivindica al hombre fuertemente apasionado por el mundo y la vida, que se reivindica a sí mismo desde las pasiones grandes, así como el significado del genio humano. ${ }^{1519}$

La labor de la vejez va asociada a los sistemas que anquilosan el devenir de la voluntad libre del hombre en su búsqueda apasionada por la vida y la explosión de las pasiones que le elevan al placer como fuente de la moralidad. Un devenir de la

consideraciones que las de la dicha o desdicha de los hombres, marcha sobre terreno desconocido y por camino sin salida". BENTHAM, J., Deontología o Ciencia de la moral, Tomo II, Méjico, Librería de Galván, 1836, pág. 10. “¿Y cuál ha sido su táctica? ¿Cuáles sus conquistas? Han tenido la habilidad de ocultar su marcha a la vista de la multitud, y sus usurpaciones a la pesquisa de la conciencia pública. Han enseñado a los hombres a ser silenciosos, secretos, sumisos y fáciles de acomodar, y aborrecer las innovaciones; a aliarse con empeño a los que querrían impedir toda entrada a la luz, a fin de ahorrarse la fatiga de examinar proyectos que afligirían su indolencia y el sentimiento de verse obligados a adoptar medidas que opondrían un dique a su codicia”. Ibid., pág. 257.

${ }^{1514}$ Cfr. TAYLOR, Ch., Fuentes del yo, pág. 449.

1515 Cfr. TAYLOR, Ch., Hegel, págs. 4,9.

1516 "Solo el deísta puede enfrentarse al ateo. El supersticioso no está a su altura. Su Dios no es más que un producto de su imaginación. Además de las dificultades de esta materia, está expuesto a todas las que se derivan de la falsedad de sus nociones". DIDEROT, Pensamientos filosóficos. El combate por la libertad. Proteus, Barcelona, 2009, pág. 56.

${ }^{1517}$ Cfr. TAYLOR, Ch., La Era Secular, tII, pág. 490. "El objeto del deontologista es enseñar al hombre a dirigir sus afecciones, de modo que estén subordinadas en lo posible a su bienestar. Cada hombre tiene sus penas y placeres que le son propios, y con los cuales nada tiene que ver el resto de los hombres; hay asimismo placeres y penas que dependen de sus relaciones con los demás hombres, y las doctrinas del deontologista tienen por objeto enseñarle en uno y otro caso a dar al placer tal dirección, que sea productivo de otros placeres; y tal dirección a la pena, que se convierta si es posible, en manantial de placer, cuando menos que se haga lo más ligera, soportable y transitoria que pueda ser". BENTHAM, J., Deontología o Ciencia de la Moral, pág. 21.

1518 TAYLOR, Ch., Fuentes del yo, pág. 451.

1519 Cfr. TAYLOR, Ch., Hegel, pág. 18. "Las pasiones amortiguadas degradan a los hombres extraordinarios. La obligación aniquila la grandeza y la energía de la naturaleza. Contemplad este árbol: debéis el frescor y la extensión de sus sombras a la exuberancia de sus ramas; podréis gozarlas hasta que llegue el invierno y lo despoje de su cabellera. Se acabará la excelencia en la poesía, en la pintura, en la música si la superstición realiza sobre el temperamento la labor de la vejez". DIDEROT, Pensamientos filosóficos. El combate por la libertad, pág. 52. 
conciencia humana expresada en resultados históricos y que puede ser estudiado frente al estudio metafísico de hechos generales y leyes constantes. Así, otro autor de la Ilustración radical, Condorcet, realiza un bosquejo del progreso del espíritu humano en relación con los individuos que han vivido en sociedades, según se ha manifestado dicho espíritu a lo largo de las distintas generaciones. ${ }^{1520}$ Para Taylor, según Condorcet, la última edad de las diez generaciones es el anticipo del radiante futuro que espera a la humanidad. ${ }^{1521}$

Taylor afirma que la neutralización que realiza el utilitarismo naturalista de los sistemas represores lleva, a algunos de estos autores, a una afirmación radical de la moral, que se identifica, llanamente, con el placer sensual. En su insistencia en la naturaleza física de la vida moral o en la reducción al placer de todas las motivaciones humanas, anulando cualquier motivación de fuerte valoración, el utilitarismo naturalista es, para Taylor, una filosofía autoencubridora y establece una relación parasitaria con las ontologías morales precedentes. ${ }^{1522}$

Además, según el pensamiento de Taylor, si la fuente de la moralidad radical ilustrada se fundamenta en la búsqueda insaciable de la felicidad humana, expresada también en términos de sensualidad, difícilmente se puede motivar a un ascendiente en el hombre hacia el compromiso con situaciones de indigencia humana, dado que se carece de un horizonte adecuado de comprensión moral. ${ }^{1523}$ Con el advenimiento de la modernidad ilustrada radical, en lugar de una fuente consistente de vida moral, tendríamos que hablar de "una amoralidad desesperada" o de "una moral reduccionista", en la que se carece de valoraciones fuertes que comprometan el horizonte humano en favor de una humanidad benevolente y solidaria. ${ }^{1524}$ Para Taylor, el lugar de las fuentes morales en esta filosofía es "extraño". Y dado que no pueden admitir sus fuentes morales, entonces se recurre a la polémica reivindicando, al mismo tiempo y de manera encubridora, los bienes vitales que el deísmo había sostenido: la razón autorresponsable, las satisfacciones de la vida ordinaria y el ideal de benevolencia universal. ${ }^{1525}$

\footnotetext{
1520 "Se puede observar también que, según las leyes generales del desarrollo de nuestras facultades, determinados prejuicios han debido de nacer en cada época de nuestro progreso, su influencia ha debido de extenderse mucho más allá de esa época, porque los hombres conservan todavía los prejuicios de su infancia, los de su país y los de su siglo mucho tiempo después de haber reconocido las verdades necesarias para destruirlos". CONDORCET, Bosquejo de un cuadro histórico de los progresos del espíritu humano, Editora Nacional, Madrid, 1980, págs. 87-88.

${ }^{1521}$ Cfr. TAYLOR, Ch., Fuentes del yo, pág. 482; cfr. TAYLOR, Ch., Dilemmas and Connections, págs. 324, 330, 344-346.

${ }_{1522}$ Cfr. TAYLOR, Ch., Fuentes del yo, págs. 449, 461-479, 485, 489, 495-499, 520-525.

${ }^{1523}$ Cfr. Ibid., págs. 450-459.

${ }^{1524}$ Dicha amoralidad desesperada se puede ver con meridiana claridad en la obra del Marqués de Sade. “¿No cavilarán que vale más dejarse llevar por la corriente que oponer resistencia? ¿No sostendrán acaso que la virtud, por bella que sea, acaba convirtiéndose en el peor partido a tomar, siendo su debilidad notoria en la lucha contra el vicio, y que, en un siglo totalmente corrompido, lo más seguro es actuar como los demás?". SADE, Elogio de la Insurrección, El Viejo topo, 1997, págs. 19-20.

${ }^{1525}$ Cfr. TAYLOR, Ch., Fuentes del yo, págs. 442-443, 463.
} 
Por otra parte, es difícil conjugar el sentido de la ética utilitarista de la benevolencia ilustrada con el materialismo sensual que se reivindica. ¿Se puede adoptar el humanismo ilustrado del orden natural benevolente para luego afirmar el materialismo y la sensualidad más explosiva? ¿No se ha llegado a un horizonte de amoralidad o reduccionismo que es difícilmente compatible con fuentes morales de la racionalidad ilustrada? ¿Es compatible el bien común desde la búsqueda insaciable de la felicidad individual? Taylor sugiere, en este sentido, un interrogante fuertemente convincente para el cuestionamiento de "la amoralidad desesperada" ¿Vale solo el mero "empeño de facto" para justificar una armonía de intereses? ¿Por qué habría yo de empeñarme ahora en la realización de una sociedad con armonía? ${ }^{1526}$

La respuesta de Taylor es clara. Sin una ontología de fondo que motive un horizonte moral de valoraciones fuertes, difícilmente se puede conseguir una pulsión moral que eleve el actuar humano. La argumentación materialista se limita a plantear una argumentación moral superior, pero carece de cualquier pulsión ontológica. Cree falsamente que con la sola argumentación científica y de la razón práctica se justifica un horizonte de compromiso moral. Es más, justifica su planteamiento desde el hecho de que hay en el hombre una incapacidad de la razón para ir más allá de dicho planteamiento, tratando de justificar 'ontológicamente' la incapacidad del ser humano para valoraciones fuertes. Según el materialismo utilitarista, la razón no llega más allá, está incapacitada para ello. Solo son posibles las valoraciones débiles de la sola argumentación moral superior, expresada desde lo que la mera razón científico-práctica es capaz de ofrecer. ${ }^{1527}$

Taylor destaca, por otra parte, esta tensión e incapacidad de la razón materialista para establecer una argumentación moral de carácter ontológico. Se trata de un momento de debilitamiento ontológico que inhabilita al hombre para hondear en las profundidades de su yo fuentes morales de valoración antropológica. Se entra en el ámbito de la psicología utilitarista que, en cierta medida, incapacita para sustentar compromisos de sentido desde valoraciones morales fuertes. La razón científica ha perdido capacidad para hondear en profundidades que posibiliten argumentaciones morales fuertes. Según Taylor, se está incapacitando al ser humano para responder al porqué de motivaciones hacia la armonía de intereses y la beneficencia general. Se da "de facto" que hay una armonía de intereses, pero, ¿por qué puedo comprometer mi interés propio en armonía con el interés general? ¿Y cuándo entran en conflicto? ¿Qué ocurre si el interés general me "desubica" en mi búsqueda insaciable de la felicidad propia? Y si solo busco el placer y evito el dolor, ¿por qué debo comprometerme en

${ }^{1526}$ Cfr. Ibid., pág. 460.

${ }^{1527}$ Cfr. Ibid., págs. 472-473. 
“armonizarlo" con el interés general? ¿No está incapacitado el utilitarismo materialista ilustrado para fundamentar una metafísica con argumentaciones ontológicas? ${ }^{1528}$

Cuando se ha llegado a una ontología reduccionista, o a una amoralidad desesperada que se encamina hacia la anti-Ilustración, difícilmente se puede justificar ningún impulso ético para la armonía de intereses, ya que la significación de las cosas es la que emerge de la naturaleza física y de nuestro ser material. ${ }^{1529}$ ¿Nos estamos encaminando hacia una antropología anti-ética que incapacita para la benevolencia universal a pesar de que se argumente a favor de ella desde la buena voluntad o mero deseo $?^{1530}$

Ahora, por primera vez, con el surgimiento de la Ilustración radical, se puede afirmar con clarividencia filosófica que la razón científica incapacita para una fundamentación ontológica de los bienes vitales, ya que sin un enraizamiento moral difícilmente se pueden establecer diferencias entre el bien y el mal o realizar apreciaciones cualitativas. Con el advenimiento de la razón radical ilustrada, y por primera vez en la historia de la humanidad, las fuentes morales surgen, como afirma Taylor, de "la retórica del argumento", con lo cual se puede afirmar que dichas fuentes son por lo menos "extrañas" en relación con la tradición filosófica occidental. ${ }^{1531}$

Esta es la clave. Taylor afirma con rotundidad que, en la Ilustración radical, nos encontramos sin fuentes morales, solo con argumentaciones que invitan a bienes vitales, pero sin reconocerlos. Es decir, que se carece de enraizamiento moral para elevar el espíritu humano hacia la comprensión ontológica de lo que se quiere vivir como bien vital. Nos encontramos con meras argumentaciones, palabras que invitan a la benevolencia, pero que no determinan el comportamiento moral del hombre, no le comprometen moralmente, el hombre empieza a sentirse en una tierra baldía en la que difícilmente se encuentran motivaciones morales para la reconstrucción moral del yo. Todo parece encaminarse hacia el agotamiento de las fuentes y la mera "motivación psicológica" que invita desde el argumento hacia la buena voluntad y el bien como posible armonía de intereses. ${ }^{1532} \mathrm{Se}$ apela a los bienes sin reconocerlos, es decir, se habla desde la razón psicológica, no desde la razón moral que apela a las fuentes de argumentación ontológica. Desde la razón científica y desde la argumentación polémica, se adentra en palabras condenatorias que no remiten a una filosofía moral, sino a una

\footnotetext{
${ }^{1528}$ Cfr. Ibid., págs. 467-469.

${ }^{1529}$ Cfr. Ibid., págs. 507, 510.

${ }^{1530}$ El deísmo, como afirmaba Diderot, se convirtió en el único interlocutor válido para los representantes de la Ilustración radical. Un deísmo que, desde la razón autorresponsable y la búsqueda de la felicidad en la vida ordinaria, permitió el paso al naturalismo materialista y utilitarista, basado en la búsqueda del placer y la evitación del dolor y que finalmente concluye en la amoralidad o en el reduccionismo.

${ }^{1531}$ Cfr. TAYLOR, Ch., La Era Secular, tII, págs. 490,541.

1532 Cfr. TAYLOR, Ch., Fuentes del yo, pág. 575.
} 
"filosofía autoencubridora y parasitaria". ${ }^{1533}$ No desvela nada, solo se remite a la propia psicología y a un argumentario que no sabe muy bien en qué se reconoce. La imagen antropológica del hombre, como fuente de moralidad, queda desprovista de un autorreconocimiento de sí en lo que realiza. Y desde ahí no se puede elevar a una motivación moral para el actuar. Es la pura neutralidad. ${ }^{1534}$

Taylor afirma que el naturalismo ontológico solo alude a sus adversarios para aprovecharse de su ímpetu moral, dado que carece de él, y al mismo tiempo no se sustenta en fuentes morales propias, ya que solo socavan y no plantean ninguna alternativa moral en la que sustentarse. Este naturalismo materialista es incapaz de reconocer las fuentes morales de las que proceden, con lo cual, en vez de plantear una base moral alternativa, simplemente niegan cualquier moralidad a un comportamiento que, o bien inhabilita para su reconocimiento moral en las fuentes originarias o simplemente se quiere negar a ello porque no-es-necesario desde el mero psicologismo causal y sensual.

Este es el recorrido, a partir del cual, del deísmo se llega a una de las fuentes morales de la modernidad laica. Una fuente que desemboca en una amoralidad y en un reduccionismo que lleva a una situación realmente compleja de situar, a un camino sin salida, caracterizado por la debilidad del argumentario que no se enraíza en fuentes morales y por su incapacidad ontológica que le conduce a una relación parasitaria con fuentes morales que no puede reconocer, dado que se niega a reconocerse en ellas. Con lo que la situación es realmente alarmante y amenazante, puesto que todo se encamina hacia el bien de la eficacia instrumental, como afirma Taylor, desenraizado de cualquier ontología de sentido.

Para Taylor, el naturalismo pretende fundamentarse moralmente, pero lo único que permite es crear más ambigüedad y autoengaño. Si en el utilitarismo encontrábamos una cierta ingenuidad del autoengaño y la negación a través de la búsqueda del placer, ahora se trata de confirmar la negación, intentando afirmar la sola naturaleza física de carácter biológico y psicológico que justifique moralmente la amoralidad. Este es el autoengaño llevado al extremo. Se trata, según Taylor, de una argumentación totalmente extraña a nuestro enraizamiento cultural. ${ }^{1535}$

El encubrimiento engañoso del naturalismo pretende buscar un bien constitutivo en la propia consideración de lo que es la naturaleza humana, en lo que emana de los seres humanos como capacidad para la autocomprensión y el entendimiento al margen de cualquier ilusión y ontología, sin dar nada por hecho e intentando remontarse a los orígenes y para encontrar que en el origen solo hubo imaginación autoengañadora. Se

\footnotetext{
${ }^{1533}$ Ibid., pág. 464.

${ }^{1534}$ Cfr. TAYLOR, Ch., Argumentos filosóficos, pág. 106.

${ }^{1535}$ Cfr. TAYLOR, Ch., La libertad de los modernos, pág. 250.
} 
pretende dar por sentado que en el origen no hay origen que explique ninguna fundamentación significativa, reforzando la crítica nietzscheana de todos los valores como algo creado y que refuerza el antropocentrismo. ${ }^{1536}$ Para el naturalismo ontológico no se trata de establecer ningún "a priori”, sino remontarse a los orígenes de la moral para ver que en el origen no había origen y que cuando se estableció un origen moral era un “a priori”. El a priori es el autoengaño. La verdad es el no-a priori moral. ${ }^{1537}$

La reducción utilitarista planteaba una amoralidad amoral en el sentido que carecía de fundamento. Ahora, con el naturalismo radical se da un paso más, se pone el fundamento en el no-fundamento, con lo que la fuente moral es la no-fuente, porque no existe ningún enraizamiento moral ya que lo moral es la amoralidad. Todo adquiere fundamento y significación en el no fundamento, con lo que la fuente moral está en lo puramente inmanente, puesto que todo lo demás no es moral. Se llega a la afirmación de que cualquier fuente moral teísta o deísta es sencillamente amoral. No existe moral para las fuentes morales porque no existen las fuentes morales. Lo único que es moral es la amoralidad de las fuentes morales. Para Taylor, lo propio del naturalismo radical es la autoafirmación racionalista y la ocultación de la afirmación moral. Se va configurando una lectura naturalista de la razón científica. ${ }^{1538}$

Evidentemente este terreno es altamente peligroso, ya que anula cualquier fuente de moralidad que remite a la autocomprensión del hombre como fuente de sentido. El sentido está en el sin-sentido porque el origen de la moral es la no-moral. Se anulan todas las fuentes de moralidad. Es la afirmación exclusiva del marco inmanente. No hay espacio para ninguna explicación ontológica, porque en el origen no hay ontología, solo afirmación de la vida y cualquier a priori ha sido poner límites a la vida. La noontología es la única ontología posible. Todo se limita a reconocer la bondad de los deseos corrientes (que) nos faculta para vivir dicha bondad desde la integridad del propio yo que los vislumbra como tales. La no ontología nos hace vivir ontológicamente lo que de verdad somos, puro deseo natural, mera afirmación de la vida en su radicalidad natural. La ética es la afirmación de la no-ética, lo auténticamente moral es la negación más absoluta de cualquier fuente moral, pues va contra la moral de la vida. Y así se llega a lo que Taylor describe como la negación de la religión y la metafísica, y la afirmación de la bondad y la significación de la naturaleza. ${ }^{1539}$ En otros términos, para Taylor, dicha lectura naturalista se basa en las proyecciones de los sujetos,

\footnotetext{
${ }^{1536}$ Cfr. TAYLOR, Ch., La ética de la autenticidad, pág. 93.

1537 Cfr. TAYLOR, Ch., La Era Secular, tII, págs. 431, 515, 573, 654.

${ }^{1538}$ Cfr. TAYLOR, Ch., Fuentes del yo, pág. 462; cfr. Ibid., págs. 544,627,661,680-681,701.

1539 "La creencia de que los seres pensantes forman parte de un gran orden físico podría despertar un cierto asombro, temor y hasta una cierta piedad natural: la reflexión que nos mueve a ello es que el pensamiento, el sentimiento, las aspiraciones morales, el conjunto de todas las cumbres intelectuales y espirituales de los logros humanos, surgen de las profundidades de un inmersos universo físico, que en la mayor parte de su inconmensurable extensión es inanimado, absolutamente insensible a nuestros propósitos, que prosiguen su camino por inexorable necesidad”. TAYLOR, Ch., Fuentes del yo, pág. 475.
} 
proyecciones que no formarán parte de las cosas, sino que tan solo reflejarán el modo en que los sujetos reaccionan a las cosas, las actitudes pro o contra que adoptan en una conexión absoluta entre naturalismo y subjetivismo. ${ }^{1540}$

B.- La segunda fuente de moralidad alternativa laica: del orden natural providente y benefactor se pasa a la consideración de la naturaleza como espacio para el reconocimiento de las profundidades morales del yo como orden inherente al ser humano.

En el siglo $\mathrm{XX}$, en la sociedad urbana y tecnológica, la naturaleza quedará relegada y se considerará como un gran depósito de energía amoral. Los cambios en la sociedad, en la teoría científica y en las imágenes que articulaban la sensibilidad, se unieron para configurar una nueva cosmovisión del mundo: se trata del modernismo antirromántico al que se llega, según Taylor, a través de tres importantes transformaciones en torno al Romanticismo. ${ }^{1541}$

Los escritores románticos celebran la bondad de la naturaleza, y en ese sentido, coincidían con los deístas y la Ilustración naturalista. Percibían el orden creado como una gran fuente de bondad. Pero rompen con la tradición anterior al reconocer que la ruptura con la naturaleza era necesaria para alcanzar la razón y la libertad.

- La primera transformación romántica fue denominada "realismo" y a veces naturalismo. Un naturalismo que perpetúa la confusión e incoherencia acerca de la moral. Autores como Zola o Flaubert niegan por completo la noción de una realidad espiritual más allá de las cosas o por detrás de ellas. Niegan todas las nociones acerca del gran torrente de vida que fluye en la naturaleza. Según Taylor, es el realismo que afirma que es preciso la valentía y compromiso para percibir las cosas tal como son, porque nuestra visión de las cosas está configurada y nublada por los falsamente consoladores modos de representación tejidos de temores y autocomplacencia. ${ }^{1542}$ Se hacen precisos nuevos retratos que desvelen el rostro real de las cosas. Es el desvelamiento en la transfiguración que permite reconocer la verdad. Es la epifanía del realismo naturalista.

- La segunda transformación romántica es la que "niega la naturaleza". Baudelaire rechaza la creencia rousseauniana de que el hombre es bueno por naturaleza. Frente a la exaltación romántica de la naturaleza que viene a expresar una rendición ante lo dado, la religión del arte de Beaudelaire se presenta como alternativa a partir de la construcción de un mundo

\footnotetext{
${ }^{1540}$ Cfr. TAYLOR, Ch., Argumentos filosóficos, págs. 64-65, 67.

${ }^{1541}$ Cfr. TAYLOR, Ch., Fuentes del yo, pág. 621.

1542 Cfr. Ibid., pág. 587.
} 
completamente aparte y así superar la banalidad opaca y superficial de la naturaleza en su mediocridad romántica. Taylor afirma, en este sentido, que si el romanticismo, como el deísmo, brota de un Cristianismo erasmista, aquí tenemos una auténtica declaración del más extremo pesimismo agustiniano. $^{1543}$. Baudelaire aporta a la vertiente romántico-expresivista la espiritualidad opuesta desde su punto de origen, no la que tiene sus raíces en el Cristianismo erasmista, sino la enraizada en el jansenismo y en un profundo sentido de la caída humana. ${ }^{1544}$

- Y la tercera transformación romántica es la que surge de la filosofía schopenhaueriana, con su "expresivismo", con el valor de los signos invertidos, puesto que tomó la idea de la naturaleza como fuente. Una energía que se expresa en las cosas que vemos a nuestro alrededor y que se objetivaba a sí misma en ellas mismas. Una realidad que constituye una jerarquía, desde la realidad inanimada a los seres conscientes en la cima. La energía que todo lo penetra es la voluntad, pero no como fuente espiritual de bien moral, sino el ciego e incontrolado afán que nos impulsa hacia una búsqueda insaciable de lo inalcanzable. ${ }^{1545}$ Según Taylor, la inversión de signo en Schopenhauer, relativa al expresivismo romántico, recuerda extrañamente las reacciones hiperagustinistas al humanismo cristiano. De hecho, la noción de una fuerza espiritual que aúna la naturaleza sencillamente desciende del neoplatonismo renacentista y su doctrina del amor. Ficino es uno de los antepasados del Romanticismo, según cree Taylor. ${ }^{1546}$ Schopenhauer introduce una corrupción radical dentro de la metafísica expresivista. Su filosofía constituyó la base de un conjunto de teorías de la transfiguración a través de la expresión artística. Se trata de una revuelta, contra la base del Cristianismo que invita a afirmar la bondad de lo que es. Para Schopenhauer, la fuente de la que fluye toda la realidad como expresión está envenenada. Pretende arrojar de una vez por todas el fardo que la civilización cristiana había fundamentado, declarando la realidad como algo malvado y perverso y de lo que es preciso deshacerse. ${ }^{1547}$

Estas son las tres transformaciones románticas que están en la génesis de esta segunda moralidad laica que surge a lo largo del siglo XIX: la realidad desespiritualizada (realismo), la naturaleza caída (Baudelaire) y la voluntad amoral (Schopenhauer). Ya en el siglo XX, con el modernismo postromántico, un Modernismo que hará completamente incomprensible la perspectiva del antiguo Romanticismo. Es el Modernismo como superación de la síntesis entre la razón desvinculada y la

\footnotetext{
${ }^{1543}$ Cfr. Ibid., pág. 591.

1544 Cfr. Ibid., pág. 597.

1545 Cfr. Ibid., pág. 600.

${ }^{1546}$ Cfr. Ibid., pág. 601.

${ }^{1547}$ Cfr. Ibid., págs. 603-604.
} 
expresividad romántica. Se trata de un giro hacia adentro, hacia la subjetividad que es a la vez la antisubjetividad, ya que puede llevarnos más allá del yo como es habitualmente comprendido, hacia una fragmentación de la experiencia que pone en entredicho las nociones comunes de identidad, hacia una nueva clase de unidad y una nueva manera de habitar en el tiempo. ${ }^{1548}$ Se impone la necesidad, según Taylor, del escape de la idea tradicional del yo unitario. De hecho, los ideales de la razón desvinculada y la realización romántica estaban vinculados a dicho yo unitario. Es el yo modernista que exige que nos abramos al flujo que traslada más allá del alcance del control o la integración romántica. Hay que escaparse de las restricciones del yo unitario. Solo somos una cohesión en el fluir del tiempo. El centro de gravedad comienza a desplazarse desde el yo hacia el fluido de la experiencia. Descentrar no es una alternativa a la interioridad, sino su complemento. ${ }^{1549}$ Es la recuperación modernista de la experiencia que intenta acceder a una experiencia más rica a través de un contacto "no mediado" con la plenitud de la vida. ${ }^{1550}$

Los ideales de la razón desvinculada (que desembocan en el naturalismo radical) y de la idealización romántica (que desembocan en el modernismo postromántico) dependían de diferentes modos del yo unitario. La primera requiere un férreo control que domina la experiencia y es capaz de construir los órdenes de la razón por la que dirigimos el pensamiento y la vida. La segunda ve el yo, originalmente dividido, llegar a la unidad en la alianza de la sensibilidad y la razón. Para el modernismo, en la medida en que queremos escapar de esa visión del yo unitario y nos abrimos al flujo que nos traslada más allá del control o la integración, es posible abarcarlo todo a través de la liberación de la experiencia y el flujo vital que trasciende el alcance del control o la integración. ${ }^{1551}$ Se trata de un escape que encuentra su expresión en el posmodernismo de Foucault y Lyotard. ${ }^{1552}$

La reacción modernista a la razón instrumental protesta posibilitando dimensiones nuevas del tiempo a partir del tiempo vivido de Bergson o haciendo del tiempo el tema principal de reflexión filosófica en relación al ser como en Heidegger. El modernismo pretendía liberarse de las explicaciones optimistas en torno al avance de la razón y la ciencia que conducen a un mayor control instrumental del mundo (yo como centro único de cálculo estratégico) y en torno a la segunda dimensión del yo unitario y unificado de la razón y la sensibilidad (yo como armonía e integración entre impulso interno y naturaleza externa).

\footnotetext{
${ }^{1548}$ Cfr. Ibid., pág. 627.

${ }^{1549}$ Cfr. Ibid., págs. 631,635.

${ }^{1550}$ Cfr. Ibid., pág. 636.

${ }^{1551}$ Cfr. Ibid., pág. 627.

${ }^{1552}$ Cfr. Ibid., págs. 663-664, 674, 687, 700-701; cfr. TAYLOR, Ch., La Era Secular, tII, págs. 119, 125, $383,475,495$.
} 
Para Taylor, las formas del modernismo son muchas. Lo que las define como más determinante es el alejamiento de las epifanías del ser, negando que sean expresiones de nada: es el giro hacia estructuras fuera del yo, sean estas transformaciones de lo intemporal y no individualizada voluntad schopenhaueriana o una más profunda conciencia mítica impersonal o constelaciones de palabras u objetos que enmarcan una epifanía. $^{1553}$

Frente a todas estas narraciones que alejan de la epifanía del ser, y que en el fondo llevan a la reducción naturalista, Taylor quiere aportar su narración en defensa de una postura filosófica que podría definirse como "fenomenológica", y cuyo intento es mostrar, de una forma u otra, que los vocabularios que necesitamos para explicar el pensamiento, la acción, los sentimientos humanos o para dar cuenta, analizar o justificarnos a nosotros mismos o unos a otros o para deliberar sobre lo que hacemos, descansan inevitablemente sobre la evaluación fuerte. ${ }^{1554}$

\section{IV.3.2.-HACIA UNA REDEFINICIÓN DE LA SECULARIDAD EN CLAVE HEGELIANA}

Hegel invita a un cambio de lenguaje y a una superación de las oposiciones para ir avanzando hacia una síntesis de la razón universal. Hay un espíritu que mueve el mundo, una historia del espíritu vivo, una historia comprendida conceptualmente que "forma el recuerdo y el calvario del espíritu absoluto, la realidad efectiva, la verdad y la certeza de su trono, sin el cual él sería lo solitario sin vida". ${ }^{1555}$ Para Taylor, si el intento filosófico de situar la libertad es el intento de ganar una concepción del hombre, en la que la acción libre es la responsable de lo que somos, entonces la filosofía hegeliana se vuelve altamente vigorosa y penetrante para seguir avanzando en la corriente de la vida que fluye. ${ }^{1556}$

I.- Reconocer el movimiento del Espíritu es la tarea del filósofo. Una tarea que invita a enfocar la mirada en el presente como eterno movimiento, como realidad que queda siempre configurada por lo anterior, por lo que está por descubrir. No es posible dar por hecho que la única razón es la razón secular o que la razón religiosa solo despierta sospechas.

Hay una razón más grande, más elevada que recorre la historia, en ese fluir de la vida hacia la autoconciencia filosófica. No es tan sencillo determinar el camino o un único camino hacia la comprensión del mundo. Es posible comprender que la filosofía es siempre la misma, comprender el espíritu universal, la conexión del todo con la

\footnotetext{
${ }^{1553}$ Cfr. TAYLOR, Ch., Fuentes del yo, págs. 628, 650-651.

${ }^{1554}$ Cfr. TAYLOR, Ch., Argumentos filosóficos, pág. 64.

1555 HEGEL, F., Fenomenología del Espíritu, pág. 517.

${ }^{1556}$ Cfr. TAYLOR, Ch., Hegel, pág. 499.
} 
razón. Es posible avanzar hacia un tiempo de síntesis, síntesis en el que "el Geist se vehicula en el hombre", o lo que es lo mismo, adentrarse con la mirada filosófica para comprender lo que siempre queda por descubrir y que se expresa como misterio o como espíritu superior o como orden cósmico. ${ }^{1557}$

Taylor asegura que una de las grandes claves del sistema hegeliano es que el hombre hace más que reflejar una naturaleza ya completa en sí misma; más bien es el vehículo en donde el espíritu cósmico trae a completud una autoexpresión que primero residía ante nosotros en la naturaleza. Ante el poder subyacente a la naturaleza, el hombre, como un ser consciente, tiende a tomar de la naturaleza lo que él ve como espíritu y lo une a su propio espíritu, reconociéndose a sí mismo como un fragmento individual del universo. En esta unión con el espíritu cósmico se requeriría que el hombre subordinara su voluntad a un ser más alto, que él aceptara la heteronomía. Sin el espíritu infinito, el espíritu finito no puede alcanzar su plena realización. Por el contrario, con Hegel el Geist alcanza esta autoconciencia en el hombre, como vehículo del Geist, a través de una síntesis superior, más fundamentada y elevada. ${ }^{1558} \mathrm{El}$ hombre es vehículo de lo trascendente. Desde esta afirmación, podemos comprender algunas de las nuevas expresiones de espiritualidad que surgen en el hombre de hoy, a partir de su voz interior que le adentra en las profundidades de su propio yo.

El hombre puede alcanzar esa mayor unidad con la naturaleza, con el espíritu que se despliega a sí mismo en la naturaleza. El hombre, como vehículo del Geist, realiza la síntesis entre naturaleza y yo a través del saber absoluto, de la autoconciencia racional. En la unidad entre ambos se realiza esa unidad superior de la Razón Absoluta que comprende al hombre como vehículo del espíritu cósmico. ${ }^{1559}$ Una Razón que va más allá de la razón instrumental, de la razón secular e incluso de la "sola razón religiosa". Hegel pretende hacernos entender que la naturaleza no puede ser comprendida solamente como sistema de engranaje mecanicista y objetivada.

Para Hegel, el yo no es el que existe porque piensa, sino "el yo que se piensa en el objeto y así funda una realidad nueva, el Espíritu-en-el-mundo que está cabe sî́. ${ }^{1560}$ Sin ese yo que se piensa en la cosa, no se puede alcanzar la autoconciencia. Es esta subjetividad autoconsciente la que hará al hombre configurar su propio acceso a la realidad, desde su ser en sí reflejado en lo otro, en el objeto, en la naturaleza, en el mundo, en Dios. En esta síntesis superior de inmanencia y transcendencia, de naturaleza y yo, de espíritu cósmico y espíritu finito, el hombre es vehículo de una integración superior. Por eso, la ontología hegeliana ayuda a superar la oposición entre subjetividad y naturaleza en una síntesis superior. La inmanencia del sujeto desvinculado de la

${ }^{1557}$ Cfr. HEGEL, F., Fenomenología del Espíritu, pág. 516.

${ }^{1558}$ Cfr. TAYLOR, Ch., Hegel, pág. 38.

${ }^{1559}$ Cfr. TAYLOR, Ch., Hegel y la sociedad moderna, pág. 98.

${ }^{1560}$ HEGEL, F., Fenomenología del Espíritu, pág. 510. 
modernidad que se autodefine no tiene por qué entrar en contradicción con la naturaleza del orden cósmico. No tiene sentido retirarnos del mundo y concentrarnos en la completa autoposesión del yo que se autodefine. Con Hegel, el hombre es el vehículo de la autoconciencia de Dios: Dios llega a conocerse a sí mismo a través del conocimiento del hombre en él. ${ }^{1561}$ Se puede realizar esta síntesis de la razón y de la naturaleza, de lo finito y lo infinito en la Razón Absoluta.

El camino que propone Taylor para comprender la secularidad es superar la ruptura entre razón y capacidad expresiva de la Modernidad. El yo que se autodefine no tiene por qué entrar en contradicción con el espíritu que habita el orden de la naturaleza. El hombre puede integrar ambos elementos como vehículo de la razón que piensa y del espíritu que emana en el cosmos. El hombre es una unidad superior que integra razón autodefinidora y espíritu cósmico.

El Dios hegeliano, según Taylor, no puede existir independientemente del hombre, no es el Dios del teísmo tradicional. Es un Geist que vive como espíritu solo a través de los hombres. La síntesis hegeliana entre inmanencia y trascendencia, entre espíritu finito e infinito alcanza su máxima expresión en este hombre que es vínculo del Geist, del espíritu cósmico, que no puede entenderse a sí mismo sin Dios, dado que Dios se piensa a sí mismo en él. En este sentido está determinado por el hombre, como afirma Feuerbach, pero yendo más allá de su inmanentismo. El hombre de la racionalidad moderna cartesiana no puede entenderse sin esa autoconciencia que le realiza como vehículo de lo trascendente. Razón inmanente y espíritu trascendente son lo mismo. Dios autocomprendiéndose en el hombre y el hombre autodefiniéndose como vehículo de dicha trascendencia. Hegel entiende así que es posible realizar la cuadratura del círculo. El hombre está unido a la totalidad y sin embargo no sacrifica su propia conciencia y voluntad autónoma. ${ }^{1562}$ Hegel resuelve el problema de unir lo finito con el espíritu infinito sin pérdida de libertad mediante el Total, el Concepto de Razón Absoluta. Dado que el orden cósmico, según Hegel, obedece a una necesidad racional incondicionada, entonces el agente racional no pierde nada de su libertad al aceptar vehicularse para dicho Espíritu. ${ }^{1563}$

Para Hegel, la filosofía llega después de la vida. De ahí que después del devenir de las contradicciones ontológicas e históricas la filosofía sea el final del recorrido y como superación última de la religión. Una filosofía que supera todas las dialécticas, el pensamiento que reconcilia el pensamiento finito y el espíritu infinito, y que implica, a criterio de Taylor, una reconciliación real en la vida. Para Taylor, según Hegel, la

\footnotetext{
${ }^{1561}$ Cfr. TAYLOR, Ch., Hegel, pág. 419.

1562 Cfr. Ibid., pág. 39.

${ }^{1563}$ Cfr. TAYLOR, Ch., Hegel y la sociedad moderna, pág. 99.
} 
filosofía siempre viene después de las transformaciones en la vida y a diferencia del arte o la religión, es una actividad de individuos, no de toda la sociedad. ${ }^{1564}$

Taylor sugiere así que una de las claves del futuro de la religión es asumir esta superación de la dialéctica de contradicciones y comenzar siendo más filósofos a través del incremento de la autoconciencia. Uno de los grandes retos es filosofar, entender, comprender el mundo y comprenderse a sí mismo como una unidad que expresa el Geist. Esta comprensión de sí mismo en proyectos de interioridad filosófica contribuye a fundamentar las bases para un futuro distinto de la religión. El hombre de hoy debe encontrar su filosofía, la que corresponde a este momento, y superar cualquier dialéctica de enfrentamiento, para adentrarse en un saber que integra todas las realidades del mundo de hoy. La religión del futuro tendrá que asumir estos retos si quiere realmente entrar en el corazón del hombre moderno.

II.- Taylor resalta a Hegel porque en su sistema filosófico está asentando dos líneas de futuro de la religión en la Modernidad y así se evita caer en la petrificación del espíritu racional. Por una parte, una religión que resalte la piedad viva que une al hombre consigo mismo, el sentimiento del corazón. Y por otra parte, una religión popular y en relación con las instituciones públicas. ${ }^{1565}$ En resumen, una religión que entre en diálogo con la Modernidad Ilustrada y que supere la magia y la superstición.

Hegel propone una Religión que unifique en el yo tanto la razón ilustrada, como la unidad expresiva del sentimiento y la voz interior en torno a la fantasía, el corazón y la sensibilidad. Y un yo no solo individual, sino colectivo, una religión del Pueblo. Frente a una religión de la "conciencia infeliz" en la que ha predominado la dominación y la servidumbre, Hegel propone una religión de la integración entre hombre y naturaleza, entre naturaleza y espíritu. Hegel intenta recuperar la religión de Jesús en la cual la voz del corazón une a los hombres en esa afinidad de espíritu con la naturaleza a través del amor. Frente a la moral kantiana del "debería" que separa el concepto moral de la realidad de los deseos, Hegel reivindica el "es" de Jesús que unifica espíritu y naturaleza en una totalidad de vida. ${ }^{1566}$

Para Hegel, no tiene ningún sentido una ruptura entre el marco inmanente y el marco trascendente. La inmanencia esconde espacios de subjetividad infinita y la trascendencia ámbitos de objetividad finita. La secularización, como ruptura entre lo inmanente y lo trascendente, "engaña el sentido del mundo". Se rompe el movimiento de la conciencia y "se desconfiguran los sótanos del universo". La razón pensante de sí mismo ha recorrido la totalidad de sus determinaciones para establecerse cabe sí reflejándose en su otro. Luego la secularización, en sentido hegeliano, es la razón

\footnotetext{
${ }^{1564}$ Cfr. TAYLOR, Ch., Hegel, pág. 446.

1565 Cfr. Ibid., pág. 47.

${ }^{1566}$ Cfr. Ibid., pág. 52.
} 
desdichada que no ha completado su recorrido. La autoconciencia filosófica lleva implícita el reconocimiento de que el hombre es el vehículo del espíritu cósmico, donde no existe ruptura entre hombre y naturaleza, entre espíritu cósmico y espíritu finito. Podríamos decir que en la autoconciencia, el Geist asume al hombre como vehículo propio de expresión. Y el hombre no encuentra otro cauce de autorrealización consciente que a través del Espíritu que le trasciende.

Taylor considera que el Hegel adulto asume cuatro síntesis que invitan a la superación del marco inmanente: la aceptación de la separación como parte de la unidad última, el desplazamiento a la filosofía como el medio crucial, el desplazamiento de una teoría centrada en el hombre a una centrada en el Geist y la noción de que la realización del hombre no está planeada por él, y que solo puede reconocerse post hoc. ${ }^{1567}$

Por lo tanto, para Hegel, el marco inmanente establecido como exclusividad rompe el sentido de la historia y de la racionalidad. El mundo finito lleva impresa la huella del espíritu y solo el espíritu finito puede poner en sintonía ese espíritu de la naturaleza con las fuentes de su propia interioridad racional convirtiéndose así en vehículo. El espíritu exteriorizado en el cosmos, en la cosa, en la naturaleza, está llamado a la unificación y a la autocomprensión en el hombre y el hombre solo puede entenderse en su racionalidad como unidad expresiva. No hay posibilidad de racionalidad que se autodefine sin autoconciencia de ser vehículo de un espíritu que se expresa. Y no hay posibilidad de existencia de un espíritu cósmico sin la autocomprensión y autorrealización de dicho espíritu infinito en el espíritu finito que es el hombre. Quedarse en el marco inmanente significa no comprender la naturaleza en su espíritu cósmico y no terminar de comprender el significado de la racionalidad inherente del ser humano llamada a la unidad expresiva con ese espíritu cósmico. Es quedarse en la cosa, en la naturaleza cosificada, y no adentrarse en la racionalidad que se identifica con la realidad efectiva.

Con la autoconciencia, la cosa deja de ser "una cosa sin más", el mundo deja de ser pura inmanencia y exterioridad cuando es alcanzado por la razón cabe sí, la autoconciencia, y llega a "ser-para-otro" en su "ser-para-sî". La cosa, el mundo, la inmanencia, la naturaleza recupera su exterioridad, su evanescencia objetual en la

\footnotetext{
${ }^{1567}$ Cfr. TAYLOR, Ch., Hegel, pág. 64. La aceptación de la separación como parte de la unidad invita a asumir que naturaleza expresiva y razón autodefinidora forman parte esencial del espíritu humano y que siendo distintas y estando separadas, sin embargo, solo se comprenden desde la unidad autorreferencial como ser humano: la razón que posibilita la apertura a horizontes de experiencia y la unidad expresiva que se realiza racionalmente. Se trata de una Razón que permite la eclosión del sentimiento expresivo. La filosofía como medio crucial y base de su sistema pretende asentar la unidad entre autonomía del yo en el ejercicio de la racionalidad del ser humano. La razón implica el sometimiento de todo al sentido de la propia autonomía. La oposición entre unidad expresiva y razón solo es posible desde un Geist que es mayor que el hombre o desde un hombre como vehículo del Geist, del espíritu cósmico. Y la idea de que el hombre no puede planificar el sentido de su vida, le abre a un sentido de la historia universal como movimiento del Geist que solo puede comprenderse post hoc.
} 
autoconciencia que se proyecta cabe sí en la exterioridad. Es la autoconciencia que permite superar la inmanencia y la trascendencia como ruptura.

Lo inmanente, la exterioridad, solo puede ser por su relación proyectiva de la autoconciencia pensante. Y solo esta "autoconsciencia cabe sî" puede alcanzar la esencialidad espiritual del objeto. Sin esta razón pensante de sí (autoconciencia), el mundo está transido de coseidad exterior. Y sin esta exterioridad objetual inmanente la razón/conciencia no puede alcanzar sus determinaciones. La conciencia ha pasado de ser razón observante "indiferente" a la cosa a ser autoconciencia cabe sí "en" la cosa. Es la síntesis final del espíritu filosófico según la cual "el ser del yo es una cosa" y "la cosa es yo". 1568 En este sentido, para Taylor, la ruptura secularizadora, implica "desconfigurar" el mundo y desontologizar la existencia. No existe el hombre sin la naturaleza cósmica espiritual ni existe el espíritu cósmico sin el hombre. Luego la trascendencia es inmanente y la inmanencia es trascendente. Reconstruir la narración de la secularidad puede tener en Hegel una ayuda innegable para superar las oposiciones y negatividades, y fomentar la circularidad dialógica.

La autoconciencia moral "sabe" el ser de la cosa y la cosa deja de ser cosa en sí para ser yo autoconsciente. Se supera la dialéctica y comienza el momento de la Filosofía. Sin esta autoconsciencia moral del yo la cosa-es-solo-en-sí, no es yo moral. El mundo como representación de Schopenhauer no permitía a la cosa el estatuto moral de autoconciencia, licenciaba a la existencia respecto al sí-mismo o, lo que es lo mismo, confería a la cosa un estatuto de existencia-en-sí-mismo. No es el saber puro del sí mismo acerca de sí en la cosa, sino el saber de la cosa-en-sí, con lo que la inmanencia permanece, dado que la realidad efectiva no es reconocida como espíritu cósmico a través del vehículo del yo. ${ }^{1569}$

Taylor afirma que todo el mobiliario del mundo está ahí para encarnar el Geist, el Concepto final, lo Total, y para manifestar lo que es esencialmente, un espíritu autocognoscente, un espíritu autopensante, una pura necesidad racional. ${ }^{1570}$ Según Taylor, el establecimiento del humanismo exclusivo, a través del marco inmanente, sería tan solo un intento de caracterizar cualquier parte del todo -el espíritu finito o la cosa- como autosuficiente, sin relacionar lo parcial con el todo. Hegel está sugiriendo el peligro de ver la existencia meramente externa de una cosa finita, de un objeto material, animal, o de un espíritu finito, como un tipo de confirmación de la existencia independiente. Toda la argumentación hegeliana le servirá a Taylor para afirmar que la postura instrumental naturalista conlleva la objetivación de la naturaleza y percibirla como orden neutro de las cosas. Taylor observa que al objetivar o neutralizar algo,

\footnotetext{
1568 HEGEL, Fenomenología del Espíritu, pág. 505.

${ }^{1569}$ Cfr. HEGEL, La Lógica I, págs. 86,93; cfr. TAYLOR, Ch., Hegel, pág. 90.

${ }^{1570}$ Cfr. TAYLOR, Ch., Hegel y la sociedad moderna, pág. 113.
} 
afirmamos nuestra separación de ello, nuestra independencia moral. ${ }^{1571}$ Para él, el camino hegeliano de recuperación de la síntesis superior invita a recuperar las valoraciones fuertes que superen el ámbito de la inmanencia y de la ruptura como separación entre el yo y la cosa, entre lo finito y lo infinito, entre la naturaleza y el sujeto. Taylor está sugiriendo esta revisión de la razón secular que se comprende a sí misma casi como la sola razón y que de manera tiránica confiere derecho a la razón religiosa para expresar algo que no está del todo claro o que despierta sospechas. Hegel invita a superar el mito de la razón Ilustrada como única razón de verdad científica y a contemplar una razón superior que engloba todo.

La religión del futuro está llamada a integrar, en sus propuestas, espacios de integración racional y unidad expresiva, invitando siempre a abrirnos a algo más. Las religiones en el futuro deberán potenciar el pensamiento y la razón autodefinidora sin olvidar enriquecer el espíritu humano con experiencias de contacto con la naturaleza como ámbito para la unidad expresiva. La religión siempre será ese camino de integración de la identidad humana en el Todo.

Siempre tendremos que recurrir a Hegel, según Taylor, dado que su obra constituye uno de los intentos más profundos y trascendentes por elaborar una visión de la subjetividad encarnada, del pensamiento y la libertad surgiendo de la corriente de la vida, encarnándose en las formas de la existencia social y descubriéndose a sí misma en relación con la naturaleza y la historia. ${ }^{1572}$

Según Hegel, la Historia es una síntesis de "pensamiento y sensibilidad". Hay una razón superior que aglutina el pensamiento y la razón, que se autodefine y controla, y la sensibilidad, que capta el orden de la belleza natural y cósmica. ${ }^{1573}$ Taylor está sugiriendo que la sola razón secular no puede erigirse a sí misma como la única razón con pretensión de verdad. Desde ella misma es posible contemplar el movimiento de la razón a lo largo de la historia y el recorrido que ha seguido. Por eso la actitud revisionista de Taylor invita a comprender que la sola razón, entendida como razón secular, es una novedad histórica frente a otros tantos momentos que no se han comprendido de esa manera, o no han tenido la arrogancia de determinarse de manera tan absoluta y cerrada.

Hegel invita a ir más allá del concepto, para hacer una amalgama que recoja el sentimiento de la esencia, un concepto que recoge la sustancia y se eleva como éxtasis, como edificación. ${ }^{1574}$ Para Taylor, según Hegel, el hombre llega a sí mismo al final, cuando se ve a sí mismo como el vehículo de un espíritu mayor, como subjetividad

\footnotetext{
${ }^{1571}$ Cfr. TAYLOR, Ch., Fuentes del yo, pág. 523.

1572 Cfr. Ibid., pág. 318.

${ }^{1573}$ Cfr. TAYLOR, Ch., Hegel, pág. 499.

${ }^{1574}$ Cfr. HEGEL, F., Fenomenología del Espíritu, Prólogo, pág. 7.
} 
cósmica. Taylor opina que en la autoconciencia hegeliana es posible cuadrar el círculo y establecer la base para una unión entre espíritu cósmico y espíritu finito, entre naturaleza y pensamiento, y así cumplir los requerimientos para que el hombre esté unido a la totalidad y no sacrifique su propia conciencia y voluntad autónoma. ${ }^{1575}$

Taylor invita a enfocar la mirada sobre aspectos que aparecen, desaparecen, se reubican, se reorientan sobre fuentes morales nuevas, o sobre otras que parecían perdidas. El movimiento del Espíritu es siempre inquietud que se manifiesta sobre realidades nuevas, un espíritu que no cesa en su recreación interior y que invita a encaminarse hacia la inmediatez simple, hacia la libertad autoconsciente que descansa en sí misma, hacia la conciencia filosófica. ${ }^{1576}$ Este es el telos de la historia, sabiendo que nunca termina de realizarse completamente. El espíritu es yo y cosa, naturaleza y pensamiento. La ciencia no puede quedarse en sí misma. Hay una historia que contempla la realización del Espíritu y hay siempre un "comienzo del nuevo espíritu" comprendido como "el indigente sentimiento de lo divino como tal" y que "mira con desdén el concepto" (como pura representación). ${ }^{1577}$

III.- Si para Hegel "lo bello, lo sagrado, lo eterno, la religión y el amor son el cebo requerido para despertar las ganas de picar, no es el concepto, sino el éxtasis, no es el frío progreso de la necesidad de la Cosa, sino el entusiasmo efervescente lo que debe ser la actitud y la guía continua que difunde la riqueza de la sustancia", ${ }^{1578}$ entonces es el espíritu, la razón absoluta, el éxtasis y el entusiasmo efervescente lo que afianza el camino para la síntesis más elevada y el afianzamiento del sujeto como vehículo del Geist. Es así como, según Taylor, Hegel cree haber resuelto todos los dualismos. ${ }^{1579}$ Taylor considera como algo extraño al movimiento del espíritu y a la tradición filosófica de Occidente, la mayoría de las opiniones que considera inadecuadas, y frente a las cuales pretende proponer las suyas, ya que las considera demasiado estrechas, invalidando algunos de los bienes fundamentales en conflicto. ${ }^{1580} \mathrm{E}$ invita a reconsiderar la valoración fuerte en línea con el devenir del Geist como "un parsimonioso movimiento y sucesión de espíritus, una galería de imágenes, cada una de las cuales se halla dotada de toda la riqueza íntegra del espíritu, y se mueve con tanta parsimonia precisamente porque el sí-mismo ha de penetrar y digerir toda esta riqueza de su sustancia". ${ }^{1581}$

\footnotetext{
${ }^{1575}$ Cfr. TAYLOR, Ch., Hegel, pág. 39.

${ }^{1576}$ Cfr. Ibid., pág. 65.

${ }^{1577}$ HEGEL, F., Fenomenología del Espíritu, pág. 8.

1578 Ibid., pág. 7.

${ }^{1579}$ Cfr. TAYLOR, Ch., Hegel, págs. 106-107. "La frivolidad y el tedio que irrumpen en lo existente, el barrunto indeterminado de algo desconocido, son los emisarios de que algo otro está en marcha. Este paulatino desmoronarse que no cambia la fisionomía del todo se ve interrumpido por el amanecer, un rayo que planta de golpe la conformación del nuevo mundo". HEGEL, Fenomenología del Espíritu, pág. 9.

1580 Cfr. TAYLOR, Ch., Fuentes del yo, pág. 679.

${ }^{1581}$ HEGEL, Fenomenología del Espíritu, pág. 516.
} 
Es decir, si en otras épocas se identifica a Dios con esa Sustancia (Geist) única y se cancelaba la autoconsciencia, ahora, con el advenimiento de la Modernidad y el surgimiento de la subjetividad del yo a partir de la razón que observa, es posible acceder al Espíritu a través del espíritu del hombre, "el hombre tiene con él una relación inmediata en el espíritu", ${ }^{1582}$ es el hombre el que aglutina dentro de sí la inmediatez, a partir de su yo, en su relación con el Espíritu. ${ }^{1583}$

Dios, como Sustancia Universal, justificaba la separación de dos mundos, el inmanente y el trascendente, y solo el marco trascendente justificaba el Todo, y Todo era uno en la Sustancia única (marco trascendente único). Sin embargo, ahora, con el descubrimiento de la subjetividad libre del sujeto en la Modernidad, será la autoconciencia moral la que descubra esta parsimonia del movimiento del Geist y realice la auténtica comprensión del mundo como síntesis entre sensibilidad y pensamiento, entre naturaleza y yo, entre esencia y forma, entre individuo y sociedad, entre cuerpo y alma. Una síntesis hegeliana que, para Taylor, concluye en un punto en el que el Geist es en cierto sentido como un alma del mundo racionalmente impenetrable.

Para Taylor, las moralidades laicas están invitadas a reconocer la contradicción de la finitud a partir del todo autosubsistente, o a comprender que la razón secular no puede determinarse a sí misma como explicación del Todo. Si no se comprende como razón de una Razón superior que quiere comprender lo Universal, difícilmente puede arrogarse ese carácter de exclusividad. Por su parte, las moralidades trascendentes, desde la ontología hegeliana, también están invitadas a contemplar lo infinito como el sistema completo de las cosas finitas y sus relaciones, sin que él mismo dependa o esté limitado por algo más. El paso al infinito verdadero, según Taylor, llega cuando vemos que cada algo, al desaparecer, es reemplazado por otro algo finito. Hay identidad en el cambio, se deduce que Algo, en su paso a otro, solo se une consigo mismo. Se puede concluir que hay algo más que un mero cambio. Se trata más bien de un proceso continuo que va a través de su llegar a ser y perecer. Esta es la identidad y la diferencia. Y este proceso no es ninguna cosa particular, sino el sistema completo. ${ }^{1584}$ Las moralidades trascendentes están invitadas a realizar su propia síntesis, afirmándose como Espíritu Infinito que mira desde el ser, el-no-ser, incluyéndolo, pero al mismo tiempo negándolo como negación e invitando a ir más allá de la epistemología de la ciencia moderna, que no es capaz de entrar en el estudio del Todo, del sistema completo. Por lo tanto, todas las fuentes morales de la Modernidad pueden ser completadas y analizadas desde esta invitación a

\footnotetext{
1582 Ibid., pág. 553. Cfr. Ibid., pág. 285.

1583 “Así pues, el espíritu de la verdad puede aparecer únicamente en la voluntad subjetiva, en la actividad particular de la voluntad; el espíritu objetivo puede aparecer cuando la intensidad del espíritu libre subjetivo se decide sobre la forma de la universalidad. En este sentido puede concebirse que el Estado se halle fundado en la religión. Estados y leyes no son otra cosa que el modo como se manifiesta la religión en las relaciones de la verdad”. Ibid., pág. 554.

${ }^{1584}$ Cfr. Ibid., pág. 208.
} 
una síntesis superior para comprender dialógica y circularmente el eterno devenir del Geist. $^{1585}$

En relación a las moralidades múltiples de la Modernidad, la unidad que propugna Hegel en el espíritu sustancial que integra la cosa del pensamiento y la sensibilidad modernas, no pueden comprenderse a sí mismas más que desde lo que fue cancelado en la afirmación propia de ellas como movimiento de la esencia deviniendo. El pensamiento y la sensibilidad del sujeto moderno integran en su negatividad la esencia eterna del ser deviniendo, con lo que hay una circularidad que no puede comprenderse a sí misma sin ese "otro" que está negado dentro. Este devenir, siendo como negatividad de la negatividad, es la afirmación de lo otro como razón absoluta, que integra tanto la sustancia eterna de la naturaleza como su expresión como subjetividad del sujeto. El espíritu es la razón y la naturaleza. O lo que es lo mismo, las diversas moralidades están deviniendo lo mismo, porque tanto la naturaleza, como el sujeto, como el espíritu, son lo mismo en un continuo devenir. El Espíritu es la auto-relación abstracta, porque es esto solo por ser el universal abstracto, sin diferenciación interna. ${ }^{1586}$

Para Taylor, la concepción ontológica hegeliana se sustenta en el ser finito como vehículo de una vida infinita, la cual no está separada de este. La dialéctica del Ser engendra al Dasein, y el Dasein se descubre como subjetividad contradictoria que mezcla realidad y negación, ser y no ser, identidad y no identidad. Y dicha naturaleza contradictoria es la finitud que está llamada a comprenderse a sí misma como superación de la barrera y por lo tanto como un impulso hacia el infinito. ${ }^{1587}$

Un devenir que está llegando hasta el hoy bajo muy diversas formas y que Taylor invita a imaginarnos como algo que puede ser nuevo, constructivo, algo que abra nuevas posibilidades, pero también puede ser una pura ficción, tal vez peligrosamente falsa. ${ }^{1588}$ Taylor asegura que las posibilidades son muy diversas porque este "devenir siendo" es algo que no termina de aparecer del todo, es la espiral hegeliana que se recrea constantemente en una creatividad que siempre está por descubrir. El Espíritu, el fundamento ontológico del mundo en la necesidad racional, está determinado a realizar la síntesis entre la naturaleza como emanación del espíritu y la necesidad de autonomía racional. $^{1589}$

\footnotetext{
${ }^{1585}$ Cfr. TAYLOR, Ch., Fuentes del yo, págs. 60, 99-100, 175, 204, 206-208, 285, 293, 348, 420, 427 428, 464-465.

${ }^{1586}$ Cfr. HEGEL, Fenomenología del Espíritu, pág. 293.

${ }^{1587}$ Cfr. Ibid., pág. 210.

${ }^{1588}$ Cfr. TAYLOR, Ch., Imaginarios sociales modernos, pág. 197.

${ }^{1589}$ Cfr. TAYLOR, Ch., Hegel, pág. 476.
} 


\section{IV.4.-OTRAS NARRACIONES DE LA SECULARIZACIÓN}

Charles Taylor denomina a los siglos XIX y XX "la era de la movilización”. Una movilización que se caracteriza en el siglo XIX como un proceso de secularización de las élites, y el siglo XX como el siglo del efecto nova, una expresión muy peculiar de Charles Taylor con la que quiere expresar esa gran variedad de posiciones disponibles que van desde creyentes a no creyentes o a una gran variedad de posiciones difíciles de clasificar y con muy diversos matices. ${ }^{1590}$

Sea lo que sea, sí que podemos afirmar que se trata de un progresivo auge de la secularización en occidente en estos dos últimos siglos en los que se va fraguando, como dice nuestro autor canadiense, una alternativa al Cristianismo que adopta los caracteres secularizadores de un humanismo exclusivo y una antropología impermeabilizada.

Recordamos los tres tipos de secularización según Taylor y cómo el que realmente nos interesaba era el tipo 3 en relación al cambio de las condiciones de la creencia tal y como expusimos al comienzo de este trabajo. La relación entre la secularización de tipo 2 y la del tipo 3 implica que, lo que en el siglo XVIII eran alternativas humanistas para una minoría, se van a ir expandiendo en el siglo XIX hasta ir llegando progresivamente a una mayoría que asienta sus fuentes morales en fundamentos no creyentes. Por otra parte, la relación entre la secularización de tipo 1 y 2 abre sus propios interrogantes en torno al debate acerca la diferenciación, sobre todo, cuando los servicios e instituciones eclesiales son asumidos por espacios de instituciones de la esfera pública. Esto no implica la ausencia de espacios para la fe dentro del ámbito de lo público, como, por ejemplo, en el caso de los médicos creyentes o el compromiso social en el ámbito de las ONG. ${ }^{1591}$

Lo que ha dado en llamarse la teoría de la difusión, por la cual se expande la secularización de las élites a grandes masas de población, es una teoría un tanto simplista que no se sostiene por los datos. No hay que olvidar que, tanto en Francia, como en Inglaterra o Estados Unidos, se produce un aumento de la afiliación religiosa desde mediados del XIX a mediados del XX, cuando se inicia un progresivo declive. Es la época de la Restauración en Francia o del Movimiento evangélico en Inglaterra. ${ }^{1592}$

\footnotetext{
${ }^{1590}$ Cfr. TAYLOR, Ch., La Era Secular, tII, págs. 14, 22, 197,669.

${ }^{1591}$ Con lo cual algunos autores hablan de la "saturación" del antiguo modelo, pero eso no implica que la religión quede marginada o que no existan motivaciones desde el ámbito de lo religioso para asumir compromisos sociales y solidarios desde la esfera de lo público. Pero, por otra parte, lo que ha dado en denominarse teoría de la diferenciación no implica saturación cuanto que la religión sea una esfera más entre otras. La saturación implica muchas veces marginación de la Religión. En cambio, la diferenciación entendida como secularización tiene otro sentido sobre el que será necesario volver para analizarlo con más detenimiento.

${ }^{1592}$ Cfr. TAYLOR, Ch., La Era Secular, tII, pág. 402.
} 
Presentamos a continuación algunos errores en relación con los distintos tipos de secularización y las teorías de la diferenciación y la difusión:

1.- Primer error: Identificar secularización con desencantamiento en relación con la diferenciación. No se sostiene que la secularización haya llevado irremediablemente al declive de la fe. Autores como M. Weber (La ética protestante y el espíritu del Cristianismo), M. Gauchet (El desencantamiento del mundo, una historia política de la religión) y $\mathrm{P}$. Berger (El dosel sagrado) afirman que el Cristianismo y el Judaísmo han promovido a lo largo de su historia procesos de desencantamiento. ${ }^{1593}$

2.- Segundo error: Identificar diferenciación y privatización. El que haya asumido un mayor protagonismo la esfera pública y la consiguiente emancipación entre ambas esferas eso no ha llevado irremediablemente a la privatización de la fe y a la marginación de la religión en el mundo moderno. Es más, algunos como Casanova, hablan de la desprivatización de la fe. ${ }^{1594}$

3.- Tercer error: Confundir el desencantamiento con el declive de la religión. Creer que por el desarrollo de la ciencia y la tecnología se llega a la muerte de Dios o pensar que las soluciones técnicas para problemas vitales nos alejan necesariamente de la religión. ${ }^{1595}$

4.- Cuarto error: Generalizar y vincular el proceso de urbanización con la secularidad del tipo 2. No es válido para Reino Unido en el siglo XIX ni para Estados Unidos en el XX. ${ }^{1596}$

Todo esto nos lleva, siguiendo a Taylor, a realizar distintos interrogantes:

1.- ¿Realmente la religión ha tenido la relevancia que supuestamente ha perdido? ¿No se le habrá concedido demasiada importancia y ahora creemos que ha perdido peso cuando quizás no haya tenido tanto? ¿Se identifica religión con catolicismo y la crisis de pertenencia la Iglesia es la secularización?

2.- ¿Qué es la Religión? ¿Son los credos asociados a ciertas religiones institucionales, o una forma de preguntarse por las grandes preguntas de sentido, o una capacidad innata en el hombre para acrecentar experiencias de interioridad y comportamiento moral? ${ }^{1597}$

\footnotetext{
${ }^{1593}$ Cfr. Ibid., págs. 496-497.

${ }^{1594}$ Cfr. TAYLOR, Ch., El multiculturalismo y la política del reconocimiento, págs. 14-15.

1595 Cfr. TAYLOR, Ch., Hegel, pág. 73; cfr. TAYLOR, Ch., La Era Secular, tII, pág. 404.

${ }^{1596}$ Cfr. TAYLOR, Ch., Hegel, págs. 472-473.

${ }^{1597}$ Cfr. HEGEL, Filosofía de la religión, págs. 51-104; cfr. TAYLOR, Ch., La Era Secular, tII, pág. 204.
} 
3.- ¿La práctica religiosa ha sido siempre mayoritaria o a lo largo de la historia ha habido excepciones con personas o grupos reticentes? ¿El alcance de la práctica religiosa era motivado por un profundo sentido de personalización en la fe o estaba motivado por el ambiente social o por ciertos imperativos que impelían a las personas a acudir a la Iglesia necesariamente?

4.- Si los procesos de secularización comenzaron antes del siglo XVI, ¿cuándo comenzaron realmente a tomar forma las fuentes morales de la laicidad moderna $y$ por qué? Este es uno de los objetivos fundamentales de nuestro estudio. ${ }^{1598}$

Siguiendo con estas ideas preliminares planteamos un riesgo que, para Taylor, condiciona buena parte de las reflexiones sobre la secularización y son los impensados que influyen en nuestra particular visión de un tema tan relevante como la secularización. Cada autor es moldeado por un "impensado", por su forma propia de acercarse al mundo de la religión y, por ende, influida por prejuicios y por las propias valoraciones morales, con lo cual, según afirma Taylor, nuestras interpretaciones de la religión están muy influenciadas por nuestras creencias sustantivas. ${ }^{1599}$

Según Taylor, nos enfrentamos a varios tipos de impensados.

i. Que la religión debe declinar porque es falsa y la ciencia demuestra que lo es.

ii. Que la religión es cada vez más irrelevante debido a las aportaciones de la ciencia y la tecnología a nuestro bienestar vital.

iii. Que con el advenimiento de la modernidad cada vez es más importante la autonomía individual.

iv. O bien los tres a la vez con sus matices propios.

Estos son los impensados que influyen de manera poderosa en los intelectuales y académicos que son los que van marcando el pensamiento y la forma de entender la vida en el mundo occidental. La mayoría de la población suele seguir el mismo ritmo de pensamiento, aunque sin ser muy consciente de ello. ${ }^{1600}$

Charles Taylor defiende que existe una cierta turbiedad acerca de lo que supone exactamente la tesis de la secularización. Pretende aportar su propia reflexión a un tema tan controvertido y que se ha sustentado frecuentemente en visiones un tanto simplistas y que contradicen la realidad. Además, para él, existen corrientes ortodoxas y corrientes

\footnotetext{
${ }^{1598}$ Cfr. TAYLOR, Ch., Imaginarios sociales modernos, págs. 214-215.

${ }^{1599}$ Cfr. TAYLOR, Ch., La Era Secular, tII., pág. 206.

${ }^{1600}$ Cfr. Ibid., págs. 207 y ss.
} 
revisionistas sobre dicha tesis que según él tienen que ver con la imagen que se tenga de la religión hoy en día. ${ }^{1601}$

El proceso de pluralización y diversificación no solo se ha instalado en el corazón de la razón y la sensibilidad, motivando el surgimiento de distintas fuentes morales, sino que también ha irrumpido en el corazón de la sociedad dando lugar a una era descentrada y fragmentada, enriquecida por la pluralidad a través de una circularidad dialógica que intenta superar cualquier pretensión de absolutez. ${ }^{1602}$

Las teorías de la secularización han estado en boga hasta la segunda mitad del siglo XX. A partir de entonces se puede afirmar con contundencia que han sido superadas debido a que se ha impuesto otra realidad, otra configuración del mundo. ${ }^{1603}$

Hoy nadie duda de la superación de dichas teorías de la secularización. Una secularización que, por otra parte, se produjo no solo en Occidente, sino en otras latitudes y tradiciones religiosas, aglutinando el concepto de "modernidades múltiples" por parte de Shmuel Eisenstadt. En dicho concepto se incluye la idea de que la secularidad occidental es una más entre otras en las que la religión ocupa un lugar destacado y distinto. ${ }^{1604}$

La teoría clásica de la secularización pone de manifiesto que se estaba hablando de una situación limitada a Europa y a una situación temporal, dado que la realidad actual no es la que suponía dicha teoría. Las teorías secularizadoras clásicas afirman que se ha producido un fenómeno indudable de descristianización en Europa y la consiguiente aparición del marco inmanente como paradigma ideológico fundamental. ${ }^{1605}$ No obstante, a pesar de la consideración de Eisenstadt de las modernidades múltiples a las que ya se ha hecho referencia, se puede afirmar que el momento actual en Europa y en el mundo contradice la versión clásica de la teoría de la secularización. La contradicción fe/razón o fe/ciencia, como algo insuperable, queda ampliamente superada, así como la idea de que modernidad es sinónimo de secularización. Todo esto invita a repensar dicha teoría clásica al propio tiempo que a

\footnotetext{
${ }^{1601}$ Cfr. Ibid., págs. 212-215.

1602 Cfr. BERMEJO, D., "Secularismo, Religión y Democracia. El giro democrático en el debate secularismo-religión" Pensamiento, Vol. 72, No 271, (2016), págs. 231-232.

${ }^{1603}$ Cfr. TAYLOR, La Era Secular, tII, págs. 52,152,208,215,250,326,381,463,733.

1604 “A principio de la década de los setenta del siglo XX, el mundo parecía empujado por Occidente hacia un proceso ineluctable de secularización. Una 'teoría' se elaboró al respecto. Cuarenta años después, la 'evidencia' estaría mostrándonos exactamente lo contrario; es decir, que la religión no solo está viva, sino que no tiende a desaparecer e incluso parece haberse fortalecido y formar parte esencial de la cultura de todos los pueblos del mundo. Después de analizar las trayectorias de las discusiones sobre el tema, tendríamos que reconocer que la crisis de la 'teoría de la secularización', ha terminado por convertirse en una redefinición de su alcance". BLANCARTE, R., "Religión y sociología. Cuatro décadas alrededor del concepto de secularización”, Revista Estudios Sociológicos, Vol. XXX, (2012), pág. 59.

${ }^{1605}$ Cfr. HABERMAS, J., Mundo de la vida, política y religión, Trotta, Madrid, 2015, pág. 112. Para Habermas, Charles Taylor, bajo el epígrafe de marco inmanente (immanent frame), esboza con demasiada superficialidad en lo relativo a las bases filosóficas que ello significa.
} 
interrogarse por el hecho de que más que de secularización, quizás se estaba hablando de deseuropeización del Cristianismo, o de triunfo del marco inmanente sobre el trascendente, pero para nada se puede afirmar que con el advenimiento de la condición posmoderna la religión haya desaparecido de Occidente o que no tenga futuro. Taylor prefiere hablar no solo de la historia de un declive, sino sobre todo de una "reubicación de lo sagrado" y lo espiritual en relación con la vida individual y social. ${ }^{1606}$

En otros términos, Taylor reconoce que la secularización se manifiesta como superioridad epistemológica de la postura inmanente, que ha penetrado en todas las estructuras políticas, sociales y culturales. ${ }^{1607}$ Una superioridad que margina, pero que no ha podido evitar la presencia de lo religioso en el mundo de hoy, manifestado desde un gran pluralismo. Taylor considera que en la era de la autenticidad, a pesar de las dificultades de transmisión del mensaje cristiano en amplias regiones, sin embargo, dichas zonas tampoco son demasiado hospitalarias con el secularismo más estrecho. ${ }^{1608}$

Si bien es cierto que ha habido una reducción de la influencia de la religión en la vida pública, no obstante, tampoco se puede afirmar que la Modernidad haya supuesto su desaparición. Está claro que se ha producido una diversificación del hecho religioso, un mayor pluralismo y lo que Taylor denomina una gran marcha en paralelo. ${ }^{1609}$ Taylor tiene como objetivo sugerir, en lugar del supuesto efecto uniforme y unilateral de la modernidad sobre la creencia y la práctica religiosas, otro modelo en el que estos cambios con frecuencia desestabilizan ciertamente las formas antiguas, pero en el que lo que le sigue depende muchísimo de las alternativas disponibles o del horizonte que se vaya estableciendo según las circunstancias. ${ }^{1610}$ Se puede afirmar incluso que, con el aumento del pluralismo religioso, ha decrecido la secularización. Veamos diferentes análisis que realizan algunos autores en torno a la Modernidad secular y de los que Taylor se hace eco.

\section{IV.4.1.-NARRACIONES SOCIOLÓGICAS}

I.- Para comprender lo que significa la secularización, es importante comenzar definiendo la palabra "religión". Durkheim considera la religión como un sistema solidario de creencias relativas a las cosas sagradas. ${ }^{1611}$ La religión surge del grado de

\footnotetext{
${ }^{1606}$ Cfr. TAYLOR, Ch., La Era Secular, tII, pág. 222.

1607 "Marginalizando y privatizando tanto las instituciones eclesiásticas como las creencias religiosas, excluyendo de la esfera pública y del debate político el lenguaje y argumentario religiosos, identificando necesariamente el ser 'moderno' con ser 'secular' y ser 'religioso' con ser 'antiguo'”. BERMEJO, D., "Repensar la secularización”, Pensamiento, Vol. 70, No 263, (2014), pág. 344.

${ }_{1608}$ Cfr. TAYLOR, Ch., La Era Secular, tII, pág. 328.

${ }^{1609}$ Cfr. TAYLOR, Ch., Imaginarios sociales modernos, pág. 214.

${ }^{1610}$ Cfr. TAYLOR, Ch., La Era Secular, tII, pág. 258.

1611 "Un sistema solidario de creencias y de prácticas relativas a las cosas sagradas, es decir separadas, interdictas, creencias y prácticas que unen en una misma comunidad moral, llamada Iglesia, a todos aquellos que se adhieren a ellas. El segundo elemento que se introduce así en nuestra definición no es
} 
intensidad de la vida social. Cuando la vida social se intensifica surge un cierto grado de efervescencia que motiva la experiencia religiosa, de tal manera que religión es efervescencia social y la sociedad podríamos decir que es la consciencia efervescente que surge de la experiencia religiosa. La intensividad social propugna una experiencia psíquica que transforma el mundo de lo real y le confiere significaciones nuevas. Es el mundo de las representaciones religiosas y que constituyen la expresión más elevada del sentimiento social del ser humano. ${ }^{1612}$

Para Durkheim, se trata de un sistema de creencias de carácter trascendente y que aglutina una comunidad moral. Insiste de manera reiterada en el hecho comunitario de la religión y no tanto en la dimensión de adhesión individual. ${ }^{1613} \mathrm{El}$ hombre es capaz de razonar y de crear civilización. La religión es un bien más de la civilización y solo se expresa en acto cuando se manifiesta como realidad colectiva. De ahí que sin la religión el hombre se ve privado de un bien cultural que le determina y le conduce a su propia identificación moral. En este sentido, la religión pertenece indisociablemente a la cultura humana y no se puede entender la cultura humana sin el hecho religioso. Creemos que esta dimensión social de la religión es un elemento clave a la hora de analizar la visión que Taylor tiene de la secularización. Es el auge del individualismo que tiene en Rousseau a un filósofo clave y que, en cierto sentido, tal y como hemos visto, inició el cambio, ya que presenta frecuentemente la cuestión de la moral como la atención que le prestamos a una voz de la naturaleza que hay dentro de nosotros. Nuestra salvación moral dependerá de la recuperación de un auténtico contacto moral con nosotros mismos. Antes de finales del siglo XVIII, nadie pensaba que las diferencias entre los seres humanos tuviesen este tipo de significación moral. Hay cierto modo de ser humano que es mi modo, mi originalidad, mi manera, ser fiel a mí mismo, ser auténtico. ${ }^{1614}$ Frente a la efervescencia social del tiempo de los orígenes, con la Modernidad se reivindica la efusividad del contacto conmigo mismo. Esta es una de las claves que configuran el cambio secularizador.

Durkheim considera el valor intrínseco de la experiencia religiosa, semejante al valor de la experiencia científica. Una experiencia que nunca es capaz de expresar en su totalidad el alcance del enraizamiento moral en el que se sustenta. De ahí que la

menos esencial que el primero. Pues, al mostrar que la idea de la religión es inseparable de la idea de Iglesia, prefigura que la religión debe ser algo eminentemente colectivo". DURKHEIM, E., Las formas elementales de la vida religiosa, Akal Editor, Madrid, 1982, pág. 42.

1612 "En una palabra, sobreañade al mundo real en que se desarrolla su vida profana otro que, en un determinado sentido, no existe más que en su pensamiento, pero al que, en comparación al primero, atribuye una especie de dignidad más elevada. Se trata, pues, en base a este doble título, de un mundo ideal”. DURKHEIM, E., pág. 393.

1613 "Pues lo que crea al hombre es ese conjunto de bienes intelectuales que constituyen la civilización, y esta es obra de la sociedad. Y así se explica el papel preponderante del culto en todas las religiones, en cualquiera de ellas". DURKHEIM, E., Las formas elementales, pág. 390.

${ }^{1614}$ Cfr. TAYLOR, Ch., El multiculturalismo y la política del reconocimiento, págs. 49-51; cfr. TAYLOR, Ch., La ética de la autenticidad, pág. 49. 
experiencia histórica siempre sea más limitada que el alcance del hecho religioso entendido como una experiencia antropológica indisociablemente unida al acontecer humano. Por eso, el hecho religioso ha variado infinitamente a lo largo de la historia y no termina por identificarse con ninguna experiencia religiosa concreta. Si la religión ha engendrado todo lo que es esencial en la sociedad es porque la idea de sociedad constituye el alma de la religión, ${ }^{1615}$ aunque la secularización, según Taylor, suponga el fin de la estructuración social en torno a dimensiones morales trascendentes. ${ }^{1616}$

Por otra parte, lo mismo que la sociedad hace surgir el hecho religioso como un elemento más de la civilización, para Durkheim también el pensamiento y el razonamiento científico tienen un origen religioso. Para que pudiera decirse que ciertos hechos eran sobrenaturales, debía tenerse ya la sensación de que existía un "orden natural de las cosas", es decir, que los fenómenos del universo están ligados entre ellos según relaciones necesarias, llamadas leyes. Una vez adquirido este principio, todo lo que se sustraiga a esas leyes debía aparecer necesariamente como fuera de la naturaleza y, por consiguiente, de la razón: pues lo que es natural en ese sentido es también racional, ya que esas relaciones necesarias no hacen más que expresar la manera en que las cosas se encadenan lógicamente. ${ }^{1617}$ La religión entra en contacto con la naturaleza de manera natural, y a partir de dicha relación, predispone para un adentramiento científico en el mundo de la naturaleza, ya que intenta expresar lo que la religión descubre en el ámbito de la naturaleza y lo que la naturaleza puede expresar como experiencia religiosa. ${ }^{1618}$ En sus orígenes la religión se mezcla con el mundo de la materia, ya que intenta descubrir el orden inherente al mundo natural y predispone para un estudio de la misma. Taylor opina que, en el marco de esta concepción precientífica del mundo y del orden cósmico, el universo está tan ordenado como para realizar la máxima riqueza. Se inicia así el camino de la ciencia desde la religión, esto es, se explica el mundo desde una comprensión mística del mismo. Posteriormente, se independizará la mecánica de cualquier mística y recobrará su autonomía para el acceso a la materia misma. Para él, la ciencia en su comprensión premoderna consiste en la captación del orden de las cosas y por qué las cosas son como son, una concepción que está estrechamente vinculada a captar la idea del bien y cómo debemos vivir los seres humanos para estar en armonía con este orden. El pensamiento científico y el ejercicio de la razón surgen dentro del ámbito de las religiones. La revolución del siglo XVII produjo una desconexión con el giro mecanicista y una concepción neutral del universo. ${ }^{1619}$

\footnotetext{
1615 Cfr. DURKHEIM, E., Las formas elementales, pág. 390.

${ }^{1616}$ Cfr. TAYLOR, Ch., Imaginarios sociales modernos, pág. 215.

1617 Cfr. DURKHEIM, E., Las formas elementales, pág. 38.

1618 Cfr. Ibid., págs. 114 y ss.; cfr. HEGEL, Filosofía de la religión, págs. 107-171.

${ }^{1619}$ Cfr. TAYLOR, Ch., Argumentos filosóficos, págs. 71,88,200,204; cfr. TAYLOR, Ch., La Era Secular, tI, págs. 107-108. "Bajo este punto de vista, tanto una como otra persiguen la misma meta; el pensamiento científico no es más que una forma más perfeccionada del pensamiento religioso. Parece, pues, natural que el segundo se difumine progresivamente ante el primero, a medida que este se hace más apto para
} 
Este es el conflicto básico entre ciencia y religión, pero la religión es ciencia metafísica y la ciencia es pensamiento religioso. Con lo cual, a veces no se ha entendido el conflicto entre ambas o porque se ha malinterpretado o porque no se ha llegado a analizar en toda su profundidad. ${ }^{1620}$

Solo hay un campo de conflicto entre ciencia y religión para Durkheim. La ciencia actual no puede aceptar el dogmatismo que la religión asumió en el pasado en relación al conocimiento del hombre y el mundo. La ciencia no niega a la religión su campo propio, sino que, con la caída de los viejos dioses, la religión está llamada a transformarse, a recrearse, a asumir nuevos ámbitos de compromiso moral y expresarlos en un lenguaje que complemente o sugiera nuevos aspectos de la realidad. En la religión hay algo eterno, afirma Durkheim, y por eso no podrá desaparecer; sí, transformarse. ${ }^{1621}$ En este sentido, Taylor afirma que la ciencia determina el alcance de la creencia: ya no se puede creer de una determinada manera. La religión o espiritualidad comporta sustituir las explicaciones erróneas y míticas basadas en "demonios y espíritus" y asumir una fe adulta y valiente. ${ }^{1622}$

Para Durkheim, los viejos dioses han muerto, pero todavía no han surgido otros nuevos. Con el advenimiento de la Modernidad, todo se ha reconfigurado, pero el hombre no puede vivir sin esa configuración social que crea la religión y que es el centro de la vida social, que sigue reactualizándose, según el razonamiento de Taylor, en formas espirituales de efervescencia colectiva. ${ }^{1623}$ Por eso, aunque la secularización se haya expresado en caída de los dioses antiguos, otros surgirán porque no podríamos sobrevivir social y culturalmente sin ellos. Por eso Durkheim expresa "una teoría de la secularización de alcance intermedio", según la cual, de tiempo en tiempo, el hombre necesita revivir la experiencia religiosa y conservar su recuerdo como guía a la humanidad. Es una teoría que confronta abiertamente con las teorías de Comte o Weber y que, según nuestro punto de vista, es muy ilustrativa y aporta visiones que completan

llevar a cabo esa tarea. DURKHEIM, E., Las formas elementales, pág. 399.

1620 “Además, en tanto que la religión es acción, en tanto que es un medio para hacer que los hombres vivan, la ciencia no puede sustituirla, pues si bien expresa la vida, no la crea; puede, sin duda, intentar dar una explicación de la fe, pero, por esa misma razón, la da por supuesta”. Ibid., pág. 400. Cfr. TAYLOR, Ch., Hegel, pág. 471.

1621 "Lo que la ciencia critica a la religión no es su derecho a existir, sino el derecho a dogmatizar sobre la naturaleza de las cosas, la especie de competencia especial que se atribuía en relación al conocimiento del hombre y del mundo. De hecho, ni siquiera se conoce a sí misma. No sabe de qué está hecha ni a qué necesidades responde. Ella misma es objeto de ciencia”. Id., pág. 400. Debido al carácter fragmentario de la ciencia, provisional y siempre inacabado, la religión marca la pauta de la ciencia y tiene el deber de "ir por delante" y "completar".

1622 Cfr. TAYLOR, Ch., La Era Secular, tII, págs. 416-418.

${ }^{1623}$ Cfr. Ibid., pág. 292. "Al mismo tiempo también se aprecian el carácter colectivo que Durkheim consideraba esencial de lo religioso (frente al individualismo utilitarista de la magia), así como la naturaleza sistémica del repertorio cultural de lo religioso, que incluye creencias y prácticas de forma integrada, no como en Taylor o en Robertson-Smith". CORNEJO VALLE, M., "Las definiciones de lo religioso en la antropología social. conceptos y discusiones clave en la búsqueda de un universal cultural”, Bandue, Vol. IX, (2016), pág. 73. 
las anteriores. ${ }^{1624}$ Taylor, en cierto sentido, piensa lo mismo cuando afirma que es un error identificar secularización y desencantamiento. ${ }^{1625}$

Cada civilización tiene, según Durkheim, su sistema de conceptos característicos y la representación colectiva de lo religioso, nunca se agota en una determinada configuración. De ahí que nuevas formas surjan constantemente, dado que pensar conceptualmente no es simplemente ver la realidad por su aspecto más general, es proyectar sobre las sensaciones una luz que las aclara, penetra y transforma. Concebir una cosa es, a la vez que aprehender mejor sus elementos esenciales, situarla en un conjunto, dado que la experiencia religiosa se fundamenta "en lo que somos" no en "lo que soy". 1626

La teoría de Durkheim pone las bases del pensamiento colectivo, de la teoría del concepto sobre la base de un oscuro sentimiento primigenio en la historia de la humanidad, que garantiza que esto pertenece a la esencia del ser humano y que difícilmente puede desaparecer. Los filósofos griegos, especialmente Platón, expresaron magníficamente esta idea en formulaciones filosóficas, algo que existía con anterioridad como un oscuro sentimiento de lo primigenio, eludiéndolo, no creándolo. ${ }^{1627}$ Con la ruptura del mecanicismo científico se pierde la comprensión del medio que nos envuelve y el sentido de la realización de nuestros propósitos, con lo que, en términos de pérdidas y ganancias, para Taylor, la revolución científica nos puede parecer como motivada de un modo no del todo racional, puesto que nos aleja de nuestra capacidad para descubrir nuestro verdadero lugar en el cosmos y de estar en armonía con él. ${ }^{1628}$ En este sentido, Taylor afirma que la atracción irresistible hacia el nuevo orden moral de la increencia fue un cambio doloroso y caracterizado por el lamento y la nostalgia. ${ }^{1629} \mathrm{Y}$ por otra parte, la lucha por la creencia nunca se ha ganado definitivamente, dado el estado de inestabilidad propio de una "mente desheredada". ${ }^{1630}$

Durkheim afirma que el ámbito social no puede asumir la incoherencia y el desorden, ni la indiferencia intelectual. La conciencia colectiva es la forma psíquica más elevada y por eso ve más alto y más lejos y solo ella pueda proporcionar al espíritu la comprensión del ser y del pensamiento, las cosas en su aspecto permanente y esencial. ${ }^{1631}$ En este sentido Jung habla de ese arquetipo colectivo de lo religioso que

\footnotetext{
${ }^{1624}$ Cfr. DURKHEIM, E., Las formas elementales, pág. 398.

1625 Cfr. TAYLOR, Ch., La Era Secular, tII, pág. 202.

${ }^{1626}$ Cfr. DURKHEIM, E., Las formas elementales, pág. 404.

${ }^{1627}$ Cfr. Ibid., pág. 405. Cfr. MUGICA MARTINENA, F., "Emile Durkheim. El principio sagrado", Cuadernos de Anuario Filosófico, No 18, (2006), pág. 44.

${ }^{1628}$ Cfr. TAYLOR, Ch., Argumentos filosóficos, pág. 73.

${ }^{1629}$ Cfr. TAYLOR, Ch., La Era Secular, tII, pág. 421.

${ }^{1630}$ Cfr. Ibid., pág. 466.

${ }^{1631}$ Cfr. DURKHEIM, E., Las formas elementales, págs. 411-412.
} 
fundamenta moralmente la humanidad. Taylor, en este mismo sentido, considera que incluso para la mayoría de los ateos siempre habrá cierto grado de irracionalidad. ${ }^{1632}$

Para Taylor, lo que vuelve la creencia problemática no es simplemente la ciencia. Se trata más bien del relato oficial que pretende construir una nueva identidad moral en lugar de llevar a cabo un mero registro de la realidad observable. ${ }^{1633}$ Por otra parte, según nuestro autor, la explicación institucional del ocaso de la religión se ve asentada por el trasfondo de la explicación cientifista. ${ }^{1634}$

II.- Otro de los autores que estudia Taylor es Max Weber, a quien considera un gran analista de la Modernidad y sobre todo en su análisis de la secularización. ${ }^{1635}$

Para Max Weber, en el ámbito de la cultura y de la sociedad de los siglos XVII y XVIII se abre camino un espíritu que considera que el tiempo es dinero y que el dinero es fecundo y provechoso. Es decir, se promueve el trabajo y se intenta ir en contra de la ociosidad. Un tiempo malgastado o no aprovechado es un tiempo en el que no se ha promovido la riqueza. Se tiene la conciencia de que la ociosidad no promueve la riqueza. Además, el gasto superfluo es un derroche, porque es lo que no se tiene, con lo que se invita a anotar minuciosamente los gastos y los ingresos, a llevar cuenta de lo que se realiza, de lo que deja de ganarse y de lo que ya no se tiene porque se ha gastado. Unos gastos que en ocasiones son pequeñas sumas, pero que pueden ser importantes, porque es lo que ya no se tiene o no se administró bien. Es el surgimiento de la economía política de Adam Smith en la modernidad, con el sistema autorregulador y la economía moderna como expresión del orden providencial de la naturaleza. ${ }^{1636}$

Tanto el tiempo como el dinero son analizados al detalle porque lo que no se promueve en el beneficio es lo que se pierde o se deja de disfrutar. Este es el "ethos del capitalismo moderno", un capitalismo que, como afirma Weber, ha existido siempre, pero sin ese ethos que se introduce en la Modernidad. ${ }^{1637}$ Taylor considera, en este sentido, que se ha ingresado de lleno en el reino de las cosas, en la soberanía de la servidumbre. El hombre se aleja de sí mismo y de alguna manera se introduce en la jaula de hierro weberiana que le conduce al encarcelamiento en lo banal. ${ }^{1638}$

Para Max Weber, el espíritu del capitalismo ha tenido que luchar denodadamente contra el tradicionalismo por naturaleza, un tradicionalismo que no promovía la riqueza ni el beneficio, sino que se conformaba con la mera subsistencia. Esta es la mentalidad

\footnotetext{
${ }^{1632}$ Cfr. TAYLOR, Ch., La Era Secular, tII, pág. 733.

${ }^{1633}$ Cfr. Ibid., pág. 423.

${ }^{1634}$ Cfr. TAYLOR, Ch., Fuentes del yo, pág. 550.

1635 Cfr. TAYLOR, Ch., La ética de la autenticidad, pág. 125 y ss.

${ }^{1636}$ Cfr. TAYLOR, Ch., Fuentes del yo, pág. 394.

${ }^{1637}$ Cfr. Ibid., pág. 308.

${ }^{1638}$ Cfr. TAYLOR, Ch., La Era Secular, tII, págs. 571,658.
} 
medieval precapitalista que no arriesga ni tiene el impulso de la ganancia. No importaba ganar menos con tal de no trabajar más; tampoco se tenía en cuenta lo que se podría ganar diariamente si se rendía al máximo. ${ }^{1639}$ Se limita a ganar lo necesario para los gastos. Frente a esta mentalidad tradicionalista que no promueve el espíritu emprendedor, Weber habla del espíritu religioso como contrapeso a esta mentalidad tradicional y que permite impulsar y romper con el sentido precapitalista. ${ }^{1640}$ Weber define el espíritu religioso como la unión entre una potencialidad de concentración de la mente y el sincero propósito de cumplir con la obligación del trabajo, que lleva a experimentar la firmeza en el propio dominio. ${ }^{1641}$

Frente al sistema de organización precapitalista caracterizado por el espíritu tradicionalista, el capitalismo incide en un sistema de racionalización bajo la premisa el que no asciende, desciende. ${ }^{1642}$ Lo que realmente importa son esas cualidades éticas que permitieron forjar ese espíritu del capitalismo; unas virtudes éticas que han forjado un nuevo tipo de empresario que afronta su tarea con un sentido distinto, hombres forjados en la ruda escuela de la vida, precavidos y audaces a un mismo tiempo, mesurados y constantes, con plena y devota entrega a lo propio, con ideas y "principios" estrictamente burgueses. ${ }^{1643}$ Taylor comparte esta teoría en sus principios fundamentales.

\footnotetext{
${ }^{1639}$ Cfr. WEBER, M., La ética protestante y el espíritu del capitalismo, Premiá Editora de Libros, Puebla, 1991, pág. 29.

${ }^{1640}$ Cfr. WEBER, M., Sociología de la Religión, La Pleyade, Buenos Aires, 1978, págs. 109 y ss.

${ }^{1641}$ Cfr. WEBER, M., La ética protestante y el espíritu del capitalismo, pág. 31.

${ }^{1642}$ Este "espíritu tradicionalista" vendría a corresponder, salvadas las diferencias, con la segunda etapa del desarrollo de la humanidad según Comte, la así llamada intermedia o metafísica. Un estado intermedio que para Comte se prolonga durante cinco siglos. Es un proceso gradual, intermedio y transitorio entre el estado teológico y el estado positivo, aunque, según Comte, este estado está más próximo al teológico que al positivo. El razonamiento metafísico, la ontología, supera la imaginación de los seres trascendentes del primer estadio, pero todavía está lejos de la verdadera ciencia positiva, aunque la reflexión filosófica posibilitará el acceso a la observación científica. Se trata de un estadio "oscilante" entre la teología y la ciencia de la naturaleza. Para Comte este estadio es una "enfermedad crónica" propia de la evolución mental entre la infancia y la virilidad. Es como un proceso que marca el paso de un momento a otro, tiene un carácter de liminalidad, de puerta, de posibilidad de acceso, con lo que esto implica de "riesgo" a la vez que de "impulso" para otra etapa. "De esta manera, durante los cinco últimos siglos el espíritu metafísico ha secundado negativamente el desarrollo fundamental de nuestra filosofía moderna, descomponiendo poco a poco el sistema teológico que había terminado por convertirse en retrógrado desde que a finales de la Edad Media quedó esencialmente agotada la eficacia social del régimen monoteísta". COMTE, A., Discurso sobre el Espíritu Positivo, Biblioteca Nueva, Madrid, 1999, pág. 76.

${ }^{1643}$ Cfr. TAYLOR, Ch., La Era Secular, tI, págs. 287,296; cfr. WEBER, M., La ética protestante y el espíritu del capitalismo, pág. 35. Pero este espíritu de racionalización puritano está en relación con la racionalidad impresa también en la vida monástica medieval, que impone su propio ejercicio de control, así como en los exercitia de San Ignacio. Todo va encaminado en la misma dirección, aunque el alcance de la racionalidad expresada en el compromiso ético de la profesión en el capitalismo adquiere sus propios matices de elevación espiritual. Comte lo expresa en estos términos cuando habla de la tercera etapa de la evolución humana como la etapa del espíritu positivo, de la racionalidad y de las ciencias de la naturaleza. "En una palabra, la revolución fundamental que caracteriza la edad madura de nuestra inteligencia consiste esencialmente en sustituir en todo, la inaccesible determinación de las causas propiamente dichas, por la simple averiguación de las leyes, o sea de las relaciones constantes que existen
} 
El ejemplo del cambio de paradigma lo pone Weber en la diferencia entre la actividad capitalista del siglo XIV y XV en Florencia, que se consideraba como tolerable desde un punto de vista ético, y la actividad económica de Pensilvania en el siglo XIX, en la que la actividad económica era vista como algo digno de alabanza desde un punto de vista ético y exigible. Esta es la nueva profesión de empresario que es aceptada y asumida como propuesta ética para todos en la convivencia sociopolítica del siglo XIX. ${ }^{1644}$

Frente al ascetismo monacal que menospreciaba los dones de Dios, se va abriendo, como afirma Weber, el ascetismo intramundano, según el cual, por una parte, hay que amar las cosas de este mundo, pero, por otra parte, detestarlas para devolver a Dios la gloria que se le debe. ${ }^{1645}$ El ascetismo medieval representaba no solo una desviación de los planes de Dios, sino también el orgullo de la presunción en la propia regeneración. Lutero va a romper con ese ascetismo y Calvino le va a dar un alcance definitivo a partir del compromiso ascético del calvinista con el mundo, y así hacer de cada cristiano un monje en el mundo, rompiendo las vallas de la separación. ${ }^{1646}$ Esta valoración ética de la actividad profesional es una de las grandes aportaciones de la Reforma, que posibilita nuevos enraizamientos morales y un cambio de paradigma en la comprensión de un "nuevo espíritu" que se va abriendo camino entre los avatares propios de la vida humana y en los que el Cristianismo ha contribuido de manera fehaciente. La jaula de hierro ha quedado vacía. Y Weber, con reminiscencias durkheimianas, habla de temporalidad o de duda en si la jaula permanecerá así siempre o si se llenará de nuevo de espíritu. ${ }^{1647}$

Según Weber, se pasa de una moral ascética medieval, a una moral del capitalismo responsable; de una sociedad monacal, a una sociedad de ciudadanos que promueven la riqueza y el beneficio mutualista. Pero este paso, que se inicia con un espíritu religioso del puritano que, movido por la fe, descubre el alcance de ser un buen profesional, va

entre los fenómenos observados". COMTE, A., Discurso sobre el Espíritu Positivo, pág. 77.

1644 "Pero, al paso que se fue afianzando en la idea de la sola fides, con todos sus resultados, y que la oposición a los 'consejos evangélicos' del catolicismo monacal, 'dictados por el diablo', fue acrecentándose, la idea de 'profesión' fijó con más precisión su fisonomía e hizo valer totalmente su significado”. WEBER, M., La ética protestante y el espíritu del capitalismo, pág. 47.

1645 Cfr. TAYLOR, Ch., Fuentes del yo, pág. 394.

1646 "De este modo, se levantaron vallas para impedir la fuga ascética del mundo; desde entonces, los temperamentos más firmes y apasionadamente íntimos, que siempre hubieron dado a la institución monacal sus más relevantes figuras, se vieron precisados a realizar con el trabajo profesional, sus aspiraciones ascéticas en el mundo. Sin embargo, el calvinismo aportó algo más efectivo en el curso de su desarrollo: la idea de que es menester verificar la fe en la vida profesional". WEBER, M., La ética protestante y el espíritu del capitalismo, pág. 81.

1647 "El espíritu se esfumó; el cofre permanece vacío sin que pueda saberse si para siempre. Como quiera que sea, el capitalismo triunfante, siendo que se apoya en bases mecánicas, ya no requiere más de la ayuda religiosa misma, es de suponer que se ha extinguido para siempre la rosácea mentalidad de la jubilosa sucesora del puritanismo, la ‘ilustración' después de todo, solo queda el recuerdo de la obligación profesional como una quimera de remotas ideas piadosas". WEBER, M., La ética protestante y el espíritu del capitalismo, pág. 135. 
adoptando cada vez más bases mecánicas en las que ya no se requiere más la ayuda religiosa. Con el tiempo, solo quedará el recuerdo de la obligación profesional sin la referencia a las ideas piadosas que lo motivaron. ${ }^{1648}$

También Taylor, aunque matiza dicha afirmación, considera con Weber, que con el advenimiento de la Modernidad llega el desencantamiento del mundo. ${ }^{1649}$ Un encanto que ha desaparecido de la vida pública y que se ha refugiado en la espiritualidad propia del corazón místico o en un mundo de fraternidad sostenido por relaciones personales. ${ }^{1650}$ Es el surgimiento del estado moderno que se irá configurando como representación de la racionalidad y como gran monopolio de poder y fuerza física, ${ }^{1651} \mathrm{y}$ en un mundo como ámbito neutro de potenciales medios para nuestros propósitos. ${ }^{1652}$

Taylor considera, en general, la falta de honestidad intelectual hacia los creyentes, desde Weber hasta el día de hoy. Es muy consciente de la necesidad de reconstruir la narración de la secularidad moderna, debido a que la imagen vigorosa de las estructuras del mundo cerrado es el relato que se ha impuesto y que nos impide ver aspectos importantes de la realidad o nos lleva a realizar análisis precipitados o superficiales. ${ }^{1653}$ Para Taylor, lo realmente relevante es que el desencantamiento no conduce a la secularización necesariamente o al establecimiento del humanismo exclusivo, sino que lo que se produjo fue un desplazamiento de la vida religiosa. ${ }^{1654}$ De ahí la importancia que tiene para Taylor reconstruir el relato de la secularidad moderna.

III.- Otro de los grandes representantes de las teorías secularizadoras es Peter Berger, quien analiza la modernidad y la secularización. El primer Berger entiende por secularización "el proceso por el cual se suprime el dominio de las instituciones y los símbolos religiosos de la sociedad y de la cultura", ${ }^{1655}$ produciéndose al mismo tiempo un proceso de secularización subjetiva de la conciencia que contempla el mundo al

\footnotetext{
${ }^{1648}$ El nuevo espíritu es el espíritu positivo del que habla Comte como la etapa de la ciencia positiva que debe escapar tanto del misticismo teológico como del mero empirismo. El positivismo comtiano debe huir de la mera observación mecánica de hechos que no consigna una relación entre los mismos y no sea capaz de deducir leyes y principios generales que expresen la interrelación entre los mismos. "Así, el verdadero espíritu positivo consiste, ante todo, en ver para prever, en estudiar lo que es, a fin de concluir de ello lo que será, según el dogma general de la invariabilidad de las leyes naturales". COMTE, A., Discurso sobre el Espíritu positivo, pág. 80.

${ }^{1649}$ Cfr. TAYLOR, Ch., La Era Secular tII, págs. 235,398; cfr. TAYLOR, Ch., Hegel, págs. 7, 345; cfr. TAYLOR, Ch., Fuentes del yo, págs. 210,258,265.

1650 "El destino de nuestra época se halla caracterizado por una racionalización o intelectualización y, sobre todo, por el desencantamiento del mundo, de modo que los valores más sublimes se han retirado de la vida pública para refugiarse en el reino trascendente de la vida mística o en la fraternidad de relaciones humanas directas y personales". WEBER, M., Ensayos de sociología contemporánea, Barcelona, Ediciones Martínez Roca, 1972, pág. 190.

${ }^{1651}$ Cfr. TAYLOR, Ch., Argumentos filosóficos, pág. 270.

${ }^{1652}$ Cfr. TAYLOR, Ch., Fuentes del yo, pág. 676.

${ }^{1653}$ Cfr. TAYLOR, Ch., La Era Secular, tII, pág. 400.

${ }^{1654}$ Cfr. Ibid., pág. 404.

${ }^{1655}$ BERGER, P., El dosel sagrado, Amorrortu Editores, Buenos Aires, 1969, pág.134.
} 
margen de explicaciones religiosas. Se trata de una definición que comparte en buena medida los tres sentidos de la secularización de Taylor. ${ }^{1656}$

En sus primeras etapas como sociólogo piensa que las raíces de la secularización se encuentran ya en la teología del pueblo de Israel, considerando que el desencantamiento del mundo se origina en el Antiguo Testamento, especialmente en la ética de los profetas. ${ }^{1657}$ Profundizando en esta idea, Taylor, junto con otros autores como M. Weber y M. Gauchet, afirma que tanto el judaísmo como el Cristianismo han alimentado, cada uno en diferentes momentos, diversos tipos de desencantamiento. ${ }^{1658}$

Para Berger, como para Weber y Comte, la secularización no tiene eficacia causal propia, sino que está en relación con procesos filosóficos y culturales. ${ }^{1659}$ Berger realiza su primer estudio de la secularización como una especie de síntesis entre Weber y Comte. ${ }^{1660}$ Por una parte, hay una variable dependiente de la religión en relación a lo que ha surgido dentro de ella y que ha motivado procesos de secularización (Weber y el nuevo espíritu de la Reforma en su valoración ética del orden y la actividad profesional); $\mathrm{y}$, por otra parte, hay determinadas infraestructuras que han surgido dentro de la propia tradición religiosa de occidente que han motivado procesos secularizadores como variables independientes y que han supuesto un revulsivo procesual para ir desencadenando progresivos procesos secularizadores (Comte y el espíritu positivo que se abre camino una vez superada la etapa metafísica medieval). ${ }^{1661}$

Así como Berger no confirma la idea de que el Protestantismo haya sido decisivo para el establecimiento del mundo moderno con el desarrollo del espíritu del capitalismo, lo que sí afirma, matizando el relato weberiano, es que el origen de la secularización está en el ámbito económico. ${ }^{1662}$ Para Berger, desde ese territorio

${ }_{1657}^{1656}$ Cfr. TAYLOR, Ch., La Era Secular, tI, págs. 21-23.

1657 "Puede decirse que la trascendentalización de Dios y el concomitante 'desencantamiento del mundo' abrieron un 'es-pacio' para la historia como escenario de las acciones divinas y humanas. Las primeras son ejecutadas por Dios, que permanece totalmente fuera del mundo. Las segundas suponen una considerable individualización en la concepción del hombre. Este aparece como el actor histórico ante el rostro de Dios (algo muy diferente, digamos al pasar, del hombre como actor frente al destino, tal cual se presenta en la tragedia griega)". BERGER, P., El dosel sagrado, pág., 148.

${ }^{1658}$ Cfr. TAYLOR, Ch., La Era Secular, tII, pág. 202.

${ }^{1659}$ Cfr. BERGER-LUCKMANN, Modernidad, Pluralismo y crisis de sentido, Paidós, Barcelona, 2008, págs. 72 y ss.

${ }_{1660}$ Cfr. BERGER, P., Para una Teoría sociológica de la Religión, Kairós, Barcelona, 1971, 258 págs.

${ }^{1661}$ Según el primer Berger han sido muchas las razones que se han dado hasta llegar aquí, unas más filosóficas: "Así puede interpretarse el mundo moderno como una realización superior del espíritu cristiano (como lo interpretó Hegel), o el cristianismo puede ser contemplado como el principal factor patógeno responsable del estado presuntamente lamentable del mundo moderno (como hicieron, por ejemplo, Schopenhauer y Nietzsche)”. BERGER, P., El dosel sagrado, pág. 139. Y otras más religiosas,

"La idea de que el protestantismo ha desempeñado un papel especial en el establecimiento del mundo moderno ha sido objeto de una amplia discusión entre sociólogos e historiadores durante los últimos cincuenta años, más o menos". Ibid., págs. 139,141-143.

1662 'La 'localización' original de la secularización, como hemos indicado, se produjo en el ámbito económico, más específicamente, en aquellos sectores de la economía formados por los procesos capitalista e industrial. Por consiguiente, los diferentes estratos de la sociedad moderna han sido influidos 
liberado se va a ir expandiendo progresivamente a toda la sociedad la secularización y, a partir de ahí, una independencia progresiva de los estados de cualquier influencia de ideología religiosa o de instituciones religiosas, en la así llamada separación IglesiaEstado. ${ }^{1663}$ Un estado emancipado, autónomo, sin tutelas de ningún tipo, más que las establecidas para el correcto funcionamiento del bien común. Un estado que no es correa de transmisión de ninguna ideología religiosa ni se deja manipular por ninguna Iglesia, como también afirmará Taylor. ${ }^{1664}$

Para Berger, todo esto implica que no hay vuelta atrás, pues los procesos de racionalización de la modernidad son irreversibles. No hay nada de misterioso en el recorrido realizado hasta aquí. Todo se ubica en los espacios liberados de la racionalidad económica y todo se va configurando de una manera distinta. Una vez iniciado el proceso, afirma Berger, todo se autoperpetúa y se autoagranda. Es irreversible y tiende cada vez más a la expansión y al acrecentamiento. Es la potencia secularizadora de la racionalización industrial capitalista como motor que, según Berger, lo cambia todo y lo seculariza, iniciando procesos irreversibles hacia una nueva configuración moral del mundo. Todos los controles tradicionales quedan desconfigurados y apenas ejercen control sobre la vida social y política. Taylor piensa exactamente lo mismo al afirmar que el proceso de industrialización del siglo XIX contribuyó a que la sociedad se sintiera profundamente desorientada e incapaz de vivir su religión tradicional. ${ }^{1665}$ Taylor considera que la economía, con su propia racionalidad intrínseca, conforma un nuevo imaginario cósmico. ${ }^{1666}$

Según Berger, se pasa a una impermeabilización secularizadora desde la economía al Estado, lo cual les hace inmunes a cualquier influencia de la esfera religiosa, quedando reducida la influencia del control tradicional de índole religioso al ámbito de la familia y a las relaciones personales y culturales vinculadas a ella. La religión pasa a adquirir caracteres de individualización y privatización, al margen de cualquier coerción social. ${ }^{1667}$ Como ya hemos estudiado, Taylor refiere dicho individualismo a la ética de la

por la secularización en forma diferente, según su impermeabilidad o su distancia con respecto a tales procesos. En la proximidad inmediata de estos mismos procesos, surgieron estratos muy secularizados". Ibid., pág. 159.

1663 'Siguiendo la tradición weberiana, Berger afirmaba que el 'portador' de la secularización en la civilización occidental 'es el proceso económico moderno, esto es la dinámica del capitalismo industrial' y la expansión de esta economía en otras partes del mundo, incluidas las de organización socialista, era la determinante principal de la secularización fuera del ámbito occidental". BLANCARTE, R., "Religión y sociología. Cuatro décadas alrededor del concepto de 'secularización””, Estudios Sociológicos, Vol. XXX, (2012), pág. 63.

${ }^{1664}$ Cfr. TAYLOR, Ch., El multiculturalismo y la política del reconocimiento, págs. 23-25.

1665 Cfr. TAYLOR, Ch., La Era Secular, tII, pág. 118.

1666 Cfr. Ibid., pág. 201.

1667 "Esto significa que la religión privada es un asunto de elección o preferencia por parte del individuo o el núcleo familiar, lo cual hace de inmediato que carezca de la cualidad de lo común y unificador. Tal religiosidad privada, por real que parezca al individuo que lo adopta, ya no puede llenar la función clásica de la religión, la de construir un mundo común dentro del cual toda la vida social recibe un significado supremo que una a todo”. BERGER, P., El dosel sagrado, pág. 164. 
autenticidad surgida a finales del siglo XVIII y sustentada sobre la racionalidad autorresponsable cartesiana. ${ }^{1668}$

No es de extrañar que la familia, configurada así por los valores tradicionales de la religión, sea una estructura excesivamente endeble a la hora de fundamentar la vida moral de las personas o con una capacidad de permanencia sujeta a toda clase de vaivenes culturales, económico-políticos y personales, debido a la pérdida del carácter vinculador común de la religión y al mismo tiempo a la influencia del politeísmo de valores inscrito en la sociedad moderna. La religión ya no representa, según Berger, el mundo de la sociedad y de las personas. Hay una ruptura de ese sentido de pertenencia social en el que se identificaba el mundo personal y el mundo social configurado por las instituciones religiosas. El estar al margen de las instituciones religiosas ya no significa estar al margen de la vida social, dado que se ha producido una ruptura en el sentido de pertenencia única al mundo en el que todo estaba identificado a partir de las valoraciones morales de la religión. En esta misma línea, la opinión de Taylor es que, salir del mundo definido por la religión ya no es caer en el caos, sino que la potencia secularizadora de la economía y la política es la que impone un sentido de pertenencia cultural, que es inmune a cualquier influencia de la religión. La Iglesia y el imperio rompen cualquier tipo de relación y las relaciones se establecen en el ámbito cultural de la economía y la política, quedando al margen de cualquier influencia de valores tradicionales de índole religioso. ${ }^{1669}$

La influencia de lo religioso se limita al ámbito de las necesidades psicológicas del individuo o a los ámbitos propios de la familia y el vecindario, dada la creciente privatización de la experiencia religiosa. Por eso, la gran mayoría de los otros ya no se dejan configurar por la religión y al mismo tiempo es cada vez más difícil promover entre todos los demás los valores propios del mundo de la religión. En esta situación, para Taylor, es lógico el descenso evidente del número de creyentes y el aumento de aquellos que se declaran ateos, agnósticos o declaran no tener religión. ${ }^{1670}$

Un segundo Berger matiza su propia teoría y habla de una secularización de la conciencia y de un nomos religioso postsecular. Si en sus obras anteriores, especialmente en El dosel sagrado, había relacionado la secularización con la industrialización y la filosofía de la modernidad, a partir de entonces, con el resurgimiento de la religión en distintas partes del mundo y a partir de las aportaciones de Casanova y otros filósofos relevantes (que afirman que la teoría de la secularización no estaba en relación con la privatización de la religión como se afirmaba hasta

\footnotetext{
${ }^{1668}$ Cfr. TAYLOR, Ch., La ética de la autenticidad, pág. 61; cfr. TAYLOR, Ch., La Era Secular, tII, págs. 14, 294.

${ }^{1669}$ Cfr. TAYLOR, Ch., La Era Secular, tI, pág. 339; cfr. TAYLOR, Ch., El multiculturalismo y la política del reconocimiento, págs. 23-25.

${ }^{1670}$ Cfr. TAYLOR, Ch., La Era Secular, tII, pág. 342.
} 
entonces), Berger se implica en el proyecto de la deconstrucción de la secularización a partir de lo que él denomina el nomos religioso postsecular. Berger será de los que reivindiquen la necesidad de un nuevo paradigma basado en el pluralismo y en la coexistencia entre el discurso secular y religioso, ${ }^{1671}$ tal y como por otra parte también reivindicará Habermas. ${ }^{1672}$ Taylor, en esta misma línea, advierte de lo peligroso y aventurado que es un cierre prematuro, al propio tiempo que afirma que conferir plausibilidad a la tesis de la secularización remitirá antes o después. ${ }^{1673}$

Berger piensa que, en esa reformulación que realiza de la teoría de la secularización, la secularización no puede ser un referente a escala global y sostiene que la secularización y la privatización de lo religioso son fenómenos globales que se expresan junto a la globalización de la modernización occidental, lo cual no implica el abandono de las religiones. ${ }^{1674}$ Berger afirma que la secularización, tal y como se ha comprendido hasta entonces, se circunscribe a Europa, no así en Estados Unidos ni en otras zonas del mundo. Por eso prefiere hablar de "eurosecularidad", porque para Berger modernidad y secularidad no son fenómenos inseparables. Eso no significa que no haya secularización, pero el alcance de los matices que dicha teoría asume en la actualidad requiere puntualizaciones dignas de un nuevo planteamiento general. Para Taylor, Berger entiende la UE como una agencia de secularización. ${ }^{1675}$

Para Berger es un fenómeno importante, pero limitado y debe ser analizado en su justa medida. La secularización no es ya el paradigma de lo religioso en el mundo actual. La secularización es una situación más entre otras muchas que expresan la gran variedad de situaciones de la religión en el mundo de hoy en sus diferentes cosmovisiones culturales. ${ }^{1676}$

Es más, para Berger la posmodernidad no es la era de la secularización, sino todo lo contrario: estamos en una época de religiosidad exuberante, con un alcance global de movimientos religiosos que proliferan por todo el mundo produciéndose también una globalización religiosa. Para Berger la mayor parte del mundo es hoy tan religioso como lo fue siempre, aunque con dos excepciones: Europa Occidental y Central (excepción geográfica) y las élites culturales de carácter transnacional formadas en humanidades y ciencias sociales (excepción sociológica). ${ }^{1677} \mathrm{Y}$ en este sentido, Berger opina que las dos

\footnotetext{
${ }^{1671}$ Cfr. TAYLOR, Ch., Imaginarios sociales modernos, pág. 215.

1672 Cfr. BERGER, P., Los numerosos altares de la Modernidad, Sígueme, Salamanca, 2016, págs. 9-16.

${ }^{1673}$ Cfr. TAYLOR, Ch., La Era Secular, tII, pág. 736.

${ }^{1674}$ SETTON, D., "Rupturas y continuidades en la sociología de la religión de Peter Berger", Sociedad y Religión, No 48, (2017), pág. 171.

1675 Cfr. TAYLOR, Ch., La Era Secular, tII, pág. 369.

${ }^{1676}$ Cfr. BERGER, P., Los numerosos altares de la Modernidad, págs. 97, 119, 169-171, 211, 216; cfr. TAYLOR, Ch., Argumentos filosóficos, págs. 324-328.

${ }^{1677}$ Cfr. BERGER, P., "Las religiones en la era de la globalización”, págs. 2-65.
} 
religiones con un mayor dinamismo globalizador en el mundo de hoy son el Protestantismo Evangélico y el Nuevo Islam.

El fenómeno del pluralismo, en Berger, no es novedoso en la historia de la humanidad. En distintos momentos históricos se ha dado el pluralismo entendido como convivencia entre cosmovisiones distintas: la India preislámica, el helenismo griego, la Edad Media cristiana en Europa. ${ }^{1678}$ No obstante, el pluralismo, en la actualidad, adquiere problemas políticos que hay que solventar, ya que frecuentemente nos movemos, según Berger, entre el fundamentalismo y el relativismo. ${ }^{1679}$ Un pluralismo religioso que también es afirmado con contundencia por Habermas cuando se refiere a la edad postsecular. ${ }^{1680}$ Para Taylor, ese pluralismo de la creencia religiosa se expresa en un variado campo de opciones que incluye diversas formas de objeción y rechazo. ${ }^{1681}$ Habermas está de acuerdo con Taylor en su afirmación de que ni siquiera la autocomprensión colectiva de una sociedad civil democrática puede salir incólume del momento religioso del pluralismo ideológico. ${ }^{1682}$

El pluralismo bergeriano, como alternativa a las teorías de la secularización, se expresa en términos de un individualismo en el que no existen valores comunes que determinen la acción en las distintas esferas de la vida, al propio tiempo que tampoco existe una realidad idéntica para todos. ${ }^{1683}$ Los sistemas globales de interpretación del mundo que identificaban a grandes masas de población se han ido diluyendo o debilitando y no son capaces de concitar las mayorías de otras épocas. De ahí que el individualismo subjetivista de la autenticidad responsable y la tolerancia sean dos características que se han ido asentando con el advenimiento de la Modernidad, tal y

\footnotetext{
${ }^{1678}$ Cfr. BERGER, P., Los numerosos altares de la Modernidad, págs. 22-24.

1679 "El problema político del pluralismo solo puede resolverse manteniendo y legitimando aquello que se extiende entre ambos extremos. Para la mayor parte de la humanidad, la religión determina cómo se contempla el mundo y cómo se debe vivir. A causa de ello, la relación entre religión y pluralismo debería resultar de interés a cualquiera, independientemente de sus propias creencias religiosas". Ibid., pág. 41.

1680 "La propia imagen occidental de la modernidad parece estar sometido a un efecto de desviación: de ser el modelo normal para el futuro del resto de todas las culturas, ha pasado a convertirse en un caso especial". Cfr. HABERMAS, J., Entre naturalismo y religión, Paidós, Barcelona, 2006, pág. 123. Habermas habla de que el entorno secularizador en que nos movemos no se adecúa a lo que significa una "etapa post-secular" que debe ser "respetuosa" con las comunidades religiosas. Nos parece muy importante esta apreciación porque por una parte Habermas habla de que "persiste la secularización" (entorno secularizador) pero que nos encontramos al mismo tiempo en una etapa post-secular, confiriendo a la palabra post-secular no solo un momento distinto y posterior al secular, sino también el significado de que el contexto es distinto y por lo tanto las religiones deben ubicarse de una manera correcta y "respetuosa" dentro del pluralismo creciente. ¿Podríamos sugerir que en Habermas la palabra "postsecular adquiere el significado de que pervive la secularidad en un entorno nuevo, post-secular o de carácter desecularizador? ¿Post-secular como pervivencia de la secularización en un entorno desecularizado por el nuevo protagonismo que adquieren las religiones?

${ }^{1681}$ Cfr. TAYLOR, Ch., La Era Secular, tII, pág. 221.

1682 Cfr. HABERMAS, J., Mundo de la vida, la política y la religión, pág. 216.

${ }^{1683}$ Cfr. BERGER, P. y LUCKMANN, T., Modernidad, Pluralismo y crisis de sentido, pág. 61.
} 
como afirma Taylor. ${ }^{1684}$ Casanova se expresa en parecidos términos cuando habla de la esfera individual en la que muchos siguen enraizando sus creencias religiosas. ${ }^{1685}$

En un mundo en el que todo el mundo habla con todo el mundo, como afirma Berger, también se produce lo que él denomina "una situación individualizadora". 1686 Una situación que, para autores como Berger y Luckmann, es un caldo de cultivo para las crisis subjetivas e intersubjetivas de sentido, dado que desde los pálidos valores supraordinales del pluralismo moderno, difícilmente se pueden contrarrestar las cosmovisiones generales. ${ }^{1687}$ Dichos valores supraordinales nos orientan en nuestras relaciones y nos hacen conscientes del pluralismo existente, pero difícilmente pueden aportar enraizamientos morales de sentido, ya que todo se determina por la subjetividad y la intersubjetividad, por las propias percepciones morales expresadas a veces ambigua y pálidamente. Charles Taylor comparte en buena medida estos planteamientos, al considerar que existe un pluralismo que no nos compromete con nada, pero que siempre está disponible para asumirlo dependiendo del momento moral en que se encuentre cada uno. ${ }^{1688}$

Sin embargo, cuando las identidades individuales son fraguadas a partir de comunidades de vida como grupos más estables, puros y de convicciones (dentro del pluralismo existente y del politeísmo de valores), dichas comunidades potencian las posibilidades de superar las crisis de sentido. Para Berger y Luckmann, no obstante, estas comunidades entendidas como islas de sentido, no pueden contrarrestar frecuentemente las precondiciones de la modernidad que orientan hacia una desorientación de sentido, ${ }^{1689}$ o si lo intentan, a veces es difícil superar la distancia entre los objetivos morales que promueven y la realidad a la que se enfrentan.

En las sociedades premodernas había una síntesis entre las percepciones del mundo, los dioses, la configuración social y el orden de valores existente. Todo estaba orientado hacia una percepción de sentido que se daba por hecho y que configuraba las

\footnotetext{
${ }^{1684}$ Cfr. TAYLOR, Ch., La ética de la autenticidad, págs. 91 y ss.

1685 "En cualquier caso, en toda Europa, desde la década de los sesenta, una parte cada vez mayor de la población ha dejado de participar en las prácticas religiosas tradicionales, al menos sobre una base regular, manteniendo al mismo tiempo niveles relativamente altos de creencias religiosas individuales privadas. En este sentido, deberíamos hablar tal vez de la deseclesiastización de la población europea y de la individualización religiosa, más que de secularización. Grace Davie $(1994,2000)$ ha caracterizado esta situación europea general como "creencia sin pertenencia". CASANOVA, José V., "La inmigración y el nuevo pluralismo religioso", Revista CIDOB 77, (2007), pág. 17.

1686 "El individuo se ve obligado a elegir, a tomar decisiones y perseverar en ellas. Es una tarea bastante complicada. Las fuentes tradicionales de apoyo social están bastante debilitadas o completamente ausentes: la familia, el parentesco más amplio, la comunidad aldeana, el clan, la tribu o la casta, la iglesia o la mezquita. De algún modo, los individuos se ven obligados a construir su propio programa personal para vivir". BERGER, P., Los numerosos altares de la modernidad, pág. 39.

${ }^{1687}$ Cfr. BERGER, P. y LUCKMANN, T., Modernidad, Pluralismo y crisis de sentido, pág. 62.

${ }^{1688}$ Cfr. TAYLOR, Ch., Argumentos filosóficos, pág. 244; cfr. TAYLOR, Ch., Imaginarios sociales modernos, pág. 218.

${ }^{1689}$ Cfr. TAYLOR, Ch., Hegel, págs. 476-477.
} 
identidades individuales. ${ }^{1690}$ Sin embargo, en las sociedades plurales, la metáfora del código de circulación es la que mejor puede ayudar a comprender el alcance de las normas que permiten el verde para todos o el rojo de las líneas rojas que no se pueden traspasar, o el naranja que posibilita las distintas oportunidades dependiendo de la situación de los demás. Aunque las normas estén establecidas para todos, según un código que todos deben respetar, sin embargo, en definitiva, cada individuo es el responsable de su propia actuación y cada uno decide por sí mismo de manera responsable a partir de un sistema de valores establecido y aceptado por todos. ${ }^{1691}$ Habermas confirma con parecidos términos esta misma reflexión. ${ }^{1692}$ Se habla así de la problematicidad de sentido, ${ }^{1693}$ que alcanza a las sociedades modernas europeas, transidas de pluralismo e individualismo. ${ }^{1694}$

Matizando algunos conceptos reseñados anteriormente, Berger habla de dos tipos de pluralismos: el pluralismo de las distintas opciones religiosas que conviven en una misma sociedad y el pluralismo del discurso secular y los distintos discursos religiosos que también coexisten. Desde el punto de vista de Berger, en el caso de los creyentes no se trata de una disyuntiva entre fe y secularidad (o bien... o bien...) sino una cópula (tanto... como...). Se trata de gestionar ambas visiones y articularlas individualmente. ${ }^{1695}$ Esta coexistencia de discursos, el secular y el religioso, no son excluyentes para la mayor parte de las personas. En el imaginario social, para Berger, la secularidad y la religión no son contradictorios entre sí. Son dos cosmovisiones distintas, dos formas de contemplar la realidad que pueden complementarse. Hay una minoría en el mundo que es completamente secular y otra minoría que es completamente religiosa. Para Berger, lo realmente relevante es cómo se gestiona la tensión a veces ineludible entre ambos discursos. Esta forma de pluralismo religioso, que necesita ser gestionada, da mucho juego y abre horizontes para la reflexión. Taylor

\footnotetext{
1690 “A causa de la modernización ha resultado más difícil, si no absolutamente imposible, imponer de un modo monopólico sistemas localizados de sentido y valores a sociedades completas. Al mismo tiempo, la modernización ha dado cabida a la formación de comunidades de convicción que trascienden el espacio (por ejemplo, mediante ideologías globales), y a partir de estas reservas de sentido podrán derivarse los sentidos compartidos de comunidades más pequeñas. A pesar de esta posibilidad, el desarrollo global genera sobre todo un alto grado de inseguridad, tanto en la orientación de las acciones individuales como de la vida entera". BERGER, P. y LUCKMANNT., Modernidad, pluralismo y crisis de sentido, pág. 66.

${ }^{1691}$ Cfr. TAYLOR, Ch., El multiculturalismo y la política del reconocimiento, pág. 26.

1692 "Basta con la capacidad epistémica de considerar reflexivamente las propias convicciones religiosas también desde fuera y de ponerlas en relación con las concepciones seculares". HABERMAS, J., La religión en la esfera pública, págs. 137 y ss.

1693 TAYLOR, Ch., La ética de la autenticidad, págs. 71-73.

1694 “El pluralismo moderno socava ese ‘conocimiento' dado por supuesto. El mundo, la sociedad, la vida y la identidad personal son cada vez más problematizados. Pueden ser objeto de múltiples interpretaciones y cada interpretación define sus propias perspectivas de acción posible. Ninguna interpretación, ninguna gama de posibles acciones puede ya ser aceptada como única, verdadera e incuestionablemente adecuada. Por tanto, a los individuos les asalta a menudo la duda de si acaso no deberían haber vivido su vida de una manera absolutamente distinta a como lo han hecho hasta ahora". BERGER, P. y LUCKMANN, T., Modernidad, Pluralismo y crisis de sentido, pág. 80.

1695 Cfr. BERGER, P., Los numerosos altares de la modernidad, pág. 107.
} 
afirma que se dan estructuras de simultaneidad y que, en este contexto postsecular, hay una gran variedad de opciones, aunque algunas son mejores que otras. ${ }^{1696}$ Habermas plantea con la palabra postsecular la pervivencia de planteamientos religiosos en las sociedades seculares o un creciente discurso religioso en medio de nuestras sociedades secularizadas y la necesidad de que ese pluralismo sea gestionado adecuadamente mediante la acción comunicativa. ${ }^{1697}$ Taylor utiliza este término postsecular, no tanto para designar una época en la que el declive de la creencia y la práctica religiosa parecen invertirse, sino más bien para referirse a una época en la que la hegemonía de los relatos de la secularización son puestos cada vez más en entredicho. ${ }^{1698}$

IV.- Una religión privatizada e incapaz de ser socialmente configurada fácilmente se convierte en una "religión invisible" tal y como afirma Luckmann. Para Thomas Luckmann, la religión tradicional de Iglesia está desconfigurada respecto a la sociedad contemporánea, ha quedado al margen, ha perdido su poder configurador de enraizamientos morales. El llamado proceso de secularización ha alterado decisivamente tanto la posición social de la religión de Iglesia, como su universo interior de significado. ${ }^{1699}$ Taylor afirma, en este mismo sentido, que vivimos en un mundo en el que la creencia ha perdido gran parte de las matrices sociales que la hacían parecer obvia e irrecusable. ${ }^{1700}$

Pero Luckmann invita a no precipitarse en los análisis que frecuentemente se hacen al respecto, criticando ciertos puntos de vista de Weber y Berger. Luckmann no comparte la premisa de la que se parte en ciertos análisis sociológicos, según la cual, Religión e Iglesia son prácticamente lo mismo. Y, por otra parte, también considera que es ingenuo afirmar que la industrialización, la racionalización urbana y la ciencia han minado por sí mismas los fundamentos de la religión. Estas premisas no hay que darlas por supuestas y además hay que plantearlas dentro de un sistema más global de consideración general.

Para Luckmann, es más consistente afirmar, de acuerdo con la teoría sociológica, que la industrialización y la racionalización urbana provocan cambios en las estructuras sociales. Una vez analizados estos cambios será posible explicar de manera más adecuada, dentro de dichos cambios, el papel decreciente que asumen las religiones tradicionales en las sociedades contemporáneas. Según este autor, una vez que las estructuras sociales se liberan de la influencia de los valores religiosos tradicionales, el cosmos religioso de los individuos también se libera de dicha influencia y queda

\footnotetext{
${ }^{1696}$ Cfr. TAYLOR, Ch., La Era Secular, tII, págs. 289,290.

${ }^{1697}$ Cfr. HABERMAS, J., Teoría de la Acción Comunicativa, Trotta, Madrid, 2010, págs. 489 y ss.

${ }^{1698}$ Cfr. TAYLOR, Ch., La Era Secular, tII, pág. 377.

${ }^{1699}$ Cfr. LUCKMANN, T., La religión invisible, Sígueme, Salamanca, 1973, pág. 47.

${ }^{1700}$ Cfr. TAYLOR, Ch., La Era Secular, tII, pág. 372.
} 
reducido a espacios de la vida familiar y privada de cada uno. ${ }^{1701}$ Viene a ser algo parecido a la "secularización subjetiva" de Berger, pero con matices. Taylor considera, en esta misma línea, que se trata ciertamente de la historia de una sustracción, pero que falta por comprender exactamente en qué consiste la secularización y las sustracciones que se han ido realizando en los procesos de construcciones de identidades nuevas. ${ }^{1702}$

Por otra parte, Luckmann afirma que hay un cosmos sagrado básico que fundamenta la configuración moral de la persona y una religión institucionalizada. En la sociedad del Medievo existía una coherencia o identidad completa entre el modelo oficial, el sistema individual de significaciones de sentido y los modelos individuales de prioridades. ${ }^{1703}$ En cambio, en las sociedades modernas todo entra en conflicto, especialmente cuando hay una separación entre mundo y religión, como afirma también Taylor. ${ }^{1704}$ Hay una situación objetiva de conflicto pudiendo producirse lo que Luckmann denomina una situación "martirial" (el adjetivo nos parece muy ilustrativo). ${ }^{1705}$ Para Taylor este conflicto es el existente entre los defensores de la subjetividad desvinculada, de la razón y libertad autorresponsables y los que protestan contra esta visión desecada y vacía. ${ }^{1706}$

Esta divergencia hace que el individuo, según Luckmann, ante el nuevo orden social moderno, reflexione y pueda adoptar distintas reacciones. Para Taylor, en este mismo sentido, con la Modernidad se abre una gran variedad de posibilidades en el mundo de la creencia. ${ }^{1707}$

1.- Puede producirse el "salto de la fe", es decir, que la persona después de asumir un proceso reflexivo adopte la fe como una decisión personal. No se trata de una simple asimilación ingenua de la fe, ya que implica al individuo en una toma de decisión personal en el que se ha producido, en alguna etapa del proceso, alguna

\footnotetext{
1701 "El decrecimiento de la religión de la iglesia tradicional debe verse como una consecuencia de la pérdida de la relevancia de los valores (institucionalizados en la religión orientada hacia la iglesia) que favorecían la integración y legitimación de la vida de cada día en la sociedad moderna". LUCKMANN, T., La religión invisible, pág. 49. Es decir que una vez que se pierde protagonismo en la influencia de los valores tradicionales de la Iglesia en las estructuras sociales la pérdida de influencia en el cosmos religioso de las personas es una consecuencia inmediata.

${ }_{1702}$ Cfr. TAYLOR, Ch., La Era Secular, tII, pág. 371.

${ }^{1703}$ Cfr. LUCKMANN, T., La religión invisible, pág. 91; cfr. Ibid., págs. 104 y ss.

${ }^{1704}$ Cfr. TAYLOR, Ch., Imaginarios sociales modernos, pág. 216. Taylor habla de la "emancipación de la política de su dependencia óntica de la religión" que invita a una total reconfiguración de las relaciones Iglesia-Estado e Iglesia-mundo.

1705 "Algunos individuos pueden continuar considerando a la letra los fines globales de las representaciones específicamente religiosas a pesar de las circunstancias que encontrábamos que debilitan la plausibilidad de estas pretensiones. Si ellos ingenuamente permanecen fieles a estas pretensiones el problema de la 'integración significante' se resuelve para ellos gracias a la eliminación. Es claro que esta solución conduce a dificultades 'objetivas' y en el caso extremo a una inhabilidad para resolver eficazmente los roles no religiosos y a cierta forma de martirio”. LUCKMANN, T., La religión invisible, pág. 97.

${ }_{1706}$ Cfr. TAYLOR, Ch., Fuentes del yo, pág. 694.

${ }^{1707}$ Cfr. TAYLOR, Ch., La Era Secular, tII, pág. 342.
} 
fase de duda. Y es esta duda la que ha llevado a la personalización y a adoptar lo que Luckmann denomina una solución individualista al problema de la vida. ${ }^{1708}$ Taylor, en otros términos, habla de que muchos creen en un Dios personal, asociado a su propia experiencia vital. ${ }^{1709}$

2.- Puede darse también la incapacidad para asumir una decisión personal y reflexiva y el individuo vuelve a adoptar una situación existencial "prerreflexiva", porque ha decidido no enfrentarse al beneficio de la propia duda y ha abandonado los caminos de la búsqueda. Según Luckmann, se pasa de la acción del mundo secular, a la acción del mundo religioso de una manera rutinaria; es decir, sería volver a una cierta ingenuidad en la que ambos mundos no se interfieren, pero que tampoco se enriquecen ni se implican. Lo rutinario significa aquí separación de ambos mundos y, por lo tanto, con más posibilidades de debilitamiento moral del yo que de acrecentamiento en una atmósfera de valoraciones morales fuertes. Para Taylor, este grupo está representado por aquellos que siguen declarando pertenecer a alguna confesión o creer en Dios. ${ }^{1710}$

3.- Y la tercera posibilidad es que se acrecienten las valoraciones seculares en detrimento del mundo religioso, con lo que puede llevar al abandono de este o a su debilitamiento progresivo o a la asunción de un oportunismo que debilita irremediablemente. ${ }^{1711}$ Este es el grupo representado por quienes se declaran ateos, agnósticos o no tienen religión, según el modo de ver de Taylor. ${ }^{1712}$

La identidad entre Religión e Iglesia, y la coherencia entre el modelo institucional de religión y los sistemas individuales de significación última se mantuvieron sin ningún tipo de problema hasta el final del Medievo. Con el advenimiento de la Modernidad, la coherencia entre el modelo oficial de institución religiosa y las significaciones subjetivas de significado se rompe.

Luckmann afirma que el momento clave es el Renacimiento, en el que se incrementa el aumento de las discrepancias entre las pretensiones de sentido subjetivo y el modelo oficial de religión institucionalizada. Es en el Renacimiento cuando se comienzan a proponer contramodelos laicos, y a pesar de los ajustes que intentan proponerse con la Reforma y la Contrarreforma, las dificultades no logran superarse e irán a más. Con la emergencia del capitalismo y la racionalización progresiva de las instituciones, que provoca un alto grado de especialización y separación de esferas, el

\footnotetext{
${ }^{1708}$ Cfr. LUCKMANN, T., La religión invisible, pág. 97.

${ }^{1709}$ Cfr. TAYLOR, Ch., La Era Secular, tII, pág. 342.

${ }^{1710}$ Cfr. Id., 342.

${ }^{1711}$ Cfr. CORDERO DEL CASTILLO, P., "La Religión y su lugar en la sociología”, Barataria, No 4, págs. 250-251. Ver las tres posturas distintas en torno a esta religión "desconfigurada" o invisible.

${ }^{1712}$ Cfr. TAYLOR, Ch., La Era Secular, tII, pág. 342.
} 
papel del individuo pierde protagonismo. ${ }^{1713}$ Para Luckmann, con el advenimiento de la racionalidad moderna y la especialización institucional, el rol de la persona queda diluido en una acción directa sin otra significación moral que la de la eficacia. El yo del individuo se difumina en una acción neutra caracterizada por la funcionalidad institucional, con lo que las connotaciones morales de la acción individual pierden consistencia y la capacidad de resistencia del yo de la persona ante cualquier conflicto de intereses entre lo personal e institucional se va debilitando progresivamente. ${ }^{1714}$

En esta misma línea, Taylor sostiene que la identidad moderna deja sin "autobiografía" amplias zonas del yo del individuo, de manera que las referencias de significado del yo pierden consistencia y la ambigüedad ontológica del yo moderno pone las bases de una autonomía que no es solo independencia o autorreferencia, sino que tiene ese otro aspecto caracterizado por la falta de autoidentificación moral, debido a que el yo se va debilitando sobre la base de unas valoraciones morales cada vez menos consistentes. ${ }^{1715}$ La autonomía no es solo autorreferencial, sino que implica debilitamiento moral o falta de valoraciones fuertes. Por otra parte, el yo del individuo se ubica en unos condicionamientos institucionales que son los que van fraguando las relaciones sociales y no la urdimbre de los individuos. La biografía del individuo pierde consistencia ante la especialización de las instituciones sociales, unas instituciones que marcan el ritmo de la vida social y que moldean de alguna manera lo que se pide al individuo. No se niega la autobiografía, pero esta se ubica o en espacios de lo privado o en las instituciones sociales en tanto y en cuanto no rompa los moldes estructurados de las mismas. ${ }^{1716}$ Taylor concluye que el resultado de este pluralismo y mutuo debilitamiento será con frecuencia un retroceso de la religión en la plaza pública. ${ }^{1717}$

V.- Según David Martin, a una religión más monopolizadora, se sigue una mayor secularización. Por lo que al mismo tiempo que se ha producido una pérdida monopolizadora de una cierta religión, en la misma medida se ha manifestado un mayor pluralismo que ha provocado una mayor influencia de las religiones en el mundo y, por ende, una pérdida de la influencia secularizadora que se daba como un hecho imparable.

\footnotetext{
1713 "La racionalidad funcional de las normas institucionales aisladas tiende a hacerlas triviales desde el punto de vista de la persona, la que por lo tanto presentará una resistencia subjetiva siempre más difícil a las mismas; una resistencia que puede estar potencialmente inspirada por el conflicto entre las normas institucionales y un presunto sistema religioso de significancia". LUCKMANN, T., La religión invisible, pág. 107. Cfr. TAYLOR, Ch., La Era Secular, tII págs. 302, 381, 383, 395, 420, 489, 601, 646.

1714 "La identidad personal se convierte esencialmente en un fenómeno privado. Este es quizás el aspecto más revolucionario de la sociedad moderna (la cursiva es nuestra). El fraccionamiento institucional ha dejado sin estructuras amplias zonas de la vida del individuo y no ha determinado el contexto biográfico global de significado. De los intersticios de la estructura social que se derivó de la fragmentación institucional emerge lo que se puede llamar la 'esfera privada'. La 'liberación' de la conciencia individual de la estructura social y de la 'libertad' en la 'esfera privada' proporciona las bases del ilusorio sentido de autonomía que caracteriza a la persona típica de la sociedad moderna”. Ibid., pág. 108.

1715 Cfr. TAYLOR, Ch., Fuentes del yo, págs. 54-56.

${ }^{1716}$ Cfr. TAYLOR, Ch., Imaginarios sociales modernos, pág. 217.

${ }^{1717}$ Cfr. TAYLOR, Ch., La Era Secular, tII, pág. 373.
} 
Lo que está claro es que no se ha producido una extinción de la religión, con lo que las teorías secularizadoras que daban por hecho la secularización como una realidad progresiva han tenido que volver a repensarse ante la presencia de nuevos paradigmas. Todo es pensado desde el giro subjetivista rousseauniano como "pensarme a mí mismo desde mi propia voz interior", pero eso no excluía a Dios necesariamente. ${ }^{1718}$ Taylor afirma, incluso, que nuestra recuperación moral depende del auténtico contacto moral con esa voz interior o la exploración del orden a través de la resonancia personal. ${ }^{1719}$ Es decir, el establecimiento del marco inmanente no invalida la dimensión trascendente de la vida.

Bryan Wilson sigue la trayectoria pesimista de Weber. Afirma que el desencantamiento del mundo es una realidad imparable y que, a pesar de la aparición de nuevas formas de espiritualidad o del surgimiento de nuevos movimientos religiosos, sin embargo, solo son intentos desesperados por adaptarse a un mundo que plantea su cara más hostil a la religión. Se podría afirmar que Wilson es uno de los representantes más destacados de la teoría clásica de la secularización en los términos a los que nos hemos referido anteriormente. ${ }^{1720}$ No obstante, al igual que Peter Berger, también Wilson realiza su propia matización a dicha teoría clásica. ${ }^{1721}$ Una matización que reconoce la pérdida de relevancia de la religión en la vida social y cultural, aunque las personas puedan seguir reconociendo la importancia de la dimensión trascendente en sus vidas. Wilson reconoce que con la secularización la religión pierde significatividad social, pero matiza el alcance secularizador tradicional en su carácter globalizador. ${ }^{1722}$ Wilson reconoce que una cosa es la dimensión social y otra cosa la importancia individual que las personas pueden conceder a la misma en sus vidas. Este es el matiz fundamental que introduce respecto a sus primeros escritos. Pone en duda que la secularización alcance a dicha dimensión privada de las personas, tanto en sus creencias como en sus prácticas religiosas. ${ }^{1723}$

\footnotetext{
${ }^{1718}$ Cfr. TAYLOR, Ch., El multiculturalismo y la política del reconocimiento, págs. $48-49$.

${ }^{1719}$ Cfr. TAYLOR, Ch., Fuentes del yo, pág. 691.

${ }^{1720}$ Cfr. GARMA NAVARRO, C., "Bryan Ronald Wilson: 1926-2004", Desacatos, No 18, (2005), págs.165-168.

${ }_{1721}$ Cfr. WILSON, B., Religion in Sociological Perspective, Claredon Press, Oxford, 1982; "Secularization: The Inherited Model", en Phillip E. Hammond (coord.), The Sacred in a Secular Age, University of California Press, Berkeley, 1985; The Social Dimensions of Sectarism, Claredon Press, Oxford, 1990.

${ }^{1722}$ Cfr. TAYLOR, Ch., Imaginarios sociales modernos, pág. 214.

1723 “(Para Wilson) el paradigma no representa necesariamente la declinación de la religión en general, asunto que como veremos adelante es más problemático, sino la pérdida de poder y control social por parte de la institución religiosa antaño dominante, que ya no puede imponerse a los miembros de una determinada sociedad". BELTRÁN CELY, W., "Secularización, ¿teoría o paradigma?" Revista Colombiana de Sociología, No 31, (2008), pág. 69. Cfr. DE LA CUEVA MERINO, J., "Conflictiva secularización: Sobre Sociología, Religión e Historia”, Historia Contemporánea, No 51, (2015), págs. 365-395.
} 
David Martin afirma que con la desaparición de los monopolios religiosos se llega a la separación Iglesia-Estado como una de las características ligadas a la Modernidad. Y con dicha desmonopolización de la religión surge el multiculturalismo, tal como afirmará Taylor, ${ }^{1724}$ y el consiguiente incremento de la religión. ${ }^{1725}$ Un incremento que se expresa como lucha entre la antigua iglesia monopolizadora y las nuevas iglesias o movimientos. Unos asumen la separación Iglesia (antigua religión monopolizadora)Estado como enfrentamiento hacia aquellos grupos políticos que han propiciado dicha separación; y los otros grupos religiosos asumen dicha separación como acercamiento a dichos grupos políticos. ${ }^{1726}$

Por otra parte, según Taylor, la separación Iglesia-Estado conlleva el asumir la laicidad o la aconfesionalidad; laicidad que no debe confundirse con laicismo, ni laicización con secularización. ${ }^{1727}$ En muchos casos, la separación Iglesia-Estado, en su dimensión laica o aconfesional, ha podido propiciar, sobre todo en los países de tradición católica, procesos secularizadores. Por el contrario, en los países de tradición protestante, la modernidad, que fue promovida en cierto modo desde la propia Reforma Protestante, facilitó que los valores religiosos fueran instaurados en la sociedad civil, surgiendo así una suerte de "religión civil", como en el caso de Estados Unidos. ${ }^{1728}$

VI.- Otro autor fundamental al que constantemente alude Taylor es Habermas en su referencia al término "postsecular" para describir una situación "inesperada" más que para hablar de un nuevo período de más abundancia religiosa. ${ }^{1729} \mathrm{Y}$ en medio de este

${ }^{1724}$ Cfr. TAYLOR, Ch., El multiculturalismo y la política del reconocimiento, págs. 91, 94; cfr. TAYLOR, Ch., Argumentos filosóficos, págs. 302-303.

1725 "Religion flourished most luxuriantly under modern conditions where church and state were separated and where there was religious pluralism and competition". MARTIN, D., On Secularization. Towards a Revised General Theory, Ashgate, Aldershot, 2005, pág. 21.

1726 "Se genera así un círculo vicioso en el que la respuesta católica despierta una nueva ofensiva de los sectores laicos. Es importante subrayar el carácter político e ideologizado que las nociones laicidad y laicización en este contexto, puesto que expresan las luchas de un sector social que busca imponer a la sociedad en general su sistema de valores, entrando en confrontación con una institución religiosa que a su vez defiende su propio sistema de valores que ha sido dominante". BELTRÁN CELY, W., “Secularización, ¿teoría o paradigma?”, pág. 73.

${ }^{1727}$ Cfr. TAYLOR-MACLURE, Laicidad y libertad de conciencia, pág. 28.

${ }^{1728}$ Cfr. TAYLOR, Ch., El multiculturalismo y la política del reconocimiento, págs. 23-25. "The prime historical circumstance was the difference between those countries, mainly Protestant, where Enlightenment and religion overlapped and even fused and those countries, mainly Catholic, where Enlightenment and religion clashed". MARTIN, D., On Secularization. Towards a Revised General Theory, pág. 20.

1729 "La persistencia religiosa insta a una reflexión sobre el lugar de la religión en la esfera pública, bien sea social o política. ¿Por qué? Porque la religión, en contra de lo que preconizaban las teorías de la secularización, no parece que vaya a desvanecerse, ni tampoco a replegarse al ámbito de lo privado, atendiendo a los datos de creencias religiosas en el mundo. Por consiguiente, y ante esta persistencia de la religión en la esfera pública, los ciudadanos y las instituciones seculares habrían de encontrar un modo de integrar las diferentes dimensiones de la religión (valores, creencias, prerrogativas de las instituciones religiosas) en su correspondiente nivel: privado o público (y, dentro de este, en la esfera social o política), al tiempo que se mantiene la necesaria separación Iglesia/Estado que caracteriza a esos "Estados seculares". ROLDÁN GÓMEZ, I., "Lo postsecular: Un concepto normativo", Revista Política y Sociedad, No 54, (2017), pág. 854. 
debate de la incertidumbre ante lo que está ocurriendo, Habermas habla de un encendido enfrentamiento entre los partidarios de la modernidad científica y tecnológica, y los portavoces de las religiones, afirmando que los primeros temen el oscurantismo de residuos sentimentales y arcaicos, y los segundos se oponen a la fe cientificista en el progreso, propia de un crudo naturalismo. ${ }^{1730}$

Para Habermas, el estallido entre la sociedad secular y la religión se produjo el 11 de septiembre en los atentados de las Torres Gemelas. Un atentado que expresa oposición, virulencia, enfrentamiento absoluto y descarnizado entre unos representantes radicalizados y violentos del Islam y la sociedad secular. Y fue precisamente este atentando el que hizo vibrar la "cuerda religiosa" de los sentimientos religiosos más escondidos de tantas personas en iglesias, mezquitas y sinagogas. Es el sentimiento religioso como autenticidad tal como lo entiende nuestro hermeneuta. ${ }^{1731}$ Taylor considera, en esta misma línea, que la autenticidad no puede defenderse con formas que hagan desplomarse los horizontes de significado. ${ }^{1732}$

Habermas define la modernidad secularizada como un proceso creador de disimilación o asimultaneidad creciente entre cultura y sociedad. Y mientras que en Europa este proceso se vivió durante siglos, y de manera imaginativa o con posibilidades creativas, en la cultura del Islam este proceso no existió, sino que la asimultaneidad entre religión y sociedad se produjo de manera imprevista e imprevisible, dando lugar a situaciones de incomodidad y sentimientos encontrados de humillación e incomprensión absoluta en muchas personas de dicha cultura islámica.

Considera Habermas que una primera lectura de la palabra secularización hace referencia a que las formas religiosas de pensar y vivir son reemplazadas por sus equivalentes racionales, confiriendo a estas últimas el carácter de superiores. Habermas afirma que, con el advenimiento de la Modernidad, surge una confrontación evidente entre dos fuerzas: la ciencia y la religión. ${ }^{1733}$ Taylor ubica esta confrontación en la aversión modernista a cualquier intento de conciliar humanismo cientifista y religión, dado que la religión es vista como antivital. Para Taylor, el giro modernista hacia dentro no significó un vuelco hacia la voz interior romántica que une razón y sensibilidad, sino hacia una huida más allá del yo y hacia una fragmentación de la experiencia como

\footnotetext{
${ }^{1730}$ Cfr. HABERMAS, J., El futuro de la naturaleza humana, ¿hacia una eugenesia liberal?, Paidós, Barcelona, 2001, pág. 129.

${ }^{1731}$ Cfr. TAYLOR, Ch., Argumentos filosóficos, pág. 296; cfr. TAYLOR, Ch., El multiculturalismo y la política del reconocimiento, págs. 28-32; 34-38.

${ }_{1732}$ Cfr. TAYLOR, Ch., La ética de la autenticidad, pág. 74.

1733 "Por un lado las fuerzas productivas de la ciencia y la técnica desencadenadas por el capitalismo, y por el otro, los poderes conservadores de la religión y la iglesia. Uno solo puede ganar a costa del otro, y además siguiendo las reglas del juego del liberalismo, lo que favorece a las fuerzas motrices de la modernidad”. HABERMAS, J., El futuro de la naturaleza humana, ¿hacia una eugenesia liberal?, pág. 132.
} 
nuevas formas de identidad. ${ }^{1734}$ De ahí que para Taylor sea fundamental reconstruir un relato de la secularidad moderna que supere ciertos reordenamientos modernistas de un cariz extraño y desconocido, ${ }^{1735}$ y reivindicar la significatividad de un orden moral que ponga en contacto con la plenitud de la vida. ${ }^{1736}$

Según el parecer de Taylor, aunque Habermas reconoce tres vertientes modernas de la vieja idea de orden (intento científico de conocer el mundo, intento de la razón práctica de determinar el derecho y las exploraciones de la integridad y la autenticidad subjetiva expresivas), sin embargo, "para Habermas no existe un lugar coherente para la exploración del orden en que nos hallamos como lugar de las fuentes morales", porque, según Taylor, Habermas tiene una visión procedimental de la razón práctica y el orden solo es accesible a través de la resonancia personal y la expresión subjetiva. ${ }^{1737}$ Por lo tanto, la significatividad del orden adquiere matices totalmente diferentes en Taylor y Habermas.

Habermas intenta poner en diálogo la racionalidad moderna y su capacidad para modelar y ubicar en contextos respetuosos las religiones. Habermas sugiere que la religión, en este contexto postsecular, tiene que reinventarse, en el sentido de renunciar, por propia convicción, a imponer de manera violenta las verdades de fe o a manipular las conciencias. En este contexto postsecular las religiones deben asumir la racionalidad del hecho religioso y tienen que reubicarse, dentro de los estados democráticos, como una institución más, en el respeto a la libertad y a la convivencia. Una religión violenta estaría totalmente fuera de juego dentro del contexto de un estado liberal que respeta y asume el pluralismo religioso y promueve la convivencia de todas las instituciones en proyectos de enraizamiento ético básicamente compartidos. ${ }^{1738}$

Habermas plantea tres grandes retos en relación a la formación de la conciencia religiosa en este contexto plural y de estado liberal y postsecular, que básicamente comparte Taylor:

1.- El pluralismo religioso debe ser asumido por todas las confesiones religiosas. Un pluralismo que asume las diferencias, los encuentros disonantes entre unas confesiones y otras, así como la capacidad para promover, dentro de estas diferencias, la reflexión racional y filosófica en torno a los aspectos que unen a unos proyectos y otros. Será la racionalidad la que establezca las diferencias y la

\footnotetext{
${ }^{1734}$ Cfr. TAYLOR, Ch., Fuentes del yo, pág. 627.

${ }^{1735}$ Cfr. Ibid., pág. 631.

${ }^{1736}$ Cfr. Ibid., pág. 636.

${ }^{1737}$ Cfr. Ibid., pág. 689.

1738 "Tales conflictos que han dominado buena parte de la historia moderna europea, hoy se dan no solo entre el mundo occidental y el islámico sino también entre los grupos militantes de ciudadanos religiosos, y los seculares en el seno de las sociedades liberales". HABERMAS, J., Carta al Papa. Consideraciones sobre la fe, Paidós, Barcelona, 2009, pág. 68. Cfr. TAYLOR, Ch., El multiculturalismo y la política del reconocimiento, págs. 23-26.
} 
que las asuma positivamente, desde el respeto y el encuentro desprovisto de prejuicios. ${ }^{1739}$ Para Taylor, la era de la autenticidad va indisociablemente unida a la política del reconocimiento: reconocer igual valor a diferentes modos de ser, reconocer las diferencias. ${ }^{1740}$

2.- La conciencia religiosa que tiene avenirse y asumir positivamente la autoridad de las ciencias que tienen la autoridad moral social del saber terrenal. $\mathrm{O}$ lo que es lo mismo, las ciencias tienen su campo propio de desenvolvimiento científico que debe respetarse y asumirse como verdad científica (Habermas habla de saber terrenal) y las religiones tienen su ámbito propio de saber metafísico y trascendente. Se trata de respetar los ámbitos propios del saber y conocer de cada institución y promover reconocimientos mutuos. Ni la ciencia puede arrogarse el saber sobre la totalidad o la consideración de la única verdad, ${ }^{1741}$ ni la religión puede desprestigiar o contradecir verdades asumidas científicamente como saber terrenal. ${ }^{172}$ Taylor reflexiona sobre el sentido y alcance que tiene la pregunta por la existencia de Dios en un mundo en el que la ciencia ha vuelto irrelevante dicha pregunta. $^{1743}$

3.- En la etapa postsecular, las religiones deben comprometerse en el respeto de alguna manera con la moral profana. De la misma manera que los estados liberales deben respetar las valoraciones morales de las religiones y su misma existencia, así también las religiones deben respetar la moral profana, los presupuestos básicos de convivencia y participación en unos valores comunes. ${ }^{1744}$

Según Habermas, la razón plural de la vida pública del Estado debe mantener una adecuada equidistancia entre las distintas fuentes de valoración moral, una sana independencia, de tal manera que la "postsecularidad" significa estar abiertos osmóticamente a ambas partes, propiciando espacios de diálogo y de racionalidad, de

1739 "El estado liberal también debe esperar de sus ciudadanos seculares que, en su condición de ciudadanos del Estado, no consideren las manifestaciones religiosas como algo meramente irracional". Ibid., pág. 74. Cfr. TAYLOR, Ch. Argumentos filosóficos, pág. 343.

${ }^{1740}$ Cfr. TAYLOR, Ch., La ética de la autenticidad, págs. 83,85.

${ }^{1741}$ La reflexión de Agazzi sobre el conocimiento de la totalidad y la separación de ámbitos propios de conocimiento es significativa. El "saber terrenal" habermasiano no puede ser identificado como el saber de la totalidad, sino como el "saber científico" que tiene su ámbito propio en la racionalidad científicotécnica. "La actitud cognitiva de la ciencia (en su sentido moderno) es la adopción de puntos de vista parciales que también implican conceptualizaciones, metodologías y estilos de argumentación parcialmente adecuados. Por lo tanto, es estrictamente anticientífico cualquier pretensión de 'extrapolar' teorías o visiones científicas que no se restrinjan a sus campos y, sobre todo, que se realicen para promoverlas como claves para la comprensión del Todo". AGAZZI, E., "Conocimiento científico y fe cristiana”, pág. 114.

${ }_{1742}$ Cfr. TAYLOR, Ch., El multiculturalismo y la política del reconocimiento, págs. 44-45.

${ }^{1743}$ Cfr. TAYLOR, Ch., La Era Secular, tII, pág. 463.

1744 " $\mathrm{Si}$ ambas posturas, la religiosa y la laica, conciben la secularización de la sociedad como un proceso de aprendizaje complementario, pueden entonces tomar en serio mutuamente sus aportaciones en temas públicos controvertidos también desde un punto de vista cognitivo". HABERMAS, J. y RATZINGER, J., Entre razón y religión. Dialéctica de la secularización, FCE, México, 2008, pág. 29. 
respeto y encuentro, de reconocimiento mutuo. La postsecularidad, entendida de esta manera, es la pervivencia de la secularidad, pero en el reconocimiento del equilibrio entre el saber y el creer, distanciándose de las cosmovisiones fuertes y las tradiciones sólidas, con la idea de asegurar la equidistancia y la independencia. Se trata de una pervivencia de la secularidad, pero bajo otros términos. Atrás ha quedado la clásica teoría de la secularidad que opone modernidad y religión. La postsecularidad habermesiana establece el equilibrio entre ambas con vistas a reconocer las aportaciones de ambas partes, el saber y el creer. Habermas plantea una postura que pretende crear un terreno común de juego en el que ambos saberes se incluyan en un diálogo respetuoso evitando el universalismo que impone el estándar científico o filosófico como obligatorio para establecer todo aquello que es racional y frente al relativismo que parte de que todas las tradiciones culturales poseen criterios de verdad y falsedad. ${ }^{1745}$ Para Habermas, es posible el diálogo creativo entre ciencia y fe, sin autoexclusiones, desde una perspectiva dialógica, siendo la ética discursiva la que ofrece racionalidad procedimental. ${ }^{1746}$ Taylor habla en este sentido de la diversidad de los bienes de los cuales cabe hacer una pretensión válida. No se trata de autoexcluirse, sino de enriquecerse en el reconocimiento mutuo. ${ }^{1747}$ Una racionalidad que reconoce la secularización del Estado no significa la secularización de la sociedad. ${ }^{1748}$

Nuestra autocomprensión del mundo está modificada por los avances científicos. Las cosmovisiones del cosmos y del hombre se vieron altamente influenciadas por las investigaciones de Galileo y Darwin. Habermas sostiene que los conocimientos científicos, cuanto más afectan a nuestro cuerpo más relevantes e impactantes son, más afectan a nuestra cosmovisión del mundo. En este sentido la revolución darwiniana fue más relevante, desde el punto de vista filosófico, que la revolución galileana. Y, por ende, la investigación fisiológica del cerebro y la importancia del inconsciente, con Freud, también han adquirido una importancia aún mayor para nuestra autocomprensión, dado que afectan a nuestro cuerpo interior, a nuestra consciencia. ${ }^{1749}$ Taylor considera, en este mismo sentido, aunque bajo otra perspectiva, que la ciencia contribuye a naturalizar cada vez más una determinada visión de las cosas. Las cosas son simplemente así y que, una vez que atendemos a la experiencia, sin concepciones previas, así es como aparece. ${ }^{1750}$

Por otra parte, el desencantamiento del mundo se inició con la desconfiguración metafísica de la naturaleza como cosmos encarnado de la Idea, con la consideración de

\footnotetext{
1745 Cfr. HABERMAS, J., Fragmentos filosófico-teológicos. De la impresión sensible a la expresión simbólica, Madrid, Trotta, 1999, págs. 42 y ss.

${ }^{1746}$ Cfr. PIZZI, J., "Habermas y la religión. Algunas consideraciones", Recerca, No 1, (2001), págs. 6465; cfr. TAYLOR, Ch., La ética de la autenticidad, pág. 69.

${ }^{1747}$ Cfr. TAYLOR, Ch., Fuentes del yo, pág. 679.

${ }^{1748}$ Cfr., HABERMAS, J., Mundo de la vida, política y religión, pág. 234.

${ }^{1749}$ Cfr. TAYLOR, Ch., Hegel, pág. 473.

${ }^{1750}$ Cfr. TAYLOR, Ch., La Era Secular, tII, pág. 414.
} 
la naturaleza limitada a un mecanicismo materialista que va estrechando progresivamente la mirada: todo está controlado por fuerzas físicas perfectamente definidas por la ciencia matemática. Habermas considera que se ha producido una naturalización del espíritu al crear una imagen científica del hombre que se expresa con los conceptos extensionales de la física, la neurofisiología o la teoría de la evolución, y que además desocializa completamente nuestra autocomprensión. ${ }^{1751}$ Este es el proceso secularizador de la Modernidad. No obstante, Habermas duda de que esta naturalización del espíritu pueda ser total o pueda llegar a expresarse a través de una comprensión de la intencionalidad, con teorías que expliquen por qué actuamos de una determinada manera o pretendan un análisis fisio-biológico de los procesos mentales. Siempre hay un campo de autocomprensión que va más allá de nuestro control o nuestra capacidad para explicar porqués o los matices que se pueden establecer entre ser y deber y el alcance de los mismos a la hora de determinar nuestro comportamiento moral, como también afirmará Taylor. ${ }^{1752}$

El comportamiento humano no solo puede ser explicado como un suceso natural, sino que también hay elementos precientíficos que exigen una justificación y que superan el alcance de las ciencias naturales. Las explicaciones neodarwinianas sobre el origen de la consciencia normativa a partir del comportamiento simbólico de animales no terminan de dar una explicación completa de la intencionalidad y la consciencia humana transida de autocomprensiones morales. Una cosa es la mera explicación natural de un suceso, y otra, la justificación lingüística con alcance de autocomprensión moral. Para Habermas, la imagen que subyace de fondo es la de personas capaces de rendirse cuentas mutuamente, en interacciones reguladas normativamente y que contactan entre ellas en un universo de razones públicas. ${ }^{1753}$ Una norma solo se justifica en la medida en que incoerciblemente sea aceptada por todos. ${ }^{1754}$ Para Taylor, por el contrario, la influencia de las religiones, que alimentan percepciones morales sustantivas, tiene que ver con un entrecruce de perspectivas, visiones, autocomprensiones morales, la conciencia de estar los unos con y frente a los otros, el vérnoslas con los demás como un "tú”, frente a un “yo". 1755

Para Taylor, en el common sense ilustrado está la garantía de la fundamentación de unos estados liberales que integren todas las sensibilidades, incluidas las comunidades de fe. ${ }^{1756}$ Habermas es crítico con los estados secularizados que solo aceptan una dirección única y ponen al margen la religión. Por eso, el término

\footnotetext{
${ }^{1751}$ Cfr. HABERMAS, J., El futuro de la naturaleza humana, ¿hacia una eugenesia liberal?, pág. 135.

1752 Cfr. TAYLOR, Ch., El multiculturalismo y la política del reconocimiento, pág. 48.

${ }^{1753}$ Cfr. HABERMAS, J., El futuro de la naturaleza humana, pág. 136; cfr. TAYLOR, Ch., Argumentos filosóficos, págs. 100, 111.

${ }_{1754}$ Cfr. TAYLOR, Ch., Fuentes del yo, pág. 132.

1755 Cfr. TAYLOR, Ch., La Era Secular, tII, pág. 463.

${ }^{1756}$ Cfr. TAYLOR, Ch., Imaginarios sociales modernos, págs. 206-207.
} 
"postsecular" es más adecuado para recoger esta percepción de carácter global que incluye en el common sense ilustrado a todas las comunidades que asumen la racionalidad y la capacidad lingüística para observar el yo de un tú y abrir al tú de un yo. Para Habermas, se trata de ir comprendiendo el pluralismo cosmovisivo y evitar visiones unilaterales que empobrecen la ubicación moral de las comunidades creyentes en los estados liberales. ${ }^{1757}$

El término "postsecular" pretende superar estos anacronismos que exigen a los creyentes compromisos difíciles de asumir por otras comunidades que integran el Estado liberal. El término "postsecular"de Habermas incide en tres elementos fundamentales a tener en cuenta:

- Las religiones pueden expresar desde la racionalidad sus convicciones morales religiosas y no tienen por qué recurrir a un lenguaje secular para expresarlas. Si esto no se le pide a ninguna comunidad del estado liberal, tampoco debería ser exigible a las comunidades de fe. Se está marginando la racionalidad propia de las argumentaciones religiosas. ${ }^{1758}$ Se impone el principio de libertad religiosa y de tolerancia. ${ }^{1759}$ Taylor opina que Habermas ha experimentado una evolución al considerar el discurso religioso como un vehículo serio de posibles contenidos de verdad. ${ }^{1760}$

- Por otra parte, no siempre se logra transferir la riqueza del contenido religioso a un lenguaje secular, con lo cual se está empobreciendo las argumentaciones morales que desde la racionalidad religiosa pueden enriquecer el common sense ilustrado que todos comparten en el estado liberal moderno. ${ }^{1761}$ Habermas considera en este sentido el empobrecimiento de los lenguajes seculares.

- La traslación del lenguaje bíblico-teológico al lenguaje de la modernidad ha supuesto en ocasiones lo que Habermas denomina "irritación" porque algo se perdió. Como si el lenguaje secular no lograra adentrarse en las profundidades

\footnotetext{
${ }^{1757}$ Cfr. HABERMAS, J., El futuro de la naturaleza humana, pág. 138.

1758 "Se espera la misma capacidad de reconocimiento — en el marco de una cultura política liberal— de los no creyentes en su trato con los creyentes. Para el ciudadano sin sensibilidad hacia lo religioso esto no supone de ningún modo una obligación trivial, ya que significa que debe determinar autocríticamente la relación entre fe y conocimiento desde la perspectiva de su conocimiento mundano". HABERMAS, J. y RATZINGER, J., Entre razón y religión. Dialéctica de la secularización, pág. 32.

${ }^{1759}$ Cfr. HABERMAS, J., Mundo de la vida, política y religión, págs. 270-271.

${ }^{1760}$ Cfr. HABERMAS, J., TAYLOR, Ch., BUTLER, J., WEST, C., El poder de la religión en la esfera pública, pág. 53.

1761 "Habermas se opone expresamente a que la religión sea expulsada del ámbito público y relegada al ámbito privado de la conciencia individual. Y esto por varias razones: en primer lugar, porque a nivel existencial las religiones son portadoras de sentido; en segundo lugar, porque las religiones producen lazos de solidaridad". MICHELINI, D., "Creyentes y no creyentes en una sociedad democrática”, Invenio, No 18, (2015), pág. 19.

Cfr. HABERMAS, J., Entre naturalismo y religión, págs. 112, 138; cfr. HABERMAS, J., El futuro de la naturaleza humana, ¿hacia una eugenesia liberal?, pág. 139.
} 
morales de la religión. Por ejemplo, lo que significa el perdón religioso no puede expresar, en toda su profundidad, el lenguaje de la culpa o de la injusticia contravenida a los otros. Hay sentimientos que proceden de la experiencia religiosa y que los lenguajes secularizados difícilmente pueden comprender. De alguna manera, se está sugiriendo que la experiencia religiosa enriquece y se adentra en abismos morales que difícilmente puede experimentar la experiencia secular. Ambas experiencias están llamadas a comprenderse y a entrar en diálogo. Para Taylor, no es que se excluyan, pero la una sin la otra se empobrecen. La experiencia secular está llamada a imbricarse con el enraizamiento moral de la experiencia religiosa y a seguir comprendiéndose en el alcance de su significación secular, y la experiencia religiosa no debe olvidar que su expresión se realiza en el espacio y tiempo seculares. ${ }^{1762}$

En el fondo, se trata de que la parte secular y la parte religiosa se acepten mutuamente porque los argumentos de ambas partes son realmente relevantes para enriquecer las fundamentaciones morales de sentido.

Aquí cabría algunas preguntas que nos hacemos: ¿Se podría exigir desde la comunidad religiosa una traslación a lenguaje religioso de las argumentaciones de sentido de la comunidad secular? ¿Enriquecería también la argumentación religiosa la argumentación secular que le es ofrecida para el debate y el autorreconocimiento? Y, por otra parte, ¿sería exigible desde la comunidad religiosa que estuviera prohibido expresar en lenguaje secular las argumentaciones propias de sentido de su ámbito propio, pidiendo un "reconocimiento implícito" de la racionalidad de las mismas y la "riqueza propia" de su argumentación al margen de cualquier traslación al lenguaje secular? En cierto sentido, la exigencia de traslación al lenguaje secular del lenguaje religioso está expresando una cierta marginación de dichas argumentaciones, que no se exigen por una parte a otras comunidades, y al mismo tiempo, como si se pusiera en duda la propia capacidad del lenguaje religioso para expresar racionalidad o establecer caminos de common sense ilustrado por sí misma. ${ }^{1763}$ Taylor afirma en este sentido que la idea de que la neutralidad es básicamente una respuesta a la diversidad encuentra dificultades para abrirse paso entre los no creyentes occidentales, extrañamente obsesionados con la religión, a la que consideran algo extraño y tal vez incluso amenazador. ${ }^{1764}$

\footnotetext{
${ }^{1762}$ Cfr. TAYLOR, Ch., Imaginarios sociales modernos, pág. 216.

${ }^{1763}$ Cfr. SCIVOLETTO, G., "La Religión en la esfera pública: análisis de la cláusula de traducción del discurso religioso al lenguaje secular", Análisis, Vol. 4, No 1, (2017), pág. 106.

${ }^{1764}$ Cfr. HABERMAS, J., TAYLOR, Ch., BUTLER, J. y WEST, C., El poder de la religión en la esfera pública, pág. 54 .
} 
Para Taylor, el reconocimiento mutuo es una asignatura pendiente en la modernidad ilustrada, ya que no siempre se ha realizado de manera correcta y adecuada. No podemos olvidar el origen religioso de los fundamentos morales del estado moderno, con lo que sería fácilmente articulable fórmulas que superaren paradojas y objeciones de exclusión. Desde la racionalidad moderna del estado liberal se deben iniciar procesos y caminos, no de dirección única, sino que en una visión novedosa y postsecular hay que enriquecer procesos de autocomprensión desde el debate compartido y la inclusión de la otra parte en la búsqueda del yo del otro a partir del reconocimiento mutuo. ${ }^{1765}$ Taylor considera que la separación Iglesia-Estado y la neutralidad garantizan la igualdad de los ciudadanos a la vez que el reconocimiento y la protección de la libertad de conciencia de las personas. ${ }^{1766}$

VII.- Danièle Hervieu-Léger es otro de los referentes de la deconstrucción de las teorías secularizadoras. También ella habla de la necesidad de una revisión teórica debido a los interrogantes que surgen en torno a la realidad del mundo de hoy en el que la religión está en plena efervescencia y donde está recuperando muchos espacios supuestamente perdidos a partir de la modernidad secularizadora.

Hervieu-Léger considera la Modernidad como un espacio en el que están surgiendo nuevas formas de creer religioso, siendo el proceso de secularización un proceso de recomposición del creer a partir de la nueva cosmovisión de la Modernidad. ${ }^{1767}$ Taylor resalta la reflexión de Hervieu-Léger en su idea del desacoplamiento de la creencia y la práctica, así como la dislocación de la creencia, la pertenencia y la identidad. ${ }^{1768}$ En esta misma línea, según el profesor Blancarte, para la socióloga francesa la secularización es el proceso de reorganización permanente del trabajo de la religión en una sociedad estructuralmente incapaz de cumplir o llenar las expectativas que necesita suscitar para existir como tal. ${ }^{1769}$

Hervieu-Léger afirma que fruto de esta reorganización y dislocación de la creencia y la identidad religiosa, surgen nuevos formatos de creencia que nos parece importante resaltar, dado que entronca con el pensamiento de Taylor. Es muy fácil establecer un paralelismo entre Taylor y Hervieu-Léger que no es necesario explicitar, en muchos casos.

\footnotetext{
${ }^{1765}$ Cfr. TAYLOR, Ch., El multiculturalismo y la política del reconocimiento, págs. 136-137; cfr. HABERMAS, J., Mundo de la vida, política y religión, pág. 271.

${ }^{1766}$ Cfr. TAYLOR, Ch. y MACLURE, J., Laicidad y libertad de conciencia, pág. 37.

${ }^{1767}$ Cfr. HERVIEU-LÉGER, D., La religión, hilo de memoria, pág. 13

${ }^{1768}$ Cfr. TAYLOR, Ch., La Era Secular, tII, pág. 343.

1769 Cfr. BLANCARTE, R., "Religión y sociología, cuatro décadas alrededor del concepto de secularización", pág. 69.
} 


\section{1.- Es sagrado todo aquello que tiene que ver con el misterio.}

Con la Modernidad lo "sagrado" se expresa en toda su amplitud y es todo aquello que tiene algún vínculo con el misterio, o con la investigación del sentido, o con la invocación de la trascendencia o con la absolutización de determinados valores. ${ }^{1770}$

Es lo que muchos sociólogos de la religión denominan como lo sagrado difusomoderno-informal, sacralidad difusa, ambigua, pero que está llenando los espacios de sentido o de búsqueda de los seres humanos llenos de interrogantes, dudas y frecuentemente perplejidad. Charles Taylor también se expresa en términos parecidos al hablar de las nuevas configuraciones de lo religioso. Y afirma que con la pérdida de influencia de las religiones tradicionales o de las instituciones que en ellas se albergaban, las sociedades modernas posindustriales se encuentran en plena búsqueda de significados de reemplazo ante la ausencia de las propuestas tradicionales. Una búsqueda llena de alternativas, deseos y a veces incomodidad. ${ }^{1771} \mathrm{Y}$ así, lo mismo que se reconoce la secularización y la desacralización, al mismo tiempo surge el interrogante sobre un resurgir de lo sagrado. Es esa búsqueda del reemplazo lo que interroga, cuestiona y necesita ser analizado detenidamente, según Taylor, y lo que provoca en él un deseo por reconstruir los relatos oficiales de la secularidad moderna. ${ }^{1772}$

Siguiendo a Hervieu-Léger nos preguntamos: ¿Hay un retorno de lo sagrado? Tras la palabra "sagrado", ¿qué significados se esconden? ¿Hay una identificación entre lo sagrado y la religión, entre religiosidad y sacralidad, o con la palabra "sagrado" estamos queriendo significar un horizonte nuevo de significatividades y cosmovisiones que entroncan con algo nuevo, aunque sin romper los lazos con las religiones tradicionales tal y como se han ido entendiendo hasta ahora? ¿Podemos decir que la religión retorna a la ciudad secular? ¿Cuál es el alcance de la palabra religión en este resurgir de lo religioso ${ }^{1773}$ ¿Se puede hablar realmente de un retorno a lo sagrado ${ }^{1774}$

\footnotetext{
${ }^{1770}$ Cfr. HERVIEU-LÉGER, D., La religión, hilo de memoria, pág. 78.

${ }^{1771}$ Cfr. TAYLOR, Ch., Imaginarios sociales modernos, págs. 222-223; cfr. TAYLOR, Ch., Ética de la autenticidad, págs. 107-108.

${ }^{1772}$ Cfr. TAYLOR, Ch., El multiculturalismo y la política del reconocimiento, págs. 31-33,48-50.

${ }^{1773}$ Cfr. TAYLOR, Ch., Ética de la autenticidad, pág. 119.

${ }^{1774}$ Cfr. HERVIEU-LÉGER, D., La religión, hilo de memoria, págs. 81 y ss. Hervieu-Léger estudia a Lilian Voyé, para quien la construcción de universos de significado en la modernidad se multiplican hacia el infinito, con lo cual se asienta en cierto punto la teoría de la secularización como pluralización o diferenciación de los universos simbólico-religiosos. En este sentido lo sagrado va más allá de lo religioso, con lo cual el así llamado "retorno a lo sagrado" de la Modernidad significaría retomar esos espacios que quizás usurparon las religiones institucionales y que desplazaron ese fondo de misterio que habita en el corazón humano hacia expresiones de lo sagrado "controlados" por la religión. Lo sagrado va más allá de los límites de las religiones establecidas institucionalmente. A partir de la reflexión de Voyé, conceptos como religión y sagrado adquieren dimensiones nuevas. Lo sagrado está en el centro de la religión y la religión es una parte de lo sagrado. Y también ¿qué parte de lo religioso se identificaría con lo sagrado en esa "parte primera" de su pertenencia a lo sagrado? ¿Y qué parte de lo sagrado es expresado
} 
Hervieu-Léger afirma que la dificultad viene cuando los investigadores a menudo manejan la noción de lo sagrado y se encuentran atrapados en un círculo analógico del que no logran salir, como si fuera imposible deshacerse de las formas contingentes de las religiones históricas. Hervieu-Léger sugiere el camino planteado por Albert Piette para escapar de esto: por un lado, la "religiosidad", que designa la presencia de elementos característicos de lo religioso en los diferentes campos seculares, y por otro, la "sacralidad" que concierne a la construcción de una dimensión sacra, sobre la base de valores contemporáneos productores de sentidos. ${ }^{1775}$

Bajo otra perspectiva, el profesor Carretero Pasín habla de la pervivencia de la religión que se metamorfosea, se transfigura en un rostro nuevo que se adapta a un nuevo escenario, como se si tratara de la persistencia de lo más viejo en lo más nuevo. ${ }^{1776}$

\section{2.- La emoción de las profundidades y la religión.}

Esta religión del sentimiento, que se refuerza en relación con lo sagrado secular y lo sagrado aproximado y derivado, es una experiencia que nos remite a esta capacidad que tiene lo sagrado de fascinar y atraer, es una experiencia que encanta el mundo y la vida del que la vive. ${ }^{1777}$

¿En qué consiste ese sentimiento de lo sagrado? Para R. Otto la religión es una experiencia que transfigura y plenifica, que ejerce sobre el hombre una fuerza que eleva y abruma, un sentimiento de lo numinoso que se realiza en lo más profundo como algo que sobrecoge y unifica. ${ }^{1778}$ También Durkheim habla de la capacidad que la

en la religión? ¿O qué parte de lo sagrado no puede ser recogido por la religión ya que o lo olvida o lo arrincona? ¿Se puede hablar de una identificación de religión institucional y lo sagrado sobre la base de una transformación de las religiones institucionales para que se "reformulen" sobre la experiencia de lo sagrado? ¿O se trata de una sacralización de unos principios laicos basados en la razón, como sustitutos de las religiones tradicionales? Taylor habla en este sentido de las nuevas condiciones de la creencia dentro del marco inmanente. Cfr. TAYLOR, Ch., La Era Secular, págs. 382 y ss.

${ }^{1775}$ Cfr. HERVIEU-LÉGER, D., La religión, hilo de memoria, pág. 83.

${ }^{1776}$ Cfr. CARRETERO PASÍN, E., "El laicismo, ¿una religión metamorfoseada?" Nómadas, No 15, (2007), pág. 244. “Como los mitos ponen ya por obra la Ilustración, así queda esta atrapada en cada uno de sus pasos más hondamente en la mitología. Todo el material lo recibe de los mitos para destruirlo, pero en cuanto juez cae en el hechizo mítico. Quiere escapar al proceso de destino y venganza ejerciendo ella misma venganza sobre dicho proceso". HORKHEIMER, M. y ADORNO, T., Dialéctica de la Ilustración, Trotta, Madrid, 1998, pág. 67.

${ }^{1777}$ Cfr. HERVIEU-LÉGER, D., La religión hilo de la memoria, pág. 92. Sobre Rousseau y el alcance de su afirmación “el sentimiento de la existencia”. Cfr. TAYLOR, Ch., El multiculturalismo y la política del reconocimiento", pág. 49; cfr. WAKSMAN, V., "Jean Jacques Rousseau: el amor de sí mismo y la felicidad pública”, Anacronismo e Irrupción, Vol. 3, No 4 (2013), págs. 104-127.

1778 "Es algo que transfunde, que transfigura, plenifica, transforma. Esto sucede con preferencia allí donde se lo experimenta como vida o como el propio ser, que es lo mismo, solo que en grado más intenso". OTTO, R., Ensayos sobre lo numinoso, Trotta, Madrid, 2009, pág. 66. 
experiencia sagrada tiene para embargar y sobrecoger a las personas en sentimientos que plenifican y llenan de sentido. ${ }^{1779}$

El gran filósofo y eminente psicólogo norteamericano William James define la religión ante todo como de una experiencia del sentimiento. Para James, la religión es una experiencia de relación personal con la divinidad, un sentimiento que se realiza y experimenta en la soledad. Con sus propias palabras, la religión significa "los sentimientos, los actos y las experiencias de hombres particulares en soledad, en la medida en que se ejercitan en mantener una relación con lo que consideran la divinidad". ${ }^{1780}$

No se trata de algo abstracto, ambiguo, sino que es como si en la conciencia humana existiese un sentido de la realidad, un sentimiento de presencia objetiva, una percepción de lo que podemos llamar algo más profundo. Lo fundamental para James es el sentimiento y solo cuando el sentimiento se asienta en la convicción fundamental de una verdad que nos supera, entonces la razón se convierte en confirmación de lo que el sentimiento ya ha intuido. ${ }^{1781}$ Taylor emplea términos como pálpito, presentimiento, confianza anticipada y salto de fe. ${ }^{1782}$

Completando las ideas de W. James, otro filósofo, Bergson, habla de dos tipos de religión: una religión estática y una religión dinámica. La religión estática es egoísta y pesimista y satisface necesidades vitales que pretenden asegurar la cohesión social. Es la religión social de las primitivas religiones cósmicas que cohesionan la sociedad desde la afirmación de lo trascendente. Por el contrario, la religión dinámica es la que da un salto y pretende asegurar ese elan vital, que pretende asegurar la relación personal con Dios y que le va a llevar a entrar en contacto, a través de él, con la humanidad. Es el ejemplo del misticismo cristiano. Para Bergson, la religión dinámica implica una decisión personal en el sentimiento de que Dios promueve la vida personal y en Él la vida de toda la humanidad. Es el sentido de la memoria que, según Ch. Peguy, nos adentra en el interior del acontecimiento para permanecer en él y remontarlo por dentro. ${ }^{1783}$

\footnotetext{
1779 "Son las impresiones de reconfortación y dependencia que la acción de la sociedad provoca en las conciencias las que los originan. En sí mismas, tales impresiones no están ligadas a la ideación de ningún objeto determinado, pero por el hecho de que son emociones y de que son particularmente intensas, resultan también eminentemente contagiosas". DURKHEIM, E., Las formas elementales de la vida religiosa, pág. 301.

${ }^{1780}$ JAMES, W., Las variedades de la experiencia religiosa, Ediciones Península, 1994, pág. 18; cfr. TAYLOR, Ch., La Era Secular, tII, pág. 347.

1781 "Las razones explícitas tan solo nos parecen convincentes cuando nuestros sentimientos no explícitos de la realidad ya han sido inducidos a favor de dicha conclusión. Entonces, ciertamente, nuestras intuiciones y nuestra razón trabajan conjuntamente y pueden surgir excelentes sistemas de gobernar el mundo, como los de la filosofía budista o católica”. Ibid., pág. 38.

${ }^{1782}$ Cfr. TAYLOR, Ch., La Era Secular, tII, pág. 698.

${ }^{1783}$ Cfr. Id., pág. 698.
} 
Por otra parte, Hervieu-Léger reflexiona en torno al retorno del éxtasis en la Modernidad. De manera bastante espontánea, se cree que el retorno de la emoción puede considerarse un resurgimiento de lo sagrado en el corazón de la modernidad y se admite, al mismo tiempo, que este retorno de lo sagrado certifica la remontada de los intereses religiosos en el corazón del universo secular. ${ }^{1784}$

Sin embargo, para Hervieu-Léger, la experiencia emocional de lo sagrado no significa el retorno de la Religión tal y como ha sido entendida tradicionalmente, sino que tiene que ver más bien con el final de un proceso de vaciamiento religioso. Para Hervieu-Léger, este tipo de retornos son, al menos, problemáticos, dado que en el fondo esconden un empobrecimiento del imaginario religioso. Hervieu-Léger piensa que es muy tentador embarcarse en esta vía, que tiene el apoyo de una larga tradición de investigación, pero que nos posiciona en una situación realmente problemática. ${ }^{1785}$

Taylor habla en términos parecidos al referirse a la experiencia de asombro que es recuperada por el materialismo de los siglos XIX y XX, así como el sentimiento de profundidad al contemplar la totalidad de la naturaleza. Reflexiona también sobre asombro ante la forma en que nosotros emergemos, tan frágiles e insignificantes, y somos, no obstante, capaces de abrazar la totalidad. En este sentido, se hace eco del junco pensante de Pascal que puede muy bien compaginarse en un registro ateo y materialista. Para Taylor, podríamos decir que esta idea de asombro, así expresada y de piedad de la pertenencia, no es solo compartible con una perspectiva inmanentista naturalista, sino que la supone. No obstante, al igual que para Hervieu-Léger, esta experiencia de asombro no puede equivocarse con la experiencia religiosa, para Taylor puede muy bien explicitarse y recuperarse en el registro de la creencia religiosa así como en otras experiencias estéticas de naturaleza epifánica. ${ }^{1786}$

3.- La experiencia emocional de lo sagrado como el final de un proceso de vaciamiento religioso del universo moderno. Lo sagrado contra la religión. ¿El final emocional de la secularización? ${ }^{1787}$

¿Se puede hablar de "religiones seculares" en la Modernidad como sucedáneos que solo conservan de la religión los aspectos más exteriores o secundarios de la

\footnotetext{
${ }^{1784}$ Cfr. HERVIEU-LÉGER, D., La religión hilo de la memoria, pág. 102.

${ }^{1785}$ Cfr. Ibid., págs. 103,105.

${ }^{1786}$ Cfr. TAYLOR, Ch., La Era Secular, tII, pág. 485.

${ }^{1787}$ Cfr. HERVIEU-LÉGER, D., La religión hilo de la memoria, pág. 111. "En este sentido, la creencia ya no está monopolizada por un solo generador de sentido. La característica de la modernidad sería, más bien, la fluidez hacia las distintas actividades humanas: 'lo religioso moderno se inscribe enteramente bajo el signo de la fluidez y de la movilidad, en el seno de un universo cultural, político, social y económico dominado por la realidad masiva del pluralismo'. Así, 'creer' en una sociedad moderna implica la posibilidad de tener múltiples fuentes últimas de sentido, lo que conlleva el tema de la crisis institucional (creer en conjunto). Los límites de la experiencia religiosa son redefinidos en la modernidad, lo que abre caminos en distintas direcciones". SUÁREZ, H.J., "A propósito de la Religion pour memoire de D.H. Léger”, Desacatos, No 18, (2005), pág. 182.
} 
misma? ¿Qué entendemos por religión? ¿Cuál es el alcance de las así llamadas religiones seculares que invitan a no limitar la religión a las religiones redentoras ni a las instituciones religiosas históricamente conocidas? ${ }^{1788}$ ¿Podemos hablar de un proceso que lleva a la religión de la salida de la religión ${ }^{1789}$ como ha dado en denominarse a la religión "metafórica" de Jean Séguy ${ }^{1790}$ ? ¿Se trata de la religión metafórica o de una religión reducida a partir de la Modernidad? ${ }^{1791}$ Taylor prefiere hablar de una "confusión" del desencantamiento con el final de la religión. ${ }^{1792}$

¿Hay realmente un proceso de metaforización degradante de las religiones? ¿Se puede seguir hablando de religión en el pleno sentido del término en la Modernidad? ¿Este proceso de metaforización de las religiones en la Modernidad conduce a su desaparición o a su integración en la cultura de la Modernidad? ¿Es la religión metaforizada de Jean Séguy la única religión posible de la Modernidad? ¿Hay una desaparición metafórica de la religión en un proceso ineludible de final, o se trata de una reorganización moderna del creer religioso ${ }^{1793}$ Taylor reflexiona en este sentido sobre la peor versión de la modernidad occidental que inflige una herida sobre lo preaxial y vierte mofa sobre las religiones postaxiales, al propio tiempo que considera una reforma postaxial que busca instaurar una forma de vida que sea buena sin más cualificaciones, como una modalidad de orden armonioso a secas. ${ }^{1794}$

Séguy considera importante la adaptación de las religiones a la Modernidad en base a lo que él denomina espiritualización e intelectualización de las creencias sin merma por ello de su autenticidad religiosa. ${ }^{1795}$ ¿Es la religión metafórica de Séguy una

\footnotetext{
1788 "Es necesario incorporar otras experiencias relacionadas con actividades típicamente seculares, pero que tienen un indudable potencial de trascendencia (como ocurre con todo lo que acontece en el ámbito científico, económico o tecnológico, o en el mundo del arte o el deporte), además de incluir aquellas otras actividades que entran en el dominio de la política y que acompañan al desarrollo de los Estados, constituyendo todas ellas ámbitos diferenciados de acción social". GARCíA, J.L., "Declinaciones de la Religión en la Modernidad", Revista Internacional de Sociología, Vol. 65, No 47, (2007), pág. 205.

1789 "Fuera de ello, una vez llevado a su término ese proceso de descomposición/recomposición del marco humano-social, nada impide considerar la supervivencia indefinida de libres sociedades de creencia y de pensamiento en el interior de una sociedad enteramente desprendida del influjo estructurante de la creencia". GAUCHET, M., El desencantamiento del mundo. Una historia política de la religión, págs. 145-146.

1790 "Jean Séguy cambia esta perspectiva reductora al hacer de la religión metafórica no ya un residuo de la religión del pasado, sino el dispositivo estructurante de lo religioso moderno. (...) Las religiones históricas se encuentran sometidas a este trabajo de metaforización por medio de la intelectualización y la espiritualización, cada vez más agudas, de las creencias sobre las que reposan”. HERVIEU-LÉGER, D., La religión hilo de la memoria, pág. 115.

1791 "Esta perspectiva conduce, en la dinámica de la metaforización, a que se ponga por delante un movimiento de desaparición, al término del cual las religiones de la modernidad difícilmente pueden ser comprendidas de otro modo que no sea considerándolas como formas degradadas de las 'religiones en el pleno sentido del término"'. Ibid., pág. 119.

${ }_{1792}$ Cfr. TAYLOR, Ch., La Era Secular, tII, pág. 403.

1793 "La religión es secular... en el sentido de que la religión ocupa un lugar distinto, compatible con el principio de que toda acción social tiene lugar en un tiempo profano". TAYLOR, Ch., Imaginarios sociales modernos, pág. 223.

${ }_{1794}$ Cfr. TAYLOR, Ch., La Era Secular, tII, pág. 495.

1795 "El trabajo de espiritualización e intelectualización de las creencias, que las rehace desde el interior,
} 
reubicación moderna de la religión que le permitirá recuperar espacios de sustantividad trascendente, o es un proceso intermedio que indica el camino del final? Y Taylor se pregunta: ¿Y qué queda de la fe cristiana? ¿Qué queda del mensaje del evangelio que ha sido retorcido de manera recurrente para que tenga sentido dentro del orden moral moderno $?^{1796}$ Taylor habla de desplazamiento de una vida religiosa a otra. ${ }^{1797}$

Lo que está claro para Hervieu-Léger es que hay una mutación de las estructuras del creer, más que un cambio en los contenidos de la creencia. El creer es la creencia en acto, es la creencia vivida. El creer, como creencias prácticas, es un creer que frecuentemente se desfundamenta y no remite a la fuente, parece no tener sentido. ${ }^{1798}$

Este "modo de creer", según Hervieu-Léger, puede adoptar dos formas de estructuración:

1.- La evidencia espontánea: un creer como algo que se da por hecho, un estado del cuerpo, algo con lo que se nace, aprendizajes primarios de los que apenas se es consciente de los mismos, ${ }^{1799}$ algo que se da como evidente. ${ }^{1800}$ Tiene que ver con el estado incorporado del que habla P. Bourdieu al que pertenecemos y al que nos incorporamos disimulada e inconscientemente. ${ }^{1801}$ Taylor considera este escenario como un ruido de fondo de pluralismo de perspectivas, religiosas y no religiosas y antirreligiosas. $^{1802}$

2.- La convicción teorizada. ${ }^{1803}$ : un creer racionalizado, formalizado, totalmente organizado en su transmisión y del que los creyentes pueden dar cuenta y del que extraen consecuencias prácticas para la vida. ${ }^{1804}$ Taylor habla de la cultura de la

no las vacía de su 'autenticidad' religiosa puesto que es, por el contrario, el medio a través del cual estas pueden conservar su pertenencia cultural y, por tanto, sobrevivir en la modernidad de manera renovada". HERVIEU-LÉGER, D., La religión hilo de la memoria, pág. 120.

${ }^{1796}$ Cfr. TAYLOR, Ch., La Era Secular, tII, pág. 540.

${ }^{1797}$ Cfr. Ibid., pág. 404.

${ }^{1798}$ Cfr. HERVIEU-LÉGER, D., La religión hilo de la memoria, págs. 121-122.

1799 "Resulta innecesario agregar que la socialización primaria comporta algo más que un aprendizaje puramente cognoscitivo. Se efectúa en circunstancias de enorme carga emocional. Existen ciertamente buenos motivos para creer que, sin esa adhesión emocional a los otros significantes, el proceso de aprendizaje sería difícil, cuando no imposible”. BERGER, P. y LUCKMANN, T., La construcción social de la realidad, pág. 165.

${ }^{1800}$ Cfr. BOURDIEU, P., Las estrategias de la reproducción social, Siglo Veintiuno Editores, Buenos Aires, 2011, pág. 214.

${ }^{1801}$ Ibid., pág. 215.

1802 Cfr. TAYLOR, Ch., La Era Secular, tII, pág. 221.

1803 "El carácter de una socialización secundaria como la citada depende del status del cuerpo de conocimiento de que se trate dentro del universo simbólico en conjunto. Se necesita entrenamiento para conseguir que un caballo tire de un carro de abono o para luchar montado sobre él en el combate". BERGER-LUCKMANN, La construcción social de la realidad, pág. 174.

1804 "Claramente se ve en ese caso la magia performativa del poder de instituir, poder de hacer ver y de hacer creer o, en una palabra, de hacer reconocer. No hay frontera que no sea mágica, es decir, impuesta y sostenida (a veces con peligro para la vida) por la creencia colectiva”. BOURDIEU, P., Las estrategias de la reproducción social, pág. 220. 
autenticidad como ser uno mismo en el mundo de hoy y cuyo imperativo moral es la autocultivación. ${ }^{1805}$

Por lo tanto, el gran interrogante aquí es: ¿está en crisis el creer en las sociedades modernas? Según Hervieu-Léger, al pasar de la razón metafísica de la premodernidad, a la razón científico-técnica de la modernidad, se pasa de las preguntas del "por qué" a las preguntas hacia la cuestión práctica del "cómo" (la modalidad del creer de Séguy) con lo que la Modernidad estaría en cierta forma más problematizada para adentrarse en el porqué de las cosas, pregunta que tiene que ver más con las preguntas metafísicas y religiosas. ${ }^{1806}$ Con la Modernidad podríamos decir que se reducen los espacios del creer o se problematizan. La pregunta metafísica del por qué se biologiza o psicologiza en la pregunta por el cómo, en el sentido de que, como afirmará Büchner, todas estas ideas de intervención inmediata de fuerzas sobrenaturales han quedado reducidas a la nada con los descubrimientos de la ciencia moderna. ${ }^{1807}$

No obstante, es indudable que la innegable pregunta por el cómo, acompañada por las respuestas de la ciencia, no agota el manantial de preguntas sobre el porqué del mundo, en la necesidad de búsqueda de seguridad en torno a la inteligibilidad del mundo y a la búsqueda insaciable de sentido. Según la teoría de Hervieu-Léger, la necesidad fundamental de conjurar la incertidumbre estructural de la condición humana no desaparece por el mero hecho de que las cosmizaciones sagradas se desvirtúen debido al proceso de racionalización. ${ }^{1808}$ El hombre moderno, por muchas respuestas a las que acceda desde la ciencia, sin embargo, sigue haciéndose preguntas sobre el porqué. ${ }^{1809}$ En este mismo sentido, según Taylor, más allá de la búsqueda insaciable de la autorrealización del yo, existen algunos bienes y motivaciones cuyo fomento tiene significación. ${ }^{1810}$

Para Hervieu-Léger, la Modernidad rompe con lo sagrado al establecer campos de racionalización mecánica del mundo. Pero esto no significa que el hombre no siga teniendo necesidad de expresar un universo de significados a través de las religiones tradicionales o las religiones seculares como ámbitos nuevos de dicha expresión. El hombre sigue necesitando identificar la condición humana y ubicarla en el orden moral

${ }^{1805}$ Cfr. TAYLOR, Ch., La Era Secular, tII, págs. 283-284.

${ }^{1806}$ Cfr. HERVIEU-LÉGER, D., La religión hilo de la memoria, pág. 123.

${ }^{1807}$ Cfr. BÜCHNER, L., Fuerza y Materia, Sempere y compañía Editores, Valencia, 1909, pág. 60.

${ }^{1808}$ Cfr. HERVIEU-LÉGER, D., La religión hilo de la memoria, pág. 124; cfr. TAYLOR, Ch., Ética de la Autenticidad, pág. 145.

1809 "No debería resultar sorprendente que el proceso de relativización desencadenado por el pluralismo derive en ansiedad. Entre los seres humanos parece existir cierta necesidad de certeza, al menos en torno a las cuestiones fundamentales de la vida: ¿Quién soy yo? ¿Cómo debería vivir? ¿Qué puedo esperar? No se debería sobrevalorar la medida o la intensidad de esta ansiedad. (...) La ansiedad está lo suficientemente extendida como para garantizar un mercado para quienes persiguen supuestas certezas. Estas pueden tener un contenido religioso o secular. BERGER, Los numerosos altares de la modernidad, pág. 126.

${ }^{1810}$ Cfr. TAYLOR, Ch., Fuentes del yo, pág. 685. 
correspondiente a un orden establecido desde el propio orden racional o desde el orden cósmico. $^{1811}$

Racionalizar el mundo no es desacralizarlo ni desencantarlo. Las demandas de significado moral que ubican la condición humana en su propia dimensión trascendente siguen estando presentes. La modernidad ha deconstruido los sistemas tradicionales del creer, sin embargo, como afirmará Hervieu-Léger, no ha vaciado el creer, sino que se expresa de manera distinta: individualizada, subjetiva, dispersa y se resuelve a través de las múltiples combinaciones y disposiciones de significados que los individuos elaboran de manera cada vez más independiente del control de las instituciones del creer. ${ }^{1812} \mathrm{El}$ hombre no puede vivir en la incertidumbre ni en el caos. Ya lo afirmaba Levi-Strauss hablando del hombre primitivo en el sentido de que cada cosa sagrada debe estar en su lugar. ${ }^{1813} \mathrm{Y}$ Taylor lanza el gran interrogante que late en el corazón del hombre moderno: ¿Es esto todo lo que hay? Hay una gran sensación de insatisfacción profunda con una vida encerrada por completo en el orden inmanente. ${ }^{1814} \mathrm{El}$ hombre no puede vivir sin orden moral y sin significados de sentido. Este es el motivo por el que Modernidad tiene que ayudar a ubicar al hombre en un nuevo universo simbólico, desde la racionalidad inherente a ella.

Las teorías de la secularización fueron muy aventuradas al afirmar sin suficiente fundamento que la Modernidad conducía irremediablemente a la secularización. Quizás lo que se entendía por "secularización" era esa deconstrucción del anterior orden moral estructurado por las religiones, pero no se reparó en lo que estaba de fondo bajo esa desfundamentación. La Modernidad deshizo un orden, pero no se negó al orden. Por eso las teorías secularizadoras se quedaron en la primera fase de la deconstrucción, pero no repararon en analizar el orden que se vislumbraba en el horizonte. Para Taylor, la religión sigue indeleble en el horizonte de la arreligión y viceversa, siendo este otro indicador de que el relato oficial requiere ser interpretado en un plano más profundo. ${ }^{1815}$

Quizás este momento representa hegelianamente un tiempo que todavía está por aparecer, algo que está por resurgir, un momento de negación de la negación, de síntesis, de autoconciencia moral cultivada. ${ }^{1816}$ Taylor describe esta situación como un

${ }^{1811}$ Cfr. HERVIEU-LÉGER, D., La religión hilo de la memoria, págs. 126-127; cfr. TAYLOR, Ch., El multiculturalismo y la política del reconocimiento, pág. 48.

${ }^{1812}$ HERVIEU-LÉGER, D., La religión hilo de la memoria, pág. 126.

1813 "Cada cosa sagrada debe estar en su lugar", observaba con profundidad un pensador indígena. Inclusive podríamos decir que es esto lo que la hace sagrada, puesto que, al suprimirla, aunque sea en el pensamiento, el orden entero del universo quedaría destruido; así pues, contribuye a mantenerlo al ocupar el lugar que le corresponde". LEVI-STRAUSS, C., El pensamiento salvaje, Fondo de Cultura Económica, México, 1997, pág. 25.

${ }^{1814}$ Cfr. TAYLOR, Ch., La Era Secular, tII, pág. 332.

${ }^{1815}$ Cfr. Ibid., pág. 464.

${ }^{1816}$ Cfr. HEGEL, F., Fenomenología del espíritu, pág. 505. "El interés del concepto de metaforización radica en mostrar de manera muy exacta el doble proceso de homogeneización y dispersión que funciona en el universo moderno del creer. (...) Esta homogeneización racional del creer es también lo que hace 
deseo irrefrenable de búsqueda en la que cada cual debe buscar su propia inspiración espiritual. $^{1817}$

VIII.- A la reflexión sobre los nuevos horizontes de la espiritualidad moral que va conformando el mundo de la modernidad, se añade otro autor importante en las teorías desecularizadoras y que también estudia Taylor. ${ }^{1818}$ Se trata de José V. Casanova, un autor que invita a repensar la secularización y a poner matices ampliando horizontes. ${ }^{1819}$ Casanova es uno de los más preclaros defensores de repensar las clásicas teorías de la secularización. A pesar de incidir en la evidente secularización entendida como emancipación de las esferas seculares (estado, economía y ciencia) de cualquier tutela religiosa, sin embargo, afirma con contundencia que las clásicas teorías secularizadoras pueden valer para Europa, pero no para Estados Unidos y otras grandes zonas del mundo. El eminente sociólogo Peter Berger ve en él una referencia fundamental a la hora de reformular su teoría de la secularización.

Casanova habla con determinación de un retorno de la religión bajo múltiples formas, al propio tiempo que afirma que lo secular y lo religioso no tienen por qué ser incompatibles. Para Casanova la secularización más importante es la que se manifiesta en la diferenciación de las esferas seculares respecto a las instituciones religiosas, al igual que para Charles Taylor. ${ }^{1820}$ Casanova asevera que el declive de las creencias religiosas y la marginalización de la religión a la esfera privada no están relacionados intrínsecamente con la Modernidad.

Para Casanova, no es fácil analizar el fenómeno secularizador, ya que hay grandes diferencias entre continentes y tradiciones culturales. La religión es una institución más entre las muchas que entran en la arena de la contestación política, por lo que los límites de tal diferenciación no están tan claros y difícilmente pueden darse por establecidos de manera totalmente definida y clara. En este sentido, Taylor afirma, apoyándose en Casanova, que a medida que va desvaneciéndose la sensación de que vivimos en la Cristiandad y que vamos reconociendo que no hay ninguna familia espiritual al mando, o que no habla por el conjunto, habrá una mayor sensación de libertad para decir con

posible el juego dinámico de intercambios entre las religiones históricas y las religiones seculares observado por Jean Séguy”. Cfr. HERVIEU-LÉGER, D., La religión hilo de la memoria, pág. 126.

1817 Cfr. TAYLOR, Ch., La Era Secular, tII, pág. 303.

${ }^{1818}$ Cfr. Ibid., pág. 202.

1819 Cfr. CASANOVA, J., Genealogías de la Secularización, Anthropos, Siglo Veintiuno Editores, Barcelona, 2012, pág. 62. "Si dicha proposición es correcta, entonces la secularización de las sociedades de Europa Occidental puede explicarse mejor en términos del triunfo del régimen del conocimiento de la secularización que en términos de procesos estructurales de desarrollo socioeconómico como la urbanización, la educación, la racionalización”. CASANOVA, J., "La inmigración y el nuevo pluralismo religioso", Revista CIDOB, No 77, (2007), pág. 18.

${ }^{1820}$ Cfr. CASANOVA, J., Genealogías de la Secularización, págs. 55 y ss.; cfr. TAYLOR, Ch., Imaginarios sociales modernos, pág. 214; cfr. TAYLOR, Ch., El Multiculturalismo y la política del reconocimiento, pág. 23; cfr. TAYLOR, Ch., Argumentos filosóficos, págs. 348-353. 
franqueza lo que se quiera $\mathrm{y}$, en algunos casos, las ideas se formularán ineludiblemente en discurso religioso. ${ }^{1821}$

Por otra parte, Casanova observa que el debate de la religión establecido con la Modernidad pudiera verse en muchos casos como una crítica a la Modernidad, por crear debates con las religiones desde prejuicios o desde confrontaciones con la religión que carecen de autenticidad y no se fundamentan de manera adecuada en la racionalidad que dicen defender. Por eso, las religiones están recuperando el espacio perdido desde ellas mismas o el espacio que se les negó por no adecuarse a los planteamientos que aparentemente las ponían al margen en la Modernidad. Taylor afirma, en esta misma línea, que da la impresión de que las religiones aparecen ahora como instituciones que están más del lado de la Modernidad que de otra cosa, y que se ha pasado de una era de la movilización (1800-1950), a una era de la autenticidad posdurkheimiana (1960). ${ }^{1822}$

Tras todos los debates que están teniendo lugar desde distintos puntos de vista, no hay que olvidar, según Casanova, que hay que seguir profundizando en el alcance de las teorías secularizadoras y analizar con detenimiento en qué medida tienen fundamento o si es necesaria una narración más lúcida y fundamentada del orden moderno de las cosas, y ver en qué medida se ha ido gestando la arqueología y la genealogía de la secularidad en la Modernidad. Según Taylor, quedan muchas cosas por desvelar o elementos que están en proceso de resurgir y que precisan de una mayor claridad para poder ser analizados en toda su complejidad. Taylor considera que esta etapa postdurkheimiana alberga grandes dosis de ambigüedad y de creencia sin pertenencia. $^{1823}$

Casanova pretende ser un punto de encuentro entre los autores europeos, defensores en su mayoría de las clásicas teorías de la secularización, y los autores americanos, más bien proclives a reducir dichas teorías a la mínima expresión, debido a su falta de validez o a ser solo un referente en algunos aspectos para la realidad europea.

Para Casanova, los sociólogos europeos consideran fundamentalmente la secularización de la diferenciación de esferas y el declive de las creencias y prácticas religiosas. Como si uno llevara irremediablemente al otro y viceversa. Para los sociólogos americanos, la secularización solo se limitaría a la segunda, como si fuera un asunto sin mayor importancia que con el tiempo se reubicará o alcanzará la expresión que le corresponda dentro de la Modernidad. En América, la sociedad está constituida secularmente desde sus orígenes y sin embargo las prácticas religiosas no solo experimentan un declive, sino que además da la impresión de un resurgimiento de las

\footnotetext{
${ }^{1821}$ Cfr. TAYLOR, Ch., La Era Secular, tII, pág. 373.

1822 Cfr. TAYLOR, Ch., Hegel, pág. 43; cfr. TAYLOR, Ch., La Era Secular, tII, pág. 344.

${ }^{1823}$ Cfr. Ibid. pág. 353.
} 
mismas. Los sociólogos americanos, según Casanova, hablan de la secularización como de un mito europeo que no se sostiene. ${ }^{1824}$

Casanova opina que, tanto los europeos como los americanos, tienden a exagerar sus puntos de vista de una manera no suficientemente lúcida y fundamentada; los americanos incidiendo en su religiosidad y los europeos en su supuesta irreligiosidad. Matizando conceptos, se podría afirmar que quizás los europeos no son tan irreligiosos como dicen ser o el alcance de dicho adjetivo debe ser matizado mucho. ${ }^{1825}$ En opinión de Taylor, siguen vivas muchas formas de la era de la movilización. ${ }^{1826}$

Por otra parte, para Casanova no todo el así llamado proceso secularizador de la Modernidad debe descansar en el mundo de las ideas filosóficas de la misma. Hay otros procesos históricos, económicos, culturales que deben ser analizados también y que, por otra parte, no homogeneizan todas las realidades geográficas europeas de la misma manera. Además, no se debe olvidar que también hay elementos, como las relaciones Iglesia-Estado, que había dentro de las propias Iglesias y en sus relaciones con los Estados, que han establecido características propias y que han determinado el alcance secularizador de muy diversas maneras. Por todo lo cual, también para Taylor, la situación no es tan sencilla de determinar y habría que matizar muchos conceptos a la hora de analizar la así llamada teoría de la secularización. ${ }^{1827}$

El futuro de la religión en Europa no es analizado en los mismos términos dependiendo si se parte de posiciones conservadoras, liberales o socialdemócratas. No obstante, todas las posiciones dan la bienvenida a todas las personas de cualquier clase, cultura, religión y condición, siempre y cuando respeten nuestra cultura y normas seculares, tradiciones e historia moderna; aunque con frecuencia se tiende a ser poco liberal cuando se quiere limitar el alcance de la religión a la esfera estrictamente privada, como si fuera una amenaza a las sociedades seculares y a la laicidad. Taylor se

\footnotetext{
1824 "Religious participation was very low in northern and western Europe many centuries before the onset of modernization. (...) The second reason to reject claims about the secularization of Europe is that current data do not reveal the arrival of an age of 'scientific atheism'. Levels of subjective religiousness remain high - to classify a nation as highly secularized when the large majority of its inhabitants believe in God is absurd". STARK, R., "Secularization RIP", Oxford Journals, Sociology of Religion, Vol. 60, No 3, (1999), pág. 254. Cfr. TAYLOR, Ch., El multiculturalismo y la política del reconocimiento, págs. 14, 20-21, 34-35; cfr. TAYLOR, Ch., Imaginarios sociales modernos, pág. 222.

1825 "En cualquier caso, en toda Europa, desde la década de los sesenta, una parte cada vez mayor de la población ha dejado de participar en las prácticas religiosas tradicionales. (...) En este sentido, deberíamos hablar tal vez de la deseclesiastización de la población europea y de la individualización religiosa, más que de secularización. Al mismo tiempo, sin embargo, muchos europeos, incluso en los países más seculares, todavía se identifican a sí mismos como 'cristianos', aduciendo una implícita, difusa y sumergida identidad cultural cristiana”. CASANOVA, J., "La inmigración y el nuevo pluralismo religioso", Revista CIDOB, No 77, (2007), pág. 17.

${ }_{1826}$ Cfr. TAYLOR, Ch., La Era Secular, tII, pág. 355.

${ }^{1827}$ Cfr. TAYLOR, Ch., Argumentos filosóficos, pág. 279.
} 
pregunta: ¿es liberal negar cualquier expresión de religión dentro de la esfera pública? ¿Cómo se armonizan los principios liberales con la libertad de expresión? ${ }^{1828}$

Por otra parte, como hemos venido insistiendo, no se puede identificar la modernidad secular europea con el mundo y no se puede identificar los procesos europeos con los vividos a escala mundial. Casanova considera que habría que hablar, más bien, de la excepcionalidad europea que de su alcance universal. Europa es una excepción no la norma o regla que define el mundo. ${ }^{1829}$ De tanto afirmar que el proceso de la modernidad secular europea es el paradigma de todos los procesos que se realizarán a nivel mundial con una perspectiva globalizadora, se llega a creer que el fenómeno de la secularización es algo prácticamente inevitable e irreversible, convirtiéndose así en una profecía que se autocumple. ${ }^{1830}$ En todo el mundo se ha producido ese resurgir de la religión, pero no precisamente siguiendo el paradigma de la modernidad secular occidental. ${ }^{1831}$

Se trata de romper con ese círculo vicioso que pone vendas a un análisis adecuado de la realidad del mundo actual. Stark y Casanova hacen referencia a Alexis de Tocqueville en su defensa del libre ejercicio de la religión, intentando superar en América los prejuicios de la Ilustración europea hacia la religión.

Casanova distingue las sociedades contemporáneas "en" la modernidad, y las sociedades contemporáneas "de" la modernidad. ¿Se puede considerar una sociedad contemporánea que está en la modernidad y no comparte la modernidad? ¿Todas las sociedades contemporáneas "en" la modernidad se encaminan irrefrenablemente hacia sociedades "de" la modernidad?

¿Se puede hablar de un "espacio global homogéneo", tal y como refiere Casanova, en el que todas las sociedades "en" la modernidad lleguen a compartir el mismo espacio "de" la modernidad como sociedades seculares liberales modernas? ¿No hay otro espacio que la globalización que va de estar "en" la modernidad a la modernidad "de" la que se forma parte de manera ineludible? ¿Tiene la globalización un alcance tan

\footnotetext{
${ }^{1828}$ Cfr. Ibid., págs. 244-245, 266-267. "El objeto de este ensayo no es el llamado libre arbitrio, sino la libertad social o civil, es decir, la naturaleza y los límites del poder que puede ejercer legítimamente la sociedad sobre el individuo, cuestión que rara vez ha sido planteada y casi nunca ha sido discutida en términos generales". MILL, J.S., Sobre la libertad, Alianza Editorial, Madrid, 1981, pág. 55.

${ }^{1829}$ Por otra parte, estos procesos de secularización tal y como se han experimentado en Europa no son válidos para religiones como el taoísmo o el confucionismo ya que en principio son "religiones mundanas" o laicas y no precisan "secularizar" algo que es de por sí secular dado que por otra parte carecen de organización eclesiástica.

${ }^{1830}$ Cfr. CASANOVA, J., Genealogías de la Secularización, págs. 62-64.

${ }^{1831}$ Cfr. KEPEL, G., La revancha de Dios. Cristianos, judios y musulmanes a la reconquista del mundo, Madrid, Anaya y Mario Muchnik, 1991.
} 
irrefrenable que ninguna sociedad contemporánea "en" la Modernidad puede dejar de formar parte "de" la Modernidad? ${ }^{1832}$

Por otra parte, según Casanova, en la modernidad latino-católica surge un enfrentamiento entre el Cristianismo y la ciencia, el capitalismo y el estado Moderno. La genealogía secularista de la modernidad en el ámbito latino-católico ha sido la historia de un enfrentamiento, de una emancipación triunfante de la razón y la secularidad frente a la religión. Por el contrario, la genealogía de la secularidad en el ámbito anglo-protestante es distinta: el Cristianismo protestante está más comprometido en el surgimiento de la secularidad moderna y no existe el conflicto que se dio en el ámbito de la modernidad latino-católica.

En este sentido, y completando la idea anterior, se pueden localizar, según Casanova, dos trayectorias desde el proyecto del Cristianismo medieval del saeculum: una trayectoria en la que se da una expansión y acrecentamiento de las narrativas seculares a costa de una reducción de la esfera religiosa; y otra trayectoria que tiene que ver con la ruptura de los muros del monasterio y la consiguiente interacción de dos mundos que interactúan mutuamente: la religión en lo secular y lo secular en la religión, produciéndose una difuminación de ambos límites y no sabiendo muy bien dónde empieza una esfera y dónde empieza la otra. Casanova cita a Asad en su obra Formations of the Secular y se pregunta si la insistencia sobre una aguda separación entre lo religioso y lo secular conlleva la paradójica pretensión de que lo secular continuamente produce a lo religioso. ${ }^{1833}$

Lo que está claro, según Taylor, es que, con la Modernidad, tanto en el ámbito católico (problemáticamente) como en el ámbito protestante (hegelianamente), se va produciendo la pérdida de identidad neodurkheimiana y la referencia religiosa en nuestra identidad no desaparece tanto como cambia, "se retira a una cierta distancia". ${ }^{1834}$

\section{IV.4.2.-NARRACIONES FILOSÓFICO-POLÍTICAS}

Hay otro tipo de relatos sobre la secularización que se enmarcan más bien dentro de una caracterización más filosófica. Para Taylor, personajes de la época romántica, como Marx, Wagner, Bakunin, Berlioz o Hugo, intentaban responder a las insatisfacciones de la época con líneas de ataque en las que se entremezclaban la vacuidad, la falta de belleza, la separación del yo y la naturaleza, el atomismo y la injusticia del mundo contemporáneo. Marx representa la única perspectiva que persiste

\footnotetext{
${ }^{1832}$ Cfr. CASANOVA, J., Genealogías de la Secularización, pág. 66.

${ }^{1833}$ Cfr. Ibid., pág. 69.

${ }^{1834}$ Cfr. TAYLOR, Ch., La Era Secular, tII, pág. 356.
} 
hasta hoy, pudiendo asimilarse su Movimiento marxista a una religión laica, aunque esta pseudorreligión está hoy en un marcado declive. ${ }^{1835}$

\section{HEGEL}

Según Taylor, hay un desplazamiento del orden benevolente expresado en la naturaleza hacia otras formas más complejas que incluyen una síntesis más completa del orden moral de la Modernidad. Partiendo del deísmo estándar se llegará a variantes secularizadas de esta religión de la naturaleza, transitando por etapas intermedias que interpretarán a Dios como luchando en la naturaleza y que halla su voz en nuestro interior. Aquí se encuentran el Romanticismo, Hegel y el primer Schelling. ${ }^{1836}$

Para Hegel, es importante hacer una trama que lleve a la síntesis entre lo finito y lo infinito. El conocimiento filosófico tiene que poner frente a frente el ámbito de la religión (la materia y la totalidad absoluta, la autoconciencia, la libertad) y el ámbito de la conciencia y de lo finito (materia finita, ciencia finita, las conexiones y relaciones entre lo determinado, el establecimiento conceptual de lo finito, establecer un sistema para sí en lo contingente...).

Esta "secularización” que lleva a no hacer síntesis filosófica entre lo finito y lo infinito es lo que Hegel denomina por una parte Idealismo"en el que todo queda inmerso en Dios en una religión de lo abstractamente positivo o quedarse en una conciencia del mundo sin centro de gravedad. En el primer caso no hay conocimiento y en el segundo se da un conocimiento finito. ${ }^{1837}$

Lo importante aquí es destacar esta perspectiva de la secularización en la que la religión y la ciencia están desplegadas en ámbitos totalmente independientes. Por una parte, la religión carece de conocimiento del mundo (no hay ciencia, no hay conocimiento) y a su vez la ciencia (conciencia) despliega un conocimiento sin centro de gravedad, es decir, se da un conocimiento de causas y relaciones en el ámbito de lo contingente y lo determinado, estableciéndose tan solo conexiones necesarias.

La superación de esta oposición en una síntesis filosófica entre religión y ciencia llevaría a establecer no solo "conexiones necesarias" en el ámbito de lo contingente, sino que llegaría a realizar "conexiones absolutas", es decir, a establecer un centro de gravedad en el conocimiento del mundo para que así las oposiciones realicen una síntesis en el ámbito de lo absoluto y superar lo contingente. Taylor, en este sentido, piensa que la filosofía de la Ilustración, que intenta trazar los fines y propósitos del hombre fuera de él mismo, carece de sentido. No puede encontrar una objetividad

\footnotetext{
${ }^{1835}$ Cfr. TAYLOR, Ch., La Era Secular, tII, pág. 151.

${ }^{1836}$ Cfr. TAYLOR, Ch., Fuentes del yo, pág. 507.

${ }^{1837}$ Cfr. HEGEL, Filosofía de la Religión, págs. 29-42. Sobre la relación entre Filosofía y Religión.
} 
verdadera. Para hacer esto, debe redescubrir el vínculo del hombre con algo más elevado, con algo mayor, con el Geist, con Dios. Por eso, para Hegel solo la filosofía ayuda a superar esta oposición secularizadora y a movernos a la forma más alta de conocimiento absoluto. Cuando la filosofía alcanza su máximo desarrollo, expresa el mismo contenido que la religión, pero de otra forma. Esta forma es la del pensamiento. Comprendiendo el absoluto en conceptos, la filosofía ve la necesidad interna que subyace al contenido de la religión revelada y lo hace manifiesto. Es la cima de la filosofía que en la síntesis hegeliana ha pretendido recapitular ultimadamente el contenido pleno en el pensamiento. Todo ha consistido en hacer posible el llegar hasta aquí, aunque en cada etapa de la filosofía lo nuclear ha sido intentar capturar el absoluto en conceptos. ${ }^{1838}$

Hegel señala el intento de realizar la síntesis representacional a partir de algo que podemos identificar como un espíritu cósmico o un proceso en el que se alcanza la autoconciencia, en su capacidad para captar lo infinito y determinarlo a partir de la filosofía, haciendo una síntesis absoluta entre objetividad y subjetividad, entre conciencia y religión, entre lo eterno y lo finito. La filosofía es el intento por descubrir, en la apariencia, "la potencialidad de lo que viene a la luz". ${ }^{1839}$

Esta reconciliación con el Absoluto en la filosofía presupone una reconciliación en la vida. Reconciliación que está personificada en el Estado. El Estado no puede ser confesional, debe desplegar sus articulaciones a partir de su mismo concepto. Ha de estar fundamentado completamente en la razón y, por tanto, no puede estar basado en la mera fe en la verdad, debe tener un fundamento independiente en la razón. Para Hegel, esta secularización del Estado ha sido posible por causas históricas, como por ejemplo la Reforma, en la que de alguna manera ha actuado la astucia de la razón. Pero, por otra parte, afirma que la religión no está superada. ${ }^{1840}$ Cuanto mayor sea la separación entre lo inmanente y lo transcendente, menos adecuada será la concepción de lo Absoluto. ${ }^{1841}$ Y cuanta menor sea la brecha entre lo sagrado y lo secular, entre lo finito y lo infinito, entre la conciencia y la religión, más adecuada es la expresión de lo Absoluto. Es decir, este crecimiento en conciencia requiere que los hombres se cultiven ellos mismos y adquieran una forma de vida que exprese lo universal. Por tanto, para que los hombres sean capaces de ver la de la Encarnación tienen que alcanzar cierta etapa de madurez. Este es el verdadero acontecimiento, el correlato objetivo de la percepción por la fe de que Dios se ha vuelto hombre. Y esto, como todo lo demás en la historia, es hasta tal

\footnotetext{
${ }^{1838}$ Cfr. TAYLOR, Ch., Hegel, págs. 440-441.

1839 TAYLOR, Ch., Argumentos filosóficos, pág. 164.

1840 “Aunque llegó a ver desde entonces la importancia suprema de la filosofía, nunca cambió de parecer respecto al rol irremplazable de la religión. Lo que se transformó más bien fue su apreciación del cristianismo ortodoxo, que vio entonces a través de los ojos de la filosofía especulativa como la religión absoluta, más que una aberración 'positiva' derivada de la enseñanza moral pura de Jesús". TAYLOR, Ch., Hegel, pág. 423.

${ }^{1841}$ Ibid., pág. 169.
} 
punto la obra del Geist, la sustancia de las cosas, que podemos hablar de esta sustancia en sí misma volviéndose realmente autoconciencia. El sí mismo Absoluto se realiza en el "mí mismo" encarnado en un Yo Puntual Divino. ${ }^{1842}$

Hay un proceso secularizador también en la evolución de las religiones naturales al Cristianismo. Unas religiones naturales en las que se puede afirmar que la expresión y la autoconciencia del Geist es muy limitada debido a que el hombre no es capaz de captar su universalidad, dado que se encuentra en una etapa muy primitiva del acceso a su autoconciencia racional. ${ }^{1843}$ Se puede rastrear la definitiva racionalidad detrás de las distintas etapas de la historia, esto es, el movimiento del Espíritu que lleva a la conducción del Geist hacia la etapa final de la autorrevelación racional. ${ }^{1844}$

Para Hegel,

"el espíritu de la religión manifiesta todavía no ha sobrepasado a su conciencia en cuanto tal, o lo que es lo mismo, su autoconciencia efectiva no es el objeto de su conciencia; él mismo, como tal, y los momentos que dentro de él se diferencian, caen en el representar y en la forma de la objetualidad. El "contenido" del representar es el Geist; y ya únicamente se trata de asumir esta mera forma o, mejor dicho: puesto que la forma pertenece a la conciencia como tal, su verdad tiene que haberse dado ya en las figuras de la conciencia". ${ }^{1845}$

En la medida en la que el espíritu infinito se va autorrevelando como autoconciencia racional, en esa misma medida el espíritu finito se va comprendiendo a sí mismo como conciencia y posibilidad hacia la comprensión de lo universal. Y será, según Hegel, la filosofía especulativa la que realizará esa integración. ${ }^{1846}$ En este sentido, sostiene Taylor que Hegel desmitifica y desteologiza el Cristianismo y considera las teologías contemporáneas de la muerte de Dios con sus nietas espirituales, dado que, según Taylor, Hegel fue un teólogo de la muerte de Dios, puesto que la muerte de Cristo es necesaria para que venga el Espíritu. ${ }^{1847}$

\section{FEUERBACH}

Para Taylor, los antiguos hegelianos se disputan entre las concepciones centradas en el hombre o en Dios, acerca de la interpretación de su sistema. Los antiguos hegelianos llevaron su filosofía al rumbo de un teísmo ortodoxo y los jóvenes hegelianos hacen una interpretación centrada en el hombre, en donde el Geist se volvía idéntico al hombre, antropologizando el espíritu de Hegel. Y esto culmina en Feuerbach

\footnotetext{
${ }^{1842}$ Cfr. TAYLOR, Ch., Hegel, pág. 179.

${ }^{1843}$ Cfr. HEGEL, Fenomenología del Espíritu, págs. 433-440

${ }^{1844}$ Cfr. TAYLOR, Ch., Hegel, pág. 170; cfr. Ibid., págs. 432-444.

1845 HEGEL, Fenomenología del Espíritu, pág. 503.

${ }^{1846}$ Cfr. Ibid., págs. 498-499.

${ }^{1847}$ Cfr. TAYLOR, Ch., Hegel, pág. 431.
} 
y el joven Marx. Para nuestro hermeneuta, ambos supuestos son falsos, pues la síntesis hegeliana no pretendía ser ni teísta ni atea.

Feuerbach, en su relato secularizador afirma que la esencia del hombre es la conciencia del infinito, el tener un espíritu universal capaz de religión y trascendencia. Una conciencia del infinito que no es otra cosa que la conciencia de la propia infinitud, es consciente de la infinitud de su propia esencia. ${ }^{1848}$ Según el pensamiento de Feuerbach, la esencia del hombre es razón, voluntad y corazón, es decir, inteligencia, carácter y amor. El hombre pues, existe para conocer, para amar y para querer. El hombre es consciencia de sí mismo, el objeto de dicha conciencia es el "sí mismo" y la conciencia es afirmarse a sí mismo, es ser consciente de la propia consciencia. Y la forma más alta de afirmarse a uno mismo es la conciencia. Al infinito lo determinan las propias facultades de la inteligencia que son las que crean dicha realidad trascendente. $\mathrm{Si}$ somos capaces de ser conscientes de la infinitud es que existe porque nosotros lo creamos. No es Dios el que crea al hombre a su imagen y semejanza, sino que es el hombre el que crea a Dios a partir de su propia especulación trascendental, de su capacidad para sentir lo que el sentimiento humano es capaz de expresar. El órgano del sentimiento crea lo divino porque el sentimiento es la esencia de lo divino y se identifica con lo que expresa. El sentimiento es divino, luego el sentimiento (como órgano y capacidad humana) crea lo divino. El hombre identifica el sentimiento con lo divino, luego el hombre crea lo divino. El sentimiento que se deleita consigo mismo es la esencia de lo divino. No hay otra esencia que ese autocontemplarse en el sentimiento. ${ }^{1849}$ Es la propia subjetividad la que crea a Dios, en continuidad con la razón trascendente kantiana.

Y a partir de ahí, Feuerbach afirma que, si la realidad divina existe por el sentimiento que la crea, entonces no tiene sentido el contenido sagrado de la fe cristiana, porque no hay necesidad de una realidad trascendente objetiva, ya que el único contenido trascendente es el que crea el hombre a través del sentimiento que se autoidentifica con lo divino.

Y si la esencia de la religión es el sentimiento que se autocontempla a sí mismo como religioso, entonces no puede haber sentimientos no-religiosos, dirá Feuerbach.

\footnotetext{
${ }^{1848}$ Cfr. FABRO, C., Feuerbach. La esencia del cristianismo, Magisterio Español, Toledo, 1977, 235 págs.; PIÑÓN GAYTÁN, J.F., "Feuerbach: Dios como esencia del hombre (Homo homini Deus)" Andamios, Vol. 11, No 24, México, 2014; LÓPEZ BOLÍVAR, M.C., "Feuerbach, el giro", Perseitas, No 6, (2018), págs. 319-350.

1849 "Por eso, todo lo que, en el sentido de la especulación trascendental, de la religión, tiene solamente el significado de algo derivado, subjetivo, humano o también de un medio, de un órgano, tiene en el sentido de la verdad el significado de lo original, de lo divino, de lo esencial y del objeto mismo. (...) El sentimiento es el órgano de lo divino. El sentimiento es lo más noble, lo más sublime y, por lo tanto, lo más divino, en el hombre. ¿Cómo podrías percibir lo divino por el sentimiento, si este no fuera de naturaleza divina? (...) Dios solo puede ser percibido por sí mismo”. FEUERBACH, L., La esencia de cristianismo, pág. 44.
} 
Todo sentimiento que se autocontempla es el fundamento de la religión. Si el sentimiento es el órgano de lo divino el sentimiento es lo divino, pues lo divino solo es percibido por lo divino. O lo que es lo mismo: la naturaleza del sentimiento es para Feuerbach la esencia de lo divino.

Por lo tanto, el Dios de Feuerbach adquiere la siguiente dimensión "atea" como sentimiento puro, limitado y libre. ${ }^{1850}$ No hay pues un Dios objetivado distinto del sentimiento. No hay que tener, según Feuerbach, miedo ni temor a reconocer el único sentimiento exclusivo que nos habita. Un sentimiento vacío de cualquier objetividad divina. Reconocer otra cosa es volver a las antiguas preguntas, a los referentes morales de una religión que autoengaña por todo tipo de prejuicios sociales. Cuando la esencia de la religión es el sentimiento, todo lo demás es engaño y mentira. No se puede ir más allá del sentimiento y crear una realidad engañosa. Por mucho que quiera ir más allá, el hombre no puede entrar en mundos de imaginación y entelequia, su esencia es el puro sentimiento y más allá no hay nada.

Dicho con otras palabras, para Feuerbach, la conciencia del objeto trascendente y la conciencia de sí mismo coinciden. No hay otro objeto que no sea la conciencia de uno mismo. La religión no es otra cosa que la conciencia del hombre de sí mismo, de su oculta subjetividad, sus pensamientos más íntimos. Esta conciencia de su esencia, de sí mismo, de su yo, no se identifica con la conciencia divina, pues sería tal como reconocer a un ser trascendente ajeno al hombre y llevaría a reconocer una esencia primaria fuera de sí, en otro ser. Esa sería una etapa primitiva de la evolución humana caracterizada por identificar la esencia propia con un Ser Exterior al margen de uno mismo. ${ }^{1851}$ Por el contrario, Dios es el yo autorrevelado del hombre. ${ }^{1852}$

Para Feuerbach, las religiones desposesionan al hombre de su propia conciencia, de su propia esencia, como si su esencia se identificara con un Ser distinto, trascendente, ajeno a él mismo. La esencia divina no es otra cosa que la esencia humana. Con lo cual el hombre religioso de alguna manera, inconsciente de su propia esencia, se ha autoinmolado en la idolatría a lo exterior divino. Cuando es consciente de su propia esencia, entonces deja de mirar fuera para mirar solo dentro de sí mismo, pues

\footnotetext{
1850 “Dios es el sentimiento puro, limitado y libre. Cualquier otro Dios que pones aquí, es un Dios impuesto a tu sentimiento por fuerzas extrañas. El sentimiento es ateo en el sentido de la fe ortodoxa y, como tal, la religión necesita un objeto externo". Ibid., págs. 47-48.

1851 "La religión anterior es idolatría para la posteridad: el hombre hizo adoración de su propia esencia. El hombre se ha objetivado, pero no se dio cuenta que el objeto era su propia esencia; la religión posterior hace este paso; cada progreso de la religión es, por lo tanto, un conocimiento más profundo de sí mismo". Ibid., pág. 54.

1852 "La conciencia de Dios es la conciencia que tiene el hombre de sí mismo, el conocimiento de Dios es el conocimiento que tiene el hombre de sí mismo. Conoces al hombre por su Dios, y viceversa, por su Dios conoces al hombre; ambas cosas son idénticas. Lo que para el hombre es Dios, es su espíritu y su alma; y lo que es el espíritu del hombre, su alma, su corazón, es precisamente su Dios, y Dios es el interior revelado, el yo perfeccionado del hombre”. Ibid., pág. 52.
} 
no hay nada ajeno a su propia esencia. Reconocer esa existencia divina como restos de una antigua religiosidad, es vivir al margen de su propia esencia, es autoengaño, dogmatismo y vivir una existencia negativa, un vivir en la tibieza. De alguna manera, como en el caso de la ética de la creencia, no se tiene el arredro para autoafirmarse en la propia verdad de la esencia humana y se vive en la autocomplacencia engañosa. Incluso Feuerbach lo define como un ateísmo sutil y astuto o una vergüenza religiosa.

Feuerbach afirma que un Dios que sea reconocido temerosamente por los restos de una religiosidad engañosa, es un Dios que no tiene la fuerza de existir o que no tiene corazón. Hay que avanzar por los caminos del olvido de la religión, porque sin ese olvido absoluto, el hombre no se reconocerá en su propia esencia. Hay que llegar a una situación existencial en la que Dios sea un olvido completo o una existencia sin sabor.

Para Feuerbach, el carácter absoluto de Dios se identifica con "lo que es para mí". No hay un Dios distinto de lo que es para mí. Soy yo el "artífice" de Dios, el que lo determino, pues concederle otras cualidades sería vivir en un mundo de entelequia y de imaginación autoengañosa. Si se hiciera distinción entre mi esencia y la esencia divina, entonces el hombre viviría en una ilusión. No aparece un objeto distinto al que aparece para mí o lo que es para mí. Dios en sí es Dios para mí, soy yo el que pongo la esencia de Dios al identificarla con mi esencia y lo que es para mí. ${ }^{1853}$

Toda realidad trascendente para Feuerbach es puro antropomorfismo, porque si los predicados divinos son imágenes antropomórficas, también lo será el sujeto, la esencia divina. Todo es mera proyección antropomórfica. ${ }^{1854}$ La idea de Dios no surge como algo que se le presente objetivamente al hombre, sino como una proyección de los predicados divinos que deben incluir una esencia divina, fruto de la conciencia histórica y el pensamiento. El hombre existe independiente de los atributos que se le puedan conceder. Lo que determina al hombre no es la proyección de predicados divinos, sino su sola existencia. Esta es su esencia. En el hombre esencia y atributos se identifican, esencia y sujeto es lo mismo, el atributo es la verdad del sujeto, el atributo es la personificación del yo. Luego no necesita de ningún ser trascendente para proyectar sobre él sus propios atributos, ya como sujeto, ya como predicado. En el hombre se encuentra la realidad completa de la existencia. Y afirmar una realidad abstracta al margen del propio sujeto sería negarse a sí mismo en su esencia. Su esencia como sujeto es Dios. Dios es el hombre. Y no puedo dudar de mi esencia, luego no puedo dudar de Dios; pero un Dios que se identifica con la esencia del hombre.

${ }^{1853}$ Cfr. TAYLOR, Ch., Hegel, pág. 62.

${ }^{1854}$ Algunos han visto en la conciencia desdichada hegeliana la "antropomorfización" del espíritu hegeliano en Marx y Feuerbach. En Hegel por el contrario el hombre es un "vehículo del espíritu". El Espíritu es algo más grande, lo que provoca en el hombre un "entusiasmo extático". Cfr. HEGEL, Fenomenología del Espíritu, págs. 143-150; cfr. TAYLOR, Ch., Hegel, pág. 139. 
Dios es para Feuerbach el ser humano contemplado como la verdad de sí mismo. ${ }^{1855}$ Dios es el hombre mismo porque el hombre es el que determina la esencia divina, el que lo crea, porque no puede haber una esencia por encima de él. No hay una realidad trascendente, en su esencia, distinta de la esencia humana. De lo que está más allá de la esencia del hombre no hay certeza. Cuando se rompe la única esencia humana vivida como consciente autocontemplación y se diferencia dicha esencia de otra esencia superior, entonces se realiza abstracción filosófica, destrucción del sujeto y la afirmación de una apariencia al margen de la propia esencia humana. Se destruye el nexo indisoluble entre sujeto y predicado como esencia humana, al atribuir una oposición entre ambos elementos de la esencia humana y rompiendo así la esencia humana como algo inmediato de lo que no se puede dudar. La afirmación de una esencia superior significaría romper la inmediatez de la esencia humana, destruyendo la propia autoidentificación del ser humano. Proyectar los atributos divinos sobre la esencia humana supondría hacer una ruptura en el sujeto finito que le impediría la autoconsciencia inmediata.

Si Dios es una esencia distinta de la esencia del hombre, ¿qué le importa al hombre su existencia o su no existencia? O Dios se identifica con el hombre, o es el hombre, o no le aporta nada. ${ }^{1856}$ Es el camino irreversible hacia el establecimiento del marco inmanente en el que, como afirma Taylor, nuestra posición nos inserta en una imagen que somos incapaces de impugnar. ${ }^{1857}$

\section{MARX}

Marx, en la crítica al artículo de Bruno Bauer titulado "Sobre la cuestión judía”, aboga por suprimir la religión para así evitar de raíz cualquier oposición entre confesiones religiosas y posibilitar que el camino de la ciencia siga su curso natural de la historia como verdad única, dejando las "pieles de la serpiente" como algo superado y del pasado. Solo entonces el hombre podrá relacionarse con otros hombres, no según una relación religiosa, sino con una relación científica y verdaderamente humana. ${ }^{1858}$

En un Estado, el alemán, en el que no hay ciudadanos porque el Estado es un estado religioso o teológico, la cuestión judía para Marx es irrelevante, porque de lo que

\footnotetext{
1855 "Solo cuando se piensa que Dios sea algo abstracto, que sus predicados sean el producto de una abstracción filosófica (...). Un Dios que tiene predicados abstractos, tiene también una existencia abstracta. La existencia y la esencia son tan diferentes como es la cualidad". FEUERBACH, L., La esencia de cristianismo, pág. 70.

${ }^{1856}$ Cfr. Ibid., pág. 125.

${ }^{1857}$ Cfr. TAYLOR, Ch., La Era Secular, tII, págs. 648,745.

1858 "Solo cuando el cristiano y el judío lleguen a ver sus religiones opuestas como meros estadios diferentes en la evolución del espíritu humano, como diversas pieles de serpiente abandonadas por la historia, y al hombre como la serpiente cuya piel han sido. Entonces dejarán de hallarse en una relación religiosa, para establecer una relación ya solo crítica, científica, una relación humana. La ciencia será entonces su unidad. Y los conflictos en la ciencia se resuelven por la ciencia misma". MARX, K., Escritos malditos. Sobre la cuestión judía y otros textos, Libros de Anarres, Buenos Aires, pág. 15.
} 
se trata es de liberar al Estado, y por ende también a los judíos, de cualquier atadura de tipo teológico, pues el Estado alemán tiene en ese momento un fundamento cristiano. $^{1859}$

Así pues, la secularización para Marx no es evitar simplemente las cuestiones religiosas, sino dar a dichas cuestiones un alcance profano. Se trata, en otras palabras, de hacer del Estado la religión del espíritu humano. Hay que ser conscientes de la reducción histórica, promovida por la superstición religiosa, y ensanchar la vida del mundo a través de una nueva comprensión de la historia. Cuando se supriman las barreras humanas que ha causado la religión de la superstición, se caerán inexorablemente las barreras religiosas, pues son estas las que han causado dichas barreras. En este sentido, Taylor incide en la idea de que, una vez demolido el viejo orden cósmico exponiéndolo como una ilusión o farsa, la Ilustración promovió un nuevo orden social al margen de dicho orden en la gran cadena del ser y se configura una nueva sociedad entendida como instrumento común que posibilite el intercambio mutuo y la felicidad. Es evidente que la nueva conciencia de la humanidad luchará contra la injusticia y todo aquello que provoque la pérdida de esa felicidad. ${ }^{1860}$ Taylor afirmará, citando a Marx, que "todo lo que es sólido se disuelve en el aire", dando a entender que, a partir de Marx, nos encaminamos hacia una pérdida de resonancia, profundidad y riqueza en nuestro entorno humano, tanto en las cosas como en los lazos que nos unen con los demás. ${ }^{1861}$

Para Marx, hay una contradicción inherente al estado religioso, pues el Estado entra en contradicción con la religión, ya que no puede desarrollar los elementos que lo definen como Estado si este tiene una fundamentación religiosa. El Estado, en este caso, desarrolla una debilidad religiosa, pues no es propio del Estado fundamentarse en la religión; y, por otra parte, tampoco desarrolla los fundamentos propios del Estado, porque la religión le limita y le reduce. ${ }^{1862}$

La religión debe ser un asunto totalmente privado y el Estado debe estar totalmente al margen de la religión. El Estado debe desarrollar los asuntos propios que le competen, al margen de la religión, y esta debe desarrollarse por la libertad y el

1859 "La existencia de la religión es la existencia de una carencia, la fuente de esta carencia no puede ser buscada sino en el mismo ser del Estado. La religión ya no es para nosotros el fundamento sino solo el fenómeno de los límites que presenta el mundo. Por tanto, las trabas religiosas de los libres ciudadanos las explicamos partiendo de sus trabas profanas. No afirmamos que tienen que superar su limitación religiosa para superar sus barreras mundanas. Afirmamos que superarán sus barreras religiosas tan pronto como destruyan sus barreras profanas. No transformamos las cuestiones profanas en teológicas. Transformamos las cuestiones teológicas en profanas. La historia ya ha sido reducida bastante tiempo a superstición, nosotros convertimos la superstición en historia” (la cursiva es nuestra). Ibid., pág. 19.

${ }^{1860}$ Cfr. TAYLOR, Ch., Hegel, pág. 478.

${ }^{1861}$ Cfr. TAYLOR, Ch., Fuentes del yo, pág. 676.

1862 "O sea que el Estado puede haberse emancipado de la religión, incluso cuando la mayoría siga siendo religiosa; y la mayoría no dejará de ser religiosa por el hecho de que su religiosidad sea algo puramente privado". MARX, Escritos malditos, pág. 20. 
compromiso privado de sus ciudadanos, no porque ningún estado deba comprometerse con ninguna religión. ${ }^{1863}$ El Estado Cristiano debe dejar paso al estado ateo, real, democrático e independiente que no elimina la religión, sino que la reubica como una estructura más del Estado entre otras muchas. El Estado cristiano es el no-estado. El fundamento del Estado democrático es el trasfondo humano del Cristianismo, no el Cristianismo en cuanto tal. ${ }^{1864}$ Marx considera que lo realmente importante es ese trasfondo humano del Cristianismo que posibilitará la secularización del espíritu de la religión y lo expresará en un estado realmente democrático y en él, una vez abolido el capitalismo, solo florecerán las flores de la libertad humana. ${ }^{1865}$ En este sentido, Taylor afirma que Marx hace una "transposición del Geist al hombre" y su posición es una síntesis entre la Ilustración radical, que ve al hombre como capaz de objetificar la naturaleza y la sociedad en la ciencia, en función de dominarlas, y la expresión expresivista por la completud. Marxismo como expresión unificada de humanismo y naturalismo. ${ }^{1866}$

De ahí que la metodología marxista consista en transformar las cuestiones teológicas en profanas y, a partir de ahí, convertir al Estado en la nueva mediación salvífica con el espíritu humano. Se trata de convertir al Estado en una nueva configuración mediadora del espíritu humano. Con la superación de la religión comienza el tiempo de la historia, cuya finalidad es establecer la verdad del acá, una vez disipada la verdad del más allá. ${ }^{1867}$

El hombre ha buscado "el sí mismo" en la fantástica realidad del cielo y para Karl Marx hay que eliminar la religión. El Estado, con esta fundamentación cristiana, produce la religión como "una conciencia subvertida del mundo". Se trata de evitar la realización fantástica del ser humano e iniciar los fundamentos de una nueva interpretación general del mundo desenmascarando la forma sagrada de la negación de la vida humana. ${ }^{1868}$ Para Taylor, en esa nueva interpretación del mundo y del Estado se otorga a la economía un valor supremo en la afirmación de la vida corriente. ${ }^{1869}$

1863 "La religión ha dejado de ser la esencia de la comunidad para convertirse en la esencia de la diferencia. Ella vuelve a ser lo que fue en su origen: la expresión de la separación del hombre con respecto a la comunidad, con él mismo y con los otros hombres. Ahora no es más que la confesión abstracta de una particularidad tergiversada, de una extravagancia personal, de la arbitrariedad". Ibid., pág. 23.

${ }^{1864}$ Cfr. Ibid., pág. 27.

1865 Cfr. TAYLOR, Ch., La ética de la autenticidad, pág. 108; cfr. TAYLOR, Ch., Hegel, págs. 477-491.

${ }^{1866}$ Cfr. TAYLOR, Ch., Hegel, pág. 482.

1867 “Ante todo, el deber de la filosofía, que está al servicio de la historia, es el de desenmascarar la aniquilación de la persona humana en su aspecto profano, luego de haber sido desenmascarada la forma sagrada de la negación de la persona humana. La crítica del cielo se cambia así en la crítica de la tierra, la crítica de la religión en la crítica del derecho, la crítica de la teología en la crítica de la política". MARX, K., "Prólogo de Karl Marx" en HEGEL, G., Filosofía del Derecho. Claridad. Buenos Aires, 1968, pág. 8.

1868 "Este Estado, esta Sociedad produce la religión, una conciencia subvertida del mundo, porque ella es un mundo subvertido. La religión es la interpretación general de este mundo, su resumen enciclopédico, su lógica en forma popular, su point d'honneur espiritualista, su exaltación, su sanción moral, su solemne 
La justificación de Marx para eliminar la religión es la miseria real que provoca en el mundo, un mundo que es un valle de lágrimas, justificado por este reflejo sagrado que es la religión; una religión que pone flores sobre las cadenas en vez de hacer florecer el rosal del mundo. ${ }^{1870}$ Es la crítica marxista a la inhumanidad del orden presente.

Según Taylor, si la sociedad es el instrumento común de los hombres que deben perseguir la felicidad, cualquier privación es una imposición salvaje en contra de la razón y la justicia. ${ }^{1871}$ En la democracia pura y en el espíritu humanista del Cristianismo, el hombre se encuentra plenamente realizado; sin embargo, en la sociedad burguesa y en el estado cristiano, el hombre se encuentra en el dualismo rupturista entre la realidad y los cielos, entre lo terrenal y lo religioso. ${ }^{1872}$ Este Cristianismo "secularizado" en su trasfondo humanista es el que ha alcanzado la elevación universal que comprende cualquier dimensión trascendente del ser humano. Se trata de una comprensión universal del Cristianismo que lo convierte en la religión del espíritu humano y la eleva a la realización más sublime de un Geist antropologizado. ${ }^{1873}$

complemento, su consuelo y justificación universal”. Ibid., pág. 7.

${ }_{1869}$ Cfr. TAYLOR, Ch., Fuentes del yo, pág. 394.

1870 "La miseria religiosa es, al mismo tiempo, la expresión de la miseria real y la protesta contra ella. La religión es el sollozo de la criatura oprimida, es el significado real del mundo sin corazón, así como es el espíritu de una época privada de espíritu. Es el opio del pueblo”. MARX, Prólogo de Karl Marx en HEGEL, pág. 7.

${ }^{1871}$ Cfr. TAYLOR, Ch., Hegel, pág. 478.

1872 Cfr. TAYLOR, Ch., Argumentos filosóficos, págs. 290,364.

1873 "El cristianismo alcanza así la expresión práctica de su significado religioso universal, cobijando bajo una forma única las concepciones más dispares y sobre todo no exigiendo de otros cristianismos sino solo religión, aunque sea cualquier otra religión. La conciencia religiosa saborea la riqueza de los contrastes religiosos y la variedad de las religiones". MARX, K., Escritos malditos. Sobre la cuestión judía y otros textos, pág. 28. 


\section{V.-CHARLES TAYLOR. REENCANTANDO EL MUNDO. EL FUTURO DE LA RELIGIÓN EN LA ESFERA PÚBLICA}




\section{V.1.-UNA SITUACIÓN NUEVA. LA RELIGIÓN COMO PROBLEMA Y MALESTAR}

Todo el relato de la secularización trazado hasta aquí, según Taylor, pretende interpretar el lugar que ocupa lo espiritual en nuestra vida. ${ }^{1874}$ Para nuestro hermeneuta canadiense, la secularización ha sido una narración que expresa más esta dificultad por redefinirse en su espacio propio que el que estuviera en un proceso de declive y desaparición. Es la desubicación que provoca una ruptura y cada una de las dos partes tiene que buscar el lugar que le corresponde en el nuevo escenario. Y este es el malestar de la religión del que habla Taylor. Un malestar provocado por todo lo que se ha analizado hasta aquí y que Taylor resume en relación con el atomismo subjetivista y el desencantamiento del mundo. ${ }^{1875}$

El futuro de la religión, según Taylor, pasa por dar respuesta a tres interrogantes que fundamentan las fuentes morales trascendentes dentro de la Modernidad y al que las religiones tienen que dar respuesta.

A.- Experiencias de orientación como "sentido y plenitud", donde nos sentimos fundamentados, capaces, restituidos y llenos de energía, donde nuestras experiencias de elevación espiritual son máximas y nuestra energía de vida de alguna manera se ordena y se fortalece. Es un tipo de experiencia que Taylor la refiere con el término plenitud y con todas las reservas que encierra el término. ${ }^{1876}$ Taylor también refiere la expresión de Schiller de belleza como juego, como capacidad de adentramiento en la experiencia de sentido que fortalece al yo interior y que encanta el alma. Con lo bueno, con lo perfecto, el hombre adopta una actitud de seriedad; con la belleza, en cambio, el hombre juega, afirma Schiller. ${ }^{1877}$ Es el moderno ideal de autenticidad y de los objetivos de autorrealización y autoplenitud a los que se refiere Taylor. ${ }^{1878}$

Para Taylor, estas experiencias de orientación nos refieren a un lugar de realización total (plenitud) . Es el sentido que configura la relación de identidad y

\footnotetext{
${ }^{1874}$ Cfr. TAYLOR, Ch., La Era Secular, tII, pág. 356.

${ }^{1875}$ Cfr. TAYLOR, Ch., La ética de la autenticidad, págs. 38-40.

1876 Taylor pone el ejemplo de la experiencia espiritual del budismo a partir del término sunyata en el que la experiencia de plenitud se explica como "un tipo vacío". No obstante, Taylor es consciente de la problemática que el término encierra. "Vacío proviene del término sánscrito sunyata, que se traduce como 'la vacuidad', la nada o como en ocasiones, el cero de las lenguas indias modernas. Sunyata es la ausencia de apego al ego y la carencia de separación entre el yo y el otro, por ende, no habría ningún yo ni otro que representar". COLINA, C., "El enigma del vacío", Konvergencias, No 27, (2018), pág.101.

1877 "Con lo ameno, con lo bueno, con lo perfecto, el hombre se comporta solo seriamente; con la belleza, en cambio, juega. (...) La belleza existente en la realidad es digna del impulso lúdico existente en la realidad; pero mediante el ideal de belleza, que la razón erige, se propone también un ideal del impulso lúdico, que, en todos sus juegos, debería el hombre tener ante los ojos”. SCHILLER, F., Cartas sobre la Educación estética del hombre, Universidad de Cuyo, Argentina, Carta 15, págs. 109-110.

${ }^{1878}$ Cfr. TAYLOR, Ch., El multiculturalismo y la política del reconocimiento, pág. 51; cfr. TAYLOR, Ch., Argumentos filosóficos, pág. 65.
} 
orientación, entre dónde estoy (lugar moral) y a qué quiero responder (identidad). ${ }^{1879}$ Estas experiencias de plenitud nos orientan, pues nos ayudan a comprender los marcos referenciales que aportan un trasfondo para nuestros juicios e intuiciones. Dichos marcos referenciales dan sentido a nuestras respuestas morales y nos permiten comprender de qué están compuestas dichas experiencias de sentido.

B.- Experiencias de orientación como "exilio y ausencia", en las que la experiencia de orientación se manifiesta en su sentido negativo, como distancia y ausencia, como incapacidad para alcanzar la plenitud y cuyo sentido de orientación se expresa como exilio, confusión y melancolía y donde se pierde la noción de dónde está la plenitud, como si se perdiera la conexión con los marcos referenciales de sentido y si puede siquiera lograrse. ${ }^{1880}$ Nuestro autor lo relaciona con el Spleen de París de Baudelaire, donde rezuma esa nostalgia del tiempo que vuelve melancólicamente sobre recuerdos, penas, espasmos, miedos, pesadillas o neurosis. ${ }^{1881}$

Se trata de una experiencia en la que, en lenguaje baudelairiano, nos acercamos a la monotonía como mitad de la nada, a países de muerte en los que una vez que somos conscientes de la experiencia vivida sentimos alivio por haber traspasado el umbral del vacío y las tinieblas. Como afirma Taylor, se trata de una experiencia de orientación, pues nos hace caer en la cuenta, cuando la narramos, de la propia vida como espacio para sentir la identidad como marco referencial en el que nos ubicamos más cerca o más lejos. Taylor habla de estos momentos de crisis de identidad como formas agudas de desorientación, como desconcertante incertidumbre respecto al lugar en el que uno se encuentra. No hay marco de referencia, no hay horizonte, se carece de trasfondo significativo para valorar lo que uno está viviendo como bueno o malo y donde no es posible percibir el sentido. Taylor define esta situación como una dolorosa y aterradora experiencia. $^{1882}$

Se pierde la conexión con el lugar de la plenitud. Para Taylor, lo terrible de este estado es que perdemos la noción de dónde está el lugar de la plenitud, e incluso, de qué podría ser la plenitud o experimentamos su olvido o admitimos que ya no podemos creer en ella. La desventura de la ausencia, de la pérdida, sigue estando ahí, y en cierta forma es aún más aguda. ${ }^{1883}$ Este estado de "olvido ontológico", respecto a un lugar de plenitud, es algo que contribuye a comprender el posicionamiento moral del hombre

\footnotetext{
1879 "Para estar capacitado para responder por sí mismo uno ha de saber dónde se encuentra y a qué quiere responder. Y por eso naturalmente nos inclinamos a hablar de nuestra orientación fundamental en términos de quiénes somos. Perder esa orientación, o no haberla encontrado, equivale a no saber quién se es. Y esa orientación, una vez conseguida, define el lugar desde el que respondes, es decir, tu identidad" (la cursiva es nuestra). TAYLOR, Ch., Fuentes del yo, pág 55.

${ }^{1880}$ Cfr. TAYLOR, Ch., La Era Secular, tII, pág. 356.

${ }^{1881}$ Cfr. TAYLOR, Ch., La ética de la autenticidad, pág. 93.

${ }^{1882}$ Cfr. TAYLOR, Ch., Fuentes del yo, pág. 52.

${ }^{1883}$ Cfr. TAYLOR, Ch., La Era Secular, tI, págs. 27-28.
} 
postmoderno y a adquirir una mejor comprensión del mundo que vivimos. ${ }^{1884}$ Se trata de una indeterminación ontológica de los lenguajes más sutiles postrománticos, que expresan indeterminación (Wordsworth), o falta de resolución (Hopkins), o direccionamiento hacia algo que apunta a la experiencia (Pater). ${ }^{1885}$ Taylor sostiene que el filósofo Hans Joas es un referente con sus planteamientos sobre la articulación de la experiencia religiosa en relación a la sacralidad del ser humano y a la genealogía afirmativa de los valores fundamentales. ${ }^{1886}$

Ahondando en esta experiencia, Taylor considera que hay una multiplicidad de formas de exilio que van desde la sensación de condena, de exclusión eterna, hasta otras imágenes de cautiverio, tal y como aparecen, por ejemplo, en el cuadro El Jardín de las Delicias del Bosco, en el que se utilizan todo tipo de metáforas pictóricas (el huevo en la cabeza, las cuatro estructuras, el baño de Venus, Adán y Eva...) para expresar estas experiencias de destierro y enajenación moral, como si se hubiera perdido el centro de referencia, como si todo se desubicara y perdiera las referencias primigenias.

C.- Experiencias de orientación como "estadio intermedio", en las que escapamos del exilio y la negación o el vacío, pero sin lograr alcanzar la plenitud. Son experiencias que tienen que ver con el orden rutinario de la vida y que adquieren un significado para nosotros y que contribuyen a fundamentarnos en la idea del bien. ${ }^{1887}$

Taylor afirma que lo propio de este estadio intermedio es que la monotonía propia de la vida ordinaria evite el terror del vacío, del exilio y la ausencia, y al mismo tiempo, que no se pierda la sensación de estar encaminados hacia la plenitud a lo largo de los años. ${ }^{1888}$ Se supera el vacío existencial de perder el fundamento a través de la afirmación de la vida cotidiana, expresada como felicidad ordinaria y, a la vez, no se pierde la conexión con la plenitud a través de sentirse encaminados hacia ella, conscientes de que el lugar y la orientación de sentido se expresan como un más o menos que se afirma con lucidez y sinceridad. Se trata de un equilibrio intermedio que se ubica entre ambos referentes de felicidad ordinaria y de mirada orientadora hacia la

\footnotetext{
${ }^{1884}$ Cfr. TAYLOR, Ch., Argumentos filosóficos, pág. 65.

1885 Cfr. TAYLOR, Ch., La Era Secular, tII, pág. 171.

1886 "Weber's disenchantment starts with the prophets, so his narrative of disenchantment is not about today, but about 2,500 years. The alternative is to be a different history of these 2,500 years and not something that may be true or not for our time. Weber did not speak about his own time, but saw the crisis of meaning as something like the end result of thousands of years of disenchantment. This process, I think, we have to see in a different light". Cfr. HEIDEGREN, C.G., "An interview with Hans Joas", Sociologisk Forskning, 54, No 3, (2017), pág. 242."El profesor Hans Joas lanza su baza más fuerte: lo crucial en la acción es su dimensión creativa, la facultad de los seres humanos para una generatividad innovadora, el poder que tenemos para responder, realmente, a las situaciones y hacernos responsables de ellas: la creatividad de la acción colectiva”. SÁNCHEZ MARTÍNEZ, G., Presentación de La creatividad de la acción de H. Joas, CIS, 2013, Madrid, pág. 38.

${ }_{1887}$ Cfr. TAYLOR, Ch., La Era Secular, tII, pág. 212.

1888 Cfr. Ibid., pág. 410.
} 
plenitud. ${ }^{1889}$ Este tipo de posición no es insignificante, ya que rehúye el materialismo o una concepción estrecha de la moralidad de beneficio mutuo y, por otra parte, no quiere regresar a las afirmaciones contundentes con sus creencias de largo alcance acerca del poder de Dios en nuestras vidas. Lo curioso de esta posición es que las personas/o las sociedades se definen en relación con los opuestos y puede representar a la mayoría en una u otra variante, afirma Taylor. ${ }^{1890}$ Se perdería el equilibrio de este estado intermedio si se renunciara a la esperanza de alcanzar la plenitud o las referencias a ese lugar fundante de sentido. ${ }^{1891}$

Para Taylor, los creyentes que se ubican en relación con este estado intermedio afirman una plenitud que se realiza en los tiempos definitivos y que encaminan su tiempo vital hacia la consecución de esa plenitud como un proyecto que empieza ya aquí y ahora. Un proyecto que está en tensión entre el "ya sí y el todavía no"; una plenitud que tiene su comienzo en la historia, pero que abre a una esperanza que tendrá su plena realización en los tiempos escatológicos.

Mientras que, para los no creyentes, afirma Taylor, este estado intermedio asume un proyecto que se dirime entre la afirmación de la plena realización en esta vida sin necesidad de recurrir a otro tipo de esperanzas ultraterrenas. Para ellos se trata de una ubicación moral que "no es poca cosa", dado que no debe haber otros planteamientos que nos despisten del compromiso con la búsqueda de esta felicidad terrena y de esta excelencia radicalmente humana. Este estadio intermedio de plenitud, para los no creyentes, explora situaciones que, según Taylor, todavía quedan por dilucidar y que tienen que ver con dos aspectos a considerar:

1.- Limitar la experiencia de plenitud a la propia realidad vital y terrena. Un encerramiento que conduce a una incapacidad ontológica para ser comprendida y experimentada la vida en todo su alcance. Experiencia que lleva a tener el sentimiento de una existencia no completamente feliz, ni realizada, de comprender que no se llega a más, de que se quiere, pero no se puede llegar a más. Se llega a la conclusión de que no se puede lograr, en toda su dimensión, eso que tanto se

\footnotetext{
${ }^{1889}$ Cfr. TAYLOR, Ch., Ética de la autenticidad, págs. 72-76.

${ }^{1890}$ Cfr. TAYLOR, Ch., La Era Secular, tII, pág. 212.

1891 Para Taylor, en estadio intermedio incluye a la mayoría de las personas de nuestra sociedad posmoderna. Taylor además afirma que hay también fuentes morales que establecen identidad espiritual cuando, por ejemplo, hacemos juicios valorativos sobre los actos de los demás y los propios, que provocan actitudes de admiración, temor o indignación, con lo que la dimensión moral del ser humano está presente de muchas maneras y como dice Mircea Eliade, el hombre nunca podrá estar totalmente desacralizado. "Como hemos dicho, el hombre arreligioso en estado puro es un fenómeno más bien raro, incluso en la más desacralizada de las sociedades modernas. La mayoría de los hombres 'sin-religión' se siguen comportando religiosamente, sin saberlo. No solo se trata de la masa de 'supersticiones' o de 'tabús' del hombre moderno, que en su totalidad tienen una estructura o un origen mágico-religioso". ELIADE, M., Lo sagrado y lo profano, pág. 125.
} 
anhela. En otros términos, la argumentación moral se nos torna un espacio cerrado y opaco. ${ }^{1892}$ Es el yo impermeabilizado del que habla frecuentemente Taylor. ${ }^{1893}$

2.- Un segundo elemento que tiene que ver con la sensación de aspirar a algo que no se termina de localizar o identificar totalmente. En cierto sentido se reconocen las bases en lo que se está, pero que no termina de reconocerse a uno mismo en su identidad plena. Hay un deseo de trascendencia que no termina de identificarse como tal, y que sigue expresándose como nostalgia, una especie de vacío y encogimiento espiritual, como si la vida se angostara. ${ }^{1894}$ Taylor se expresa en términos realmente existencialistas: angustia, desgarro, desventura. ${ }^{1895}$

Estos dos aspectos del estadio intermedio, tal y como son experimentados por los no creyentes, abren posibilidades de diálogo con muchas realidades que nos superan y no logramos domeñar. Taylor considera en este sentido que queda un lugar por recorrer y que hay que afrontar la verdad evidente. Está sugiriendo horizontes para reflexiones que permitan explorar caminos nuevos para una filosofía que, de una vez por todas, posibilite el diálogo entre creyentes y no creyentes a partir de estos lamentos y nostalgias, a partir de estas insatisfacciones del alma humana. ${ }^{1896}$ En este sentido, Taylor invita a superar muchas visiones de la creencia y la no creencia como teorías a las que nos adherimos, sugiriendo caminos para entenderlas como estados vividos, esto es, llegar a realizar una aprehensión de la diferencia de la experiencia vivida, en relación con el sentimiento de la existencia de Rousseau, que contempla el orden de la naturaleza como expresión de nuestras motivaciones más profundas. ${ }^{1897}$ Es la cultura de la Modernidad que tanto tiene que ver con la expresión del sentimiento y de una cierta melancolía, en relación a la excelsitud de los sentimientos que resuenan en nuestro interior. $^{1898}$

Taylor quiere enfatizar la importancia que tiene la experiencia creyente en clave relacional, en la que el yo es enriquecido por un don que nos es dado gratuitamente, en una plenitud que comienza aquí y se expresa en devociones y actitudes que nos acercan a la plenitud, pero que no termina de realizarse completamente. Esta experiencia creyente necesitaría ser reformulada o aprehendida de una forma más oriental, si cabe, y no tan racionalizada, en la que se valore más ciertos espacios entre la soledad y la comunicación, así como la apertura del yo a acoger un don que va más allá de nosotros. Esta reformulación tayloriana de la creencia invita a un replanteamiento de la misma

\footnotetext{
1892 Cfr. TAYLOR, Ch., Argumentos filosóficos, pág. 89.

${ }^{1893}$ Cfr. TAYLOR, Ch., La Era Secular, tII, págs. 302, 381, 383, 395, 420,4 89, 601, 646; cfr. TAYLOR, Ch., La Era Secular, tI, págs. 212, 228, 362, 368.

${ }^{1894}$ Cfr. TAYLOR, Ch., La ética de la autenticidad, pág. 50.

1895 Cfr. Ibid., págs. 147,421.

${ }^{1896}$ Cfr. TAYLOR, Ch., La Era Secular, tII, pág. 416.

${ }^{1897}$ Cfr. TAYLOR, Ch., Argumentos filosóficos, págs. 191-192; cfr. TAYLOR, Ch., Hegel, pág. 477.

${ }^{1898}$ Cfr. TAYLOR, Ch., Fuentes del yo, págs. 407, 410.
} 
experiencia religiosa, a partir no solo de teorías que buscan adhesiones, sino a partir de lo que supone la experiencia vivida. ${ }^{1899}$ Se trata de una creencia que hace hincapié no tanto en lo que supone la adhesión teórica a algo dado, cuanto en la capacidad de apertura del yo para que el don gratuito de la fe pueda ser asumido personal y conscientemente y que entronca con la tradición romántica del sentimiento de existencia de la vida y la capacidad de expresión como resonancia interior. En este sentido, la ciencia moderna ha fundamentado las fuentes morales del yo en el marco inmanente. Sin embargo, nuestro autor piensa que esto se puede vivir de muchas formas, no incompatibles, unas abiertas a la trascendencia y otras cerradas. Se pueden vivir, en todo caso, como complementarias y abiertas la una a la otra, o en tándem con otras que las modifican o las limitan o se les puede otorgar un lugar central, sin rival. ${ }^{1900}$ Desde la perspectiva de Taylor, la revolución expresivista ha debilitado el vínculo entre la fe cristiana y el orden civilizador. ${ }^{1901} \mathrm{El}$ futuro de la religión pasa por estar abiertos a las formas sociales posdurkheimianas que potencian dicho vínculo. ${ }^{1902}$

Taylor intenta comprender también la no creencia moderna como un estado vivido. Para la modernidad no creyente el poder de alcanzar la plenitud está dentro, y en todas sus formas de vinculación no trascendente, ${ }^{1903}$ es decir, propugnando la transformación de las religiones redentoras en cultos seculares, no solo en su dimensión política, sino en ideologías de progreso. ${ }^{1904}$ Para Taylor, el materialismo científico ha convertido su relato oficial en verdad moral bajo la perspectiva de humanismo exclusivo. ${ }^{1905}$ Sin embargo, el relato de la Modernidad secular, bajo la perspectiva de la ética de la autenticidad, posibilita reconstruir la narración de la secularidad bajo otras perspectivas. Una autenticidad que se manifiesta en una serie de variantes de plenitud que se ubican en diferentes lugares o momentos: experiencias de oración, momentos de especial plenitud, vidas de autoencierro extremo. Son variantes que nuestro autor canadiense refiere como posibilidades de plenitud, pero que al mismo tiempo se entremezclan con la duda. Taylor lo define como una duda que siempre asalta, nunca

\footnotetext{
${ }^{1899}$ Cfr. TAYLOR, Ch., La Era Secular, tII, págs. 658, 689, 691.

${ }^{1900}$ Cfr. Ibid., pág. 425.

${ }^{1901}$ Cfr. Ibid., pág. 308.

1902 Cfr. Ibid., págs. 304, 337, 345, 367, 669.

${ }^{1903}$ Para Taylor estas concepciones inmanentes son tan hostiles a la religión como las concepciones de la razón desvinculada del punto anterior. Las otras variantes vinculadas a un poder no trascendente se tratarán posteriormente. Valga por el momento las que plantea Taylor bajo la forma de títulos generales: la voz de las profundidades internas como sentimientos o instintos (teorías de la inmanencia del Romanticismo), la voz de la naturaleza en sus teorías de ecología profunda (deep ecology) y finalmente las modalidades contemporáneas del posmodernismo que van asociadas (metafísica como ejemplo de la 'problematización' en la interpretación entre lo inmanente y lo trascendente). Todas ellas niegan tanto el poder y el regocijo autosuficiente de la razón desvinculada como las fuentes morales que se descubren en la naturaleza o en el sentimiento romántico, quedando al margen del establecimiento de fuentes morales y destacando la ausencia de plenitud y no encontrando una posibilidad de sentido o destacando la propia incapacidad para encontrarlo.

${ }_{1904}$ Cfr. GARCÍA, J.L., "Declinaciones de la Religión en la Modernidad”, pág. 208.

1905 Cfr. TAYLOR, Ch., Fuentes del yo, pág. 429.
} 
dejo de dudar, en el sentido de que siempre hay algo inapropiado o invitaciones al replanteamiento desde las otras perspectivas o un acercamiento a otras alternativas de plenitud. Es algo típico de nuestra condición moderna y que cada uno, desde su condición creyente o no creyente experimenta de una manera u otra. Las viejas concepciones y lealtades están gastadas, los viejos horizontes de seguridad han desaparecido, el océano de la fe se retira. ${ }^{1906}$

Con la Modernidad no se puede evitar mirar de reojo de vez en cuando, es decir, se instala la duda sistemática, la incertidumbre, la falta de certezas, el estado propio de no estar seguro de casi nada, "aunque siempre se necesita volver a mirar otra vez por si acaso". Se trata de la identidad del hombre moderno, una identidad asentada en un "relativismo blando", caracterizado por asentar los significados en el yo subjetivo que así lo cree o lo piensa, ${ }^{1907}$ no dando noada por concluido. La condición del hombre moderno expresa esta incomodidad natural en la que se ha instalado, como una nueva forma de espiritualidad, de plenitud o de exilio. Todo constituye un desplazamiento esencial que se presenta como descubrimiento y ante lo cual no se sabe muy bien qué decir, aunque se dé por descontando que eso es lo cierto. ${ }^{1908}$ Parece ex post facto, como si no hubiera ninguna alternativa racional, aunque siempre se vuelva sobre ello. ${ }^{1909}$

Taylor considera que con la Modernidad tiene lugar la pérdida de la ingenuidad creyente o de la certidumbre inmediata. ${ }^{1910}$ Se trata de un contexto de politeísmo axiológico, de distintas opciones, unas más plausibles que otras, y cada uno opta por una que le identifica moralmente. Taylor habla de la opción por omisión, es decir, que más que optar decididamente desde una valoración moral fuerte se opta por lo que indirectamente no se elige, quedando una opción como la más abrumadoramente plausible pero no la más autoidentificadora. Al no tomar opción decidida por una, cualquiera de las otras opciones puede ejercer poder de atracción en cualquier momento, resultando un relativismo moral o lo que Taylor define como "una concepción del mundo desde ninguna parte" siguiendo a Nagel. ${ }^{1911}$

Es el gran cambio que se produjo con la Modernidad. Se pasa de una fuente moral de carácter trascendente asumida con ingenuidad a una situación en la que se presentan distintas fuentes morales, siendo la opción trascendente apenas una entre muchas otras, como dice Taylor. Son los dos puntos de vista taylorianos: uno vinculado en el que nos identificamos con un punto de vista que nos conforma moralmente y otro desvinculado

\footnotetext{
${ }^{1906}$ Cfr. TAYLOR, Ch., La Era Secular, tII, pág. 431.

${ }^{1907}$ Cfr. TAYLOR, Ch., La ética de la autenticidad, pág. 72.

1908 Cfr. TAYLOR, Ch., La Era secular, tII, pág. 433.

${ }^{1909}$ Cfr. Ibid., pág. 428.

${ }^{1910}$ Cfr. Ibid., pág. 199.

${ }^{1911}$ Cfr. TAYLOR, Ch., Argumentos filosóficos, pág. 201; cfr. Ibid., págs. 91,96,97,239. Cfr. LA TORRE, M., "Mirando desde ningún lugar. Una breve introducción a la Filosofía de Thomas Nagel", Doxa, No 10, (1991), págs. 141-171.
} 
en el que asumimos la existencia de distintas fuentes de moralidad y coexistimos con dicha diversidad, asumiendo una de ellas o por omisión o por identificación más plausible. $^{1912}$

Taylor afirma que nos movemos entre estos dos puntos de vista: por una parte, hay una vinculación moral hacia una fuente que nos mueve y nos identifica, pero por otra parte, nos desvinculamos cuando vemos que hay otras posibilidades que en un momento $\mathrm{u}$ otro puedan atraernos o movernos en dirección a ellas y así iniciar procesos de cambio hacia otras moralidades identificadoras. Se pierde la exclusividad en un doble sentido: asumimos de entrada una variedad de fuentes morales y la que se asume como autoidentificadora puede ser la más plausible, la opción por omisión o la que atrae con mayor fuerza, pero abierta a posibles reinterpretaciones o cambios en el curso de la vida, dado que no existe la exclusividad de una fuente moral entendida como referencia única y con carácter inapelable. Para Taylor, es la "soledad orgullosa del yo de Freud". 1913

Se ha pasado de una situación en la que la creencia o la moralidad trascendente se asumía con ingenuidad por una mayoría, y los no creyentes la veían como una opción plausible o permanecían abiertos a configurarse moralmente por ella, a un mundo en el que la no creencia es en principio la más plausible. Los creyentes asumen un papel de creyentes semipaganos y los ateos olvidan el anterior estado de ingenuidad abierta para pasar a considerarse ateos convencidos que encuentran grandes dificultades para comprender otra visión que no sea la atea. Los no creyentes asumen visiones no ingenuas de su ateísmo, lo cual los lleva a identificar la creencia con el miedo a la incertidumbre, la debilidad de espíritu nietzscheana o el sentimiento de culpa. En este sentido el ateísmo no ingenuo cierra cualquier posibilidad a otras opciones plausibles desde una voluntad generadora de visiones negativas hacia la creencia. ${ }^{1914}$ Taylor habla de un agente sobreimpermeabilizado, impasible, cerrado. ${ }^{1915}$

Nuestro hermeneuta canadiense asegura que no todo el mundo asume dichos planteamientos de la no creencia, pero es la visión más relevante desde el punto de vista socio-cultural e intelectual, constituyéndose en una atalaya que influye y determina una visión globalizadora que lo envuelve casi todo. Se puede afirmar que existe un contexto experiencial no creyente que motiva y configura el mundo, siendo la opción por omisión más plausible, asumida ingenuamente o reflexivamente: ingenuamente para aquellos que viven desvinculadamente, asumiéndola como la más certera entre otras muchas (una minoría); y reflexivamente, cuando se abandona cualquier ingenuidad atea

${ }^{1912}$ Cfr. TAYLOR, Ch., El multiculturalismo y la política del reconocimiento, págs. 65-69; cfr. TAYLOR, Ch., Argumentos filosóficos, pág. 106.

${ }^{1913}$ TAYLOR, Ch., La Era Secular, tI, pág. 222.

${ }^{1914}$ Cfr. TAYLOR, Ch., Hegel, pág. 491.

${ }^{1915}$ Cfr. TAYLOR, Ch., La Era Secular, tI, pág. 220. 
y se asume una visión crítica despectiva respecto a la creencia (una mayoría). En Taylor, el sentido mayoritario del nuevo trasfondo viene definido por la última perspectiva reflexiva que abandona cualquier tipo de ingenuidad, haciendo de dicha elección la meta primitiva de fundamento moral. ${ }^{1916} \mathrm{Y}$ lo que es más relevante para Taylor, se llega a identificar el locus de nuestra más elevada capacidad e inspiración moral sin hacer referencia a Dios, en el marco de capacidades estrictamente mundano. ${ }^{1917}$

Para Taylor, se ha producido un cambio de tales dimensiones que la creencia en Dios no es la misma en el año 1500 que en el año 2020. Un cambio que tiene que ver con lo que él denomina nuevo trasfondo en el sentido wittgensteiniano; es decir, que no tengo mi imagen del mundo porque me haya convencido a mí mismo de que sea la correcta ni de que esté convencido de su corrección. Se trata del trasfondo que me viene dado y sobre el que distingo entre lo verdadero y lo falso. ${ }^{1918}$ Es el marco contextual en el que decidimos creer o no creer en Dios. ${ }^{1919}$ Taylor afirma que, en el nuevo contexto, el agente debe ser capaz de una auténtica convicción y ser fiel a ella. Todas las elecciones son igualmente válidas, pero deben ser elecciones. Esta es la convicción moral que atribuye ese carácter absoluto a la libertad de elección en el ejercicio de la autoconciencia y autonomía personales para no quedarnos empantanados en la indolencia. ${ }^{1920}$

¿Cómo se llega a esta situación en la que la falta de fe y de visiones trascendentes se convierte para muchos en la principal opción por omisión? Una opción que viene caracterizada más que por una decisión, por una no-decisión (omisión) en la que se permanece en una tierra de nadie o en la que la incertidumbre y la inseguridad es la principal opción. Taylor plantea las visiones de los unos respecto de los otros. Los teístas piensan que los ateístas expresan su falta de fe por el desmoronamiento del sentido de plenitud tal y como había sido expresado desde la moralidad trascendente; y por otro lado, los ateístas piensan que muchas veces los teístas solo hablan de teorías y que en el fondo olvidan la dimensión última de la realidad que es inmanente. Taylor defiende que, tanto para teístas como para ateístas, estamos ante un nuevo modo de experimentar el mundo, como una experiencia y sensibilidad dentro del mundo inmanente que nos permite acceder a nuevos campos de visión plenificadora, una

\footnotetext{
${ }^{1916}$ Cfr. TAYLOR, Ch., La ética de la autenticidad, pág. 73.

1917 Cfr. TAYLOR, Ch., La Era Secular, tI, pág. 387.

${ }^{1918}$ Cfr. WITTGENSTEIN, L., Sobre la certeza, No 94; cfr. DREYFUS, H., Being in the world, MIT Press, Massachusetts, 1991, págs 58-59; cfr. SEARLE, J., La construcción de la realidad social, Paidós, Barcelona, 1997, pág.126.

${ }^{1919}$ BLOUIN, S., "Rethinking Conversion: Beyond the Religious and the Secular", RSCAS, (2016), pág. 1.

${ }^{1920}$ Cfr. TAYLOR, Ch., La libertad de los modernos, págs. 236,238; cfr. TAYLOR, Ch., Argumentos filosóficos, págs. 85,88-89; cfr. TAYLOR, Ch., La Era Secular, tI, págs. 38-39.
} 
plenitud que tiene que ver, por ejemplo, con la conversión de Claudel en Notre Dame de París. ${ }^{1921}$

Por una parte, se produjo la ruptura entre lo natural y lo sobrenatural. Ya no existe ese mundo arcaico en el que todo estaba lleno de religión y espíritus. Pero por otra parte, en nuestra civilización occidental se ha dado otro cambio igualmente fundamental: se ha pasado de estar en un mundo en el que la plenitud y las fuentes morales identificadoras estaban fuera o más allá de este mundo, a un mundo en el que esa ubicación ha cambiado. Esa plenitud y fuentes morales están dentro de la vida humana y dentro del yo que busca, tal y como afirma Hume, ${ }^{1922}$ pensando, según Taylor, que el "hombre está más cerca de Dios como indagador del orden moral de la Razón misma que como adorador de Dios". 1923

Se rompe así con la tradición occidental de relación intrínseca entre lo inmanente y lo sobrenatural, y la implicación mutua entre ambos polos, para explicar el mundo como realidad total. Con la ciencia postgalileana, se empieza a romper la atracción e interacción entre ambos polos y se empieza a plantear el polo inmanente como trasfondo de nuestro pensamiento. ${ }^{1924}$

Para Taylor, esta ruptura se trata de "la historia de una sustracción", está profundamente arraigada en la conciencia humanista moderna. Una historia que, para Taylor, pretende justificarse como la historia en la que los seres humanos adquieren la capacidad de deshacerse de la ética antigua y ultramundana del ascetismo. La creencia es producto de la privación, la humillación y la falta de esperanza. Se trata de un relato que otorga demasiada importancia a las transformaciones de la creencia, en contraposición a las sufridas por la experiencia y la sensibilidad. Según Taylor, esta teoría concede demasiado poco espacio a los cambios culturales obrados por la modernidad occidental y tiene tendencia a considerar que la modernidad es la liberación de un núcleo persistente de creencias y deseo de toda una capa de ilusión metafísicoreligiosa que la distorsionaba y la inhibía. La teoría de la sustracción se basa en dos narraciones: la idea kantiana de alcanzar la adultez y superar la minoría de edad y asumir lo que queda como fruto de la ciencia, esto es, la sola verdad material de las cosas, incluidos nosotros mismos. Según nuestro hermeneuta, esta explicación olvida una visión más amplia de los cambios de la experiencia humana. Taylor presenta otra historia, más convincente, una "narración maestra", una imagen marco más amplia en la

\footnotetext{
${ }^{1921}$ Cfr. TAYLOR, Ch., Imaginarios sociales modernos, págs. 216,220.

1922 Cfr. HUME, D., Tratado de la Naturaleza humana, pág. 203.

1923 TAYLOR, Ch., Hegel, pág. 28.

${ }^{1924}$ Cfr. TAYLOR, Ch., Argumentos filosóficos, págs. 74-77.
} 
que se desarrolla toda esta historia que estamos analizando, frente a las teorías reduccionistas de la historia de sustracción. ${ }^{1925}$

Asimismo, nuestro autor piensa que la Modernidad occidental, en la que incluye la secularidad, es más bien algo reciente y novedoso y no puede explicarse en términos de ciertos rasgos permanentes de la vida humana. ${ }^{1926}$ Taylor define esta situación como una sensación de déficit, entendida como una ausencia, como un vaciamiento progresivo de presencia de lo divino en el mundo. Todo comienza a verse como causalidad natural, como desaparición cada vez más absoluta del encanto divino a través de un Creador que estaba en el origen y que acompañaba con su presencia misteriosa (Idea Platónica) y misericordiosa (Cristianismo). Se va pasando a un reconocimiento cada vez más debilitado de la presencia de lo trascendente y a reconocer que se exige una creencia en algo que no se da por hecho o que no termina de verse. Es un proceso de desconfiguración, de mecanicismo utilitarista, de naturalismo cientificista en el que no se sabe muy bien de qué se trata con la Idea del Origen, aunque en los comienzos se reconoce que hay un "Relojero" que ha puesto orden a una naturaleza que funciona por sí misma. Posteriormente se irá pasando poco a poco a la idea de que el orden natural no necesita del Ordenador-Configurador-Relojero. Lo que ha iniciado el cambio tendrá consecuencias ontológicas de carácter irremediable.

Frente a la historia oficial de la sustracción, Taylor propone la historia de una recuperación, de reconstruir la narración de la secularidad moderna en un intento de descubrir bienes enterrados a través de la rearticulación y, con ello, impulsar de nuevo esas fuentes, devolver el aire a los pulmones medio colapsados del Espíritu. Por eso el subtítulo de nuestra tesis: reencantando el mundo. ${ }^{1927}$ Taylor prefiere hablar de la necesidad de articular los bienes constitutivos a través de una valoración fuerte, de los paisajes kairóticos en que nos movemos y de la capacidad personal por decidir lo que queremos ser. $^{1928}$

¿Quién inició el cambio y cómo comenzó? Lo que empezó siendo un cambio de muebles en la misma sala ha llevado a un cambio de casa. Y lo que es más importante, ¿el hombre se siente en casa? ¿Como en casa, o como un extraño en su propia casa? ${ }^{1929}$ La gran pregunta que nos hacemos es cómo ha llegado el hombre a pasar de estar en una casa creada por Dios y viviendo feliz en ella, a una casa vaciada, en la que solo queda la idea lejana de que Alguien la construyó o incluso a no saber si alguien la construyó o estuvo ahí, desde siempre, sin saber muy bien por qué o cómo. O si tiene algún sentido preguntarse por ello.

${ }^{1925}$ Cfr. TAYLOR, Ch., La Era Secular, tII, págs. 435-439.

${ }^{1926}$ Cfr. TAYLOR, Ch., Argumentos filosóficos, págs. 73, 88-89, 179-180.

${ }^{1927}$ Cfr. TAYLOR, Ch., Fuentes del yo, pág. 702.

${ }^{1928}$ Cfr. TAYLOR, Ch., La libertad de los modernos, págs. 297 y ss.

${ }^{1929}$ Cfr. DUCH, Ll., Un extraño en nuestra casa, Herder, Barcelona, 2007, 502 págs. 
La gran pregunta que interesa es "cuándo, cómo y por qué" el hombre empezó a sentirse así, vaciado, con esa sensación de déficit en las profundidades de su propio yo. Esto es lo que realmente interesa aquí. Para Taylor, todo empieza con el deísmo. Se trata de un comienzo que hace posible todo: la desvinculación, la neutralización moral, el subjetivismo relativista y el reduccionismo naturalista. ${ }^{1930}$ Un comienzo en el que se piensa que para poner paz en el mundo la religión no puede ser fuente de conflictos. Y así comienza a sostenerse que lo verdaderamente importante de la Religión no era lo que la separaba de los demás, sino los vínculos que era capaz de trabar. Y se llega a la conclusión de que lo que une a todas las religiones es la práctica moral, no el culto y los dogmas. Y a partir de esta actitud ecuménica aparecen autores como Herbert de Cherbury, Locke, Toland, Tindal, Shaftsburhy, Rousseau, Voltaire y otros que han aparecido en nuestro estudio. Finalmente, Kant configurará racionalmente este inicio secularizador deísta al afirmar que la verdadera religión era aquella que presente los rasgos esenciales de la razón y de la universalidad. Y esa es la religión natural, deísta, la que expresaba el alcance del orden moral a partir de la razón misma. Y todo empezará a partir de esta "religión ecuménica" que plantea la creencia en un dios personal, creador del universo y primera causa del mundo, pero que niega la providencia divina y la religión revelada. ${ }^{1931}$

Todo irá conduciendo, como afirma Taylor, a una decibilidad de los principios de la moral configurada a partir de un solo principio, relegando la realización personal a un rango inferior entre nuestros objetivos. Es la cultura postiluminista moderna y liberal que atribuye a la justicia y benevolencia una exclusividad e importancia sin precedentes en la historia humana y que mira cualquier otra percepción moral como anticuada, confusa o misántropa. Es la reducción de la moral al ideal de libertad para elegir fines sin pretender que estos tengan validez externa (I. Berlin). ${ }^{1932}$

\section{V.2.-ESTAMOS ABIERTOS A “ALGO MÁS”...}

Podemos afirmar que con la Modernidad el mundo y la realidad están configurados por la Idea del Bien, no tanto desde la Idea platónica del orden trascendente, sino desde el bien que toda persona desea alcanzar y vivir en su vida, como voz interior de la razón que se expresa en la armonía con el mundo natural. El hombre se ve a sí mismo en su libertad autorresponsable como alcanzado por una armonía de la naturaleza que le sobrecoge. ${ }^{1933}$ Muchas personas se sienten atraídas por el ejemplo de personas que viven según ideales que comprometen la vida en función de

\footnotetext{
${ }^{1930}$ Cfr. TAYLOR, Ch., Argumentos filosóficos, pág. 64.

1931 Cfr. MARTíNEZ, M.L., "Genealogía de la Secularización. Revisión Historiográfica del desencantamiento del mundo", Fides et Ratio, No 3, (2018), págs. 139-140.

${ }^{1932}$ Cfr. TAYLOR, Ch., La libertad de los modernos, págs. 285,289; cfr. TAYLOR, Ch, La Era Secular, tII, pág. 449.

${ }^{1933}$ Cfr. TAYLOR, Ch., Hegel, pág. 477.
} 
los demás, de una experiencia plenificadora que tiene que ver con la búsqueda del bien propio, de un futuro vivido como un sueño esperanzador, y al mismo tiempo, con el compromiso solidario hacia los demás. Se trata de una experiencia de plenitud en la que los demás están ahí, formando parte de la autorrealización personal. ${ }^{1934}$

Para la gran mayoría de las personas, según opinión de Taylor, la idea del bien como algo configurador del mundo moral de las personas está en relación con una referencia a lo trascendente. Difícilmente se puede uno hacer a la idea del bien sin un enraizamiento moral en lo trascendente, adquiera la trascendencia un sentido más o menos definido de carácter deísta o teísta. A veces, una gran mayoría de personas no logra definir esta apertura a lo trascendente, pero lo que está claro es que la trascendencia ayuda a configurar el sentido del bien en la propia vida y en el compromiso moral hacia los demás. Es lo que Taylor denomina abismo normativo, debido al estremecimiento para reafirmarse en la propia autoridad para configurar las normas morales y al mismo tiempo por la fuerza que dicha responsabilidad otorga al yo que la asume. ${ }^{1935}$ En otros términos, Taylor habla de inconmensurabilidad, en relación tanto con la ponderación de los bienes como con una idea de complementariedad. Ponderación y complementariedad en la que los bienes supuestamente más elevados o supremos, según Taylor, tienen muchos modos de relacionarse con otros a lo largo de la vida, más allá del mero desplazamiento de estos últimos a un rango y una prioridad menores. ${ }^{1936}$

En esa indefinición del alcance moral de la idea de bien, caben muy diversas interpretaciones. Taylor afirma que se puede redefinir a lo largo de la vida o a veces las personas pasan por períodos en los que el bien supremo se delimita desde el ámbito de lo puramente inmanente; a veces la razón moral adquiere un sentido deísta que intenta configurar el orden de la propia vida como referencia del orden natural; aunque en la mayoría de los casos, según Taylor, se puede afirmar que no logramos desconectar la idea del bien del sentido trascendente, a pesar de que la moral sin Dios puede ya dejar de ser inconcebible, aun cuando todavía no sea plenamente verosímil para nosotros. ${ }^{1937}$

Lo cual nos ayuda a entender que el hombre actual (¿posmoderno?) está definido por un relativismo moral blando, como denomina Taylor, o como afirmará Bloom, la relatividad de la verdad como postulado moral en una sociedad libre. ${ }^{1938}$ Pero al mismo tiempo, sigue estando abierto a lo transcendente, bien sea porque es lo que mejor le ayuda a entenderse a sí mismo, bien sea como inquietud de la que no logra desconectar,

\footnotetext{
${ }^{1934}$ Cfr. TAYLOR, Ch., La ética de la autenticidad, págs. 83-87.

1935 Cfr. TAYLOR, Ch., La Era Secular, tII, pág. 447.

1936 Cfr. TAYLOR, Ch., La libertad de los modernos, págs. 283,299,301.

1937 Cfr. TAYLOR, Ch., La Era Secular, tII, pág. 390.

1938 Cfr. BLOOM, A., El cierre de la mente moderna, PJ Editores, Barcelona, 1989, pág. 25. Cfr. TAYLOR, Ch., La ética de la autenticidad, pág. 57.
} 
a pesar de estar inmerso en un marco inmanente que supuestamente se ha desvinculado con el orden de lo sagrado. ${ }^{1939}$ Es decir, que cuando las naciones se encuentran configuradas social y políticamente, hay un sentimiento colectivo que embarga dicha idea del bien moral y que está asociada a un cierto sentido trascendente, del que a veces no se sabe muy bien dar explicación. Hay un sentimiento de identidad social que marca y determina unas referencias morales aglutinadas en torno a lo sagrado o hacia una consustancialidad, como dice Taylor, con la idea de Dios. Peter Berger habla, en este mismo sentido, de rumores de lo trascendente en medio de un mundo inmanente. ${ }^{1940}$

Es indudable que eso está ahí y está influyendo en todos. Ya sea en la experiencia americana o en la experiencia europea, con otros matices. Pero que no deja de influir y establecer una porosidad que nos pone en conexión con la idea de Dios. Una idea que siempre aparece en el inconsciente colectivo, bien sea como cuestionamiento para el debate, bien sea como inquietud que no deja de hacerse presente de una manera u otra, bien sea como referente social que a uno le llega e influye a la hora de no sentirse totalmente aislado. Se trata de algo que está ahí y que en muchos casos nos hace sentirnos partícipes, aunque solo sea en determinados momentos o situaciones, o como un sentimiento que da paz y tranquilidad a pesar de que no se sepa decir cómo ni en qué consiste. Taylor considera, en este sentido, que la idea de que se ha llegado a la madurez al dejar de lado la fe tiene también otra lectura que invita a la reflexión: adultez como capacidad para afrontar la pérdida de significado de las cosas mostrándose dispuesto a encontrar, buscar, proyectar significado ante un universo que carece de sentido. De ahí las dudas ante una confianza excesiva en la ciencia o la valentía de la imaginación para adentrarse en profundidades de espiritualidad que aporten energía para la creación de significado. ${ }^{1941}$ Situación que anima a Taylor a reconstruir el relato de la Modernidad secular.

Aunque el marco inmanente es el que envuelve y define el ámbito filosófico y cultural del mundo en el que se vive, sin embargo, las grandes masas de población de la cultura occidental se dejan influenciar por sentimientos que tienen que ver con lo trascendente. Masas que reconocen la influencia del mundo trascendente de otras épocas y que vincula a algo que, aunque no desee vincularse, sin embargo, no deja de estar ahí y se reconoce como presente y digno de consideración. ${ }^{1942}$ Se trata del reconocimiento de algo que es positivo y que, aunque todo esté configurado a partir del marco

\footnotetext{
1939 "No se trata solo de mi experiencia del bien, sino de algo que está entretejido con una identidad colectiva apreciada y crucial, ya sea la de una nación, un grupo ético o un movimiento religioso. Aquí hay un bien colectivo esencial que parece 'consustancial' a Dios o que guarda alguna relación esencial con la trascendencia”. Cfr. TAYLOR, Ch., La Era Secular, tII, pág. 391.

${ }^{1940}$ Cfr. BERGER, P., Los numerosos altares de la modernidad, págs. 43-70.

${ }^{1941}$ Cfr. TAYLOR, Ch., La Era Secular, tII, pág. 459.

${ }^{1942}$ Cfr. Ibid., págs. 389-392.
} 
inmanente, no deja de estar completamente olvidado o no deja de sentirse su presencia como algo que "está ahí-a-la-mano", aunque no vincule personalmente. ${ }^{1943}$

¿Podríamos hablar de un marco inmanente potenciador de apertura a lo trascendente? O lo que es lo mismo, ¿se trata de un marco inmanente que no puede entenderse a sí mismo sin una cierta porosidad que permite la connivencia con lo trascendente? Incluso aún más, ¿podemos hablar de un marco inmanente en el que no terminamos de estar del todo satisfechos y que irremediablemente nos conduce a experiencias de trascendencia que solo se pueden comprender desde el sentido inmanente? ¿Podemos afirmar con Talal Asad que lo secular continuamente produce lo religioso ${ }^{1944}$ Taylor se pregunta qué ontología necesitamos para dar sentido a nuestra vida moral y sugiere algunos modelos: la solución kantiana, la globalización de la ética, ampliar los horizontes morales en torno a la solidaridad interhumana. Incluso llega a sugerir la necesidad de sintonizar nuestra fenomenología con una ontología adecuada, ya sea enriqueciendo la ontología de que disponemos o revisando o cuestionando la fenomenología. ${ }^{1945}$

Por nuestra parte, sugerimos algunos ejemplos a modo de interrogante:

-. Cuando Víctor Frankl habla de "experiencias de sentido" que son inherentes a la experiencia humana, ¿son experiencias de trascendencia dentro del marco inmanente? Y cuando afirma con contundencia lo espiritual y religioso dentro de una sana psicología humana, ¿está Frankl afirmando que el hombre no puede limitarse al marco inmanente y que por lo tanto la experiencia trascendente va asociada al orden del logos y del sentido? ${ }^{1946}$

-. Cuando Maslow habla de "experiencias cumbre" que toda persona tiene en esta vida, en un momento u otro, bajo un aspecto u otro, en una dimensión u otra, ¿se trata también de experiencias de trascendencia?

-. Cuando Mircea Eliade habla de que el "hombre nunca podrá estar totalmente desacralizado", ¿se está refiriendo a que en el marco inmanente nunca podremos retirarnos a un marco de humanismo exclusivo, sino que estamos "siempre" ontológicamente abiertos a la experiencia de lo trascendente?

-. Cuando el filósofo López Quintás habla de que hay un "sentido de trascendencia de la realidad" en clave fenomenológica, ¿se está refiriendo a

\footnotetext{
1943 Cfr. TAYLOR, Ch., Argumentos filosóficos, págs. 297-299.

1944 Cfr. SEIDEL, K., "The Religious and the Secular. Talal Asad: Geneaolgies of Religion, and Formations of the Secular", Iowa Journal of Cultural Studies, Vol. 7, No 1, (2005), págs. 113-117.

1945 Cfr. TAYLOR, Ch., La Era Secular, tII, págs. 487-489.

${ }^{1946}$ Cfr. FRANKL, V., El hombre doliente, Herder, Barcelona, 2000; cfr. FRANKL, V., El hombre en búsqueda de sentido, Herder, Barcelona, 1979.
} 
que la realidad inmanente "esconde" un sentido oculto que nos abre irremediablemente al sentido de Dios? ${ }^{1947}$

-. Cuando R. Otto habla del misterio como una realidad "tremendum et fascinans", ¿está invitándonos a considerar ese sentido oculto de lo inmanente que no puede dejarnos completamente cerrados a una realidad que buscamos insaciablemente debido a que lo sagrado tiene ese elemento fascinans que nos lleva infatigablemente a buscar algo más allá de lo puramente inmanente? ¿Desarrolla el hombre solo la razón instrumental o pertenece al fundamento ontológico del ser humano preguntarse y adentrarse en lo suprarracional?

-. Cuando Durkheim habla del sentido social de la vida humana, ¿se está refiriendo a ese ámbito social en el que nos encontramos inmersos y que, desde el inconsciente colectivo de Jung, sigue invitándonos a "estar abiertos a" realidades valiosas configurados por la moral trascendente pues la identidad colectiva ha sido establecida en sus orígenes como una identidad en torno a lo sagrado?

-. Cuando Luckmann habla de la necesidad de que el marco trascendente recupere la relevancia que nunca debió dejar de tener, ¿se está refiriendo a que la religión ha configurado tradicionalmente las sociedades y que si ha establecido identidad social no puede la religión por lo tanto dejar de configurar una de las señales de la identidad del hombre como "ser social por naturaleza? ¿Ha contribuido la religión a configurar moralmente al hombre como ser social? ¿Es por lo tanto la religión "una marca positiva” en la historia de la humanidad que ha contribuido a que el hombre se entienda mejor a sí mismo a partir de su identidad social?

-. Cuando Luckmann y Berger hablan de la construcción social de la realidad, ¿se están refiriendo también a la contribución de las religiones, a la cohesión social y a la identificación de la identidad colectiva con la búsqueda del bien?

-. Cuando James H. Leuba habla de la búsqueda insaciable de la armonía moral en el hombre, ¿se está refiriendo a que dentro del marco inmanente del ser humano hay un espíritu que le eleva incondicionalmente hacia el sentido trascendente? ¿Se puede alcanzar la armonía moral del hombre, sin que este se haya preguntado por el sentido trascendente de la vida?

-. Cuando Jung habla del inconsciente colectivo como un inconsciente que expresa los arquetipos en mitos y ritos a lo largo de la historia de la humanidad, ¿se está afirmando que el hombre, desde que el hombre es hombre, y desde las

${ }^{1947}$ Cfr. LÓPEZ QUINTAS, A., Estética de la Creatividad, Rialp, Madrid, 1998. 
configuraciones sociales primitivas, no puede dejar de estar abierto a lo trascendente como "predisposición arquetípica" de toda la humanidad? ${ }^{1948}$

-. Cuando Van der Leeuw habla de que hay un aspecto objetivo y otro subjetivo de la experiencia religiosa, ¿se está refiriendo a que el hombre siempre ha logrado vislumbrar una experiencia objetiva en el hecho religioso más allá del propio ámbito de la experiencia personal y subjetiva? ¿Qué alcance tiene el aspecto objetivo del sentido trascendente? ¿Es una realidad que está ahí y que no podemos dejar de interpelarnos por él? ${ }^{1949}$

-. Cuando Henry Dumery habla de lo sagrado como un valor aparte, ¿está señalando que no podemos dejar de considerar el siempre controvertido marco inmanente en la vida del hombre? ¿Se trata de un valor aparte como algo que no puede dejar de ser pensando y experimentado por el hombre? Y cuando afirma que el espíritu humano es creador de valores y de sí mismo, ¿está sugiriendo que el hombre no puede renunciar a autoafirmarse en un sentido trascendente y como apertura a valores que van más allá de sí mismo? ${ }^{1950}$

-. Cuando Erich Fromm afirma que el hombre nunca puede dejar de tener fe y que la fe abarca muchas experiencias, no solo la trascendente, ¿está afirmando que no podemos dejar de estar abiertos a la realidad de Dios? ¿Será que la experiencia moral del ser humano va indisociablemente unida a la experiencia de fe en torno a un sentido de esperanza que está en íntima relación con la búsqueda de sentido y de trascendencia?

-. Cuando Max Weber habla de que el protestantismo contribuyó de manera innegable a afirmar la vida social, política y económica pasando de una sociedad de monjes a una sociedad de ciudadanos, y de una sociedad del ascetismo medieval a una sociedad racional y disciplinada, ¿está afirmando que el marco sagrado y trascendente no está al margen del compromiso con el mundo, sino que el mundo ha evolucionado y desarrollado la razón en buena medida por la contribución del hecho religioso a la evolución positiva de la humanidad en todas sus dimensiones?

-. Cuando Peter Berger habla de "rumores de lo trascendente en medio del marco inmanente" en el que nos movemos, ¿no se está refiriendo a que la secularización ha borrado muchas huellas de lo trascendente en el mundo occidental pero que sin embargo "no puede borrar del todo" algo que pertenece

\footnotetext{
1948 JUNG, C.G., Arquetipos e inconsciente colectivo, Paidós, Barcelona, 1970.

1949 VAN DER LEEUW, G., Fenomenología de la Religión, FCE, México, 1964.

${ }^{1950}$ DUMERY, H., Phénoménologie et religion. París, PUF, 1962; Philosophie de la religion: Essai sur la signification du christianisme. París, PUF, 1957, 2 vols.
} 
a la riqueza moral del hombre y que siempre habrá "rumores" de lo trascendente en medio de lo inmanente?

-. Cuando William James habla de que la religión es ante todo experiencia y sentimiento, ¿está aludiendo a este ámbito misterioso que se esconde en el corazón del marco inmanente y que nos invita a transcender la vida ordinaria invitando a una felicidad que va más allá del disfrute de las cosas comunes? Y cuando habla del hombre que nace una vez y del hombre que nace dos veces, ¿está invitando a volver a retomar el sentido de la propia vida a partir de las experiencias más significativas de la vida?

-. Cuando Erikson habla de que la experiencia religiosa es una experiencia saludable para el ser humano, que ayuda a integrar todos los momentos de la biografía de cada uno y que cohesiona todas las facetas del yo, ¿está afirmando que estamos dispuestos para abrirnos a lo trascendente como algo que nos plenifica y nos otorga la salud del alma? Y cuando habla de que "yo soy lo que sobrevive de mí”, ¿se está refiriendo a esa transcendentalidad de la vida como algo que se va realizando bajo la mirada positiva y enternecedora del que se abre a experiencias de encuentro y autoconciencia? ${ }^{1951}$

-. Cuando Allport habla de que la religión y el marco trascendente forman parte integrante de una personalidad madura y cohesionada interiormente, ¿está haciendo referencia a la necesidad inherente al ser humano de la experiencia religiosa? ¿Puede el hombre alcanzar la madurez al estar abierto a la experiencia de lo sagrado? ¿Puede desarrollar el hombre una rica personalidad, caracterizada por la madurez y la salud psicológica, sin estar abierto a la vida espiritual? ${ }^{1952}$

-. Cuando desde la Teología autores como Von Balthasar, Paul Tillich, W. Pannenberg, J. Bleeker, H. de Lubac, J. Ratzinger, T. de Chardin, K. Rahner, M. D. Chenu, Y. Congar... invitan a plantear el sentido trascendente del hombre como una búsqueda insaciable del corazón humano, ¿también están interrogando la condición humana como una condición en la que lo trascendente y lo espiritual no pueden obviarse y que la revelación no solo incluye a Dios que se manifiesta en la historia, sino la revelación del ser humano como algo que queda por descubrir dentro del plan de Dios para cada uno?

Retomando la idea de "estar abiertos a algo más", vemos que en el futuro de la religión esta apertura se manifiesta, dentro del marco inmanente en el que nos

${ }^{1951}$ Cfr. ERIKSON, E., El ciclo vital completado, Paidós, Barcelona, 2000.

${ }^{1952}$ Cfr. ALLPORT, G., La personalidad, Herder, Barcelona, 1985. 
encontramos, como lo que Taylor refiere con el término "sensación de asfixia", debido al reduccionismo ontológico en el que nos encontramos precisamente por la influencia del naturalismo y del utilitarismo instrumental en el que nos vemos envueltos. ${ }^{1953}$ Una sensación de incomodidad que se manifiesta de muchas maneras y en la que hay una característica común: la identidad impermeabilizada entendida como humanismo exclusivo. ${ }^{1954}$ Por eso, la necesidad de estar abiertos es, en muchas ocasiones, la única salida. Un estar abiertos que se manifiesta en ciertos momentos y lugares como una mirada positiva y tranquila hacia el marco trascendente como algo que se reconoce y que se expresa como una sensación de pérdida, de añoranza, pero sin determinar un cambio de marco. Se da por hecho que el marco inmanente es el marco único, el exclusivo, aunque con una necesidad de apertura. Estar abiertos significa que hay ciertos momentos que requieren el cambio de mirada y hay ciertos espacios que contribuyen a respirar hondo y a entrar en otras dimensiones a las que estamos acostumbrados. Es la dimensión de lo que algunos autores denominan "lo festivo", aquello que ayuda a romper la cotidianeidad inmanente que es la que realmente configura moralmente el mundo y al hombre. Tanto para las mayorías que se encuentran en el marco inmanente vivido casi como exclusividad, como para las personas más identificadas con el marco trascendente, y que también viven en el marco inmanente, se les invita a situarse con fervor, con vitalidad evangelizadora y como levadura en la masa en esta situación de semipaganismo. ${ }^{1955}$

Taylor considera que no nos encontramos ante el fin de la religión en la esfera pública, antes bien, se trata de un estadio decisivo en el desarrollo de nuestro mundo moderno, donde la creencia y su contrario coexisten como alternativas válidas. $\mathrm{Ni}$ tampoco es el fin de la religión personal. Es el fin de una sociedad estructurada a partir de su dependencia respecto de Dios o del más allá. ${ }^{1956}$

\section{... PERO DESDE EL MARCO INMANENTE}

Estamos abiertos a algo más..., pero desde el marco inmanente. Un marco inmanente que para Taylor no significa que deje abierta la cuestión de si, con fines de explicación última o de dotación de sentido final, podríamos invocar a algo trascendente. Lo realmente relevante para Taylor es que, cuando el marco inmanente se

\footnotetext{
1953 Cfr. TAYLOR, Ch., Fuentes del yo, pág. 462.

1954 Cfr. TAYLOR, Ch., La Era Secular, tI, págs. 371-372.

1955 Cfr. HILAIRE, I. M., "Entrevista”, Anuario de Historia de la Iglesia, No 7, (1998), pág. 310. "Se mezclan elementos de secularización, quizá una cierta descristianización, con elementos de cristianización, de evangelización, que son activos y que están en marcha. Lo que siempre me ha llamado la atención en el período reciente es la sorprendente aparición de un fervor religioso donde no era previsible, la existencia de movimientos de renovación espiritual en diferentes países de Europa que son ignorados por los medios de comunicación”. Ibid., pág. 316.

${ }^{1956}$ Cfr. TAYLOR, Ch., Imaginarios sociales modernos, pág. 215.
} 
trenza de una determinada manera, se impone un relato oficial que da por hecha la interpretación cerrada del mundo. ${ }^{1957}$

En las sociedades occidentales el punto de equilibro general está anclado con firmeza en la inmanencia, donde muchas personas tienen incluso problemas para comprender cómo una persona sensata puede creer en Dios y donde la narración secularizadora dominante, según Taylor, tiende a culpar a nuestro pasado religioso de gran parte de los males de nuestro mundo. ${ }^{1958}$

Lo que define al yo, según Taylor, mi identidad, está esencialmente definido por la manera en que las cosas son significativas para mí. ${ }^{1959}$ La identidad del yo incluye no solo su posición en cuestiones morales y espirituales, sino también una referencia a una urdimbre de la interlocución. ${ }^{1960}$ Este es el proyecto filosófico de Taylor en el que se quiere implicar y que conecta con la síntesis hegeliana que pretende de las dos grandes tradiciones de la modernidad: la unidad expresiva y la autonomía radical. Un yo que se establece como libertad autodeterminada, pero que al mismo tiempo se reconoce "expresivamente" abierto a realidades que le interrogan y le inquietan. ${ }^{1961}$ Taylor plantea estar en el punto medio de las presiones contrapuestas que definen a nuestra cultura y que esencialmente adopta dos formas: la del universo ordenado impersonal ya sea en su forma científico materialista o en su variante más espiritualizada, y la de la búsqueda de sentido espiritual. La primera forma se expresa como lamento y nostalgia, incluso dolor, como estar sin luz y caminar hacia el olvido. La segunda forma es una forma de reacción al mundo plano y vacío, reduccionista y materialista. ${ }^{1962}$

Taylor afirma que, desde el siglo XVIII, abunda la idea de que el Cristianismo, en muchos aspectos, desencaja con el orden moral moderno. Un Cristianismo que es visto con incomodidad provocando una atmósfera de malestar y de prejuicios en relación a ciertos elementos del misterio cristiano que no se comprenden del todo como verdad revelada o como si la ciencia y la tecnología predispusieran en contra de ciertos aspectos difícilmente compatibles con la racionalidad moderna.

Por otra parte, según Taylor, el Cristianismo es consciente de esa situación de desventaja, al estar asentado el marco inmanente como el marco desde el que se parte, el que se da por hecho, del que no se duda que sea el más compatible con el mundo de hoy. Cristianismo que, a veces, como reacción natural, adopta una actitud a la defensiva o apela a una lealtad a la que muchas personas no piensan corresponder. Un Cristianismo que es presentado, en esta situación de desventaja, a partir de valoraciones

\footnotetext{
${ }^{1957}$ Cfr. TAYLOR, Ch., La Era Secular, tII, pág. 468.

${ }^{1958}$ Cfr. Ibid., pág. 736.

${ }^{1959}$ Cfr. Ibid., pág. 61.

${ }^{1960}$ Cfr. Ibid., pág. 64.

${ }^{1961}$ Cfr. TAYLOR, Ch., Hegel, pág. 43.

${ }^{1962}$ Cfr. TAYLOR, Ch., La Era Secular, tII, págs. 464-465.
} 
morales fuertes, con lo que a menudo se posiciona en una situación de cierta incapacidad para entrar en diálogo, por su predisposición inicial o por cómo se presenta en relación con otras fuentes de la moralidad moderna. Y cuando, además, desde el Cristianismo se invita a aspirar a bienes superiores de sentido trascendente que van más allá de la felicidad de la vida ordinaria, se interpreta frecuentemente como algo distorsionante o una especie de amenaza para el sentido del bien moral propio del carácter inmanente y del liberalismo de la neutralidad. ${ }^{1963}$ Es lo que Taylor denomina presiones contrapuestas derivadas de la atracción que ejercen, por una parte, las narraciones de la inmanencia cerrada y, por otra, la sensación de su inadecuación, de su incapacidad para explicar el todo, para dar con ese sentido que sobrecoja totalmente el deseo en su búsqueda insaciable de plenitud. ${ }^{1964}$

El Cristianismo se encuentra en una posición en la que no termina de ubicarse en el marco inmanente que está establecido. Porque el Cristianismo siempre tenderá a plantear un marco trascendente y cuando casi exclusivamente se parte de lo inmanente, el espacio que queda para la afirmación trascendente cristiana es un espacio o reducido o que se ve, en el mejor de los casos, con prejuicio o con sospecha.

Pero al mismo tiempo, se produce una ambivalencia digna de reseñar. Por un lado, se afirma el humanismo exclusivo (marco inmanente) y, por otra parte, no se quiere dejar de estar abiertos a momentos y espacios de trascendencia. Se podría definir esta situación como de incomodidad, no solo para las grandes mayorías que se sienten aglutinadas por el marco inmanente (que reivindican espacios de trascendencia), sino también para el Cristianismo, que no termina de encontrar su puesto ni logra encajar en el marco inmanente, dado que no deja de ser una propuesta que va más allá de la inmanencia y de la identidad que se autodefine. ${ }^{1965}$

En la Modernidad, el Cristianismo a veces encuentra acomodo en esos espacios de apertura dentro de la inmanencia, aunque en otras ocasiones no termina de comprenderse a partir de dicho marco de referencia. El Cristianismo, que ha forjado la cultura Occidental y que ha contribuido de manera decisiva al establecimiento de las fuentes morales de la Modernidad, está desplazado y se siente tratado con desdén, porque ha perdido el protagonismo de otras épocas $\mathrm{y}$, sobre todo, porque no logra seguir creando cultura o difícilmente lo puede hacer desde el marco inmanente en el que nos encontramos, caracterizado por el subjetivismo y el naturalismo. ${ }^{1966}$

\footnotetext{
${ }^{1963}$ Cfr. TAYLOR, Ch., La ética de la autenticidad, págs. 50-54.

${ }^{1964}$ Cfr. TAYLOR, Ch., La Era Secular, tII, pág. 468.

1965 Cfr. TAYLOR, Ch., Argumentos filosóficos, págs. 34-35; cfr. TAYLOR, Ch., El multiculturalismo y la política del reconocimiento, págs. 51,79-81.

${ }^{1966}$ Cfr. TAYLOR, Ch., Hegel, págs. 471-472; cfr. TAYLOR, Ch., Argumentos filosóficos, pág. 65.
} 
Taylor considera que los prejuicios con que es visto el Cristianismo por la Modernidad sigue siendo un elemento motivador para reforzar el marco inmanente como el marco exclusivo. Situación que es aprovechada por la Modernidad para favorecer experiencias de cierre y de exclusividad. Todo lo que suponga arrinconar al Cristianismo es presentado frecuentemente como autodefensa frente al fanatismo o la exclusión, con lo cual el panorama para el Cristianismo es ciertamente desolador, ya que no cesan de reforzarse ciertas cosmovisiones con carácter de exclusividad. ${ }^{1967}$ El Cristianismo no solo es visto, frecuentemente, como una amenaza para unos bienes que son compartidos por la mayoría, sino que en los últimos dos siglos esa amenaza se ha manifestado, para asegurar la autodefensa, como un discurso contracultural, debido a que la buena vida, vista desde la modernidad, no es potenciada por el Cristianismo como la vida buena, con lo que el enfrentamiento entre ambas fuentes de moralidad entra en una flagrante oposición. Si la vida buena del Cristianismo no potencia la buena vida, en todas sus dimensiones de sensualidad y disfrute, entonces se refuerza el discurso anticristiano como opuesto radicalmente a las valoraciones de la modernidad en su búsqueda de la buena vida. ${ }^{1968}$ Esto es lo que ha motivado el surgimiento de ciertos movimientos anticlericales del siglo XIX. Se ha pasado frecuentemente de ver el Cristianismo como una amenaza a considerarlo como oposición radical. ${ }^{1969}$ Taylor llega a hablar, incluso, de posiciones extremas. ${ }^{1970}$

Una de las fuentes morales de la modernidad más importantes para Taylor y que ejercen una enorme influencia en el mundo de hoy es la idea de que somos parte de la naturaleza, una naturaleza que nos invita a vivir según todos los elementos que se encuentran insertos en ella, también la dimensión del placer y la sensualidad. Formamos parte de un todo y nosotros estamos dentro de este sistema natural y a él le pertenecemos. No estamos por encima, sino dentro de. Y al mismo tiempo, este sentido de pertenencia, nos lleva a resaltar el misterio que se esconde en nuestro propio yo: cómo algo tan grande como la naturaleza humana pudiera proceder de un origen que desconocemos o que nos lleva a indagar sobre los comienzos. ${ }^{1971}$ Taylor considera, por

\footnotetext{
1967 Cfr. TAYLOR, Ch., Hegel, pág. 9; cfr. TAYLOR, Ch., Imaginarios sociales modernos, pág. 203.

1968 "El bien humano es en su propia esencia sensual, terreno; aquel que lo identifique con un objetivo trascendente se aparta de él, lo traiciona”. TAYLOR, Ch., La Era Secular, tII, pág. 393; cfr. TAYLOR, Ch., Fuentes del yo, capítulo I.

1969 "Los anticlericales pertenecían a trasfondos religiosos muy diversos. Entre ellos había ateístas, como grupo creciente, pero que de ninguna manera era el único. En los distintos trasfondos religiosos se manifestaba la pluralización religiosa del siglo XIX, que en parte significaba también un proceso de descristianización en el sentido de un alejamiento de las iglesias oficiales. Los críticos podían ser católicos liberales o liberales católicos. Además, entre los anticlericales se encontraban deístas, teístas, espiritistas y otras representantes de ideas religiosas alternativas". DITTRICH, L., "Anticlericalismo y vías de secularización en la Europa del siglo XIX: La excepcionalidad española”, Conferencia, pág. 3. ${ }^{1970}$ Cfr. TAYLOR, Ch., La Era Secular, tII, pág. 473.

${ }^{1971}$ Cfr. TAYLOR, Ch., La ética de la autenticidad, págs. 71-75.
} 
otra parte, que el marco inmanente también tiene sus propias versiones de la plenitud, dado que de lo contrario todo sería desesperante e insoportable. ${ }^{1972}$

Es aquí, en este misterio y en este deseo de plenitud, donde nos encontramos tanto naturalistas como creyentes. Los naturalistas para extrañarse de que la naturaleza humana proceda de un orden cósmico del que formamos parte y que ha devenido en realizarse como un ser racional que explica la evolución dentro de las especies. Una naturaleza rodeada de misterio antes de que surgiera la mente humana y el sentido de la voluntad libre. Naturalistas que reconocen que la ciencia que todo lo explica no es capaz de evitar el misterio y que siempre hay algo que se nos escapa en nuestro afán por controlar el todo. Y los creyentes para profundizar en el análisis sobre cómo el misterio puede asumir la forma de un milagro que es posible desde un Ser Superior que ha establecido el orden natural y el surgimiento de un ser creado y que lleva la huella de Dios. $^{1973}$

Este misterio de las profundidades de los orígenes y la común búsqueda de plenitud probablemente permita un diálogo entre naturalistas y teístas, aunque las diferencias sean tan profundas que difícilmente se pueda llegar a un acuerdo en el alcance del misterio o en lo que Taylor denomina el dilema moral humano: tanto la atracción por la ética del valiente conocedor de la realidad como nuestra idea de la atracción que sentimos por la fe, no eran tanto una señal de una posibilidad real, como el rescoldo de una debilidad, un ansia de consuelo ante un mundo carente de sentido. ${ }^{1974}$

Lo que parece relevante destacar aquí es el necesario debate abierto y sin prejuicios y el diálogo sin compromisos, porque el misterio y el sentido de plenitud son reconocibles para unos y para otros. Los naturalistas reconocen que no todo se puede explicar por la causalidad natural, dando así paso a lo que Taylor denomina agujeros o pinchazos en el orden natural de las cosas. ${ }^{1975}$ Reconocer que el misterio no se desentraña del todo o que la naturaleza admite rupturas es tanto como estar abiertos a un diálogo con otras posibilidades que van más allá de la ciencia y la naturaleza.

No obstante, hay que reconocer que sigue existiendo un rechazo contundente del naturalismo a cualquier admisión de lo trascendente, a pesar de sus extrañezas ante el misterio que se escapa, aunque hay un tipo de naturalismo metodológico más proclive al encuentro. Sin embargo, ciertas posiciones radicales naturalistas, neonietzscheanas y materialistas siguen luchando por establecer el marco inmanente cerrado, con un yo impermeabilizado y decidido a establecer como única realidad la química orgánica o la física natural, así como la ciencia y la tecnología. En este sentido, lo mismo que

\footnotetext{
1972 Cfr. TAYLOR, Ch., La Era Secular, tII, pág. 476.

1973 Cfr. TAYLOR, Ch., Argumentos filosóficos, págs. 64-65, 88-89.

1974 Cfr. TAYLOR, Ch., La Era Secular, tII, pág. 480.

1975 Cfr. Ibid., pág. 394.
} 
Wittgenstein afirma que "una imagen nos tuvo cautivos" en relación con la epistemología cartesiana, ${ }^{1976}$ también podemos decir que el naturalismo nos puede llevar a una cautividad ontológica, según la cual, se da por hecho que solo existe la razón científica de carácter instrumental o un subjetivismo expresivo que se limita al reconocimiento del yo como autorreferente en la determinación del orden moral propio. Posibilitar un diálogo que rompa prejuicios es el mejor servicio que se puede hacer para una correcta comprensión del momento en que vivimos, evitando posturas irreconciliables que encierran y solo hacen fiable el relato oficial. Para Taylor, sigue siendo fundamental reconfigurar el relato de la secularidad moderna, que es lo que permitió que fuentes alternativas tuvieran tanta potencia y se impusieran como narración exclusiva sobre la base de un humanismo naturalista e impermeabilizado. ${ }^{1977}$

A partir de todo lo afirmado anteriormente, se plantea una doble disyuntiva ante la cual se exige coherencia intelectual y moral: o bien podemos ver lo trascendente como una amenaza, una tentación peligrosa, una distracción o un obstáculo para nuestro bien supremo, o bien podemos interpretar que responde a nuestras ansias, necesidades y realización más profundos del bien. ${ }^{1978}$ Para Taylor, el futuro de la religión hoy, en su época posdurkheimiana, pasa por el reconocimiento de que cada uno siga el camino de su propia inspiración espiritual. Aceptar lo realmente verdadero de nuestro propio yo espiritual nos posiciona en una apertura al diálogo con cualquier visión que ensalce la naturaleza del ser humano venga de donde venga. ${ }^{1979}$

\section{V.3.-EL FUTURO DE LA RELIGIÓN. PERSPECTIVAS. RETOS. REFLEXIONES}

El relato oficial de la Modernidad, según Taylor, se ha presentado como el surgimiento de un orden inmanente cerrado, como narraciones que nuestro autor denomina como de autoacreditación, que no posibiliten otra alternativa que la que se acredita como verdad oficial con pretensión de exclusividad. Y Taylor se pregunta: ¿Quién ha decretado que las transformaciones que podemos esperar y por las que debemos esforzarnos en la vida se circunscriban a las que se pueden desarrollar en un universo sin sentido carente de una fuente trascendente? ${ }^{1980}$

Taylor pretende reconstruir dicho relato y aportar otras visiones que también explican la secularidad moderna bajo otras perspectivas y superando las visiones contrapuestas. Él opina que con la Modernidad se produce una reubicación de la religión, ya que esta supuso un cambio de tales dimensiones, que el rol de la religión

\footnotetext{
${ }^{1976}$ WITTGENSTEIN, Investigaciones filosóficas, pág. 113.

1977 Cfr. TAYLOR, Ch., Fuentes del yo, pág. 434.

1978 Cfr. TAYLOR, Ch., La Era Secular, tII, pág. 396.

1979 Cfr. TAYLOR, Ch., Las variedades de la religión hoy, pág. 110.

${ }^{1980}$ Cfr. TAYLOR, Ch., La Era Secular, tII, pág. 460.
} 
también tuvo que adaptarse. ${ }^{1981}$ Algunos autores hablan de una recomposición de la misma dependiendo del punto de vista que adopten, sea ortodoxo o revisionista. ${ }^{1982}$

Según nuestro punto de vista, la Modernidad y la Religión establecieron una relación compleja, en ocasiones difícil, pero en ningún momento se puede hablar de incompatibilidad. Probablemente, el siglo XIX haya sido el siglo más complejo en relación con la Religión, quizás porque también haya sido el siglo que ha experimentado cambios más relevantes y profundos. ${ }^{1983}$ Taylor plantea algunos dilemas, como el que se produce entre humanismo y trascendencia, que necesitan ser resueltos. Su narración maestra pretende ser su aportación a nueva narración sobre la secularidad y a un intento por recuperar la ontología moral. ${ }^{1984}$

Creemos que la Modernidad, en lugar de crear conflicto con Dios y las religiones, quizás contribuye, como decía Wittgenstein, a agudizar el enfoque y a crear un mayor sentido de autenticidad para comprender el significado de Dios en la vida del hombre, pero de otra manera. Una época de cambios para un cambio de época. Un cambio de época que, como siempre que esto acontece, conduce a un cambio de paradigma. Y a partir de dicho cambio de época, Dios y las religiones tienen que recomponer su presencia, porque lo que está en juego no es su significado, sino el alcance con el que se comprende dicho significado. Taylor afirma que hoy los individuos tienen su propia percepción de la experiencia religiosa, sin preocuparse demasiado por cómo encaja a nivel social o por cómo afecta al destino de las diferentes iglesias. ${ }^{1985}$ Para nuestro hermeneuta, el establecimiento del marco inmanente con sus estructuras de mundo cerrado no significa que todo esté cerrado intrínsecamente a lo religioso. Antes bien, puede ser una oportunidad, para comprender de manera más adecuada el papel de la religión en el mundo actual, así como la crítica de la misma al desenvolvimiento histórico de la Modernidad Ilustrada. ${ }^{1986}$

Si para Foucault el hombre es solo una invención reciente, una figura que no tiene ni dos siglos, un simple pliegue en nuestro saber y que desaparecerá en cuanto este encuentre una forma nueva, ${ }^{1987}$ y si con la Modernidad, para Hegel, el hombre adquiere su

\footnotetext{
1981 "Podemos llamar a esto subjetividad negativa, ya que solo se afirma en el momento de su supresión, en el instante donde afirma lo Infinito, o que lo erige como limitación. Esta subjetividad se convertirá en positiva, en el momento mismo en que pase a ser el fundamento del conocimiento. Cuando las fuerzas en el hombre entren en contacto con fuerzas de la finitud, surgirá una subjetividad humana". BARCENAS MONROY, I., "El hombre como pliegue del saber", Ciencia Ergo Sum, Vol. 14-1, (2007), pág. 30.

1982 Cfr. TAYLOR, Ch., La Era Secular, tII, págs. 212-215.

1983 "Nacida de la autoidentificación con el hecho de saberse nuevo, es una actitud que aparece reflejada principalmente en un discurso filosófico y artístico moderno marcado por el desarrollo de la conciencia autónoma del yo, es decir, por la liberación de la subjetividad individual que fue elevada por Hegel a la categoría de problema filosófico". PÉREZ-ARGOTE, J.M., "Redescripción del concepto clásico de Modernidad", Sociología Histórica, No 7, (2017), pág. 14.

${ }^{1984}$ Cfr. TAYLOR, Ch., La Era Secular, tII, págs. 503 y ss.

1985 Cfr. TAYLOR, Ch., Las variedades de la religión hoy, pág. 121.

${ }^{1986}$ Cfr. TAYLOR, Ch., El multiculturalismo y la política del reconocimiento, págs. 50,52,56.

1987 "Sin embargo, reconforta y tranquiliza el pensar que el hombre es solo una invención reciente, una figura que no tiene ni dos siglos, un simple pliegue en nuestro saber y que desaparecerá en cuanto este
} 
propia figura y configuración una vez establecida la conciencia antropológica del hombre desde la razón que se eleva como autoconciencia espiritual, ${ }^{1988}$ podríamos decir que con la Posmodernidad se vuelve a configurar un nuevo modelo paradigmático en el que el sujeto cede y se diluye en el nihilismo. ${ }^{1989}$

En este sentido, según Heidegger, con la afirmación de Nietzsche, 'Dios ha muerto`, se está afirmando el fin del Dios de la onto-teología, es decir, lo sagrado se ha hecho indiferente al hombre. Heidegger interpreta que la muerte de Dios de Nietzsche es la muerte metafísica de Dios. Heidegger, siguiendo a Nietzsche, viene a afirmar que la filosofía occidental en tanto historia de la metafísica no ha tenido la altura para plantear la idea de Dios. Dios ha estado siempre "más allá". Es el desfallecimiento de los teísmos. El fundamento del mundo suprasensible se ha vuelto irreal. Para Heidegger se trataría de repensar lo divino y lo sagrado a partir de la pregunta por el Ser en una renovada experiencia de lo sagrado y Dios. Un Dios que sería el Totalmente Otro, Alguien completamente distinto al Dios de la Cristiandad. Es la desacralización del mundo en Heidegger que permite que todo funcione de otra manera. ${ }^{1990}$

Por eso, para Taylor, el proyecto de Hegel fracasó al no superarse la contradicción entre la razón objetivadora del mundo y la expresión del sentimiento como proyección del orden de la naturaleza e imponerse finalmente la objetivación mecanicista del mundo bajo su modalidad nihilista. ${ }^{1991}$ De ahí el proyecto tayloriano de reivindicar a Hegel en su síntesis filosófica para poder reconstruir una narración abierta de la secularidad moderna que incluya las valoraciones fuentes y el diálogo, con las fuentes morales trascendentes.

Lo mismo que surge el sujeto moderno sobre la base de la autonomía y la subjetividad, también tiene que surgir un sujeto moderno religioso sobre bases nuevas, que establezcan el nuevo lugar de la religión y el papel que está llamada a desempeñar en el nuevo contexto que configura la modernidad: el naturalismo cientifista y el sujeto impermeabilizado. La razón objetivadora del mundo ha persistido en encapsular enconada y confinadamente el mundo, de tal manera que la corriente expresivista quedó diluida, con lo que la razón impermeabilizadora ha comprometido en muchos casos el futuro del sentimiento y la expresión religiosa.

\footnotetext{
encuentre una forma nueva". FOUCAULT, M., Las palabras y las cosas, pág. 9.

1988 "En suma, el individuo autónomo que se inventa a sí mismo es aquel que se autoconstituye como un yo hacia dentro, ente subjetivo que se autopercibe como una identidad autónoma y traza un límite respecto de su identidad colectiva impulsándola hacia un horizonte de elegibilidad. Este proceso supone la interiorización de las fuentes morales del yo que, según la descripción de Taylor, residían anteriormente en un exterior que para San Agustín era Dios o para Platón el orden cósmico". PÉREZ-ARGOTE, J.M., "Redescripción del concepto clásico de Modernidad", págs.16-17.

1989 "En el sentido heideggeriano, el nihilismo sería pues la indebida pretensión de que el ser, en lugar de subsistir de manera autónoma, independiente y propia, esté en poder del sujeto. Pero probablemente no sea esta la significación última de la definición heideggeriana del nihilismo, aislada en estos términos, terminaría por hacer pensar que Heidegger quiere sencillamente volcar la relación subjeto-objeto en favor del objeto". VATTIMO, G., El fin de la Modernidad, pág. 24.

${ }^{1990}$ Cfr. HEIDEGGER, M., Nietzsche, Ariel, Barcelona, 2014, págs. 679-682.

${ }^{1991}$ Cfr. TAYLOR, Ch., Hegel, pág. 477.
} 
En todo este proceso del surgimiento del yo religioso moderno, está el papel que desempeña la tradición. Si la religión es expresión de unas creencias, la memoria de una comprensión vivida de las mismas y la legitimación por parte de una institución que las institucionaliza, entonces comprenderemos la crisis que la Modernidad supuso en relación con la tradición, puesto que ya no se daba nada por hecho. Por otra parte, el subjetivismo contribuyó a atomizar la experiencia religiosa y a determinarla en función de la propia conciencia del individuo. Todo se desfundamenta y todo tiene que reorganizarse a partir del propio yo que siente, vive y se configura desde su propia razón y autonomía moral. ${ }^{1992}$

Si la razón moderna está definida por dos fuentes morales (la razón y el orden de la naturaleza) todo lo que contribuya a afianzar, también desde la religión, ambas fuentes morales, estará bien visto. Y, tal y como hemos dicho, ni la razón ni la naturaleza son ajenas a la religión, antes bien, se trata de dos fuentes morales que tienen mucho que ver con la moralidad trascendente de la forma en la que se ha expresado a lo largo de la narración de esta historia. La síntesis hegeliana, como afirma Taylor, ha sido totalmente antropologizada, bloqueada en su comprensión como "autoconciencia en sî" para referirla exclusivamente hacia el hombre. Sin duda que ha habido humanismos en otras épocas, ámbitos de lo inmanente en los que la vida se desenvolvía, realidades propias del mundo que se desarrollaban desde sí mismas o en relación a lo trascendente en mayor o menor grado. Lo que es característico de la secularidad moderna es ese humanismo exclusivo, el ámbito inmanente que lo llena todo y desde el cual todo, también la dimensión trascendente, tiene su sentido. ${ }^{1993}$ Esa es la narración oficial que se ha establecido como verdad única. Frente a esta narración, Taylor propone otra narración en la que se plantean dilemas que dirimen una batalla crucial para definir cómo se vive la vida: humanismo y trascendencia o las raíces de la violencia. ${ }^{1994}$ Es necesario redefinir nuestras más altas aspiraciones espirituales o morales para los seres humanos, al tiempo que se muestra un camino para la transformación implicada en ello, de tal forma que no aplaste, mutile o niegue lo que es esencial a nuestra humanidad. ${ }^{1995}$

\section{V.3.1.-LA ETAPA POST-DURKHEIMIANA COMO UNA BÚSQUEDA INSACIABLE DE AUTENTICIDAD}

Taylor afirma que no es posible que, partiendo de tanto, nos encontremos con tan poco. Afirmación que le lleva a preguntarse: ¿Pero es que no hay más?, ¿es ese todo lo que hay?, ¿ha merecido la pena realizar este peregrinaje histórico-filosófico para encontrarnos con lo que tenemos entre manos? Taylor no acepta lo que a menudo parece

\footnotetext{
${ }^{1992}$ Cfr. TAYLOR, Ch., Argumentos filosóficos, págs. 63-64,67; cfr. TAYLOR, Ch., El multiculturalismo y la política del reconocimiento, págs. 102-105.

${ }^{1993}$ Cfr. TAYLOR, Ch., La Era Secular, tI, págs. 19,39,64,79,93,150,159,220,306,425.

${ }^{1994}$ Cfr. TAYLOR, Ch., La Era Secular, tII, págs. 509,511.

${ }^{1995}$ Cfr. Ibid., págs. 523,535.
} 
ser una premisa tácita acerca de la motivación humana subyacente a esta narración principal de la secularización. Pretende contribuir a una comprensión distinta de la secularidad, en la que el marco inmanente posibilite ir más allá del naturalismo utilitarista y de las estructuras del mundo cerrado. ${ }^{1996}$

Para Taylor la revolución de la subjetividad moderna se torna en el siglo XX, a partir de 1960, en la búsqueda insaciable de la autenticidad, como individualismo expresivo generalizado ${ }^{1997}$ que se remonta al siglo XVIII y a las élites del Romanticismo ${ }^{1998}$. Lo que ocurre es que, según Taylor, la ética de la autenticidad es la expresión generalizada de dicho individualismo en el siglo XX. Un expresivismo que se muestra en mayo del 68 en el que algunos quieren ver un cambio de época, un cambio de paradigma intelectual caracterizado por el reductivismo determinista, ${ }^{1999} \mathrm{el}$ nihilismo acosmista y antihumanista, ${ }^{2000}$ y la egología secularista. ${ }^{2001}$ Taylor, cambiando el enfoque, prefiere hablar del imperativo de la autocultivación no definido por el egoísmo vulgar de carácter materialista, sino por una búsqueda personal insaciable de elevación espiritual, experimentalmente variada y que potencia la autoestima y el enriquecimiento social. $^{2002}$

En la búsqueda de la autenticidad del yo, conectada al subjetivismo y a la experiencia del encuentro personal con la armonía y el equilibrio centrado de uno mismo, está el resurgir de lo que ha dado en llamarse "espiritualidad" frente a religión tradicional. Una espiritualidad que tiene que ver más con el subjetivismo, la atomización social y el relativismo que con el sentido de pertenencia a una religiosidad

\footnotetext{
${ }^{1996}$ Cfr. Ibid., págs. 370,391.

${ }^{1997}$ Cfr. Ibid., págs. 277 y ss. Sobre la búsqueda de la felicidad individual cfr. Ibid., págs. 296 y ss.

1998 "Pero lo que nos hace humanos es precisamente que no nos ceñimos a lo que la naturaleza hizo de nosotros. Somos capaces de volver sobre sus pasos, mediante el uso de la razón, para recorrer el camino que la naturaleza trazó antes, transformando así la obra de la necesidad en una obra del libre albedrío, y elevando la necesidad física a necesidad moral". SCHILLER, F., Cartas sobre la Educación Estética de la Humanidad, Carta III, pág. 13.

1999 Cfr. CASTRO HERNÁNDEZ, Entre-lugares de la Modernidad, Siglo XXI Editores, Madrid, 2017, págs. 167 y ss.

2000 “'Así, debo ser lo que 'tengo-de-ser' por el hecho mismo de escapar a ello... Nihilización, negación interna, reversión determinante sobre el ser-ahí que soy... Así, mi libertad viene a conferirme mi sitio". SARTRE, J.P., El ser y la nada, Losada, Buenos Aires, 2017, pág. 669. Cfr. TAYLOR, Ch., Imaginarios sociales modernos, pág. 209.

${ }^{2001}$ Cfr. DOMÍNGUEZ PRIETO, X.M., "Posmodernidad, personalismo y persona", Mayo del 68, una época de cambios un cambio de época, Editorial UFV, Madrid, 2019, págs. 163-166.

${ }^{2002}$ Cfr. TAYLOR, Ch., La ética de la autenticidad, pág. 65. "Pese a que algunos consideran que en el contexto de la globalización las expresiones de lo hierofánico tenderán a desaparecer, nosotros apostamos a que más bien la fe, lo sagrado, lo profano, las significaciones, los símbolos, los mitos, los ritos, los tabúes, la magia y otras expresiones religiosas se van a reconfigurar, e incluso podría incrementarse el número de creyentes, en tanto que las nuevas tecnologías de información permitirán la transmisión de valores y simbolismos religiosos como nunca antes se había podido lograr". MACARENA ADAMETUNAL SANTIAGO, "La religión como una dimensión de la cultura”, págs. 13-14.
} 
colectiva y a un ritualismo comunitario, tal y como se ha analizado a partir de algunas narraciones de la secularidad. ${ }^{2003}$

La autenticidad del yo supone, por una parte, el paso de un régimen paleodurkheimiano en el que se daba por hecho la conexión con lo sagrado a través de la integración en una Iglesia que era más o menos sinónimo de sociedad, a un régimen postdurkheimiano, caracterizado por su perspectiva expresivista y de autenticidad. Pero antes de llegar a esta última etapa, Taylor define una etapa intermedia, denominada neodurkheimiana. ${ }^{2004}$ La etapa neodurkheimiana está caracterizada por la afirmación de la elección personal, en la que las personas no dan por hecho que se integran en una Iglesia porque sí, sino que la libertad y la optatividad personal son los que definen la incorporación a dicha Iglesia. ${ }^{2005}$ Con la etapa tercera, denominada de autenticidad o posdurkheimiana, se intenta superar el marco global prefijado del modo neodurkheimiano, para hacer hincapié en la singularidad espiritual que uno vive y que justifica un proceso evolutivo hacia la interioridad personal, caracterizada porque lo que decido "debe decirme algo", más allá de ningún marco determinado de doctrina o tradición. ${ }^{2006}$ Ser fiel a mí mismo es mi identidad y eso es lo más importante que debo articular y descubrir. ${ }^{2007}$ Ahora, en opinión de Taylor, lo que decido "tiene que expresar mi senda espiritual”, el lugar en el que me siento más incardinado y más cómodo. ${ }^{2008} \mathrm{Se}$ pasa, pues, de una etapa en la que se da por hecha la incorporación a una Iglesia, a una etapa intermedia en la que yo decido y elijo en virtud de unas determinadas conexiones personales para, finalmente, concluir en una etapa final en la que "expreso" lo que soy tomando parte en una espiritualidad determinada. Es un expresivismo espiritual que no necesita del vínculo con el marco trascendente a través de Instituciones o de una religión de Estado.

El futuro de la religión, en esta interpretación postdurkheimiana de la que habla Taylor, no pasa por una inserción necesaria en un marco mediador. Puede que exista esa posibilidad, pero también puede darse la posibilidad de que no exista ningún marco referencial. Hay numerosos altares, como afirma Peter Berger. El futuro pasa por estar abiertos a una multiplicidad de experiencias, en las que probablemente las más

\footnotetext{
${ }^{2003}$ Cfr. TAYLOR, Ch., La ética de la autenticidad, pág. 49; cfr. TAYLOR, Ch., La Era secular, tII, págs. 290-293.

${ }^{2004}$ Cfr. TAYLOR, Ch., Las variedades de la religión hoy, págs.102-103.

${ }^{2005}$ Cfr. TAYLOR, Ch., La Era secular, tII, págs. 251,254,299,301,307,347,389,745.

${ }^{2006}$ Cfr. Ibid., págs. 304,308,337,345,367,669. "Los hombres se han convertido en completamente privados, es decir, han sido desposeídos de ver y oír a los demás, de ser vistos y oídos por ellos. Todos están encerrados en la subjetividad de su propia experiencia singular, que no deja de ser singular si la misma experiencia se multiplica innumerables veces. El fin del mundo común ha llegado cuando se ve solo bajo un aspecto y se le permite presentarse únicamente bajo una perspectiva". ARENDT, H., $L a$ condición humana, Paidós, Barcelona, 2018, pág. 67.

${ }^{2007}$ Cfr. TAYLOR, Ch., La multiculturalidad y la política del reconocimiento, pág. 51.

${ }^{2008}$ Cfr. GRÜN, A. y BOFF, L., Lo divino en el ser humano y el universo. Camino hacia la unificación, Trotta, Madrid, 2019, págs. 43-47. Lo divino como espacio interior de quietud.
} 
numerosas se realicen a través del contacto directo entre la persona y lo sagrado (subjetivismo). ${ }^{2009} \mathrm{Ni}$ será obligatorio ni se dará por hecho la presencia de ningún marco mediacional. Lo que será relevante, eso sí, será la expresión personal de lo que me define como identidad espiritual. Lo espiritual como tal ha dejado de estar relacionado intrínsecamente con la sociedad, según Taylor. ${ }^{2010}$

La etapa postdurkheimiana está caracterizada por lo que algunos autores denominan la naturalización de la espiritualidad, en el sentido de que lo que se valora tiene que ver con el acrecentamiento en una identidad espiritual que conecte con las fuentes morales del propio yo que busca con autenticidad y deseo. Es la nueva autoconciencia expresiva que invita a vivir la propia vida ahondando en el propio sentido de felicidad personal a través de una búsqueda que permita contactar con Dios a través de lo que "yo soy" y "yo siento". ${ }^{2011}$ Es el sentimiento de felicidad individual entendido como expresión elevada y consciente de sí mismo. Para Taylor, en este momento postmoderno, la intuición personal profundamente sentida se convierte en nuestro recurso espiritual más valioso. ${ }^{2012}$ Lo realmente decisivo es la importancia que se da a las profundidades del yo para escuchar los rumores de las aguas transcendentes. ${ }^{2013}$

En esta etapa postdurkheimiana caracterizada, según Schleiermacher, por los cultos desdeñosos de la religión, lo realmente relevante es la experiencia y el sentimiento espiritual. ${ }^{2014}$ Se trata de proponer el camino del sentimiento y la intuición espiritual. Cada uno sigue su propio peregrinaje espiritual, no importando el que encaje en mayor o menor medida en la ortodoxia oficial de una determinada religión. ${ }^{2015}$ Taylor

\footnotetext{
2009 "Por eso he insistido en que a Dios lo encontramos donde únicamente lo podemos encontrar nosotros, que somos seres humanos, nacidos en nuestra inmanencia, y que en ella permanecemos y estaremos mientras vivamos, por más que nos imaginemos que la podemos rebasar, superar o transcender de la manera que sea”. CASTILLO, J.M., La humanidad de Dios, Trotta, Madrid, 2019, pág. 116.

${ }^{2010}$ Cfr. TAYLOR, Ch., La Era Secular, tII, pág. 305; cfr. BELLAH, R., Hábitos del corazón, Alianza Editorial, Madrid, 1999, 424 págs.

${ }^{2011}$ Cfr. GARZÓN VALLEJO, I., "Postsecularidad: ¿un nuevo paradigma de las ciencias sociales?, Revista de Estudios Sociales, No 50, (2014), pág. 105.

${ }^{2012}$ Cfr. TAYLOR, Ch., La Era Secular, tII, pág. 303. No obstante, la naturalización de la espiritualidad también incluye la dimensión romántica de la voz de la naturaleza que es capaz de expresar una idea espiritual o un orden benevolente y de significados y que vibra, al mismo tiempo, con el yo que se relaciona consigo mismo. Es la voz de la naturaleza en nuestro interior. El elan que fluye a través de la naturaleza y brota, inter alia, en la voz interior. Cfr. TAYLOR, Ch., Fuentes del yo, págs. 505, 507. En este sentido Taylor, comentando a Hegel, afirma que compartió la esperanza de que esta síntesis sin precedentes pudiera ser realizada solo si uno podía ganar una visión de la realidad espiritual que subyace a la naturaleza, un sujeto cósmico, con el cual el hombre pudiera relacionarse él mismo y en quien pudiera en último término encontrarse a sí mismo. Cfr. TAYLOR, Ch., Hegel, págs. 43, 465.

2013 "El hombre tiene que ser uno solo en sí mismo, buscando tal estado en su fuero interno y en lo Uno y recibiéndolo dentro de lo Uno; esto quiere decir: contemplar únicamente a Dios". MAESTRO ECKHART, Tratados y sermones: obras alemanas, Edhasa, Barcelona, 1983, pág. 232.

${ }^{2014}$ Cfr. SCHLEIERMACHER, F., Sobre la Religión, Tecnos, Madrid, 1990; La Fe Cristiana, Sígueme, Salamanca, 2013.

${ }^{2015}$ Cfr. TAYLOR, Ch., Las variedades de la religión hoy, pág. 109; cfr. CASANOVA, J, Religiones públicas en el mundo moderno, PPC, Madrid, 2000. Probablemente si se estableciera una etapa
} 
afirma que es un mundo, en definitiva, que depende mucho más que antes de las intuiciones claras de los individuos que irradian en los demás. ${ }^{2016}$ De alguna manera es el camino que había iniciado la reforma en el que se busca encontrar la unión con Dios en una manera interna, buscando el testimonio interno del propio espíritu. ${ }^{2017}$

La era postdurkheimiana se caracteriza por una cultura fracturada en la que, por un lado, hay personas perdidas en una cultura atomizada y en un imaginario social caracterizado por un sentido común irreflexivo plagado de prejuicios atomistas. ${ }^{2018} \mathrm{Y}$, por otro lado, personas que han sido captadas por la cultura consumista y que no encuentran referentes trascendentes de ningún tipo, encontrándose arrojadas en un mundo hostil.

Con el desencantamiento del mundo y el descrédito de los órdenes de la Gran Cadena del Ser, el hombre va teniendo la conciencia de que se ha ido perdiendo algo muy importante, que la fundamentación ontológica del ser se ha ido debilitando y que da la impresión de que la dimensión heroica de la vida, por la que merece la pena vivir, se hubiera difuminado. Ha aparecido el individualismo que todo lo llena. ${ }^{2019}$ Con el advenimiento de la razón instrumental, parece como si la tecnociencia y la neurobiología dieran sentido a todo y no se necesitaran otros fundamentos más sólidos, produciéndose una búsqueda fragmentada que desconecta de lo sagrado. ${ }^{2020} \mathrm{El}$ poder de las organizaciones e instituciones de la Modernidad es tal, que imponen su visión del mundo, encontrándonos cada vez más limitados en nuestra capacidad de toma de decisiones. Para Taylor, se está en peligro de perder el control de nuestro destino, viéndose amenazada nuestra dignidad como ciudadanos. ${ }^{2021}$ ¿Ha merecido la pena llegar hasta aquí? O en clave hegeliana: ¿Merece la pena vivir abúlica e inconscientemente, dejándose sorprender por los impulsos? ${ }^{2022}$

posdurkheimiana en la sociedad no habría espacio para la religión en la esfera pública. Lo que está claro es que la interpretación posdurkheimiana es la que tendrá más futuro en el devenir de la religión. Es de alguna manera el recorrido que se ha ido realizando en los tres últimos siglos (XVIII-XIX y XX) hacia la razón desvinculada, el mundo desencantado y hacia el triunfo de la subjetivación moderna. Por otra parte, creemos que esta es la propuesta "a la carta" de la New Age con una religión que acepta solo aquello que desde las profundidades del yo parezca más correcto. Se rompe con cualquier marco que admita pluralismo para quedarse en un "pluralismo ilimitado" (tal y como afirma Taylor) sin marcos encorsetadores.

${ }^{2016}$ Cfr. TAYLOR, Ch., La Era Secular, tII, pág. 372.

${ }^{2017}$ Cfr. TAYLOR, Ch., Hegel, pág. 453.

${ }^{2018}$ Cfr. TAYLOR, Ch., Argumentos filosóficos, pág. 248.

${ }^{2019}$ Cfr. TAYLOR, Ch., Imaginarios sociales modernos, pág. 223.

${ }^{2020}$ Cfr. TAYLOR, Ch., La Era Secular, tII, pág. 375."Las condiciones de la existencia humana... nunca pueden 'explicar' lo que somos o responder a la pregunta de quiénes somos por la sencilla razón de que jamás nos condicionan absolutamente”. ARENDT, H., La condición humana, pág. 25.

${ }^{2021}$ Cfr. TAYLOR, Ch., La ética de la autenticidad, pág. 45.

2022 "Pero esta inocencia desaparece aquí, en esta oposición que vimos; porque justamente el ser natural inconsciente y abúlico del hombre es lo que no debe ser y es declarado malo ante la unidad pura, ante la pureza perfecta que yo reconozco como verdad absoluta. Lo antedicho implica que lo inconsciente y lo abúlico deben ser considerados como lo esencialmente malo. Y así la contradicción permanece siempre, 
En este contexto de individualismo expresivo y de alternativa a las religiones tradicionales surge lo que ha dado en llamarse una nueva espiritualidad, asociada a la New Age, el Neopaganismo y a Nuevos Movimientos Religiosos. ¿Se puede plantear la dicotomía espiritualidad frente a religión? Como afirma el profesor Frigerio, la palabra "espiritualidad" permite entender y visibilizar una forma cada vez más creciente de religiosidad, que enfatiza tanto la experiencia religiosa subjetiva, que prescinde de, o desenfatiza el rol de los grupos religiosos tradicionales, posicionando al individuo como árbitro último de su validez. ${ }^{2023}$

En este sentido la palabra "espiritualidad" recoge el escepticismo posmoderno frente a las autoridades jerárquicas tradicionales e impulsa el subjetivismo como invitación a una experiencia religiosa en la que el individuo expresa su propia percepción del mundo. ${ }^{2024}$ Una espiritualidad que se adentra en la emoción de las profundidades, ${ }^{2025}$ y hace hincapié en una experiencia religiosa que se confunde con la experiencia emocional de lo sagrado. ${ }^{2026}$ La espiritualidad en William James adquiere esa dimensión de "experiencia interior del hombre" y adquiere una valoración moral que va más allá del sentido social y de adhesión a una teología tal y como es transmitida por la tradición. ${ }^{2027}$ Para James, la religión enfatiza esta dimensión personal y tiene que ver con una relación que va de corazón a corazón. ${ }^{2028}$ Linda Woodhead habla de la

cualquiera fuera el lado hacia el que uno se vuelva. En tanto aquella pretendida inocencia se determina como lo malo, permanece mi inadecuación respecto de mi esencia, de lo absoluto y sé siempre que, de este o de aquel lado, no soy lo que debo ser". HEGEL, F., Filosofía de la Religión. Últimas Lecciones, pág. 252.

${ }^{2023}$ FRIGERIO, A., "La ¿nueva? Espiritualidad: ontología, epistemología y sociología de un concepto controvertido" Ciencias Sociales y Religión, No 24, (2016), pág. 209.

2024 "En la Modernidad Avanzada, al menos en Occidente, la religión tradicional o histórica se ha retirado a la periferia de la significación social, contemplándose como una opción de carácter privado ante la emergencia de otras posibilidades a elegir que ofrecen una religiosidad experiencial, emocional, mística, fuertemente ecléctica, con una orientación salvadora pragmática, aquí y ahora, y un holismo o universalismo teñido de cientificidad, ecología y humanitarismo genérico (religión a modo de 'espiritualidad de la humanidad', 'religión cósmica', 'espiritualidad planetaria', 'religión ecológica'). Se trata de una religiosidad transversal, global, híbrida y compleja”. ALBERT RODRIGO-HERNÁNDEZ MARTÍ, "Los movimientos psico-espirituales en la modernidad globalizada", AIBR, Revista de Antropología Iberoamericana, Vol. 9, No 3, (2014), pág. 277. Cfr. DE LA TORRE, R., "La espiritualización de la religiosidad contemporánea”, Ciencias Sociales y Religión, No 24, (2016), págs. 10-11; cfr. CORNEJO VALLE, M. y BLÁZQUEZ RODRÍGUEZ, M., "La convergencia de salud y espiritualidad en la sociedad postsecular” Revista de Antropología Experimental, No 13, (2013), Texto 2: $11-30$.

2025 Cfr. BRAUN, R., "La experiencia de conexión existencial como concepto naturalista de espiritualidad", Persona, No 20, (2017), págs. 86-87, donde se exploran términos como espiritualidad secular y conexión existencial.

${ }^{2026}$ HERVIEU-LEGER, D., La religión, hilo de memoria, pág. 93. Hervieu-Léger también cita a autores como Joachim Wach, Bergson, Roger Bastide en sus referencias a una religión vivida, "experimentada", dinámica, frente a las tradicionales vinculaciones de la religión a lo estático, cerrado o "en conserva".

${ }^{2027}$ Cfr. TAYLOR, Ch., Argumentos filosóficos, pág. 239.

2028 "En cierta forma la religión personal vendrá a demostrar que es fundamental en mayor medida que cualquier teología o sistema eclesiástico. Las iglesias, una vez establecidas, viven por tradición de segunda mano, pero los fundadores de cada iglesia debían originalmente su poder al hecho de su comunión personal directa con la divinidad. No solo los fundadores sobrehumanos, Cristo, Buda, Mahoma, sino también todos los creadores de sectas cristianas han experimentado en esta situación. Por 
religión como una subjective life spirituality, aunque sin olvidar otros aspectos a tener en cuenta. ${ }^{2029}$ Heelas plantea una self spirituality como el rostro nuevo de la religión entendida como una experiencia espiritual del yo en relación con lo sagrado, sin mediaciones. ${ }^{2030} \mathrm{Y}$ Mikhail Epstein sugiere el concepto de "religión minimalista" caracterizada por ser una espiritualidad vivida en el círculo más inmediato a uno mismo, con la familia y amigos, en lugar de las Iglesias, una vida especialmente consciente de lo particular y lo que experimento en lo que me rodea. ${ }^{2031}$ Lo institucional se va desvaneciendo y la religión aparece como un rostro invisible, en el que todo se adapta al contorno líquido de una experiencia emocional personal y en la que todo se desfundamenta para fluidificarse y adaptarse al yo. ${ }^{2032}$

Taylor afirma que se propone el empeño decidido porque nada ni nadie aparte a uno de su propia inspiración espiritual. ${ }^{2033}$

Taylor pretende recuperar para su relato sobre la secularidad moderna el "espacio abierto jamesiano" en el que se puede sentir la atracción por ambas direcciones: optar por un universo ordenado e impersonal que capta la pérdida de un mundo de belleza y calidez como un sentimiento de nostalgia y pérdida, o bien optar por algún tipo de búsqueda de sentido espiritual y a menudo hacia Dios.

\section{V.3.2.-LA RELIGIOSIDAD POPULAR, ¿UNA NUEVA ESPIRITUALIDAD SECULAR?}

Desde las dos fuentes de la moralidad moderna de las que se ha hablado anteriormente, y a partir de los malestares de la modernidad, se plantean a continuación tres preguntas fundamentales como pórtico de este apartado. ${ }^{2034}$

consiguiente, la religión personal todavía debería parecer la cosa primordial, incluso a quienes siguen considerándola completa solo parcialmente". JAMES, W., Las variedades de la experiencia religiosa, pág. 17.

2029"The first two concepts discussed religion as culture, and religion as identity dominate recent social scientific work. The third religion as relationship has been important in sociology where social relations are concerned, but less so when relations with super-social beings are also introduced. The fourth religion as practice has long been central in anthropology and is currently being taken more seriously in the sociology of religion. And the fifth religion power is recessive in sociology, but in urgent need of revival". WOODHEAD, L., "Five concepts of Religion", International Review of Sociology, Vol. 21, No 1, (2011), pág. 123.

2030 "To be reflexively spiritual... is to maintain a constant awareness of the ever-increasing variety of religious meanings available in the modern world, and to engage in an intentional but critical assimilation of those meanings into one's own spiritual outlook". BESECKE, K., 2002, en BENDLE, M., "Reflexive Spirituality and Metanoia in High Modernity” Australian Religion Studies Review, Vol.16, No 1, pág. 8. ${ }^{2031}$ Cfr. TAYLOR, Ch., La Era Secular, tII, pág. 376.

2032 "Los tiempos modernos encontraron a los sólidos premodernos en un estado bastante avanzado de desintegración; y uno de los motivos más poderosos que estimulaba su disolución era el deseo de descubrir o inventar sólidos cuya solidez fuera - por una vez-duradera, una solidez en la que se pudiera confiar y de la que se pudiera depender, volviendo al mundo predecible y controlable". BAUMAN, Z., Modernidad Líquida, págs. 9-10.

${ }^{2033}$ Cfr. TAYLOR, Ch., Las variedades de la religión hoy, pág. 109. 
1.- Primera fuente de malestar: el individualismo. ¿Tiene sentido hablar de religiosidad popular cuando la Modernidad tardía o Posmodernidad nos ha conducido al subjetivismo, a la desinstitucionalización y al individualismo? ${ }^{2035}$

2.- Segunda fuente de malestar: la razón instrumental. ¿Tiene futuro hablar de la religiosidad popular cuando la Modernidad nos ha conducido al predominio casi absoluto de la razón instrumental y a procesos de secularización en un mundo desencantado y de humanismo exclusivo?

3.- Tercera fuente de malestar: la sociedad del despotismo blando que impone su tiranía. ¿La desprivatización de lo religioso en la edad postsecular está llamada a configurarse como una religiosidad popular? ¿Se puede ser religioso en una sociedad en la que la gente termina convirtiéndose en ese tipo de individuos que están encerrados en sus corazones? ${ }^{2036}$

Con la Modernidad y el subjetivismo aumentan en gran número las personas que quieren ser religiosas "a su manera", tal y como se ha sugerido anteriormente. Se trata de personas a la búsqueda de Dios, en la comprensión que cada uno puede hacer de Él, en el Dios que cada uno ubica en el sentido de su existencia. ${ }^{2037}$ La religiosidad popular posibilita esa simbiosis entre individualismo e identidad colectiva, en la que las personas expresan su sentido del alma interior y al mismo tiempo se sienten partícipes de una identidad colectiva que les enraíza en la cultura y la tradición. En cierto sentido, las personas se ponen en los límites de lo institucional y lo manifiestan con su propia idiosincrasia. Esta espiritualidad es un ámbito para canalizar inquietudes, expresar sentimientos que van más allá de lo establecido en las religiones tradicionales, como por ejemplo la sensibilidad romántica hacia la naturaleza. ${ }^{2038}$ El profesor Emilio Justo considera que hay que tener en cuenta los "sentimientos colectivos" y las tradiciones de los pueblos. Las tradiciones y los símbolos culturales de los pueblos se deben considerar como vivencias impregnadas por experiencias religiosas que han generado una cultura y formas de convivencia enriquecedoras. ${ }^{2039}$

En relación con la primera fuente de la moralidad moderna, el subjetivismo y el individualismo, la religiosidad popular está en estrecha sintonía con aquellas

\footnotetext{
${ }^{2034}$ Cfr. TAYLOR, Ch., La ética de la autenticidad, págs. 37-47.

${ }^{2035}$ Cfr. TAYLOR, Ch., Hegel, pág. 46.

${ }^{2036}$ Cfr. TAYLOR, Ch., La ética de la autenticidad, pág. 44; cfr. TAYLOR, Ch., La Era Secular, tII, pág. 202.

${ }^{2037}$ Cfr. TAYLOR, Ch., Hegel, pág. 28.

2038 "Por eso no es extraño que en la religiosidad popular los elementos de procedencia natural tengan una gran importancia. A menudo son la referencia sobre la cual se asientan las fiestas más importantes, como ocurre con el ejemplo muy significativo de los solsticios y los equinoccios y su efecto sobre la Tierra y sobre las personas". SAN JOSÉ PRISCO, J., "La religiosidad popular. Aspectos antropológicos, culturales y canónicos", REDC, No 63, (2006), pág. 312. Cfr. DELGADO, M., "La religiosidad popular. En torno a un falso problema", Gazeta de Antropología, No 10, (1993), págs. 12-13.

${ }^{2039}$ Cfr. JUSTO, E., Después de la Modernidad, págs. 174.
} 
expresiones religiosas que se salen de lo establecido y que de alguna manera responden a inquietudes que permiten elegir a las personas por sí mismas, sin olvidar el sentido de identidad colectiva. Unas manifestaciones que siguen su ritmo, que mantienen la vinculación con las religiones institucionales pero que por otra parte se expresan como colectividad, a su manera, con sus características propias y que no tienen que ver exactamente con las regulaciones de la religión institucionalizada. Es un paso intermedio en el camino de la desinstitucionalización de las religiones. Para el profesor Lira Latuz, frente al carácter apolíneo de las religiones institucionales caracterizado por el orden, las leyes y regulaciones, la espiritualidad popular expresa esa dimensión dionisíaca del sentimiento colectivo en su carácter extático. ${ }^{2040}$ En cierto sentido, la religiosidad popular tiene esa dimensión de la forma neodurkheimiana de la religión, tal y como la describe Taylor, según la cual no hay ninguna forma de estar en la Iglesia en general, sino a través de la decisión del individuo y el derecho de elección. ${ }^{2041}$ Así como en el modelo paleodurkheimiano la pertenencia a la Iglesia y a la sociedad se identificaban a través de lo que Taylor denomina "la religión popular", en el modelo neodurkheimiano se conjugan lo colectivo con la capacidad de expresión personal en el ámbito de la decisión individual. ${ }^{2042}$ ¿Se puede relacionar dicho modelo con "la religiosidad popular"?

Es más, si las religiones tradicionalmente ofrecieron a las sociedades una comprensión del mundo y el cosmos en su vinculación con lo sagrado, en el caso de la religiosidad popular se compagina ese aspecto de lo social y colectivo, tan vinculado a los orígenes de las religiones, con la posibilidad de expresar "de otra manera", de manera moderna, las posibilidades que ofrece la nueva configuración filosófica del cosmos y el mundo, ${ }^{2043}$ en una síntesis armónica entre el subjetivismo del yo que busca y se expresa y la necesidad de mantener los lazos con los demás. En este mismo sentido, Hegel considera la religión en su dimensión subjetiva y objetiva, en el espíritu realizado en la vida de un pueblo. ${ }^{2044}$

Por lo tanto, la religiosidad popular sería la síntesis cuasiperfecta entre colectividad y modernidad entendida esta como una expresión religiosa distinta de la establecida en las religiones institucionales. ${ }^{2045}$ Una religiosidad un tanto difuminada y no centrada en lo doctrinal. Una experiencia religiosa que se basa en lo básico de la

\footnotetext{
${ }^{2040}$ Cfr. LIRA LATUZ, C., "En torno al concepto de religiosidad popular", Aisthesis, No 60, (2016), pág. 297.

${ }^{2041}$ Cfr. TAYLOR, Ch., La Era Secular, tII, pág. 299.

${ }^{2042}$ Cfr. Ibid., págs. 223-225.

${ }^{2043}$ Cfr. TAYLOR, Ch., La ética de la autenticidad, pág. 71.

${ }^{2044}$ Cfr. TAYLOR, Ch., Hegel, págs. 13,47.

${ }^{2045}$ Taylor habla de la religión popular del Ancien Régime. "Entonces, en realidad, el término 'cristianismo difuso' fue acuñado por la religión popular no oficial de un período más moderno, pero todavía no contemporáneo, el final del siglo XIX y el principio del siglo XX en el Reino Unido". TAYLOR, Ch., La Era Secular, tII, pág. 351.
} 
afirmación de Dios, de Jesucristo como hombre bueno que invita al amor a Dios y los hombres, que nos promete la vida eterna, con una cierta indiferencia hacia lo institucional que no hostilidad, comprometiéndose a la participación semanal en el culto, funerales, fiestas anuales, tiempos superiores. Se pone especial énfasis en la sencillez de la creencia y lo comunitario más que en la teología y lo individual. ¿Encaja la religiosidad popular con el pensamiento de la modernidad asociado a un cierto relativismo blando? ? $^{2046}$

Por una parte, se enfrenta a la primera forma de malestar de la modernidad, al individualismo, al potenciar lo colectivo $\mathrm{y}$, por otra parte, retoma la línea de la expresión subjetiva propia, entendida como libertad para expresarse de forma diferente a la establecida oficialmente. En este sentido, podríamos decir que se relaciona con el ideal de la autenticidad, pues la religiosidad popular tiene que ver con manifestar un ideal religioso auténtico al no darse por hecho lo que las religiones tradicionales establecen como vía ordinaria. Con la religiosidad popular, se trataría de una expresión peculiar, propia de una colectividad, expresada en la autenticidad de la tradición y los sentimientos compartidos.

Además, conjuga lo específico frente a algo establecido/dado de lo institucional, contribuyendo a expresar una identidad colectiva. La religiosidad popular contribuye a configurar identidades nacionales en base a las tradiciones culturales propias de cada pueblo. ${ }^{2047}$ ¿Es la religiosidad popular la expresión moderna del sentido de identidad particular que proporciona el sentimiento de ser lo que se quiere ser sin olvidar lo que se ha sido y encontrar la forma de realizarse, pero en un sentido colectivo? ¿Es la religiosidad popular una expresión de que no todo emana de la superestructura del poder? ${ }^{2048}$

La religiosidad popular viene a ser una confirmación, en Occidente, de que la secularización no es la única salida a la evolución histórica asumible y explicable al proceso secularizador vivido en las sociedades. Es una expresión de que las religiones siguen ocupando sus propios espacios de vida social y que no hay una única salida a la evolución experimentada por las sociedades. ${ }^{2049}$ Incluso para Habermas, la edad

${ }^{2046}$ Cfr. TAYLOR, Ch., La ética de la autenticidad, págs. 54, 57.

2047 "Son infinidad las sociedades y Estados en todo el mundo en los que la religión constituye una marca o seña de identidad nacional, hasta el punto de que bastantes movimientos nacionalistas se definen no solo sobre particularismos étnicos, culturales, históricos o lingüísticos, sino que los refuerzan mediante una adscripción a una religión dada". GARCÍA PICAZO, P., "Perspectivas sobre el hecho religioso en el sistema mundial contemporáneo", Estudios, Vol. LXII, No 2, (2010), pág. 129.

${ }^{2048}$ Cfr. TAYLOR, Ch., El multiculturalismo y la política del reconocimiento, pág. 103.

2049 "No se niega la evidencia de que existe una importante secularización en estos países; sin embargo, las religiones se siguen reproduciendo en diversas modalidades y configuraciones. Esta coexistencia de la secularización y de la postsecularización crea sociedades en las que conviven ciudadanos religiosos y ciudadanos no religiosos. Unos y otros tienen formas diversas de religiosidad y de no religiosidad". DÍAZ SALAZAR, R., Modernización, religiones y laicidad en el sistema-mundo”, Sistema, No 239, (2015), pág. 68. 
postsecular se caracteriza por el pluralismo de cosmovisiones en el que la religión ocupa su propio ámbito y la necesaria diferenciación de discursos en una complicada arquitectónica. ${ }^{2050}$ La religiosidad popular sería, en este sentido, una expresión clara de que la religión no ha sido superada en las sociedades secularizadas de Occidente, que tiene su propio ámbito de expresión y que la religión no queda limitada al ámbito de lo privado. $^{2051}$

Por otra parte, la religiosidad popular entendemos que es moderna en el sentido que expresa el pluralismo de las sociedades modernas. Ya no hay una única forma institucional, cerrada, de expresar el sentido trascendente de la vida. Hay un pluralismo que expresa esa sociedad líquida, y en la que se ha superado esa visión estática de fundamento único. Es una forma más de expresar que hay una múltiple variedad de manifestaciones religiosas que se adaptan a los intereses y momentos de las sociedades y a la vida concreta de cada ser humano. ${ }^{2052}$ ¿Se podría incluso afirmar que la religiosidad popular es una de las nuevas formas de espiritualidad secular? Se entiende aquí, por espiritualidad secular, esa espiritualidad que, según Taylor, recoge el momento presente secularizador, en donde el marco inmanente permite expresar el sentido trascendente de la vida y donde se canalizan los ritos de iniciación, la sensibilidad romántica hacia la naturaleza y la ecología, el enraizamiento moral y cultural, el sentido de pertenencia en el respeto a la identidad del yo junto con la revitalización del arte y el folclore. ${ }^{2053}$ La religiosidad popular expresaría ese carácter secular también en su intento de superar los monopolios religiosos que ya no pueden contar con la fidelidad absoluta de sus feligreses a través de la tradición y la imposición jerárquica. ${ }^{2054}$

La religiosidad popular tiene que ver con ese retroceso de las religiones tradicionales, mucho más institucionalizadas, para potenciar un sentido trascendente no tan anquilosado en ritos y doctrinas; una religiosidad que tiene que ver más con lo cotidiano y con las personas en sus realidades concretas: deseos, compromisos, experiencias, accesibilidad hacia lo cotidiano. ${ }^{2055}$ Taylor en cierto sentido se refiere a lo

${ }^{2050}$ Cfr. HABERMAS, J., Entre naturalismo y religión, págs. 83 y ss.

2051 "La tendencia universal dominante es la dimensión pública de las religiones y en las sociedades secularizadas estamos experimentando una desprivatización de las religiones. Esta desprivatización en nuestros países occidentales y el refuerzo de la dimensión pública en aquellos donde el proceso de secularización no se ha desarrollado con fuerza tiene diversas expresiones". DÍAZ SALAZAR, R., "Modernización, religiones y laicidad en el sistema-mundo", pág. 68.

2052 "Se trata de una sociedad que hace gala de diferentes modos de decir-representar la realidad (economía, política, ciencia, etc.) que, ubicados en la experiencia mundano-secular, disponen de lógicas y resortes simbólicos irreductibles entre sí. Se trata de una sociedad sin la tutela religiosa omnipresente en las sociedades premodernas". SANCHEZ CAPDEQUÍ, C., "Las formas de la religión en la sociedad moderna”, Papers, No 54, (1998), pág. 179.

${ }^{2053}$ Cfr. TAYLOR, Ch., Hegel, págs. 475-477.

2054 "En efecto, al mismo tiempo que los monopolios religiosos ya no pueden contar con la fidelidad de sus feligreses, la tradición religiosa, antaño impuesta de forma autoritaria, ahora es un producto que depende del marketing”. SÁNCHEZ CAPDEQUÍ, C., pág. 181.

2055 "El punto de partida y de encuentro de la experiencia trascendente se achica y banaliza, pero se expande por la sociedad. Entramos en lo que un T. Luckmann ha denominado 'pequeñas trascendencias y 
mismo cuando habla, refiriéndose a Chantal Millon, de ese "deseo de eternidad" que reúne en un gran todo único, los momentos de significado dispersos en la vida de cada uno y de las sociedades.

En este sentido la religiosidad popular va en sintonía con las pequeñas y medianas trascendencias de Luckmann, aunque sin desvincularse de lo específicamente sagrado y los ritos de las religiones institucionales. Se caracteriza por un cierto achicamiento, caracterizado por la popularización de la expresión religiosa. Es el pueblo el que asume el protagonismo expresando una religiosidad desde abajo, establecida por sus propios sentimientos. Se podría incluso afirmar que es un tipo de expresión religiosa que contribuye a superar la tensión propia de la laicidad moderna hacia el mundo de la religión.

Además, tal y como afirma el profesor De La Torre y en relación con la etapa neodurkheimiana de Taylor, la religiosidad popular supone una elaboración religiosa en la que se intenta realizar una síntesis primera entre lo local y lo universal, entre lo tradicional y lo nuevo y entre lo social y lo individual. Es decir, que indica un camino nuevo hacia una síntesis distinta, pues se ubica entre todos estos extremos, configurándolos desde una posición innovadora. Los incluye todos y al mismo tiempo los supera en una creatividad ennoblecedora que debe tenerse en cuenta. ${ }^{2056}$ Taylor considera que en el efecto neodurkheimiano se funden las nociones de pertenencia grupal y confesional, y los aspectos morales de la historia del grupo tienden a formularse en categorías religiosas. ${ }^{2057}$

Concluimos, afirmando con Taylor, que la Modernidad supuso en muchos casos, una ruptura con la religión que alejaba a ciertos estratos populares de la Iglesia, sin ofrecerles necesariamente ninguna alternativa ante el decaimiento rápido del tipo paleodurkheimiano. ${ }^{2058}$ En este sentido, la religiosidad popular está en relación con el tipo "neo" que tiene que ver con las posibilidades expresivas y con la defensa colectiva de una identidad frecuentemente amenazada, tal y como lo refiere frecuentemente Charles Taylor.

medianas trascendencias' y el alejamiento de la 'gran trascendencia'. De esta suerte el encuentro con lo sagrado, puede tener lugar, ya no en una iglesia o mezquita y en compañía de las grandes imágenes, sino en un acontecimiento musical, deportivo, político". Ibid., pág. 182.

2056 "Es un espacio umbral de negociación constante donde se tradicionaliza lo emergente, y se construye la vigencia de lo antiguo, donde lo global se enraíza, y las raíces étnicas y nativistas se transnacionalizan. No solo representa un residuo del pasado, sino el dinamismo constante, en que se redefine lo nuevo y lo tradicional, dotando de continuidad y anclaje territorial a las nuevas situaciones, prácticas y formas culturales que provienen de lugares inaccesibles en el tiempo y el espacio convencional y próximo". DE LA TORRE, R., “La religiosidad popular como 'entre-medio' entre la religión institucional y la espiritualidad individualizada", pág. 519.

${ }^{2057}$ Cfr. TAYLOR, Ch., Las variedades de la religión hoy, pág. 87.

${ }^{2058}$ Cfr. TAYLOR, Ch., Fuentes del yo, pág. 462. 


\section{V.3.3.-EDAD SECULAR Y NATURALIZACIÓN DE LA ESPIRITUALIDAD}

¿Se está produciendo una naturalización de la espiritualidad, por influencia del naturalismo? No pretendemos analizar el naturalismo, solo plantear los retos que lanza al mundo de las religiones y la espiritualidad desde la visión de Charles Taylor. A partir del naturalismo, pretendemos explorar caminos de diálogo entre ambas fuentes morales o por lo menos ver en qué medida pueden evitarse los prejuicios y las autoexclusiones. De ahí el planteamiento como interrogante en torno a la posibilidad de una naturalización de la espiritualidad.

1.- Taylor sostiene que el mapa de la actualidad distribuye las fuentes morales en tres grandes ámbitos: la modalidad teísta, el naturalismo de la razón desvinculada y el expresivismo romántico-modernista, ámbitos que no permanecen iguales, sino que constantemente toman prestado de uno y de otro y se influyen entre sí. ${ }^{2059}$ Por ello, hablar de espiritualidad y de naturalización de la espiritualidad es apelar a ese intercambio de influencias que llega de un lado y del otro e intenta, en este caso, esbozar un pequeño esquema que permita plantear la posibilidad de una espiritualidad naturalizada, esto es, una espiritualidad que mira al naturalismo de la razón desvinculada e intenta comprender qué elementos pueden enriquecer su propia comprensión como valoración moral trascendente. Por otra parte, para Taylor, dentro del marco inmanente que lo envuelve todo como ámbito de humanismo exclusivo, un subjetivismo total y plenamente consciente y un naturalismo desvinculado, ciertamente conducirían a la vacuidad. En opinión de Taylor, se impone algo más que la autorrealización subjetiva o la idea de que la ciencia se sostiene a sí misma por entero a través del materialismo en el afrontamiento moral de la verdad evidente de que solo somos seres materiales en un mundo material. ${ }^{2060}$

Según el punto de vista de Taylor, la autoimagen del naturalismo ilustrado es la que gana más credibilidad en el siglo XIX, una vez que la fe religiosa ha sido desplazada como moral predominante. ${ }^{2061}$ Mientras que la ciencia confería una forma teórica clara a una idea de orden inmanente que se pudiera comprender por sí misma, sin hacer referencia a intervenciones externas, la vía del individuo impermeabilizado instrumentalmente eficaz en el tiempo secular creó el contexto práctico en el seno del cual la autosuficiencia de este ámbito inmanente se pudiera convertir en un dato de la experiencia, a partir del espectador imparcial o la simpatía innata o la libertad racional. Todo se puede inmanentizar por completo sin vincularlo a la naturaleza, sino a la motivación humana en general. ${ }^{2062}$

\footnotetext{
${ }^{2059}$ Cfr. Ibid., pág. 670.

${ }^{2060}$ Cfr. TAYLOR, Ch., Fuentes del yo, pág. 685; cfr. TAYLOR, Ch., La Era Secular, tII, págs. 416-417.

${ }^{2061}$ Cfr. TAYLOR, Ch., Fuentes del yo, pág. 462.

${ }^{2062}$ Cfr. TAYLOR, Ch., La Era Secular, tII, págs. 387-388.
} 
Comenzamos constatando la existencia de tres tipos de naturalismo:

- Un naturalismo epistemológico según el cual la ciencia permite la metodología de conocimiento que asegura más fiabilidad y grado de certeza o lo que algunos han afirmado que la ciencia es la forma genuina de conocimiento o la forma más racional de afrontar cualquier situación o problema. Sellars es uno de sus más relevantes representantes cuando afirma que para describir y explicar el mundo, la ciencia es la medida de todas las cosas: de lo que es en cuanto es y en cuanto no es. ${ }^{2063} \mathrm{Si}$ la ciencia en la forma más fiable y no falsable de todos los conocimientos, entonces ¿qué sentido tiene la epistemología filosófica? Si la ciencia va ocupando ámbitos del saber que tradicionalmente eran propios de la filosofía, como el estudio de las causas y del movimiento, el origen de las especies, ¿ocupará la ciencia al final todos los ámbitos del conocimiento de forma que se llegará a la disolución final de la filosofía en la ciencia? ${ }^{2064}$ ¿Se pueden reducir ciertas disciplinas filosóficas a capítulos de ciencias naturales, a través de una epistemología naturalizada (psicología experimental) o de una ética naturalizada (conciencia moral como producto de estructuras biológico-evolutivas) $?^{2065}$

- Un naturalismo ontológico, ${ }^{2066}$ según el cual solo existen entidades, procesos o propiedades naturales, o en forma resumida, que no hay más realidad que la natural. ${ }^{2067}$ Naturalismo que tiene en Dawkins y en Hawking a sus más preclaros representantes. Para Dawkins la naturaleza son fuerzas ciegas de la física, aunque desplegadas de manera especial. Dios es un relojero ciego que

\footnotetext{
${ }^{2063}$ Cfr. SELLARS, W., Empirismo y filosofía de la mente, pág. 337.

${ }^{2064}$ DIÉGUEZ, A., "La opción naturalista. Una respuesta a Francisco Soler", Naturaleza y Libertad, No 1, (2012), pág. 240.

${ }^{2065}$ Cfr. AGAZZI, E., La ciencia y el alma de occidente, pág. 286.

${ }^{2066}$ Cfr. SÁNCHEZ, A., "La concepción del yo en Daniel Dennett: Un análisis de la relación entre la perspectiva heterofenomenológica y el enfoque mimético”, Logos, No 24 (1), (2014), págs. 40-50. Cfr. VELÁZQUEZ FERNÁNDEZ, H., "En torno a la naturalización de la conciencia sugerida por Daniel Dennett", Naturaleza y Libertad. Revista de Estudios interdisciplinares, No 4, (2014), págs. 239 y ss. Cfr. MOYA, A., "Las peligrosas ideas de Darwin", Teorema, Vol. 28, No 2, (2009), págs. 5-13. En este sentido parece relevante señalar que algunos de dichos autores están "repensando" en la actualidad sus posiciones al respecto, afirmando que el declive del cristianismo está afectando seriamente la sociedad, en dos debates que tuvieron lugar en Londres y Dublín en julio de 2018 que aparece en la página web religión digital. No se necesita considerar cré́ble el cristianismo para darse cuenta que es necesario. Incluso alguno de ellos se describe como "cristiano ateo".

${ }^{2067}$ Cfr. DIÉGUEZ LUCENA, A., "Delimitación y defensa del naturalismo metodológico. En la ciencia y en la filosofía”, pág. 26. En GUTIÉRREZ LOMBARDO-SAN MARTÍN, La filosofía desde la ciencia, México, Centro de Estudios Filosóficos, Políticos y Sociales Vicente Lombardo Toledano, 2014. "La filosofía de Quine conducen inequívocamente a una negación del sujeto (u objeto, en terminología lógica): el individuo no sería una realidad independiente, en sí, sino que sería algo desconocido, totalmente ignoto, que solo podemos concebirlo dentro de un lenguaje. Esta 'desconstrucción' del sujeto, tematizada en Quine como 'relatividad ontológica', concluiría en la tesis fuerte de que 'no hay filosofía primera'. Sin embargo, Quine no se queda en esa desconstrucción, sino que ofrece, especialmente en sus últimas obras, una auténtica ontología de los objetos". GARCÍA MARQUÉS, A.T., "La desactivación de la ontología en Quine”, Thémata, No 37, (2006), pág. 237.
} 
no prevé ni ve. La selección natural es un proceso automático, ciego e inconsciente y que es la explicación de la existencia y forma de cualquier tipo de vida con un propósito aparente y que no tiene ninguna finalidad en mente. Carece de mente e imaginación. No planifica el futuro. ${ }^{2068}$ Aun así, para Dawkins, los resultados vivos de la selección natural nos impresionan de forma irresistible, por su apariencia de haber sido diseñados por un maestro relojero, nos impresionan con la ilusión del diseño y la planificación". ${ }^{2069}$ En este diseño sin mente y planificación, los pensamientos y las emociones humanas surgen de interconexiones de entidades físicas extremadamente complejas dentro del cerebro. No hay nada más allá del mundo natural y físico, y no existe ninguna naturaleza creativa sobrenatural escondiéndose detrás del universo observable, ni un alma que dure más que el cuerpo. ${ }^{2070}$ Para Hawking, no hay ninguna necesidad física de un comienzo. No tendría sentido suponer qué fue creado antes del big bang. Un universo en expansión no excluye la figura de un creador, pero pone límites a cuándo Él podría haber realizado su obra. ${ }^{2071}$

- Y, finalmente, un naturalismo metodológico que adopta la metodología científica como la única forma válida de acceder al conocimiento de la realidad. ${ }^{2072}$ Intenta probar las hipótesis y eventos científicos con referencia a eventos y causas científicas. Para los científicos religiosos, sus creencias afectan a la forma en que piensan sobre las implicaciones de su trabajo, pero no la forma en que practican la ciencia. ${ }^{2073}$

Partiendo de estos diferentes naturalismos analizaremos la influencia de los mismos en la fe religiosa, así como en el imaginario social. El problema para las relaciones entre ciencia y fe estriba en extender el naturalismo metodológico al epistemológico y ontológico. ${ }^{2074}$ Ciertamente que el naturalismo entendido en sus tres dimensiones se atribuye a sí mismo la explicación del Todo, con lo que se plantean serios problemas de alcance filosófico, cuando no científico también. ${ }^{2075}$ En este

${ }^{2068}$ Cfr. DAWKINS, R., El relojero ciego, Tusquets Editores, Barcelona, 2015, pág. 21.

${ }^{2069}$ Cfr. Ibid. pág. 41.

${ }^{2070}$ Cfr. DAWKINS, R., El espejismo de Dios, Espasa Calpe, Madrid, 2007, pág. 23.

${ }^{2071}$ HAWKING, S., La teoría del Todo, Primera Conferencia, Penguin Random House, Barcelona, 2019, pág. 23.

2072“"Con el avance de nuestros conocimientos hemos de proceder como si solo hubiese entidades y causas naturales. Solo las causas naturales y las regularidades que las gobiernan tienen auténtica capacidad explicativa. Apelar a causas o a entidades sobrenaturales, como el espíritu (en el caso de la actividad mental) o la fuerza vital (en el caso de la vida), es lo mismo que no explicar nada". DIÉGUEZ LUCENA, A., "Delimitación y defensa del naturalismo metodológico", pág. 32.

${ }^{2073}$ Cfr. PÉREZ MARCOS, M., Exposición y Crítica de las tesis básicas de la cosmovisión naturalista, San Esteban, Salamanca, 2021.

${ }^{2074}$ Para el Nuevo Ateísmo de Dawkins y su naturalismo ontológico solo existe aquello que es empíricamente demostrable por el método científico y si Dios no es asimilable y cognoscible por dicho método, se puede concluir que no existe. "Darwin hizo posible ser un ateo intelectualmente satisfecho". DAWKINS, R., El Espejismo de Dios, Espasa, Madrid, 2007, pág. 30.

${ }^{2075}$ Cfr. AGAZZI, E., La ciencia y el alma de occidente, págs. 321-341. 
sentido, Taylor afirma, comentando la simplificación de argumentos de Dawkins en su distinción entre fe y ciencia, que suponer que en la labor de un científico no hay ninguna presuposición que no esté basada en la evidencia es un reflejo de una fe ciega o de una fe que ni siquiera puede percibir el estremecimiento de la duda. ${ }^{2076}$

Esto significa que las relaciones entre ciencia y fe están reubicando el mundo de las religiones y que las religiones no pueden abstraerse a los retos que le está lanzando el naturalismo. Salvando las diferencias entre unas visiones naturalistas más radicales y reduccionistas, y otras visiones más amplias o comprensivas, está claro que el naturalismo está configurando el imaginario social moderno a partir de la visión omnicomprensiva de la ciencia y del subjetivismo que tiende a desacreditar la idea de la evaluación fuerte; retos que, según Taylor, deben ser afrontados con coherencia intelectual, apostando por un relato fenomenológico que permita mostrar que los vocabularios que necesitamos para explicar el pensamiento, la acción y los sentimientos descansan sobre evaluaciones cualitativas y una definida ontología moral. ${ }^{2077}$ Taylor afirma que hay muchos modos de describir la naturaleza y que todos ellos pueden ser verdad. Un realismo pluralista robusto puede evitar el realismo reduccionista y realismo científico. $^{2078}$

Por otra parte, se puede afirmar que se puede ser naturalista metodológico y creyente, puesto que se puede afirmar que Dios actúa comúnmente a través de causas naturales y que es la forma natural de actuar divina, sin romper las leyes naturales, puesto que Él las ha creado y ha configurado el mundo "tal cual es". ${ }^{2079}$ Se trata, claro, de un naturalismo de carácter metodológico que no asume la metafísica naturalista. En este sentido, la religión del futuro tiene que considerar siempre las relaciones con la ciencia y que asumir un naturalismo metodológico no es incongruente con la fe ni tiene por qué serlo. Para el profesor Novoa, no hay, en principio, alguna razón para negar la racionalidad de la aceptación de la teoría de la evolución en conjunción con la tesis

Una lista de preguntas que surgen al hilo de la relación entre fe y ciencia: ¿Se ha resuelto el problema de la división en la Modernidad entre ontología y epistemología? ¿La ciencia ha desmetafisicado el mundo? ¿La ciencia se está considerando a sí misma como la "auténtica guardiana de la verdad" identificando ciencia y verdad? No estaría mal que frente al ensoberbecimiento científico en torno a la comprensión del Todo y el problema de la Vida, la ciencia reconociera sus posibilidades epistemológicas y afirmándolas, no olvide algo que Píndaro afirmó como verdad semi-eterna: "aprende a ser lo que eres" (ontología) para "llegar a conocerte a ti mismo" (epistemología). ¿Es capaz la ciencia de reconocer su campo propio de conocimiento para desde ahí establecer una relación adecuada con “el problema del Todo?” (ontología).

${ }^{2076}$ Cfr. TAYLOR, Ch., La Era Secular, tII, pág. 419.

${ }^{2077}$ Cfr. TAYLOR, Ch., Argumentos filosóficos, pág. 64.

${ }^{2078}$ Cfr. TAYLOR, Ch., DREYFUS, H., Recuperar el realismo, pág. 259.

${ }^{2079}$ Cfr. BYLICA, P. y SAGAN, D., "God, Design and Naturalism: implications of methodological naturalism in Science for Science-Religion relation", Pensamiento, Vol. 64, No 242, (2008), págs. 242 y ss. 
teísta. No es la teoría de la evolución la que es incompatible con el teísmo, sino la conjunción de aquella con el naturalismo metafísico. ${ }^{2080}$

Para el profesor Diéguez Lucena, el naturalismo metodológico asume que en el avance de nuestros conocimientos hemos de proceder "como si" solo hubiese entidades y causas naturales. Esto no implica afirmar que de hecho solo existieran entidades naturales. Afirmar la ciencia como método más genuino (naturalismo metodológico) significa concederle a la ciencia el estatuto propio de su ámbito de conocimiento y que Dios no entra en las regularidades del mundo natural, ni pretende estarlo, aunque sí puede actuar (para un creyente) rompiendo cualquier tiempo de secuencia regular. Por otra parte, el "como si solo hubiese entidades naturales", deja abierto el campo a otro tipo de realidades y que la ciencia solo contempla como principio las entidades y causas naturales. $^{2081}$

De hecho, la Iglesia católica ha reconocido al naturalismo metodológico como un modo adecuado de proceder en la ciencia. ${ }^{2082}$

2.- En el diálogo entre ciencia y fe, un reconocido filósofo como Platinga rechaza el naturalismo metodológico en cuestiones que tienen que ver con el origen del ser humano y del universo. La ciencia en cuanto búsqueda de la verdad no tiene por qué rechazar a priori las causas y explicaciones sobrenaturales. ${ }^{2083}$ No se pueden rechazar las realidades sobrenaturales porque hayamos definido la ciencia de una determinada manera a partir de Descartes, Locke y la Ilustración naturalista. Taylor se interroga en este sentido si puede la epistemología derivada de la ciencia natural, con su sesgo metafísico en favor de un universo neutral, excluir nuestras más lúcidas autocomprensiones en términos evaluativamente fuertes. ${ }^{2084} \mathrm{El}$ profesor Agazzi denuncia el cientificismo como un riesgo y una arbitrariedad intelectual y afirma que es asumido como verdadero y propio programa intelectual por influyentes corrientes de

${ }^{2080}$ Cfr. NOVOA RIVERA, A., "Pragmatismo y evolución: ¿es racional ser teísta y naturalista? Tópicos, Revista de Filosofía, 57, México, (2019), pág. 5. Por otra parte, creemos que hay congruencia y continuidad entre evolucionismo y teísmo, planteándose relaciones enriquecedoras para ambos campos, desde la coherencia intelectual que implica ubicarse en el ámbito propio de cada disciplina.

2081 "Scientists relying on methodological naturalism principle do not claim to prove that there is no God. For them referring to God as the Creator, however, is to violate the Ockham's razor, because purely naturalistic forces seem to be enough to explain the origin of universe, life and human beings, and the scientifically built picture of the world is for scientists as just the true one. In this sense the principle of methodological naturalism leads to ontological naturalism. On the other hand, it is the metaphysical naturalism that provides justification for naturalistic methodology of science understood as the way to discover "how the things really are"”. BYLICA.P-SAGAN D., "God, Design and naturalism: implications of methodological naturalism in science for science-religion relation”, pág. 24.

2082 McMULLIN, E., "Plantinga's Defense of Special Creation”, Christian Scholar's Review, Vol. 21., No 1, (1991), págs. 55-79.

${ }^{2083}$ PLATINGA, A., “Methodological Naturalism?", en J. van der Meer (ed.) Facets of Faith and Science, Vol. 1, Lanham, MD, University Press of America, 1996, págs. 177-221.

${ }^{2084}$ Cfr. TAYLOR, Ch., Argumentos filosóficos, pág. 65. 
pensamiento que asumen el positivismo en sus dos componentes más esenciales, el cientificismo y el materialismo. ${ }^{2085}$

Taylor considera que hay una "rama no absurda" del naturalismo en la cultura científica actual. ${ }^{2086}$ Expresado en otros términos podríamos decir que es racional ser creyente y naturalista metodológico. ${ }^{2087} \mathrm{Y}$ afirma que el problema está cuando el naturalismo pretende explicar la vida humana y hasta qué punto ha de ser explicada en términos modelados por la ciencia natural. Es lo que Taylor denomina el temperamento naturalista del pensamiento moderno. ${ }^{2088}$ Conceder el valor de superior a un cierto tipo de argumentación, según Taylor, frente a anteriores posturas epistémicas, no da razones a priori para refugiarse en un relativismo agnóstico, ${ }^{2089} \mathrm{o}$ atacar a la religión desde el error, el fraude o la superstición, en palabras fuerza condenatorias. ${ }^{2090} \mathrm{El}$ profesor Agazzi se pregunta si en el fondo el naturalismo como posición filosófica es más bien un regreso con respecto a cuanto la civilización occidental ha conquistado fatigosamente a lo largo de siglos de reflexión, una naturalización del hombre que supondría un retroceso al nivel de las filosofías presocráticas. ${ }^{2091}$ Taylor habla de un problema epistemológico que es inseparable de un problema ontológico y, por lo tanto, no puede dejar de ser relevante para nuestros conceptos de la ciencia y de la conducción adecuada de la investigación. Se trata de un problema ontológico que desde el siglo XVII se ha presentado en términos de consideraciones epistemológicas juzgadas irrebatibles por algunos. ${ }^{2092}$ Descartes y Locke han ganado a Platón y la teoría del logos óntico. ${ }^{2093}$ De ahí la pretensión de Taylor de completar el relato de la modernidad secular sobre la base de la ontología moral.

Si por un lado las religiones asumen el campo específico que le es propio y que la ciencia es la forma más genuina de comprensión del mundo, también, desde las religiones, hay que afirmar con contundencia que hay realidades que van más allá de la comprensión de la ciencia y que difícilmente pueden ser analizadas empíricamente desde la ciencia: las experiencias subjetivas (entre las cuales se incluye la experiencia religiosa y la experiencia mística), las relaciones afectivas y de inteligencia emocional, las experiencias de la belleza estética o la experiencia moral como grado de adhesión a la idea del bien, la experiencia de la libertad, el sentido de la vida personal o los procesos cognitivos que nos elevan hacia la creación de cultura. Son situaciones que nos

\footnotetext{
${ }^{2085}$ Cfr. AGAZZI, E., La ciencia y el alma de Occidente, pág. 286.

${ }^{2086}$ Cfr. TAYLOR, Ch., Argumentos filosóficos, pág. 179.

${ }^{2087}$ Cfr. NOVOA RIVERA, A., "Pragmatismo y evolución. ¿Es racional ser teísta y evolucionista?”, págs. 1-30.

${ }^{2088}$ Cfr. TAYLOR, Ch., Argumentos filosóficos, pág. 65.

${ }^{2089}$ Cfr. Ibid., pág. 89.

${ }^{2090}$ Cfr. TAYLOR, Ch., Fuentes del yo, pág. 463.

${ }^{2091}$ Cfr. AGAZZI, E., La ciencia y el alma de occidente, pág. 287.

${ }^{2092}$ Cfr. TAYLOR, Ch., La libertad de los Modernos. pág. 146.

${ }^{2093}$ Cfr. TAYLOR, Ch., Fuentes del yo, pág. 414.
} 
ubican en otro ámbito de conocimiento por mucho que la ciencia desee considerar como naturales los procesos mentales o la psicología conductista. ${ }^{2094}$ Está claro que la ciencia tiene límites y que tiene su campo propio. Y hay que evitar cualquier tipo de trivialización. ${ }^{2095}$ El vínculo entre naturalismo y subjetivismo es muy claro. ${ }^{2096}$ Además hay que evitar el reduccionismo epistemológico naturalista que pretende desacreditar la idea de lo que Taylor denomina evaluación fuerte. ${ }^{2097}$ Taylor reivindica, frente a la única pretensión de verdad naturalista basada en la posición desvinculada y el universo neutral, la postura filosófica fenomenológica que trata de enfrentar la pretensión de exclusividad de la verdad científica, que en ocasiones puede llevar a la marginación de la cosmovisión teísta o conducir a un individualismo de la fe en clave protestante. ${ }^{2098}$ Para Taylor, el naturalismo no logra esclarecer sus fuentes morales solo sobre la base de la negación de la religión y la metafísica y la afirmación de la bondad y significación de la naturaleza. ${ }^{2099}$

Con la influencia del naturalismo en la filosofía actual, por la sobredimensión de la ciencia en el mundo y la cultura, tanto en su ámbito neurocientífico como tecnocientífico, volvemos a la pregunta del principio: ¿Se está produciendo una naturalización de la espiritualidad por influencia del naturalismo? Si solo se puede conocer aquello que puede ser conocido por el método científico (naturalismo epistemológico) y si solo existe aquello que puede ser conocido por el método científico (naturalismo ontológico), la imagen naturalista pretende continuar desplazando la fe religiosa y ganar prestigio en un nuevo contexto de pluralidad de fuentes, tal y como afirma Taylor. ${ }^{2100}$ Sería la conciencia hegeliana del yo que domina el mundo solo desde la parte que niega lo otro. ${ }^{2101}$ Se puede llegar por este camino no solo al escepticismo subjetivista de valoración débil, sino también a la idolatría intelectual. ${ }^{2102}$ Según el criterio de Taylor, es la afirmación de la racionalidad científica a secas, para luego adoptar o el utilitarismo o alguna forma de humanismo ilustrado. ${ }^{2103}$

\footnotetext{
2094 “La pretensión es identificar y luego neutralizar aquellas características del modo en que el mundo se muestra y que dependen de nuestro modo de ser particular". TAYLOR, Ch., Argumentos filosóficos, pág. 201.

${ }^{2095}$ Cfr. TAYLOR, Ch., La ética de la autenticidad, pág. 75.

${ }^{2096}$ Cfr. TAYLOR, Ch., DREYFUS, H., Recuperar el realismo, págs. 176 y ss. ¿Existe la posibilidad de desconectar de la "realidad" por parte de la ciencia entendiendo por realidad no solo las leyes naturales sino el "todo" que configura al hombre como una realidad simbólica y de significados últimos?

${ }^{2097}$ Cfr. TAYLOR, Ch., Argumentos Filosóficos, págs. 64,88-89,112.

${ }^{2098}$ Cfr. TAYLOR, Ch. y MACLURE, J., Laicidad y libertad de conciencia, pág. 109.

${ }^{2099}$ Cfr. TAYLOR, Ch., Fuentes del yo, pág. 469.

${ }^{2100}$ Cfr. Ibid., pág. 462.

2101 "Hemos contrapuesto el ser y Dios. En la medida en que se comienza por el ser, este es inmediatamente, según su primer aparecer, lo finito. Pero en tanto se dan estas determinaciones, podemos comenzar también por Dios y pasar al ser”. HEGEL, F., Filosofía de la Religión, pág. 94.

${ }^{2102}$ Cfr. TAYLOR, Ch., El multiculturalismo y la política del reconocimiento, pág. 32.

${ }^{2103}$ Cfr. TAYLOR, Ch., Fuentes del yo, pág. 462.
} 
3.- En este reto que el naturalismo lanza a la religión, como crítica y negación, la religión tiene que asumir un nuevo protagonismo frente a la pretensión del materialismo naturalista que arrasa con todo y que no solo se ha solidificado, sino que se ha vuelto más profundo. ${ }^{2104}$ Por eso la pregunta del principio: ¿Se puede hablar de una naturalización de la espiritualidad, esto es, una espiritualidad no vinculada a la experiencia religiosa? En un mundo secularizado, ¿se puede hablar de una espiritualidad sin necesaria conexión con la experiencia religiosa?

El ser humano es un ser espiritual, que se comprende a sí mismo desde su interioridad y su capacidad para sentirse abierto a unas posibilidades espirituales que van más allá de las religiones constituidas en nuestro mundo cultural occidental y que indagan en posibilidades como la búsqueda de sentido, el acrecentamiento en formas de conciencia superiores, ${ }^{2105} \mathrm{o}$ un bálsamo para las soledades de la existencia, ${ }^{2106} \mathrm{o}$ un ahondamiento en las emergencias de la vida. ${ }^{2107}$

En este sentido nos parece que esta naturalización de la espiritualidad no pretende quedarse en sí misma, reducida o desubicada, sino que se plantea como un sustrato sobre el que empezar a construir una espiritualidad religiosa que sea responsable y maduramente asumida. Esta es una de las posibilidades que nos ofrece la espiritualidad del futuro, en su complejidad de experiencias y valoraciones. Una espiritualidad como religiosidad primera que sirva de sustrato para posteriores experiencias de apertura madura a la religiosidad, tal y como se entiende en las religiones establecidas. ${ }^{2108}$

\footnotetext{
${ }^{2104}$ Cfr. TAYLOR, Ch., La Era Secular, tII, pág. 115.

2105 "Investigar de forma directa la naturaleza de la consciencia, mediante una introspección continuada, no deja de ser otra forma de práctica espiritual. Debería quedar claro que es posible cualquier transformación de nuestra experiencia, y que cualquier cambio que se obtenga tras pasar cuarenta días y cuarenta noches en el desierto, veinte años en una cueva, o después de liberar alguna nueva serotonina en las sinapsis, será un cambio que tendrá lugar en el contenido de tu consciencia". HARRIS, S., El fin de la fe, Paradigma, Barcelona, 2007, pág. 118. Y así para Harris es posible hablar de espiritualidad como proceso hacia la desvinculación con la religión.

2106 "El hombre no puede verse solo. La supervivencia es, por su puesto, una tensión biológica profunda y arraigada en nuestros genes; cuando hay problemas de subsistencia se convierte en un objetivo prioritario, sin racionalidad que valga, aquello del pan nuestro de cada día". MOYA, A., Pensar desde la ciencia, Trotta, Madrid, 2010, pág. 90. "En definitiva, lo que me hace sentirme vivo es saber que puedo crear, que creo minucias o grandezas. Sin remedio, la actitud creativa, ya no la crítica, rompe con las primeras letras del escrito". Ibid., pág. 91.

${ }^{2107}$ Cfr. FONT, J., "Naturalización de la Espiritualidad "Revista Pensamiento, Vol. 73, No 276, (2017), págs. 631-647.

${ }^{2108}$ Cfr. BRAUN, R., "La experiencia de conexión existencial como concepto naturalista de espiritualidad", Persona, No 20, (2017), págs. 83-93. Con este artículo Braun habla de la "experiencia de conexión existencial" como expresión radical de la naturalización de la espiritualidad, para así evitar cualquier tipo de connotación religiosa y reducir la espiritualidad a una experiencia humana. Y para ello reivindica "la desvinculación de la supuesta relación necesaria con las actitudes y creencias religiosas" (pág. 86). Y así se hay desde el naturalismo filosófico de espiritualidad como "espiritualidad secular" o de "reflexividad" y también de "conexión existencial" siendo este último el que mejor expresaría la desconexión naturalista con las espiritualidades religiosas y con las religiones institucionales. Este término "conexión existencial" expresaría así cualquier vinculación a lo religioso y espiritual, al propio tiempo que afirmaría su conexión con una psicología naturalista que es la que pretende defender el autor.
} 
Estos caminos de la espiritualidad naturalizada encuentran sintonía con el hombre de hoy, en su desvalimiento e incapacidad para comprender las religiones o adentrarse en ellas con la facilidad que se asumía en épocas anteriores. Una espiritualidad que establece vínculos con lo trascendente a través de las ciencias del espíritu y cosmovisiones teístas y deístas en sus explicaciones cuasicausales que incorporan visiones teleológicas y de sentido. ${ }^{2109}$

Por eso, pretendemos aportar una reflexión en torno a la necesaria reubicación de la religión en relación a los retos que plantea el naturalismo que, según Taylor, apela a los bienes constitutivos sin reconocerlos. ${ }^{2110} \mathrm{Si}$ el naturalismo ontológico no reconoce ciertos bienes de significado moral aunque recurre a ellos de alguna manera u otra, se podría hacer referencia a ciertos previos (entendidos como religiosidad primera) que puede plantear la naturalización de la espiritualidad de cara al futuro de la religión, sabiendo que puede ser un terreno abonado sobre el que se pueden fundamentar experiencias auténticas de espiritualidad y religiosidad cristianas. ${ }^{2111}$ Se trata de entablar un diálogo y propiciar la búsqueda sin término de Popper. ${ }^{2112}$

Para Taylor, las formas más ricas del materialismo naturalista, abiertas al misterio y al sobrecogimiento ante la emergencia de la conciencia y la sensibilidad humanas, permiten el diálogo. En realidad, esta apertura a la belleza de lo estético fundó en la cultura moderna una Iglesia generalista que incluyó en su seno a católicos, anglicanos y a representantes de un espiritualismo menos definido. ${ }^{213}$ Este poder de la belleza para restablecernos y para devolvernos de nuevo a la unidad, es una experiencia espiritual de una presencia elevadora del espíritu hacia ese reconocimiento del orden de las cosas y poder inferir su origen trascendente, o la apertura al misterio o admitir que algo no termina de ser comprendido del todo. También somos conscientes de que en la mente

No obstante, al final el autor habla de conexión existencial religiosa y teísta y de conexión existencial no religiosa. Creemos que la expresión "conexión existencial religiosa teísta" es incluida en el estudio por la conclusión final que establece el autor según la cual "los estándares adecuados de la rigurosidad científica ante un fenómeno existente que trasciende el mundo de los creyentes religiosos y que, obviamente los incluye" (pág. 91).

${ }^{2109}$ Cfr. PÉREZ TAPIAS, J.A., Ser Humano. Cuestión de dignidad entre todas las culturas,Trotta, Madrid, 2019, pág. 89.

${ }^{2110}$ Cfr. TAYLOR, Ch., Fuentes del yo, pág. 463.

${ }^{2111}$ Cfr. TAYLOR, Ch., El multiculturalismo y la política del reconocimiento, pág. 65. Nuestro autor nos invita a reflexionar sobre "el potencial humano universal". Creo que abre muchos horizontes.

${ }^{2112}$ Cfr. POPPER, K., Búsqueda sin término, Tecnos, Madrid, 1977; cfr. POPPER, K., La sociedad abierta y sus enemigos, Paidós, Barcelona, 1982; cfr. POPPER, K., La lógica de la investigación científica, Tecnos, Madrid, 1977. "Esta honradez y modestia intelectuales, esta gran estima hacia la verdad que no poseemos, sino que buscamos, esta actitud ética es aquello que ha conducido hasta la ciencia natural, aquello que la ciencia natural ha establecido. Esos filósofos de moda que son enemigos de la ciencia natural y que, a sus enemigos, los defensores de la ciencia, acusan de cientificistas nunca han comprendido el ethos de la búsqueda de la verdad ni su disciplina". POPPER, K., "Ciencia, conocimiento e ignorancia", Apeiron, No 6, (2017), pág. 66. Cfr. ARANA, J., "Determinismo y libertad en K. Popper", Anuario Filosófico, No 34, (2001), págs. 119-138; cfr. ARTIGAS, M., "El término de una búsqueda sin término", Aceprensa, No 124, (1994), pág. 2.

${ }^{2113}$ Cfr. TAYLOR, Ch., La Era Secular, tII, pág. 166. 
del hombre, o en el eco del sentimiento como voz interior hay un movimiento y un espíritu del que no podemos desentendernos y que traspasa las diferencias entre la creencia y la no creencia. ${ }^{2114}$

Eric Fromm es un autor que apela a ciertas valoraciones fuertes cuando afirma que el ser humano es un ser espiritual que se comprende a sí mismo desde su interioridad y que nunca puede dejar de creer en algo, sea en una dimensión transcendente o inmanente, dado que la fe se basa en nuestra experiencia de vivir y reconfigurarnos en relación con nosotros mismos y con los demás. ${ }^{2115}$

En esta misma línea de autores que se refieren a ciertos bienes está también Comte-Sponville, que procedente de una tradición católica, aunque abandonada posteriormente, afirma que se puede prescindir de la religión, pero no del amor, ni de la belleza, ni del sentido de la vida, ni de la felicidad, ni de la fidelidad, ni del amor, ni de la espiritualidad. Se trata de una manera de habitar en el universo o en el absoluto. Carecer de religión no es una razón para arrinconar la espiritualidad. La espiritualidad es el aspecto más noble del hombre que nos distingue de las bestias. ${ }^{2116}$

Desde estos previos que apelan a ciertos bienes morales, aunque no lleguen a reconocerlos, para Comte-Sponville, se puede posibilitar un diálogo abierto entre personas religiosas y ateas. ${ }^{2117}$ Según Comte-Sponville, el vínculo no se crea en cada generación más que a condición de que primero se transmita necesidad de una moral, de una comunión, de una fidelidad, para poder subsistir de una manera que nos parezca humanamente aceptable. No podemos vivir sin apelar a dichos bienes más allá de que se reconozcan como tales.

Comte-Sponville, materialista y ateo, no necesita de la religión para afirmar los valores de la sinceridad y la verdad. En este diálogo entre el naturalismo, la fe y el ateísmo, este autor afirma que la moral no depende de una decisión trascendente, sino que el hombre está invitado a explorarla en su interior y cada cual la encuentra en la medida en que cada uno se descubre a sí mismo, bien sea en la naturaleza, en la educación o en Dios. ${ }^{2118}$ Taylor va más allá de dicha apelación naturalista, ya que para

\footnotetext{
${ }^{2114}$ Cfr. Ibid., pág. 167.

${ }^{2115}$ Cfr. FROMM, E., La revolución de la esperanza, pág. 23; cfr. FROMM, E., El miedo a la libertad, págs. 54-55, 370-371.

${ }_{2116}$ Cfr. COMTE-SPONVILLE, A., El alma del ateísmo, Paidós, Barcelona, 2006, págs. 143-144.

2117 "El ateísmo no es ni un deber ni una necesidad. Tampoco la religión. Lo que tenemos que hacer es aceptar nuestras diferencias. La tolerancia es la única respuesta satisfactoria para nuestra pregunta así entendida". Ibid., pág. 29.

${ }_{2118}$ Cfr. Ibid., pág. 41. En este sentido, para Comte Sponville, la fe no siempre es "la condición suficiente" de la fidelidad. Puede existir fidelidad sin fe y la ausencia de fe "debe seguir comprometiéndonos con la fidelidad". Creemos que esta invitación a la búsqueda insaciable de la fidelidad es un camino honesto para el diálogo entre creyentes y no creyentes, pues la fidelidad es el valor primigenio sobre el que construir cohesión social y desde la fidelidad los caminos del diálogo siempre deberán permanecer abiertos. Creemos que esto también tiene que ver con las dos fuentes de la moralidad
} 
él no se trata de una mera libertad negativa, sino de un fuerte compromiso moral por buscar la verdad de cada uno y configurarse responsablemente, reconociendo las fuentes morales de donde brotan los significados que dan sentido a la vida. ${ }^{2119}$

En este planteamiento de la naturalización de la espiritualidad hay otro filósofo, Owen Flanagan, que procede del naturalismo filosófico y que aporta una visión realmente luminosa y motivadora, ya que aporta otro tipo de previo a considerar en dicha apelación a los bienes morales. Flanagan, desde su neurofisicalismo e intentando explicar the really hard problem, esto es, la configuración de la conciencia a partir de los procesos neuronales materiales, considera que hay seis espacios de significado en el que todos los seres humanos participamos, entre ellos, la espiritualidad. ${ }^{2120}$ Flanagan intenta ir más allá de la propia experiencia científico-empírica para captar otros ámbitos de sentido de la realidad y de la vida a la que la ciencia no puede llegar, asumiendo el riesgo de la ciencia de adentrarse en la "explicación del todo", algo que excede su propio ámbito de verdad científica. Para él, la ciencia corre el riesgo de aventurarse en visiones absolutas que superan el campo propio de la ciencia. Se impone el camino de la coherencia intelectual y de la búsqueda insaciable. ${ }^{2121}$

4.- Conclusión: La espiritualidad postdurkheimiana y la subjetividad naturalista como camino interior y de búsqueda según Charles Taylor. Aceptar solo lo que a tu yo interior le parezca cierto es un camino que se impone en la modernidad y que posibilita experiencias de diálogo a partir del ethos de la búsqueda leal y coherente con uno mismo. Se trata de una forma de espiritualidad que Taylor ubica como propia de la etapa postdurkheimiana y que asume el pluralismo religioso y la apertura a muy diferentes sensibilidades. Se trata de adherirse a una espiritualidad interior, propia de cada uno, la que nos conmueve e inspira. En el fondo se trata de propiciar el ideal de la autocultivación y la autenticidad. ${ }^{2122}$ Esa interioridad entendida como ethos insaciable

moderna laicas, que se ubicarían (salvando las diferencias) en la fidelidad sin fe. Una fidelidad que, en el caso de la moralidad laica, debe hondear en los orígenes de los que proceden pues la fidelidad no solo es presente, sino también memoria. Por eso la fidelidad entendemos que es una buena aliada entre las fuentes de la moralidad laica y la moralidad teísta.

${ }^{2119}$ Cfr. TAYLOR, Ch., Argumentos filosóficos, pág. 336.

2120 “A saber, arte, ciencia, tecnología, ética, política y espiritualidad, que ofrecen una imagen del hombre y el sentido de la vida, y de los que todos los seres humanos participamos, y dentro de los cuales (en la coherencia entre los mismos) debe hallarse el sentido de la existencia concreta de cada organismo". REDONDO ORTA, I., Reseña al libro de FLANAGAN, O., The Really Hard Problem: Meaning in a Material World, , MIT Press, Cambridge, 2007 en Enrahonar, No 47, (2011), pág. 254.

2121 "Para contrarrestar estos excesos, la ciencia debe entrar en un diálogo fructífero con otros espacios de significado de los que los seres humanos participamos como agentes culturales. Estos otros espacios configuran el otro sentido en el que Flanagan utiliza el término scientia. Flanagan habla del aristotelismo (concretamente de la Ética a Nicómaco) y del budismo (Abbidharma) como dos de estas tradiciones que han explorado el sentido de la vida de forma sistemática y que, por tanto, debemos tomar en consideración para inducir una eudaimonics scientia". Ibid., pág. 255. Cfr. SANZ BAYÓN, P., "Increencias, ciencia y religión. El necesario diálogo entre la espiritualidad trascendente y la naturalizada", Pensamiento, Vol. 73, No 276, págs. 761-766.

2122 "Mi propia identidad depende de modo crucial de mi relación dialógica con otros". TAYLOR, Ch., $L a$ ética de la autenticidad, pág. 81; cfr. TAYLOR, Ch., La Era Secular, tII, págs. 304,284; cfr. BERMEJO, 
de búsqueda hace que las distintas fuentes morales puedan dialogar desde los fundamentos sobre las que se asientan sus convicciones morales y a partir de ahí descubrir posibilidades de síntesis dialógica. ${ }^{2123}$

Según Taylor, la insatisfacción que produce el eclipse de la creencia puede devolver a algunas personas a la búsqueda e incrementar el sentido del deseo. Pero también sienten dicha insatisfacción aquellos que, aunque no toleren el retorno a lo trascendental, sí están abiertos a formas que la posibiliten y superen la expresión de la religión tradicional. ${ }^{2124}$ Para Taylor, este deseo de rehabilitar lo ordinario y lo corporal en la cultura moderna ha sido la afirmación de la bondad esencial y de la inocencia humana innata. El mal tiende a considerarse como algo exógeno, provocado por la sociedad, la historia, el patriarcado, el capitalismo o el "sistema". ${ }^{2125}$

En esas influencias de naturalismo y religión se encuentra lo que Taylor describe como la transferencia de muchas cuestiones que antes se consideraban morales a un registro terapéutico. Este giro terapéutico supone un reduccionismo ontológico empobrecedor que tiene consecuencias ambiguas para la dignidad humana. Lo que antes era pecado ahora se ve como enfermedad a tratar terapéuticamente. Nuestros yos enfermos son tratados como cosas y nos aproximamos a algo parecido a afirmar la dignidad del pecado o a sentir simpatía entre iguales o a algo que simplemente se entiende. ${ }^{2126}$ Frente a una terapia meramente inmanentista, Taylor propone buscar una respuesta adecuada a la realidad espiritual, una unificación espiritual del ser humano en la afirmación de la capacidad de decisión/elección moral y la posibilidad de terapias que impulsen y reeduquen. El mal crea patologías y las patologías también pueden ser tratadas. $^{2127}$

En este sentido, la naturalización de la espiritualidad puede ser un camino abierto para iniciar esa síntesis de la que habla Taylor. Una síntesis que reconoce las posibilidades de la psicología como ciencia para adentrarse en el conocimiento del yo y en lo que condiciona nuestro crecimiento humano. La naturalización del espíritu humano, en lo que supone de un mayor conocimiento de nuestro psiquismo, no implica un abandono de la interioridad espiritual intrínseca a nuestra dignidad moral que es definida ontológicamente. Por lo tanto, la naturalización de la espiritualidad permite adentrarnos en esos espacios de autocomprensión psicológica, autodominio, autoconocimiento, que no tienen por qué olvidarse de nuestra dimensión constitutiva

D., La identidad en sociedades plurales, Anthropos Editorial, Barcelona, 2011, pág. 82.

${ }^{2123}$ Cfr. TAYLOR, Ch., Hegel, pág. 476.

${ }^{2124}$ Cfr. TAYLOR, Ch., La Era Secular, tII, pág. 30.

${ }^{2125}$ Cfr. Ibid., pág. 504.

${ }^{2126}$ Cfr. Ibid., pág. 506.

${ }^{2127}$ Cfr. Ibid., pág. 510. 
como seres que buscan un significado ontológico a la idea del bien y que se adentran en el reconocimiento de las fuentes morales.

El propio reconocimiento de la ruptura del yo, como realidad psicológica y como enfermedad, puede ayudar a una mejor comprensión del "ethos de la búsqueda" de un bien constitutivo que nos define moralmente. Aquí ubicamos el gran interrogante de Taylor: cómo definir nuestras más altas aspiraciones espirituales o morales para los seres humanos, al tiempo que mostramos un camino para la transformación implicada en ello y que no aplaste, mutile o niegue lo que es esencial a nuestra humanidad. ${ }^{2128}$

La negación del sentido espiritual y moral del ser humano no acrecienta las posibilidades de crecimiento y autocomprensión. Las fuentes morales facultan para una orientación y autorreconocimiento. ${ }^{2129}$ Taylor piensa que el naturalismo considera los valores como meras proyecciones psicológicas, desconectando de la metaexplicación relevante que conecta con nuestra experiencia moral. ${ }^{2130}$ En este sentido, la naturalización del espíritu humano empobrece nuestras posibilidades éticas, así como nuestro compromiso constitutivo con la idea del bien. De ahí que una naturalización de la espiritualidad, como propuesta, pretende recorrer el camino del reconocimiento de la naturaleza humana que no cierra las posibilidades de conexión moral en la búsqueda de los bienes constitutivos. El bien constitutivo interpela, faculta, mueve y es un error naturalizarlo como "emoción no moral". ${ }^{2131}$ Un naturalismo que no tiene un lugar para el bien, reduce la dimensión moral del ser humano con el consiguiente riesgo de desembocar en la automutilación. El camino, según Taylor, para la reconciliación entre naturalismo y espiritualidad estaría en capacitarnos para reconocer los bienes a los que no podemos por menos que ser fieles en todo su alcance. La reconciliación entre el encorsetado naturalismo y la potente afirmación de los hiperbienes, entendidos como espiritualidad, es posible. ${ }^{2132}$ No podemos olvidar que la aportación más relevante y reconocida que el pensamiento moderno ha acarreado a la filosofía es el estudio de la subjetividad, es decir que la dimensión de lo real no se reduce a la materia y a sus leyes. ${ }^{2133}$ La historia de la filosofía occidental parte del hecho de que al comienzo el hombre se consideró a sí mismo como parte de la naturaleza, como cosa entre las cosas y que todo empieza a cambiar con la pregunta de Sócrates: ¿Qué es el hombre? Esta es la gran pregunta sobre la verdad del hombre que recorre la búsqueda filosófica sobre el sentido de lo universal. Solo hay una filosofía, como afirmará Taylor. Y será esta afirmación de que existe en el mundo un ser irreducible, esencialmente distinto al orden de la naturalidad. Luego el hombre no podrá nunca comprenderse a sí mismo sin esa

\footnotetext{
${ }^{2128}$ Cfr. Ibid., pág. 535.

${ }^{2129}$ Cfr. TAYLOR, Ch., Fuentes del yo, pág. 144.

${ }^{2130}$ Cfr. Ibid., pág. 148.

${ }^{2131}$ Cfr. Ibid., pág. 152.

${ }^{2132}$ Cfr. Ibid., pág. 158.

${ }^{2133}$ Cfr. AGAZZI, E., La ciencia y el alma de occidente, pág. 288.
} 
capacidad para inquietarse moralmente en torno a la gran pregunta: ¿Quién soy yo? Preguntarse por uno mismo es reconocer ese fondo moral que nos identifica como seres racionales y capaces de espiritualidad, esto es, capaces de articular significados y motivaciones, capaces de autotrascendencia y anhelo de infinito.

\section{V.3.4.-¿TIENE FUTURO LA RELIGIÓN? ¿UNA SEGUNDA ERA AXIAL?}

I.- Para Jaspers, la primera era axial consistió en que el hombre se elevó a la conciencia de la totalidad del Ser, de sí mismo y de sus límites, sintió la terribilidad del mundo y la propia impotencia y tomó conciencia de sus límites, al propio tiempo que se propuso a sí mismo las finalidades más altas. ${ }^{2134}$ La profesora Ilia Delio considera que, si dirigimos nuestra atención al siglo XXI, podemos observar otra transformación de la conciencia, que Cousins denomina segunda era axial y que, al igual que la primera, esta nueva era ha estado desarrollándose durante varios siglos y ha alcanzado un punto crítico, una segunda era axial caracterizada por la integración entre lo material y lo espiritual, entre lo inmanente y lo trascendente. ${ }^{2135}$

Para Armstrong, nuestra cultura científica nos educa para enfocarnos en el mundo físico y material y hacia la eliminación del sentido de lo espiritual y lo sagrado que impregnó la vida de personas y sociedades y que constituyó en su momento un componente esencial en la experiencia humana del mundo. ${ }^{2136}$ Una historia que Taylor pretende reconstruir a partir de lo que él denomina "era secular" y conceptos como estructuras del mundo cerrado, mundo inmanente, humanismo exclusivo y teorías de la secularización. ${ }^{2137}$

Kolakowski, el gran filósofo polaco que evolucionó del marxismo a la fe, afirma que "nunca estoy seguro de qué es la religión". ${ }^{2138}$ Este es el sentido de nuestra época, no saber dónde nos encontramos, nunca estamos seguros de casi nada y también en relación con la religión. Pero la frase de Kolakowski esconde un secreto: indirectamente está sugiriendo que la religión es adentrarnos en un terreno en el que nunca lo tenemos del todo claro y en el que casi todo queda por descubrir. Según Taylor, la religión del futuro, de la era secular, será la religión de la creatividad, de lo radicalmente nuevo, de

\footnotetext{
${ }^{2134}$ Cfr. JASPERS, K., Origen y meta de la historia, págs. 20-21.

2135 "Mientras que la primera era axial produjo una conciencia individual e introspectiva, la segunda era se caracteriza por la conciencia global. La segunda era axial es, en gran medida, resultado de la creatividad y el ingenio humanos. La tecnología ha modificado radicalmente nuestra visión del mundo y de nosotros mismos... La segunda era axial interpela a las religiones a llevar a cabo una nueva integración de lo espiritual y lo material, de la energía sagrada y la energía secular en una única energía humana global. Por tanto, esta era fomenta el diálogo, la comunidad y las relaciones con una conciencia creciente de que cada persona es parte de un todo". DELIO, I., Cristo en evolución, Sal Terrae, ComillasSantander, 2014, págs. 57-58.

${ }^{2136}$ Cfr. ARMSTRONG, K., A History of God, Vintage Books, Londres, 1999, pág. 10.

${ }^{2137}$ Cfr. TAYLOR, Ch., La Era Secular, tII, págs. 52,152,208,215,250,326,381,463,733.

${ }^{2138}$ KOLAKOWSKI, L., Si Dios no existe... Tecnos, Madrid, 2002, pág. 11.
} 
lo insospechado, de adoradores en espíritu y verdad, una religión que nos ayuda a descubrir la voz interior que resuena dentro, la huella de Dios que nos hace conscientes de que la fuente reside en el interior y que nos ayuda a saborear el propio sentido de autenticidad. $^{2139}$

Y este Dios de vida, de experiencia y de amor, que invita a los hombres a adentrarse en la sabiduría divina que como arquitecto establecía los fundamentos del mundo y jugaba por el orbe de la tierra es el Dios que tendrá algo que decir al hombre del futuro. ${ }^{2140}$ Un Dios que llena completamente la vida y la felicidad del hombre. Es el Dios que experimentaba Pascal, como un Dios que apasionaba el corazón del hombre. ${ }^{2141}$ No el Dios de la filosofía matemática cartesiana, ${ }^{2142}$ sino el Dios que invita a adentrarse en la mística del evangelio, tal y como afirmó K. Rahner. ${ }^{2143}$ Una religión que, como afirma Taylor, permite que cada cual siga el camino de su propia inspiración espiritual, su intuición o sentimiento espiritual; ${ }^{2144}$ sin olvidar que desde la perspectiva de la fe hay un amplio espectro de casos que van desde el compromiso religioso profundamente sentido, hasta situaciones en las que se manipula cínicamente el símbolo religioso para movilizar a la gente. ${ }^{2145}$

Es este pluralismo de experiencias religiosas lo que lleva a Taylor a considerar que con la era secular la gama de creencias en algo trascendente se diversifica ampliamente: muchos afirman creer en un Dios personal, mientras que hay más personas que se aferran a algo así como una fuerza impersonal, un amplio espectro de personas expresa creencias religiosas que se apartan de la ortodoxia cristiana y otras muchas se inscriben en religiones no cristianas, o en modalidades de prácticas y de

\footnotetext{
${ }^{2139}$ Cfr. TAYLOR, Ch., La ética de la autenticidad, págs. 61-62.

${ }^{2140}$ Cfr. Prov. 8,27-30.

2141 "En la esfera de la intimidad, la relación sentimental que forma la identidad tiene una importancia crucial”. PASCAL, B., Pensamientos, 199-72, pág. 90.

2142 "El matemático y filósofo Pascal había experimentado al Dios vivo, al Dios de la fe, y en tal encuentro vivo con el tú de Dios, comprendió, con asombro manifiestamente gozoso y sobresaltado, qué distinta es la irrupción de la realidad de Dios en comparación con lo que la filosofía matemática de un Descartes, por ejemplo, sabía decir sobre Dios". RATZINGER, J., El Dios de la fe y el de los filósofos, Encuentro, Madrid, 2006, pág. 8.

2143 "La espiritualidad cristiana sigue teniendo un potencial humanizador, capaz de activar, en tiempos de increencia, los valores de la fraternidad, la solidaridad y la memoria colectiva y la esperanza". VIDE, V., "Senderos de trascendencia en tiempos de increencia", Revista de Espiritualidad, No 72, (2013), pág. 363.

${ }^{2144}$ Cfr. TAYLOR, Ch., Las variedades de la religión hoy, pág. 109.

${ }^{2145}$ Cfr. Ibid., pág. 125. "El acto de fe y de confianza en Dios tiene que preceder a la capacidad de ver su mano en el curso de los acontecimientos y en la tristeza de la historia humana. En una palabra: credo $u t$ intelligam. La investigación filosófica es siempre incapaz de producir, sustituir o siquiera estimular el acto de fe y probablemente nadie se ha convertido nunca a la fe por medio de la discusión filosófica, excepto, quizá, cuando esta ha servido como causa 'ocasional'”. KOLAKOWSKI, L., Si Dios no existe..., pág. 55.
} 
concepciones que salvan la brecha entre humanista y espiritual o que vinculan espiritualidad y terapia. ${ }^{2146}$

II.- Según opinión de Taylor, la religión del futuro se expresará a partir de un gran pluralismo religioso y en una amplia variedad de matices.

1.- La religión del futuro tendrá lugar en un mundo marcado por la inmanencia y el humanismo exclusivo, pero al mismo tiempo dentro de una gran pluralidad religiosa. ${ }^{2147}$ Pluralidad que se expresa de muy diversas formas y maneras, ${ }^{2148}$ tanto dentro de las propias confesiones religiosas, como en la gran variedad de propuestas de espiritualidad y religiones a la carta. ${ }^{2149} \mathrm{El}$ pluralismo religioso dentro de la propia Iglesia, con una gran variedad de movimientos religiosos y que incluyen todo tipo de vocaciones: Focolares, Opus Dei, Neocatecumenales, Comunión y Liberación, Carismáticos... Movimientos que potencian el carácter laical de la vida cristiana pero que son capaces de entrar en comunión, dentro de la misma espiritualidad, con todas las vocaciones que tradicionalmente estaban asociadas a las Órdenes Religiosas: sacerdotes, religiosos y religiosas, consagrados con distintos niveles de compromisos y estilos de vida.

El pluralismo religioso se expresa en la gran variedad de Iglesias que se hacen presentes en todas las latitudes y que hasta hace poco eran Iglesias asociadas a determinadas culturas. ${ }^{2150}$ En Washington, podemos encontrar, tal y como dice Berger, y valga como ejemplo, todo tipo de Iglesias desde el Capitolio al Hospital Walter Reed. ${ }^{2151}$ Es el supermercado religioso de la posmodernidad.

2.- Taylor considera que el número de personas que abandonan la práctica activa seguirá incrementándose, aunque siguen declarando pertenecer a alguna confesión o creer en Dios. Se avanza de manera irremediable hacia lo que G. Davie afirmaba en su famoso lema believing without belonging, esto es, una creencia sin pertenencia como ocurre en otros muchos campos de la sociedad. ${ }^{2152}$ Un creer caracterizado por la pérdida

${ }^{2146}$ Cfr. MACLURE, J. y TAYLOR, Ch., Laicidad y libertad de conciencia, págs. 24,37,134; cfr. TAYLOR, Ch., La Era Secular, tII, pág. 342.

${ }^{2147}$ Cfr. TAYLOR, Ch., Argumentos filosóficos, pág. 342. Reflexión sobre la "metalocalidad" o "metatopicalidad" propia de los escenarios modernos de la esfera pública.

2148 "El núcleo definidor de la posmodernidad es la pluralidad radical. Pluralidad radical significa, expresado de modo sintético, diferencias de base y no solo diferencias sobre una base común". BERMEJO, D., Posmodernidad: Pluralidad y Transversalidad, Anthropos Editorial, Barcelona, 2016, pág. 145.

${ }^{2149}$ Cfr. TAYLOR, Ch., Las variedades de la religión hoy, págs. 114-115; GARCÍA, E., "Posmodernidad y Religión. Nueva Era, Teoría y Praxis, No 12, (2008), págs. 1-17.

${ }_{2150}$ Cfr. DÍAZ, C., Este hombre, este mundo, Ediciones Palabra, Madrid, 2005, pág. 151.

2151 "Si América es la 'sociedad vanguardista' en el pluralismo religioso (el término de Talcott Parson es bastante apropiado aquí), tampoco es el único lugar donde se puede observar este fenómeno". BERGER, P., "Las religiones en la era de la globalización", pág. 65.

${ }^{2152}$ Cfr. TAYLOR, Ch., La Era Secular, tII, págs. 343,354,373. "The important observation that religious believing seems to have become detached from religious belonging should be understood in relation to 
progresiva de la referencia a un Dios personal y la metaforización (o la simbolización) creciente de los objetos de la creencia religiosa. En cierto sentido se trata de un proceso de etnización de la religión que puede hacer, por ejemplo, que, cuando se lleva a su término, se la confunda con una moral de los Derechos del Hombre, como afirmaba Hervieu-Léger. ${ }^{2153}$

Para Taylor, esta situación de nebulosa en la que cada uno se encuentra inmerso en una creencia sin pertenencia, refuerza la inseguridad de las personas en sus creencias, al faltarle el apoyo comunitario, al propio tiempo que se asienta el subjetivismo como forma de creer ${ }^{2154}$ Cada uno cree lo que le parece creer, porque no está impelido a creer por la fuerza del grupo al que pertenece, sino por los sentimientos que acompañan la propia experiencia subjetiva. ${ }^{2155}$ La gama de creencias se ensancha a partir de los sentimientos propios, pudiéndose incluso llegar a hablar de una religión individual, donde existirían tantas religiones como personas, porque todo está transido de subjetividad. $^{2156}$

3.- Taylor considera también la persistencia de otro grupo de personas que vendría definido por querer creer, con una gran variedad de opciones y sensibilidades: personas que rezan sin saber si creen o no, personas que adoptan una mezcla de credos o fundamentos religiosos de distintas tradiciones religiosas. Son los creyentes que se encuentran más ubicados en el ámbito de la tradición cultural que en el campo de la representación sagrada que remite a una fe religiosa. Lo mismo que existe el grupo de creer sin pertenecer, existe, en este caso, el grupo de pertenecer con una creencia cada vez más difuminada, vaga, desfundamentada. Algunos autores hablan de una institucionalidad débil, con poca fuerza de cohesión social y que se ve envuelta en incertidumbres e interrogantes existenciales. En el fondo es una expresión de la privatización de la religión, con una vivencia personal de la religión, donde uno decide el alcance de la creencia, aunque finalmente lo refiera a una institución a la que dice pertenecer. $^{2157}$

the parallel observation that virtually all voluntary associations have been finding it difficult in the last few decades to attract and retain members. In other words, belonging has been simultaneously losing its popularity in religion and in many other fields as well". DAVIE, G., "Believing without Belonging. A Liverpool Case Study/Croyance sans appartenance. Le cas de Liverpool", Archives des Sciences Sociales des Religions. No 81, (1993), pág. 84.

${ }^{2153}$ Cfr. HERVIEU-LEGER, D., La religión, hilo de la memoria, pág. 259.

${ }^{2154}$ Cfr. TAYLOR, Ch., La ética de la autenticidad, pág. 99.

${ }^{2155}$ Cfr. TAYLOR, Ch., El multiculturalismo y la política del reconocimiento, págs. 102-105.

2156 "El nuevo marco tiene un componente individualista fuerte, pero esto no significará que el contexto sea individualizador. Muchas personas se descubrirán uniéndose a comunidades religiosas extremadamente cohesionadas. Porque ahí es adonde el sentido de lo espiritual de muchas personas les conducirá". TAYLOR, Ch., La Era Secular, tII, pág. 347.

${ }^{2157}$ Cfr. MARTÍN HUETE, F., La persistencia de la secularización en la era de la desecularización, Tesis Doctoral Inédita, Universidad de Navarra, Pamplona, 2015, pág. 161. 
4.- El Cristianismo del futuro estará marcada fuertemente por la subjetividad de la experiencia religiosa y por un individualismo difuso, en el que no se sabe muy bien en qué se cree, pero del que tampoco se quiere desprender, como afirma Taylor. ${ }^{2158}$ Pero al mismo tiempo, se ofrecerá todo tipo de experiencias de encuentro con otras personas, incorporándose a Iglesias, o participando en una amplia gama de eventos que, por otra parte, las personas también individualmente consideren apropiados: peregrinaciones, jornadas mundiales de la juventud, funerales colectivos de celebrities, encuentros de oración (Taizé), macrofiestas o conciertos de rock que no manifiestan un sentido exclusivamente secular o desencantado.

En este sentido, Taylor sugiere que las Jornadas Mundiales de la Juventud son una peregrinación cristiana en la era de la autenticidad. ${ }^{2159}$ ¿Son las peregrinaciones y JMJ ese movimiento de la religión que precisa "salir a la luz" en medio de una religiosidad individualista y subjetiva? ¿Es el "hilo rojo” del que habla Hervieu-Léger? ${ }^{2160}$ ¿Son hoy (y serán en el futuro) las religiones institucionales el hilo de la memoria que asegura el sentido de pertenencia a un linaje del que no podemos desprendernos a pesar del individualismo en el que nos movemos? Necesitamos "ponernos en movimiento" en determinados momentos, asentando pertenencias institucionales, o salir en peregrinaje desde nuestros individualismos hacia el encuentro con otras personas como JMJ o Taizé. ${ }^{2161} \mathrm{Y}$ a partir de estos momentos de especial intensidad espiritual o de sentimientos de luminosidad cegadora, muchas personas pretenden continuar con esa experiencia vivida bajo muy diversas formas.

Las personas que deseen vivir una vida devota de especial compromiso lo encontrarán en una gran variedad de formas, tanto tradicionales, como combinando todo tipo de realidades y experiencias espirituales. Un Cristianismo de relación a distancia con la Iglesia, desde una cierta apatía, pero a la que al mismo tiempo se aprecia y en la que se quiere estar formando parte, en parte como titular de una memoria ancestral y, en parte, como un recurso para alguna necesidad futura (por ejemplo, su necesidad de algún rito de paso, sobre todo un funeral), o como fuente de consuelo y orientación tras alguna catástrofe colectiva. ${ }^{2162}$

\footnotetext{
${ }^{2158}$ Cfr. TAYLOR, Ch., Hegel, pág. 498.

${ }^{2159}$ Cfr. TAYLOR, Ch., La era de la autenticidad, pág. 87.

2160 "Una religión es, en esta perspectiva, un dispositivo ideológico, práctico y simbólico por el cual es constituido, mantenido, desarrollado y controlado el sentido individual y colectivo de la pertenencia a un linaje creyente particular". HERVIEU-LÉGER, D., El peregrino y el convertido, Ediciones del Helénico, México, 2004, pág. 23.

${ }^{2161}$ Cfr. TAYLOR, Ch., La Era Secular, tII, págs. 354-357. Taylor habla también de ceremonias oficiales de Estado (contra las que los sectores más laicistas manifiestan su oposición), cuando se produce alguna catástrofe.

${ }^{2162}$ Cfr. TAYLOR, Ch., La Era Secular, tII, pág. 356.
} 
No se trata, pues, de una religión personal y de fundamento vital como hablaría Ortega y Zubiri. ${ }^{2163}$ Se trata más bien de un individualismo a la carta, difuso, descomprometido, desconectado, en el que se mantiene el contacto por dos aspectos: por sentirse parte de una memoria (Cristianismo cultural) y "por si" se necesita cualquier "servicio ritual-sacramental de iniciación cristiana".

Taylor entiende que se trata de un individualismo cultural, no solo por ser la característica imperante de la posmodernidad (casi nadie se implica colectivamente en casi nada), sino porque es la característica más concreta del que está en la distancia. ${ }^{2164}$

En relación al primer aspecto de la memoria cultural del Cristianismo, se trata de un vínculo individualizado en el sentido de que cada uno lo mantiene a su manera y definido por no querer perder las raíces culturales que han conferido identidad nacional o local. Se trata de un sentido solidario con nuestros antepasados, pero en lo que yo no me implico personalmente, solo me afecta culturalmente, manteniendo un suave hilo de contacto con mis ancestros. Este individualismo cultural, según Taylor, permite un contacto potente en el recuerdo, pero también una especie de fondo de reserva de fuerza o consuelo espiritual. Cambia de una forma acalorada a otra fría, según las circunstancias. La forma acalorada requiere una identidad fuerte y participativa y/o un marcado sentido de que el Cristianismo es el baluarte del orden moral. La forma más fría ampara cierta ambigüedad acerca de la identidad histórica, así como cierto grado de disidencia de la moral oficial de la iglesia. ${ }^{2165}$ Un individualismo forjado en la cultura moderna de la subjetividad en la que se quiere disfrutar de la sensación de poder y libertad sin límites, entregados a lo que Taylor denomina, "estética del yo". Lo espiritual tiende a deslizarse hacia lo superficial, agradable y autocomplaciente, formas no muy exigentes, postmodernas, huecas y, en diversos tipos de conformidad, forzada como la hipocresía, la estultificación espiritual, la revuelta interior contra el evangelio y la confusión entre fe y poder. ${ }^{2166}$

5.-Siguiendo a William James, Taylor opina que hay un locus de la religión hoy que no podemos ni debemos olvidar: el sentimiento. ${ }^{2167}$ Para W. James, el sentimiento está en la base de la experiencia religiosa. Para Taylor, en la experiencia religiosa todo pasa por el corazón, que es donde reside en la biblia el sentimiento, la capacidad de

\footnotetext{
2163 “Solo en la vida personal 'se actualiza formalmente la religación' y desde esta perspectiva se ilumina toda la vida y la existencia. La vida humana no está solo 'arrojada' sino también 'religada'. La religación no pertenece a la 'naturaleza' del hombre, sino a su 'persona', a su naturaleza personalizada, a la vida personal. Por eso Zubiri prefiere hablar de 'religión personal'". BERMEJO, D. y CONILL SANCHO, J.M., ¿Dios a la vista?, Editorial Dykinson, Madrid, 2013, pág. 464.

${ }_{2164}$ Cfr. TAYLOR, Ch., La ética de la autenticidad, pág. 93.

${ }^{2165}$ Cfr. TAYLOR, Ch., La Era Secular, tII, pág. 356; cfr. PÉREZ ARGOTE, A., "La religión como identidad colectiva. Las relaciones sociológicas entre religión e identidad", Papeles del CEIC, No 2, (2016), págs. 1-19.

${ }^{2166}$ Cfr. TAYLOR, Ch., Las variedades de la religión hoy, págs. 123-124.

${ }^{2167}$ Cfr. GRUN-BOFF, Lo divino en el ser humano y en el universo, págs. 25-47.
} 
sentir y percibir la experiencia espiritual, un sentimiento que embarga el alma y la vida de la persona, como una experiencia de felicidad, algo que eleva el espíritu hacia experiencias inefables. ${ }^{2168}$

Aquí también encuentra Taylor un punto claramente mejorable en W. James. El sentimiento y la religión de la ternura afectiva es algo a seguir potenciando. No obstante, no hay que olvidar que la religión incluye también teología, siendo muy importante el vínculo entre razón y fe. ${ }^{2169}$ Taylor comenta en relación con el sentimiento y la carga melancólica que conlleva, que la melancolía premoderna tenía que ver más con el sentido profundo de indagar en la idea del Bien y el orden existente en el cosmos como elementos llenos de significados. Para el hombre moderno la melancolía adquiere por el contrario un sentimiento de vacío asociado a la idea de agotamiento y desilusión dolorosa. $^{2170}$

Con esta reflexión sobre el sentimiento melancólico Taylor pretende adentrarse en algunas claves de lo que nos pasa. La acedia premoderna contribuía a adentrarse en la experiencia religiosa como una experiencia de significados y de elevación espiritual. La melancolía moderna nos adentra en un mundo de vacío y de agotamiento que duele y del que a veces no logramos salir. Una melancolía de exilio espiritual y como de ruptura que incapacita para seguir buscando, "solos en un universo mudo". ${ }^{2171}$ Pareciera como si el hombre moderno comenzara a estar incapacitado, por agotamiento, para la experiencia trascendente, o comenzara a comprender que no merece la pena o que no necesita más, aunque no del todo o que todo se desvanece en el descontento y el deseo de rescate baudelairiano de los vahos corruptores del mundo. De ahí la importancia de aunar ambas experiencias con el sentido de pertenencia a una colectividad y a la necesidad de dar impulso intelectual a lo que se cree.

\footnotetext{
2168 "Por mi parte creo que la actual tendencia expresivista se debe a que, en sus rasgos generales, dicho cambio ha penetrado muy profundamente en nuestra cultura. En una época que parece dominada por 'los cultos desdeñosos con la religión', según la frase de Schleiermacher, lo realmente valioso es la intuición/sentimiento espiritual. Este beberá inevitablemente de un lenguaje que tendrá una resonancia especial para la persona que lo posee". TAYLOR, Ch., Las variedades de la religión hoy, pág. 109. "Lo que diferencia al movimiento de la nueva era de otros movimientos postsesentistas es, justamente, su carácter religioso: la absolutización de la autonomía individual, la negación de toda influencia del entorno sobre el sujeto, lleva a la elaboración de explicaciones sobrenaturales (...) y la postulación de un interior no socializado sabio, sano y conectado energéticamente al universo como motor de las transformaciones individuales". CAROZZI, M.J., "La autonomía como religión: la nueva era", Alteridades, Vol. 9, No 18, (1999), pág. 37.

2169 "Pero la vida devota, práctica y sacramental (si existe) requiere una mínima articulación en cuanto a su contenido: es inevitable establecer algunas formulaciones proposicionales... Del mismo modo que no se puede separar la vida religiosa de su expresión colectiva, tampoco puede verse privada de un mínimo de formulaciones expresas. La fe y la esperanza deben ser en algo". TAYLOR, Ch., Las variedades de la religión hoy, pág. 37.

${ }^{2170}$ Cfr. Ibid., pág. 49.

${ }^{2171}$ TAYLOR, Ch., Ética de la autenticidad, pág. 101.
} 
Para Taylor, la visión de William James de la religión como experiencia interior y sentimiento es muy adecuada para confrontar la perspectiva religiosa y secular. ${ }^{2172}$ William James y su experiencia religiosa contribuye a conciliar dialógicamente las diversas perspectivas morales de la Modernidad. Las fuentes de la moralidad laica que establecen casi en exclusividad el marco inmanente como marco de referencia, pueden, desde la perspectiva de W. James, entrar en diálogo y contacto con las fuentes de la moralidad trascendente, pues tanto la razón ilustrada como el sentimiento romántico del orden natural sintonizan muy bien a partir de la experiencia de interioridad y el sentimiento del rumor trascendente jamesianos. ${ }^{2173}$

6.- El Cristianismo del futuro seguirá aportando valoraciones morales fuertes. No se sabe si a una minoría o a grandes poblaciones. Lo que está claro es que dichas valoraciones morales no pueden ser ni tan fuertes ni tan mayoritarias, ya que mutan, cambian, se adaptan líquidamente a otros contextos y circunstancias. Y, además, en lo que se refiere a la extensión poblacional indicar que, si lo que define la relación con la Iglesia en general es la distancia, está claro que las personas que manifiestan valoraciones morales fuertes serán una minoría, pues difícilmente se puede sostener lo contrario desde la distancia.

En este contexto cultural naturalista e inmanente, las valoraciones morales fuertes están desacreditadas o fuera de lugar, ya que, si lo característico es la mutación, el paso del acaloramiento al enfriamiento según momentos y circunstancias, entonces la fortaleza de las convicciones morales tampoco puede ser fuerte. Según Taylor, surge un Cristianismo de dos velocidades: una minoría que manifiesta convicciones morales fuertes pero que cambian según las circunstancias y una mayoría que expresa un Cristianismo en la distancia, que mantiene la memoria, como un vínculo individual con la tradición cultural y como necesidad para ciertos ritos de iniciación que confieren ese débil sentido de pertenencia. Se correspondería en buena medida con lo que se ha dicho de la religiosidad popular.

El Cristianismo en la distancia en Europa, y al contrario de lo que ocurre en EE.UU., seguirá confiriendo una cierta identidad nacional y un leve sentido de pertenencia a una memoria del pasado y tendrá una débil capacidad para configurar moralmente a las personas. En EE.UU., la identidad norteamericana puede estar identificada e integrada a través de la fe, es decir, que la fe confiere no solo identidad religiosa sino también identidad nacional, ${ }^{2174}$ mientras que en Europa eso ya no es así.

\footnotetext{
${ }^{2172}$ Cfr. TAYLOR, Ch., Las variedades de la religión hoy, pág. 26.

2173 Todo es transparencia de Dios para el hombre, como lo fue para San Agustín. Dios dentro de mí, en el que entre el Tu de Dios y mi yo no hay espacio. Y Dios fuera de mí: "Recorrimos como por escalones el mundo entero y tocamos a Dios suavemente con todo el impulso de nuestros corazones". HIPONA, A. de, Confesiones, III, 6, 11; y IX, 10, 24.

${ }^{2174}$ Cfr. TAYLOR, Ch., La Era Secular, tII, pág. 359.
} 
La identidad religiosa no confiere identidad nacional, debido a que las perspectivas trascendentes frecuentemente han sido dejadas al margen como inadecuadas, en un mundo moderno, naturalista y postsecular. ${ }^{2175}$

Mientras que en Europa los países están pasando por una profunda crisis de identidad nacional y religiosa, Estados Unidos continúa fuertemente cohesionado tanto por una marcada identidad neodurkheimiana como por su vinculación a una religión civil de carácter omnicomprensivo cristiano. ${ }^{2176}$ No obstante, en estos momentos, también se puede hablar de una crisis norteamericana promovida por movimientos secularistas y liberales que de alguna manera plantean el paso a una era postdurkheimiana de pluralismo religioso y religión individualista. ${ }^{2177}$

Se puede afirmar que, en el caso de la religión, en Europa la crisis es doble: crisis de identidades nacionales y crisis de religión. La identidad de cada nación ya no se define a partir de la religión y la nación (como concepto cultural) tampoco define a muchos de sus integrantes. Además, la nueva configuración en torno a la Unión Europea tampoco termina de configurar identidades, ni a través de la religión (no se integró a Dios y la tradición cultural cristiana en la Constitución europea) ni a través de lo que pueda significar la nueva realidad cultural europea (la identidad europea todavía está en el aire y hay muchos niveles de autoidentificación dependiendo de las naciones).

Según esto, y a partir de la reflexión tayloriana, nos hacemos algunas preguntas: ¿el camino que le queda a Europa es la desconfiguración cultural de las antiguas naciones para integrarse en la eurosecularidad? ¿Se puede afirmar que la ética de la autenticidad en Europa ha desenraizado moralmente las identidades nacionales a partir del deseo de la Modernidad de rebelarse contra todo tipo de convenciones y tradiciones culturales heredadas? ${ }^{2178}$ ¿Qué realidades crean en estos momentos efervescencia apasionada que contribuyan a cohesionar políticamente a las viejas naciones europeas?

\footnotetext{
${ }^{2175}$ Cfr. Ibid., pág. 654. Para Taylor, mientras que Europa está configurada fundamentalmente desde los modelos paleo y neodurkheimianos, la experiencia norteamericana está definida exclusivamente por los modelos neodurkheimianos de la era de la movilización. Además en Europa, según Taylor, y al contrario de lo que ocurrió en EE.UU., la ética de la autenticidad de la década de 1960 desconfiguró las formas anteriores de la religión y produjo dos aspectos a tener en cuenta: debilitamiento de las configuraciones neodurkheimianas que conferían identidad política nacional y por otra parte la ruptura de la relación entre fe y vida afectivo-sexual que contribuye a desconfigurar las fuentes morales de identidad personal.

${ }^{2176}$ Cfr. TAYLOR, Ch., Imaginarios sociales modernos, págs. 176-177.

${ }^{2177}$ Cfr. MACLURE, J. y TAYLOR, Ch., Laicidad y libertad de conciencia, págs. 107-110. "No obstante, por contagios posmodernos (en su mayoría de origen europeo-continental), parece que se pretende sacar a la religión de la ecuación identitaria, llegando a confundir su propia Historia - reduciéndola a un cúmulo de historias, v.g. historia de los afroamericanos, de los asiáticoamericanos, de los latinoamericanos, de las mujeres y de género-, desde propuestas tropológicas (de narrativas ideológicas patéticas — de agitación del espíritu, de manera melancólica y revanchistas-, desde la corrección política, la discriminación positiva, el pensamiento débil y el relativismo, hasta la memoria histórica y la literatura testimonial)". SÁNCHEZ BAYÓN, A., FUENTE, C., CAMPOS, G., "Revelaciones sobre la religión civil estadounidense: influjo en su configuración nacional y crisis postglobalizatoria", Journal of the Sociology and Theory of Religion, Vol. 1, (2017), pág. 25.

${ }^{2178}$ TAYLOR, Ch., La ética de la autenticidad, pág. 98.
} 
¿Nos estamos moviendo en lo que Taylor denomina la solitaria multitud que aglutina, pero no identifica? ${ }^{2179}$

III.- Taylor, como Historiador y como Filósofo hermeneuta, pretende hacer su propia contribución en la narración de la modernidad secular superando el relato oficial y proponer su narración maestra que incluya esas fuentes morales de valoración fuerte del espíritu humano que ha ido incrementando su experiencia del mundo a través de una subjetividad acrecentada. Un recorrido en el que Taylor reconoce que no es partidario de las teorías ortodoxas de la secularización, sino que más bien se posiciona en el revisionismo filosófico y sociológico de dicha teoría. Un revisionismo que le lleva a afirmar ese deseo de infinito que ha recorrido todas las fuentes morales del yo a lo largo de la historia de Occidente en su enraizamiento en la idea del Bien como valor de reconocimiento significativo y ontológico. Un deseo vivido como anhelo trascendente. Un anhelo por ir más allá y por configurarse como animal metafísico, capaz de adentrarse en su propia subjetividad creadora de interioridad y por ahondar en la autoconciencia capaz de configurar el mundo. Taylor pretende realizar una síntesis para el mundo de hoy y situar la subjetividad relacionándola con nuestra vida como seres encarnados y sociales, sin reducirla a una función de naturaleza objetificada. ${ }^{2180}$

Bajo esta perspectiva tayloriana del deseo de eternidad presente en el ser humano, más allá de la coyuntura histórica de la Modernidad, creemos que se establece la conclusión final de nuestra tesis. Que el espíritu humano es un espíritu trascendente, que va más allá de los momentos secularizadores por el que va transcurriendo el devenir humano y que siempre se expresará como capacidad inherente para reconocer los bienes a los que no podemos dejar de ser fieles. ${ }^{2181}$

Todo puede resumirse como la historia de una pérdida, en la que somos conscientes de que algo se nos ha ido de las manos y de no saber muy bien cómo y por qué, y si ha merecido la pena llegar hasta aquí y estar como estamos. Pero lo que también está claro, siguiendo a Taylor, es que no se puede crear una sociedad de acceso directo, sin reconocernos a nosotros mismos a partir de nuestras raíces morales. La Modernidad ha creado un imaginario social en el que se rechaza la idea de que haya algo más allá de una identidad configurada sobre la acción común en un tiempo secular. ${ }^{2182}$ Recuperar ese deseo de eternidad y de infinitud es la esperanza que recorre el espíritu humano y que está inscrito en el corazón del hombre a fuego; es uno de los grandes objetivos que configuran el relato filosófico de Taylor: recuperar y proponer

\footnotetext{
2179 TAYLOR, Ch., Imaginarios sociales modernos, pág. 198.

2180 TAYLOR, Ch., Hegel, pág. 498.

2181 Cfr. TAYLOR, Ch., Fuentes del yo, pág. 158; cfr. FERRER ARELLANO, J., Filosofía y fenomenología de la religión. Cristianismo y religiones. Ediciones Palabra, Madrid, 2013, págs. 280 y ss. ${ }^{2182}$ Cfr. TAYLOR, Ch., Imaginarios sociales modernos, pág. 183 y ss.
} 
una ontología moral y la valoración fuerte de los bienes significativos. ${ }^{2183}$ Configurar el mundo a partir del tiempo secular, sin otra conexión que la objetificación y la naturalización, no contribuye a conferir identidad moral ni a crear cosmovisiones. Esta es la deconstrucción moral en la que nos encontramos. Una deconstrucción en la que el naturalismo ontológico y el humanismo exclusivo pretenden identificar el sentido moral con la propia autodeterminación como libertad autorreferencial para encontrar el propósito de la vida al margen de cualquier instancia exterior. ${ }^{2184} \mathrm{Y}$ esto vale no solo para la identidad personal, sino que también pudiéramos decir que es válido para las identidades nacionales. Todo está caracterizado por la inmediatez de la propia búsqueda y los enraizamientos culturales y morales quedan supeditados al momento de lo que está por definir. Taylor afirma en este sentido que la autenticidad no está reñida con la tradición moral y que la autenticidad no siempre va de la mano de la autodeterminación moral del yo. ${ }^{2185}$ El giro antropocéntrico tiene consecuencias ontológicas. La mirada sobre la realidad está totalmente nublada por nuestras reacciones. Es el lenguaje de la autoabsorción. La articulación creativa es vista de manera perversa como una mera expresión de nuestra facultad de introspección, desvinculando o llegando al olvido de la articulación de la autenticidad sobre la base de cualquier horizonte de moralidad externa, con la consiguiente deslegitimación de los horizontes de significado. ${ }^{2186} \mathrm{Se}$ afirma así el contacto no mediado con la plenitud de las fuentes morales. Se abandona cualquier tipo de control racional para entregarse a las fuerzas psíquicas de lo inconsciente de psicología postfreudiana, a la vez que se reconoce la fuerza ilimitada de la voluntad transformadora en la capacidad de generar una civilización industrial sobre la base del poder científico y tecnológico. ${ }^{2187}$

Estamos en un mundo del "consenso solapado", en el que las intuiciones claras de los individuos jugarán, tal y como Taylor afirma, un papel fundamental. ${ }^{2188}$ Intuiciones que pasan por los sentimientos, las percepciones, las circunstancias. Cualquier posibilidad de búsqueda moral que conecte con espacios de significado, pero que no conecten directamente con lo-meramente-centrado-en-lo-humano, son desacreditados por sistema. Según Taylor, la ética de la autenticidad ha ido mucho más allá de lo que jamás se hubiera pensado. Con Derrida y otros pensadores postheideggerianos, así como ciertas interpretaciones de Wittgenstein, se sigue imponiendo la idea de que tenemos que limitarnos al subjetivismo en las articulaciones morales de significado y a reconocernos en nuestras capacidades psíquicas del inconsciente y la voluntad. Situación que lleva al miedo, al solipsismo, al aislamiento moral en un yo psíquico, al

\footnotetext{
${ }^{2183}$ Cfr. TAYLOR, Ch., Fuentes del yo, pág. 661.

${ }^{2184}$ Cfr. TAYLOR, Ch., Argumentos filosóficos, págs. 111-112.

${ }^{2185}$ Cfr. TAYLOR, Ch., La ética de la autenticidad, pág. 100.

${ }^{2186}$ Cfr. TAYLOR, Ch., Fuentes del yo, págs. 584 y ss.

${ }^{2187}$ Cfr. TAYLOR, Ch., Imaginarios sociales modernos, pág. 196; cfr. TAYLOR, Ch., Fuentes del yo, pág. 636; cfr. SANGUINETI, J.J., Filosofía de la mente, Ediciones Palabra, Madrid, 2007, págs. 305 y ss.

${ }^{2188}$ Cfr. TAYLOR, Ch., La Era Secular, tII, págs. 373,616,629.
} 
desamparo y a la más absoluta impotencia e inseguridad. ${ }^{2189}$ Erich Fromm define al hombre en esta situación como abrumado por la duda y por la falta de puntos de anclaje moral, paralizando la vida y con una libertad negativa que no contribuye a reconstruir las fuentes morales del yo. ${ }^{2190}$ Es la desconexión radical, la neutralidad absoluta, porque todo queda a expensas del afianzamiento de la integridad de un yo individual entendido como experiencia de la propia autenticidad. Es una situación de libertad encadenada. ${ }^{2191}$ Según Taylor, es la cultura expresivista fracturada, con su interpretación postdurkheimiana avanzada, y que parece muy inhóspita para la creencia. ${ }^{2192}$

Lo que está claro, más allá de la filosofía deconstructiva, es que la historia humana es la historia del espíritu encarnado, del espíritu realizado en sus tres dimensiones básicas: un espíritu racional, un espíritu de eternidad y un espíritu del yo en su autoconciencia expresiva. Son los tres elementos que recorren la historia del espíritu humano y que expresan la historia del hombre y del mundo. Por lo tanto, la historia, más allá del momento que nos toca vivir, se adentrará por los caminos que tenga que recorrer el espíritu. Un espíritu que, en unas ocasiones, se expresará a través de grandes manifestaciones y efervescencia filosófica y elevación del espíritu humano y, en otras ocasiones, aparecerá en su dimensión más limitada o deconstructiva. Taylor pretende recuperar con su relato filosófico ese movimiento del espíritu que recorre la experiencia humana y que no desaparecerá porque desaparecería el sentido mismo de la vida humana y del ser. Todo se ha problematizado mucho más y la Religión no termina de encontrar su espacio en el marco inmanente y secular. La duda invade el compromiso intelectual del hombre y la esperanza a la que el corazón humano se adhiere constantemente, se va estrechando cada vez más. Creencia ya no significa confianza, empeño y compromiso, sino que ha llegado a ser un asentimiento intelectual, una proposición más o menos dudosa, tal y como afirma Armstrong. ${ }^{2193}$

Habermas, con el que Taylor entra en diálogo, habla también del futuro de la Religión. ${ }^{2194}$ Un futuro que él define con el término postsecular para hacer referencia a la continuidad de la religión a pesar de la influencia secularizadora de carácter globalizador. ${ }^{2195}$ Habermas reconoce que la religión puede hacer aportes insustituibles a la sociedad y no solo en el ámbito de la existencia individual. ${ }^{2196}$ Para algunos autores,

\footnotetext{
${ }^{2189}$ Cfr. TAYLOR, Ch., Argumentos filosóficos, págs. 38,40,112,132,140-141.

${ }^{2190}$ Cfr. FROMM, E., El miedo a la libertad, págs. 363 y ss.

${ }^{2191}$ Cfr. TAYLOR, Ch., Hegel, pág. 499.

${ }^{2192}$ Cfr. TAYLOR, Ch., La Era Secular, tII, pág. 669.

${ }^{2193}$ Cfr. ARMSTRONG, K., En defensa de Dios. El sentido de la Religión. Paidós. Barcelona, 2009, pág. 358.

${ }^{2194}$ Cfr. TAYLOR, Ch., HABERMAS, J., BUTLER, J. y WEST, C., El poder de la religión en la esfera pública, págs. 61-68.

2195 Cfr. TAYLOR, Ch., Argumentos filosóficos, págs. 39,141,338,343,345,353. Cfr. TAYLOR, Ch., Fuentes del yo, págs. 101,130,132,147,687,689.

${ }^{2196}$ Cfr. MICHELINI, D.J., "Creyentes y no creyentes, en una sociedad democrática. La religión en el pensamiento actual de J. Habermas”, Invenio, No 18, (2015), pág. 18.
} 
entre ellos Taylor, puede ser el nuevo paradigma frente a las teorías de la secularización, siempre y cuando logre explicar tanto los procesos de secularización como los de sacralización en el mundo contemporáneo y establezca las condiciones cognitivas de una síntesis entre lo secular y la religión. ${ }^{2197}$ Con su afirmación de la era postsecular, Habermas no solo afirma la positividad de la religión, sino que cree también que la religión enriquece el sentido moral del hombre y no se pueden ni deben olvidar sus aportaciones en la articulación de las identidades culturales en las sociedades premodernas y modernas. ${ }^{2198}$ La expresión "era postsecular" nos remite al término "era secular" de Taylor, abriendo un diálogo filosófico entre ambos a partir del significado de la secularidad en la Modernidad. ${ }^{2199}$

Para los profesores Roldán Gómez y Simbaña el concepto postsecular no hace referencia solo a una voluntad de reconocimiento de la religión en el espacio público y tampoco se limita a la necesidad hermenéutica de la razón secular de saldar cuentas con su pasado religioso. Lo postsecular, además, tiene consecuencias para las relaciones políticas entre los ciudadanos, reconociendo la influencia y contribución de la Religión a la democracia del siglo XXI. ${ }^{2200}$ Habermas reconoce no solo su aportación, sino el ser "memoria" para el futuro de una vinculación con lo mejor de nuestro pasado. ${ }^{2201}$ Pero

2197 Cfr. TAYLOR, Ch., Argumentos filosóficos, págs. 349-354; cfr. GARZÓN VALLEJO, I., "Postsecularidad, ¿un nuevo paradigma de las ciencias sociales?”, Revista de Estudios Sociales, No 50, (2014), pág. 110.

2198 "En síntesis, lo postsecular aludiría al fenómeno de persistencia o resurgencia de lo religioso en las esferas públicas de los Estados seculares, y a las implicaciones (morales, políticas y, en última instancia, también filosóficas) que ello podría tener para los ciudadanos". ROLDÁN GÓMEZ, I., "Lo postsecular: un concepto normativo", pág. 855.

${ }^{2199}$ Cfr. LYOTARD, J.F., La condición posmoderna, Cátedra, Madrid, 1987; cfr. VATTIMO, G., El fin de la modernidad. Nihilismo y hermenéutica en la cultura posmoderna. Gedisa, Barcelona, 1987; cfr. LYPOVETSKY, G., La era del vacío. Ensayos sobre el individualismo contemporáneo, Anagrama, Barcelona, 2000.

Citamos aquí también la polémica entre Karl Löwith y Hans Blumemberg en torno al origen de la secularización a partir de sus obras El hombre en el centro de la historia y La legitimación de la edad moderna, respectivamente. Karl Löwith insiste en la explicación de la secularización a partir de la evolución del concepto escatológico del Cristianismo al sentido del progreso humano como realización última del devenir histórico. Hans Blumemberg desestima dicha explicación aludiendo al hecho de que mientra que la escatología cristiana asume una invervención externa de la divinidad, el progreso es un proceso inmanente en el que el hombre va asumiendo una conciencia del progreso humano a partir de sí mismo. Además Blumemberg incide en otros dos elementos: la influencia de la ciencia astronómica y el conflicto entre antigüedad y modernidad según el cual cada época desarrolla su propio espíritu y puede desarrollar sus propios modelos culturales. Cfr. LÖWITH, K., El hombre en el centro de la historia, Aguilar, Madrid, 1958; BLUMEMBERG, H., La legitimación de la edad moderna, Pre-Textos, Valencia, 2008.

${ }^{2200}$ Cfr. ROLDÁN GÓMEZ, I., "Lo postsecular", pág. 862; cfr. SIMBAÑA Q. R., "La religión en la esfera pública: Habermas y el resurgimiento de la religión", Revista de Ciencias sociales y Humanidades, No 1, (2016), pág. 79.

2201 "Las tradiciones religiosas están provistas de una fuerza especial para articular intuiciones morales, sobre todo en atención a las formas sensibles de la convivencia humana. Este potencial convierte al hablar religiosa, cuando se trata de cuestiones políticas pertinentes, en un serio candidato para posibles contenidos de verdad, que pueden ser traducidos entonces desde el vocabulario de una comunidad religiosa determinada a un lenguaje universalmente accesible". HABERMAS, Entre naturalismo y religión, pág. 139. "La modernidad ya no puede ni quiere tomar sus criterios de orientación de modelos de otras épocas, tiene que extraer su normatividad de sí misma”. HABERMAS, El discurso filosófico de 
Taylor ve también una limitación en la aportación de Habermas. Al propio tiempo que reconoce su aportación en torno a la importancia del intercambio comunicativo y del lenguaje como reconocimiento de subjetividad moral; sin embargo, para Taylor su relato no ofrece garantía contra la pérdida de significado moral del momento actual, ni la superación de la fragmentación. En su visión no termina de superarse la visión generalizada posmoderna y deconstructiva, porque no termina de comprender la importancia de la búsqueda de las fuentes morales fuera del sujeto y su reconocimiento como tales, ya que para él dicha búsqueda se ve limitada a la expresividad de significado que resuena dentro de él a través de la comunicación lingüística. No logra superar la visión incoherente de que haya que afirmar un orden mayor fuera, ${ }^{2202}$ recelando de una ética crítica y verdaderamente universal. ${ }^{2203}$

Según comenta Taylor, Habermas parte de la obligación de los ciudadanos de dirigirse a sus compatriotas en el lenguaje de la razón secular para hacerles inteligible así su posición. Sin embargo, Taylor se pregunta: ¿Por qué motivo hay que pensar que la 'razón natural' ofrece una especie de esperanto ideológico? ¿Fueron los conciudadanos de M. Luther King incapaces de entender lo que él defendía cuando abogaba por la

la modernidad, Taurus, Madrid, 1993, pág. 18. Para Habermas, a partir de su lectura de Hegel, encuentra las dificultades de la Modernidad para reconciliarse con determinados elementos de la tradición medieval y en su necesidad de ser "rescatados" por la novedad que la aparición de la Modernidad representó. "En punto de referencia de la modernidad se convierte ahora la actualidad que se consume a sí misma, que ocupa la extensión de un tiempo de tránsito, de un tiempo novísimo - de unos decenios de duraciónconstituido en el centro de la nova aetas o Edad Moderna". Ibid., pág. 20. Cfr. SCIVOLETTO, G., "La religión en la esfera pública: análisis de la cláusula de traducción del discurso religioso al lenguaje secular", págs. 93-116; cfr. PIZZI, J., "Habermas y la religión. Algunas consideraciones”, págs. 53-68. "Lo importante de la religión era vivir de forma intensa y fecunda aquí y ahora. Las personas religiosas son ambiciosas. Quieren una vida rebosante de sentido. Siempre desearon integrar en su vida cotidiana los momentos de éxtasis y discernimiento a los que accedían en sueños, en su contemplación de la naturaleza y en su relación con los otros y con el mundo animal. En lugar de quedar aplastados y amargados por el sufrimiento de la vida, siempre trataron de conservar su paz y su serenidad en medio de su dolor. (...) Trataron de honrar el inefable misterio que percibían en cada ser humano y crearon sociedades que honraban al extranjero, al diferente, al pobre y al oprimido. Claro está, con frecuencia fracasaron. Pero, por encima de todo comprobaron que la disciplina de la religión les ayudaba a conseguirlo. Quienes se aplicaron más asiduamente mostraron que los hombres y las mujeres mortales podían vivir en un plano superior, divino o semejante a dios, y así despertar a su verdadero yo". ARMSTRONG, K., En defensa de Dios. El sentido de la religión, pág. 363. "Las creencias y prácticas religiosas instituidas no son sino la forma 'administrada' de una experiencia fundante, anterior a toda formalización filosófica y teológica y que pone en juego, de manera intensa, incluso incandescente, los sentimientos y la afectividad de quienes la realizan". HERVIEU-LÉGER, D., La religión, hilo de memoria, pág. 103.

${ }^{2202}$ Cfr. TAYLOR, Ch., Fuentes del yo, pág. 689. Para Taylor hay tres áreas de tensión que se desenvuelven dentro del deconstructivismo y el nihilismo nietzscheano con otras fuentes de moralidad: el debate sobre los bienes constitutivos, el conflicto entre el instrumentalismo desvinculado y la propuesta romántica contra él y finalmente si la moral de la autenticidad radical no está poniendo en riesgo ciertos elementos de la integridad moral por su carácter reduccionista y deconstructivo. Cfr. TAYLOR, Ch., Imaginarios sociales modernos, págs. 199 y ss; cfr. TAYLOR, Ch., Argumentos filosóficos, pág. 16. Sobre Derrida y el antisubjetivismo como "imagen especular del subjetivismo”, Cfr. Ibid., págs. 112,132,331.

${ }^{2203}$ Cfr. TAYLOR, Ch., Argumentos filosóficos, pág. 39. 
igualdad en términos bíblicos? Habermas opina que la razón secular/filosófica no implica socialización religiosa, como sí lo necesita la razón religiosa. ${ }^{2204}$

Por otra parte, para Habermas la relación de la fe con la ciencia y de esta con la fe ayudan a configurar el mundo de una manera distinta. En los presupuestos del diálogo y consenso del Estado liberal democrático subyacen valores que tienen que ver con la tradición judeo-cristiana que ha contribuido de manera fehaciente a su configuración como tal. En dicha configuración del Estado moderno se reubican las relaciones entre ciencia y fe, dado que no se puede comprender el estado moderno sin la contribución de ambos elementos. El Estado moderno no surge de la nada, sino que tiene un recorrido en el que se reconfiguran todo tipo de fuentes morales y en las que la fe no puede quedar al margen de lo que es relevante para el hombre de hoy, dado que su aportación a la moralidad es fundamental y enriquece el sentido del hombre como concepto universal en el mundo y de la historia. ${ }^{2205}$ De ahí la necesidad, según Taylor, de una redefinición radical del secularismo y de una comprensión de la misma basada en la autonomía de la persona y la plena igualdad de ateos y agnósticos y los distintos creyentes en la común preocupación de universalidad de la esfera pública. ${ }^{2206}$

${ }^{2204}$ Cfr. TAYLOR, Ch. y HABERMAS, J., El poder de la religión en la esfera pública, pág. 55.

2205 "La controversia también se hace extensiva a la cuestión epistemológica de la relación entre la fe y el saber, la cual atañe de nuevo a elementos esenciales del entendimiento de fondo de la modernidad. Y es interesante que tanto los intentos filosóficos como los teológicos por determinar autorreflexivamente la relación entre la fe y el saber susciten cuestiones de gran alcance acerca de la genealogía de la modernidad". HABERMAS. J., Entre naturalismo y religión, pág. 153.

${ }^{2206}$ Cfr. MACLURE, J. y TAYLOR, Ch., Laicidad y libertad de conciencia, págs. 38-39; Cfr. TAYLOR, Ch. y HABERMAS, J., El poder de la religión en la esfera pública, págs.. 61-67. 
VI.-CONCLUSIÓN GENERAL 


\section{PROPUESTAS PARA UNA NUEVA TEORÍA SOBRE LA SECULARIZACIÓN. LA RELIGIÓN EN LA ESFERA PÚBLICA}

A lo largo de este prolongado estudio de Historia y Filosofía, se han podido comprobar los espacios de relación entre el marco trascendente y el marco inmanente, lo finito como lo infinito, la esencia y el sujeto, lo subjetivo y lo objetivo y cómo se han ido reubicando de manera permanente. ${ }^{2207}$ En definitiva, lo que Taylor pretende es ensamblar y reescribir el retrato de la identidad moderna a través de su historia. ${ }^{2208}$

Se trata de la narración de múltiples historias que llevan a la mecanización de la visión del mundo y su consiguiente desencantamiento. ${ }^{2209}$ Una historia que Taylor denomina la historia de la Desviación Intelectual (DI), pero que no puede bastar como relato principal subyacente a la secularización. Nuestro autor considera fundamental el giro que provoca la Narración Maestra de la Reforma (NMR) que elimina la distancia de la fe de la cristiandad e induce a un desplazamiento antropocéntrico. En todo caso, según Taylor, para explicar la religión hoy en día son necesarias tanto la DI como la NMR.

La tesis que Taylor propone es que tenemos a nuestra disposición recursos potencialmente ricos para ayudarnos en la toma de decisiones, aunque la filosofía moral contemporánea ha tendido a ignorarlos. Si nos situamos fuera del terreno ordenado y bien explorado de las filosofías modernas de la obligación moral, que resuelven el problema de la pluralidad negándolo, o reconocemos que esas valoraciones fuertes de la moralidad son indefendibles, nos sentimos abrumados por una gran diversidad de bienes difíciles de arbitrar y gestionar. ${ }^{2210}$

1.- Taylor considera la narración vigente y oficial como la historia de una sustracción en clave de inevitabilidad secularizadora. Su propuesta podría definirse en los siguientes términos:

i.- La necesidad de repensar el alcance y significado de la secularización a partir de una nueva narración globalizadora que supere un debate inarticulado o dado por hecho en términos que han quedado superados.

\footnotetext{
2207 “Por qué me interesó Hegel? (...) No puedes tratar ciertos asuntos filosóficos sin tener en cuenta la historia, sin ser consciente de que las preguntas sobre la libertad, sobre el tipo adecuado de la sociedad, sobre la clase de sociedad que debemos escoger, no pueden realmente tratarse sin entender cómo estos asuntos se desarrollaron con el tiempo". TAYLOR, Ch., BERNSTEIN, R. y GAMPER, D., Diálogos, pág. 49.

${ }^{2208}$ Cfr. TAYLOR, Ch., Fuentes del yo, pág. 672.

${ }^{2209}$ Cfr. TAYLOR, Ch., La Era Secular, tII, pág. 743.

${ }^{2210}$ Cfr. TAYLOR, Ch., La libertad de los modernos, pág. 301.
} 
ii.-Analizar en toda su profundidad y alcance por qué sigue estando vigente y actuando el fenómeno de la secularización en las sociedades postsecularizadas.

Taylor es consciente de que la DI no agota todo el alcance de la secularización y que se precisan nuevos elementos de análisis. Por otra parte, bajo la secularización persistente, se puede afirmar, sin temor a equivocarse, que late un mundo de contradicciones y regresiones, de dicotomías y dilemas que Taylor analiza con detenimiento bajo la perspectiva del pluralismo y el politeísmo de valores. Frente a todos los padres de la sociología que preconizaron la teoría de la secularización (K. Marx, A. Comte, J.G. Frazer, J. Stuart Mill, F. Tönnies, M. Weber, G. Simmel, E. Durkheim, y otros muchos), Taylor invita, como otros autores a los que también hemos hecho referencia, a dar por superado el paradigma de la secularización y a afirmar la existencia de una postsecularidad que debe ser redefinida en nuevos términos y articulada con profundidad. Taylor se adentra por los espacios abiertos jamesianos en los que sopla el viento que se puede sentir desde ambas direcciones. Para Taylor, la religión sigue indeleble en el horizonte de la arreligión.

La superación de las teorías de la secularización y la apertura hacia nuevos horizontes permitirán, según asegura Taylor, que se superen los prejuicios o la negatividad a priori del hecho religioso y que el Cristianismo sea visto cada vez más como una propuesta en la que la creencia en Dios es el mejor aval para la afirmación del deseo y anhelo humanos.

Todo ello nos lleva a afirmar, en opinión de Taylor, la complejidad del fenómeno religioso. Una complejidad que le lleva a ubicar la comprensión de la religión hoy bajo la perspectiva del binomio trascendencia-inmanencia. La trascendencia implica un ser o existir más allá, una búsqueda de un sentido de plenitud que no se agota aquí. Para nuestro autor, la autenticidad del sentido trascendente nos ubica moralmente en una búsqueda del sentido de plenitud en el que todos estamos implicados. Las palabras identidad, plenitud y trascendencia son fundamentales en la articulación tayloriana de las fuentes morales del yo en línea con Gauchet y la historia antropológica de la religión. ${ }^{2211}$ Esta plenitud nos hace reconocernos como "necesitados", a la búsqueda de un sentido moral del que no podemos desentendernos. En esta dirección apunta el Cristianismo.

En la etapa postdurkheimiana de la fe, en la que la autenticidad determina el propio camino interior de búsqueda espiritual, el marco trascendente queda determinado por la inmanencia del yo interior, potenciando una suerte de expresivismo difuso que responde a nuestras intuiciones espirituales originales y propias. Son formas religiosas más personalizadas y experimentales. De ahí la importancia, para Taylor, de redefinir y

${ }^{2211}$ Cfr. GAUCHET, M., El desencantamiento del mundo, pág. 296. 
repensar la definición de secularidad desde el marco inmanente en el que nos encontramos creyentes y no creyentes.

El orden inmanente nos permite adherirnos a estructuras de un mundo cerrado (EMC) pero tenemos la posibilidad de mantenernos abiertos a diversas versiones de trascendencia, tal como se ha visto anteriormente. Se trata, pues, de un orden que nos permite incluirnos en cualquiera de las dos opciones. De lo que se trata, pues, es de evitar cualquier pretensión fundamentalista que se niegue a asumir el espacio abierto en el contexto pluralista y politeísta en el que nos encontramos, en el que todas las posiciones son discutibles y donde muchas personas sienten el atractivo o las fuerzas que provienen de otras fuentes morales.

Taylor sostiene, junto con M. Heidegger y M. Merleau Ponty, que desde la perspectiva de la hermenéutica fenomenológica se pretende superar la tentación de adherirnos a la perspectiva cerrada que nos mantiene cautivos en el mundo de la representación inmanente y que conduce inexorablemente al cientificismo que observa el mundo como vacío y desprovisto de cualquier significado o fuente de orientación moral. ${ }^{2212}$ Esto es lo que pretende Taylor, en su lucha infatigable por propiciar posturas de reconciliación, implicándose en el enorme esfuerzo intelectual por articular ser y tiempo, verdad y método, naturaleza e historia, finitud e infinitud, marco inmanente y marco trascendente. Todo ello bajo la inspiración maestra e ineludible de Hegel.

2.- En esta misma línea configuradora de un nuevo relato sobre la historia de la secularización, hay que diferenciar la laicización de un Estado de la secularización de una sociedad. ${ }^{2213}$ En el fondo el laicismo y la secularidad pretenden articular formas de diálogo entre las diversas fuentes de la moralidad en la Modernidad, de tal forma que se pueda realizar una forma de convivencia pacífica entre las diversas fuentes morales a través de la neutralidad y la libertad de conciencia en los poderes públicos. El problema de fondo reside en que, a pesar de la pluralidad de fuentes morales, en muchas ocasiones, los individuos no toman postura. Podríamos decir que nos movemos entre el deseo de creer y la impotencia, encontrándonos prácticamente incapacitados para asumir responsabilidades, dado que hay una nivelación que en ocasiones impide tomar decisiones y con ello la capacidad de asumir riesgos para poder entablar diálogos enriquecedores.

\footnotetext{
2212 "En el acontecer el proyecto se configura mundo, es decir, en el proyectar brota algo y se abre a posibilidades y de este modo irrumpe en lo real encuanto tal, para experimentarse a sí mismo en toanto que irrumpido como realmente ente en medio de aquello que ahora puede estar manifiesto como ente".

HEIDEGGER, M., Los conceptos fundamentales de la metafísica, Alianza Editorial, Madrid, 2017, pág 432

2213 "El estado debe intentar laicizarse sin fomentar por ello la secularización". TAYLOR, Ch. y MACLURE, J., Laicidad y libertad de conciencia, Alianza Editorial, Madrid, 2011, pág. 28.
} 
El principio de igualdad y de libertad universales hace que los compromisos morales de las distintas religiones queden un tanto diluidos o difuminados, ya que lo que las distingue queda reducido a un compromiso individual. Las religiones no son determinantes a la hora de saber qué es lo que nos diferencia, ya que hay un compromiso previo que unifica y nivela todo sobre la base de la igualdad y la libertad. Es fundamental tener esto en cuenta a la hora de percatarnos de que, si por un lado las religiones pierden fuerza diferenciadora de carácter moral, por otro lado, se posibilita sobre esa misma base que diluye elementos que refuerzan el diálogo y la cercanía en aquello que nos une. Lo único que permanece inalterable es la voluntad personal del yo, tanto como identidad de autorrealización personal como sujeto político.

Lo que está claro es que el marco inmanente, tal y como habla Taylor, es el espacio que ocupa el protagonismo fundamental. Por eso habla de "era secular", y en términos sociológicos, de pluralismo. Secularidad que viene definida por la diversidad y el pluralismo de fuentes morales, en un momento decisivo en el que la creencia y su contrario coexisten como alternativas válidas. Algunos autores caracterizan este momento como "policontextual", esto es, un contexto en el que como seres dialógicos debemos ejercitar el consenso y el encuentro con las distintas redes de interlocución para así aprender a orientarnos y realizar una articulación jerárquica de los propios bienes que enriquezca al propio tiempo la de los demás.

No obstante, Taylor considera que antes de ejercitar la circularidad dialógica hay que tener en cuenta los juicios de valor involucrados tanto en el reconocimiento de la pluralidad diferencial, como en la consiguiente aproximación a la misma, dado que con frecuencia no somos conscientes de ello. Es lo que nuestro autor denomina "fondo tácito de entendimiento" como clave hermenéutica inequívoca, puesto que las líneas de batalla son múltiples y desconcertantes y existen profundas fisuras en lo que concierne a los bienes constitutivos y a las fuentes morales que apuntalan esos parámetros: la fundamentación teísta, el naturalismo de la razón desvinculada y científica y el expresivismo romántico y modernista.

Para Taylor, la edad secular está definida por dos elementos: por la separación Iglesia-Estado y por la neutralidad o principio de distancia. Una separación IglesiaEstado para evitar que ninguna Iglesia determinada se arrogue derechos sobre otras visiones del mundo. $\mathrm{Y}$ un principio de distancia que asegure la independencia del Estado respecto a cualquier condición ideológica. Separación y neutralidad que adopta distintas formas según los países: desde EE.UU. con la así llamada experiencia americana de la libertad religiosa como el lustre del país, hasta las distintas experiencias europeas que van desde la preservación formal de la Iglesia anglicana en Inglaterra, al estado laicista francés que reduce el libre ejercicio de la religión. 
3.- Taylor afirma que la secularidad pretende articular, debido al politeísmo de valores, no solo las relaciones entre el Estado y la Religión, sino sobre todo qué deben hacer los Estados democráticos y liberales para organizar la diversidad y así permitir una sana convivencia dentro del marco constitucional entre las distintas identidades morales, protegiendo dichas diferencias, permitiéndolas, procurando la igualdad de todas las personas sobre la base de la afirmación universal de la común dignidad de todo ser humano. Se trata de establecer, por un lado, la política de la diferencia y, por otro lado, el reconocimiento entendido desde el punto de vista de defensa de aquello que compartimos. En todo caso, se pretende emancipar la política de la dependencia óntica de la Religión, a través de democracias que aseguren el reconocimiento igualitario en las diferencias identitarias.

Una vez que está definida la esfera pública como espacio de acuerdo, que incluye las comprensiones comunes respectivas, no hay que olvidar, por otra parte, la relevancia del individualismo de la autenticidad que potencia la soledad y la comunicación como espacio de reconocimiento recíproco. Frente al vacío del narcisismo y la egolatría que conduce a un futuro de desesperanza, Taylor propone la perspectiva de la ética de la autenticidad que aglutina perspectivas y un trasfondo sobre el que configurar la vida y las tensiones posibles entre el vacío ególatra y el empuje del ideal. Una autenticidad que eleva espiritualmente sobre el camino de la libertad responsable.

En este sentido, parece adecuado para una sana convivencia entre las distintas percepciones de sentido moral, que cada una de ellas defienda sus principios éticos en los que se fundamenta para adoptar sus compromisos morales, siempre y cuando el Estado democrático, desde el respeto a dichos principios, se abstenga de favorecer cualquiera de las razones de fondo sobre las que se sustentan. Hay principios éticos que todos comparten, no así las razones de fondo que sustentan sus decisiones morales. Por eso el Estado debe favorecer el diálogo entre las distintas fuentes morales a partir de los principios éticos que se desprenden de dichas fuentes, abstrayéndose de la defensa de cualquier razón de fondo de tipo moral. En este sentido, se trata de una cultura que se sustenta en lo que Taylor denomina una lucha continua. Una lucha en la que trata de conciliar la política de la dignidad universal con la política de la diferencia, evitando conflictos no deseados. No se puede legislar sobre la base de los derechos de las minorías, rompiendo así políticas de igualdad en la que otros grupos sociales puedan sentirse discriminados. Se trata de gestionar adecuadamente estas políticas de la diferencia sobre la base de reconocer dichas diferencias como derechos que se sustentan sobre la común igualdad y dignidad.

La política de la dignidad que iguala a las personas en sus derechos universales nos remite al concepto de dignidad kantiano. Un concepto que para Taylor es la base de la concepción moderna de la dignidad humana. Para Kant 
“en el orden de los fines, el ser humano sea 'un fin en sí mismo', es decir, que nunca pueda ser utilizado como un simple medio por nadie (ni aun por el mismo Dios) sin verse tratado al mismo tiempo como el fin que es o, dicho con otras palabras, que la humanidad haya de suponer algo sagrado en nuestra propia persona, son cosas que ahora se siguen de suyo, habida cuenta de que, al ser el sujeto de la ley moral, el ser humano también lo es de algo sacrosanto en sí y permite dar ese calificativo a todo cuanto esté de acuerdo con ello. Pues esta ley moral se funda sobre la autonomía de su voluntad como voluntad libre que, con arreglo a sus leyes universales, debe poder estar de acuerdo con aquello a lo cual debe someterse". 2214

Es la dignidad como seres racionales frente al orden de la naturaleza y de las distinciones cualitativas en el orden del ser. La dignidad no es, pues, la razón última para la obligación ética. Esta obligación radica, por el contrario, en la capacidad del ser humano para constituirse en autolegislador, en el ser racional o en la ley moral dentro de mí. Y ahí radica su dignidad. Es la autonomía, es decir la capacidad para establecer y seguir la ley moral, lo que nos permite decir que los seres humanos (como seres racionales) ostentan una dignidad. ${ }^{2215}$

Sin embargo, la mentalidad moderna, la idea de la dignidad universal contiene características diferentes a las kantianas. Taylor afirmará que la Modernidad entenderá la dignidad como potencial humano universal, como algo que es común a todos los seres humanos. Este potencial es lo que confiere dignidad a cada persona, independientemente de lo que cada persona haga o merezca como tal: todas las personas se merecen ese reconocimiento y respeto en lo que es igual a todos.

Por otra parte, en relación con la política de la diferencia y del reconocimiento, Taylor también habla de un potencial universal como capacidad de definir nuestra diferencia identitaria como individuos y como cultura. Todas las diferencias deben reconocerse como tal, y se merecen ese respeto, respeto de lo peculiar y distinto. Taylor piensa que no hemos de ver, en este sentido, la religión a priori como una amenaza y que se debe huir del fetichismo de las soluciones institucionales preferidas a la hora de reconocer las diferencias y afrontar los conflictos. En todo caso, lo que hay que evitar es que el mantenimiento de una radical neutralidad estatal en cuestiones religiosas pueda conllevar como consecuencia no deseada la implantación de una forma de vida incompatible con las demandas surgidas de otras formas de vida, espirituales o religiosas. $^{2216}$

Las distintas fuentes de la moralidad moderna comparten principios éticos y son dichos principios los que los Estados modernos deben favorecer y potenciar para poner

\footnotetext{
${ }^{2214}$ KANT, I., Crítica de la Razón Práctica, A-237.

${ }^{2215}$ Cfr. KANT, I., Fundamentación para una metafísica de las costumbres, IV-435

Cfr. AGUIRRE-PABÓN, J.O., "Dignidad, derechos humanos y la filosofía práctica de Kant”, Universitas, No 123, (2017), págs., 50.61.

${ }^{2216}$ RODRÍGUEZ GARCÍA, S., "Educar en la laicidad. Revisando conceptos con Charles Taylor”, pág. 215.
} 
en diálogo a los ciudadanos, sean cuales sean las convicciones morales que están en el fondo de dichos principios. La ética común es la que une en la diversidad de fuentes morales y la que deben potenciar los Estados democráticos para un sano diálogo y convivencia pacífica entre ciudadanos. Las razones morales en las que se sustentan dichos principios éticos nos posicionan en lugares morales distintos; por eso, en esas diferencias, los Estados se mantienen al margen y deben evitar posicionarse en favor de ninguna de ellas, en una laicidad abierta. Además, de lo que aquí se trata no es tanto de cuestiones filosóficas, cuanto del imaginario social en el que cada uno es libre en virtud del hecho de que nos gobernamos a nosotros mismos y las decisiones individuales de cada uno se reconocen como parte de la soberanía común. La ley común protege a todos y defiende los mismos derechos. Es una sociedad que defiende la libertad individual y la de todos.

Por otra parte, está claro que las distintas fuentes de moralidad configuran identidades que permiten posicionarse moralmente y diferenciarse. Uno puede decir, "yo creo en algo en lo que otros no creen". De alguna manera el orden natural romántico potenciaba esas diferencias, invitando a ser conscientes de las distintas percepciones morales y asentar la individualidad de la experiencia religiosa. La experiencia religiosa es algo individual y se expresa en el sentimiento. Pero al mismo tiempo, la otra fuente de la Modernidad Ilustrada, la de la razón exclusiva y humanista, potenciaba la necesidad de dar motivos a dicha decisión diferenciadora y racionalizar los fundamentos del creer. Y a partir de ambas fuentes de moralidad, basadas en el sentimiento individual de la experiencia religiosa y las razones del creer, se vuelve relevante la cuestión de la aprobación y el reconocimiento social. Las configuraciones de la identidad moral laica han potenciado el sentido racional del creer (para creer o no creer) y la experiencia individual del sentimiento religioso que nos hace distintos a unos de otros (para ubicar la experiencia religiosa en el ámbito del sentimiento y del yo individual que la percibe); pero al mismo tiempo, precisan de una comunidad visible como necesidad de reconocimiento a dicho sentimiento espiritual y ser conscientes de las diferencias con otras formas de creer o de no creer. En este sentido, las fuentes de la moralidad trascendente, que potencian el sentido comunitario de la experiencia religiosa, pueden encontrar motivación moral en el interior de las fuentes de la moralidad no trascendente.

Por lo tanto, es muy esclarecedor ese sentido de pertenencia a una sociedad que protege y defiende los derechos individuales y en el que todos nos reconocemos en una identidad común e individual. De ahí la importancia del compromiso y participación de los ciudadanos para continuar incrementando ese sentido de pertenencia y reconocimiento social. En la medida en que esos bienes sean relevantes para la vida de las personas, estas se identificarán con mayor responsabilidad y sentido de pertenencia, y se promoverá así una mayor participación en la vida socio cultural y política de los 
gobiernos. Sin ese vínculo fuerte y profundo entre democracia y participación en la agencia colectiva es muy difícil asentar las bases de una ética común en la que todos participan, porque se sienten partícipes y protegidos por una ley que nos da los mismos derechos y protege el desarrollo de la libertad individual. Además, desde esta agencia colectiva no se difuminan las diferencias entre identidades, sino que se enriquecen y protegen desde el diálogo y la participación común. Es aquí donde Taylor ubica el papel relevante que debe desempeñar la Religión en el Estado Moderno. Dios puede ser muy importante no solo para la identidad personal, sino también para la política. Ya no se trata de espacios, lugares y tiempos sagrados, cuanto de una afirmación de lo trascendente como fuente de interioridad personal que se expresa en un orden que determina la vida personal y social.

Se trata pues de una comunidad social y política que visibiliza no solo las diferencias de unos y otros, sino la pluralidad de situaciones morales asociadas a la experiencia de trascendencia o inmanencia. La razón y el sentimiento han lanzado a la Modernidad al pluralismo y a la necesidad de visibilizar todas esas diferencias. Frente a las minorías ortodoxas y basadas en la autoridad religiosa y las minorías ateístas, la mayoría acepta algunos componentes de la fe religiosa, en una gran variedad de adhesiones a credos y sensibilidades con componentes tomados de distintas configuraciones morales, tradiciones y culturas, e incluso dependiendo del momento vital en que cada uno se encuentre. Y es ahí, en ese pluralismo de opciones y situaciones, donde los Estados deben potenciar el secularismo o la laicidad positiva que permita toda esta gama de pluralismo y variedad de sentimientos religiosos.

4.- En este sentido, la tesis fuerte de Taylor consiste en que una vez asentados los bienes morales de la libertad de conciencia, de igualdad de trato y de fraternidad entre todos los grupos, no hay razón para considerar a la religión como un caso aparte. La laicidad del Estado no debe fundamentarse tanto en la neutralidad, en la separación Iglesia-Estado o en la diferencia entre esfera pública y privada (fetichismo de los medios), cuanto en la construcción de una sociedad solidaria con los bienes anteriormente mencionados.

Para Taylor, el dilema entre el asunto de lo religioso y lo secular es un planteamiento equivocado. El problema real es la mentalidad cerrada, la mentalidad excluyente que puede asumir una forma secular, religiosa o la forma de la laicidad. Los Estados democráticos deben procurar articular formas de convivencia pacífica entre todas las razones morales de fondo sobre la base de los principios éticos comunes, evitando cualquier forma de exclusión entre dichas fuentes morales. En su opinión, los Estados que merecen ser denominados "seculares" no son los que se enfrentan radicalmente a la razón religiosa, sino aquellos que intentan configurar sus soluciones 
institucionales, no para mantenerse fieles a una tradición sacralizada, sino para maximizar las metas básicas de libertad e igualdad entre creencias básicas.

Los Estados liberales y las democracias no pueden fundar la convivencia en el politeísmo de valores y en el pluralismo acudiendo solo a los valores democráticos, a la neutralidad y respeto entre iguales, sino que también se necesitan fundamentaciones y referencias de sentido que incluyan elementos filosóficos, de tradiciones culturales y el papel de las religiones en la construcción de la identidad moral de los pueblos. En este sentido, Taylor sostiene que la sola razón secular no es la única que puede fundamentar la laicidad que respeta la neutralidad y la igualdad entre los seres humanos. Conviene no olvidar que tanto las fuentes de la moralidad laica como la de la moralidad creyente enriquecen el alcance de la laicidad que establece los principios de libertad e igualdad. Marginar la moralidad creyente por no ser necesaria para la fundamentación de la convivencia común o porque podría contaminar el principio de la neutralidad, es equivocar los fundamentos de las tres moralidades a las que venimos haciendo referencia.

Es peligroso afirmar que la razón religiosa o bien llega a las mismas conclusiones que la secular, y entonces es superflua, o bien llega a conclusiones contrarias, y entonces es peligrosa y perjudicial y por lo tanto hay que mantenerla al margen. La ruptura epistémica entre la razón secular y la razón teológica de Habermas, dando preferencia siempre a la primera, no hace justicia a la comprensión de la razón en su totalidad y no abre horizontes para una adecuada relación entre moralidades que potencie la circularidad dialógica. En este sentido Taylor discrepa por igual de Rawls y Habermas; de Habermas en lo referente al requisito de la traducción, y de Rawls, en su obsesión por la eliminación de todas las referencias religiosas del estado.

Para Taylor, no se puede sostener que la razón religiosa está menos fundamentada racionalmente que la razón secular. En este sentido hay que superar la visión de la religión como una amenaza para la convivencia pública o como si hubiera que marginar el pensamiento religioso por problemático para la relación entre iguales. Se trata de superar la visión de que la religión se fundamenta en un pensamiento menos racional o un modo incompleto de razonamiento. El diálogo entre las distintas fuentes morales ayudaría a evitar prejuicios y a reconocerse en la razón como la base común en la que se sustentan las distintas configuraciones morales. ${ }^{2217}$

\footnotetext{
${ }^{2217}$ No compartimos los miedos y temores que expresa Lilla en su libro El Dios que no nació al defender a ultranza la gran separación entre la teología política y el pensamiento político antropocéntrico. Creer que Dios es una amenaza para el razonamiento que lleva "por sí solo" a una elevación del pensamiento político hacia metas de concordia y neutralidad política es un prejuicio que no se sostiene más allá de los conflictos históricos que puedan haber existido. Una cosa es la historia y otra cosa es el fundamento epistemológico que afirma la "minoría de edad de la razón teológica" sobre la "sola razón secular" capaz de fundamentar por sí misma el estado laicista que garantiza la igualdad y la neutralidad. Como si el
} 
La modernidad es secular no en el sentido de una ausencia de religión, sino en el sentido de que la religión ocupa un lugar distinto. Esto es lo que se ha pretendido fundamentar con esta Tesis Doctoral siguiendo a nuestro gran hermeneuta canadiense: descubrir el lugar que ocupa la religión en el mundo actual y qué papel está llamada a desempeñar en el futuro. Lo realmente relevante para Taylor no es el establecimiento del marco inmanente con carácter casi exclusivo, sino la variedad de formas con que se puede vivir. Algunas están abiertas a la trascendencia y otras se inclinan por el cierre. Es posible, afirma Taylor, vivirlas a la par con otras, que las modifican o las limitan; o se les puede otorgar un lugar central, sin rival y sin diálogo posible. Para nuestro autor se trata de evitar el cierre en la inmanencia exclusiva e insertarse en una imagen que no se pueda impugnar. Taylor invita a permanecer en el espacio abierto jamesiano donde sopla el viento y donde se puede sentir la atracción desde ambas direcciones. Se trata de permanecer en el punto medio de las presiones contrapuestas que definen nuestra cultura, para la que, según Taylor, Hegel puede ser un referente fundamental, como filósofo de una síntesis superior.

Taylor prevé un futuro alternativo en el que las modalidades de plenitud reconocidas por los humanismos exclusivos, y otras que se mantienen en el marco inmanente, en el fondo, están respondiendo, a la realidad trascendente, pero sin reconocerla correctamente. Todos, creyentes y ateos, estamos comprometidos en la búsqueda del sentido de plenitud, y reconocerse en esa búsqueda es el primer paso para encontrarnos en un diálogo abierto y fructífero. Es posible la reconciliación que motiva al diálogo y al encuentro con el otro en sus peculiaridades epistémicas y morales; en el reconocimiento de la multiculturalidad se ubican las mejores posibilidades para una mejor autocomprensión de lo que somos y de lo que podemos llegar a ser. ${ }^{2218}$ En este

atrévete a pensar de la Ilustración kantiana (Sapere Aude) estuviera en condiciones de superioridad respecto a otras formas de racionalidad previas a la Modernidad. "Ilustración significa el abandono por parte del hombre de una minoría de edad cuyo responsable es él mismo. Esta minoría de edad significa la incapacidad para servirse de su entendimiento sin verse guiado por alguno otro. Uno mismo es el culpable de dicha minoría de edad cuando su causa no reside en la falta de entendimiento, sino en la falta de resolución y valor para servirse del suyo propio sin la guía del de algún otro. Sapere aude! ¡Ten valor para servirte de tu propio entendimiento! Tal es el lema de la Ilustración”. KANT, I., ¿Qué es la Ilustración?, pág. 319. Compartimos, antes bien, en este sentido, la idea de Taylor sobre los regímenes que merecen ser calificados de 'seculares' en la democracia contemporánea y que son los que intentan configurar sus soluciones institucionales para maximizar las metas básicas de libertad e igualdad entre creencias básicas. Cfr. TAYLOR, Ch., El poder de la religión en la esfera pública, pág. 60 . Taylor defiende claramente el diálogo entre las distintas fuentes de moralidad. "Para abrir el campo a un proyecto de intercambio significativo - un proyecto de razonamiento hermenéutico - lo primero es rebatir la creencia en argumentos infalibles y definitivos. Los malentendidos respecto a esto, que viene de la misma estrechez de cierto tipo de perspectiva, son muy considerables, quizás un tanto menos entre filósofos". TAYLOR, Ch., BERNSTEIN, R. y GAMPER, D., Diálogos, pág. 103.

${ }_{2218}$ "El movimiento gradual de los últimos siglos dentro del Cristianismo, que ha ido en la dirección de los ideales sociales de la Ilustración, es un signo de la paulatina debilitación de la adoración a Dios como poder y su gradual reemplazo por la adoración a Dios como amor. Pienso en el declinar del logos metafísico como un declinar en la intensidad de nuestro intento por participar en el poder y en la grandeza. La transición del poder a la caridad y la del logos metafísico al pensamiento posmetafísico son ambas expresiones de una voluntad de aprovechar las oportunidades que se nos ofrecen, en lugar del 
sentido, los Estados deben reconocer y garantizar la autonomía moral de sus individuos, sean cuales sean sus opciones morales: seculares, religiosas o espirituales. Taylor invita a los Estados a "pensar la libertad de conciencia".

intento de escapar de nuestra finitud alineándonos con un poder infinito”. RORTY, R. y VATTIMO, G., El futuro de la religión. Solidaridad, caridad, ironía, Paidós, Barcelona, 2006, pág. 86. Y Vattimo nos da también otra clave a tener en cuenta: "La frase de Nietzsche 'no hay hechos, solo interpretaciones' y la ontología hermenéutica de Heidegger no hacen sino llevar a sus últimas consecuencias este principio. Lo que aquí propongo consiste más bien, en comprender que la hermenéutica en su sentido más radical, que se expresa en la frase de Nietzsche y en la ontología de Heidegger, no es sino el desenvolvimiento y la maduración del mensaje cristiano". VATTIMO, G., Ética de la interpretación, Paidós, Barcelona, 1991, pág. 70 . 


\section{BIBLIOGRAFÍA}




\section{OBRAS DE CHARLES TAYLOR: FUENTES PRIMARIAS}

- Animal de Lenguaje (Elena Álvarez, Trad.), Rialp, Madrid, 2017, 450 págs. (The Language Animal, Harvard University Press, Cambridge, 2016).

- Argumentos filosóficos (Fina Birulés Bertrán, Trad.), Paidós, Barcelona, 1997, 382 págs. (Philosophical Arguments, Harvard University Press, Cambridge, 1995).

- Diálogos (en colaboración con BERNSTEIN, R., GAMPER, D.), Gedisa, Barcelona, 2017, 110 págs.

- Dilemmas and Connections, Harvard University Press, Cambridge, 2011, 414 págs.

- El multiculturalismo y la política del reconocimiento (Mónica Utrilla de Neira, Liliana Andrade Llanas y Gerard Vilar Roca, Trad.), Fondo de Cultura Económica, México, 1993, 157 págs. (Multiculturalism and the Politics of recognition, Princeton University Press, Princeton, 1992).

- El poder de la religión en la esfera pública (en colaboración con HABERMAS, J.; BUTLER, J. y WEST, C.), (José María Carabante y Rafael Serrano, Trad.), Trotta, Madrid, 2011, 145 págs. (The power of Religion in the public sphere, Columbia University Press, New York, 2011).

- Encanto y desencantamiento (José Pérez Escobar, Trad.), Sal Terrae, Santander, 2015, 101 págs. (Incanto e disincanto, Centro Editoriale Dehoniano, Bologna, 2013).

- Fuentes del yo (Ana Lizón, Trad.), Paidós, Barcelona, 2006, 794 págs. (Sources of the self. The making of the modern identity, Harvard University Press, Cambridge, 1989).

- "Two theories of Modernity", Hastings Center Report, Vol. 25, No 2, (1995), págs. 24-33.

- Hegel (Francisco Castro Merrifield, Carlos Mendiola Mejía y Pablo Lazo Briones, Trad.), Anthropos, 2010, Barcelona, 465 págs. (Hegel, Cambridge University Press, Cambridge, 1975). 
- Hegel y la sociedad moderna, Fondo de Cultura Económica, México, 2014. (Hegel and Modern Society, Cambridge University Press, Cambridge, 1979).

- Human Agency and Language. Philosophical Papers 1, Cambridge University Press, Cambridge, 1985, 294 págs.

- Human Agency and Language. Philosophical Papers 2, Cambridge University Press, Cambridge, 1985.

- Imaginarios Sociales Modernos (Ramón Vilà Vernis, Trad.), Paidós, Barcelona, 2006, 226 págs. (Modern Social Imaginaries, Duke University Press, Durham, 2004).

- La Era Secular I (Ricardo García Pérez, Trad.), Gedisa, Barcelona, 2014, 478 págs. (A Secular Age, Harvard University Press, Cambridge, 2007).

- La Era Secular II (Ricardo García Pérez, Trad.), Gedisa, Barcelona, 2015, 765 págs. (A Secular Age, Harvard University Press, Cambridge, 2007).

- La Ética de la autenticidad (Pablo Carbajosa Pérez, Trad.), Paidós, Barcelona, 1994, 146 págs. (The Malaise of Modernity, House of Anansi Press Limited, Montreal. Reeditado como The Ethicis of Authenticity, Harvard University Press, Cambridge, 1991).

- La libertad de los modernos (Horacio Pons, Trad.), Amorrortu Editores, Madrid, 2005, 305 págs. (La liberté des Modernes, Presses Universitaires de France, París, 1997).

- Laicidad y libertad de conciencia (en colaboración con MACLURE, J.), (María Hernández Díaz, Trad.), Alianza Editorial, Madrid, 2011, 162 págs. (Laicité et liberté de conscience, Les Éditions du Boréal, París, 2010).

- Las variedades de la religión hoy, Paidós, Barcelona, 2003, 126 págs. (Varieties of Religion Today. Harvard University Press, Cambridge, 2002).

- Recuperar el realismo (en colaboración con DREYFUS, H.), (José María Carabante Rialp, Trad.), Madrid, 2016, 271 págs. (Retrieving Realism, Harvard Universtiy Press, Cambridge, 2016). 


\section{OTRAS FUENTES BIBLIOGRÁFICAS}

ABBEY, R., Charles Taylor, Princeton University Press, Princeton, 2001.

- Charles Taylor, CUP, New York, 2004.

ADORNO, T., Consignas, Amorrortu Editores, Buenos Aires, 1973.

AGAZZI, E., "Conocimiento científico y fe cristiana", Persona y Cultura, 9, (2011), págs. 90-140.

- La ciencia y el alma de Occidente, Tecnos, Madrid, 2011.

AGUIRRE-PABÓN, J.O., "Dignidad, derechos humanos y la filosofía práctica de Kant”, Universitas, No 123, (2011), págs. 45-74.

ALBERT RODRIGO, M. y HERNÁNDEZ MARTÍ, G.M., "Los movimientos psicoespirituales en la modernidad globalizada", AIBR, Vol. 9, No 3, (2014), págs. 274-295.

ALCOBERRO, R., "Edmund Burke, la crítica conservadora a los Derechos Humanos y las reflexiones sobre la Revolución Francesa”, págs. 1-6.

ALIGHIERI, D., La Divina Comedia, Centro Cultural Latium, Buenos Aires, 1922.

ALLPORT, G., La personalidad, Herder, Barcelona, 1985.

ÁLVAREZ CÉSPEDES, J.F., "La ciencia y el poder en el pensamiento de Francis Bacon. ¿Una propuesta pública que iguala los entendimientos?”, Versiones, No 9, (2016), págs. 44-61.

ALVIRA, T.; CLAVELL, L. y MELENDO, T., Metafísica, Eunsa, Pamplona, 2001.

ANDERSON, B., Comunidades imaginadas, Fondo de Cultura Económica, México, 1993.

AQUINO, T. de, La Suma contra los Gentiles, Gredos, Madrid, 2018

- Suma Teológica, BAC, Madrid, 2001.

ARANA, J., "Determinismo y libertad en K. Popper", Anuario Filosófico, 34, (2001), págs. 119-138.

- Los sótanos del universo, Biblioteca Nueva, Madrid, 2012. 
ARCE CARRASCO, J.L., "Merleau-Ponty. El hombre como unidad ontológicoproyectiva”, Convivium, 14, (2001), págs. 144-167.

ARENDT, H., La condición humana, Paidós, Barcelona, 2018.

ARISTÓTELES, Acerca del cielo, Gredos, Madrid, 1996.

- Ética Nicomáquea, Gredos, Madrid, 2018.

- Física, Gredos, Madrid, 1995.

- Metafísica, Gredos, Madrid, 1994.

- Meteorológicos, Gredos, Madrid, 1996.

- Política, Gredos, Madrid, 1988.

ARMSTRONG, K., A History of God, Vintage Books, Londres, 1999.

- En defensa de Dios. El sentido de la Religión. Paidós. Barcelona, 2009.

ARNAULD, A., Arte de pensar o lógica admirable. Imprenta Antonio Muñoz, Madrid, 1759.

- Recreaciones del hombre sensible, Tomo II, Imprenta Leonardo Núñez, Madrid, 1831.

ARTIGAS, M., "El término de una búsqueda sin término", Aceprensa, 124, (1994), págs. 1-6.

AUERBACH, E., The Representation of Reality in Western Literature, Princeton University Press, Princeton, 1974.

AULUS GELIUS, Noctes Atticae, Liber IV, IX, 1-2.

AYLLON, J.R. y CONESA, F., El eclipse de Dios. Viejos náufragos y nuevos ateos, Palabra, Madrid, 2012.

BACON, Novum Organum, Editorial Sarpe, Madrid, 1984.

BAILYN, B, The Ideological origins of the American Revolution, Belknap Press, Cambridge, 1967.

BAJTIN, M., La cultura popular en la Edad Media y el Renacimiento, Alianza Editorial, Madrid, 2003. 
BALANDIER, G., El desorden, la teoría del caos y las ciencias sociales. Elogio de la fecundidad del movimiento, Gedisa. Barcelona, 1993.

BARCENAS MONROY, I., "El hombre como pliegue del saber", Ciencia Ergo Sum, Vol. 14, No 1, (2007), págs. 27-37.

BATAILlE, G., Teoría de la Religión, Taurus, Madrid, 1981.

BAUMAN, Z., Modernidad Líquida, Fondo de Cultura Económica, México, 2002.

BEATRIZ SÁNCHEZ, S., "Los festivales de la Revolución Francesa. Símbolos y sentimientos en las fiestas revolucionarias. 1789-1799", Revista Ecuatoriana de Historia, No 27, (2008), págs. 43-56.

BELlAH, R., "Religious evolution", American Sociological Review, Vol. 29, No 3 (1964), págs. 358-374.

- Hábitos del corazón, Alianza Editorial, Madrid, 1999.

BELTRÁN CELY, W., "Secularización, ¿teoría o paradigma?", Revista Colombiana de Sociología, No 31, (2008), págs. 61-70.

BENDLE, M., "Reflexive Spirituality and Metanoia in High Modernity", Australian Religion Studies Review, Vol.16, No 1, págs. 6-23.

BENEDICTO XVI, "Discurso del Santo Padre en la Universidad de Ratisbona" (12-IX2006).

- El Dios de la fe y el de los filósofos, Encuentro, Madrid, 2006.

BENEDICTO RODRÍGUEZ, R., "Charles Taylor. El ser humano y el bien”, Contrastes, Vol. XVII, (2012), págs. 47-64.

BENTANO, F., Aristóteles, Editorial Labor, Barcelona, 1983.

BENTHAM, J., Deontología o Ciencia de la moral, Tomo II, Librería de Galván, México, 1836.

BERGER, P., “Las religiones en la era de la globalización”, Iglesia Viva, 218, (2004), págs. 2-65.

- El dosel sagrado, Amorrortu Editores, Buenos Aires, 1969.

- Los numerosos altares de la Modernidad, Sígueme, Salamanca, 2016. 
- Para una Teoría sociológica de la Religión, Kairós, Barcelona, 1971.

- The Desecularization of the World, Ethics and Public Policy Center and Eerdmans Publishing Co, Washington, 1999.

BERGER-LUCKMANN, Modernidad, Pluralismo y crisis de sentido, Paidós, Barcelona, 2008.

BERGSON, H., Historia de la idea del tiempo. Lección sexta. Paidós, Barcelona, 2018.

BERIAIN, J., "Modernidades múltiples y encuentro de civilizaciones", Revista Mad, No. 6, (2002), págs. 1-41.

BERKELEY, G., Principios del Conocimiento humano, Gredos, Madrid, 2018.

BERLIN, I., El erizo y la zorra, Ed. Península, Washington, 1980.

BERMEJO, D, “Repensar la secularización”, Pensamiento, Vol. 70, No. 263, (2014), págs. 341-368.

- La identidad en sociedades plurales, Anthropos, Barcelona, 2011.

- "Secularismo, Religión y Democracia. El giro democrático en el debate secularismo-religión” Pensamiento, Vol. 72, No 271, (2016), págs. 229-256.

- Posmodernidad: pluralidad y transversalidad, Anthropos, Barcelona, 2016.

BERMEJO, D. y CONILL SANCHO, J., ¿Dios a la vista?, Editorial Dykinson, Madrid, 2013.

BICH, M., "De la Epistemología clásica a la antropología filosófica de Charles Taylor". Persona y Sociedad, Vol. XXX, No 2, (2016), págs. 13-36.

BISHOP, J. D., The moral philosophy of Hutcheson, Tesis Doctoral Inédita. University of Edinburgh, 1979.

BLANCARTE, R., "Religión y sociología. Cuatro décadas alrededor del concepto de secularización”, Revista Estudios Sociológicos, XXX, (2012), págs. 59-81.

BLOOM, A., El cierre de la mente moderna, Plaza\&Janés, Barcelona, 1989.

BLOUIN, S., "Rethinking Conversion: Beyond the Religious and the Secular", EUI Working Paper RSCAS, (2016), No 11, págs. 9-25. 
BLUMENBERG, H., La legitimación de la edad premoderna, Pretextos, Valencia, 2008.

BONNIN AGUILÓ, F., "Roger Bacon y la ciencia experimental", Indagación, No 4, (1999), págs. 27-42.

BOSSUET, J.B., Discurso sobre la Historia Universal, Compañía General de Impresores y Libreros, Madrid, 1842.

BOURDIEU, P., El sentido práctico, Siglo XXI Editores, Buenos Aires, 2007.

- Las estrategias de la reproducción social, Siglo XXI Editores, Buenos Aires, 2011.

BRAGUE, R., La sabiduría del Mundo. Historia de la experiencia humana del universo. Ediciones Encuentro. Madrid, 2008.

BRAUN, R., "La experiencia de conexión existencial como concepto naturalista de espiritualidad”, Persona, No 20, (2017), págs. 83-93.

BROWN, P., El cuerpo y la sociedad. Los cristianos y la renuncia sexual, Muchnik Editores, Barcelona, 1993.

BRUNO, G., Del Infinito: el universo y los mundos, Alianza Editorial, Madrid, 1993.

BÜCHNER, L., Fuerza y Materia, Sempere y Compañía Editores, Valencia, 1909.

BUCKLEY, M., At the origins of modern atheism, New Haven, Yale University Press, 1987.

BUNYAN, J., Cómo orar en el espíritu, Editorial Portavoz, Michigan, 1992.

BURKE, E., Reflexiones sobre la Revolución en Francia, Empresas Oficina Martín Rivera, México, 1826.

- La cultura popular en la Europa Moderna, Alianza Editorial, Madrid, 1996.

BURLANDO, G., "El Espíritu, surco del yo en San Agustín", Mirabilia 25, No 2, (2017), págs. 77-93.

BURT, E. A., Los fundamentos metafísicos de la ciencia moderna, Editorial Sudamericana, Buenos Aires, 1980.

BUTLER, J., Fifteen Sermons preached at the Rolls Chapel, Printed by W. Botham, Londres, 1726. 
BYLICA, P. y SAGAN, D., "God, Design and Naturalism: Implications of methodological naturalism in science for science-religion relation", Pensamiento, Vol. 64, No 242, (2008), págs. 621-638.

CABANCHIK, S., "La noción de sentido en el Tractatus Lógico-Philosophicus de L. Wittgenstein", Revista de Filosofía y Teoría Politica, No 26-27, (1986), págs. 219-223.

CALVINO, J., Institución de la Religión Cristiana, Editorial Felire, Barcelona, 1999.

CAMARENA ADAME, M.E. y TUNAL SANTIAGO, G., "La religión como una dimensión de la cultura", Nómadas 22, No 2, (2009), págs. 1-16.

CAÑÓN LOYES, C., "Naturalización de la espiritualidad”, Pensamiento, Vol. 73, No 276, (2017), págs. 609-629.

CAPRA, F., El punto crucial, Editorial Troquel, Buenos Aires, 1992.

CÁRCAMO LANDERO, S., "Lenguaje de contrastes sutiles. El sentido hermenéutico de las ciencias humanas según Charles Taylor", Alfa, No 41, (2018), págs. 269-281.

CAROZZI, M.J., "La autonomía como religión: La nueva era”, Alteridades, Vol. 9, No 18, (1999), págs. 19-38.

CARRETERO PASÍN, A.E., "El laicismo, ¿una religión metamorfoseada?” Nómadas, No 15, (2007), págs. 239-248.

CASANOVA, J., “A Secular Age: Dawn or Twilight?”, GEM 6125-10, (2009), págs. 265-281.

- Five lectures in the Sociology of Religion, Renmin University, Beijing, 2010.

- Genealogías de la Secularización, Anthropos, Siglo XXI Editores, Barcelona, 2012.

- Religiones públicas en el mundo moderno, PPC, Madrid, 2000.

- "La inmigración y el nuevo pluralismo religioso", Revista CIDOB, No 77, (2007), págs. 13-39.

CASSIRER, E., "Kant y el problema de la metafísica", Humanitas, Año III, No 8, (1957), págs. 105-129.

- Filosofía de la Ilustración, Fondo de Cultura Económica, México, 1972. 
CASTELlANOS, R., "Magia, religión y ciencia”, Cap. VI., pág. 181. Disponible en www. juridicas.unam.mx. (2-V-2019).

CASTILlO, J.M., La humanidad de Dios, Trotta, Madrid, 2019, pág. 116.

CASTRO HERNÁNDEZ, O., Entre-lugares de la Modernidad, Siglo XXI Editores, Madrid, 2017.

CELY Q., M., "La ética económica de los puritanos”, RS 21, Vol.14, No 1 (2012), págs. 1-44.

CERRILLO MARTÍN DE CÁCERES, E., “Arqueología de las Religiones primitivas y arqueología de las religiones organizadas. Una reflexión”, Zephirus, Vol. 43, (1990), págs. 189-192.

CERRILLO, E.; ONGIL, M. I. y SAUCEDA, M. I., "Espacio y religión, aproximación a una arqueología de la religión”, Arqueología espacial, I, (1985), págs. 41-54.

CHAMPION, J., Republican Learning. J. Toland and the crisis of Christian culture 1696-1722, Manchester University Press, 2003.

CHESTERTON, G.K., El hombre eterno, Cristiandad, Madrid, 2004.

CHOZA, J., Historia de los sentimientos, Editorial Thémata, Sevilla, 2011.

CICERÓN, Del Supremo bien y del supremo mal, Gredos, Madrid, 2015.

CINCUNEGUI, J.M., "El yo en el espacio moral”, Eikasia, No 58, (2014), págs. 267-294.

- Charles Taylor y la identidad Moderna. Tesis Doctoral inédita. Universitat Ramon Llull. Facultad de Filosofía.

- "Los límites de la transparencia. Taylor sobre Hegel en contexto". Nuevo Pensamiento, Vol. III, (2013), págs. 264-292.

CLARKE, J., Foundation of Morality, Printed by Thomas Gent, York, 1730.

CLIFFORD, K. y JAMES, W., La voluntad de creer. Un debate sobre la ética de la creencia, Tecnos, Madrid, 2003.

CLIFFORD, W.K., The Ethics of Belief and other Essays, Watts Ed., Londres, 1947.

COHEN, B., La revolución newtoniana y la transformación de las ideas científicas. Alianza Universidad, Madrid, 1983. 
COLINA, C., "El enigma del vacío", Konvergencias, No 27, (2018), págs. 99-105.

COMTE, A., Curso de Filosofía positiva. Ediciones Orbis, Barcelona, 1985.

- Discurso sobre el Espíritu Positivo, Biblioteca Nueva, Madrid, 1999.

COMTE-SPONVILLE, A., El alma del ateísmo, Paidós, Barcelona, 2006.

CONDORCET, Bosquejo de un cuadro histórico de los progresos del espíritu humano, Editora Nacional, Madrid, 1980.

COPÉRNICO, N., Sobre las revoluciones, Editora Nacional, Madrid, 1982.

CORDERO DEL CASTILLO, P., "La Religión y su lugar en la sociología”, Barataria, No 4, (2001),

CORNEJO VALLE, M. y BLÁZQUEZ RODRÍGUEZ, M., "La convergencia de salud y espiritualidad en la sociedad postsecular" Revista de Antropología Experimental, 13, (2013), págs. 11-30.

CORNEJO VALLE, M., "Las definiciones de lo religioso en la antropología social. Conceptos y discusiones clave en la búsqueda de un universal cultural", Bandue, No 9, (2016), págs. 67-88.

CORONA FERNÁNDEZ, J., La irrupción de la subjetividad moderna, Pliego Filosofía, México, 2007.

COX, H., La ciudad secular, Ediciones Península, Barcelona, 1968.

CRUZ ESQUIVEL, J., “¿Declinación, retorno o reconfiguración de lo religioso? Balances de la sociología de la religión en los últimos 25 años”, Espacio Abierto, Vol. 25, No 3, (2016), págs. 65-78.

CUSA, N., "La búsqueda de Dios", Cuadernos de Anuario Filosófico, No 235, (2011), págs. 201-250.

- La caza de la sabiduría, Sígueme, Salamanca, 2014.

- La docta ignorancia, Ediciones Orbis, Barcelona, 1981.

DARWIN, Ch., El origen de las especies, Austral, Madrid, 2017.

- El origen del hombre, Sempere Editores, Valencia, 1909.

DAVIDSON, D., Sobre la Verdad y la Interpretación, Gedisa, Barcelona, 2019. 
DAVIE, G., "Believing without Belonging. A Liverpool Case Study/Croyance sans appartenance. Le cas de Liverpool", Archives des Sciences Sociales des Religions, No 81, (1993), págs. 79-89.

DAVIES, D. y TATE, M., "Religion and the individual: belief, practice and identity", MDPI, (2017), págs. 1-182.

DAWKINS, R., El espejismo de Dios, Espasa Calpe, Madrid, 2007.

- El relojero ciego, Tusquets Editores, Barcelona, 2015.

DE CHARDIN, T., El fenómeno humano, Taurus, Madrid, 1967.

DE LA CUEVA MERINO, J., "Conflictiva secularización: Sobre Sociología, Religión e Historia”, Historia Contemporánea, No 51, (2015), págs. 365-395.

DE LA TORRE, R., "La espiritualización de la religiosidad contemporánea", Ciencias Sociales y Religión, Vol. 18, No 24, (2016), págs. 10-17.

- “La religiosidad popular como 'entre-medio' entre la religión institucional y la espiritualidad individualizada", Civitas, Vol. 12, No 3, (2012), págs. 506-521.

DEBUS, A., El hombre y la naturaleza en el Renacimiento, Fondo de Cultura Económica, México, 1985.

DEL GIUDICE, G., Giordano Bruno: El Profeta del Universo Infinito. Electronic Edition, 2014.

DELGADO, M., "La religiosidad popular. En torno a un falso problema", Gazeta de Antropología, No 10, (1993), págs. 1-16.

DELIO, I., Cristo en evolución, Sal Terrae, Santander, 2014.

DELlA MIRANDOLA, P., Discurso sobre la Dignidad del Hombre, Edición Álvaro Lobo, Medellín, 2006.

DELUMEAU, J., El miedo en Occidente, Taurus, Madrid, 1978.

DERRIDA, J., Fuerza de Ley. El fundamento místico de la autoridad. Tecnos, Madrid, 1997.

DESCARTES, R., Correspondencia con Isabel de Bohemia, Gredos, Madrid, 2011.

- Discurso del Método, Gredos, Madrid, 2018. 
- Investigación de la verdad por la luz natural, Gredos, Madrid, 2018.

- Las pasiones del alma, Gredos, Madrid, 2018.

- Meditaciones Metafísicas, Gredos, Madrid, 2018.

- Reglas para la dirección del espíritu, Gredos, Madrid, 2018.

DÍAZ SALAZAR, R., "Modernización, religiones y laicidad en el sistema-mundo", Sistema, No 239, (2015), págs. 65-82.

DÍAZ, C., Este hombre, este mundo, Ediciones Palabra, Madrid, 2005.

- Manual de Historia de las Religiones, Desclee de Brouwer, Bilbao, 2004.

DIDEROT, D., Pensamientos filosóficos. El combate por la libertad, Proteus, Barcelona, 2009.

- Sobre la Interpretación de la naturaleza, Anthropos, Barcelona, 1992.

DILTHEY, W., Hombre y mundo en los siglos XVI y SVII, Fondo de Cultura Económica, México, 2013.

DITTRICH, L., “Anticlericalismo y vías de secularización en la Europa del siglo XIX: La excepcionalidad española”, Hispona, (2014), págs. 1-6.

DOMÍNGUEZ HERRERO, C., El nacimiento de la Yoidad, Gráficas Lope, Salamanca, 2011.

DOMÍNGUEZ PRIETO, X.M., "Posmodernidad, personalismo y persona", págs. 163166 en Mayo del 68, una época de cambios un cambio de época, Actas Congreso Internacional Universidad Francisco de Vitoria, Editorial UFV, Madrid, 2019.

DREYFUS, H, Being in the world, MIT Press, Massachusetts, 1990.

DUCH, L1., Un extraño en nuestra casa, Herder, Barcelona, 2007.

DUMMERY, H., Critique et religion: Problèmes de méthode en philosophie de la religion. París, SEDES, 1957.

- Phénoménologie et religión, PUF, París, 1962.

- Philosophie de la religion: Essai sur la signification du christianisme, PUF, París, 1957. 
DUMONT, L., Ensayos sobre el Individualismo. Una perspectiva antropológica sobre la ideología moderna, Alianza Editorial, Madrid, 1983.

DUPRÉ, L., Passage to Modernity, Yale University Press, New Haven, 1993.

- Religion and Modern Culture, University of Notre Dame Press, Indiana, 2008.

DUQUE, F., Historia de la Filosofía Moderna. La era de la crítica, Akal, Madrid, 1998.

DURKHEIM, E., Las formas elementales de la Vida Religiosa. Akal Editor, Madrid, 1982.

EISENSTADT, S., "La era axial: la emergencia de las visiones trascendentales y el ascenso de los clérigos", Sociología Histórica, Vol. 7, (2017), págs. 385-406.

- "Las primeras múltiples modernidades: identidades colectivas, esferas públicas y orden político en las Américas”, Nueva Época, Vol. 58, No 218, (2013), págs. 52-55.

- "Multiple modernities”, Daedalus, Vol. 129, No 1, (2000), págs. 1-29.

ELIADE, M., Lo sagrado y lo profano, Paidós, Barcelona, 2014.

ELIAS, N., El proceso de la civilización, Fondo de Cultura Económica, Madrid, 2010.

EMERSON, W.E., "The American Scholar", Selected Essays, Viking Penguin, Nueva York, 1982.

EPICURO, Obras Completas, Cátedra, Madrid, 2012.

ERIKSON, E., El ciclo vital completado, Paidós, Barcelona, 2000.

FABRO, C., Feuerbach. La esencia del Cristianismo, Magisterio Español, Toledo, 1977.

FANON, F., Los condenados de la tierra, Fondo de Cultura Económica, México, 1983.

FAZIO, M., Historia de las ideas contemporáneas. Una lectura del proceso de secularización, Rialp, Madrid, 2017.

FEBVRE, L., El problema de la incredulidad en el siglo XVI: La religión de Rabelais, Akal, Madrid, 1993. 
FERNÁNDEZ, C.J., Causalidad, Conocimiento y Omnipotencia divina en el pensamiento de G. de Ockham, Tesis Doctoral Inscrita, Universidad de Buenos Aires, 2005.

FERRANDO LÓPEZ, A., El elemento religioso en J.J. Rousseau. Deísmo y religión civil, UOC, Barcelona, 2016.

FERRER ARELlANO, J., Filosofía y fenomenología de la religión. Cristianismo y religiones, Ediciones Palabra, Madrid, 2013.

FEUERBACH, L., La esencia de Cristianismo. Disponible en www. Ataun.net, (8-VI2018), pág. 26.

FICHTE, J., Lecciones de Filosofía Práctica, Sígueme, Salamanca, 2017.

FICINO, M., De Amore, Tecnos, Madrid, 2001.

FIERRO VALBUENA, A., "Epistemología moderna y ciencias sociales. Un análisis crítico de Charles Taylor", Pensamiento y Cultura. Vol. 11, No 2, (2008), págs. 281-301.

FIGES, O., A People's tragedy. A History of the Russian Revolution, CUP, Cambridge, 1996.

FOLGER, R., “Hacia la subjetividad moderna”, Ibero, (2016), págs. 161-177.

FONT, J., "Naturalización de la Espiritualidad", Pensamiento, Vol. 73, No 276, (2017), págs. 631-647.

FORERO REYES, Y.M., Epifanías de la identidad. La comprensión multiculturalista de Charles Taylor, Anábasis, Bogotá, 2008.

FOUCAUlT, M., Historia de la Locura en la época clásica, Fondo de Cultura Económica, Colombia, 1998.

- Las palabras y las cosas, Siglo XXI Editores, Buenos Aires, 1968.

- Microfísica del poder. Nietzsche, la genealogía, la historia, Ediciones La Piqueta, Madrid, 1992.

- Vigilar y Castigar: el nacimiento de la prisión, Siglo XXI Editores, Buenos Aires, 1976.

FRANCISCO, Fratelli Tutti, BAC, Madrid, 2020. 
FRANKL, V., El hombre doliente, Herder, Barcelona, 2000.

- El hombre en búsqueda de sentido, Herder, Barcelona, 1979.

FRAZER, J., La rama dorada. Magia y religión, Fondo de Cultura Económica, México, 1981.

FREUD, S., El malestar en la cultura, Biblioteca Libre Omegalfa, 2010.

- El porvenir de una ilusión, Alianza Editorial, Madrid, 2015.

- Esquema del Psicoanálisis, Alianza Editorial, Madrid, 2016.

- Psicología de Masas, Alianza Editorial, Madrid, 2015.

FRIGERIO, A., "La ¿nueva? Espiritualidad: ontología, epistemología y sociología de un concepto controvertido", Ciencias Sociales y Religión, No 24, (2016), págs. 209-231.

FROMM, E., El miedo a la libertad, Paidós, Barcelona, 2018.

GADAMER, Verdad y Método. Fundamentos de una hermenéutica filosófica. Sígueme, Salamanca, 1993.

GALFIONE, M.V., "Historia natural y temporalización: consideraciones sobre la Historia Natural de Buffon”, História, Ciencias, Saúde-Manguinhos, Vol. 20, No 3, (2013), págs. 813-829.

GALLEGO, F., "La religiosidad en los primeros años de la Infancia. Perspectivas Teóricas”, Consonancias, 9, No 34, (2010), págs. 1-19.

GAMPER, D., La fe en la ciudad secular, Trotta, Madrid, 2014.

GARCÍA ÁlVAREZ, P. y SESENTO GARCÍA, L., "David Hume, de la razón y pasiones en los animales", Revista Caribeña de las Ciencias Sociales, (2012), págs. 1-8.

GARCÍA DE LA SIENRA, A., "Una filosofía nominalista", Stoa, Vol. 1, No 1, (2009), págs. 77-97.

GARCÍA GARCÍA, D., "Ronald Dworkin. En defensa de la comunidad liberal", Eunomia, No 6, (2014), págs. 369-376.

GARCÍA GONZÁLEZ, J.A., "La naturaleza según Nicolás de Cusa”, Espíritu, LVI, (2007), págs. 5-13. 
GARCÍA MARQUÉS, A., "La desactivación de la ontología en Quine", Thémata, Vol. 17, (2006), págs. 237-249.

GARCÍA MORENTE, M., La filosofía de Kant, Ediciones Cristiandad, Madrid, 2018.

GARCÍA PICAZO, P., "Perspectivas sobre el hecho religioso en el sistema mundial contemporáneo", Estudios, Vol. LXII/2, (2010), págs. 111-148.

GARCÍA, E., "Posmodernidad y Religión. Nueva Era". Teoría y Praxis, No 12, (2008), págs. 1-17.

GARCÍA, J.L., "Declinaciones de la Religión en la Modernidad", Revista Internacional de Sociología, Vol. 65, No 47, (2007), págs. 203-211.

GARIN, E., La revolución cultural del Renacimiento, Editorial Crítica, Barcelona, 1984.

GARMA NAVARRO, C., "Bryan Ronald Wilson: 1926-2004”, Desacatos, No 18, (2005), págs. 165-168.

GARZÓN VALLEJO, I., "Postsecularidad: ¿un nuevo paradigma de las ciencias sociales?, Revista de Estudios Sociales, No 50, (2014), págs. 101-112.

GAUCHET, M., El desencantamiento del mundo. Una historia política de la religión. Trotta. Madrid, 2005.

- El inconsciente cerebral, Ediciones Nueva visión, Buenos Aires, 1994.

GAY, P., The Enlightenment: An Introduction. The Raise of Modern Paganism, Weidenfeld-Nicolson Edition, Londres, 1967.

GIL GIMENO, J., "Religiones universales y creatividad”, Imagonautas, No 10, (2017), págs. 65-86.

- "Secularizaciones múltiples", Sociología Histórica, No 7, (2017), págs. 291-319.

- "Secularizaciones y manifestaciones religiosas. Las teorías de la secularización a través del Religion Monitor de la Fundación Bertelsmann", RIPS, 15, No 1, (2016), págs. 9-28.

GIUSANI, L., El sentido de Dios y el hombre moderno, Encuentro, Madrid, 2005.

GONZÁLEZ GARCÍA, M., Filosofía y Cultura, Madrid, Siglo XXI Editores, 1992. 
GONZÁLEZ SEARA, L., La metamorfosis de la ideología, Centro de Estudios Ramón Areces, Madrid, 2011.

GONZÁLEZ, A.L., "Intuición y escepticismo en Ockham”, Anuario Filosófico, Vol. 10, No 1, (1977), págs. 105-129.

- "La doctrina de Nicolás de Cusa sobre la mente", Studia Philologica Valentina, Vol. 10, No 7, (2007), págs. 1-24.

GONZÁLEZ, R. y TAVIRA, G., "Fenomenología del entrecruce del cuerpo y el mundo en Merleau-Ponty", Ideas y Valores, No 145, (2011), págs. 113-130.

GRACIA CALANDÍN, J., "Legado filosófico en Charles Taylor", Asimov, No 46, (2009), págs. 171-187.

- "Modernidad hermenéutica en Charles Taylor", Quaderns de Filosofia i Ciencia, No. 40, (2010), págs. 105-114.

GRANADA, M.A., Cosmología, Religión y política en el Renacimiento. Anthropos, Barcelona, 1988.

GROCIO, H., Del Derecho de la Guerra y de la Paz, Editorial Reus, Madrid, 1925.

GRUBE, G.M.A., El pensamiento de Platón, Gredos, Madrid, 1987.

GRÜN-BOFF, L., Lo divino en el ser humano y el universo. Camino hacia la unificación, Trotta, Madrid, 2019.

GUSDORF, G., Dieu, la nature, l’homme au Siècle des Lumières, Payot, París, 1972.

- Les príncipes de la pensé au Siêcle des Lumieres, Payot, París, 1971.

- Naissance de la conscience romantique au Siècle des Lumieres, Payot, París, 1976.

GUTIÉRREZ LOMBARDO, R. y SANMARTÍN, J., "La Filosofía desde la ciencia", Daimon, No 76, (2014), págs. 227-231.

GUZMÁN ROBLEDO, G.N., La inversión de la inmanencia. Georges Bataille y la negatividad hegeliana, Taberna Libraria Editores, México, 2017.

HABERMAS, J. y RATZINGER, J., Entre razón y religión. Dialéctica de la secularización, FCE, México, 2008. 
HABERMAS, J., Carta al Papa. Consideraciones sobre la fe. Paidós, Barcelona, 2009.

- El discurso filosófico de la modernidad, Taurus, Madrid, 1993.

- El futuro de la naturaleza humana, ¿hacia una eugenesia liberal?, Paidós, Barcelona, 2001.

- Entre naturalismo y religión, Paidós, Barcelona, 2006.

- Fragmentos filosófico-teológicos. De la impresión sensible a la expresión simbólica, Madrid, Trotta, 1999.

- Historia y crítica de la opinión pública, Editorial Gustavo Gili, Barcelona, 1982.

- Mundo de la vida, política y religión, Trotta, Madrid, 2015.

- Teoría de la Acción comunicativa, Trotta, Madrid, 2010.

HARRIS, S., El fin de la fe, Paradigma, Barcelona, 2007.

HAWKING, S., La teoría del Todo, Penguin Random House, Barcelona, 2019.

HAZARD, P., El pensamiento europeo del siglo XVIII, Alianza Editorial, Madrid, 1991.

HEBERT MEAD, G., Mind, Self and Society, The University of Chicago Press, Chicago, 1937.

HEGEL, G.W., El concepto de religión, Fondo Cultura Económica, Madrid, 1998.

- Fenomenología del Espíritu, Gredos, Madrid, 2014.

- Filosofía de la Religión. Últimas Lecciones, Trotta, Madrid, 2018.

- Filosofía del Derecho, Editorial Claridad, Buenos Aires, 1968.

- $\quad$ La Lógica, Vol I-II, CPSIA, Lavergne, 2020.

- Lecciones de Filosofía de la Historia, Gredos, Madrid, 2019.

- Lecciones sobre la Filosofía de la Historia Universal, Alianza Editorial, Madrid, 1999.

HEIDEGGER, M., Caminos de Bosque, Alianza Editorial, Madrid, 2010.

- Carta sobre el Humanismo, Alianza Editorial, Madrid, 2006. 
- La época de la imagen del mundo, Anales de la Universidad de Chile, 1958.

- La vuelta, Editorial Universitaria, Santiago de Chile, 1993.

- Nietzsche, Ariel, Madrid, 2014.

- Ser y Tiempo, Trotta, Madrid, 2003.

- Los conceptos fundamentales de la Metafísica, Alianza Editorial, Madrid, 2017.

HEIDEGREN, C.G., “An interview with Hans Joas”, Sociologisk Forskning, 54, No 3, (2017), págs. 233-243.

HELLER, A., El hombre del Renacimiento, Ediciones Península, Barcelona, 1980.

HELVECIO, C.A., Del Espíritu, Editora Nacional, Madrid, 1984.

HERDER, J.G., Ensayo sobre el origen del lenguaje, Gredos, Madrid, 2019.

- Filosofía de la Historia para la Educación de la Humanidad, Gredos, Madrid, 2019.

HERVIEU-LÉGER, D., El peregrino y el convertido, Ediciones del Helénico, México, 2004.

- La religión, hilo de memoria, Herder, Barcelona, 2005.

HIGUERO, F.J., "La contextualización moral del sujeto en el pensamiento de Charles Taylor", Convivium, No 19, (2006), págs. 101-116.

HILAIRE, I.M., "Entrevista", Anuario de Historia de la Iglesia, No 7, (1998), págs. 303-321.

HIPONA, A. de, Cartas, BAC 8-11a-11b, Madrid.

- Confesiones, Gredos, Madrid, 2018.

- La ciudad de Dios, BAC 16-17, Madrid.

- La corrección y la gracia, BAC 6, Madrid.

- La Trinidad, BAC 5, Madrid.

- El combate cristiano, BAC 12, Madrid.

HOBBES, T., Leviatán, Gredos, Madrid, 2018. 
HOLBACH, P.H., Sistema de la Naturaleza, Editora Nacional, Madrid, 1982.

HOMERO, Obras Completas de Homero. La Ilíada, Montaner y Simón Editores, Barcelona, 1927.

HORKHEIMER, M. y ADORNO, T., Dialéctica de la Ilustración,. Trotta, Madrid, 1998.

HUME, D., Investigación sobre el conocimiento humano, Altaya, Barcelona, 1994.

- Tratado de la Naturaleza humana, Gredos, Madrid, 2019.

HUSSERL, E., La crisis de las ciencias europeas y la fenomenología trascendental, Prometeo Libros, 2008.

HUTCHESON, F., An Essay on the Nature and Conduct of the Passions, Liberty Fund, Indianapolis, 2002.

- Una investigación sobre el origen de nuestra idea de belleza, Tecnos, Madrid, 1992.

HYPOLITTE, J., Génesis y Estructura de la Fenomenología del Espíritu, Península, Barcelona, 1973.

ISAR HERNÁNDEZ, M.C., "Evolución de la relación hombre-Dios desde Platón hasta el siglo II d. C” Anuario de Estudios Filosóficos, Vol. 16, (1993), págs. 207-214.

ISLER SOTO, C., "El Nominalismo, ¿está asociado necesariamente a una concepción voluntarista de la ley natural? El caso de Ockham y Hobbes", Praxis Filosófica Nueva serie, No 38, (2014), págs. 175-200.

JAMES, W., Las variedades de la experiencia religiosa, Ediciones Península, Barcelona, 1994.

JASPERS, K., Origen y meta de la historia, Alianza Editorial, Madrid, 1980.

JORDANA, R., "El origen del hombre: estado actual de la investigación paleoantropológica", Scripta Theologica, No 20, (1988), págs. 65-99.

JOSA I LLORCA, J., Introducción. El origen de las especies, Austral, Madrid, 2017.

JUAN PABLO II, "Mensaje del Santo Padre a los miembros de la Academia Pontificia de las Ciencias" (22-X-1996).

JUNG, C.G., Arquetipos e inconsciente colectivo, Paidós, Barcelona, 1970. 
JUSTO, E.J., Después de la modernidad, Sal Terrae, Cantabria, 2020.

KANT, I., Contestación a la pregunta ¿Qué es la Ilustración?, Gredos, Madrid, 2018.

- Crítica de la Razón Práctica, Madrid, Gredos, 2019.

- Crítica de la Razón Pura, Gredos, Madrid, 2018.

- Crítica del Juicio, Gredos, Madrid, 2018.

- El conflicto de las facultades en tres partes, Gredos, Madrid, 2018.

- Fundamentación de la metafísica de las costumbres, Gredos, Madrid, 2018

- La paz Perpetua. Ediciones Alamanda, Madrid, 2018.

- La religión dentro de los límites de la razón, Alianza Editorial, Madrid, 1981.

- Principios metafísicos de la ciencia de la naturaleza, Alianza Editorial, Madrid, 1989.

KANTOROWICZ, E., Los dos cuerpos del Rey. Un estudio de Teología política medieval. Akal, Madrid, 2012.

KEPEL, G., La revancha de Dios. Cristianos, judíos y musulmanes a la reconquista del mundo, Anaya y Mario Muchnik, Madrid, 1991.

KOLAKOWSKI, L., Si Dios no existe, Tecnos, Madrid, 2002.

KOYRÉ, A., Del mundo cerrado al universo infinito, Siglo XXI Editores, Madrid, 1999.

KRISTELLER, P.O., El pensamiento renacentista y sus fuentes, Fondo de Cultura Económica, México, 1982.

KUHN, T.S., La estructura de las revoluciones científicas, Fondo de Cultura Económica, Mexico, 1971.

LA TORRE, M., "Mirando desde ningún lugar. Una breve introducción a la Filosofía de Thomas Nagel”, Doxa, 10, (1991), págs. 141-171.

LACTANCIO, L.C., Instituciones Divinas, Gredos, Madrid, 1990.

LAMBERT, Y., "Religion in Modernity as a New Axial Age: Secularization or New Religious Forms?” Sociology of Religion, Vol. 60, No 3, (1999), págs. 303-333. 
LARRE, O., Guillermo de Ockham, Disponible en:

https://www.philosophica.info/voces/ockham/Ockham.html (17-I 2018).

- "La justificación de la libertad del hombre frente a la omnipotencia divina en la ética de Guillermo de Ockham", Revista Española de Filosofía Medieval, No 11, (2004), págs. 149-166.

LAZCANO, R., "El amor a la verdad según Agustín de Hipona", Revista Española de Filosofía Medieval, No 17, (2010), págs. 11-20.

LE BOURLEGAT, C.A. y DE CASTILHO, M.A., "Lo sagrado en el contexto de la territorialidad", Polis, No 8, (2004), págs. 1-8.

LEIBNIZ, G., Discurso de Metafísica, Gredos, Madrid, 2018.

- Nuevos Ensayos sobre el entendimiento humano, Editorial Nacional, Madrid, 1983.

LESSING, G.E., La educación del género humano, Encuentro, Barcelona, 2008.

LEVI STRAUSS, C., El pensamiento del hombre salvaje, Fondo de Cultura Económica, México, 1964.

LEVINAS, M.L. y SZAPIRO, A., "El carácter histórico de la concepción cusana de verdad", Revista Latinoamericana de Filosofía, Vol. 37, No 1, (2011), págs. 67-95.

LIENDHART, G., Divinidad y experiencia. La religión de los dinkas. Madrid, Akal, 1985.

LILLA, M., El Dios que no nació, Debate, Barcelona, 2010.

LIPSIO, J., La política, Los seis libros de las Políticas o Doctrina civil de Justo Lipsio, Imprenta Real, Madrid, 1604.

- Sobre la constancia, Matías Clavijo, Sevilla, 1616.

LIRA LATUZ, C., "En torno al concepto de religiosidad popular", Aisthesis, No 60, (2016), págs. 297-302.

LLEDO, E., La memoria del Logos, Debolsillo, Barcelona, 2018.

LLINAS BEGÓN, J.L., "Sobre el concepto de Filosofía y Experiencia en Montaigne, y su repercusión sobre el concepto de Filosofía y experiencia en Montaigne", Cuadernos Salmantinos de Filosofía, No. 40, (2013), págs. 71-84. 
LOCKE, J., Ensayo sobre el entendimiento humano, Gredos, Madrid, 2015.

- Escritos sobre la tolerancia, Gredos, Madrid, 2015.

- La racionalidad del Cristianismo, Paulinas, Madrid, 1977.

- Segundo Tratado sobre el Gobierno, Gredos, Madrid, 2015.

LÓPEZ BOLÍVAR, M.C., "Feuerbach, el giro antropológico de la teología”, Perseitas, No 6, (2018), págs. 319-350.

LÓPEZ CASTELLANO, F., "La literatura de la pobreza: Malthus y la falacia de la beneficencia”, Disponible en pdf de aehe.es, (5-X-2020), pág. 3.

LÓPEZ QUINTAS, A., Estética de la Creatividad, Rialp, Madrid, 1998.

LOVEJOY, A., La Gran Cadena del Ser, Icaria Editorial, Barcelona, 1983.

LÖWITH, K., El hombre en el centro de la historia, Aguilar, Madrid, 1958.

LOYOLA, I., Ejercicios Espirituales, Principio y Fundamento, No 23.

LOZANO, V., “Heidegger y la cuestión del ser”, Espíritu, LIII, (2004). págs. 197-212.

LUCKMANN, T., La religión invisible, Sígueme, Salamanca, 1973.

LUHMANN, N., La religión de la sociedad, Trotta, Madrid, 2018.

LYOTARD, J.F., La condición posmoderna, Cátedra, Madrid, 1987.

LYPOVETSKY, G., La era del vacío. Ensayos sobre el individualismo contemporáneo, Anagrama, Barcelona, 2000.

MACINTYRE, A., Ética en los conflictos de la Modernidad. Rialp, Madrid, 2017.

MACKENN, R., La Europa del siglo XVI. Ediciones Akal, 1996, Madrid.

MAESTRO ECKHART, Tratados y sermones: obras alemanas, Edhasa, Barcelona, 1983.

MANCHETA, J., "Introducción”, en Nicolás de Cusa. Un ignorante discurre acerca de la mente, Biblos, Buenos Aires, 2005.

MARCOS, A., "Naturaleza humana y derechos animales", en Hombres y animales: ¿Qué hemos aprendido de Darwin? Curso de verano de la Universidad de Málaga, (2010), pág. 6. 
MARITAIN, J., Tres Reformadores, Epesa, Madrid, 1948.

MARRAMO, G., Cielo y tierra. Genealogía de la secularización, Paidós, Barcelona, 1998.

MARTÍN HUETE, F., La persistencia de la secularización en la era de la desecularización, Tesis Doctoral Inscrita, Universidad de Navarra, Pamplona, 2015.

MARTIN, D., On Secularization. Towards a Revised General Theory, Ashgate, Cornwall, 2005.

MARTÍNEZ, M.L., “Genealogía de la Secularización. Revisión Historiográfica del desencantamiento del mundo", Fides et Ratio, No 3, (2018), págs. 125-152.

MARX, K. y ENGELS, F., Obras Escogidas. Del Socialismo Utópico al Socialismo Científico, Ediciones en Lenguas Extranjeras, Moscú, 1962.

MARX, K., Escritos malditos. Sobre la cuestión judía y otros textos, Libros de Anarres, Buenos Aires, 2013

MATHIEZ, A., Los orígenes de los cultos revolucionarios 1789-1792, CIS, Madrid, 2012.

MAYR, E., “¿Puede la evolución explicar la ética?”, Ars Medica, Vol. 7, No 2, (2008), págs. 222-240.

MEDINA, C., "La fenomenología del lenguaje y el concepto de la razón práctica en el pensamiento de Charles Taylor", Cinta Moebio, No 50, (2014), págs. 53-69.

MEINECKE, F., La idea de la razón de Estado en la Edad Moderna, I.E.P. Madrid, 1959.

MERINO, J.A., Historia de la Filosofía Medieval, BAC, Madrid, 2011.

MERLEAU-PONTY, M., Fenomenología de la Percepción, Planeta Agostini, Barcelona, 1994.

MICHELINI, D.J., “Creyentes y no creyentes, en una sociedad democrática. La religión en el pensamiento actual de J. Habermas", Invenio, No 35, (2015), págs. 11-27.

MIKUNDA FRANCO, E., "J. Lipsio: Neoestoicismo, iusnaturalismo y derechos humanos", Anuario de Filosofía del Derecho, VII, (1990), págs. 356-357.

MILL, J.S., Sobre la libertad, Alianza Editorial, Madrid, 1981. 
MOLINA URETA, J., "Filosofía del inconsciente", Liberabit, No 13, (2007), págs. 57-62.

MONTAIGNE, M., Ensayos, Madrid, Cátedra, 1987.

MONTES DE OCA NAVAS, E., "Leonardo da Vinci, un gran artista del Renacimiento", La Colmena, No 67/68, (2010), págs. 19-29.

MONTESQUIEU, El espíritu de las leyes, Librería Valeriano Suárez, Madrid, 1906.

MORRIS, B., Introducción al estudio antropológico de la Religión, Paidós, Barcelona, 2009.

MOYA, A., "Las peligrosas ideas de Darwin", Teorema, Vol. 28, No 2, (2009), págs. 5-13.

- Pensar desde la ciencia, Trotta, Madrid, 2010.

MÚGICA MARTINENA, F., Emile Durkheim. El principio sagrado, Cuadernos de Anuario Filosófico, No 18, Publicaciones Universidad de Navarra, 2006.

MURDOCH, I., "Contra la aridez. Esbozo polémico", Daimon, No 60, (2013), págs. $13-18$.

NEWTON, I., Diálogo sobre los dos máximos sistemas del mundo ptolemaico y copernicano, Alianza Editorial, Madrid, 2011.

- Principios Matemáticos de la filosofía natural, Editora Nacional, Madrid, 1982.

NICOLE, P., Ensayos de Moral, Imprenta Real, Madrid, 1800.

NIETZSCHE, F., Así habló Zaratustra, Gredos, Madrid, 2018.

- El Anticristo, 38, Gredos, Madrid, 2009.

- El caminante y su sombra, Gredos, Madrid, 2018.

- El crepúsculo de los ídolos, Gredos, Madrid, 2018.

- La genealogía de la moral, Gredos, Madrid, 2018.

- Más allá del bien y del mal, Gredos, Madrid, 2018.

- Sobre verdad y mentira en sentido extramoral, Gredos, Madrid, 2018.

NOVALIS, Himnos a la noche, No 1, Fontamara, México D.F., 2008. 
NOVOA RIVERA, A., "Pragmatismo y evolución: ¿es racional ser teísta y naturalista? Tópicos, No 57, (2019), págs. 176-206.

OAKLEY, F., Kingship. The politics of enchantment. Blackwell Publishing, Oxford, 2006.

OCKHAM, G. de, Suma de Lógica, Editorial Norma, Bogotá, 1994.

- Tratado sobre los Principios de la Teología, Aguilar, Buenos Aires, 1980.

OCTAVI PIULTAS, R., "La filosofía trascendental de Kant y la cuestión del escepticismo", Thémata, No 45, (2012), págs. 331-341.

OTTO, R., Ensayos sobre lo numinoso, Editorial Trotta, Madrid, 2009.

- Lo santo, lo racional y lo irracional en la idea de Dios, Alianza Editorial, Madrid, 1980.

PALACIOS CRUZ, V., "Una crítica de la Modernidad desde la reconciliación con la finitud”, Valenciana, Vol. 6, No 11, (2013), págs. 7-31.

PANNENBERG, W., Una historia de la filosofía desde la idea de Dios, Ediciones Sígueme, Salamanca, 2016.

PASCAL, B, Pensamientos, Gredos, Madrid, 2018.

PELE, A., "Kant y la dignidad humana", Revista Brasileira de Estudios Políticos, No 111, (2015), págs. 15-46.

PÉREZ ARGOTE, A., "La religión como identidad colectiva. Las relaciones sociológicas entre religión e identidad", Papeles del CEIC, No 2, (2016), págs. 1-29.

PÉREZ MARCOS, M., Exposición y Crítica de las tesis básicas de la cosmovisión naturalista, San Esteban, Salamanca, 2021.

PÉREZ TAPIAS, J.A., Ser humano. Cuestión de dignidad en todas las culturas, Trotta, Madrid, 2019.

PÉREZ-ARGOTE, J.M., "Redescripción del concepto clásico de Modernidad", Sociología Histórica, No 7, (2017), págs. 11-41.

PETRARCA, BRUNI, VALLA, PICO DELLA MIRANDOLA y ALBERTI, Manifiestos del Humanismo, Ediciones Península, Barcelona, 2000. 
PINTOR-RAMOS, A., "Rousseau: en el crepúsculo de la teología natural”, Cuadernos Salmantinos de Filosofía, No 33, (2006), págs. 181-230.

- El deísmo religioso de Rousseau, Universidad Pontificia de Salamanca, Kadmos, Salamanca, 1982.

PIÑÓN GAYTÁN, J.F., "Feuerbach: Dios como esencia del hombre (Homo homini Deus)", Andamios, Vol. 11, No 24, (2014), págs. 191-214.

PIO XII, Humani generis, Amicizia Cristiana, Roma, 2008.

PIRACOCA FAJARDO, C., "El saber vivir de Montaigne: entre la preocupación por el mundo y la realización de la autárkeia”, Cuadrantephi, No 26-27, 7, (2013), págs. 1-24.

PIZZI, J., “Habermas y la religión. Algunas consideraciones”, Recerca, No 1, (2001), págs. 53-68.

PLATÓN, Fedón, Gredos, Madrid, 1918.

- Gorgias, Gredos, Madrid, 2018.

- $\quad$ La República, Gredos, Madrid, 2018.

- Teeteto, Gredos, Madrid, 2018.

- Timeo, Gredos, Madrid, 2018.

PLOTINO, Enéada III, Sobre el Amor, Gredos, Madrid, 2015.

- Enéadas, Sobre la Eternidad y el tiempo, Gredos, Madrid, 1987.

POLO, L., Evidencia y realidad en Descartes, Eunsa, Navarra, 1996.

POPE, A., Ensayo sobre el hombre, Imprenta Nacional, Madrid, 1821.

POPPER, K., “Ciencia, conocimiento e ignorancia”, Apeiron, 6, (2017), págs. 57-69.

- Búsqueda sin término, Tecnos, Madrid, 1977.

- La lógica de la investigación científica, Tecnos, Madrid, 1977.

- La sociedad abierta y sus enemigos, Paidós, Barcelona, 1982.

PRAT I CARÓS, J., "El carnaval y sus rituales: algunas lecturas antropológicas”, Temas de antropología aragonesa, No 4, (1993), págs. 285-289. 
PRIETO LÓPEZ, L., "El espíritu de la Filosofía Moderna en sus rasgos esenciales", Thémata, No 43, (2010), págs. 333-347.

PUECH, H.C., Historia de las Religiones Antiguas I, Siglo XXI Editores, Madrid, 1979.

RAMÍREZ, Z., "Martín Lutero y la Reforma del Cristianismo Occidental”, RAM, Vol. 5, No 1 (2014), págs. 65-86.

RAWLS, J., El liberalismo político, Fondo de Cultura Económica, México, 2006.

- Sobre las libertades, Paidós, Barcelona, 1990.

REDONDO ORTA, I., Reseña al libro de FLANAGAN, O., The Really Hard Problem: Meaning in a Material World, MIT Press, 2007, en Enrahonar, No 47, (2011), pág. 254.

REYES MARRERO, A.J., Dioses, héroes y alegoría en la Ilíada de Homero. Trabajo de fin de grado. Inédito. Universidad La Laguna, 2016, págs. 38-39.

RICOEUR, P., La Memoria, la historia, el olvido, Trotta, Madrid, 2010.

RIZZUTTO, A.M., El nacimiento del Dios vivo. Un estudio psicoanalítico, Trotta, Madrid, 2006.

RODRÍGUEZ ALCÁZAR, F.J., "La radicalización del naturalismo", Revista de Filosofía, Vol. VIII, No 14, (1995), págs. 107-134.

RODRÍGUEZ GARCÍA, S., “Antropología filosófica y filosofía antropológica en la obra de Charles Taylor", Actas I Congreso Internacional de la Red española de Filosofía, Vol. II, (2015), págs. 83-96.

ROLDÁN GÓMEZ, I., "Lo postsecular: Un concepto normativo", Revista Política y Sociedad, Vol. 54, No 3, (2017), pág. 847-863.

RORTY, R. y VATTIMO, G., El futuro de la religión. Solidaridad, caridad, ironía, Paidós, Barcelona, 2006.

RORTY, R., La filosofía y el espejo de la naturaleza, Cátedra, Madrid, 2017.

ROTTERDAM, E. de, Elogio de la locura, Austral, 2008, Madrid.

ROUSSEAU, J.J., De la desigualdad entre los hombres, Gredos, Madrid, 2014.

- Discurso sobre las ciencias y las artes, Gredos, Madrid, 2014. 
- El contrato social, Austral, Madrid, 2007.

- El contrato social, Gredos, Madrid, 2014.

- Emilio o la Educación, Gredos, Madrid, 2018.

- Las confesiones, José Codina Editor, Barcelona, 1870.

RUBIO FERRERES, J.M., “¿Resurgimiento religioso versus secularización?”, Gazeta de Antropología, No 14, (1998), págs. 1-25.

RUSSELL, B., Exposición crítica de la filosofía de Leibniz, Siglo XXI Editores, Buenos Aires, 1977.

SACRINI FERRAZ, M., "La fenomenología practicada por Merleau-Ponty", Investigaciones Fenomenológicas. Volumen Extra, (2008), págs. 1-24.

SADE, Elogio de la Insurrección, El Viejo topo, Barcelona, 1997, págs. 19-20.

SÁEZ RUEDA, L., Movimientos filosóficos actuales, Trotta, Madrid, 2012.

SALES, F., Introducción a la vida devota, Apostolado Mariano, Sevilla, 2000.

SALGADO LÉVANO, C., “Acerca de la Psicología de la Religión y la espiritualidad”. En Tesis Doctoral Inédita. Universidad San Ignacio de Loyola, (2016).

SAN JOSÉ PRISCO, J., "La religiosidad popular. Aspectos antropológicos, culturales y canónicos” REDC, No 63, (2006), págs. 305-331.

SÁNCHEZ BAYÓN, A.; FUENTE, C. y CAMPOS, G., "Revelaciones sobre la religión civil estadounidense: influjo en su configuración nacional y crisis posglobalizatoria", Journal of the Sociology and Theory of Religion, Vol. 6, (2017), págs. 1-30.

SÁNCHEZ CAPDEQUÍ, C., "Las formas de la religión en la sociedad moderna", Papers, No 54, (1998), pág. 169-185.

- "Las formas de la religión en la sociedad moderna", Papers, No 54, (1998), págs. 169-185.

SÁNCHEZ MARTÍNEZ, G., Presentación de La creatividad de la acción, de H. Joas, CIS, Madrid, 2013.

SÁNCHEZ MECA, D., En torno al Superhombre. Nietzsche y la crisis de la modernidad, Anthropos, Madrid, 1989. 
SÁNCHEZ, A. "La concepción del yo en Daniel Dennett: Un análisis de la relación entre la perspectiva heterofenomenológica y el enfoque memético", Logos, Vol. 24, No 1, (2014), págs. 40-50.

SÁNCHEZ, V., “¿Hacia una edad postsecular?” Fundación Manuel Giménez Abad, (2011), págs. 17-36.

SANDEL, M., "America`s search for a public philosophy", The Atlantic Monthly, (1996), págs. 57-73.

SANGUINETI, J.J., "Individuo y naturaleza en Guillermo de Ockham", Scripta Theologica, No 17, (1985), págs. 845-861.

- Filosofía de la mente, Ediciones Palabra, Madrid, 2007.

SANZ ALONSO, S., "Indagando en los orígenes aristotélicos de Marx", Nómadas, No 8, (2003), págs. 1-12.

SANZ BAYÓN, P., "Increencias, ciencia y religión. El necesario diálogo entre la espiritualidad trascendente y la naturalizada", Pensamiento, Vol. 73, No 276, págs. 761-766.

SAPHIRO, A., "La Filosofía experimental de Newton", Estudios Filosóficos, No 35, (2007), págs. 111-147.

SARTRE, J.P., El ser y la nada, Losada, Buenos Aires, 2017.

SCHELER, M., El puesto del hombre en el cosmos, Editorial Losada, Buenos Aires, 1994.

SCHELLING, Sistema del Idealismo Trascendental, Gredos, Madrid, 2018.

SCHILLER, F., Cartas sobre la Educación estética del hombre, Universidad de Cuyo, Argentina, 2016.

SCHLEIERMACHER, F., La Fe Cristiana, Sígueme, Salamanca, 2013.

- Sobre la Religión, Tecnos, Madrid, 1990.

SCHMITT, J.C., "El Cuerpo en Cristiandad", Anales de Historia Antigua, Medieval y Moderna, No 31, (1998), págs. 51-62. 
SCHOPENHAUER, A., De la Cuádruple Raíz del Principio de Razón suficiente, Gredos, Madrid, 1998.

- El mundo como voluntad y representación, Trotta, Madrid, 2013.

SCIVOLETTO, G., "La religión en la esfera pública: análisis de la cláusula de traducción del discurso religioso al lenguaje secular", Revista de Investigación filosófica, Vol. 4, No 1, (2017), págs. 93-116.

SEARLE, J., La construcción de la realidad social, Paidós, Barcelona, 1997.

SEIDEL, K., "The Religious and the Secular. Talal Asad: Genealogies of Religion, and Formations of the Secular", Iowa Journal of Cultural Studies, Vol. 7, No 1, (2005), págs. 113-117.

SÉNECA, Diálogos. Sobre la vida feliz, Gredos, Madrid, 2014.

- Epístolas morales a Lucilio, Gredos, Madrid, 2014.

SETTON, D., "Rupturas y continuidades en la sociología de la religión de Peter Berger", Sociedad y Religión, Vol. XXVII, No 48, (2017), págs. 164-174.

SHERIDAN, P., "The Metaphysical Morality of Francis Hutcheson: A Consideration of Hutcheson's Critique of Moral Fitness Theory", Sophia, Vol. 46, (2007), págs. 263-275.

SIMBAÑA, Q.R., "La religión en la esfera pública: Habermas y el resurgimiento de la religión" Revista de Ciencias sociales y Humanidades, Vol.1, (2016), págs. 66-81.

SIMÓN, P., “El ‘zorro' contra el ‘erizo'. Una consideración histórica de la disputa de Berlín contra Carr”. Cuadernos de Historia Contemporánea, No 16, (1994), págs. 151-166.

SMITH, A, La riqueza de las Naciones, Alianza Editorial, Madrid, 1996.

- Teoría de los sentimientos morales, Fondo Cultura Económica, México, 1978.

SMITH, J., The Cambridge Platonists. Existence and nature of God, Oxford, Clarendon Press, 1901.

SOLÉ PUIG, C., “Acerca de la Modernización, la Modernidad y el riesgo", REIS, No 80/97, (2007), págs. 111-131. 
SOTO BRUNA, M.J., "La Metafísica del Infinito en Giordano Bruno", Cuadernos de Anuario Filosófico, No 47, (1997), págs. 5-84.

SOUROUJON, G., "La propuesta hermenéutica de Charles Taylor. Una crítica a la Epistemología dominante en la ciencia política”, Atenea Digital, Vol. 15, No 1, (2015), págs. 274-275.

SPINOZA, B., Tratado de la Reforma del Entendimiento, edicioneselaleph.com, 2000.

STARK, R., "Secularizacion RIP”, Sociología de la Religión, Vol. 60, No 3, (1999), págs. 249-273.

SUÁREZ, H.J., “A propósito de la Religion pour memoire de D.H. Leger”, Desacatos, No 18, (2005), págs. 179-182.

TAINE, H., The French Revolution, Liberty Fund, 2002.

THIEBAUT, C., Cabe Aristóteles, Visor, Madrid, 1988.

TINDAL, M., Christianity as old as Creation, Londres, 1730.

TOCQUEVILlE, A., La democracia en América, Fondo de Cultura Económica, México, 1963.

TOLAND, J., Christianity not Mysterious, Sam Buckley Edition, Londres, 1696.

TOLCACHIER, J., El Humanismo como expresión de lo sagrado, Parques de Estudio y Reflexión, Paravachasca, 2012, págs. 1-75.

TOURAINE, A., ¿Podremos vivir juntos?, Fondo de Cultura Económica, México, 2000.

TREVOR-ROPER, H., La crisis del siglo XVII. Religión, Reforma y Cambio social. Katz Editores, Madrid, 2009.

TURNER, V., El proceso ritual. Estructura y antiestructura, Taurus, Madrid, 1988.

UÑA JUÁREZ, A., "Guillermo de Ockham rechaza las Ideas. El giro filosófico de la modernidad y Platón”, Anales del Seminario de Historia de la Filosofía, No 8, (1990), págs. 9-40.

VALLS PLANA, R., Del yo al nosotros, Editorial Estela, Barcelona, 1971.

VAN DER LEEUW, G., Fenomenología de la Religión, FCE, México, 1964.

VAN GENNEP, A., Ritos de Paso, Alianza Editorial, Madrid, 2013. 
VANZAGO, L., Breve historia del alma, Fondo de Cultura Económica, México, 2011.

VATTIMO, G., El fin de la modernidad. Nihilismo y hermenéutica en la cultura posmoderna. Gedisa, Barcelona, 1987.

- Ética de la Interpretación, Paidós, Barcelona, 1991.

VÁZQUEZ, A., "De las religiones a la espiritualidad", Iglesia Viva, No 222, (2005), págs. 2-18.

VELARDE LOMBRAÑA, J., "Raíces del Agnosticismo en el pensamiento inglés del siglo XIX”, Pensamiento, Vol. 62, No 232, (2006), págs. 89-119.

VELÁZQUEZ FERNÁNDEZ, H., En torno a la naturalización de la conciencia sugerida por Daniel Dennett, Naturaleza y Libertad. Revista de Filosofía, No 4, Málaga, 2014.

VIDE, V., "Raíces Antropológicas del secularismo. Un acercamiento fenomenológico", Seminario. Desafíos del Secularismo a la Iglesia del siglo XXI. Centro Loyola Pamplona, (2014), págs. 1-17.

- "Senderos de trascendencia en tiempos de increencia", Revista de Espiritualidad, No 72, (2013), págs. 343-363.

VILLACAÑAS, J.L., Estudio Introductorio a la Crítica de la Razón Pura de Kant, Gredos, Madrid, 2008.

VILLORIO, L., El pensamiento moderno. Filosofía del Renacimiento. Fondo de Cultura Económica, México, 1992.

VIVES, J.L., Tratado del Socorro de los pobres, Imprenta de Benito Monfort, Valencia, 1781.

VOLTAIRE, Cartas Filosóficas, Diccionario Filosófico, Gredos, Madrid, 2018.

- Cartas Filosóficas, Sobre los pensamientos del Sr. Pascal, Gredos, Madrid, 2018.

- Opúsculos. Cuentos, Gredos, Madrid, 2018.

WAKSMAN, V., "Jean Jacques Rousseau: el amor de sí mismo y la felicidad pública", Anacronismo e Irrupción, Vol. 3 No 4, (2013), págs. 104-127.

WALZER, M., La revolución de los santos, Katz Editores. Barcelona, 2005. 
WARNER, M., VANANTWERPEN, J. y CALHOUN, C., Varieties of Secularism in a secular age, Harvard University Press, Cambridge, 2010.

WEBER, M., El político y el científico, Alianza Editorial, Madrid, 1979.

- La ética protestante y el espíritu del capitalismo, Fondo de Cultura Económica, México, 2014.

- La ética protestante y el espíritu del capitalismo, Premiá Editora de Libros, Puebla, 1991.

- Sociología de la Religión, La Pléyade, Buenos Aires, 1978.

WEIL, S., Primeros Escritos Filosóficos, Trotta, Madrid, 2018.

WHICHCOTE, B., The Cambridge Platonists. The Venerable Nature and Transcendent Benefit of Christian Religion, Clarendon Press, Oxford, 1901.

WILSON, B., "Secularization: The Inherited Model", en Phillip E. Hammond (coord.), The Sacred in a Secular Age, University of California Press, Berkeley, 1985.

- Religion in Sociological Perspective, Clarendon Press, Oxford, 1982.

- The Social Dimensions of Sectarism, Clarendon Press, Oxford, 1990.

WINCH, P., "Para comprender a una sociedad primitiva", Alteridades, Vol. 1, No 1, (1991), pág. 82-101.

WITTGENSTEIN, L., Investigaciones filosóficas, Gredos, Madrid, 2019.

- Sobre la certeza, Gredos, Madrid, 2018.

WOODHEAD, L., "Five concepts of Religion”, International Review of Sociology, Vol. 21, No 1, (2011), págs. 121-143. 
